
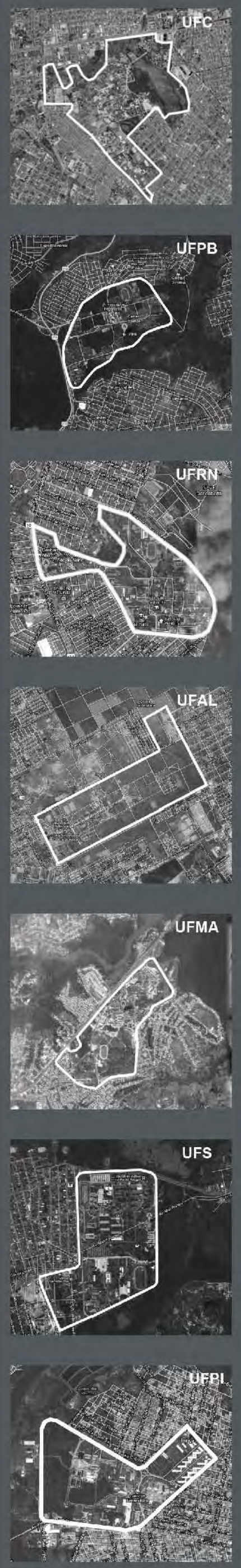

UNIVERSIDADE DE SÃO PAULO

FACULDADE DE ARQUITETURA E URBANISMO

UNIVERSIDADE FEDERAL DO CEARÁ

DEPARTAMENTO DE ARQUITETURA E URBANISMO

DOUTORADO INTERINSTITUCIONAL EM ARQUITETURA E URBANISMO

MAGDA CAMPÊLO

\section{Campus no Nordeste: Reforma Universitária de 1968}

São Paulo 2012 


\section{Campus no Nordeste: Reforma Universitária de 1968}

Tese apresentada ao Programa de PósGraduação da Faculdade de Arquitetura e Urbanismo da Universidade de São Paulo para obtenção do título de Doutora em Arquitetura e Urbanismo.

Área de Concentração: História e Fundamentos da Arquitetura e Urbanismo.

Orientador: Prof. Dr. Hugo Segawa 
AUTORIZO A REPRODUÇÄO E DIVULGAÇÃO TOTAL OU PARCIAL DESTE TRABALHO, POR QUALQUER MEIO CONVENCIONAL OU ELETROONICO, PARA FINS DE ESTUDO E PESQUISA, DESDE QUE CITADA A FONTE.

E-MAIL: magdacampelo@ufc.br

magdacampelo@baydenet.com.br

Campêlo, Magda

C193c Campus do Nordeste : Reforma Universitária de 1968 /

Magda Campêlo. --São Paulo, 2012.

$637 \mathrm{p}$. : il.

Tese (Doutorado - Área de Concentração: História e Fundamentos da Arquitetura e Urbanismo - FAUUSP)

Orientador: Hugo Segawa

1.Universidades (Arquitetura ; Planejamento) - Nordeste 3.Reforma Universitária de 1968 I.Título

CDU $727.3(812 / 813)$ 


\section{DEDICATÓRIA}

Aos meus pais,

VALDIR DE MEDEIROS CAMPÉLO (in memoriam) e MARIA DE LOURDES DE SOUZA CAMPÉLO pelos valiosos ensinamentos e dedicação que me deram.

\section{À MINHA FAMÍLIA,}

com amor e gratidão pelo incentivo e incansável apoio ao longo do período de elaboração deste trabalho.

Ao Reitor da Universidade Federal do Ceará,

Prof. Dr. ÍCARO MOREIRA (in memoriam), pelo exemplo de homem institucional. 


\title{
AgRADECIMENTOS
}

\author{
A Deus, sempre!
}

Ao meu pai (in memoriam) e a minha mãe, pelos valiosos ensinamentos sobre a importância da contribuição profissional para uma sociedade mais justa e fraterna.

Ao meu marido Helder, pelo apoio e esforço de compreender as horas ausentes.

Aos meus filhos, Caio, Vito e André, e à minha nora Cristina, pelo apoio, incentivo e crédito à importância deste trabalho para a minha vida profissional.

À Universidade Federal do Ceará, nas pessoas do Reitor, Prof. Dr. Jesualdo Pereira Farias, e do Pró-reitor de Pesquisa e Pós-Graduação, Prof. Dr. Gil de Aquino Farias, pelo apoio institucional. Um agradecimento especial ao Prof. Dr. Jesualdo Pereira Farias pela colaboração na minha pesquisa de campo.

Aos professores da Universidade de São Paulo que participaram do doutorado transmitindo seus saberes e conhecimentos, representados, aqui, pelas professoras Marta Dora Grostein, Maria Cristina da Silva Leme e Maria Ângela Faggin Pereira Leite, que conduziram o programa DINTER de forma irretocável.

Ao Prof. Dr. Hugo Segawa, pela orientação competente e pela amizade a mim depositada no desenvolvimento deste trabalho.

Ao Prof. Dr. Ricardo Figueiredo Bezerra, pela coordenação local do DINTER.

Aos professores da banca de qualificação, Prof. Dr. Rodrigo Cristiano Queiroz e Prof. Dr. Carlos Roberto Monteiro de Andrade, pelas valiosas contribuições para o desenvolvimento do trabalho.

Aos Reitores, Prof. Dr. Josué Modesto dos Passos Subrinho, da UFS, Prof. Dr. Natalino Salgado, da UFMA, e Prof. Dr. Luiz de Sousa Santos Júnior, da UFPI, pelo apoio à pesquisa documental.

Aos escritórios técnicos das universidades federais do Maranhão, Piauí, Rio Grande do Norte, Paraíba, Alagoas e Sergipe, pelo acolhimento à minha pesquisa, permitindo o acesso aos seus acervos e documentos.

Aos arquitetos Alcyr Meira, Ronaldo Pinto Marques, João Alberto Monteiro, Hugo Lucini, Aristides Oliveira e Neudson Braga, pelos depoimentos.

À família de Wit-Olaf Prochnik, na pessoa de sua filha Marta Prochnik, pelo apoio e confiança no acesso ao acervo de projetos e documentos do arquiteto. 
Aos profissionais Ana Carolina Mendonça, Bruna Lima de Almeida, Emanuelle Carvalho Oliveira de Almeida, Vanine Borges Amaral, Conceição Prado, Clóres Holanda Silva, Waldete Freitas, Regina Cunha, Newton Backer, Aureliano Carvalho, Emil Bronk, Reinaldo Silva e Venilma Venâncio, pelo apoio na pesquisa documental.

Ao Departamento de Arquitetura e Urbanismo da UFC, nas pessoas dos professores José Lemenhe e Joaquim Aristides de Oliveira, chefes do Departamento no período de realização do doutorado, pelo apoio institucional.

À Fundação Cearense de Pesquisa e Cultura, na pessoa do seu presidente, Francisco Antônio Guimarães, e ao Setor de Prestação de Contas, na pessoa de Alexandre Pereira, pelo apoio na gerência dos recursos.

Ao Banco do Nordeste do Brasil, na pessoa do seu presidente, Robert Smith, pelo apoio financeiro para a realização do Doutorado Interinstitucional (DINTER), realizado entre a FAU/USP e o DAU/UFC.

Aos meus irmãos, pelo incentivo. Em especial ao irmão, também arquiteto, Joaquim Campêlo, sempre pronto a me ajudar!

À arquiteta, amiga e quase irmã Carol Nóbrega, pelo apoio na formatação do trabalho e especialmente por me acolher nas horas de angústias e incertezas.

Ao amigo Marcos Moreira, pelas sugestões e apoio na formatação gráfica.

À jornalista Denise Yamashiro, pelas leituras e correções nos textos.

A Natália Boris, uma filha que ganhei, pelo carinho e apoio no período de desenvolvimento da pesquisa.

Aos colegas da Oficina de Texto, Nara Grossi, Ricardo Castor, Oigres Macêdo, Malu Freitas, Gabriella Lima e Liziane Mangil, pelas trocas de experiências.

Aos colegas doutorandos, Ignácio Montenegro, Lucila Novaes, Ricardo Fernandes, Romeu Duarte, Paulo Costa, Margarida Andrade, Beatriz Diógenes e Caetano Aragão, pelas trocas de experiências.

Ao Prof. Dr. Jacques Therrien e à Profa. Dra. Sílvia Nóbrega Therrien pelas orientações sobre os procedimentos metodológicos.

À equipe da CPG da FAU/USP, na pessoa de Cristina Arguejo, pelo apoio logístico.

Às bibliotecárias do DAU/UFC e da CPG/FAU, pela colaboração na pesquisa bibliográfica.

A Marly, minha secretária doméstica que, nas ausências, sempre cuida zelosamente de minha família.

Enfim, a todos que comigo dividiram seu tempo e seu conhecimento, dispondo-se a me ouvir e indicar caminhos, para o enriquecimento desta tese: Minha Gratidão! 


\section{Resumo}

Análise das realizações urbano-arquitetônicas das universidades federais do Ceará (UFC), da Paraíba (UFPB), do Rio Grande do Norte (UFRN), de Alagoas (UFAL), Maranhão (UFMA), de Sergipe (UFS) e do Piauí (UFPI), executadas a partir da Reforma Universitária de 1968, com o objetivo de demonstrar que esses espaços universitários, em sua reformulação ou constituição física, obedecendo ao projeto reformista, adotaram o padrão de campus norte-americano e produziram no Nordeste configurações urbanísticas e arquitetônicas com características que evidenciam respostas submetidas ao contexto local. A primeira parte aborda a implantação da Reforma Universitária e suas características. Destaca o modelo do campus concebido para responder aos intentos de eficiência e racionalidade da organização universitária e as orientações do Manual, de autoria do consultor norte-americano Rudolph Atcon (1970), que foi utilizado como documento base para o seu planejamento e execução. A segunda parte aborda a criação das sete universidades. A partir de uma matriz de análise formulada com base nas recomendações do Manual de Atcon, descrevem-se as características e se analisa cada campus em relação ao tecido urbano existente, as concepções urbanística e arquitetônica, as características construtivas e tipologias produzidas, evidenciando-se aspectos da racionalização (padronização dos elementos construtivos), funcionalidade (distribuição dos ambientes), modulação (estrutural e/ou módulo-base) e flexibilidade (remanejamento e expansão da edificação). Questões como o isolamento ou a integração dos campi na estrutura urbana, o zoneamento como instrumento de organização funcional e, ao mesmo tempo, indutor de segregação, as limitações dos procedimentos e sistemas construtivos frente aos conceitos de racionalização da construção são examinados mais de 40 anos após a implantação da Reforma.

Palavras-chave: campus universitário; Reforma Universitária de 1968 - Brasil; universidade arquitetura; universidade - urbanismo. 


\section{ABSTRACT}

Analysis of the urban architectural achievements of the federal universities of Ceara (UFC), Paraiba (URPB), Rio Grande do Norte (UFRN), Alagoas (UFAL), Maranhão (UFMA), Sergipe (UFS), and Piaui (UFPI) executed after the University Reform of 1968, designed to demonstrate that such university spaces, in their physical reformulation or constitution, according to the reformist project, adopted the standard of North American campus and produced urban and architectural configurations in the Northeast, with features highlighting responses submitted to the local context. The first part addresses the implementation of the University Reform and its features. It focuses on the campus model designed to meet the aims of efficiency and rationality of the university organization and the guidelines of the Manual by North American consultant Rudolph Atcon (1970), which was used as the basic document for its planning and execution. The second part addresses the creation of the seven universities. Based on an analysis matrix formulated from the recommendations of the Atcon Manual, the features are described and each campus is analyzed in accordance with the existing urban fabric, the urban and architectural conceptions, the constructive characteristic and the produced typologies, highlighting the rationalization aspects (standardization of the constructive elements), functionality (distribution of environments), modulation (structural or basis module) and flexibility (building relocation and expansion). Issues relating to the isolation or integration of the campuses in the urban structure, to the zoning as instrument of functional organization and as a segregation inductor, and to the limitation of procedures and constructive systems in the building rationalization concepts are examined forty years after the implementation of the Reform in 1968.

Key words: university campus; University Reform of 1968 - Brazil; University - Architecture; University - Urbanism. 


\section{LISTA DE ABREVIATURAS}

Al-5 - Ato Institucional $n^{\circ} 5$

ASPLAN/UFPI - Assessoria de Planejamento/UFPI

BID - Banco Interamericano de Desenvolvimento

BNH - Banco Nacional da Habitação

CAPES - Coordenação de Aperfeiçoamento de Pessoal de Nível Superior

CEDATE - Centro de Desenvolvimento e Apoio Técnico à Educação

CEPLAN - Centro de Planejamento Oscar Niemeyer

CERES - Centro Regional de Ensino Superior do Seridó

CFE - Conselho Federal de Educação

CNDU - Conselho Nacional de Desenvolvimento Urbano

CONESCAL - Centro Regional de Construcciones Escolares para América Latina y la Región del Caribe.

CRUB - Conselho de Reitores das Universidades Brasileiras

CRUTAC - Centro Rural Universitário de Treinamento e Ação Comunitária

DES - Diretoria do Ensino Superior

EUA - Estados Unidos da América

ETA - Escritório Técnico Administrativo

FAPESP - Fundação de Amparo à Pesquisa do Estado de São Paulo

FUM - Fundação Universidade do Maranhão

FUNDUSP - Fundo de Construção da Universidade de São Paulo,

FUPI - Fundação Universidade Federal do Piauí

GERES - Grupo Executivo para a Reformulação da Educação Superior

GTRU - Grupo de Trabalho da Reforma Universitária

HUWC - Hospital Universitário Walter Cantídio

IAB-GB - Instituto de Arquitetos do Brasil - Guanabara

IBAM - Instituto Brasileiro de Administração Municipal

INEP - Instituto Nacional de Estudos e Pesquisas Educacionais Anísio Teixeira

IPES - Instituto de Pesquisas e Estudos Sociais

IPHAN - Instituto do Patrimônio Histórico e Artístico Nacional

LDB - Lei de Diretrizes e Bases da Educação Nacional

MAUC - Museu de Arte da Universidade Federal do Ceará

MEAC - Maternidade-Escola Assis Chateaubriand

MEC - Ministério da Educação e Cultura, atual Ministério da Educação. 
MEC/DAU-UFBA/ISP - Convênio Ministério da Educação e Cultura/Departamento de Assuntos Universitários - Universidade Federal da Bahia/Centro de Estudos Interdisciplinares para o Setor Público

MINTER - Ministério do Interior

MOBRAL - Movimento Brasileiro de Alfabetização

NDHIR/UFPB - Núcleo de Documento e Informação Histórica

Regional/Universidade Federal da Paraíba

PREMESU - Programa de Expansão e Melhoramento das Instalações no Ensino Superior

SESu - Secretaria de Ensino Superior

SOMACS - Sociedade Maranhense de Cultura Superior

UFAL - Universidade Federal de Alagoas

UFBA - Universidade Federal da Bahia

UFC - Universidade Federal do Ceará

UFMA - Universidade Federal do Maranhão

UFMG - Universidade Federal de Minas Gerais

UFPA - Universidade Federal do Pará

UFPB - Universidade Federal da Paraíba

UFPE - Universidade Federal de Pernambuco

UFRPE - Universidade Federal Rural de Pernambuco

UFPI - Universidade Federal do Piauí

UFRJ - Universidade Federal do Rio de Janeiro

UFRN - Universidade Federal do Rio Grande do Norte

UFS - Universidade Federal de Sergipe

UFSC - Universidade Federal de Santa Catarina

UFSCAR - Universidade Federal de São Carlos

UnB - Universidade de Brasília

UNE - União Nacional dos Estudantes

USAID - United States Agency for International Development (Agência Americana para o Desenvolvimento Internacional)

USP - Universidade de São Paulo 


\section{LISTA DE FIGURAS}

Figura 1: Planta esquemática do Campus - setores. $\quad 84$

Figura 2: Planta esquemática do Campus - setores e departamentos. $\quad 84$

Figura 3: Mapa da Região Nordeste. $\quad 89$

Figura 4: UFC - Mapa do Ceará. Localização dos municípios que sediam a UFC. $\quad 95$

Figura 5: UFC - Primeiras edificações com predominância de construções 101 ecléticas.

Figura 6: Mapa de Localização da UFC em Fortaleza. $\quad 102$

Figura 7: UFC - Palacete Gentil - Período da instalação da Reitoria em 1956, 103

$\begin{array}{ll}\text { Figura 8: UFC - Bairro do Benfica. } & 104\end{array}$

$\begin{array}{ll}\text { Figura 09: UFC - Benfica. } & 106\end{array}$

Figura 10: UFC - Vista do conjunto edificado do Benfica - 1971. 107

Figura 11: UFC - Vista do conjunto edificado do Benfica - 1971. 107

Figura 12: UFC - Escola de Engenharia - Década de 1960.

Figura 13: Concha Acústica com auditório ao ar livre. $\quad 110$

Figura 14: UFC - Antigo Departamento de Cultura - Ano 1967.

Figura 15: UFC - Antigo Departamento de Cultura - Ano 2000. 112

Figura 16a: UFC - Faculdade de Filosofia - Planta Pavimento Térreo. $\quad 114$

Figura 16b: UFC - Faculdade de Filosofia - Planta Pavimento Superior. $\quad 114$

Figura 16c: UFC - Faculdade de Filosofia - Fachada. $\quad 115$

Figura 16d: UFC - Faculdade de Filosofia - Implantação. 115

Figura 17: UFC - Faculdade de Filosofia Ciências e Letras. $\quad 113$

Figura 18: UFC - Conjunto arquitetônico da Faculdade de Filosofia Ciências e $\quad 117$ Letras - Anos 1970.

Figura 19: UFC - Museu de Arte - Década de 1960.

Figura 20: UFC - Conjunto arquitetônico dos antigos Institutos Básicos. 119

Figura 21: UFC - Antigo Instituto Básico - Ano 1967. 120

Figura 22: UFC - Residência Universitária - Projeto de arquitetura. $\quad 122$

Figura 23: UFC - Residência Universitária - Ano 2008.

Figura 24: UFC - Residência Universitária - Ano 2008.

Figura 25: UFC - Museu de Arte. $\quad 124$

Figura 26: UFC - Faculdade de Direito - Ano 1966. 
Figura 27: UFC - Faculdade de Medicina do Ceará.

Figura 28: UFC - Hospital de Isolamento.

Figura 29: UFC - Planta do loteamento da Vila Porangabuçu.

Figura 30: Planta do Porangabuçu em 1966.

Figura 31: Vista aérea do Porangabuçu - Final da década de 1960.

Figura 32: UFC - Unidades da Saúde no Porangabuçu - Final da década de 1970.

Figura 33: UFC - Redesenho da planta térrea original do Hospital das Clínicas.

Figura 34: UFC - Hospital das Clínicas.

Figura 35: UFC - Hospital de Cirurgia. Foto do prédio original em 1966.

Figura 36: Antigo Instituto Anatomia e Medicina Legal.

Figura 37: UFC - Maternidade-escola - Projeto de Arquitetura.

Figura 38: UFC - Maternidade-escola.

Figura 39: UFC - Maternidade-escola.

Figura 40: UFC - Futuro Campus do Pici.

Figura 41: UFC - Gleba do Pici - ano 1966.

Figura 42: UFC - Instituto de Zootecnia - ano 1966.

Figura 43: UFC - Mapa do zoneamento em três setores.

Figura 44: Plano de Desenvolvimento de 1966/1970.

Figura 45: UFC - Zoneamento funcional proposto no Plano de Desenvolvimento de $1966 / 1970$

Figura 46: UFC - Caracterização de blocos-padrões.

Figura 47: UFC - Esquema de associação dos blocos-padrões.

Figura 48: UFC - Implantação das unidades no Setor $C$.

Figura 49: UFC - Instituto de Química. .

Figura 50: UFC - Associação dos tipos AD, CA e CE.

Figura 51: UFC - Planta física do Pici apresentada ao Programa MEC/BID 1.

Figura 52: UFC - Proposta do Campus universitário constituído pelas áreas do Pici e Porangabuçu - 1972

Figura 53: UFC - Planta geral do Campus do Pici. Zoneamento da zona estrutura acadêmica da Universidade

Figura 54: UFC - Planta geral do Campus do Pici. Distribuição das novas unidades

Figura 55: UFC - Vista área do Campus do Pici na década de 1970. 
Figura 57: UFC - Planta geral do Campus do Pici - Zoneamento.

Figura 58: UFC - Campus Universitário. Formado por três áreas distribuídas na cidade.

Figura 59: UFC - Campus Universitário - Proposta geral do sistema viário.

Figura 60: UFC - Campus Universitário Área 1 - Constatação 1979.

Figura 61: UFC - Campus Universitário Área 1 - Concebido como área isolada.

Figura 62: UFC - Campus Universitário Área 2 - Constatação 1979.

Figura 63: UFC - Campus Universitário Área 2 - Proposta.

Figura 64: UFC - Campus Universitário Área 3 - Constatação 1979.

Figura 65: UFC - Campus Universitário Área 3 - Proposta.

Figura 66: UFC - Campus do Pici - 2008.

Figura 67: UFC - Campus Universitário do Pici - Década de 1970.

Figura 68: UFC - Campus Universitário do Pici - Década de 1970.

Figura 69: UFC - Campus Universitário do Pici - Década de 1970. A padronização construtiva proporciona identidade visual ao conjunto

Figura 70: UFC - Campus Universitário do Pici - Década de 1970. Os conjuntos se articulam por passarelas cobertas

Figura 71: UFC - Departamento de Biologia /Projeto de Arquitetura. Campus Universitário do Pici - Década de 1970

Figura 72: UFC - Departamento de Matemática / Projeto de Arquitetura. Campus Universitário do Pici - Década de 1970

Figura 73: UFC - Campus Universitário do Pici.

Figura 74: UFC - Campus Universitário do Pici - Década de 1970.

Figura 75: UFC - Biblioteca Central / Fachada oeste - Década de 1970.

Figura 76: UFC - Biblioteca Central / vista da fachada leste - Década de 1970.

Figura 77: UFC - Biblioteca Central / vista das fachadas norte e leste - Década de 1970

Figura 78: Núcleo de Processamento de Dados da UFC - Década de 1970.

Figura 79: UFPB - Mapa da Paraíba. Localização dos municípios que sediam a UFPI

Figura 80: UFPB - Campus de Campina Grande - início de 1978.

Figura 81: UFPB - Campus de Areia - início de 1978.

Figura 82: UFPB - Mapa da Relação Cidade / Campus Universitário.

Figura 83: UFPB - Mapa da cidade de João Pessoa.

Figura 84: UFPB - Instalações de origem. 
Figura 86: UFPB - Planta do terreno da UFPB - Área inicial.

Figura 87: UFPB - Plano Piloto de Stuckert.

Figura 88: UFPB - Construção da cidade universitária [1968?].

Figura 89: UFPB - Visita de autoridades à Escola de Engenharia - 4 de nov. de 1967

Figura 90: UFPB - Maquete da Escola de Engenharia - 12 de agosto de 1969.

205

Figura 91: UFPB - Instituto de Química - ano 1966.

205

Figura 92: UFPB - Encontro de personalidades -12 de agosto de 1969.

206

Figura 93: UFPB - Via de contorno com a rede de energia - ano 1978.

206

Figura 94: UFPB - Conj. da Escola de Engenharia - primeira metade década de 1970

207

Figura 95: UFPB - Prédio da Reitoria.

208

Figura 96: UFPB - Hospital Universitário Lauro Wanderley - Ano 1995.

208

Figura 97: Plano Piloto da UFPB apresentado pela empresa Consultec (1966).

Figura 98: UFPB - Plano Diretor -1967.

Figura 99: UFPB - Plano Diretor -1967. Definição do sistema viário.

Figura 100: UFPB - Plano Diretor -1967.

Figura 101: Ofício do reitor Guilardo Martins Alves - Gestão 1964 a 1971.

Figura 102: UFPB - Plano diretor de 1971 - Esquema de integração das funções Universitárias

Figura 103: UFPB - Plano diretor de 1971 - Esquema de racionalização das funções Universitárias

Figura 104: UFPB - Plano diretor de 1971 - Esquema de flexibilidade do espaço universitário

Figura 105: UFPB - Plano diretor de 1971 - Esquema de expansibilidade na estrutura espacial.

Figura 106: UFPB - Zoneamento funcional do Campus Universitário.

Figura 107: UFPB - Organização espacial dos centros no Campus Universitário.

Figura 108: UFPB - Planta do sistema viário.

Figura 109: UFPB - Campus: planta de constatação (1972).

Figura 110: UFPB - Passarelas.

Figura 111: UFPB - Passarelas.

Figura 112: UFPB - Campus da UFPB - Meados da década de 1970.

Figura 113: UFPB - Campus I - Planta Geral (ano 2002).

Figura 114: UFPB - Vista aérea do Campus Universitário - Ano 2008.

Figura 115: UFPB - Conjunto da Escola de Engenharia - 1974. 
Figura 116a: UFPB - Escola de Engenharia - Bloco de Aulas.

Figura 116b: UFPB - Escola de Engenharia - Bloco B: Laboratórios. 230

Figura116c: UFPB - Escola de Engenharia - Bloco C: Laboratórios. 231

Figura 116d: UFPB - Escola de Engenharia - Blocos F, G, He I: Laboratórios. 232

Figura 116e: UFPB - Escola de Engenharia - Bloco Departamentos. 233

Figura 116f: UFPB - Escola de Engenharia - Bloco Departamentos (detalhes). 234

Figura 117: UFPB - Diagrama do partido arquitetônico. 228

Figura 118: UFPB - Detalhes construtivos. $\quad 235$

Figura 119: UFPB - Detalhes construtivos. $\quad 236$

Figura 120a: UFPB - Administração - Planta. $\quad 237$

Figura 120b: UFPB - Administração - Coberta. 238

Figura 120c: UFPB - Administração - Cortes / Detalhes. 239

Figura 121: UFPB - Bloco Administrativo / Fachada principal. 241

Figura 122: UFPB - Bloco Administrativo. 241

Figura 123: UFPB - Laboratório de Hidráulica / Planta de Arquitetura. 242

Figura 124a: UFPB - Laboratório de Hidráulica - Corte / Fachadas. 243

Figura 124b: UFPB - Laboratório de Hidráulica - Detalhes. 244

Figura 125: UFPB - Galpão para laboratórios de hidráulica de ensaios de 245 materiais e pavilhão mecânico - Década de 1960

Figura 126: UFPB - Hospital Universitário Lauro Wanderley - início da década 246 de 1970

Figura 127a: UFPB - Hospital Universitário - Planta Pavto. Tipo (Bloco AB). 247

Figura 127b: UFPB - Hospital Universitário - Planta Bloco C. 247

Figura 128: UFPB - Vista aérea do Conjunto Humanístico - Década de 1970.

Figura 129: UFPB - Planta do Conjunto Humanístico. 250

Figura 130: UFPB - Conjunto Humanístico. 251

Figura 131: UFPB - Conjunto Humanístico / Corte Transversal. 253

Figura 132: UFPB - Conjunto Humanístico - ano 2009.

Figura 133: UFRN - Mapa do Rio Grande do Norte. Localização dos municípios $\quad 257$ que sediam a UFRN

Figura 134: UFRN - Prédio do Colégio Atheneu.

Figura 135: UFRN - Prédio reformado do antigo Atheneu. 259

Figura 136: UFRN - Conjunto arquitetônico destinado à Faculdade de Farmácia e $\quad 260$ Odontologia

Figura 137: UFRN - Unidade do CRUTAC no Rio Grande do Norte - década1960 
Figura 138: UFRN - Prédio da antiga Faculdade de Direito-(A) ano 1971/(B) ano 2011

Figura 139: UFRN - Maternidade-Escola Januário Cicco - Ano [2008?].

264

Figura 140: UFRN - Prédio da antiga Faculdade de Ciências Econômicas.

265

Figura 141: UFRN - Primeira sede da Reitoria da UFRN (foto do final da década de 1960)

Figura 142: UFRN - Prédio da antiga Escola de Serviço Social - Ano 1971.

266

Figura 143: UFRN - Hospital Universitário Onofre Lopes, antigo Hospital Miguel Couto, depois Hospital das Clínicas - Ano 1971

Figura 144: UFRN - Prédio da antiga Faculdade de Farmácia e Odontologia Primeira metade da década de 1960

Figura 145: UFRN - Prédio da Faculdade de Odontologia - meados de 1960.

269

Figura 146: UFRN - Prédio da Faculdade de Odontologia -ano1966.

269

Figura 147: UFRN - Prédio da Faculdade de Farmácia - Segunda metade da década de 1960 .

270

Figura 148: UFRN - Prédio do Antigo Instituto de Antropologia - Década de 1960.

271

Figura 149: UFRN - Prédio da Faculdade de Medicina - década de 1960.

Figura 150: UFRN - Localização das unidades universitárias da UFRN no centro urbano de Natal

Figura 151: UFRN - Construção do Campus Universitário da UFRN - Primeira metade da década de 1970

Figura 152: UFRN - Foto aérea do Campus Lagoa Nova.

Figura 153: UFRN - Plano Diretor. A proposta é de autoria do arquiteto Alcyr Meira e sua equipe

Figura 154: UFRN - Levantamento Planialtimétrico - 1972.

282

Figura 155: UFRN - Planta Geral do Campus - Março de 1997.

283

Figura 156: UFRN -Levantamento Planialtimétrico - 1972.

286

Figura 157: UFRN - Plano Diretor - Julho de1976.

Figura 158: UFRN - Plano Diretor - Outubro de 1976.

Figura 159: UFRN - Plano Diretor - Julho de 1976.

Figura 160: UFRN - Mapa do Campus Central - Meados de 1970.

Figura 161: UFRN - Mapa do Campus Central - Final de 1970.

Figura 162: UFRN - Foto aérea do Campus Central - Final de 1970.

Figura 163: UFRN - llustração do Restaurante Universitário.

Figura 164: UFRN - Planta do Restaurante Universitário.

Figura 165: UFRN - Restaurante Universitário - Primeira metade década 1970 
Figura 166: UFRN - Setor de Aulas Teóricas I. Blocos padronizados articulados pela circulação da passarela

Figura 167: UFRN - Setor de Aulas Teóricas I - Projeto de Arquitetura / Planta. 296

Figura 168: UFRN - Setor de Aulas Teóricas I - Projeto de Arquitetura / Cortes. 297

Figura 169: UFRN - Setor de Aulas Teóricas I - Projeto de Arquitetura I 298 Fachadas.

Figura 170: UFRN - Setor de Aulas Teóricas I - Primeira metade da década de 1970

Figura 171: UFRN - Setor de Aulas Teóricas I - ano 2009.

300

Figura 172: UFRN - Ilustração da Passarela do Setor de Aulas Teóricas.

300

Figura 173: UFRN - Imagens da passarela do Setor de Aulas Teóricas.

301

Figura 174: UFRN - Setor Didático-Administrativo - Planta de Arquitetura. 303

Figura 175: UFRN - Setor Didático-Administrativo - Primeira metade da década 305 de 1970

Figura 176: UFRN - Setor Didático-Administrativo - Canteiro de obras.

305

Figura 177: UFRN - Prédio da antiga Escola de Serviço Social - ano 1971.

Figura 178: UFRN - Bloco de Laboratórios - Projeto de Arquitetura / Planta. $\quad 307$

Figura 179: UFRN - Bloco de Laboratórios - Projeto de Arquitetura / Cortes. 308

Figura 180: UFRN - Bloco de Laboratórios - Projeto de Arquitetura / Fachadas. 309

Figura 181: UFRN - Ilustração do laboratório de Física. 306

Figura 182: UFRN - Bloco de Laboratórios - Primeira metade da década de 311 1970.

Figura 183: UFRN - Biblioteca Central - Projeto de Arquitetura / Planta niveis $1 \mathrm{e}$

Figura 184: UFRN - Biblioteca Central - Projeto de Arquitetura / Planta nível 2.

Figura 185: UFRN - Biblioteca Central - Projeto de Arquitetura / Cortes Longitudinais

Figura 186: UFRN - Biblioteca Central - Projeto de Arquitetura / Cortes Transversais

Figura 187: UFRN - Biblioteca Central - Projeto de Arquitetura / Fachadas.

Figura 188: UFRN - Biblioteca Central - Primeira metade da década de 1970.

Figura 189: UFRN - Biblioteca Central - ano 2009.

Figura 190: UFRN - Conj. Monumental da Praça Cívica e Capela do Campus 317

Figura 191: UFRN - Planta da Praça Cívica - junho de 1972.

Figura 192: UFRN - Cerimônia de Colação de Grau na Praça Cívica do Campus $\quad 318$

Figura 193: UFRN - Capela - concluída em 1974.

Figura 194: UFRN - Reitoria da UFRN - Final da década de 1970. 
Figura 195: UFRN - Reitoria da UFRN - meados da década de 1970.

Figura 196: UFRN - Centro de Biociências.

Figura 197: UFRN - Laboratório de Tecnologia - ano 1979.

Figura 198: UFRN - Obras de construção do Campus Universitário.

Figura 199: UFRN-Campus Central - Levantamento Planimétrico / 1997.

Figura 200: UFRN - Vista aérea do Campus Central - [2008?].

Figura 201: UFAL - Mapa de Alagoas. Localização dos municípios que sediam a UFAL.

Figura 202: UFAL - Mapa de localização do Campus periférico.

335

Figura 203: UFAL - Antiga Faculdade de Medicina - primeira metade da década de 1950

Figura 204: UFAL - Vista aérea do Campus A. C. Simões.

Figura 205: Cidade Universitária da UFSM.

Figura 206: UFAL - Área urbanizada - Início da década de 1960.

Figura 207: UFAL - Plano Diretor - 1973.

Figura 208: UFAL - Plano Diretor - 1978.

Figura 209: UFAL - Esquema de organização espacial do Campus A. C. Simões.

Figura 210: UFAL - Construção da Cidade Universitária - segunda metade da década de 1960

Figura 211: UFAL - Construção da Cidade Universitária - segunda metade da década de 1960

Figura 212: UFAL - Prédio da Imprensa Universitária - 1968.

Figura 213: UFAL - Hospital Universitário - 1968.

Figura 214: UFAL - Prédio do Instituto de Química - Segunda metade da década de 1960

Figura 215: UFAL - Prédio do Instituto de Física - Segunda metade da déc. de 1960

351

Figura 216: UFAL - Prédio do Instituto de Geociências - Segunda metade da década de 1960

351

Figura 217: UFAL - Prédio do Instituto de Filosofia e Ciências Humanas - 1969.

353

Figura 218: UFAL - Prédio do Centro de Pesquisas Tecnológicas.

Figura 219: UFAL - Avenida Central-1969. Vista da avenida com os antigos Institutos

Figura 220: UFAL - Planta das obras concluídas - 1971.

Figura 221: UFAL - Campus Tamandaré.

Figura 222: UFAL - Composição dos Departamentos e Centros, por unid. de 
Figura 223: UFAL - Planta de situação do Centro de Ciências da Saúde - 1974.

Figura 224: UFAL - Situação dos ambulatórios do Hospital Universitário - 1974.

Figura 225: UFAL - Hospital Universitário - 1974.

Figura 226: UFAL - Hospital Universitário - ano 2000.

Figura 227: UFAL - Centro de Ciências Agrárias - 1982.

Figura 228: UFAL - Planta de situação das Unidades Dispersas - 1982.

Figura 229: UFAL - Planta de situação das Unidades Dispersas - 1982.

Figura 230: UFAL - Esquema de organização espacial do Campus A. C. Simões - Final da década de 1970

Figura 231: UFAL - Área urbanizada do Campus A. C. Simões - Final da déc. de 197066

Figura 232: UFAL - Modelo da Trama Direcional.

Figura 233: UFAL - Tipologias do Plano Diretor Físico.

Figura 234: UFAL - Esquema da organização espacial em estrutura de Trama Direcional

Figura 235: UFAL - Estudo do zoneamento funcional no Campus A. C. Simões. 371

Figura 236: UFAL - Trama Direcional lançada sobre o terreno da UFAL.

Figura 237: UFAL - Zoneamento funcional proposto.

Figura 238: UFAL - Zona Central.

Figura 239: UFAL - Plano Físico Final.

375

Figura 240: UFAL - Vista aérea do Campus A. C. Simões - Início da década de 1990.

377

Figura 241: Vista da Avenida Central do Campus A. C. Simões - Ano 2009.

Figura 242: Planta do Campus A. C. Simões - Ano 2009.

Figura 243: UFMA - Mapa do Maranhão com localização dos Campi.

Figura 244: UFMA - Solar do Barão de Grajaú, construído na segunda metade do século XIX

Figura 245: UFMA - Palácio do Cristo Rei. 396

Figura 246: UFMA - Planta do Sítio Sá Viana. 398

Figura 247: UFMA - Mapa da relação Campus cidade. 399

Figura 248: UFMA - Localização do Campus I - Bacanga. 400

Figura 249: UFMA - Vista da Barragem do Bacanga (2008). 400

Figura 250 UFMA - Mapa da relação campus/região. 402

Figura 251: UFMA - Mapa do eixo viário São Francisco - Bacanga - Itaqui. 402 Figura 252: UFMA - Planta de ocupação para o Campus do Bacanga - 1967. 
Figura 253: UFMA - Ilustração do conjunto arquitetônico para o Campus do Bacanga - 1967

Figura 254: UFMA - Ilustração da sala de aula prática - 1967.

407

Figura 255: UFMA - Planta de zoneamento do Campus.

408

Figura 256: UFMA - Planta de situação das unidades e sistema viário do Campus.

409

Figura 257: UFMA - Planta de situação e zoneamento do Campus do Bacanga 1971

410

Figura 258: UFMA - Planta de situação e zoneamento do Campus do Bacanga 1971

Figura 259: UFMA - Instituto de Ciências Físicas e Naturais - 1972.

Figura 260: UFMA - Instituto de Ciências Físicas e Naturais - Projeto de Arquitetura.

Figura 261: UFMA - Instituto de Ciências Físicas e Naturais - 1972.

416

Figura 262: UFMA - Instituto de Ciências Físicas e Naturais - 1972.

417

Figura 263: UFMA - Instituto de Ciências Físicas e Naturais - 1972.

Figura 264: UFMA - Instituto de Ciências Físicas e Naturais - 1972. Vista Externa.

Figura 265: UFMA - Instituto de Ciências Físicas e Naturais - 1972. Pátio coberto.

Figura 266: UFMA - Instituto de Ciências Físicas e Naturais - 1972.

Figura 267a: UFMA - Foto das primeiras edificações do Campus do Bacanga/Década de 1970

Figura 267b: UFMA - Foto das primeiras edificações do Campus do Bacanga/Década de 1970

Figura 268: UFMA - Alojamento de Estudantes - [1971].

Figura 269: UFMA - Laboratório de Aplicação Médica e Radioisótopos - 1972.

Figura 270: UFMA - Centro de Estudos Básicos - Década de 1970.

Figura 271: UFMA - Centro de Estudos Básicos - Ano 2009.

Figura 272: UFMA - Obras do Centro Esportivo.

Figura 273: UFMA - Quadras co bertas do Setor Esportivo.

Figura 274: UFMA - Setor Esportivo - [1971].

Figura 275: UFMA - Planta do Campus do Bacanga - 1971.

Figura 276: UFMA - Centro de Ciências Sociais - meados da década de 1970.

Figura 277: UFMA - Restaurante Universitário, concluído em 1981.

Figura 278: UFMA - Planta do Campus do Bacanga. 
Figura 280: UFMA - Vista aérea do Campus do Bacanga. 435

Figura 281: UFMA - Planta do desmembramento do Campus. O levantamento 436 realizado em 1979 indicava a redução de 78 há

Figura 282: UFMA - Planta do Campus do Bacanga. O levantamento realizado em 1980 indicava uma área aproximada de 220 há

Figura 283: UFMA - Planta do Campus I - Bacanga - ano 2007. Atualmente o Campus do Bacanga possui uma área aproximada de 110 há

437

437

Figura 284: UFMA - Vista aérea do Campus I - Bacanga - ano 2009.

438

Figura 285: UFMA - Mapa do Campus do Bacanga - ano 1979.

440

Figura 286: UFMA - Mapa do Campus do Bacanga - ano 1979.

441

Figura 287: UFMA - Plano Diretor Físico. Esquema do desenvolvimento físico do Plano

444

Figura 288: UFMA - Plano Diretor Físico - Modelo Espacial.

446

Figura 289: UFMA - Plano Diretor Físico - Modelo Espacial. $\quad 447$

Figura 290: UFMA - Vista aérea do Campus do Bacanga. $\quad 450$

Figura 291: UFMA - Levantamento planialtimétrico do Campus do Bacanga Década de 1980

Figura 292: Centro de Ciências Humanas - 2009. Tipologia construtiva para o $\mathrm{CCH}$.

Figura 293: Centro de Ciências Exatas e Tecnológicas - 2009. Tipologia construtiva para o CCET

Figura 294: UFMA - Levantamento planialtimétrico do Campus do Bacanga 2009.

Figura 295: UFS - Mapa de Sergipe, Localização dos municípios que sediam a UFS.

Figura 296: UFS - Mapa de localização das Unidades no centro urbano Década de 1960.

Figura 297: UFS - Planta de situação do Campus Universitário.

464

Figura 298: UFS - Vistas do terreno do Campus - Início da década de 1970.

Figura 299: UFS - Planta do terreno do Campus Universitário. $\quad 467$

Figura 300: UFS - Zoneamento do Campus Universitário. $\quad 469$

Figura 301: UFS - Sistema viário do Campus Universitário. $\quad 470$

Figura 302: UFS - Tipologias construtivas do Campus Universitário. $\quad 471$

Figura 303: UFS - Planta Geral do Campus Universitário. $\quad 472$

Figura 304: UFS - Planta do Campus - Ano 1980.

Figura 305: UFS - Vista da maquete do Campus - Ano 1976.

Figura 306: UFS - Vista das obras do Campus Universitário - Meados da década $\quad 475$ de 1970 . 
Figura 307: UFS - Vista da cabine de entrada e controle do Campus - Segunda metade da década de 1970

Figura 308: UFS - Obras de construção do Campus Universitário - Meados da década de 1970 .

Figura 309: UFS - Obras de construção do Campus Universitário - meados da década de 1970.

Figura 310: UFS - Vista Geral do Campus Universitário - Década de 1980.

Figura 311: UFS - Vista do Setor Esportivo (SE) - Segunda metade da década de 1970.

Figura 312a: UFS - Ginásio Poliesportivo - Projeto de Arquitetura / Planta.

480

Figura 312b: UFS - Ginásio Poliesportivo - Projeto de Arquitetura / Cortes.

Figura 312c: UFS - Ginásio Poliesportivo - Projeto de Arquitetura / Fachadas.

Figura 313: UFS - Vistas do ginásio poliesportivo - Segunda metade da década de 1970.

Figura 314: UFS - Localização do Conjunto Didático e Administração Departamental na planta do Campus Universitário

Figura 315: UFS - Detalhe do Conjunto Didático/Administração Departamental Década de 1980

Figura 316: UFS - Vista do Conjunto Didático - segunda metade da década de 1970

483

484

Figura 317: UFS - Vista do Conjunto da Administração Departamental Segunda metade da década de 1970

Figura 318: UFS - Detalhe do Conjunto Didático - Segunda metade da década de 1970.

Figura 319a: UFS - Ginásio Poliesportivo - Projeto de Arquitetura / Planta Pavto. Térreo

Figura 319b: UFS - Ginásio Poliesportivo - Projeto de Arquitetura / Planta Pavto. Superior

Figura 320: UFS - Bloco Didático Tipo 1 - Composição volumétrica.

Figura 321: UFS - Tipologia didática Tipo 1 - Segunda metade da década de 1970.

489

Figura 322: UFS - Execução do sistema estrutural da tipologia didática Tipo 1.

490

Figura 323: UFS - Bloco Didático Tipo 1 - Segunda metade da década de 1970.

Figura 324: UFS - Vista do Bloco Didático Tipo 1 - Segunda metade da década de 1970

Figura 325: UFS - Bloco Didático Tipo 2 - Arquitetura Planta Pavto. Térreo

Figura 326: UFS - Bloco Didático Tipo 2/fachada norte - Segunda metade da 492 década de 1970 
Figura 327: UFS - Vista do Bloco Didático Tipo 2 / fachada sul - Segunda metade da década de 1970

Figura 328: UFS - Bloco Didático Tipo 2/volumetria em bloco tipo barra.

Figura 329: UFS - Bloco Didático Tipo 2 - Segunda metade da década de 1970.

494

Figura 330a: UFS - Bloco Departamental Tipo 1- Projeto de Arquitetura / Planta

494 Pavto. Térreo

Figura 330b: UFS - Bloco Departamental Tipo 1-Projeto de Arquitetura/Planta Pavto. Superior

Figura 330c: UFS - Bloco Departamental Tipo 1 -Projeto de Arquitetura / Cortes Transversais

Figura 330d: UFS - Bloco Departamental Tipo 1 -Projeto de Arquitetura / Cortes Longitudinais

496

496

497

497

Figura 330e: UFS - Bloco Departamental Tipo 1 - Projeto de Arquitetura /

498 Fachadas

Figura 331a: UFS - Bloco Departamental Tipo 2 -Projeto de Arquitetura / Planta Pavto.Térreo

Figura 331b: UFS - Bloco Departamental Tipo 2-Projeto de Arquitetura/Planta Pavto. Superior

Figura 332: UFS - Bloco Departamental Tipo 1 - Segunda metade da década de 1970

499

499

501

Figura 333: UFS - Bloco Departamental Tipo 1 - Segunda metade da década de 1970

501

Figura 334: UFS - Bloco Departamental Tipo 1 - Segunda metade da década e 1970

502

Figura 335; UFS - Implantação da Biblioteca, Restaurante e Reitoria.

502

Figura 336: UFS - Detalhe da implantação da Biblioteca, Restaurante e Reitoria.

503

Figura 337a: UFS - Biblioteca - Projeto de Arquitetura / Planta Pavto. Térreo.

504

Figura 337b: UFS - Biblioteca - Projeto de Arquitetura / Planta Pavto. Superior.

505

Figura 337c: UFS - Biblioteca - Projeto de Arquitetura / Cortes - Elevações.

506

Figura 337d: UFS - Biblioteca - Projeto de Arquitetura / Cortes - Elevações.

507

Figura 337e: UFS - Biblioteca - Projeto de Arquitetura / Cortes - Elevações. $\quad 508$

Figura 337f: UFS - Biblioteca - Projeto de Arquitetura / Cortes - Elevações. $\quad 509$

Figura 338: UFS - Vista do Bloco da Biblioteca em fase de finalização da obra Final década de 1970

Figura 339: UFS - Vista da caixa d'água que faz parte do conjunto arquitetônico da Biblioteca.

Figura 340: UFS - Detalhe da estrutura concreto aparente - final década 1970.

Figura 341: UFS - Detalhe dos elementos de proteção solar - Final década de 1970. 
Figura 342: UFS - Vista da fachada de acesso principal - Final década 1970.

Figura 343: UFS - Biblioteca Central - ano 2009.

Figura 344: UFS - Biblioteca Central - ano 2009.

Figura 345a: UFS - Reitoria - Projeto de Arquitetura / Planta Pavto. Térreo.

Figura 345b: UFS - Reitoria - Projeto de Arquitetura / Planta Pavto. Superior.

Figura 345c: UFS - Reitoria - Projeto de Arquitetura / Cortes.

Figura 345d: UFS - Reitoria - Projeto de Arquitetura / Superior.

Figura 346: UFS - Esquema ilustrativo da planta da Reitoria.

Figura 347: UFS - Maquete da Reitoria (1978).

Figura 348: UFS - Esquema do partido arquitetônico.

Figura 349: UFS - Reitoria - ano 2009.

Figura 350: UFS - Edifício da Reitoria/fachada principal (final da década 1970).

Figura 351: UFS - Edifício da Reitoria/fachada sul (final da década 1970).

Figura 352a: UFS - Restaurante - Projeto de Arquitetura / Planta Pavto. Térreo.

Figura 352b: UFS - Restaurante - Projeto de Arquitetura / Cortes.

Figura 352c: UFS - Restaurante - Projeto de Arquitetura / Fachadas.

Figura 353: UFS - Restaurante - Composição volumétrica.

Figura 354: UFS - Restaurante (final década 1970, em fase execução).

Figura 355: UFS - Restaurante (final década 1970 em fase execução).

Figura 356: UFS - Restaurante (década de 1980).

Figura 357: UFS - Centro de Ciências Biológicas e da Saúde e Centro de Ciências Exatas e Tecnológicas

Figura 358: UFS - Planta dos Laboratórios de Biologia II - Blocos 4 e 5.

Figura 359: UFS - Laboratórios de Biologia.

Figura 360: UFS - Laboratórios de Biologia - Corte transversal.

Figura 361: UFS - Laboratórios de Biologia - Fachada de um bloco-padrão.

Figura 362: UFS - Conjunto do Centro de Ciências Biológicas e da Saúde e do Centro de Ciências Exatas e Tecnológicas em construção (meados da década de 1980)

Figura 363: UFS - Centro de Ciências Biológicas e da Saúde e Centro de Ciências Exatas e Tecnológicas (meados da década de 1980)

Figura 364: UFS - Centro de Ciências Biológicas e da Saúde e Centro de Ciências Exatas e Tecnológicas (meados da década de 1980)

Figura 365: UFS - Planta geral do Campus (atualização em 2008).

Figura 366: UFS - Vista Aérea do Campus Universitário de São Cristóvão (ago. de 2007). 
Figura 367: UFPI - Mapa do Piauí. Localização dos municípios que sediam a UFPI.

Figura 368: UFPI - Edifício do antigo Seminário Arquidiocesano de Teresina.

Figura 369: Vista da cidade de Teresina - década de 1960.

Figura 370: Vista da cidade de Teresina - década de 1970.

Figura 371: UFPI - Mapa esquemático da localização do Campus da Ininga, na cidade de Teresina

Figura 372: UFPI - Mapa esquemático da relação Campus $x$ cidade.

552

Figura 373: UFPI - Ilustração do Campus com a distribuição dos setores funcionais

Figura 374: UFPI - Ilustração do sistema viário

557

Figura 375: UFPI - Ilustração do zoneamento

558

Figura 376: UFPI - llustração dos setores funcionais

559

Figura 377: UFPI - A primeira etapa de implantação se daria no primeiro semicírculo

560

Figura 378: UFPI - Movimento de expansão das áreas internas ao anel semicircular.

Figura 379: UFPI - Proposta para a construção de uma nova ponte ligando o campus à cidade e a construção de um setor habitacional

Figura 380: UFPI - llustração das estratégias de conforto térmico

564

Figura 381: UFPI - Plano Diretor do Campus da Ininga (1972).

566

Figura 382: UFPI - Detalhe da proposta geral do Campus.

568

Figura 383: UFPI - Setor de Serviços Gerais (1977)

571

Figura 384: Vista aérea do Setor de Serviços Gerais - Final da década de 1970.

571

Figura 385: UFPI - Vista da caixa d'água, ano 1980.

572

Figura 386: UFPI - Vista das obras de infraestrutura do Campus - Final da década de 1970 .

Figura 387: UFPI - Vista das obras de infraestrutura do Campus - ano 1980.

573

Figura 388: UFPI - Planta do Campus da Ininga - 1976.

576

Figura 389: UFPI - Zoneamento do Campus da Ininga - 1977.

Figura 390: UFPI - Campus da Ininga - Setores funcionais. 578

Figura 391: UFPI - Campus da Ininga - Sistema viário. $\quad 579$

Figura 392: UFPI - Campus da Ininga - Redes de infraestrutura. 580

Figura 393: UFPI - Campus da Ininga - Redes de infraestrutura. 581

Figura 394: UFPI - Campus da Ininga - Redes de infraestrutura. $\quad 582$

Figura 395: UFPI - Campus da Ininga - Partido arquitetônico. 
Figura 396: UFPI - Campus da Ininga - Fatores ambientais.

Figura 397: UFPI - Planta do Campus do Socopo.

Figura 398: UFPI - Planta do Campus Ministro Reis Veloso, implantado na cidade de Parnaíba

Figura 399: UFPI - Planta do Campus Arapuá, situado na cidade de Floriano.

Figura 400: UFPI - Planta do Campus do Junco, localizado na cidade de Picos.

Figura 401: UFPI - Campus da Ininga, atual Campus Ministro Petrônio Portela Século XXI.

Figura 402: UFPI - Galpão metálico.

Figura 403: UFPI - Galpão do Setor de Serviços Gerais.

591

Figura 404: UFPI - Planta de arquitetura do Galpão SG-04.

Figura 405: UFPI - Planta de arquitetura do Galpão SG-11.

Figura 406: UFPI - Planta de arquitetura do Galpão SG-13.

Figura 407: UFPI - Planta de arquitetura do Galpão SG-16.

Figura 408: UFPI - Diretoria: gabinete do diretor.

Figura 409: UFPI - Coordenação de cursos: secretaria.

Figura 410: UFPI - Departamento: secretaria.

Figura 411: UFPI - Departamento: sala para professores / sala para monitores.

Figura 412: UFPI - Sala para aulas expositivas: tipo 1 - de 42 a 56 alunos.

Figura 413: UFPI - Sala para aulas expositivas: tipo 2 - de 30 a 42 alunos.

Figura 414: UFPI - Síntese do sistema construtivo proposto.

Figura 415: UFPI - Gráfico de insolação para o Campus da Ininga.

Figura 416: UFPI - Gráfico de sombras máximas na latitude $5^{\circ} 5^{\prime}$.

Figura 417: UFPI - Estudo do controle da insolação - Elevação norte.

Figura 418: UFPI - Estudo do controle da insolação - Elevação sul.

Figura 419: UFPI - Estudo do controle da insolação - Elevações leste e oeste no solstício de inverno

Figura 420: UFPI - Estudo do controle da insolação - Elevações leste e oeste no solstício de verão

Figura 421: UFPI - Estudo de aplicação dos brises na planta. $O$ beiral garante o sombreamento do ambiente, exceto na fachada oeste.

Figura 422: UFPI - Diagrama esquemático para cálculo de remoção do ar quente dos ambientes.

Figura 423: UFPI - Estudo preliminar para o Centro de Ciências e Letras - planta de arquitetura 
Figura 425: UFPI - Centro de Ciências Humanas (1980). 610

Figura 426: UFPI - Vista do conjunto do CCHL (esquerda) e do CCE (direita). 611

Figura 427a: UFPI - CCE / Planta de Arquitetura (1996). 612

Figura 427b: UFPI - CCE / Detalhe da Trama. $\quad 612$

Figura 428: UFPI - Vista do edifício do CCE (2009). $\quad 611$

Figura 429: UFPI - Vista aérea do Campus Ministro Petrônio Portela. 613

Figura 430: UFPI - Planta geral do Campus Ministro Petrônio Portela (2005). 614

\section{LISTA DE QUADROS}

Quadro 1: Universidades Federais do Nordeste existentes em 1968

Quadro 2: Matriz de Análise $\quad 52$

Quadro 3: Número de graduados na UFC no período de 1955/1965 98

Quadro 4: Estrutura Acadêmica da UFC - Decreto $n^{\circ}$ 62.279/1968 99

Quadro 5: Organização das unidades acadêmicas da UFC - Decreto $n^{\circ} 99$ $62.279 / 20 / 1968$

Quadro 6: UFMA - Organização básica proposta pelo Estatuto de 1967

Quadro 7: UFMA - Organização básica proposta pelo Estatuto de 1969

Quadro 8: UFMA - Zoneamento do Campus - Ano 1971

Quadro 9: Resumo das Edificações fora do Campus do Bacanga - final da década 431 de 1970

Quadro 10: Resumo das edificações construídas no do Campus do Bacanga - final da década de 1970 


\section{SUMÁRIO}

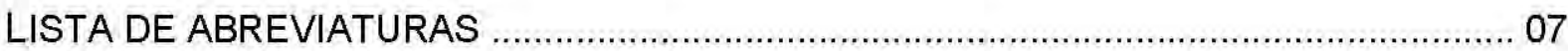

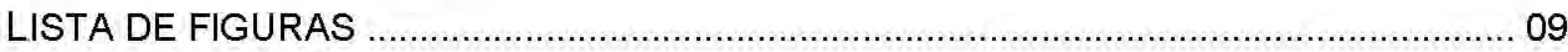

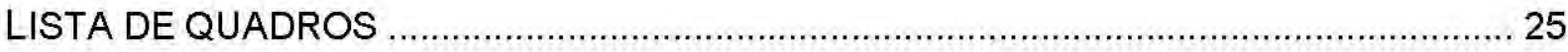

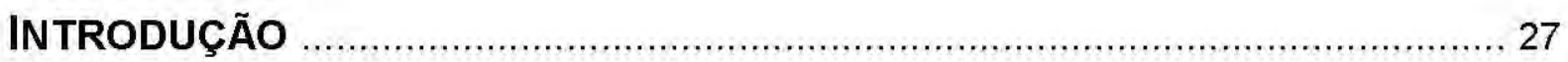

PARTE 1 - A TRANSFORMAÇÃO DA UNIVERSIDADE BRASILEIRA .............. 63

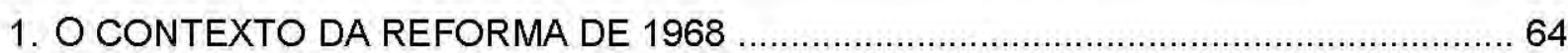

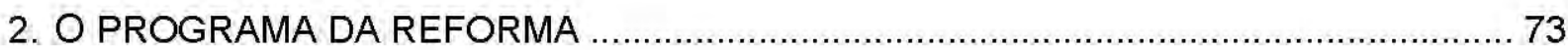

3. O MODELO ESPACIAL DA REFORMA

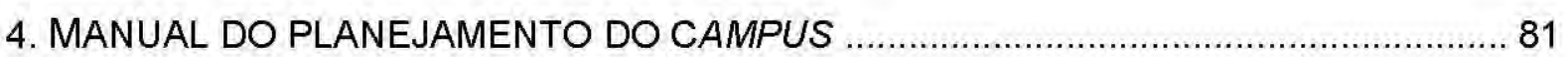

PARTE 2 - CAMPUS UNIVERSITÁRIO NO NORDESTE: planos e realizações..87

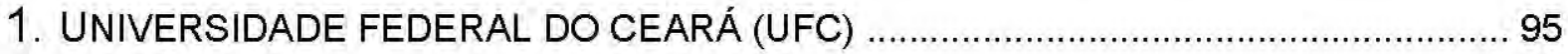

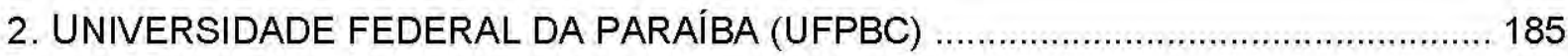

3. UNIVERSIDADE FEDERAL DO RIO GRANDE DO NORTE (UFRN) ........................ 257

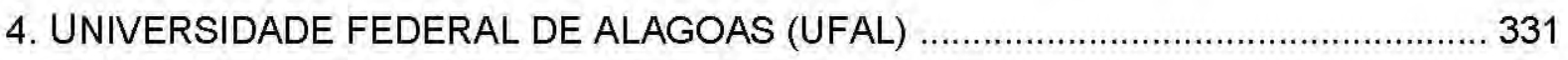

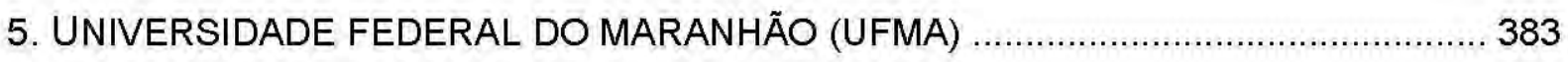

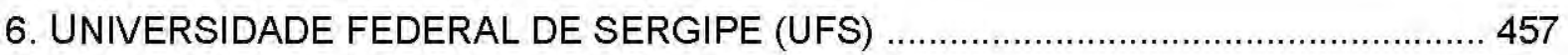

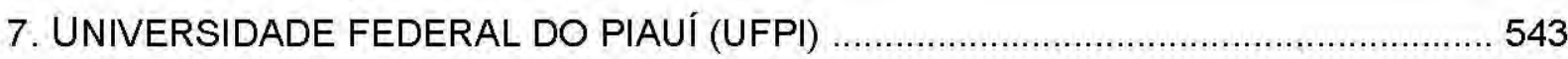

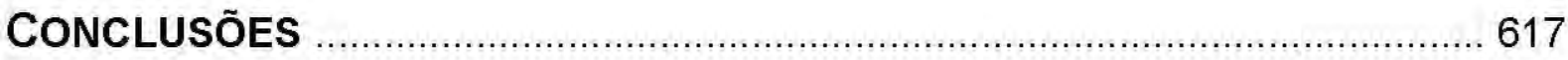

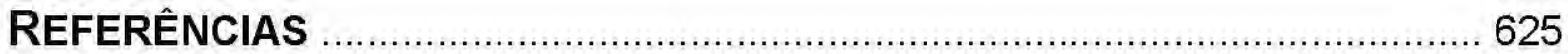




\section{INTRODUÇÃo}

A presente tese tem como âmbito de abordagem o campus universitário adotado como modelo espacial na reestruturação do ensino superior brasileiro instituída pela Lei Federal $n^{\circ}$ 5.540/1968, que ficou mais conhecida por Reforma Universitária de 1968.

As premissas que orientaram este estudo decorrem das atividades profissionais que exercemos na Universidade Federal do Ceará (UFC), onde atuamos como arquiteta e urbanista desde 1985, desenvolvendo projetos de arquitetura e acompanhando a execução de obras do Campus, além de exercermos funções na área do planejamento físico e na gestão de obras e projetos buscando, no exercício da profissão, dotar a Universidade de instalações condizentes com o desenvolvimento das atividades de ensino, pesquisa e extensão.

Com este propósito, o presente trabalho dará continuidade às atividades de pós-graduação, que resultaram na dissertação de mestrado defendida junto à Faculdade de Arquitetura da Universidade de São Paulo (FAUUSP), em 2005, com o tema As interferências físicas na arquitetura dos edifícios para a educação superior: o caso da UFC, que tomou como referências teóricas o projeto da Reforma Universitária de 1968 e a introdução da arquitetura moderna no Ceará, elementos estruturais na configuração espacial e nas instalações dessa Instituição, suscitado pelas inquietações da atividade projetual.

Durante o desenvolvimento da referida dissertação, pudemos constatar a escassez de trabalhos acadêmicos referentes à arquitetura e ao urbanismo das universidades que resultaram da Reforma. A carência de trabalhos na área referendou a escolha do tema, o qual busca trazer à luz do conhecimento os resultados desse processo de reestruturação acadêmica e administrativa das universidades brasileiras, com foco nos campi do Nordeste.

O conhecimento dessa experiência vivenciada pela universidade brasileira há mais de quarenta anos torna-se relevante para subsidiar os setores envolvidos com o planejamento, a manutenção e a adequação dos espaços universitários num contexto de constantes mudanças. Herdeira de um projeto que afetou radicalmente a sua estrutura organizacional, introduzindo alterações na sua base física, tem colocado em pauta a validade das decisões arquitetônicas e construtivas no processo de intervenção dos seus espaços. A pesquisa traz uma perspectiva de reflexão e crítica no fazer arquitetônico do espaço universitário. 


\section{CAMPUS UNIVERSITÁRIO: o modelo espacial da Reforma de 1968}

O território das instituiçōes universitárias, na forma urbanística de campus e nas tipologias arquitetônicas que configuram sua morfologia, constitui um viés da estruturação espacial no processo de formação da universidade brasileira. Essa concepção é campo de estudo amplo e instigante, à medida que representou, nas décadas de 1960 e 1970, a materialização do projeto governamental que propalava a modernização do ensino superior sob a égide da eficiência e racionalização.

O início dos anos de 1960 constituiu período de intensos debates para a reformulação do ensino superior brasileiro. O ritmo de desenvolvimento do país, provocado pela industrialização e pelo crescimento econômico, herdado da década de 1950 , somado às transformações no campo sociocultural, levaram, de forma mais ou menos explícita, à tomada de consciência, por vários setores da sociedade, da situação precária em que se encontravam as universidades no Brasil (FÁVERO, 2006, p. 29).

A tramitação do primeiro projeto de Lei de Diretrizes e Bases da Educação Nacional (LDB), aprovado em 1961, com vistas à elaboração de uma reforma geral no ensino primário, secundário e superior, tornou oficial o debate que assinalava a existência de uma defasagem nas instituições universitárias para acompanhar o processo de modernização nacional em curso. Destacava-se uma incapacidade para conseguir efetivar a formação de um número ampliado de candidatos ao mercado, enfatizando-se o seu acesso que se limitava às elites da sociedade; para absorver a demanda existente e responder com variedade de cursos e programas compatíveis com as exigências da nova ordem econômica.

O modelo estrutural de origem - uma soma de faculdades isoladas - com predomínio do ensino de cunho profissionalizante, distanciado da pesquisa científica e das atividades de extensão à população era reconhecido na comunidade acadêmica como principal fator de perpetuação da inércia em que se encontrava a universidade brasileira.

Os debates atingiram seu ápice com a criação da Universidade de Brasília (UnB), que surgiu não apenas como paradigma de modernidade, mas como divisor de águas na história das instituições universitárias, quer por suas finalidades, quer por sua organização institucional (FÁVERO, 2006, p. 29). Nesse momento, a participação do movimento estudantil ocorreu, de forma intensa, por meio da União Nacional dos Estudantes (UNE), que postulava transformações nas instituições universitárias, julgadas arcaicas e elitistas. As discussões por mudanças se processavam em todos os setores da sociedade. $O$ movimento reivindicatório por uma reforma adquiriu corpo e tornou-se iminente. 
Em 1968, o governo da ditadura militar, entendendo haver uma crise universitária, instituiu a reforma no ensino superior, que, atropelando os debates em curso, incorporou com modificações parte das discussões e reivindicações do movimento estudantil. O projeto do governo federal foi formalizado por força da lei, que ficou também ficou conhecida como Lei da Reforma do Ensino Superior de 1968.

Explicitando a organização e o funcionamento do ensino superior, a Reforma Universitária, ressalvados os aspectos discricionários do regime militar então vigente, é referenciada por diversos autores (BUFFA e PINTO, 2009; FRAUCHES, 2004; PAULA, 2002; BOMENY, 1994; VIEIRA, 1980;) como marco de modernização da universidade brasileira. Expressava, na sua concepção, o objetivo de situar a universidade a serviço do desenvolvimento nacional e promover a expansão do ensino superior, ajustando-a, de forma imediata e funcional, às demandas do mercado de trabalho, da economia nacional e da sociedade.

Apresentava como metas básicas as ideias de eficiência e racionalização das atividades universitárias e de expansão dos cursos a um número crescente de candidatos, sem desperdício dos investimentos financeiros, com a plena utilização da capacidade instalada e dos recursos humanos necessários, apontando para o princípio da não-duplicação de meios para fins idênticos ou equivalentes, das quais derivam as demais diretrizes do seu projeto, como flexibilidade (capacidade de se adequar às transformações e ao desenvolvimento ante - permanente contexto de mudanças da sociedade), expansão (dos cursos e das vagas), integração (entre ensino, pesquisa e extensão) e autonomia (administrativa, financeira e científica), princípios que deveriam nortear sua sistematização.

Nessa concepção de reforma defendida pelo governo propalava-se sua contraposição à universidade tradicional, segmentada pela justaposição de vários cursos, a qual deveria ser sucedida por um projeto cuja estrutura integrasse as diversas atividades universitárias e que fosse, ao mesmo tempo, dinâmica e flexível para atender às necessidades de crescimento acelerado e de transformações permanentes, sob a ótica da racionalização do ensino objetivo básico da proposta. Consagrou a estrutura de departamentos visando fundamentalmente à eficiência e à produtividade do ensino superior.

O governo pressupôs a necessidade de um esforço integrador da estrutura física e do uso adequado dos seus equipamentos, para efetivar o princípio de concentração dos meios, de maneira que a disposição das unidades propiciasse uma administração otimizada do tempo e do espaço, garantindo a racionalidade pretendida na sua utilização.

Amparado no paradigma das universidades dos Estados Unidos, o modelo espacial de campus foi oficializado para responder, no âmbito físico, aos objetivos econômicos da Reforma de 1968 , num contexto de expansão da estrutura universitária. Seu planejamento e 
construção fizeram parte das estratégias de dinamização do processo de reformulação do ensino superior, incorporando-lhe o ideal de modernidade requerido no contexto de uma instituição universitária identificada com os novos tempos. Estudos (RODRIGUES, 2001; CUNHA, 2003; PAULA, 2002) apontam que serviu também para dispersar o movimento estudantil.

Para auxiliar as universidades na nova organização física, foi elaborado o Manual sobre o Planejamento Integral do Campus Universitário (ATCON, 1970), de autoria do consultor norte-americano Rudolph Atcon, por solicitação do Conselho de Reitores das Universidades Brasileiras (CRUB). O documento tinha como objetivo orientar o planejamento físico dos campi universitários, existentes ou novos, a serem construídos dentro da filosofia de uma universidade integral, com vistas à implementação da reforma universitária recémelaborada.

Do ponto de vista da configuração urbana e das edificações, propõe princípios para aquisição do terreno, zoneamento funcional das áreas edificadas conforme atividades afins, sistema viário hierarquizado, definição de gabarito e tipologia dos prédios, que deveriam ser flexíveis, com máxima capacidade para alterações, seja para crescer, reduzir ou modificar. A organização espacial seria dividida rigidamente em zonas funcionais, onde se distribuíriam as áreas acadêmico-científica, adminstrativa e de serviços, contornadas por uma via periférica - anel protetor - criada externamente em torno delas. Este zoneamento se desenvolvia a partir do setor básico, colocado ao centro, com as unidades de ensino profissional ao seu redor, resguardadas por uma área de contorno transformada em parque que protegeria todo o campus. $O$ arcabouço das diretrizes expresso no zoneamento funcional e na hierarquização das vias de circulação evidencia as ressonâncias dos postulados da cidade moderna formalizados na Carta de Atenas (1933). As recomendações do Manual ${ }^{1}$ exerceram influência no planejamento e construção do campus universitário da Reforma de 1968.

Orientadas pelas diretrizes de racionalização, flexibilidade, expansão e integração, as universidades estabeleceram a estrutura morfológica do campus num território de extensas áreas, apartado da malha urbana da cidade e organizado internamente por um zoneamento de atividades acadêmicas (ensino e pesquisa) por áreas de conhecimentos afins, de setores esportivo, administrativo (reitoria), serviços e de equipamentos de uso comunitário (biblioteca, restaurante), interligados por um sistema de circulação hierarquizado - estrutura viária que privilegia o automóvel e o separa do pedestre. A solução arquitetônica pressupunha a idéia do edifício flexível, concebido pela racionalidade que se apoia na 
modulação espacial e na padronização dos componentes construtivos, com o crescimento por etapas conforme as necessidades requeridas pelas áreas do conhecimento (arquitetura tipificada e modulada, segundo princípios funcionalistas visando à unidade arquitetônica) configurando, assim, o campus universitário brasileiro daquele período.

Definidas as relações em termos de ensino, pesquisa e recursos utilizados (laboratórios, equipamentos, bibliotecas e serviços diversos), caberia à organização espacial possibilitar e ampliar a trama das relações acadêmicas garantindo o máximo possível de racionalidade em termos de espaço, tempo e custo. Este estudo estava definido em um planejamento físico, que, por sua vez, estava articulado com o acadêmico. Dentro dessa orientação, o campus universitário constituiria a base unificada destinada a abrigar toda a estrutura física, dela derivando as propostas urbanística e arquitetônica de ocupação e desenvolvimento da instituição.

O planejamento do campus, transformado numa questão de urbanismo, tornou-se lugar de realizações urbano-arquitetônicas por parte dos profissonais ligados a essas disciplinas.

No final da década de 1970 , deu-se início ao processo de falência referente ao desenvolvimento do modelo, evidenciado pela ausência de investimentos financeiros por parte do governo federal para a sua consolidação e pelos encontros e seminários organizados por técnicos e profissionais ligados ao planejamento físico universitário, que passaram a questionar a validade do seu desenho e da sua relação com a cidade. A proposta de moldar a estrutura departamental no modelo de campus, embora, não tenha se estabelecido na íntegra, faz com que, ainda hoje, as universidades tragam vestígios do paradigma reformista instituído por força de lei a partir de 1968.

\section{RESPOSTA URBANO-ARQUITETÔNICA DO CAMPUS NO NORDESTE}

A constatação desse processo histórico que institucionalizou o campus universitário em nível nacional nos reportou à percepção da existência de uma geração de campi também no Nordeste, executados no contexto de uma região marcada por contrastes e diversidades de aspectos naturais, humanos e econômicos.

A apreensão dessa realidade nos conduziu à formulação do fio condutor que norteou a investigação da pesquisa: como as instituições universitárias dessa região compatibilizaram os propósitos de racionalização e produtividade, dos quais derivam as diretrizes de flexibilidade, expansão e integração na arquitetura e no urbanismo dos seus respectivos campi? 
A problemática exposta desmembrou-se em questões centrais que fomentaram a investigação sobre o conjunto edificado no campus universitário da região:

- O que mudou com a Reforma?

- Como a nova matriz acadêmica foi rebatida na configuração físico-espacial (linguagem e organização espacial) dos campi do Nordeste?

- Como a arquitetura intermediou as especificidades locais referentes aos condicionantes climáticos, práticas construtivas e tecnologias acessíveis, já que se tratava de uma região com baixo desenvolvimento urbano-industrial naquele período?

Os questionamentos expressos nos levaram aos seguintes pressupostos:

- A configuração espacial do campus tomou como padrão urbanístico o princípio do zoneamento funcional presente no Manual de Atcon (1970).

- O processo de reestruturação física da Reforma, nas instiuições universitárias do Nordeste ensejou tipologias construtivas amparadas no conceito de flexibilidade e racionalização.

- A transposição dos propósitos reformista resultou numa produção conforme contexto local.

- Hipótese

Os pressupostos formulados conduziram à hipótese de que a reestruturação física das universidades federais no Nordeste, instituída pela Reforma Universitária de 1968, adotando - modelo de campus, produziu tipologias espaciais de configurações urbanística e arquitetônica referenciadas respectivamente no zoneamento funcional e no conceito da racionalidade construtiva, cujas características evidenciam respostas que se submeteram ao contexto local.

\section{- Objetivos do estudo}

A problematização nos conduziu aos propósitos de aprofundar o arcabouço morfológico adotado nos campi do Nordeste e de embasar o campo fértil da instrumentação crítica no contexto da interação entre espaços universitários e condicionantes locais. Nesse sentido, podemos destacar como objetivos gerais da pesquisa:

1. Realizar o levantamento e $\circ$ reconhecimento das tipologias arquitetônicas e urbanísticas construídas e/ou reformuladas para compor o campus, ensejando contribuir para ampliar o panorama da arquitetura brasileira por meio de uma geração de projetos e obras ainda não referenciados na sua historiografia.

2. Identificar as diretrizes de projeto adotadas na organização físico-espacial do campus universitário, por meio da recuperação dos valores das realizações 
arquitetônicas e urbanísticas decorrentes do processo de implantação da Reforma (1968), contribuindo para embasar a atividade prática do projeto.

Apresentamos como objetivo específico:

3. Caracterizar a configuração arquitetônica e urbanística dos campi das universidades federais do Ceará (UFC), Rio Grande do Norte (UFRN), Paraíba (UFPB), Alagoas (UFAL), Maranhão (UFMA), Sergipe (UFS) e Piauí (UFPI) que foram construídos e/ou reformulados para a compatibilização física com o programa da Reforma.

As questões apresentadas se atêm à morfologia arquitetônica e urbanística do território moldado para a Reforma, entendidas como aquelas referentes à:

a. Localização/relação campus universitário x cidade.

b. Organização espacial interna do campus universitário.

c. Arquitetura do campus.

Com base nos objetivos formulados, fixamos os limites da investigação definidos nos cortes temporal e espacial.

\section{- Recorte Temporal}

O período estudado parte da reestruturação do ensino universitário instituído pela Reforma Universitária de 1968 e percorre sua trajetória até fins de 1970 , incorporando a constatação da atual configuração física do campus no contexto da malha urbana da cidade.

Ao definirmos o recorte proposto nos deparamos com a existência de um processo histórico cujas transformações apontavam num primeiro momento a Lei Federal $n^{\circ} 5.540 / 1968$, como referência temporal a partir do qual deveríamos iniciar o reconhecimento e a caracterização da produção a ser investigada. A reconstituição dos marcos cronológicos que caracterizaram a história da Reforma nos permitiu a compreensão de que a citada Lei foi a culminância de um processo que tomou corpo no início da década de 1960 , quando começaram os questionamentos sobre o papel desempenhado pela universidade no contexto modernizante herdado da década de 1950. Não se tratava, portanto, de um marco de ruptura, pois a Lei de 1968, na verdade, consagrava as diretrizes da reestruturação que até então estavam dispersas em decretos-lei e relatórios oficiais que antecederam a promulgação do projeto federal e que já vinham sendo gradativamente implantados nas universidades.

Norteada pela questão expressa identificamos três marcos significativos da história das universidades com a materialização do seu território: sua criação, a implantação da Reforma 
Universitária e o momento atual. Em todos eles estão presentes a formação das relações entre a instituição e o seu território.

O estudo está estruturado a partir da criação dos estabelecimentos selecionados para a pesquisa, quando suas bases físicas espelham a organização de escolas justapostas, passando pelo processo histórico da Reforma Universitária com a construção dos seus respectivos territórios de referências no paradigma norte-americano de campus até ao final da década de 1970, quando começou o questionamento sobre o desenho do campus e o encolhimento dos investimentos financeiros para a construção desses complexos. A esse recorte foi incorporada uma visão comparativa da atual relação dos campi com a malha urbana da cidade.

\section{- Recorte Espacial}

Para a definição da delimitação espacial pontuamos três eventos basilares: (1) a identificação das dez universidades nordestinas que estavam federalizadas no ano de 1968 , (2) a abrangência dos programas financeiros oficiais nas instituições do Nordeste responsáveis pela implantação de campi federais ${ }^{2}$ e (3) as que empreenderam a construção elou reformulação física com base no programa da Reforma (dados no quadro 1).

A interseção desses dados, conforme será apresentado no seguimento do texto, direcionou a seleção de sete universidades federais, dentre as dez existentes naquele período, que constituíram o universo de investigação: Ceará (UFC), Paraíba (UFPB), Rio Grande do Norte (UFRN), Alagoas (UFAL), Maranhão (UFMA), Sergipe (UFS) e Piauí (UFPI).

A implantação do campus no país contou com recursos provenientes de acordos financeiros firmados entre o Ministério da Educação e Cultura (MEC) e o Banco Interamericano de Desenvolvimento (BID), nomeados de Programas MEC-BID I, II e III, a partir de meados da década de 1960 e que segundo Rodrigues (2001, p. 146) foram os principais responsáveis pela implantação desse modelo espacial. Conforme dados levantados pelo mesmo autor, oito universidades federais do Nordeste receberam o financiamento: UFBA, UFPE, UFC, UFPB, UFRN, UFAL UFMA e UFS (RODRIGUES, 2001, p. 145-156).

A partir de 1974, esses investimentos permaneceram gerenciados pelo MEC, porém, por meio do Programa de Expansão e Melhoramentos das Instalações de Ensino Superior (PREMESU) com vigência até 1978. Dentre eles, o Programa PREMESU IV, que foi voltado especificamente para o Desenvolvimento Físico Universitário de Campus Federal (BRASIL, 1979, p. 90) e beneficiou quatro universidades federais do Nordeste: UFBA, UFPB, UFRN e UFS.

${ }^{2}$ Rodrigues (2001, p. 145-156) discorre sobre o papel do BID na construção do campus universitário da Reforma, apresentando dados quantificados em tabelas sobre os montantes financeiros aplicados nas universidades. 
Quadro 1: Universidades Federais do Nordeste existentes em 1968.

(Fonte: elaboração própria com base em dados oficiais das respectivas instituições)

\begin{tabular}{|c|c|c|c|c|}
\hline \multicolumn{5}{|c|}{ Universidades Federais do Nordeste - ano 1968} \\
\hline & $\begin{array}{l}\text { Instituição } \\
\text { Universitária }\end{array}$ & $\begin{array}{l}\text { Cidade } \\
\text { Sede }\end{array}$ & $\begin{array}{c}\text { Criação/ } \\
\text { Federalização }\end{array}$ & $\begin{array}{l}\text { Campus Universitário da Reforma de } \\
1968\end{array}$ \\
\hline 1 & $\begin{array}{l}\text { Universidade } \\
\text { Federal da Bahia } \\
\text { UFBA }\end{array}$ & $\begin{array}{l}\text { Salvador } \\
\text { (BA) }\end{array}$ & $1946 / 1950$ & $\begin{array}{l}\text { Até final da década de } 1970 \text { não tinha } \\
\text { previsão de construção de um território } \\
\text { unificado (campus da Reforma). }\end{array}$ \\
\hline 2 & $\begin{array}{l}\text { Universidade } \\
\text { Federal de } \\
\text { Pernambuco } \\
\text { UFPE }\end{array}$ & $\begin{array}{l}\text { Recife } \\
(\mathrm{PE})\end{array}$ & $1946 / 1955$ & $\begin{array}{l}\text { Construiu a Cidade Universitária a partir de } \\
1948 \text {, em área de } 156 \text { ha }_{\text {; na periferia da }} \\
\text { zona urbana. Implantou a Reforma sem } \\
\text { alterações na configuração espacial } \\
\text { existente. }\end{array}$ \\
\hline 3 & $\begin{array}{l}\text { Universidade } \\
\text { Federal Rural de } \\
\text { Pernambucol } \\
\text { UFRPE }\end{array}$ & $\begin{array}{l}\text { Recife } \\
(\mathrm{PE})\end{array}$ & $1947 / 1955$ & $\begin{array}{l}\text { Em } 1968 \text { estava em área de } 147 \text { ha, no } \\
\text { bairro Dois Irmãos, zona limítrofe de Recife, } \\
\text { onde permanece. Não há registros de } \\
\text { investimentos financeiros para a } \\
\text { reformulação física da Reforma durante as } \\
\text { décadas de } 1960 \text { e } 1970 \text {. }\end{array}$ \\
\hline 4 & $\begin{array}{l}\text { Universidade } \\
\text { Federal do Ceará } \\
\text { UFC }\end{array}$ & $\begin{array}{l}\text { Fortaleza } \\
\qquad \text { (CE) }\end{array}$ & $\begin{array}{c}1954 \\
\text { Criada como } \\
\text { autarquia } \\
\text { federal }\end{array}$ & $\begin{array}{l}\text { Nos primeiros anos de } 1970 \text { foi iniciada a } \\
\text { reformulação física na gleba de } 232 \mathrm{ha} \text {, em } \\
\text { subúrbio afastado, que deu origem ao } \\
\text { Campus do Pici. }\end{array}$ \\
\hline 5 & $\begin{array}{l}\text { Universidade } \\
\text { Federal da } \\
\text { Paraíba } \\
\text { UFPB } \\
\end{array}$ & $\begin{array}{l}\text { João } \\
\text { Pessoa } \\
\text { (PB) }\end{array}$ & $1955 / 1960$ & $\begin{array}{l}\text { Iniciou a construção da Cidade } \\
\text { Universitária, em } 1965 \text {, em área de } 115,48 \\
\text { ha, na zona periférica de João Pessoa. Em } \\
\text { 1971, elaborou plano de reformulação para } \\
\text { configuração do Campus da Reforma. }\end{array}$ \\
\hline 6 & $\begin{array}{c}\text { Universidade } \\
\text { Federal do Rio } \\
\text { Grande do Norte } \\
\text { UFRN }\end{array}$ & $\begin{array}{l}\text { Natal } \\
\text { (RN) }\end{array}$ & $1958 / 1960$ & $\begin{array}{l}\text { A construção do Campus Central foi } \\
\text { iniciada nos primeiros anos de } 1970 \text { numa } \\
\text { área de } 123 \text { ha. }\end{array}$ \\
\hline 7 & $\begin{array}{l}\text { Universidade } \\
\text { Federal de } \\
\text { Alagoas } \\
\text { UFAL }\end{array}$ & $\begin{array}{l}\text { Maceió } \\
\text { (AL) }\end{array}$ & $\begin{array}{l}1961 \\
\text { Criada como } \\
\text { autarquia } \\
\text { federal }\end{array}$ & $\begin{array}{l}\text { Iniciou a construção da Cidade Universitária } \\
\text { em } 1966 \text { numa área de } 210 \text { ha, em } \\
\text { subúrbio afastado, e elaborou plano para } \\
\text { adequação ao Campus A.C. Simões no } \\
\text { final da década de } 1970 \text {. }\end{array}$ \\
\hline 8 & $\begin{array}{l}\text { Universidade } \\
\text { Federal do } \\
\text { Maranhão } \\
\text { UFMA }\end{array}$ & $\begin{array}{l}\text { São Luís } \\
\text { (MA) }\end{array}$ & $\begin{array}{l}1966 \\
\text { Criada como } \\
\text { fundação } \\
\text { federal }\end{array}$ & $\begin{array}{l}\text { A construção do Campus do Bacanga foi } \\
\text { iniciada nos primeiros anos de } 1970 \text { em } \\
\text { área de } 271 \text { ha, na periferia da zona } \\
\text { urbana. }\end{array}$ \\
\hline 9 & $\begin{array}{l}\text { Universidade } \\
\text { Federal de } \\
\text { Sergipe } \\
\text { UFS }\end{array}$ & $\begin{array}{l}\text { São } \\
\text { Cristóvão } \\
\text { (SE) }\end{array}$ & $\begin{array}{c}1967 \\
\text { Criada como } \\
\text { fundação } \\
\text { federal }\end{array}$ & $\begin{array}{l}\text { Em meados da década de } 1970 \text {, iniciou a } \\
\text { construção do Campus, na gleba de } 117 \\
\text { ha, fora da zona urbana. }\end{array}$ \\
\hline 10 & $\begin{array}{c}\text { Universidade } \\
\text { Federal do Piauí } \\
\text { UFPI }\end{array}$ & $\begin{array}{l}\text { Teresina } \\
\text { (PI) }\end{array}$ & $\begin{array}{c}1968 \\
\text { Criada como } \\
\text { fundação } \\
\text { federal }\end{array}$ & $\begin{array}{l}\text { Iniciou as primeiras obras do Campus do } \\
\text { Ininga em } 1972 \text {, numa área de } 151 \text { ha, na } \\
\text { zona periférica de Teresina. }\end{array}$ \\
\hline
\end{tabular}


Também na esfera do MEC e com a mesma finalidade, as instituições federais contaram com recursos provenientes do Fundo de Apoio ao Desenvolvimento Social (FAS) que, no Nordeste, agenciou, entre outras, a implantação das primeiras obras de construção do Campus da UFPI no decorrer da década de 1970 (FUPI/DIPRO, 1981). No caso da UFRPE, dados apresentados, em 1979, pela Secretaria de Ensino Superior do MEC (BRASIL, 1979, p. 83 e 93) demonstraram que essa instituição foi contemplada apenas com recursos do Programa PREMESU II voltados para aquisição de equipamentos.

A Universidade Federal da Bahia, embora contemplada com recursos para a implantação do seu campus, mantinha o funcionamento de suas unidades em edifícios espalhados na malha urbana de Salvador. Segundo Fernandes (1974, p. 83), conforme os dados fornecidos pelo setor de planejamento do campus da UFBA em meados da década de 1970 , essa Instituição, resultante histórica da reunião de unidades dispersas, não dispunha de um território de base unificada e não poderia cogitar, a curto e médio prazo, da construção do mesmo. Seu território espacial estava configurado em duas áreas da cidade que passaram a ser nomeadas de Campus da Federação e Campus do Canela, embora suas condições físicas e dimensões de terreno não se adequassem ao paradigma da Reforma. $O$ texto apresentado por aquele setor do planejamento deixa, entretanto, entendido que se tratava de um projeto a ser atingido em futuro próximo.

A Universidade Federal de Pernambuco, também constituída pela justaposição de escolas isoladas, deu início à implantação do seu território com base unificada, em 1948, com a construção da cidade universitária na gleba do antigo Engenho do Meio, situado na periferia da zona urbana de Recife. O projeto de autoria do arquiteto italiano Mario Russo seguiu as linhas gerais da concepção orientada pelo zoneamento das áreas de atividades afins, com as edificações espalhadas pelos setores funcionais definidos sobre a gleba de 156 ha, permeados por espaços verdes e afastados da circulação de tráfego de automóveis, da qual faz parte a Avenida Perimetral - que margeia o terreno (CABRAL, 2003, p. 45). O desenho evidenciava a adequação aos fatores climáticos, num claro respeito aos aspectos locais.

Na segunda metade da década de 1950 , o arquiteto italiano saiu da cidade de Recife e, concomitantemente, seu projeto, que ainda não fora executado na íntegra, recebeu modificações a partir de um novo plano urbanístico, que alterou, entre outros, o sistema viário, que permanece até os dias atuais.

Nos anos de 1970, em consonância com a organização acadêmica da Reforma, que instituiu a criação de departamentos (menor estrutura acadêmica) a serem organizados em centros (macro estrutura acadêmica), foram projetados prédios para abrigar o Centro de Ciências Biomédicas, o Centro de Ciências Sociais Aplicadas, o Centro da Educação e Centro de 
Ciências Exatas e da Natureza, dentre outros, que, entretanto só vieram a ter parte deles construídos na década de 1980 .

Em 1972, o paisagista Burle Marx desenvolveu um projeto alterando o sistema viário e implantando uma praça cívica. Sobre esse trabalho, Cabral $(2003$, p. 83) faz referência ao modelo, assinalando que o campus é idealizado como um sistema integrado de prédios, com os caminhos de pedestres que se abrem em espaços mais amplos e arborizados, alamedas de palmeiras, ruas asfaltadas para a circulação de veículos e ainda um riacho, que se desdobra.

As menções da pesquisadora nos evidenciam a sintonia do plano de Burle Marx com a adequação da Cidade Universitária ao modelo espacial da Reforma. Ele, entretanto, como afirma Cabral (2003, p. 83) não foi executado. No final da década de 1970 , a cidade universitária não apresentava reformulações na estrutura física nos termos da Reforma.

Considerando que a UFBA, UFPE e UFRPE não procederam à renovação física recomendada no Manual de Atcon (1970), decidimos pela exclusão dessas instituições do universo da investigação.

\section{PROCEDIMENTOS METODOLÓGICOS}

A história como construção contemporânea, baseada na dialética entre passado e presente, é uma forma de acesso ao conhecimento da arquitetura. Nesse sentido, o arquiteto Edson Mahfuz (2000) infere que ela só pode ser entendida como estratificação de hipóteses, soluções, êxitos e fracassos, como sedimentação histórica considerada num momento de transformação: o hoje. As questões foram colocadas pelo arquiteto em seu trabalho sobre o papel desempenhado pela teoria, história e crítica no ensino do projeto arquitetônico, onde define que a

[...] história da arquitetura que interessa à prática de projeto é aquela que está voltada para o descobrimento de seus valores universais e suas aplicações circunstanciais, explicando porque determinadas obras de arquitetura são como são (MAHFUZ, 2000, n.p.).

Encontramos nessa acepção amparo teórico para evidenciar as concepções que deram suporte e condições de sua aplicação na produção dos campi, desvendando as características que the deram materialização em um momento histórico específico. Nessa construção, fomos buscar por meio do exame e do estudo de obras produzidas para a 
concretização do campus universitário como as intenções às quais estavam vinculadas foram entendidas e valorizadas na obra arquitetônica.

A pesquisa sobre o campus, segundo estudo realizado na Região Nordeste, descrevendo eventos que determinaram a sua produção urbano-arquitetônica, face ao problema gerado pela introdução de uma nova matriz acadêmica, procurando identificar as características de um conjunto de projetos e obras desenvolvidos com aquela finalidade, constituiu o fio condutor de acesso ao conhecimento da arquitetura. História e Projeto se inter-relacionam:

- Construção histórica: a Reforma Universitária de 1968 que determinou o fazer arquitetônico.

- Prática do projeto: a organização espacial e os elementos formais/construtivos concebidos para atender ao projeto da Reforma.

$\mathrm{Na}$ perspectiva de identificar e aprofundar as características da organização espacial e construtiva dos campi ante as possíveis configurações morfológicas voltadas para a materialização do projeto da Reforma de 1968 foram definidos os métodos para uma descrição densa de sua arquitetura e urbanismo.

\section{- Procedimentos}

Para o levantamento e o reconhecimento das tipologias arquitetônicas e urbanísticas, foram realizadas tanto a pesquisa bibliográfica, que incluiu obras, artigos e documentos de reconhecido domínio científico (fontes secundárias) quanto a de campo, referente ao mapeamento dos campi, com a inclusão de material que não recebeu tratamento científico (fontes primárias).

1. Pesquisa bibliográfica e obras de referência

A bibliografia buscou trabalhos acerca (1) da Reforma Universitária de 1968 e (2) do campus universitário.

O primeiro grupo - Reforma Universitária de 1968 - abrangeu as questões programáticas e o projeto acadêmico na reformulação do ensino superior. Elementos e fatos históricos que desencadearam, pautaram e determinaram a Reforma, sua ideologia, o autoritarismo burocrático-militar no Brasil e a evolução da política educacional decorrente da legislação reformista são algumas das abordagens reconhecidas.

Foi consultada a legislação da Reforma (leis, decretos e decretos-lei), identificando o papel desempenhado pelos Decretos-lei $n^{\circ 5} 53 / 1966$ e 256/1967, que antecederam a Lei $n^{\circ}$ $5.540 / 1968$ e que constituíram a linha dorsal da Reforma. Destacamos as publicações elaboradas pela Universidade de Brasília (1969) - Documentação: textos da Reforma 
Universitária e pelo MEC (1969) - Reforma Universitária 1968-1969: leis, decretos-leis, decretos, portarias, pareceres, resoluções, que procedem a uma compilação cronológica dos textos da Reforma.

$\mathrm{Na}$ linha de interpretação sobre conteúdo e objetivos da Reforma de 1968, destacamos a publicação de Sofia Lerche Vieira (1982) - O Discurso da Reforma Universitária - e a sua dissertação (1980) - Ensino Superior: o discurso do projeto da reforma de 1968. A autora examina o relatório geral do Grupo de Trabalho onde estão as principais justificativas da Lei $n^{\circ} 5.540 / 1968$. Os temas definidos no estudo englobam a concepção do projeto da reforma, princípios (racionalização, expansão, flexibilidade, interação e autonomia), estrutura da reforma projetada (gestão, organização atividades fins) e análise sobre as causas, eventos e implicações da Reforma de 1968.

A tese de Guiomar de Oliveira Passos (1985) - A Universidade Federal do Piauí e suas marcas de nascença: conformação da Reforma Universitária de 1968 à sociedade piauiense - aborda a consolidação da Universidade Federal do Piauí com foco na reforma estrutural do ensino. $O$ estudo embasou a compreensão do contexto histórico na criação e implantação do campus da Universidade Federal do Piauí.

A dissertação de Maria Stela Santos Graciani (1980) - O Ensino Superior no Brasil: um estudo sobre a estrutura burocrática da universidade pós-reforma - realiza uma análise da instituição universitária em seus aspectos estruturais formais, ligados à sua organização interna, atrelada ao contexto histórico em que esta se manifesta. A análise procura identificar os eventos que antecederam a Reforma e o papel do Estado como definidor da legislação reformista. Para a autora, a Reforma reforçou o modelo burocrático de organização e o sistema de autoridade.

O artigo de Helena Bomeny (1994) - A Reforma Universitária de 1968: 25 anos depois traça um panorama dos fatos e eventos nacionais e internacionais que foram determinantes no processo de consolidação da Reforma e realiza uma aferição dos seus resultados nas universidades após um distanciamento de 25 anos do ano de sua implantação legal. O estudo levanta a hipótese de que a Reforma de 1968 buscou conciliar dois padrões de estabelecimentos de ensino superior: o norte-americano e o francês. A autora assinala também a conclusão de que a legislação da Reforma, sobretudo a Lei $n^{\circ} 5.540 / 1968$, cometeu um erro ao tratar essencialmente da universidade e não do sistema de ensino superior.

A dissertação de Clóvis Neves Filho (1998) - A vitória dos vencidos? O movimento pela reforma universitária $(1950$ - 1970) - analisa os fatores que influenciaram a Reforma de 
1968, demonstrando que a mesma, ainda que absorvesse aspectos do ensino superior dos Estados Unidos, teve como paradigma dominante o modelo da Universidade de Brasília.

A publicação de Maria de Fátima de Paula (2002) - A modernização da Universidade e a transformação da intelligentzia universitária - apresenta as modificações pelas quais passou a universidade brasileira, promovendo a geração de uma elite de cientistas sociais. Segundo a autora, estas transformações levaram à diluição da universidade enquanto locus privilegiado de resistência crítica, política e cultural, provocando crescente perda da autonomia do campo intelectual universitário. Nesse estudo, o capítulo 4 - A Reforma Universitária de 1968 e a Modernização da Universidade Brasileira - explicita as medidas adotadas pelo governo via Ministério da Educação e Cultura, para transformar estruturalmente as universidades, visando eficiência e racionalização do sistema universitário. Um importante dado apresentado neste capítulo diz respeito ao papel dos técnicos dos Estados Unidos que prestaram consultoria para a Diretoria do Ensino Superior do Ministério da Educação e Cultura, fruto de acordos entre os dois países. A autora assinala o papel desempenhado pelo consultor Rudolph Atcon, que, em 1965, após viagens por doze universidades brasileiras, elaborou um relatório, que foi publicado em 1966 pelo MEC, - Rumo à reformulação estrutural da universidade brasileira - expondo sua visão sobre os problemas a serem enfrentados e propondo recomendações, que vão desde as administrativas até as financeiras, para a reorganização das universidades. Dentre as universidades federais visitadas no Nordeste, foram incluídas as do Ceará, Rio Grande do Norte, Paraíba, Pernambuco e Bahia.

As publicações de Maria de Lourdes de Albuquerque Fávero (2006) - A Universidade no Brasil: das origens à Reforma Universitária de 1968, (1991) - Da universidade "modernizada" à universidade disciplinada: Atcon e Meira Matos - e (1977) - A universidade brasileira: em busca de sua identidade -; de Sucupira (1973) - A condição atual da universidade e a reforma universitária brasileira - e a de Fernandes (1979) - A Universidade Brasileira: reforma ou revolução - que tratam do contexto histórico e do cerne dos debates acerca da concepção de universidade segundo a Reforma Universitária de 1968 trazem ao nosso conhecimento as reflexões sobre os acertos e descaminhos dessa lei.

As publicações oficiais (BRASIL/MEC, 1975, 1969, 1968) que tratam dos aspectos da Reforma que dizem respeito à definição da estrutura e organização, administração, inserção na sociedade, relação com o Estado, fixação de critérios de expansão do ensino superior e seu financiamento contribuíram para ampliar o contexto dos fatos e das versões vinculados à Reforma. 
Os artigos de Celso da Costa Frauches (2009) - A Livre Iniciativa e Reforma Universitária Brasileira - e Vania Regina Boschetti (2009) - Plano Atcon e Comissão Meira Mattos: construção do ideário da universidade do pós-64 - foram utilizados em nossas reflexões acerca do projeto universitário de 1968.

O segundo grupo de referências utilizadas, que trata do campus universitário pela óptica da arquitetura e do urbanismo, nos revelou que a produção acadêmica brasileira sobre o tema se deu a partir da década de 1980 , talvez um reflexo das discussões sobre as ações desenvolvidas para a implantação dos campi, iniciadas no final dos anos 1970.

Seguindo a cronologia de teses e dissertações, o primeiro trabalho identificado foi a dissertação de Jaime Gonçalves de Almeida (1983) intitulada Campus do milagre: contribuição à análise das propostas arquitetônicas dos campus universitários, implantados na década de 1970 , tendo em vista a relação entre a autonomia da instituição e a organização espacial. Esse estudo fomenta o debate sobre o vínculo entre autonomia universitária e localização espacial do campus em relação à cidade, bem como sobre as contribuições do movimento da arquitetura moderna para a organização física das unidades acadêmicas no campus. Almeida (1983) defende o argumento de que a concepção de um território afastado da cidade tem origem na intenção de criar autonomia, na ideia de uma instituição autossuficiente, à medida que, afastada da malha urbana, não se submeteria às legislações municipais e estaduais vigentes, além de contribuir para a autonomia em determinados serviços (livraria, restaurante, entre outros) e na infraestrutura física (sistema viário, urbanização e iluminação próprias, prefeitura local para a manutenção dos edifícios e áreas urbanizadas, e escritórios técnicos de projetos de arquitetura e engenharia).

A dissertação de João Roberto Leme Simões (1984) - Arquitetura na Cidade Universitária "Armando de Salles Oliveira" - o espaço construído - aborda o projeto de obras modulares desenvolvidas na década de 1970 para o campus da USP, visando à construção do edifício por etapas sem que o todo fosse mutilado, inviabilizado como obra de arquitetura, após o tempo necessário e suficiente para sua maturação física (SIMÕES, 1984, p. 170).

A tese apresentada por Adilson Costa Macedo (1987) - Ideias preliminares para o projeto urbano da Cidade Universitária Armando de Salles Oliveira - realiza um estudo sobre o campus da Universidade de São Paulo e sua relação física com o tecido da cidade, segundo critérios da cidade-jardim e rígidos princípios de zoneamento. $O$ trabalho busca primordialmente estabelecer uma relação entre intenções e objetivos na prática do projeto.

A dissertação de Matheus Gorovitz (1989), referenciada por Almeida (2008, p. 30) - Os riscos do projeto: Universidade do Brasil, 1936 - analisa as propostas não executadas para a Universidade do Brasil, de 1936, de autoria de Le Corbusier e Lucio Costa e equipe. 
Esse estudo enfoca o tema cidade universitária, discorrendo sobre a ideia de campus no Brasil, e sistematiza dados sobre o processo de projeto da cidade universitária da Universidade do Brasil.

A dissertação de Neyde Angela Joppert Cabral (1997) - Arquitetura moderna e o alojamento universitário: leitura de projetos e uma análise sobre projetos de edificações para alojamentos estudantis - traz foco para a produção da arquitetura moderna na instituição universitária.

A tese de Luiz Augusto Fernandes Rodrigues (2001) - Universidade e a fantasia moderna: a falácia de um modelo espacial único - aponta os equívocos das realizações de campus no Brasil, ao produzir tipologias espaciais apartadas da cidade. Esse estudo trouxe especial contribuição à pesquisa de que cuidamos na formulação de uma reflexão crítica sobre os projetos de arquitetura e urbanismo desenvolvidos para as universidades no modelo espacial de campus.

A dissertação de Klaus Chaves Alberto (2003), Três projetos para uma cidade universitária do Brasil, realiza um panorama sobre o pensamento urbanístico das cidades universitárias da década de 1930 , período em que se consolida o ensino superior e a ideia de universidade no país. Nesse estudo, o autor contrapõe três projetos, correspondentes aos de autoria de Lucio Costa, Le Corbusier e Marcello Piacentini para um mesmo terreno.

Ainda nessa linha de pesquisa, encontram-se duas dissertações que têm como objeto de investigação o campus da llha do Fundão (UFRJ): de Antônio J. B. Oliveira (2003) - Das ilhas à cidade - a universidade visível. A construção da cidade universitária da Universidade do Brasil (1935 - 1950) -, e a de Maria Lúcia Ribeiro Vilarinhos (2002) - O Campus da UFRJ na Ilha do Fundão: análise de sua localização e organização espacial.

Sobre a produção arquitetônica nas universidades federais do Nordeste, encontram-se estudos em que o território físico universitário é parte da produção investigada. A dissertação de Renata Campello Cabral (2003) - Mario Russo: um arquiteto racionalista italiano em Recife -, elabora um panorama da obra e da metodologia de trabalho desse arquiteto, fazendo menção ao projeto da cidade universitária da Universidade Federal de Pernambuco, no Recife, criada na década de 1950 , pelo arquiteto Mario Russo com um plano urbanístico de preceitos modernos. A dissertação de Fúlvio Barros Pereira (2008) Novos edifícios, nova visão urbana - difusão da arquitetura moderna na cidade de João Pessoa -, enfoca o processo de formação do campus universitário da Universidade Federal da Paraíba, que resultou na reformulação física da cidade universitária, com a construção iniciada em 1965. Esses trabalhos trouxeram significativa contribuição no 
desenvolvimento da pesquisa, que permitiu visualizar as relações do movimento moderno no desenvolvimento das universidades federais no Nordeste.

A tese de Neyde Angela Joppert Cabral (2004) - A Universidade de São Paulo: modelos e projetos - apresenta o debate sobre a integração e a convivência formadora do espírito universitário, com foco nos espaços da Cidade Universitária Armando de Salles Oliveira. O trabalho faz contraponto com os projetos formulados para a Universidade Federal do Rio de Janeiro (UFRJ) com o da Universidade de Brasília (UnB), passando mais superficialmente por outras universidades federais brasileiras, como a de Minas Gerais, de Santa Catarina e de Pernambuco. Destaca as alterações no projeto da Cidade Universitária da USP em consequência da Reforma Universitária de 1968, particularizando a introdução dos sistemas construtivos modulares expansíveis e o planejamento físico do campus. Apresenta um rico material de plantas, mapas e projetos dos exemplos referenciados.

Duas dissertações têm como objeto de estudo o campus da Universidade Federal do Ceará: a de Joaquim Aristides de Oliveira (2005) e a nossa, Campêlo (2005). A primeira - A Universidade e seu território: um estudo sobre as concepções de campus e suas configurações no processo de formação do território da Universidade Federal do Ceará -, aborda os impactos da Reforma Universitária de $1968 \mathrm{com}$ foco na tipologia espacial de campus. O recorte é significativo à pesquisa que desenvolvemos, pois elabora uma análise apontando o campus como modelo espacial da Reforma de 1968 , norteando a feitura do objeto a ser investigado. Contribui ainda seu posicionamento na análise das diferenças conceituais entre cidade universitária e campus. A de nossa autoria - Leitura e análise das interferências físicas na arquitetura dos edifícios para a educação superior: o caso da UFC -, faz um estudo sobre as transformações ocorridas na arquitetura dos edifícios da UFC projetados na década de 1960, cuja concepção está apoiada nas referências teóricas de flexibilidade e modulação, que resultou na proposta de tipificação das edificações, caracterizadas por uma arquitetura de linguagem homogênea, relacionando-as com os princípios da Reforma Universitária de 1968. O trabalho desenvolve uma metodologia de análise das alterações da arquitetura original, servindo-se de um conjunto de diagramas gráficos, que visualiza aspectos formais, funcionais e construtivos.

A tese de Klaus Chaves Alberto (2008) - Formalizando o ensino superior da década de 1960: a cidade universitária da UnB e seu projeto urbanístico - realiza um estudo das universidades, direcionado à criação da UnB, enfocando a concepção do modelo desta instituição para o sistema universitário brasileiro. Esse estudo elabora extensa revisão bibliográfica sobre trabalhos que têm o território geográfico das universidades como objeto de estudo, contribuindo para ampliar as referências bibliográficas definidas no início do 
plano de pesquisa. Dedica, na feitura do objeto, uma abordagem sobre conceituação de cidade universitária $\times$ campus.

No panorama internacional, embora não ligada às questões brasileiras, encontramos a tese da pesquisadora portuguesa Maria Madalena Matos (1999) - As cidades e os campi: contributo para os estudos dos territórios universitários em Portugal -, que investiga a relação dos espaços universitários com a cidade, no âmbito do seu país.

Entre as publicações internacionais com abordagem sobre os campi norte-americanos, destacamos as de Paul Vernable Turner (1987) - Campus: an American planning tradition -, que faz extensa trajetória desde os primeiros momentos de campi dos EUA até a década de 1970 , contribuindo para compreensão da influência que exerceram no modelo de adotado nas universidades brasileiras, a de Stefan Muthesius (2000) - The postwar university utopianist campus and college -, que compõe um panorama internacional das tipologias espaciais de campus, iniciado após a Segunda Guerra Mundial até a década de 1960, e a de Mildred F. Schmertz (1972) - Campus Planning and Design - que traz uma compilação de artigos publicados entre 1966 a 1970 sobre o desenho e a arquitetura produzida nos campi norte-americanos no período. Esses trabalhos trouxeram importante contribuição na compreensão da transposição do paradigma norte-americano para a experiência brasileira.

O livro de Fausto Castilho (2008) - Conceito de universidade no projeto da UNICAMP que examina diversos aspectos da questão da universidade no Brasil e, ainda que de forma sucinta, aborda a formação do território universitário, diferenciando o conceito de cidade universitária do de campus acadêmico, contribuiu para nossas reflexões sobre o rebatimento de uma matriz pedagógica na morfologia do seu território.

A publicação de Ester Buffa e Gelson de Almeida Pinto (2009) - Arquitetura e educação: câmpus universitários brasileiros - elabora um percurso histórico da universidade, que, originada na Europa Medieval como instituição urbana, passou por transformações no tempo e no espaço, chegou ao Brasil em território apartado da cidade e se constituiu como campus universitário. Referencia projetos de planejamento e construção do campus de algumas renomadas universidades brasileiras: UFRJ, UFRGS, UnB e UNICAMP.

Uma publicação de caráter mais catalográfico, elaborado pelo Centro Cultural da USP (2005) - Cidades universitárias: patrimônio urbanístico e arquitetônico da USP - contribui para o material iconográfico relacionado aos campi brasileiros.

A produção de artigos evidencia um vínculo cronológico ao estágio de desenvolvimento do campus. Estudos publicados na primeira metade da década de 1970 relacionam o tema do ensino superior com a atuação do arquiteto na atividade de planejamento e projeto de elementos físicos destinados à chamada educação do $3^{\circ}$. Grau (LIMA; KOHL, 1974, p. 35). 
A constatação, naqueles anos, de uma "espantosa" expansão do ensino superior decorrente da Reforma de 1968, trouxe para a disciplina da arquitetura dados que revelavam a importância da participação do arquiteto em planos e projetos de universidades. Dentre eles o artigo de Ari Vicente Fernandes (1974) - Campus e meio urbano universitário desenvolve concepções de campus e cidade universitária e como se configura sua espacialização física. Este trabalho nos trouxe contribuição primordial na compreensão da acepção do campus da Reforma de 1968 .

O artigo de Ari Vicente Fernandes Fernandes et al. (1974) - 1960/1970: dez anos para a universidade, a mais ou a menos? - incorporou ao debate questões sobre o desenvolvimento da universidade brasileira decorrente das transformações estruturais ocorridas no Brasil, que segundo seus autores foram condições que deram suporte ao capitalismo de dependência externa.

Do final da década de 1970, encontram-se as publicações extraídas de encontros e seminários sobre o planejamento de campi universitários que nos dão pistas do início dos debates que trouxeram desconfianças ao modelo espacial do campus, enquanto espaço de integração social. Dentre eles a publicação referente ao Seminário Nacional sobre o Planejamento de Campi Universitários (1978), realizado em Brasília em 1975 e o estudo de Carlos Nelson Santos (1979) - O campus universitário no Brasil: arquitetura - aspectos ideológicos.

conteúdo dos artigos, a partir da década de 1980 , evidencia os conflitos trazidos pelo campus apartado da cidade e sua organização espacial interna, constatando oficialmente o seu isolamento como espaço social e sua desarticulação com o desenvolvimento urbano das cidades.

Os textos extraídos dos anais do Seminário de Conceituação de Campus Universitário, realizado em Brasília no ano de 1981, sob a organização da então Coordenadoria de Desenvolvimento das Instalações do Ensino Superior (PREMESU) sobre o planejamento físico da universidade a partir da Reforma de 1968, foi compilado na publicação Campus Universitário: textos, editada por Brasil (1984). Trata-se de palestras, exposições e debates que levantavam à constatação da inadequação do modelo de organização interna do campus com a integração acadêmica propalada no discurso da Reforma e os custos financeiros de implantação e manutenção que demonstravam ser onerosos.

O Seminário Avaliação da Morfologia Urbanística do Campus Universitário Brasileiro (1985) realizado em Brasília, sob a coordenação do Centro de Desenvolvimento e Apoio Técnico à Educação (CEDATE) mantinha dentre outras as discussões sobre a necessidade de uma reflexão e análise tanto do papel do campus no processo histórico de formação e 
estruturação do espaço urbano quanto da relação entre a configuração do campus e a instituição e a práxis da vida universitária. Incorporavam também questões sobre a linguagem arquitetônica adotada na produção edilícia e seus respectivos aspectos tecnológicos e de custo.

O Seminário sobre Desenho Urbano no Brasil, realizado em Brasília, também em 1986, produziu trabalhos que relacionam o campus universitário no estudo do desenho urbano. Dentre eles, destacamos dois: o artigo de Maurício Malta (1986) - Campus Universitário Brasileiro: algumas questões - que trata da organização interna do campus e a atuação do CEDATE na produção das instalações físicas de ensino superior, especialmente naquelas do sistema federal e o de Carneiro, Kohlsdorf e Zimbres (1986) - O campus do pósmilagre: alternativa para o caso da UnB, que utiliza o campus da UnB como estudo de referência sobre a morfologia desse modelo e sua relação com um processo de segregação sócio-espacial.

Na década de 1990, os artigos de Paulo Zimbres (1993) - Cidadelas do saber: novos edifícios nos campi universitários, e (1992) - A gestão democrática do espaço do campus, - de Adilson Costa Macedo (1996a) - O desenho do campus universitário - e (1996b) - O meio ambiente e o campus universitário e seu projeto - trazem princípios de organização espacial que propiciasse à integração das atividades universitárias no campus.

Em 2003, o artigo de Luiz Antônio Cunha (2003) - Câmpus Universitário: Opção ou Destino? - traz uma discussão sobre a origem do termo campus no Brasil trazido das universidades norte-americanas, pela Reforma de 1968, que segundo análise do autor passou a substituir o termo cidade universitária, de origem francesa. Discorre sobre as transformações no espaço universitário decorrentes da Reforma Universitária de 1968. Incorpora uma avaliação sobre a generalização do termo campus à universidade que segundo ele (2003, n.p.) parece constituir elemento indispensável de qualquer instituição digna desse status.

Muitos trabalhos realizados por setores das instituições universitárias e órgãos do governo federal, com o objetivo de definir o planejamento físico das universidades, contribuíram para compreendermos a formação do território físico das universidades. Dentre eles estão:

- o de autoria de Hélio de Queiroz Duarte e Ernesto R. C. Mange (1957) - Plano da cidade universitária de Santa Catarina - apresenta um minucioso estudo sobre o planejamento daquela cidade universitária, tomando como base o sistema universitário e seu rebatimento na solução espacial do plano-piloto da instituição;

- o da Universidade Federal de Minas Gerais (1970) com o estudo O Território Universitário: proposta de modelo para um sistema ambiental, exibido pelo Instituto de 
Arquitetos do Brasil (IAB) ao XIII Congresso Pan-americano de Arquitetura e que teve como objetivo apresentar métodos de racionalização das necessidades espaciais da universidade de forma a definir as características do território acadêmico.

- o de autoria de Luiz Felipe da Gama Lobo D’Eça [1972?], para o Segundo Seminário de Assistência Técnica do Convênio MEC/BID - Administração e Planejamento de "Campus" Universitário - com o trabalho Administração de tempos e espaços, apresenta um modelo teórico e esquemático de campus. O mesmo integra todos os espaços caracterizados num território universitário, destacando, sobre um zoneamento básico, uma trama modular de arquitetura a partir da qual se desenvolvem a produção edilícia e a infraestrutura do mesmo. O modelo instrumentalizava o projeto do campus para garantir remanejamento contínuo da organização espacial, integração das atividades universitárias, capacidade de expansão das edificações, dentre outros, segundo o princípio da racionalização e eficiência de meios.

- o de autoria de Luciano Bernini (1974), para o Fundo de Construção da USP (FUNDUSP), intitulado Universidade Federal de Sergipe: planejamento do campus trata do plano para construção daquela instituição e apresenta suas diretrizes e formulações técnicas, atendendo aos requisitos da Reforma Universitária de 1968;

- o de autoria de Severiano Mário Porto (1973) para a Universidade do Amazonas, intitulado Planejamento do campus universitário, define as diretrizes físicas do território daquela instituição.

- o trabalho realizado pelo BRASIL/MEC/CEDATE (1984), com o título Universidade Federal do Maranhão no centro histórico de São Luís, foi elaborado com vistas à expansão do Campus Universitário da Universidade do Maranhão (UFMA), com a recuperação de prédios no centro histórico da capital timbira. Trata-se de uma proposta para integração da Universidade com a malha urbana da cidade, diferenciando-se da ideia de campus isolado.

\section{Levantamento Documental}

Para o reconhecimento das tipologias arquitetônicas e urbanísticas e identificação das diretrizes de projeto foi realizada uma pesquisa documental em arquivos das universidades escritórios técnicos (Prefeitura dos Campi e Superintendências de infraestrutura), assessorias de comunicação, setores de arquivo geral -, acervos particulares e no Instituto Nacional de Estudos e Pesquisas Educacionais Anísio Teixeira (INEP). Possivelmente uma das contribuições mais relevantes da nossa pesquisa é a variada documentação primária levantada da arquitetura e do urbanismo dos campi. Destacamos o fato de que boa parte desse acervo constitui material inédito. São: 


\subsection{Plano Diretor ou Plano Diretor Físico}

Os Planos Diretores ou Planos Diretores Físicos (conforme notação encontrada no material pesquisado) constituíram os primeiros documentos analisados. Antecederam os mapas e o reconhecimento dos projetos de arquitetura. Introduzem as diretrizes e bases do planejamento que deveria orientar o crescimento físico da instituição. Constatamos que foram elaborados como parte da reestruturação física prevista pela Reforma de 1968. O Plano Diretor Físico era instrumento de parte da política de desenvolvimento das universidades, materializada em planos e projetos específicos, os quais tinham o atributo da "boa flexibilidade", levando-se em conta a definição de necessidades, aplicação de investimentos, apropriação e uso do espaço em um determinado tempo, contexto e local.

Seguem a seguinte estrutura:

a. Apresentam a nova organização acadêmica da universidade, definida em centros, os quais abrangem os departamentos, com seus respectivos cursos vinculados. Exibem dados da população acadêmica (pessoal discente, docente, técnico e administrativo).

b. Elaboram um sucinto diagnóstico da gleba do campus, com dados físicos (área, topografia, clima, ventos dominantes, solo-vegetação, infraestrutura e edificações existentes e vias municipais de acesso) e estudo da relação campus/cidade.

c. Apresentam a proposta de zoneamento, dos setores de conhecimento afins e definição das áreas de estacionamento, vivência, esportivas e administrativas (Reitoria, Prefeitura Universitária, Centro de Processamento de Dados e demais órgãos suplementares) e serviços de apoio (oficinas, garagens, imprensa universitária, almoxarifado central, centrais de água, gás, eletricidade e outros).

d. Produzem plantas com a definição dos fluxos de veículos e de pedestres que integram as áreas de vivência, setor esportivo, grandes equipamentos (Biblioteca Central, Restaurante Universitário), centros e todo o conjunto dos edifícios.

e. Apresentam plantas com propostas de edificações.

O Plano Diretor-Físico das universidades constituiu documentação primordial para compor a história do urbanismo e da configuração tipológica das edificações. A percepção do planejamento proposto apontou para pressupostos levantados: indicação do urbanismo funcional e adoção de um partido de implantação das edificações, que busca atender ao crescimento da instituição dentro dos princípios de flexibilidade e expansibilidade. Significava assegurar o crescimento ordenado e disciplinado, conforme o surgimento das necessidades. 


\subsection{Cadastro Físico dos campi.}

Registram as transformações no terreno. Evidenciam o desenvolvimento físico do campus orientado inicialmente pelo Plano Diretor e as alterações no decorrer da implantação. O emprego dessa documentação obedece a uma ordem cronológica com o objetivo de avaliar o desenvolvimento físico:

a. Levantamento planialtimétrico - elaborado para a construção do campus, registra dados do terreno, indicando a poligonal do sítio, curvas de níveis, elementos hidrográficos, área de vegetação, ocupações circunvizinhas, vias de acesso e quadro de áreas com indicação das áreas original, desmembrada, excluída e ocupada.

b. Planta geral - indica edificações construídas, projetadas e previstas, edifícios propostos para expansão, circulação de veículos e de pedestres e áreas de vegetação.

c. Planta de zoneamento - registra a ocupação do campus - centros, área de vivência, setor esportivo, setor administrativo, setor de serviços.

d. Planta atualizada - corresponde à planta do campus com as intervenções atualizadas por período. Contrapõe a proposta original com o que de fato fol executado, permitindo a visualização das intervenções no decorrer do período pesquisado.

e. Planta digitalizada - planta cadastrada em arquivo digital, com a ocupação atualizada até o ano de 2009, indicando as edificações existentes e projetadas, sistema viário atualizado e previsão de ampliação.

\subsection{Projetos de Arquitetura.}

Correspondem às edificações construídas e/ou reformadas para implantação do campus. O material coletado compreende os desenhos originais de plantas, cortes e fachadas e detalhes construtivos. Permitem identificar o partido arquitetônico, o programa funcional, os materiais, as soluções construtivas e o sistema estrutural, os elementos de circulação e acessos, a autoria dos profissionais envolvidos e o ano de elaboração

\subsection{Material Iconográfico}

São fontes esclarecedoras sobre a implantação do campus, suas tipologias edilícias e o diagnóstico da situação atual. Dada a diversidade do período dessa documentação, classificamos por ordem cronológica: 
a. Início do campus - fotos do período da construção do campus que registram o terreno, canteiro de obras, edificações em fase de implantação, trabalhos de terraplenagem e detalhes da construção dos prédios.

b. Imagens aéreas do campus e fotos dos edifícios nos anos de 2009 e 2010 , registradas durante a pesquisa de campo.

c. Fotos antigas de inauguração do campus e dos seus edifícios.

2.5 Documentos e publicações institucionais.

São anais, relatórios, estatutos, contratos, discursos de reitores, ofícios, portarias internas de nomeação de gestores, contratação de serviços e obras, catálogos, teses, dissertações e jornais das universidades. Este material é fonte esclarecedora da cronologia e dos agentes envolvidos na implantação do campus. Sinalizam o contexto histórico da época e da atualidade.

\subsection{Entrevistas}

As entrevistas desempenharam papel de desvendamento dos fatos e concepções que se refletiram na proposta física, acrescentando dados que complementaram os contornos da pesquisa. Contribuíram para reforçar o pressuposto da existência de tipologias adaptadas ao contexto local, referendando os questionamentos que levaram à formulação da hipótese e confirmação nos encaminhamentos dados para o desenvolvimento da pesquisa. Destacamos as seguintes entrevistas:

- Arquiteto e engenheiro paraense professor Alcyr Meira, da Universidade Federal do Pará (UFPA), que foi representante do MEC na década de 1970 para compor equipes de trabalho na elaboração de projetos de campi universitários. ${ }^{3}$ Especificamente para o Nordeste, foi autor do plano diretor e de projetos de novas edificações para o campus da UFRN (1972/1974), assim como do plano diretor da UFPB (1971/1972) e do plano diretor e de projetos de prédios para o campus da Universidade Estadual do Rio Grande do Norte UERN (1972/1974).

- Os arquitetos João Alberto Cardoso Monteiro, formado pela Universidade Federal do Ceará (UFC), e Ronaldo Pinto Marques, pela Universidade de Brasília (UnB), que pertenceram ao quadro técnico da UFPI e foram contratados para coordenar e acompanhar a construção do campus, bem como foram autores dos projetos das primeiras edificações.

\footnotetext{
${ }^{3}$ Na década de 1970, o arquiteto e engenheiro Alcyr Meira foi nomeado pelo então Ministro da Educação e Cultura, Jarbas Passarinho, mediante portaria $n^{\circ} 327 / \mathrm{BSB}$, de 12 de junho de 1973, para compor equipe na montagem de um projeto a ser submetido ao Banco Interamericano do Desenvolvimento (BID) com vistas à obtenção de empréstimo destinado aos campi universitários.
} 
- O arquiteto Neudson Braga, da Universidade Federal do Ceará (UFC), que participou da equipe de elaboração do plano diretor e foi autor de projetos das edificações no Campus da UFC.

Os dados coletados nessas entrevistas nos permitiram traçar um perfil da gestão política e técnica de implantação dos campi naquele período.

3. Sistematização dos Levantamentos.

O conjunto das informações foi processado e compõe os capítulos da Parte 2. A estrutura da apresentação dos dados foi elaborada com a seguinte organização:

1. Dados da história da criação da universidade e seu campus universitário.

2. Proposta do plano diretor físico para o campus universitário.

3. Projeto executado para o campus universitário.

4. Levantamento do conjunto arquitetônico edificado.

5. Levantamento planialtimétrico atualizado do campus.

Para identificar as diretrizes de projeto adotadas na organização físico-espacial dos campi elaboramos uma matriz de análise, que serviu como ferramenta fundamental da investigação. Decidimos pela formulação de chaves de análise amparadas nos princípios e parâmetros formulados no Manual de Atcon (1970), uma vez que o mesmo foi o instrumento orientador do MEC para o planejamento e a construção dos campi.

Essa matriz permitiu estabelecer relações entre os princípios do Manual e o executado. Ao mesmo, o desenvolvimento dessa dialética evidenciou a resposta de cada campus à organização espacial do modelo da Reforma. $O$ caráter aberto desse modelo possibilitou a inserção de outras variáveis, respeitando as particularidades de cada campus. Foi definido pela composição de categorias de abordagens, organizadas em três conjuntos:

1. Aspectos físicos do lugar - avalia as características do terreno, das condições ambientais, do entorno imediato e dos acessos para a cidade.

2. Diretrizes do plano urbano - analisa os princípios de organização do espaço urbano e das relações de integração entre os espaços livres e os edificados.

3. Características da obra arquitetônica - examina os princípios e as relações de organização do programa funcional, do sistema construtivo, do conforto ambiental, dos elementos e materiais da linguagem arquitetônica, da expressividade estética e das relações com as demais edificações.

Das categorias derivaram as chaves de análise sintetizadas no quadro 2. 
Quadro 2: Matriz de Análise

(Fonte: Elaboração da própria a partir do Manual de Atcon - 1970)

\begin{tabular}{|c|c|c|}
\hline \multicolumn{3}{|c|}{ MATRIZ DE ANÁLISE } \\
\hline $\begin{array}{l}\text { Categorias de } \\
\text { Abordagem }\end{array}$ & $\begin{array}{c}\text { Chaves de Análise } \\
\text { (princípios e/ou questōes } \\
\text { arquitetônicas) }\end{array}$ & Conteúdo \\
\hline \multirow[b]{2}{*}{$\begin{array}{l}\text { Aspectos Físicos do } \\
\text { Lugar }\end{array}$} & - Topografia & - curvas de níveis/características do solo. \\
\hline & - Condicionantes Ambientais & $\begin{array}{l}\text { - orientação solar, ventilação predominante, } \\
\text { regime de chuvas, recursos hídricos, } \\
\text { vegetação predominante. }\end{array}$ \\
\hline \multirow{3}{*}{$\begin{array}{l}\text { Diretrizes do Plano } \\
\text { Urbanístico }\end{array}$} & - Zoneamento & $\begin{array}{l}\text { - setorização funcional por áreas de } \\
\text { conhecimento. } \\
\text { - setorização das tipologias construtivas - } \\
\text { edifícios específicos e não especificos. } \\
\text { - relação das áreas verdes com o conjunto } \\
\text { arquitetônico. }\end{array}$ \\
\hline & - Hierarquia & $\begin{array}{l}\text { - vias de circulação - veículos, pedestres, de } \\
\text { serviços - acessos. }\end{array}$ \\
\hline & - Relação & $\begin{array}{l}\text { - articulação das áreas e edifícios de } \\
\text { convivência - espaços de integração. } \\
\text { - relação com a cidade e áreas de cercanias, } \\
\text { - vias de acesso, propriedades, comércio e } \\
\text { desenvolvimento urbanístico existentes. } \\
\text { - serviços urbanos existentes. }\end{array}$ \\
\hline \multirow{6}{*}{$\begin{array}{l}\text { Características da } \\
\text { Obra Arquitetônica }\end{array}$} & - Partido Arquitetônico & $\begin{array}{l}\text { - organização do programa de } \\
\text { necessidades. } \\
\text { - articulação: programa x circulações x } \\
\text { acessos. } \\
\text { - processo construtivo. } \\
\text { - estrutura - articulação com a expressão } \\
\text { plástica do edifício. }\end{array}$ \\
\hline & - Estudo da Forma. & $\begin{array}{l}\text { - composição da forma arquitetônica - } \\
\text { volumetrias, espaços e superfícies. } \\
\text { - elementos da linguagem arquitetônica. }\end{array}$ \\
\hline & - Flexibilidade & $\begin{array}{l}\text { - modulação dos espaços. } \\
\text { - padronização dos elementos construtivos. } \\
\text { - adequações das engenharias - estrutura e } \\
\text { instalações prediais. }\end{array}$ \\
\hline & - Expansibilidade & $\begin{array}{l}\text { - diretrizes de crescimento - eixos e/ou } \\
\text { tipificação das tipologias. } \\
\text { - relações de crescimento com o entorno } \\
\text { imediato. } \\
\text { - soluções de crescimento das instalações } \\
\text { prediais e reprodução do elemento } \\
\text { estrutural. }\end{array}$ \\
\hline & - Integração & $\begin{array}{l}\text { - definição de espaços de convivência. } \\
\text { - possibilidades de circulaçőes. }\end{array}$ \\
\hline & - Conforto Ambiental & $\begin{array}{l}\text { - estratégias e elementos construtivos para } \\
\text { controle da ventilação, da proteção solar. }\end{array}$ \\
\hline
\end{tabular}


No procedimento de análise contamos com o acervo documental, já referenciado: desenhos, diagramas gráficos, mapas, planos, projetos arquitetônico, fotografias, imagens digitais. Com a construção histórica do panorama arquitetônico e urbanístico foram introduzidas chaves de análise as quais, interagindo com o inventário, evidenciavam as relações espaciais, formais e construtivas sintetizadas naquela produção.

\section{ESTRUTURA DA TESE}

A tese está organizada em duas partes, sendo a segunda dividida em sete capítulos.

A Parte 1 - A Transformação da Universidade Brasileira - aborda implantação da Reforma Universitária de 1968, que se constitui no elemento teórico estruturador da tese.

Começa com a construção da Reforma no contexto histórico da década de 1960: (1) o binômio educação e desenvolvimento, herdado dos anos de 1950, que encontrou na estrutura do ensino superior vigente na época obstáculo a ser ultrapassado: responder pela qualificação de um número ampliado de profissionais para atuar frente às novas exigências do mercado de trabalho, (2) a criação da UnB com uma nova estrutura acadêmica tornou perceptivel a defasagem da universidade tradicional, (3) a atuação do movimento estudantil, reivindicando a democratização do ensino superior, (4) o governo militar, a partir 1964, que ampliou a participação na esfera federal de consultores norte-americanos na definição da política educacional do país e (5) o poder discricionário da ditadura militar, impondo a reestruturação do ensino superior por força de lei, com vistas à sua rentabilidade.

O capítulo discorre sobre a estrutura do novo projeto universitário que consagrava o sistema departamental, em substituição à cátedra vitalícia, apontando para a não duplicação de meios para fins idênticos ou equivalentes. Disserta sobre o campus da Reforma referenciado no paradigma norte-americano para responder aos intentos de eficiência e racionalidade da nova estrutura universitária. No âmbito da reformulação física pressupõe novos requisitos de desenho do edifício e uma organização urbanística baseada no princípio do zoneamento funcional. Finaliza com o detalhamento do Manual de Atcon (1970).

A Parte 2 - Campus Universitário no Nordeste: planos e realizações - constitui o vigamento central da pesquisa desenvolvida. Cuida das realizações arquitetônicas e urbanísticas dos campi das universidades federais do Ceará (UFC), Paraíba (UFPB), Rio Grande do Norte (UFRN), Alagoas (UFAL), Maranhão (UFMA), Sergipe (UFS) e Piauí (UFPI), apresentando desde as primeiras instalações que deram suporte ao seu funcionamento até a criação do campus da Reforma de 1968. 
Em cada capítulo dedicado a um campus realiza um levantamento e o reconhecimento das tipologias urbano-arquitetônicas construídas e/ou reformadas para atender às diretrizes do MEC. Apoiada na matriz de análise descreve as características predominantes de cada campus. Para cada universidade pesquisada, o estudo enfoca: (1) o histórico da criação da instituição, identificando as características de organização espacial e da concepção arquitetônica dos edifícios construídos e/ou reformulados para o seu funcionamento, (2) a mudança da organização acadêmica vigente, a qual foi substituída pela estrutura departamental, (3) as especificidades do terreno para a construção do campus, (4) a concepção do plano físico que estabeleceu as diretrizes a serem adotadas na configuração urbanística do campus e das suas edificações, (5) a conformação morfológica construída ou reformulada para a implantação da nova organização acadêmica, (6) a relação com a malha urbana da cidade, (7) as tipologias construtivas do Manual, com o reconhecimento da concepção arquitetônica e características construtivas, sendo evidenciadas as questões da racionalização (padronização dos elementos construtivos), dos aspectos da funcionalidade (distribuição dos ambientes por setores), da modulação (estrutural e/ou módulo básico na definição da proposta arquitetônica) e da flexibilidade (formas de remanejamento e expansão da edificação) e (8) o reconhecimento da ordenação atual do campus com a malha urbana da cidade. Por fim realiza as conclusões.

\section{CAMPUS UNIVERSITÁRIO: considerações sobre o termo no contexto da pesquisa}

Esta introdução não estaria completa sem uma consideração sobre o significado de campus no contexto desse trabalho. O termo campus em latim e o seu plural campi tornaram-se, a partir da década de 1960 , expressões usadas mundialmente para designar o território ocupado pelas instalações de uma instituição universitária.

Segundo Turner (1995, apud OLIVEIRA, 2005, p. 14-15), quando utilizada pela primeira vez na Universidade de Princeton, por volta de 1770 , tinha apenas seu sentido comum em latim - campo -, expressando as qualidades físicas da verde extensão de terra que caracterizava aquela instituição americana. Nesse sentido, Muthesius (2001, p. 24) aponta que campus indica primeiramente uma localização: o campo.

Oliveira (2005, p. 14-15) acrescenta que rapidamente o termo rompeu com seu sentido etimológico original, assumindo acepção mais ampla, passando a englobar a propriedade inteira, incluindo os edifícios nela existentes. Infere que frequentemente situado na periferia ou fora da cidade, o campus buscava dela isolar-se e diferenciar-se, criando uma ambiência própria. Alimentado pelo ideal norte-americano de formar o cidadão separado das forças 
corruptoras da cidade transformou-se numa espécie de microcosmo, onde o homem era a expressão desse pequeno universo.

A acepção do vocábulo foi estudada por Fernandes (1974, p.72), que faz um paralelo com o conceito de cidade universitária. A pesquisa por ele desenvolvida, vai buscar as raízes dos seus significados nas primeiras universidades europeias surgidas na segunda metade do período medieval, com o nome de Studia Generalia e Universitas Magistrorum et Escholarium e que eram instituições de ensino implantadas em meio urbano.

Explica que partindo de um conjunto de poucos prédios - destinados às salas de aula, reuniões e biblioteca - e, às vezes, de um só edifício, essas universidades cresceram em tamanho e importância, principalmente a partir do período renascentista, assumindo relevância cultural sem precedente no mundo cristão ocidental (FERNANDES, 1974, p. 72). Incorporados às cidades, deram início a uma nova categoria de prédios urbanos.

É nesse período - fim da Idade Média - que Fernandes $(1974$, p.72) encontra as primeiras referências ao campus, identificando-o como o espaço de uso coletivo configurado pela distribuição dos prédios de aulas, museus, academias, e pelos equipamentos ao ar livre que pertenciam às universidades, permeado pelos espaços abertos da cidade com a livre circulação de cidadãos, ligados ou não à instituição universitária. Ressalta que não se trata de analogias, ainda que apenas formais, entre aqueles espaços e as configurações espaciais dos campi do século $\mathrm{XX}$, pois a noção de campus como território especializado das funções universitárias, delimitado e isolado da cidade, não estava presente na instituição europeia daquele período, exatamente porque naquele continente a universidade tinha vínculo direto com a cidade. Ela surgiu e se desenvolveu como instituição urbana.

Com base nos determinantes históricos, Fernandes (1974, p. 72) conceitua que o campus é especialmente definido pelo conjunto dado de edificações destinado ao ensino superior, somado aos seus equipamentos e aos serviços que em função de sua presença the são agregados naturalmente. Acrescenta que esta definição confere ao campus um caráter de continente, ou seja, de conter todos os elementos que formam a universidade oficialmente, e, naturalmente, incluem-se aqui as edificações, ruas, praças e equipamentos urbanos que, mesmo não vinculados à universidade, encontram-se dentro de seus entornos, ou seja, em seu campus (FERNANDES, 1974, p. 72).

A partir dessa acepção estabelece a diferença conceitual de cidade universitária: um território de limites físicos precisos, que abriga o campus. Nessa situação, Fernandes (1974, p. 73) infere que o campus de que trata a cidade universitária, não é uma simples transposição das relações, de um ponto a outro da área urbana, pois verifica uma deturpação do conceito de campus (no seu sentido mais amplo estrutural) e não somente 
uma variação de escala. Afirma que o novo campus, no contexto da cidade universitária, não conserva o esquema de relações anteriores com o meio urbano e com a população não-universitária dos entornos (FERNANDES, 1974, p. 73).

Nas suas palavras, estas relações são anuladas e substituídas por um novo elenco, gerado artificialmente, das relações entre os "contribuintes" do ensino superior, limitados inclusive geograficamente a um espaço exclusivo: a cidade universitária modema (FERNANDES, 1974, p.73). Considera que o

[...] novo campus, o da cidade universitária, perde seu aspecto de "continente", passa a ser "contido" - espacial e socialmente. De conjunto espacial, o campus é reduzido a simples elemento do plano, sendo rebatizado com a mais moderna terminologia urbanística de "centro de vivência", "conjunto social", "zona de convívio", etc. O novo campus está livre dos elementos "estranhos à vida universitária"; a cidade em seu crescimento desordenado, não invade mais o território da universidade. Nem esta invade o da cidade (FERNANDES, 1974, p. 72).

Fernandes (1974, p.73) esclarece ainda que a ideia de cidade universitária na América Latina é resultante, antes de tudo, de características históricas bem determinadas, entre elas a de que, do ponto de vista da urbanização, sua construção está diretamente ligada

[... a um momento de crescimento desordenado das cidades, a um congestionamento e "deterioração" crescentes das zonas centrais mais antigas de nossas metrópoles (locais onde geralmente se localiza a maioria das faculdades), e, principalmente, a um momento em que o valor do solo urbano aumenta consideravelmente e passa a ser um elemento fundamental na determinação da "moderna configuração do Uso do Solo".

As definições e ponderações elaboradas por Fernandes (1974, p. 72-73) nos mostram a existência de um campus abstrato, materializado espacialmente pela reunião de todos os elementos que dão suporte às funções universitárias, incluindo as relações entre os membros da população universitária, exercidas em sua plenitude, e tendo como objeto a visão crítica e politica da sociedade, que são compartilhadas com os moradores, trabalhadores e frequentadores da área em questão. Nessa acepção o território do campus não possui contornos definidos, nem se encontra limitado ou cercado por barreiras físicas. Conforma-se em território inserido na cidade. Esta acepção abre caminho para nortear os debates e publicações onde o campus e a cidade universitária têm sido usados como palavras sinônimas. 
No Brasil, segundo Cunha (2003, n.p.), a palavra campus foi trazida das universidades norte-americanas, em substituição ao termo cidade universitária, de origem francesa.

Alberto (2008, p.129) confirma que o vocábulo entrou em circulação no país nos anos 1960 , decorrente principalmente dos acordos MEC-USAID ${ }^{4}$ que passaram a trabalhar oficialmente com o termo, ao invés de cidade universitária. O pesquisador cria um divisor temporal a partir de suas observações em textos justificativos e títulos de pranchas de projetos das principais universidades brasileiras tanto nos anos 1930 , quanto nos anos $1940 / 50$, bem como nos anteprojetos para a cidade de Brasília, constatando até aí o uso predominante da expressão cidade universitária. Confere, entretanto que no Brasil, cidade universitária e campus universitário possuem o mesmo significado.

Buffa e Pinto (2009, p. 47) indicam que o termo cidade universitária foi utilizado no Brasil por ocasião da criação da USP, nos anos 1930, e também por Gustavo Capanema nas suas indicativas para a criação da Universidade do Brasil. Inferem que embora os termos sejam utilizados como sinônimos apresentavam, em suas origens, diferença na autonomia do seu funcionamento. Para os autores, a cidade universitária é uma região delimitada, autônoma, regida por regras acadêmicas e que foi pensada como um núcleo com capacidade para oferecer ensino, centros de pesquisa, acolher alunos e professores, abastecidos por todos os serviços próprios de qualquer cidade, embora não tenha atingido esse estágio. Embora semelhante, segundo os mesmos autores, o campus supõe um território fechado, com administração independente, abrigando espaços de ensino, aprendizagem e pesquisa, porém com alguns poucos serviços fundamentais, tais como refeitórios, lanchonetes, xérox, papelaria, livraria e bancos, situação que o torna dependente diretamente da infraestrutura da cidade que o cerca (BUFFA e PINTO, 2009, p. 16-17, 46-47).

Rodrigues (2001, p.74) historia que, já a partir da década de 1930, o Brasil procurou consolidar um espaço universitário inspirado no campus norte-americano, esclarecendo que se tratava de um modelo espacial afastado da zona urbana.

Na sua narração sobre o plano urbanístico executado em 1944 para a Universidade Federal do Rio de Janeiro (UFRJ), antiga Universidade do Brasil, na atual Itha do Fundão, explica que a condição da estrutura universitária, regida na época pelo sistema de cátedras e de institutos e escolas autossuficientes, permitiu sua organização física no conceito de "Cidade" universitária (RODRIGUES, 2001, p. 83). Refere-se o autor às formulações urbanas da cidade moderna, onde o projeto urbanístico para agrupar fisicamente a Universidade no mesmo local foi desenvolvido com base num zoneamento por grandes quadras, cada uma delas destinada a uma área do saber, com claras influências da Carta de Atenas, com os 
edifícios cercados por extensa área verde e com um ambicioso projeto viário. Nessa acepção, ao inserir o campus numa visão urbana racionalista, Rodrigues (2001, p.33) situa seu surgimento como uma área da cidade regida pelo princípio do zoneamento. Nessa gleba, bem definida e delimitada, aponta que os técnicos tiveram a oportunidade de pôr em prática os princípios da cidade moderna: a cidade universitária.

Destaca que a reunião de toda a Universidade no mesmo local com as soluções urbanísticas mencionadas configurava um modelo espacial de campus único que encontra paralelos mundiais ${ }^{5}$ (RODRIGUES 2001, p. 92). Nessa acepção, inferimos que o campus de Fernandes (1974) foi materializado em um território de localização definida e delimitado fisicamente com organização espacial regida pelos princípios do urbanismo racional moderno, vigente naquele período. Entretanto, como explicou Fernandes (1974, 73), as relações que definem o campus na cidade universitária não ocorrem naturalmente, mas por uma condição pré-definida.

Rodrigues (2001, p. 93) deixa claro que sua menção ao termo campus nesse estudo se deu pelo fato de estar se referenciando à publicação da Universidade do Brasil (1953), onde o texto já faz alusão ao termo. Destaca o fato, pois, à época, no Brasil, a terminologia adotada era a de cidade universitária, como então ficaram conhecidas todas as instalações universitárias e que o termo campus universitário somente passou a ter predominância a partir da década de 1960 (RODRIGUES, 2001, p. 93). Levanta a hipótese de que a adoção do vocábulo na publicação já poderia ser uma influência das visitas de Rudolph Atcon planejador universitário norte-americano - que se encontrava em visita ao Brasil no ano de 1952 (RODRIGUES, 2001, p. 93).

Retoma a proposição ao fazer vínculo com o movimento de reformas universitárias dos anos 1960 e o tema dos espaços físicos, quando então afirma que a influência dos Estados Unidos trouxe o modelo físico universitário de campus, caracterizado por ser independente dos demais espaços das cidades, tonando-se segregado por barreiras das mais diversas: assentamento periférico, em busca de reclusão e isolamento, linguagem morfológica distinta do restante da cidade, etc. (RODRIGUES, 2001, p. 141).

Complementa que internamente também ocorre a segregação espacial, decorrente dos seus espaços interiores, marcados por locais que pouco estimulam a aproximação e interação entre as pessoas: prédios distantes, vazios sem praças, edificios com tendência a isolar os alunos segundo seus cursos, etc. (RODRIGUES, 2001, p. 19).

${ }^{5}$ Rodrigues (2001, p. 92) exemplifica os casos das universidades de Roma, Atenas, Oslo, Madri, México, Bogotá, Tucumán, Caracas e Miami, dentre outras. 
ALMEIDA (1983, p. 11-12) faz pertinência do termo campus à Reforma de 1968. Define-o como modelo espacial de território para as atividades universitárias compatibilizado com a reformulação do ensino superior de 1968. Destaca que se sua existência não estiver limitada à Reforma de 1968, sua divulgação uniforme em todos os Estados da federação é um fato constatado, marcadamente para abrigar as instituições de ensino superior federais, dentro delas as universidades. Assinala que as características do campus são facilmente observadas:

[...] na sua maioria estão implantados nas capitais estaduais e se destacam do desenho das cidades pelas extensas áreas de sua propriedade, pela irregularidade de implantação dos seus edifícios em relação ao desenho das cidades, pela peculiaridade de sua arquitetura e, fundamentalmente pela localização distante dos centros urbanos e zona habitacional (RODRIGUES, 2001, p. 93).

Na vertente de campus da Reforma, interessa-nos especificamente a definição formulada no Manual de Atcon (1970). O consultor norte-americano estabelece sua acepção entre o campus e a cidade universitária. Nas suas palavras o campus universitário seria

[...] um local geográfico que reúne todas as atividades de uma universidade e as integra da maneira mais econômica e funcional num serviço acadêmico-científico coordenado e da maior envergadura possível, respeitadas as limitações dos seus recursos humanos, técnicos e financeiros (ATCON, 1970, p. 8).

Expressa também que o campus brasileiro era a representação da universidade integral alimentada pelo ideal de formar o cidadão completo. Sua organização espacial, assim como a cidade universitária adotada pelas universidades da primeira metade do século $X X$, também foi, segundo recomendação do Manual de Atcon (1970), orientada pelos princípios do urbanismo moderno, principalmente pelo zoneamento funcional. Sobre a cidade universitária faz um contraponto indicando que ela

[...] corresponde à universidade tradicional - dá, numa só área geográfica, expressão física ao desejo de união das unidades isoladas e dispersas que a compõem. Porém, não ultrapassa u'a mera aproximação dos edifícios que abrigam autarquias independentes entre si $\left(\right.$ ATCON $_{i} 1970$, p. 8).

As definições de Atcon limitam o campus a um território físico que abriga a estrutura universitária baseada nos departamentos, reunidos em centros, sob a égide da eficiência e produtividade. Nesse caso, o campus definido por Fernandes (1974) não encontra 
aproximação, já que Atcon (1970) não pressupõe relações sociais a partir das vivências espaciais, da interação entre o campus e o entorno circundante; entre o campus e a cidade e entre a universidade e a sociedade. Atcon limita-se a contrapor a cidade universitária como o território físico que abriga espacialmente unidades acadêmicas isoladas.

O parecer n 848/1968 da Câmara do Ensino Superior do Conselho Federal de Educação estabelece, entretanto, o termo campus e cidade universitária como estruturas semelhantes:

[...] campus representa, hoje, a integração espacial que é uma condição altamente conveniente para realizar-se a integração estrutural e funcional da universidade, concebida como totalidade organicamente articulada, em vez de simples coleção de equipamentos auto-suficentes. Assim os princípios de integração e organicidade da atual reforma, só podem objetivar-se plenamente no campus ou seu equivalente, entre nós, a cidade universitária (apud CABRAL, 2004, p. 194).

O levantamento sobre o termo campus evidencia que no Brasil seu significado está relacionado aos distintos momentos da materialização física da instituição universitária e que tem sido comumente permeado pela ideia de cidade universitária. Isso se dá pelo fato de que campus é o espaço imaginário onde ocorrem as relações pertinentes às atividades da instituição universitária, materializado em um território físico, que assume distintos modelos espaciais na sua consolidação.

$\mathrm{Na}$ nossa acepção, a cidade universitária é uma tipologia espacial que abriga o campus resultante da reunião de escolas isoladas e que tinha o propósito de criar o espírito universitário. O campus universitário é uma tipologia espacial destinada ao desenvolvimento do espaço das relações universitárias geradas na organização acadêmica e administrativa do sistema departamental e regidas pela ideia de eficiência e produtividade. As configurações físicas dos dois modelos pouco diferenciam um do outro. O resultado espacial desses conceitos se materializa em área especializada e dissociada do espaço urbano, porém inseridos em momentos históricos e propósitos diferenciados.

No contexto da presente tese, o termo campus representa a tipologia espacial da Reforma, o território que pressupunha uma base física unificada da organização universitária.

Essas considerações não estariam completas se não trouxéssemos as acepções que definem o sentido atual de campus. Cunha (2003, n.p.) situa o termo campus no sentido que para ele hoje é aceito, tratando-se de um espaço contínuo, delimitado e exclusivo, onde se reúnem os edifícios de uma universidade, podendo estar situado dentro da cidade, na sua periferia ou fora dela. Explica que a materialidade do termo está limitada ao território que reúne todas as instalações de uma universidade, inclusive as residências de docentes, 
discentes e funcionários. Constata, assim como Buffa e Pinto (2009, p. 47), que nenhuma universidade brasileira encontra-se assim implantada, mas que a ideia não deixa de estar presente em todas elas, de um modo ou de outro (CUNHA, 2003, n.p.).

Oliveira $(2005,15)$ atualiza o termo campus, incorporando-lhe além do seu significado físico a identidade institucional. Defende que o vocábulo representa

[...] o espírito manente da escola, seu genius loci, encarnado na sua arquitetura e no seu território. Através do tempo, o campus assumiu alguma coisa do próprio significado da instituição subentendendo, além de sua materialização como o território onde a universidade exerce sua missão social, a realização de sua finalidade e a afirmação de sua identidade (OLIVEIRA, 2005, p. 14-15). 


\title{
PARTE 2 \\ CAMPUS UNIVERSITÁRIO NO NORDESTE: planos e realizações
}

\begin{abstract}
A Reforma Universitária (1968) teve alcance em todas as universidades federais brasileiras existentes na década de sua implantação $(1960)^{15}$, as quais tiveram que se adequar à nova organização acadêmica, construindo ou reformando suas instalações físicas. Assim é que, embasadas pela legislação federal e acompanhadas por vultosos investimentos governamentais na área da educação superior, elaboraram planos e projetos que gradativamente foram sendo executados, embora o planejamento proposto quase sempre não tenha sido cumprido na íntegra.
\end{abstract}

No Nordeste, cada instituição vivenciou contextos diferenciados e as obras construídas como parte do processo da Reforma tiveram soluções próprias e diversas, embora as diretrizes arquitetônicas e urbanísticas adotadas tenham sido pautadas pelos mesmos princípios: flexibilidade, modulação, padronização, zoneamento funcional, ênfase construtiva na estrutura independente em concreto aparente e urbanismo racional (edifícios isolados em vasta área verde). Para essa empreitada, contaram com profissionais de diferentes regiões brasileiras, os quais, por meio de convênios institucionais, contribuíram para a construção dos campi do Nordeste.

Importante ressaltar que, nos anos 1960, a arquitetura moderna com ascendência da escola carioca ainda encontrava na Região Nordeste seguidores impregnados do ideário arquitetônico originado no Rio de Janeiro, porém utilizando adaptações climáticas e recursos tecnológicos, como elementos vazados, brises, panos de combogós, meia-parede, colchões de ar, azulejos e vidros, dentre outros. Neste período, destaca-se a influência da arquitetura produzida na cidade de Recife $^{16}$, que se justificava pela situação privilegiada daquela capital

\footnotetext{
${ }^{15} \mathrm{Em} \mathrm{1973,} \mathrm{havia} 31$ instituições federais de ensino superior: Universidade Federal do Pară (UFPA), Fundação Universidade Federal do Amazonas (FUAM), Universidade Federal do Piauí (UFPI), Universidade Federal de Sergipe (UFS), Universidade Federal Rural de Pernambuco (UFRPE), Fundação Universidade Federal do Maranhão (FUMA), Universidade Federal do Rio Grande do Norte (UFRN), Universidade Federal de Alagoas (UFAL), Universidade Federal do Ceará (UFC), Universidade Federal da Paraiba (UFPB), Universidade Federal de Pernambuco (UFPE), Universidade Federal da Bahia (UFBA), Universidade Federal de Juiz de Fora (UFJF), Universidade Federal de Goiás (UFGO), Universidade Federal de Mato Grosso (UFMT), Universidade de Brasilia (UnB), Universidade Federal do Rio de Janeiro (UFRJ), Universidade Federal do Espírito Santo (UFES), Universidade Federal Rural do Rio de Janeiro (UFRRJ), Universidade Federal de Minas Gerais (UFMG), Universidade Federal de Viçosa (UFV), Universidade Federal de Ouro Preto (UFOP), Universidade Federal de São Carlos (UFSC), Fundação Universidade Federal de Uberlândia (FUBER), Universidade Federal de Pelotas (UFPEL), Universidade Federal do Paraná (UFPR), Universidade Federal de Santa Catarina (UFSC), Universidade Federal do Rio Grande do Sul (UFGS), Universidade Federal de Santa Maria (UFSM), Fundação Universidade do Rio Grande (FURG).

${ }^{16}$ São os arquitetos Acácio Gil Borsoi e Delfim Fernandes Amorim os principais protagonistas daquela produção e foram responsáveis pela formação dos jovens arquitetos que passaram a atuar nas principais capitais do Nordeste.
} 
em termos econômicos e culturais dentro da Região Nordeste. Ali se desenvolveu uma arquitetura de sintaxe modernista, mas que buscava adaptação às condicionantes regionais. Concomitantemente, em meados da mesma década, quando a arquitetura brasileira já havia iniciado seu declínio no panorama internacional e os arquitetos apresentavam novas experiências, no Nordeste, a produção arquitetônica moderna se amplifica e se desdobra com a contribuição de profissionais que buscavam a racionalização construtiva (embora a mão de obra nacional na época não acompanhasse o ideário de racionalização da construção), a valorização estética dos materiais e da verdade estrutural, que explicita os sistemas estruturais para os limites da edificação, promovendo, em vários exemplos, composições que exploram a plasticidade do concreto.

Surgiu, na região, uma arquitetura que passou a trabalhar com os materiais brutos em sua forma natural, como o tijolo aparente, a pedra, superfícies revestidas de pastilha, azulejos ou revestimentos cerâmicos nos elementos de vedação, com o concreto utilizado em estruturas portantes e peças pré-fabricadas de concreto aparente para proteção da insolação. Outras experiências expressavam preocupações com a racionalização e com a pré-fabricação dos elementos construtivos.

É nesse panorama de intercâmbio de ideias e aproximações criativas, patrocinado pelo poder arbitrário do regime militar, que se deu a produção urbano-arquitetônica do território das universidades federais do Nordeste apartado das funções urbanas, visando conformar o modelo espacial da Reforma. Inseridas numa região marcada por graves indicadores socioeconômicos e que tinha naqueles anos um baixo desenvolvimento urbano-industrial, as instituições federais nordestinas realizaram uma produção com distintas respostas.

\section{- Região Nordeste}

A Região Nordeste é a terceira maior do Brasil com área de $1.558 .196 \mathrm{~km}^{2}$ e constituída por nove Estados: Alagoas, Bahia, Ceará, Maranhão, Paraíba, Piauí, Pernambuco (incluindo o Distrito Estadual de Fernando de Noronha), Rio Grande do Norte e Sergipe (ver figura 1). Localiza-se entre os paralelos de $01^{\circ} 02^{\prime} 30^{\prime \prime}$ de latitude norte e $18^{\circ} 20^{\prime} 07^{\prime \prime}$ de latitude sul, próxima à linha do equador, situação que promove intensa radiação solar ao longo de todo o ano. Em relação aos aspectos naturais, predominam o clima tropical semiárido e a cobertura vegetal da caatinga. No litoral leste, ocorrem faixas importantes de Mata Atlântica, com clima quente-úmido, e no litoral norte, prevalece a vegetação de Mata dos Cocais, com clima tropical quente (TAMDJIAN e MENDES, 2004, p. 70-87). 
Com uma população de mais de 53 milhões de habitantes (IBGE/2010) ${ }^{17}$, a Região, a segunda brasileira em contingente populacional, é a que conta com maior número de pessoas em situação de extrema pobreza ${ }^{18}$, apresentando os mais graves indicadores socioeconômicos: o maior percentual de famílias pobres e de população rural, as maiores taxas de analfabetismo, mortalidade infantil e fecundidade, a menor esperança de vida ao nascer e o menor grau de urbanização. A baixa escolaridade tem sido apontada como um dos principais fatores para a pobreza no Nordeste. Esses dados evidenciam um território marcado por profundas desigualdades entre as macrorregiões do País.

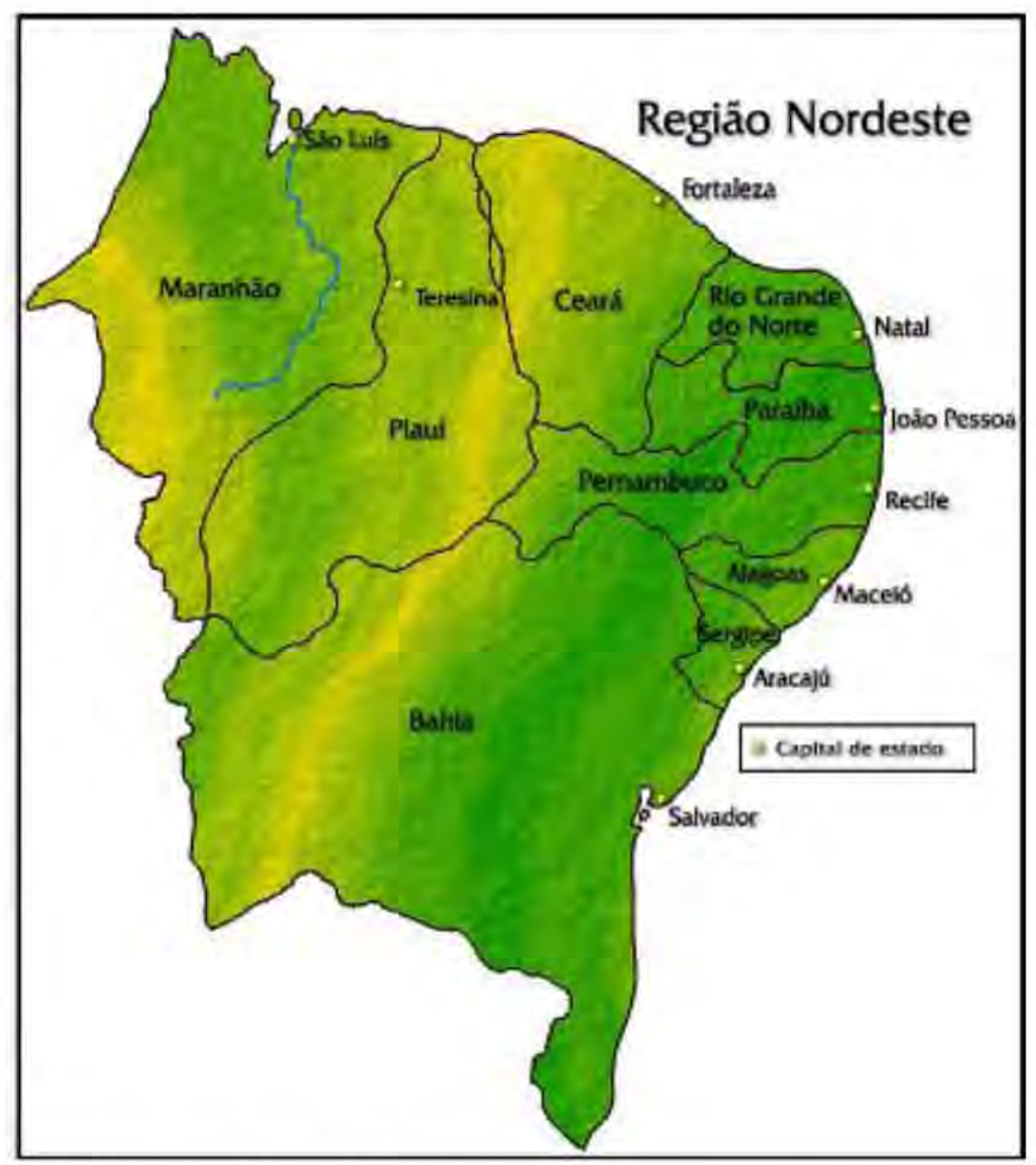

Figura 3: Mapa da Região Nordeste.

(Fonte: Disponivel em: <http://wnw.redebrasileira.com/mapas/regioes/nordeste.asp>. Acesso em: 4 set. 2010).

Historicamente, a Região caracteriza-se por apresentar um intenso processo migratório, que desde a década de 1940 tem se constituído num centro expulsor de população para o

\footnotetext{
${ }^{17}$ Dados mais detalhadas estão disponiveis em <http://Www.ibge.gov.br/censo2010/>.

${ }^{18}$ Dados do Censo 2010 revelam que a região Nordeste é a que conta com mais pessoas em extrema pobreza, sendo $18,8 \%$ da população, em comparação com os $8,5 \%$ nacionais. Em seguida aparecem o Norte $(16,8)$, Centro-Oeste $(4)$, Sudeste $(3,4)$ e Sul $(2,6)$.

Disponivel em: <http://Www.ibge.gov.br/censo2010/>.
} 
restante do país. Esses movimentos migratórios foram mais fortes e intensos durante as décadas de 1960 e 1970, especialmente para centros urbanos, com destaque para a região Sudeste, onde a cidade de São Paulo estava em pleno desenvolvimento econômico e industrial e a construção civil conseguia absorver toda essa mão de obra nordestina. Concorre para este cenário a política econômica implantada pelos governos militares, a partir de 1964, voltada para o setor industrial e o de infraestrutura, que tinha como finalidade principal elevar o país à condição de grande potência, associando-se ao capital estrangeiro, como forma de acelerar o desenvolvimento econômico.

Seguindo as diretrizes da política econômica vigente (1960-1970), os Estados nordestinos, principalmente suas capitais, começam a receber as primeiras ações da Superintendência do Desenvolvimento do Nordeste (SUDENE). O caráter urbano-industrial da política desse órgão, que se caracterizou pela concentração de volumosos investimentos nos grandes centros urbanos da região, provocou a migração do interior para as capitais regionais. importante mencionar que, sobretudo entre os anos 1960 e 1970, a modernização da infraestrutura econômica, notadamente a de transporte e de produção e distribuição elétrica, constituiu a base sobre qual a economia nordestina cresceu e diversificou sua estrutura produtiva.

As transformações econômicas, sociais e políticas, verificadas naqueles anos, demonstram o deslocamento da economia essencialmente agrária para a urbana. Por conseguinte, o dinamismo econômico acarretou a expansão horizontal das cidades, trazendo problemas socioespaciais, com repercussão nas classes mais pobres da população atingidas pela carência de serviços urbanos, além do que a presença dos empreendimentos industriais acarretou a valorização do solo nas áreas melhor servidas. O fato é que o processo de urbanização foi dissociado do crescimento econômico, pelo menos no mesmo ritmo, o que, juntamente com o despreparo da mão de obra, promoveu o desemprego e o subemprego, com consequentes reflexos negativos na qualidade de vida das populações urbanas.

Neste contexto, o processo de urbanização no Nordeste, embora lento quando comparado ao outras regiões brasileiras, deu-se de forma intensa nas cidades de médio e grande porte, que se destacavam economicamente. Enquanto no censo demográfico de 1940 não havia nessa Região cidade com população superior a 400 mil habitantes, em 1970, Recife e Salvador ultrapassavam um milhão de habitantes e Fortaleza se aproximava dessa cifra.

Verifica-se, hoje, uma diminuição desses movimentos porque, dentre outros aspectos, já não há na construção civil capacidade de absorver todo o contingente, e cada vez mais é exigida mão de obra qualificada, especializada, de acordo com a divisão social e territorial do trabalho que se torna complexo nas metrópoles brasileiras. Entretanto, esses fluxos 
migratórios ainda se mantêm representativos na configuração da mobilidade espacial brasileira, sobretudo, para suprir a falta de trabalho no Nordeste.

É neste quadro de intensa mobilidade espacial, catalisada pelo surto de desenvolvimento econômico que marcou o período 1968-1973, conhecido como Milagre Brasileiro, e assolado pelo baixo índíce de desenvolvimento humano (IDHM) da região que, em 1970, era de apenas de 0,299 , enquanto o do País como um todo alcançava o valor de 0,494 (MINISTÉRIO DA INTEGRAÇÃO NACIONAL et all; 2006, p.32), que se deu a reformulação e expansão do ensino universitário no Nordeste.

\section{- A Reforma no Nordeste}

As universidades federais do Nordeste, assim como as demais de todo o País, iniciam o processo de implantação da Reforma, buscando atender aos princípios básicos da não duplicação de meios para fins idênticos ou equivalentes e da integração do ensino, da pesquisa e da extensão. Como decorrência, o espaço físico passou a ser objeto de atenção especial, principalmente porque na organização anterior, com a configuração de escolas isoladas, não havia o compartilhamento dos recursos entre elas. Contrapondo-se a esse quadro, a distribuição das construções deveria, portanto, aproximar as instalações do sistema básico entre si, e mantê-las adjacentes às correspondentes áreas profissionalizantes. Na base física, encontraram, então, obstáculos a serem vencidos, antes que se pudesse, a rigor, adotar os princípios na prática.

Vultosos investimentos, feitos anteriormente, na construção e
instalação de escolas, quer em áreas muito densas, quer em 'campi'
planejados de acordo com parâmetros característicos de um ensino
eminentemente profissionalizante, exigiram cuidadoso
remanejamento do espaço físico (MEC/ISP, 1975, p. 386).

Para aplicação dos recursos financeiros, o Governo estabeleceu critérios para a expansão do espaço físico, no artigo $2^{\circ}$ do Decreto 63.341 , de $1^{\circ}$. outubro de 1968 , destacando (MEC/ISP, 1975, p. 386):

1. A importância do campus, como local de concentração das construções universitárias.

2. A preferência a ser dada, dentro de cada universidade, à construção das unidades do sistema básico.

3. A necessidade de ser evitada a construção de novos hospitais de clínicas. 
Com o objetivo de avaliar, dentre outros, a atitude assumida pelas universidades depois da Reforma, quanto à distribuição do espaço físico, o MEC elaborou pesquisa, publicada no documento intitulado Avaliação da Implantação da Reforma Universitária Universidades Federais (MEC/ISP, 1975), que apresenta uma análise da situação atualizada até o ano de 1975.

Nesse sentido, o estudo procurou analisar a localização das instalações, as características das edificações e as áreas construídas para as diversas atividades universitárias (MEC/ISP, 1975, p. 386). Em relação ao local das instituições federais do Nordeste, constatou-se que:

1. A Universidade Federal de Sergipe (UFS) implantou inicialmente mais de $50 \%$ de sua área construída, depois da Reforma, na malha urbana da cidade. Somente em 1974, com a aquisição do terreno é que se inicia a construção do campus e a posterior transferência de parte das suas instalações.

2. A Universidade Federal de Alagoas (UFAL) direcionou o planejamento para a construção de todas as suas instalações no campus, ao contrário da orientação tomada pela Universidade Federal do Rio Grande do Norte (UFRN) que, mesmo já possuindo o espaço definido para o campus, edificou $55 \%$ de sua área total existente fora deste.

3. As Universidades Federais de Pernambuco (UFPE) e da Bahia (UFBA) mesmo antes da Reforma se preocupavam em estabelecer suas unidades em território unificado, dando início à construção da cidade universitária, já tendo, inclusive, edificado nesses espaços grande percentagem de sua área total existente naquele período. Com essa configuração, tornava-se fácil se adequar à proposta de campus.

Em relação às demais universidades federais nordestinas, nossa pesquisa constatou que:

4. A Universidade Federal do Ceará (UFC) decidiu pela transferência das instalações em área de campus, em terreno de sua propriedade, embora tendo parte de suas construções implantadas em áreas diferentes da cidade de Fortaleza.

5. A Universidade Federal do Piauí (UFPI) funcionou em edificações já existentes na malha urbana da cidade até a aquisição do terreno do campus, quando iniciou suas construções e posterior transferência.

6. A Universidade Federal do Maranhão (UFMA), da mesma forma que a do Piauí, teve suas primeiras instalações na malha urbana da cidade, na área do centro histórico, e em 1972 inaugurou suas novas instalações no campus universitário.

7. A Universidade Federal da Paraíba (UFPB), que havia erguido parte das suas construções na proposta de cidade universitária, deu prosseguimento, readequando sua base física ao modelo de campus universitário. 
Com referência às características das construções, o documento destaca 0 caráter de sobriedade, ressaltando que o novo cenário indicava que já estava ultrapassada a fase de construções suntuosas e com grandes espaços ociosos (MEC/ISP, 1975, p. 388). Sobre as edificações das instituições nordestinas (MEC/ISP, 1975, p. 388-389), revela que:

1. A UFPI apresentou dois padrões: um para a construção de edificações destinadas aos serviços gerais, em estrutura de ferro, cobertura de cimento amianto e paredes divisórias de tijolo aparente; e outro para aquelas voltadas ao ensino e à pesquisa, com estrutura de concreto armado e paredes divisórias móveis.

2. A UFAL adotou construções com estrutura de concreto armado, paredes de alvenaria, divisórias com painéis removiveis, cobertura de telhas de cimento-amianto, pisos de cerâmica, de madeira ou alumínio.

3. A UFC procurou uma solução que permitia condições de flexibilidade e versatilidade do sistema. Adotou a esquematização de blocos padronizados, com sistema construtivo em concreto armado, "materiais simples" e de fácil manutenção, e coberta em telhas de amianto.

4. A UFRN destacou a proposta de espaços internos e externos modulares, com esquadrias de alumínio e divisórias de madeira, revestimentos com pedra e prédios térreos, basicamente.

5. A UFPB, também com edificações em piso térreo, adotou blocos modulados e fachada de concreto e tijolo aparente.

6. A UFPE informou que adotou padrão de construção compativel com a realidade nordestina e disponibilidade de recursos financeiro, mas não forneceu maiores esclarecimentos (MEC/ISP, 1975, p. 389). [Não foi identificado na pesquisa].

7. A UFBA comunicou que estudou uma tipologia visando construções econômicas, moduladas e flexíveis (MEC/ISP, 1975, p. 389). [Não foi identificado na pesquisa].

8. A UFS, conforme avaliação realizada, não apresentou um padrão de construção préfixado.

9. A UFMA adotou o padrão de construção em concreto aparente, destacando tratar-se de estruturas em quadros hiperstáticos de concreto aparente (MEC/ISP, 1975, p. 389).

Os dados apresentados pelo MEC (1975) revelam que a universidade brasileira vivenciava um intenso momento de reformulação da base física, onde o campus era a tipologia espacial predominante almejada. 


\section{UNIVERSIDADE FEDERAL DO CEARÁ (UFC)}

A Universidade Federal do Ceará é uma instituição autárquica vinculada ao Ministério da Educação e com sede na cidade de Fortaleza, capital do Ceará. Atua em vários municípios com a seguinte estrutura: em Fortaleza, com os campi do Pici, do Porangabuçu e do Benfica (que sedia a Administração Superior) além de unidades dispersas como a Casa José de Alencar, o Laboratório de Ciências do Mar (LABOMAR) e Fazendas Experimentais; em Sobral e Quixadá, com campi que levam o nome dessas cidades; e, na Região do Cariri, o Campus Cariri, que abrange os municípios de Juazeiro do Norte, Barbalha e Crato (ver figura 4).

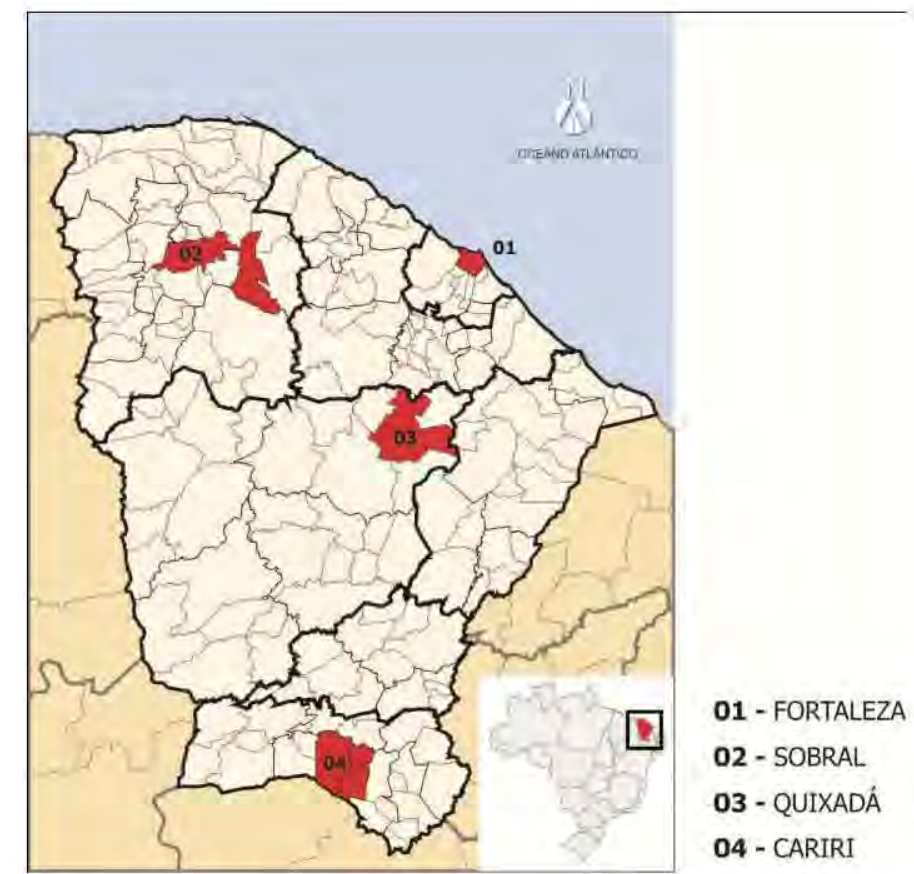

Figura 4: UFC - Mapa do Ceará.

Localização dos municípios que sediam a UFC.

(Fonte: UFC, 2006, p.17).

\subsection{CRIAÇÃO DA UFC}

A criação de uma universidade no Ceará tem origem nos anos de 1940. A historiografia da Instituição registra que a mesma resultou de um amplo movimento de opinião pública, liderado por entidades culturais. Nas palavras do arquiteto Joaquim Oliveira, professor do Departamento de Arquitetura da UFC, 
Sua criação foi produto de um longo processo de maturação nascido da fantasia de alguns poucos visionários que, alimentado pela mobilização favorável dos estudantes da época, resultou na formação do "Movimento Pró-Criação de uma Universidade no Ceará". Este movimento foi o responsável por manter a sociedade cearense unida em prol da pretendida universidade por uma década inteira, entre os anos 1944 e 1954 , que corresponde ao período de mobilização despendido para a concretização deste sonho. (OLIVEIRA, 2005, p.36)

O movimento buscou o apoio dos estabelecimentos de ensino superior do Estado, tendo como principal interlocutor o intelectual e professor da Faculdade de Direito do Ceará Antônio Martins Filho, que se tornou o primeiro reitor da Instituição.

Em 1944, quando se deu concretamente a primeira manifestação, em documento oficial, sobre a criação de uma universidade com sede em Fortaleza, por ocasião do processo de refederalização da Faculdade de Direito do Ceará, funcionavam na capital as seguintes unidades de ensino superior com seus respectivos anos de fundação: a mencionada Faculdade de Direito do Ceará (1903), a Faculdade de Farmácia e Odontologia do Ceará (1916), a Escola de Agronomia do Ceará (1918), a Faculdade de Ciências Econômicas do Ceará (1936) e a Escola de Enfermagem São Vicente de Paula (1943).

Embora as intenções de fundar uma universidade não tenham deixado de ser objeto das cogitações de importantes setores da opinião pública do Estado, foi somente em 1947 com a criação da Faculdade Católica de Filosofia, que o tema voltou efetivamente ao debate, tendo em vista o crescente número de estabelecimentos de ensino superior - condição de favorecimento à criação de uma instituição universitária, conforme determinação da legislação em vigor.

Em 1951, no contexto de federalização de faculdades e sua reunião para formar novas universidades, empreendida pela ação populista do Governo Federal (OLIVEIRA, 2005, p.37), vislumbrou-se uma nova oportunidade de encaminhamento dos esforços iniciados. Naquele ano, o quadro de estabelecimentos de ensino superior em Fortaleza, graças ao processo de expansão, contava com o funcionamento da Faculdade de Medicina (1948) e da Escola de Serviço Social (1950). Entretanto, somente em 1953 é que as articulações junto ao Governo Federal, agora no sentido de criar uma universidade federal, culminaram com a promulgação da Lei $n^{\circ} 2.373$ de 16 de dezembro de 1954 , criando a Universidade Federal do Ceará.

Foi constituída pela Faculdade de Direito do Ceará, Faculdade de Farmácia e Odontologia do Ceará, Escola de Agronomia do Ceará - todas mantidas pelo Governo Federal - e 
Faculdade de Medicina do Ceará - de caráter particular, sustentada pelo Instituto de Ensino Médico, federalizada pela mesma deliberação. Posteriormente, incorporou a Faculdade de Engenharia, que passou a se chamar Escola de Engenharia, criada pela Lei $n^{\circ} 2.383$ de 3 de janeiro de 1956 . A instalação ocorreu no ano seguinte à sua criação em sessão do dia 25 de junho.

\begin{abstract}
As medidas adotadas pela Reitoria, para a rápida consolidação da Universidade, relacionaram-se com a promulgação da Lei $n^{\circ} 2.700$, de 29 de dezembro de 1955 , que definiu com mais precisão sua autonomia administrativa, com a ampliação da Faculdade de Medicina, com a instalação imediata da Escola de Engenharia (1957) e, sobretudo, com a dotação de recursos orçamentários que permitissem executar as tarefas iniciais que se impunham (UFC, 1966, p.9).
\end{abstract}

A partir de então disputas por poder e prestígio se constituíram nos principais elementos que conformaram o contexto de implantação da nova instituição ${ }^{19}$. Dentre eles, destacamos o embate pela consolidação e divisão do poder interno, com a participação de três segmentos - os advogados, os médicos e os agrônomos - que foi determinante na produção do espaço físico-geográfico da UFC.

Partindo do modelo de reunião de faculdades profissionais dispersas na malha urbana, esse desenho logo se transformou, concentrando as instalações em torno de três áreas de interesse: uma no bairro do Benfica, onde se instalou a Reitoria, outra no Porangabuçu, para onde se transferiu a Faculdade de Medicina, sob o domínio dos médicos e terceira, a do $\mathrm{Pici}$, onde se concentrou a Escola de Agronomia, área de influência dos agrônomos. $\mathrm{O}$ arquiteto e professor do Departamento de Arquitetura da UFC, Joaquim Oliveira avalia que a formação do território em áreas distintas garantia as condições de poder dos grupos de maior prestígio:

[...] o poder da burocracia do Estado, representado pela Reitoria e o prestígio das corporações profissionais de médicos e agrônomos, que vão ter na delimitação de seus territórios a cidadela para a afirmação da sua singularidade, requisito indispensável à preservação do controle das condições de promoção dos seus interesses (OLIVEIRA 2005, p.42).

Em tal circunstância, o novo arranjo institucional trouxe repercussões no mapa geográfico da Universidade, que resultou na produção do espaço de característica fragmentada, 
moldada pelo território das três áreas que acabaram se consolidando, conforme será exposto com maior aprofundamento no decorrer do capítulo.

Nos primeiros dez anos de sua existência, a UFC deu ênfase às atividades de ensino, sobretudo ao nível de graduação, tendo em vista a crescente demanda por maior número de vagas e as necessidades dos seus próprios quadros. Conforme dados da Universidade, considerando-se os cursos de graduação, a matrícula que, em 1955, era de 1.081 alunos, evoluiu, em 1965, para 3.964, o que representou uma quadruplicação no decênio (UFC, 1966, p.5).

O crescimento apresentado espelhava a demanda do mercado de trabalho que requeria profissionais agrônomos, engenheiros e economistas e para serviços médico-sanitarista, assim como a expansão do ensino médio, que causou uma pressão crescente no sentido de ampliação de vagas à UFC (UFC, 1966, p.5). Ao final de 1965, a estrutura acadêmica constituía-se de faculdades, escolas e institutos, com número de graduados em especialidades conforme quadro 3 abaixo:

Quadro 3: Número de graduados na UFC no período de 1955/1965.

(Fonte: UFC, 1966, p.19, edição nossa).

\begin{tabular}{|c|c|}
\hline Unidades Acadêmicas & $\begin{array}{c}\mathbf{N}^{0} \text {. de } \\
\text { graduados }\end{array}$ \\
\hline Faculdade de Direito & 828 \\
\hline Faculdade de Medicina & 407 \\
\hline Escola de Agronomia & 357 \\
\hline Escola de Engenharia & 138 \\
\hline Faculdade de Ciências Econômicas & 362 \\
\hline Faculdade de Farmácia & 170 \\
\hline Faculdade de Odontologia & 259 \\
\hline Faculdade de Filosofia Federal & 16 \\
\hline Faculdade de Filosofia Católica de Fortaleza & 1.111 \\
\hline Escola de Serviço Social & 199 \\
\hline Escola de Enfermagem & 106 \\
\hline Instituto de Química & 4 \\
\hline Instituto de Física & 2 \\
\hline Instituto de Matemática & 4 \\
\hline Total & 3.963 \\
\hline
\end{tabular}

No tocante às atividades de pesquisa, ainda era um processo incipiente, com trabalhos concentrados nos setores de bioquímica, agronomia, biologia marinha, saúde pública e ciências sociais, enquanto que as de extensão estavam voltadas ao setor das letras e artes. $\mathrm{Na}$ segunda metade da década de 1960, a partir dos Decretos $n^{\circ} 53 / 1966$ e n $252 / 1967$, a UFC realizou, por meio do Decreto $n^{\circ} 62.279$, de 20 de fevereiro de 1968, reformas, organizando sua estrutura acadêmica em unidades de estudos básicos e de aplicação (ver 
quadro 4) - divididas em departamentos (menor fração da estrutura universitária) - e reunida em órgãos setoriais - centros - conforme quadro 5.

Quadro 4: Estrutura Acadêmica da UFC - Decreto n 62.279/1968.

(Fonte: Decreto $n^{0} 62.279,1968$, p.5-6)

\begin{tabular}{l|l}
\hline \multicolumn{1}{c|}{ Estudos Básicos } & \multicolumn{1}{c}{ De Aplicação } \\
\hline Instituto de Matemática & Escola de Engenharia \\
\hline Instituto de Física & Escola de Agronomia \\
\hline Instituto de Química & Faculdade de Medicina \\
\hline Instituto de Geociências & Faculdade de Odontologia \\
\hline Instituto de Biologia & Faculdade de Farmácia \\
\hline Faculdade de Estudos Sociais e & Faculdade de Ciências Econômicas e \\
Filosofia & Administrativas \\
\hline Faculdade de Letras & Faculdade de Direito \\
\hline Faculdade de Artes e Arquitetura & Faculdade de Educação \\
\hline
\end{tabular}

Quadro 5: Organização das unidades acadêmicas da UFC - Decreto n 62.279/20/1968.

(Fonte: Decreto $\mathrm{n}^{\circ} 62.279,1968, \mathrm{p} .7$ )

\begin{tabular}{|c|c|c|}
\hline \multicolumn{2}{|r|}{ Órgãos Setoriais } & \multirow{2}{*}{$\begin{array}{l}\text { Unidades Acadêmicas } \\
\text { - Instituto de Matemática } \\
\text { - Instituto de Física } \\
\text { - Instituto de Química } \\
\text { - Instituto de Geociências } \\
\text { - Instituto de Biologia }\end{array}$} \\
\hline a) & Centro de Ciências & \\
\hline b) & Centro de Humanidades & $\begin{array}{l}\text { - Faculdade de Estudos Sociais e } \\
\text { Filosofia } \\
\text { - Faculdade de Letras } \\
\text { - Faculdade de Artes e Arquitetura }\end{array}$ \\
\hline c) & Centro Tecnológica & $\begin{array}{l}\text { - Escola de Engenharia } \\
\text { - Escola de Agronomia }\end{array}$ \\
\hline d) & Centro de Ciências da Saúde & $\begin{array}{l}\text { - Faculdade de Medicina } \\
\text { - Faculdade de Odontologia } \\
\text { - Faculdade de Farmácia }\end{array}$ \\
\hline \multirow[t]{3}{*}{ e) } & $\begin{array}{l}\text { Centro de Estudos Sociais } \\
\text { Aplicados }\end{array}$ & - Faculdade de Direito \\
\hline & & $\begin{array}{l}\text { - Faculdade de Ciências Econômicas } \\
\text { e Administrativas }\end{array}$ \\
\hline & & - Faculdade de Educação \\
\hline
\end{tabular}

decreto de 1968 previa que, numa segunda fase da sua reestruturação, a UFC deveria desfazer os níveis intermediários, vinculando os departamentos diretamente aos respectivos centros, resultando na eliminação dos institutos. Com a lei da reforma - Lei $n^{\circ} 5.540 / 1968$ - a Universidade deu prosseguimento à sua reformulação acadêmica, consolidando o sistema departamental por meio do Decreto $n^{\circ} 71.882$ de 1973. A partir desse documento, a estrutura da Universidade estava oficialmente em consonância com a matriz ditada pelo projeto do Governo Federal, compondo-se por Reitoria (constituída pelos Órgãos Administrativos, de Coordenação, Suplementares e Auxiliares) e seis centros de 
conhecimentos afins (Centro de Ciências, Centro de Humanidades, Centro de Tecnologia, Centro de Ciências Agrárias, Centro de Ciências da Saúde e o Centro de Estudos Sociais Aplicados).

A nova estrutura acadêmica, introduzida com a Reforma e que também trouxe implicações na organização espacial, indicando a adoção do território único, demandou da Universidade a elaboração de planos e projetos visando proceder à reforma física no modelo de campus universitário. A história da UFC revela, entretanto, que o anseio de superar sua condição de origem, com a reunião de estabelecimentos dispersos na malha urbana da cidade, delineou tipologias espaciais que sempre estiveram envolvidas com a proposição de organização em base unificada, onde a Reforma foi efetivamente o principal patrocinador do intento de consolidação do campus único.

\subsection{O TERRITÓRIO DA UFC: configuração espacial tripartida}

A recém-criada universidade iniciou suas atividades nos imóveis das instituições que the deram origem. Foram encampados na forma da lei, passando a constituir seu patrimônio imobiliário, os prédios da Faculdade de Medicina, da Faculdade de Farmácia e Odontologia e o da Faculdade de Direito, situados na estrutura urbana da cidade e dois terrenos localizados em áreas mais afastadas, sendo um no sítio do Pici, Distrito de Antônio Bezerra, onde já funcionava a Escola de Agronomia e uma gleba de terra no Porangabuçu, doada ao instituto de Ensino Médico para a construção do hospital-escola da Faculdade de Medicina, onde funcionava com financiamento do Estado um pavilhão de isolamento (OLIVEIRA, 2005, p.42). As edificações caracterizavam-se pela filiação estilística que variava entre uma arquitetura de feições neoclássicas e estilo art déco, revestidas pelos ditames do ecletismo, assumido pelas elites como expressão de bom gosto até a primeira metade do século XX em Fortaleza (ver figura 5).

Com as unidades dispersas na malha urbana, a Universidade empreendeu num primeiro momento esforços de reuni-las gradativamente em uma mesma área, procurando consolidar sua base física unificada em zona urbana consolidada. A proposta diferia de outras instituições congêneres que escolheram glebas de grandes extensões para se instalar nos moldes de uma cidade universitária. Houve, entretanto, iniciativas para a aquisição de terrenos com a finalidade de construir essa tipologia espacial em terreno situado em subúrbio afastado. A opção, diante dos conflitos de interesses das corporações profissionais que the deram origem, foi inviabilizada, situação que determinou a consolidação das três 
áreas que moldaram seu território físico-espacial: Benfica, Pici e Porangabuçu. Atualmente, elas se encontram imersas no tecido urbano da cidade, conforme se constata na figura 6.0 contexto histórico que determinou a materialização de cada uma delas esclarece suas características urbanas e arquitetônicas.

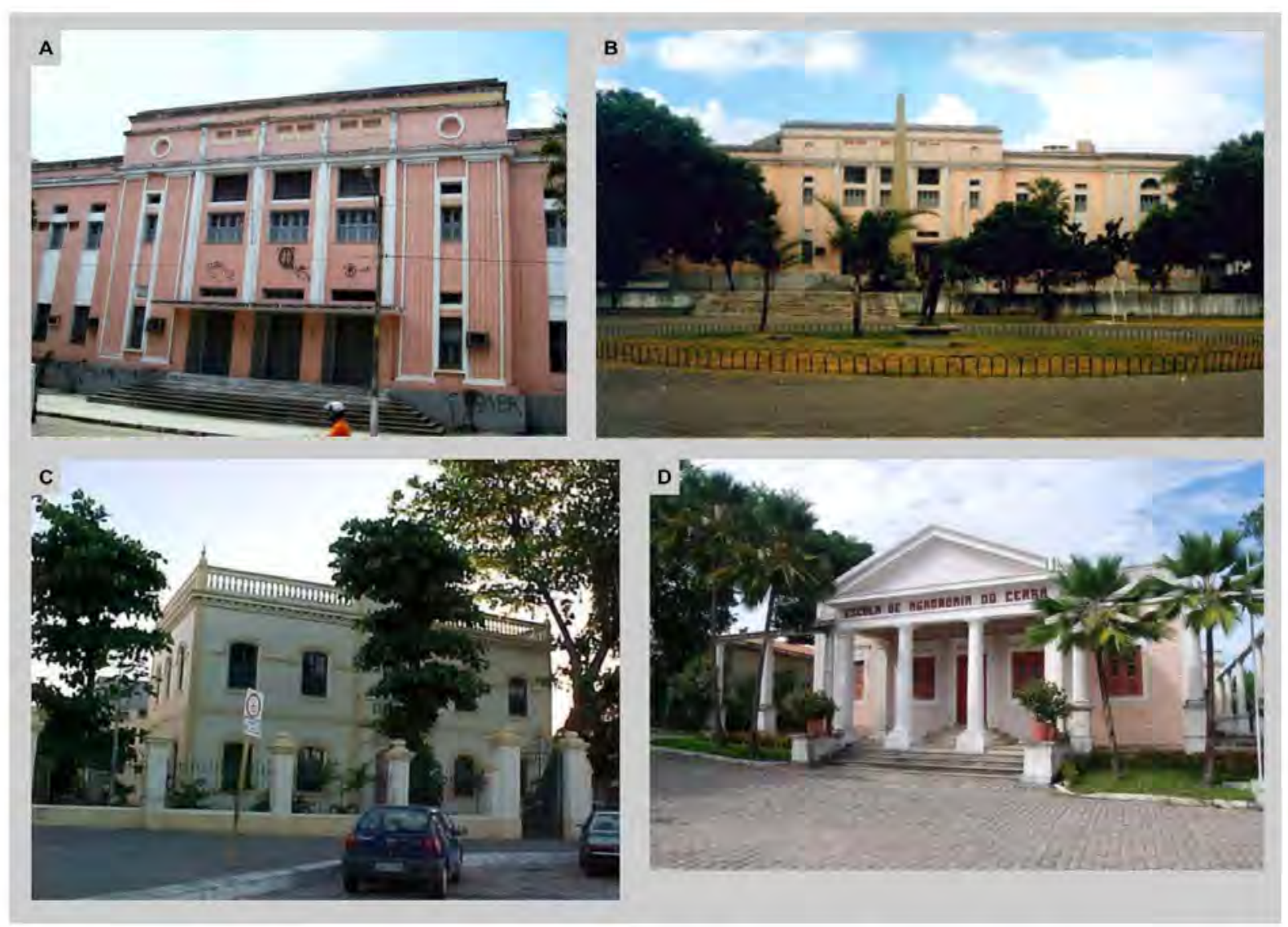

Figura 5: UFC - Primeiras edificações com predominância de construções ecléticas.

(A) Prédio da antiga Faculdade de Direito do Ceará - Década de 1980. Localizado próximo ao centro da cidade, foi incorporado ao patrimônio da UFC, onde permanece funcionando o Curso de Direito.

(Fonte: Disponível em <http://www. panoramio.com/photo/16928877> Acesso em: 06 mar. 2012)

(B) Faculdade de Direito da UFC - ano 2011. Vista pela Praça Clóvis Bevilacqua, localizada defronte à fachada principal do edifício.

(Fonte: disponivel em <http://www.direitoce.com.br/>. Acesso em: 06 mar. 2012)

(C) Prédio da antiga Faculdade de Medicina do Ceará - Década de 1980. Situado no centro da cidade, desde 1987 passou a sediar o IPHAN.

(Fonte: disponivel em < http://fortalezanobre.blogspot.com/2009/11/escola-normal-de-fortaleza.html>. Acesso em: 06 mar. 2012)

(D) Edifício da antiga Escola de Agronomia do Ceará. Situado no atual Campus do Pici, foi incorporado ao patrimônio da UFC, onde funciona a sede administrativa do Centro de Ciências Agrárias.

(Fonte: disponível em < http://www.panoramio.com/photo/27437361>. Acesso em: 06 mar. 2012). 


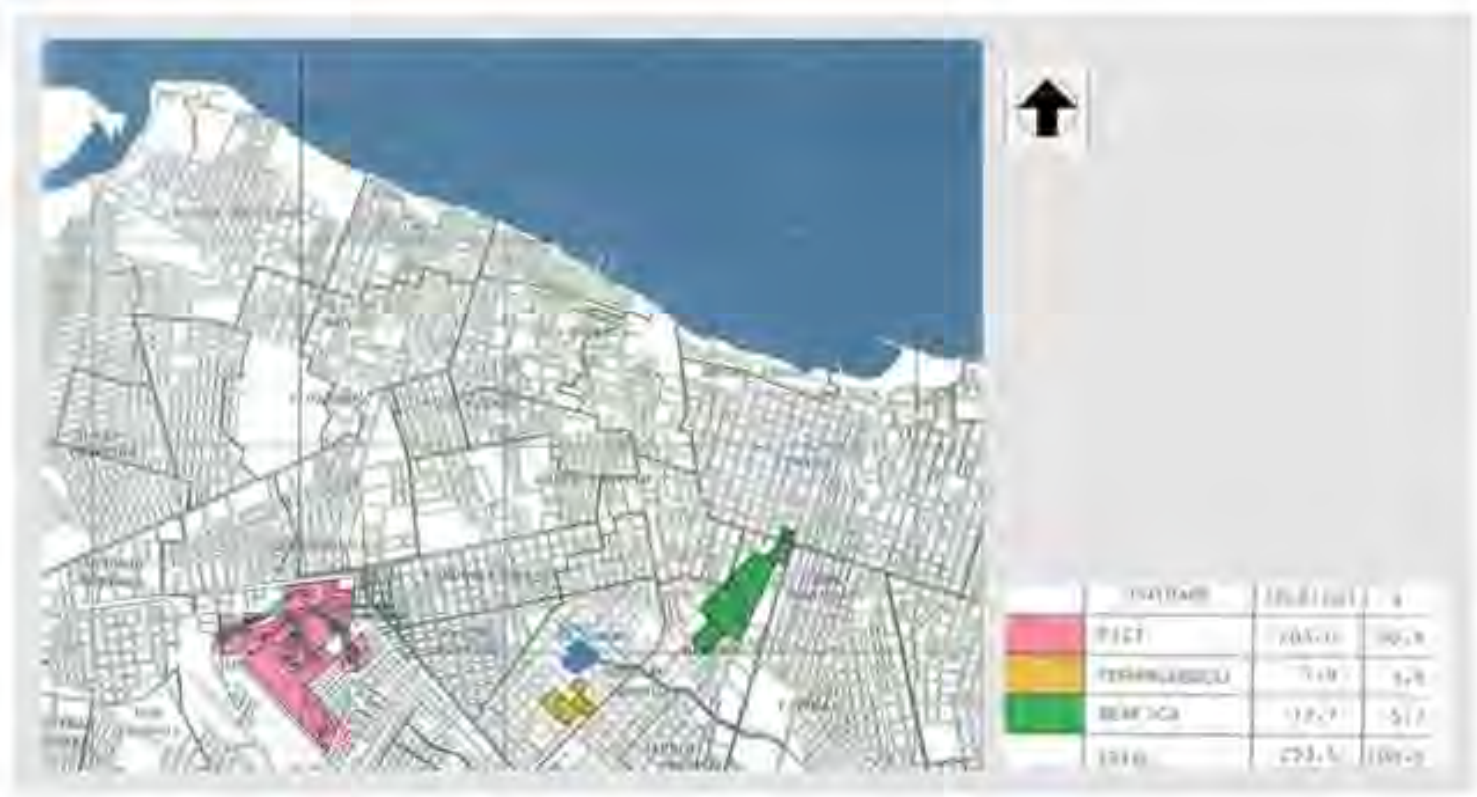

Figura 6: Mapa de Localizaçã̃o da UFC em Fortaleza.

Faculdade de Medicina implantada na gleba denominada Porangabuçu e na Administraçä́o Central que se instalou no bairro do Benfica, ao longo do eixo da Avenida Visconde de Cauipe, que logo passou a se chamar Avenida da Universidade.

(Fonte: UFC, 1996 apud CAMPÉLO, 2005, p.45)

\section{- O Benfica e sua produção urbano-arquitetônica}

A área do Benfica tem origem na atuaçẩo do primeiro reitorado que ali instalou a sede da Reitoria, dando inicio a uma tipologia espacial de conformação urbana. Tratada pela Administraçăo Central com imperiosa relevância, fato que pode ser evidenciado pela crescente aquisição de imóveis até meados de 1960 destinados ao funcionamento das atividades universitárias, tinha o propósito de materializar a universidade recém-criada.

Para dar sentido concreto à nova instituiçäo, o funcionamento da Reitoria foi uma das primeiras preocupaçổes, tanto que apenas quatro meses depois de instalada a Universidade, passou a ter sua sede próxima à Faculdade de Direito, ainda que provisória. O reitor Martins Filho, primeiro dirigente da nova instituição, assim explica:

Com efeito, consegui, mediante aluguel bem vantajoso, firmar um contrato de locação do imóvel tipo bangalô situado à Rua Senador Pompeu $n^{\circ}$. 1613 (na Praça da Bandeira, hoje, Clóvis Bevilacqua), a uns 100 metros do edifício da Faculdade de Direito. (MARTINS FILHO, 1999, p.41).

A importância, entretanto, de marcar a presença da jovem instituição no melo cultural da cidade e mesmo em sua paisagem urbana (CASTRO, 2004, p.191) culminou com a compra do imóvel que passou a sediar a unidade administrativa superior. Assim é que após um funcionamento provisório de seis meses à Rua Senador Pompeu, ela foi transferida para o 
bairro do Benfica, quando em abril de 1956, foi adquirida a propriedade onde hoje está instalada a Reitoria. Tratava-se da residência de José Gentil Alves de Carvalho, figura destacada na sociedade loca ${ }^{20}$, conhecida como o Solar da Família Gentil (ver figura 7 ).

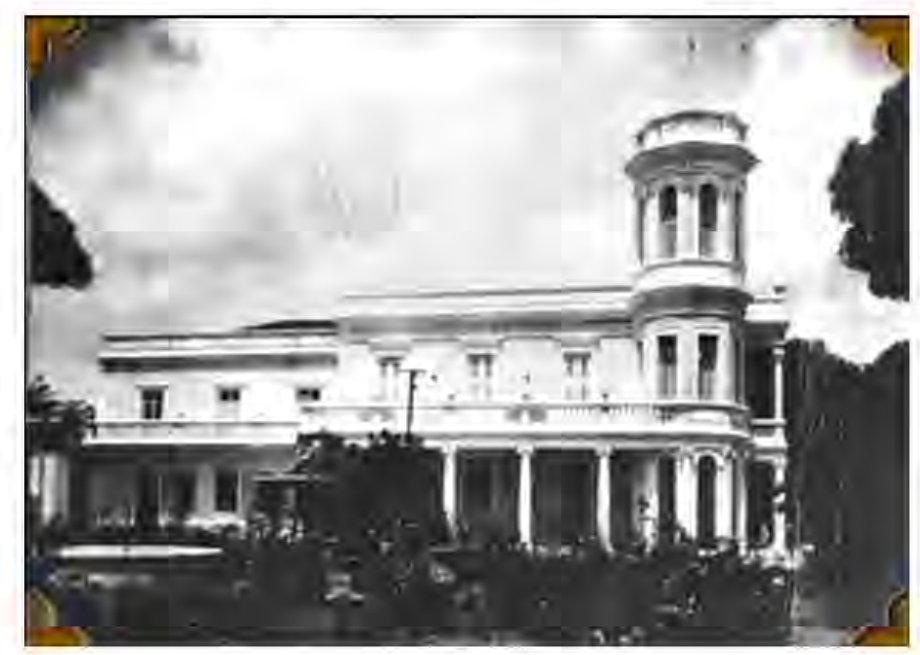

Figura 7: UFC - Palacete Gentil - Período da instalação da Reitoria em 1956.

Edifício de linguagem arquitetônica eclética.

(Fonte: Disponivel em < http://fortalezan obre.blogspot.com/2010/04/gentilandiapalacetes-sobrados-e.html Acesso em: 06 mar. 2012)

Em ambas as realizações, vale apontar que a intenção era a de se instalar no tecido urbano. No primeiro caso, vizinho à Faculdade de Direito, e no segundo, a cerca de um quilômetro dessa unidade, que nesse caso, conforme Oliveira (2005, p.43-44), propiciava um desejável distanciamento do centro da cidade onde se concentravam as outras unidades, situação que permitiria a afirmação da autoridade da Reitoria, transformando-se no centro do poder acadêmico e conferindo materialidade e identidade à instituição. Além do que a localização oferecia facilidade de acesso e disponibilidade de terreno para futuras ampliações.

Com situação estratégica na estrutura urbana, correspondendo ao cruzamento de importantes eixos de ligação norte/sul - Avenida da Universidade - e leste/oeste - Avenida 13 de Maio - da cidade, a localização da Reitoria permitia estabelecer relações com os demais setores da cidade, bem como com as duas outras áreas de unidades acadêmicas estabelecidas no Porangabuçu e no Pici.

Importante destacar que o Benfica foi considerado, no primeiro quartel do século $X X$, um dos bairros mais elegantes de Fortaleza, preferido pelas classes dominantes. Conformava uma ocupação predominante em chácaras de terrenos generosos, que passaram a representar símbolo de status social e econômico (ver figura 8). Embora no período de

\footnotetext{
${ }^{20}$ O imóvel havia sido residência do empresário, João Gentil, entre o final do século XIX até início dos anos 1940, quando veio a falecer. A família Gentil destacava-se pela pujança econômica advinda do comércio do algodão e posteriomente de negócios bancários, comércio de terra e empreendimentos im obiliários.
} 
aquisição e instalação da sede definitiva da Reitoria, o mesmo já estivesse em declínio com o deslocamento das elites para o bairro da Aldeota, ainda permanecia a carga simbólica de poder e ostentação no imaginário da sociedade local, situação que contribuía para a escolha daquele endereço. A partir de então, gradativamente no decorrer dos anos, importantes órgãos e unidades acadêmicas foram sendo instalados ao redor da Reitoria, consolidando a estrutura administrativa e acadêmica naquela área.

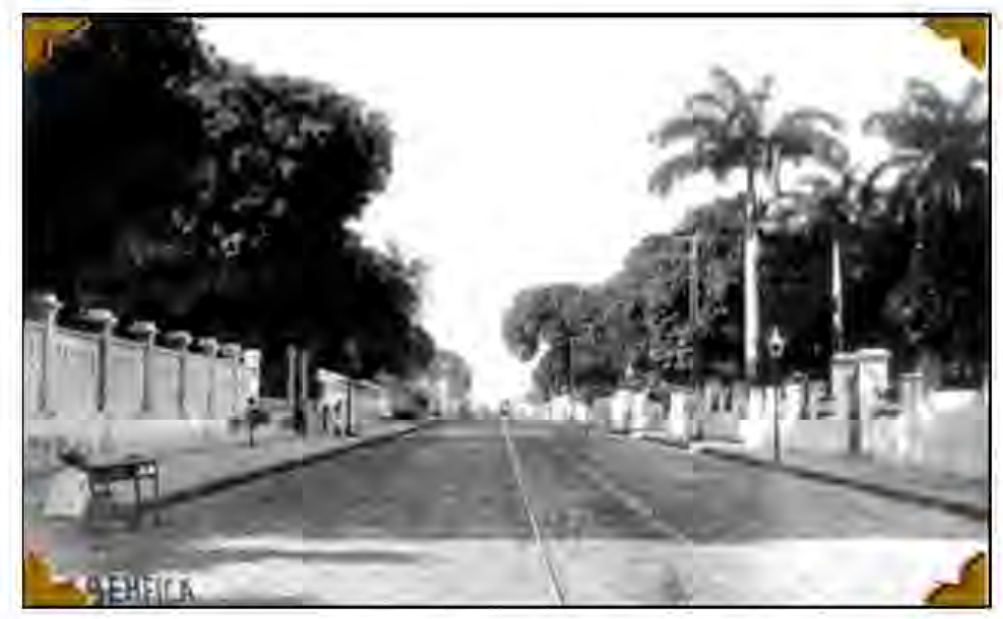

Figura 8: UFC - Bairro do Benfica.

Vista da Avenida da Universidade, então Avenida Visconde de Cauípe - anos1930 (Foto anterior à instalação da Reitoria). A quadra à direita foi adquirida para sediar a Reitoria. A paisagem era dominada pela densa arborização das chácaras.

(Fonte: CASTRO, 1997, n.p.)

\section{- Quadra - unidade territorial da configuração urbanística}

O território universitário que passou a se configurar não foi, entretanto, resultado de uma ação planejada. O processo de ocupação foi se dando pela compra de imóveis disponíveis para a venda. Posteriormente, a Universidade passou a definir suas demandas, selecionando aqueles que the interessava comprar e gradativamente conformar o território da Universidade. Oliveira $(2005, \mathrm{p} .92)$ analisa que o urbanismo que moldou a estrutura física da Instituição naquela área foi movido pelo propósito de integrar e promover o convívio da comunidade que ali se instalava. A partir de então um intenso processo de demolição, construção e reformas passou a ser executado: as edificações que serviam às suas necessidades foram preservadas, adequadas e ampliadas, enquanto que aquelas que não se prestavam às novas funçōes foram substituídas por outras. Na estrutura fundiária, o lote passou a ser trocado pela quadra como unidade territorial básica. Eliminando os muros entre eles, os lotes foram reagrupados, criando glebas compativeis com as dimensões das novas demandas sem o risco de fracionamento espacial ou do isolamento das unidades 
(OLIVEIRA, 2005, p.92), condição que contrariava o sentido de unidade que se pretendia construir (ver figura 9). Nas palavras de Oliveira, a

[...] quadra aberta ao livre trânsito das pessoas perde o sentido de barreira que the é inerente, permitindo a apropriação pública deste espaço e estimulando, em quem por ali circula, o sentimento de inclusão e pertenciamento, fazendo com que universidade e cidade se integrem numa simbiose perfeita. Com seus espaços abertos ocupados pela presença massiva de seus equipamentos e a pela agitação da vida estudantil, e animados pela realização de grandes eventos, o território da Universidade, no Benfica, passa a ser identificado como um local de todos, universitários ou não, transformando-se no grande espaço cívico da cidade. [...] Seria configurada mediante elementos estruturadores da vida universitária, com o core estabelecido na Reitoria, o espaço estudantil no Centro dos Estudantes Universitários e Residências Estudantis, as unidades de ensino e pesquisa e os diversos equipamentos culturais espalhados por toda área, complementados pela implantação de um setor esportivo com a futura incorporação do Estádio Presidente Vargas [Primeiro estádio oficial de futebol em Fortaleza] (OLIVEIRA, 1982, p.92).

O resultado positivo demonstrado com a expansão paulatina no Benfica por unidades acadêmicas e equipamentos culturais ensejou a ideia de ali se estabelecer o território definitivo da UFC. Com esse propósito, a Administração Superior realizou estudos para a desapropriação de uma extensa área, tendo como eixo de ocupação a Avenida da Universidade (eixo norte/sul da cidade), que formaria um corredor cultural, iniciado na Faculdade de Direito e - passando pela Reitoria - se estenderia até o canal do Jardim América, próximo ao Porangabuçu, onde estava sendo implantado o setor da Medicina. Ficaria limitada em um dos lados pela Avenida Carapinima e no outro pelas ruas Senador Pompeu e Marechal Deodoro. A área a ser desapropriada abrangeria quase todas as suas unidades universitárias, com exceção da Escola de Agronomia, funcionando no Pici. A proposta previa uma desocupação total dos limites mencionados, eliminando usos e atividades que não fizessem parte da Universidade. $O$ arquiteto Oliveira analisa que a proposta não caracterizava uma tipologia de bairro universitário, à moda da tradição francesa, mas um território exclusivo, monofuncional, tendo a Universidade, como usuária única do espaço exercendo, o domínio completo sobre ele (OLIVEIRA, 2005, p.93). Esta concepção de território universitário inserido na malha urbana, servindo-se da infraestrutura, aberto e permeável à comunidade contrapunha-se ao modelo de cidade universitária apartada do centro urbano, que, conforme já mencionado, se estabeleceu nas universidades brasileiras (ver figuras 10 e 11). 


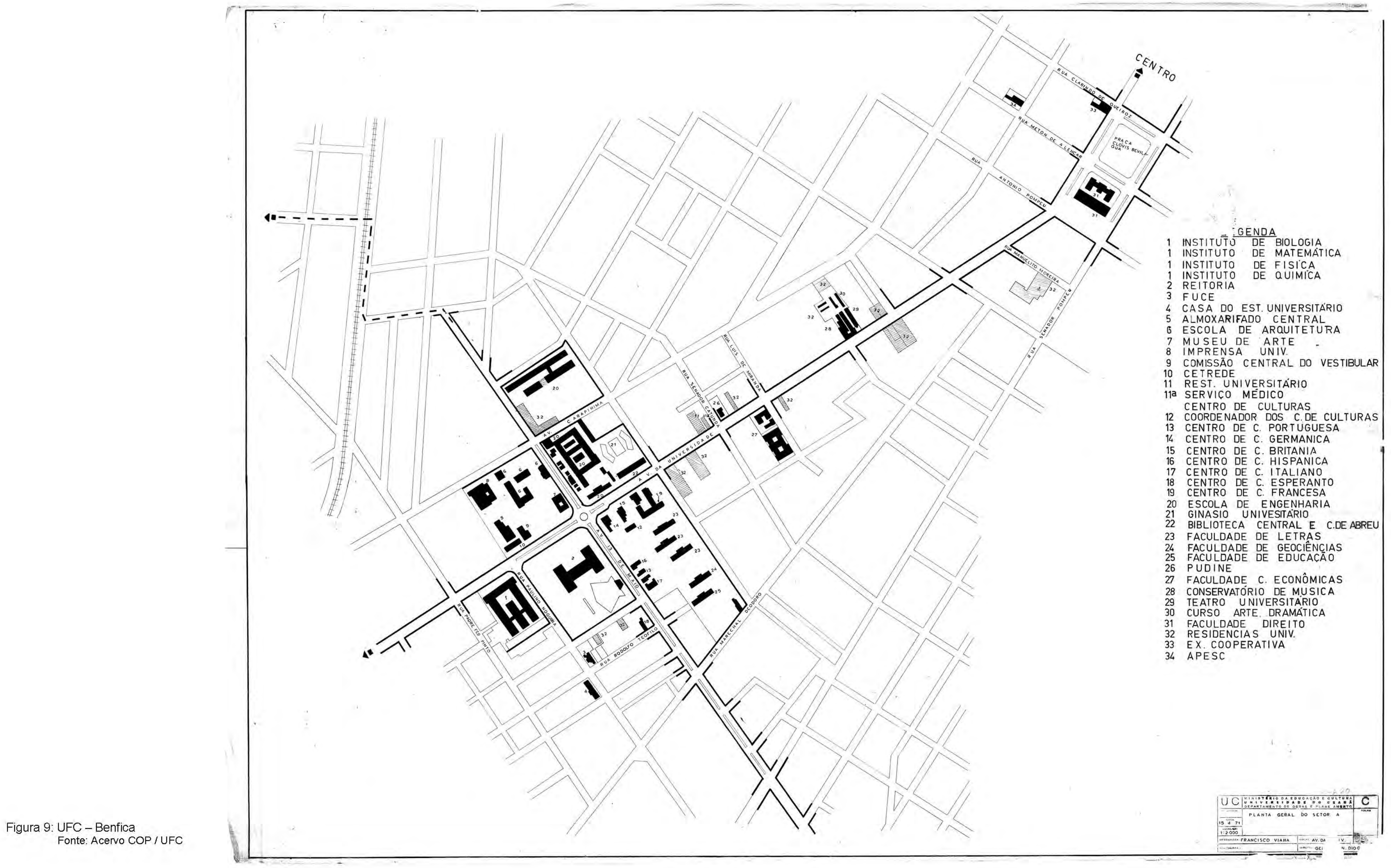




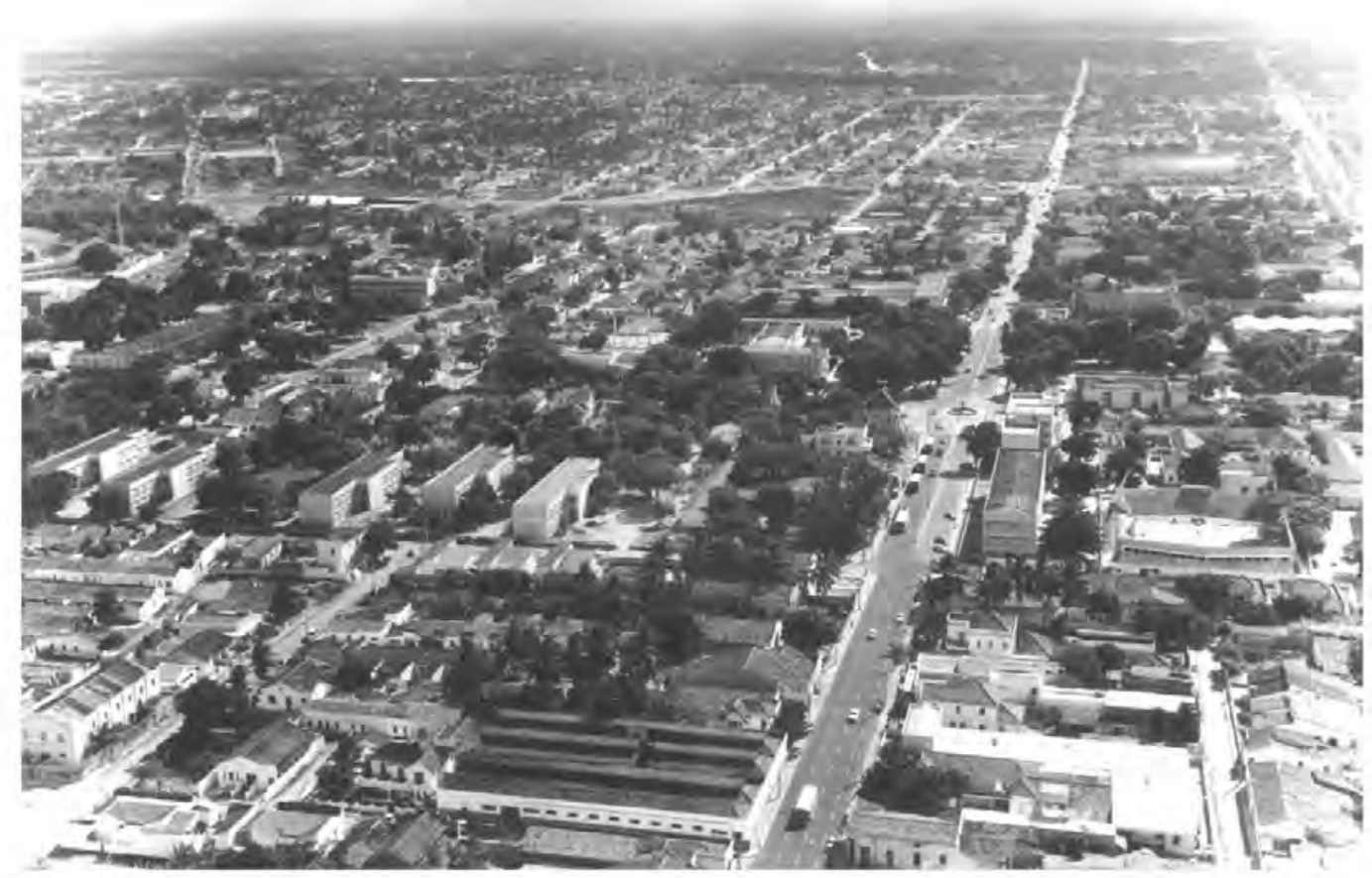

Figura 10: UFC - Vista do conjunto edificado do Benfica - 1971.

A ocupação se deu ao longo da Avenida da Universidade - via de ligação norte / sul da cidade. À esquerda, destacam-se os blocos da Faculdade de Filosofia Ciências e Letras. (Fonte: Acervo COP / UFC)

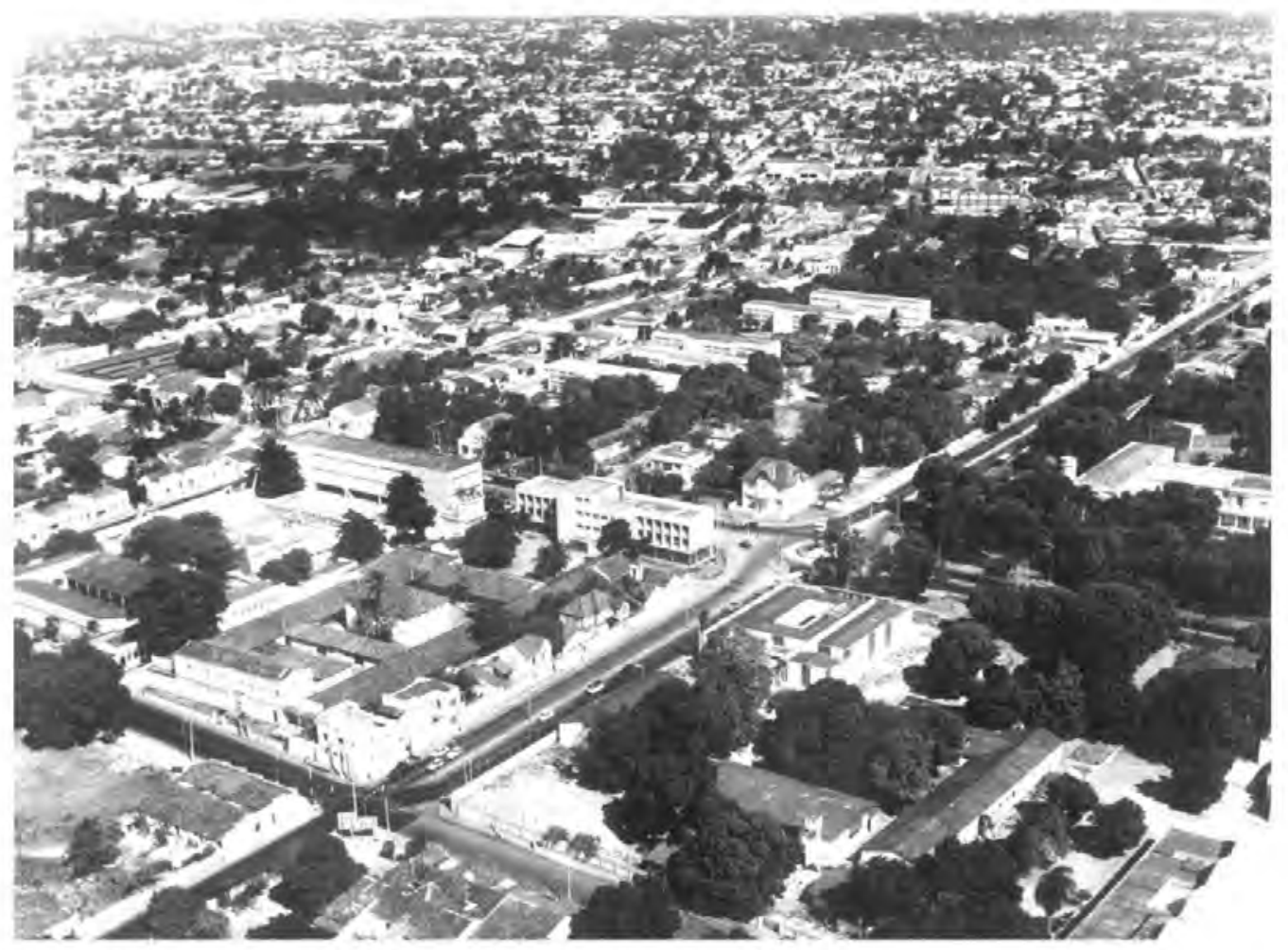

Figura 11: UFC - Vista do conjunto edificado do Benfica - 1971.

Destaca-se no centro da foto o cruzamento das avenidas 13 de maio - eixo de ligação leste / oeste da cidade - com a da Universidade. $\mathrm{Na}$ confluência das avenidas formam-se quatro quadras de ocupação da UFC: na quadra superior, à direita está a Reitoria, e à esquerda, o conjunto da Faculdade de Filosofia Ciências e Letras e as Casas de Cultura; na quadra inferior, à direita está implantado o Museu de Arte, e à esquerda, a Escola de Engenharia. (Fonte: Acervo COP / UFC) 
O estudo teve a participação do arquiteto cearense, José Liberal de Castro, que pertenceu aos quadros da UFC. Segundo o arquiteto cearense Neudson Braga, que também pertenceu aos quadros da Universidade, quando iniciado o planejamento de desapropriação da área demandada constatou-se, entretanto sua inviabilidade, tendo em vista que seria necessário desalojar um contingente populacional similar naquela época ao da cidade cearense de Iguatu (Informação verbal ${ }^{21}$ ). Além disso, os lotes eram de pequenas dimensões, tendo alguns remanescentes com palacetes como aquele no qual havia se instalado a Reitoria, fatores que tornavam oneroso o processo de aquisição. A proposta foi descartada após as constatações mencionadas, fato que, entretanto não impediu uma produção edilícia de importante valor arquitetônico no processo de ocupação do Benfica.

Para Oliveira (2005, p.72), a construção do território do Benfica foi regida por dois momentos distintos: um presidido pela necessidade de atender às demandas imediatas $e$ outro pelo desejo deliberado de ali se estabelecer, circunscrevendo-se a um espaço definido, para firmar sua identidade hegemônica como local de produção e transmissão do saber, consolidando-se como espaço legitimador da ciência e da cultura.

\section{- A obra de referências moderna}

O panorama arquitetônico que se desenvolveu manifestava os fundamentos do modernismo brasileiro praticado nas principais capitais do país. Essa produção foi favorecida pela atuação de jovens arquitetos nascidos no Ceará e que após diplomados em outros estados retornaram à terra natal a partir de meados da década de 1950 , introduzindo o legado do traço moderno que se contrapunha aos ditames da arquitetura eclética que ainda persistia em se manter na cidade de Fortaleza. Sobre esse aspecto o arquiteto cearense Liberal de Castro aferiu que $o$ quadro de ausência qualitativa projetual e construtiva era mantido pela atuação de leigos, inabilitados para desenvolver qualquer formulação teórica. Nas palavras do arquiteto,

[...] é possível identificar umas poucas obras, pelo menos até 1945 , com características de um modernismo arquitetônico local, sem, entretanto, evidenciar preocupação permanente com as inovações, de modo que se chega a supor que os projetistas talvez tentassem fazer o moderno como uma variante do ecletismo (CASTRO,1982, p.12).

Gradativamente a arquitetura de linhas modernas vai ganhando espaço, com a colaboração dos profissionais que haviam assimilado o novo repertório formal e projetual (CAMPÊLO,

${ }^{21}$ Entrevista concedida pelo arquiteto Neudson Braga em Fortaleza, 27 de abril de 2004. O texto é parte da Dissertação de Mestrado de nossa autoria (CAMPÉLO, 2005, p.288). 
2005 , p.33-34). A presença dos pilotis, da planta livre, da modulação estrutural que marca a fachada, diferenciando-se das vedações, a volumetria funcional e a adoção de elementos para proteção solar tais como o brise-soleil e o manuseio do combogó e da cor são soluções que marcaram a produção moderna com clara filiação à Escola Carioca.

No Benfica, o prédio da Escola de Engenharia e a concha acústica com auditório ao ar livre são dois dos primeiros testemunhos do novo cenário arquitetônico iniciado ainda na década de 1950 e que se entendeu aos anos sessenta.

\section{- Escola de Engenharia (1957)}

A Escola de Engenharia funcionou inicialmente em imóvel alugado, transferindo-se em 1957 para sede própria construída na quadra diagonalmente oposta à Reitoria, correspondendo à confluência das avenidas 13 de Maio e da Universidade, tendo sido a primeira das novas faculdades instalada no Benfica. A localização contribuiu para a transformação do entorno da Reitoria em área predominantemente universitária.

O edifício de três pavimentos foi projetado pelo engenheiro cearense Luciano Pamplona e o partido arquitetônico evidencia a volumetria funcional que destaca a caixa prismática retangular com dimensões de $50,30 \mathrm{~m} \times 9,50 \mathrm{~m}$, destinada às atividades acadêmicas, apoiada sobre pilotis e justaposta à caixa da escada e sanitários pela fachada de fundo. Confere aos pilotis a função de espaço de convivência, concebido como uma ampla área aberta, onde compartilham os pilares de geometria cilíndrica e uma alvenaria de combogó em forma curvilínea, que desempenha o papel de proteção à via. A fachada principal é marcada pelas esquadrias de alumínio e vidro modulada a cada $2,50 \mathrm{~m}$ em composição com o revestimento de pastilha cerâmica, que foi adotada no conjunto moderno da UFC (ver figura 12).

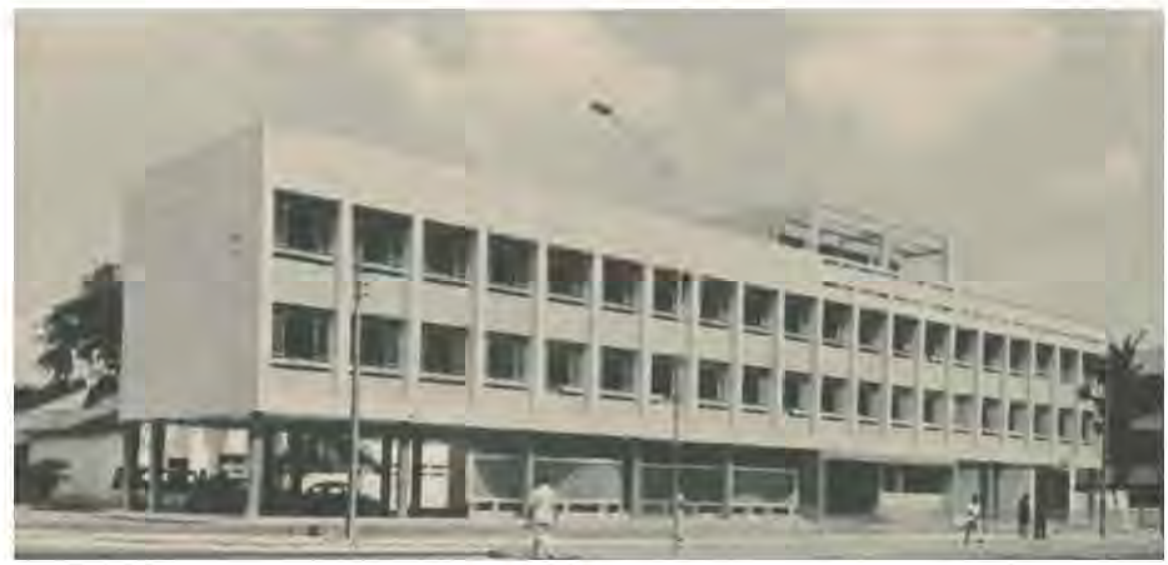

Figura 12: UFC - Escola de Engenharia - Década de 1960.

Vista do edifício pela fachada principal voltada para a Avenida da Universidade. (Fonte: UFC, 1966, n.p.) 
- Concha Acústica (1959)

A Concha Acústica com auditório ao ar livre, inaugurada em 1959, foi construída nos jardins da Reitoria. O projeto, de autoria dos arquitetos Fábio Kok de Sá Moreira e Ruth Kok de Sá Moreira, diplomados pela USP em 1958, resultou de concurso realizado pela FAU-USP. A obra de referências modernistas apresentava um programa composto pelas arquibancadas, com capacidade para 2.500 pessoas, palco e bloco de serviços. $O$ palco dividido em dois pavimentos abriga no térreo os camarins com banheiros e local para piano. No subsolo, localizam-se o depósito e a casa de bombas. A arquibancada se distribui em quatro módulos de bancos, divididos pelas circulações, tendo ao centro o principal corredor de acesso. As arquibancadas são ladeadas por sanitários no lado leste e por sanitários e cantina no lado oeste.

A forma arquitetônica se destaca pela estrutura em concreto armado, correspondendo à extensa laje plana inclinada sobre o palco, que liga as vigas das extremidades com a solução de pórtico engastado e desempenha a função de reflexão e difusão do som (ver figura 13).

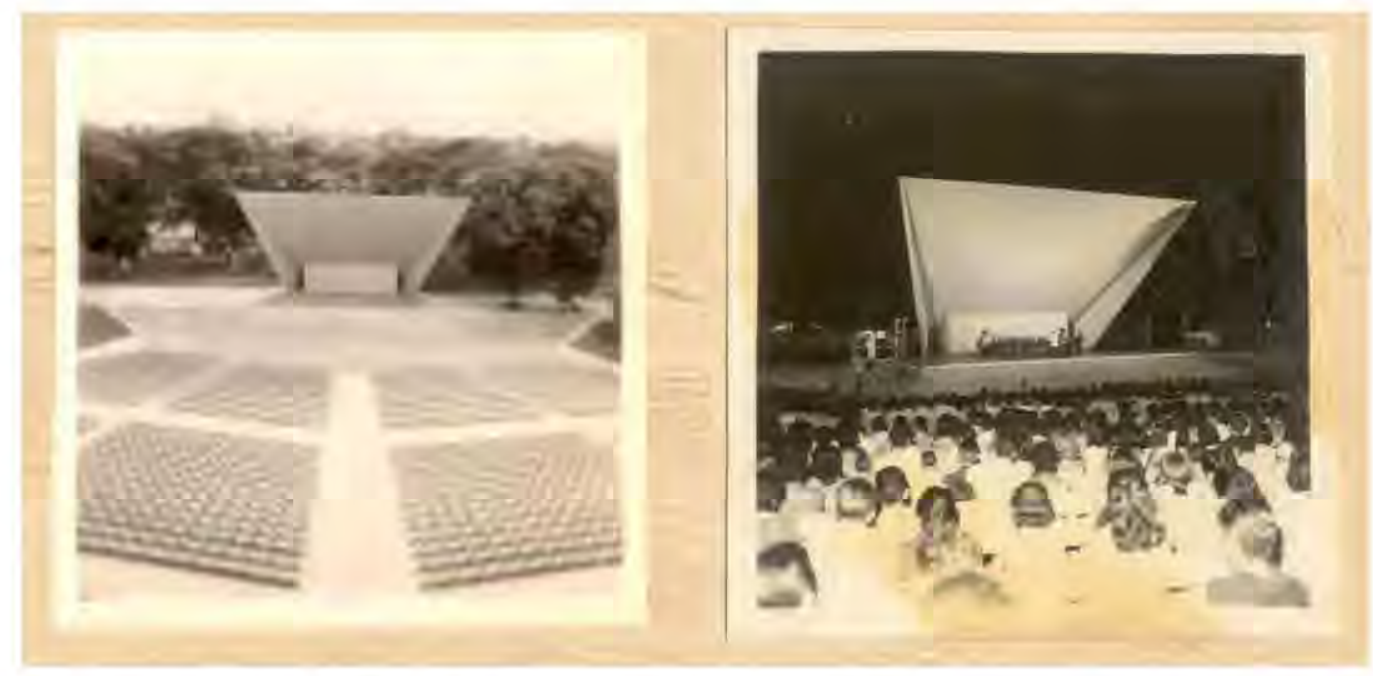

Figura 13: Concha Acústica com auditório ao ar livre. (Fonte: Acervo MAUC/UFC)

A produção de referências modernas do Benfica prosseguiu na década de 1960 , tendo agora a participação dos arquitetos cearenses José Liberal de Castro, Neudson Braga e Ivan Brito, os dois primeiros diplomados no Rio de Janeiro e o último no Recife, que vieram trabalhar no recém-criado Departamento de Obras e Planejamento da UFC, contribuindo para o patrimônio edificado de reconhecido valor modernista. 
Fato relevante que favoreceu a disseminação da nova arquitetura foi a criação, em fins de 1964, da Escola de Arquitetura da UFC, instalada no ano seguinte em imóvel existente na quadra defronte à Reitoria. Teve como primeiro diretor o arquiteto paulista Hélio Duarte, professor da Universidade de São Paulo, que contou com a colaboração dos profissionais pertencentes ao Departamento de Obras e Planejamento [dentre esses, os arquitetos cearenses acima mencionados]. São exemplares desse período, dentre outras, as instalações construídas para o Departamento de Cultura, para a Faculdade de Filosofia Ciências e Letras, para os Institutos Básicos - de Química, Matemática e Física, para o Museu de Arte, para a Residência Universitária e para a Imprensa Universitária.

\section{- Departamento de Cultura da UFC (1960)}

O prédio destinado originalmente ao Departamento de Cultura foi construído em 1960 na quadra defronte à Reitoria com a fachada principal voltada para a Avenida da Universidade. O projeto teve a autoria dos arquitetos Neudson Braga e Liberal de Castro que conceberam um edifício de dois pavimentos com planta livre de configuração retangular e dimensões de $30,60 \mathrm{~m} \times 8,85 \mathrm{~m}$, que se desenvolve em conformidade com o vão estrutural de $3,35 \mathrm{~m}$, evidenciando a busca da racionalização como diretriz operativa.

A forma arquitetônica destaca o módulo estrutural articulado com a esquadria de madeira e venezianas móveis - tipologias de fabricação local - arrematada pela platibanda da coberta que confere horizontalidade à volumetria de linhas retas do pavimento superior. Participam da composição, a marquise de laje plana que desempenha a função de linguagem de acesso ao saguão do edifício e os pilares de geometria cilíndrica destacados da alvenaria de vedação no pavimento térreo (ver figura 14).

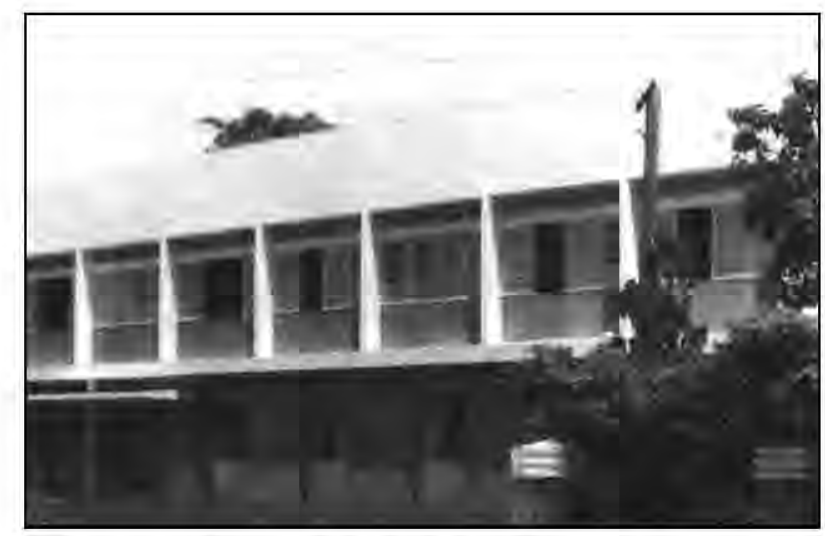

Figura 14: UFC - Antigo Departamento de Cultura - Ano 1967. A fachada principal voltada para a Avenida da Universidade é marcada pelo ritmo modulado da esquadria de madeira. (Fonte: DUARTE et al, 1996, 77) 
Castro (2004, p.209) esclarece que o saguão dividia o pavimento térreo em dois setores: à esquerda, estava o salão destinado à exposição de livros editados pela Imprensa Universitária ou recebidos de outras editoras, como a montagem de pequenas mostras de obras de arte, além de servir como palco para atos culturais de frequência restrita, cuja vedação frontal se dava pelo pano da esquadria de alumínio e vidro de piso a laje, conferindo transparência ao ambiente (ver figura 15). À direita do saguão, vedado com alvenaria de tijolo, o ambiente podia ser repartido por divisórias removíveis, proposto para atendimento ao público (CASTRO, 2004, p.209). A composição formal harmoniosa da arquitetura proposta testemunhava a filiação dos arquitetos aos cânones modernistas, que deram base às suas formações profissionais, porém buscando inserir a nova produção nos procedimentos construtivos da região.

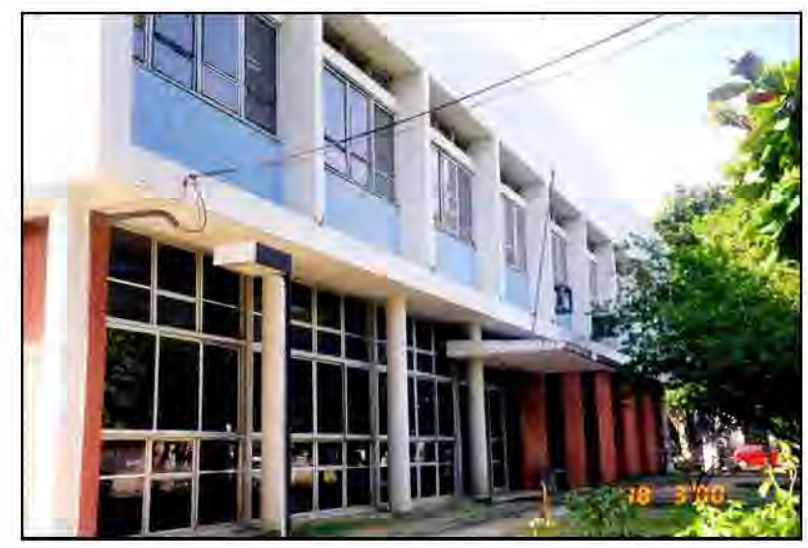

Figura 15: UFC - Antigo Departamento de Cultura - Ano 2000.

Vista da fachada principal com detalhe dos pilares, da marquise e do antigo salão destinado à exposição de livros com vedação em esquadria de alumínio e vidro. A pastilha cerâmica em cores (azul e branca) e o revestimento cerâmico vermelho compõem a forma arquitetônica de referências da Escola Carioca. As esquadrias de madeira foram substituídas por tipologias de alumínio e vidro.

(Fonte: Acervo COP / UFC)

\section{- Faculdade de Filosofia Ciências e Letras (1965)}

No mesmo ano de 1960, a UFC procurando romper com a estrutura universitária fundamentada na justaposição de instituições isoladas propôs a criação da Faculdade de Filosofia, Ciências e Letras como núcleo central de uma nova concepção estrutural de universidade, desvinculando-se da tradição herdada.

Instalada na quadra vizinha à Reitoria, em imóveis existentes que ali se estabeleceram no início do segundo quartel do século $X X$, logo a nova faculdade teve necessidade de mais 
espaço que resultou na construção de outros prédios, os quais foram erguidos na mesma quadra. Os três primeiros, dos cinco que seriam ali construídos, foram inaugurados em 1965 e o projeto teve a autoria do arquiteto Neudson Braga, que adotou o partido de princípio funcional-racionalista.

O edifício de dois pavimentos, concebido com a planta livre obedecendo à modulação de $1,25 \mathrm{~m} \times 1,25 \mathrm{~m}$, é constituído pelo conjunto volumétrico da caixa prismática retangular, em forma de barra, destinada às atividades didáticas, e por um volume justaposto que abriga os sanitários, copa e almoxarifado, interligados pela circulação longitudinal (ver projeto de arquitetura da figura $16 a$ à $16 \mathrm{~d}$ ). Com essa separação, o partido favorece a flexibilidade na organização espacial do corpo didático.

Destaca-se na fachada do corpo principal a estrutura modulada de $2,50 \mathrm{~m}$ que rege a padronização das esquadrias de madeira com venezianas móveis e vidro fixo na faixa superior - uma tipologia de fabricação própria da região largamente empregada em Fortaleza - a solução permite o controle da radiação solar direta sem impedir a circulação do ar. A composição arquitetônica é complementada pelo revestimento em pastilha cerâmica de cores claras, também de fabricação local, que contribui para o partido de formas singelas e de intenções racionalistas (ver figura 17).

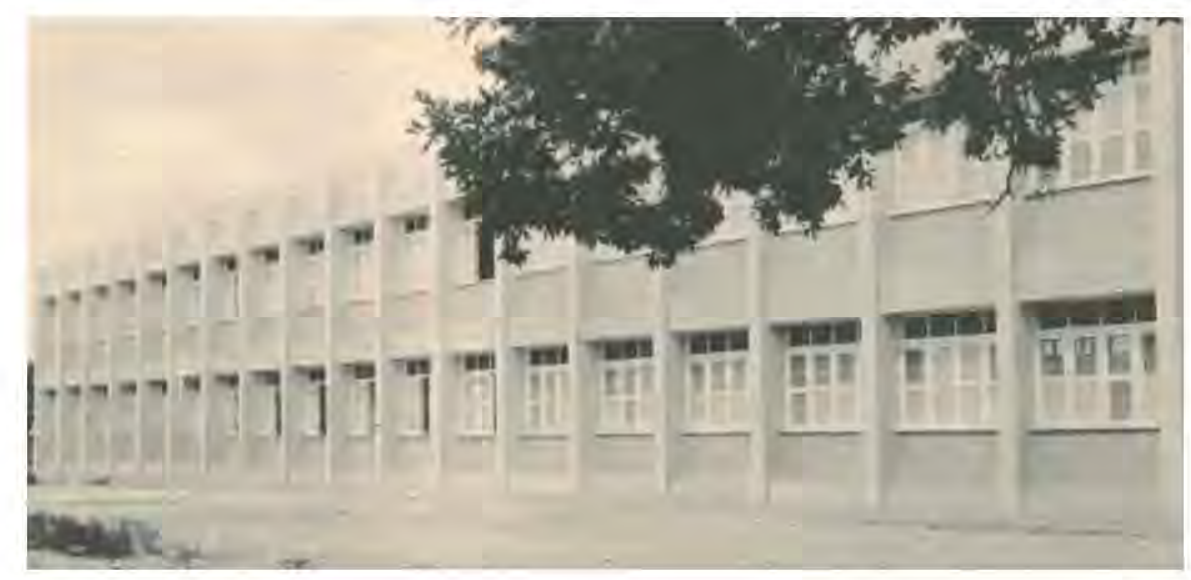

Figura 17: UFC - Faculdade de Filosofia Ciências e Letras (Fonte: UFC, 1966) 

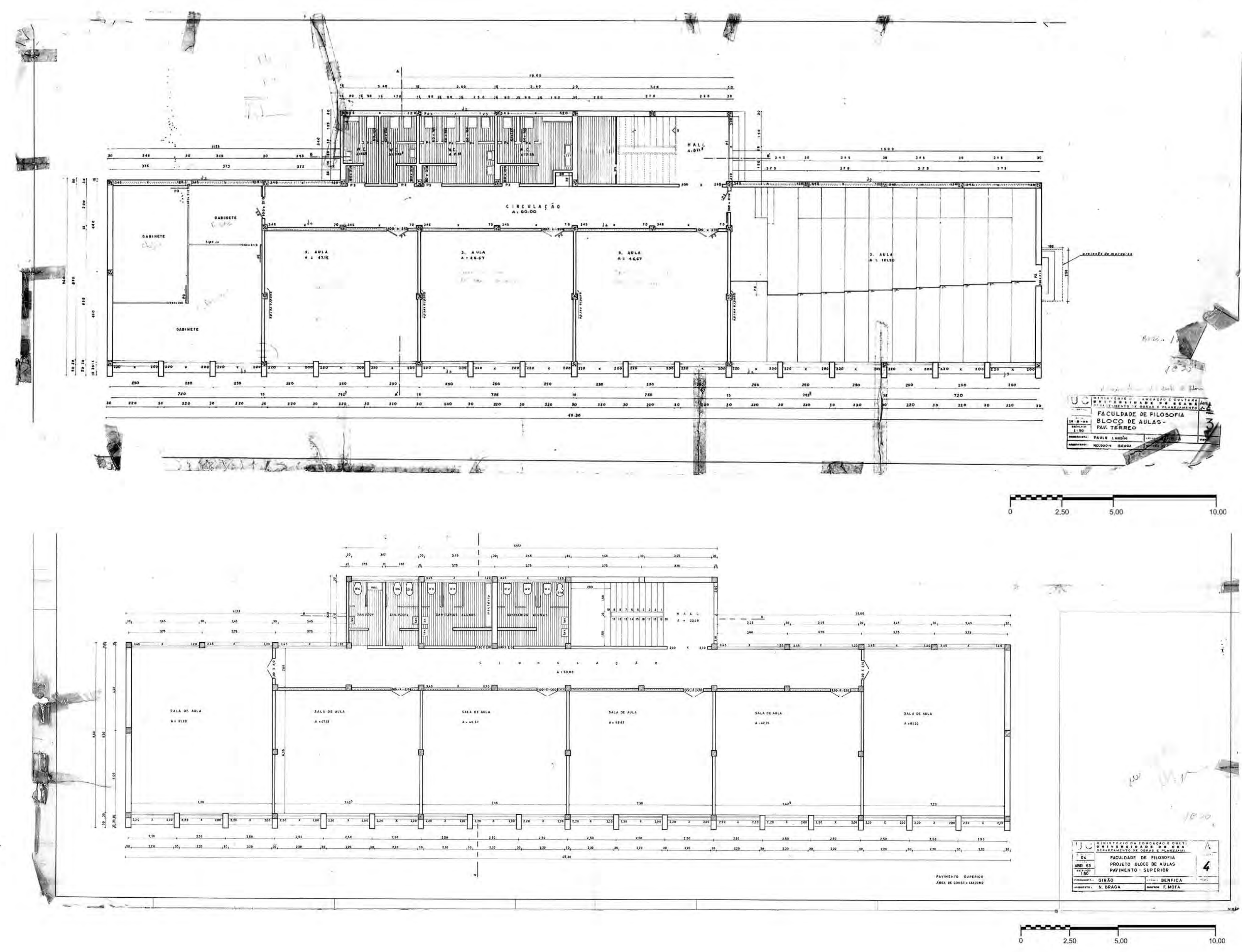

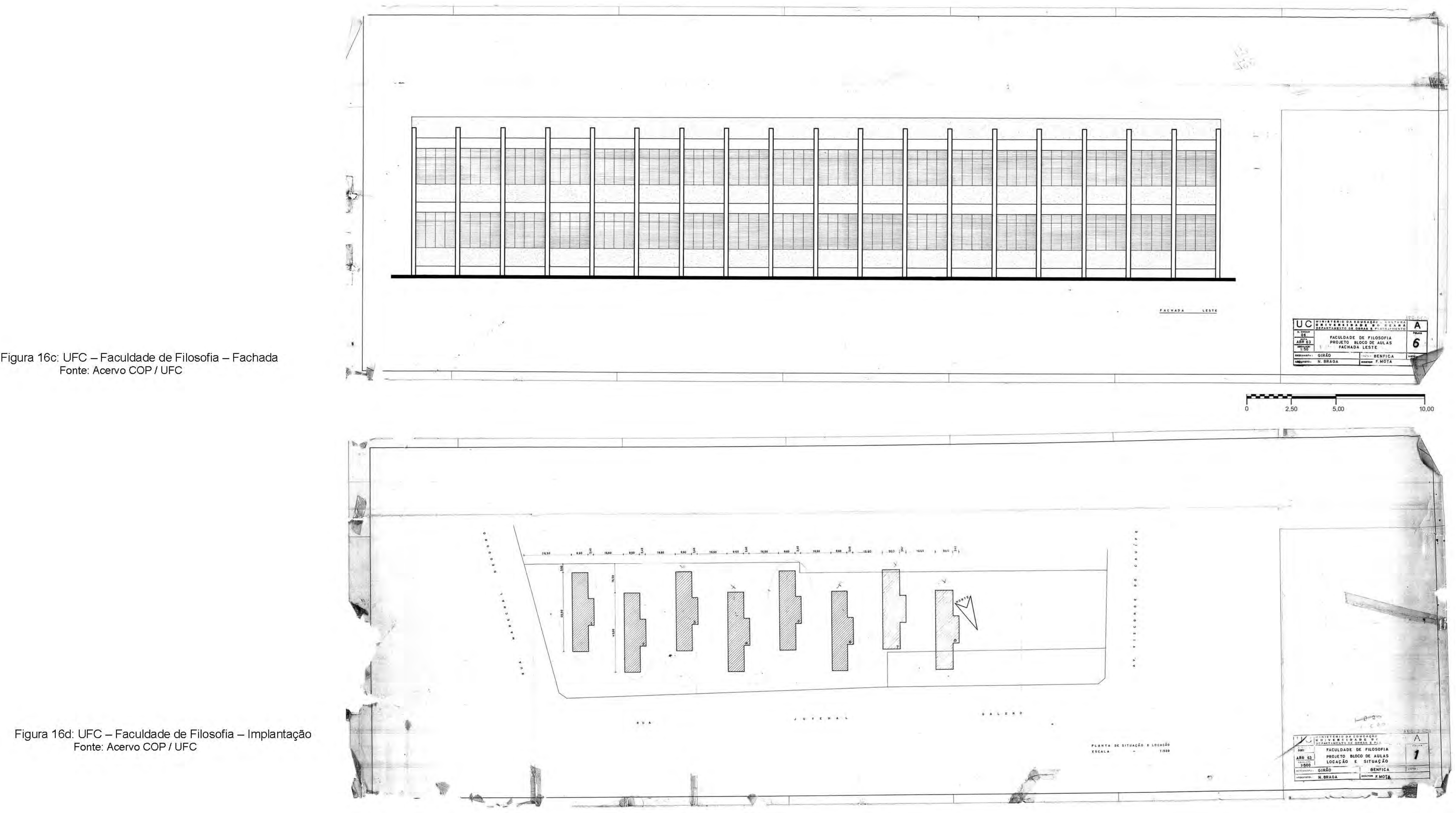
Parte 2 - Universidade Federal do Ceară 
Na implantação, Braga rompeu com o modelo tradicional do lote urbano, segundo o qual a edificação é voltada para a via de acesso, e implanta o conjunto de edifícios da Faculdade de Filosofia, Ciências e Letras seguindo o modelo urbanístico da quadra livre com os acessos orientados para o interior da mesma, eliminando assim a concepção de frente e fundos. Dispondo os blocos padrões paralelamente, com recuos de dimensões alternadas em relação ao limite do terreno, o arquiteto visava propiciar o melhor aproveitamento da ventilação natural (ver figura 18).

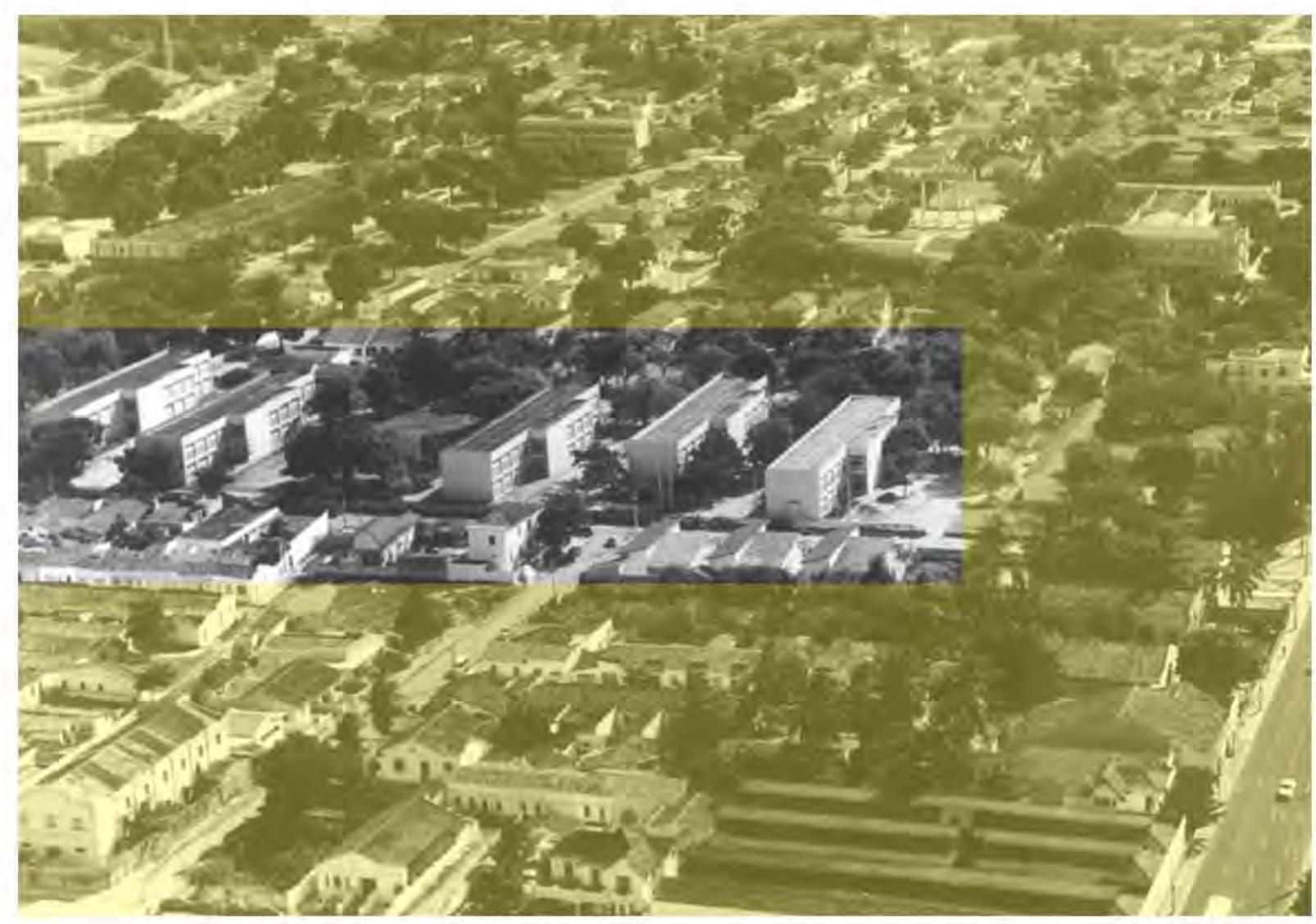

Figura 18: UFC - Conjunto arquitetônico da Faculdade de Filosofia Ciências e Letras - Anos 1970. A implantação dos cinco blocos adotou o modelo da quadra livre.

(Fonte: Acervo COP/UFC apud CAMPÊLO, 2005, p.89)

A tipologia arquitetônica de linguagem estilística moderna foi reproduzida em outras unidades acadêmicas no decorrer da década seguinte, empregada por Braga na área do Pici, que veio a constituir o conjunto de edifícios destinados ao Centro de Tecnologia e ao Centro de Ciências Agrárias, atendendo ao projeto da Reforma de 1968, conforme será apresentado no decorrer do capítulo. 
- Museu de Arte da UFC - MAUC (1965)

O Museu de Arte da UFC, criado em 1961, passou a funcionar provisoriamente em galpões localizados na quadra defronte à Reitoria. Quatro anos depois, foi construída a sede definitiva no mesmo local, inaugurada em 24 de junho de 1965, com projeto dos arquitetos Neudson Braga e Liberal de Castro. Com localização privilegiada, na confluência das avenidas 13 de maio e da Universidade [situação similar à da Escola de Engenharia], o edifício de pavimento térreo evidencia suas referências modernistas, com a volumetria de linhas retas e incorporando à fachada principal um painel em pastilha cerâmica do artista plástico cearense Zenon Barreto, uma clara filiação ao repertório da Escola Carioca (ver figura 19). O espaço interior foi contemplado com um jardim ao ar livre, que permite a exaustão do ar e a penetração da luz natural, enriquecendo os ambientes com espaços alternados de luz e sombra - um percurso agradável às obras de arte da UFC.

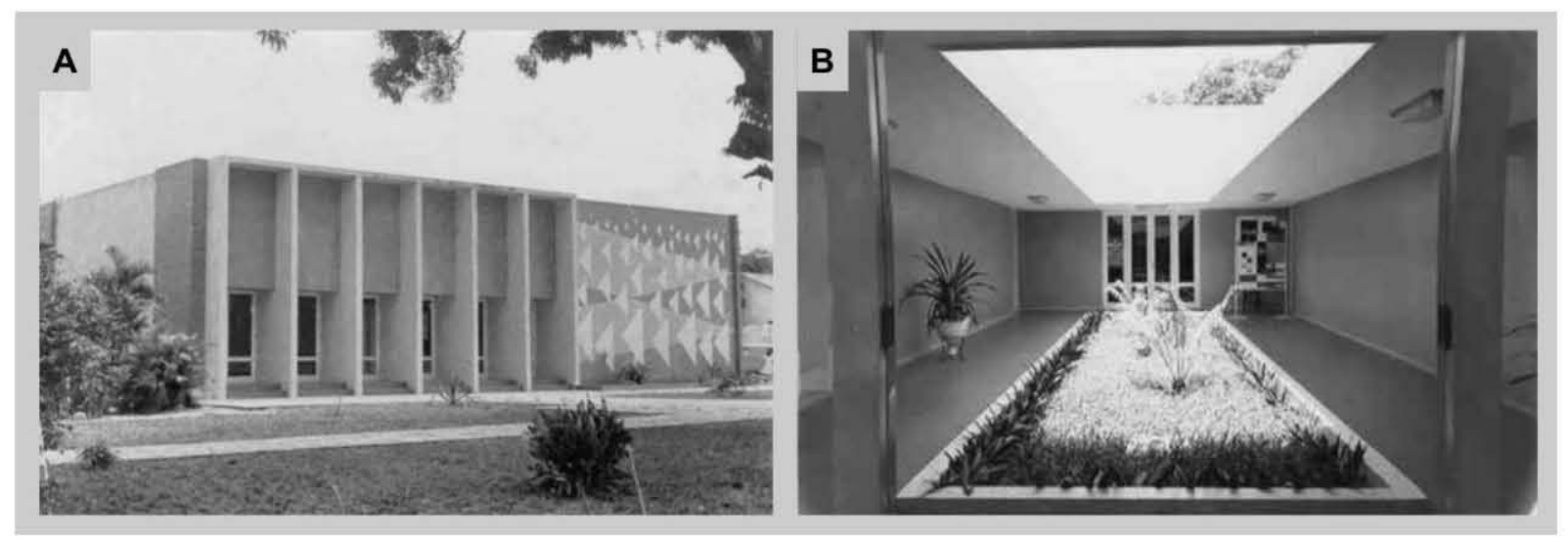

Figura 19: UFC - Museu de Arte - Década de 1960. (a) Vista da fachada voltada para a Avenida da Universidade com painel cerâmico do artista Zenon Barreto. (b) Vista do jardim interno. (Fonte: Acervo MAUC / UFC)

- Institutos Básicos: Química, Matemática e Física (1965)

A proposta para o estabelecimento dos institutos básicos se deu no bojo da criação da Faculdade de Filosofia, Ciências e Letras, que correspondia à nova estrutura acadêmica desejada pela UFC. Previu-se inicialmente a implantação dos Institutos de Matemática, Química e Física, ficando para um segundo momento os de Biologia, Geociências e Ciências Sociais.

Os primeiros prédios construídos constituíam um conjunto de quatro blocos, situados na quadra lindeira à Reitoria - no lado oposto à quadra da Faculdade de Filosofia, Ciências e Letras - os quais foram feitos por etapas, tendo sido o primeiro deles inaugurado em 1965. Originalmente, foi projetado para abrigar alunas da Escola de Serviço Social, porém, 
segundo Castro (2004, p. 200), depois de erguido, o prédio foi cedido por pressões ao Instituto de Matemática Aplicada, fundado na ocasião. Logo outros setores da área de ciências, conseguiram que fossem construídos novos blocos semelhantes, sendo um destinado aos Institutos de Química e Tecnologia e o outro ao recém-criado Instituto de Física.

O projeto de autoria do arquiteto Liberal de Castro caracteriza-se pela articulação de blocos com geometria retangular e configuração longitudinal, sendo três paralelos entre si e à Rua Paulino Nogueira e o quarto, perpendicular aos demais e paralelo à Avenida da Universidade (ver figura 20).

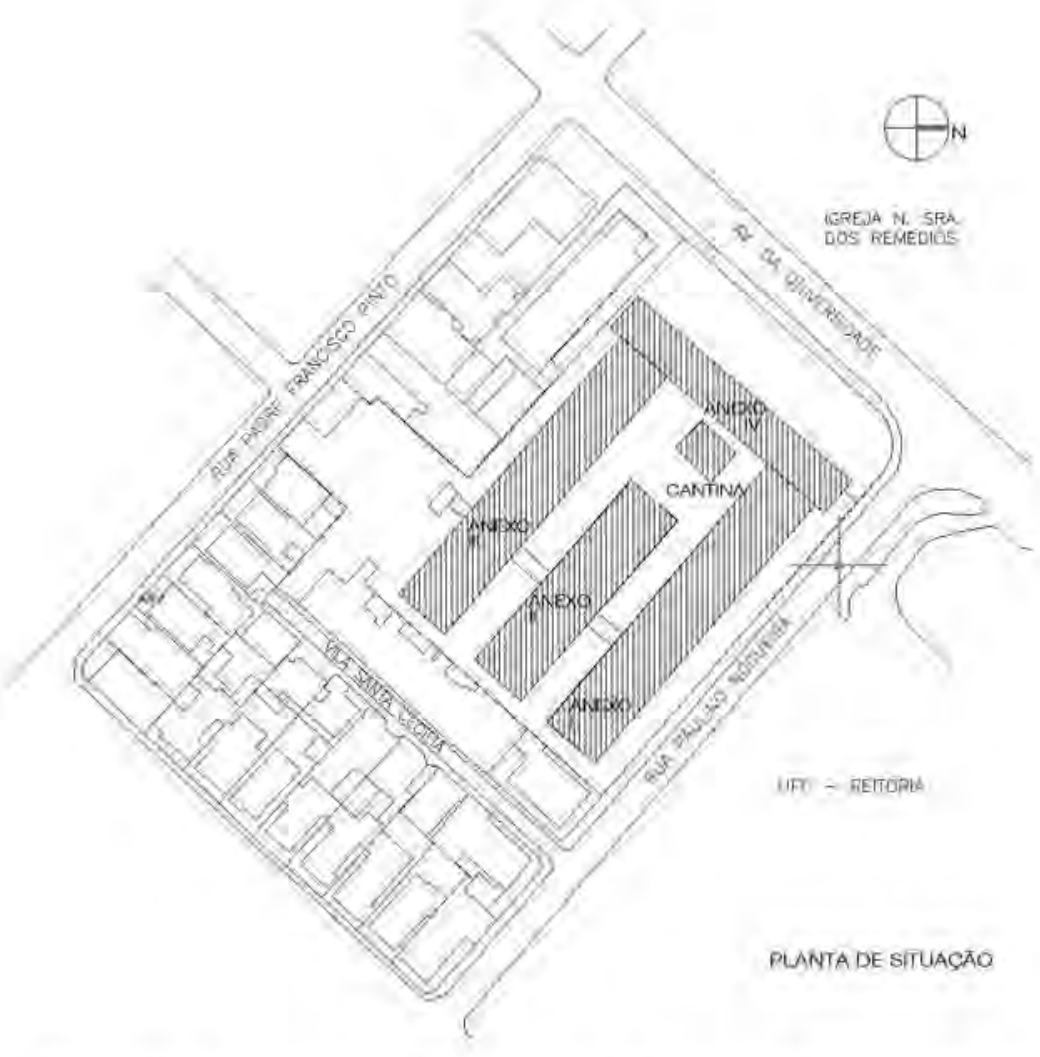

Figura 20: UFC - Conjunto arquitetônico dos antigos Institutos Básicos. Atualmente encontra-se ocupado por funções administrativas vinculadas à Reitoria com a denominação de Anexos I, II, III e IV.

(Fonte: Acervo COP / UFC, edição nossa)

O partido adota a planta livre concebida pela modulação estrutural. Os três blocos longitudinais leste-oeste possuem dois pavimentos e estão separados por áreas ajardinadas, porém articulados por uma circulação central que os atravessa transversalmente. O pavimento superior é ladeado longitudinalmente por estreitas circulações tipo varandas, balizadas por um correr de esbeltas colunas muito próximas umas das outras (CASTRO, 2004, p.201). O arquiteto Castro esclarece que esses apoios, 
sem qualquer função estática, demarcavam unicamente "os aposentos das alunas, todos de uso individual com 2,25m de largura, servidos por pequenas varandas privativas" (CASTRO, 2004, p.201).

No mesmo ano, o conjunto recebeu o acréscimo do quarto bloco, com três pavimentos, cuja implantação se dá em posição ortogonal aos demais, interligando-se aos dois blocos das extremidades. A fachada longitudinal voltada para a Avenida da Universidade apresenta uma composição que destaca a articulação entre a modulação estrutural e os extensos painéis de combogós, incorporando ritmo e marcação à forma arquitetônica (ver figura 21). A solução evidencia as questões climáticas locais, de forte incidência solar, assim como a intenção de propor uma arquitetura de caráter local. $O$ arquiteto Oliveira analisa que a composição resultante

[...] se aproximava do modelo de quadra fechada, com pátio interno, obtido a partir de uma releitura, em linguagem moderna, da estrutura tradicional dos "colleges" ingleses, aplicada experimentalmente no Ceará. A unidade espacial obtida neste conjunto serviu para descaracterizar completamente o sentido de faculdade isolada que se pretendia. Com este novo edifício, os vários institutos ali abrigados passaram a constituir uma nova unidade [...]. Embora cada um preserve sua identidade própria, nasce um novo ente universitário conhecido, agora, simplesmente como Institutos Básicos, imbuído do caráter coletivo que se queria emprestar para a disseminação de um verdadeiro espírito universitário (OLIVEIRA, 2005, p.89).

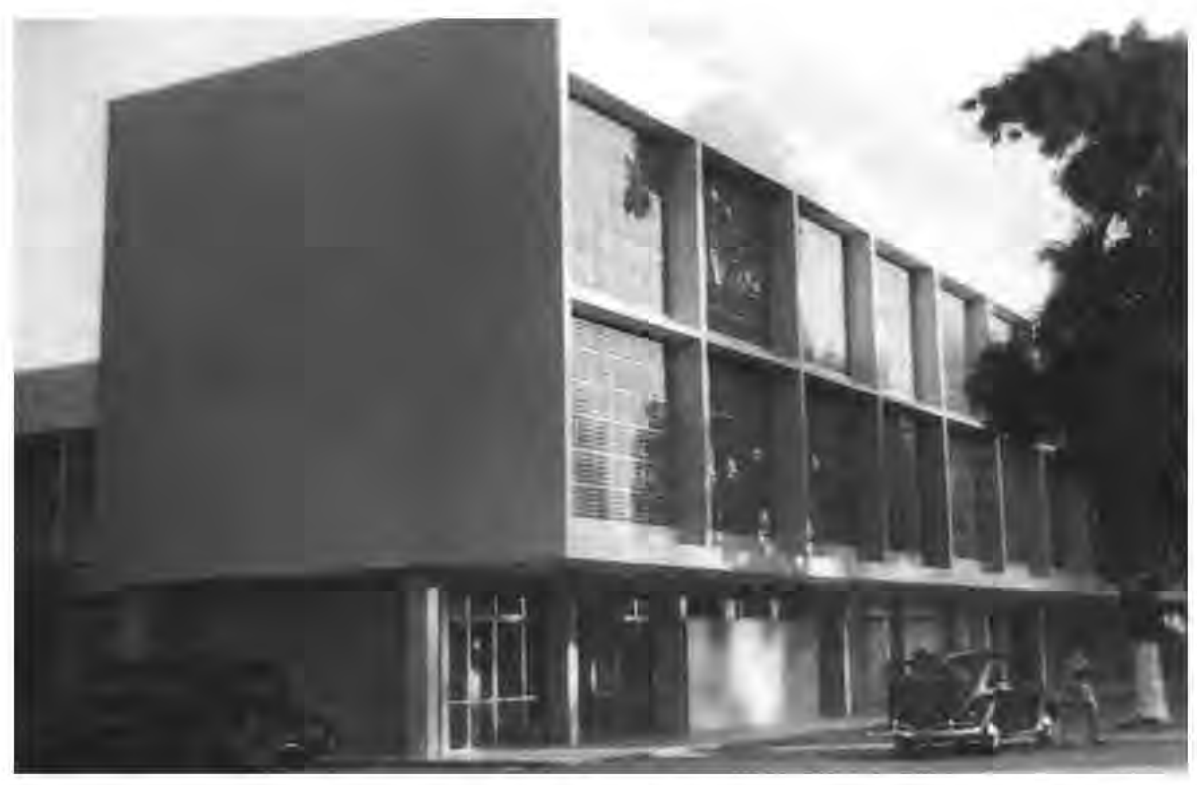

Figura 21: UFC - Antigo Instituto Básico - Ano 1967. (Fonte: DUARTE et al, 1996, p. 77) 


\section{- Residência Universitária (1966)}

A Residência Universitária (RU), situada também nas imediações da Reitoria foi construída a partir da pressão do Governo Federal para atender a demanda por alojamentos estudantis. $\mathrm{Na}$ qualidade de profissional do Departamento de Obras e Planejamento da UFC, o arquiteto cearense Ivan Brito elaborou o projeto da RU, que foi inaugurado em 1966, e se constitui em patrimônio de reconhecido valor modernista, tendo sido inventariado pelo IPHAN e que marca até os dias de hoje - pela sua qualidade arquitetônica - a paisagem urbana do Benfica.

Brito, que foi aluno e estagiário do arquiteto italiano Mário Russo durante sua graduação na Escola de Belas Artes da Universidade do Recife em 1955, não esconde a influência daquele profissional na sua diretriz projetual - pesquisa funcional, estrutural e construtiva que deveria resultar na síntese arquitetônica do edifício moderno. $O$ estágio no Escritório Técnico da Cidade Universitária sob a supervisão de Russo valeu-lhe a vivência em estudos da forma arquitetônica, bem como o acompanhamento de obras, o domínio sobre cálculo estrutural, instalações prediais e orçamentos. Toda essa experiência levou ao entendimento da "arquitetura integral", onde fatores climáticos, sistema construtivo, instalações complementares deveriam responder de forma articulada ao fator econômico, resultando em uma arquitetura plástica (Informação verbal ${ }^{22}$ ).

O programa da RU previa apartamentos para dois estudantes, formando uma unidade padrão de alojamento mínimo com quarto, banheiro e pequeno hall de entrada, funcionando também como copa, além de áreas coletivas que incluíam salão de jogos, cantina e sala de leitura, área para o centro estudantil, administração e auditório. Brito explica que a concepção do projeto se iniciou a partir do cálculo das dimensões mínimas necessárias para - alojamento, considerando também a estimativa de cubagem do ar necessário para as boas condições de conforto ambiental.

Implantado em um lote de duas esquinas de configuração retangular e de pouca profundidade - sendo a frente de $37,40 \mathrm{~m}$ voltada para a Rua Paulino Nogueira e as de $12,90 \mathrm{~m}$ de largura, para as ruas laterais - o arquiteto concebeu o edifício em quatro pavimentos ${ }^{23}$, sendo o térreo e o mezanino destinados ao setor de lazer e cultura, e os dois últimos definidos como pavimento-tipo, destinados às unidades de alojamento estudantil, todos articulados verticalmente com a caixa da escada e com a torre onde deveria ser instalado um elevador (ver projeto de arquitetura na figura 22).

\footnotetext{
${ }^{22}$ Informação verbal concedida pelo arquiteto Ivan Brito em entrevista realizada na sua residência, em Fortaleza no dia 25 de março de 2007.

${ }^{23}$ Profissionais que trabalharam com Brito especulam que a proposta original previa um edificio de seis pavimentos, mas com recursos financeiros limitados o projeto teve que ser ajustado para quatro. Brito, entretanto, não confirma os relatos, assim como o engenheiro responsável pelo cálculo estrutural, o cearense Hugo Mota, que afirma nunca ter sido discutida tal proposta (informação verbal concedida em entrevista).
} 


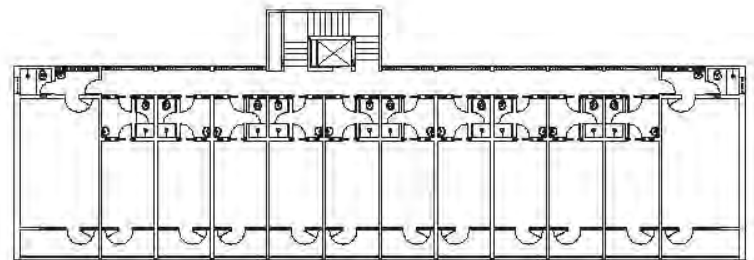

PLANTAPAYMENTOO TIPO

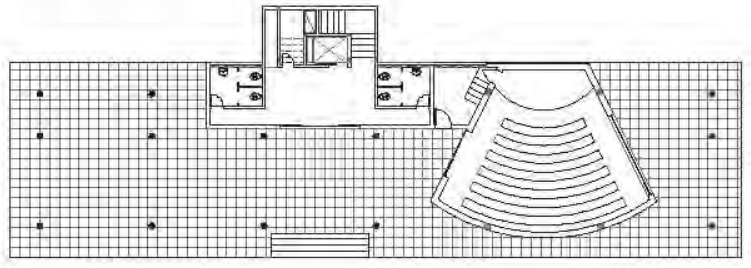

PLANTAPAMMENTO TÉREEO

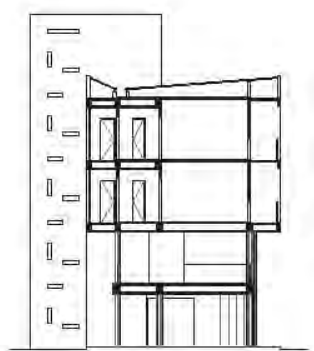

CORTE TRANSYERSAL

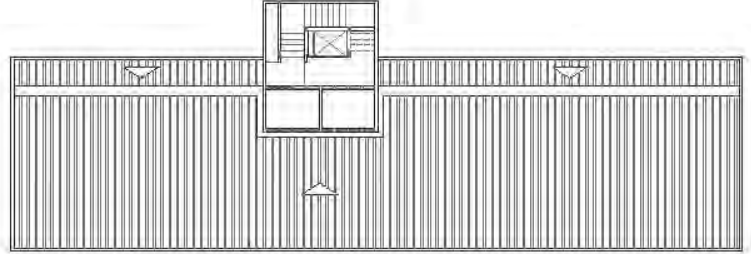

PLANITADECOBERT A.
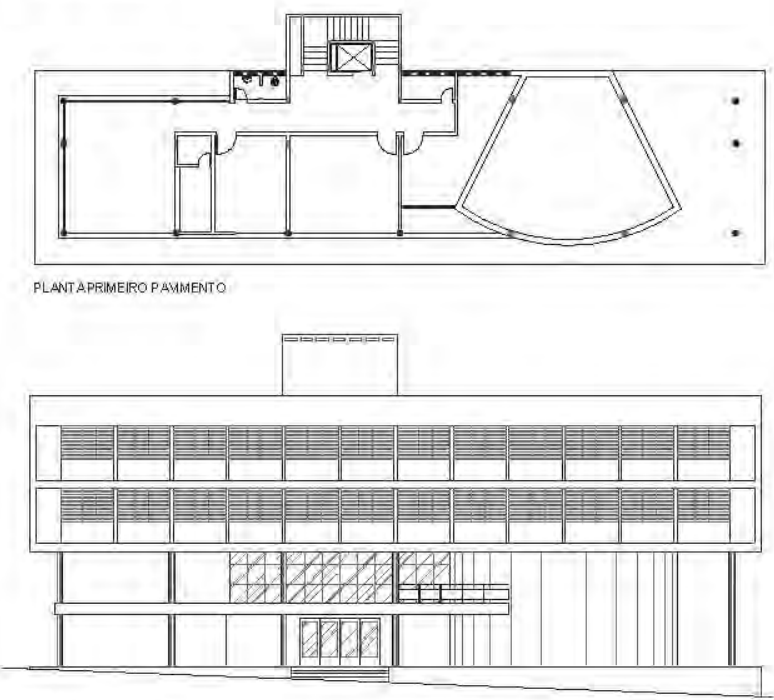

FACHADAPRINGCP Q Q

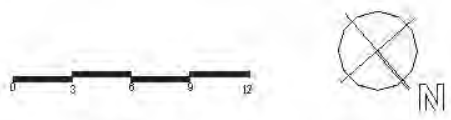

Figura 22: UFC - Residência Universitária - Projeto de arquitetura.

(Fonte: desenhos digitalizados a partir das plantas originais - Acervo COP / UFC)

Dentro do partido de referências modernas o piloti é concebido como espaço da integração social, uma área aberta com acesso ao auditório e vista para a rua - espaço semiprivado. A implantação tirou partido da maior dimensão do terreno, voltando os alojamentos para a direção dos ventos dominantes. Brito atenua o rigor climático com soluções locais tais como o uso de varandas que favorece o sombreamento nos quartos, esquadrias de madeira com venezianas articuladas ${ }^{24}$ e com o manuseio do combogó: formando uma cortina de proteção solar na fachada de fundo, vedação permeável à ventilação no salão de jogos e no térreo com a função de anteparo à rua. Merece registro, o sistema construtivo adotado, elegendo o concreto armado convencional e o uso da laje dupla para permitir a passagem das tubulações prediais (ver figuras 23 e 24).

${ }^{24}$ Trata-se de um modelo de fabricação local amplamente utilizado nas residências de Fortaleza. 


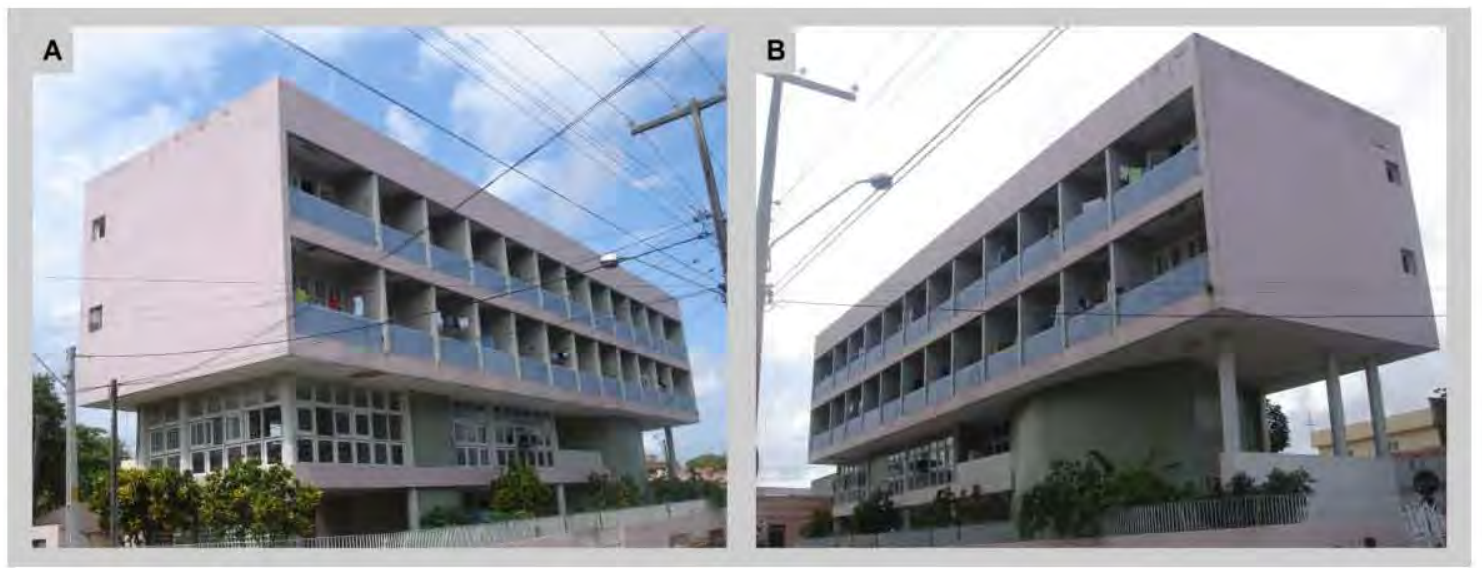

Figura 23: UFC - Residência Universitária - Ano 2008. As imagens destacam a volumetria funcional. (A) Vista do corpo principal sobre o mezanino com painéis de esquadria em madeira e vidro.

(B) Vista da caixa prismática apoiada no auditório que conforma o volume de parede curvilínea e nos pilares com pé-direito duplo.

(Fonte: Acervo Magda Campêlo, 2009)

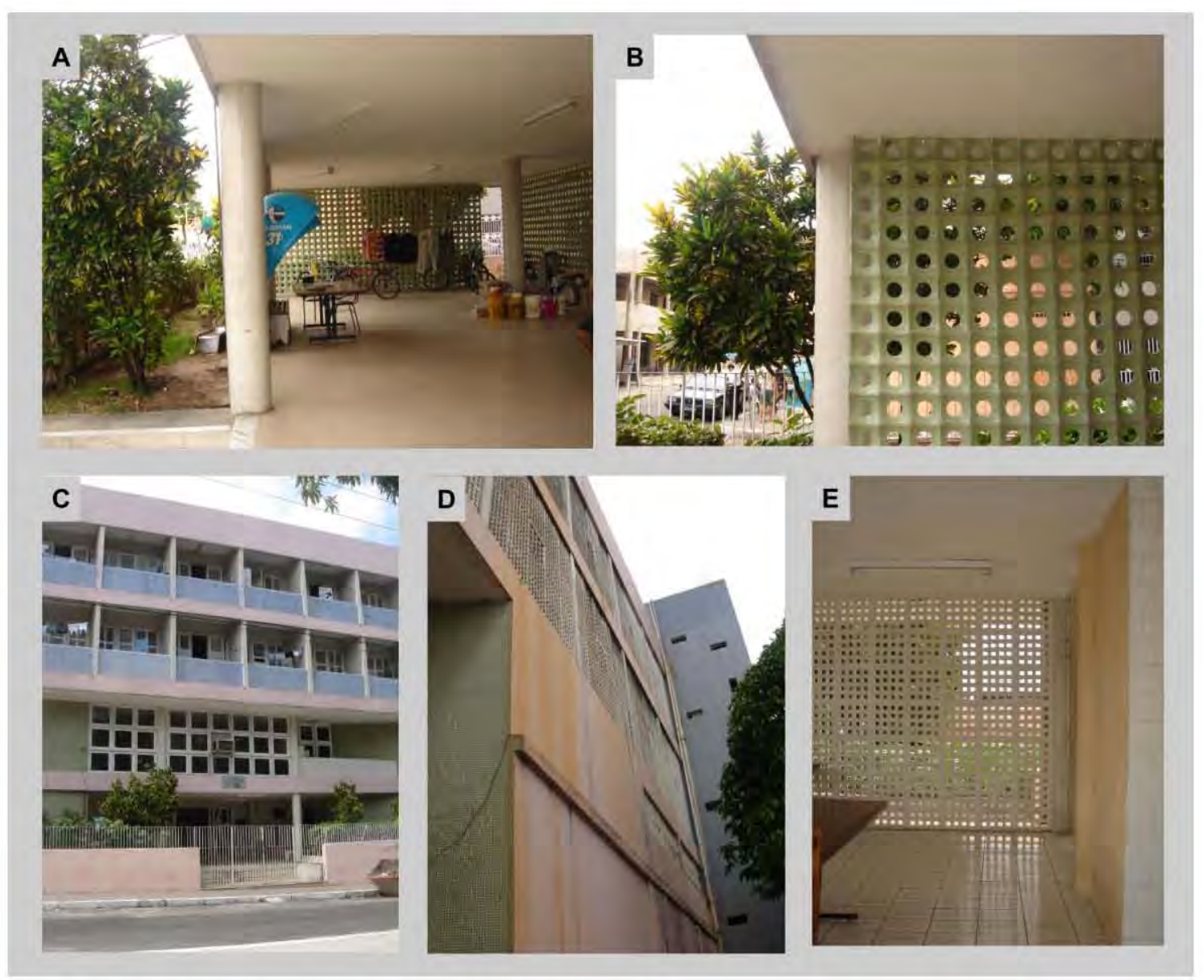

Figura 24: UFC - Residência Universitária - Ano 2008.

(A) Vista dos piloti.

(B) Detalhe do combogó cerâmico do piloti

(C) Detalhe da fachada principal com as esquadrias de madeira $e$ venezianas nas varandas.
(D) Vista da cortina de combogó na fachada de fundo.

(E) Vista da cortina de combogó no salão de jogos.

(Fonte: Acervo Magda Campêlo, 2009) 


\section{- Imprensa Universitária (1967)}

No ano seguinte foi inaugurada mais uma obra de concepção modemista. Tratava-se da Imprensa Universitária, que teve origem em 1956, quando o Conselho Universitário autorizou a aquisição da Tipografia Lusitana. Funcionando inicialmente em instalações provisórias, no dia 25 de maio de 1967, foi inaugurada sua sede própria, complementando o conjunto moderno edificado na quadra defronte à Reitoria, composto pelo Museu de Arte e pelo Departamento de Cultura, já analisados.

O projeto é de autoria dos arquitetos José Liberal de Castro e José Neudson Bandeira Braga. Concebido com um pavimento, o programa de necessidades está organizado em duas áreas funcionais: a primeira que corresponde aos setores administrativos e de serviços e a segunda que abriga o grande galpão destinado às atividades de impressão. Tendo em vista as necessidades físicas diferenciadas em cada área funcional, os arquitetos adotaram o sistema estrutural de concreto convencional para o setor administrativo e a estrutura metálica na parte de impressão, que necessitava de ampla área livre e pé-direito duplo. A forma arquitetônica resulta da organização funcional da planta, trabalhada com esquadrias de madeira com venezianas e combogós (ver figura 25).

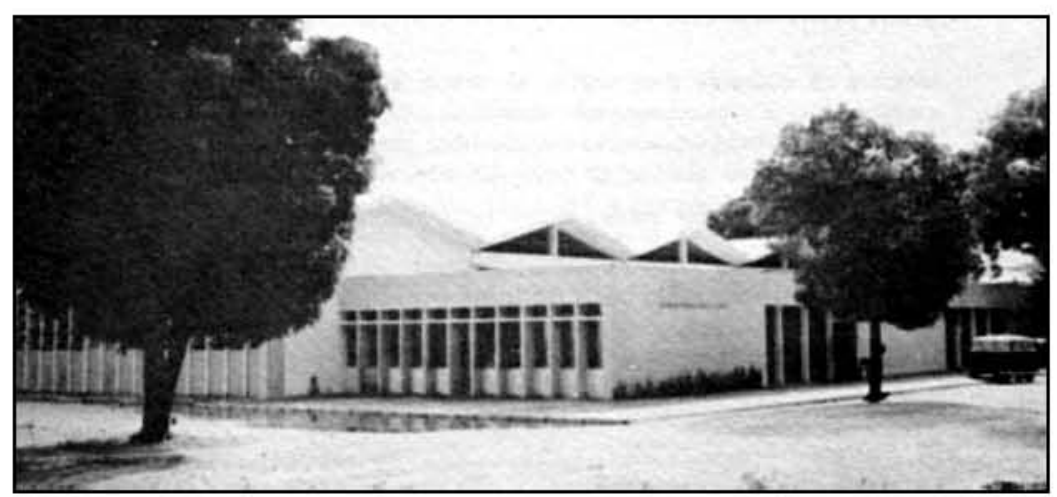

Figura 25: UFC - Museu de Arte.

(Fonte: Disponivel em <http://hww.imprensa.ufc.br/s. Acesso em: 10 abr. 2012)

\section{- Faculdade de Direito (1967)}

No mesmo ano de 1967, as instalações da Faculdade de Direito são ampliadas com a incorporação de um novo bloco, construído atrás do antigo edifício de arranjo eclético. Projetado por Liberal de Castro para abrigar um auditório (capacidade para 400 pessoas), salas de aula e cantina, mantém o partido de linhas modernas que o arquiteto vinha adotando nas outras unidades. Constituído de dois pavimentos com planta livre, a forma arquitetônica se destaca pela volumetria prismática superior com dimensões de $88,90 \mathrm{~m} \mathrm{x}$ $18,55 \mathrm{~m}$, apoiada sobre pilares de geometria cilíndrica. No pavimento térreo, o hall de acesso 
com a escada revestida em mármore e centralizada no ambiente de pé-direito duplo dá corpo ao espaço de caráter austero.

A edificação de linhas retas adota o partido de composição modular que padroniza as esquadrias de alumínio e vidro das fachadas longitudinais. $O$ revestimento em pastilha cerâmica de cor clara incorpora à produção atributos de elegância e leveza visual, que garantem interação junto ao antigo edifício de arranjo eclético herdado na criação da Universidade (ver figura 26).

A Universidade intensificava sua presença na área do Benfica, enquanto concomitantemente iam se conformando as áreas do Porangabuçu, com domínio da classe médica, e do Pici, sob o comando dos agrônomos.

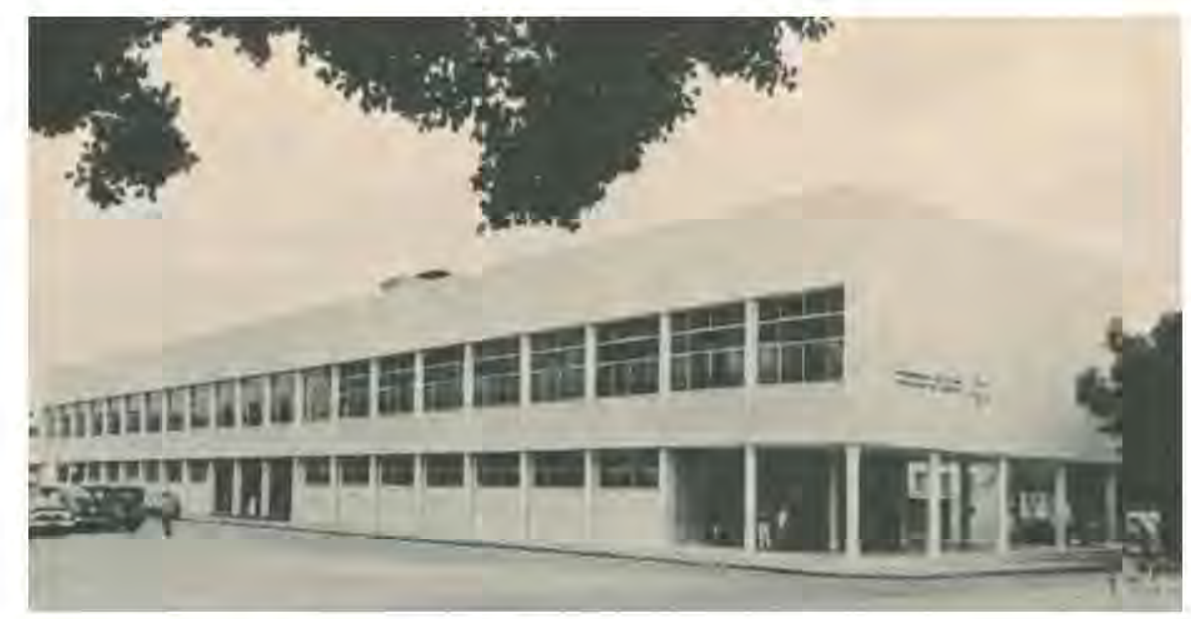

Figura 26: UFC - Faculdade de Direito - ano 1966.

(Fonte: UFC, 1966)

\section{- Porangabuçu: Território da Saúde}

A ocupação da UFC no bairro do Porangabuçu ${ }^{25}$ está vinculada ao processo de desenvolvimento da Faculdade de Medicina do Ceará ${ }^{26}$ criada em 1948 pelo Instituto de Ensino Médico do Ceará, entidade de direito privado constituída pela classe médica de Fortaleza com a finalidade de fundar, instalar e manter a futura instituição voltada para o ensino superior da saúde ${ }^{27}$.

Iniciou suas atividades em imóvel doado pelo governo do Estado - edificação do século XIX (ver figura 27), situado na Praça José de Alencar, no centro da cidade e que foi incorporado

\footnotetext{
${ }^{25}$ Conforme Freitas (2005, p.139), o antigo bairro do Porangabuçu, cuja denominação é de origem da língua indígena tupi composta de porangaba $=$ beleza e açu $=$ grande - teve essa denominação por muitos anos, sendo posteriormente substituida pelo de Rodolfo Teófilo.

${ }^{26}$ Sobre a criação da Faculdade de Medicina ler o capítulo 3 da Dissertação de Mestrado, Espaço Hospitalar - o caso do Hospital Universitário Walter Cantídio / UFC, de autoria da arquiteta Waldete Freitas (2005).

${ }^{27} \mathrm{O}$ Instituto de Ensino Médico passou a ser a partir de 28 de julho de 1947 o órgão com os encargos jurídicos para a manutenção da Faculdade de Medicina.
} 
ao patrimônio da UFC conforme já relatado - tendo o apoio da Santa Casa de Misericórdia, localizada nas proximidades, onde eram realizadas as práticas clínicas e hospitalares.

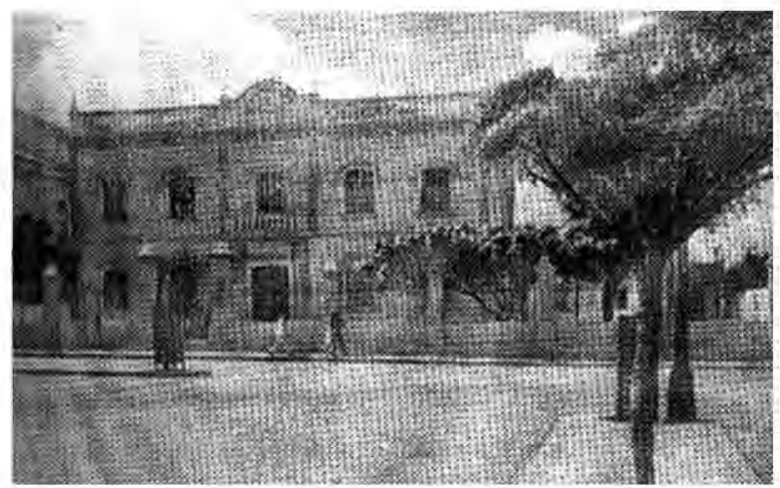

Figura 27: UFC - Faculdade de Medicina do Ceará.

O prédio onde iniciou suas atividades em 1948, no centro da cidade, foi construído em 1884 com projeto de autoria do austríaco Henrique Foglare para abrigar a Escola Normal. O prédio de dois pavimentos com área de $500 \mathrm{~m}^{2}$ é uma construção de arranjo eclético com traços neoclássicos e art déco.

(Fonte: Araripe, 1998 apud FREITAS, 2005, p.121)

O conflito de interesses, entretanto, gerado entre os médicos da Faculdade de Medicina e os da Santa Casa, posto que na visão dos dirigentes desta entidade, as suas prioridades nem sempre coincidiam com as dos professores, já que não contemplavam o progresso científico como objetivo maior, culminou com os professores da Faculdade decidindo lutar por um hospital de ensino (GIRÃO, 1994, p.20 apud FREITAS, 2005, p.122).

A oportunidade surgiu no ano seguinte ao da criação, com a doação pelo governo estadual de um terreno de $57.000 \mathrm{~m}^{2}$, localizado no então afastado bairro do Porangabuçu, onde havia sido iniciada pelo Estado, em 1944, a construção de um hospital de isolamento, com o objetivo de criar um centro de referência em doenças infectocontagiosas. A obra, porém, encontrava-se paralisada, no estágio de execução das fundações por falta de recursos. A doação efetivou-se em 1949 mediante a condição imposta pelo governo do Estado de que a Faculdade de Medicina assumiria a responsabilidade de encontrar, por conta própria, os meios para a conclusão do empreendimento e de manter funcionando no hospital uma enfermaria de isolamento que seria financiada pela Secretaria de Saúde (OLIVEIRA, 2005, p.51). A obra foi retomada e, em 1952 , deu-se a inauguração do pavilhão de isolamento, embrião do então futuro Hospital das Clínicas da UFC (ver figura 28).

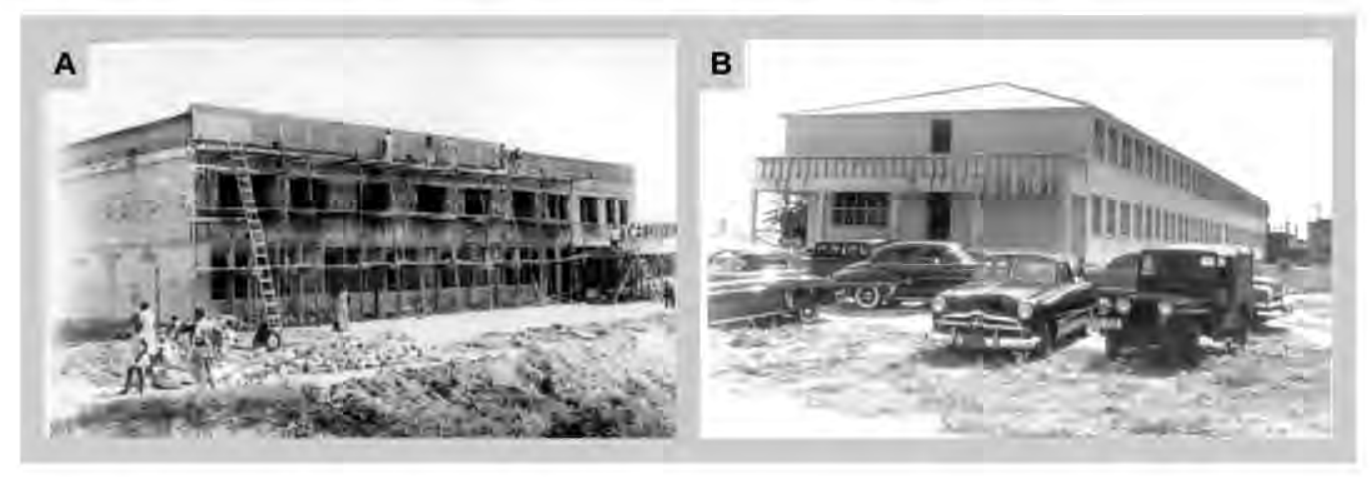

Figura 28: UFC - Hospital de Isolamento.

(A) Construção do primeiro bloco no início da década de 1950.

(B) Conclusão do Bloco de isolamento em 1952.

(Fonte: Arquivo HUWC apud FREITAS, 2005, p.136) 
No início de 1954, as dificuldades financeiras surgidas para a continuação da obra do hospital foram contornadas pela atuação da Fundação Júlio Pinto ${ }^{28}$, entidade que ajudou a concretizar o complexo de saúde que veio a se desenvolver na área do Porangabuçu com as seguintes unidades: Hospital Universitário (1959), Maternidade Escola de Fortaleza (1965) e Instituto Evandro Chagas (1955). Com a criação da UFC, no final daquele ano, a obra do Hospital das Clínicas foi assumida com relevância pela Administração Central, contribuindo para a consolidação do território da Universidade nessa área.

O Porangabuçu era, então, um bairro de periferia ainda praticamente desocupado, situado a oeste da cidade logo depois da linha férrea. Esta área havia sido objeto de um loteamento popular aprovado em 1943 [ver figura 29], ainda praticamente desocupado nessa época. $\mathrm{Na}$ cidade ocupava região, localizada a sotavento aonde habitualmente se destinavam os flagelados da seca e a população pobre e também os equipamentos insalubres como os matadouros, as rampas de lixo e os hospitais de isolamento (OLIVEIRA, 2005, p.51).

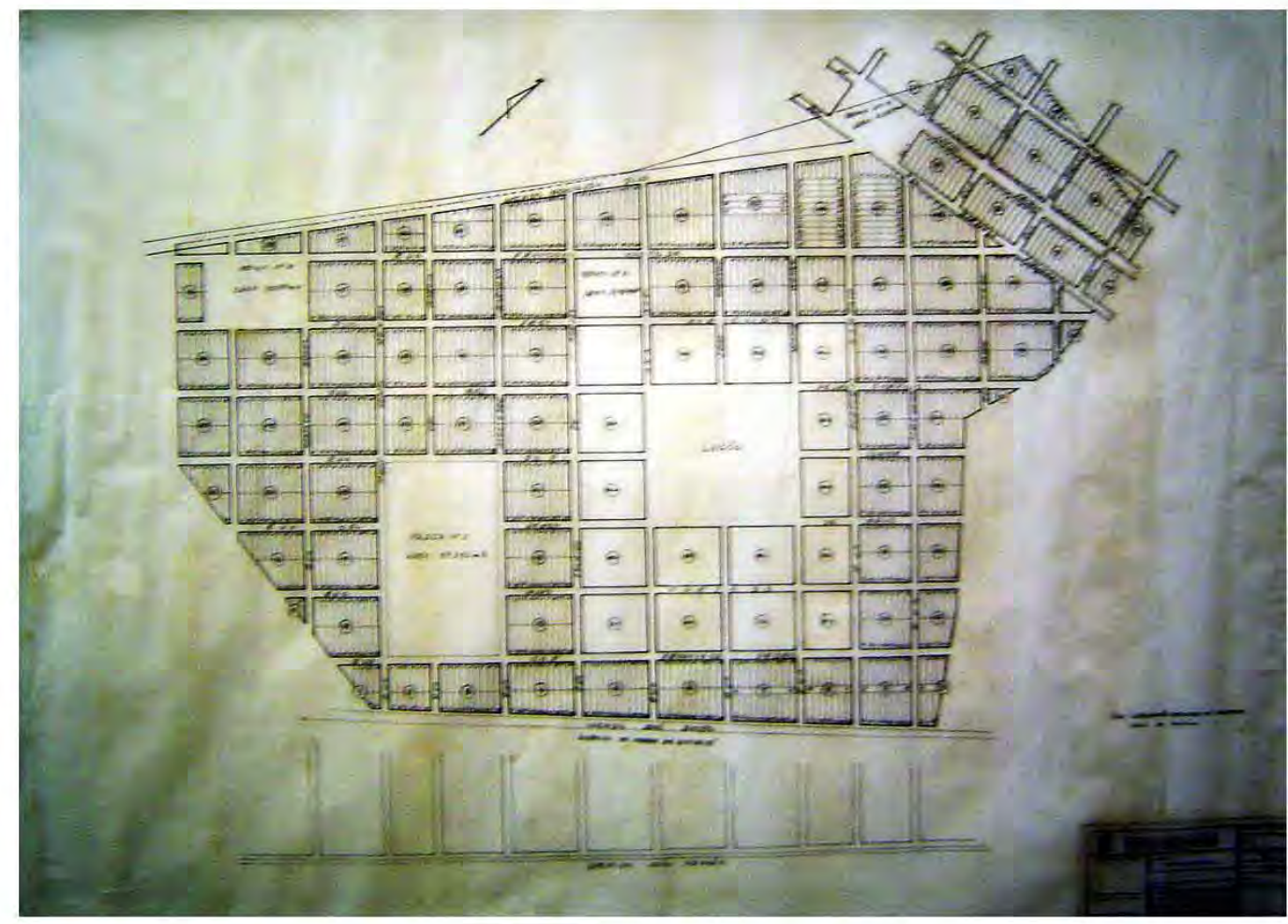

Figura 29: UFC - Planta do loteamento da Vila Porangabuçu. Aprovado pela Prefeitura em 1943. (Fonte: Arquivo COP / UFC apud FREITAS, 2005, p.138)

\footnotetext{
${ }^{28}$ A Fundação Júlio Pinto foi criada com a participação do rico empresário cearense, Fernando Pinto, contando com o apoio dos governos municipal e estadual, do Instituto de Ensino Médico e da Faculdade de Medicina. Segundo Araripe (1998 Freitas, 2005 , p. 135), tinha a finalidade de cooperar com o Instituto de Ensino Médico e a Faculdade de Medicina, construir e manter o Hospital das Clínicas, construir e manter a Maternidade Popular Escola de Fortaleza, construir e manter o Instituto Evandro Chagas, dentre outros.
} 
A distância ao centro urbano e as dificuldades de acesso não se contrapuseram, entretanto à implantação do setor de saúde naquela área. A visão dos médicos higienistas, desde o século XIX, indicando a direção a sotavento como condição ideal para a instalação de equipamentos hospitalares destinados às populações carentes, orientação que em Fortaleza não comprometeria o meio nem os ares das áreas situadas a barlavento, onde se fixava a fração da população de poder aquisitivo mais alto (FREITAS, 2005, p.139), associada à disponibilidade do terreno, doado pelo Estado, com dimensões para futuras expansões, colocou-se como fator de favorecimento à implantação daquele equipamento de saúde. Com essa concepção, deu-se, em 1957, a transferência da Faculdade de Medicina do centro da cidade para as dependências do Hospital no Porangabuçu, catalisando a partir daí a permanência da Universidade naquela área.

Paralelamente, outros equipamentos correlatos foram se estabelecendo nas circunvizinhanças, transformando gradativamente o Porangabuçu em um espaço de feição especializada voltada para o setor da saúde. Ao final de 1960, estava instalado o Instituto Evandro Chagas (1955), o Hospital de Cirurgia (1956), o Instituto de Anatomia e Medicina Legal (1957), e a Maternidade Popular Escola (1965), atual Maternidade Escola Assis Chateaubriand (MEAC), e a Faculdade de Farmácia conforme se constata nas figuras 30 e 31. Na década de 1970 , o complexo foi complementado pela construção do prédio da Unidade Didática e Biblioteca (projeto de 1969), o Departamento de Patologia (1974) e o Departamento de Fisiologia e Farmacologia (projeto de 1976) - ver figura 32.

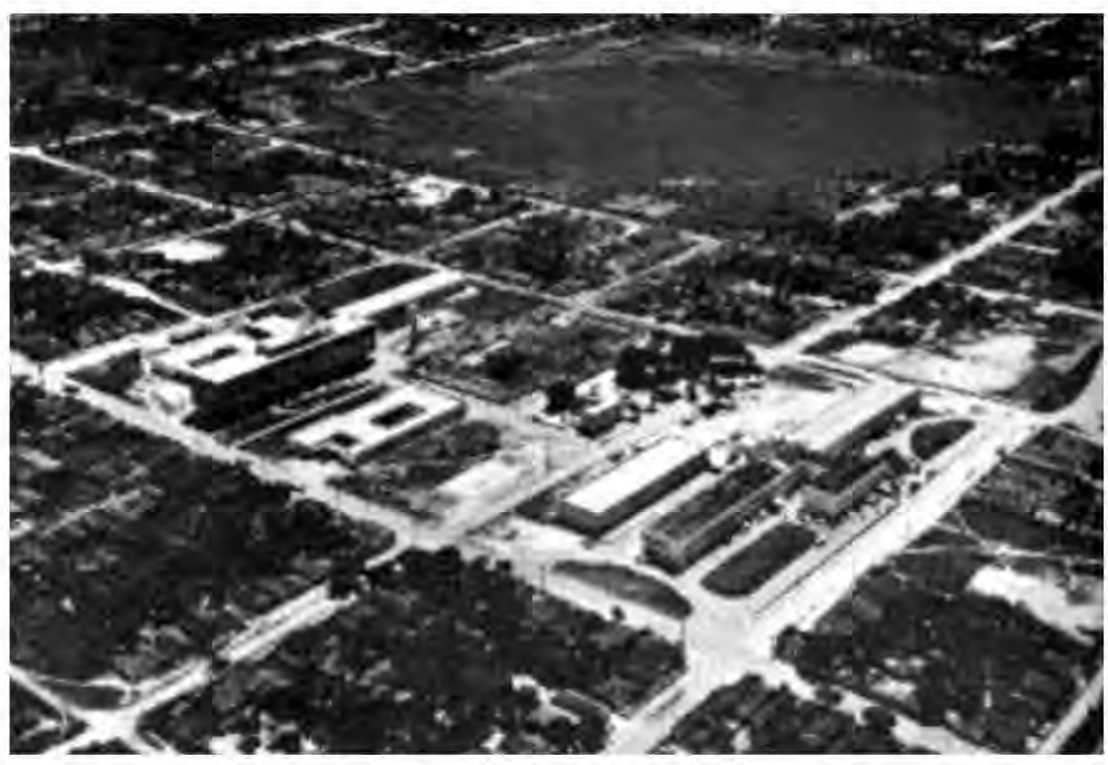

Figura 30: Vista aérea do Porangabuçu - final da década de 1960. (Fonte: LEAL, 1979 apud FREITAS, 2005, p.161) 


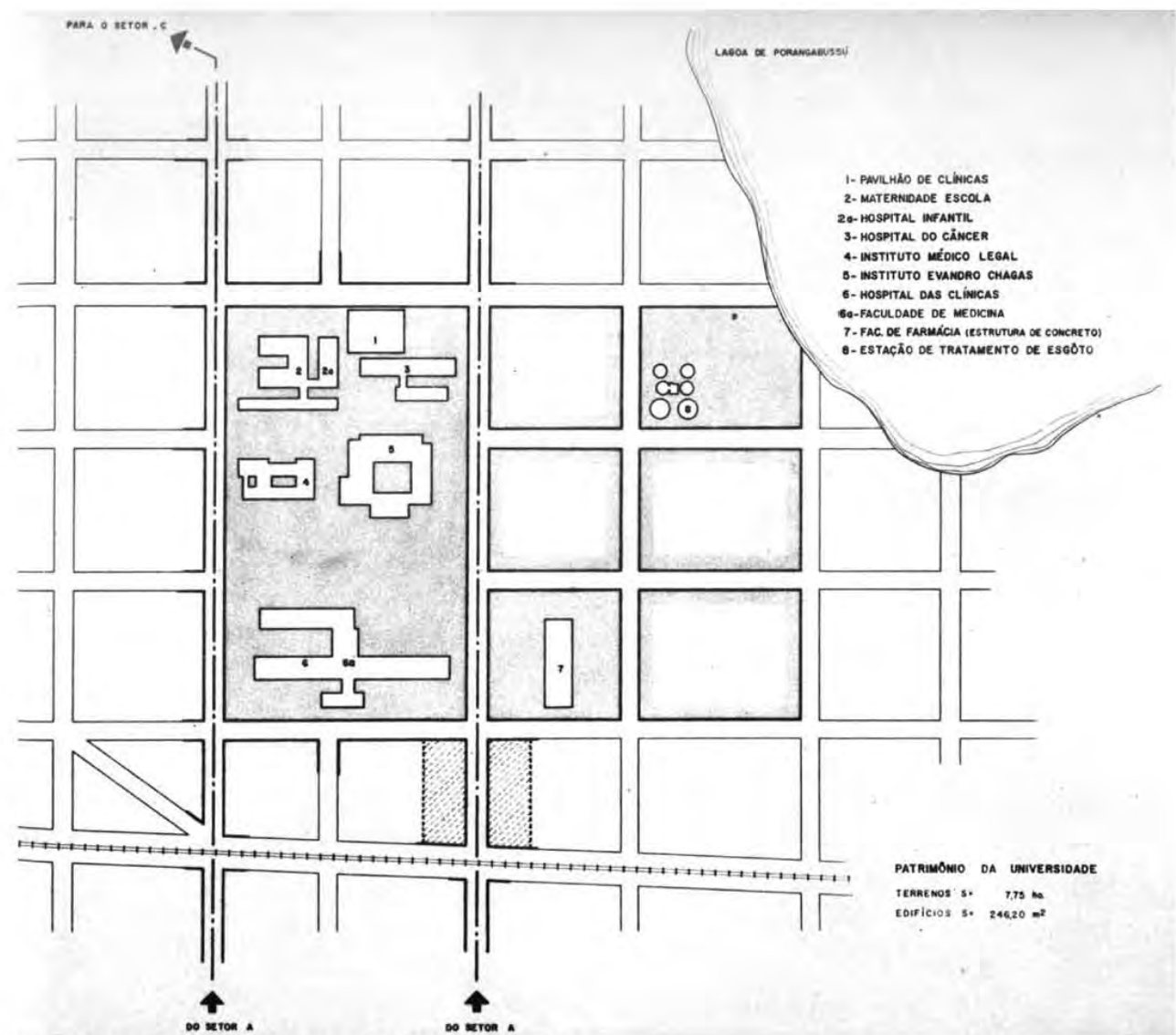

Figura 31: Planta do Porangabuçu em 1966.

(Fonte: UFC, 1966, n.p.)

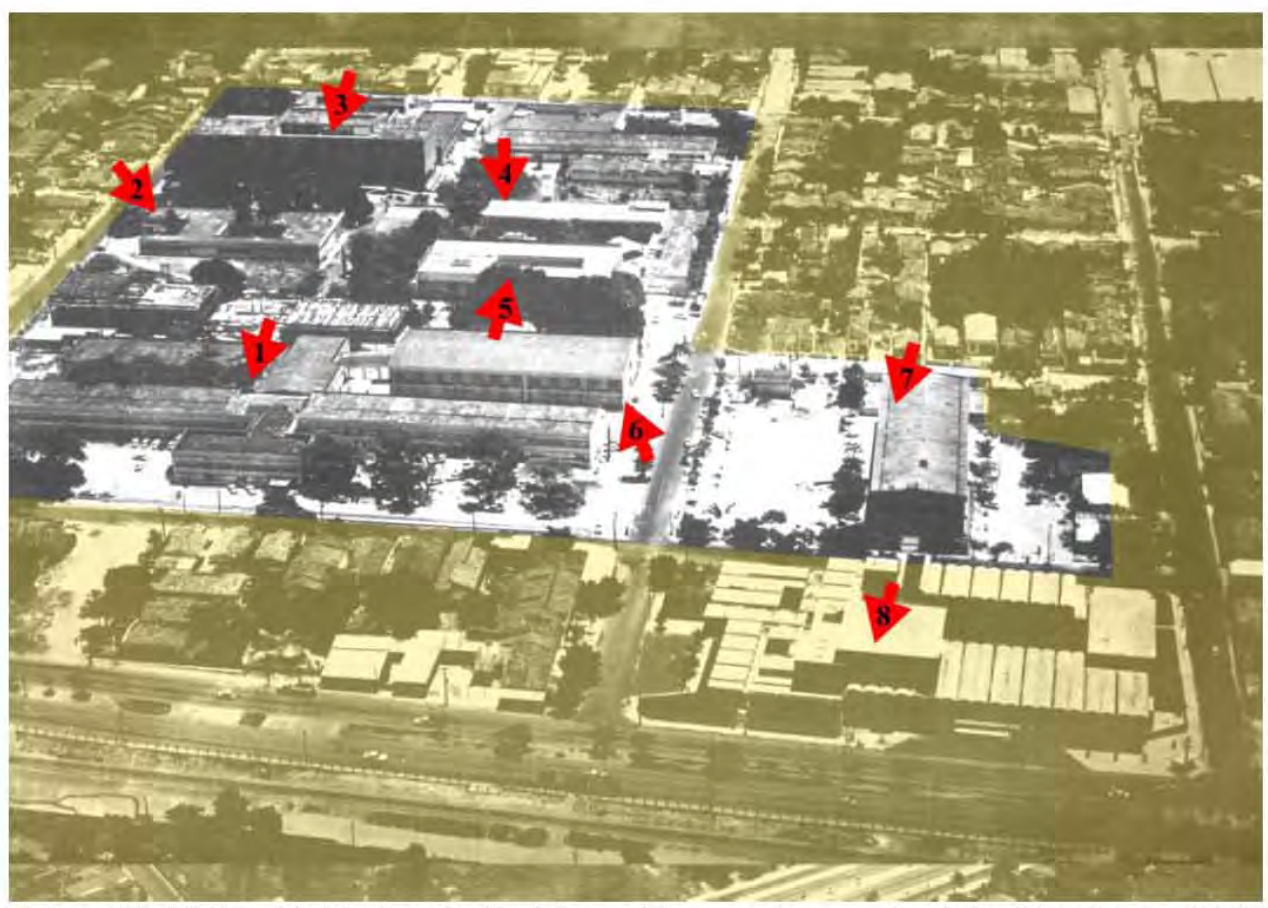

Figura 32: UFC - Unidades da Saúde no Porangabuçu - final da década de 1970. Legenda:
1. Hospital
5. Patologia
2. Morfologia
6. Biblioteca
3. Maternidade
7. Farmácia
4. Fisiologia
8. Hemocentro.

(Fonte: CAMPÉLO, 2005, p.62) 
Da mesma forma que o Benfica, a ocupação no Porangabuçu foi feita sem um planejamento, mas movida tão somente pelas demandas imediatas e condicionadas pelos recursos provenientes do Governo Federal. A concepção urbanística eliminou anteparos e barreiras físicas entre as unidades, neutralizando a percepção do lote como unidade territorial. Não se evidencia, entretanto uma diretriz que tenha ordenado a gradativa implantação das unidades. De maneira geral as unidades se abrem para a testada da rua, criando espaços intersticiais no centro da quadra, com livre acesso, sem circulações definidas. As características arquitetônicas do conjunto edificado resultaram da atuação de profissionais filiados à arquitetura moderna brasileira, permitindo-nos compreender a extensão desse movimento na cidade de Fortaleza.

\section{- A obra moderna na saúde}

Os arquitetos Roberto Nadalutti, Oscar Waldetaro e Israel Barros Correa com escritório no Rio de Janeiro desenvolveram três projetos: o Hospital das Clínicas (UFC), a Maternidade Escola e o Hospital do Câncer do Ceará. Os arquitetos, Liberal de Castro e Ivan Brito, participaram, dentre outros, com os do Instituto de Anatomia e Medicina Legal, a Biblioteca e a Faculdade de Farmácia. Na década de 1970, o arquiteto cearense Nearco Araújo, oriundo da geração de profissionais já formados pela Escola de Arquitetura da UFC e pertencente ao quadro técnico da mesma universidade contribuiu com as unidades da Patologia, Fisiologia e Farmacologia. Os exemplos selecionados para ilustração dessa produção - abaixo descritos - seguiram a ordem cronológica de projeto e/ou execução.

\section{- Hospital das Clínicas}

Em 10 de janeiro de 1955, as entidades que atuavam na gestão do Hospital das Clínicas (Instituto de Ensino Médico e a Fundação Júlio Pinto) contrataram o escritório do arquiteto Roberto Nadalutti, para elaborar um reestudo desse equipamento, considerando a existência do pavilhão de isolamento que já estava em construção, conforme mencionado.

Adotando o partido pavilhonar, a equipe de arquitetos concebeu um edifício que resultava da junção de cinco blocos de configuração retangular e longitudinal desenvolvidos em dois pavimentos justapostos ao bloco centralizado de mesma configuração geométrica e de dois pavimentos e um subsolo, funcionando como eixo de ligação do complexo hospitalar, totalizando uma área de $12.500 \mathrm{~m}^{2}$ (ver figura 33). A solução beneficiava o aproveitamento da ventilação e iluminação natural, além do que possibilitava a construção por etapas, conforme as disponibilidades dos recursos financeiros. 
O projeto datado de 1955 constava de um programa físico de hospital geral com setor de internação com circulação central e enfermarias de dois, três e quatro e seis leitos, quartos de um leito com banheiro acoplado, totalizando 300 leitos, cinco salas de cirurgia, central de esterilização, cozinha, refeitório, almoxarifado, salas para atendimento ambulatorial, laboratórios, capela, conforto de pessoal e outros ambientes necessários ao funcionamento pleno do edifício.

Os acessos eram bem definidos e as circulações permitiam fluxos diferenciados (FREITAS, 2005, p.146-147).

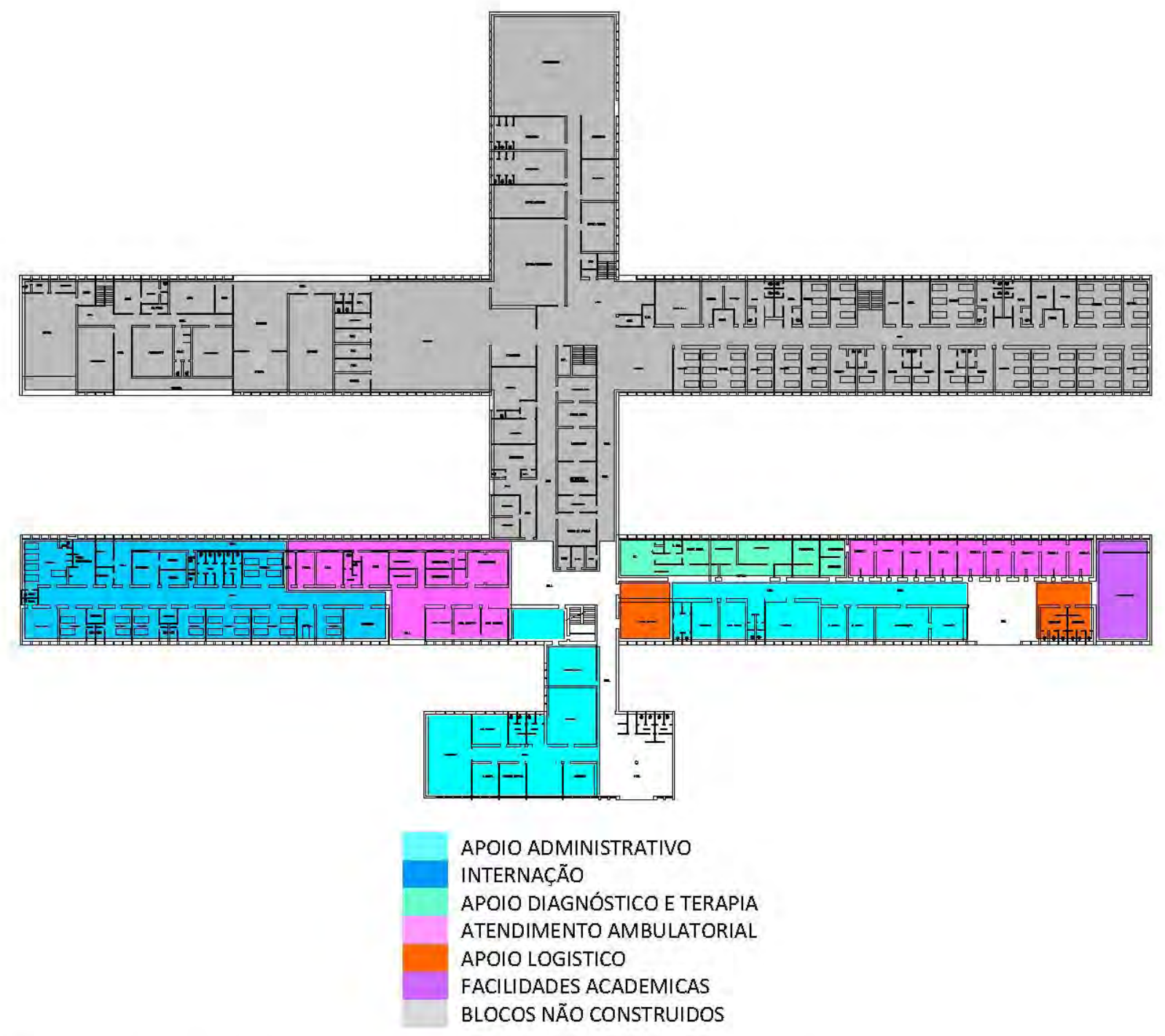

Figura 33: UFC - Redesenho da planta térrea original do Hospital das Clínicas. (Fonte: FREITAS, 2005, p.155) 
Os projetistas empregaram o módulo de $1,20 \mathrm{~m}$ que rege a padronização dos componentes construtivos. Por consequência a forma arquitetônica resulta em um conjunto volumétrico prismático marcado pelos planos de vedação que destacam as esquadrias moduladas, criando ritmo às fachadas. A marquise em laje plana apoiada nos pilares inclinados desempenha a função de linguagem de acesso ao mesmo tempo que cria um contraponto à estabilidade das formas de linha retas (ver figura 34). Dos cinco blocos, somente três foram construídos e inaugurados em 1957. O projeto original não foi implantado na íntegra e outras edificações foram anexadas: o bloco da nutrição, da lavanderia e o central, no início dos anos 1960 e, no final da década de 1970, foi construído um prédio anexo de quatro pavimentos com novos serviços.

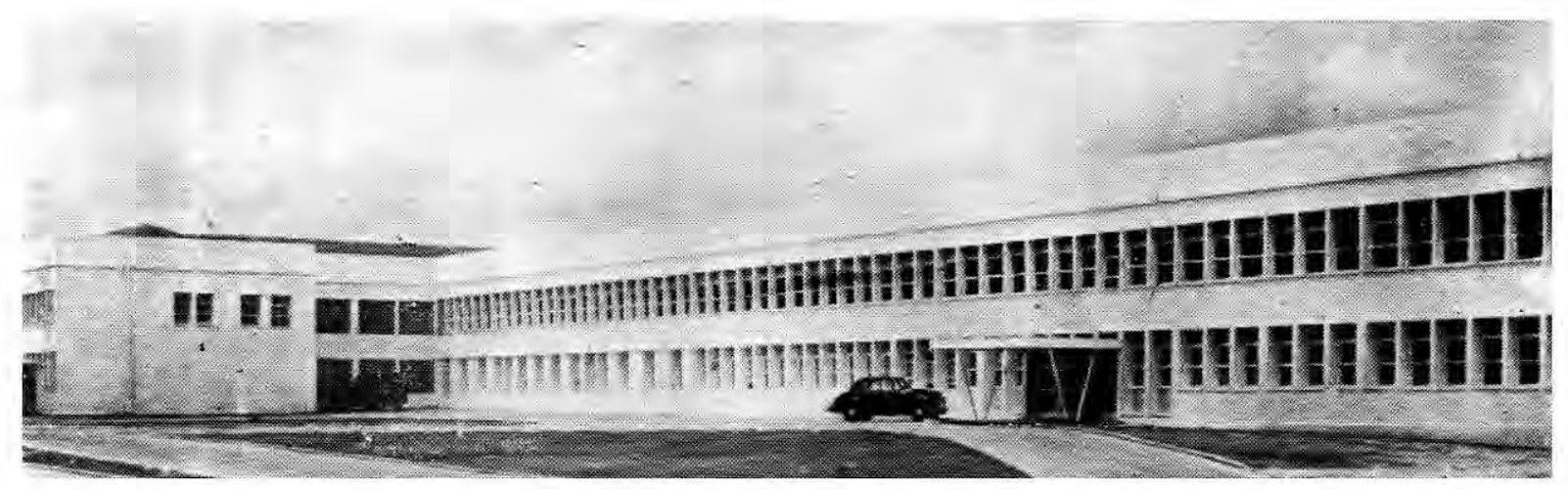

Figura 34: UFC - Hospital das Clínicas.

Vista da fachada principal - edificação concluída em 1957

(Fonte: Araripe, 1998 apud FREITAS, 2005, p.157)

\section{- Instituto Evandro Chagas}

Também no ano de 1955, o complexo da saúde foi ampliado com a construção do Instituto Evandro Chagas que abrigou laboratórios, biblioteca e a administração da Faculdade de Medicina. O projeto, de autoria desconhecida, constituía-se de um edifício térreo cuja planta se desenvolvia em torno de um pátio central rodeado por circulações e passarelas. A construção respondia adequadamente ao clima de altas temperaturas. Foi demolido no início da década de 1970 .

\section{- Hospital de Cirurgia}

Em 1956, novamente os arquitetos Roberto Nadalutti, Oscar Waldetaro e Israel Barros Correa tiveram a oportunidade de projetar outra unidade de saúde na área do Porangabuçu. Desta vez, tratava-se do Hospital de Cirurgia pertencente ao Instituto de Câncer do Ceará, que havia pleiteado a cessão de seis quadras da área doada ao Instituto de Ensino Médico. As limitações financeiras, entretanto permitiram apenas a construção de um bloco térreo, 
cuja arquitetura se define pela estrutura de concreto abobadada, com evidente referência no conjunto arquitetônico de Pampulha, em Belo Horizonte, de autoria do arquiteto Oscar Niemeyer (ver figura 35). Em 1962, o edifício foi ampliado com projeto do arquiteto Liberal de Castro.

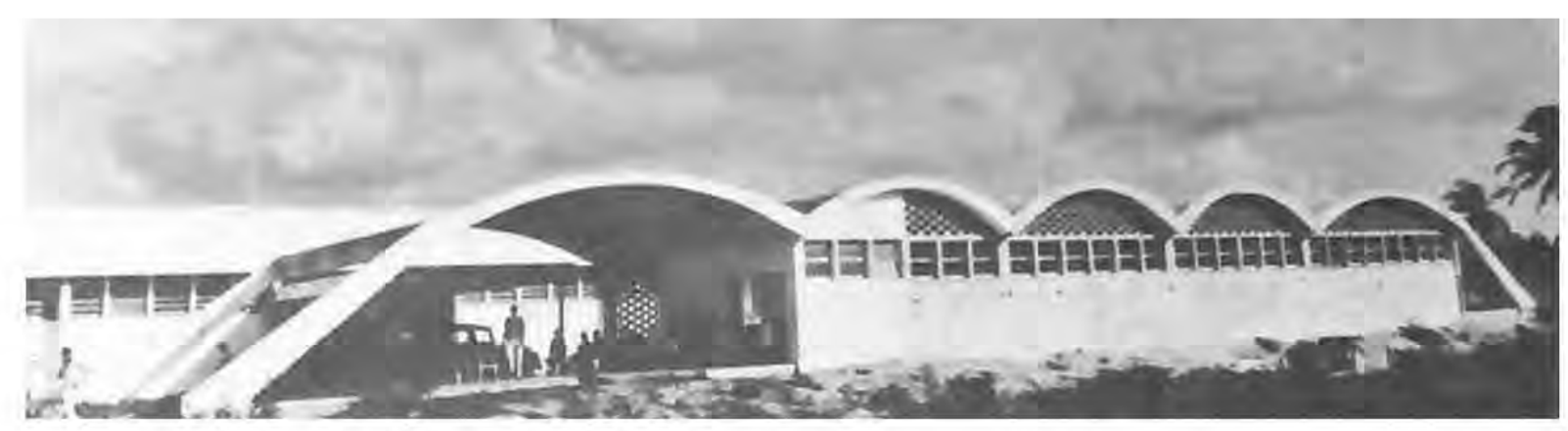

Figura 35: UFC - Hospital de Cirurgia. Foto do prédio original em 1966. (Fonte: UFC, 1966, n.p.)

\section{- Instituto de Anatomia e Medicina Legal}

Em 1957, foi construído o prédio destinado ao Instituto de Anatomia e Medicina Legal que teve a autoria do arquiteto Liberal de Castro. Tratava-se de um edifício térreo cuja planta se desenvolvia em torno de pátios centrais. Sua forma resultava da volumetria de linhas retas vedada pela cortina de esquadrias padronizadas em alumínio e vidro, assemelhando-se à linguagem estilística do hospital adotada no projeto original (ver figura 36 ). Foi demolido em 1980.

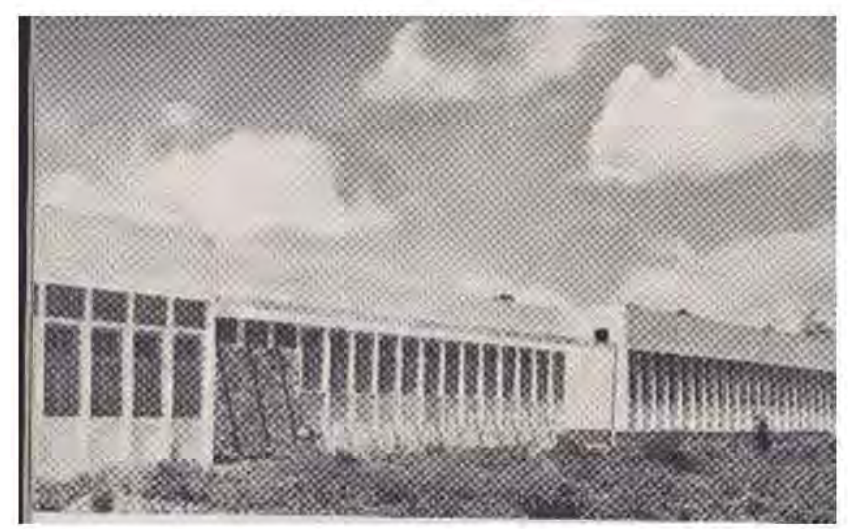

Figura 36: UFC - Antigo Instituto Anatomia e Medicina Legal.

(Fonte: UNIVERSIDADE DO CEARÁ, 1960 apud FREITAS, 2005, p. 160) 


\section{- Matemidade-Escola}

O edifício da Maternidade Popular de Fortaleza inaugurado em 1965 constitui até os dias de hoje em importante exemplar do patrimônio moderno cearense. A concretizaçẫo desse equipamento de saúde pública foi uma iniciativa conjunta da sociedade cearense e do governo estadual com o objetivo de suprir o déficit alarmante de leitos disponiveis para as gestantes carentes do Ceará.

Projetado pelos arquitetos cariocas Roberto Nadalutti, Oscar Waldetaro e Israel Barros Correa - já mencionados - o prédio evidencia a filiaçẫo de seus autores ao Movimento Moderno na Arquitetura Brasileira. O edificio de composiçẫo elegante destaca a volum etria funcional de linhas retas, concebida por uma modulaçẫo estrutural de $6,00 \mathrm{~m}$, valorizando o arcabouço de concepçẫo independente. O programa de necessidades é organizado em setores funcionais, refletindo-se na forma arquitetônica que resulta da junçẫo de um volume prismático frontal de quatro pavimentos, destinado à internaçẫo e administraçẫo, justaposto a outro bloco horizontal, que originalm ente abrigava os servicos complem entares e de apoio logístico (ver figura 37 e 38 ).

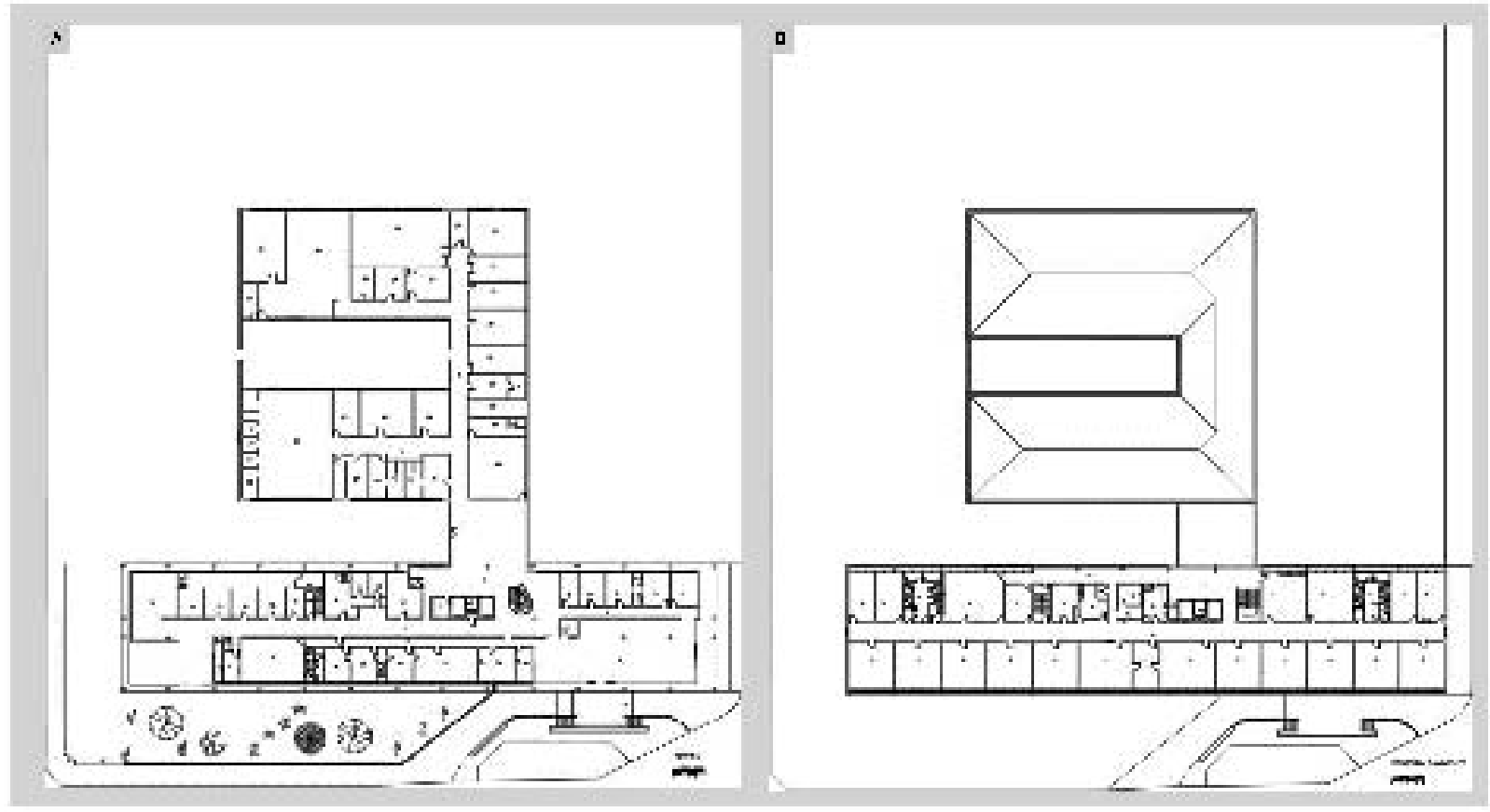

F igura 37: UFC - Maternidade-Escola- Projeto de Arquitetura.

(A) Planta do pavimento térreo: área administrativa, ambulatórios, apoio técnico e apoio logistico.

(B) Planta 10. Pavimento: área de internação.

(Fonte: CAMPELO, FREITAS, TARALLI, 2010) 


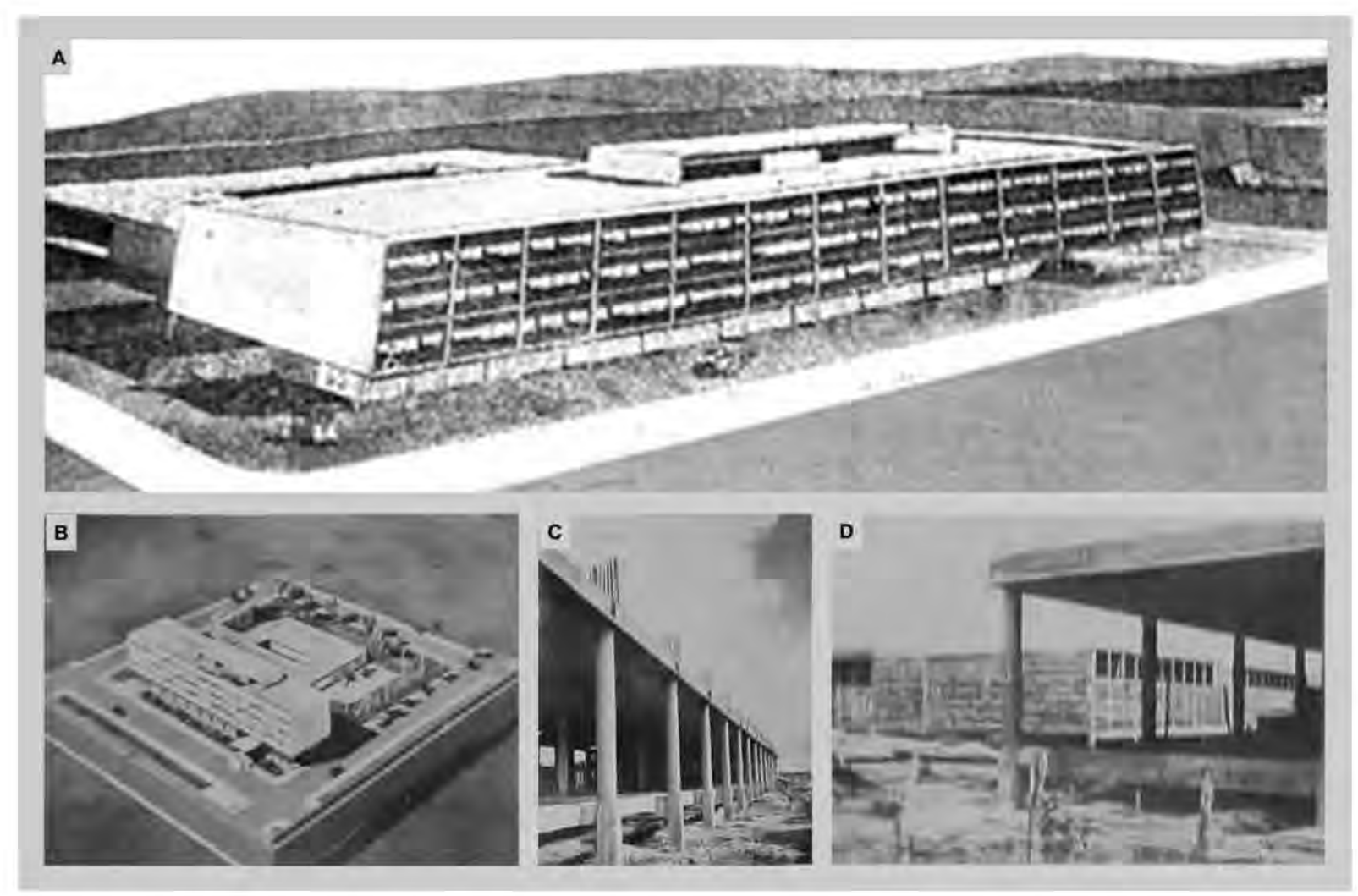

Figura 38: UFC - Maternidade-Escola.

(A) llustração da futura Maternidade-escola.

(B) Foto da maquete - destaca-se a volumetria funcional.

(C) e (D) Fotos da estrutura de concreto em fase execução.

[Fonte: (A) FREITAS et al, 2010. (B), (C) e (D) Acervo COP/UFC]

Os componentes construtivos, tais como os painéis de vedação das amplas aberturas concebidos em estruturas de madeira com venezianas e funcionamento tipo guilhotina, e os materiais de revestimento cerâmico demonstram sua proposta de adequação às características do clima local. Inserido na paisagem, sua concepção modernista contribui para sua identidade e reconhecimento social (CAMPÊLO, FREITAS, TARALLI; 2010). Construído em terreno de esquina, sua implantação original permitia o acesso sem barreiras físicas. Conferindo permeabilidade e integração, os pilotis, em conjunto com a rampa de acesso constituíam-se em um convite aos que por ali passavam (ver figura 39). 


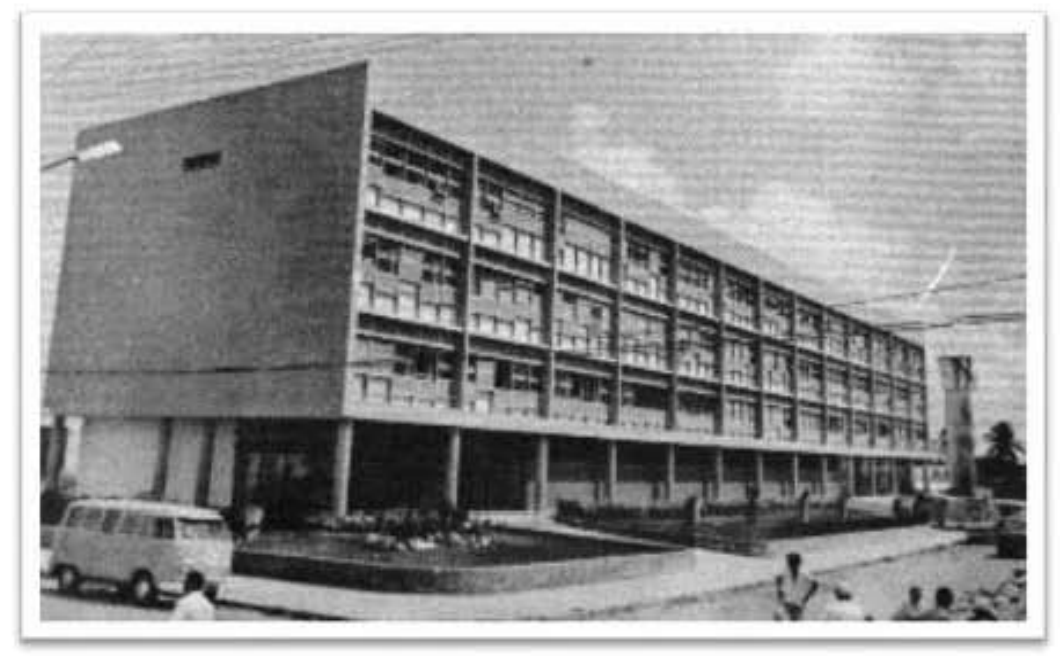

Figura 39: UFC - Maternidade-Escola.

Vista do edifício pela fachada principal, caracterizada pela volumetria prismática do corpo principal composta pelos painéis de vedação em madeira com venezianas.

(Fonte: CAMPELO, FREITAS E TARAШI, 2010)

\section{- Década de 1970: uma nova orientação projetual}

Na década de 1970, novas unidades foram implantadas no Porangabuçu. O prédio da Unidade Didática e Biblioteca, de autoria do arquiteto Ivan Brito, foi construído na mesma quadra do Hospital das Clínicas, criando limitaçổes à expansão daquele equipamento. 0 projeto de 1969 é formado por um edifício de dois pavimentos com planta de configuraçăo retangular que abriga salas de aula e dependências da biblioteca. A volumetria compacta, revestida de pastilha cerâmica e esquadriais de madeira com venezianas móveis năo reproduz a beleza do partido adotado por Brito no edifício da Residência Universitária do Benfica. É possivel evidenciar uma nova orientaçẫo projetual caracterizada pela compacidade da volumetria.

Em 1974 e 1976, o arquiteto Nearco Araújo contribuiu com o projeto dos edifícios destinados ao Departamento de Biologia e ao Departamento de Fisiologia e Farmacologia respectivamente. Concebidos em dois pavimentos o partido construtivo afasta-se da elegância e singeleza peculiar da produção dos anos 1960.

\section{- Pici: território segregado}

A origem do território universitánio do Pici está vinculada a implantação da Escola de Agronomia do Ceará, fundada em 1918. Pela natureza das suas atividades, a Instituição requeria área física com condiçôes específicas para realizar seus procedimentos práticos: laboratórios especializados e implementos próprios, extensos campos para experimentação 
e manejo das diversas culturas, solos apropriados e disponibilidade permanente de água (OLIVEIRA, 2005, p.55). Por estas características não poderia se adaptar à natureza de parcelamento do solo em centro urbano, onde o lote é a unidade territorial. O Sítio do Pici, localizado na região oeste da capital, tornou-se então a alternativa técnica e econômica viável para a concretização da Escola.

O início das suas atividades se deu em imóvel doado pelo governo do Estado, localizado no centro da cidade de Fortaleza ${ }^{29}$. Para o atendimento das especificidades práticas, entretanto foi instalado em terreno situado em subúrbio afastado, também doado pelo Estado. As características da gleba, localizada às margens da BR-222, no Distrito Antônio Bezerra, com presença de água constante, terra fértil e vias de acesso, atendia às especificidades das suas atividades e aos interesses dos profissionais que ali iriam trabalhar.

Em 1937, após ser encampada pelo Estado em decorrência do novo modelo de ensino agrícola no país, que passou a ser subordinado ao Ministério da Agricultura, perdeu sua natureza privada, mas ampliou sua infraestrutura de laboratórios, oficinas, estábulos, pocilgas e galpões para máquinas, intensificou as culturas de campo e expandiu o ensino, abrangendo cursos para trabalhadores rurais (OLIVEIRA, 2005, p.56). Seu funcionamento no subúrbio da cidade chegou a ser questionado pelo governo, decorrendo daí um movimento em defesa da sua interiorização no ano de 1945.

Prevaleceram, entretanto, os anseios dos integrantes da Escola, professores da elite intelectual urbana, que não aceitou trocar o conforto da vida na cidade pelas carências e limitações do meio rural ${ }^{30}$. Tal condição foi reforçada com a sua inclusão entre as unidades que constituíram a Universidade Federal do Ceará em 1954.

Embora tenha havido reação por parte dos dirigentes da Instituição à sua incorporação na recém-criada universidade, preocupados em ter que dividir os seus recursos em benefício das outras unidades, fato superado pela habilidosa atuação da Administração Central, o funcionamento da Escola de Agronomia na área do Pici foi definitivamente selado, funcionando até os dias de hoje.

Oliveira (2005, p.60) avalia que os requisitos necessários à especificidade do seu funcionamento, fizeram da sua presença naquela região uma condição quase compulsória, reforçada pela possibilidade de anexar terrenos desocupados existentes no seu entorno e assim ampliar os seus limites. Essa última condição foi avaliada no início da implantação da UFC como estratégica para a materialização do território da Universidade no modelo de cidade universitária a exemplo de outras instituições, tais como a USP, cujos representantes

\footnotetext{
${ }^{29}$ Instalou-se inicialmente no antigo edificio do Liceu do Ceará, localizado na Praça dos Voluntários, que foi posteriormente demolido e deu lugar ao atual prédio da Secretaria de Polícia e Segurança Pública (CASTRO, 1979, p.84).

${ }^{30}$ Sobre esse assunto ver o capitulo 2 , páginas 55 a 63 , da dissertação de mestrado de autoria de Oliveira (2005).
} 
do escritório técnico responsável pela construção da cidade universitária estiveram em Fortaleza, a convite da UFC, para apresentar o projeto do seu território unificado.

Importante esclarecer que a região do Pici era constituída originalmente por sítios, destacando-se dentre eles o Sítio Pici ${ }^{31}$, que foi doado à Escola de Agronomia, como já foi mencionado. Na década de 1940, período da Segunda Guerra Mundial, os americanos instalaram nas circunvizinhanças um posto de comando e construíram um aeroporto com toda estrutura preparada para guerra, de onde partiam os aviões para bombardear os países não aliados.

Na década de 1950, depois da retirada dos americanos, os sítios foram se transformando em loteamentos e as terras da base ficaram sob a vigilância da Aeronáutica de Fortaleza, as quais faziam limite com a gleba da Escola de Agronomia e, estando desocupadas, configuravam-se como área livre.

Foi então que a Administração Superior, vislumbrando a possiblidade de ampliar a área da UFC e assim criar as condições para a implantação da futura cidade universitária, manifestou oficialmente em sessão do Conselho Universitário, realizada em 14 de novembro de 1956, o propósito de adquirir aqueles terrenos. A intenção era favorecida por tratar-se de propriedade da União, o que facilitava as negociações para incorporá-la aos terrenos da Escola de Agronomia (ver figura 40).

Com esse propósito, o então reitor Antônio Martins Filho foi levado a conhecer as obras de implantação da cidade universitária da USP, no bairro do Butantã, em São Paulo. Vale ressaltar que foi nessa ocasião que se estabeleceu contato com o arquiteto Hélio de Queiroz Duarte, professor catedrático da Faculdade de Arquitetura e Urbanismo daquela universidade e um dos integrantes da Comissão de Execução daquela obra.

Em 1957, ele esteve em Fortaleza, para proferir conferência sobre o Plano de Construção da Cidade Universitária da USP, retornando na primeira metade da década de 1960 para assessorar a UFC na criação da Escola de Arquitetura [já mencionado na história do Benfica] e na coordenação do planejamento físico para expansão da Universidade - Plano de Desenvolvimento de 1966 / 1970, que será tratado no decorrer do presente capítulo.

\footnotetext{
${ }^{31}$ Além do Sítio Pici, havia o Sítio Ipanema, Sítio do Papai e os terrenos das irmãs do asilo de Parangaba e da Base Aérea. Em 1958, com a base dos americanos desativada, algumas famílias ocuparam os "paióis" ou casamatas, local onde eram camufladas as munições do Exército Americano. Gradativamente, foram surgindo, a partir dessa época, os bairros PanAmericano, Pici, Ipanema Antônio Bezerra e Casa Popular, que foi o primeiro conjunto habitacional construído em Fortaleza, sendo atualmente o bairro Henrique Jorge (Sobre esse assunto consultar o blog de Leonardo Sampaio, disponível em <leonardofsampaio.blogspot.com/2007/12/historia-do-pici.html>.)
} 


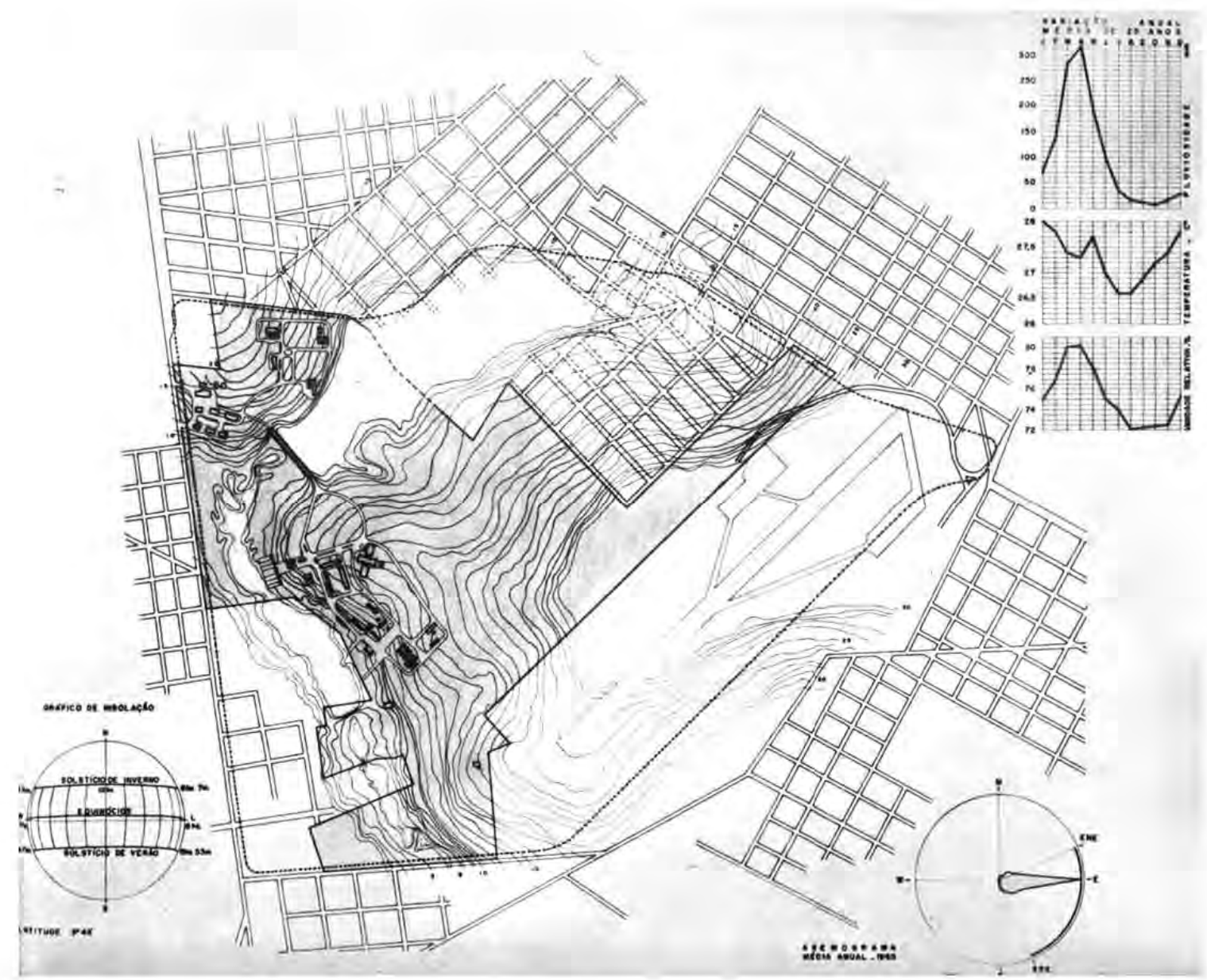

Figura 40: UFC - Futuro Campus do Pici.

Gleba do Pici com anexação dos terrenos da antiga Base Aérea do Pici construída pelos americanos na Segunda Guerra Mundial.

(Fonte: UFC, 1966, n.p.)

O processo de aquisição dos terrenos do campo de pouso do Pici, entretanto não logrou êxito: a demora nas negociações, associada à inexistência de fontes de recursos para financiar os investimentos necessários, arrefeceu as expectativas de concretizar o propalado modelo espacial único. A ideia do território unificado não foi, entretanto eliminada, tanto que a Universidade passou a adquirir lotes circunvizinhos, mantendo o propósito de ampliar a área do Pici. Entretanto, é importante lembrar que o contexto vivenciado pelo embate dos dirigentes das antigas faculdades que deram origem à UFC - Direito, Medicina e Agronomia - sobrepõe-se ao desenvolvimento da base física, que culminou com três áreas diferenciadas, conforme já descrito. Oliveira $(2005$, p.63) infere que a materialização da UFC foi produto das relações sociais que se estabeleceram a partir desse arranjo institucional, tendo concretamente como suporte físico inicial os imóveis oriundos do patrimônio imobiliário das unidades que Ihe deram origem. 
- Pici: ocupação a partir de núcleos dispersos

A gleba do Pici com área de 158,8 ha foi ocupada predominantemente até meados da década de 1960 pelas unidades vinculadas à Escola de Agronomia. Conforme se constata na planta da figura 41 , até essa época, a ocupação resultava da distribuição de três setores edificados - a Escola de Agronomia, o Instituto de Tecnologia Rural e o Instituto de Zootecnia - que formavam núcleos dispersos na área de grande extensão. Somente no início da década de 1970 após o advento do primeiro plano de desenvolvimento físico elaborado pela UFC é que a gleba do Pici iniciou o processo de transformação da sua configuração urbano-arquitetônica, orientada pelas diretrizes do planejamento físico de origem no urbanismo moderno, dominando a paisagem edificada desse território e deixando suas marcas até os dias de hoje.

A produção edilícia do primeiro momento caracterizava-se pelo conjunto de construções de arranjo eclético ou vernacular e poucos projetados por profissionais herdeiros da Escola Carioca, merecendo destaque nessa produção o edifício-sede do Instituto de Zootecnia junto com a torre da caixa d'água de autoria do cearense Enéas Botelho referenciado por seus pares como o primeiro arquiteto a atuar na cidade de Fortaleza.

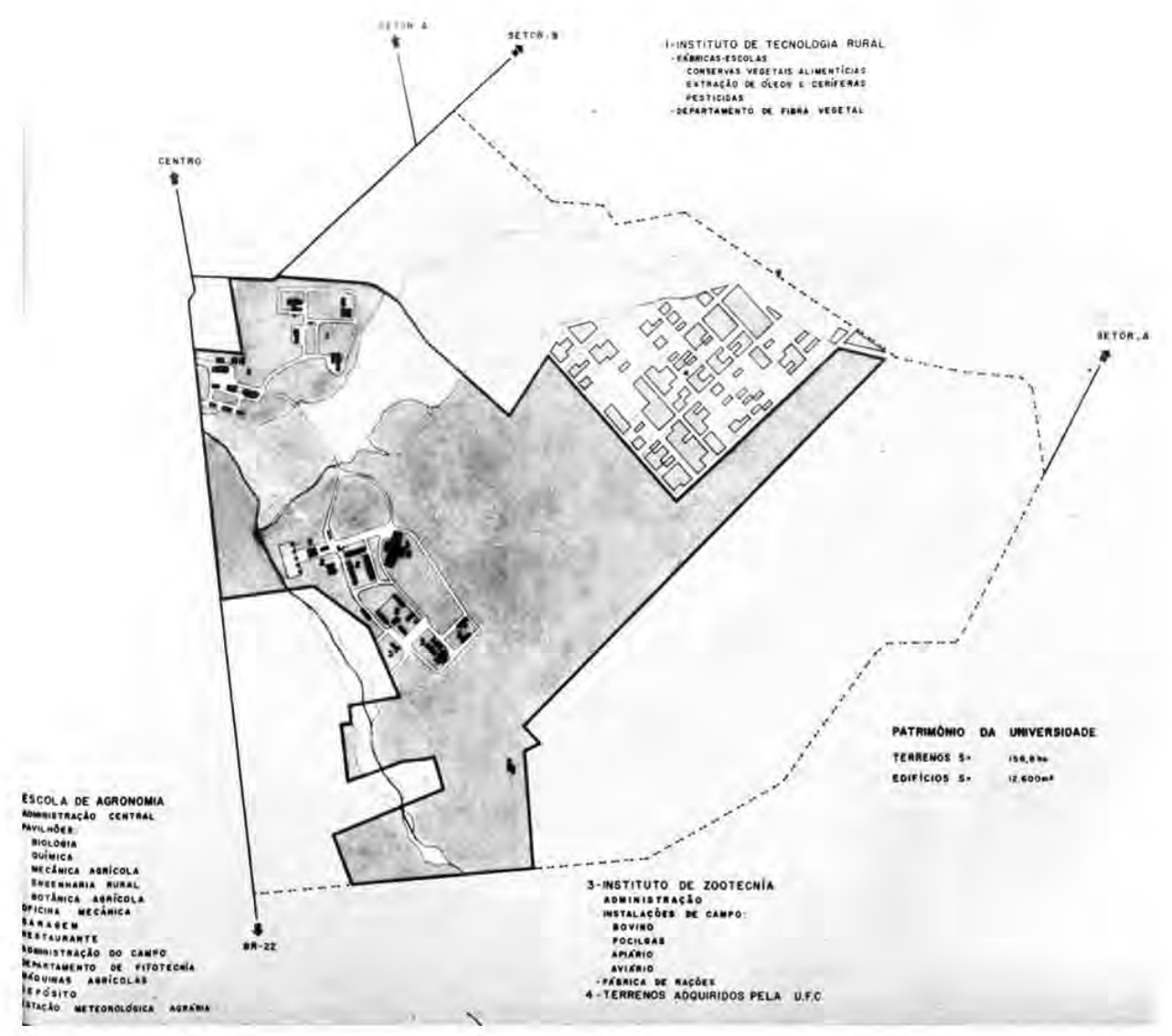

Figura 41: UFC - Gleba do Pici - ano 1966.

(Fonte: UFC, 1966, n.p.) 


\section{- Instituto de Zootecnia: a chegada do moderno}

Botelho concebeu para o Instituto de Zootecnia um edifício de estrutura arrojada para aquele período em Fortaleza. Resultava da junção de três blocos funcionais, sendo um centralizado destacado plasticamente pela estrutura de concreto armado em pórticos de geometria abobadada, e dois de configuração retangular interligados ao primeiro por passarelas cobertas e opostos entre si, formando um conjunto de composição simétrica e arquitetura de linhas leves (ver figura 42). Na fachada de acesso destacava-se a caixa d'água de concepção monumental, composta pela junção de três reservatórios suspensos por pórticos em forma de arcos. As edificações estavam integradas com a proposta urbanística concebida pelas vias de circulação - veículos e pedestres - de configuração curvilínea, que limitava a praça frontal e áreas livres de jardins, resultando em um desenho talvez alimentado por referências ao projeto do Parque do Ibirapuera, de autoria do arquiteto Oscar Niemeyer, inaugurado em 1954 na cidade de São Paulo.

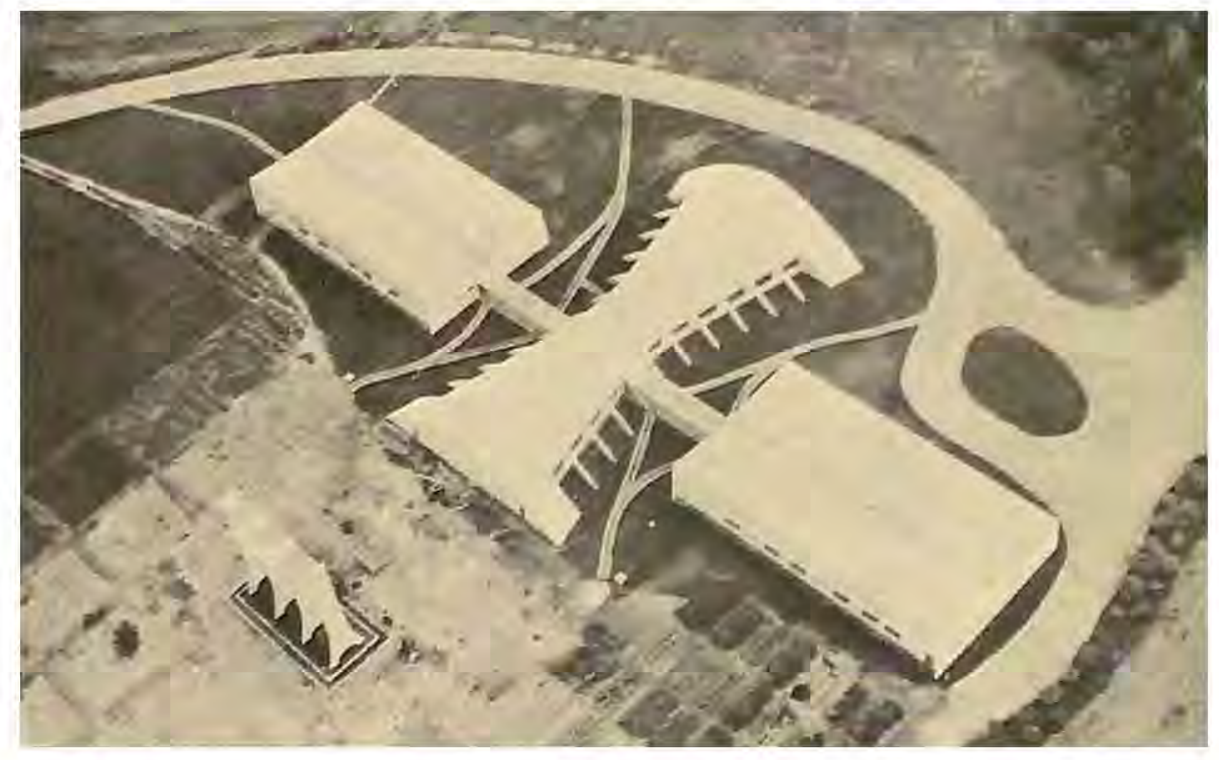

Figura 42: UFC - Instituto de Zootecnia - ano 1966. (Fonte: UFC, 1966, n.p.)

Os exemplos acima testemunham o processo de formação do território do Pici nos primeiros anos de sua implantação. Da mesma forma que nas demais áreas (Benfica e Porangubuçu) o cenário urbano-arquitetônico não era regido por uma diretriz operativa de ocupação. 0 conjunto edificado, apesar dos estilos de origem diversificada, não deixa de manifestar a chegada do repertório arquitetônico modernista. Com as três áreas, a materialização da Universidade era um processo irreversível e já na primeira metade da década de 1960 enfrentava estrangulamento das suas ações, revelando a importância de adequar-se às exigências surgidas. 
- Plano de Desenvolvimento - 1966/1970: a semente do urbanismo racional moderno

O acelerado crescimento da Instituição e a vivência dos dez primeiros anos de sua existência indicavam a necessidade de um planejamento para ordenar sua expansão, Ao mesmo tempo, as diretrizes do desenvolvimento nacional tornavam as instituições de ensino superior responsáveis pela qualificação de profissionais para atender às demandas requeridas no campo socioeconômico.

Neste cenário, a UFC constatou a incapacidade das suas instalações e a escassez de recursos humanos e materiais para atender à crescente procura por vagas para ingresso na Universidade, avaliação que corroborava com a importância do planejamento que se destinava a traçar as perspectivas para o seu crescimento no quinquênio 1966/1970.

A referida revisão crítica que resultou dos seminários anuais realizados com a participação dos professores culminou com o Plano de Desenvolvimento da Universidade Federal do Ceará, publicado em 1966.

Elaborado a partir de criterioso estudo das demandas regionais a serem atendidas e com base no diagnóstico da estrutura e dos dados relativos ao crescimento do seu primeiro decênio de existência, o Plano definiu as novas exigências da Instituição em termos de zoneamento, urbanização, edificações, serviços básicos, equipamentos, pessoal docente e pesquisadores. Reconhecido como documento institucional, buscou credenciamento junto ao Banco Interamericano de Desenvolvimento (BID) objetivando a obtenção de recursos a serem investidos na concretização desses objetivos.

Foi elaborado tendo como princípios orientadores a integração e a expansão. Entretanto, a fragmentação espacial caracterizada pelas três áreas em localizações distintas foi identificada como uma contradição a ser superada. Por outro lado, os investimentos imobiliários nelas realizados não poderiam ser desperdiçados.

Para contornar o conflito, os profissionais responsáveis pelo planejamento físico valeram-se dos princípios racionalistas do urbanismo moderno, que conferia ao zoneamento funcional a solução de uniformidade dos usos para propor a nova organização espacial. Estabeleceram a vocação funcional de cada uma das três áreas, que passaram a ser denominadas de Setor $A$, Setor $B$ e Setor $C$, correspondendo respectivamente às do Benfica, Porangabuçu e Pici (ver figura 43). 


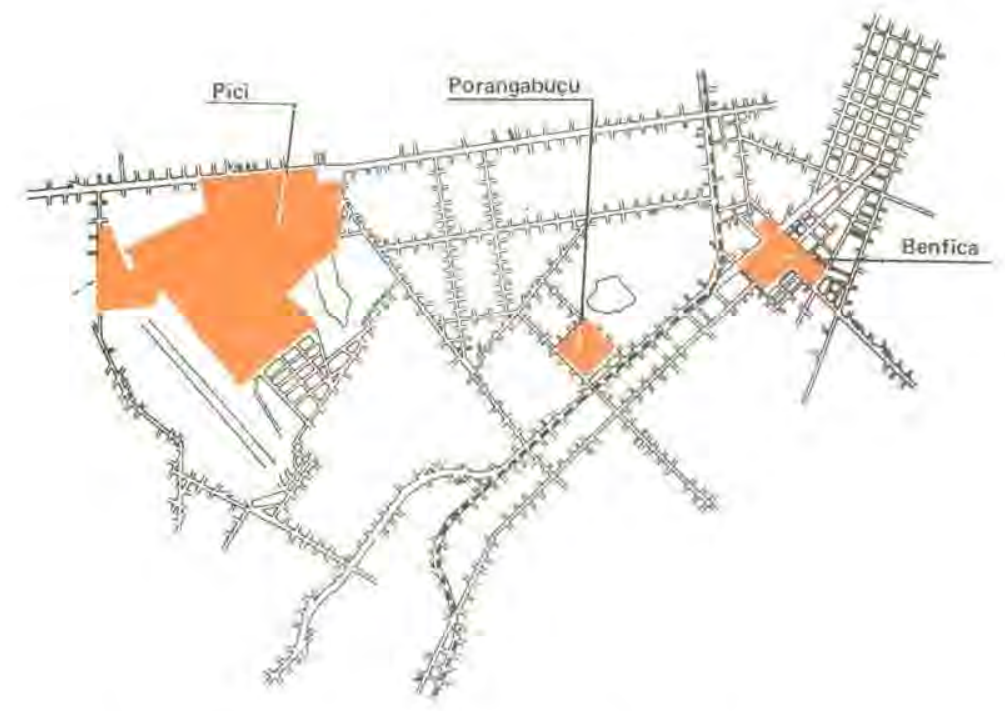

Figura 43: UFC - Mapa do zoneamento em três setores (Fonte: UFC, 1980, p.50)

A consolidação funcional seria obtida pelo gradativo remanejamento de parte das unidades entre os três setores, ao mesmo tempo que seriam construídas outras novas identificadas com o zoneamento proposto. Eles ficariam assim constituídos (ver figura 44):

- Setor A - permaneceriam as unidades de Ciências Sociais, Educação, Letras, Artes e órgãos da Administração Superior. Essas unidades, por desenvolverem atividades de extensão ligadas ao atendimento de expressivo contingente de público, seriam favorecidas pela localização próxima ao centro da cidade.

- Setor $B$ - permaneceriam as unidades de Ciências Biomédicas, praticamente consolidadas, contando inclusive com a presença do Hospital das Clínicas. Deveriam ser realizados os seguintes investimentos: conclusão do edifício da Faculdade de Farmácia, construção de novas instalações para a Faculdade de Odontologia e ampliação das unidades da Faculdade de Medicina.

- Setor C - permaneceria o conjunto da Agronomia e receberia as unidades do setor Tecnológico, bem como dos Institutos Básicos, transferidos do Benfica. Por constituir-se na área de maior extensão territorial, foi identificada como potencialmente capaz de vir a se transformar em território único. Os investimentos gradativos culminariam na concretização desse projeto, instrumentalizado pelo Plano de Desenvolvimento, orientador da futura conformação urbano-arquitetônica.

A Universidade era integrada também por unidades esparsas:

- Unidades Esparsas - abrangiam a construção do Setor de Arte Teatral e a Estação de Biologia Marinha em local a ser definido. 


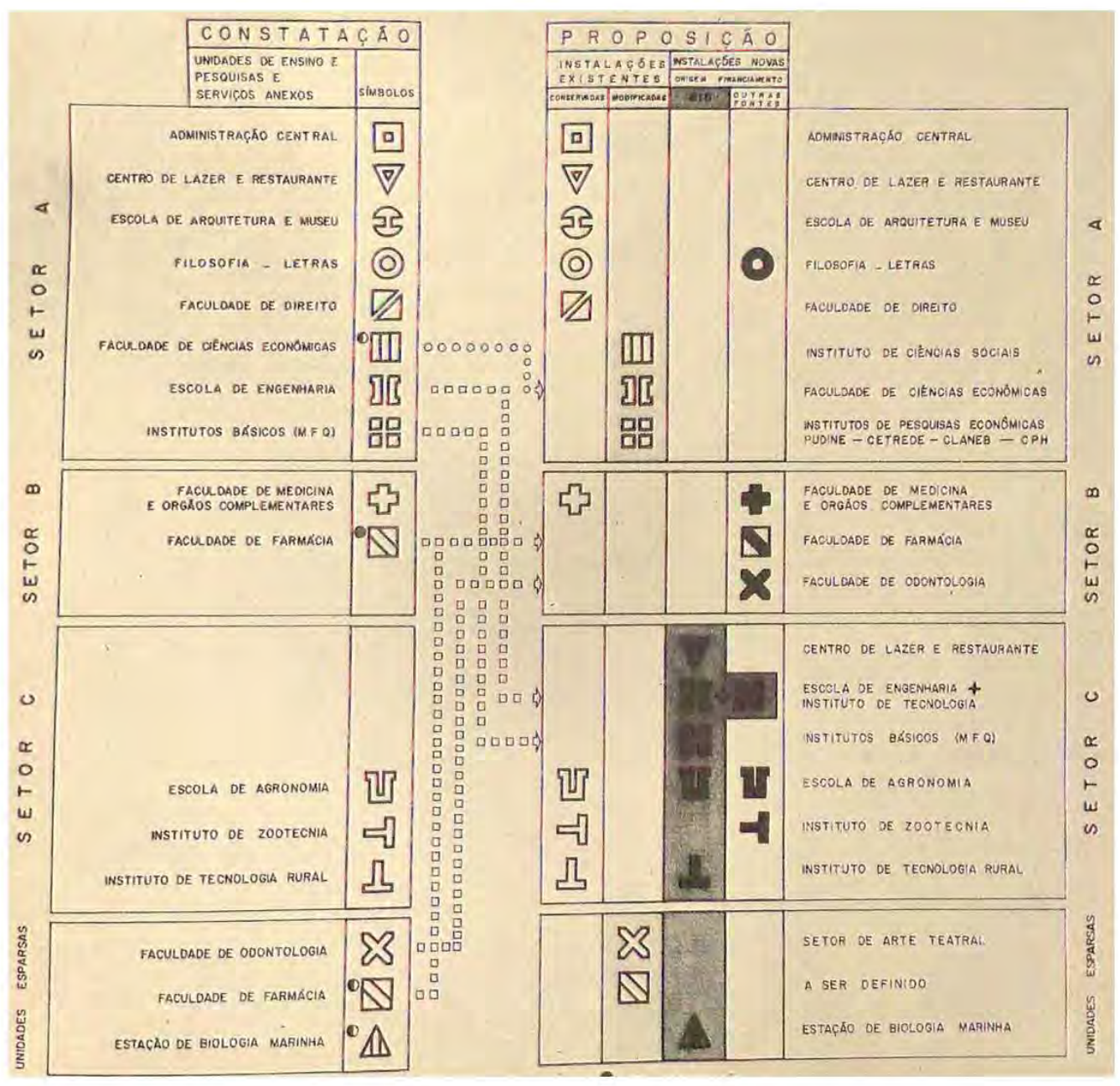

Figura 44: Plano de Desenvolvimento de 1966/1970.

Esquema de remanejamento das unidades estabelecido no para a formação das zonas funcionais.

(Fonte: UFC, 1966, n.p.)

Considerando as potencialidades do Setor $C$, o Plano definiu as bases do seu desenvolvimento físico, estabelecendo sua divisão em áreas funcionalmente predefinidas, considerando inclusive aquelas destinadas à expansão e à inserção de novas unidades que viessem a ser requeridas. Estavam esquematizadas as zonas Tecnológica (constituída pelos Institutos de Ciências Básicas e pela Escola de Engenharia) e Agronômica (com a Escola de Agronomia e institutos correlatos). Com a presença do Açude Santo Anastácio, identificado na planta como "lago", suas margens foram destinadas à implantação do setor de lazer e em pontos periféricos da gleba seriam instalados setores residenciais.

A organização espacial regida pelo princípio do zoneamento resultou no conjunto das áreas funcionais fisicamente separadas, porém articuladas por um sistema viário hierarquizado. Constituía-se da via perimetral de contorno, ramificada em vias secundárias que margeavam as zonas funcionais e propiciavam o seu acesso por meio de bolsões de estacionamento 
distribuídos e dimensionados conforme a localização dos edifícios e necessidades das unidades instaladas. Internamente a esse terreno foi projetada a circulação de pedestres, isolada do tráfego de veículos, assim concebida para proporcionar segurança e tranquilidade aos transeuntes. A mais alta cota de nível foi reservada para constituir-se em core permanente, caracterizando o campo cívico e o relacionamento social universitário (ver figura 45). A concepção adotada revela o entendimento de que a Universidade deveria ser um todo integrado, cabendo às bases do seu desenvolvimento físico garantir essa condição, o que ocorreria por meio da organização espacial funcional, subordinada ao crescimento racional orgânico.

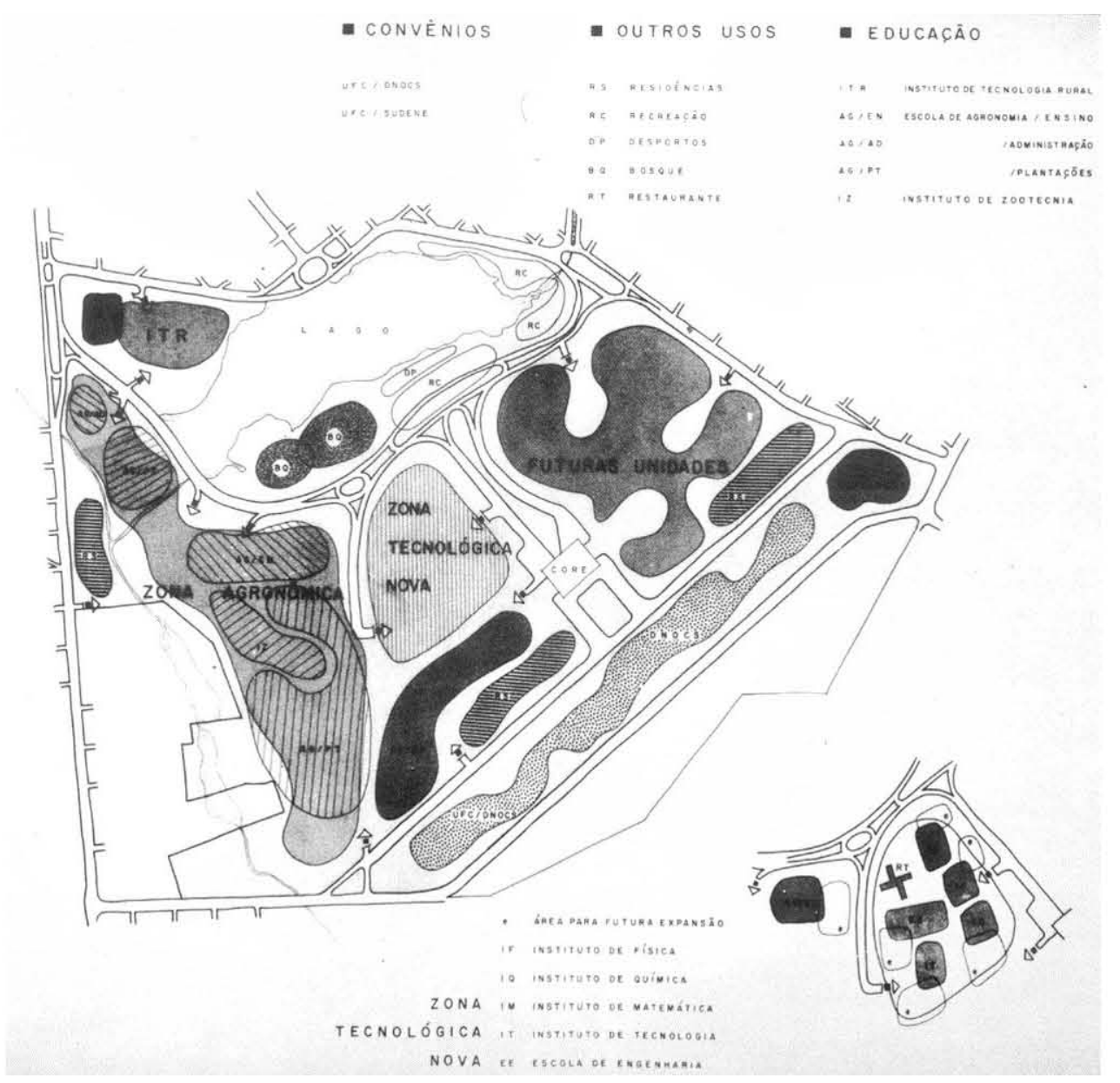

Figura 45: UFC - Zoneamento funcional proposto no Plano de Desenvolvimento de 1966 / 1970. (Fonte: UFC, 1966, n.p.)

O Plano também estabeleceu a concepção arquitetônica dos edifícios a serem implantados, que seriam regidos pelos princípios de racionalidade e flexibilidade, atributos necessários para garantir sua reprodução com economia e capacidade de adaptação às diversas solicitações acadêmicas. Com tais premissas o processo de projeto adotou, a partir do programa de necessidades, o conceito do zoneamento como princípio organizativo do arranjo espacial. Os conjuntos funcionais definidos seriam articulados pelas circulações, 
concebidas para eliminar confluências e distâncias desnecessárias, de forma a promover eficiência e celeridade no desenvolvimento das atividades. $O$ processo construtivo procuraria permitir adequaçâo espacial no atendimento de novas funçôes, com o mínimo de custos operacionais e financeiros, obtidos por meio da modulaçâo e consequente padronizaçăo dos componentes da edificaçẩo - princípios basilares da racionalidade almejada - além de dar unidade visual ao conjunto edificado. Facilidade construtiva e ausência de monumentalidade eram objetivos almejados.

Orientado pelas premissas acima referidas, o Plano sintetizou uma metodologia de projeto que consistiu em tipificar e ordenar as necessidades funcionais dos espaços, resultando na esquematização de sete blocos padrốes (caracterizados na figura 46) que poderiam ser associados, permitindo gerar a soluçẩo dos conjuntos programados para cada unidade, conforme esquema da figura 47 (CAMPELO, 2005, p.66-67). As unidades projetadas resultavam do processo de projeto que envolvia os conceitos do zoneamento funcional, da malha modular e da padronização construtiva, permitindo sua execuçäo com economia e rapidez (ver figuras 48 à 50 ).

SA-1 - Utilização: Salas de aula

Área coberta: $475 \mathrm{~m}^{2}$

Caracteristicas: compöe-se de quatro salas de aula para 50 alunos cada e conjunto sanitário:

GP - Utilização: Gabinetes de professores e oficinas leves.

Area coberta: $656 \mathrm{~m}^{2}$

Caracteristicas: Bloco de dois pavimentos para gabinetes de professores (individuais ou pera dois professores).

\section{CA - Utilização: Cantina}

Área coberta: $112 \mathrm{~m}^{2}$

Caracteristicas: compốe-se o bloco de uma área livre para estar e recreação e um pequeno reservado para serviços.

\section{AD - Utilização: Administração}

Área coberta: $1.300 \mathrm{~m}^{2}$

Características: Bloco de dois pavimentos para instalação da administração e serviços normais (diretoria, secretarias, almoxarifado, sanitários, etc). A área do segundo pavimento foi reservada para bibliotecae sala de reuniōes de professores e congregação.

\author{
SA-2 - Utilizaçăo: Salas de aula - Auditório \\ Área coberta: $218 \mathrm{~m}^{2}$ \\ Características: Auditório para 200 pessoas e \\ cabine de projeçāo.
}

OF - Utilização: Oficinas e salas de estudo

Área coberta: $900 \mathrm{~m}^{2}$

Caracteristicas: compōe-se de quatro oficinas e 22 boxes.

\section{CE - Utilização: Circulaçăo externa.}

Características: àrea que faz a ligação extema entre os blocos e áreas de recreaçăo e estar.

LBDp - Utilização: Laboratónos didáticos e de pesquisas.

Area coberta: $1,350 \mathrm{~m}^{2}$

Caracteristicas: Bloco de dois pavimentos, ficando quatro laboratórios didáticos no térreo e seis laboratórios de pesquisa no superior.

Figura 46: UFC - Caracterizaçẫo de blocos-padrốes.

(Fonte: UFC, 1966, ediçấo nossa) 


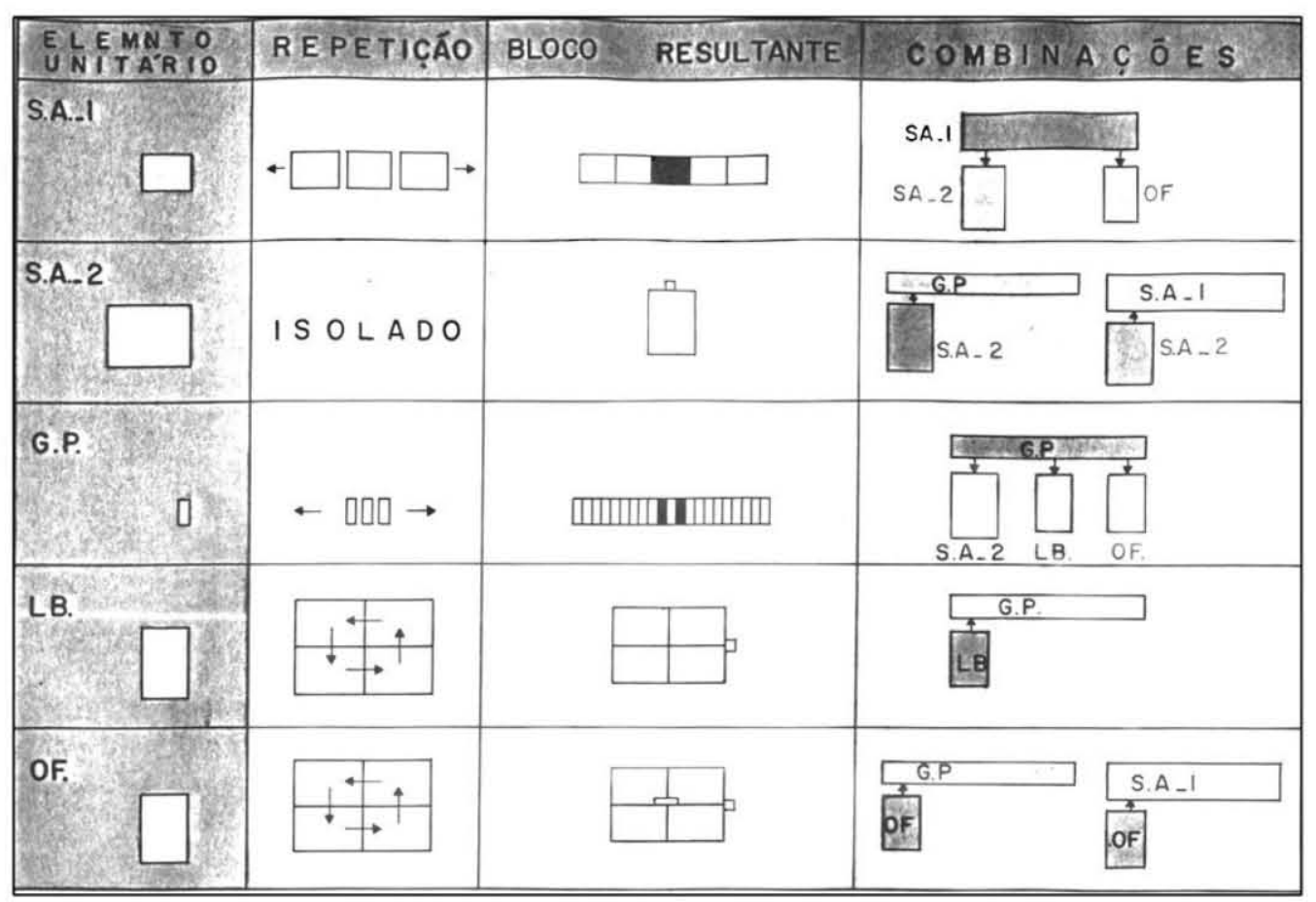

Figura 47: UFC - Esquema de associação dos blocos-padrões. (Fonte: UFC, 1966, n.p.)

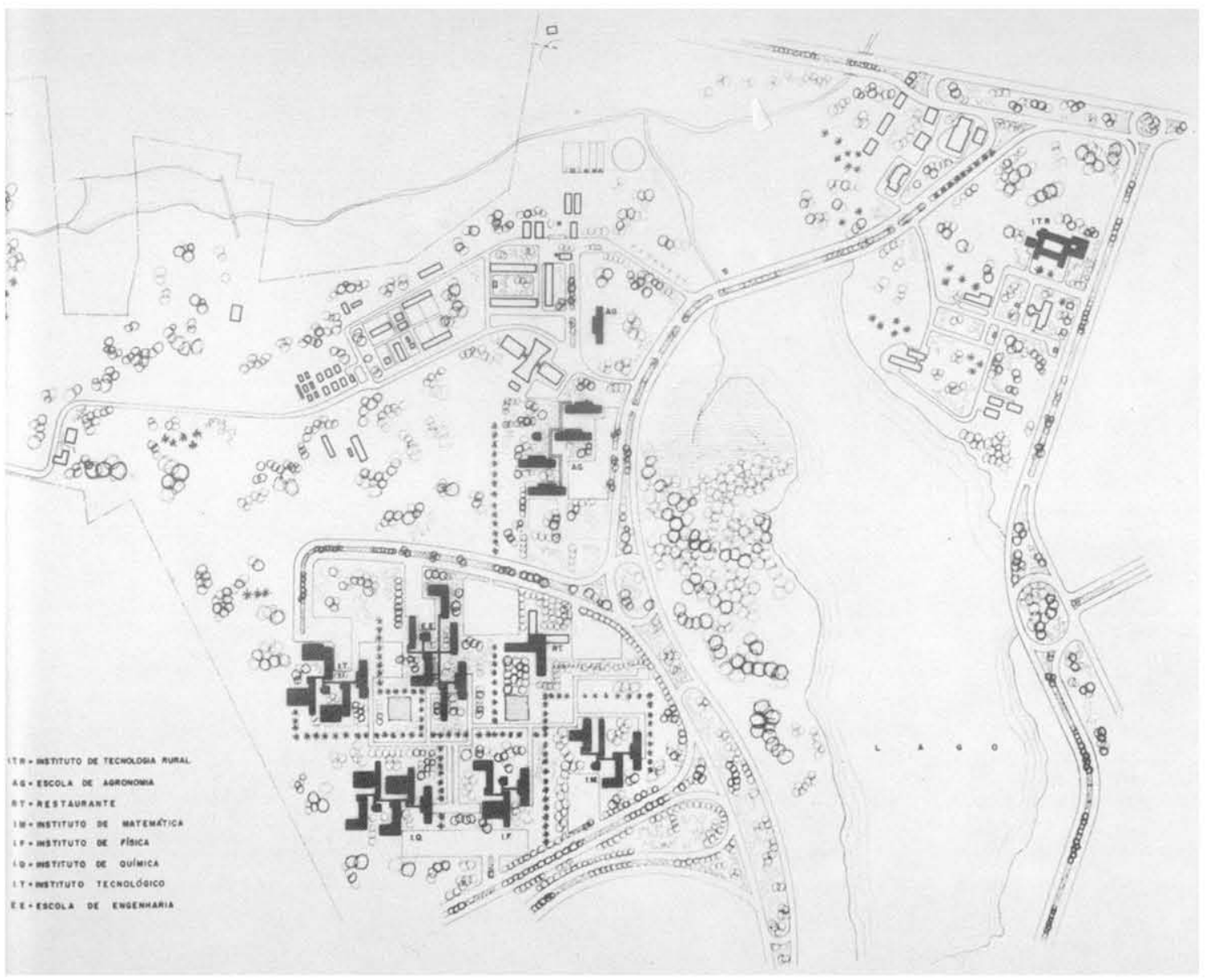

Figura 48: UFC - Implantação das unidades no Setor C. (Fonte: UFC, 1966, n.p.) 

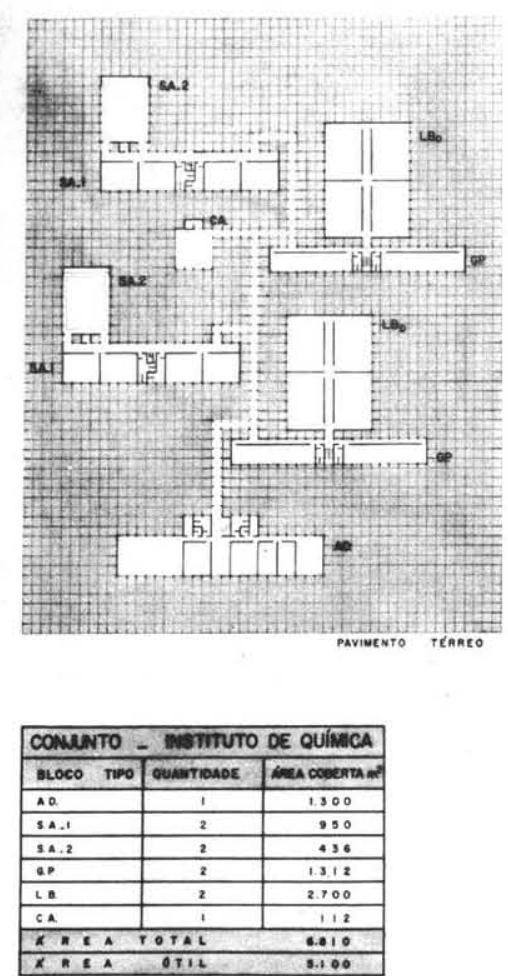

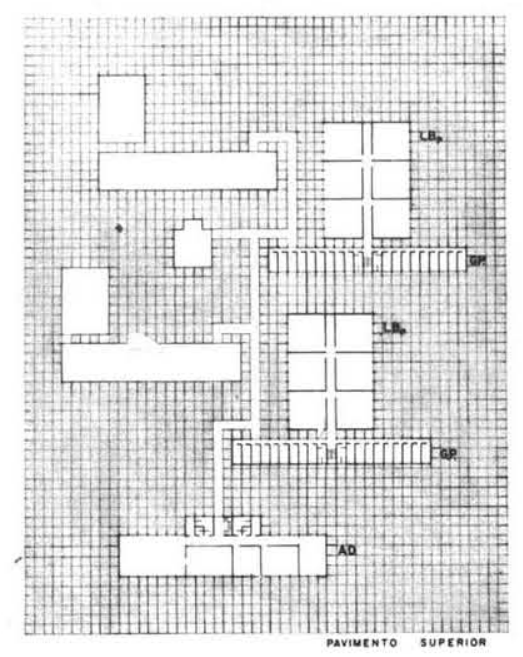

能

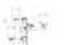

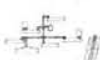

Figura 49: UFC - Instituto de Química.

Esquema de associação dos blocos-padrões para compor o Instituto de Química. Eles se articulam por meio de passarelas.

(Fonte: UFC, 1966, n.p.)

$A D$.
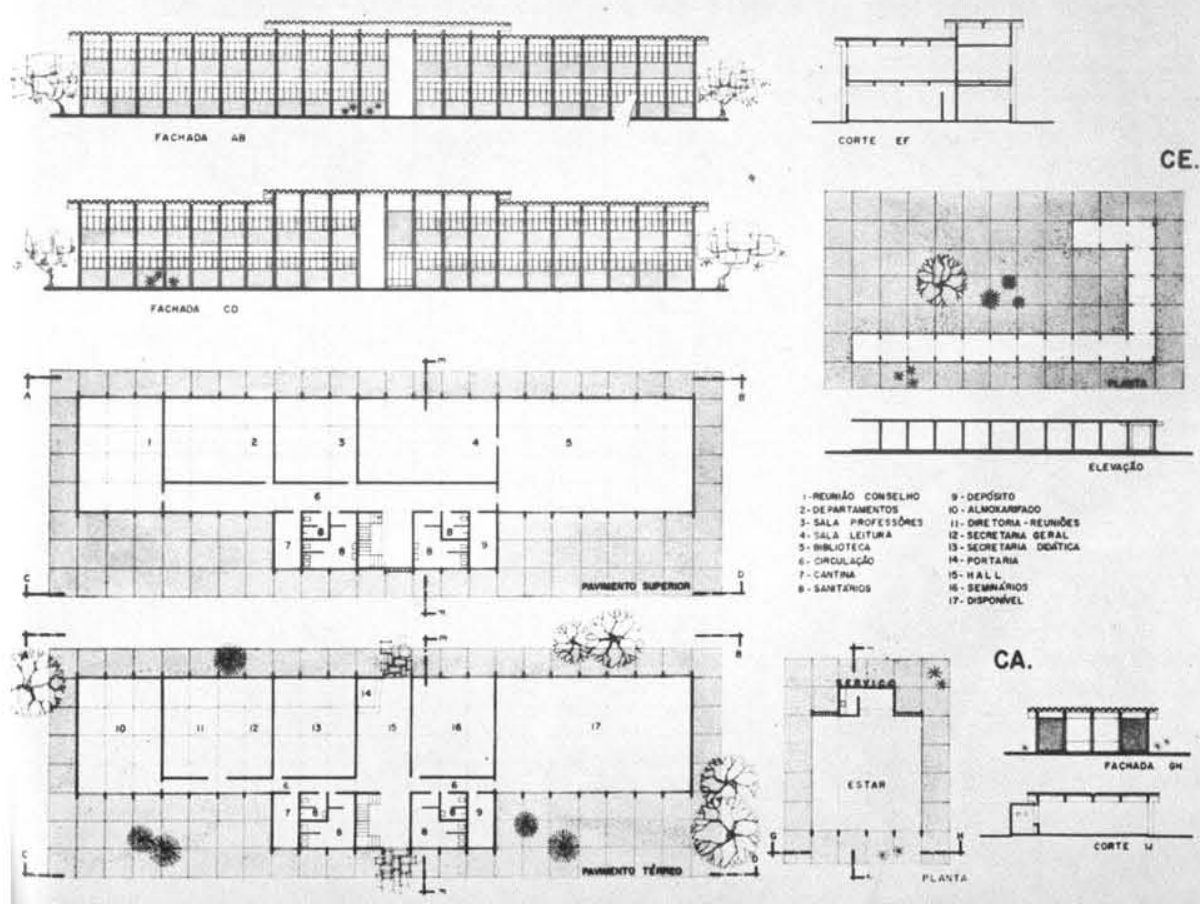

Figura 50: UFC - Associação dos tipos AD, CA e CE. (Fonte: UFC, 1966, n.p.) 
Plano não foi implantado conforme planejado. Sua execução estava vinculada aos recursos pleiteados junto ao BID, os quais foram garantidos em 1967 por meio do contrato conhecido como Acordo MEC/BID-1. Sua vigência, porém só veio a ser efetivada com o advento da Reforma Universitária de 1968, quando os investimentos contratados foram definidos. O Acordo teve, entretanto uma abrangência menor do que a projetada no Plano de Desenvolvimento e restringia o montante dos recursos pleiteados. Nessas condições foi necessária uma revisão das metas programadas e da organização espacial projetada.

\section{- Planos e Projetos da Reforma}

Com os recursos disponibilizados em 1970, outra proposta foi apresentada ao Programa MEC/BID-1 para a área do Pici, procurando adequar-se ao modelo de campus universitário preconizado na Reforma (1968) e que veio a se constituir nas bases do futuro Campus Universitário do Pici. Apoiado na nova estrutura acadêmica, o local passou a ser dividido em áreas acadêmico-científicas, de maneira que ao centro ficava os institutos básicos.

O aporte financeiro restringia sua aplicação à área de Ciências e Tecnologias Aplicadas. Foi construída a Escola de Engenharia com $7.870 \mathrm{~m}^{2}$ de área, iniciados os blocos dos Departamentos de Química, Física e Matemática e os primeiros conjuntos do Laboratório de Ciências do Mar com $3.055 \mathrm{~m}^{2}$ de área, estes localizados na orla maritima de Fortaleza. Com a nova organização espacial, a construção das referidas unidades na área do Pici não obedeceu à localização original indicada no Plano de Desenvolvimento (1966). Por este projeto a Zona Tecnológica seria constituída pela Escola de Engenharia e pelos Institutos Básicos, conforme anteriormente mencionado. Obedecendo ao zoneamento do projeto reformista, os Institutos, transformados em Básico Geral, foram deslocados para uma posição centralizada, em torno da qual seriam gradativamente construídas as outras unidades, a exemplo das novas instalações da Escola de Engenharia previstas para serem iniciadas. O sistema viário era composto por uma via principal, projetada como único acesso ao Campus, que se prolongava transformando-se em uma via periférica circundando o núcleo central comum formado pelas unidades de ciências básicas, conforme se constata na planta da figura 51. No decorrer da década de 1970, a proposta foi parcialmente executada, mantendo a configuração básica do urbanismo projetado.

A proposta evidencia claras referências ao Manual de Atcon (1970), onde o território estava dividido em zonas funcionais, constituídas pelas áreas acadêmico-científicas, administrativas e de serviços, que se distribuíam em torno do setor básico, ficando resguardadas pela via de circulação periférica ("anel protetor") e com os setores e equipamentos de acesso público situados em áreas contíguas. 
Parte 2 - Universidade Federal do Ceará

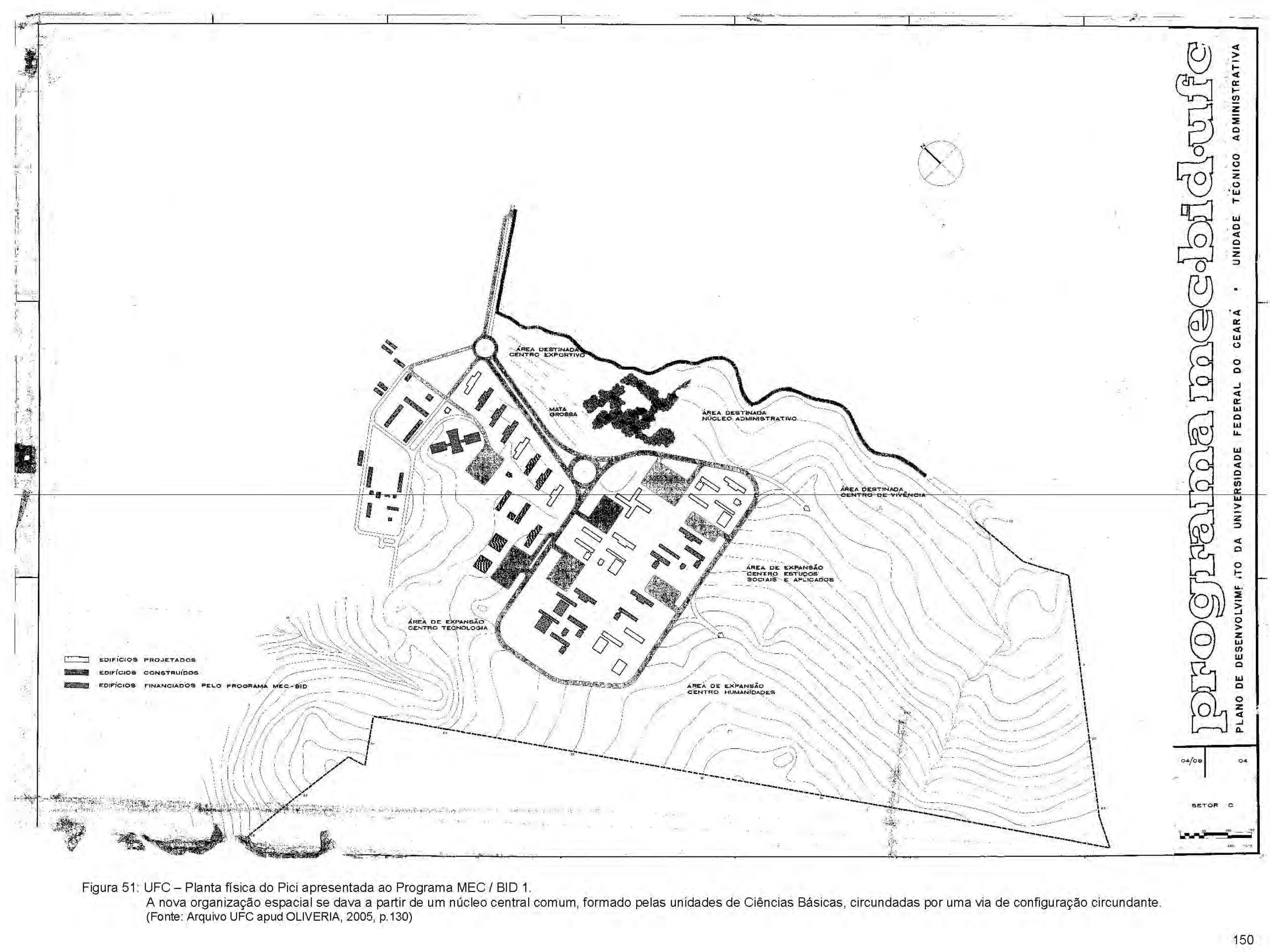


A partir daquela proposta podemos constatar que com a nova estrutura acadêmica imposta pela Reforma (1968) a linha de orientação na formação do território da UFC foi alterada. Até aquela data, a organização espacial vinha sendo determinada pelas gradativas mudanças introduzidas na estrutura organizacional da instituição.

A partir de 1968 , esta lógica se inverte, com o arranjo físico sendo configurado para moldar uma nova estrutura funcional, passando de condição acessória a fator de garantia real da implantação da nova estrutura de funcionamento das universidades que, conforme os ideais da reforma universitária se pretendi

Esta inversão no papel desempenhado pelo espaço físico passou a ser a característica dominante que presidiu a concepção de campus nos vários projetos que a UFC desenvolveu vinculados aos acordos MEC/BID durante a primeira metade da década de 1970 (OLIVEIRA, 2005, p.126).

\section{- Primeira Proposta: referências ao Manual de Atcon (1970)}

Diante do ideal reformista de uma instituição funcional e integrada, a composição da base física em três setores distintos passou novamente a ser questionada pela UFC, considerando a premência de reformulá-la em território único embasado no modelo de campus universitário propalado pela Reforma (1968).

Oportunamente, a elaboração do II Plano de Desenvolvimento, que tinha o objetivo de consolidar os investimentos do programa MEC/BID 1, culminou com o resgate das ideias do Plano de 1966 que identificava as potencialidades da área do Pici em vir a se transformar no futuro território único da UFC, devido às suas características de extensa gleba e possibilidade de anexar terrenos vizinhos [já mencionado]. Entretanto, imposições de ordem financeira e recusa da classe médica inviabilizaram a transferência das unidades da saúde instaladas no Porangabuçu que contava com hospital, maternidade e ambulatórios em funcionamento. Em tais condições, foi instituído oficialmente, em 1972, o primeiro projeto de campus universitário da Reforma (1968): O Campus do Pici com uma área de Ciências da Saúde no Porangabuçu (ver figura 52).

A configuração com áreas de localização distinta contrariava, entretanto a proposta da Reforma. A justificativa foi dada no documento intitulado Avaliação da Reforma Universitária no Âmbito de uma Universidade: a Universidade Federal do Ceará, publicado em 1973, que assim expressava: 
O novo campus, na realidade a expansão natural do polo inicial representado pela Escola de Agronomia, virá a oferecer realmente unidade à UFC, sem prejuízo de uma divisäo funcional das áreas e dos espaços para a realização de todos os atos acadêmicos, com representaçăo harmônica de todos os símbolos da mesma universidade, desde os anfiteatros às praças de conveniência (MEC, 1973, p.70).

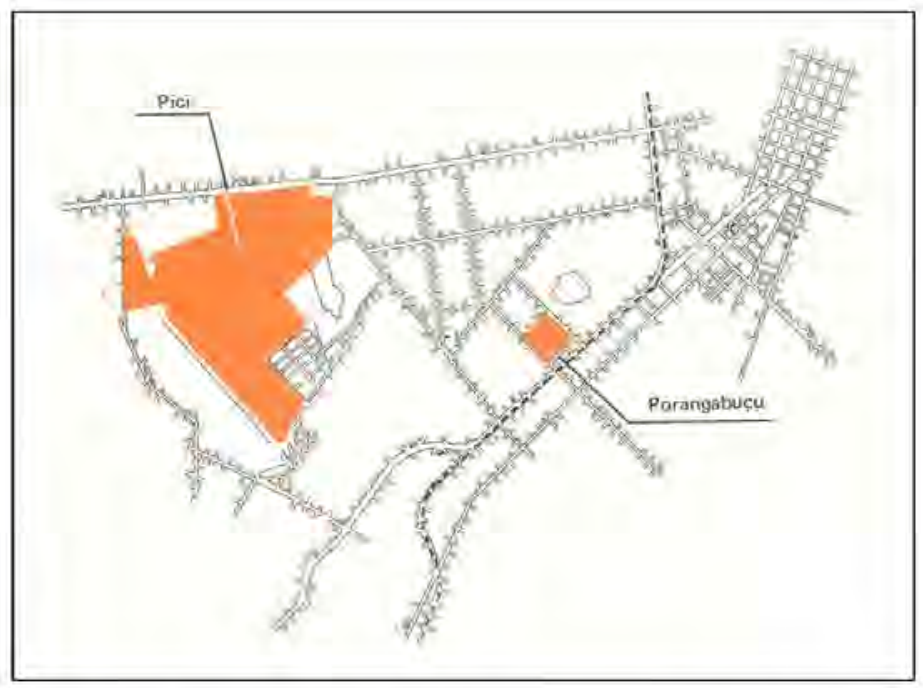

Figura 52: UFC - Proposta do campus universitário constituido pelas áreas do Pici e Porangabuçu1972. A divisão em áreas distintas contrariava a proposta da Reforma Universitária de 1968. (Fonte: UFC, 1980, p.51 apud CAMPÉLO, 2005, p.58)

Em relação à permanência das unidades da saúde no Porangabuçu, o documento manifestava que a dispersão seria superada por se encontrarem num eixo de apenas 1800 metros de distância, percorrida por vias naturais de acesso fácil e amplo (MEC, 1973, p.70). Além do que se constatava que o seu distanciamento em relação ao Pici favorecia o afastamento da grande massa não acadêmica das áreas de convivência do campus (MEC, 1973, p.70).

A proposta apresentada no II Plano de Desenvolvimento considerava uma área maior do que aquela pertencente à UFC e a organização espacial resultava do conjunto de zonas funcionais, constituidas pelas faculdades que seriam agregadas formando os centros, implantados em torno do Setor Básico, seguindo o mesmo princípio de organização iniciado na proposta do programa MEC /BID - 1. Complementando a estrutura do campus estavam previstos nas áreas periféricas do terreno o setor esportivo e o de vivẽncia, em cujas circunvizinhanças estavam as habitaçōes para professores e estudantes. Indicava também um setor de administração do campus, incluído pela complexidade da nova estrutura que se formava (ver figuras 53 e 54) 


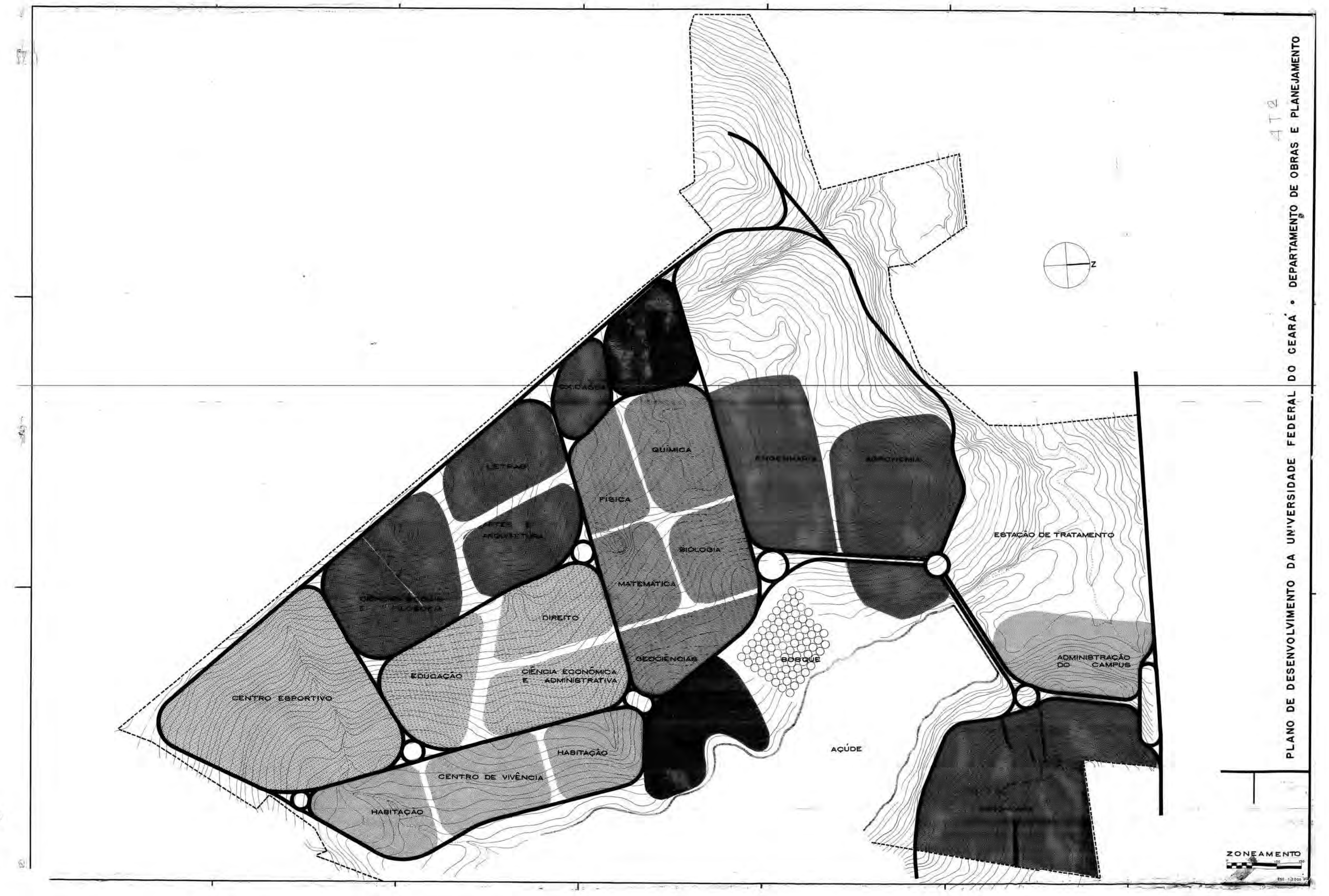




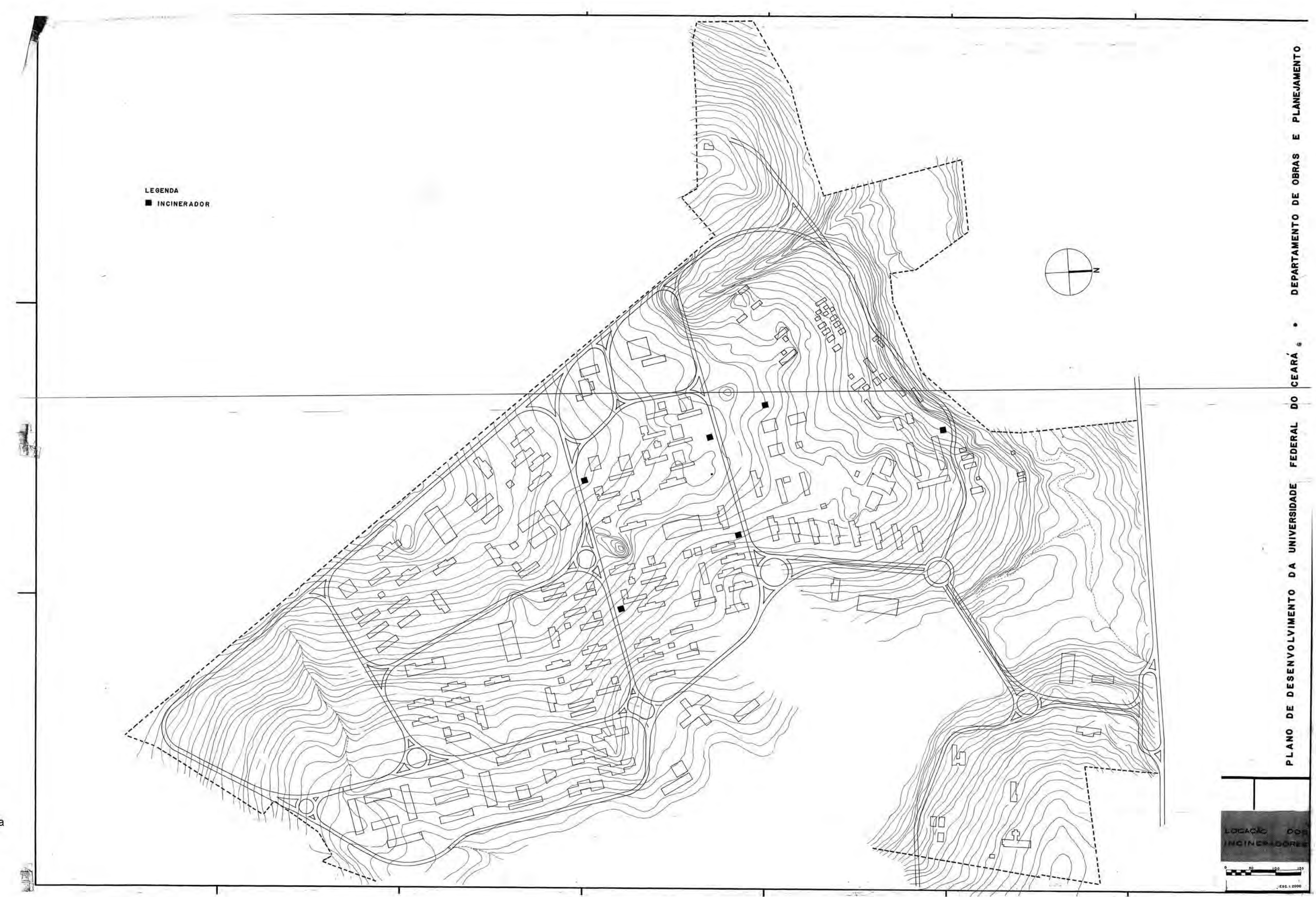


O sistema viário mantinha o anel circundante do Setor Básico e criava outros relacionados com as zonas funcionais projetadas. Conservava o acesso único, contribuindo para enfatizar - caráter de segregação, de isolamento da cidade, fazendo o Campus se constituir em aglomerado apartado, autônomo, voltado para dentro e preocupado exclusivamente com as relações que se estabeleceriam entre suas próprias partes. Essa característica diferia do Plano de Desenvolvimento de 1966/1970, cuja proposta estava articulada com a estrutura urbana. Herdava, entretanto a mesma tipologia de edifícios e a padronização construtiva, que seriam construídos por etapas, permitindo o funcionamento dos centros na medida em que se dava sua expansão.

Efetivamente, do proposto foram executadas apenas as redes de infraestrutura e urbanização dos setores existentes e já iniciados como os da Agronomia, Engenharia e Institutos Básicos; consolidada a configuração geral do Setor Básico; e definida a atual localização do Setor de Esportes, cuja construção foi iniciada pela pista de atletismo para atender aos Jogos Universitários Brasileiros de 1972, realizados em Fortaleza (ver figura $55)$.

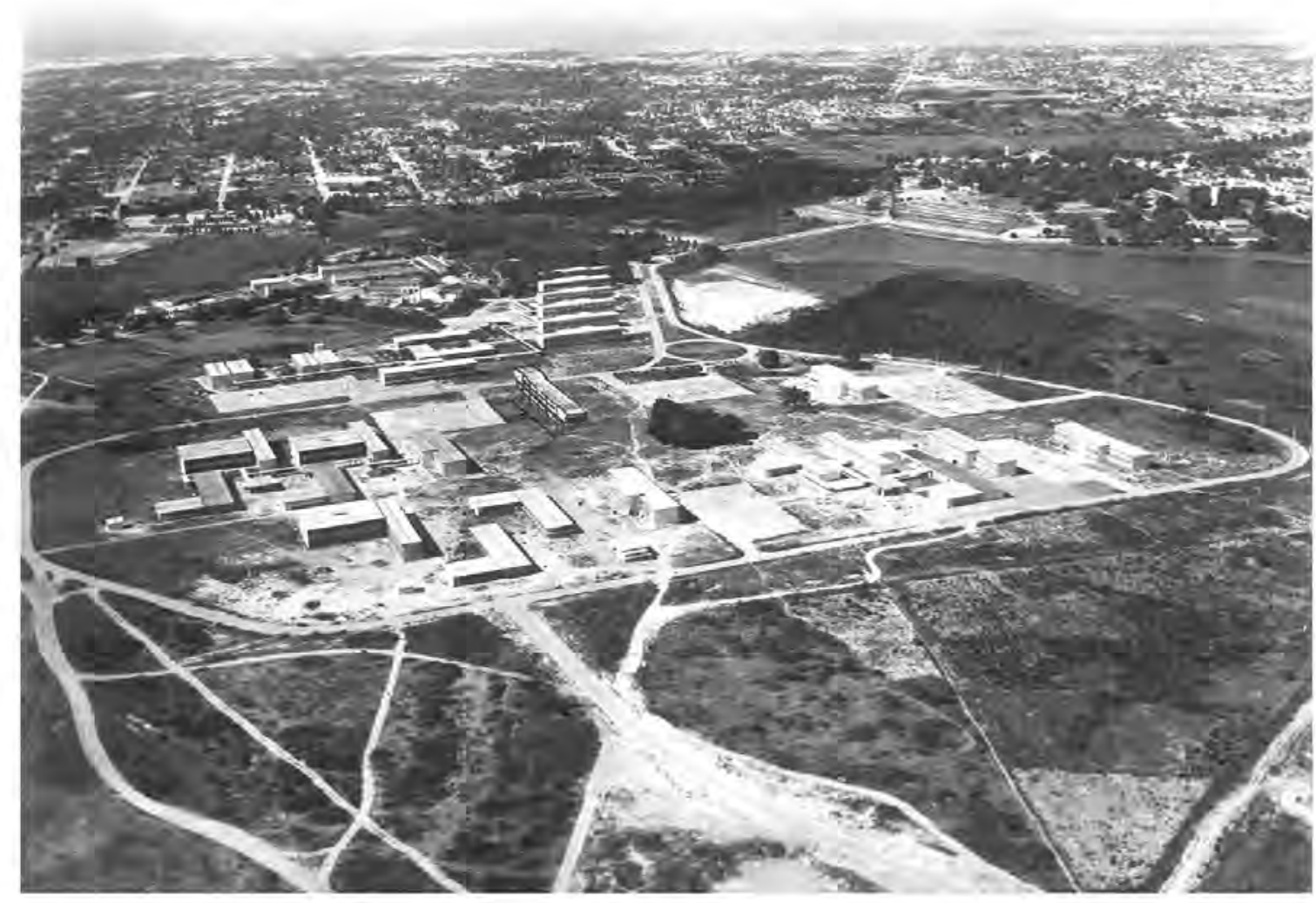

Figura 55: UFC - Vista área do Campus do Pici na década de 1970.

Mantendo as diretrizes urbanísticas da proposta apresentada ao MEC / BID 1 tem-se em primeiro plano, o Centro de Ciências circundado pelo anel viário (protetor) e ao fundo, o Centro de Tecnologia e o Centro de Ciências Agrárias - áreas acadêmico-científicas distribuídas em torno do setor básico.

(Fonte: PLANOP / UFC apud CAMPÊLO, 2005, p.59) 


\section{- Segunda Proposta: tentativa de um território unificado}

A validade de um campus com duas áreas (Pici e Porangabuçu) passou posteriormente a ser questionada em decorrência das dificuldades que vinham sendo enfrentadas para desapropriar terrenos no Porangabuçu com vistas à expansão das unidades ali instaladas e especificamente pelo impasse gerado para a construção das novas instalações da Faculdade de Odontologia, que ainda funcionava no centro da cidade.

Uma segunda proposta foi elaborada a partir da primeira, procurando incorporar a área do Centro de Ciências da Saúde. Entretanto, o Plano destinava para esse Centro apenas uma área para o prédio da Odontologia, ou seja, uma unidade isolada, contrariando o modelo da Reforma que vinha sendo proposto.

O urbanismo proposto mantinha o mesmo princípio de organização funcional a partir da formação de setores especializados, resultado do agrupamento das faculdades para a criação dos centros correspondentes às respectivas áreas de conhecimento afins (ver figura 56). Diferia da proposta anterior por eliminar o setor da habitação, o que segundo Oliveira (2005, p.138) pode ter sido vetado pelos analistas do MEC. Incorporava um segundo acesso ao campus pelo lado sul do terreno, possibilitando uma possível integração com a estrutura urbana da cidade, já que permitia cruzar o campus por meio de um sistema viário geral.

A construção do prédio destinado à Faculdade de Odontologia foi iniciada, porém a restrição por parte da classe médica que mantinha a rejeição referente à transferência do Centro de Ciências da Saúde para o Pici, impediu o seu prosseguimento. A obra, que já contava coma estrutura de concreto, ficou inacabada até a década de 1980, quando passou a ser ocupada com outras finalidades.

\section{- Terceira Proposta: um novo zoneamento}

Em 1973, o Decreto $n^{\circ} 71.882$ firmou a estrutura da UFC, dando-lhe o delineamento proposto pela Reforma Universitária de 1968. Ficava oficialmente constituída pela Reitoria (Órgãos Administrativos, de Coordenação, Suplementares e Auxiliares) e seis centros: Centro de Ciências, Centro de Humanidades, Centro de Tecnologia, Centro de Ciências Agrárias, Centro de Ciências da Saúde e Centro de Estudos Sociais Aplicados (UFC, 1974, p.19).

Com base na estrutura acima mencionada, naquele mesmo ano, foi desenvolvida uma terceira proposta apresentada no "Projeto de Expansão do Campus". Da mesma forma que as anteriores, a configuração do Campus resultava da organização das zonas funcionais articuladas pelo sistema de vias hierarquizadas. Mantinha praticamente o mesmo desenho, porém adequando outras funções. Não mais constava a previsão da Faculdade de 
Figura 56: UFC - Planta geral do Campus do Pici. Incorporando o setor da saúde.
(Fonte: Arquivo UFC apud OLIVERIA, 2005,
p.135)

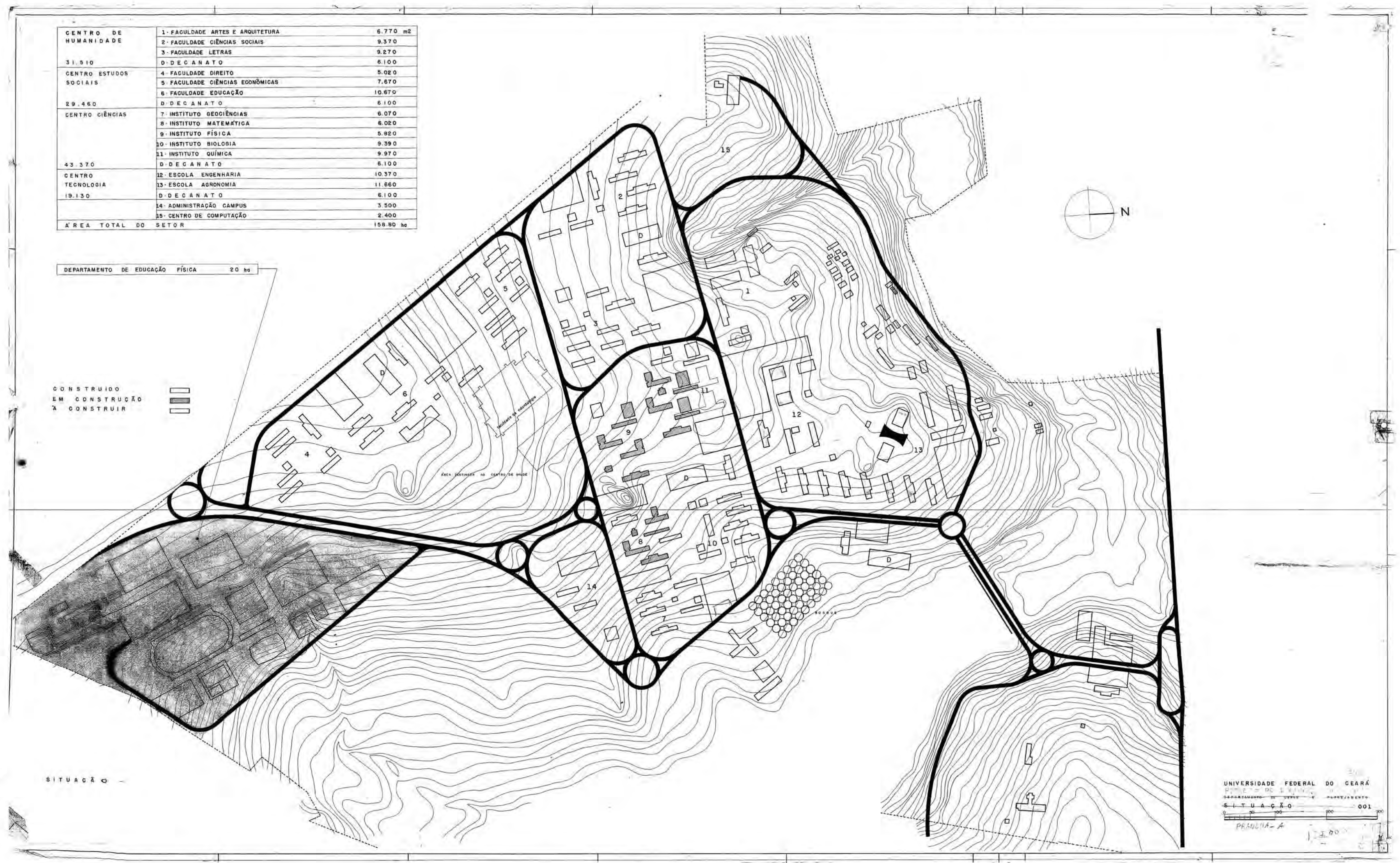


Parte 2 - Universidade Federal do Ceara 
Odontologia, porém incorporava um setor destinado à Administração Superior da Universidade, que ocupava localização destacada na entrada do Campus, ficando, entretanto isolada dos demais setores em função da presença do Açude Santo Anastácio, que atravessa o terreno na direção sudeste-noroeste. $O$ local selecionado estava em concordância com as recomendações do Manual de Atcon (1970) que orientava para que as áreas de acesso ao público externo deveriam ficar em pontos periféricos, próximas à via principal de acesso, evitando assim interferência nas atividades da Universidade. $\mathrm{Na}$ margem oposta do açude, estavam previstos equipamentos de uso comum tais como a Biblioteca, Restaurante e o Centro de Processamento de Dados, os quais foram executados no decorrer da mesma década. A proposta, conforme apresentada na figura 57 , mais uma vez não se consolidou na íntegra: o sistema viário não foi executado na sua totalidade e a reitoria permaneceu na área do Benfica.

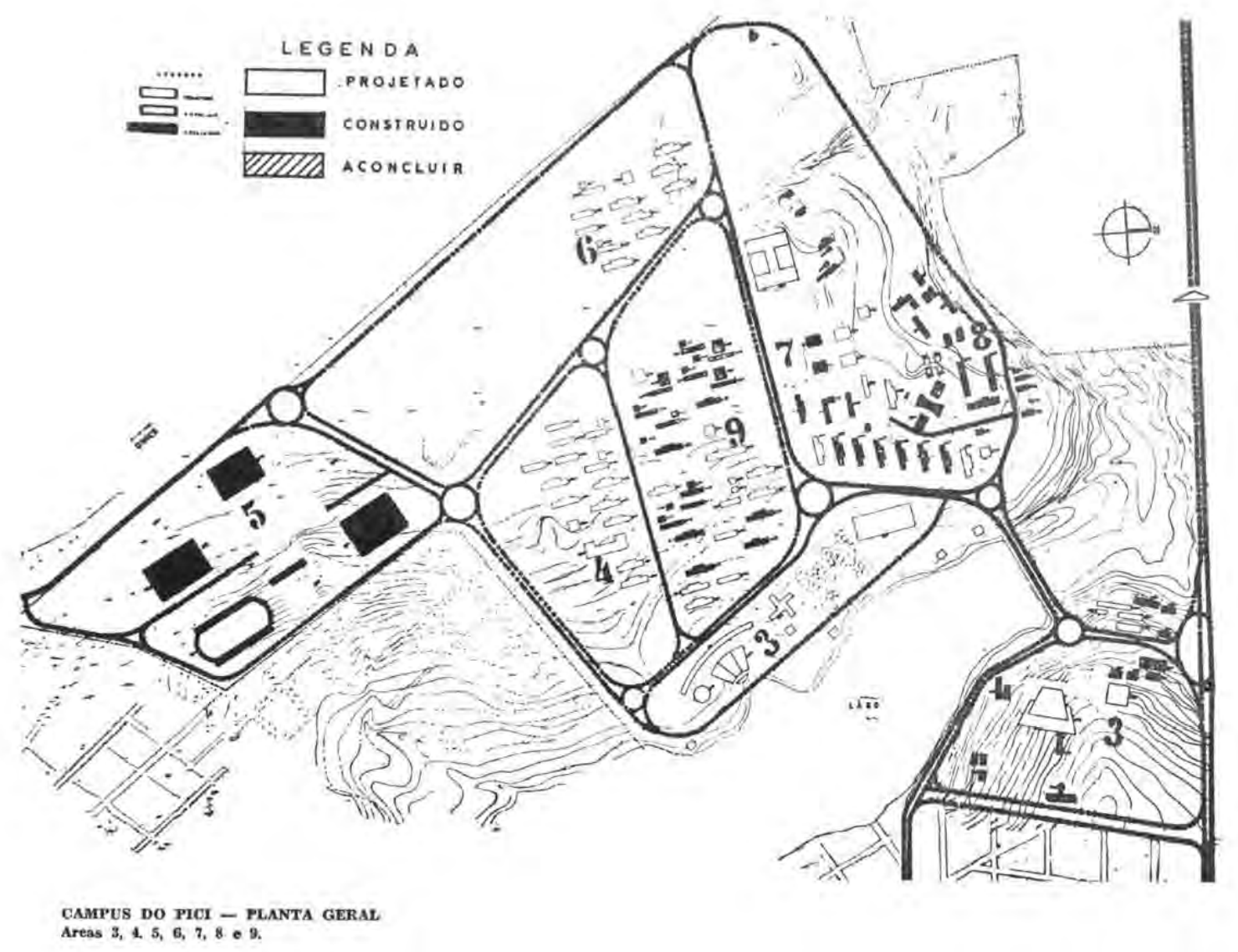

Figura 57: UFC - Planta geral do Campus do Pici.

O zoneamento incluía a Administração Central e equipamentos de utilização comum (Restaurante, Biblioteca, Centro de Processamento de Dados). Legenda:
3. Administração Superior
7. Centro de Tecnologia
4. Centro de Estudos Sociais Aplicados
5. Área dos Esportes
8. Centro de Ciências Agrárias
6. Centro de Humanidades
9. Centro de Ciências

(Fonte: UFC, 1974, p. 15 apud CAMPÉLO, 2005, p. 58) 
- Plano Diretor de 1979: a permanência do isolamento

Em 1979, quando a UFC já estava questionando a validade da Reforma Universitária e consequentemente a transferência das suas unidades para o Campus do Pici, a Administração Superior decidiu elaborar um Plano Diretor do Campus, de modo a tomar uma posição definitiva em relação ao desenvolvimento das bases físicas da Instituição.

O Plano retoma a proposta de um zoneamento funcional definido pelas três áreas nas quais a Universidade já vinha concentrando as instalações desde sua origem. Com nova denominação estavam assim definidas (ver figura 58):

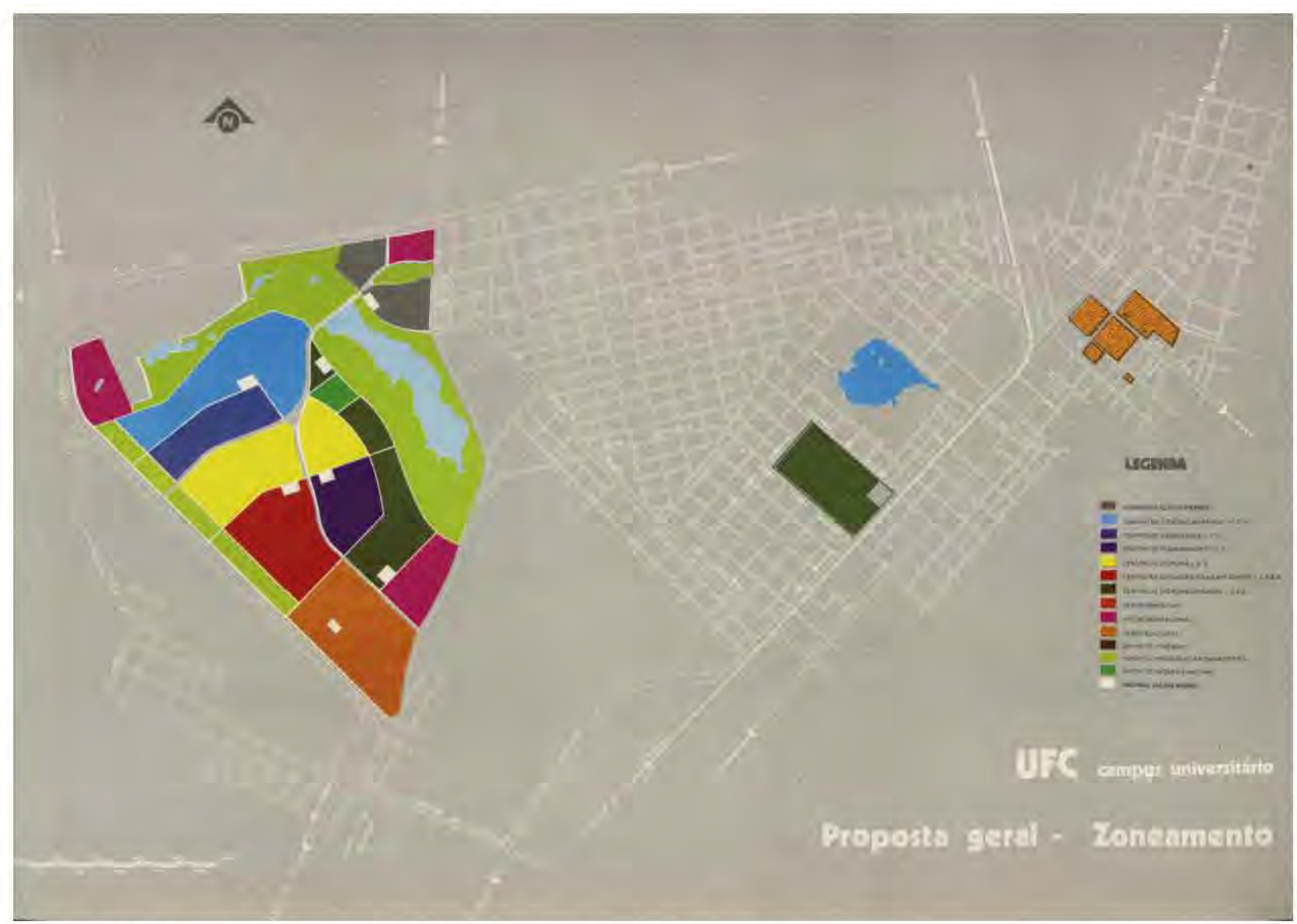

Figura 58: UFC - Campus Universitário - Zoneamento Geral.

Formado por três áreas distribuídas na cidade, consolidando a situação existente (Fonte: UFC, 1980, p. 79)

- ÁREA 1 - Correspondendo à gleba do Pici, abrangia as instalações da Administração Superior (Reitoria e Órgãos Complementares), Setor Esportivo, Setor de Vivência (incluindo a Biblioteca Central e o Restaurante), Setores Habitacionais (para servidores) e os Centros de Ciências, Humanidades, Estudos Sociais Aplicados, Ciências Agrárias e Tecnologia.

- ÁREA 2 - Localizada no Porangabuçu, permanecia com as instalações do Centro de Ciências da Saúde, incorporando áreas de vivência relativas ao Centro. 
- ÁREA 3 - Situada no Benfica, compreendia as instalações ligadas às atividades de extensão e artístico-culturais (Museu de Arte, Centros de Cultura, Setores de Música, Teatro e Cinema, Concha Acústica e o prédio da Reitoria abrigaria as atividades de extensão) a Imprensa Universitária e Residências Universitárias.

Assim como no Plano de Desenvolvimento de 1966 / 1970, as áreas ficariam integradas pelo sistema viário da cidade, através dos seus corredores de circulação (ver figura 59).

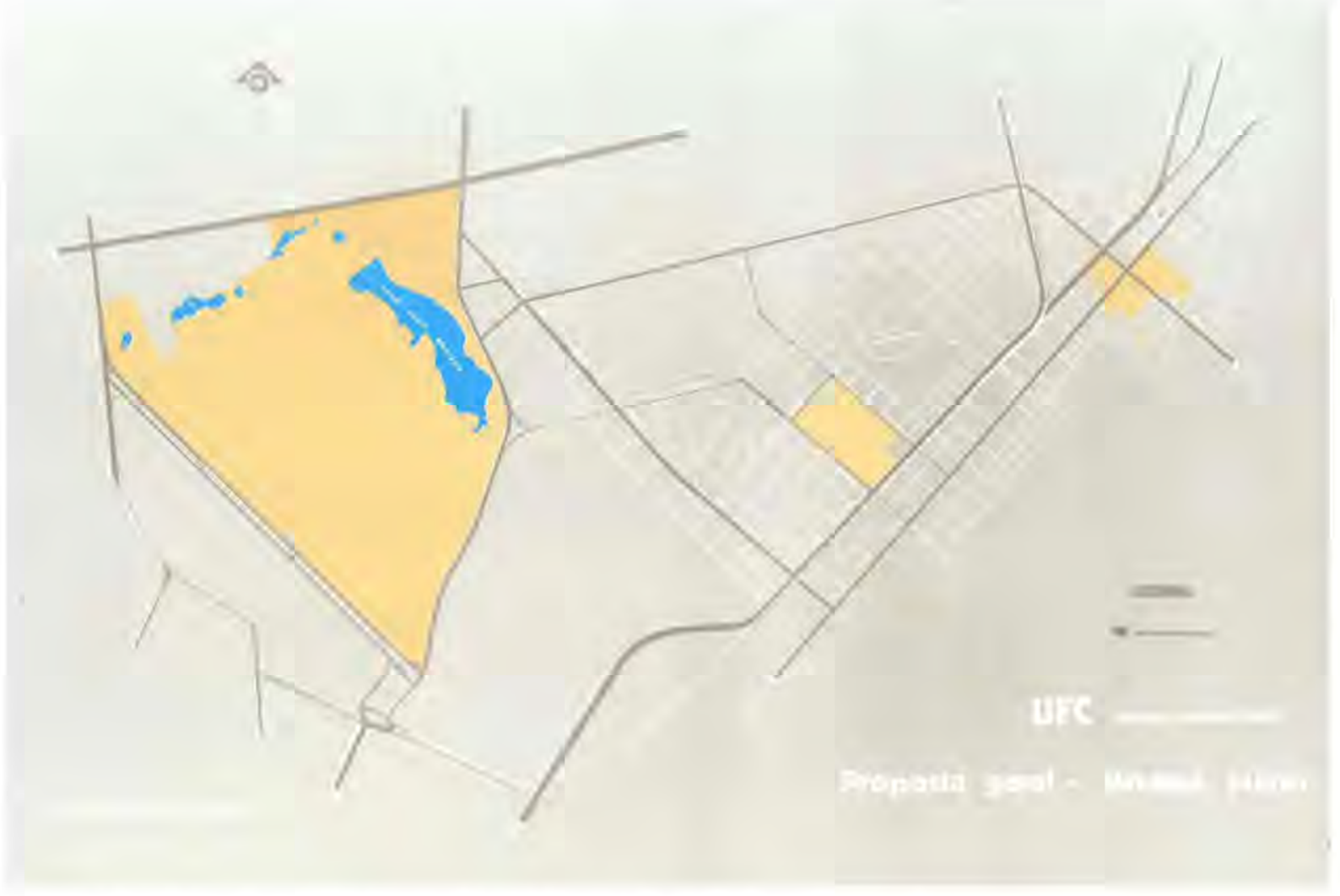

Figura 59: UFC - Campus Universitário - Proposta geral do sistema viário.

As três áreas se interligavam por vias da malha urbana.

(Fonte: UFC, 1980, p. 83)

Assim como nas propostas anteriores, a área do Pici ficou reservada para reunir a maior concentração de unidades, abrangendo os órgãos da Administração Superior, o Setor de Vivência, o Setor Esportivo e, também, cinco dos seis Centros (definidos no Decreto $\mathrm{n}^{\circ}$ 71.882 / 1973 - já mencionado - ficando fora apenas o Centro de Ciências da Saúde) que, na época, compunham sua estrutura acadêmica, além de conjuntos habitacionais para servidores.

Mantendo a mesma concepção de território isolado, os setores funcionais eram fisicamente definidos por um sistema de vias internas, limitadas por uma via principal periférica, destinada ao transporte coletivo (ver figuras 60 e 61). Esta interligava as unidades a três 
terminais coletores, localizados na periferia do Campus em pontos estratégicos de acesso e distribuição. Complementavam o sistema viário, as chamadas vias de penetração que conduziam aos estacionamentos setoriais, concepção que proporcionava a separação entre tráfego de veículos e pessoas de modo a garantir segurança ao trânsito de pedestres.

Tirando partido dos recursos naturais existentes, como a presença do Açude Santo Anastácio, suas margens foram pensadas para implantar o Setor de Vivência, como na proposta de 1973. Aspecto importante é a tentativa de atenuar a condição de espaço segregado. No sentido de promover uma maior integração do Campus com a cidade,

[...] o zoneamento proposto abrangeu uma área maior do que os terrenos pertencentes à Universidade, permitindo a definição do seu contorno, utilizando-se as próprias ruas do sistema viário básico como limites. As desapropriações previstas nesta disposição permitiram definir um contorno servido por importantes vias da malha urbana, onde circula o sistema de transporte coletivo ligando esta área a todos os pontos da cidade (OLIVEIRA, 2005, p.142).

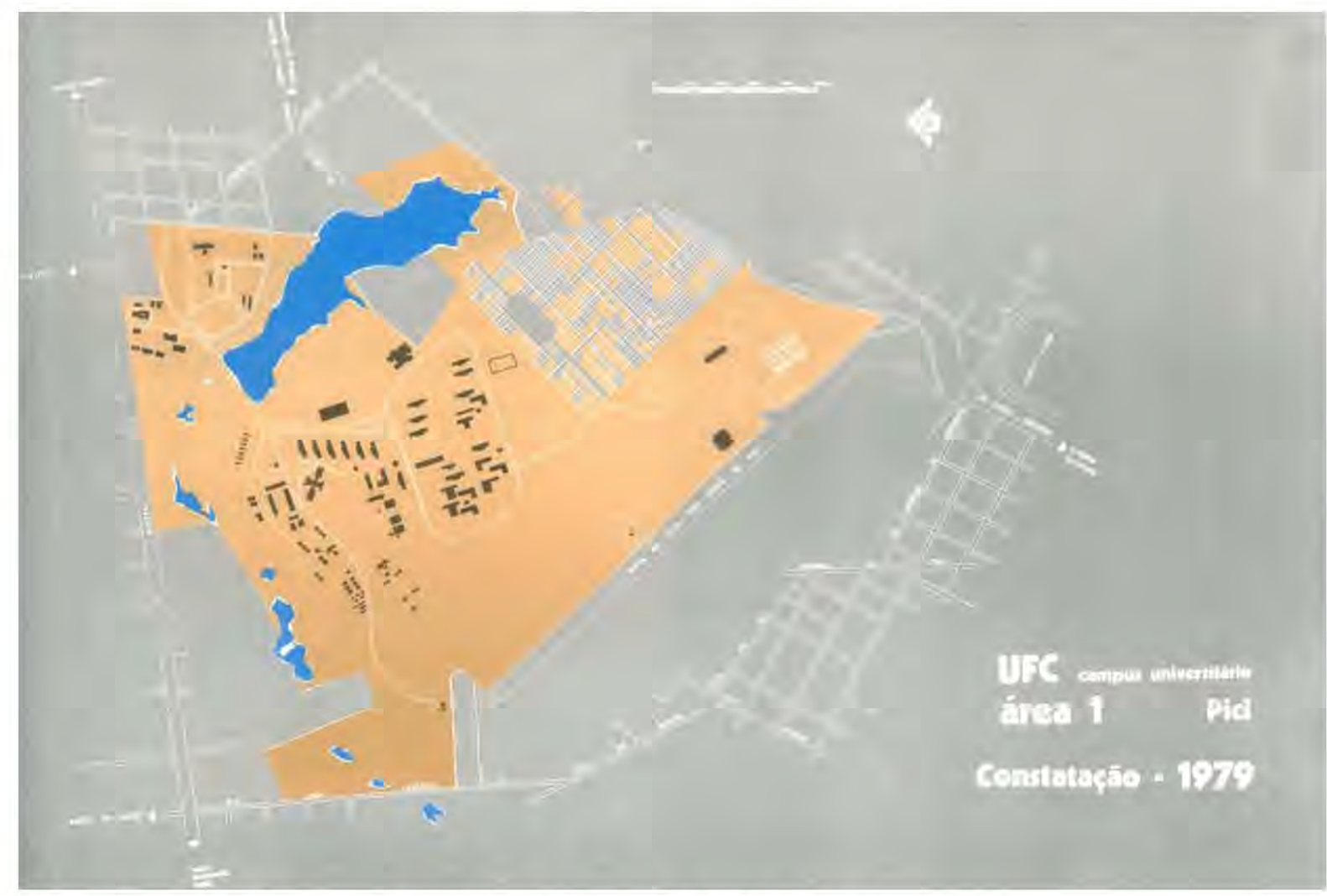

Figura 60: UFC - Campus Universitário Área 1 - Constatação 1979.

Foi constatado que em 1979 havia uma ocupação de baixa densidade, caracterizada pela relação da gleba de grande extensão e algumas unidades implantadas.

(Fonte: UFC, 1989, p.96) 
A organização espacial resultante da junção de setores embasados pelo princípio da especialização funcional, com acessos e estacionamentos próprios, separados entre si pelo sistema viário ou por elementos da paisagem natural tornando-os territórios setoriais autônomos, revela sua concepção de caráter segregador. Mesmo os locais destinados à integração da comunidade universitária - setores esportivos, de vivência, da administração superior e da habitação - estavam concebidos como áreas independentes, sem estabelecer relações com os demais. Independentes entre si e sem pontos de convergência natural dos fluxos internos, a proposta indicava a produção de um espaço fadado à incapacidade de promover a integração ensejada.

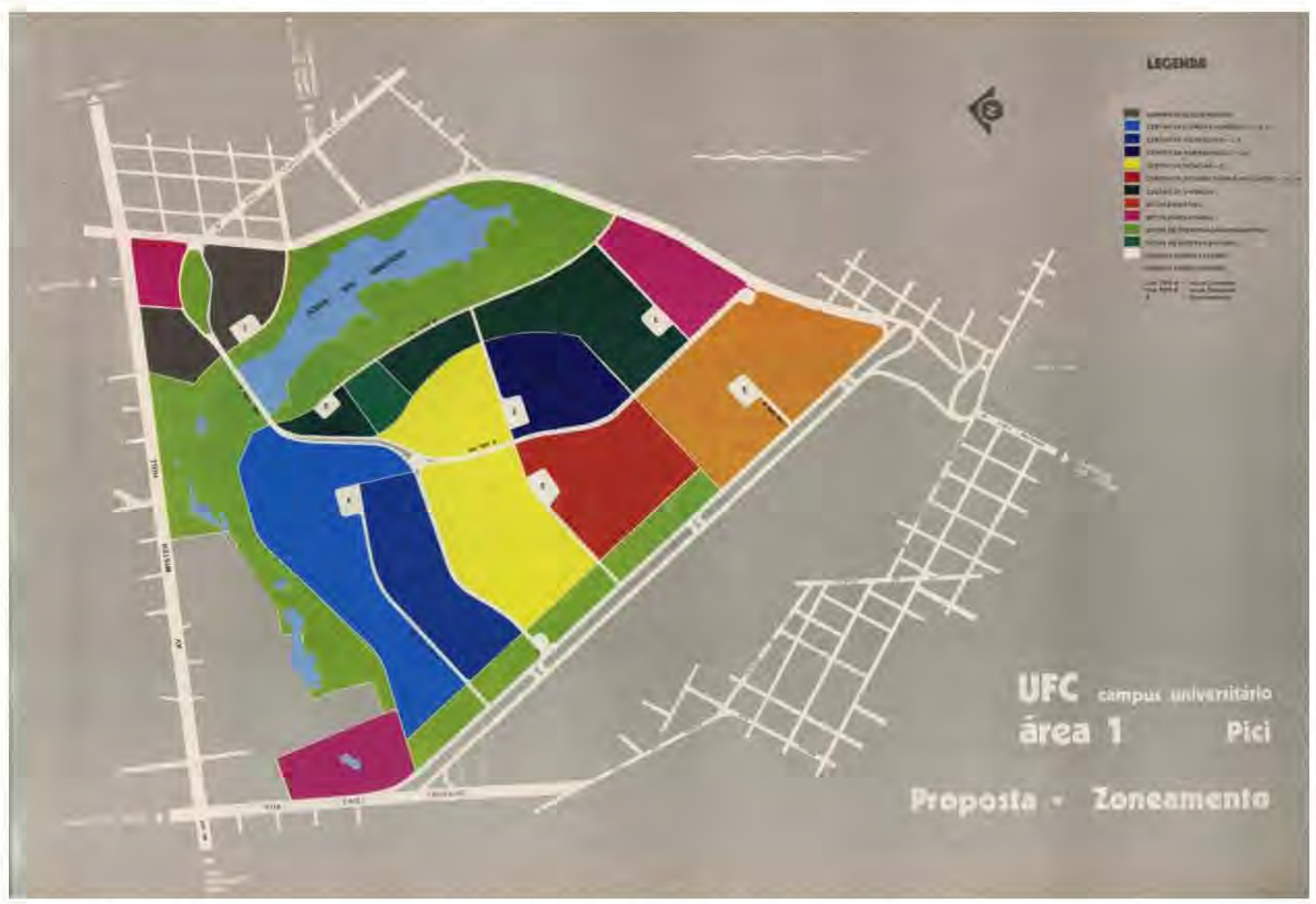

Figura 61: UFC - Campus Universitário Área 1. Proposta - Zoneamento.

Concebido como área isolada, protegido com via circular periférica e com a circulação interna operacionalizada por meio de sistema de transporte próprio em via exclusiva. (Fonte: UFC, 1989, p.101)

A Área 2, mantida para o setor da saúde, foi mais uma vez justificada pelos investimentos já realizados e principalmente pela presença do Hospital que construía um bloco para o centro cirúrgico. O impasse para a expansão das unidades, gerado pela restrita disponibilidade de área pertencente à UFC - cerca de 6,5 ha -, teve novamente que ser superado com a ampliação das terras disponíveis mediante a desapropriação das quadras limítrofes. 
Ignorando as dificuldades já vivenciadas para aquisição de terrenos quando da proposição de transferir a Faculdade de Odontologia para instalações a serem construídas nesse local, - Plano propôs a incorporação de uma área final correspondente a 15 ha. Com base nisto, foi formulada uma proposta com características de território unificado, onde as vias públicas seriam transferidas para a periferia do conjunto, integrando as unidades com circulação de pedestres, área de lazer, bem como previsão de bolsões de estacionamento. A configuração urbanística resultante delineava uma unidade setorial de característica isolada, embora imersa na malha urbana (ver figuras 62 e 63).

A Área 3, destinada às atividades de extensão e à cultura, foi planejada para ser gradativamente desocupada pela transferência das unidades acadêmicas para ○ Pici, decorrendo daí um planejamento específico para adequar as edificações existentes aos novos usos e instalar outras conforme as demandas. Os imóveis remanescentes seriam alienados. O território do Benfica mantinha suas características urbanísticas de origem, entre elas a configuração da quadra como unidade territorial da malha urbana (ver figuras 64 e 65). O Plano Diretor de 1979 reconstituía o território da Universidade mais uma vez permeado pelo princípio do isolamento.

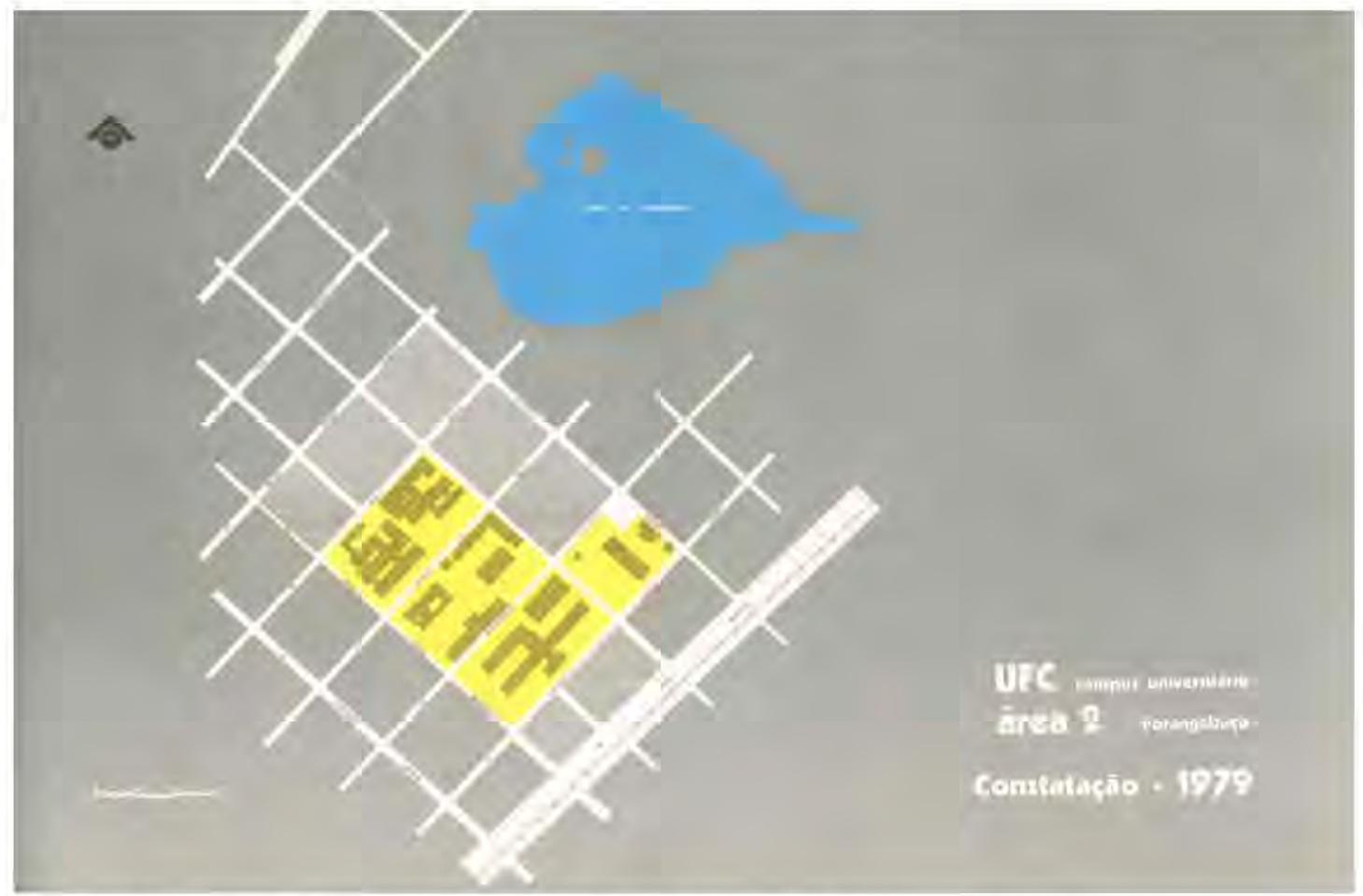

Figura 62: UFC - Campus Universitário Área 2 - Constatação 1979.

Constatação em 1979 da necessidade de ampliação com a desapropriação de quadras vizinhas.

(Fonte: UFC, 1980, p.111) 


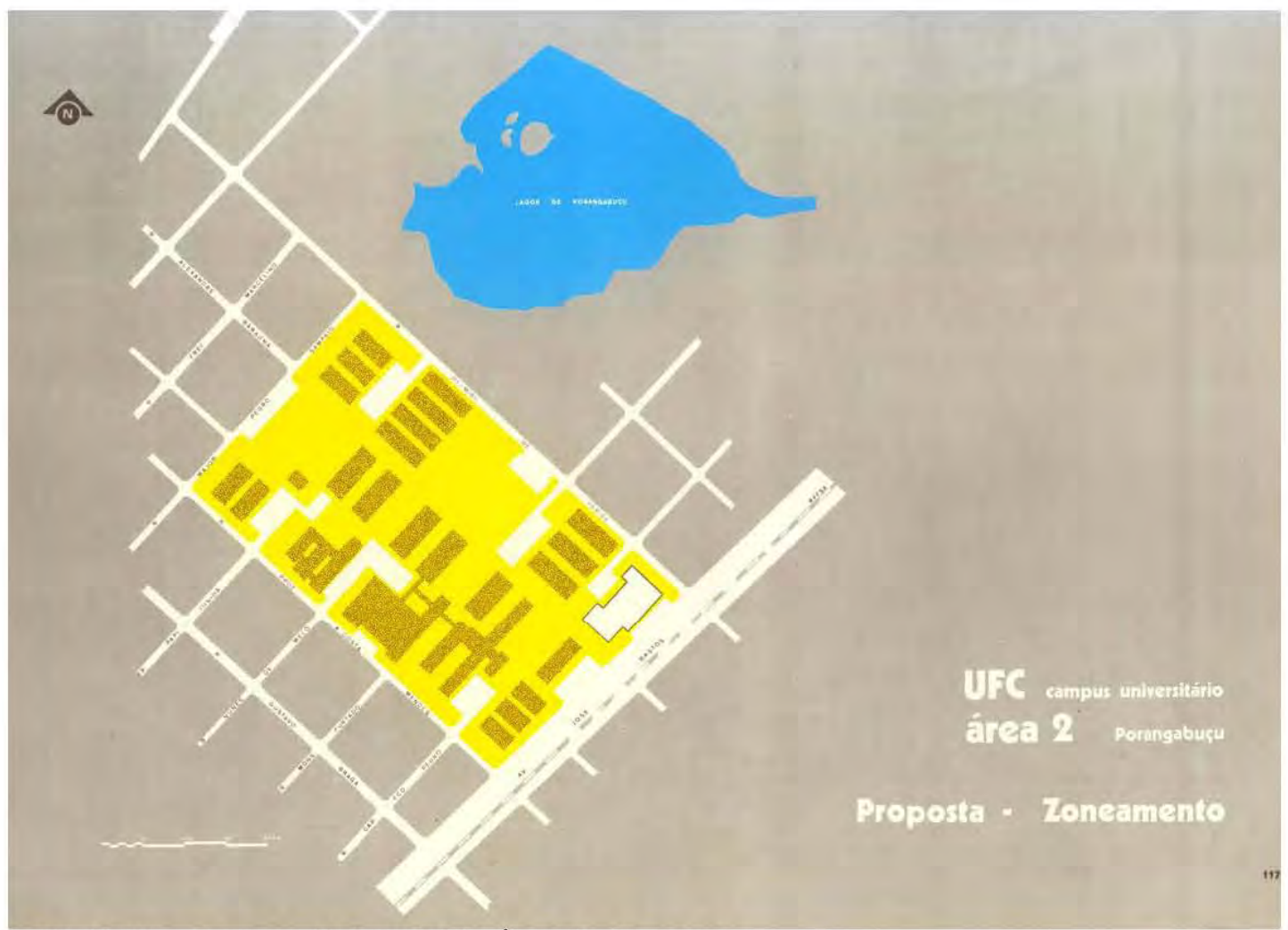

Figura 63: UFC - Campus Universitário Área 2 - Proposta.

A proposta estabelecia configuração urbanística caracterizada pelo isolamento do setor por meio do anel viário periférico, formando um espaço de uso exclusivo da Universidade.

(Fonte: UFC, 1979, p.117)

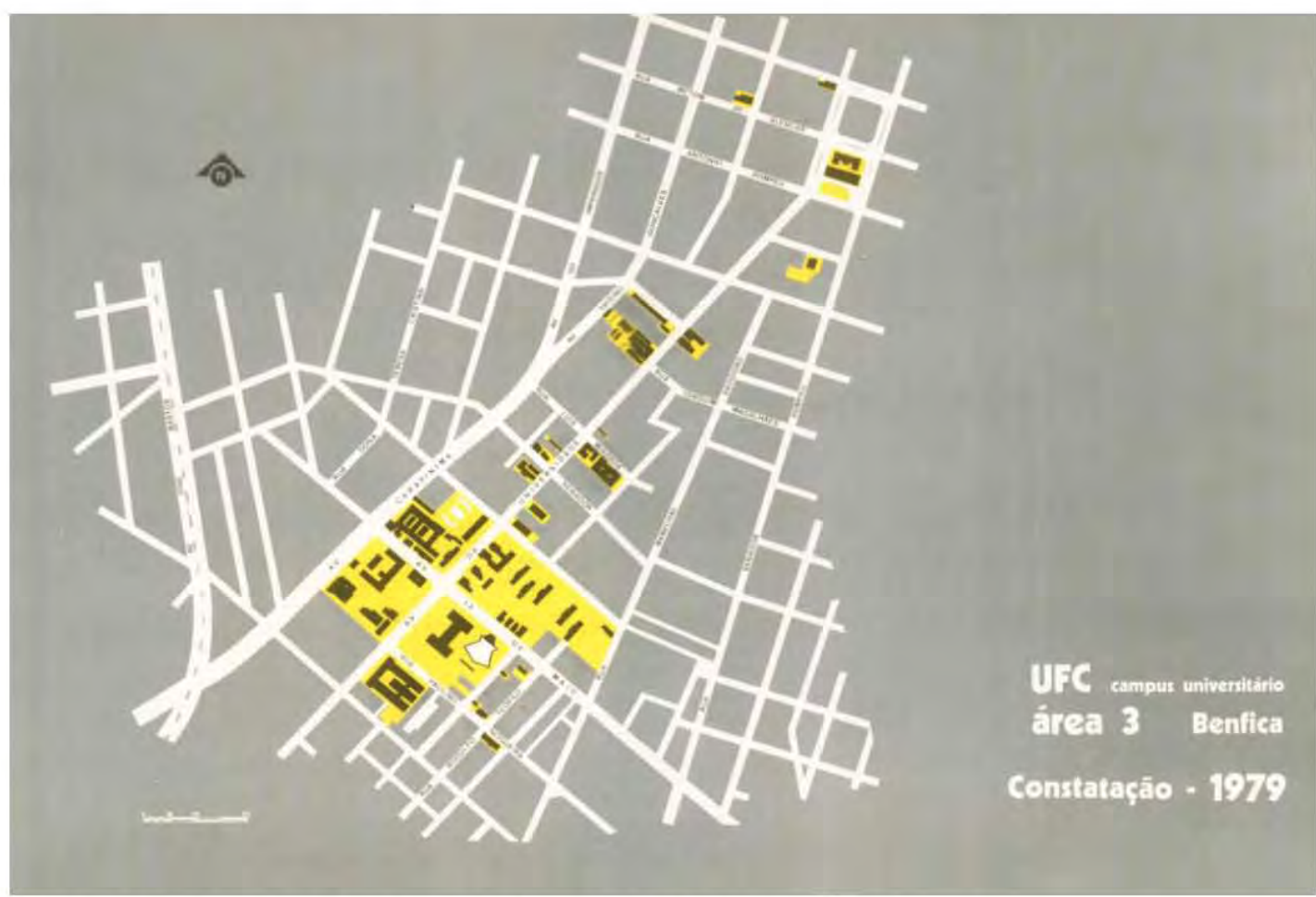

Figura 64: UFC - Campus Universitário Área 3 - Constatação 1979.

O Benfica, pela concentração de equipamentos culturais, passaria por remanejamento de áreas e das unidades existentes, visando consolidar uma zona cultural em torno da Reitoria. (Fonte: UFC, 1980, p. 133) 


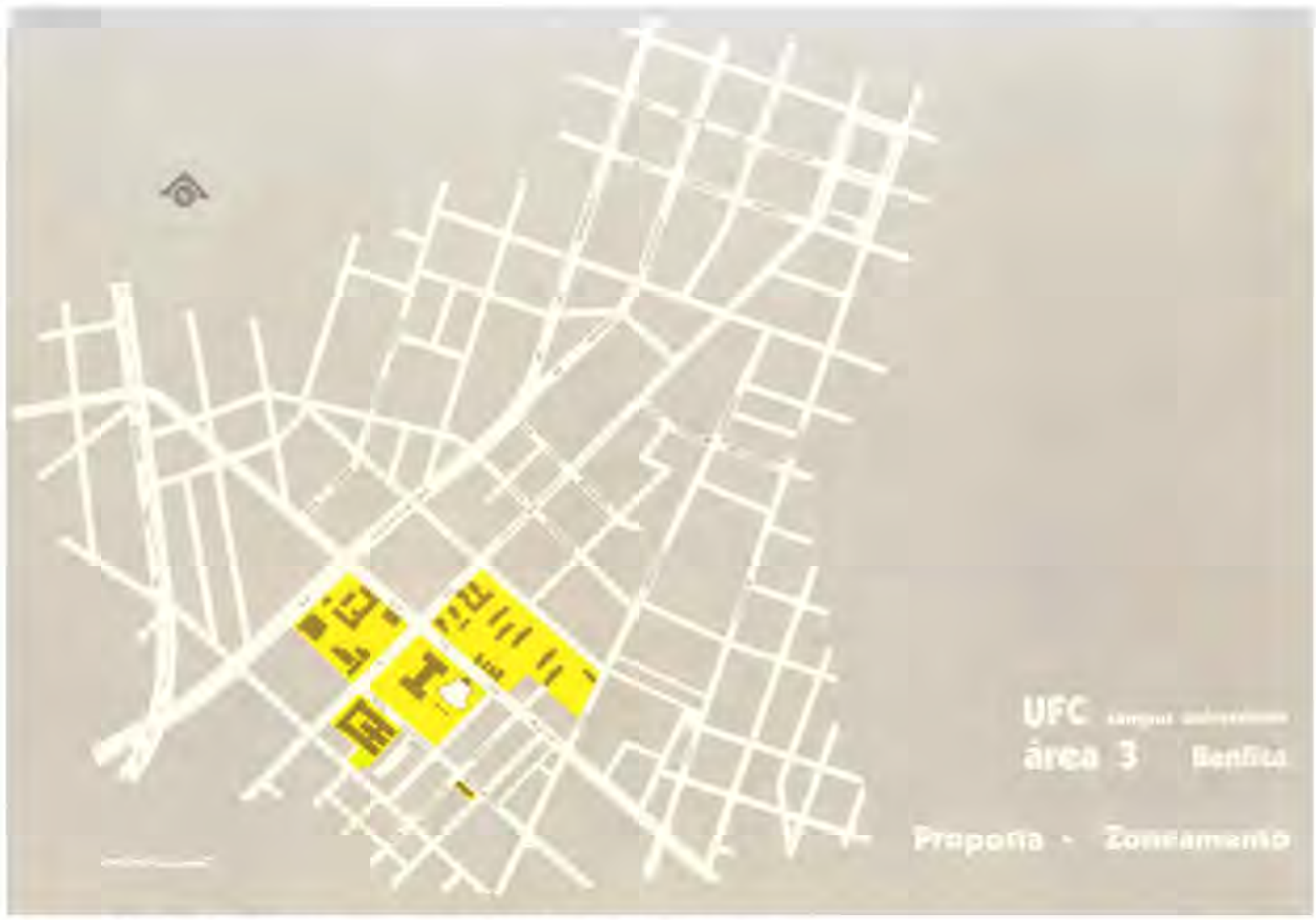

Figura 65: UFC - Campus Universitário Área 3 - Proposta.

(Fonte: UFC, 1980, p. 133)

Apesar do esforço desenvolvido na elaboração de vários projetos e dos vultosos investimentos para concretização do seu campus, a UFC chegou ao final da década de 1970 , sem ter conseguido a concretização da sua base física em território unificado. As concepções urbanísticas que deram suporte ao campus do Pici deixaram as marcas de uma tipologia espacial moldada para a compatibilização da Reforma de 1968 (ver figura 66)

\section{- Produção Arquitetônica da Reforma}

Os princípios de racionalidade e flexibilidade que dominavam a nova forma de organização universitária fizeram da padronização o critério adotado para dar corpo à estrutura acadêmica da Reforma na UFC. Visando superar a pressão por rapidez e custos acessíveis na construção dos edifícios, a malha modular e a padronização construtiva foram adotadas na concepção arquitetônica dessa produção.

\section{- O Conjunto Arquitetônico do Pici: concepção padronizada}

Herdando do Plano de Desenvolvimento de 1966/1977 a solução de esquematização de blocos padronizados, o conjunto edificado no Pici é o principal testemunho dessa arquitetura que pretendeu responder ao desafio do crescimento acelerado e das mudanças constantes. 


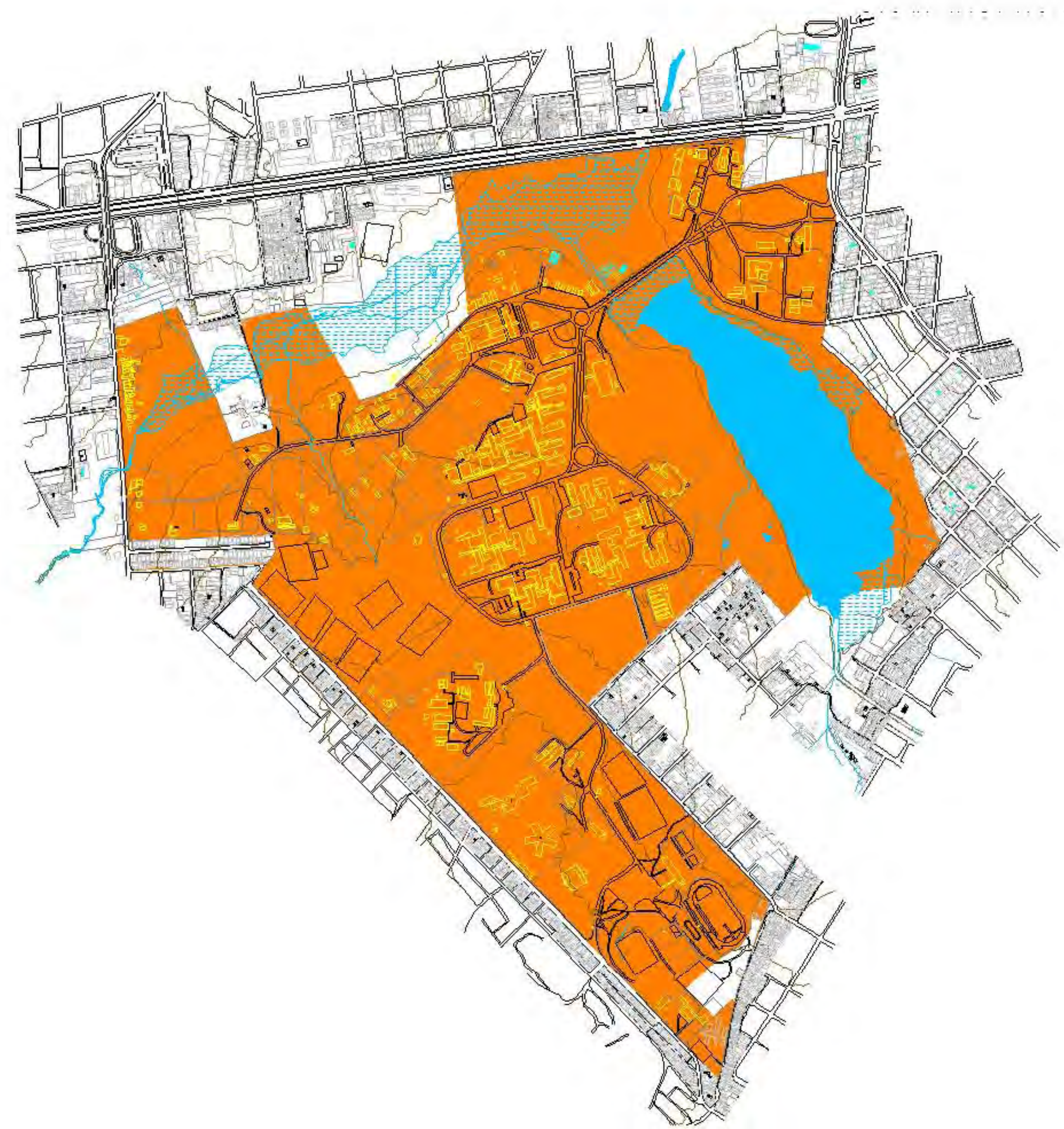



Os edifícios executados resultaram da associação dos oito blocos-tipo articulados por passarelas, que conformam a solução dos conjuntos, caracterizados pela diversidade de composição, porém mantendo uma unidade visual, onde a flexibilidade era o princípio operativo da proposta (ver figuras 67 a 70). Importante avaliar que, nesse caso, a flexibilidade referia-se às possibilidades de adaptação e expansão dos arranjos, condizente com a natureza do programa e concepção da Reforma Universitária que previa um processo de crescimento gradativo, porém sem dados precisos das futuras demandas. A filosofia era construir por partes, sem comprometer o todo, inviabilizando como obra de arquitetura.

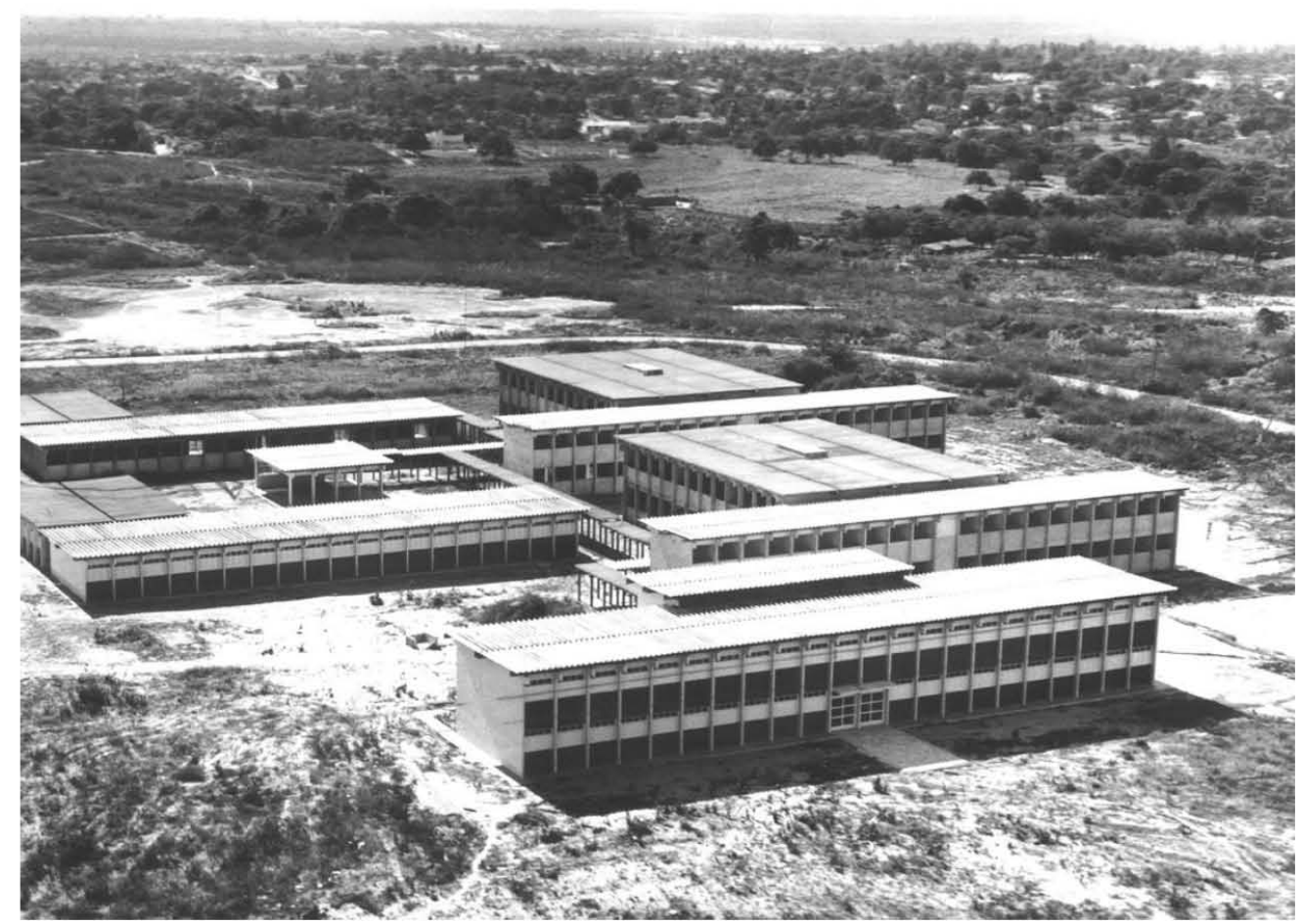

Figura 67: UFC - Campus Universitário do Pici - Década de 1970.

Conjunto do Centro de Ciências. Resultou da associação dos blocos-tipo, propiciando composição diversificada e mesma identidade visual.

(Fonte: Acervo UFC apud CAMPÉLO, 2005, p.71)

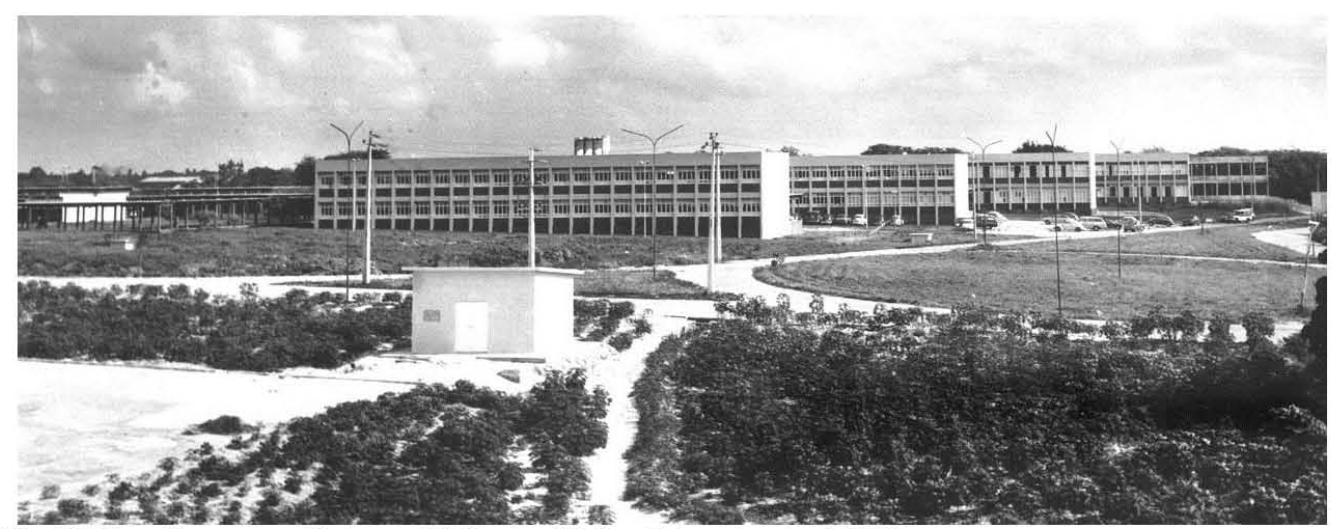

Figura 68: UFC - Campus Universitário do Pici - Década de 1970.

Conjunto do Centro de Tecnologia, inicialmente projetados para a Escola de Engenharia. Caracteriza-se pela padronização construtiva de predominância horizontal.

(Fonte: Acervo UFC apud CAMPÉLO, 2005, p.92) 


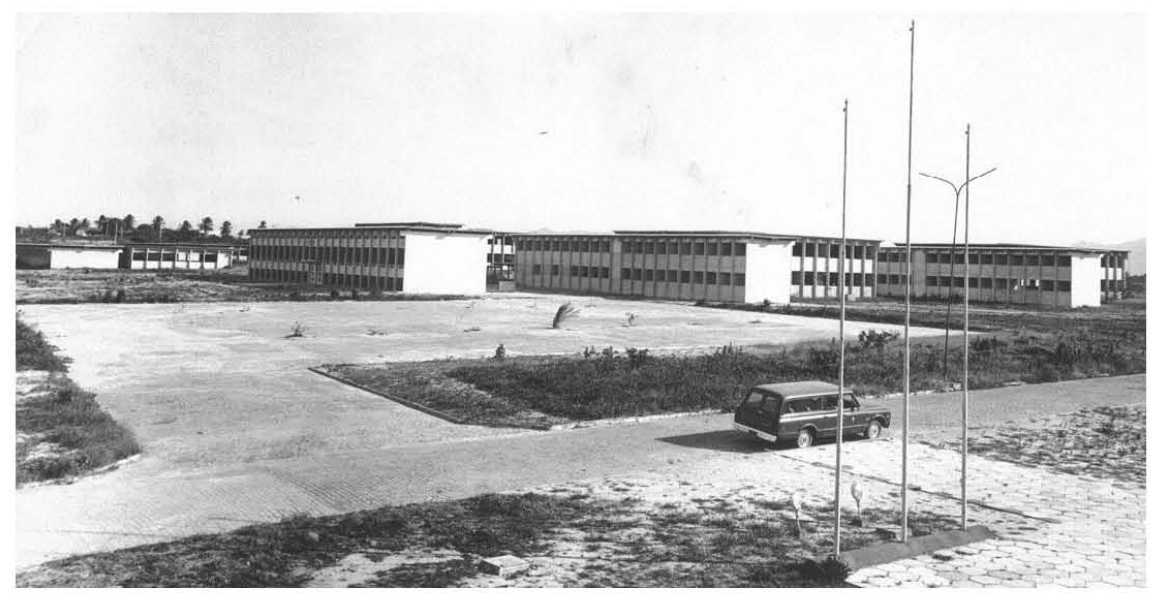

Figura 69: UFC - Campus Universitário do Pici - Década de 1970.

A padronização construtiva proporciona identidade visual ao conjunto. (Fonte: Acervo UFC apud CAMPÉLO, 2005, p.76)

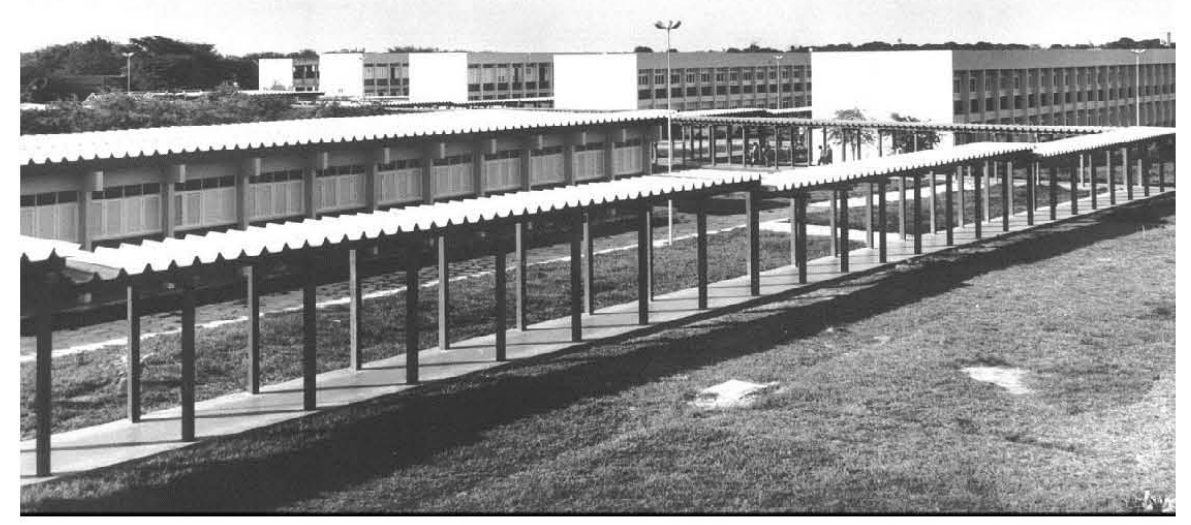

Figura 70: UFC - Campus Universitário do Pici - Década de 1970. Os conjuntos se articulam por passarelas cobertas. (Fonte: Acervo UFC apud CAMPÊLO, 2005, p.72)

As tipologias concebidas adotaram a planta livre de configuração geométrica predominantemente retangular, em blocos de um ou dois pavimentos. Nelas, as atividades foram organizadas seguindo o conceito do zoneamento funcional, que resultou em conjuntos de funções correlatas distribuídos sobre a malha modular de 1,25 x 1,25m e articulados pela circulação horizontal do tipo corredor e escadas, no caso de dois pavimentos (ver projeto das figuras 71 e 72). A modulação indicava a padronização do sistema estrutural, dos materiais de revestimento e dos elementos de vedação. Segundo depoimento do arquiteto Braga que participou da elaboração desses projetos, foi escolhido o módulo-base de $2,50 \mathrm{~m}$ $\times 2,50 \mathrm{~m}$, que estava referenciado nas dimensões do menor ambiente projetado: o gabinete de professores. Este seria o que proporcionaria melhores possibilidades de conjugação e economia do sistema estrutural adotado, a partir do qual foram definidos os demais componentes construtivos. Novamente, o princípio da flexibilidade se fazia presente na concepção do projeto, com a convicção de que mudanças na planta, decorrentes de alterações no programa, seriam possíveis, mantendo-se a integridade do edifício. 


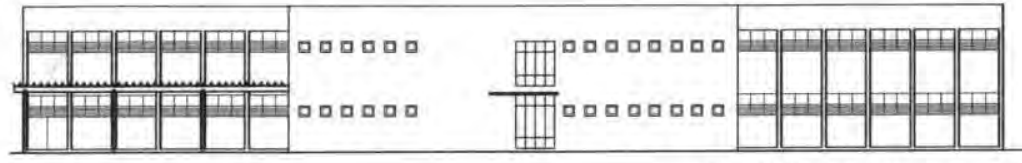

FACHADA PRINCIPAL

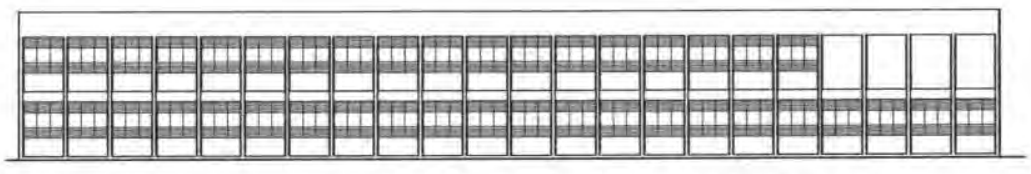

FACHADA POSTERIOR

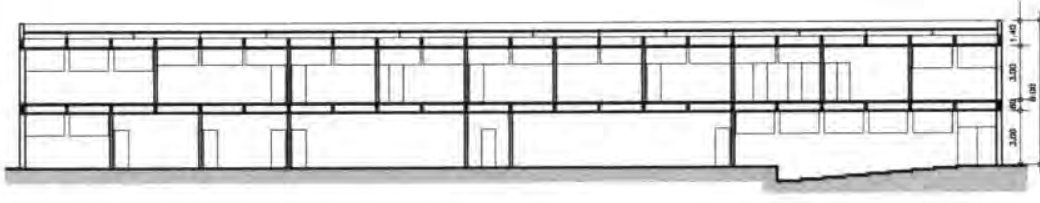

CORTE LONGITUDINAL

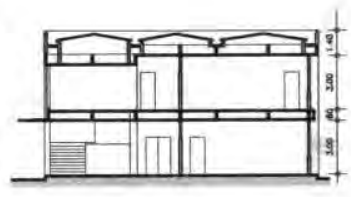

CORTE TRANSVERSAL

\begin{tabular}{|c|c|c|}
\hline \multirow{2}{*}{$\begin{array}{l}\text { UNIVERSIDADE FEDERAL DO CEARA } \\
\text { CADASTRO DOS EDIFICIOS DO } 3^{\circ} \text { GRAU }\end{array}$} & NEDA00 909 & CAMPUS $_{\text {PICI }}$ \\
\hline & $\begin{array}{l}\text { ARCACONSTRAOAA } \\
1.456,56 \mathrm{~m} 2\end{array}$ & $\operatorname{CSCALA} O$ \\
\hline If EDIOO. DEPARTAMENTO DE BIOLOGIA & UNDADE CENTRO DE CIENCIAS & DATA 1971 \\
\hline
\end{tabular}

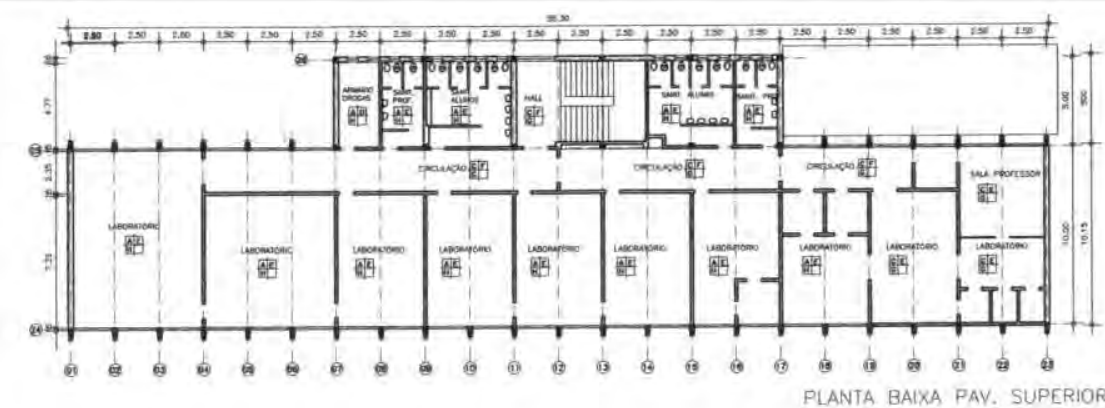

LEGENDA REVESTIMENTOS PISO

A PISO CERAMICO

B PISO DE TACO COM SINTECO

C PISO VINILICO

PAREDE

D PINTURA lavavel.

E AZULEJO

TETQ

G teratr acosmco

PLANTA BAIXA PAY. SUPERIOR

H LANE PINTADA

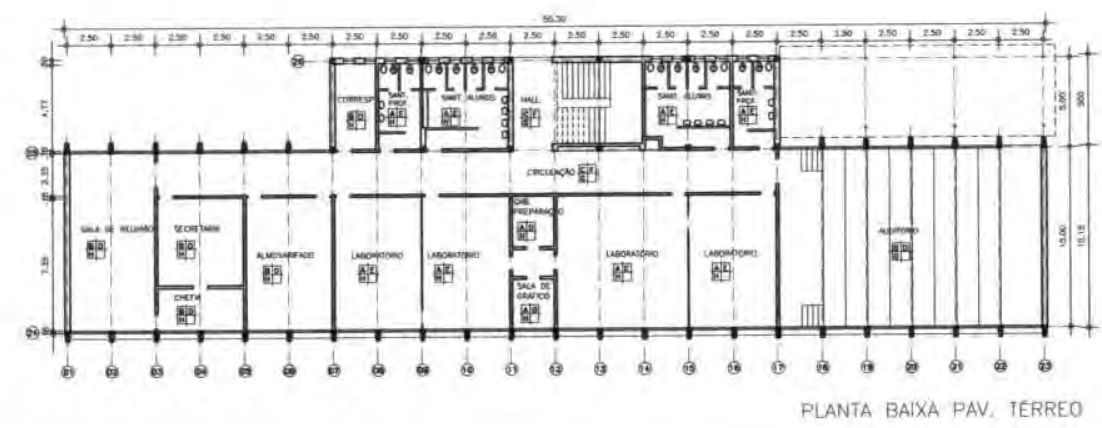

UNIVERSIDADE FEDERAL DO CEARÁ

CADASTRO DOS EDIFICIOS DO $3^{\circ}$ GRAU

If EDFOO. DEPARTAMENTO DE BIOLOGIA

\begin{tabular}{|c|c|}
\hline NEDPCOO $_{909}$ & CAPUS $_{\text {PICI }}$ \\
\hline AREACONSTIRTOA & $\operatorname{ESCALA}{ }_{2}^{2}-1$ \\
\hline UNOADE CENTRO DE CIENCIAS & DATA 1971 \\
\hline
\end{tabular}

Figura 71: UFC - Departamento de Biologia / Projeto de Arquitetura.

Campus Universitário do Pici - Década de 1970.

(Fonte: Acervo UFC - desenhos digitalizados a partir dos projetos originais, edição nossa) 


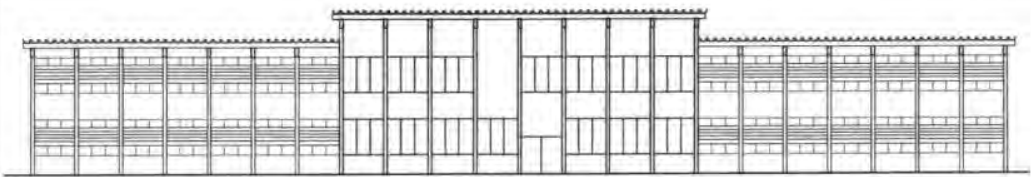

FACHADA PRINCIPAL

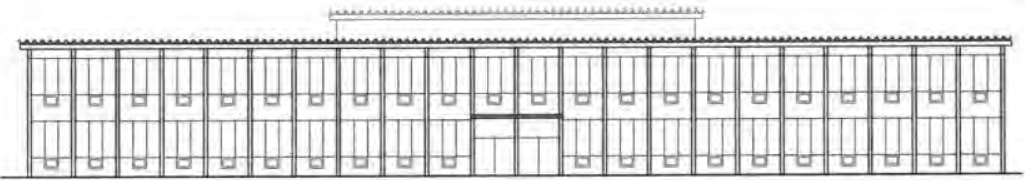

FACHADA POSTERIOR

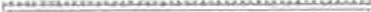

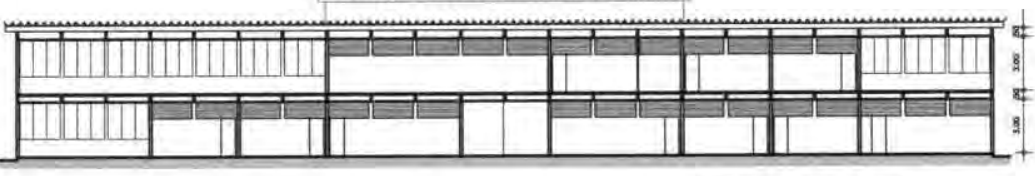

CORTE LONGITUDINAL

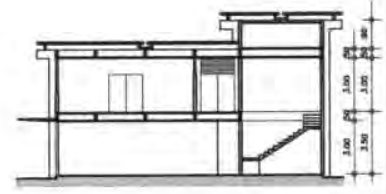

CORTE TRANSVERSAL

\begin{tabular}{|c|c|c|}
\hline UNIVERSIDADE FEDERAL DO CEARA & NEDACOO 914 & CANDUS $_{\text {PICI }}$ \\
\hline XADASTRO DOS EDIFICIOS DO $3^{\circ}$ GRAU & $\begin{array}{l}\text { AECAOCNSTRUOA } \\
1.346,64 \mathrm{m2}\end{array}$ & ISCALA: \\
\hline 18 ERICO DEPARTAMENTO DE & UNOWOC CENTRO DE GIENCIAS & DATA 1971 \\
\hline
\end{tabular}

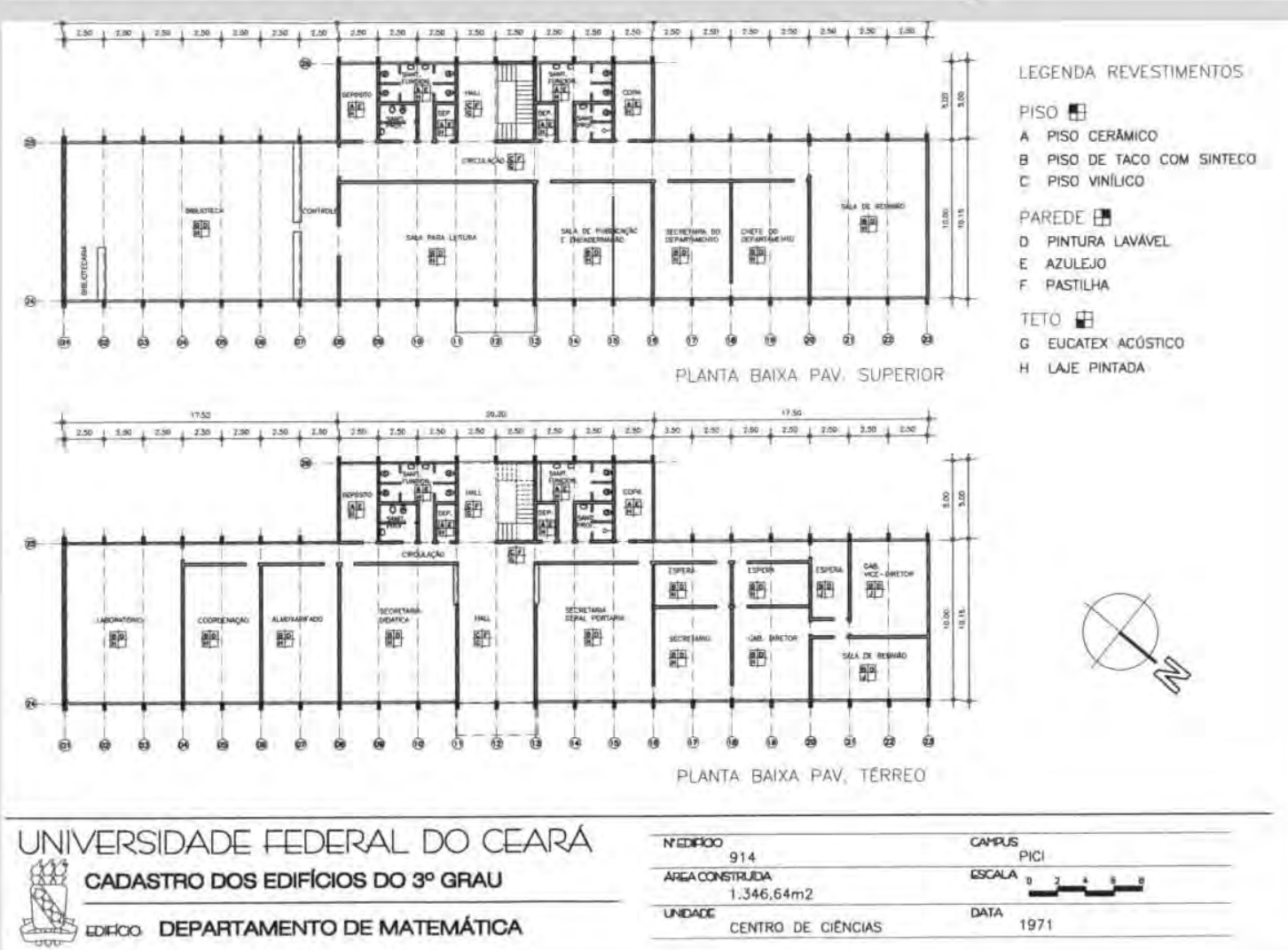

Figura 72: UFC -Departamento de Matemática / Projeto de Arquitetura.

Campus Universitário do Pici - Década de 1970.

(Fonte: Acervo UFC - desenhos digitalizados a partir dos projetos originais, edição nossa 
A orientação projetual não abrangia, entretanto, uma flexibilidade integral para alterações dos arranjos internos da edificação. Mesmo com a estrutura independente das vedações, a solução construtiva para divisões internas era a alvenaria de tijolo, que embora passível de ser demolida, é onerosa, contrariando as diretrizes de economia e racionalização que deveriam nortear as futuras demandas, decorrentes de mudanças no programa pedagógico. Nos tipos em que foram adotadas as divisórias em chapas de madeira compensada, a fabricação seguia um processo artesanal, com peças executadas no canteiro de obras e confeccionadas de acordo com as dimensões da cada ambiente. Isso se devia provavelmente às dificuldades de acesso aos produtos industrializados durante aqueles anos na cidade de Fortaleza. Outro aspecto a ser aferido é o da limitação de adequação das instalações prediais aos novos layouts, devido aos custos operacionais e construtivos incompatíveis com a filosofia escolhida.

Convém mencionar que a solução adotada pelo arquiteto Hélio Duarte para o projeto da Escola de Engenharia da Universidade de São Carlos, no interior de São Paulo, no qual o princípio da flexibilidade que direcionou toda a proposta construtiva do edifício abrangia não apenas a estrutura resistente e seus elementos de vedação, mas também a possibilidade de maleabilidade nas instalações complementares (luz, telefone, esgoto, água e gás). A solução permitia remanejamentos sem interferência com os demais sistemas do prédio. Para Duarte a flexibilidade integral ${ }^{32}$ foi a ideia básica que norteou o projeto e que compreendia o remanejamento de todos os elementos que participavam da edificação.

As esquadrias empregadas buscaram atender duplamente ao princípio da padronização e de solução na amenização do rigor climático local com o modelo de madeira com venezianas de réguas articuláveis, executadas no vão livre entre pilares (módulo-base de $2,50 \mathrm{~m} \times 2,50 \mathrm{~m}$ ), que se destacam na fachada segundo o princípio da verdade estrutural. Para propiciar a ventilação natural cruzada, foram colocadas esquadrias nas vedações opostas às aberturas de entrada dos ventos dominantes (ver figura 73). A preocupação com a incidência solar manifesta-se também na implantação dos edifícios, cuja configuração longitudinal está orientada na direção leste-oeste, embora alguns contrariem essa condição, indicando a prevalência por uma ordenação de caráter funcional.

No conjunto da padronização destacam-se os materiais de revestimento aplicados nas fachadas: pastilha cerâmica de fabricação local. No sistema de cobertura foram empregadas duas soluções, uma aparente com telhas autoportantes de fibrocimento em duas águas, uma apoiada na estrutura de madeira e outra com platibanda e calhas impermeabilizadas.

\footnotetext{
${ }^{32}$ Este conceito de "flexibilidade integral" foi apresentado por Hélio Duarte, na publicação "Espaços Flexiveis - uma consequência em Arquitetura" de sua autoria. Neste trabalho o arquiteto disserta sobre o tema da Flexibilidade e detalha a solução desenvolvida no edifício da Escola de Engenharia da Universidade de São Carlos, em São Paulo.
} 

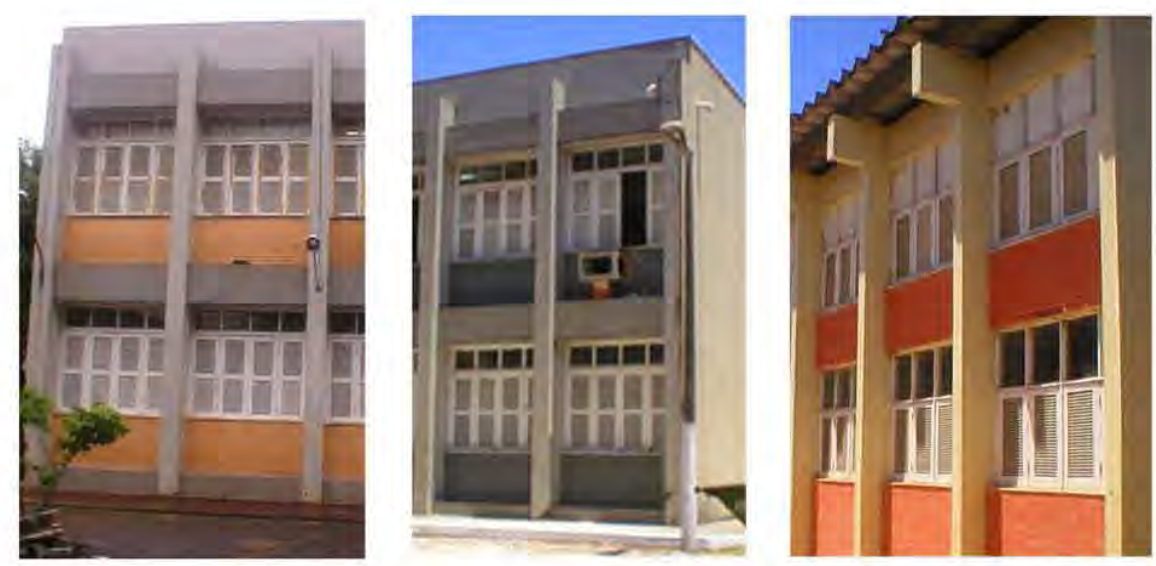

Figura 73: UFC - Campus Universitário do Pici.

Proposta de padronização das esquadrias, concebidas como elemento de vedação associado ao módulo-base estrutural de $2,50 \mathrm{~m} \times 2,50 \mathrm{~m}$. Os pilares se destacam proporcionando ritmo às fachadas.

(Fonte: Acervo UFC apud CAMPÉLO, 2005, p. 90)

A forma arquitetônica resulta da planta funcional, que gera a volumetria prismática de predominância horizontal. As formas puras e de linhas retas, desprovidas de ornamentos, criam um conjunto de clara intenção racionalista, onde a forma arquitetônica simples expressa a função utilitária para a qual foi projetado, dentro dos princípios de economia e facilidade construtiva (ver figura 74). De autoria do arquiteto Neudson Braga, os atributos dessa produção evidenciam seus vínculos com a Escola Carioca, embora com características de adaptação aos condicionantes locais.

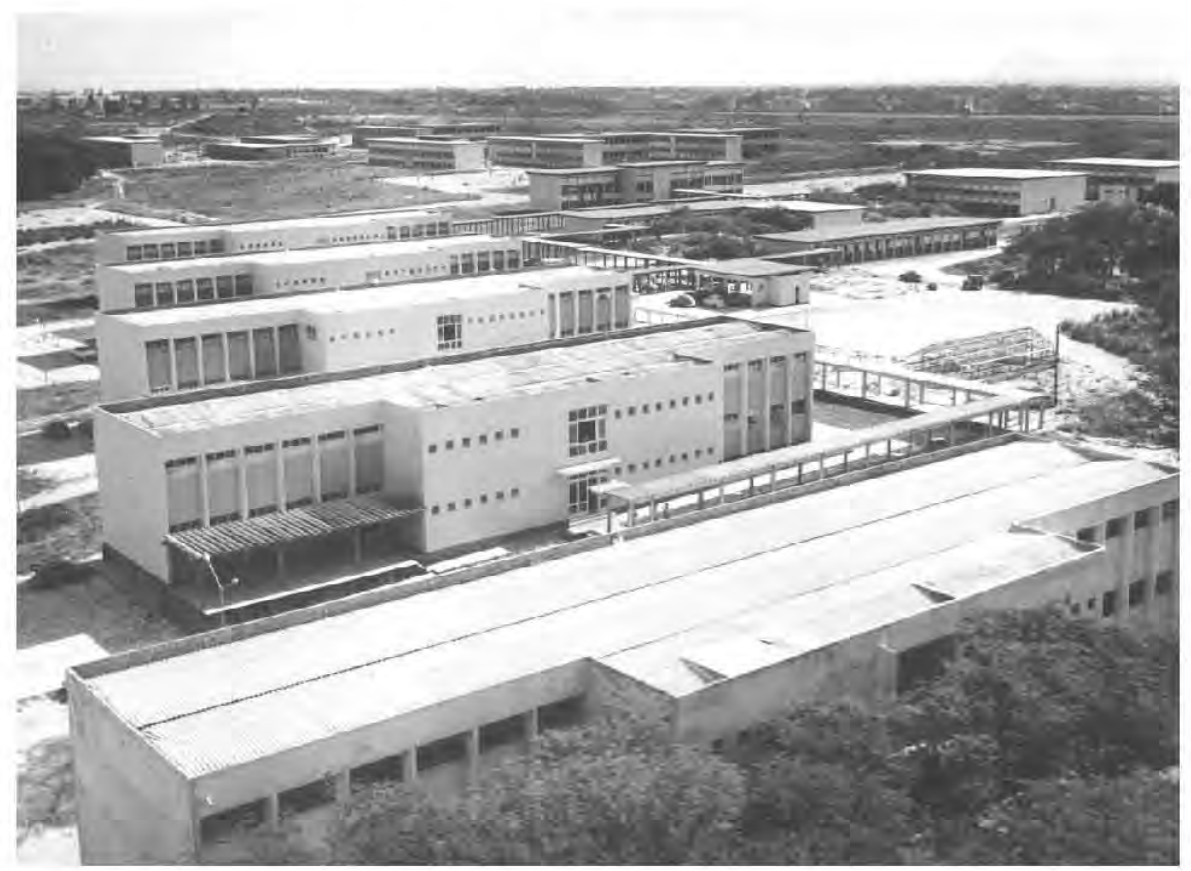

Figura 74: UFC - Campus Universitário do Pici - Década de 1970.

Composição volumétrica por justaposição de blocos prismáticos e interligados por passarelas.

(Fonte: Acervo UFC apud CAMPELO, 2005, p.88) 


\section{- Biblioteca e Núcleo de Processamento de Dados: o rompimento com a padronização}

Contrapondo-se a essa arquitetura de escala singela, foram erguidos em meados da década de 1970, os edifícios destinados à Biblioteca e ao Núcleo de Processamento de Dados, que rompiam com a proposta de blocos padronizados. A produção de volumetria robusta, ressaltada pelo uso do concreto aparente como expressão do caráter dos edifícios, se sobressai na paisagem construída do Pici, interferindo na ordem visual do conjunto de identidade única. Os projetos são de autoria do arquiteto Nearco Araújo desenvolve uma arquitetura cuja postura projetual revela suas referências à outras experiências ligadas ao uso do concreto aparente, que estavam ocorrendo nos anos 1970 em várias outras regiões.

\section{- Biblioteca}

O edifício da Biblioteca, implantado às margens do Açude Santo Anastácio, foi concebido como bloco único e abriga uma área construída de $7.716,67 \mathrm{~m}^{2}$ distribuída em três níveis de pavimentos. Os espaços são definidos pela estrutura de concreto armado, regida pela malha modular de $10,00 \times 10,00 \mathrm{~m}$. Tais características conferem ao edifício o atributo da monumentalidade. É possível que a recomendação dada pelo Manual de Atcon (1970), de que a arquitetura do edifício da biblioteca deveria expressar sua condição de relevância na hierarquia da estrutura acadêmica da Reforma, tenha permeado a orientação de uma arquitetura monumental.

O partido adotado destaca a forma arquitetônica de composição volumétrica em forma de caixa, que resulta da planta de configuração retangular com dimensões de $35,40 \times 85,15 \mathrm{~m}$. Introduzindo dinamicidade a essa volumetria, o arquiteto agrega elementos, para criar fachadas diferenciadas. $\mathrm{Na}$ oeste, voltada para a via de veículos e de acesso ao público, a horizontalidade da "caixa", reforçada pela linha reta da platibanda, é suavizada pelo volume vertical da escada justaposto, pela rampa de concreto aparente que faz a ligação do passeio com a entrada do edifício e por "cortinas" em formato de grelha que resultam da associação de elementos verticais e horizontais, com a clara intenção de aliar plasticidade aos fatores de proteção solar. Este propósito, entretanto não é atingido em face do equívoco gerado pelas dimensões das estruturas, que não impedem a radiação solar direta nos ambientes (ver figura 75 ).

$\mathrm{Na}$ fachada leste, com acessos de serviço, Araújo enfatiza a modulação estrutural, destacando os pilares em concreto aparente entre as vedações de alumínio e vidro, assim como a platibanda constituída por peças verticais também de concreto aparente, que seguem a regularidade da modulação. Tirando partido das áreas de leitura, localizadas no primeiro andar, o arquiteto expande o piso do pavimento, que desempenha a tripla função de varanda, de marquise e de elemento de composição arquitetônica. Com essa solução, 
solta o edifício do solo e tem a estrutura recuada, atenuando a solidez da forma e a tendência ao "peso" visual (ver figura 76). As fachadas laterais são tratadas como extensão da fachada leste, diferentemente da platibanda, que retoma a plasticidade da faixa contínua de concreto aparente adotado na fachada oeste (ver figura 77 ).

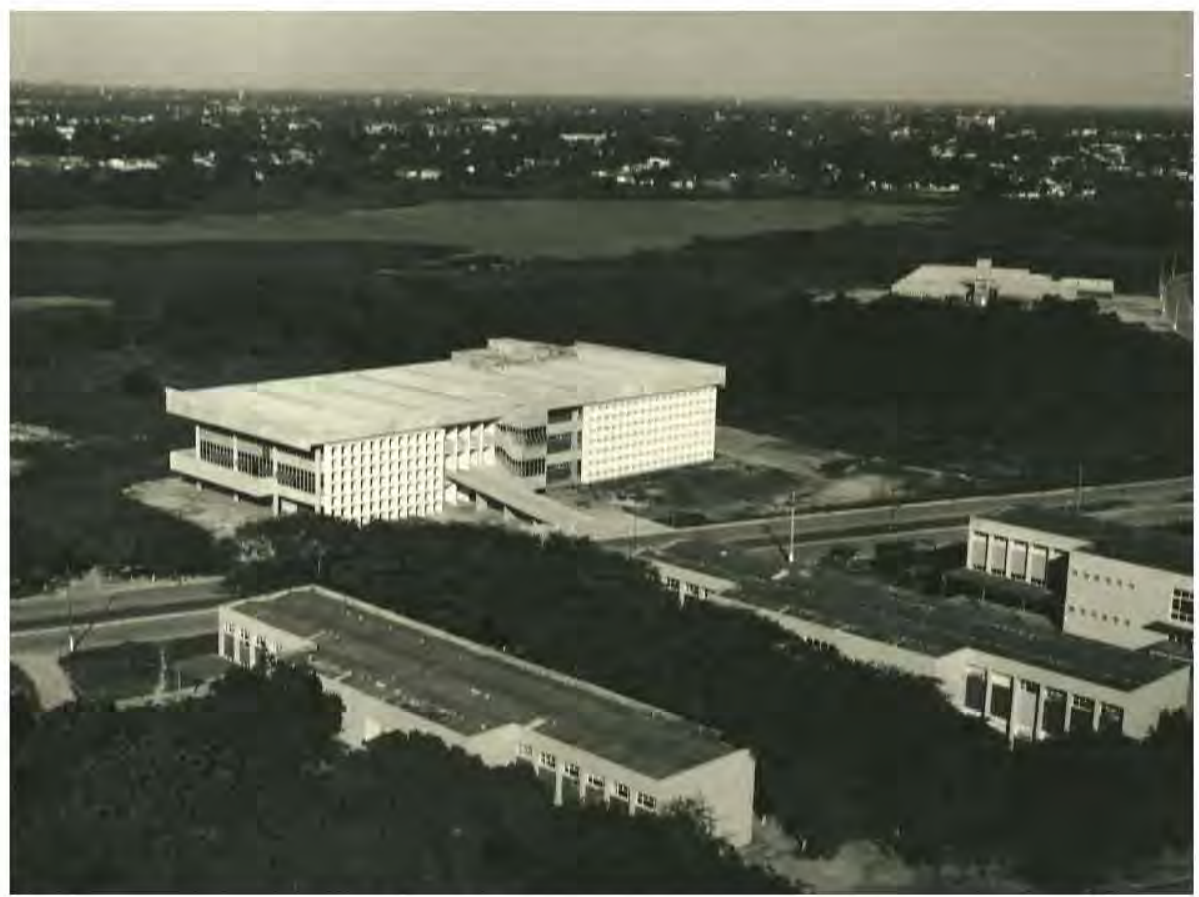

Figura 75: UFC - Biblioteca Central / Fachada oeste - Década de 1970.

A relação com o entorno se dá por contraste visual, realizando a integração com o ambiente externo por meio da clareza do acesso, destacado pela rampa de concreto aparente.

(Fonte: Acervo COP / UFC)

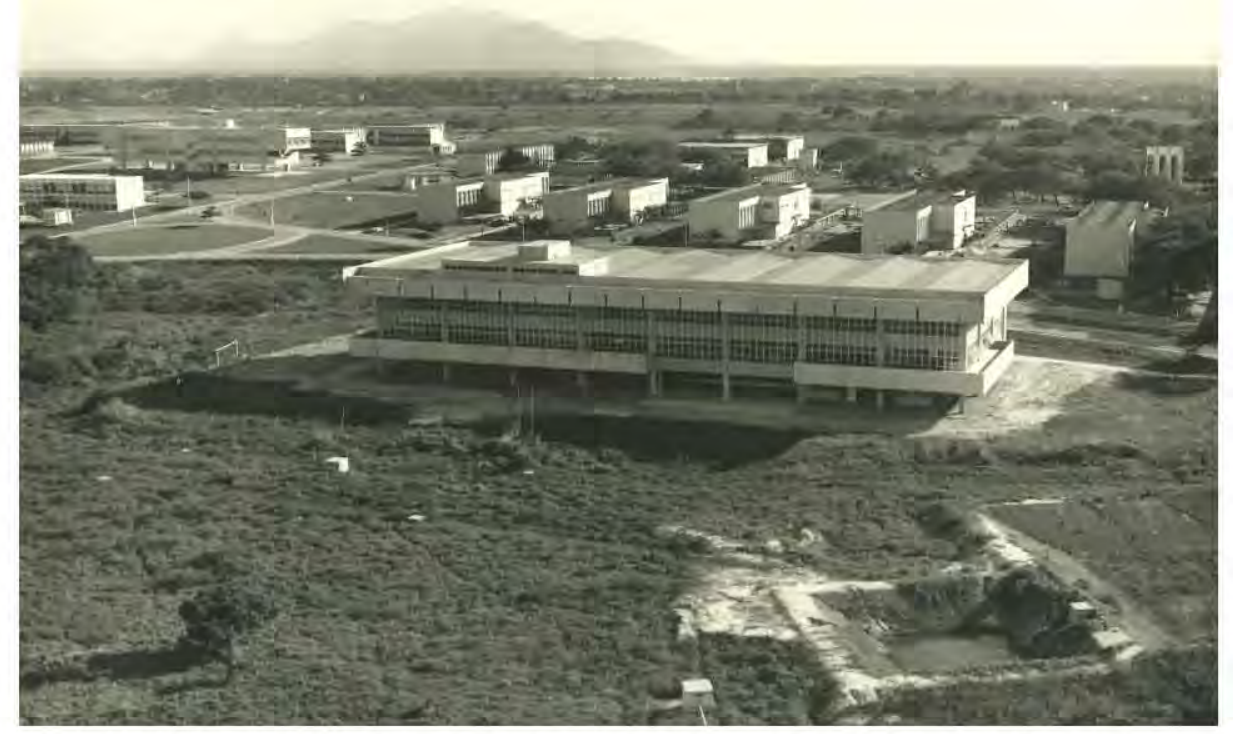

Figura 76: UFC - Biblioteca Central / vista da fachada leste - Década de 1970.

A volumetria horizontal do edifício é associada à clareza da solução estrutural. (Fonte: Acervo COP / UFC) 


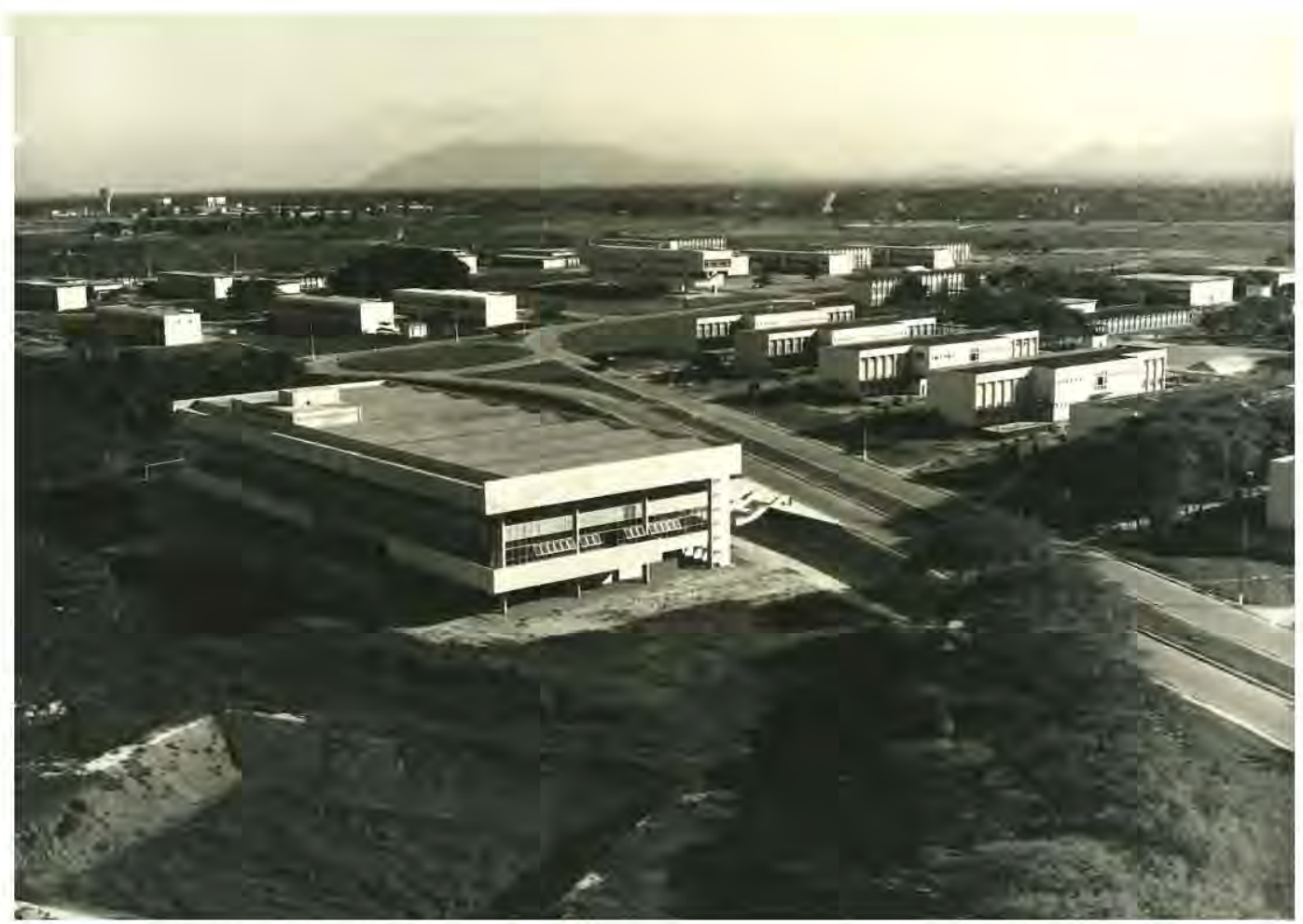

Figura 77: UFC - Biblioteca Central / vista das fachadas norte e leste - Década de 1970.

A restrição na variedade dos materiais usados confere austeridade e homogeneidade à solução arquitetônica.

(Fonte: Acervo COP / UFC)

\section{- Núcleo de Processamento de Dados}

O edifício construído para abrigar as atividades do Núcleo de Processamento de Dados adota o partido de um monobloco longitudinal com três níveis de pavimentos e dimensões de projeção horizontal da ordem de $12 \mathrm{~m} \times 80 \mathrm{~m}$, perfazendo a área total construída de $2.665,64 \mathrm{~m}^{2}$.

O programa do Núcleo é resolvido nos dois últimos pavimentos que se organizam ao longo da circulação centralizada, conformando duas alas longitudinais de serviços. O pavimento térreo, com os pilares localizados nos limites da sua projeção, é liberado de funções específicas, tornando-se um espaço livre, permeável, propício à convivência da comunidade acadêmica.

O partido explora o emprego dos grandes vãos e a exacerbação da tecnologia do concreto armado. Apoiado nos pilares que vencem vãos de $20,00 \mathrm{~m}$ no eixo longitudinal e balanços nas extremidades $-3,00 \mathrm{~m}$ no primeiro e $5,00 \mathrm{~m}$ no segundo pavimento - e com o fechamento dos planos verticais realizado pela estrutura de concreto aparente com as esquadrias de vidro e alumínio, a forma arquitetônica se destaca pela volumetria maciça conferida pelo concreto aparente e acima de tudo pela grande escala que se contrapõe aos blocos do Centro de Ciências, junto aos quais se encontra implantado (ver figura 78). 
Diferindo da Biblioteca, nẫo há elementos que identifiquem a intençẫo de neutralizar os efeitos climáticos de intensa radiaçẫo solar ou de inserção na paisagem edificada do Centro de Ciências. $O$ esforço arquitetônico reside na formulaçẫo da obra de grande escala. 0 papel preponderante da estrutura de concreto, a restriçẩo do número de materiais e a ausência de revestimentos conformam a forma arquitetônica o atributo da monumentalidade.

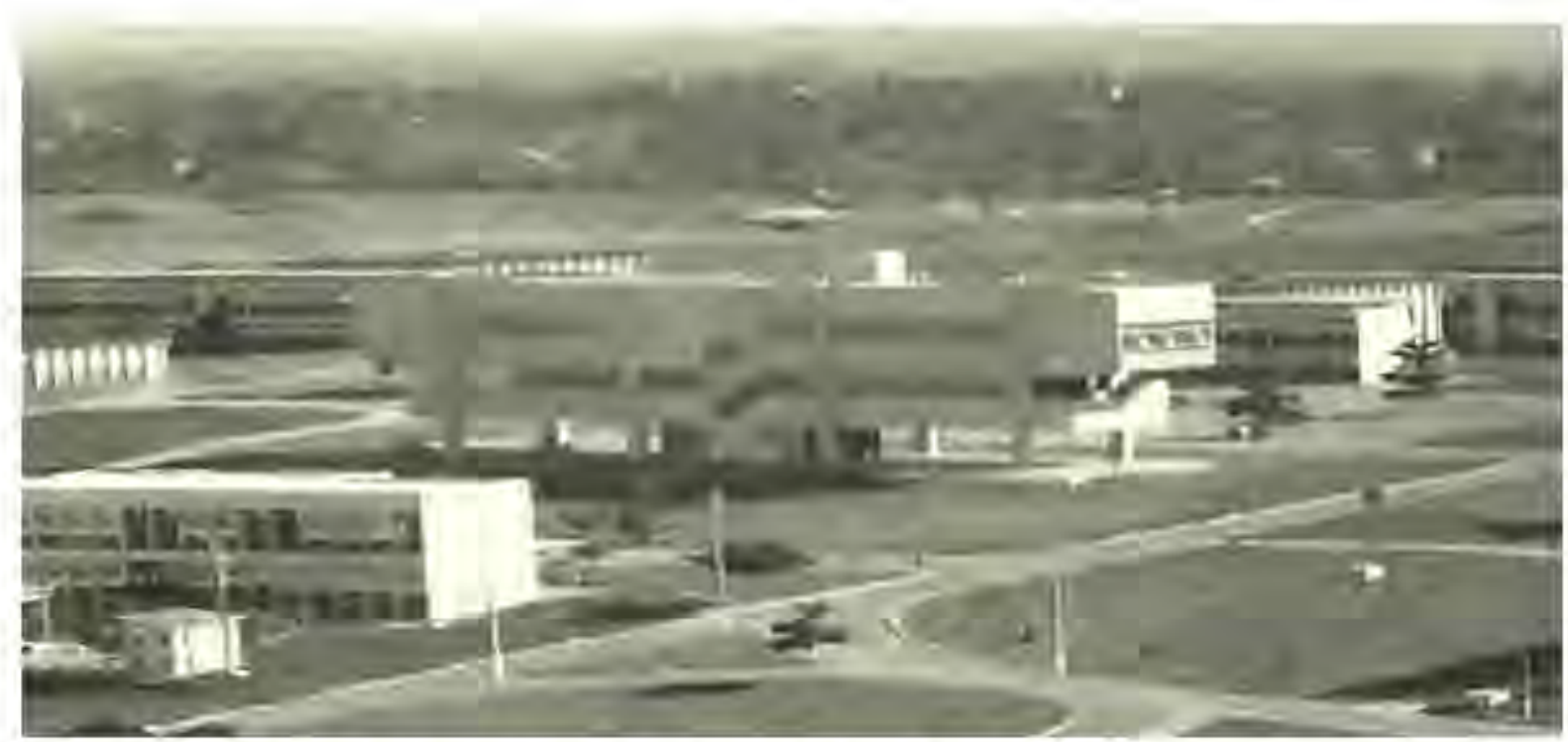

Figura 78: Núcleo de Processamento de Dados da UFC - Década de 1970.

A singularidade da volumetria maciça do edifício gera relaçấo de conflito visual com o entorno de escala padronizada.

(Fonte: Acervo COP I UFC)

\section{- Restaurante Universitário: 0 distanciamento do edifício racionalista}

Outra produção da década de 1970 no Camous do Pici foi o edifício projetado pelo arquiteto Neudson Braga para o Restaurante Universitário. A arquitetura desenvolvida revela uma mudança da visẫo do edifício centrado no racionalismo das formas puras para uma proposta mais aberta, que considera as condiçổes do lugar e a composiçẫo orgânica das formas. Embora mantendo a escala e a similaridade com a linguagem dos materiais empregados nos blocos padronizados, 0 partido deixa evidente a intençäo de romper com a proposta pioneira.

Tirando partido da topografia, o edifício possui dois niveis de pavimentos, sendo o térreo com acesso ao passeio e o segundo, situado abaixo do primeiro, aproveita a encosta do terreno, voltando-se às margens do Açude Santo Anastácio. O programa do restaurante refeitórios, setor administrativo, sanitários, cozinha e serviços de apoio -, está concentrado no payimento térreo, enquanto que o nivel inferior abriga uma generosa área de estar aberta 
à paisagem, abastecida por sanitários e áreas de estocagem de material, totalizando $4.675,38 \mathrm{~m}^{2}$ de área construída.

A planta se desenvolve sobre o módulo-base estrutural de $10 \mathrm{~m} \times 10 \mathrm{~m}$, que desempenha o papel ordenador dos setores funcionais. O processo de projeto propicia organicidade à planta, que se espalha no terreno atendendo ao correto fluxo das atividades. $O$ resultado revela o rompimento projetual com o rigor geométrico das formas puras. A volumetria única não é mais o elemento que dá força à forma arquitetônica. Agora são os planos verticais das fachadas, com ênfase na verdade estrutural, onde a diferenciação dos elementos de concreto aparente (vigas, pilares e platibanda) das superfícies de vedação (alvenarias revestidas de cerâmica e panos de combogó), compõem forma arquitetônica.

Braga revela domínio na problemática do conforto ambiental, propiciando o fluxo da ventilação cruzada por meio dos extensos panos de combogó, estrategicamente dispostos nas áreas do refeitório, que também funcionam como filtros da iluminação natural. $\mathrm{A}$ estratégia é apoiada pela abertura do refeitório da fachada de fundo, que integra a paisagem natural do açude ao ambiente. Não há excessos. $O$ edifício se insere na paisagem e a arquitetura potencializa a função para a qual foi projetada.

\subsection{Considerações}

A Universidade Federal do Ceará, com sede na cidade de Fortaleza, foi instituída pela Lei Federal $n^{\circ} 2.373$, de 16 de dezembro de 1954, a partir da justaposição da Faculdade de Direito, Faculdade de Farmácia e Odontologia, Escola de Agronomia, Escola de Medicina e no ano seguinte incorporou a Faculdade de Engenharia. A historiografia da Instituição credita sua criação ao amplo movimento de opinião pública, tendo como principal interlocutor o intelectual e professor da Faculdade de Direito do Ceará Antônio Martins Filho, que se tornou o primeiro reitor da Universidade.

Instalada em 1955, iniciou suas atividades nas dependências das instituições que foram encampadas, situadas predominantemente na malha urbana da cidade, excetuando-se a Escola de Agronomia que, pelas características rurais das suas atividades, funcionava em terreno localizado no subúrbio afastado, denominado Sítio do Pici, onde foi implantado o Campus do Pici. As edificações, construídas na primeira metade do século XIX para outros fins, apresentavam uma arquitetura de arranjo eclético com traços neoclássicos e art déco.

Procurando superar sua condição inicial de ser formada pela reunião de faculdades e escolas isoladas, espalhadas pela cidade, a Universidade logo tratou de promover o gradativo agrupamento físico das unidades em uma mesma área, visando criar e consolidar 
um território unificado. A primeira ideia foi erguer uma cidade universitária na gleba do Sítio do Pici. Entretanto, os conflitos e interesses das corporações profissionais que the deram conformação - advogados, médicos e agrônomos - e o poder que se instalou na Reitoria foram determinantes para a construção do território da UFC dividido em três áreas dispersas na malha urbana da cidade, configuração que se mantém até os dias de hoje. Trata-se das áreas do Benfica, do Porangabuçu e do Pici. Essa opção, que a princípio foi tomada como provisória, se concretizou, apesar do empenho desenvolvido pelas sucessivas administrações no propósito de unificar a base física da Universidade.

A área do Benfica, situada no bairro do mesmo nome, próximo ao centro da cidade, conformava uma zona residencial das elites cearenses, porém em declínio nos anos de 1950. A presença da Faculdade de Direito nas suas circunvizinhanças fortaleceu a decisão da então Administração Superior de comprar o imóvel para a implantação da sede da Reitoria naquela região. A condição de favorecimento na aquisição de outros edifícios próximos a essa unidade administrativa, associada ao fator de localização estratégica na estrutura urbana, que permitia estabelecer relações com as áreas do Porangabuçu e do Pici, ajudaram o processo de ocupação das unidades e equipamentos universitários naquela área.

O território universitário que passou a se formar não foi, entretanto, resultado de uma ação planejada, mas se deu pela compra de imóveis disponíveis para a venda e posteriormente selecionados conforme as demandas da Instituição. Procurando moldar um espaço integrado e de convívio da comunidade, a Universidade procedeu a um intenso processo de demolição, construção e reformas dos imóveis adquiridos, eliminando os muros entre eles, de maneira a reagrupar os terrenos, substituindo a estrutura fundiária baseada no lote pela quadra como unidade territorial básica. Dessa forma foram se conformando glebas que permitiam a instalação das unidades sem o fracionamento espacial ou isolamento das mesmas.

O resultado positivo demonstrado com a expansão paulatina no Benfica de unidades acadêmicas e equipamentos culturais ensejou a ideia de ali se estabelecer o território definitivo da UFC. A proposta, entretanto foi abandonada a partir da constatação de inviabilidade na desapropriação da área total a ser adquirida. Esta concepção de instituição, inserida na malha urbana, servindo-se da infraestrutura, aberta e permeável aos habitantes da cidade, contrariava o modelo espacial de cidade universitária que se estabelecera nas universidades brasileiras. O urbanismo adotado moldava naquela área uma zona especializada, de domínio da Universidade e integrado às circunvizinhanças. 
A demanda crescente por projetos para a construção das novas unidades acadêmicas favoreceu a atuação de jovens arquitetos, formados em instituições do Rio de Janeiro e do Recife, que retornando a Fortaleza, encontraram na UFC ambiente propício para materializar uma produção embasada pelos princípios do modernismo arquitetônico brasileiro. Dentre eles, os arquitetos cearenses Liberal de Castro, Neudson Braga, Ivan Brito e Enéas Botelho, que passaram a fazer parte dos quadros da Universidade, foram autores de um panorama edilício que testemunha até hoje os cânones modernistas da Escola Carioca, adaptados às técnicas e procedimentos construtivos da região. No Benfica, exemplares como a Residência Universitária de autoria de Brito, o Departamento de Cultura da UFC, projeto de Castro e a Faculdade de Filosofia, Letras e Artes, desenhada por Braga, fazem parte da história da arquitetura moderna do Ceará.

No caso do Porangabuçu, sua concretização foi favorecida pela transferência, em 1957, da Faculdade de Medicina, que funcionava no centro da cidade para as dependências do Hospital das Clínicas, construído nesse bairro, atual Rodolfo Teófilo, onde eram exercidas as atividades práticas. $O$ evento propiciou a expansão da Universidade naquele local, sob o domínio da classe médica. Nesse período, o Porangabuçu era uma área periférica, ocupada pela população de baixa renda e para onde habitualmente se dirigiam os flagelados da seca. Embora a ocupação também tenha se dado sem um planejamento, gradativamente se conformou o espaço de feição especializada, voltado para o setor da saúde, com a implantação de unidades e equipamentos pertinentes ao setor. Ali também foram erguidos edifícios cuja arquitetura era embasada pelos princípios modernistas. Dentre eles, o edifício da Maternidade-Escola, de autoria dos arquitetos cariocas Roberto Nadalutti, Oscar Waldetaro e Israel Barros Correia, se destaca na paisagem construída do Porangabuçu por seu partido modernista com elementos de construção local.

A consolidação da Universidade na área do Pici foi uma decorrência da presença da Escola de Agronomia que ali se instalou em função das suas especificidades, que exigiam grandes extensões de terra e proximidade a fontes de água, condições que foram reforçadas pela possibilidade de anexar terrenos desocupados existentes no seu entorno. A condição de ampliação dos seus limites tornou-se fator de favorecimento para ali se instalar o futuro território unificado da UFC, manifestado nas várias tentativas empreendidas pelo planejamento físico da Instituição, durante os anos 1960 e 1970.

Vale salientar que a ocupação do Pici por unidades correlatas à Escola de Agronomia no primeiro decênio de criação da Universidade também favoreceu o surgimento de uma produção de linguagem modernista. O Instituto de Zootecnia, de autoria do arquiteto Enéas Botelho, representa um exemplar pioneiro dessa geração. A ocupação da gleba não teve até meados da década de 1960 a orientação de um plano físico, conformando o adensamento 
das unidades em núcleos dispersos. Somente com a oficialização do primeiro plano diretor da Universidade em 1966 é que foi concebida a estrutura urbanística mantida até os dias atuais.

O dinamismo e a celeridade no crescimento da UFC, ocorridos nos primeiros dez anos do seu funcionamento, tornaram sua estrutura cada vez mais complexa e, associados à crescente demanda por ampliação de vagas, indicaram a premente necessidade de um planejamento institucional que viesse a ordenar 0 crescimento acadêmico e físico da Instituição por um prazo de seis anos. Dessa intenção resultou o Plano de Desenvolvimento de 1966/1970 que contou com a participação de todos os setores da Universidade. A coordenação do planejamento físico coube ao arquiteto carioca Hélio Duarte, que também participou da instalação da Escola de Arquitetura da UFC, criada em 1964.

O Plano procurou estabelecer diretrizes gerais de crescimento embasadas pelos objetivos de integração e expansão, bem como direcionamento para promover flexibilidade e funcionalidade no desenvolvimento da Instituição. A garantia das bases estabelecidas encontrava, entretanto, um conflito: diante do objetivo de conferir maior funcionalidade ao sistema por intermédio de melhor integração entre as unidades, era preciso superar a dispersão espacial em três áreas distintas por meio do planejamento. Por outro lado qualquer solução a ser adotada não poderia descartar os investimentos já consolidados nesses terrenos. A ferramenta utilizada para contornar o impasse foi a proposição de um zoneamento que estabelecesse a vocação funcional de cada área, dando inteireza à fragmentação espacial e funcionalidade e integração entre as unidades.

A especialização proposta definiu três setores:

- Setor $A$, correspondendo ao Benfica - voltado para o campo de humanas, administração central e equipamentos de cultura e lazer; Setor $B$,

- correspondendo ao Porangabuçu - destinado às ciências biomédicas e o

- Setor $C$, correspondendo ao Pici - dirigido às áreas tecnológicas, agronômicas, institutos básicos e futuras ocupações que fossem gradativamente conformando aquele setor como território único da Universidade, tendo esse último um plano de ocupação com base na organização de zonas acadêmicas articuladas por um sistema viário geral, com evidente inspiração nos princípios racionalistas do urbanismo moderno. A concretização dos referidos setores seria operada por meio do gradativo remanejamento das unidades para o seu respectivo Setor e com construção de outras que se fizessem necessárias.

A execução do Plano estava vinculada à liberação dos recursos garantidos por meio do Programa MEC/BID, o que só veio acontecer em 1970, durante o processo de implantação 
da Reforma de 1968, introduzindo novas orientações ao planejamento. Procurando se adequar ao modelo de campus universitário da Reforma, a UFC elabora para o Pici uma proposta de organização espacial situando o setor básico em posição central, circundado por um anel viário periférico, ao redor do qual se estabeleceriam as futuras faculdades profissionais reunidas por afinidades, o que evidenciava referências ao Manual de Atcon (1970). Foram executados o setor básico, que na nova matriz acadêmica conformou o Centro de Ciências, e o anel viário periférico.

Durante a primeira metade da década de 1970 foram formuladas mais três propostas de características espaciais similares que tentavam dar materialidade à estrutura de seis centros e uma Reitoria no modelo de campus na área do Pici. A primeira proposta instituiu o "Campus do Pici com a área da saúde no Porangabuçu", já que não conseguiu neutralizar os impasses para a transferência desse setor. Entretanto, com base nessa configuração primeira, definiu uma segunda organização que incorporava a Faculdade de Odontologia, tendo em vista a indisponibilidade de terrenos no Porangabuçu para a construção das instalações daquela unidade que ainda funcionava no centro da cidade. Por último, incorporou ao Pici o setor administrativo da Reitoria.

Em todas elas a organização espacial estava baseada no zoneamento das funções, estabelecendo os setores de conhecimentos afins - os centros - e o setor esportivo, de vivência e administrativo. Articulavam-se por meio de um sistema de circulação hierarquizado, que separava o sistema viário geral das vias secundárias que davam acesso aos estacionamentos setoriais, enquanto a circulação de pedestres era feita no interior das zonas sem interferência de veículos. Nenhuma delas foi executada na íntegra.

Para atender aos imperativos de rapidez e baixo custo na construção das unidades acadêmicas exigidos pelo processo de implantação da Reforma, a UFC adotou a padronização como critério construtivo - herança do Plano de Desenvolvimento de $1966 / 1970$, Foram concebidos blocos de dois pavimentos com a planta livre, de geometria predominantemente retangular que se desenvolve sobre a malha modular de $1,25 \times 1,25 \mathrm{~m}$. Com base no módulo estrutural definido a cada $2,50 \mathrm{~m}$ de vão, foram projetados os componentes construtivos, tais como as esquadrias de madeira com venezianas articuláveis de fabricação local. Essa padronização foi adotada nas unidades dos centros de Ciências, de Tecnologia e de Agronomia implantados no Pici.

$\mathrm{Na}$ segunda metade da década de 1970 , outra produção de viés arquitetônico com ênfase no concreto aparente foi erguida no Campus do Pici, causando forte contraste visual com o conjunto dos blocos de identidade padrão. Os edifícios destinados à Biblioteca e ao Núcleo de Processamento de Dados são exemplares desse período. 
Em 1979, quando as instituições começaram a questionar a validade da Reforma Universitária de 1968, a UFC elaborou um plano diretor com o objetivo de estabelecer definitivamente as bases físicas da Instituição. Resgatando a proposição do zoneamento de três setores estabelecido no Plano de 1966/1970, o novo documento admitia a configuração de um campus tripartido, conformado pelas áreas Área 1 - Pici, Área 2 - Pornagabuçu e Área 3 - Benfica. Predominou, entretanto, na sua concepção a ideia de campus visto como território isolado, autônomo e segregado em relação à cidade.

Com base no processo histórico que se deu na UFC com vistas à materialização do seu território, podemos identificar três tipologias espaciais concebidas pela instituição. A primeira, quando da sua criação, tentou dar forma a um território inserido na malha urbana de Fortaleza, fazendo da quadra a unidade territorial básica. Posteriormente, propôs uma zona constituída pela junção de três áreas especializadas, articuladas entre si pela estrutura urbana existente. Uma terceira concepção foi pensada como território isolado, no modelo de campus da Reforma.

O Campus do Pici encontra-se envolvido pela estrutura urbana, porém não se integra com as áreas do entorno. Cercado por muros, a presença da população de baixa renda nas suas vizinhanças torna seus limites em fronteiras de conflitos gerados por ameaças de invasões. 


\section{UNIVERSIDADE FEDERAL DO CEARÁ (UFC)}

A Universidade Federal do Ceará é uma instituição autárquica vinculada ao Ministério da Educação e com sede na cidade de Fortaleza, capital do Ceará. Atua em vários municípios com a seguinte estrutura: em Fortaleza, com os campi do Pici, do Porangabuçu e do Benfica (que sedia a Administração Superior) além de unidades dispersas como a Casa José de Alencar, o Laboratório de Ciências do Mar (LABOMAR) e Fazendas Experimentais; em Sobral e Quixadá, com campi que levam o nome dessas cidades; e, na Região do Cariri, o Campus Cariri, que abrange os municípios de Juazeiro do Norte, Barbalha e Crato (ver figura 4).

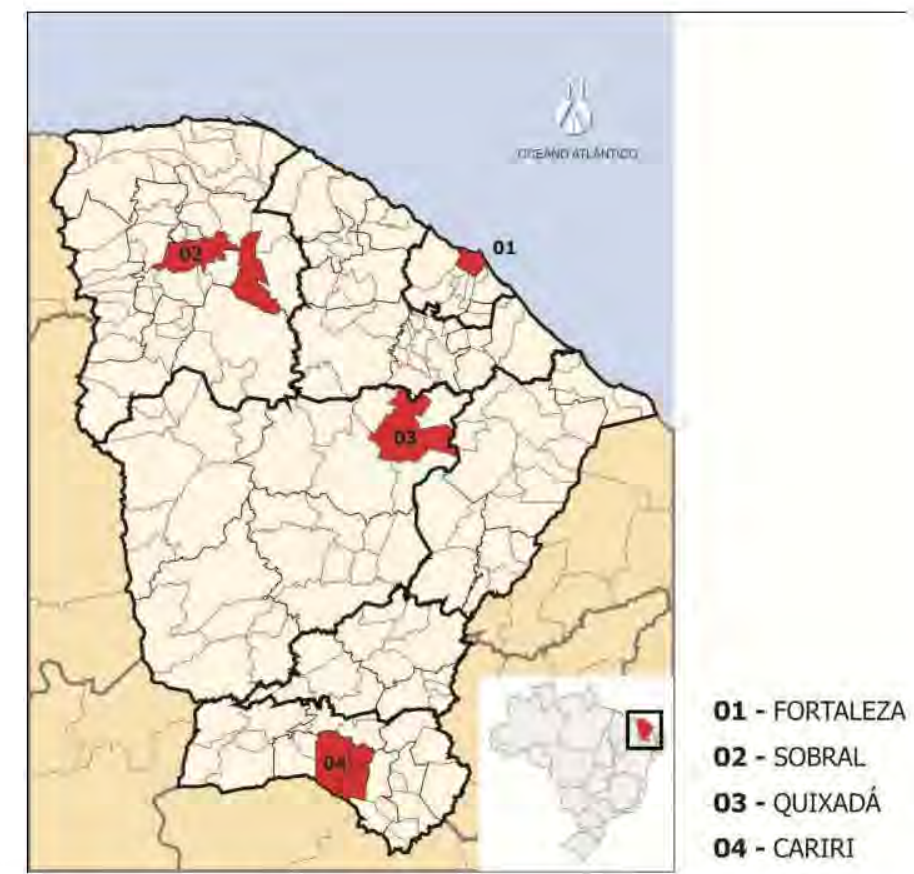

Figura 4: UFC - Mapa do Ceará.

Localização dos municípios que sediam a UFC.

(Fonte: UFC, 2006, p.17).

\subsection{CRIAÇÃO DA UFC}

A criação de uma universidade no Ceará tem origem nos anos de 1940. A historiografia da Instituição registra que a mesma resultou de um amplo movimento de opinião pública, liderado por entidades culturais. Nas palavras do arquiteto Joaquim Oliveira, professor do Departamento de Arquitetura da UFC, 
Sua criação foi produto de um longo processo de maturação nascido da fantasia de alguns poucos visionários que, alimentado pela mobilização favorável dos estudantes da época, resultou na formação do "Movimento Pró-Criação de uma Universidade no Ceará". Este movimento foi o responsável por manter a sociedade cearense unida em prol da pretendida universidade por uma década inteira, entre os anos 1944 e 1954 , que corresponde ao período de mobilização despendido para a concretização deste sonho. (OLIVEIRA, 2005, p.36)

O movimento buscou o apoio dos estabelecimentos de ensino superior do Estado, tendo como principal interlocutor o intelectual e professor da Faculdade de Direito do Ceará Antônio Martins Filho, que se tornou o primeiro reitor da Instituição.

Em 1944, quando se deu concretamente a primeira manifestação, em documento oficial, sobre a criação de uma universidade com sede em Fortaleza, por ocasião do processo de refederalização da Faculdade de Direito do Ceará, funcionavam na capital as seguintes unidades de ensino superior com seus respectivos anos de fundação: a mencionada Faculdade de Direito do Ceará (1903), a Faculdade de Farmácia e Odontologia do Ceará (1916), a Escola de Agronomia do Ceará (1918), a Faculdade de Ciências Econômicas do Ceará (1936) e a Escola de Enfermagem São Vicente de Paula (1943).

Embora as intenções de fundar uma universidade não tenham deixado de ser objeto das cogitações de importantes setores da opinião pública do Estado, foi somente em 1947 com a criação da Faculdade Católica de Filosofia, que o tema voltou efetivamente ao debate, tendo em vista o crescente número de estabelecimentos de ensino superior - condição de favorecimento à criação de uma instituição universitária, conforme determinação da legislação em vigor.

Em 1951, no contexto de federalização de faculdades e sua reunião para formar novas universidades, empreendida pela ação populista do Governo Federal (OLIVEIRA, 2005, p.37), vislumbrou-se uma nova oportunidade de encaminhamento dos esforços iniciados. Naquele ano, o quadro de estabelecimentos de ensino superior em Fortaleza, graças ao processo de expansão, contava com o funcionamento da Faculdade de Medicina (1948) e da Escola de Serviço Social (1950). Entretanto, somente em 1953 é que as articulações junto ao Governo Federal, agora no sentido de criar uma universidade federal, culminaram com a promulgação da Lei $n^{\circ} 2.373$ de 16 de dezembro de 1954 , criando a Universidade Federal do Ceará.

Foi constituída pela Faculdade de Direito do Ceará, Faculdade de Farmácia e Odontologia do Ceará, Escola de Agronomia do Ceará - todas mantidas pelo Governo Federal - e 
Faculdade de Medicina do Ceará - de caráter particular, sustentada pelo Instituto de Ensino Médico, federalizada pela mesma deliberação. Posteriormente, incorporou a Faculdade de Engenharia, que passou a se chamar Escola de Engenharia, criada pela Lei $n^{\circ} 2.383$ de 3 de janeiro de 1956 . A instalação ocorreu no ano seguinte à sua criação em sessão do dia 25 de junho.

\begin{abstract}
As medidas adotadas pela Reitoria, para a rápida consolidação da Universidade, relacionaram-se com a promulgação da Lei $n^{\circ} 2.700$, de 29 de dezembro de 1955 , que definiu com mais precisão sua autonomia administrativa, com a ampliação da Faculdade de Medicina, com a instalação imediata da Escola de Engenharia (1957) e, sobretudo, com a dotação de recursos orçamentários que permitissem executar as tarefas iniciais que se impunham (UFC, 1966, p.9).
\end{abstract}

A partir de então disputas por poder e prestígio se constituíram nos principais elementos que conformaram o contexto de implantação da nova instituição ${ }^{19}$. Dentre eles, destacamos o embate pela consolidação e divisão do poder interno, com a participação de três segmentos - os advogados, os médicos e os agrônomos - que foi determinante na produção do espaço físico-geográfico da UFC.

Partindo do modelo de reunião de faculdades profissionais dispersas na malha urbana, esse desenho logo se transformou, concentrando as instalações em torno de três áreas de interesse: uma no bairro do Benfica, onde se instalou a Reitoria, outra no Porangabuçu, para onde se transferiu a Faculdade de Medicina, sob o domínio dos médicos e terceira, a do $\mathrm{Pici}$, onde se concentrou a Escola de Agronomia, área de influência dos agrônomos. $\mathrm{O}$ arquiteto e professor do Departamento de Arquitetura da UFC, Joaquim Oliveira avalia que a formação do território em áreas distintas garantia as condições de poder dos grupos de maior prestígio:

[...] o poder da burocracia do Estado, representado pela Reitoria e o prestígio das corporações profissionais de médicos e agrônomos, que vão ter na delimitação de seus territórios a cidadela para a afirmação da sua singularidade, requisito indispensável à preservação do controle das condições de promoção dos seus interesses (OLIVEIRA 2005, p.42).

Em tal circunstância, o novo arranjo institucional trouxe repercussões no mapa geográfico da Universidade, que resultou na produção do espaço de característica fragmentada, 
moldada pelo território das três áreas que acabaram se consolidando, conforme será exposto com maior aprofundamento no decorrer do capítulo.

Nos primeiros dez anos de sua existência, a UFC deu ênfase às atividades de ensino, sobretudo ao nível de graduação, tendo em vista a crescente demanda por maior número de vagas e as necessidades dos seus próprios quadros. Conforme dados da Universidade, considerando-se os cursos de graduação, a matrícula que, em 1955, era de 1.081 alunos, evoluiu, em 1965, para 3.964, o que representou uma quadruplicação no decênio (UFC, 1966, p.5).

O crescimento apresentado espelhava a demanda do mercado de trabalho que requeria profissionais agrônomos, engenheiros e economistas e para serviços médico-sanitarista, assim como a expansão do ensino médio, que causou uma pressão crescente no sentido de ampliação de vagas à UFC (UFC, 1966, p.5). Ao final de 1965, a estrutura acadêmica constituía-se de faculdades, escolas e institutos, com número de graduados em especialidades conforme quadro 3 abaixo:

Quadro 3: Número de graduados na UFC no período de 1955/1965.

(Fonte: UFC, 1966, p.19, edição nossa).

\begin{tabular}{|c|c|}
\hline Unidades Acadêmicas & $\begin{array}{c}\mathbf{N}^{0} \text {. de } \\
\text { graduados }\end{array}$ \\
\hline Faculdade de Direito & 828 \\
\hline Faculdade de Medicina & 407 \\
\hline Escola de Agronomia & 357 \\
\hline Escola de Engenharia & 138 \\
\hline Faculdade de Ciências Econômicas & 362 \\
\hline Faculdade de Farmácia & 170 \\
\hline Faculdade de Odontologia & 259 \\
\hline Faculdade de Filosofia Federal & 16 \\
\hline Faculdade de Filosofia Católica de Fortaleza & 1.111 \\
\hline Escola de Serviço Social & 199 \\
\hline Escola de Enfermagem & 106 \\
\hline Instituto de Química & 4 \\
\hline Instituto de Física & 2 \\
\hline Instituto de Matemática & 4 \\
\hline Total & 3.963 \\
\hline
\end{tabular}

No tocante às atividades de pesquisa, ainda era um processo incipiente, com trabalhos concentrados nos setores de bioquímica, agronomia, biologia marinha, saúde pública e ciências sociais, enquanto que as de extensão estavam voltadas ao setor das letras e artes. $\mathrm{Na}$ segunda metade da década de 1960, a partir dos Decretos $n^{\circ} 53 / 1966$ e n $252 / 1967$, a UFC realizou, por meio do Decreto $n^{\circ} 62.279$, de 20 de fevereiro de 1968, reformas, organizando sua estrutura acadêmica em unidades de estudos básicos e de aplicação (ver 
quadro 4) - divididas em departamentos (menor fração da estrutura universitária) - e reunida em órgãos setoriais - centros - conforme quadro 5.

Quadro 4: Estrutura Acadêmica da UFC - Decreto n 62.279/1968.

(Fonte: Decreto $n^{0} 62.279,1968$, p.5-6)

\begin{tabular}{l|l}
\hline \multicolumn{1}{c|}{ Estudos Básicos } & \multicolumn{1}{c}{ De Aplicação } \\
\hline Instituto de Matemática & Escola de Engenharia \\
\hline Instituto de Física & Escola de Agronomia \\
\hline Instituto de Química & Faculdade de Medicina \\
\hline Instituto de Geociências & Faculdade de Odontologia \\
\hline Instituto de Biologia & Faculdade de Farmácia \\
\hline Faculdade de Estudos Sociais e & Faculdade de Ciências Econômicas e \\
Filosofia & Administrativas \\
\hline Faculdade de Letras & Faculdade de Direito \\
\hline Faculdade de Artes e Arquitetura & Faculdade de Educação \\
\hline
\end{tabular}

Quadro 5: Organização das unidades acadêmicas da UFC - Decreto n 62.279/20/1968.

(Fonte: Decreto $\mathrm{n}^{\circ} 62.279,1968, \mathrm{p} .7$ )

\begin{tabular}{|c|c|c|}
\hline \multicolumn{2}{|r|}{ Órgãos Setoriais } & \multirow{2}{*}{$\begin{array}{l}\text { Unidades Acadêmicas } \\
\text { - Instituto de Matemática } \\
\text { - Instituto de Física } \\
\text { - Instituto de Química } \\
\text { - Instituto de Geociências } \\
\text { - Instituto de Biologia }\end{array}$} \\
\hline a) & Centro de Ciências & \\
\hline b) & Centro de Humanidades & $\begin{array}{l}\text { - Faculdade de Estudos Sociais e } \\
\text { Filosofia } \\
\text { - Faculdade de Letras } \\
\text { - Faculdade de Artes e Arquitetura }\end{array}$ \\
\hline c) & Centro Tecnológica & $\begin{array}{l}\text { - Escola de Engenharia } \\
\text { - Escola de Agronomia }\end{array}$ \\
\hline d) & Centro de Ciências da Saúde & $\begin{array}{l}\text { - Faculdade de Medicina } \\
\text { - Faculdade de Odontologia } \\
\text { - Faculdade de Farmácia }\end{array}$ \\
\hline \multirow[t]{3}{*}{ e) } & $\begin{array}{l}\text { Centro de Estudos Sociais } \\
\text { Aplicados }\end{array}$ & - Faculdade de Direito \\
\hline & & $\begin{array}{l}\text { - Faculdade de Ciências Econômicas } \\
\text { e Administrativas }\end{array}$ \\
\hline & & - Faculdade de Educação \\
\hline
\end{tabular}

decreto de 1968 previa que, numa segunda fase da sua reestruturação, a UFC deveria desfazer os níveis intermediários, vinculando os departamentos diretamente aos respectivos centros, resultando na eliminação dos institutos. Com a lei da reforma - Lei $n^{\circ} 5.540 / 1968$ - a Universidade deu prosseguimento à sua reformulação acadêmica, consolidando o sistema departamental por meio do Decreto $n^{\circ} 71.882$ de 1973. A partir desse documento, a estrutura da Universidade estava oficialmente em consonância com a matriz ditada pelo projeto do Governo Federal, compondo-se por Reitoria (constituída pelos Órgãos Administrativos, de Coordenação, Suplementares e Auxiliares) e seis centros de 
conhecimentos afins (Centro de Ciências, Centro de Humanidades, Centro de Tecnologia, Centro de Ciências Agrárias, Centro de Ciências da Saúde e o Centro de Estudos Sociais Aplicados).

A nova estrutura acadêmica, introduzida com a Reforma e que também trouxe implicações na organização espacial, indicando a adoção do território único, demandou da Universidade a elaboração de planos e projetos visando proceder à reforma física no modelo de campus universitário. A história da UFC revela, entretanto, que o anseio de superar sua condição de origem, com a reunião de estabelecimentos dispersos na malha urbana da cidade, delineou tipologias espaciais que sempre estiveram envolvidas com a proposição de organização em base unificada, onde a Reforma foi efetivamente o principal patrocinador do intento de consolidação do campus único.

\subsection{O TERRITÓRIO DA UFC: configuração espacial tripartida}

A recém-criada universidade iniciou suas atividades nos imóveis das instituições que the deram origem. Foram encampados na forma da lei, passando a constituir seu patrimônio imobiliário, os prédios da Faculdade de Medicina, da Faculdade de Farmácia e Odontologia e o da Faculdade de Direito, situados na estrutura urbana da cidade e dois terrenos localizados em áreas mais afastadas, sendo um no sítio do Pici, Distrito de Antônio Bezerra, onde já funcionava a Escola de Agronomia e uma gleba de terra no Porangabuçu, doada ao instituto de Ensino Médico para a construção do hospital-escola da Faculdade de Medicina, onde funcionava com financiamento do Estado um pavilhão de isolamento (OLIVEIRA, 2005, p.42). As edificações caracterizavam-se pela filiação estilística que variava entre uma arquitetura de feições neoclássicas e estilo art déco, revestidas pelos ditames do ecletismo, assumido pelas elites como expressão de bom gosto até a primeira metade do século XX em Fortaleza (ver figura 5).

Com as unidades dispersas na malha urbana, a Universidade empreendeu num primeiro momento esforços de reuni-las gradativamente em uma mesma área, procurando consolidar sua base física unificada em zona urbana consolidada. A proposta diferia de outras instituições congêneres que escolheram glebas de grandes extensões para se instalar nos moldes de uma cidade universitária. Houve, entretanto, iniciativas para a aquisição de terrenos com a finalidade de construir essa tipologia espacial em terreno situado em subúrbio afastado. A opção, diante dos conflitos de interesses das corporações profissionais que the deram origem, foi inviabilizada, situação que determinou a consolidação das três 
áreas que moldaram seu território físico-espacial: Benfica, Pici e Porangabuçu. Atualmente, elas se encontram imersas no tecido urbano da cidade, conforme se constata na figura 6.0 contexto histórico que determinou a materialização de cada uma delas esclarece suas características urbanas e arquitetônicas.

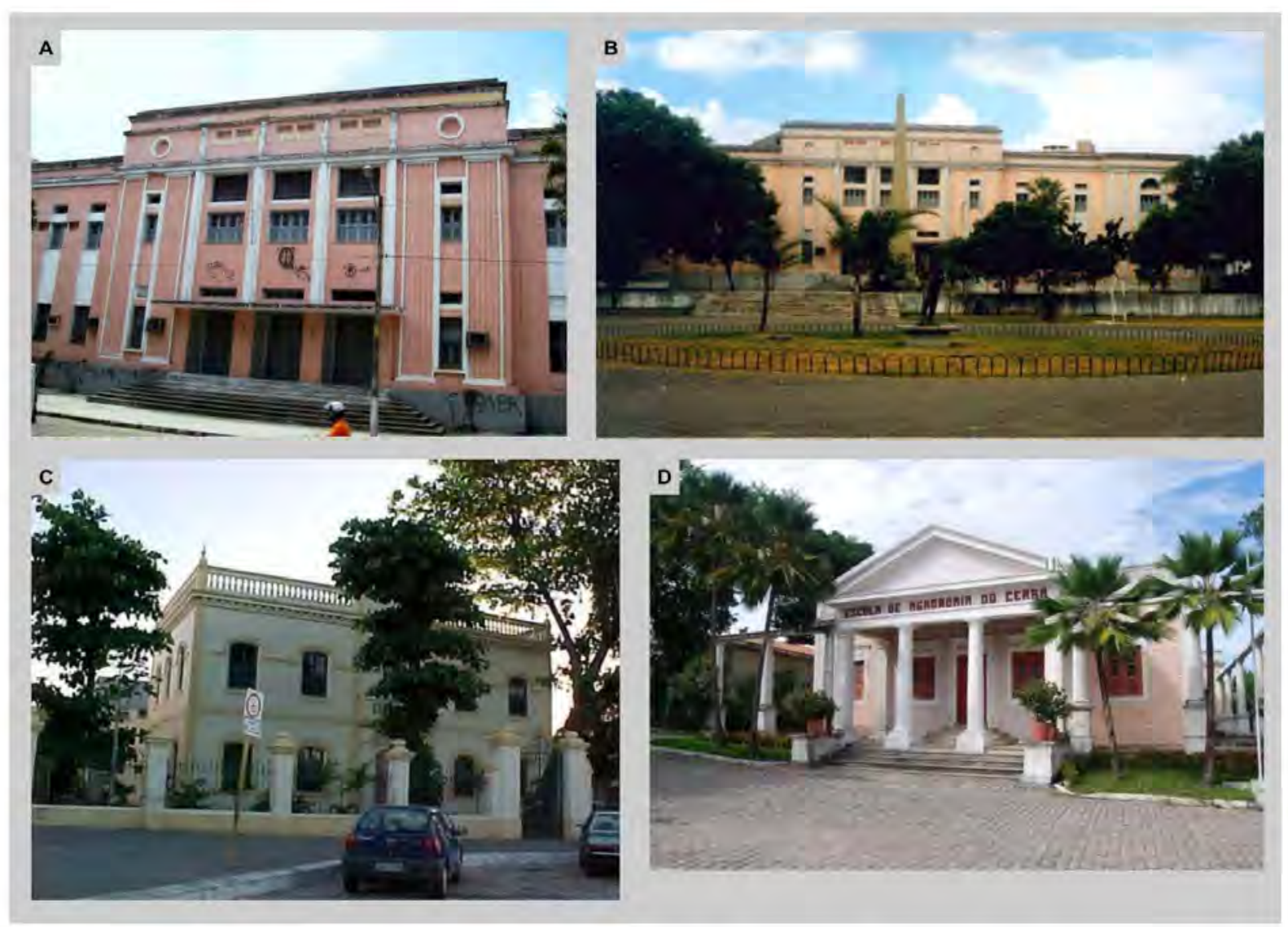

Figura 5: UFC - Primeiras edificações com predominância de construções ecléticas.

(A) Prédio da antiga Faculdade de Direito do Ceará - Década de 1980. Localizado próximo ao centro da cidade, foi incorporado ao patrimônio da UFC, onde permanece funcionando o Curso de Direito.

(Fonte: Disponível em <http://www. panoramio.com/photo/16928877> Acesso em: 06 mar. 2012)

(B) Faculdade de Direito da UFC - ano 2011. Vista pela Praça Clóvis Bevilacqua, localizada defronte à fachada principal do edifício.

(Fonte: disponivel em <http://www.direitoce.com.br/>. Acesso em: 06 mar. 2012)

(C) Prédio da antiga Faculdade de Medicina do Ceará - Década de 1980. Situado no centro da cidade, desde 1987 passou a sediar o IPHAN.

(Fonte: disponivel em < http://fortalezanobre.blogspot.com/2009/11/escola-normal-de-fortaleza.html>. Acesso em: 06 mar. 2012)

(D) Edifício da antiga Escola de Agronomia do Ceará. Situado no atual Campus do Pici, foi incorporado ao patrimônio da UFC, onde funciona a sede administrativa do Centro de Ciências Agrárias.

(Fonte: disponível em < http://www.panoramio.com/photo/27437361>. Acesso em: 06 mar. 2012). 


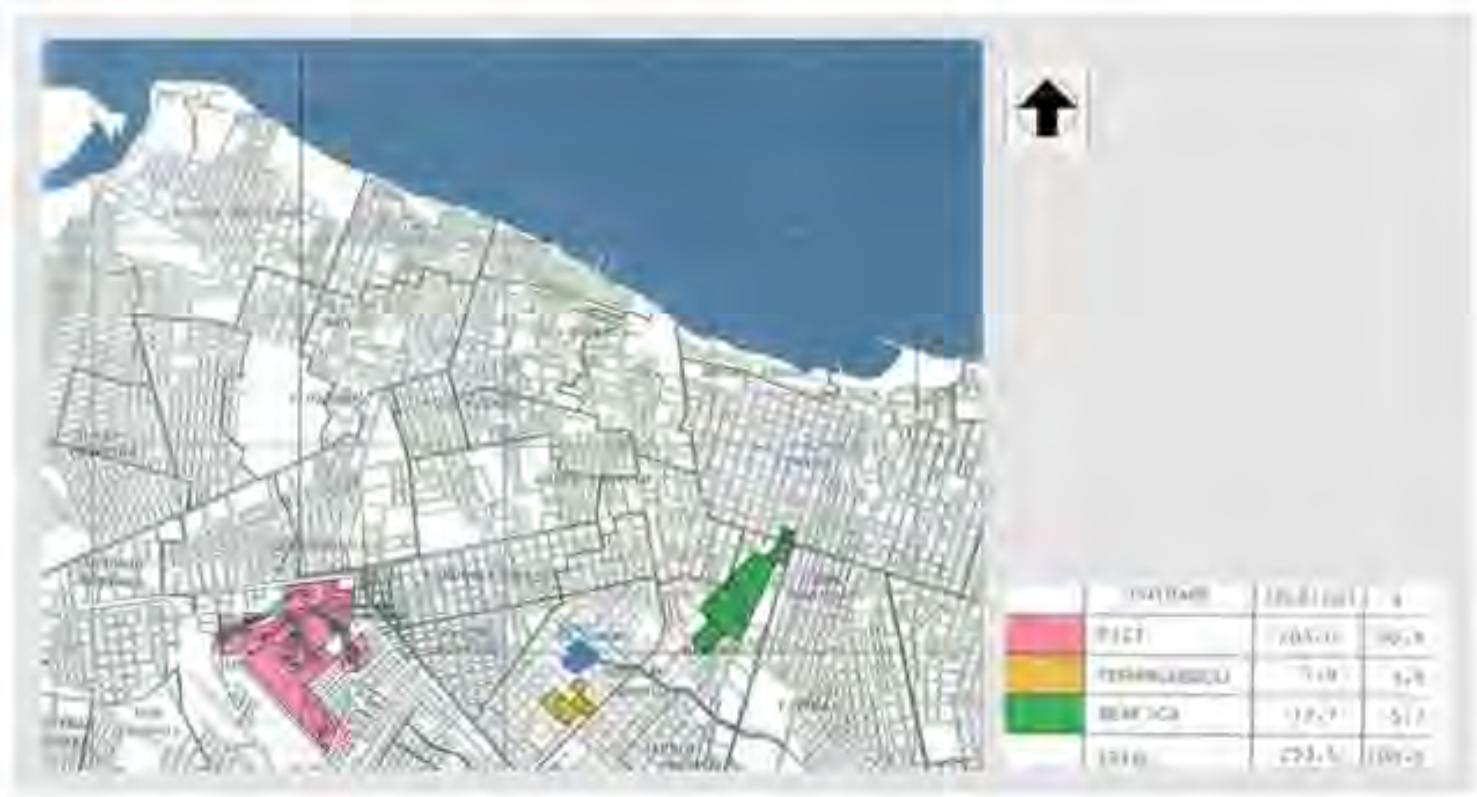

Figura 6: Mapa de Localizaçã̃o da UFC em Fortaleza.

Faculdade de Medicina implantada na gleba denominada Porangabuçu e na Administraçä́o Central que se instalou no bairro do Benfica, ao longo do eixo da Avenida Visconde de Cauipe, que logo passou a se chamar Avenida da Universidade.

(Fonte: UFC, 1996 apud CAMPÉLO, 2005, p.45)

\section{- O Benfica e sua produção urbano-arquitetônica}

A área do Benfica tem origem na atuaçẩo do primeiro reitorado que ali instalou a sede da Reitoria, dando inicio a uma tipologia espacial de conformação urbana. Tratada pela Administraçăo Central com imperiosa relevância, fato que pode ser evidenciado pela crescente aquisição de imóveis até meados de 1960 destinados ao funcionamento das atividades universitárias, tinha o propósito de materializar a universidade recém-criada.

Para dar sentido concreto à nova instituiçäo, o funcionamento da Reitoria foi uma das primeiras preocupaçổes, tanto que apenas quatro meses depois de instalada a Universidade, passou a ter sua sede próxima à Faculdade de Direito, ainda que provisória. O reitor Martins Filho, primeiro dirigente da nova instituição, assim explica:

Com efeito, consegui, mediante aluguel bem vantajoso, firmar um contrato de locação do imóvel tipo bangalô situado à Rua Senador Pompeu $n^{\circ}$. 1613 (na Praça da Bandeira, hoje, Clóvis Bevilacqua), a uns 100 metros do edifício da Faculdade de Direito. (MARTINS FILHO, 1999, p.41).

A importância, entretanto, de marcar a presença da jovem instituição no melo cultural da cidade e mesmo em sua paisagem urbana (CASTRO, 2004, p.191) culminou com a compra do imóvel que passou a sediar a unidade administrativa superior. Assim é que após um funcionamento provisório de seis meses à Rua Senador Pompeu, ela foi transferida para o 
bairro do Benfica, quando em abril de 1956, foi adquirida a propriedade onde hoje está instalada a Reitoria. Tratava-se da residência de José Gentil Alves de Carvalho, figura destacada na sociedade loca ${ }^{20}$, conhecida como o Solar da Família Gentil (ver figura 7 ).

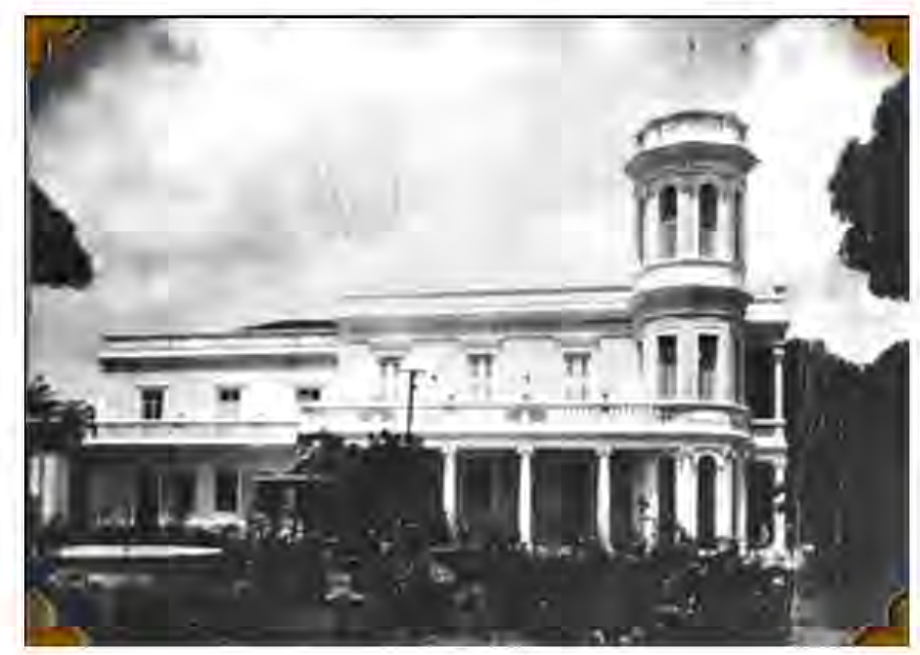

Figura 7: UFC - Palacete Gentil - Período da instalação da Reitoria em 1956.

Edifício de linguagem arquitetônica eclética.

(Fonte: Disponivel em < http://fortalezan obre.blogspot.com/2010/04/gentilandiapalacetes-sobrados-e.html Acesso em: 06 mar. 2012)

Em ambas as realizações, vale apontar que a intenção era a de se instalar no tecido urbano. No primeiro caso, vizinho à Faculdade de Direito, e no segundo, a cerca de um quilômetro dessa unidade, que nesse caso, conforme Oliveira (2005, p.43-44), propiciava um desejável distanciamento do centro da cidade onde se concentravam as outras unidades, situação que permitiria a afirmação da autoridade da Reitoria, transformando-se no centro do poder acadêmico e conferindo materialidade e identidade à instituição. Além do que a localização oferecia facilidade de acesso e disponibilidade de terreno para futuras ampliações.

Com situação estratégica na estrutura urbana, correspondendo ao cruzamento de importantes eixos de ligação norte/sul - Avenida da Universidade - e leste/oeste - Avenida 13 de Maio - da cidade, a localização da Reitoria permitia estabelecer relações com os demais setores da cidade, bem como com as duas outras áreas de unidades acadêmicas estabelecidas no Porangabuçu e no Pici.

Importante destacar que o Benfica foi considerado, no primeiro quartel do século $X X$, um dos bairros mais elegantes de Fortaleza, preferido pelas classes dominantes. Conformava uma ocupação predominante em chácaras de terrenos generosos, que passaram a representar símbolo de status social e econômico (ver figura 8). Embora no período de

\footnotetext{
${ }^{20}$ O imóvel havia sido residência do empresário, João Gentil, entre o final do século XIX até início dos anos 1940, quando veio a falecer. A família Gentil destacava-se pela pujança econômica advinda do comércio do algodão e posteriomente de negócios bancários, comércio de terra e empreendimentos im obiliários.
} 
aquisição e instalação da sede definitiva da Reitoria, o mesmo já estivesse em declínio com o deslocamento das elites para o bairro da Aldeota, ainda permanecia a carga simbólica de poder e ostentação no imaginário da sociedade local, situação que contribuía para a escolha daquele endereço. A partir de então, gradativamente no decorrer dos anos, importantes órgãos e unidades acadêmicas foram sendo instalados ao redor da Reitoria, consolidando a estrutura administrativa e acadêmica naquela área.

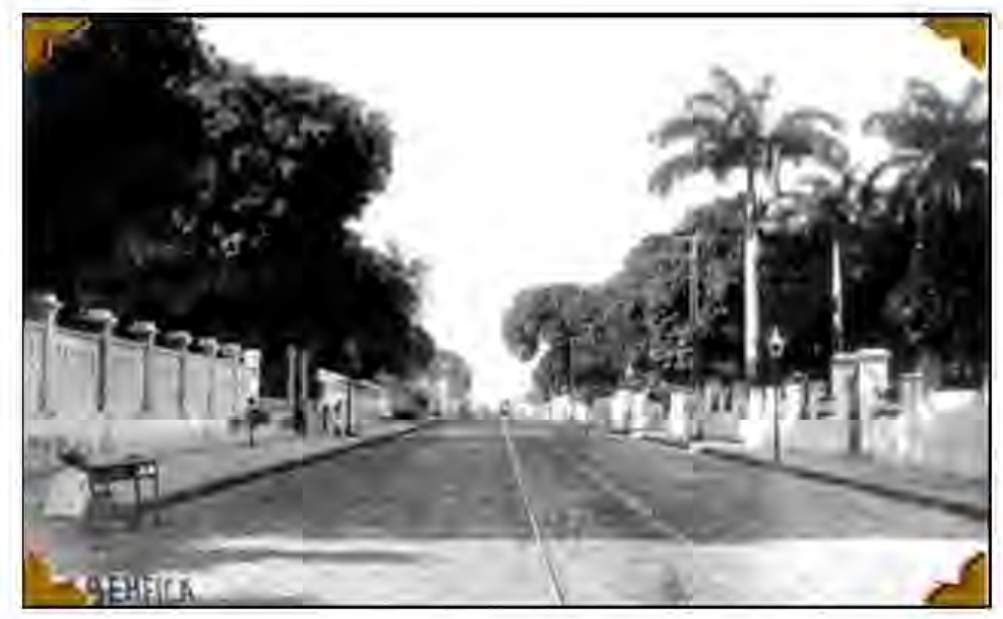

Figura 8: UFC - Bairro do Benfica.

Vista da Avenida da Universidade, então Avenida Visconde de Cauípe - anos1930 (Foto anterior à instalação da Reitoria). A quadra à direita foi adquirida para sediar a Reitoria. A paisagem era dominada pela densa arborização das chácaras.

(Fonte: CASTRO, 1997, n.p.)

\section{- Quadra - unidade territorial da configuração urbanística}

O território universitário que passou a se configurar não foi, entretanto, resultado de uma ação planejada. O processo de ocupação foi se dando pela compra de imóveis disponíveis para a venda. Posteriormente, a Universidade passou a definir suas demandas, selecionando aqueles que the interessava comprar e gradativamente conformar o território da Universidade. Oliveira $(2005, \mathrm{p} .92)$ analisa que o urbanismo que moldou a estrutura física da Instituição naquela área foi movido pelo propósito de integrar e promover o convívio da comunidade que ali se instalava. A partir de então um intenso processo de demolição, construção e reformas passou a ser executado: as edificações que serviam às suas necessidades foram preservadas, adequadas e ampliadas, enquanto que aquelas que não se prestavam às novas funçōes foram substituídas por outras. Na estrutura fundiária, o lote passou a ser trocado pela quadra como unidade territorial básica. Eliminando os muros entre eles, os lotes foram reagrupados, criando glebas compativeis com as dimensões das novas demandas sem o risco de fracionamento espacial ou do isolamento das unidades 
(OLIVEIRA, 2005, p.92), condição que contrariava o sentido de unidade que se pretendia construir (ver figura 9). Nas palavras de Oliveira, a

[...] quadra aberta ao livre trânsito das pessoas perde o sentido de barreira que the é inerente, permitindo a apropriação pública deste espaço e estimulando, em quem por ali circula, o sentimento de inclusão e pertenciamento, fazendo com que universidade e cidade se integrem numa simbiose perfeita. Com seus espaços abertos ocupados pela presença massiva de seus equipamentos e a pela agitação da vida estudantil, e animados pela realização de grandes eventos, o território da Universidade, no Benfica, passa a ser identificado como um local de todos, universitários ou não, transformando-se no grande espaço cívico da cidade. [...] Seria configurada mediante elementos estruturadores da vida universitária, com o core estabelecido na Reitoria, o espaço estudantil no Centro dos Estudantes Universitários e Residências Estudantis, as unidades de ensino e pesquisa e os diversos equipamentos culturais espalhados por toda área, complementados pela implantação de um setor esportivo com a futura incorporação do Estádio Presidente Vargas [Primeiro estádio oficial de futebol em Fortaleza] (OLIVEIRA, 1982, p.92).

O resultado positivo demonstrado com a expansão paulatina no Benfica por unidades acadêmicas e equipamentos culturais ensejou a ideia de ali se estabelecer o território definitivo da UFC. Com esse propósito, a Administração Superior realizou estudos para a desapropriação de uma extensa área, tendo como eixo de ocupação a Avenida da Universidade (eixo norte/sul da cidade), que formaria um corredor cultural, iniciado na Faculdade de Direito e - passando pela Reitoria - se estenderia até o canal do Jardim América, próximo ao Porangabuçu, onde estava sendo implantado o setor da Medicina. Ficaria limitada em um dos lados pela Avenida Carapinima e no outro pelas ruas Senador Pompeu e Marechal Deodoro. A área a ser desapropriada abrangeria quase todas as suas unidades universitárias, com exceção da Escola de Agronomia, funcionando no Pici. A proposta previa uma desocupação total dos limites mencionados, eliminando usos e atividades que não fizessem parte da Universidade. $O$ arquiteto Oliveira analisa que a proposta não caracterizava uma tipologia de bairro universitário, à moda da tradição francesa, mas um território exclusivo, monofuncional, tendo a Universidade, como usuária única do espaço exercendo, o domínio completo sobre ele (OLIVEIRA, 2005, p.93). Esta concepção de território universitário inserido na malha urbana, servindo-se da infraestrutura, aberto e permeável à comunidade contrapunha-se ao modelo de cidade universitária apartada do centro urbano, que, conforme já mencionado, se estabeleceu nas universidades brasileiras (ver figuras 10 e 11). 


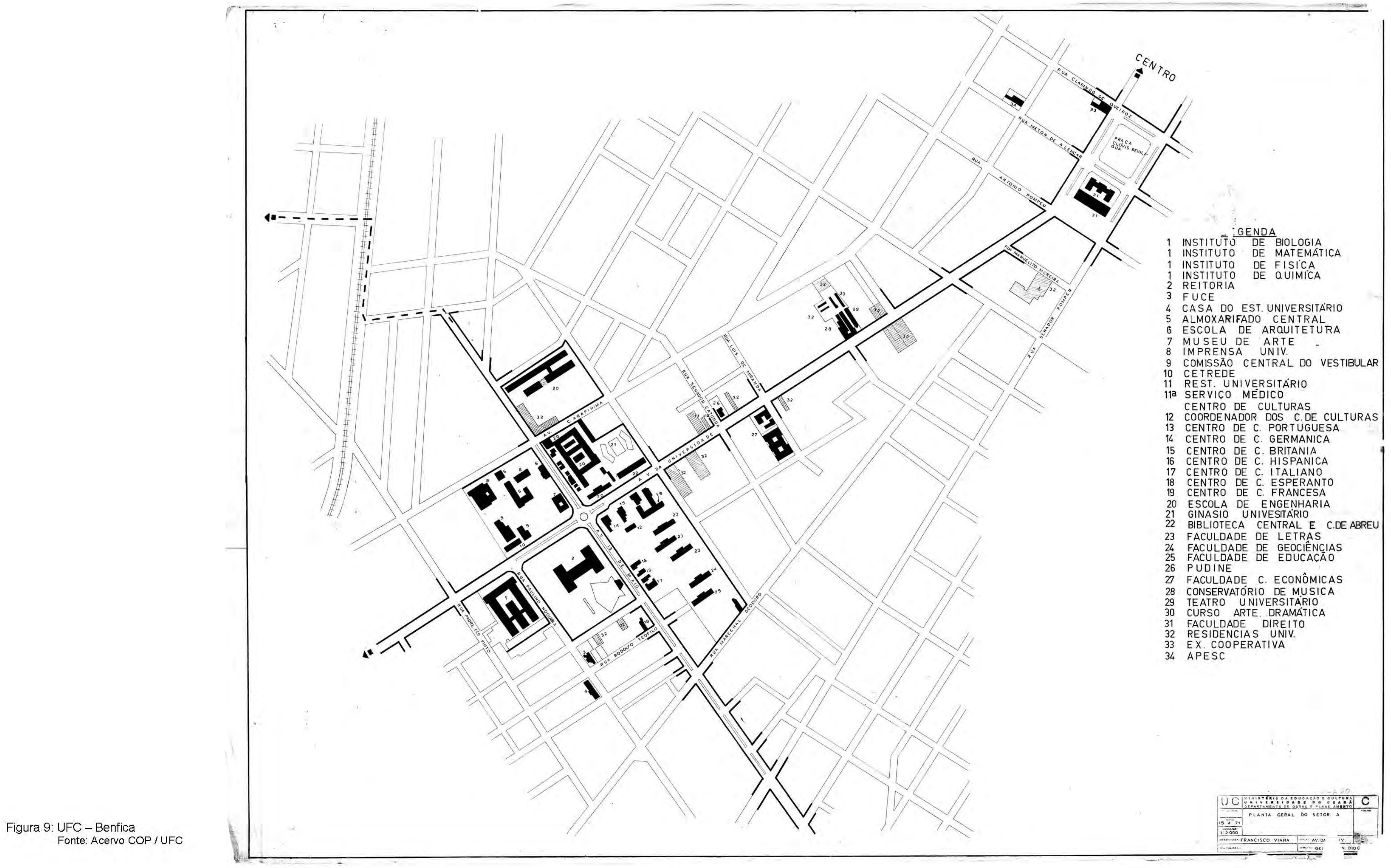




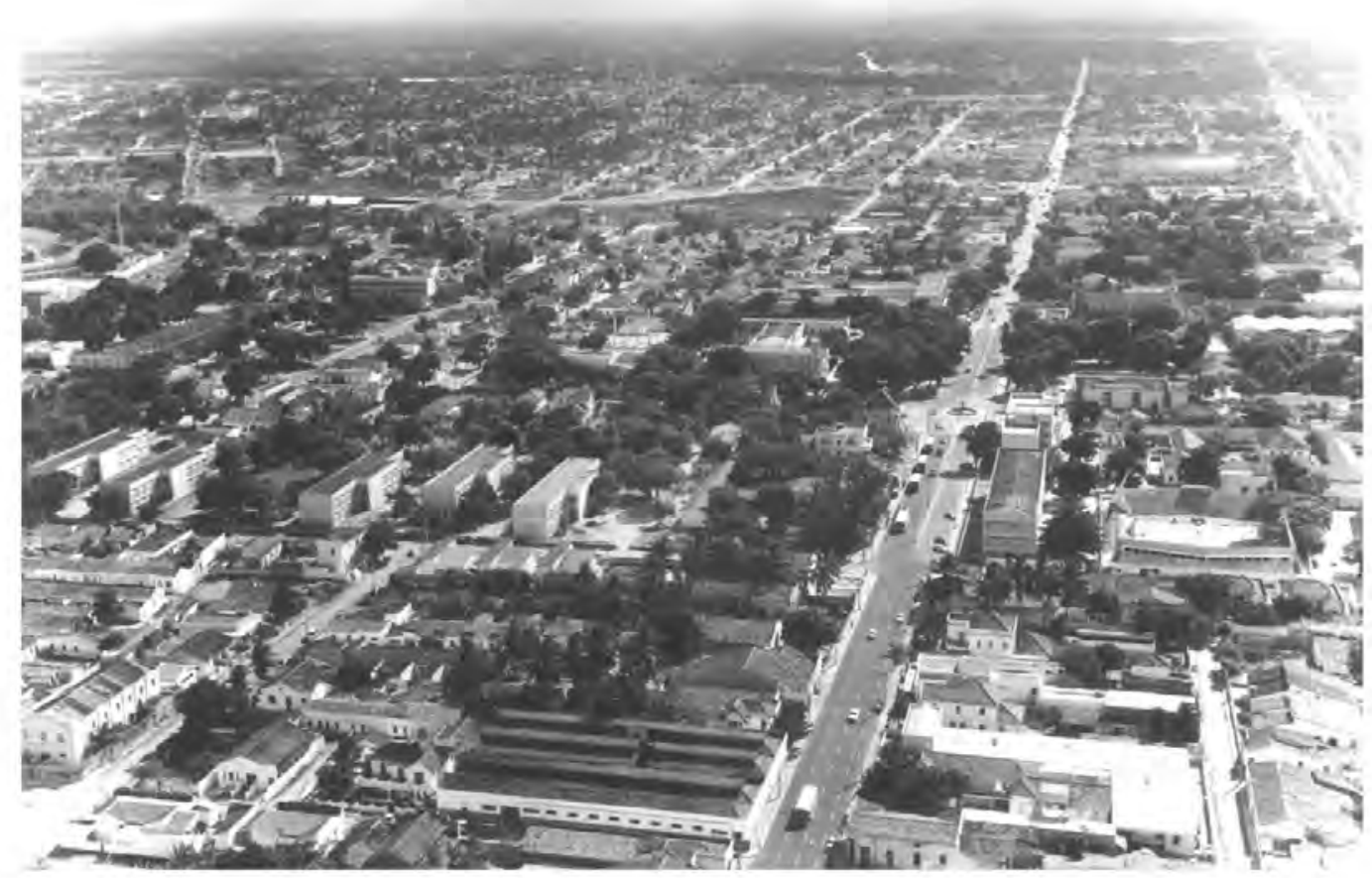

Figura 10: UFC - Vista do conjunto edificado do Benfica - 1971.

A ocupação se deu ao longo da Avenida da Universidade - via de ligação norte / sul da cidade. À esquerda, destacam-se os blocos da Faculdade de Filosofia Ciências e Letras. (Fonte: Acervo COP / UFC)

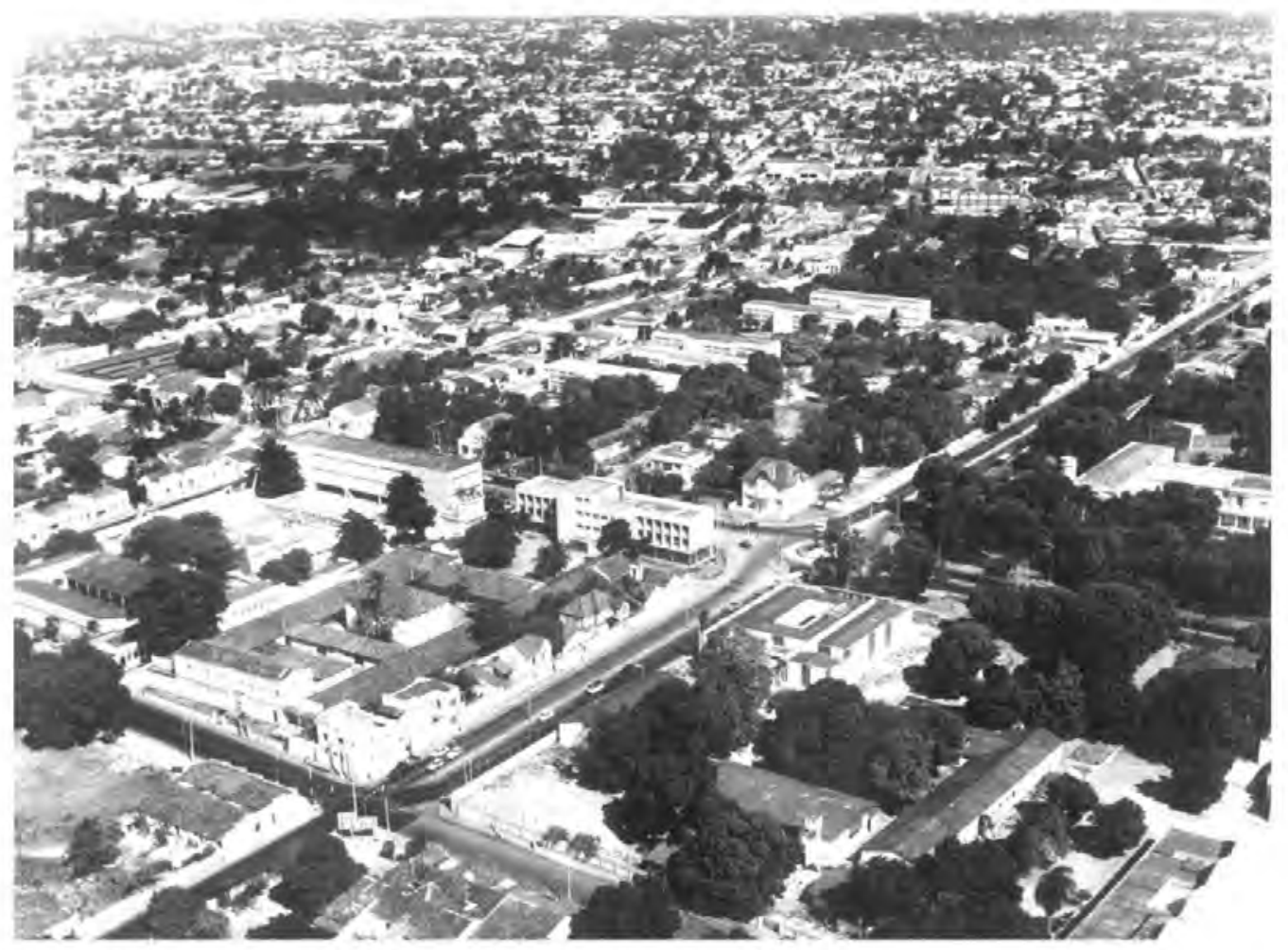

Figura 11: UFC - Vista do conjunto edificado do Benfica - 1971.

Destaca-se no centro da foto o cruzamento das avenidas 13 de maio - eixo de ligação leste / oeste da cidade - com a da Universidade. $\mathrm{Na}$ confluência das avenidas formam-se quatro quadras de ocupação da UFC: na quadra superior, à direita está a Reitoria, e à esquerda, o conjunto da Faculdade de Filosofia Ciências e Letras e as Casas de Cultura; na quadra inferior, à direita está implantado o Museu de Arte, e à esquerda, a Escola de Engenharia. (Fonte: Acervo COP / UFC) 
O estudo teve a participação do arquiteto cearense, José Liberal de Castro, que pertenceu aos quadros da UFC. Segundo o arquiteto cearense Neudson Braga, que também pertenceu aos quadros da Universidade, quando iniciado o planejamento de desapropriação da área demandada constatou-se, entretanto sua inviabilidade, tendo em vista que seria necessário desalojar um contingente populacional similar naquela época ao da cidade cearense de Iguatu (Informação verbal ${ }^{21}$ ). Além disso, os lotes eram de pequenas dimensões, tendo alguns remanescentes com palacetes como aquele no qual havia se instalado a Reitoria, fatores que tornavam oneroso o processo de aquisição. A proposta foi descartada após as constatações mencionadas, fato que, entretanto não impediu uma produção edilícia de importante valor arquitetônico no processo de ocupação do Benfica.

Para Oliveira (2005, p.72), a construção do território do Benfica foi regida por dois momentos distintos: um presidido pela necessidade de atender às demandas imediatas $e$ outro pelo desejo deliberado de ali se estabelecer, circunscrevendo-se a um espaço definido, para firmar sua identidade hegemônica como local de produção e transmissão do saber, consolidando-se como espaço legitimador da ciência e da cultura.

\section{- A obra de referências moderna}

O panorama arquitetônico que se desenvolveu manifestava os fundamentos do modernismo brasileiro praticado nas principais capitais do país. Essa produção foi favorecida pela atuação de jovens arquitetos nascidos no Ceará e que após diplomados em outros estados retornaram à terra natal a partir de meados da década de 1950 , introduzindo o legado do traço moderno que se contrapunha aos ditames da arquitetura eclética que ainda persistia em se manter na cidade de Fortaleza. Sobre esse aspecto o arquiteto cearense Liberal de Castro aferiu que $o$ quadro de ausência qualitativa projetual e construtiva era mantido pela atuação de leigos, inabilitados para desenvolver qualquer formulação teórica. Nas palavras do arquiteto,

[...] é possível identificar umas poucas obras, pelo menos até 1945 , com características de um modernismo arquitetônico local, sem, entretanto, evidenciar preocupação permanente com as inovações, de modo que se chega a supor que os projetistas talvez tentassem fazer o moderno como uma variante do ecletismo (CASTRO,1982, p.12).

Gradativamente a arquitetura de linhas modernas vai ganhando espaço, com a colaboração dos profissionais que haviam assimilado o novo repertório formal e projetual (CAMPÊLO,

${ }^{21}$ Entrevista concedida pelo arquiteto Neudson Braga em Fortaleza, 27 de abril de 2004. O texto é parte da Dissertação de Mestrado de nossa autoria (CAMPÉLO, 2005, p.288). 
2005 , p.33-34). A presença dos pilotis, da planta livre, da modulação estrutural que marca a fachada, diferenciando-se das vedações, a volumetria funcional e a adoção de elementos para proteção solar tais como o brise-soleil e o manuseio do combogó e da cor são soluções que marcaram a produção moderna com clara filiação à Escola Carioca.

No Benfica, o prédio da Escola de Engenharia e a concha acústica com auditório ao ar livre são dois dos primeiros testemunhos do novo cenário arquitetônico iniciado ainda na década de 1950 e que se entendeu aos anos sessenta.

\section{- Escola de Engenharia (1957)}

A Escola de Engenharia funcionou inicialmente em imóvel alugado, transferindo-se em 1957 para sede própria construída na quadra diagonalmente oposta à Reitoria, correspondendo à confluência das avenidas 13 de Maio e da Universidade, tendo sido a primeira das novas faculdades instalada no Benfica. A localização contribuiu para a transformação do entorno da Reitoria em área predominantemente universitária.

O edifício de três pavimentos foi projetado pelo engenheiro cearense Luciano Pamplona e o partido arquitetônico evidencia a volumetria funcional que destaca a caixa prismática retangular com dimensões de $50,30 \mathrm{~m} \times 9,50 \mathrm{~m}$, destinada às atividades acadêmicas, apoiada sobre pilotis e justaposta à caixa da escada e sanitários pela fachada de fundo. Confere aos pilotis a função de espaço de convivência, concebido como uma ampla área aberta, onde compartilham os pilares de geometria cilíndrica e uma alvenaria de combogó em forma curvilínea, que desempenha o papel de proteção à via. A fachada principal é marcada pelas esquadrias de alumínio e vidro modulada a cada $2,50 \mathrm{~m}$ em composição com o revestimento de pastilha cerâmica, que foi adotada no conjunto moderno da UFC (ver figura 12).

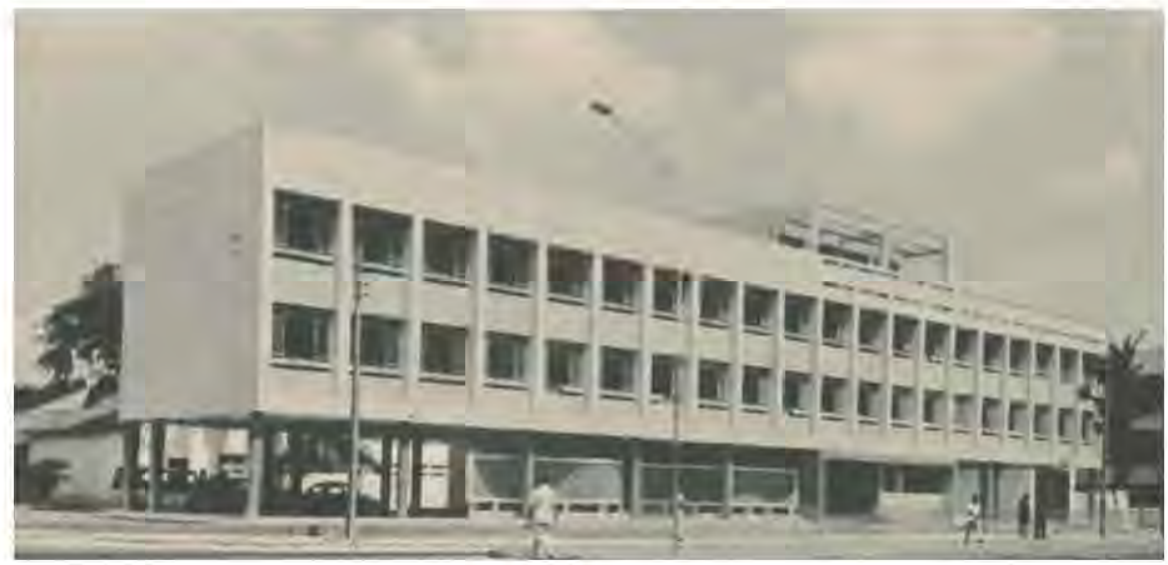

Figura 12: UFC - Escola de Engenharia - Década de 1960.

Vista do edifício pela fachada principal voltada para a Avenida da Universidade. (Fonte: UFC, 1966, n.p.) 
- Concha Acústica (1959)

A Concha Acústica com auditório ao ar livre, inaugurada em 1959, foi construída nos jardins da Reitoria. O projeto, de autoria dos arquitetos Fábio Kok de Sá Moreira e Ruth Kok de Sá Moreira, diplomados pela USP em 1958, resultou de concurso realizado pela FAU-USP. A obra de referências modernistas apresentava um programa composto pelas arquibancadas, com capacidade para 2.500 pessoas, palco e bloco de serviços. $O$ palco dividido em dois pavimentos abriga no térreo os camarins com banheiros e local para piano. No subsolo, localizam-se o depósito e a casa de bombas. A arquibancada se distribui em quatro módulos de bancos, divididos pelas circulações, tendo ao centro o principal corredor de acesso. As arquibancadas são ladeadas por sanitários no lado leste e por sanitários e cantina no lado oeste.

A forma arquitetônica se destaca pela estrutura em concreto armado, correspondendo à extensa laje plana inclinada sobre o palco, que liga as vigas das extremidades com a solução de pórtico engastado e desempenha a função de reflexão e difusão do som (ver figura 13).

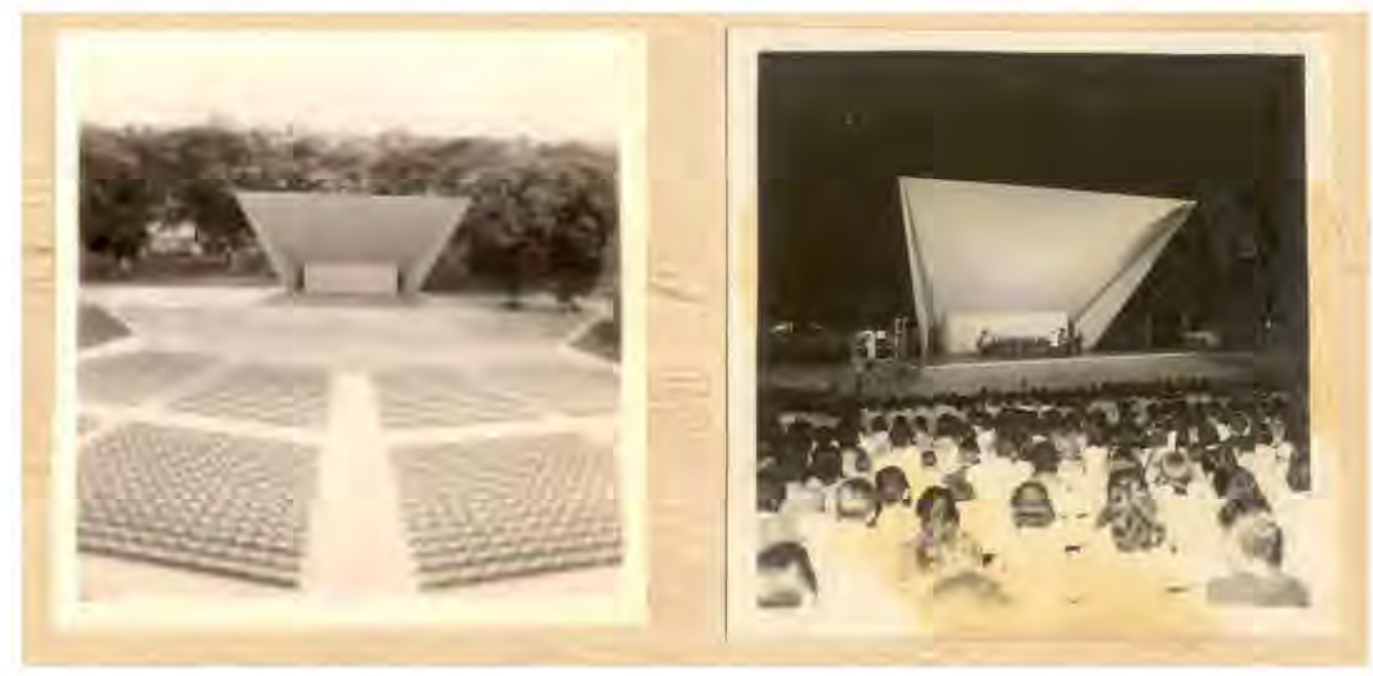

Figura 13: Concha Acústica com auditório ao ar livre. (Fonte: Acervo MAUC/UFC)

A produção de referências modernas do Benfica prosseguiu na década de 1960 , tendo agora a participação dos arquitetos cearenses José Liberal de Castro, Neudson Braga e Ivan Brito, os dois primeiros diplomados no Rio de Janeiro e o último no Recife, que vieram trabalhar no recém-criado Departamento de Obras e Planejamento da UFC, contribuindo para o patrimônio edificado de reconhecido valor modernista. 
Fato relevante que favoreceu a disseminação da nova arquitetura foi a criação, em fins de 1964, da Escola de Arquitetura da UFC, instalada no ano seguinte em imóvel existente na quadra defronte à Reitoria. Teve como primeiro diretor o arquiteto paulista Hélio Duarte, professor da Universidade de São Paulo, que contou com a colaboração dos profissionais pertencentes ao Departamento de Obras e Planejamento [dentre esses, os arquitetos cearenses acima mencionados]. São exemplares desse período, dentre outras, as instalações construídas para o Departamento de Cultura, para a Faculdade de Filosofia Ciências e Letras, para os Institutos Básicos - de Química, Matemática e Física, para o Museu de Arte, para a Residência Universitária e para a Imprensa Universitária.

\section{- Departamento de Cultura da UFC (1960)}

O prédio destinado originalmente ao Departamento de Cultura foi construído em 1960 na quadra defronte à Reitoria com a fachada principal voltada para a Avenida da Universidade. O projeto teve a autoria dos arquitetos Neudson Braga e Liberal de Castro que conceberam um edifício de dois pavimentos com planta livre de configuração retangular e dimensões de $30,60 \mathrm{~m} \times 8,85 \mathrm{~m}$, que se desenvolve em conformidade com o vão estrutural de $3,35 \mathrm{~m}$, evidenciando a busca da racionalização como diretriz operativa.

A forma arquitetônica destaca o módulo estrutural articulado com a esquadria de madeira e venezianas móveis - tipologias de fabricação local - arrematada pela platibanda da coberta que confere horizontalidade à volumetria de linhas retas do pavimento superior. Participam da composição, a marquise de laje plana que desempenha a função de linguagem de acesso ao saguão do edifício e os pilares de geometria cilíndrica destacados da alvenaria de vedação no pavimento térreo (ver figura 14).

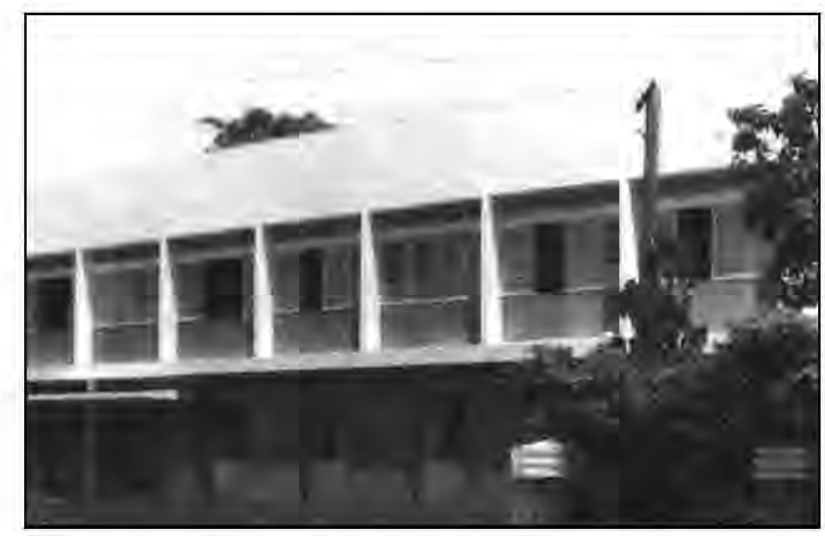

Figura 14: UFC - Antigo Departamento de Cultura - Ano 1967. A fachada principal voltada para a Avenida da Universidade é marcada pelo ritmo modulado da esquadria de madeira. (Fonte: DUARTE et al, 1996, 77) 
Castro (2004, p.209) esclarece que o saguão dividia o pavimento térreo em dois setores: à esquerda, estava o salão destinado à exposição de livros editados pela Imprensa Universitária ou recebidos de outras editoras, como a montagem de pequenas mostras de obras de arte, além de servir como palco para atos culturais de frequência restrita, cuja vedação frontal se dava pelo pano da esquadria de alumínio e vidro de piso a laje, conferindo transparência ao ambiente (ver figura 15). À direita do saguão, vedado com alvenaria de tijolo, o ambiente podia ser repartido por divisórias removíveis, proposto para atendimento ao público (CASTRO, 2004, p.209). A composição formal harmoniosa da arquitetura proposta testemunhava a filiação dos arquitetos aos cânones modernistas, que deram base às suas formações profissionais, porém buscando inserir a nova produção nos procedimentos construtivos da região.

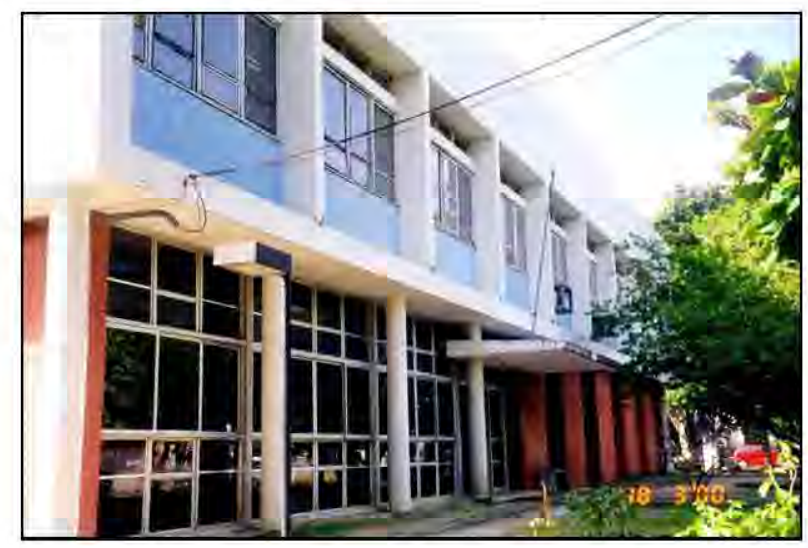

Figura 15: UFC - Antigo Departamento de Cultura - Ano 2000.

Vista da fachada principal com detalhe dos pilares, da marquise e do antigo salão destinado à exposição de livros com vedação em esquadria de alumínio e vidro. A pastilha cerâmica em cores (azul e branca) e o revestimento cerâmico vermelho compõem a forma arquitetônica de referências da Escola Carioca. As esquadrias de madeira foram substituídas por tipologias de alumínio e vidro.

(Fonte: Acervo COP / UFC)

\section{- Faculdade de Filosofia Ciências e Letras (1965)}

No mesmo ano de 1960, a UFC procurando romper com a estrutura universitária fundamentada na justaposição de instituições isoladas propôs a criação da Faculdade de Filosofia, Ciências e Letras como núcleo central de uma nova concepção estrutural de universidade, desvinculando-se da tradição herdada.

Instalada na quadra vizinha à Reitoria, em imóveis existentes que ali se estabeleceram no início do segundo quartel do século $X X$, logo a nova faculdade teve necessidade de mais 
espaço que resultou na construção de outros prédios, os quais foram erguidos na mesma quadra. Os três primeiros, dos cinco que seriam ali construídos, foram inaugurados em 1965 e o projeto teve a autoria do arquiteto Neudson Braga, que adotou o partido de princípio funcional-racionalista.

O edifício de dois pavimentos, concebido com a planta livre obedecendo à modulação de $1,25 \mathrm{~m} \times 1,25 \mathrm{~m}$, é constituído pelo conjunto volumétrico da caixa prismática retangular, em forma de barra, destinada às atividades didáticas, e por um volume justaposto que abriga os sanitários, copa e almoxarifado, interligados pela circulação longitudinal (ver projeto de arquitetura da figura $16 a$ à $16 \mathrm{~d}$ ). Com essa separação, o partido favorece a flexibilidade na organização espacial do corpo didático.

Destaca-se na fachada do corpo principal a estrutura modulada de $2,50 \mathrm{~m}$ que rege a padronização das esquadrias de madeira com venezianas móveis e vidro fixo na faixa superior - uma tipologia de fabricação própria da região largamente empregada em Fortaleza - a solução permite o controle da radiação solar direta sem impedir a circulação do ar. A composição arquitetônica é complementada pelo revestimento em pastilha cerâmica de cores claras, também de fabricação local, que contribui para o partido de formas singelas e de intenções racionalistas (ver figura 17).

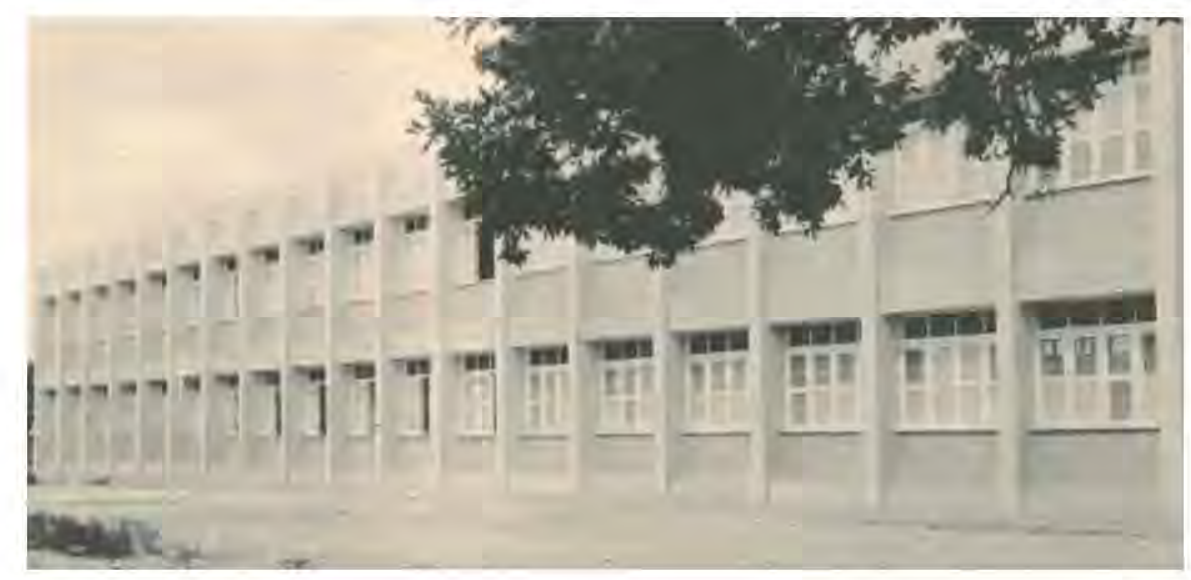

Figura 17: UFC - Faculdade de Filosofia Ciências e Letras (Fonte: UFC, 1966) 

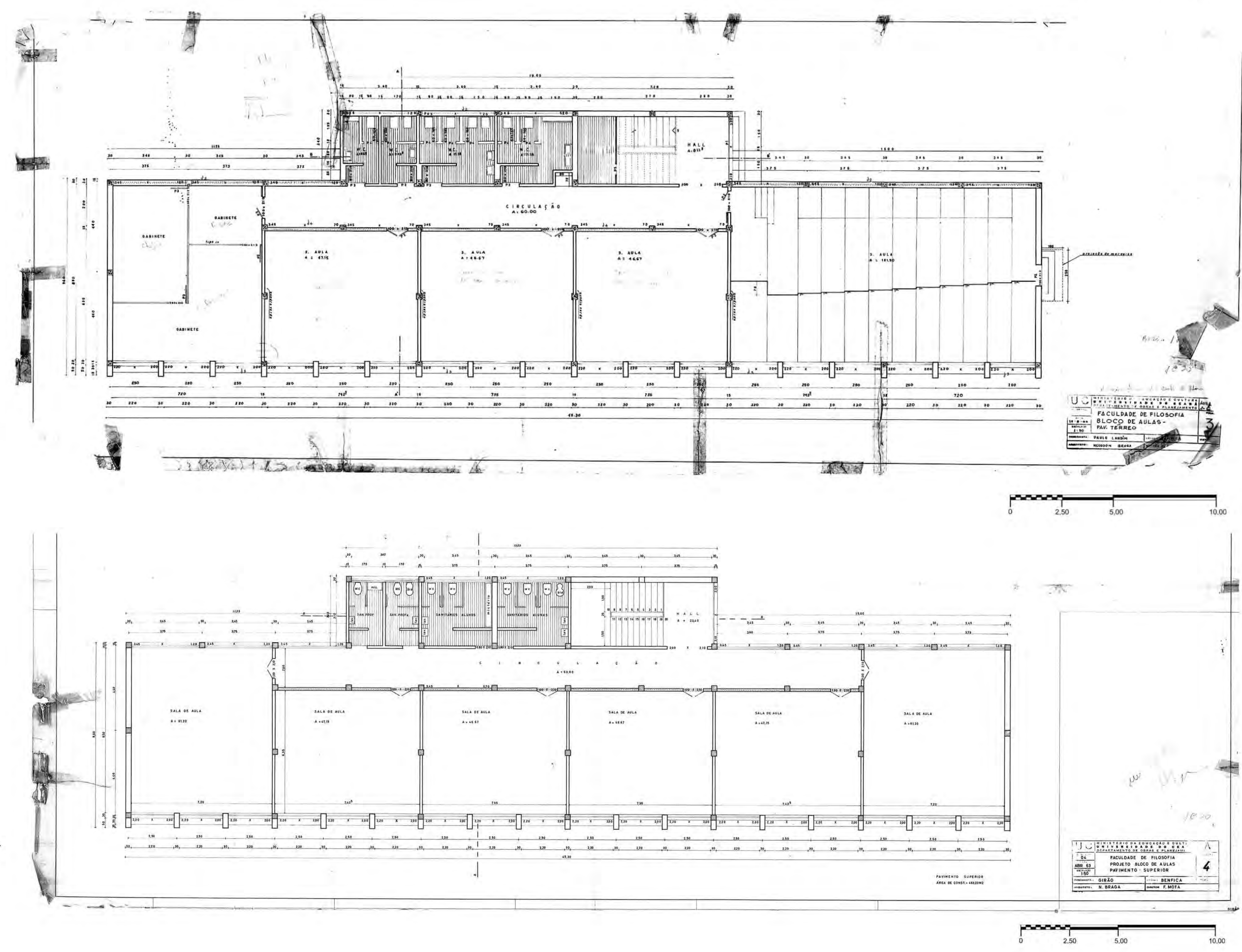

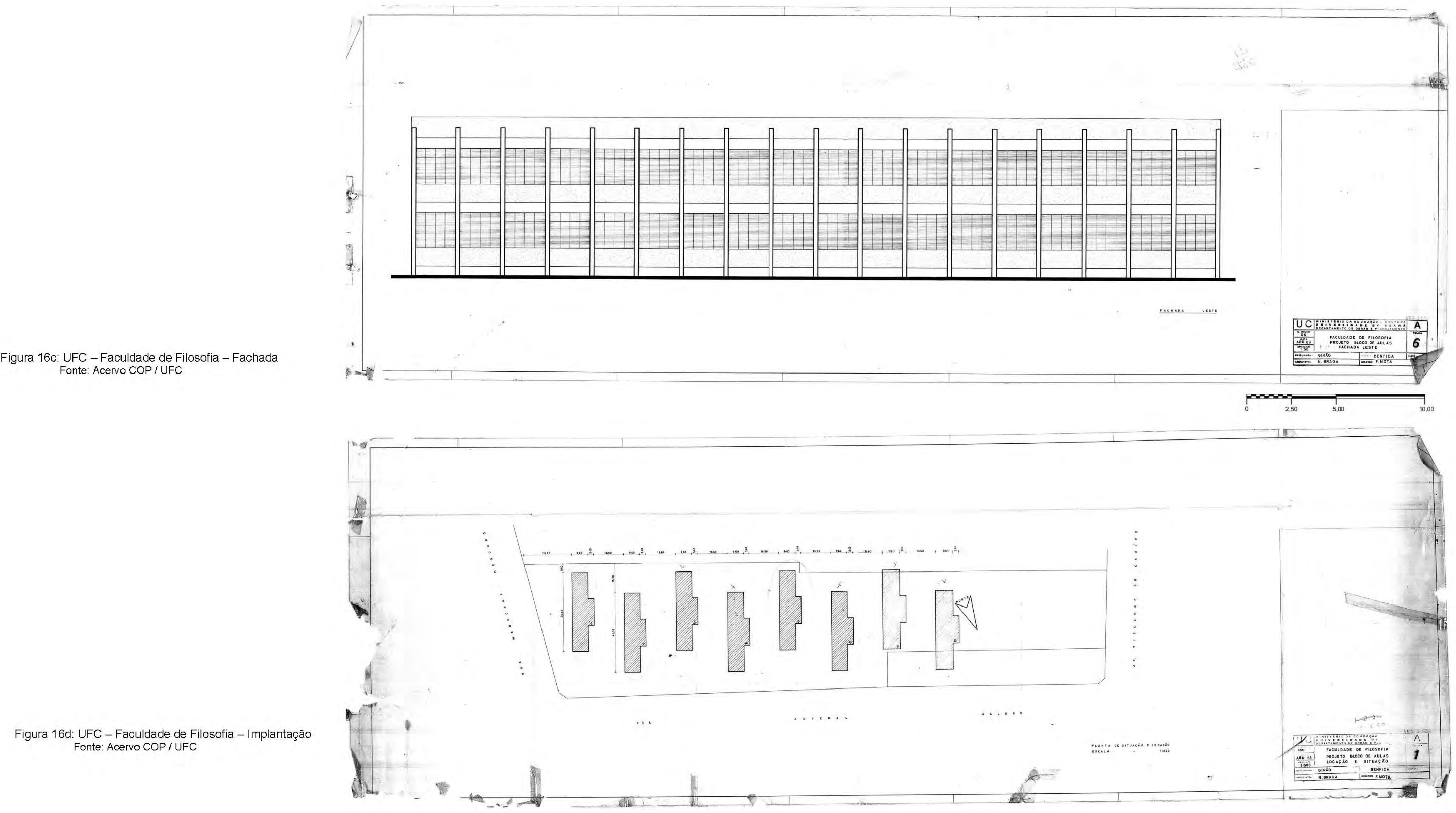
Parte 2 - Universidade Federal do Ceară 
Na implantação, Braga rompeu com o modelo tradicional do lote urbano, segundo o qual a edificação é voltada para a via de acesso, e implanta o conjunto de edifícios da Faculdade de Filosofia, Ciências e Letras seguindo o modelo urbanístico da quadra livre com os acessos orientados para o interior da mesma, eliminando assim a concepção de frente e fundos. Dispondo os blocos padrões paralelamente, com recuos de dimensões alternadas em relação ao limite do terreno, o arquiteto visava propiciar o melhor aproveitamento da ventilação natural (ver figura 18).

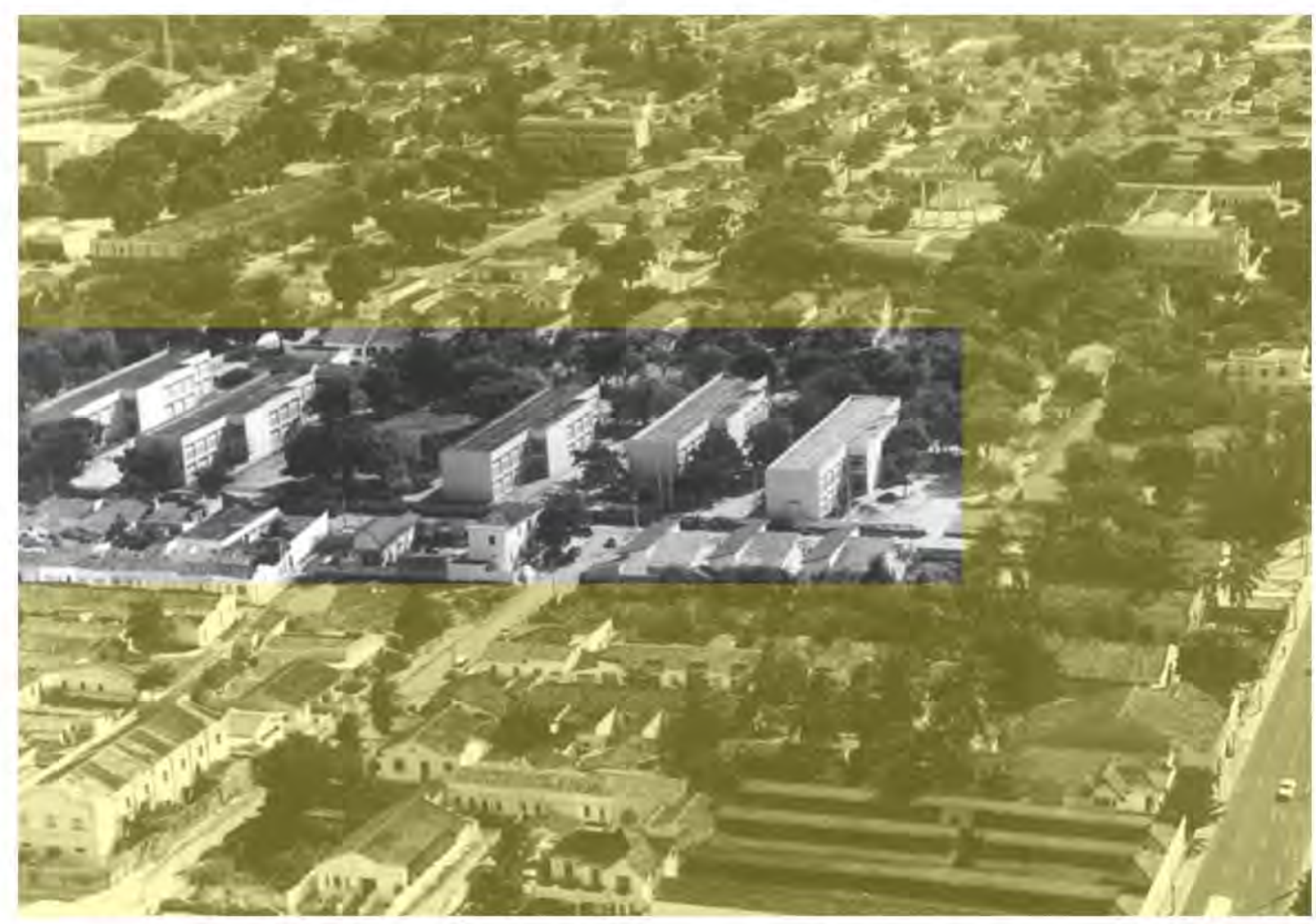

Figura 18: UFC - Conjunto arquitetônico da Faculdade de Filosofia Ciências e Letras - Anos 1970. A implantação dos cinco blocos adotou o modelo da quadra livre.

(Fonte: Acervo COP/UFC apud CAMPÊLO, 2005, p.89)

A tipologia arquitetônica de linguagem estilística moderna foi reproduzida em outras unidades acadêmicas no decorrer da década seguinte, empregada por Braga na área do Pici, que veio a constituir o conjunto de edifícios destinados ao Centro de Tecnologia e ao Centro de Ciências Agrárias, atendendo ao projeto da Reforma de 1968, conforme será apresentado no decorrer do capítulo. 
- Museu de Arte da UFC - MAUC (1965)

O Museu de Arte da UFC, criado em 1961, passou a funcionar provisoriamente em galpões localizados na quadra defronte à Reitoria. Quatro anos depois, foi construída a sede definitiva no mesmo local, inaugurada em 24 de junho de 1965, com projeto dos arquitetos Neudson Braga e Liberal de Castro. Com localização privilegiada, na confluência das avenidas 13 de maio e da Universidade [situação similar à da Escola de Engenharia], o edifício de pavimento térreo evidencia suas referências modernistas, com a volumetria de linhas retas e incorporando à fachada principal um painel em pastilha cerâmica do artista plástico cearense Zenon Barreto, uma clara filiação ao repertório da Escola Carioca (ver figura 19). O espaço interior foi contemplado com um jardim ao ar livre, que permite a exaustão do ar e a penetração da luz natural, enriquecendo os ambientes com espaços alternados de luz e sombra - um percurso agradável às obras de arte da UFC.

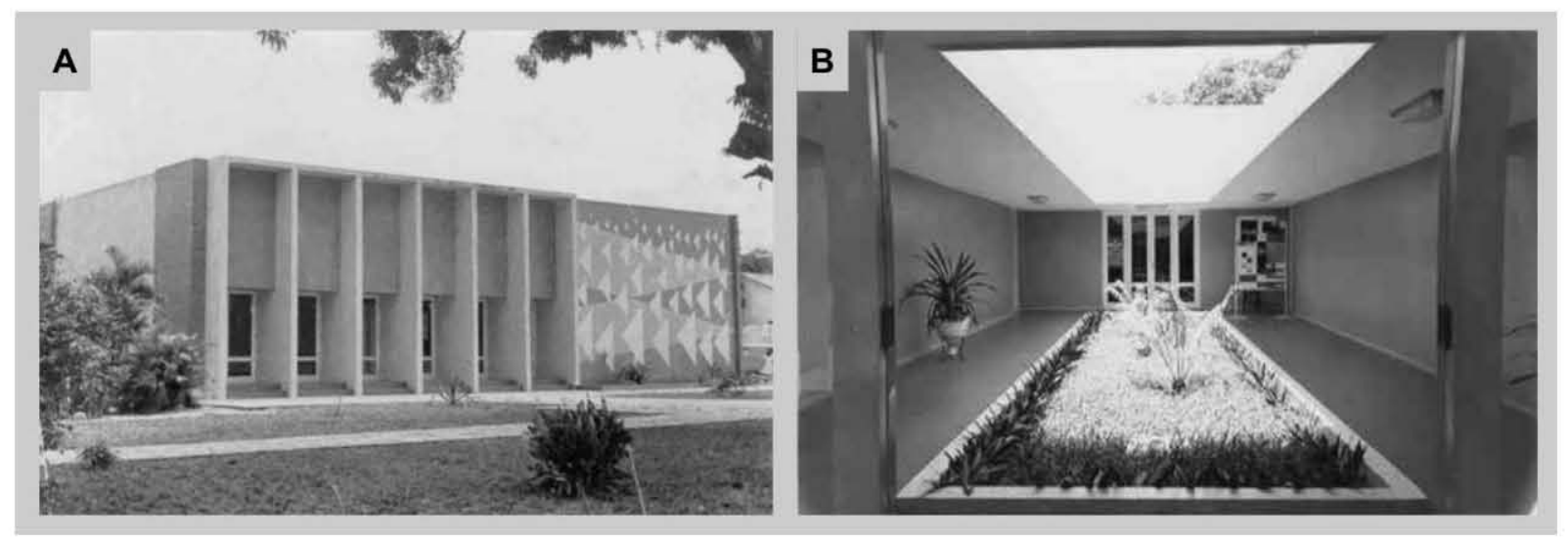

Figura 19: UFC - Museu de Arte - Década de 1960. (a) Vista da fachada voltada para a Avenida da Universidade com painel cerâmico do artista Zenon Barreto. (b) Vista do jardim interno. (Fonte: Acervo MAUC / UFC)

- Institutos Básicos: Química, Matemática e Física (1965)

A proposta para o estabelecimento dos institutos básicos se deu no bojo da criação da Faculdade de Filosofia, Ciências e Letras, que correspondia à nova estrutura acadêmica desejada pela UFC. Previu-se inicialmente a implantação dos Institutos de Matemática, Química e Física, ficando para um segundo momento os de Biologia, Geociências e Ciências Sociais.

Os primeiros prédios construídos constituíam um conjunto de quatro blocos, situados na quadra lindeira à Reitoria - no lado oposto à quadra da Faculdade de Filosofia, Ciências e Letras - os quais foram feitos por etapas, tendo sido o primeiro deles inaugurado em 1965. Originalmente, foi projetado para abrigar alunas da Escola de Serviço Social, porém, 
segundo Castro (2004, p. 200), depois de erguido, o prédio foi cedido por pressões ao Instituto de Matemática Aplicada, fundado na ocasião. Logo outros setores da área de ciências, conseguiram que fossem construídos novos blocos semelhantes, sendo um destinado aos Institutos de Química e Tecnologia e o outro ao recém-criado Instituto de Física.

O projeto de autoria do arquiteto Liberal de Castro caracteriza-se pela articulação de blocos com geometria retangular e configuração longitudinal, sendo três paralelos entre si e à Rua Paulino Nogueira e o quarto, perpendicular aos demais e paralelo à Avenida da Universidade (ver figura 20).

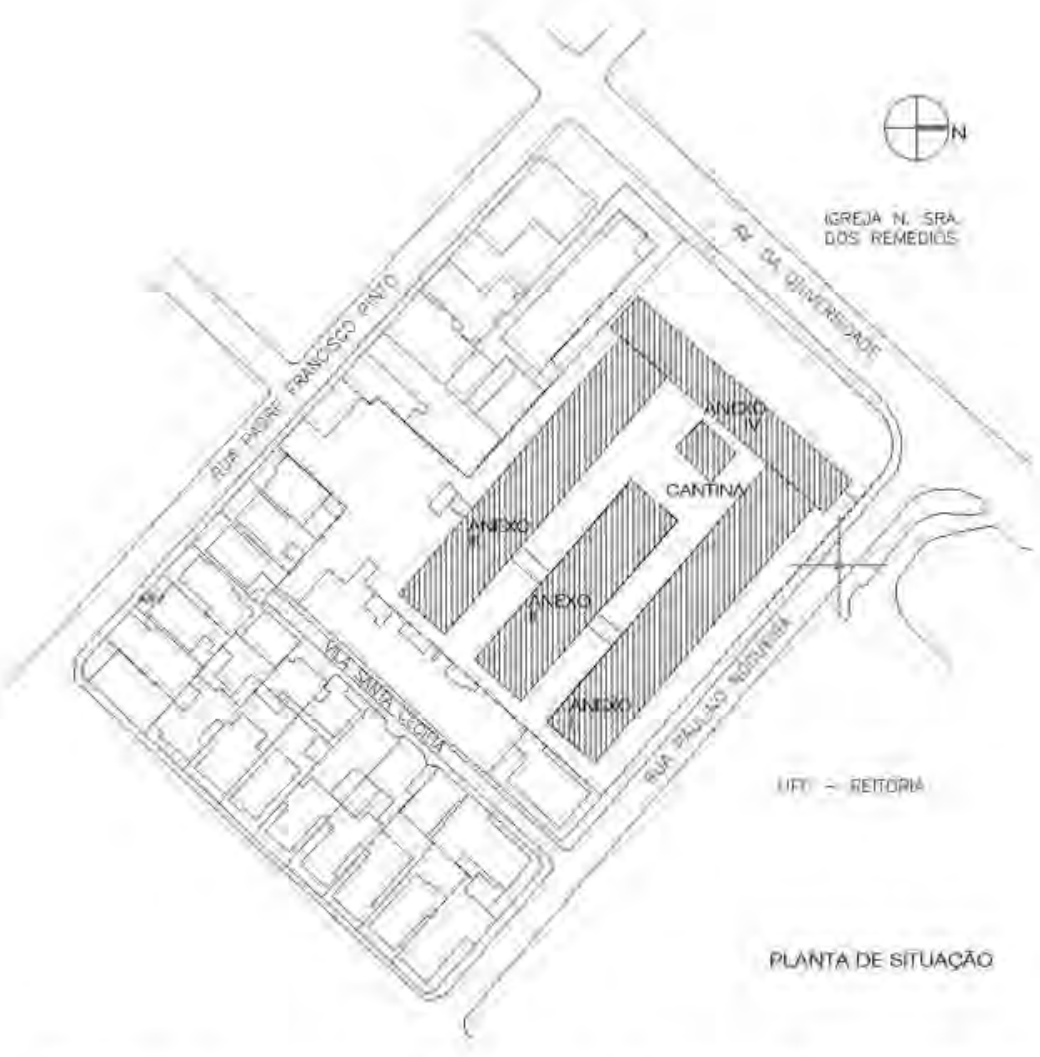

Figura 20: UFC - Conjunto arquitetônico dos antigos Institutos Básicos. Atualmente encontra-se ocupado por funções administrativas vinculadas à Reitoria com a denominação de Anexos I, II, III e IV.

(Fonte: Acervo COP / UFC, edição nossa)

O partido adota a planta livre concebida pela modulação estrutural. Os três blocos longitudinais leste-oeste possuem dois pavimentos e estão separados por áreas ajardinadas, porém articulados por uma circulação central que os atravessa transversalmente. O pavimento superior é ladeado longitudinalmente por estreitas circulações tipo varandas, balizadas por um correr de esbeltas colunas muito próximas umas das outras (CASTRO, 2004, p.201). O arquiteto Castro esclarece que esses apoios, 
sem qualquer função estática, demarcavam unicamente "os aposentos das alunas, todos de uso individual com 2,25m de largura, servidos por pequenas varandas privativas" (CASTRO, 2004, p.201).

No mesmo ano, o conjunto recebeu o acréscimo do quarto bloco, com três pavimentos, cuja implantação se dá em posição ortogonal aos demais, interligando-se aos dois blocos das extremidades. A fachada longitudinal voltada para a Avenida da Universidade apresenta uma composição que destaca a articulação entre a modulação estrutural e os extensos painéis de combogós, incorporando ritmo e marcação à forma arquitetônica (ver figura 21). A solução evidencia as questões climáticas locais, de forte incidência solar, assim como a intenção de propor uma arquitetura de caráter local. $O$ arquiteto Oliveira analisa que a composição resultante

[...] se aproximava do modelo de quadra fechada, com pátio interno, obtido a partir de uma releitura, em linguagem moderna, da estrutura tradicional dos "colleges" ingleses, aplicada experimentalmente no Ceará. A unidade espacial obtida neste conjunto serviu para descaracterizar completamente o sentido de faculdade isolada que se pretendia. Com este novo edifício, os vários institutos ali abrigados passaram a constituir uma nova unidade [...]. Embora cada um preserve sua identidade própria, nasce um novo ente universitário conhecido, agora, simplesmente como Institutos Básicos, imbuído do caráter coletivo que se queria emprestar para a disseminação de um verdadeiro espírito universitário (OLIVEIRA, 2005, p.89).

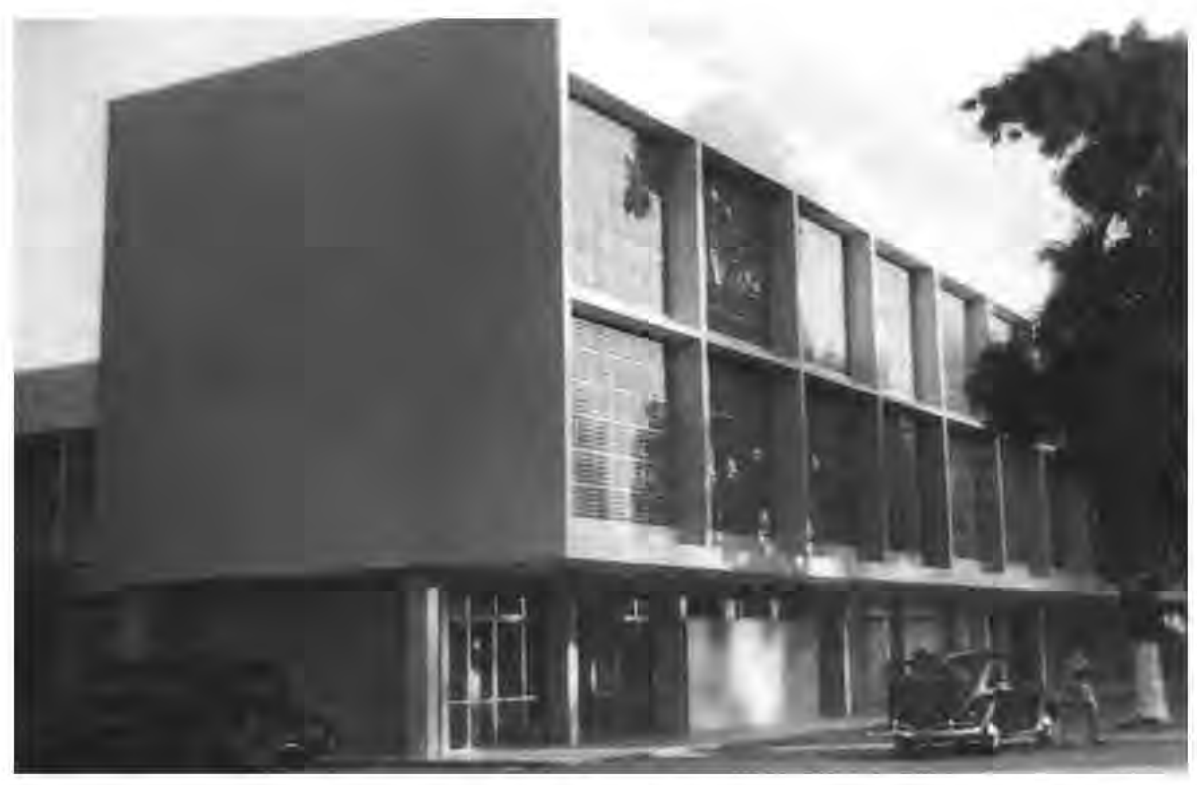

Figura 21: UFC - Antigo Instituto Básico - Ano 1967. (Fonte: DUARTE et al, 1996, p. 77) 


\section{- Residência Universitária (1966)}

A Residência Universitária (RU), situada também nas imediações da Reitoria foi construída a partir da pressão do Governo Federal para atender a demanda por alojamentos estudantis. $\mathrm{Na}$ qualidade de profissional do Departamento de Obras e Planejamento da UFC, o arquiteto cearense Ivan Brito elaborou o projeto da RU, que foi inaugurado em 1966, e se constitui em patrimônio de reconhecido valor modernista, tendo sido inventariado pelo IPHAN e que marca até os dias de hoje - pela sua qualidade arquitetônica - a paisagem urbana do Benfica.

Brito, que foi aluno e estagiário do arquiteto italiano Mário Russo durante sua graduação na Escola de Belas Artes da Universidade do Recife em 1955, não esconde a influência daquele profissional na sua diretriz projetual - pesquisa funcional, estrutural e construtiva que deveria resultar na síntese arquitetônica do edifício moderno. $O$ estágio no Escritório Técnico da Cidade Universitária sob a supervisão de Russo valeu-lhe a vivência em estudos da forma arquitetônica, bem como o acompanhamento de obras, o domínio sobre cálculo estrutural, instalações prediais e orçamentos. Toda essa experiência levou ao entendimento da "arquitetura integral", onde fatores climáticos, sistema construtivo, instalações complementares deveriam responder de forma articulada ao fator econômico, resultando em uma arquitetura plástica (Informação verbal ${ }^{22}$ ).

O programa da RU previa apartamentos para dois estudantes, formando uma unidade padrão de alojamento mínimo com quarto, banheiro e pequeno hall de entrada, funcionando também como copa, além de áreas coletivas que incluíam salão de jogos, cantina e sala de leitura, área para o centro estudantil, administração e auditório. Brito explica que a concepção do projeto se iniciou a partir do cálculo das dimensões mínimas necessárias para - alojamento, considerando também a estimativa de cubagem do ar necessário para as boas condições de conforto ambiental.

Implantado em um lote de duas esquinas de configuração retangular e de pouca profundidade - sendo a frente de $37,40 \mathrm{~m}$ voltada para a Rua Paulino Nogueira e as de $12,90 \mathrm{~m}$ de largura, para as ruas laterais - o arquiteto concebeu o edifício em quatro pavimentos ${ }^{23}$, sendo o térreo e o mezanino destinados ao setor de lazer e cultura, e os dois últimos definidos como pavimento-tipo, destinados às unidades de alojamento estudantil, todos articulados verticalmente com a caixa da escada e com a torre onde deveria ser instalado um elevador (ver projeto de arquitetura na figura 22).

\footnotetext{
${ }^{22}$ Informação verbal concedida pelo arquiteto Ivan Brito em entrevista realizada na sua residência, em Fortaleza no dia 25 de março de 2007.

${ }^{23}$ Profissionais que trabalharam com Brito especulam que a proposta original previa um edificio de seis pavimentos, mas com recursos financeiros limitados o projeto teve que ser ajustado para quatro. Brito, entretanto, não confirma os relatos, assim como o engenheiro responsável pelo cálculo estrutural, o cearense Hugo Mota, que afirma nunca ter sido discutida tal proposta (informação verbal concedida em entrevista).
} 


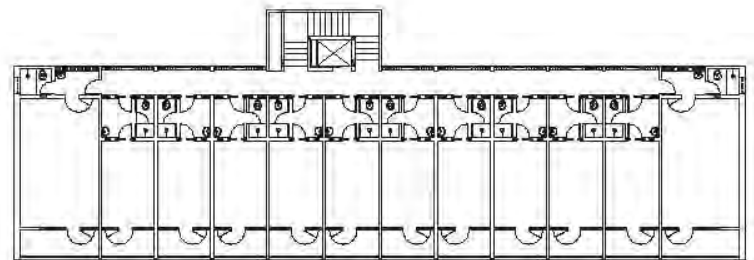

PLANTAPAYMENTOO TIPO

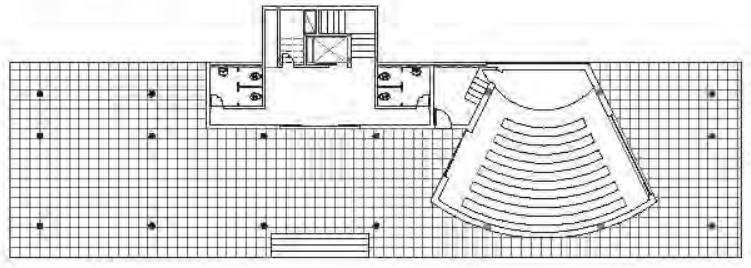

PLANTAPAMMENTO TÉREEO

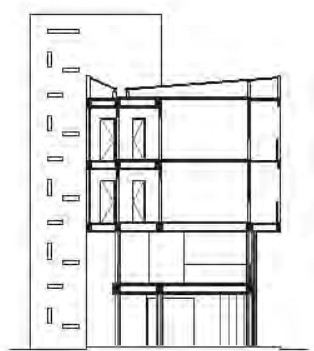

CORTE TRANSYERSAL

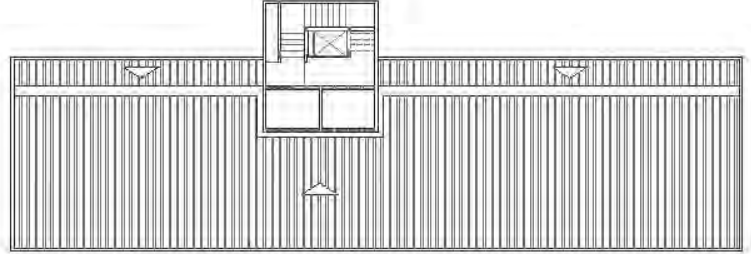

PLANITADECOBERT A.
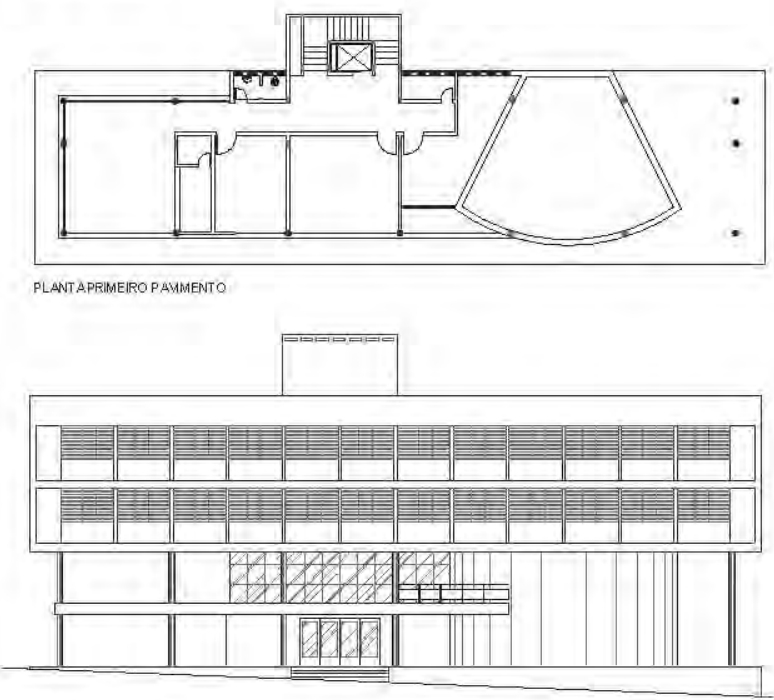

FACHADAPRINGCP Q Q

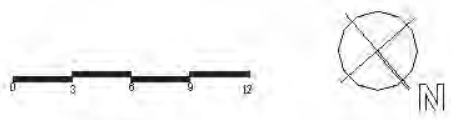

Figura 22: UFC - Residência Universitária - Projeto de arquitetura.

(Fonte: desenhos digitalizados a partir das plantas originais - Acervo COP / UFC)

Dentro do partido de referências modernas o piloti é concebido como espaço da integração social, uma área aberta com acesso ao auditório e vista para a rua - espaço semiprivado. A implantação tirou partido da maior dimensão do terreno, voltando os alojamentos para a direção dos ventos dominantes. Brito atenua o rigor climático com soluções locais tais como o uso de varandas que favorece o sombreamento nos quartos, esquadrias de madeira com venezianas articuladas ${ }^{24}$ e com o manuseio do combogó: formando uma cortina de proteção solar na fachada de fundo, vedação permeável à ventilação no salão de jogos e no térreo com a função de anteparo à rua. Merece registro, o sistema construtivo adotado, elegendo o concreto armado convencional e o uso da laje dupla para permitir a passagem das tubulações prediais (ver figuras 23 e 24).

${ }^{24}$ Trata-se de um modelo de fabricação local amplamente utilizado nas residências de Fortaleza. 


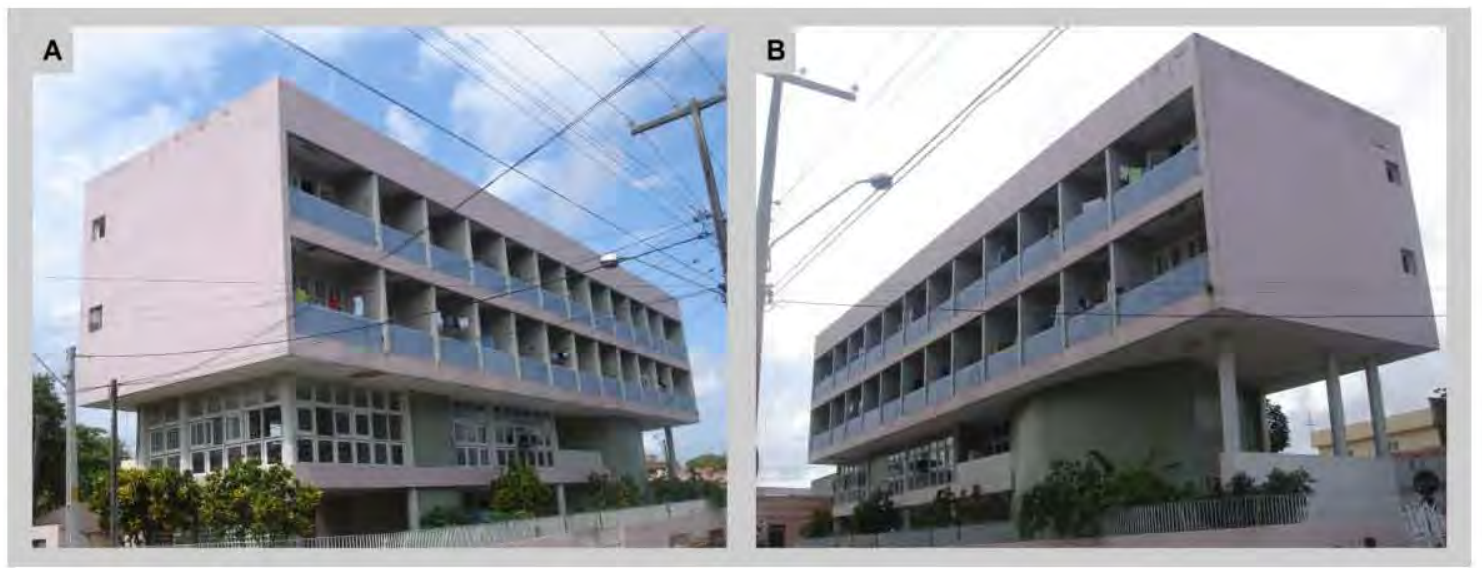

Figura 23: UFC - Residência Universitária - Ano 2008. As imagens destacam a volumetria funcional. (A) Vista do corpo principal sobre o mezanino com painéis de esquadria em madeira e vidro.

(B) Vista da caixa prismática apoiada no auditório que conforma o volume de parede curvilínea e nos pilares com pé-direito duplo.

(Fonte: Acervo Magda Campêlo, 2009)

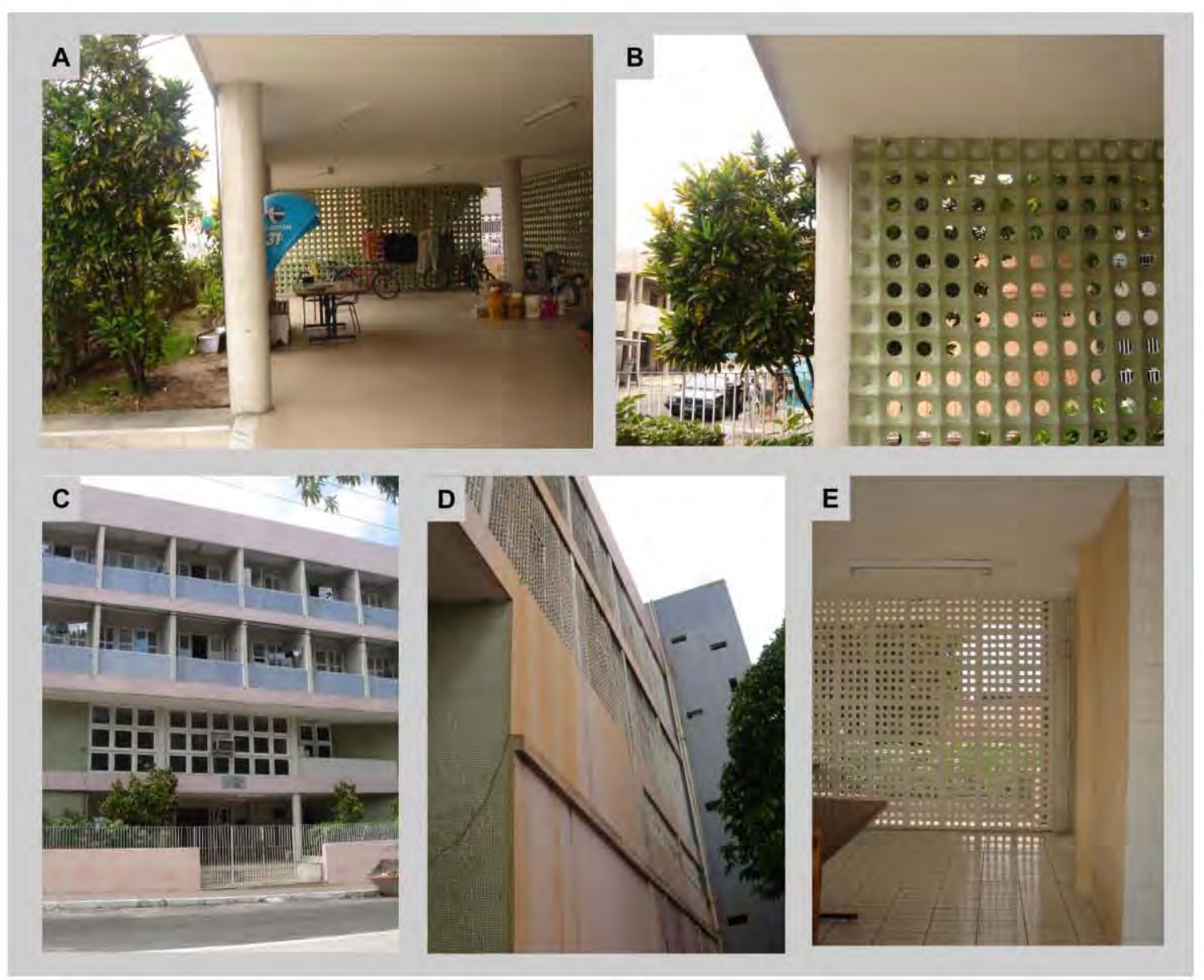

Figura 24: UFC - Residência Universitária - Ano 2008.

(A) Vista dos piloti.

(B) Detalhe do combogó cerâmico do piloti

(C) Detalhe da fachada principal com as esquadrias de madeira $e$ venezianas nas varandas.
(D) Vista da cortina de combogó na fachada de fundo.

(E) Vista da cortina de combogó no salão de jogos.

(Fonte: Acervo Magda Campêlo, 2009) 


\section{- Imprensa Universitária (1967)}

No ano seguinte foi inaugurada mais uma obra de concepção modemista. Tratava-se da Imprensa Universitária, que teve origem em 1956, quando o Conselho Universitário autorizou a aquisição da Tipografia Lusitana. Funcionando inicialmente em instalações provisórias, no dia 25 de maio de 1967, foi inaugurada sua sede própria, complementando o conjunto moderno edificado na quadra defronte à Reitoria, composto pelo Museu de Arte e pelo Departamento de Cultura, já analisados.

O projeto é de autoria dos arquitetos José Liberal de Castro e José Neudson Bandeira Braga. Concebido com um pavimento, o programa de necessidades está organizado em duas áreas funcionais: a primeira que corresponde aos setores administrativos e de serviços e a segunda que abriga o grande galpão destinado às atividades de impressão. Tendo em vista as necessidades físicas diferenciadas em cada área funcional, os arquitetos adotaram o sistema estrutural de concreto convencional para o setor administrativo e a estrutura metálica na parte de impressão, que necessitava de ampla área livre e pé-direito duplo. A forma arquitetônica resulta da organização funcional da planta, trabalhada com esquadrias de madeira com venezianas e combogós (ver figura 25).

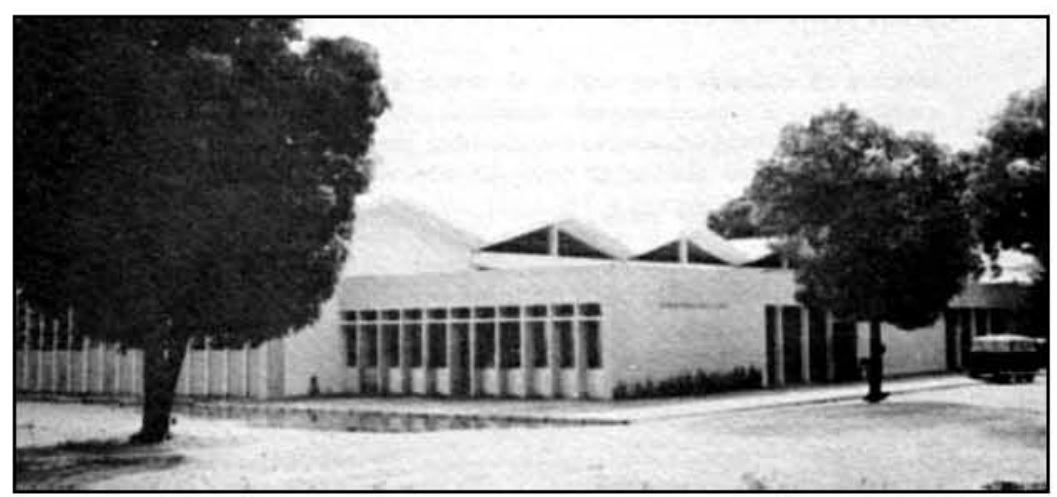

Figura 25: UFC - Museu de Arte.

(Fonte: Disponivel em <http://hww.imprensa.ufc.br/s. Acesso em: 10 abr. 2012)

\section{- Faculdade de Direito (1967)}

No mesmo ano de 1967, as instalações da Faculdade de Direito são ampliadas com a incorporação de um novo bloco, construído atrás do antigo edifício de arranjo eclético. Projetado por Liberal de Castro para abrigar um auditório (capacidade para 400 pessoas), salas de aula e cantina, mantém o partido de linhas modernas que o arquiteto vinha adotando nas outras unidades. Constituído de dois pavimentos com planta livre, a forma arquitetônica se destaca pela volumetria prismática superior com dimensões de $88,90 \mathrm{~m} \mathrm{x}$ $18,55 \mathrm{~m}$, apoiada sobre pilares de geometria cilíndrica. No pavimento térreo, o hall de acesso 
com a escada revestida em mármore e centralizada no ambiente de pé-direito duplo dá corpo ao espaço de caráter austero.

A edificação de linhas retas adota o partido de composição modular que padroniza as esquadrias de alumínio e vidro das fachadas longitudinais. $O$ revestimento em pastilha cerâmica de cor clara incorpora à produção atributos de elegância e leveza visual, que garantem interação junto ao antigo edifício de arranjo eclético herdado na criação da Universidade (ver figura 26).

A Universidade intensificava sua presença na área do Benfica, enquanto concomitantemente iam se conformando as áreas do Porangabuçu, com domínio da classe médica, e do Pici, sob o comando dos agrônomos.

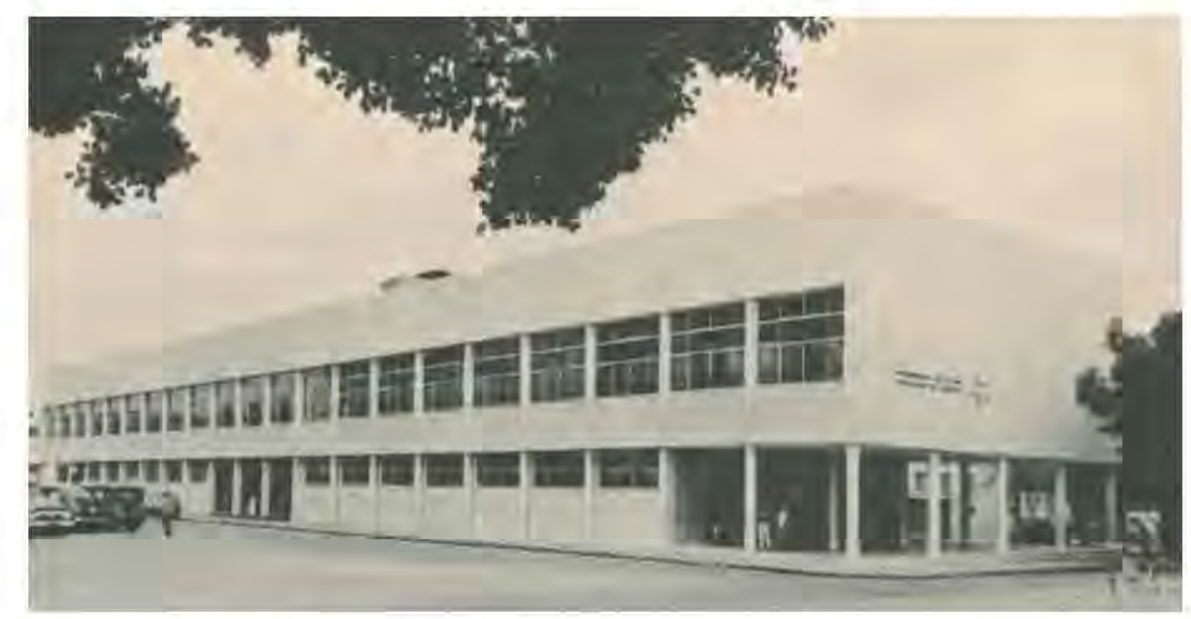

Figura 26: UFC - Faculdade de Direito - ano 1966.

(Fonte: UFC, 1966)

\section{- Porangabuçu: Território da Saúde}

A ocupação da UFC no bairro do Porangabuçu ${ }^{25}$ está vinculada ao processo de desenvolvimento da Faculdade de Medicina do Ceará ${ }^{26}$ criada em 1948 pelo Instituto de Ensino Médico do Ceará, entidade de direito privado constituída pela classe médica de Fortaleza com a finalidade de fundar, instalar e manter a futura instituição voltada para o ensino superior da saúde ${ }^{27}$.

Iniciou suas atividades em imóvel doado pelo governo do Estado - edificação do século XIX (ver figura 27), situado na Praça José de Alencar, no centro da cidade e que foi incorporado

\footnotetext{
${ }^{25}$ Conforme Freitas (2005, p.139), o antigo bairro do Porangabuçu, cuja denominação é de origem da língua indígena tupi composta de porangaba $=$ beleza e açu $=$ grande - teve essa denominação por muitos anos, sendo posteriormente substituida pelo de Rodolfo Teófilo.

${ }^{26}$ Sobre a criação da Faculdade de Medicina ler o capítulo 3 da Dissertação de Mestrado, Espaço Hospitalar - o caso do Hospital Universitário Walter Cantídio / UFC, de autoria da arquiteta Waldete Freitas (2005).

${ }^{27} \mathrm{O}$ Instituto de Ensino Médico passou a ser a partir de 28 de julho de 1947 o órgão com os encargos jurídicos para a manutenção da Faculdade de Medicina.
} 
ao patrimônio da UFC conforme já relatado - tendo o apoio da Santa Casa de Misericórdia, localizada nas proximidades, onde eram realizadas as práticas clínicas e hospitalares.

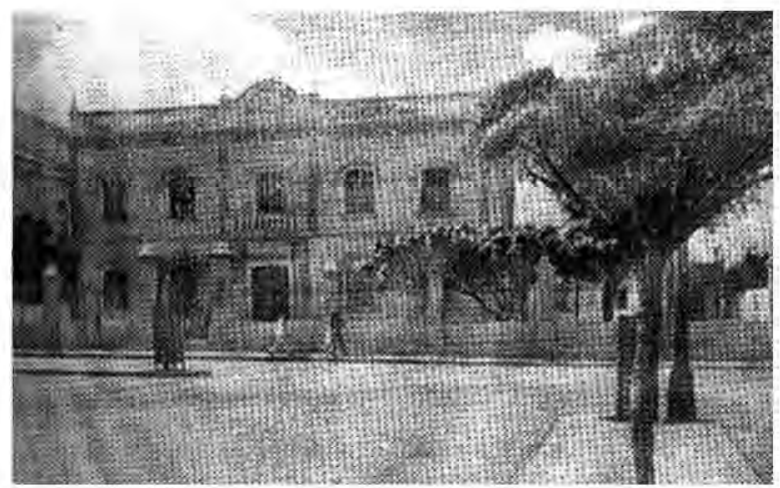

Figura 27: UFC - Faculdade de Medicina do Ceará.

O prédio onde iniciou suas atividades em 1948, no centro da cidade, foi construído em 1884 com projeto de autoria do austríaco Henrique Foglare para abrigar a Escola Normal. O prédio de dois pavimentos com área de $500 \mathrm{~m}^{2}$ é uma construção de arranjo eclético com traços neoclássicos e art déco.

(Fonte: Araripe, 1998 apud FREITAS, 2005, p.121)

O conflito de interesses, entretanto, gerado entre os médicos da Faculdade de Medicina e os da Santa Casa, posto que na visão dos dirigentes desta entidade, as suas prioridades nem sempre coincidiam com as dos professores, já que não contemplavam o progresso científico como objetivo maior, culminou com os professores da Faculdade decidindo lutar por um hospital de ensino (GIRÃO, 1994, p.20 apud FREITAS, 2005, p.122).

A oportunidade surgiu no ano seguinte ao da criação, com a doação pelo governo estadual de um terreno de $57.000 \mathrm{~m}^{2}$, localizado no então afastado bairro do Porangabuçu, onde havia sido iniciada pelo Estado, em 1944, a construção de um hospital de isolamento, com o objetivo de criar um centro de referência em doenças infectocontagiosas. A obra, porém, encontrava-se paralisada, no estágio de execução das fundações por falta de recursos. A doação efetivou-se em 1949 mediante a condição imposta pelo governo do Estado de que a Faculdade de Medicina assumiria a responsabilidade de encontrar, por conta própria, os meios para a conclusão do empreendimento e de manter funcionando no hospital uma enfermaria de isolamento que seria financiada pela Secretaria de Saúde (OLIVEIRA, 2005, p.51). A obra foi retomada e, em 1952 , deu-se a inauguração do pavilhão de isolamento, embrião do então futuro Hospital das Clínicas da UFC (ver figura 28).

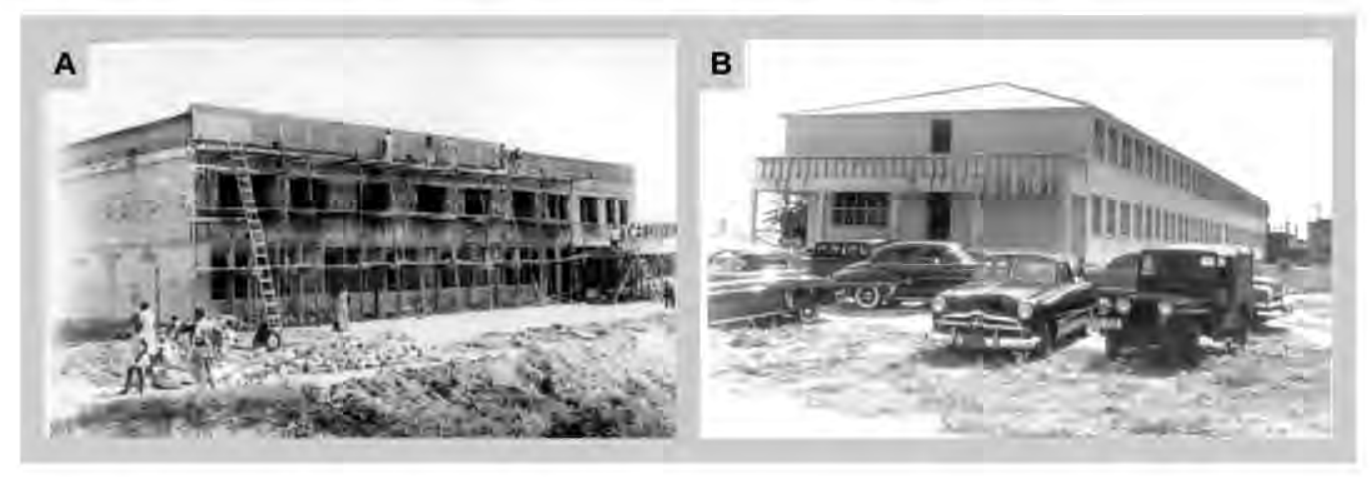

Figura 28: UFC - Hospital de Isolamento.

(A) Construção do primeiro bloco no início da década de 1950.

(B) Conclusão do Bloco de isolamento em 1952.

(Fonte: Arquivo HUWC apud FREITAS, 2005, p.136) 
No início de 1954, as dificuldades financeiras surgidas para a continuação da obra do hospital foram contornadas pela atuação da Fundação Júlio Pinto ${ }^{28}$, entidade que ajudou a concretizar o complexo de saúde que veio a se desenvolver na área do Porangabuçu com as seguintes unidades: Hospital Universitário (1959), Maternidade Escola de Fortaleza (1965) e Instituto Evandro Chagas (1955). Com a criação da UFC, no final daquele ano, a obra do Hospital das Clínicas foi assumida com relevância pela Administração Central, contribuindo para a consolidação do território da Universidade nessa área.

O Porangabuçu era, então, um bairro de periferia ainda praticamente desocupado, situado a oeste da cidade logo depois da linha férrea. Esta área havia sido objeto de um loteamento popular aprovado em 1943 [ver figura 29], ainda praticamente desocupado nessa época. $\mathrm{Na}$ cidade ocupava região, localizada a sotavento aonde habitualmente se destinavam os flagelados da seca e a população pobre e também os equipamentos insalubres como os matadouros, as rampas de lixo e os hospitais de isolamento (OLIVEIRA, 2005, p.51).

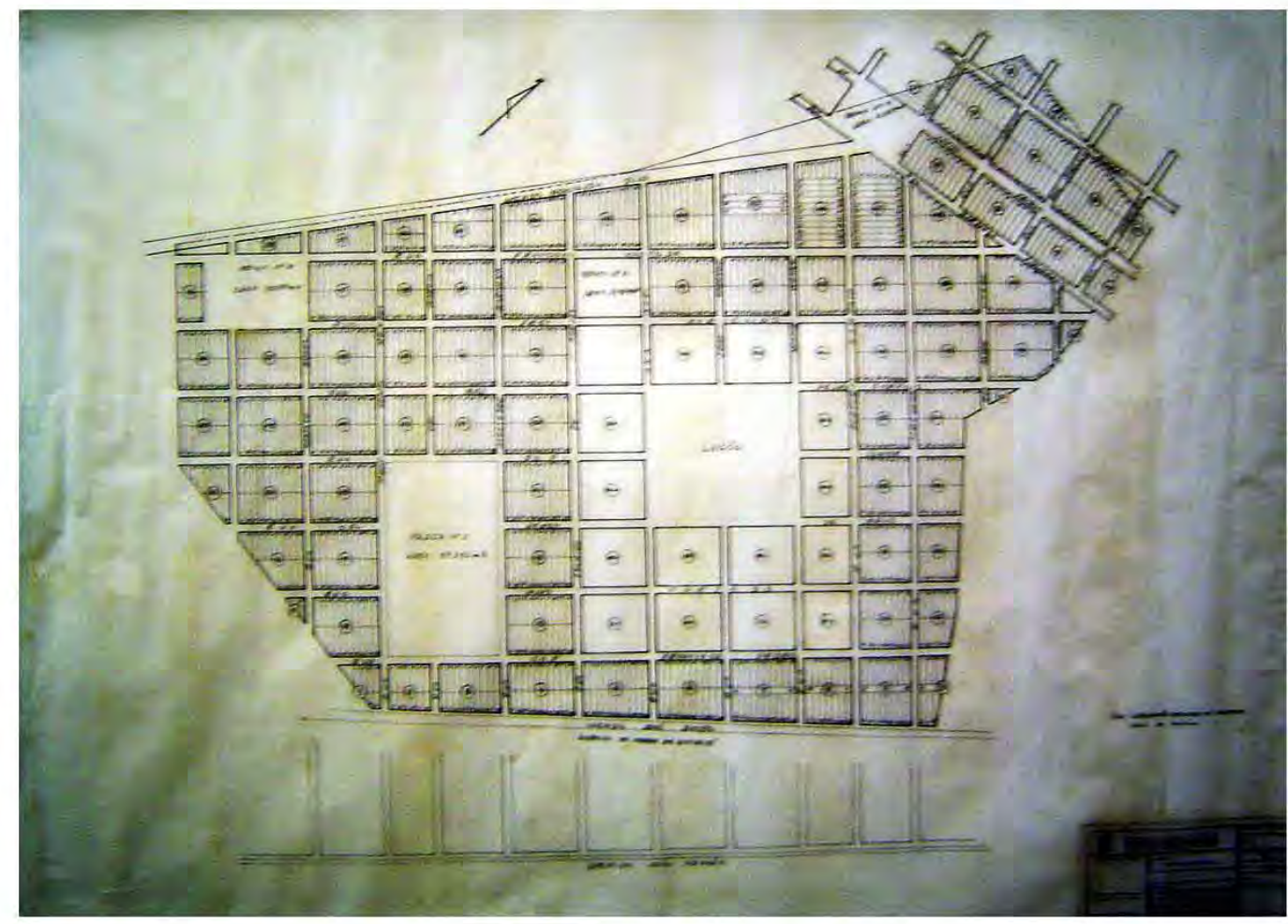

Figura 29: UFC - Planta do loteamento da Vila Porangabuçu. Aprovado pela Prefeitura em 1943. (Fonte: Arquivo COP / UFC apud FREITAS, 2005, p.138)

\footnotetext{
${ }^{28}$ A Fundação Júlio Pinto foi criada com a participação do rico empresário cearense, Fernando Pinto, contando com o apoio dos governos municipal e estadual, do Instituto de Ensino Médico e da Faculdade de Medicina. Segundo Araripe (1998 Freitas, 2005 , p. 135), tinha a finalidade de cooperar com o Instituto de Ensino Médico e a Faculdade de Medicina, construir e manter o Hospital das Clínicas, construir e manter a Maternidade Popular Escola de Fortaleza, construir e manter o Instituto Evandro Chagas, dentre outros.
} 
A distância ao centro urbano e as dificuldades de acesso não se contrapuseram, entretanto à implantação do setor de saúde naquela área. A visão dos médicos higienistas, desde o século XIX, indicando a direção a sotavento como condição ideal para a instalação de equipamentos hospitalares destinados às populações carentes, orientação que em Fortaleza não comprometeria o meio nem os ares das áreas situadas a barlavento, onde se fixava a fração da população de poder aquisitivo mais alto (FREITAS, 2005, p.139), associada à disponibilidade do terreno, doado pelo Estado, com dimensões para futuras expansões, colocou-se como fator de favorecimento à implantação daquele equipamento de saúde. Com essa concepção, deu-se, em 1957, a transferência da Faculdade de Medicina do centro da cidade para as dependências do Hospital no Porangabuçu, catalisando a partir daí a permanência da Universidade naquela área.

Paralelamente, outros equipamentos correlatos foram se estabelecendo nas circunvizinhanças, transformando gradativamente o Porangabuçu em um espaço de feição especializada voltada para o setor da saúde. Ao final de 1960, estava instalado o Instituto Evandro Chagas (1955), o Hospital de Cirurgia (1956), o Instituto de Anatomia e Medicina Legal (1957), e a Maternidade Popular Escola (1965), atual Maternidade Escola Assis Chateaubriand (MEAC), e a Faculdade de Farmácia conforme se constata nas figuras 30 e 31. Na década de 1970 , o complexo foi complementado pela construção do prédio da Unidade Didática e Biblioteca (projeto de 1969), o Departamento de Patologia (1974) e o Departamento de Fisiologia e Farmacologia (projeto de 1976) - ver figura 32.

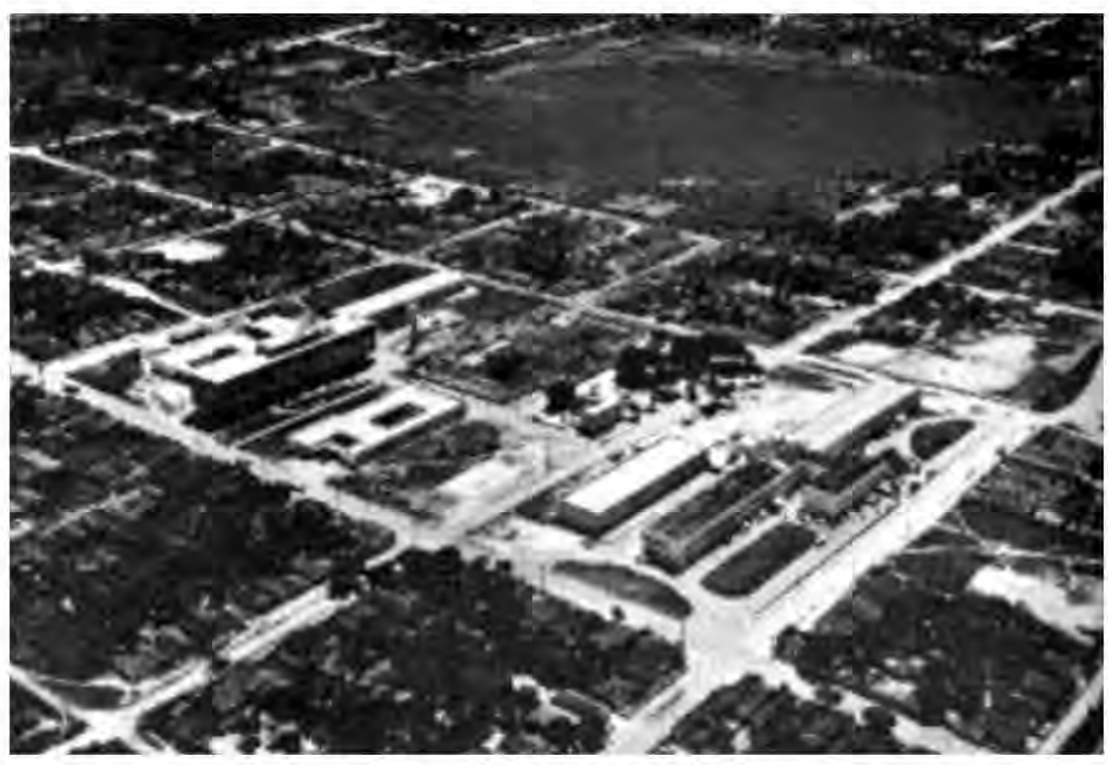

Figura 30: Vista aérea do Porangabuçu - final da década de 1960. (Fonte: LEAL, 1979 apud FREITAS, 2005, p.161) 


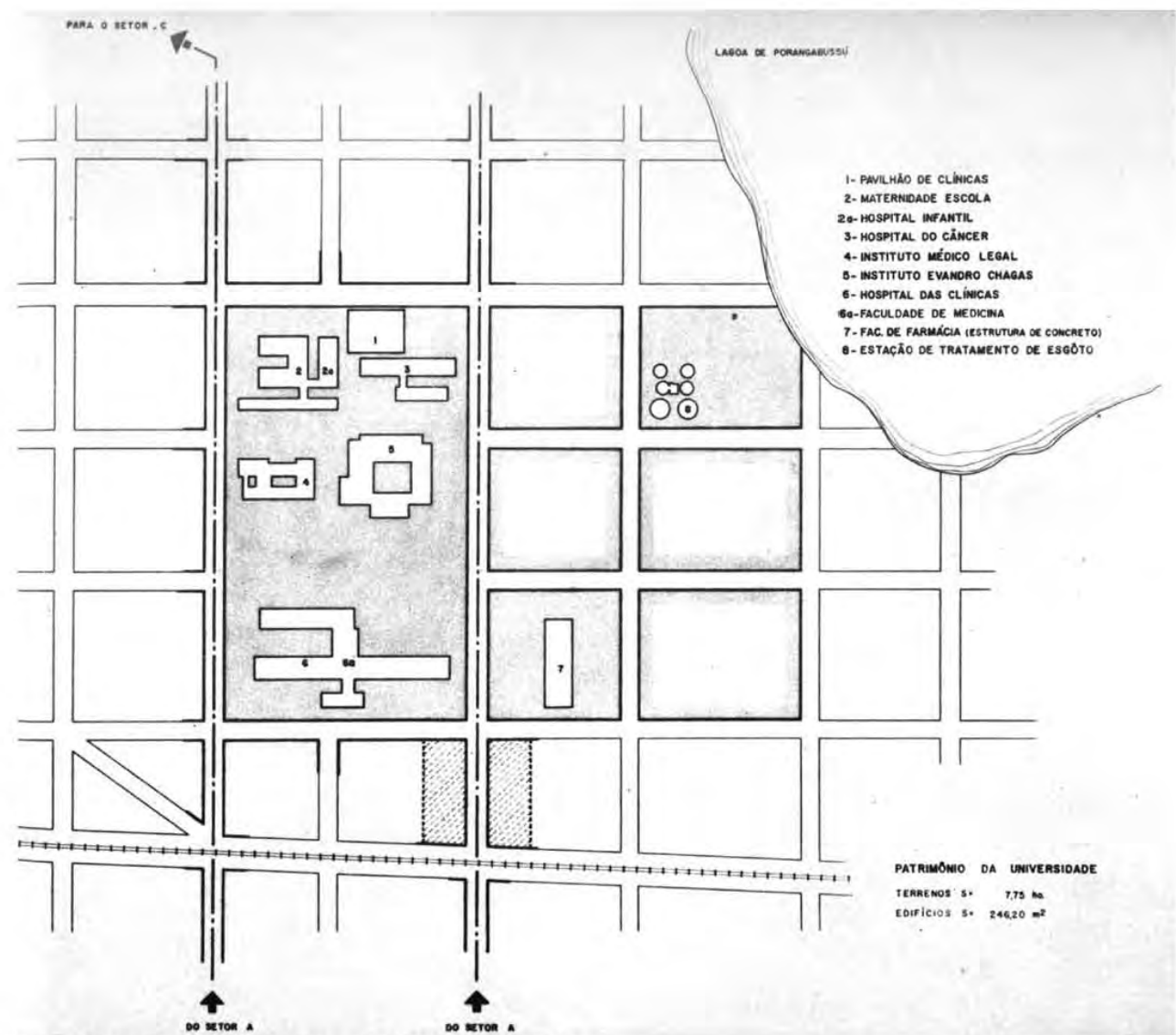

Figura 31: Planta do Porangabuçu em 1966.

(Fonte: UFC, 1966, n.p.)

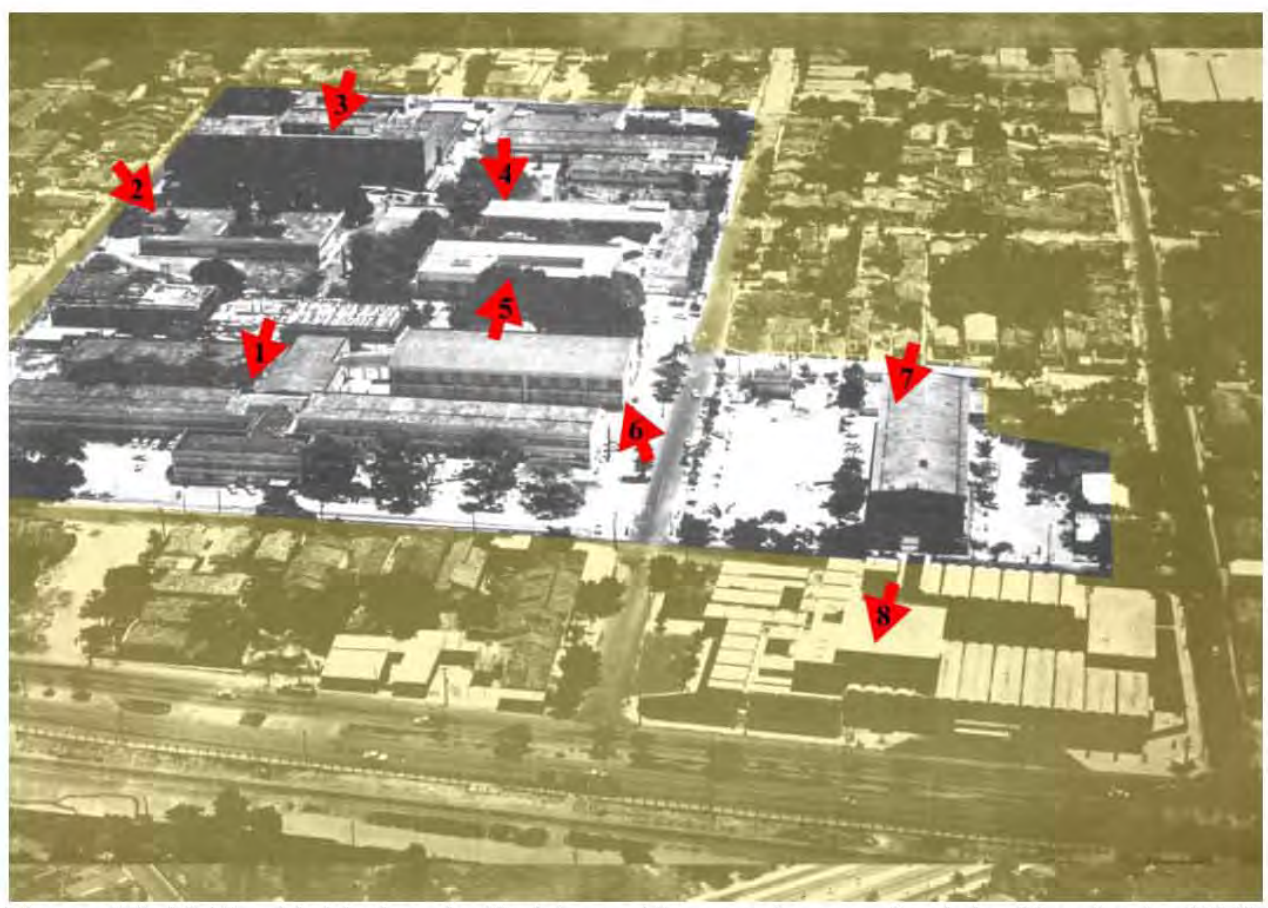

Figura 32: UFC - Unidades da Saúde no Porangabuçu - final da década de 1970. Legenda:
1. Hospital
5. Patologia
2. Morfologia
6. Biblioteca
3. Maternidade
7. Farmácia
4. Fisiologia
8. Hemocentro.

(Fonte: CAMPÉLO, 2005, p.62) 
Da mesma forma que o Benfica, a ocupação no Porangabuçu foi feita sem um planejamento, mas movida tão somente pelas demandas imediatas e condicionadas pelos recursos provenientes do Governo Federal. A concepção urbanística eliminou anteparos e barreiras físicas entre as unidades, neutralizando a percepção do lote como unidade territorial. Não se evidencia, entretanto uma diretriz que tenha ordenado a gradativa implantação das unidades. De maneira geral as unidades se abrem para a testada da rua, criando espaços intersticiais no centro da quadra, com livre acesso, sem circulações definidas. As características arquitetônicas do conjunto edificado resultaram da atuação de profissionais filiados à arquitetura moderna brasileira, permitindo-nos compreender a extensão desse movimento na cidade de Fortaleza.

\section{- A obra moderna na saúde}

Os arquitetos Roberto Nadalutti, Oscar Waldetaro e Israel Barros Correa com escritório no Rio de Janeiro desenvolveram três projetos: o Hospital das Clínicas (UFC), a Maternidade Escola e o Hospital do Câncer do Ceará. Os arquitetos, Liberal de Castro e Ivan Brito, participaram, dentre outros, com os do Instituto de Anatomia e Medicina Legal, a Biblioteca e a Faculdade de Farmácia. Na década de 1970, o arquiteto cearense Nearco Araújo, oriundo da geração de profissionais já formados pela Escola de Arquitetura da UFC e pertencente ao quadro técnico da mesma universidade contribuiu com as unidades da Patologia, Fisiologia e Farmacologia. Os exemplos selecionados para ilustração dessa produção - abaixo descritos - seguiram a ordem cronológica de projeto e/ou execução.

\section{- Hospital das Clínicas}

Em 10 de janeiro de 1955, as entidades que atuavam na gestão do Hospital das Clínicas (Instituto de Ensino Médico e a Fundação Júlio Pinto) contrataram o escritório do arquiteto Roberto Nadalutti, para elaborar um reestudo desse equipamento, considerando a existência do pavilhão de isolamento que já estava em construção, conforme mencionado.

Adotando o partido pavilhonar, a equipe de arquitetos concebeu um edifício que resultava da junção de cinco blocos de configuração retangular e longitudinal desenvolvidos em dois pavimentos justapostos ao bloco centralizado de mesma configuração geométrica e de dois pavimentos e um subsolo, funcionando como eixo de ligação do complexo hospitalar, totalizando uma área de $12.500 \mathrm{~m}^{2}$ (ver figura 33). A solução beneficiava o aproveitamento da ventilação e iluminação natural, além do que possibilitava a construção por etapas, conforme as disponibilidades dos recursos financeiros. 
O projeto datado de 1955 constava de um programa físico de hospital geral com setor de internação com circulação central e enfermarias de dois, três e quatro e seis leitos, quartos de um leito com banheiro acoplado, totalizando 300 leitos, cinco salas de cirurgia, central de esterilização, cozinha, refeitório, almoxarifado, salas para atendimento ambulatorial, laboratórios, capela, conforto de pessoal e outros ambientes necessários ao funcionamento pleno do edifício.

Os acessos eram bem definidos e as circulações permitiam fluxos diferenciados (FREITAS, 2005, p.146-147).

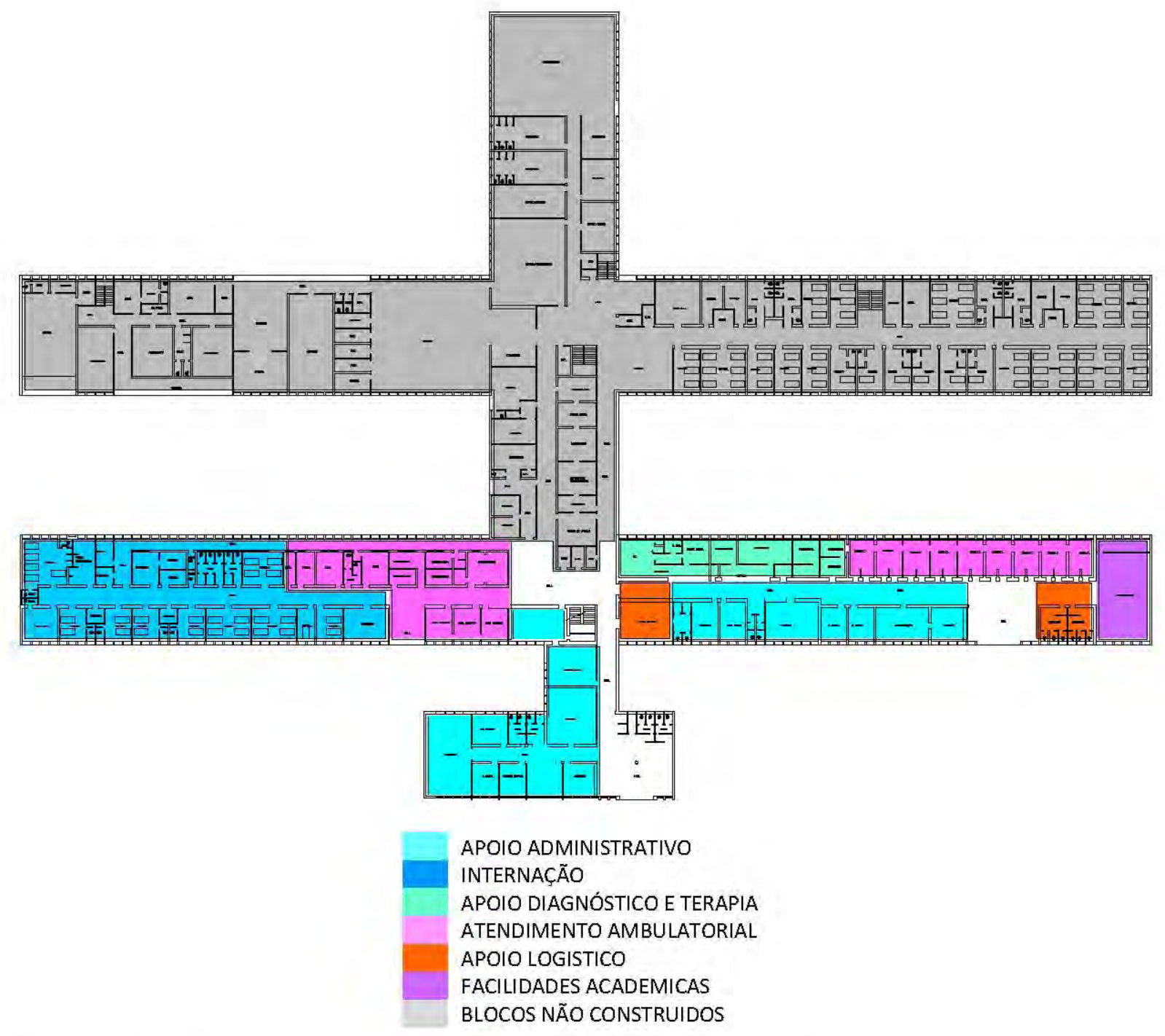

Figura 33: UFC - Redesenho da planta térrea original do Hospital das Clínicas. (Fonte: FREITAS, 2005, p.155) 
Os projetistas empregaram o módulo de $1,20 \mathrm{~m}$ que rege a padronização dos componentes construtivos. Por consequência a forma arquitetônica resulta em um conjunto volumétrico prismático marcado pelos planos de vedação que destacam as esquadrias moduladas, criando ritmo às fachadas. A marquise em laje plana apoiada nos pilares inclinados desempenha a função de linguagem de acesso ao mesmo tempo que cria um contraponto à estabilidade das formas de linha retas (ver figura 34). Dos cinco blocos, somente três foram construídos e inaugurados em 1957. O projeto original não foi implantado na íntegra e outras edificações foram anexadas: o bloco da nutrição, da lavanderia e o central, no início dos anos 1960 e, no final da década de 1970, foi construído um prédio anexo de quatro pavimentos com novos serviços.

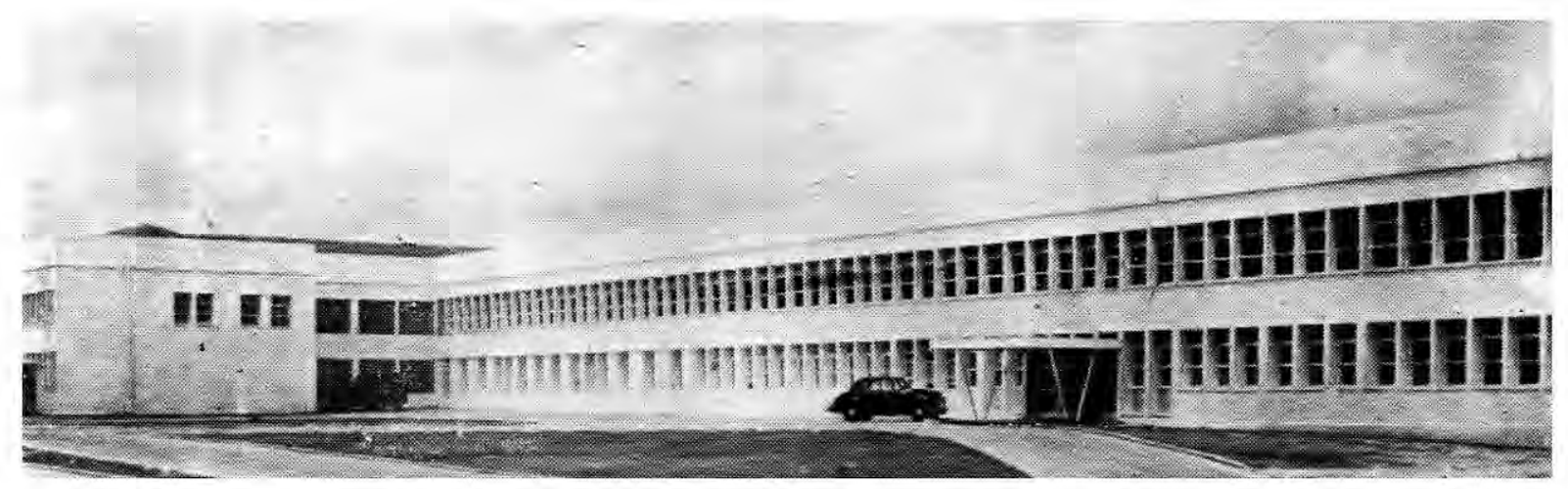

Figura 34: UFC - Hospital das Clínicas.

Vista da fachada principal - edificação concluída em 1957

(Fonte: Araripe, 1998 apud FREITAS, 2005, p.157)

\section{- Instituto Evandro Chagas}

Também no ano de 1955, o complexo da saúde foi ampliado com a construção do Instituto Evandro Chagas que abrigou laboratórios, biblioteca e a administração da Faculdade de Medicina. O projeto, de autoria desconhecida, constituía-se de um edifício térreo cuja planta se desenvolvia em torno de um pátio central rodeado por circulações e passarelas. A construção respondia adequadamente ao clima de altas temperaturas. Foi demolido no início da década de 1970 .

\section{- Hospital de Cirurgia}

Em 1956, novamente os arquitetos Roberto Nadalutti, Oscar Waldetaro e Israel Barros Correa tiveram a oportunidade de projetar outra unidade de saúde na área do Porangabuçu. Desta vez, tratava-se do Hospital de Cirurgia pertencente ao Instituto de Câncer do Ceará, que havia pleiteado a cessão de seis quadras da área doada ao Instituto de Ensino Médico. As limitações financeiras, entretanto permitiram apenas a construção de um bloco térreo, 
cuja arquitetura se define pela estrutura de concreto abobadada, com evidente referência no conjunto arquitetônico de Pampulha, em Belo Horizonte, de autoria do arquiteto Oscar Niemeyer (ver figura 35). Em 1962, o edifício foi ampliado com projeto do arquiteto Liberal de Castro.

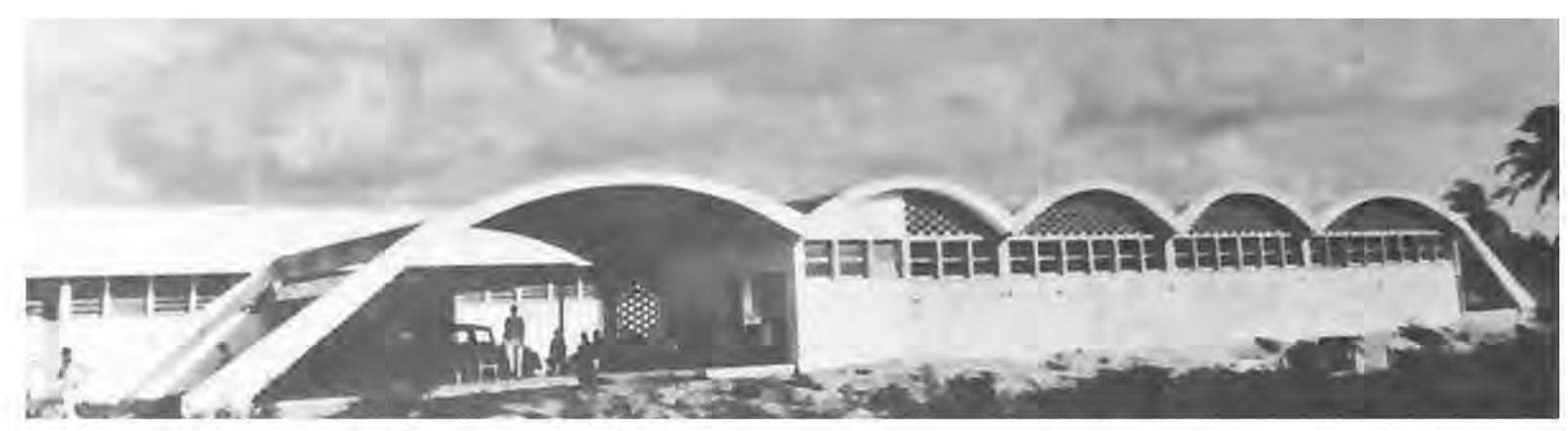

Figura 35: UFC - Hospital de Cirurgia. Foto do prédio original em 1966. (Fonte: UFC, 1966, n.p.)

\section{- Instituto de Anatomia e Medicina Legal}

Em 1957, foi construído o prédio destinado ao Instituto de Anatomia e Medicina Legal que teve a autoria do arquiteto Liberal de Castro. Tratava-se de um edifício térreo cuja planta se desenvolvia em torno de pátios centrais. Sua forma resultava da volumetria de linhas retas vedada pela cortina de esquadrias padronizadas em alumínio e vidro, assemelhando-se à linguagem estilística do hospital adotada no projeto original (ver figura 36 ). Foi demolido em 1980.

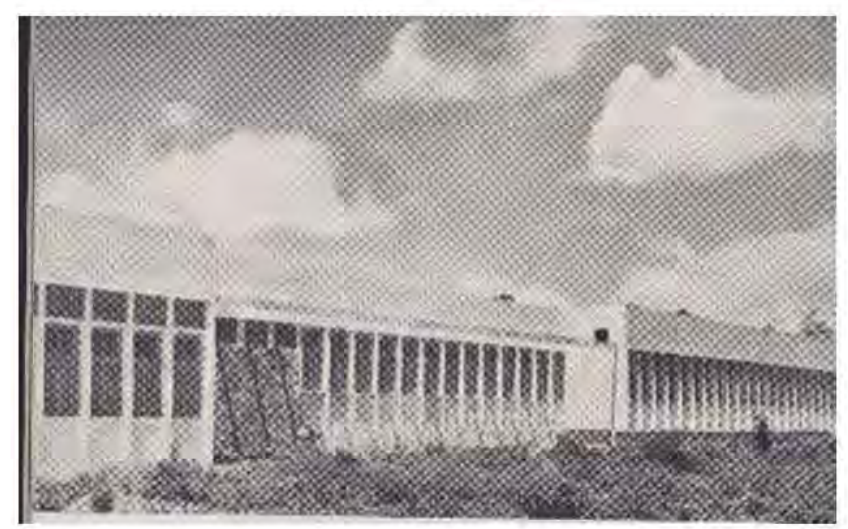

Figura 36: UFC - Antigo Instituto Anatomia e Medicina Legal.

(Fonte: UNIVERSIDADE DO CEARÁ, 1960 apud FREITAS, 2005, p. 160) 


\section{- Matemidade-Escola}

O edifício da Maternidade Popular de Fortaleza inaugurado em 1965 constitui até os dias de hoje em importante exemplar do patrimônio moderno cearense. A concretizaçẫo desse equipamento de saúde pública foi uma iniciativa conjunta da sociedade cearense e do governo estadual com o objetivo de suprir o déficit alarmante de leitos disponiveis para as gestantes carentes do Ceará.

Projetado pelos arquitetos cariocas Roberto Nadalutti, Oscar Waldetaro e Israel Barros Correa - já mencionados - o prédio evidencia a filiaçẫo de seus autores ao Movimento Moderno na Arquitetura Brasileira. O edificio de composiçẫo elegante destaca a volum etria funcional de linhas retas, concebida por uma modulaçẫo estrutural de $6,00 \mathrm{~m}$, valorizando o arcabouço de concepçẫo independente. O programa de necessidades é organizado em setores funcionais, refletindo-se na forma arquitetônica que resulta da junçẫo de um volume prismático frontal de quatro pavimentos, destinado à internaçẫo e administraçẫo, justaposto a outro bloco horizontal, que originalm ente abrigava os servicos complem entares e de apoio logístico (ver figura 37 e 38 ).

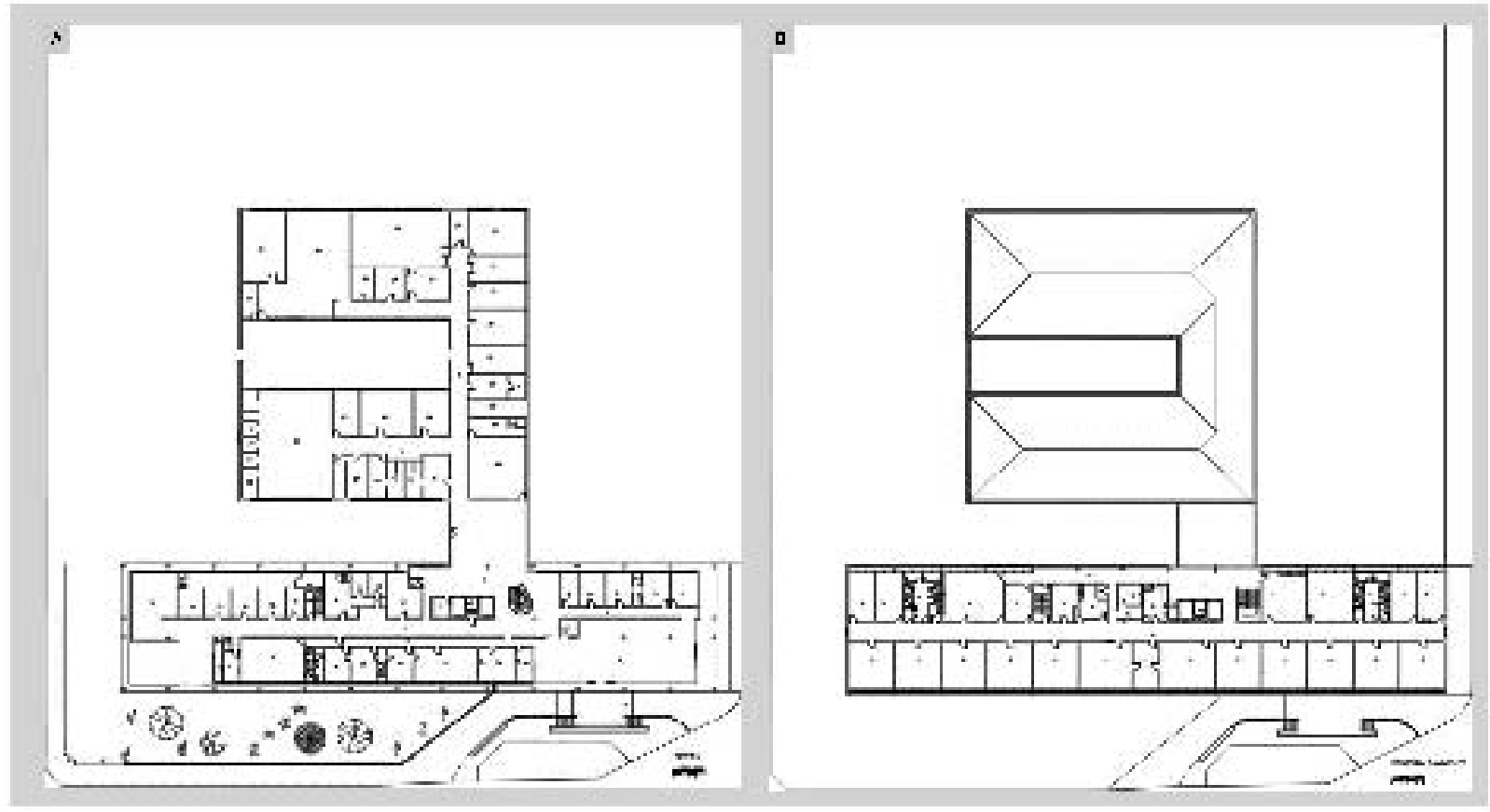

F igura 37: UFC - Maternidade-Escola- Projeto de Arquitetura.

(A) Planta do pavimento térreo: área administrativa, ambulatórios, apoio técnico e apoio logistico.

(B) Planta 10. Pavimento: área de internação.

(Fonte: CAMPELO, FREITAS, TARALLI, 2010) 


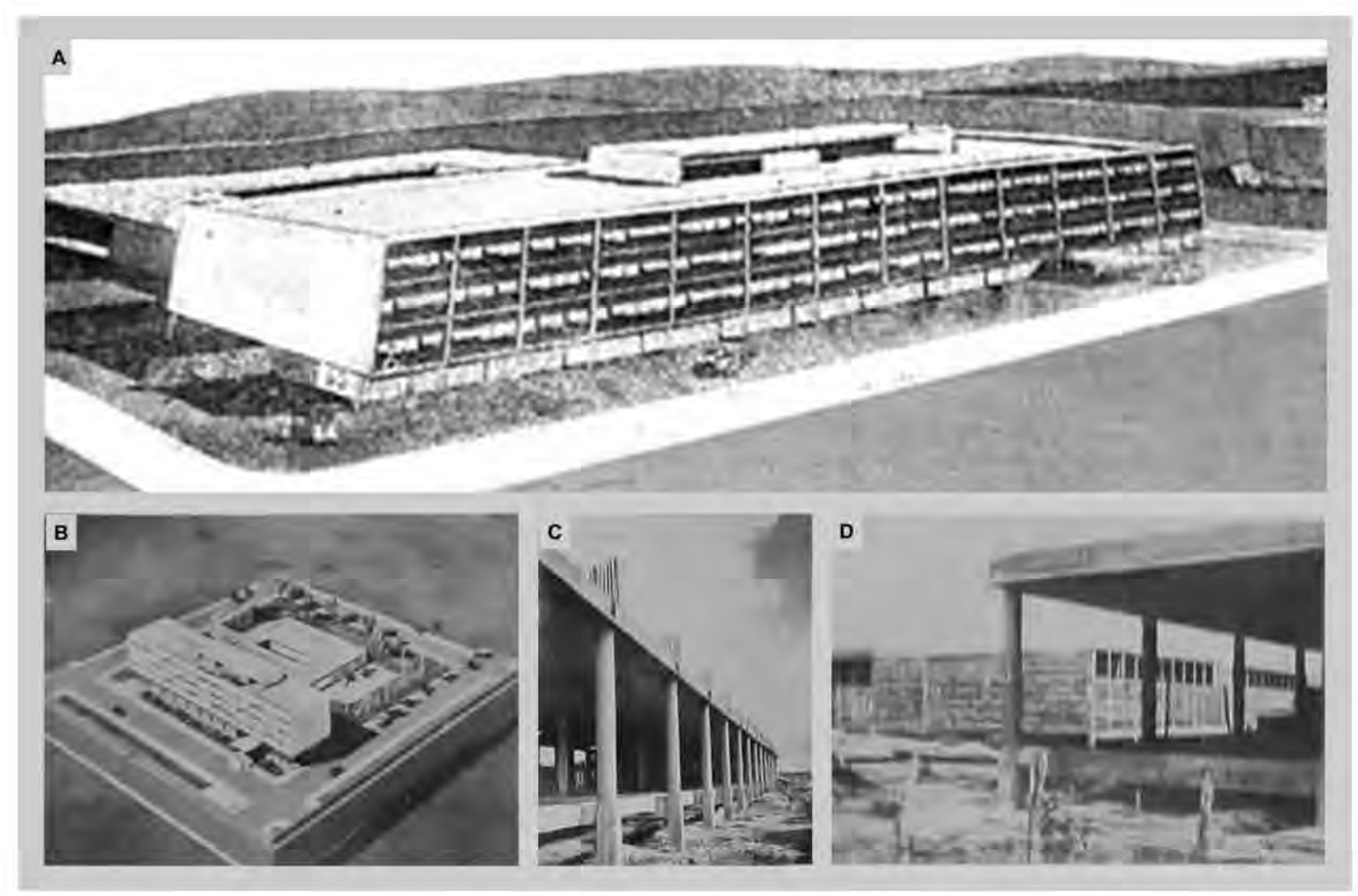

Figura 38: UFC - Maternidade-Escola.

(A) llustração da futura Maternidade-escola.

(B) Foto da maquete - destaca-se a volumetria funcional.

(C) e (D) Fotos da estrutura de concreto em fase execução.

[Fonte: (A) FREITAS et al, 2010. (B), (C) e (D) Acervo COP/UFC]

Os componentes construtivos, tais como os painéis de vedação das amplas aberturas concebidos em estruturas de madeira com venezianas e funcionamento tipo guilhotina, e os materiais de revestimento cerâmico demonstram sua proposta de adequação às características do clima local. Inserido na paisagem, sua concepção modernista contribui para sua identidade e reconhecimento social (CAMPÊLO, FREITAS, TARALLI; 2010). Construído em terreno de esquina, sua implantação original permitia o acesso sem barreiras físicas. Conferindo permeabilidade e integração, os pilotis, em conjunto com a rampa de acesso constituíam-se em um convite aos que por ali passavam (ver figura 39). 


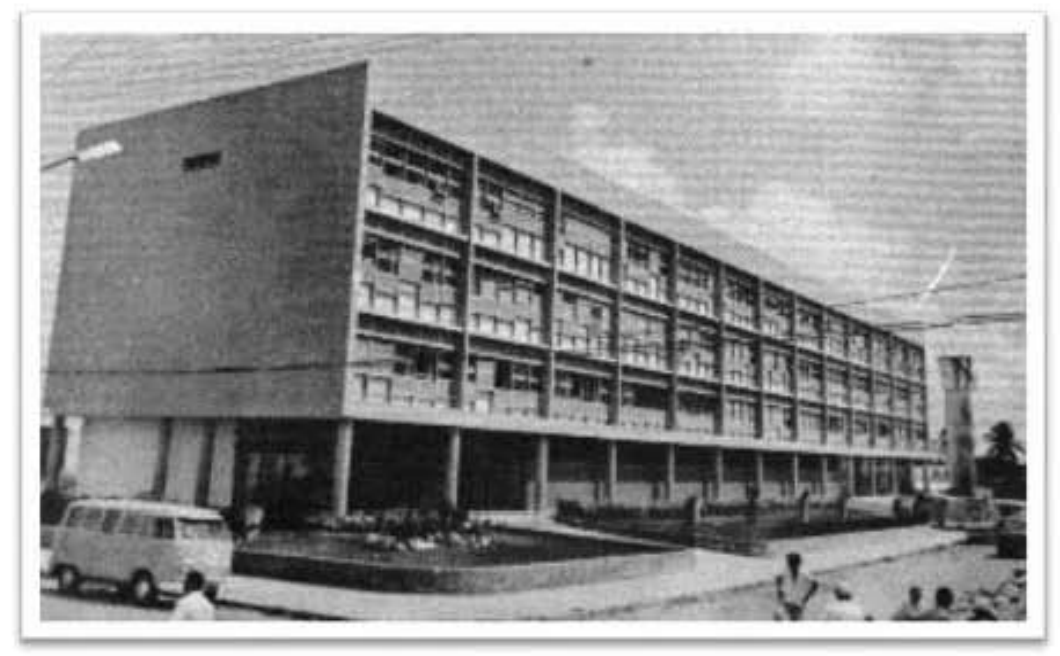

Figura 39: UFC - Maternidade-Escola.

Vista do edifício pela fachada principal, caracterizada pela volumetria prismática do corpo principal composta pelos painéis de vedação em madeira com venezianas.

(Fonte: CAMPELO, FREITAS E TARAШI, 2010)

\section{- Década de 1970: uma nova orientação projetual}

Na década de 1970, novas unidades foram implantadas no Porangabuçu. O prédio da Unidade Didática e Biblioteca, de autoria do arquiteto Ivan Brito, foi construído na mesma quadra do Hospital das Clínicas, criando limitaçổes à expansão daquele equipamento. 0 projeto de 1969 é formado por um edifício de dois pavimentos com planta de configuraçăo retangular que abriga salas de aula e dependências da biblioteca. A volumetria compacta, revestida de pastilha cerâmica e esquadriais de madeira com venezianas móveis năo reproduz a beleza do partido adotado por Brito no edifício da Residência Universitária do Benfica. É possivel evidenciar uma nova orientaçẫo projetual caracterizada pela compacidade da volumetria.

Em 1974 e 1976, o arquiteto Nearco Araújo contribuiu com o projeto dos edifícios destinados ao Departamento de Biologia e ao Departamento de Fisiologia e Farmacologia respectivamente. Concebidos em dois pavimentos o partido construtivo afasta-se da elegância e singeleza peculiar da produção dos anos 1960.

\section{- Pici: território segregado}

A origem do território universitánio do Pici está vinculada a implantação da Escola de Agronomia do Ceará, fundada em 1918. Pela natureza das suas atividades, a Instituição requeria área física com condiçôes específicas para realizar seus procedimentos práticos: laboratórios especializados e implementos próprios, extensos campos para experimentação 
e manejo das diversas culturas, solos apropriados e disponibilidade permanente de água (OLIVEIRA, 2005, p.55). Por estas características não poderia se adaptar à natureza de parcelamento do solo em centro urbano, onde o lote é a unidade territorial. O Sítio do Pici, localizado na região oeste da capital, tornou-se então a alternativa técnica e econômica viável para a concretização da Escola.

O início das suas atividades se deu em imóvel doado pelo governo do Estado, localizado no centro da cidade de Fortaleza ${ }^{29}$. Para o atendimento das especificidades práticas, entretanto foi instalado em terreno situado em subúrbio afastado, também doado pelo Estado. As características da gleba, localizada às margens da BR-222, no Distrito Antônio Bezerra, com presença de água constante, terra fértil e vias de acesso, atendia às especificidades das suas atividades e aos interesses dos profissionais que ali iriam trabalhar.

Em 1937, após ser encampada pelo Estado em decorrência do novo modelo de ensino agrícola no país, que passou a ser subordinado ao Ministério da Agricultura, perdeu sua natureza privada, mas ampliou sua infraestrutura de laboratórios, oficinas, estábulos, pocilgas e galpões para máquinas, intensificou as culturas de campo e expandiu o ensino, abrangendo cursos para trabalhadores rurais (OLIVEIRA, 2005, p.56). Seu funcionamento no subúrbio da cidade chegou a ser questionado pelo governo, decorrendo daí um movimento em defesa da sua interiorização no ano de 1945.

Prevaleceram, entretanto, os anseios dos integrantes da Escola, professores da elite intelectual urbana, que não aceitou trocar o conforto da vida na cidade pelas carências e limitações do meio rural ${ }^{30}$. Tal condição foi reforçada com a sua inclusão entre as unidades que constituíram a Universidade Federal do Ceará em 1954.

Embora tenha havido reação por parte dos dirigentes da Instituição à sua incorporação na recém-criada universidade, preocupados em ter que dividir os seus recursos em benefício das outras unidades, fato superado pela habilidosa atuação da Administração Central, o funcionamento da Escola de Agronomia na área do Pici foi definitivamente selado, funcionando até os dias de hoje.

Oliveira (2005, p.60) avalia que os requisitos necessários à especificidade do seu funcionamento, fizeram da sua presença naquela região uma condição quase compulsória, reforçada pela possibilidade de anexar terrenos desocupados existentes no seu entorno e assim ampliar os seus limites. Essa última condição foi avaliada no início da implantação da UFC como estratégica para a materialização do território da Universidade no modelo de cidade universitária a exemplo de outras instituições, tais como a USP, cujos representantes

\footnotetext{
${ }^{29}$ Instalou-se inicialmente no antigo edificio do Liceu do Ceará, localizado na Praça dos Voluntários, que foi posteriormente demolido e deu lugar ao atual prédio da Secretaria de Polícia e Segurança Pública (CASTRO, 1979, p.84).

${ }^{30}$ Sobre esse assunto ver o capitulo 2 , páginas 55 a 63 , da dissertação de mestrado de autoria de Oliveira (2005).
} 
do escritório técnico responsável pela construção da cidade universitária estiveram em Fortaleza, a convite da UFC, para apresentar o projeto do seu território unificado.

Importante esclarecer que a região do Pici era constituída originalmente por sítios, destacando-se dentre eles o Sítio Pici ${ }^{31}$, que foi doado à Escola de Agronomia, como já foi mencionado. Na década de 1940, período da Segunda Guerra Mundial, os americanos instalaram nas circunvizinhanças um posto de comando e construíram um aeroporto com toda estrutura preparada para guerra, de onde partiam os aviões para bombardear os países não aliados.

Na década de 1950, depois da retirada dos americanos, os sítios foram se transformando em loteamentos e as terras da base ficaram sob a vigilância da Aeronáutica de Fortaleza, as quais faziam limite com a gleba da Escola de Agronomia e, estando desocupadas, configuravam-se como área livre.

Foi então que a Administração Superior, vislumbrando a possiblidade de ampliar a área da UFC e assim criar as condições para a implantação da futura cidade universitária, manifestou oficialmente em sessão do Conselho Universitário, realizada em 14 de novembro de 1956, o propósito de adquirir aqueles terrenos. A intenção era favorecida por tratar-se de propriedade da União, o que facilitava as negociações para incorporá-la aos terrenos da Escola de Agronomia (ver figura 40).

Com esse propósito, o então reitor Antônio Martins Filho foi levado a conhecer as obras de implantação da cidade universitária da USP, no bairro do Butantã, em São Paulo. Vale ressaltar que foi nessa ocasião que se estabeleceu contato com o arquiteto Hélio de Queiroz Duarte, professor catedrático da Faculdade de Arquitetura e Urbanismo daquela universidade e um dos integrantes da Comissão de Execução daquela obra.

Em 1957, ele esteve em Fortaleza, para proferir conferência sobre o Plano de Construção da Cidade Universitária da USP, retornando na primeira metade da década de 1960 para assessorar a UFC na criação da Escola de Arquitetura [já mencionado na história do Benfica] e na coordenação do planejamento físico para expansão da Universidade - Plano de Desenvolvimento de 1966 / 1970, que será tratado no decorrer do presente capítulo.

\footnotetext{
${ }^{31}$ Além do Sítio Pici, havia o Sítio Ipanema, Sítio do Papai e os terrenos das irmãs do asilo de Parangaba e da Base Aérea. Em 1958, com a base dos americanos desativada, algumas famílias ocuparam os "paióis" ou casamatas, local onde eram camufladas as munições do Exército Americano. Gradativamente, foram surgindo, a partir dessa época, os bairros PanAmericano, Pici, Ipanema Antônio Bezerra e Casa Popular, que foi o primeiro conjunto habitacional construído em Fortaleza, sendo atualmente o bairro Henrique Jorge (Sobre esse assunto consultar o blog de Leonardo Sampaio, disponível em <leonardofsampaio.blogspot.com/2007/12/historia-do-pici.html>.)
} 


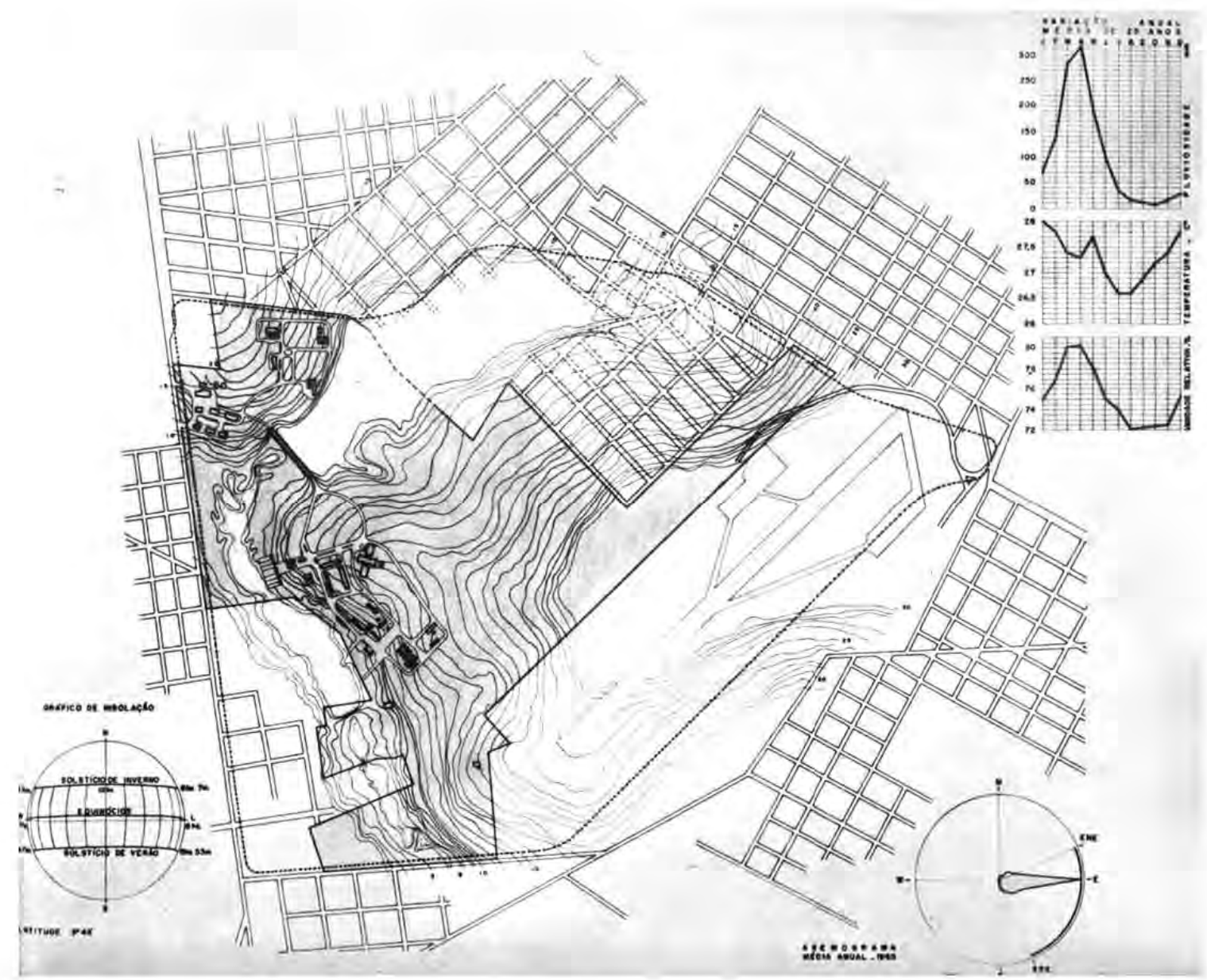

Figura 40: UFC - Futuro Campus do Pici.

Gleba do Pici com anexação dos terrenos da antiga Base Aérea do Pici construída pelos americanos na Segunda Guerra Mundial.

(Fonte: UFC, 1966, n.p.)

O processo de aquisição dos terrenos do campo de pouso do Pici, entretanto não logrou êxito: a demora nas negociações, associada à inexistência de fontes de recursos para financiar os investimentos necessários, arrefeceu as expectativas de concretizar o propalado modelo espacial único. A ideia do território unificado não foi, entretanto eliminada, tanto que a Universidade passou a adquirir lotes circunvizinhos, mantendo o propósito de ampliar a área do Pici. Entretanto, é importante lembrar que o contexto vivenciado pelo embate dos dirigentes das antigas faculdades que deram origem à UFC - Direito, Medicina e Agronomia - sobrepõe-se ao desenvolvimento da base física, que culminou com três áreas diferenciadas, conforme já descrito. Oliveira $(2005$, p.63) infere que a materialização da UFC foi produto das relações sociais que se estabeleceram a partir desse arranjo institucional, tendo concretamente como suporte físico inicial os imóveis oriundos do patrimônio imobiliário das unidades que Ihe deram origem. 
- Pici: ocupação a partir de núcleos dispersos

A gleba do Pici com área de 158,8 ha foi ocupada predominantemente até meados da década de 1960 pelas unidades vinculadas à Escola de Agronomia. Conforme se constata na planta da figura 41 , até essa época, a ocupação resultava da distribuição de três setores edificados - a Escola de Agronomia, o Instituto de Tecnologia Rural e o Instituto de Zootecnia - que formavam núcleos dispersos na área de grande extensão. Somente no início da década de 1970 após o advento do primeiro plano de desenvolvimento físico elaborado pela UFC é que a gleba do Pici iniciou o processo de transformação da sua configuração urbano-arquitetônica, orientada pelas diretrizes do planejamento físico de origem no urbanismo moderno, dominando a paisagem edificada desse território e deixando suas marcas até os dias de hoje.

A produção edilícia do primeiro momento caracterizava-se pelo conjunto de construções de arranjo eclético ou vernacular e poucos projetados por profissionais herdeiros da Escola Carioca, merecendo destaque nessa produção o edifício-sede do Instituto de Zootecnia junto com a torre da caixa d'água de autoria do cearense Enéas Botelho referenciado por seus pares como o primeiro arquiteto a atuar na cidade de Fortaleza.

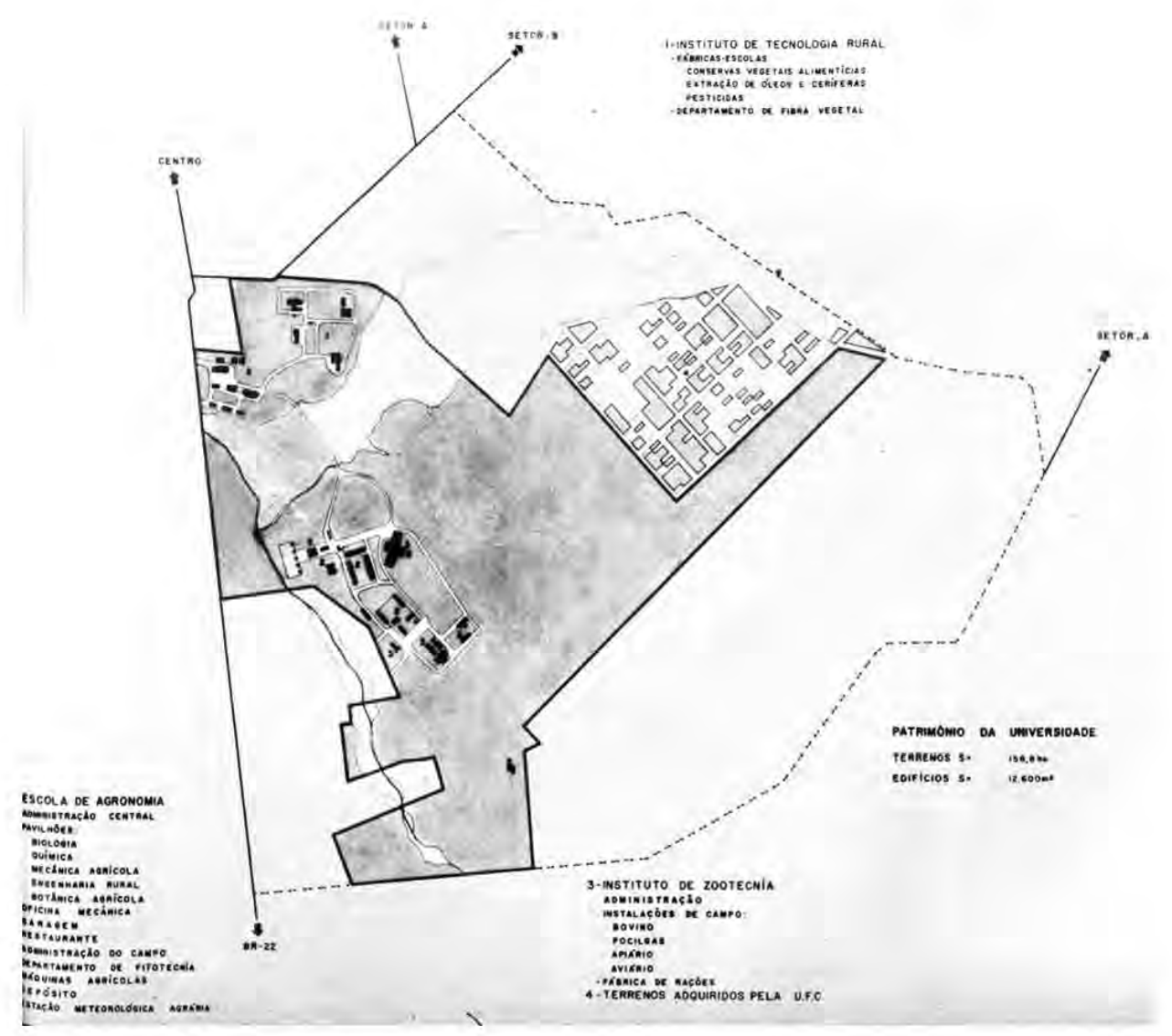

Figura 41: UFC - Gleba do Pici - ano 1966.

(Fonte: UFC, 1966, n.p.) 


\section{- Instituto de Zootecnia: a chegada do moderno}

Botelho concebeu para o Instituto de Zootecnia um edifício de estrutura arrojada para aquele período em Fortaleza. Resultava da junção de três blocos funcionais, sendo um centralizado destacado plasticamente pela estrutura de concreto armado em pórticos de geometria abobadada, e dois de configuração retangular interligados ao primeiro por passarelas cobertas e opostos entre si, formando um conjunto de composição simétrica e arquitetura de linhas leves (ver figura 42). Na fachada de acesso destacava-se a caixa d'água de concepção monumental, composta pela junção de três reservatórios suspensos por pórticos em forma de arcos. As edificações estavam integradas com a proposta urbanística concebida pelas vias de circulação - veículos e pedestres - de configuração curvilínea, que limitava a praça frontal e áreas livres de jardins, resultando em um desenho talvez alimentado por referências ao projeto do Parque do Ibirapuera, de autoria do arquiteto Oscar Niemeyer, inaugurado em 1954 na cidade de São Paulo.

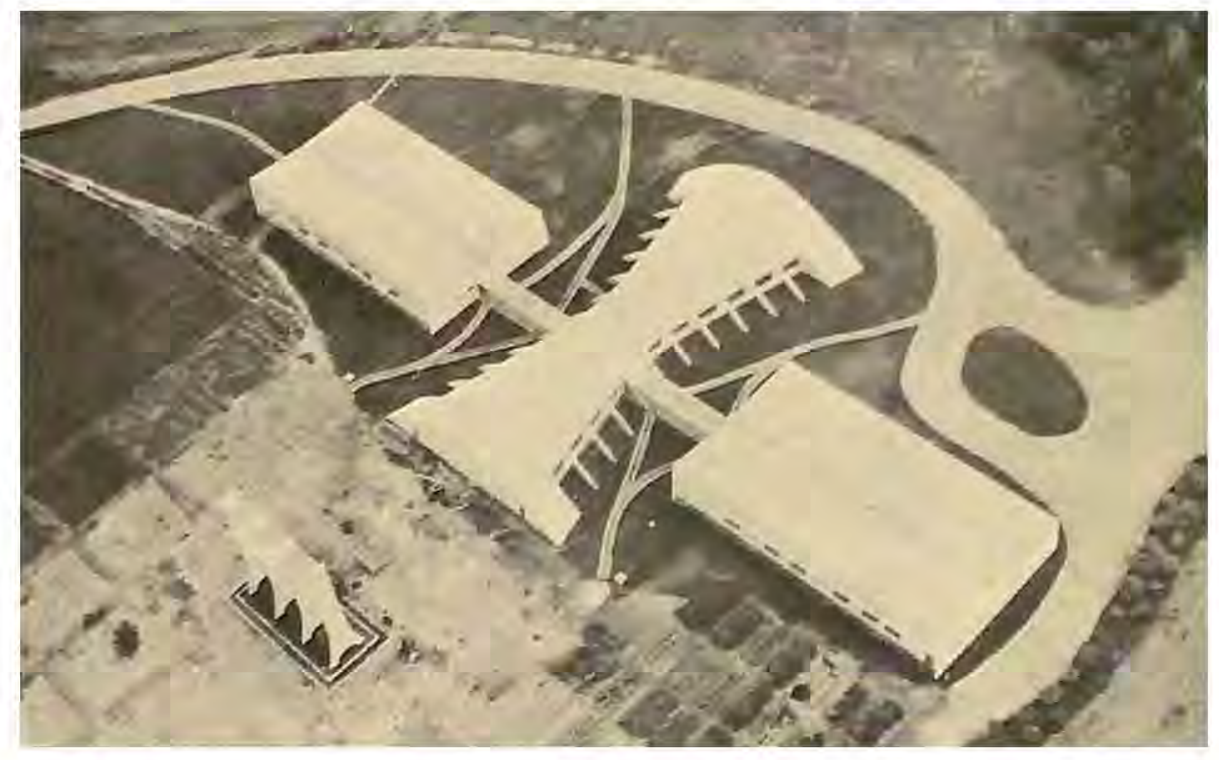

Figura 42: UFC - Instituto de Zootecnia - ano 1966. (Fonte: UFC, 1966, n.p.)

Os exemplos acima testemunham o processo de formação do território do Pici nos primeiros anos de sua implantação. Da mesma forma que nas demais áreas (Benfica e Porangubuçu) o cenário urbano-arquitetônico não era regido por uma diretriz operativa de ocupação. 0 conjunto edificado, apesar dos estilos de origem diversificada, não deixa de manifestar a chegada do repertório arquitetônico modernista. Com as três áreas, a materialização da Universidade era um processo irreversível e já na primeira metade da década de 1960 enfrentava estrangulamento das suas ações, revelando a importância de adequar-se às exigências surgidas. 
- Plano de Desenvolvimento - 1966/1970: a semente do urbanismo racional moderno

O acelerado crescimento da Instituição e a vivência dos dez primeiros anos de sua existência indicavam a necessidade de um planejamento para ordenar sua expansão, Ao mesmo tempo, as diretrizes do desenvolvimento nacional tornavam as instituições de ensino superior responsáveis pela qualificação de profissionais para atender às demandas requeridas no campo socioeconômico.

Neste cenário, a UFC constatou a incapacidade das suas instalações e a escassez de recursos humanos e materiais para atender à crescente procura por vagas para ingresso na Universidade, avaliação que corroborava com a importância do planejamento que se destinava a traçar as perspectivas para o seu crescimento no quinquênio 1966/1970.

A referida revisão crítica que resultou dos seminários anuais realizados com a participação dos professores culminou com o Plano de Desenvolvimento da Universidade Federal do Ceará, publicado em 1966.

Elaborado a partir de criterioso estudo das demandas regionais a serem atendidas e com base no diagnóstico da estrutura e dos dados relativos ao crescimento do seu primeiro decênio de existência, o Plano definiu as novas exigências da Instituição em termos de zoneamento, urbanização, edificações, serviços básicos, equipamentos, pessoal docente e pesquisadores. Reconhecido como documento institucional, buscou credenciamento junto ao Banco Interamericano de Desenvolvimento (BID) objetivando a obtenção de recursos a serem investidos na concretização desses objetivos.

Foi elaborado tendo como princípios orientadores a integração e a expansão. Entretanto, a fragmentação espacial caracterizada pelas três áreas em localizações distintas foi identificada como uma contradição a ser superada. Por outro lado, os investimentos imobiliários nelas realizados não poderiam ser desperdiçados.

Para contornar o conflito, os profissionais responsáveis pelo planejamento físico valeram-se dos princípios racionalistas do urbanismo moderno, que conferia ao zoneamento funcional a solução de uniformidade dos usos para propor a nova organização espacial. Estabeleceram a vocação funcional de cada uma das três áreas, que passaram a ser denominadas de Setor $A$, Setor $B$ e Setor $C$, correspondendo respectivamente às do Benfica, Porangabuçu e Pici (ver figura 43). 


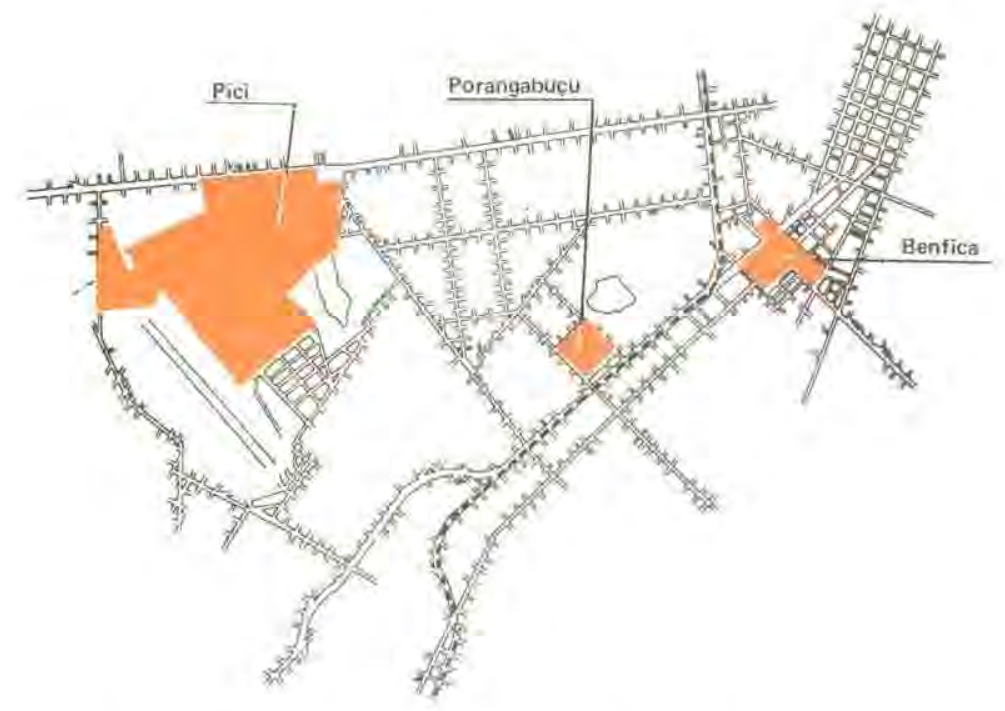

Figura 43: UFC - Mapa do zoneamento em três setores (Fonte: UFC, 1980, p.50)

A consolidação funcional seria obtida pelo gradativo remanejamento de parte das unidades entre os três setores, ao mesmo tempo que seriam construídas outras novas identificadas com o zoneamento proposto. Eles ficariam assim constituídos (ver figura 44):

- Setor A - permaneceriam as unidades de Ciências Sociais, Educação, Letras, Artes e órgãos da Administração Superior. Essas unidades, por desenvolverem atividades de extensão ligadas ao atendimento de expressivo contingente de público, seriam favorecidas pela localização próxima ao centro da cidade.

- Setor $B$ - permaneceriam as unidades de Ciências Biomédicas, praticamente consolidadas, contando inclusive com a presença do Hospital das Clínicas. Deveriam ser realizados os seguintes investimentos: conclusão do edifício da Faculdade de Farmácia, construção de novas instalações para a Faculdade de Odontologia e ampliação das unidades da Faculdade de Medicina.

- Setor C - permaneceria o conjunto da Agronomia e receberia as unidades do setor Tecnológico, bem como dos Institutos Básicos, transferidos do Benfica. Por constituir-se na área de maior extensão territorial, foi identificada como potencialmente capaz de vir a se transformar em território único. Os investimentos gradativos culminariam na concretização desse projeto, instrumentalizado pelo Plano de Desenvolvimento, orientador da futura conformação urbano-arquitetônica.

A Universidade era integrada também por unidades esparsas:

- Unidades Esparsas - abrangiam a construção do Setor de Arte Teatral e a Estação de Biologia Marinha em local a ser definido. 


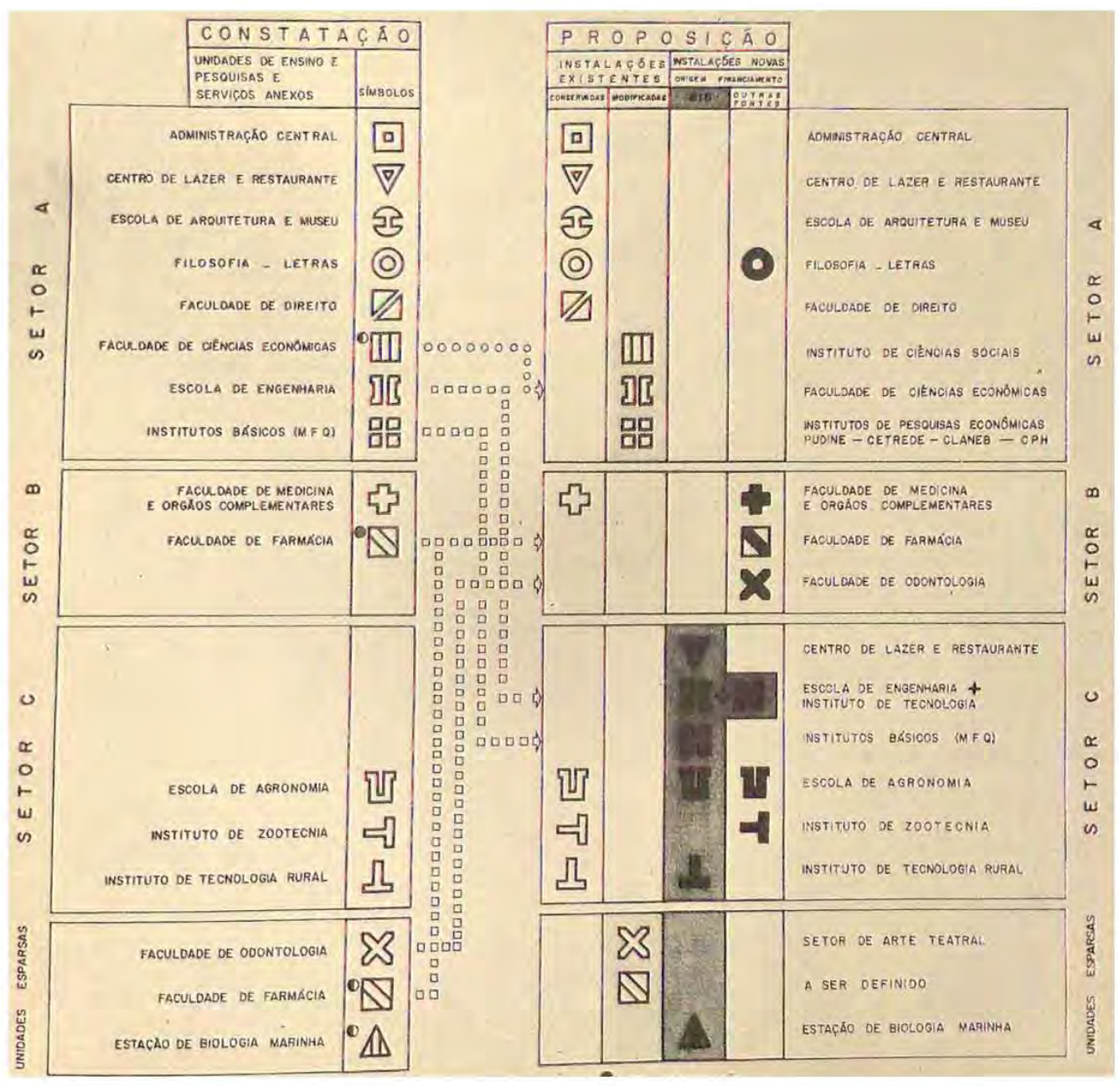

Figura 44: Plano de Desenvolvimento de 1966/1970.

Esquema de remanejamento das unidades estabelecido no para a formação das zonas funcionais.

(Fonte: UFC, 1966, n.p.)

Considerando as potencialidades do Setor $C$, o Plano definiu as bases do seu desenvolvimento físico, estabelecendo sua divisão em áreas funcionalmente predefinidas, considerando inclusive aquelas destinadas à expansão e à inserção de novas unidades que viessem a ser requeridas. Estavam esquematizadas as zonas Tecnológica (constituída pelos Institutos de Ciências Básicas e pela Escola de Engenharia) e Agronômica (com a Escola de Agronomia e institutos correlatos). Com a presença do Açude Santo Anastácio, identificado na planta como "lago", suas margens foram destinadas à implantação do setor de lazer e em pontos periféricos da gleba seriam instalados setores residenciais.

A organização espacial regida pelo princípio do zoneamento resultou no conjunto das áreas funcionais fisicamente separadas, porém articuladas por um sistema viário hierarquizado. Constituía-se da via perimetral de contorno, ramificada em vias secundárias que margeavam as zonas funcionais e propiciavam o seu acesso por meio de bolsões de estacionamento 
distribuídos e dimensionados conforme a localização dos edifícios e necessidades das unidades instaladas. Internamente a esse terreno foi projetada a circulação de pedestres, isolada do tráfego de veículos, assim concebida para proporcionar segurança e tranquilidade aos transeuntes. A mais alta cota de nível foi reservada para constituir-se em core permanente, caracterizando o campo cívico e o relacionamento social universitário (ver figura 45). A concepção adotada revela o entendimento de que a Universidade deveria ser um todo integrado, cabendo às bases do seu desenvolvimento físico garantir essa condição, o que ocorreria por meio da organização espacial funcional, subordinada ao crescimento racional orgânico.

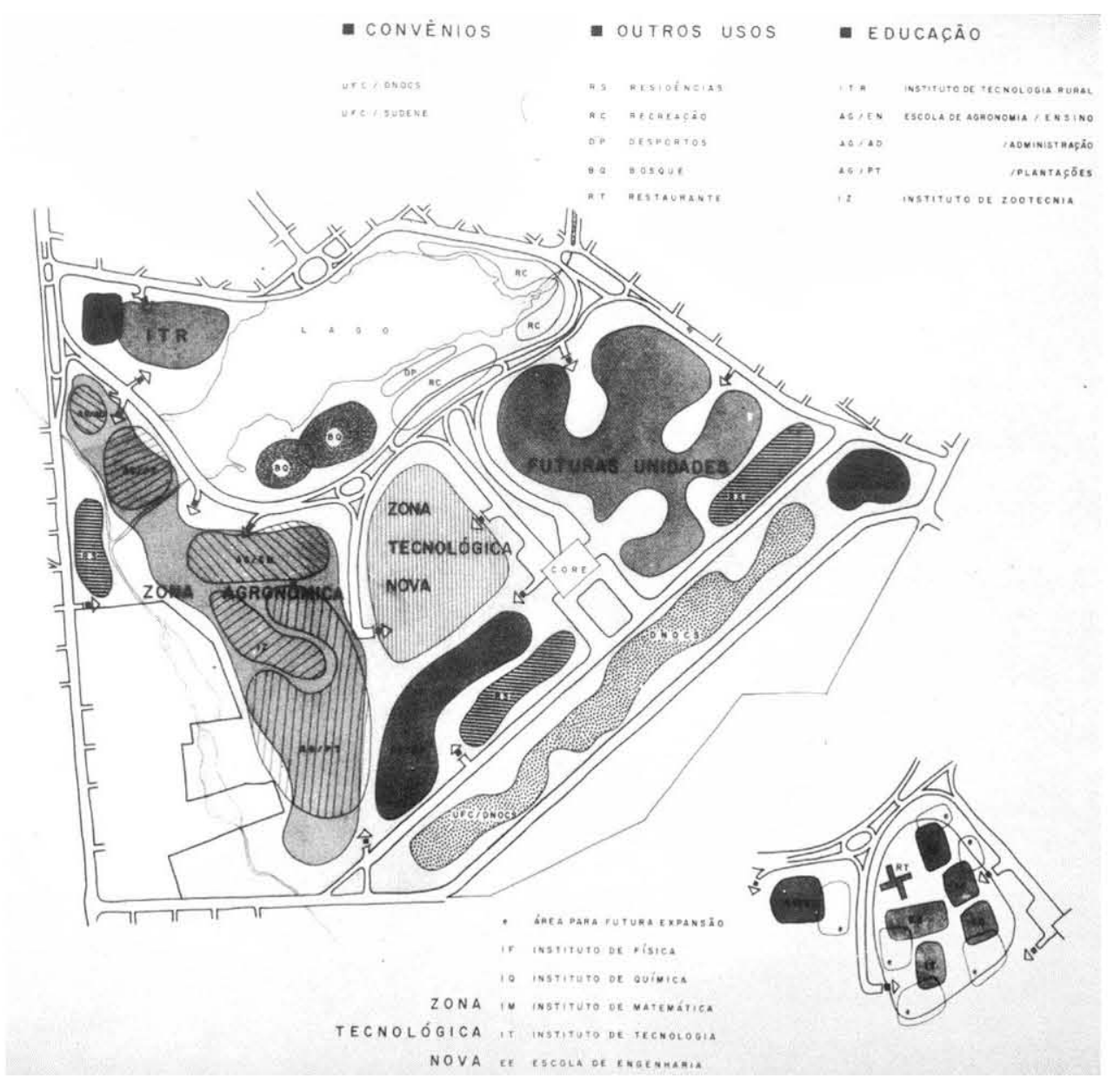

Figura 45: UFC - Zoneamento funcional proposto no Plano de Desenvolvimento de 1966 / 1970. (Fonte: UFC, 1966, n.p.)

O Plano também estabeleceu a concepção arquitetônica dos edifícios a serem implantados, que seriam regidos pelos princípios de racionalidade e flexibilidade, atributos necessários para garantir sua reprodução com economia e capacidade de adaptação às diversas solicitações acadêmicas. Com tais premissas o processo de projeto adotou, a partir do programa de necessidades, o conceito do zoneamento como princípio organizativo do arranjo espacial. Os conjuntos funcionais definidos seriam articulados pelas circulações, 
concebidas para eliminar confluências e distâncias desnecessárias, de forma a promover eficiência e celeridade no desenvolvimento das atividades. $O$ processo construtivo procuraria permitir adequaçâo espacial no atendimento de novas funçôes, com o mínimo de custos operacionais e financeiros, obtidos por meio da modulaçâo e consequente padronizaçăo dos componentes da edificaçẩo - princípios basilares da racionalidade almejada - além de dar unidade visual ao conjunto edificado. Facilidade construtiva e ausência de monumentalidade eram objetivos almejados.

Orientado pelas premissas acima referidas, o Plano sintetizou uma metodologia de projeto que consistiu em tipificar e ordenar as necessidades funcionais dos espaços, resultando na esquematização de sete blocos padrốes (caracterizados na figura 46) que poderiam ser associados, permitindo gerar a soluçẩo dos conjuntos programados para cada unidade, conforme esquema da figura 47 (CAMPELO, 2005, p.66-67). As unidades projetadas resultavam do processo de projeto que envolvia os conceitos do zoneamento funcional, da malha modular e da padronização construtiva, permitindo sua execuçäo com economia e rapidez (ver figuras 48 à 50 ).

SA-1 - Utilização: Salas de aula

Área coberta: $475 \mathrm{~m}^{2}$

Caracteristicas: compöe-se de quatro salas de aula para 50 alunos cada e conjunto sanitário:

GP - Utilização: Gabinetes de professores e oficinas leves.

Area coberta: $656 \mathrm{~m}^{2}$

Caracteristicas: Bloco de dois pavimentos para gabinetes de professores (individuais ou pera dois professores).

\section{CA - Utilização: Cantina}

Área coberta: $112 \mathrm{~m}^{2}$

Caracteristicas: compốe-se o bloco de uma área livre para estar e recreação e um pequeno reservado para serviços.

\section{AD - Utilização: Administração}

Área coberta: $1.300 \mathrm{~m}^{2}$

Características: Bloco de dois pavimentos para instalação da administração e serviços normais (diretoria, secretarias, almoxarifado, sanitários, etc). A área do segundo pavimento foi reservada para bibliotecae sala de reuniōes de professores e congregação.

\author{
SA-2 - Utilizaçăo: Salas de aula - Auditório \\ Área coberta: $218 \mathrm{~m}^{2}$ \\ Características: Auditório para 200 pessoas e \\ cabine de projeçāo.
}

OF - Utilização: Oficinas e salas de estudo

Área coberta: $900 \mathrm{~m}^{2}$

Caracteristicas: compōe-se de quatro oficinas e 22 boxes.

\section{CE - Utilização: Circulaçăo externa.}

Características: àrea que faz a ligação extema entre os blocos e áreas de recreaçăo e estar.

LBDp - Utilização: Laboratónos didáticos e de pesquisas.

Area coberta: $1,350 \mathrm{~m}^{2}$

Caracteristicas: Bloco de dois pavimentos, ficando quatro laboratórios didáticos no térreo e seis laboratórios de pesquisa no superior.

Figura 46: UFC - Caracterizaçẫo de blocos-padrốes.

(Fonte: UFC, 1966, ediçấo nossa) 


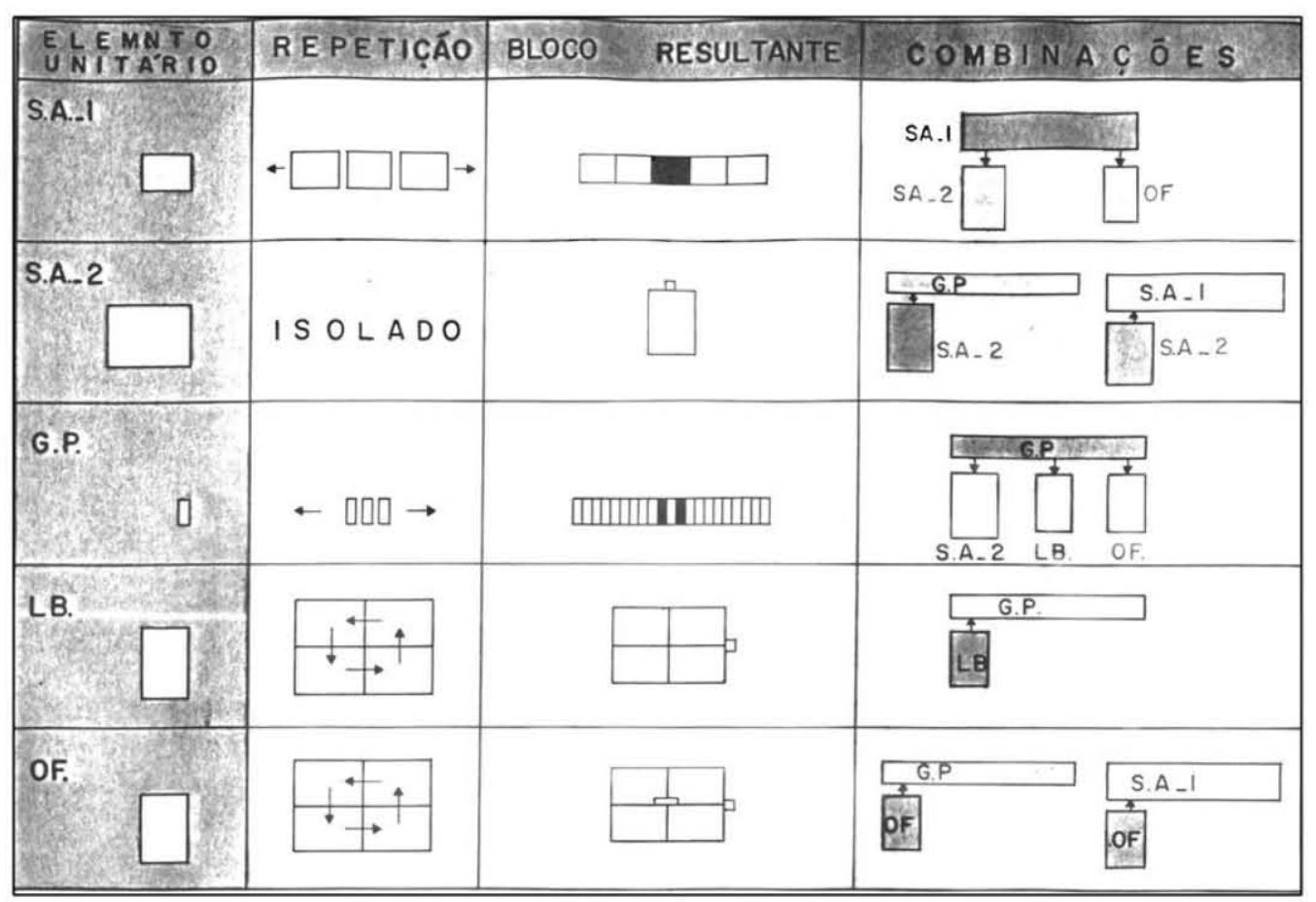

Figura 47: UFC - Esquema de associação dos blocos-padrões. (Fonte: UFC, 1966, n.p.)

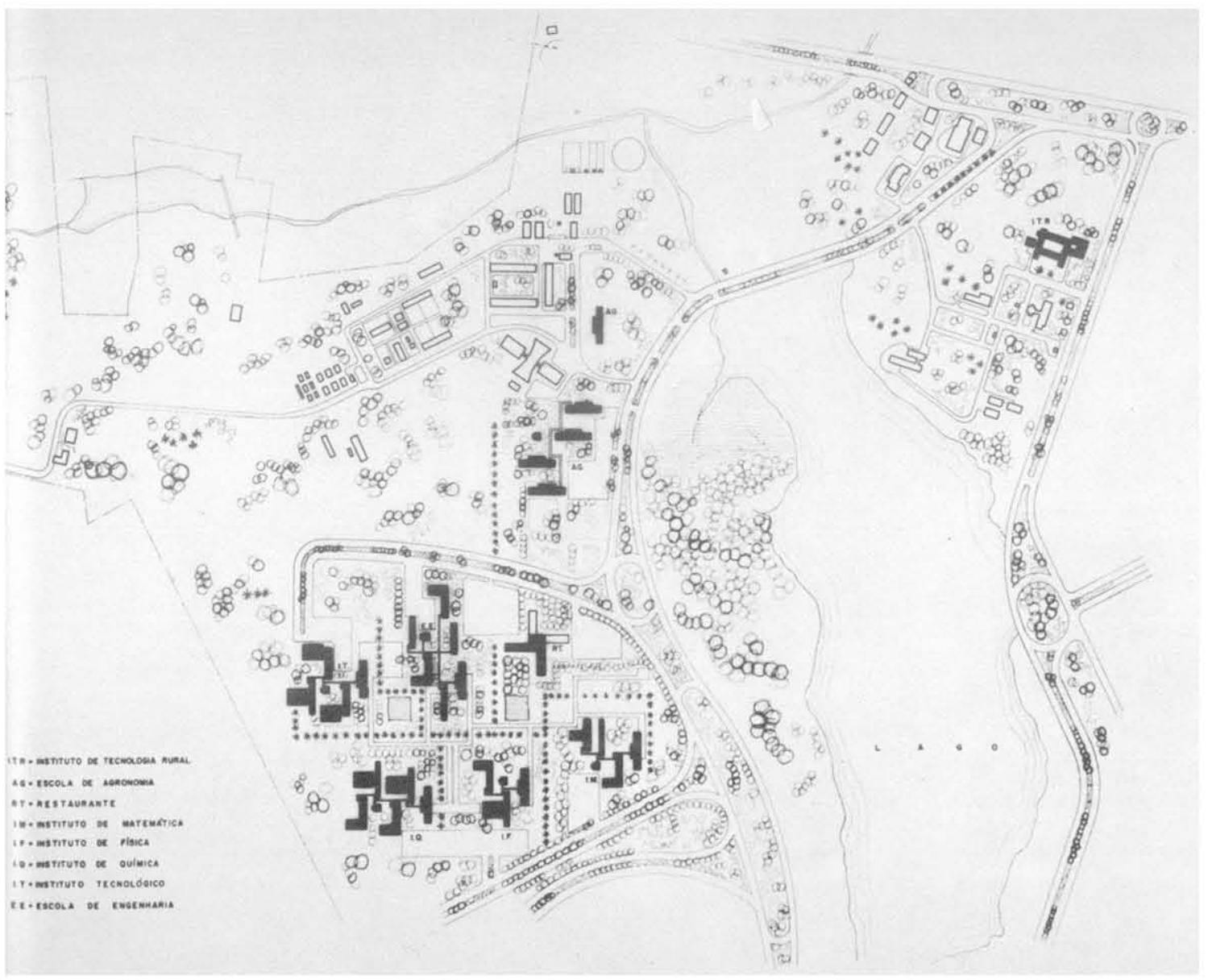

Figura 48: UFC - Implantação das unidades no Setor C. (Fonte: UFC, 1966, n.p.) 

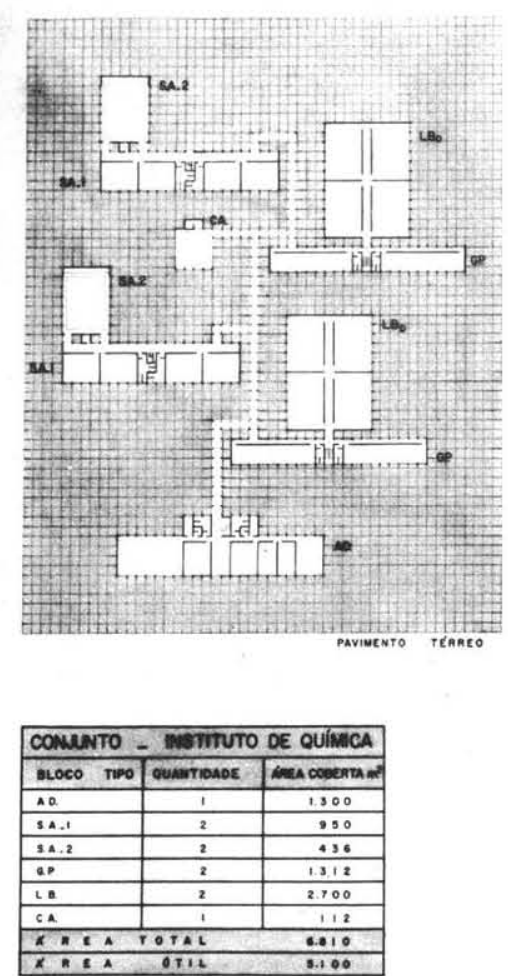

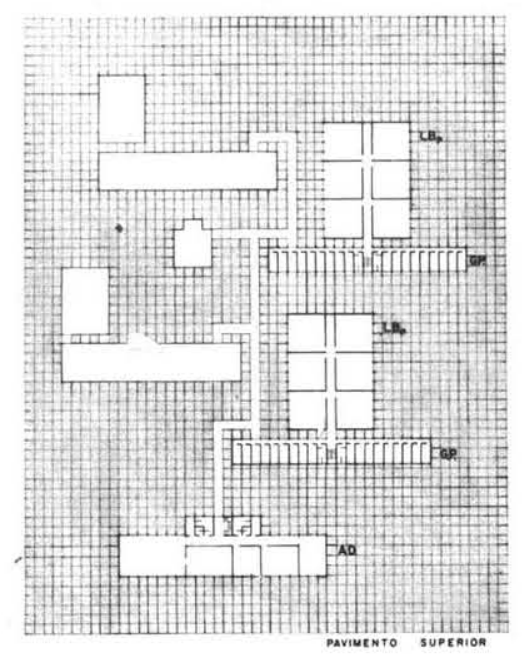

能

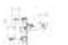

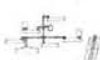

Figura 49: UFC - Instituto de Química.

Esquema de associação dos blocos-padrões para compor o Instituto de Química. Eles se articulam por meio de passarelas.

(Fonte: UFC, 1966, n.p.)

$A D$.
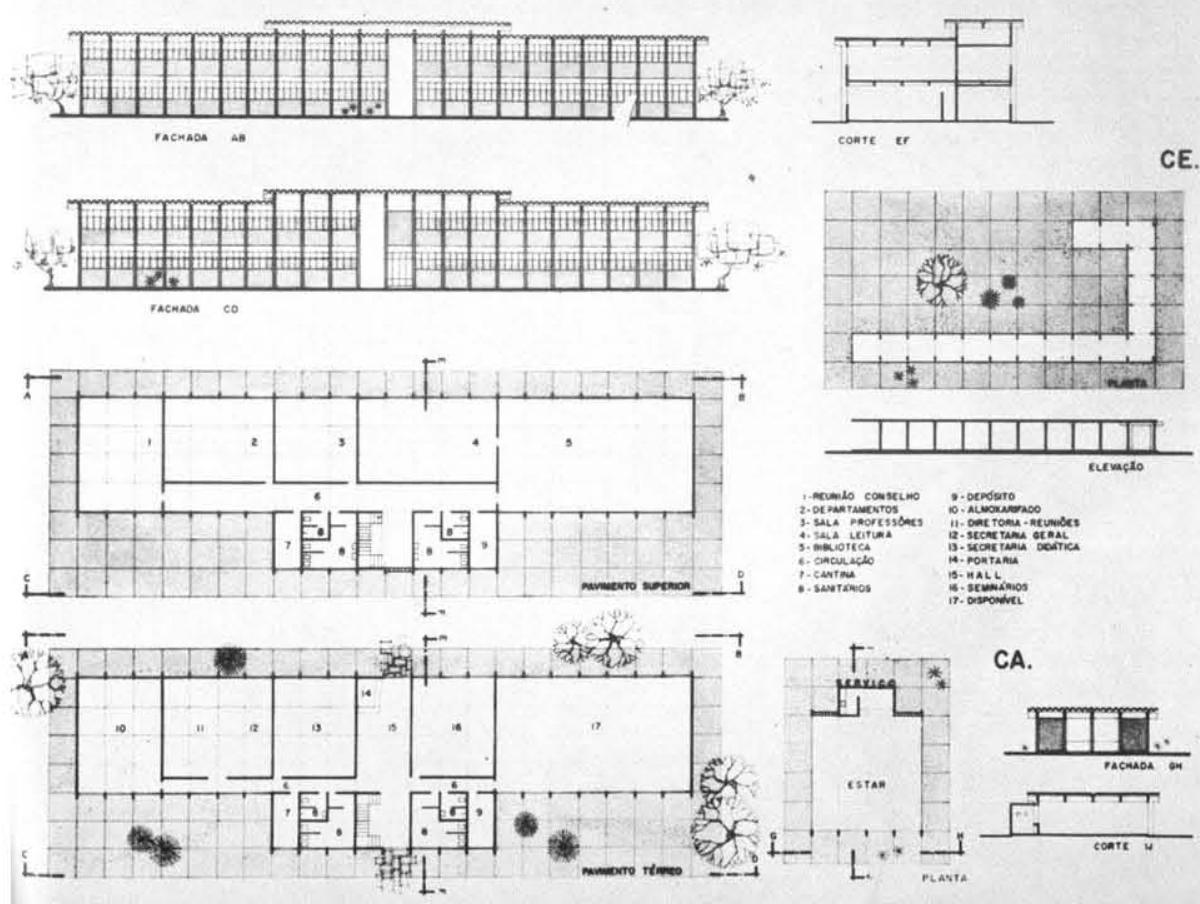

Figura 50: UFC - Associação dos tipos AD, CA e CE. (Fonte: UFC, 1966, n.p.) 
Plano não foi implantado conforme planejado. Sua execução estava vinculada aos recursos pleiteados junto ao BID, os quais foram garantidos em 1967 por meio do contrato conhecido como Acordo MEC/BID-1. Sua vigência, porém só veio a ser efetivada com o advento da Reforma Universitária de 1968, quando os investimentos contratados foram definidos. O Acordo teve, entretanto uma abrangência menor do que a projetada no Plano de Desenvolvimento e restringia o montante dos recursos pleiteados. Nessas condições foi necessária uma revisão das metas programadas e da organização espacial projetada.

\section{- Planos e Projetos da Reforma}

Com os recursos disponibilizados em 1970, outra proposta foi apresentada ao Programa MEC/BID-1 para a área do Pici, procurando adequar-se ao modelo de campus universitário preconizado na Reforma (1968) e que veio a se constituir nas bases do futuro Campus Universitário do Pici. Apoiado na nova estrutura acadêmica, o local passou a ser dividido em áreas acadêmico-científicas, de maneira que ao centro ficava os institutos básicos.

O aporte financeiro restringia sua aplicação à área de Ciências e Tecnologias Aplicadas. Foi construída a Escola de Engenharia com $7.870 \mathrm{~m}^{2}$ de área, iniciados os blocos dos Departamentos de Química, Física e Matemática e os primeiros conjuntos do Laboratório de Ciências do Mar com $3.055 \mathrm{~m}^{2}$ de área, estes localizados na orla maritima de Fortaleza. Com a nova organização espacial, a construção das referidas unidades na área do Pici não obedeceu à localização original indicada no Plano de Desenvolvimento (1966). Por este projeto a Zona Tecnológica seria constituída pela Escola de Engenharia e pelos Institutos Básicos, conforme anteriormente mencionado. Obedecendo ao zoneamento do projeto reformista, os Institutos, transformados em Básico Geral, foram deslocados para uma posição centralizada, em torno da qual seriam gradativamente construídas as outras unidades, a exemplo das novas instalações da Escola de Engenharia previstas para serem iniciadas. O sistema viário era composto por uma via principal, projetada como único acesso ao Campus, que se prolongava transformando-se em uma via periférica circundando o núcleo central comum formado pelas unidades de ciências básicas, conforme se constata na planta da figura 51. No decorrer da década de 1970, a proposta foi parcialmente executada, mantendo a configuração básica do urbanismo projetado.

A proposta evidencia claras referências ao Manual de Atcon (1970), onde o território estava dividido em zonas funcionais, constituídas pelas áreas acadêmico-científicas, administrativas e de serviços, que se distribuíam em torno do setor básico, ficando resguardadas pela via de circulação periférica ("anel protetor") e com os setores e equipamentos de acesso público situados em áreas contíguas. 
Parte 2 - Universidade Federal do Ceará

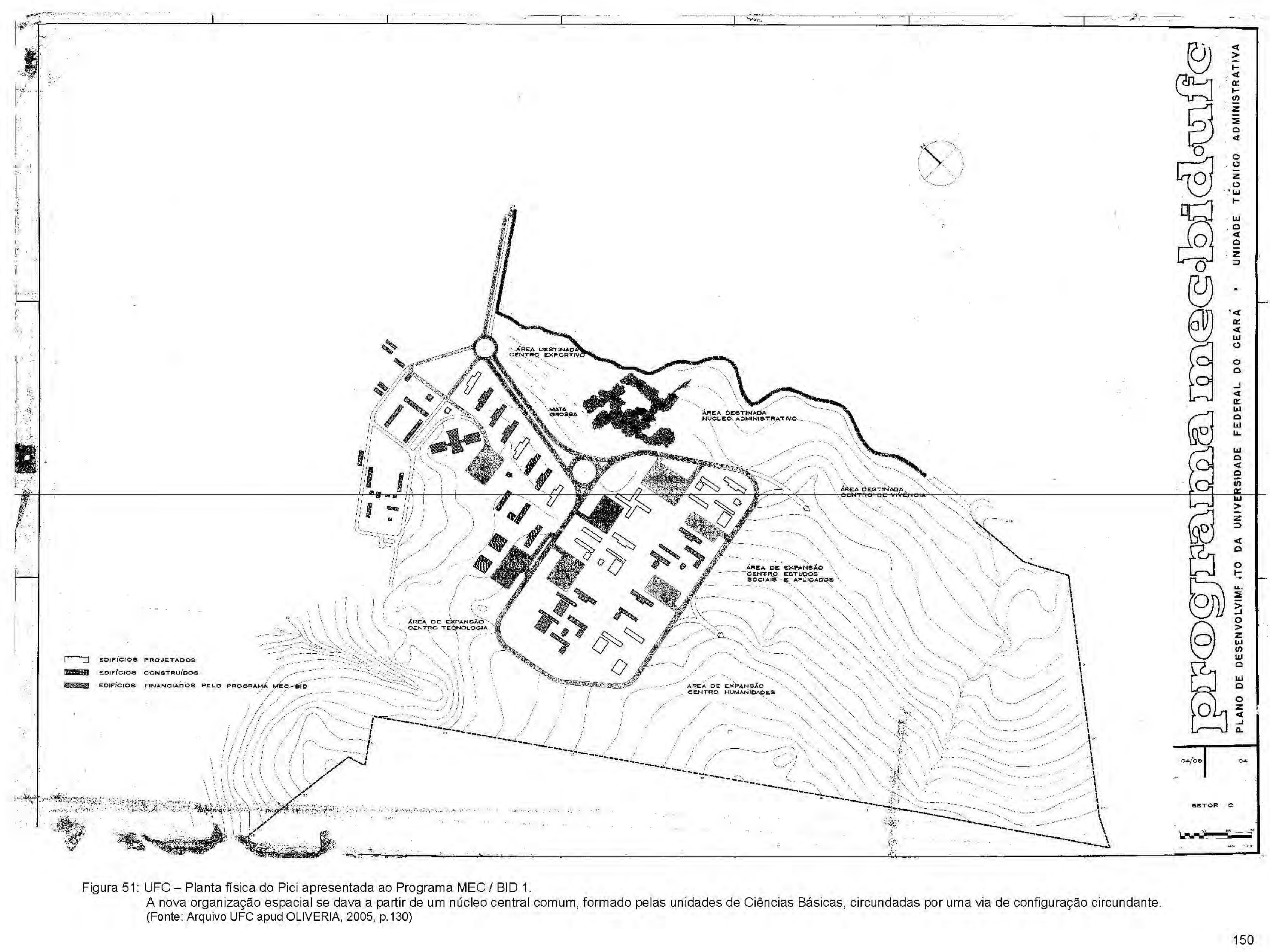


A partir daquela proposta podemos constatar que com a nova estrutura acadêmica imposta pela Reforma (1968) a linha de orientação na formação do território da UFC foi alterada. Até aquela data, a organização espacial vinha sendo determinada pelas gradativas mudanças introduzidas na estrutura organizacional da instituição.

A partir de 1968 , esta lógica se inverte, com o arranjo físico sendo configurado para moldar uma nova estrutura funcional, passando de condição acessória a fator de garantia real da implantação da nova estrutura de funcionamento das universidades que, conforme os ideais da reforma universitária se pretendi

Esta inversão no papel desempenhado pelo espaço físico passou a ser a característica dominante que presidiu a concepção de campus nos vários projetos que a UFC desenvolveu vinculados aos acordos MEC/BID durante a primeira metade da década de 1970 (OLIVEIRA, 2005, p.126).

\section{- Primeira Proposta: referências ao Manual de Atcon (1970)}

Diante do ideal reformista de uma instituição funcional e integrada, a composição da base física em três setores distintos passou novamente a ser questionada pela UFC, considerando a premência de reformulá-la em território único embasado no modelo de campus universitário propalado pela Reforma (1968).

Oportunamente, a elaboração do II Plano de Desenvolvimento, que tinha o objetivo de consolidar os investimentos do programa MEC/BID 1, culminou com o resgate das ideias do Plano de 1966 que identificava as potencialidades da área do Pici em vir a se transformar no futuro território único da UFC, devido às suas características de extensa gleba e possibilidade de anexar terrenos vizinhos [já mencionado]. Entretanto, imposições de ordem financeira e recusa da classe médica inviabilizaram a transferência das unidades da saúde instaladas no Porangabuçu que contava com hospital, maternidade e ambulatórios em funcionamento. Em tais condições, foi instituído oficialmente, em 1972, o primeiro projeto de campus universitário da Reforma (1968): O Campus do Pici com uma área de Ciências da Saúde no Porangabuçu (ver figura 52).

A configuração com áreas de localização distinta contrariava, entretanto a proposta da Reforma. A justificativa foi dada no documento intitulado Avaliação da Reforma Universitária no Âmbito de uma Universidade: a Universidade Federal do Ceará, publicado em 1973, que assim expressava: 
O novo campus, na realidade a expansão natural do polo inicial representado pela Escola de Agronomia, virá a oferecer realmente unidade à UFC, sem prejuízo de uma divisäo funcional das áreas e dos espaços para a realização de todos os atos acadêmicos, com representaçăo harmônica de todos os símbolos da mesma universidade, desde os anfiteatros às praças de conveniência (MEC, 1973, p.70).

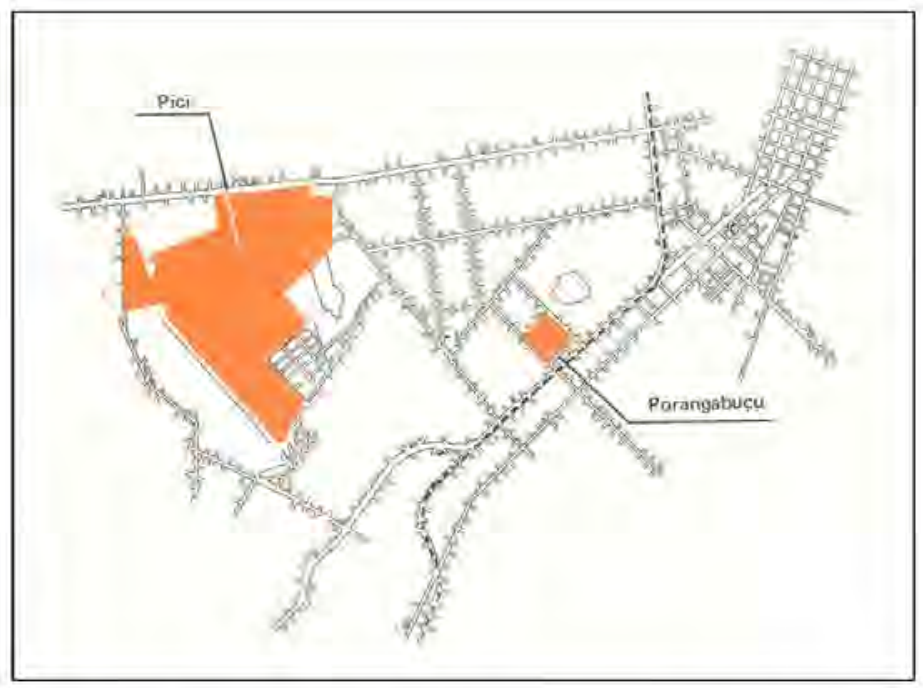

Figura 52: UFC - Proposta do campus universitário constituido pelas áreas do Pici e Porangabuçu1972. A divisão em áreas distintas contrariava a proposta da Reforma Universitária de 1968. (Fonte: UFC, 1980, p.51 apud CAMPÉLO, 2005, p.58)

Em relação à permanência das unidades da saúde no Porangabuçu, o documento manifestava que a dispersão seria superada por se encontrarem num eixo de apenas 1800 metros de distância, percorrida por vias naturais de acesso fácil e amplo (MEC, 1973, p.70). Além do que se constatava que o seu distanciamento em relação ao Pici favorecia o afastamento da grande massa não acadêmica das áreas de convivência do campus (MEC, 1973, p.70).

A proposta apresentada no II Plano de Desenvolvimento considerava uma área maior do que aquela pertencente à UFC e a organização espacial resultava do conjunto de zonas funcionais, constituidas pelas faculdades que seriam agregadas formando os centros, implantados em torno do Setor Básico, seguindo o mesmo princípio de organização iniciado na proposta do programa MEC /BID - 1. Complementando a estrutura do campus estavam previstos nas áreas periféricas do terreno o setor esportivo e o de vivẽncia, em cujas circunvizinhanças estavam as habitaçōes para professores e estudantes. Indicava também um setor de administração do campus, incluído pela complexidade da nova estrutura que se formava (ver figuras 53 e 54) 


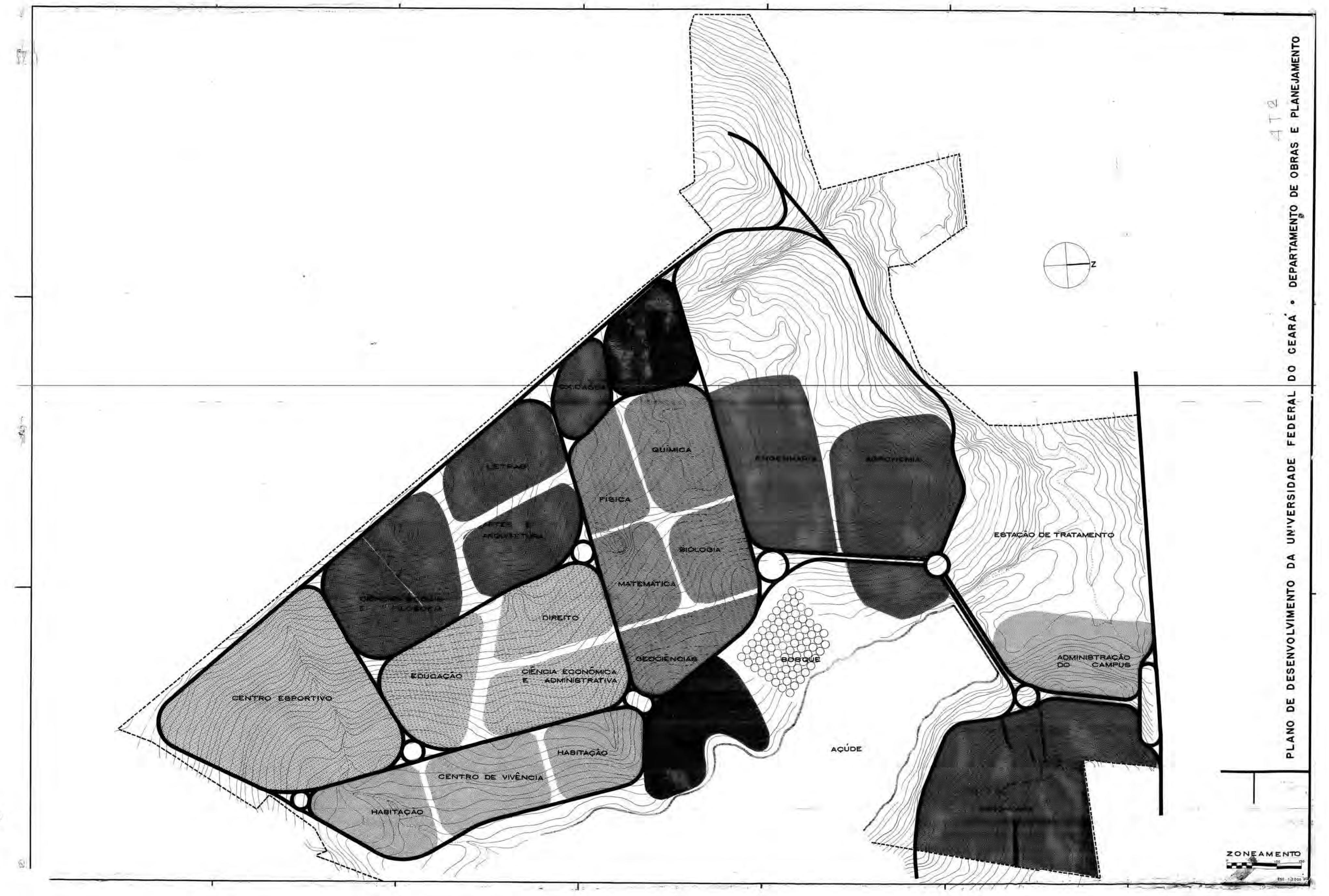




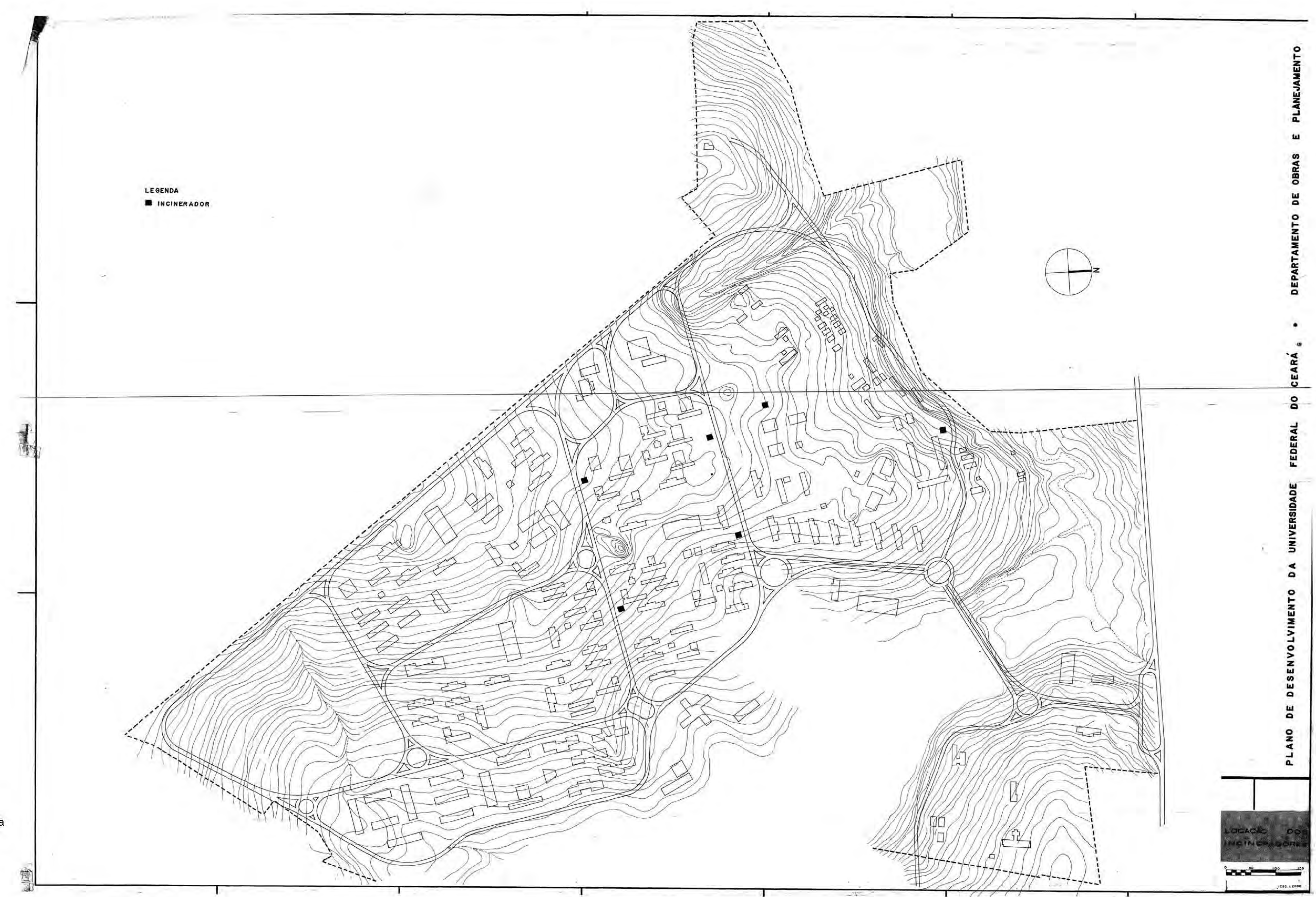


O sistema viário mantinha o anel circundante do Setor Básico e criava outros relacionados com as zonas funcionais projetadas. Conservava o acesso único, contribuindo para enfatizar - caráter de segregação, de isolamento da cidade, fazendo o Campus se constituir em aglomerado apartado, autônomo, voltado para dentro e preocupado exclusivamente com as relações que se estabeleceriam entre suas próprias partes. Essa característica diferia do Plano de Desenvolvimento de 1966/1970, cuja proposta estava articulada com a estrutura urbana. Herdava, entretanto a mesma tipologia de edifícios e a padronização construtiva, que seriam construídos por etapas, permitindo o funcionamento dos centros na medida em que se dava sua expansão.

Efetivamente, do proposto foram executadas apenas as redes de infraestrutura e urbanização dos setores existentes e já iniciados como os da Agronomia, Engenharia e Institutos Básicos; consolidada a configuração geral do Setor Básico; e definida a atual localização do Setor de Esportes, cuja construção foi iniciada pela pista de atletismo para atender aos Jogos Universitários Brasileiros de 1972, realizados em Fortaleza (ver figura $55)$.

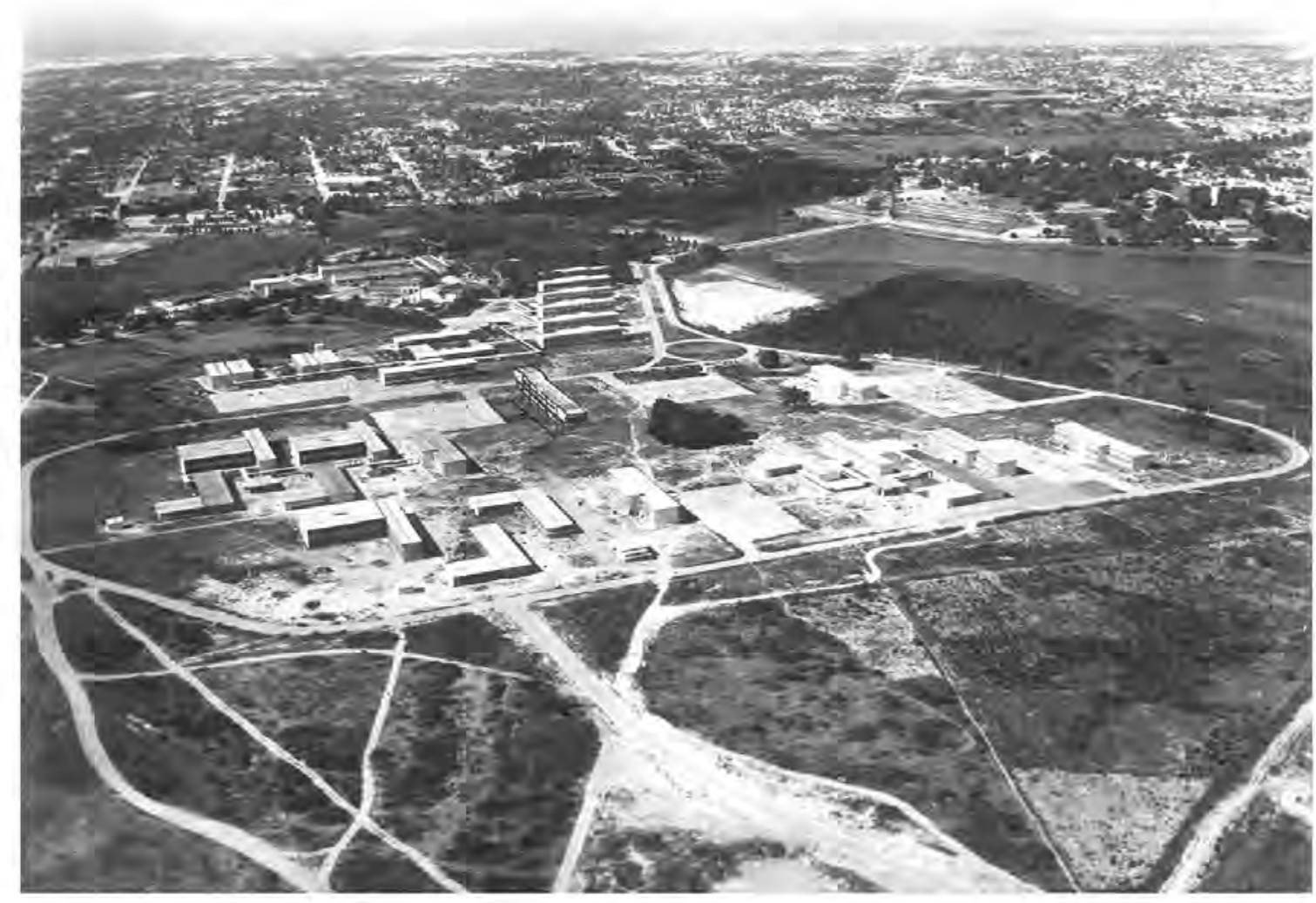

Figura 55: UFC - Vista área do Campus do Pici na década de 1970.

Mantendo as diretrizes urbanísticas da proposta apresentada ao MEC / BID 1 tem-se em primeiro plano, o Centro de Ciências circundado pelo anel viário (protetor) e ao fundo, o Centro de Tecnologia e o Centro de Ciências Agrárias - áreas acadêmico-científicas distribuídas em torno do setor básico.

(Fonte: PLANOP / UFC apud CAMPÊLO, 2005, p.59) 


\section{- Segunda Proposta: tentativa de um território unificado}

A validade de um campus com duas áreas (Pici e Porangabuçu) passou posteriormente a ser questionada em decorrência das dificuldades que vinham sendo enfrentadas para desapropriar terrenos no Porangabuçu com vistas à expansão das unidades ali instaladas e especificamente pelo impasse gerado para a construção das novas instalações da Faculdade de Odontologia, que ainda funcionava no centro da cidade.

Uma segunda proposta foi elaborada a partir da primeira, procurando incorporar a área do Centro de Ciências da Saúde. Entretanto, o Plano destinava para esse Centro apenas uma área para o prédio da Odontologia, ou seja, uma unidade isolada, contrariando o modelo da Reforma que vinha sendo proposto.

O urbanismo proposto mantinha o mesmo princípio de organização funcional a partir da formação de setores especializados, resultado do agrupamento das faculdades para a criação dos centros correspondentes às respectivas áreas de conhecimento afins (ver figura 56). Diferia da proposta anterior por eliminar o setor da habitação, o que segundo Oliveira (2005, p.138) pode ter sido vetado pelos analistas do MEC. Incorporava um segundo acesso ao campus pelo lado sul do terreno, possibilitando uma possível integração com a estrutura urbana da cidade, já que permitia cruzar o campus por meio de um sistema viário geral.

A construção do prédio destinado à Faculdade de Odontologia foi iniciada, porém a restrição por parte da classe médica que mantinha a rejeição referente à transferência do Centro de Ciências da Saúde para o Pici, impediu o seu prosseguimento. A obra, que já contava coma estrutura de concreto, ficou inacabada até a década de 1980, quando passou a ser ocupada com outras finalidades.

\section{- Terceira Proposta: um novo zoneamento}

Em 1973, o Decreto $n^{\circ} 71.882$ firmou a estrutura da UFC, dando-lhe o delineamento proposto pela Reforma Universitária de 1968. Ficava oficialmente constituída pela Reitoria (Órgãos Administrativos, de Coordenação, Suplementares e Auxiliares) e seis centros: Centro de Ciências, Centro de Humanidades, Centro de Tecnologia, Centro de Ciências Agrárias, Centro de Ciências da Saúde e Centro de Estudos Sociais Aplicados (UFC, 1974, p.19).

Com base na estrutura acima mencionada, naquele mesmo ano, foi desenvolvida uma terceira proposta apresentada no "Projeto de Expansão do Campus". Da mesma forma que as anteriores, a configuração do Campus resultava da organização das zonas funcionais articuladas pelo sistema de vias hierarquizadas. Mantinha praticamente o mesmo desenho, porém adequando outras funções. Não mais constava a previsão da Faculdade de 
Figura 56: UFC - Planta geral do Campus do Pici. Incorporando o setor da saúde.
(Fonte: Arquivo UFC apud OLIVERIA, 2005,
p.135)

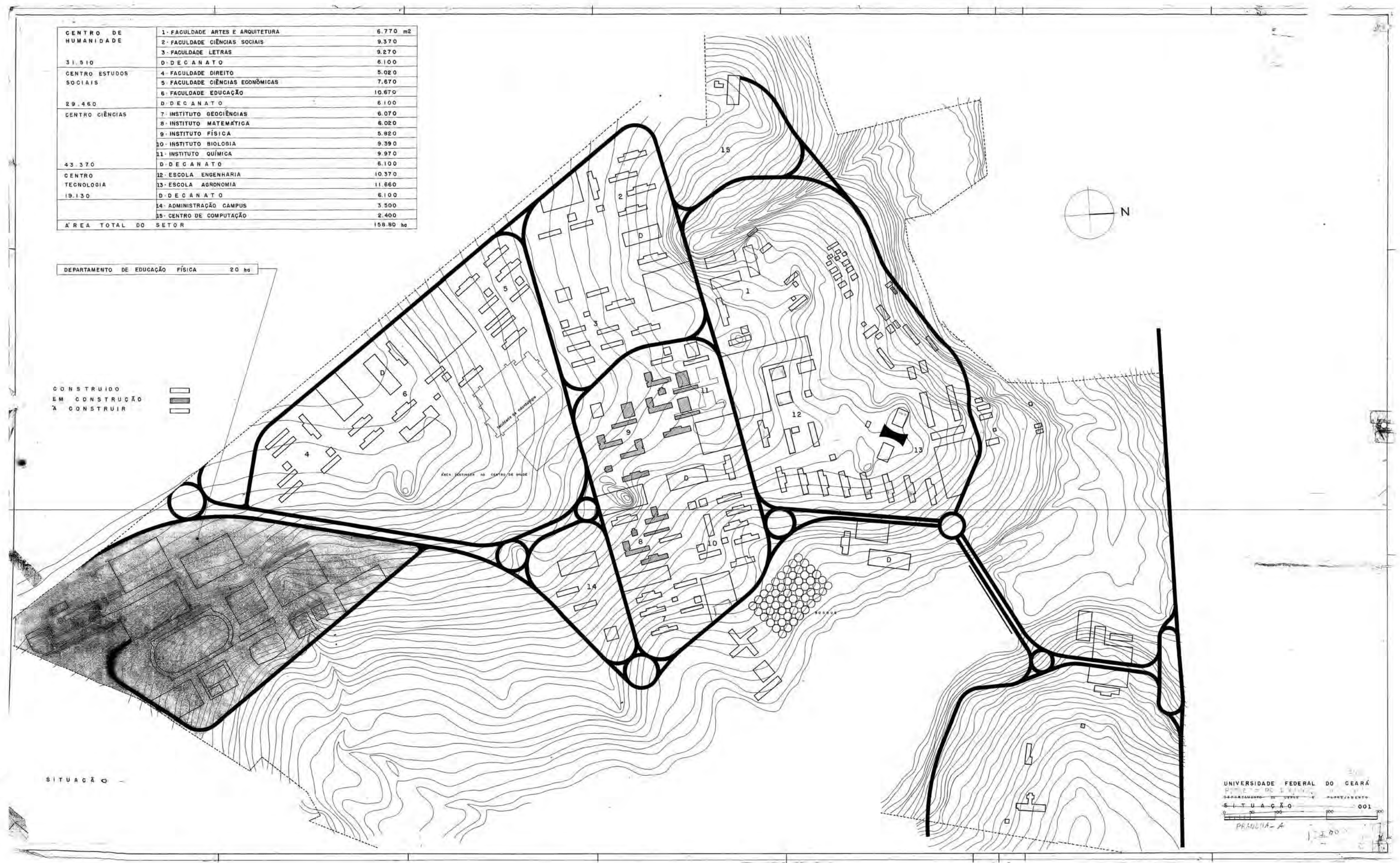


Parte 2 - Universidade Federal do Ceara 
Odontologia, porém incorporava um setor destinado à Administração Superior da Universidade, que ocupava localização destacada na entrada do Campus, ficando, entretanto isolada dos demais setores em função da presença do Açude Santo Anastácio, que atravessa o terreno na direção sudeste-noroeste. $O$ local selecionado estava em concordância com as recomendações do Manual de Atcon (1970) que orientava para que as áreas de acesso ao público externo deveriam ficar em pontos periféricos, próximas à via principal de acesso, evitando assim interferência nas atividades da Universidade. $\mathrm{Na}$ margem oposta do açude, estavam previstos equipamentos de uso comum tais como a Biblioteca, Restaurante e o Centro de Processamento de Dados, os quais foram executados no decorrer da mesma década. A proposta, conforme apresentada na figura 57 , mais uma vez não se consolidou na íntegra: o sistema viário não foi executado na sua totalidade e a reitoria permaneceu na área do Benfica.

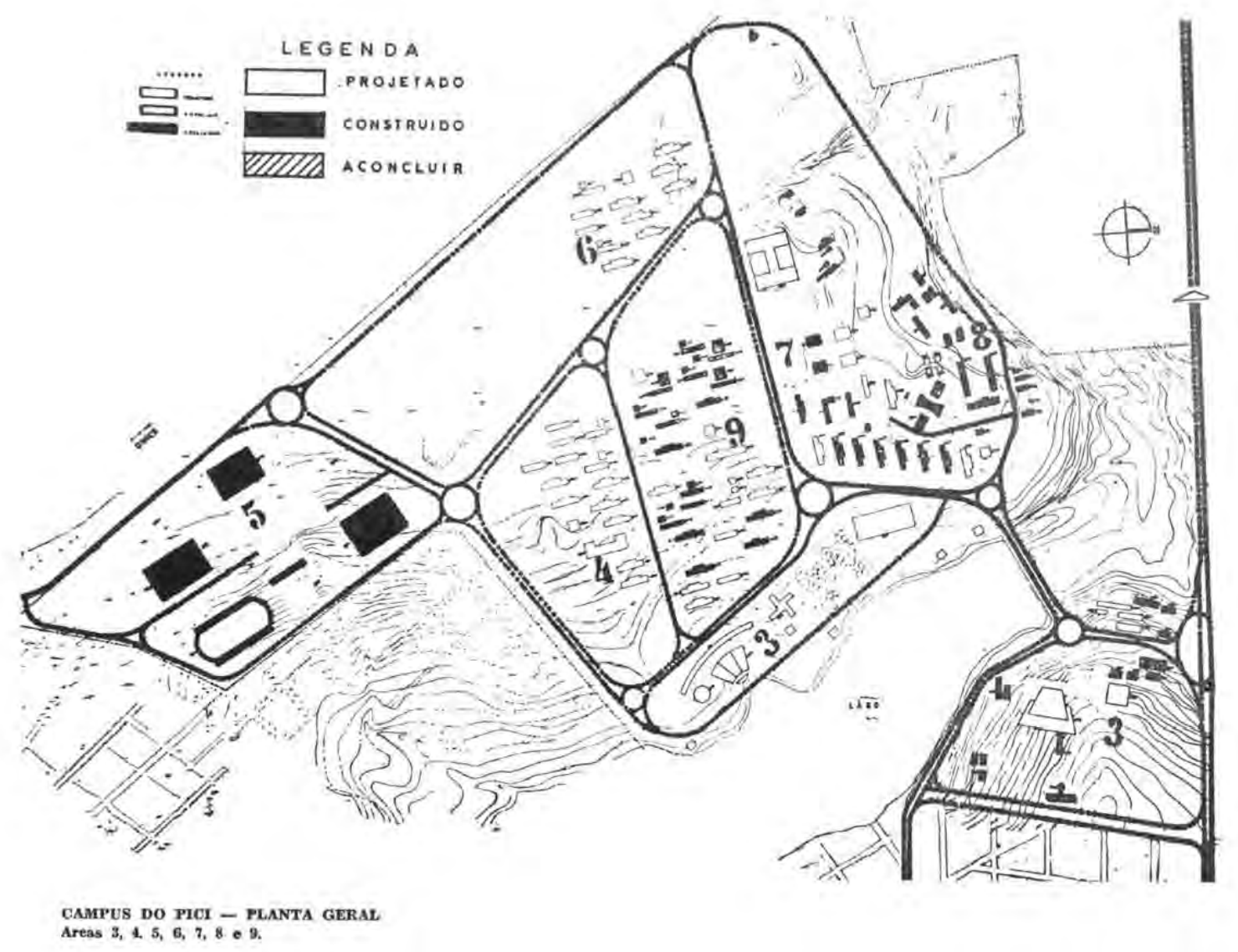

Figura 57: UFC - Planta geral do Campus do Pici.

O zoneamento incluía a Administração Central e equipamentos de utilização comum (Restaurante, Biblioteca, Centro de Processamento de Dados). Legenda:
3. Administração Superior
7. Centro de Tecnologia
4. Centro de Estudos Sociais Aplicados
5. Área dos Esportes
8. Centro de Ciências Agrárias
6. Centro de Humanidades
9. Centro de Ciências

(Fonte: UFC, 1974, p. 15 apud CAMPÉLO, 2005, p. 58) 
- Plano Diretor de 1979: a permanência do isolamento

Em 1979, quando a UFC já estava questionando a validade da Reforma Universitária e consequentemente a transferência das suas unidades para o Campus do Pici, a Administração Superior decidiu elaborar um Plano Diretor do Campus, de modo a tomar uma posição definitiva em relação ao desenvolvimento das bases físicas da Instituição.

O Plano retoma a proposta de um zoneamento funcional definido pelas três áreas nas quais a Universidade já vinha concentrando as instalações desde sua origem. Com nova denominação estavam assim definidas (ver figura 58):

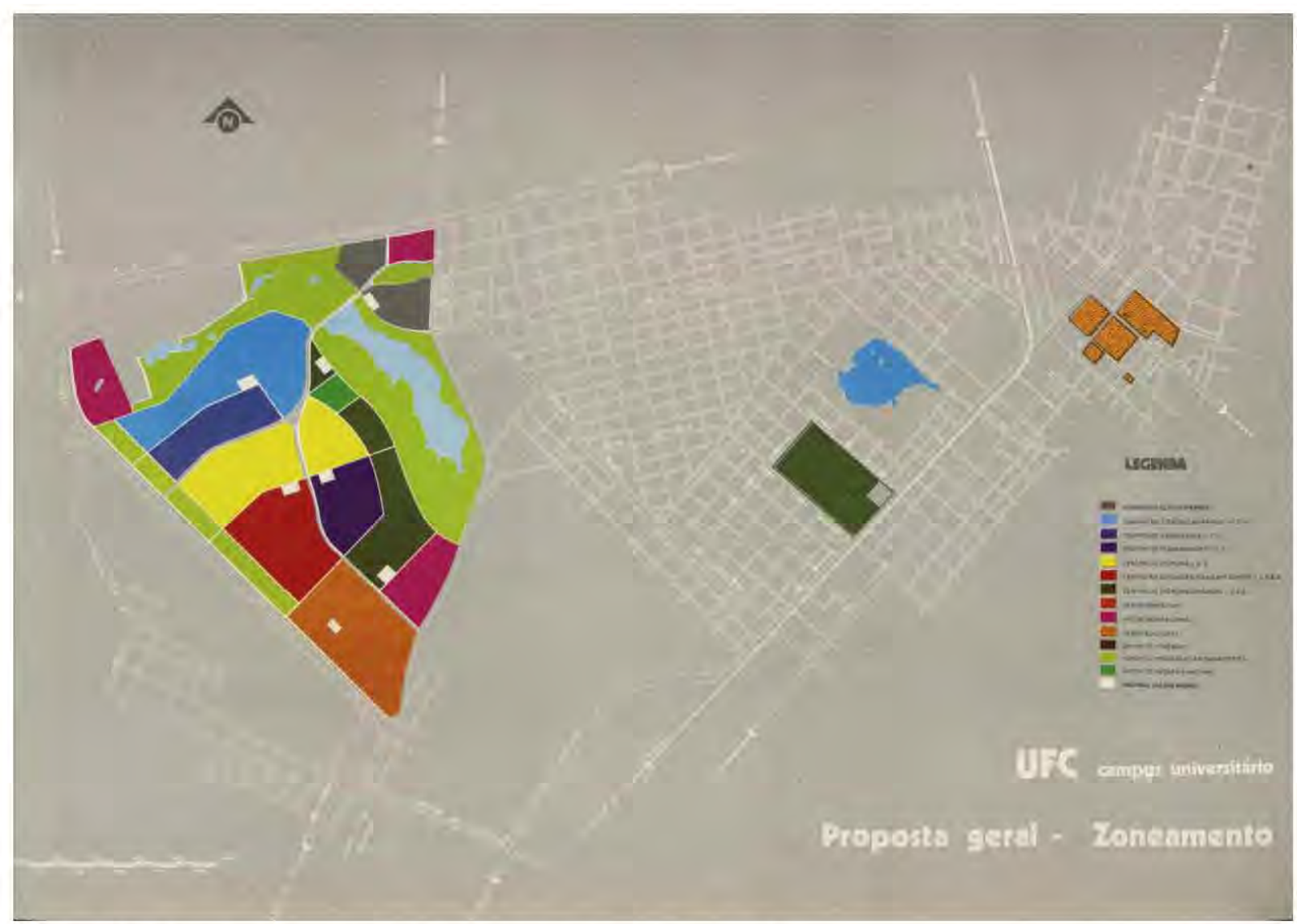

Figura 58: UFC - Campus Universitário - Zoneamento Geral.

Formado por três áreas distribuídas na cidade, consolidando a situação existente (Fonte: UFC, 1980, p. 79)

- ÁREA 1 - Correspondendo à gleba do Pici, abrangia as instalações da Administração Superior (Reitoria e Órgãos Complementares), Setor Esportivo, Setor de Vivência (incluindo a Biblioteca Central e o Restaurante), Setores Habitacionais (para servidores) e os Centros de Ciências, Humanidades, Estudos Sociais Aplicados, Ciências Agrárias e Tecnologia.

- ÁREA 2 - Localizada no Porangabuçu, permanecia com as instalações do Centro de Ciências da Saúde, incorporando áreas de vivência relativas ao Centro. 
- ÁREA 3 - Situada no Benfica, compreendia as instalações ligadas às atividades de extensão e artístico-culturais (Museu de Arte, Centros de Cultura, Setores de Música, Teatro e Cinema, Concha Acústica e o prédio da Reitoria abrigaria as atividades de extensão) a Imprensa Universitária e Residências Universitárias.

Assim como no Plano de Desenvolvimento de 1966 / 1970, as áreas ficariam integradas pelo sistema viário da cidade, através dos seus corredores de circulação (ver figura 59).

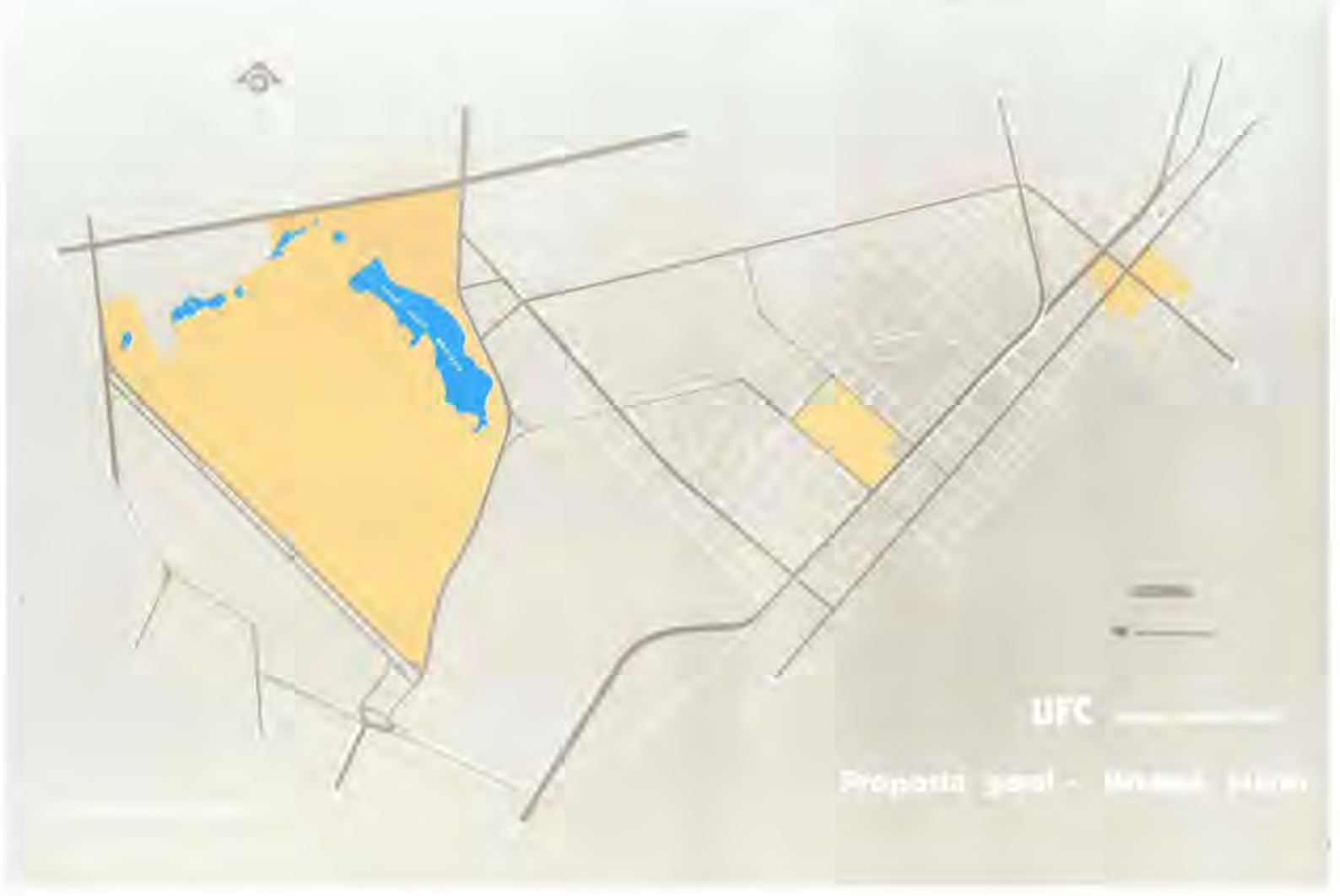

Figura 59: UFC - Campus Universitário - Proposta geral do sistema viário.

As três áreas se interligavam por vias da malha urbana.

(Fonte: UFC, 1980, p. 83)

Assim como nas propostas anteriores, a área do Pici ficou reservada para reunir a maior concentração de unidades, abrangendo os órgãos da Administração Superior, o Setor de Vivência, o Setor Esportivo e, também, cinco dos seis Centros (definidos no Decreto $\mathrm{n}^{\circ}$ 71.882 / 1973 - já mencionado - ficando fora apenas o Centro de Ciências da Saúde) que, na época, compunham sua estrutura acadêmica, além de conjuntos habitacionais para servidores.

Mantendo a mesma concepção de território isolado, os setores funcionais eram fisicamente definidos por um sistema de vias internas, limitadas por uma via principal periférica, destinada ao transporte coletivo (ver figuras 60 e 61). Esta interligava as unidades a três 
terminais coletores, localizados na periferia do Campus em pontos estratégicos de acesso e distribuição. Complementavam o sistema viário, as chamadas vias de penetração que conduziam aos estacionamentos setoriais, concepção que proporcionava a separação entre tráfego de veículos e pessoas de modo a garantir segurança ao trânsito de pedestres.

Tirando partido dos recursos naturais existentes, como a presença do Açude Santo Anastácio, suas margens foram pensadas para implantar o Setor de Vivência, como na proposta de 1973. Aspecto importante é a tentativa de atenuar a condição de espaço segregado. No sentido de promover uma maior integração do Campus com a cidade,

[...] o zoneamento proposto abrangeu uma área maior do que os terrenos pertencentes à Universidade, permitindo a definição do seu contorno, utilizando-se as próprias ruas do sistema viário básico como limites. As desapropriações previstas nesta disposição permitiram definir um contorno servido por importantes vias da malha urbana, onde circula o sistema de transporte coletivo ligando esta área a todos os pontos da cidade (OLIVEIRA, 2005, p.142).

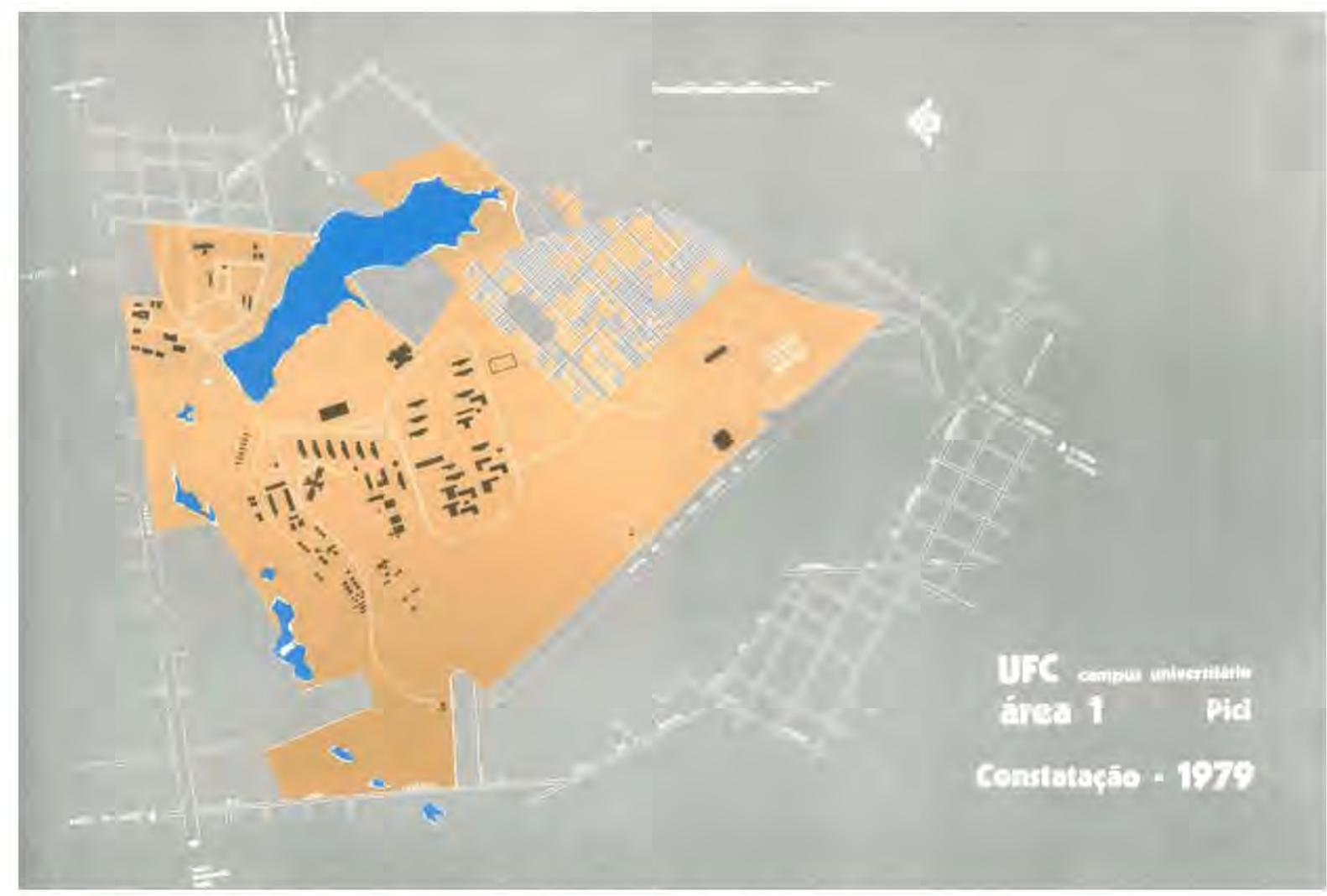

Figura 60: UFC - Campus Universitário Área 1 - Constatação 1979.

Foi constatado que em 1979 havia uma ocupação de baixa densidade, caracterizada pela relação da gleba de grande extensão e algumas unidades implantadas.

(Fonte: UFC, 1989, p.96) 
A organização espacial resultante da junção de setores embasados pelo princípio da especialização funcional, com acessos e estacionamentos próprios, separados entre si pelo sistema viário ou por elementos da paisagem natural tornando-os territórios setoriais autônomos, revela sua concepção de caráter segregador. Mesmo os locais destinados à integração da comunidade universitária - setores esportivos, de vivência, da administração superior e da habitação - estavam concebidos como áreas independentes, sem estabelecer relações com os demais. Independentes entre si e sem pontos de convergência natural dos fluxos internos, a proposta indicava a produção de um espaço fadado à incapacidade de promover a integração ensejada.

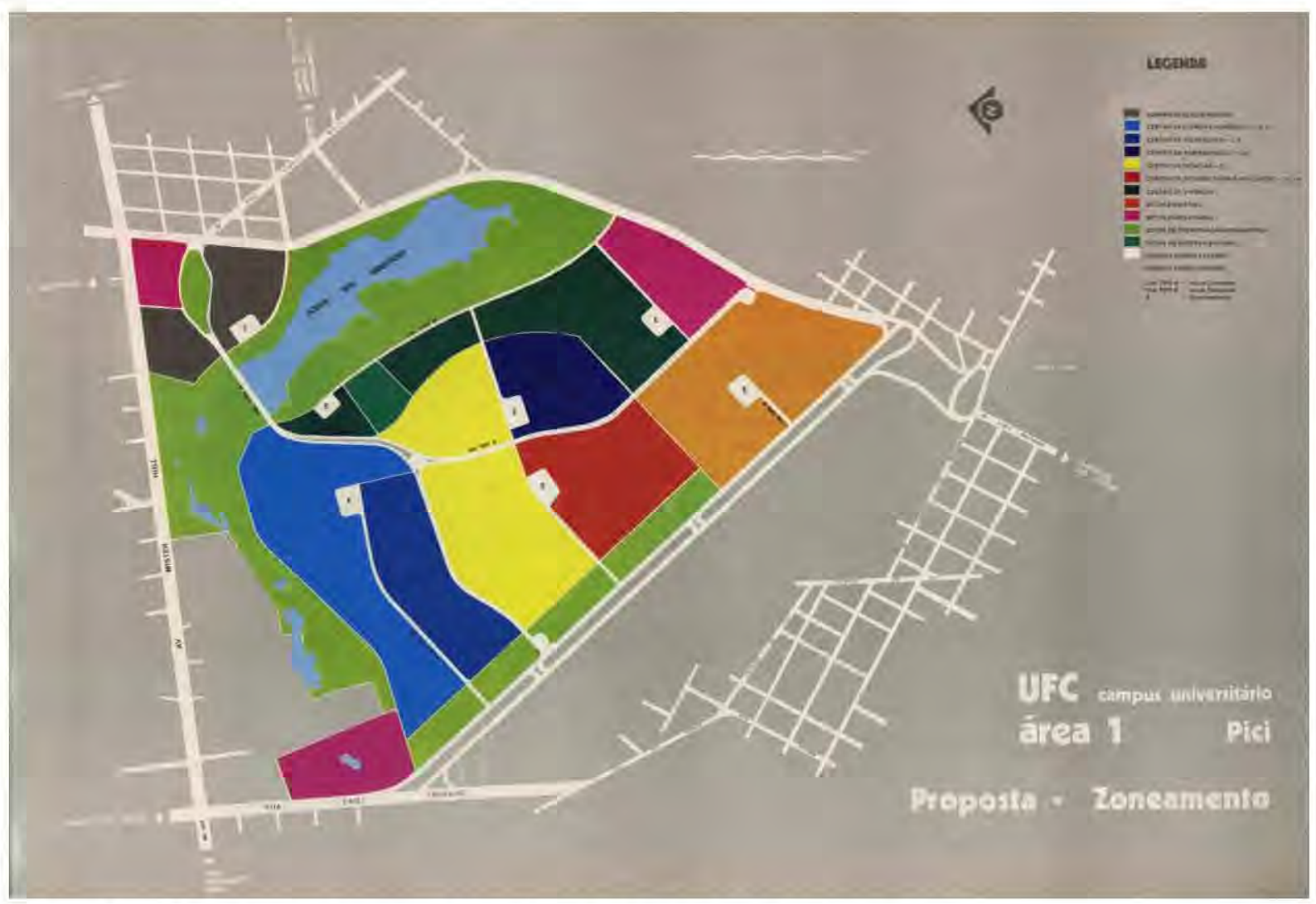

Figura 61: UFC - Campus Universitário Área 1. Proposta - Zoneamento.

Concebido como área isolada, protegido com via circular periférica e com a circulação interna operacionalizada por meio de sistema de transporte próprio em via exclusiva. (Fonte: UFC, 1989, p.101)

A Área 2, mantida para o setor da saúde, foi mais uma vez justificada pelos investimentos já realizados e principalmente pela presença do Hospital que construía um bloco para o centro cirúrgico. O impasse para a expansão das unidades, gerado pela restrita disponibilidade de área pertencente à UFC - cerca de 6,5 ha -, teve novamente que ser superado com a ampliação das terras disponíveis mediante a desapropriação das quadras limítrofes. 
Ignorando as dificuldades já vivenciadas para aquisição de terrenos quando da proposição de transferir a Faculdade de Odontologia para instalações a serem construídas nesse local, - Plano propôs a incorporação de uma área final correspondente a 15 ha. Com base nisto, foi formulada uma proposta com características de território unificado, onde as vias públicas seriam transferidas para a periferia do conjunto, integrando as unidades com circulação de pedestres, área de lazer, bem como previsão de bolsões de estacionamento. A configuração urbanística resultante delineava uma unidade setorial de característica isolada, embora imersa na malha urbana (ver figuras 62 e 63).

A Área 3, destinada às atividades de extensão e à cultura, foi planejada para ser gradativamente desocupada pela transferência das unidades acadêmicas para ○ Pici, decorrendo daí um planejamento específico para adequar as edificações existentes aos novos usos e instalar outras conforme as demandas. Os imóveis remanescentes seriam alienados. O território do Benfica mantinha suas características urbanísticas de origem, entre elas a configuração da quadra como unidade territorial da malha urbana (ver figuras 64 e 65). O Plano Diretor de 1979 reconstituía o território da Universidade mais uma vez permeado pelo princípio do isolamento.

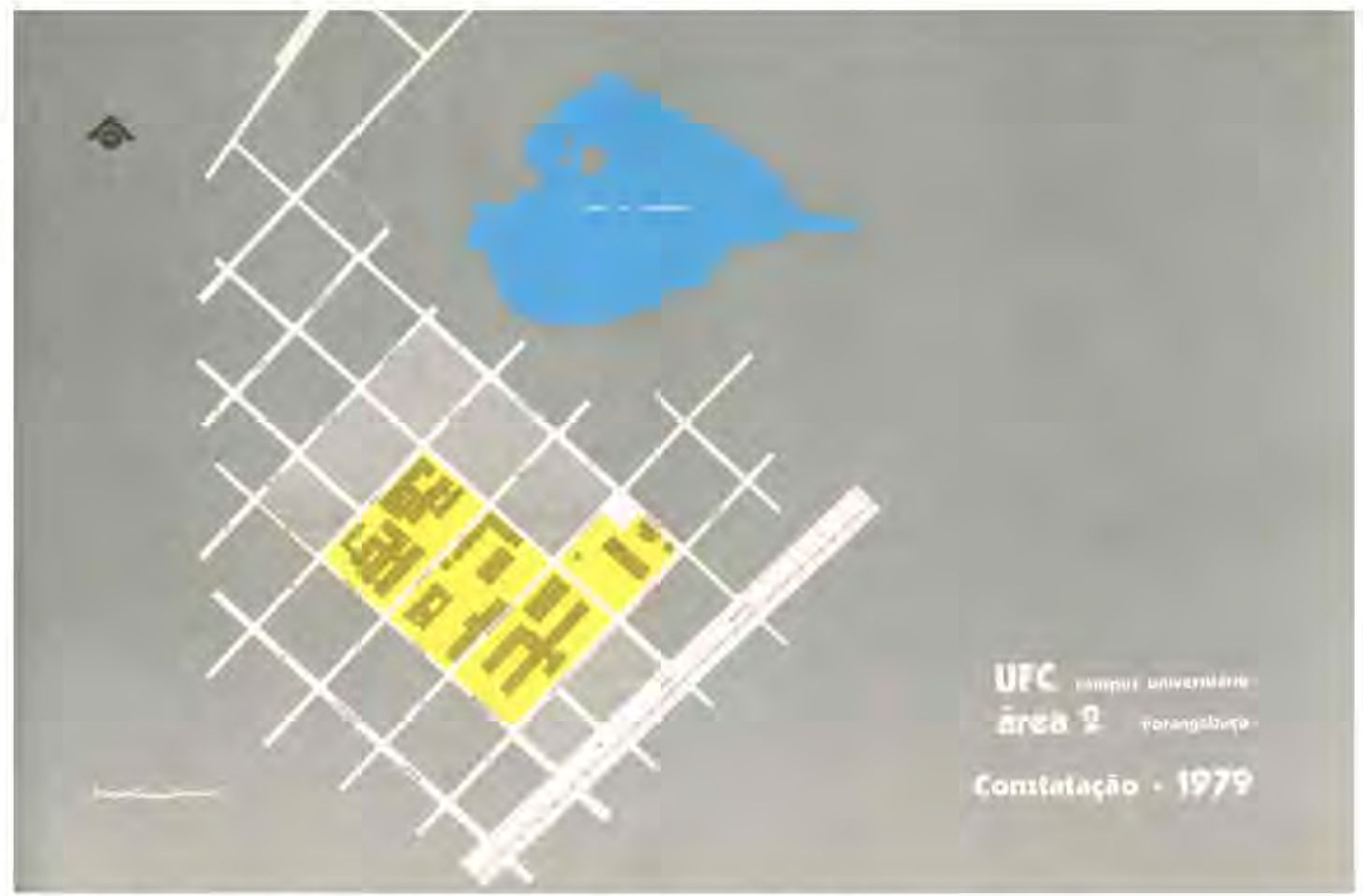

Figura 62: UFC - Campus Universitário Área 2 - Constatação 1979.

Constatação em 1979 da necessidade de ampliação com a desapropriação de quadras vizinhas.

(Fonte: UFC, 1980, p.111) 


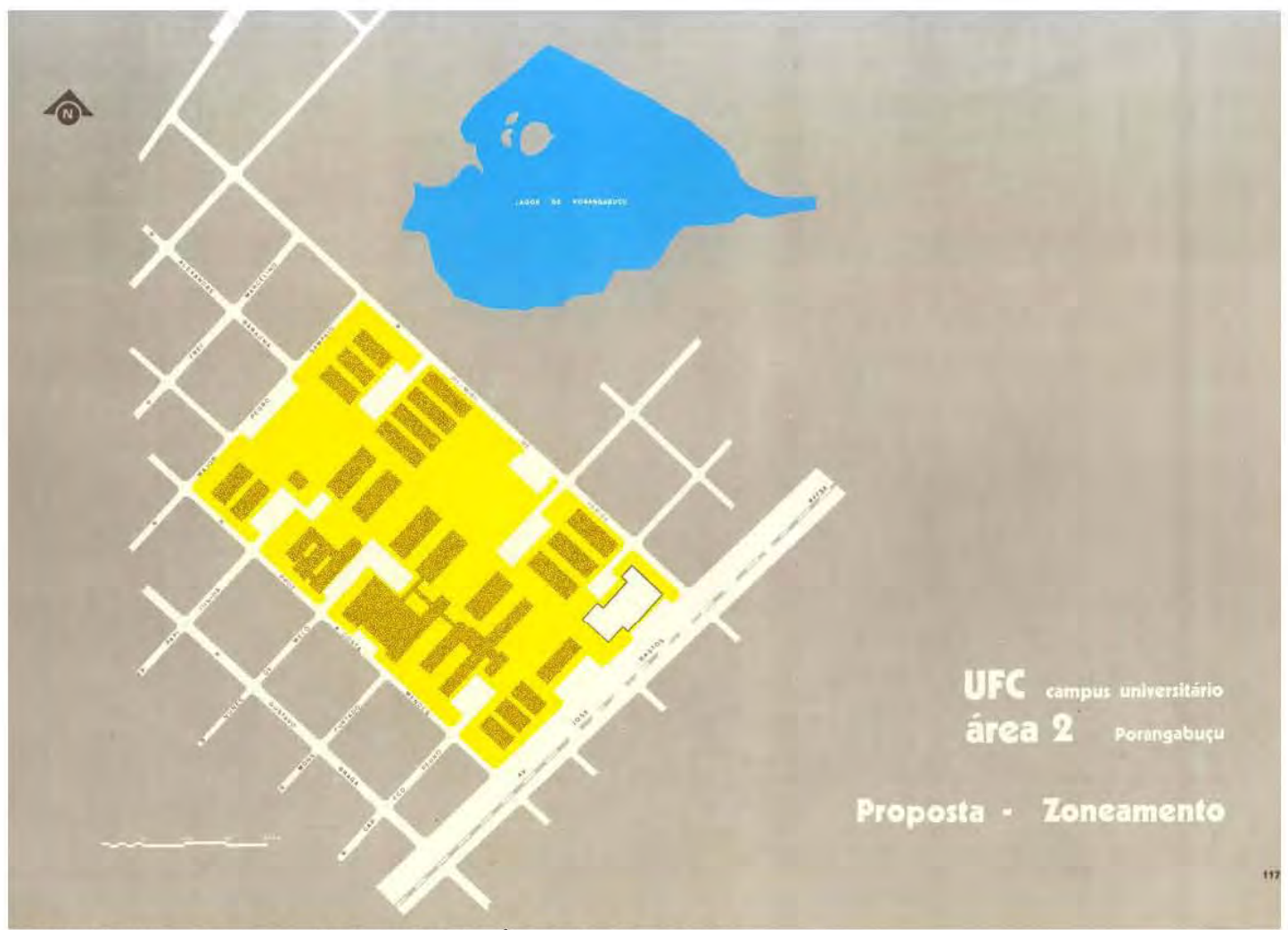

Figura 63: UFC - Campus Universitário Área 2 - Proposta.

A proposta estabelecia configuração urbanística caracterizada pelo isolamento do setor por meio do anel viário periférico, formando um espaço de uso exclusivo da Universidade.

(Fonte: UFC, 1979, p.117)

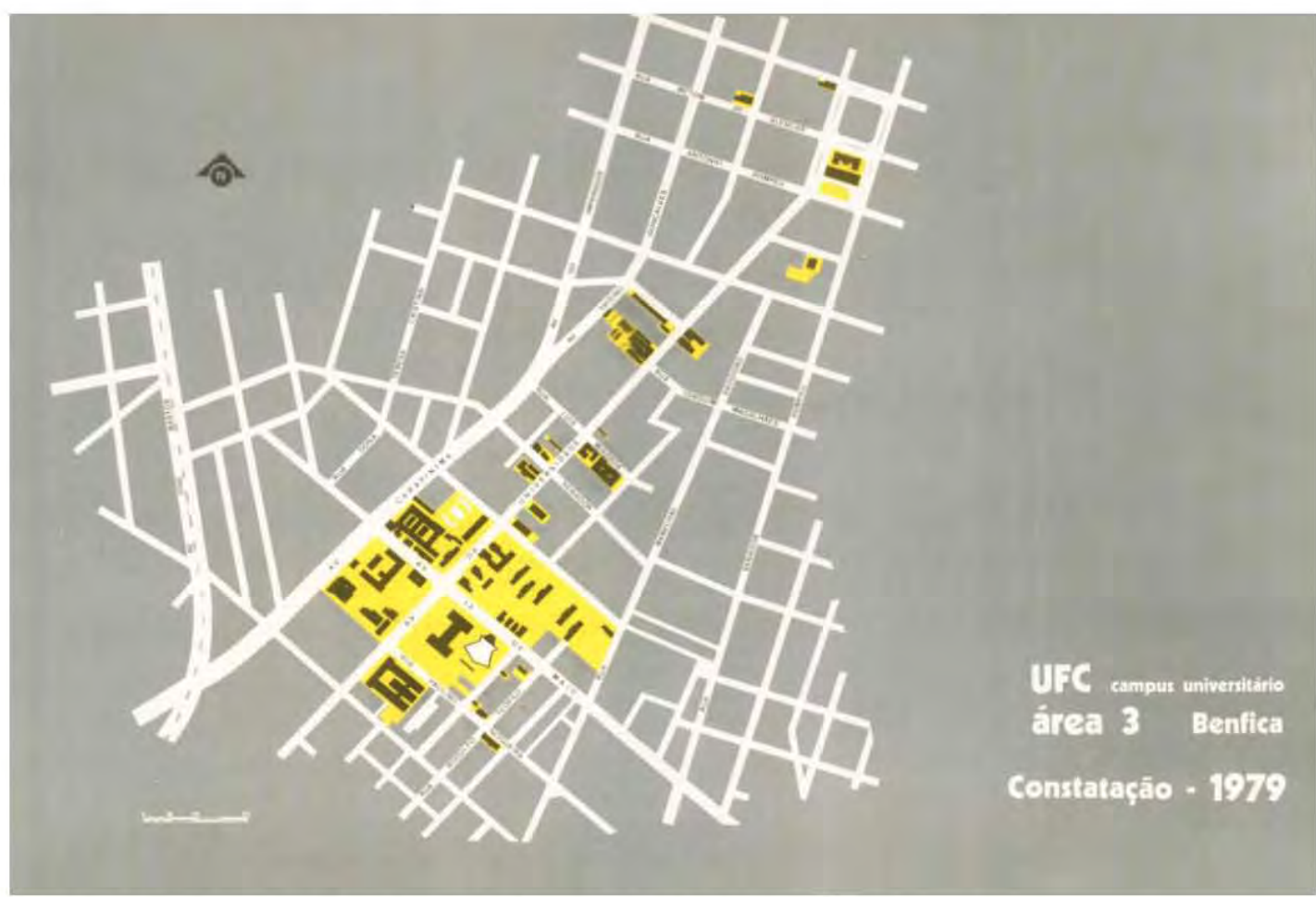

Figura 64: UFC - Campus Universitário Área 3 - Constatação 1979.

O Benfica, pela concentração de equipamentos culturais, passaria por remanejamento de áreas e das unidades existentes, visando consolidar uma zona cultural em torno da Reitoria. (Fonte: UFC, 1980, p. 133) 


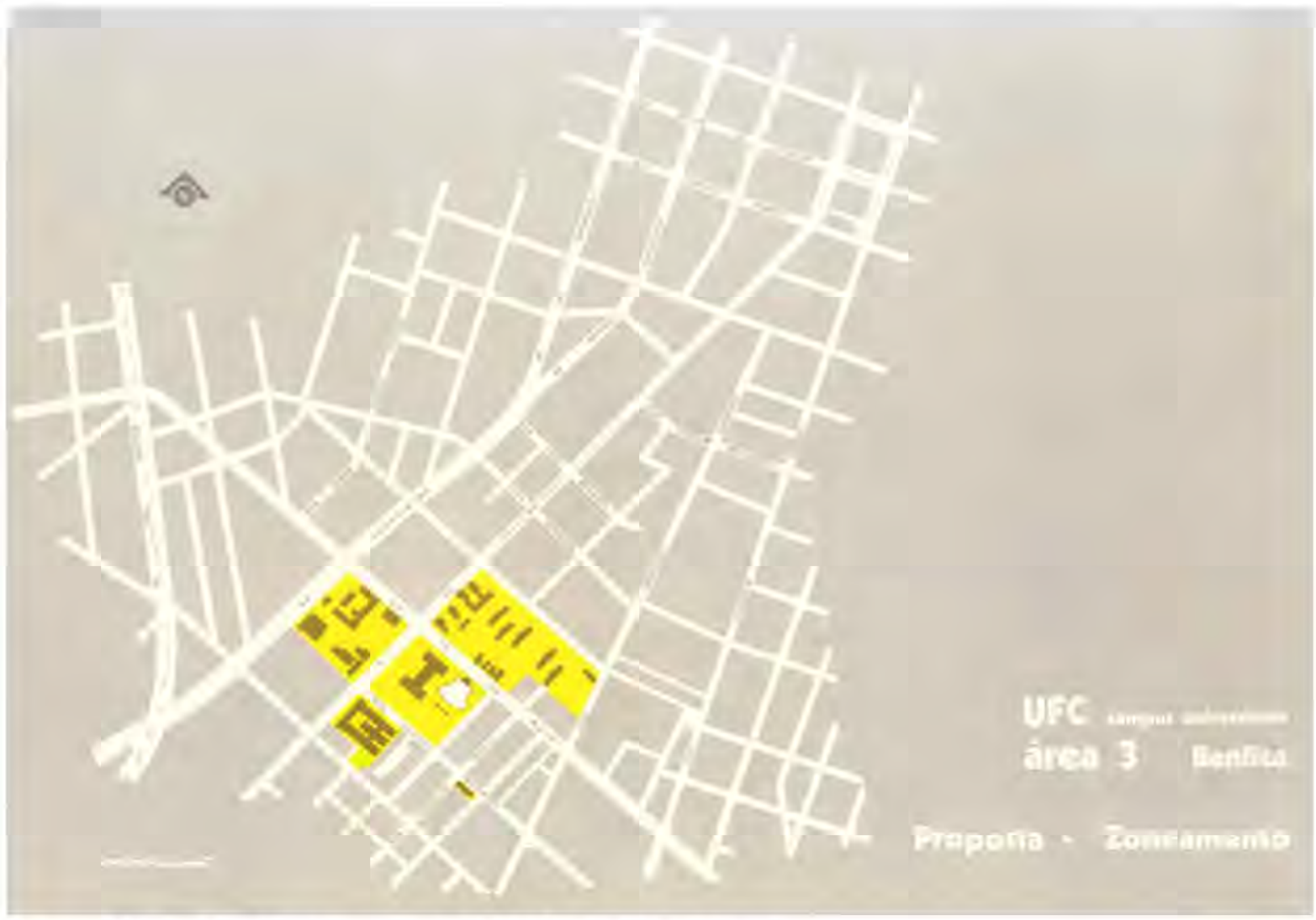

Figura 65: UFC - Campus Universitário Área 3 - Proposta.

(Fonte: UFC, 1980, p. 133)

Apesar do esforço desenvolvido na elaboração de vários projetos e dos vultosos investimentos para concretização do seu campus, a UFC chegou ao final da década de 1970 , sem ter conseguido a concretização da sua base física em território unificado. As concepções urbanísticas que deram suporte ao campus do Pici deixaram as marcas de uma tipologia espacial moldada para a compatibilização da Reforma de 1968 (ver figura 66)

\section{- Produção Arquitetônica da Reforma}

Os princípios de racionalidade e flexibilidade que dominavam a nova forma de organização universitária fizeram da padronização o critério adotado para dar corpo à estrutura acadêmica da Reforma na UFC. Visando superar a pressão por rapidez e custos acessíveis na construção dos edifícios, a malha modular e a padronização construtiva foram adotadas na concepção arquitetônica dessa produção.

\section{- O Conjunto Arquitetônico do Pici: concepção padronizada}

Herdando do Plano de Desenvolvimento de 1966/1977 a solução de esquematização de blocos padronizados, o conjunto edificado no Pici é o principal testemunho dessa arquitetura que pretendeu responder ao desafio do crescimento acelerado e das mudanças constantes. 


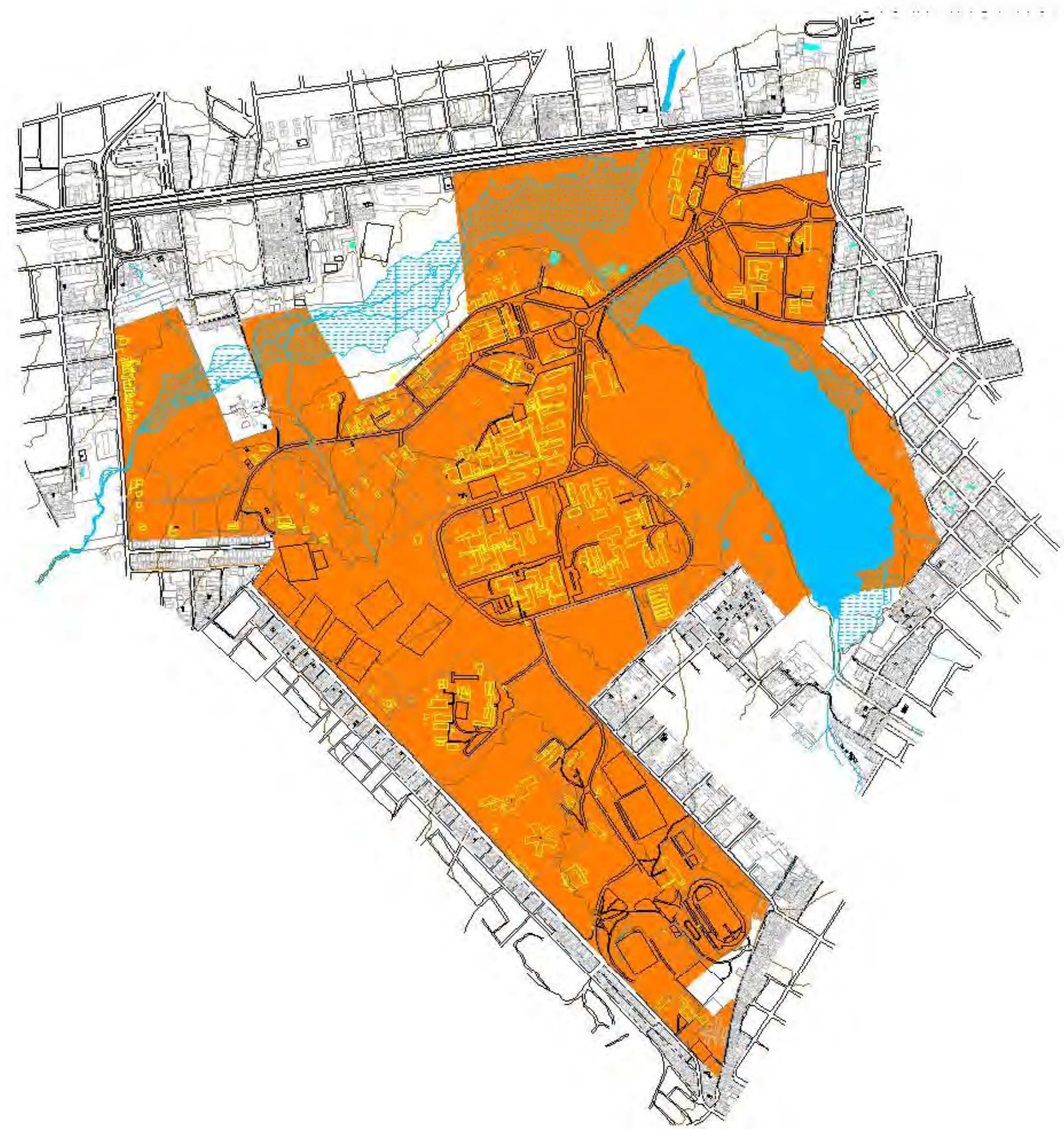



Os edifícios executados resultaram da associação dos oito blocos-tipo articulados por passarelas, que conformam a solução dos conjuntos, caracterizados pela diversidade de composição, porém mantendo uma unidade visual, onde a flexibilidade era o princípio operativo da proposta (ver figuras 67 a 70). Importante avaliar que, nesse caso, a flexibilidade referia-se às possibilidades de adaptação e expansão dos arranjos, condizente com a natureza do programa e concepção da Reforma Universitária que previa um processo de crescimento gradativo, porém sem dados precisos das futuras demandas. A filosofia era construir por partes, sem comprometer o todo, inviabilizando como obra de arquitetura.

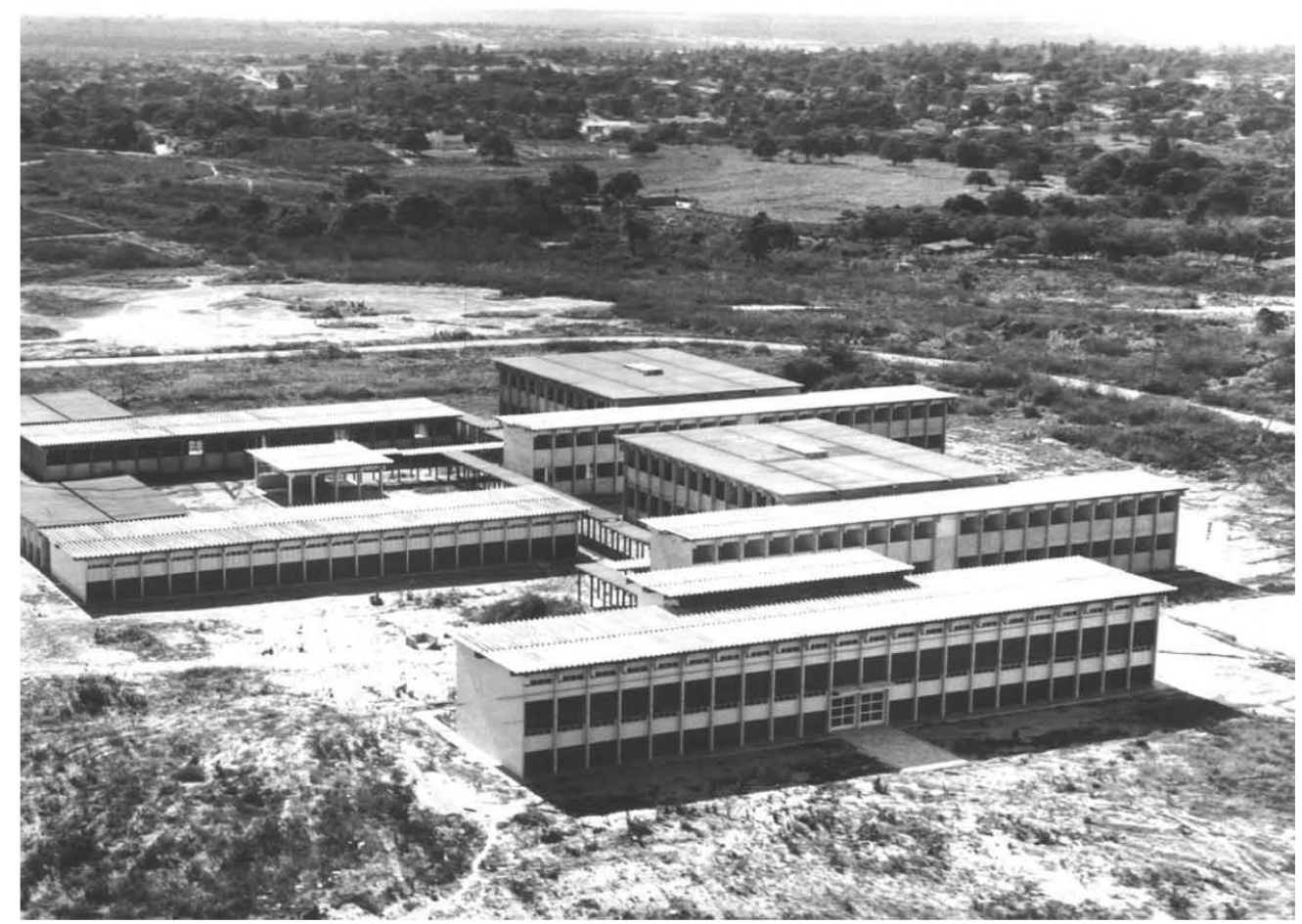

Figura 67: UFC - Campus Universitário do Pici - Década de 1970.

Conjunto do Centro de Ciências. Resultou da associação dos blocos-tipo, propiciando composição diversificada e mesma identidade visual.

(Fonte: Acervo UFC apud CAMPÉLO, 2005, p.71)

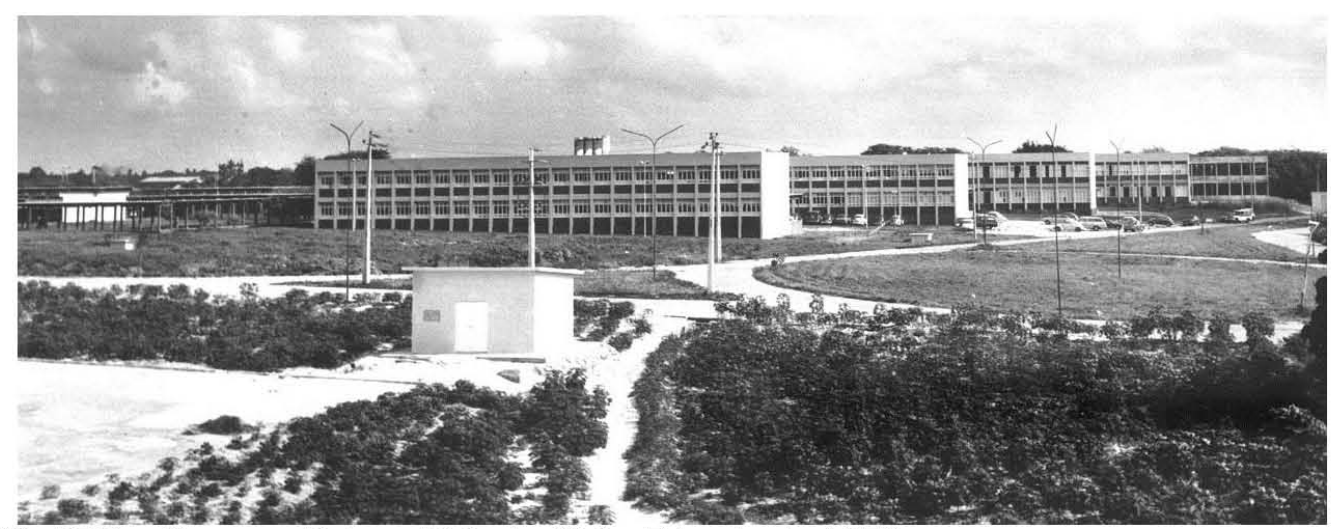

Figura 68: UFC - Campus Universitário do Pici - Década de 1970.

Conjunto do Centro de Tecnologia, inicialmente projetados para a Escola de Engenharia. Caracteriza-se pela padronização construtiva de predominância horizontal.

(Fonte: Acervo UFC apud CAMPÉLO, 2005, p.92) 


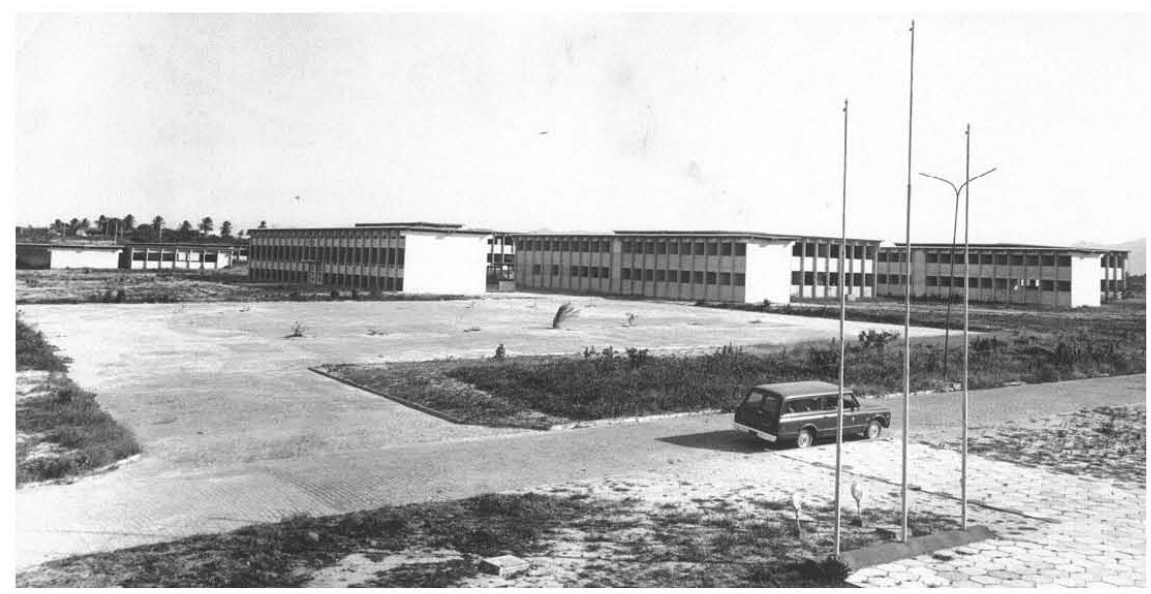

Figura 69: UFC - Campus Universitário do Pici - Década de 1970.

A padronização construtiva proporciona identidade visual ao conjunto. (Fonte: Acervo UFC apud CAMPÉLO, 2005, p.76)

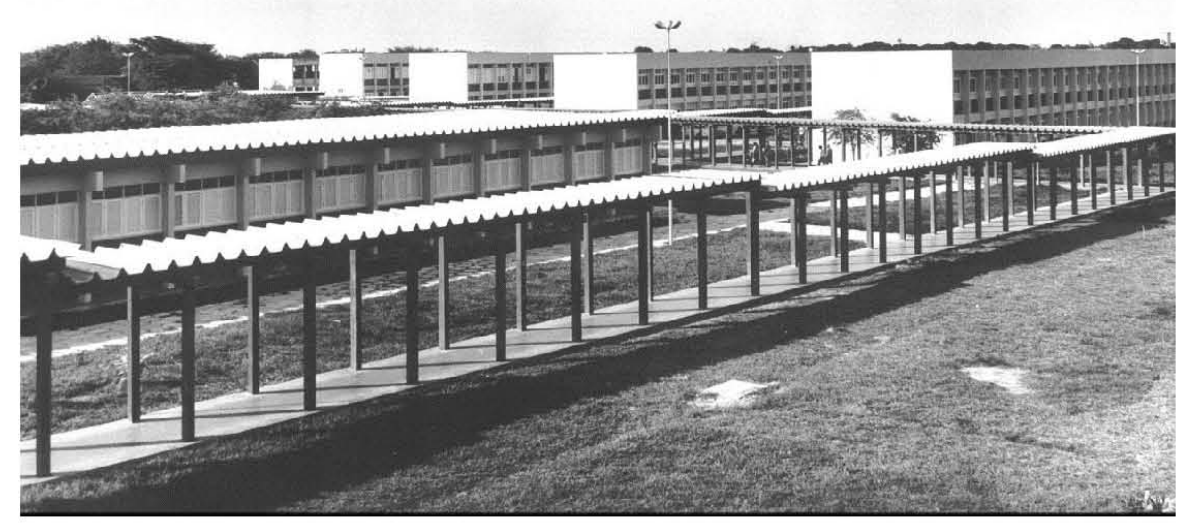

Figura 70: UFC - Campus Universitário do Pici - Década de 1970. Os conjuntos se articulam por passarelas cobertas. (Fonte: Acervo UFC apud CAMPÊLO, 2005, p.72)

As tipologias concebidas adotaram a planta livre de configuração geométrica predominantemente retangular, em blocos de um ou dois pavimentos. Nelas, as atividades foram organizadas seguindo o conceito do zoneamento funcional, que resultou em conjuntos de funções correlatas distribuídos sobre a malha modular de 1,25 x 1,25m e articulados pela circulação horizontal do tipo corredor e escadas, no caso de dois pavimentos (ver projeto das figuras 71 e 72). A modulação indicava a padronização do sistema estrutural, dos materiais de revestimento e dos elementos de vedação. Segundo depoimento do arquiteto Braga que participou da elaboração desses projetos, foi escolhido o módulo-base de $2,50 \mathrm{~m}$ $\times 2,50 \mathrm{~m}$, que estava referenciado nas dimensões do menor ambiente projetado: o gabinete de professores. Este seria o que proporcionaria melhores possibilidades de conjugação e economia do sistema estrutural adotado, a partir do qual foram definidos os demais componentes construtivos. Novamente, o princípio da flexibilidade se fazia presente na concepção do projeto, com a convicção de que mudanças na planta, decorrentes de alterações no programa, seriam possíveis, mantendo-se a integridade do edifício. 


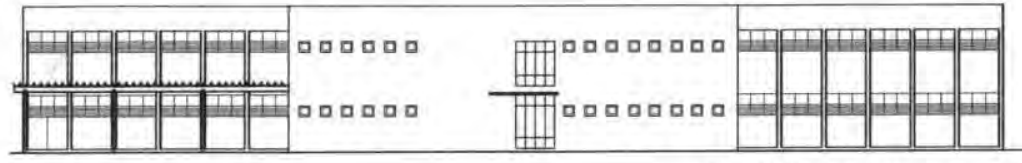

FACHADA PRINCIPAL

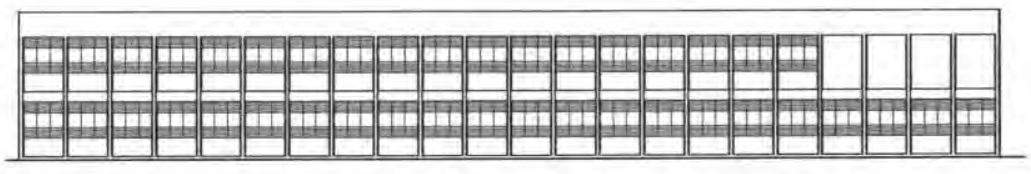

FACHADA POSTERIOR

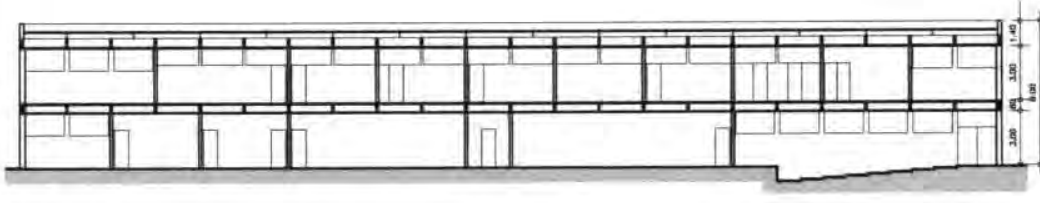

CORTE LONGITUDINAL

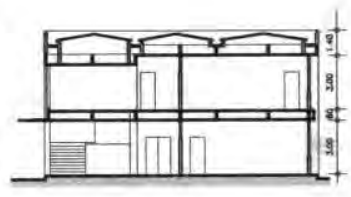

CORTE TRANSVERSAL

\begin{tabular}{|c|c|c|}
\hline \multirow{2}{*}{$\begin{array}{l}\text { UNIVERSIDADE FEDERAL DO CEARA } \\
\text { CADASTRO DOS EDIFICIOS DO } 3^{\circ} \text { GRAU }\end{array}$} & NEDA00 909 & CAMPUS $_{\text {PICI }}$ \\
\hline & $\begin{array}{l}\text { ARCACONSTRAOAA } \\
1.456,56 \mathrm{~m} 2\end{array}$ & $\operatorname{CSCALA} O$ \\
\hline If EDIOO. DEPARTAMENTO DE BIOLOGIA & UNDADE CENTRO DE CIENCIAS & DATA 1971 \\
\hline
\end{tabular}

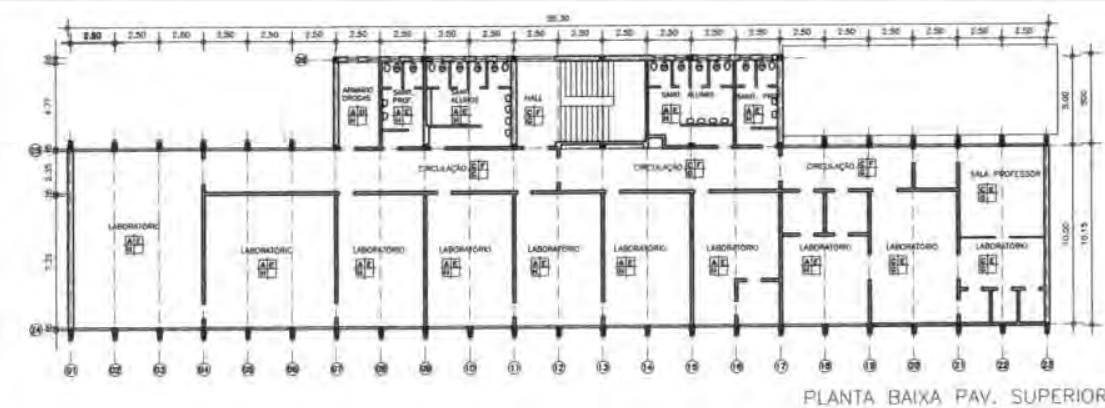

LEGENDA REVESTIMENTOS PISO

A PISO CERAMICO

B PISO DE TACO COM SINTECO

C PISO VINILICO

PAREDE

D PINTURA lavavel.

E AZULEJO

TETQ

G teratr acosmco

PLANTA BAIXA PAY. SUPERIOR

H LANE PINTADA

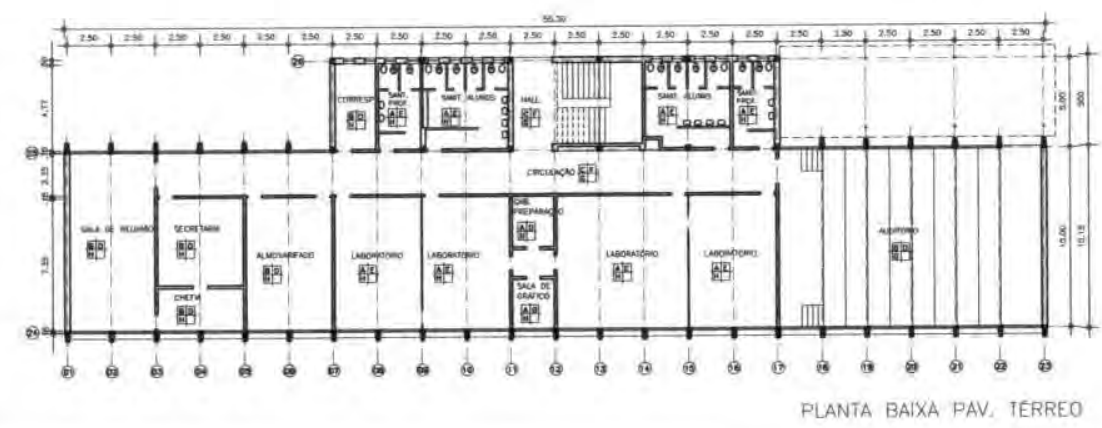

UNIVERSIDADE FEDERAL DO CEARÁ

CADASTRO DOS EDIFICIOS DO $3^{\circ}$ GRAU

If EDFOO. DEPARTAMENTO DE BIOLOGIA

\begin{tabular}{|c|c|}
\hline NEDPCOO $_{909}$ & CAPUS $_{\text {PICI }}$ \\
\hline AREACONSTIRTOA & $\operatorname{ESCALA}{ }_{2}^{2}-1$ \\
\hline UNOADE CENTRO DE CIENCIAS & DATA 1971 \\
\hline
\end{tabular}

Figura 71: UFC - Departamento de Biologia / Projeto de Arquitetura.

Campus Universitário do Pici - Década de 1970.

(Fonte: Acervo UFC - desenhos digitalizados a partir dos projetos originais, edição nossa) 


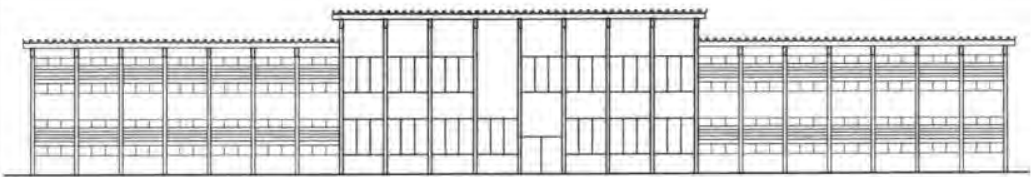

FACHADA PRINCIPAL

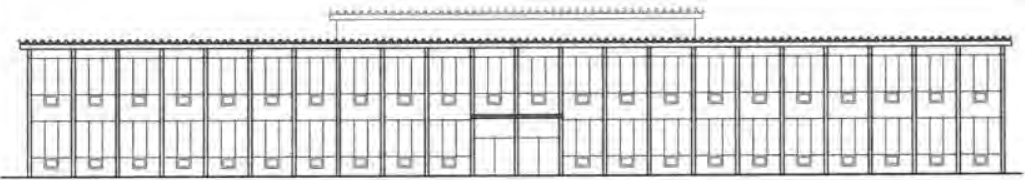

FACHADA POSTERIOR

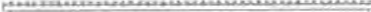

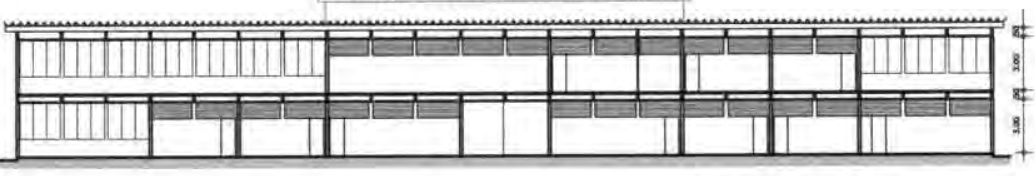

CORTE LONGITUDINAL

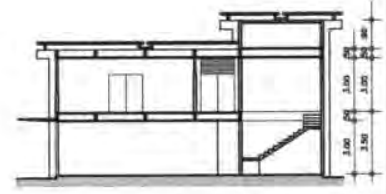

CORTE TRANSVERSAL

\begin{tabular}{|c|c|c|}
\hline UNIVERSIDADE FEDERAL DO CEARA & NEDACOO 914 & CANDUS $_{\text {PICI }}$ \\
\hline XADASTRO DOS EDIFICIOS DO $3^{\circ}$ GRAU & $\begin{array}{l}\text { AECAOCNSTRUOA } \\
1.346,64 \mathrm{m2}\end{array}$ & ISCALA: \\
\hline 18 ERICO DEPARTAMENTO DE & UNOWOC CENTRO DE GIENCIAS & DATA 1971 \\
\hline
\end{tabular}

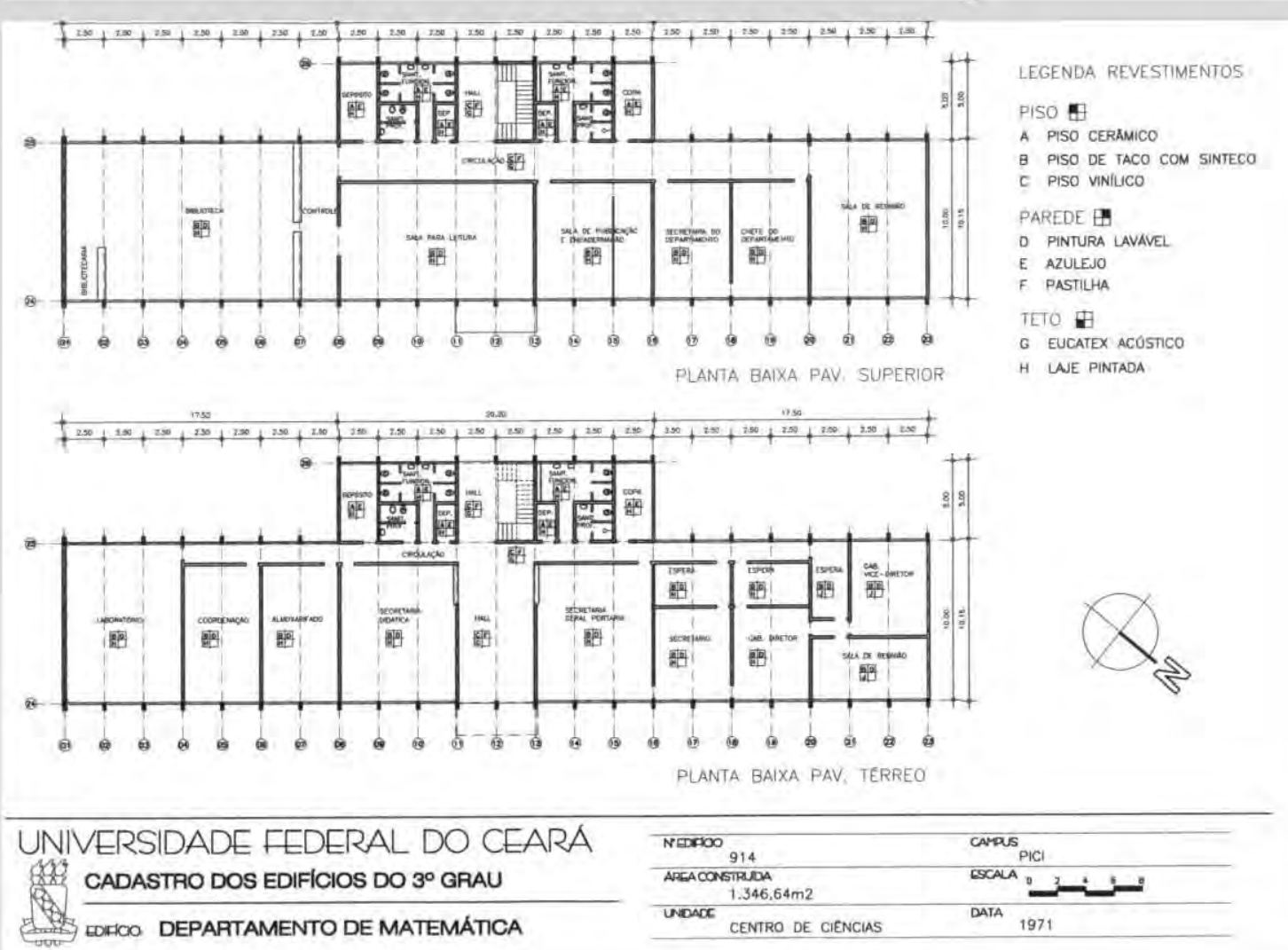

Figura 72: UFC -Departamento de Matemática / Projeto de Arquitetura.

Campus Universitário do Pici - Década de 1970.

(Fonte: Acervo UFC - desenhos digitalizados a partir dos projetos originais, edição nossa 
A orientação projetual não abrangia, entretanto, uma flexibilidade integral para alterações dos arranjos internos da edificação. Mesmo com a estrutura independente das vedações, a solução construtiva para divisões internas era a alvenaria de tijolo, que embora passível de ser demolida, é onerosa, contrariando as diretrizes de economia e racionalização que deveriam nortear as futuras demandas, decorrentes de mudanças no programa pedagógico. Nos tipos em que foram adotadas as divisórias em chapas de madeira compensada, a fabricação seguia um processo artesanal, com peças executadas no canteiro de obras e confeccionadas de acordo com as dimensões da cada ambiente. Isso se devia provavelmente às dificuldades de acesso aos produtos industrializados durante aqueles anos na cidade de Fortaleza. Outro aspecto a ser aferido é o da limitação de adequação das instalações prediais aos novos layouts, devido aos custos operacionais e construtivos incompatíveis com a filosofia escolhida.

Convém mencionar que a solução adotada pelo arquiteto Hélio Duarte para o projeto da Escola de Engenharia da Universidade de São Carlos, no interior de São Paulo, no qual o princípio da flexibilidade que direcionou toda a proposta construtiva do edifício abrangia não apenas a estrutura resistente e seus elementos de vedação, mas também a possibilidade de maleabilidade nas instalações complementares (luz, telefone, esgoto, água e gás). A solução permitia remanejamentos sem interferência com os demais sistemas do prédio. Para Duarte a flexibilidade integral ${ }^{32}$ foi a ideia básica que norteou o projeto e que compreendia o remanejamento de todos os elementos que participavam da edificação.

As esquadrias empregadas buscaram atender duplamente ao princípio da padronização e de solução na amenização do rigor climático local com o modelo de madeira com venezianas de réguas articuláveis, executadas no vão livre entre pilares (módulo-base de $2,50 \mathrm{~m} \times 2,50 \mathrm{~m}$ ), que se destacam na fachada segundo o princípio da verdade estrutural. Para propiciar a ventilação natural cruzada, foram colocadas esquadrias nas vedações opostas às aberturas de entrada dos ventos dominantes (ver figura 73). A preocupação com a incidência solar manifesta-se também na implantação dos edifícios, cuja configuração longitudinal está orientada na direção leste-oeste, embora alguns contrariem essa condição, indicando a prevalência por uma ordenação de caráter funcional.

No conjunto da padronização destacam-se os materiais de revestimento aplicados nas fachadas: pastilha cerâmica de fabricação local. No sistema de cobertura foram empregadas duas soluções, uma aparente com telhas autoportantes de fibrocimento em duas águas, uma apoiada na estrutura de madeira e outra com platibanda e calhas impermeabilizadas.

\footnotetext{
${ }^{32}$ Este conceito de "flexibilidade integral" foi apresentado por Hélio Duarte, na publicação "Espaços Flexiveis - uma consequência em Arquitetura" de sua autoria. Neste trabalho o arquiteto disserta sobre o tema da Flexibilidade e detalha a solução desenvolvida no edifício da Escola de Engenharia da Universidade de São Carlos, em São Paulo.
} 

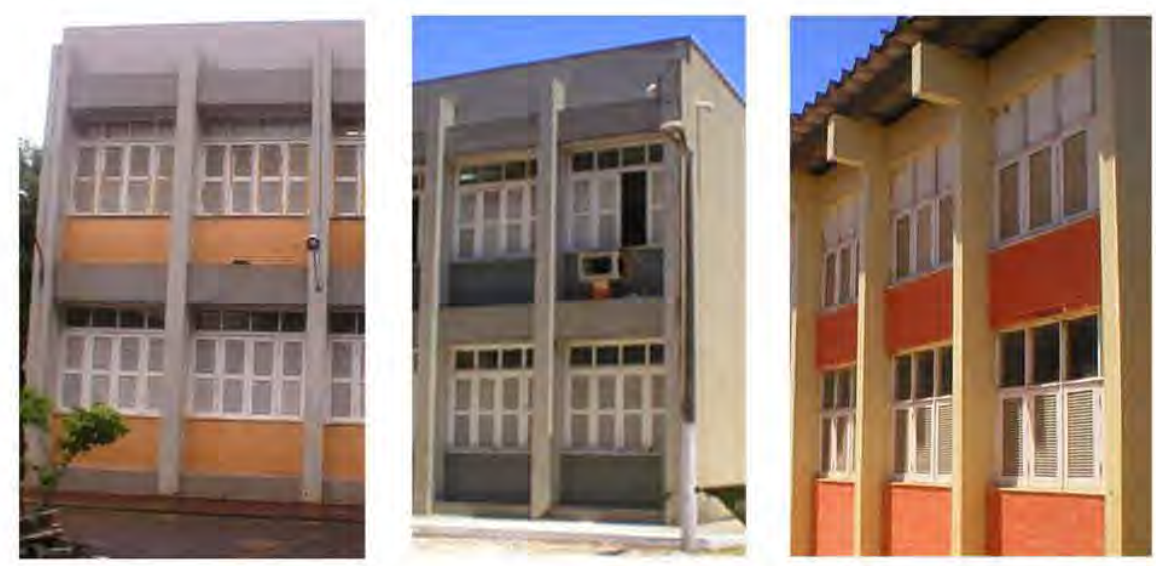

Figura 73: UFC - Campus Universitário do Pici.

Proposta de padronização das esquadrias, concebidas como elemento de vedação associado ao módulo-base estrutural de $2,50 \mathrm{~m} \times 2,50 \mathrm{~m}$. Os pilares se destacam proporcionando ritmo às fachadas.

(Fonte: Acervo UFC apud CAMPÉLO, 2005, p. 90)

A forma arquitetônica resulta da planta funcional, que gera a volumetria prismática de predominância horizontal. As formas puras e de linhas retas, desprovidas de ornamentos, criam um conjunto de clara intenção racionalista, onde a forma arquitetônica simples expressa a função utilitária para a qual foi projetado, dentro dos princípios de economia e facilidade construtiva (ver figura 74). De autoria do arquiteto Neudson Braga, os atributos dessa produção evidenciam seus vínculos com a Escola Carioca, embora com características de adaptação aos condicionantes locais.

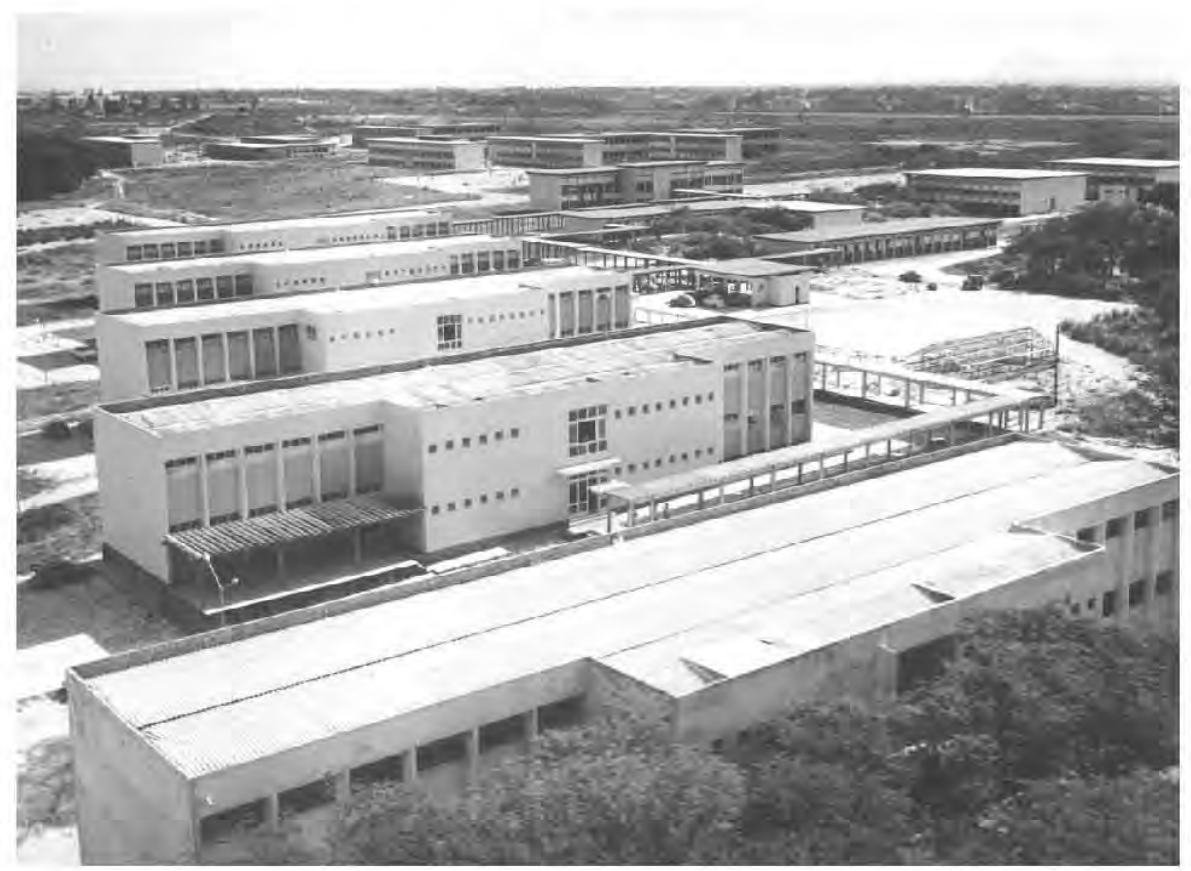

Figura 74: UFC - Campus Universitário do Pici - Década de 1970.

Composição volumétrica por justaposição de blocos prismáticos e interligados por passarelas.

(Fonte: Acervo UFC apud CAMPELO, 2005, p.88) 


\section{- Biblioteca e Núcleo de Processamento de Dados: o rompimento com a padronização}

Contrapondo-se a essa arquitetura de escala singela, foram erguidos em meados da década de 1970, os edifícios destinados à Biblioteca e ao Núcleo de Processamento de Dados, que rompiam com a proposta de blocos padronizados. A produção de volumetria robusta, ressaltada pelo uso do concreto aparente como expressão do caráter dos edifícios, se sobressai na paisagem construída do Pici, interferindo na ordem visual do conjunto de identidade única. Os projetos são de autoria do arquiteto Nearco Araújo desenvolve uma arquitetura cuja postura projetual revela suas referências à outras experiências ligadas ao uso do concreto aparente, que estavam ocorrendo nos anos 1970 em várias outras regiões.

\section{- Biblioteca}

O edifício da Biblioteca, implantado às margens do Açude Santo Anastácio, foi concebido como bloco único e abriga uma área construída de $7.716,67 \mathrm{~m}^{2}$ distribuída em três níveis de pavimentos. Os espaços são definidos pela estrutura de concreto armado, regida pela malha modular de $10,00 \times 10,00 \mathrm{~m}$. Tais características conferem ao edifício o atributo da monumentalidade. É possível que a recomendação dada pelo Manual de Atcon (1970), de que a arquitetura do edifício da biblioteca deveria expressar sua condição de relevância na hierarquia da estrutura acadêmica da Reforma, tenha permeado a orientação de uma arquitetura monumental.

O partido adotado destaca a forma arquitetônica de composição volumétrica em forma de caixa, que resulta da planta de configuração retangular com dimensões de $35,40 \times 85,15 \mathrm{~m}$. Introduzindo dinamicidade a essa volumetria, o arquiteto agrega elementos, para criar fachadas diferenciadas. $\mathrm{Na}$ oeste, voltada para a via de veículos e de acesso ao público, a horizontalidade da "caixa", reforçada pela linha reta da platibanda, é suavizada pelo volume vertical da escada justaposto, pela rampa de concreto aparente que faz a ligação do passeio com a entrada do edifício e por "cortinas" em formato de grelha que resultam da associação de elementos verticais e horizontais, com a clara intenção de aliar plasticidade aos fatores de proteção solar. Este propósito, entretanto não é atingido em face do equívoco gerado pelas dimensões das estruturas, que não impedem a radiação solar direta nos ambientes (ver figura 75 ).

$\mathrm{Na}$ fachada leste, com acessos de serviço, Araújo enfatiza a modulação estrutural, destacando os pilares em concreto aparente entre as vedações de alumínio e vidro, assim como a platibanda constituída por peças verticais também de concreto aparente, que seguem a regularidade da modulação. Tirando partido das áreas de leitura, localizadas no primeiro andar, o arquiteto expande o piso do pavimento, que desempenha a tripla função de varanda, de marquise e de elemento de composição arquitetônica. Com essa solução, 
solta o edifício do solo e tem a estrutura recuada, atenuando a solidez da forma e a tendência ao "peso" visual (ver figura 76). As fachadas laterais são tratadas como extensão da fachada leste, diferentemente da platibanda, que retoma a plasticidade da faixa contínua de concreto aparente adotado na fachada oeste (ver figura 77 ).

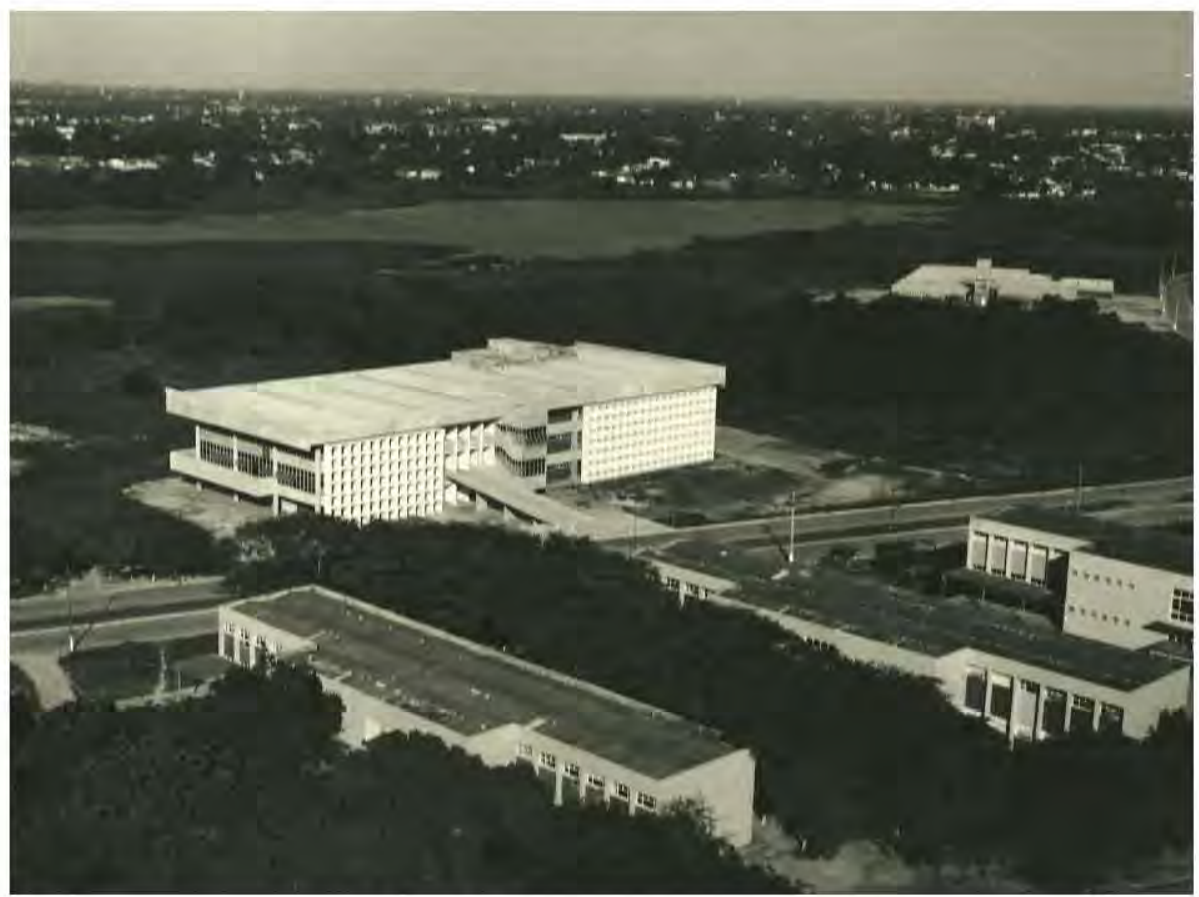

Figura 75: UFC - Biblioteca Central / Fachada oeste - Década de 1970.

A relação com o entorno se dá por contraste visual, realizando a integração com o ambiente externo por meio da clareza do acesso, destacado pela rampa de concreto aparente.

(Fonte: Acervo COP / UFC)

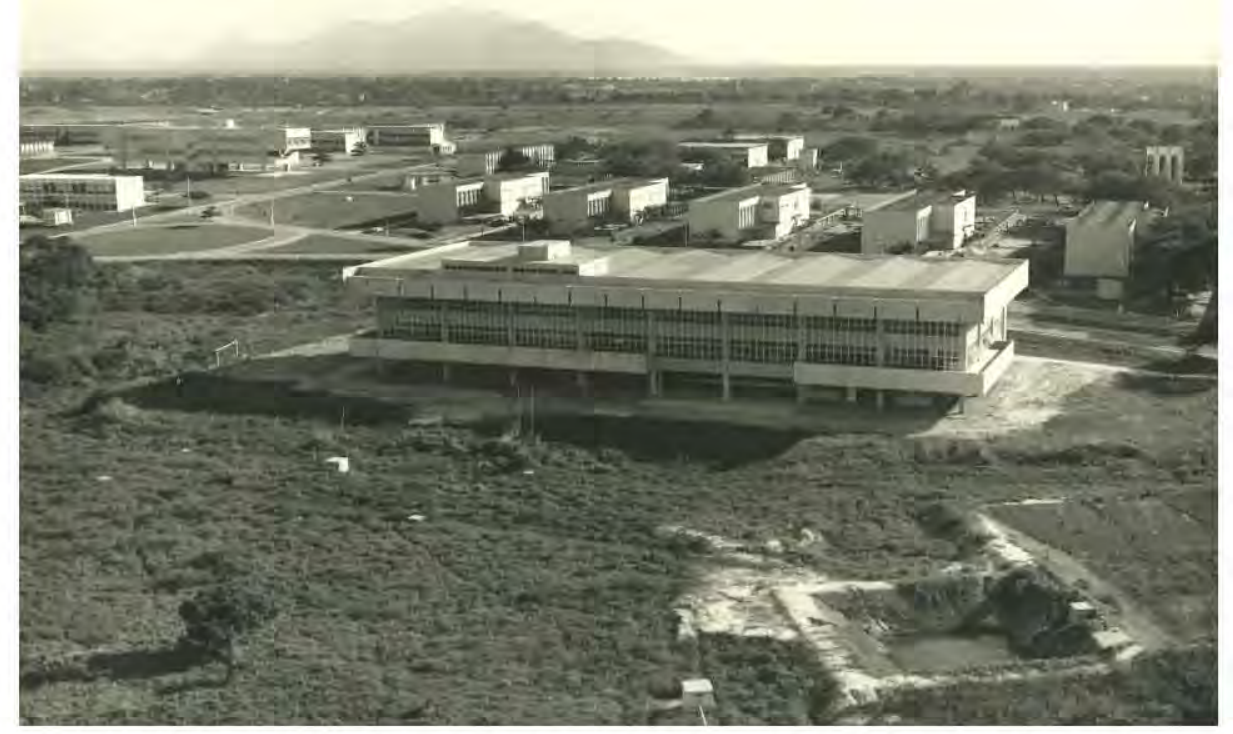

Figura 76: UFC - Biblioteca Central / vista da fachada leste - Década de 1970.

A volumetria horizontal do edifício é associada à clareza da solução estrutural. (Fonte: Acervo COP / UFC) 


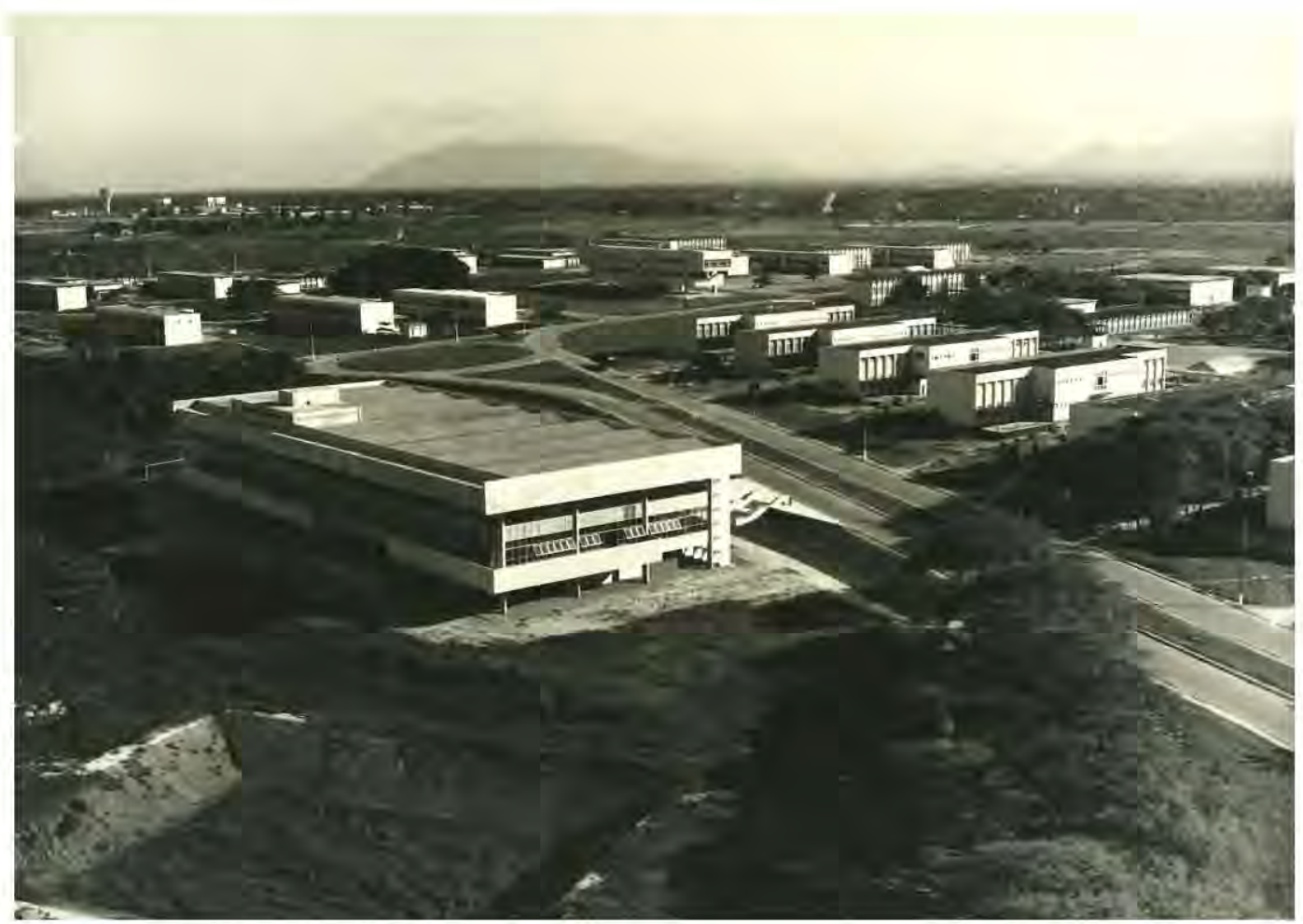

Figura 77: UFC - Biblioteca Central / vista das fachadas norte e leste - Década de 1970.

A restrição na variedade dos materiais usados confere austeridade e homogeneidade à solução arquitetônica.

(Fonte: Acervo COP / UFC)

\section{- Núcleo de Processamento de Dados}

O edifício construído para abrigar as atividades do Núcleo de Processamento de Dados adota o partido de um monobloco longitudinal com três níveis de pavimentos e dimensões de projeção horizontal da ordem de $12 \mathrm{~m} \times 80 \mathrm{~m}$, perfazendo a área total construída de $2.665,64 \mathrm{~m}^{2}$.

O programa do Núcleo é resolvido nos dois últimos pavimentos que se organizam ao longo da circulação centralizada, conformando duas alas longitudinais de serviços. O pavimento térreo, com os pilares localizados nos limites da sua projeção, é liberado de funções específicas, tornando-se um espaço livre, permeável, propício à convivência da comunidade acadêmica.

O partido explora o emprego dos grandes vãos e a exacerbação da tecnologia do concreto armado. Apoiado nos pilares que vencem vãos de $20,00 \mathrm{~m}$ no eixo longitudinal e balanços nas extremidades $-3,00 \mathrm{~m}$ no primeiro e $5,00 \mathrm{~m}$ no segundo pavimento - e com o fechamento dos planos verticais realizado pela estrutura de concreto aparente com as esquadrias de vidro e alumínio, a forma arquitetônica se destaca pela volumetria maciça conferida pelo concreto aparente e acima de tudo pela grande escala que se contrapõe aos blocos do Centro de Ciências, junto aos quais se encontra implantado (ver figura 78). 
Diferindo da Biblioteca, nẫo há elementos que identifiquem a intençẫo de neutralizar os efeitos climáticos de intensa radiaçẫo solar ou de inserção na paisagem edificada do Centro de Ciências. $O$ esforço arquitetônico reside na formulaçẫo da obra de grande escala. 0 papel preponderante da estrutura de concreto, a restriçẩo do número de materiais e a ausência de revestimentos conformam a forma arquitetônica o atributo da monumentalidade.

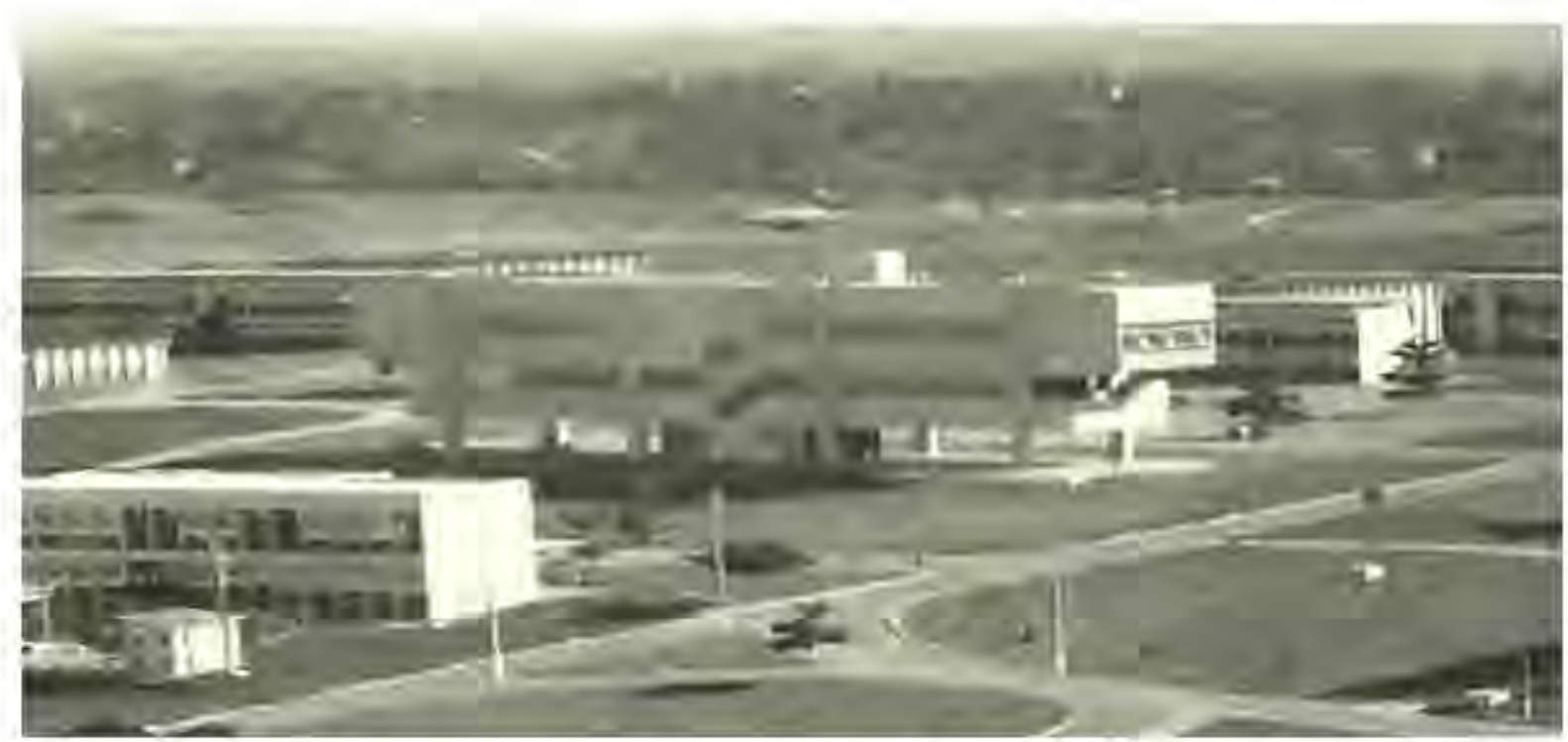

Figura 78: Núcleo de Processamento de Dados da UFC - Década de 1970.

A singularidade da volumetria maciça do edifício gera relaçấo de conflito visual com o entorno de escala padronizada.

(Fonte: Acervo COP I UFC)

\section{- Restaurante Universitário: 0 distanciamento do edifício racionalista}

Outra produção da década de 1970 no Camous do Pici foi o edifício projetado pelo arquiteto Neudson Braga para o Restaurante Universitário. A arquitetura desenvolvida revela uma mudança da visẫo do edifício centrado no racionalismo das formas puras para uma proposta mais aberta, que considera as condiçổes do lugar e a composiçẫo orgânica das formas. Embora mantendo a escala e a similaridade com a linguagem dos materiais empregados nos blocos padronizados, 0 partido deixa evidente a intençäo de romper com a proposta pioneira.

Tirando partido da topografia, o edifício possui dois niveis de pavimentos, sendo o térreo com acesso ao passeio e o segundo, situado abaixo do primeiro, aproveita a encosta do terreno, voltando-se às margens do Açude Santo Anastácio. O programa do restaurante refeitórios, setor administrativo, sanitários, cozinha e serviços de apoio -, está concentrado no payimento térreo, enquanto que o nivel inferior abriga uma generosa área de estar aberta 
à paisagem, abastecida por sanitários e áreas de estocagem de material, totalizando $4.675,38 \mathrm{~m}^{2}$ de área construída.

A planta se desenvolve sobre o módulo-base estrutural de $10 \mathrm{~m} \times 10 \mathrm{~m}$, que desempenha o papel ordenador dos setores funcionais. O processo de projeto propicia organicidade à planta, que se espalha no terreno atendendo ao correto fluxo das atividades. $O$ resultado revela o rompimento projetual com o rigor geométrico das formas puras. A volumetria única não é mais o elemento que dá força à forma arquitetônica. Agora são os planos verticais das fachadas, com ênfase na verdade estrutural, onde a diferenciação dos elementos de concreto aparente (vigas, pilares e platibanda) das superfícies de vedação (alvenarias revestidas de cerâmica e panos de combogó), compõem forma arquitetônica.

Braga revela domínio na problemática do conforto ambiental, propiciando o fluxo da ventilação cruzada por meio dos extensos panos de combogó, estrategicamente dispostos nas áreas do refeitório, que também funcionam como filtros da iluminação natural. $\mathrm{A}$ estratégia é apoiada pela abertura do refeitório da fachada de fundo, que integra a paisagem natural do açude ao ambiente. Não há excessos. $O$ edifício se insere na paisagem e a arquitetura potencializa a função para a qual foi projetada.

\subsection{Considerações}

A Universidade Federal do Ceará, com sede na cidade de Fortaleza, foi instituída pela Lei Federal $n^{\circ} 2.373$, de 16 de dezembro de 1954, a partir da justaposição da Faculdade de Direito, Faculdade de Farmácia e Odontologia, Escola de Agronomia, Escola de Medicina e no ano seguinte incorporou a Faculdade de Engenharia. A historiografia da Instituição credita sua criação ao amplo movimento de opinião pública, tendo como principal interlocutor o intelectual e professor da Faculdade de Direito do Ceará Antônio Martins Filho, que se tornou o primeiro reitor da Universidade.

Instalada em 1955, iniciou suas atividades nas dependências das instituições que foram encampadas, situadas predominantemente na malha urbana da cidade, excetuando-se a Escola de Agronomia que, pelas características rurais das suas atividades, funcionava em terreno localizado no subúrbio afastado, denominado Sítio do Pici, onde foi implantado o Campus do Pici. As edificações, construídas na primeira metade do século XIX para outros fins, apresentavam uma arquitetura de arranjo eclético com traços neoclássicos e art déco.

Procurando superar sua condição inicial de ser formada pela reunião de faculdades e escolas isoladas, espalhadas pela cidade, a Universidade logo tratou de promover o gradativo agrupamento físico das unidades em uma mesma área, visando criar e consolidar 
um território unificado. A primeira ideia foi erguer uma cidade universitária na gleba do Sítio do Pici. Entretanto, os conflitos e interesses das corporações profissionais que the deram conformação - advogados, médicos e agrônomos - e o poder que se instalou na Reitoria foram determinantes para a construção do território da UFC dividido em três áreas dispersas na malha urbana da cidade, configuração que se mantém até os dias de hoje. Trata-se das áreas do Benfica, do Porangabuçu e do Pici. Essa opção, que a princípio foi tomada como provisória, se concretizou, apesar do empenho desenvolvido pelas sucessivas administrações no propósito de unificar a base física da Universidade.

A área do Benfica, situada no bairro do mesmo nome, próximo ao centro da cidade, conformava uma zona residencial das elites cearenses, porém em declínio nos anos de 1950. A presença da Faculdade de Direito nas suas circunvizinhanças fortaleceu a decisão da então Administração Superior de comprar o imóvel para a implantação da sede da Reitoria naquela região. A condição de favorecimento na aquisição de outros edifícios próximos a essa unidade administrativa, associada ao fator de localização estratégica na estrutura urbana, que permitia estabelecer relações com as áreas do Porangabuçu e do Pici, ajudaram o processo de ocupação das unidades e equipamentos universitários naquela área.

O território universitário que passou a se formar não foi, entretanto, resultado de uma ação planejada, mas se deu pela compra de imóveis disponíveis para a venda e posteriormente selecionados conforme as demandas da Instituição. Procurando moldar um espaço integrado e de convívio da comunidade, a Universidade procedeu a um intenso processo de demolição, construção e reformas dos imóveis adquiridos, eliminando os muros entre eles, de maneira a reagrupar os terrenos, substituindo a estrutura fundiária baseada no lote pela quadra como unidade territorial básica. Dessa forma foram se conformando glebas que permitiam a instalação das unidades sem o fracionamento espacial ou isolamento das mesmas.

O resultado positivo demonstrado com a expansão paulatina no Benfica de unidades acadêmicas e equipamentos culturais ensejou a ideia de ali se estabelecer o território definitivo da UFC. A proposta, entretanto foi abandonada a partir da constatação de inviabilidade na desapropriação da área total a ser adquirida. Esta concepção de instituição, inserida na malha urbana, servindo-se da infraestrutura, aberta e permeável aos habitantes da cidade, contrariava o modelo espacial de cidade universitária que se estabelecera nas universidades brasileiras. O urbanismo adotado moldava naquela área uma zona especializada, de domínio da Universidade e integrado às circunvizinhanças. 
A demanda crescente por projetos para a construção das novas unidades acadêmicas favoreceu a atuação de jovens arquitetos, formados em instituições do Rio de Janeiro e do Recife, que retornando a Fortaleza, encontraram na UFC ambiente propício para materializar uma produção embasada pelos princípios do modernismo arquitetônico brasileiro. Dentre eles, os arquitetos cearenses Liberal de Castro, Neudson Braga, Ivan Brito e Enéas Botelho, que passaram a fazer parte dos quadros da Universidade, foram autores de um panorama edilício que testemunha até hoje os cânones modernistas da Escola Carioca, adaptados às técnicas e procedimentos construtivos da região. No Benfica, exemplares como a Residência Universitária de autoria de Brito, o Departamento de Cultura da UFC, projeto de Castro e a Faculdade de Filosofia, Letras e Artes, desenhada por Braga, fazem parte da história da arquitetura moderna do Ceará.

No caso do Porangabuçu, sua concretização foi favorecida pela transferência, em 1957, da Faculdade de Medicina, que funcionava no centro da cidade para as dependências do Hospital das Clínicas, construído nesse bairro, atual Rodolfo Teófilo, onde eram exercidas as atividades práticas. $O$ evento propiciou a expansão da Universidade naquele local, sob o domínio da classe médica. Nesse período, o Porangabuçu era uma área periférica, ocupada pela população de baixa renda e para onde habitualmente se dirigiam os flagelados da seca. Embora a ocupação também tenha se dado sem um planejamento, gradativamente se conformou o espaço de feição especializada, voltado para o setor da saúde, com a implantação de unidades e equipamentos pertinentes ao setor. Ali também foram erguidos edifícios cuja arquitetura era embasada pelos princípios modernistas. Dentre eles, o edifício da Maternidade-Escola, de autoria dos arquitetos cariocas Roberto Nadalutti, Oscar Waldetaro e Israel Barros Correia, se destaca na paisagem construída do Porangabuçu por seu partido modernista com elementos de construção local.

A consolidação da Universidade na área do Pici foi uma decorrência da presença da Escola de Agronomia que ali se instalou em função das suas especificidades, que exigiam grandes extensões de terra e proximidade a fontes de água, condições que foram reforçadas pela possibilidade de anexar terrenos desocupados existentes no seu entorno. A condição de ampliação dos seus limites tornou-se fator de favorecimento para ali se instalar o futuro território unificado da UFC, manifestado nas várias tentativas empreendidas pelo planejamento físico da Instituição, durante os anos 1960 e 1970.

Vale salientar que a ocupação do Pici por unidades correlatas à Escola de Agronomia no primeiro decênio de criação da Universidade também favoreceu o surgimento de uma produção de linguagem modernista. O Instituto de Zootecnia, de autoria do arquiteto Enéas Botelho, representa um exemplar pioneiro dessa geração. A ocupação da gleba não teve até meados da década de 1960 a orientação de um plano físico, conformando o adensamento 
das unidades em núcleos dispersos. Somente com a oficialização do primeiro plano diretor da Universidade em 1966 é que foi concebida a estrutura urbanística mantida até os dias atuais.

O dinamismo e a celeridade no crescimento da UFC, ocorridos nos primeiros dez anos do seu funcionamento, tornaram sua estrutura cada vez mais complexa e, associados à crescente demanda por ampliação de vagas, indicaram a premente necessidade de um planejamento institucional que viesse a ordenar 0 crescimento acadêmico e físico da Instituição por um prazo de seis anos. Dessa intenção resultou o Plano de Desenvolvimento de 1966/1970 que contou com a participação de todos os setores da Universidade. A coordenação do planejamento físico coube ao arquiteto carioca Hélio Duarte, que também participou da instalação da Escola de Arquitetura da UFC, criada em 1964.

O Plano procurou estabelecer diretrizes gerais de crescimento embasadas pelos objetivos de integração e expansão, bem como direcionamento para promover flexibilidade e funcionalidade no desenvolvimento da Instituição. A garantia das bases estabelecidas encontrava, entretanto, um conflito: diante do objetivo de conferir maior funcionalidade ao sistema por intermédio de melhor integração entre as unidades, era preciso superar a dispersão espacial em três áreas distintas por meio do planejamento. Por outro lado qualquer solução a ser adotada não poderia descartar os investimentos já consolidados nesses terrenos. A ferramenta utilizada para contornar o impasse foi a proposição de um zoneamento que estabelecesse a vocação funcional de cada área, dando inteireza à fragmentação espacial e funcionalidade e integração entre as unidades.

A especialização proposta definiu três setores:

- Setor $A$, correspondendo ao Benfica - voltado para o campo de humanas, administração central e equipamentos de cultura e lazer; Setor $B$,

- correspondendo ao Porangabuçu - destinado às ciências biomédicas e o

- Setor $C$, correspondendo ao Pici - dirigido às áreas tecnológicas, agronômicas, institutos básicos e futuras ocupações que fossem gradativamente conformando aquele setor como território único da Universidade, tendo esse último um plano de ocupação com base na organização de zonas acadêmicas articuladas por um sistema viário geral, com evidente inspiração nos princípios racionalistas do urbanismo moderno. A concretização dos referidos setores seria operada por meio do gradativo remanejamento das unidades para o seu respectivo Setor e com construção de outras que se fizessem necessárias.

A execução do Plano estava vinculada à liberação dos recursos garantidos por meio do Programa MEC/BID, o que só veio acontecer em 1970, durante o processo de implantação 
da Reforma de 1968, introduzindo novas orientações ao planejamento. Procurando se adequar ao modelo de campus universitário da Reforma, a UFC elabora para o Pici uma proposta de organização espacial situando o setor básico em posição central, circundado por um anel viário periférico, ao redor do qual se estabeleceriam as futuras faculdades profissionais reunidas por afinidades, o que evidenciava referências ao Manual de Atcon (1970). Foram executados o setor básico, que na nova matriz acadêmica conformou o Centro de Ciências, e o anel viário periférico.

Durante a primeira metade da década de 1970 foram formuladas mais três propostas de características espaciais similares que tentavam dar materialidade à estrutura de seis centros e uma Reitoria no modelo de campus na área do Pici. A primeira proposta instituiu o "Campus do Pici com a área da saúde no Porangabuçu", já que não conseguiu neutralizar os impasses para a transferência desse setor. Entretanto, com base nessa configuração primeira, definiu uma segunda organização que incorporava a Faculdade de Odontologia, tendo em vista a indisponibilidade de terrenos no Porangabuçu para a construção das instalações daquela unidade que ainda funcionava no centro da cidade. Por último, incorporou ao Pici o setor administrativo da Reitoria.

Em todas elas a organização espacial estava baseada no zoneamento das funções, estabelecendo os setores de conhecimentos afins - os centros - e o setor esportivo, de vivência e administrativo. Articulavam-se por meio de um sistema de circulação hierarquizado, que separava o sistema viário geral das vias secundárias que davam acesso aos estacionamentos setoriais, enquanto a circulação de pedestres era feita no interior das zonas sem interferência de veículos. Nenhuma delas foi executada na íntegra.

Para atender aos imperativos de rapidez e baixo custo na construção das unidades acadêmicas exigidos pelo processo de implantação da Reforma, a UFC adotou a padronização como critério construtivo - herança do Plano de Desenvolvimento de $1966 / 1970$, Foram concebidos blocos de dois pavimentos com a planta livre, de geometria predominantemente retangular que se desenvolve sobre a malha modular de $1,25 \times 1,25 \mathrm{~m}$. Com base no módulo estrutural definido a cada $2,50 \mathrm{~m}$ de vão, foram projetados os componentes construtivos, tais como as esquadrias de madeira com venezianas articuláveis de fabricação local. Essa padronização foi adotada nas unidades dos centros de Ciências, de Tecnologia e de Agronomia implantados no Pici.

$\mathrm{Na}$ segunda metade da década de 1970 , outra produção de viés arquitetônico com ênfase no concreto aparente foi erguida no Campus do Pici, causando forte contraste visual com o conjunto dos blocos de identidade padrão. Os edifícios destinados à Biblioteca e ao Núcleo de Processamento de Dados são exemplares desse período. 
Em 1979, quando as instituições começaram a questionar a validade da Reforma Universitária de 1968, a UFC elaborou um plano diretor com o objetivo de estabelecer definitivamente as bases físicas da Instituição. Resgatando a proposição do zoneamento de três setores estabelecido no Plano de 1966/1970, o novo documento admitia a configuração de um campus tripartido, conformado pelas áreas Área 1 - Pici, Área 2 - Pornagabuçu e Área 3 - Benfica. Predominou, entretanto, na sua concepção a ideia de campus visto como território isolado, autônomo e segregado em relação à cidade.

Com base no processo histórico que se deu na UFC com vistas à materialização do seu território, podemos identificar três tipologias espaciais concebidas pela instituição. A primeira, quando da sua criação, tentou dar forma a um território inserido na malha urbana de Fortaleza, fazendo da quadra a unidade territorial básica. Posteriormente, propôs uma zona constituída pela junção de três áreas especializadas, articuladas entre si pela estrutura urbana existente. Uma terceira concepção foi pensada como território isolado, no modelo de campus da Reforma.

O Campus do Pici encontra-se envolvido pela estrutura urbana, porém não se integra com as áreas do entorno. Cercado por muros, a presença da população de baixa renda nas suas vizinhanças torna seus limites em fronteiras de conflitos gerados por ameaças de invasões. 


\section{UNIVERSIDADE FEDERAL DA PARAÍBA (UFPB)}

A Universidade Federal da Paraíba é uma instituição autárquica de regime especial de ensino, pesquisa e extensão, vinculada ao Ministério da Educação. Atua em várias regiões do Estado com a seguinte estrutura: Campus I, que sedia a Instituição, em João Pessoa; Campus II, na cidade de Areia, o Campus III, na cidade de Bananeiras e o Campus IV, nas cidades de Mamanguape e Rio Tinto (ver figura 79).

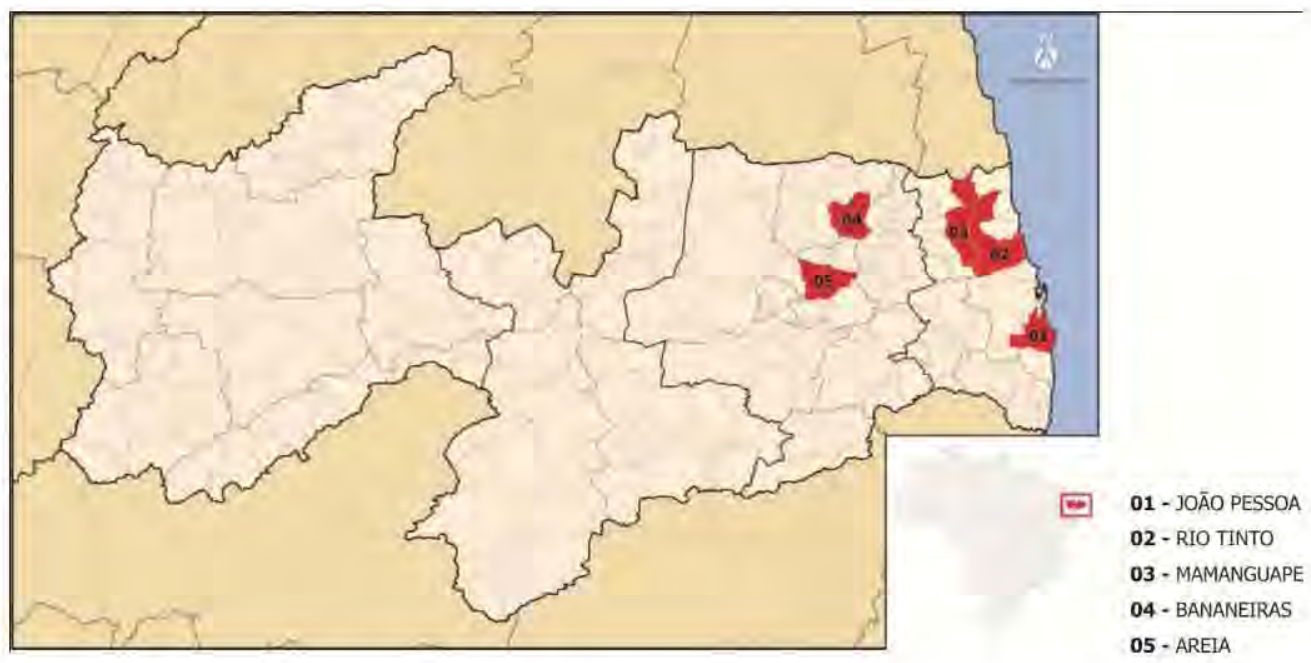

Figura 79: UFPB - Mapa da Paraíba.

Localização dos municípios que sediam a UFPI.

(Fonte: disponível em: <http://pt. wikipedia.org/wiki/Anexo:

Lista_de_munic\%C3\%ADpios_de_Paraíba>. Acesso em: 01 fev. 2012).

\subsection{A CRIAÇÃO DA UFPB}

A Universidade Federal da Paraíba (UFPB) é uma instituição de ensino superior, com sede na cidade de João Pessoa, capital do Estado da Paraíba, constituída como autarquia educacional de regime especial vinculada ao Ministério da Educação. Surgiu como um estabelecimento estadual, "sob a égide de uma administração central, de escolas isoladas pré-existentes, oficiais e particulares" (UFPB, [1980?], p. 5).

Criada em 1934, a Escola de Agronomia do Nordeste, na cidade de Areia (Zona do Brejo), foi a primeira de nível superior no Estado, mas só veio a funcionar regularmente em 1937, financiada pelo governo do estadual. Deu origem ao Centro de Ciências Agrárias da futura 
UFPB. Sua criação contrariava as tendências profissionais do período, que eram fortemente acentuadas para medicina, advocacia ou sacerdócio, carreiras já tradicionais entre famílias da classe dominante rural e àquela altura aspirações dos setores de classe média da população ${ }^{33}$ (LIMEIRA e FORMIGA, 1986, p.5). Tal fato se explicaria pela força política das oligarquias paraibanas ainda atuantes naquele Estado, que passaram a encarar esse tipo de ensino como um determinante de ascensão social por meio da formação de filhos de fazendeiros. Além do que o momento histórico daqueles anos, impregnado pela ideologia do progresso e da modernização pode ter contribuído para a criação de uma escola agrícola naquele Estado, vista como meio de superação do atraso das técnicas de produção do setor agrícola.

Embora o contexto histórico nacional da década de 1930 tenha se caracterizado por um processo significativo de urbanização, industrialização e surgimento de camadas médias urbanas e assalariadas, que passaram a reivindicar certo grau de instrução, na Paraíba esse cenário só começou a se delinear nas décadas de 1940 e 1950.

Seguiu-se em 1947, por ordem de antiguidade, a Faculdade de Ciências Econômicas da Paraíba, situada na capital, fundada como estabelecimento particular. Até aquele momento, havia apenas duas outras instituições que, a nível médio, formavam pessoal para a área do comércio: a Escola Técnica do Comércio "Epitácio Pessoa" e a Escola Comercial "Underwood". Segundo Ferreira e Guerra (2006, p.27), a faculdade representou um marco divisório entre duas épocas: a primeira em que predominaram os estabelecimentos de ensino superior secundário, e posteriormente a que se iniciava com a instituição de cursos superiores. Revestindo-se de importância, a Faculdade de Ciências Econômicas aparece no quadro cronológico da história do ensino superior da Paraíba como sendo a transição do ensino médio para a formação do Ensino Superior.

No ano seguinte, o governo estadual, instituiu uma comissão $(1948)^{34}$, que desencadeou a formação de um ambiente propício ao debate sobre a introdução do ensino superior no Estado $^{35}$. A partir de então se estabeleceu uma mobilização mais efetiva, com a participação de diversos segmentos da sociedade paraibana, representantes das diversas profissões liberais, que deveriam elaborar projetos com tal finalidade e encaminhar sua operacionalização.

\footnotetext{
${ }^{33}$ Sobre esse assunto ver o texto Criação da Escola de Agronomia do Nordeste: um compromisso político (1934), que integra a publicação da UFPB (FERREIRA e GUERRA, 2006, p. 26) comemorativa do cinquentenário de sua fundação.

${ }^{34}$ A comissão era composta pelos presidentes do Tribunal de Justiça, Tribunal Regional Eleitoral, Ordem dos Advogados, Instituto dos Advogados da Paraiba, Associação Paraibana de Cirurgiões Dentistas, Academia Paraibana de Letras, Associação Comercial, pelo diretor da Faculdade de Ciências Econômicas e um representante do governo do Estado (RODRIGUES, 1986 , p. 39).

${ }^{35}$. A medida era condizente com a política educacional adotada em todo o país, no período de 1946 a 1964 (BEZERRA, 2006 , p. 38).
} 
Finalizando a década, em $1949^{36}$, foi instituída a Faculdade de Filosofia e Letras (FAFI), com sede na capital, apoiada legalmente pela Constituição Estadual de 1947, que previa em seu art. 16 a criação da mesma. Cumprindo a finalidade profissionalizante de formar professores, preencheria também os vazios humanísticos deixados por outros cursos superiores que vieram a existir (FERREIRA e GUERRA, 2006, p. 29). Entretanto, ela só veio a funcionar em 1952.

A expansão do ensino superior se deu efetivamente na década de 1950 , quando a Paraíba vivenciou a criação de quase todas as escolas isoladas que viriam a constituir a futura Universidade Estadual. Logo no ano de 1951, foram instaladas as faculdades de Direito ${ }^{37}$ e de Medicina da Paraíba. A primeira foi uma iniciativa do Instituto dos Advogados da Paraíba, financiada com capital privado e sede em João Pessoa. $O$ anelão de advogado era perseguido tanto por componentes de classes altas, como reforço ao status, como pela classe média, como forma de ascensão social (FERREIRA e GUERRA, 2006, p. 30).

A Faculdade de Medicina surgiu em 1950 por iniciativa de um grupo de médicos da Paraíba, entusiasmados com o êxito da de Direito. Começou a funcionar com recursos do setor privado. A instituição recém-criada eliminava o transtorno do deslocamento para outros estados, mesmo considerando a proximidade com a cidade do Recife, onde funcionava o curso de medicina mais próximo.

No âmbito estadual, o governo reconhecia que esse curso, além de ser prioridade, já que ampliaria a assistência médica estadual e municipal, contemplaria as necessidades das cidades interioranas que se ressentiam da ausência de unidades sanitaristas, o que só poderia ocorrer se houvesse profissionais qualificados da área de saúde. No âmbito estadual, o governo considerava-o prioritário, já que permitiria a ampliação da assistência médica estadual e municipal, além de contemplar as necessidades das cidades interioranas, que somente seriam atendidas se houvesse profissionais qualificados na área da saúde em número suficiente.

Nesse mesmo contexto, a entidade de classe dos dentistas, encabeçada pela Associação Paraibana de Cirurgiões-Dentistas tratou de dar corpo ao movimento pela criação de uma faculdade de odontologia autônoma, contrariando a concepção original de uma faculdade de medicina, odontologia e farmácia. Criada em 1951 pelo governo do Estado, devido a entraves financeiros e burocráticos, só veio a funcionar em 1953, com sede na capital. Já a Faculdade de Farmácia foi oficializada apenas em 1958.

\footnotetext{
${ }^{36}$ Constatamos divergência na data de criação da Faculdade de Filosofia Ciências e Letras: a UFPB ([1980?], p. 5) in dica o ano de 1948, enquanto que Ferreira e Guerra (2006, p. 29) informam o ano de 1949. Adotamos o de 1949 tendo em vista que os autores esclarecem ter sído esse ano em que a FAFI foi criada oficialmente.

${ }^{87}$. Embora criada em 11 de novembro de 1949 , só foi instalada na década seguinte.
} 
Ainda no ano de 1951 , dentro do quadro favorável à proliferação de instituições de nível superior em todo o país, foi fundada a Escola de Serviço Social com o apoio da Igreja e do governo do Estado. Entretanto, por ser de caráter privado, teve dificuldades provenientes da escassez de recursos, sobrevivendo até ser encampada pela UFPB.

Também no início da década de 1950, foi criada a Escola Politécnica de Campina Grande propiciada pela conjuntura econômica desta cidade, que tendo se tornado um ativo entreposto comercial da Zona da Mata-Sertão-Brejo, permitiu o desenvolvimento de novo foco científico-cultural na Paraíba, destacando-se de outras cidades interioranas. Essa situação possibilitou o projeto de uma escola técnica de nível superior, a qual abria perspectivas de integrar a cidade no desenvolvimento técnico-industrial do Estado. Contou desde o princípio com $\circ$ apoio de setores locais das áreas financeiro-comerciais, interessados na iniciativa, que assumiram de forma concreta compromisso de colaboração. Os debates prosseguiram até que no dia 6 de outubro de 1952, foi criada a Escola Politécnica de Campina Grande através da Lei estadual no 792 . Foram mobilizadas entidades particulares, federais e estaduais, cujo apoio financeiro permitiu a implantação de toda a infraestrutura necessária ao seu funcionamento, inclusive equipamentos de boa qualidade.

No mesmo ano, foi criada de Engenharia da Paraíba, por iniciativa do Clube de Engenharia. A historiografia da UFPB situa a euforia redemocratizadora pós-1945 como o contexto predominante na fundação dessa instituição. A normalidade democrática teria gerado em todo o país um clima de debates acerca dos problemas nacionais mais candentes, como: nacionalização e estatização do petróleo, questões de saúde, de educação (UFPB, 2010, n.p.). A iniciativa, entretanto foi encarada com certa descrença pela comunidade, uma vez que sendo de origem privada, logo poderiam surgir transtornos oriundos da falta de recursos financeiros, além do que a Escola Politécnica de Campina Grande estava em pleno funcionamento e, sendo da área estadual, gozava de boas condições financeiras.

Em 1953, no bojo do mesmo processo de criação da Faculdade de Medicina foi formada a Escola Superior de Enfermagem. A implantação das faculdades de Medicina e Odontologia abriu perspectivas no mercado de trabalho para os profissionais de enfermagem, criando condições para a fundação dessa instituição de nível superior.

Em 1955, existiam no Estado onze escolas de nível superior, o que possibilitou a criação da Universidade da Paraíba através da Lei estadual $n^{\circ} 1.366$, de 2 de dezembro de 1955. Além disso, houve uma conjunção de vários fatores: o funcionamento precário de algumas escolas pela escassez de recursos financeiros, acarretando a inadequação das instalações físicas; a dificuldade de locomoção para outros centros em busca de especialização 
profissional sensibilizava a sociedade; o funcionamento efetivo das escolas superiores isoladas estaduais e particulares com contingente satisfatório de alunos, abrindo margem para uma crescente procura de cursos e a formação de mercado de trabalho nos diversos ramos profissionais (LIMEIRA e FORMIGA, 2006, p. 36).

A Universidade da Paraíba passou a ser integrada por oito unidades isoladas, existentes nas cidades de João Pessoa e Campina Grande. Foram incorporadas: Faculdade de Filosofia da Paraíba, Faculdade de Odontologia da Paraíba, Escola Politécnica da Paraíba (em Campina Grande) e a Escola de Enfermagem da Paraíba; e agregadas: Faculdade de Direito da Paraíba, Faculdade de Ciências Econômicas da Paraíba, Escola de Engenharia da Paraíba e Escola de Serviço Social da Paraíba (UFPB, [1980?], p.6). "As instituições incorporadas pela Universidade da Paraíba, em 1955, eram públicas, enquanto as agregadas eram particulares" (BEZERRA, 2006, p.42).

Os custos de manutenção e operação da nova universidade se tornavam, entretanto difíceis de serem mantidos pelo governo. Tratando-se de um Estado de poucos recursos, os elevados encargos financeiros de algumas faculdades oneravam os cofres estaduais. A possibilidade de federalização, graças à política do presidente Juscelino Kubitschek que visava o desenvolvimento industrial do país e que só seria possível com a expansão do ensino, surgiu como uma forma de salvação. Representava a sobrevivência da instituição, bem como a liberação do Estado do pesado encargo de mantê-la, mesmo que precariamente.

No final do mandato presidencial, a Universidade da Paraíba foi federalizada pela Lei $n^{\text {o }}$ 3.835 de 13 de dezembro de 1960, constituída por onze unidades, sendo nove em João Pessoa - Faculdade de Ciências e Letras, Faculdade de Odontologia, Faculdade de Direito, Faculdade de Medicina, Escola de Enfermagem, anexa à Faculdade de Medicina, Faculdade de Ciências Econômicas, Escola de Engenharia, Escola de Serviço Social, Faculdade de Farmácia; e duas em Campina Grande - Faculdade Politécnica e Faculdade de Ciências Econômicas.

Em 1973, atendendo aos ditames da Reforma de 1968, o Conselho Universitário aprovou a reformulação da estrutura acadêmica da UFPB, através da Resolução $n^{\circ}$ 12/1973, em consonância com o disposto nos Decretos-leis $n^{\circ}$ s 53/1966 e 252/1967, e na Lei $n^{\circ}$ $5.540 / 1968$, passando a se organizar em Centros como órgãos intermediários e de concentração dos Departamentos por áreas de conhecimentos básicos e profissionais. $\mathrm{A}$ reformulação ficou conhecida na instituição como "reforma cêntrica". 
A partir de então, a Universidade Federal da Paraíba ficou estruturada da seguinte forma: Campus I, na cidade de João Pessoa; Campus II, na cidade de Campina Grande; Campus III, na cidade de Areia; Campus IV, na cidade de Bananeiras; Campus $V_{4}$ na cidade de Cajazeiras; Campus $V_{1}$, na cidade de Sousa e Campus VII, na cidade de Patos.

Após uma luta de vários anos, envolvendo a comunidade acadêmica, a sociedade como um todo e a classe política local, foi criada a Universidade Federal de Campina Grande, com o desmembramento da Universidade Federal da Paraíba, através da Lei $n^{\circ} 10.419$, de 09 de abril de 2002, integrada pelo Campus I, na cidade de Campina Grande, abrangendo o Centro de Ciências e Tecnologia - CCT; Centro de Humanidades - $\mathrm{CH}$ e Centro de Ciências Biológicas e da Saúde - CCBS; Campus II, na cidade de Cajazeiras, abrange o Centro de Formação de Professores - CFP; Campus III, na cidade de Sousa, abrange o Centro de Ciências Jurídicas e Sociais - CCJS e o Campus IV, na cidade de Patos, abrange o Centro de Saúde e Tecnologia Rural -CSTR (UFPB, 2010, n.p.)

Conforme site oficial da Universidade, até o presente ano de 2012, suas unidades estão organizadas com os seguintes centros:

- no Campus I, estão o Centro de Ciências Exatas e da Natureza - CCEN; Centro de Ciências Humanas, Letras e Artes - CCHLA; Centro de Ciências da Saúde - CCS; Centro de Ciências Sociais Aplicadas - CCSA; Centro de Educação - CE; Centro de Tecnologia CT e o Centro de Ciências Jurídicas;

- no Campus II, o Centro de Ciências Agrárias - CCA;

- no Campus III, o Centro de Formação de Tecnólogos - CFT e o

- no Campus IV estão o Centro de Ciências Aplicadas e Educação - CCAE.

\subsection{REFORMA CÊNTRICA: mudanças na organização acadêmica}

A sequência de execução das obras da UFPB esteve certamente ligada a mudanças na organização acadêmico-administrativa da universidade. Enquanto instituição estadual (Universidade da Paraíba) mantinha a estrutura que the deu origem, resumida em: (a) administração superior, (b) faculdades e escolas incorporadas e (c) faculdades e escolas agregadas. 
Conforme publicação da Universidade (UFPB, [1980?], p. 7), tal configuração foi praticamente mantida com a federalização, até 1967, período em que ocorreram alterações de certo relevo, tais como:

a) A criação dos institutos centrais de Química (15 out. 1962), de Matemática (27 fev. 1965) e de Física (5 mar. 1965), com funções de coordenação do ensino e da pesquisa das ciências básicas.

b) O surgimento da Comissão Central de Pesquisa (11 dez. 1965), como órgão gestor de planos de pesquisas.

c) A transformação do antigo conselho técnico administrativo em conselho departamental, com funções análogas, embora somente em algumas faculdades e escolas começassem a funcionar departamentos (UFPB, [1980?], p. 7).

Essas mudanças se anteciparam aos Decretos-leis $n^{\text {os }} 53 / 1966$ e 252/1967, que formaram a espinha dorsal da Reforma de 1968. Com base na nova legislação, a UFPB realizou seu primeiro plano de reestruturação aprovado pelo Decreto $\mathrm{n}^{\circ} 61.920$, de 19 de dezembro de 1967, e consubstanciado no estatuto aprovado em 1969. Tal estrutura delineava a organização acadêmico-administrativa em duas bases: (I) órgãos de administração superior e (II) órgãos de ensino e pesquisa. Este último foi constituído por sete institutos centrais e dez faculdades e escolas, divididos em três áreas de conhecimento, a saber:

- 1 - Tecnológica: Instituto Central de Química, Instituto Central de Matemática, Instituto Central de Geociências ${ }^{38}$, Escola de Engenharia e Escola Politécnica (Campina Grande).

- 2 - Biocientífica: Instituto Central de Ciências Biológicas, Faculdade de Medicina ${ }^{39}$, Faculdade de Odontologia, Faculdade de Farmácia e a Escola de Agronomia, incorporada no ano seguinte pelo Decreto $n^{\circ} 62.715$, de 16 de maio de 1968 , com sede na cidade de Areia [mencionada na introdução]. Com ela a UFPB expandia sua atuação no interior do Estado, além de Campina Grande (ver figuras 80 e 81).

- 3 - Humanística: Instituto Central de Filosofia e Ciências Humanas, Instituto Central de Letras, Instituto Central de Artes ${ }^{40}$, Faculdade de Direito, Faculdade de Ciências Econômicas (João Pessoa), Faculdade de Ciências Econômicas (Campina Grande) e Faculdade de Educação.

\footnotetext{
${ }^{38}$ O Instituto Central de Geociência não foi implantado.

. A Escola de Enfermagem, até então anexa à Faculdade de Medicina, passou a ser um de seus departamentos.

${ }^{40}$. O Instituto Central de Artes não foi implantado.
} 


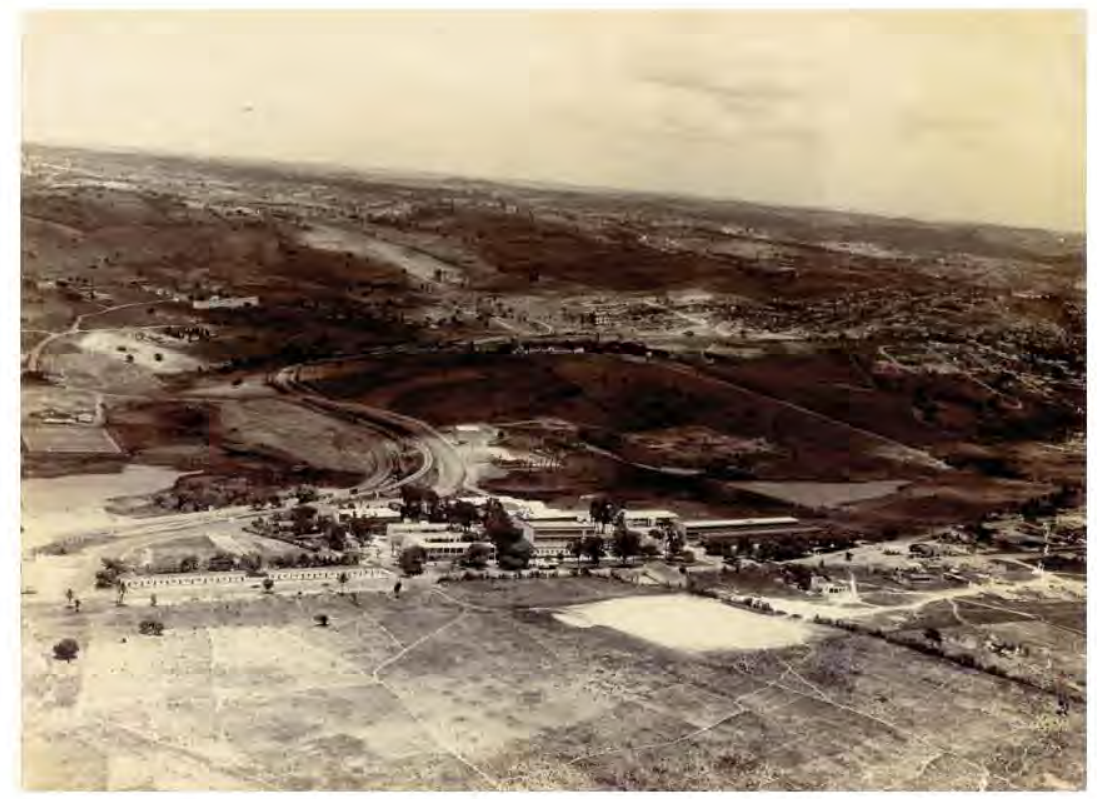

Figura 80: UFPB - Campus de Campina Grande - início de 1978. (Fonte: Acervo NDIHR/UFPB)

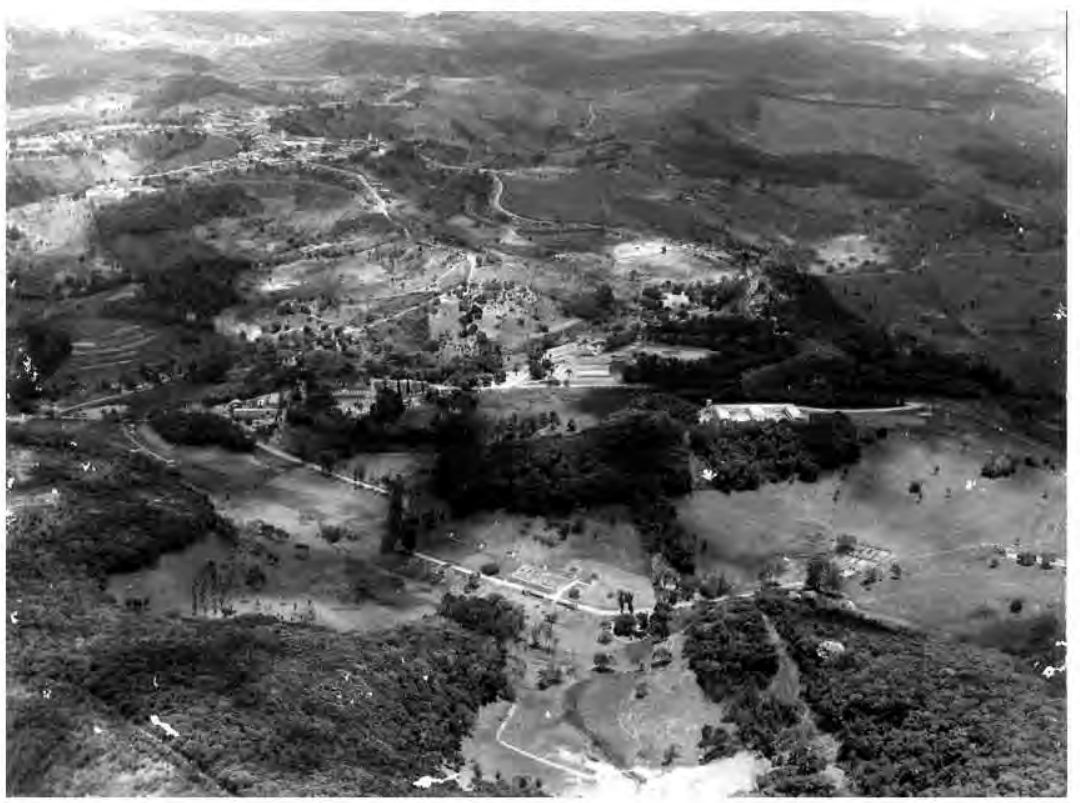

Figura 81: UFPB - Campus de Areia - início de 1978.

A Escola de Agronomia deu origem ao Centro de Ciências Agrárias.

(Fonte: Acervo NDIHR/UFPB)

As unidades (órgãos de ensino e pesquisa mencionados) foram didaticamente estruturadas com base no sistema departamental. Tal concepção decorreu do fato de ser o departamento igualmente órgão de ensino e pesquisa, caracterizado por definição legal como a célula de organização acadêmica e base da estrutura didático-científica (UFPB, 1972, n.p.). Ressaltese que ainda não estavam agrupados em centros, o que só viria a ocorrer na primeira metade da década de 1970 com a reforma cêntrica. 
Em 1968, com a Reforma Universitária, a UFPB procedeu à segunda revisão estrutural dentro dos princípios de racionalidade e integração acadêmica, que norteavam a lei reformista. O novo plano concebeu a organização da universidade com base nos departamentos, como órgão de ensino e pesquisa, porém coordenados e integrados no nível de administração intermediária, por centros, como órgãos setoriais. Os planos diretores que surgiram a partir dessa data caracterizaram-se pela finalidade de propor a compatibilização da estrutura física com a nova organização acadêmica, indicada no modelo espacial de campus.

Entretanto, somente em 1974, é que foi aprovada a reestruturação proposta, por meio do Decreto $n^{\circ} \mathbf{7 3 . 7 0 1}$, de 28 de fevereiro do citado ano, que resultou na fusão, transformação ou extinção das antigas unidades (institutos centrais, faculdades e escolas). Tal reforma ficou conhecida na UFPB como "reforma cêntrica". Foram redimensionados e numericamente reduzidos os departamentos da universidade que, agrupados por afinidade de áreas de conhecimento ficaram integrados em seis centros, a saber:

a) de ensino e pesquisa básicos:

- Centro de Ciências Exatas da Natureza (CCEN)

- Centro de Ciências Humanas, Letras e Artes (CCHLA)

b) de ensino profissional e pesquisa aplicada:

- Centro de Ciências da Saúde (CCS)

- Centro de Ciências Sociais Aplicadas (CCSA)

- Centro de Tecnologia (CT)

- Centro de Ciências e Tecnologia (CCT) (UFPB, [1980?], p. 8).

O CCT integrava os departamentos situados em Campina Grande (campus de Campina Grande) e passou a ser incorporada outra área de atuação, na cidade de Bananeiras. Ao todo a UFPB passou a ter quatro campi:

- um em João Pessoa, num total de 162 ha, a 6 km do centro da capital paraibana;

- um em Campina Grande, com 32 ha, no bairro Bodocongó, a 120 km de João Pessoa;

- um em Bananeiras, com 370 ha, a 145 km da capital;

- um campus agrário com 300 ha, em Areia, a $120 \mathrm{~km}$ de João Pessoa.

A menção a estas transformações na estrutura da UFPB torna-se relevante para a compreensão da organização espacial, ocorrida nas décadas de 1960 e 1970. 


\subsection{INSTALAÇÕES FÍSICAS: de unidades isoladas à cidade universitária}

Assim que foi fundada, sob a égide do governo do Estado, a Universidade da Paraíba tratou de providenciar um local para as futuras instalações em João Pessoa, tendo como modelo, a concepção vigente de cidade universitária. As discussões em torno de uma instituição concebida em extensa gleba, afastada do centro urbano, foi adotada desde a sua origem, contrapondo-se ao funcionamento das atividades em edificações dispersas no centro urbano da capital.

Já em fevereiro de 1956, a administração superior ${ }^{41}$ colocou em pauta de reunião junto aos diretores das faculdades o tema referente à escolha do terreno para a construção do novo território universitário, que resultou no convite ao engenheiro Luiz Hidelbrando de Barros Horta Barbosa ${ }^{42}$, diretor do Escritório Técnico da Universidade do Brasil, no Rio de Janeiro, para se dirigir à cidade de João Pessoa em novembro do mesmo ano com a finalidade de orientar na definição dos parâmetros para escolha do local (PEREIRA, 2008, p. 95).

O engenheiro, após percorrer toda a capital paraibana selecionou, inicialmente, a gleba correspondente à Fazenda Boi Só, onde hoje segundo Nóbrega (1979 apud UFPB 2006, p. 103) está o Estádio José Américo. As características geofísicas do terreno, um planalto com altitude variando 30 a 40 metros acima do nível do mar, não exigiria grandes movimentos de terra, com cortes ou aterros, nem vastos volumes para aterramento de áreas alagadiças e pântanos (PLANEJAMENTO da futura "Cidade Universitária" do Est. da Paraíba, 1956, p. 4 apud PEREIRA, 2008, p.95). Além disso, o clima predominante, que favorecia a ventilação, contribuiu para sua seleção. Apesar de tais vantagens, destacadas pela imprensa, que ressaltava também a localização na zona de expansão da cidade (CONSTRUÇÃO da cidade universitária, 1956, p.2 apud PEREIRA, 2008, p.96), a alternativa foi preterida, devido a suas pequenas dimensões, como justificou o próprio Horta Barbosa (S. RAFAEL - local mais indicado para a cidade universitária, 1956, p. 8 apud PEREIRA, 2008, p. 96).

Nóbrega (1979 apud UFBP, 2006, p.103) revela que antes da Fazenda Boi Só

[...] o governo Oswaldo Trigueiro tinha reservado o antigo campo de aviação da Imbiribeira para o futuro campus universitário. Mas o governador que o sucedeu (José Américo) resolveu lotear aquele local que estava desativado para fazer o calçamento da Avenida Epitácio Pessoa.

\footnotetext{
${ }^{41}$. Reitorado de Dumerval Trigueiro, período de 1955 a 1956.

${ }^{42}$. O engenheiro convidado fez parte, como representante da Associação dos Engenheiros, da comissão julgadora do concurso para o Plano Piloto de Brasilia, junto a outros profissionais tais como Israel Pinheiro, William Holford, André Sive, Stamo Papadaki, Oscar Niemeyer e Paulo Antunes Ribeiro (PEREIRA, 2008, p. 95).
} 
Partiu-se então para outra opção que, além de ser uma área de maiores dimensões e não habitada, pertencia ao governo do Estado, situação que evitaria custos de desapropriação. Tratava-se da Fazenda São Rafael (ver figura 82).

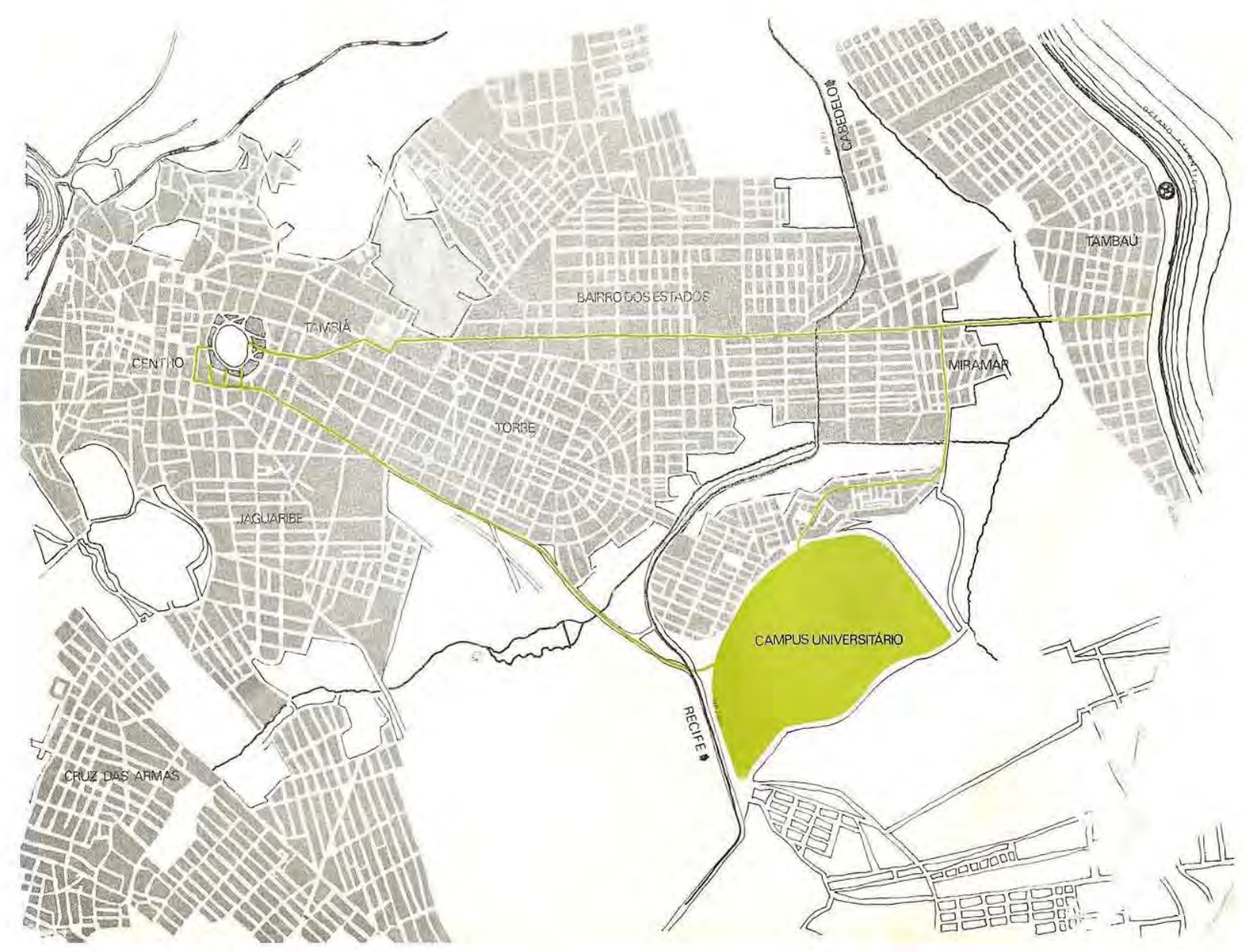

Figura 82: UFPB - Mapa da Relação Cidade / Campus Universitário. (Fonte: UFPB, 1972, n.p.)

Além das vantagens acima mencionadas, havia a facilidade de acesso, ressaltada por Horta Barbosa, e a existência de uma cobertura vegetal nativa, que permitiria uma solução urbanística com os edifícios e a natureza integrados. Contribuiria ainda para a expansão urbana na direção sudeste da cidade, impulsionada pela construção do anel rodoviário e pela implantação do distrito industrial, em meados de 1963 (PEREIRA, 2008, p.96-97). A figura 83 destaca a relação geográfica entre o centro urbano, o campus da UFAL e distrito indústria, evidenciando os propósitos especulativos implícitos na escolha da Fazenda São Rafael. 


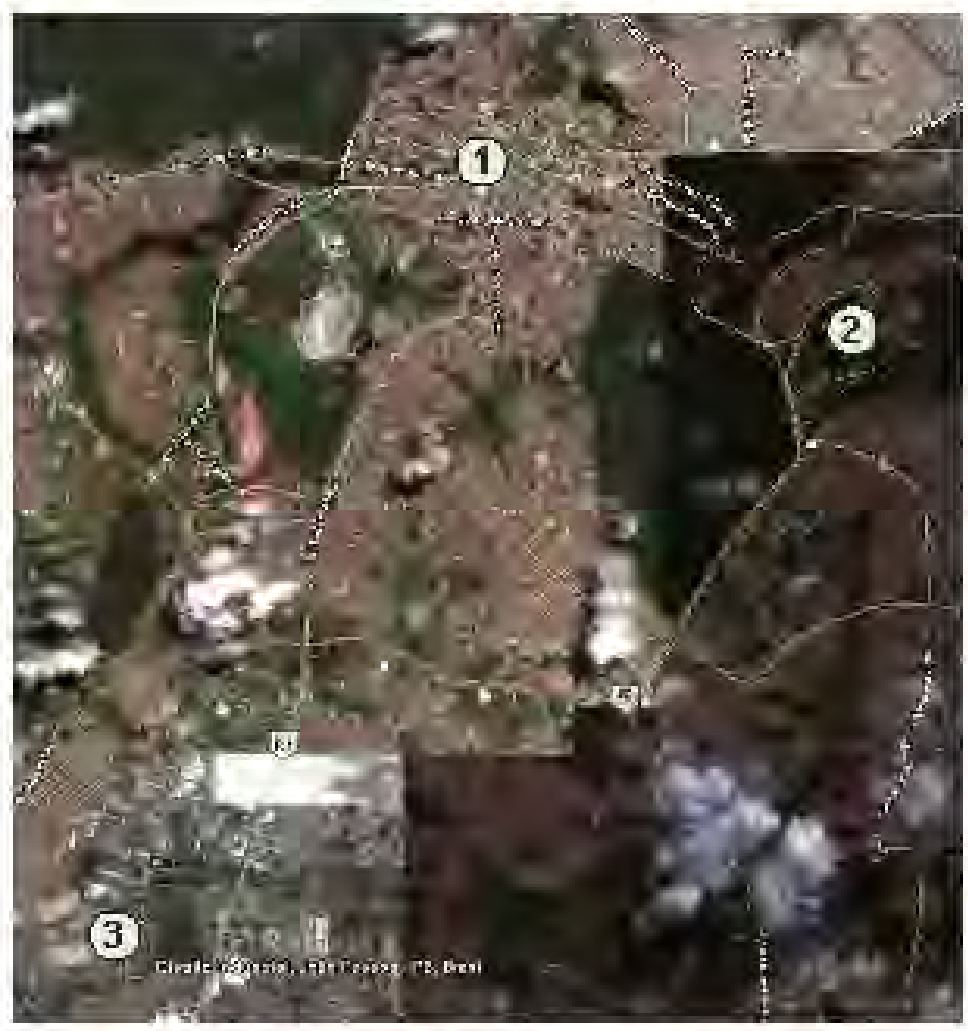

Figura 83: UFPB - Vista Joẫo Pessoa

A imagem destaca as seguintes áreas: (1) centro urbano de Joấo Pessoa, (2) campus universitário - UFPB e (3) distrito industrial. O anel viário margeia o campus e dá acesso ao distrito industrial. (Fonte: Google Earth. Acesso 11 now. 2011, grifo nosso).

Nos estudos realizados para a escolha do terreno destacaram-se a localizaçẫo geográfica afastada do centro urbano e sua oc upaçã̃o rarefeita, condiçốes perseguidas no modelo de cidade universitária, que supunha o isolamento e a autonomia em relaçã̃o ao meio urbano. Ficou evidente, ainda, que os condicionantes de infraestrutura e de serviços urbanos adequados ao futuro equipamento nẫo foram considerados. Por outro lado ressaltaram se as boas condiçốes físico-geográficas que favoreceriam um plano urbanístico de "destaque". Além do que, nẫo se ignorava que uma obra desse porte provocaria a especulaçẫo imobiliária das áreas adjacentes, induzindo o crescimento da cidade.

Entretanto, a doaçầo do terreno da Fazenda Sẫo Rafael realizada pelo governo do Estado em 11 de novembro de 1958 nẫo levou à construçẫo imediata das novas instalaçốes e, consequentemente, à transferência das atividades para o novo território. Isso só viria a ocorrer em meados da década de 1960 , quando se iniciou a edificaçấo das primeiras unidades universitárias. A demora deveu-se à inviabilidade de garantir os recursos financeiros necessários.

Tratando-se de um Estado de poucos recursos tornava-se dificil à Paraíba manter a universidade, principalmente com os elevados custos de algumas faculdades como as de 
medicina e odontologia, que oneravam sobremaneira os cofres estaduais. O governo estadual tinha condições de manter apenas precariamente o aparelho administrativo, agravando as carências das faculdades e escolas (MELO, 2006, p. 39).

Diante do quadro de inviabilidade financeira, a administração superior decidiu pelo aproveitamento das edificações existentes no centro urbano, invalidando o propósito inicial de construção da cidade universitária nos moldes que vinham sendo adotados pelas universidades brasileiras. Pereira $(2008$, p.97) registra que, em 1959, a imprensa local noticiou o evento, enaltecendo a decisão do conselho universitário, uma vez que além da economia de recursos financeiros, a instituição já possuía uma, constituída pelos prédios situados na malha urbana da cidade, em contato efetivo com o meio social, que seria eliminado, em prejuizo do próprio aluno.

O posicionamento contrariava o conceito de cidade universitária implantado no Brasil com a criação das universidades, na primeira metade do século XX. A proposta de um espaço integrador, que garantisse o "espírito universitário" por meio de um território isolado e autônomo em relação ao meio urbano, não encontrava correspondência naquela reportagem. É provável que o sentimento de modernidade emanado daquele modelo de organização espacial fosse, na verdade, o cerne motivador de uma instituição que queria parecer moderna. Negá-la seria como se manter algemado pelas tradições. Mesmo a resistência de alguns cursos como o da Faculdade de Direito, que continua até hoje funcionando na área central da cidade, talvez estivesse mais ligada a uma questão de comodidade, do que ao desejo de inserção com suas vizinhanças. Isso se explicaria pela facilidade de acesso aos serviços comerciais existentes e também pela rejeição a deslocamentos para outra zona da cidade, ainda desabitada, além do que a estrutura universitária baseada na cátedra tenderia a não desejar alterar sua rotina.

A opção de permanecer funcionando em edificações urbanas dispersas reproduzia a tipologia espacial do edifício isolado que predominou nos primeiros momentos de implantação da instituição universitária brasileira, ocorrida na primeira metade do século XX. O conjunto era composto pelos edifícios das faculdades e escolas que constituíram a universidade na sua fundação. Dentre eles, destacamos as seguintes unidades: Faculdade de Direito, Faculdade de Ciências Econômicas, Faculdade de Farmácia, Faculdade de Odontologia, Faculdade de Enfermagem, Faculdade de Filosofia, Escola de Engenharia e Escola de Serviço Social. A linguagem arquitetônica predominante nesses edifícios transitava entre a influência do estilo neocolonial e as linhas do art deco, com exceção do prédio da Escola de Engenharia, que apresenta uma composição mais retilínea, e o da Faculdade de Direito, que originalmente abrigou o Convento dos Jesuítas, no século XVIII, e se destaca por sua arquitetura colonial (ver figura 84 ). 


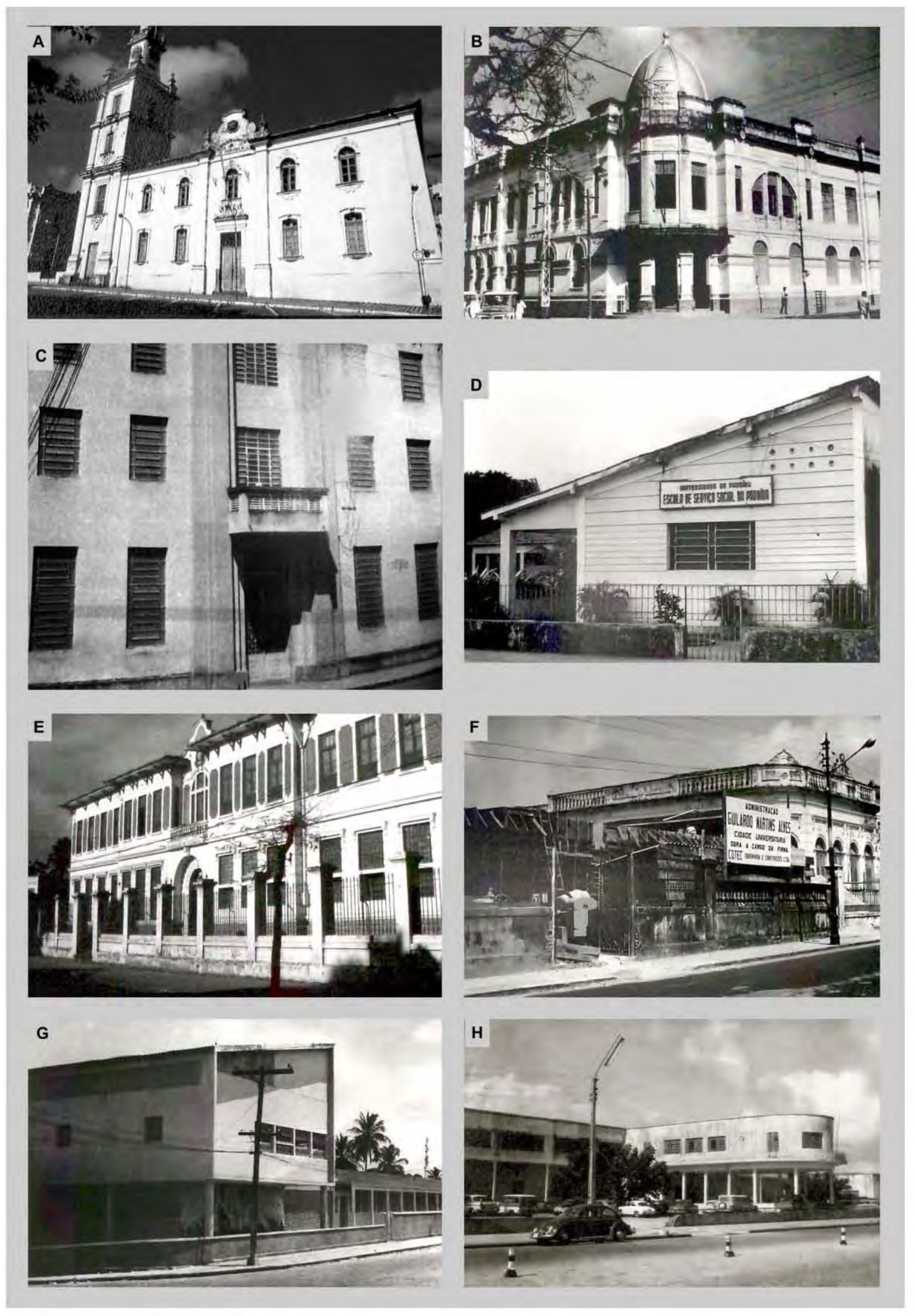

Figura 84: UFPB - Instalações de origem.
(A) Faculdade de Direito
(B) Faculdade de Ciências Econômicas
(C) Escola de Engenharia
(D) Escola de Serviço Social
(E) Faculdade de Farmácia
(G) Faculdade de Enfermagem
(F) Faculdade de Odontologia
(H) Faculdade de Filosofia

(Fonte: UFPB, 2006, p. 27 - 37) 
A esse conjunto no centro da cidade somou-se posteriormente 0 antigo prédio da reitoria (atual Ministério da Previdência e Assistência Social), construído entre 1962 e $1966^{43}$, projeto do arquiteto baiano Leonardo Stuckert Fialho, formado pela Escola Nacional do Rio de Janeiro e que veio para João Pessoa em 1957, mas teve curta permanência na cidade. Participou do quadro de profissionais do serviço de engenharia da universidade, criado em 7 de maio de 1962, setor responsável pelas obras, do qual também faziam parte o engenheiro Guilherme da Cunha Pedrosa, seu diretor, e o arquiteto paraibano Mario Glauco Di Lascio, formado pela Escola de Belas-Artes de Pernambuco, que projetou as primeiras unidades da futura cidade universitária, conforme será analisado no decorrer do capítulo.

O novo edifício viria suprir necessidades aparentemente imediatas por espaços destinados a serviços administrativos, biblioteca central, oficina gráfica e auditório (PEREIRA, 2008, p.98). A arquitetura se destaca pela adoção dos elementos da linguagem moderna difundida pelo arquiteto suiço, naturalizado francês, Le Corbusier, constituindo-se em um importante exemplar da arquitetura moderna na cidade (TINEM et al, n.p.). A planta-livre possibilitada pela estrutura independente, o piloti, as janelas corridas e a forma arquitetônica destacada pela composição volumétrica funcional revelam uma produção inserida no movimento moderno brasileiro, que encontrava espaço de recepção e difusão na cidade de João Pessoa, desde a década de 1950 (ver figura 85).

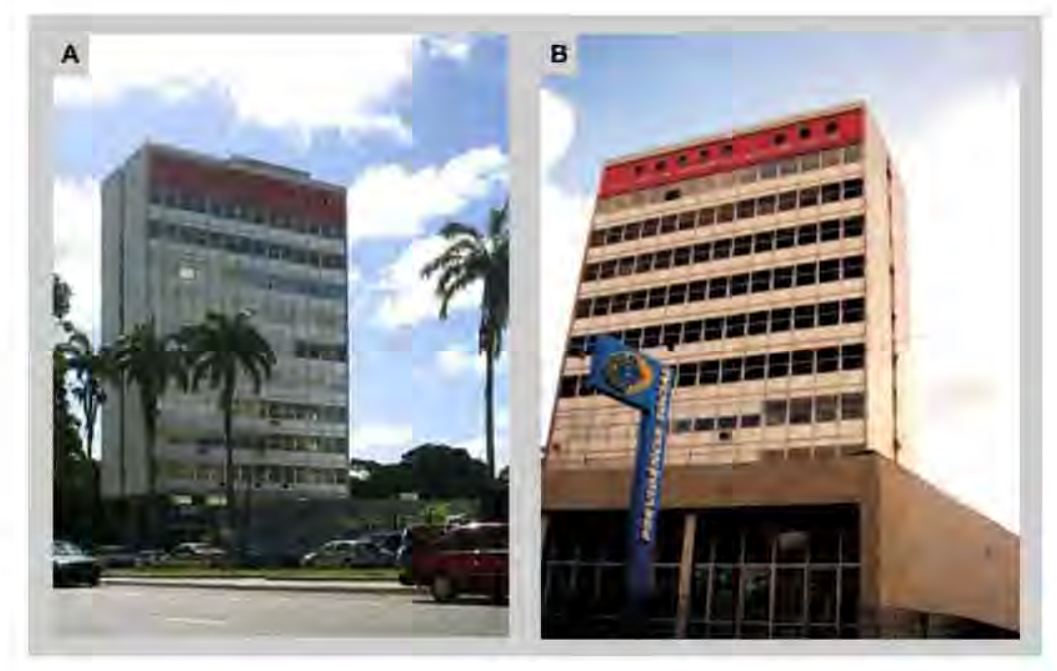

Figura 85: UFPB - Antigo prédio da Reitoria da UFPB.

(A) Fachada principal: o piloti libera o edifício do solo. O vidro confere leveza ao volume vertical.

(B) Detalhe do volume horizontal que faz contraponto à lâmina vertical.

(Fonte: Disponivel em < http://arqpb.blogspot.com/2007/11/leonardo-stuckert-filho-mrio-glauco-

di.html>. Acesso em 20 out. 2011)

\footnotetext{
${ }^{43}$.Encontramos divergência na data de conclusão do edifício: (1) Pereira (2008, p.98) indica o ano de 1963, (2) Nelcim et al registram o período de 1962 a 1968 para a construção do edifício e (3) Rodrigues (1997, p.127) registra em foto a data de 5 de maio de 1966 para a solenidade de inauguração do novo prédio da reitoria, que contou com as presenças do reitor Guilardo Martins Alves, do diretor da Faculdade de Medicina, prof. Lauro Wanderley e do presidente da República Humberto de Alencar Castelo Branco.
} 


\subsection{CIDADE UNIVERSITÁRIA: a universidade em subúrbio afastado}

Mesmo com a decisão de manter suas atividades no centro urbano, a Universidade continuava lutando com dificuldades financeiras. A federalização apresentava-se como a única saída viável para melhoria das carências que se avolumavam, além do que significava para o alunato o ensino gratuito, ampliando dessa forma as oportunidades de acesso das camadas menos favorecidas da sociedade ao ensino superior (MELO, 2006, p. 39). Inicialmente, embora encarada com desconfiança e descrença por parte de setores da universidade, o quadro favorável à federalização de universidades estaduais e particulares, a nível nacional, culminou com a adesão da instituição, federalizada pela Lei $n^{\circ} 3.835$, de 13 de dezembro de 1960.

\section{- O plano piloto de Leonardo Stuckert $-1^{\text {a }}$. proposta}

A partir de então, a opção pela construção da cidade universitária foi novamente ativada. Para dar seguimento, o serviço de engenharia da universidade elaborou o primeiro plano de ocupação para o terreno da Fazenda São Rafael, que possuía inicialmente uma área de 115,48 ha (RODRIGUES, 1997, p. 104), sendo depois ampliada, em 1968, para 161,75 ha (ver figura 86).

O terreno situa-se a $33 \mathrm{~m}$ acima do nível do mar, encravado em floresta densa tropical. Apresenta uma topografia predominantemente plana, tendo cerca de $80 \%$ da sua área com declividade média abaixo de $3 \%$. "Apenas uma faixa estreita dos seus limites, ao sul, é acidentada e forma um extenso grotão coberto pela mata natural" (UFPB, 1972, n.p.). Predomina o clima quente e úmido com temperaturas médias na faixa de $22^{\circ} \mathrm{C}$ a $28^{\circ} \mathrm{C}$ e umidade relativa de $83,3 \%$ (média anual). Os ventos dominantes de sudeste $\mathrm{e}$ as características geológicas do subsolo, arenoargiloso e semipermeável, tornaram-se adequados para fundações diretas. As características foram consideradas no intento de adequação às condições naturais do sítio.

O plano piloto, cuja autoria é atribuída ao arquiteto e professor da Escola de Engenharia Leonardo Stuckert ${ }^{44}$, teve início em 1963 (COUTINHO e outros, 2010, n.p.). O partido urbanístico adotado constituía-se de um eixo viário central que articulava o acesso aos edifícios, dispostos perpendicularmente ao eixo e paralelos entre si. Segundo Coutinho e

\footnotetext{
${ }^{44}$.Segundo Pereira (2008, p.99), a autoria do plano piloto de 1963 atribuída ao arquiteto Leonardo Stuckert foi negada pelos profissionais Mário Di Lascio e Guilherme de Cunha Pedrosa que atuaram no serviço de engenharia da universidade. A equipe afirma que tal projeto nunca foi elaborado. $O$ questionamento não interfere no desenvolvimento da presente pesquisa. Interessa-nos a concepção urbanística que deu origem à cidade universitária da UFPB.
} 
Figura 86: UFPB - Planta do terreno da UFPB - Área inicial.
Formado por um poligono irregular, distava $4 \mathrm{~km} \mathrm{de}$ Formado por um poligono irregular, distava $4 \mathrm{~km}$ de João Pessoa.
Fonte: Acervo da Prefeitura de Campus Universitario)

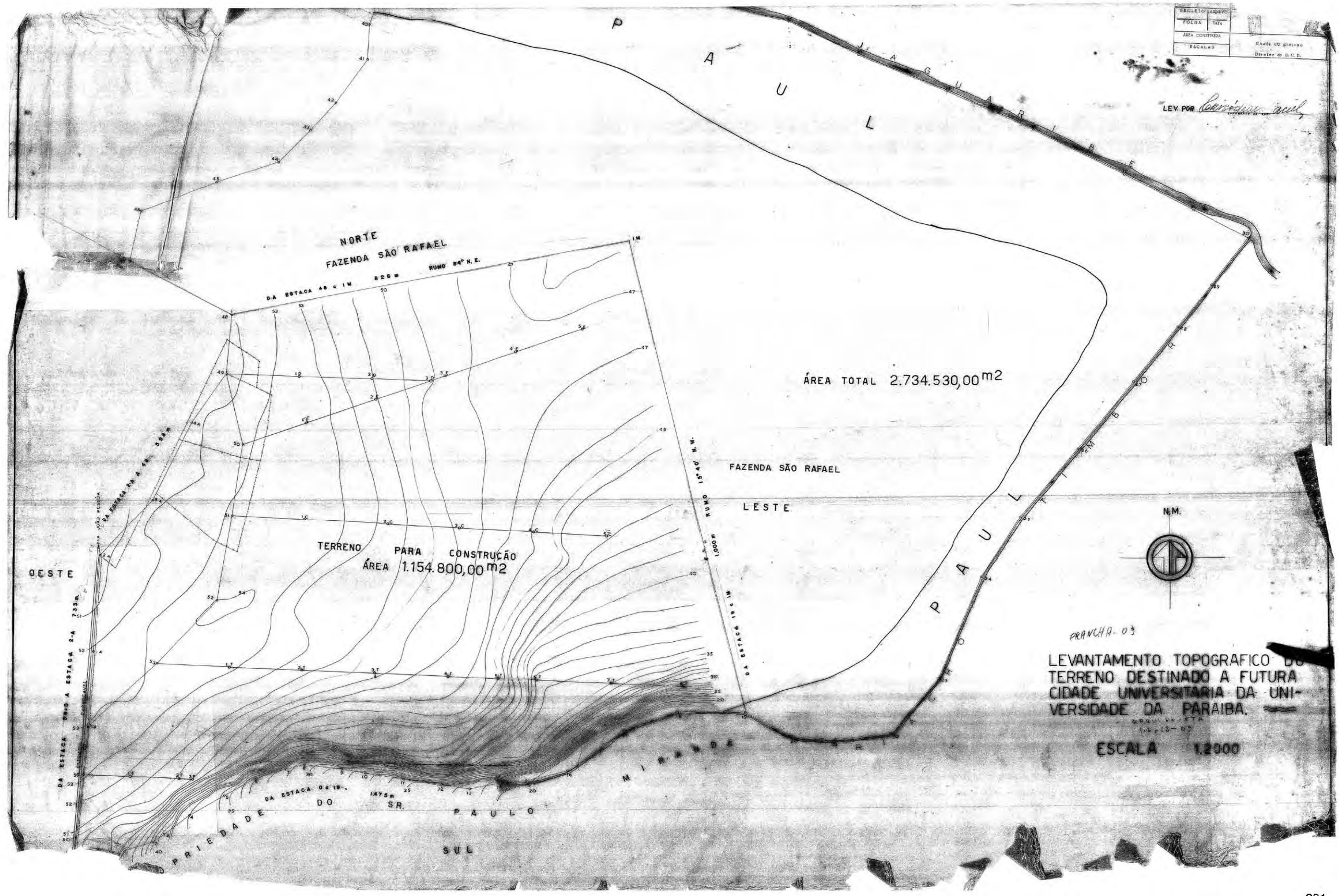


Parte 2 - Universidade Federal da Paraiba 
outros (2010, n.p.) a ocupaçẫo da gleba pelos conjuntos edificados se deu nas áreas abertas destinadas ao antigo pasto, que correspondia à porçăo sul do terreno. Essa concepçẩo de implantaçấo estaria ligada à idéia de preservaçấo da mata nativa que esteve presente na definiçẫo da escolha do sitio.

Outro aspecto a ser destacado é a orientação dos edificios alongados no eixo lestejoeste. situaçầo que evidencia a preocupaçẫo com as condiçổes climáticas da regiẫo. Q rigor das altas temperaturas e a radiação solar excessiva tende a ser minimizados com a ventilação dominante de sudeste que atravessa o edifício no sentido transversal. A planta apresenta um desenho desprovido de qualquer complexidade urbanística, tendo sinteticamente a definição dos eixos vários e as edificaçổes a serem implantadas no primeiro momento, bem como o acesso existente por onde se dava a entrada ao canteiro de obras (ver figuras $87 \mathrm{e}$ 88). De toda maneira nẫo podemos deixar de associar a definiçẫo do eixo central estruturador com o modelo de concepçẫo urbanística previsto na organizaçẫo espacial de cidade universitária, caracterizado por um eixo viário monumental.

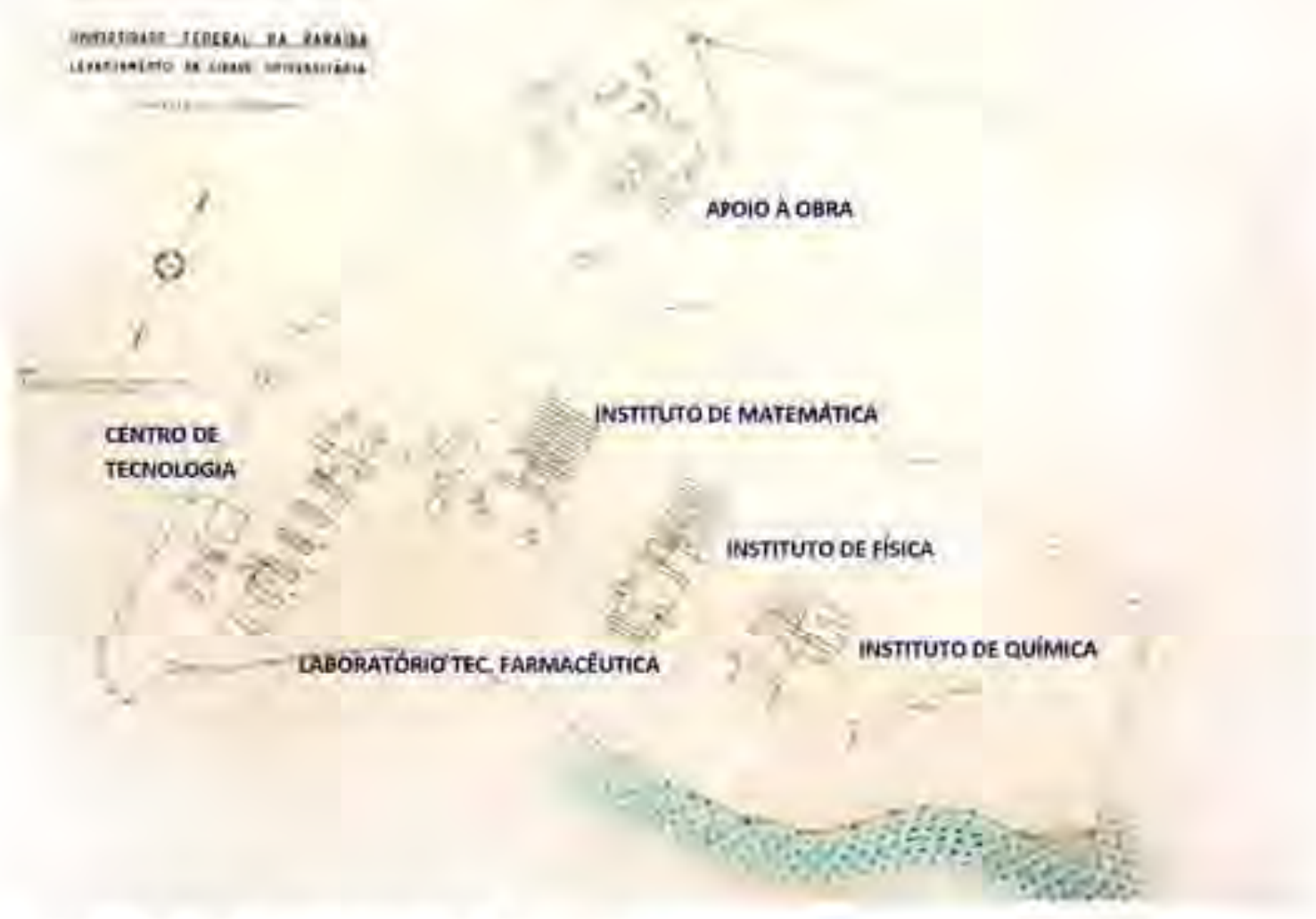

Figura 87: UFPB - Plano Piloto de stuckert.

A implantaçẫo do eixo de circulaçẫo ladeado pelas unidades do Centro Tec nologia e das Ciências Exatas e da natureza.

(Fonte: Prefeitura do Campus apud COUTINHO et al., 2010, n.p.) 


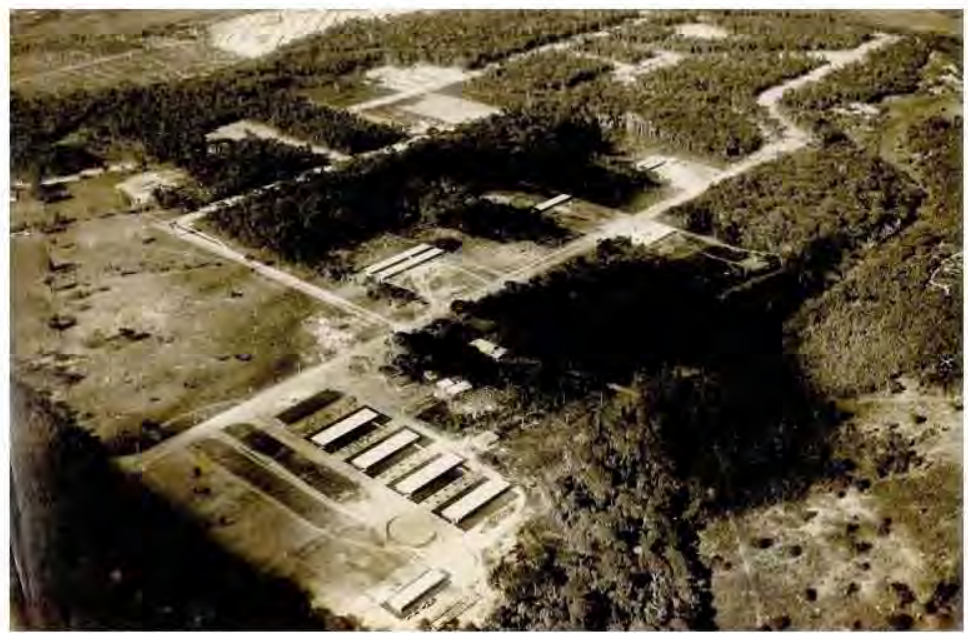

Figura 88: UFPB - Construção da cidade universitária [1968?].

O conjunto da Escola de Engenharia em fase de execução (primeiro plano) e parte dos institutos de Matemática, Física e Química (plano central). Os eixos viários seguem o desenho de Stuckert.

(Fonte: Acervo Núcleo de Documentação e Informação Histórica Regional (NDIHR) / UFPB)

\section{- As obras da década de 1960}

Tomando como base o plano piloto, deu-se início às obras, em dezembro de 1965 , com a Escola de Engenharia, atual Centro de Tecnologia, cujas atividades foram transferidas para o local em 1967 (ver figura 89). O projeto de 1963 e autoria do arquiteto Leonardo Stuckert forma um conjunto arquitetônico de predominância horizontal composto por edifícios de um pavimento que inclui o da administração, os blocos-padrões destinados às salas de aula, laboratórios e oficinas, e o galpão para o Laboratório de Hidráulica e Ensaios de Materiais, estando referenciado no acervo de exemplares da arquitetura moderna da Paraíba [serão analisados no decorrer do capítulo] (ver figura 90).

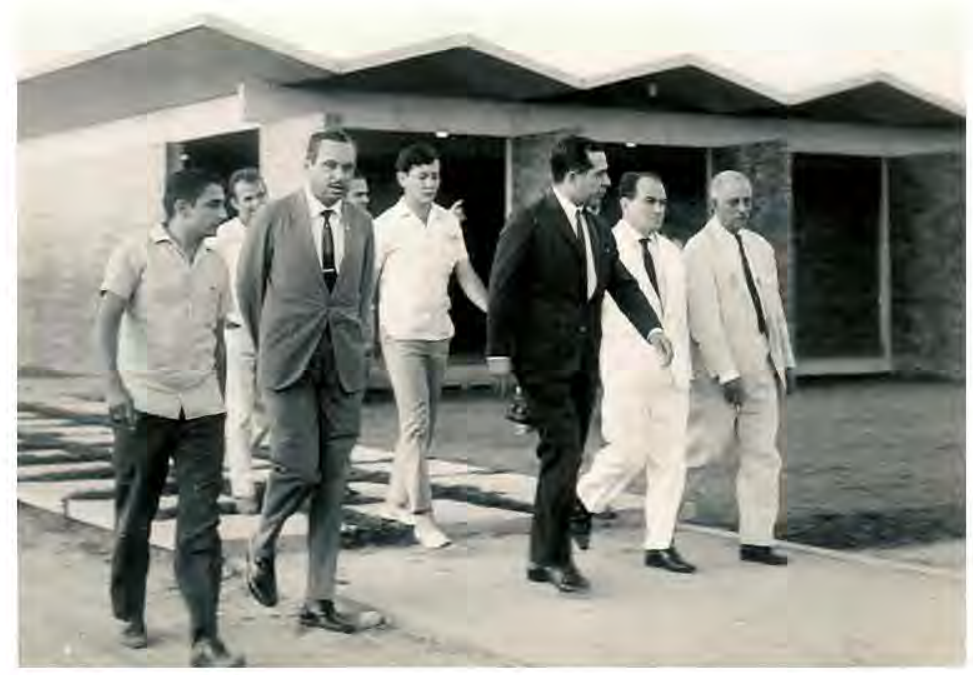

Figura 89: UFPB - Visita de autoridades à Escola de Engenharia - 4 de novembro de 1967.

A comitiva estava acompanhada do reitor Guilardo Martins Alves (ao centro de terno escuro. O acesso aos blocos ocorre por passarela descoberta, perpendicular ao conjunto. (Fonte: Acervo NDIHR/UFPB) 


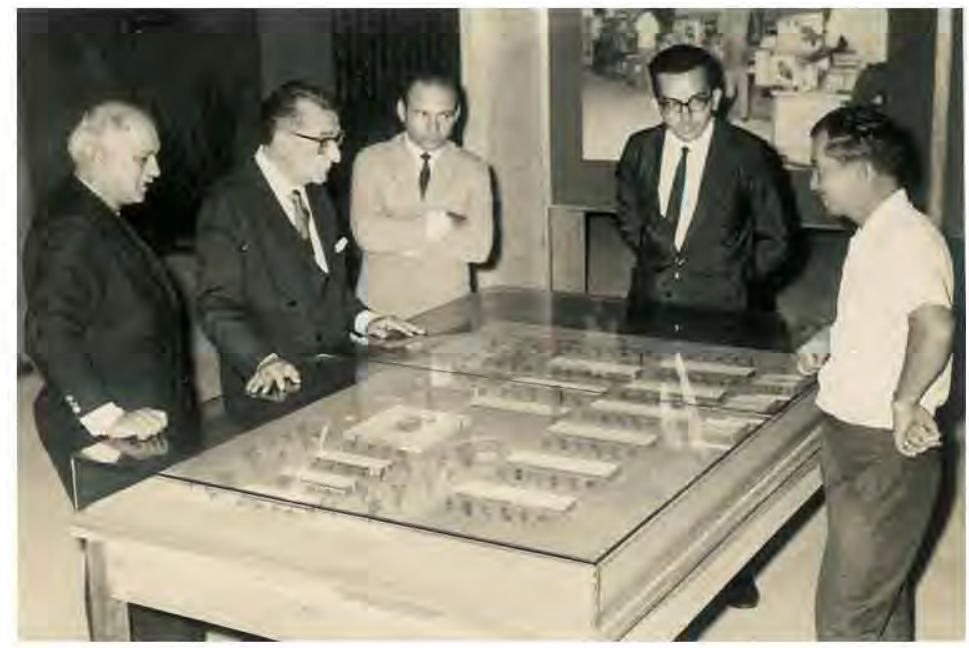

Figura 90: UFPB - Maquete da Escola de Engenharia - 12 de agosto de 1969. Autoridades observam o conjunto da Escola de Engenharia. Possuía praça circular com anfiteatro, bloco da administração, doze unidades de blocos acadêmicos (foram construídos oito) e três blocos de laboratórios (foram construídos dois).

(Fonte: Acervo NDIHR/UFPB)

Foi nos anos 1960 que a UFPB vivenciou a edificação de unidades acadêmicas que pudemos identificar como tendo sido a primeira etapa de construção da cidade universitária. Por ordem cronológica, seguiram-se:

- Instituto de Química, em 1966, de autoria do arquiteto norte-americano David Scott Ellinwood (ver figuras 91 e 92); que pertencia ao Escritório Técnico Universitário da UFPB (COUTINHO et al, 2010, n.p.).

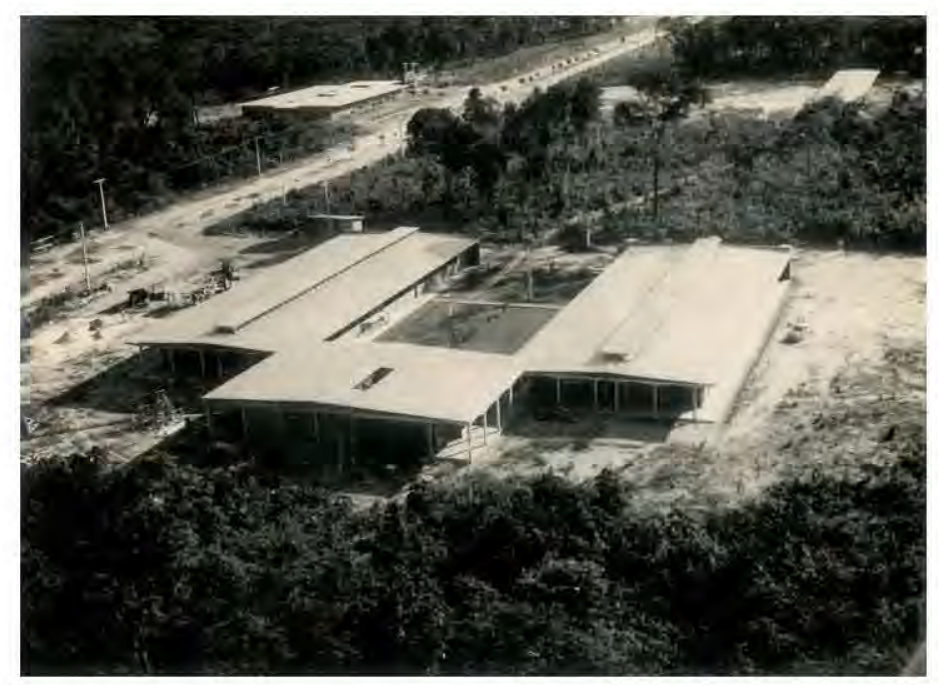

Figura 91: UFPB - Instituto de Química - ano 1966.

A imagem registra, também, já construídos o Laboratório de Produtos Farmacêuticos (plano superior esquerdo) e o Instituto de Física (plano superior direito).

(Fonte: Acervo NDIHR/UFPB) 
- Também no ano de 1966, os institutos de Matemática e de Física, e o Laboratório de Produtos Farmacêuticos, de autoria do escritório ETAU Arquitetos ${ }^{45}$, de Recife (ver figura 92).

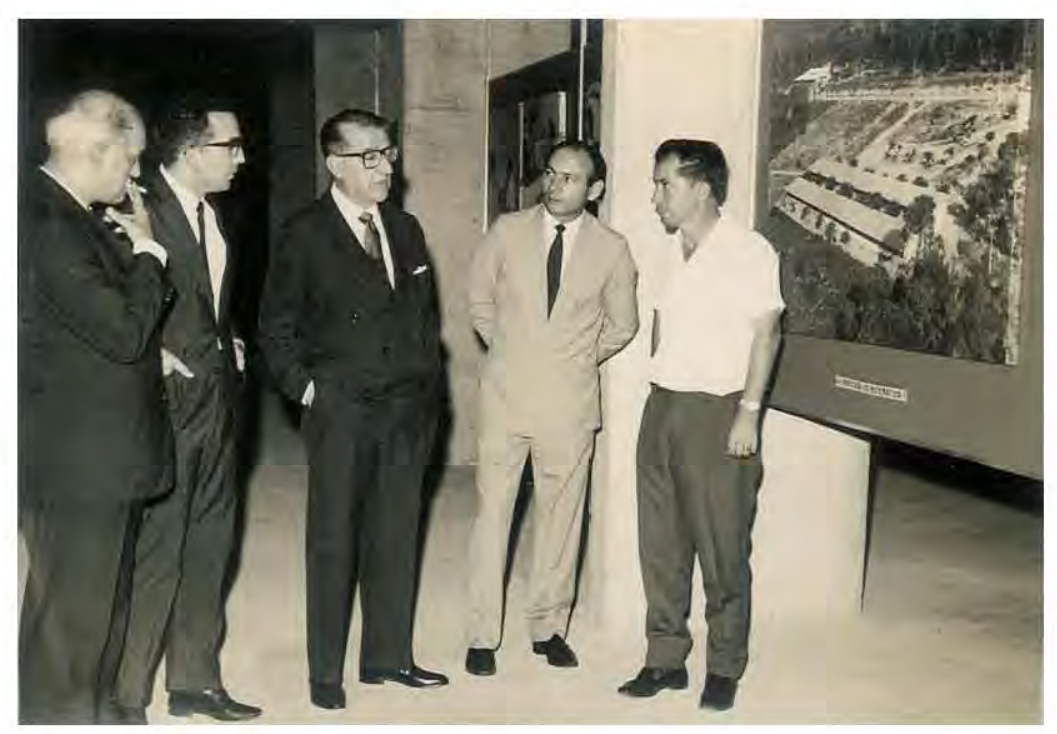

Figura 92: UFPB - Encontro de personalidades -12 de agosto de 1969. No pôster à direita foto do Instituto de Matemática já construído. (Fonte: Acervo NDIHR/UFPB)

- Conjunto Biológico (ver figura 93), de autoria de Pedro Dieb, que também pertencia ao Escritório Técnico Universitário da UFPB (COUTINHO et al, 2010, n.p.)

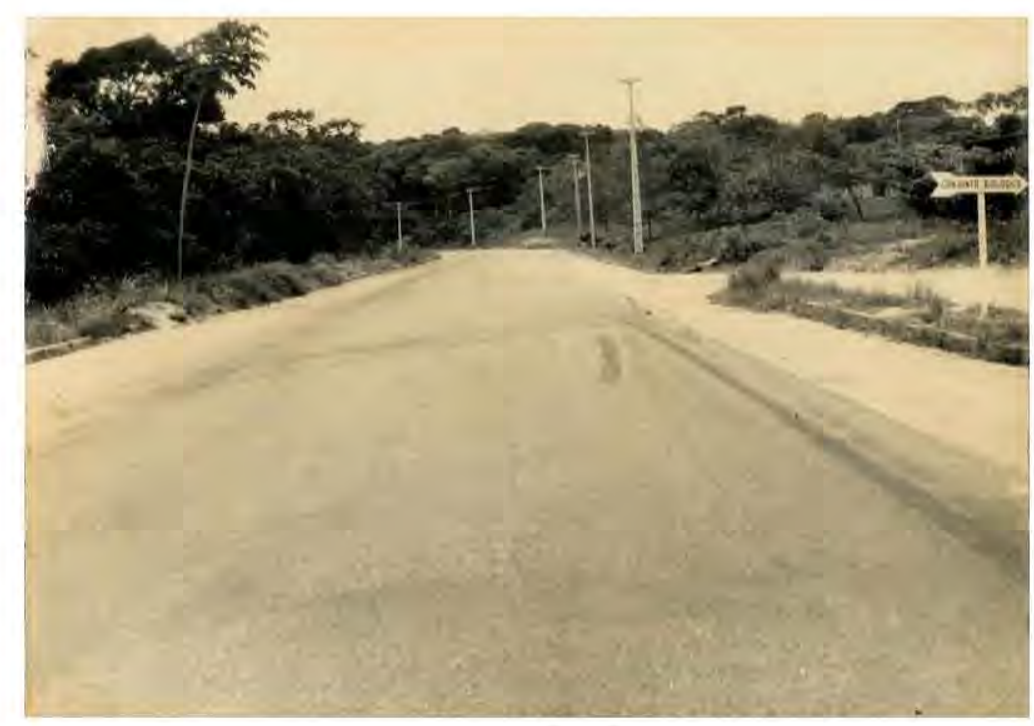

Figura 93: UFPB - Via de contorno com a rede de energia - ano 1978.

A seta (à direita) indica o Conjunto Biológico criado em 1967

e implantado em 1970.

(Fonte: Acervo NDIHR/UFPB)

\footnotetext{
${ }^{45}$ Escritório formado pelos profissionais Waldecy Pinto, Renato Torres e Antônio Pedro Didier (PEREIRA, 2008, p.99).
} 
As realizações citadas constituem-se de edificações de um pavimento e processo construtivo em estrutura de concreto pré-moldado com vedações de alvenaria e instalações elétricas e hidrossanitárias aparentes, predominando o princípio da economia. É provável que tenha também prevalecido o intento de possibilitar adequações nos arranjos funcionais, decorrentes de novos programas, situação que se consegue com sensível barateamento nos custos de reformas, já que ficam eliminadas demolições e reconstrução das instalações prediais.

- Bloco administrativo da Escola de Engenharia com projeto datado de 1968 e concluído no final da década (ver figura 94).

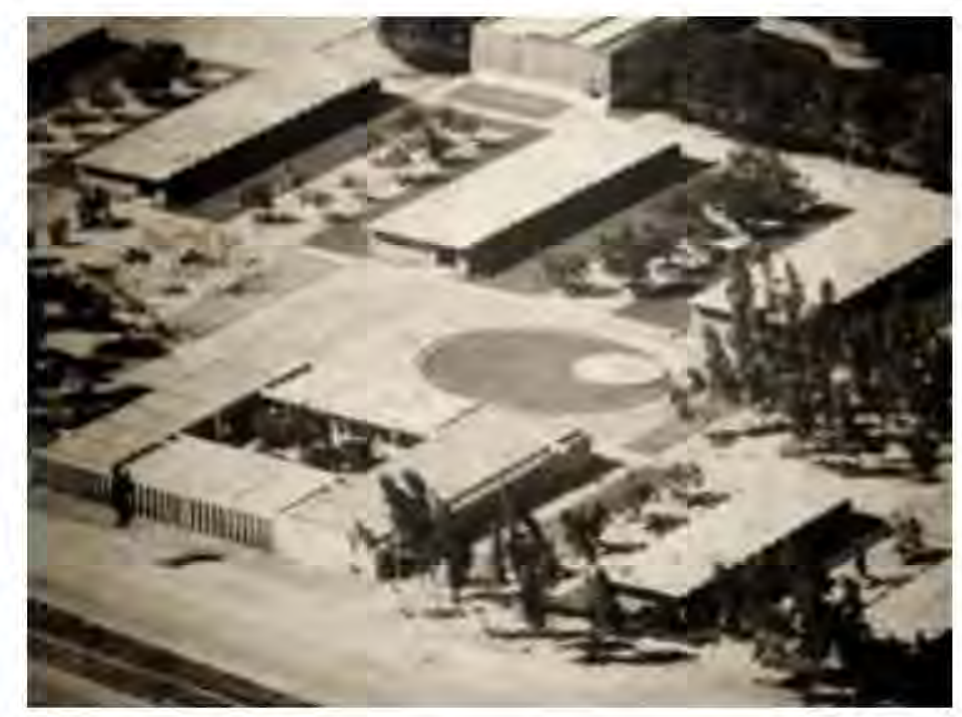

Figura 94: UFPB - Conjunto da Escola de Engenharia - primeira metade década de 1970. O bloco administrativo (canto inferior esquerdo) (Fonte: Acervo UFPB/Centro de Tecnologia)

- Ainda em 1968, foi contratado o projeto da biblioteca central, de autoria do arquiteto pernambucano Acácio Gil Borsoi, vencedor do concurso realizado pela UFPB, do qual também participaram Leonardo Stuckert, Waldecy Pinto, Carlos Alberto Correia de Lima (PEREIRA, 2008, p. 99).

Quando construído, o prédio foi gradativamente ocupado também por setores da administração superior, situação que levou Borsoi a realizar um estudo de adequação aos dois programas, até que a reitoria se instalou definitivamente com sua transferência do centro urbano para o campus por volta de $1976^{46}$. Um novo projeto foi então realizado para a biblioteca central, que lá se instalou na década de 1980 (ver figura 95).

\footnotetext{
${ }^{46}$.A transferência da reitoria se deu no início do reitorado do prof. Lynaldo Cavalcanti de Albuquerque - gestão de 1976 a 1980 (UFPB, 2006, p. 123).
} 


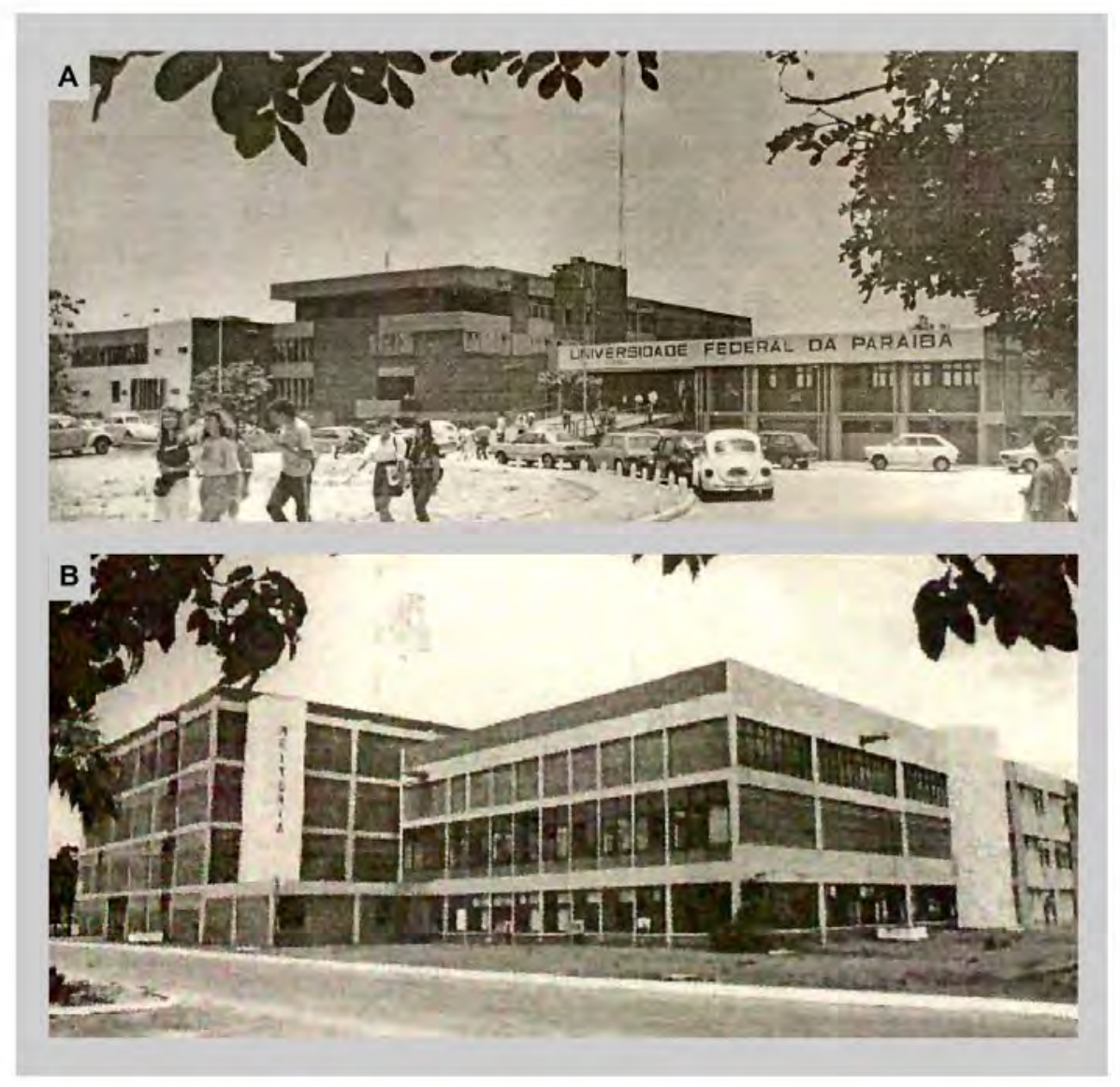

Figura 95: UFPB - Prédio da Reitoria.

(A) Acesso principal.

(B) Fachada

(Fonte: RODRIGUES, 1997, p. 13)

- Ao final da década de 1960 foi também iniciado a construção do Hospital Universitário Lauro Wanderley, projetado pelo Escritório Técnico da USP através de convênio com a UFPB, que também prestava consultoria a outras instituições (ver figura 96) [será analisado na seção das tipologias].

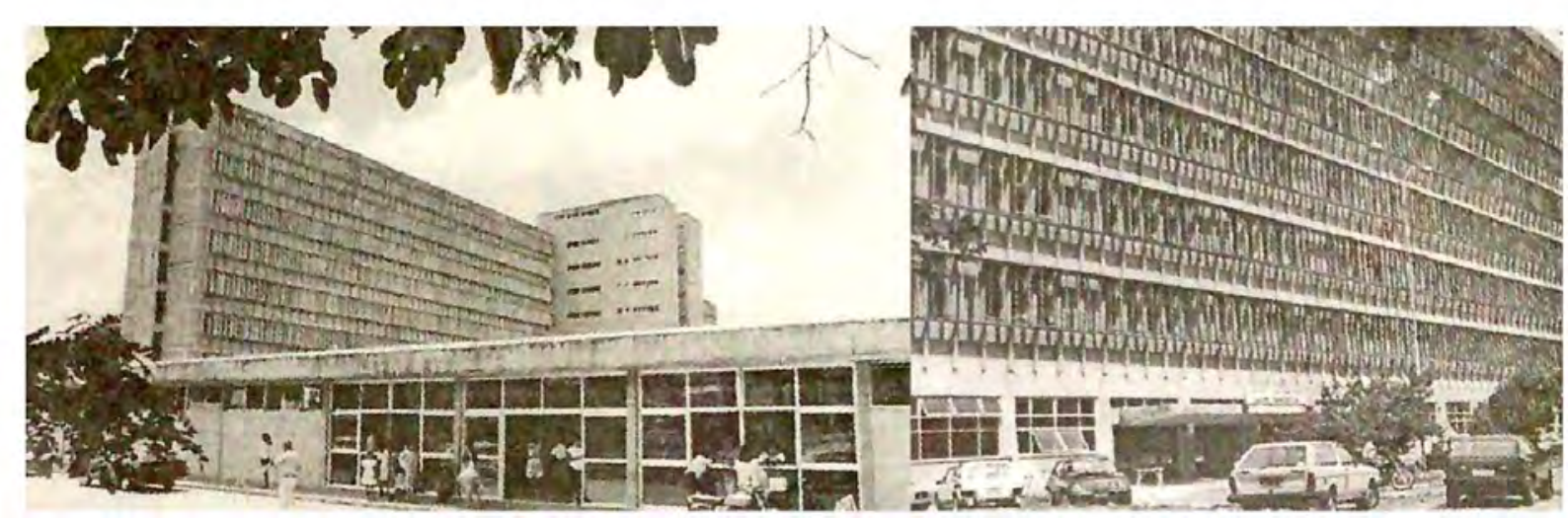

Figura 96: UFPB - Hospital Universitário Lauro Wanderley - Ano 1995.

(Fonte: RODRIGUES, 1997, p. 46) 


\section{- O plano da Consultec - 2a. proposta}

Objetivando elaborar um plano diretor que consolidasse o desenvolvimento da primeira etapa de implantação da cidade universitária, com a construção das primeiras edificações indicadas no plano piloto de Stuckert, a UFPB contratou em 1966 a empresa de assessoria técnica Consultec. A planta por ela elaborada manteve o escopo original do traçado viário proposto por Stuckert, com uma localização esquemática dos edifícios, cuja ocupação apresentava uma organização ordenada, porém dispersa na gleba e sem indicativos de como articula-los entre si. A ausência na demarcação dos acessos e circulações denotava imprecisão na proposta. Pereira $(2008$, p.100) destaca que a reitoria não foi indicada no plano, já que se encontrava instalada no centro da cidade, assim como o hospital universitário, que, conforme justificativa da Consultec deveria funcionar em área urbana, cuja infraestrutura de serviços se adequava àquele tipo de equipamento (CONSULTEC, 1966 , p. 8/10-8/11 apud PEREIRA, 2008, p.100). A imprecisão do plano possivelmente refletiu na decisão de desenvolver outra proposta (ver figura 97 ).

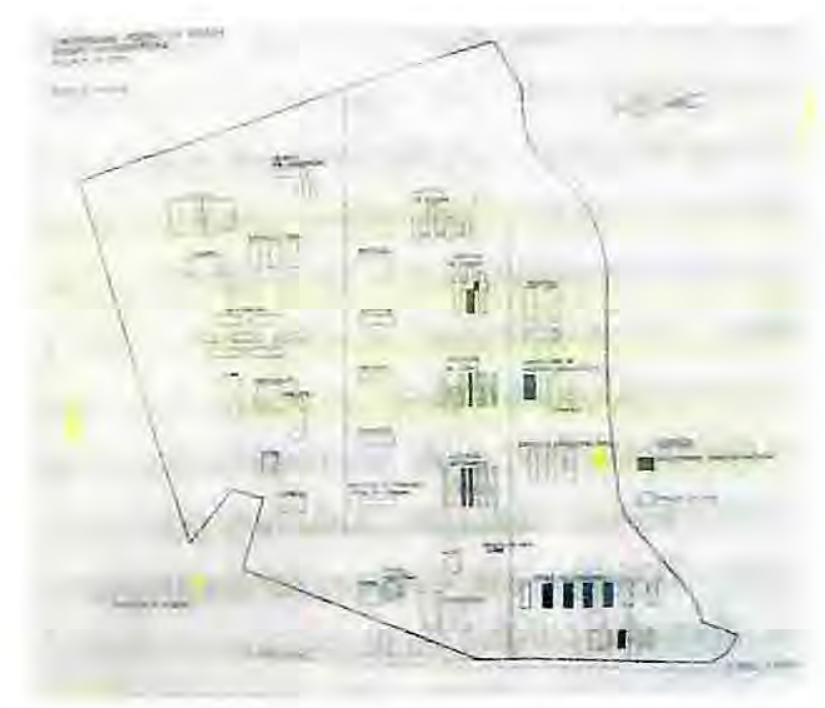

Figura 97: Plano Piloto da UFPB apresentado pela empresa Consultec (1966).

(Fonte: PEREIRA, 2008, p.101)

\section{- O plano de Mário Rosa - $3^{\mathrm{a}}$. proposta}

Em 1967, segundo Coutinho et al (2010, n.p.) os dados sistematizados sobre a situação de implantação da universidade na gleba, foram repassados ao arquiteto Mário Rosa Soares, do Escritório Técnico da Universidade de São Paulo (USP), que elaborou um estudo naquele ano, através de convênio celebrado entre as duas instituições.

O plano proposto pelo arquiteto paulista considerava a existência das unidades já implantadas e propunha uma organização por setor, totalizando catorze, orientados pelo 
zoneamento funcional (ensino, administração, lazer e moradia) em que predominava uma ocupação extensiva da gleba, resultando na eliminação de grande parte da cobertura vegetal (ver figuras 98 à 100).

Os setores funcionais, com independência de funcionamento, estavam divididos pelo sistema viário, hierarquizado por vias principais de sentido predominante leste/oeste e constituída de via dupla com canteiro central, e vias secundárias perpendiculares. Uma via de contorno periférica englobava o conjunto edificado e intermediava a ligação da universidade com a cidade por meio de acessos providos de rotatórias. Bolsões de estacionamento ao longo das vias estabeleciam os limites máximos de acesso dos veículos aos setores, garantindo rígida separação com a circulação de pedestres, que se localizava internamente aos setores, articulando o acesso às unidades edificadas.

O zoneamento estabelecia a concentração dos setores de ensino no centro da área e distribuía o setor administrativo próximo ao acesso, o esportivo pelo limite norte do terreno, e o hospital a leste sem interferência dos demais. A introdução do setor de integração, do setor de convivência geral e do setor residencial concretizava uma proposta com referência nos princípios funcionais da cidade moderna: habitação, trabalho, circulação e lazer.

Embora prevalecendo o conceito de uma cidade autônoma e com a identificação de Cidade Universitária de João Pessoa (escrito no carimbo da planta), o traçado urbanístico se afastava da organização física em que predominava o eixo monumental linear com ponto focal no prédio da reitoria. Mesmo com a praça cívica delimitada por espaços administrativos e de convivência, a proposta parecia estar mais ligada à idéia de irradiação da cultura e do lazer.

Pereira (2008, p.100) destaca as evidências do projeto com relação a preocupações de adequação climática, tendo em vista a geometria das edificações alongadas no sentido leste/oeste, orientação que favoreceria a ventilação nos ambientes. $O$ arquiteto Rosa assinala, entretanto, na planta da figura 21 , que os números e volumes dos edifícios indicados não implicavam em compromissos formais, dado que os mesmos insinuavam apenas relações de reciprocidade dentro e fora dos setores.

A concepção urbanística do estudo estava marcada pelo sistema viário de caráter regulador e ordenador da implantação dos setores. A concepção de extensas quadras, reunindo setores afins, circundadas por vias com bolsões de estacionamentos periféricos refletia-se num desenho com traçado de fácil reconhecimento para quem por ali trafegasse. O sistema viário proposto considerava uma integração entre a Universidade e a futura expansão da cidade, provendo a gleba com três acessos principais $(A, B$ e $C$ ) que se aglutinava com as vias públicas. A solução rompia com a idéia de um território isolado e delimitado. 

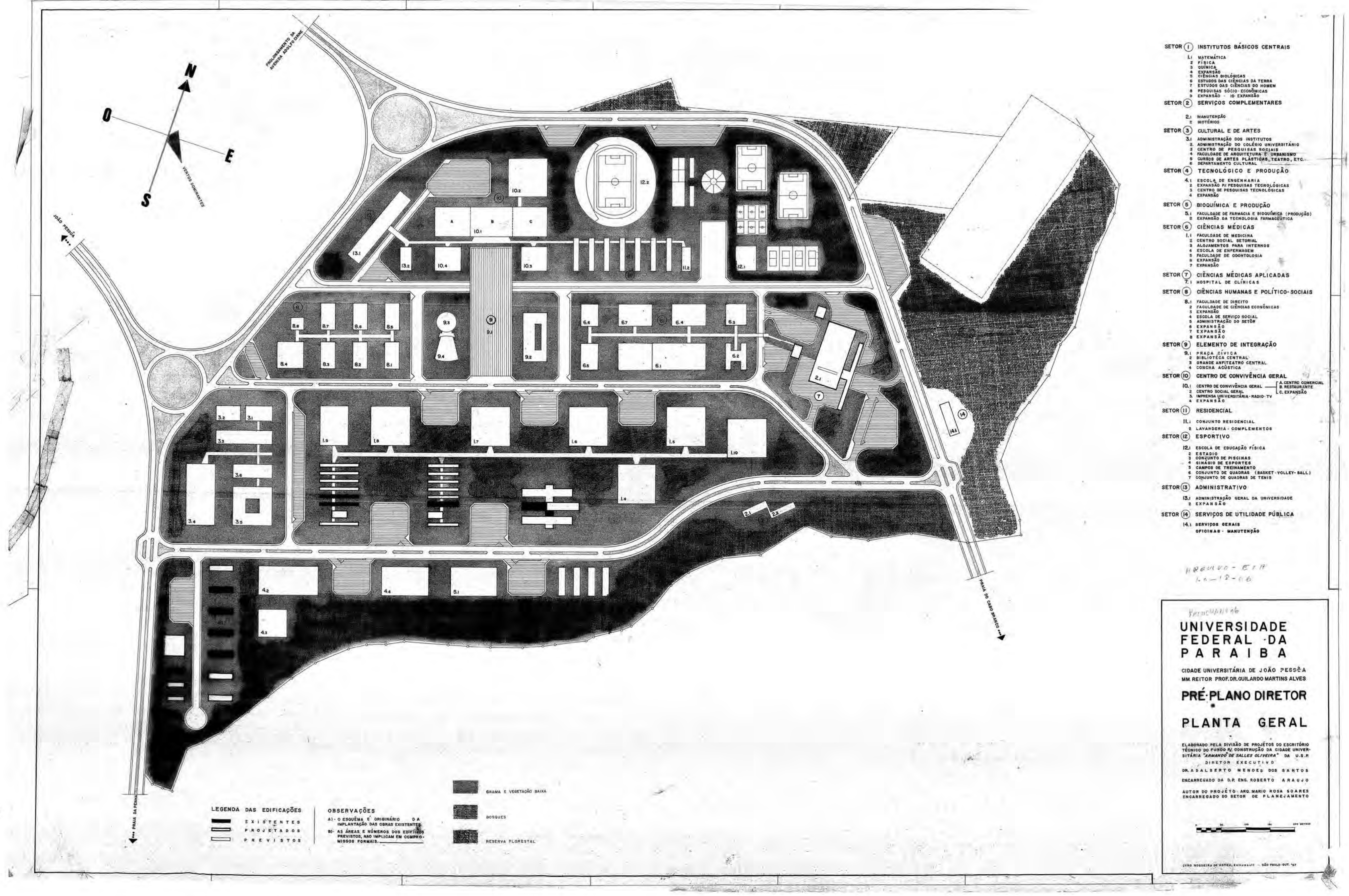


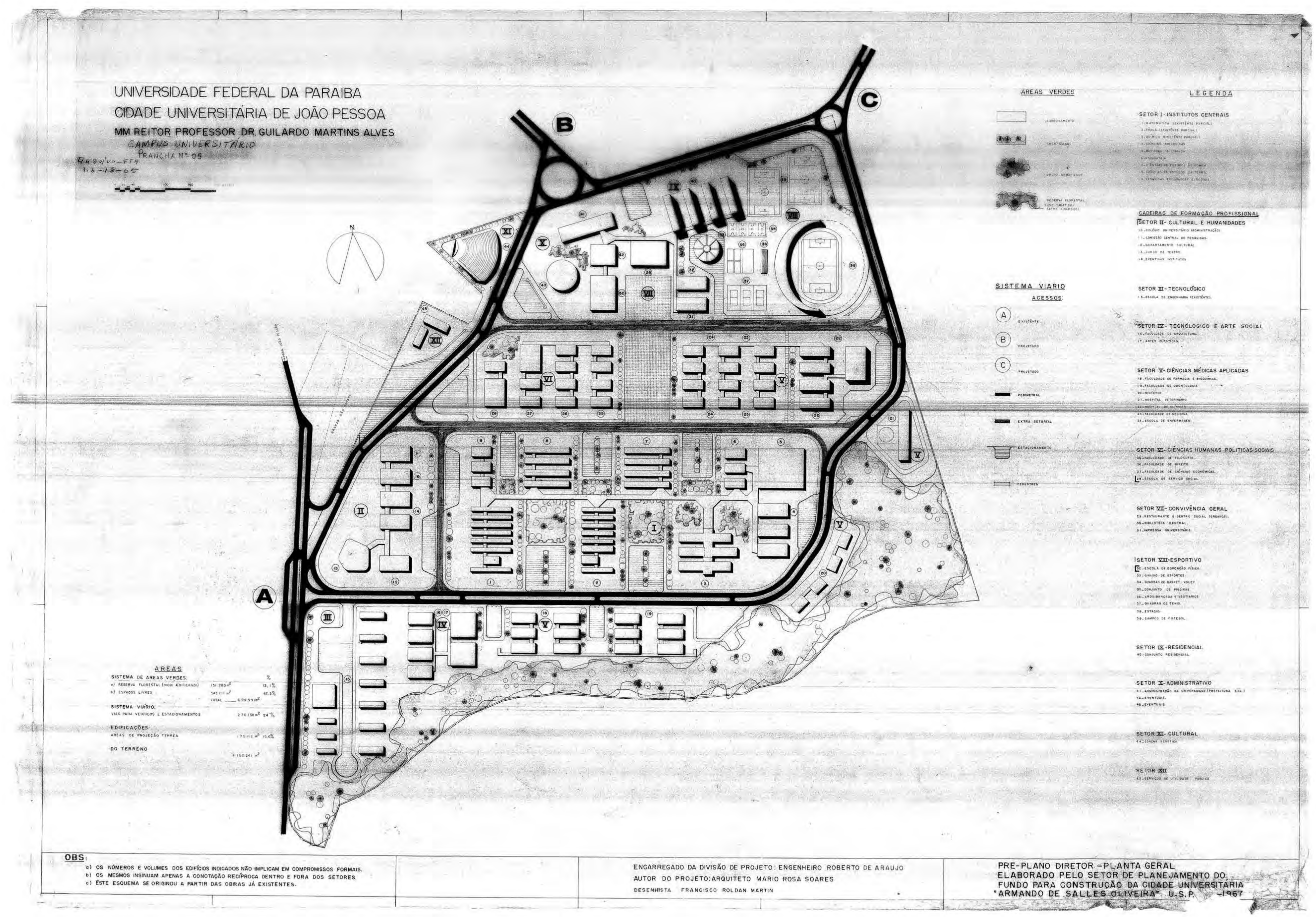


Parte 2 - Universidade Federal da Paraiba 
O plano de Mario Rosa não foi levado adiante. É provável que a promulgação da Lei da Reforma Universitária no ano seguinte, consolidando institucionalmente a nova organização universitária, tenha anulado a validade do estudo que tinha como base os institutos centrais. Além do que a orientação do modelo espacial do campus abrigando os departamentos reunidos em centros tenha prevalecido na decisão encontrar outra solução urbanística.

\subsection{CAMPUS UNIVERSITÁRIO: a Reforma}

Em 1969, a UFPB sediou o primeiro Seminário Sobre Planejamento do Campus Universitário, patrocinado pelo Conselho de Reitores das Universidades Brasileiras, realizado em João Pessoa no período de 16 a 19 de junho. $O$ evento contou com a participação do arquiteto paraense Alcyr Meira ${ }^{47}$, que integrava a equipe de profissionais do MEC responsável pela implantação da Reforma de 1968, que envolvia a construção de campi universitários ou adequação de cidades universitárias ao novo modelo espacial. Meira, com formação profissional em engenharia civil e arquitetura, elaborou nas décadas de 1960 e 1970 planos diretores de campus universitário para seis instituições de ensino superior no Brasil e um no Paraguai ${ }^{48}$.

\section{- O plano de Alcyr Meira - 1 ${ }^{\text {a }}$. proposta}

Com a Reforma, Meira foi indicado, pelo então ministro da educação e cultura, Jarbas Passarinho, para elaborar o novo Plano Diretor Físico da Universidade Federal da Paraíba, concluído em 1971. Nas palavras do arquiteto, o trabalho tinha como objetivo

\section{[...] uma perfeita caracterização física da UNIVERSIDADE FEDERAL DA PARAÍBA, através da definição de fórmulas gerais, inerentes a nova estrutura da UNIVERSIDADE BRASILEIRA, fruto da REFORMA UNIVERSITÁRIA (MEIRA, 1971, n.p.).}

A administração superior da universidade também manifestava apoio à nova estrutura organizacional imposta pelo governo federal, confirmando a importância do campus como elemento estratégico de implantação da Reforma (ver figura 101). Cumpre destacar que

\footnotetext{
${ }^{47}$ Informação verbal concedida em entrevista com o arquiteto, realizada em 10 de novembro de 2009 , na cidade de Belém (Pará). A participação de Alcyr Meira está documentada no certificado assinado pelo reitor prof. Guilardo Martins Alves e pelo prof. Harry Ransom, coordenador geral.

${ }_{48}$. Meira formou-se inicialmente em engenharia civil, pela Escola de Engenharia do Estado do Pará (1956) e posteriormente em arquitetura pelo Centro Tecnológico da Universidade Federal do Pará, criado na década de 1960 . Foi autor de planos diretores das seguintes instituições: Universidade Federal do Pará (1966/1968), Universidade Federal do Rio Grande do Norte (1972/1974), Universidade Estadual do Rio Grande do Norte - Mossoró (1972), Fundação Cultural e Educacional do Território Federal do Amapá (1976), Fundação Centro Universitário do Território Federal de Rondônia (1976) e o da Universidade Nacional de Asunción no Paraguai (1977/1979). Em 1973, Meira integrou a comissão encarregada pelo MEC "para a montagem de um Projeto a ser submetido ao Banco Interamericano do Desenvolvimento (BID) com vistas à obtenção de empréstimo destinado aos Campi Universitários" (PORTARIA n-327/355 de 12 de julho de 1973).
} 
nenhum outro plano apresenta menção valorosa das personalidades universitárias como o de Meira.

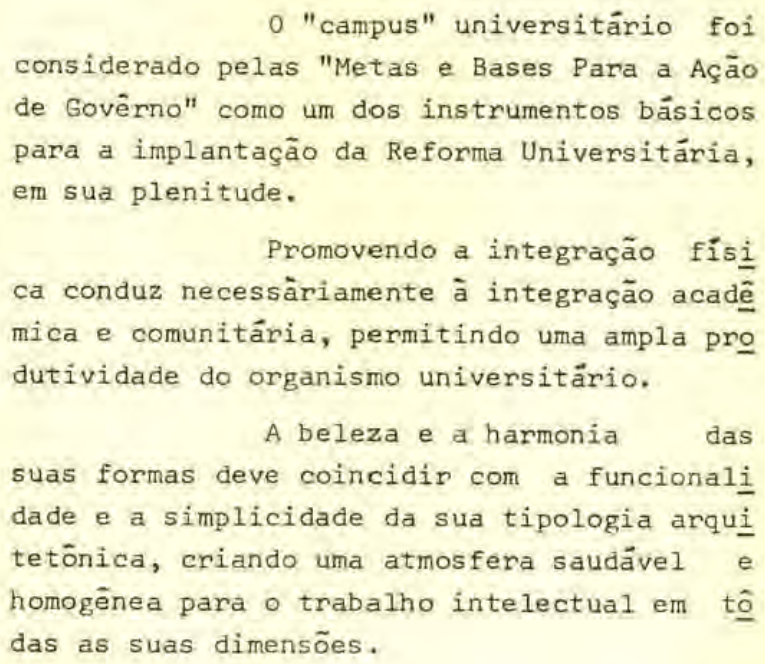

Figura 101: Ofício do reitor Guilardo Martins Alves - gestão 1964 a 1971.

O documento ressaltava 0 atributo da integração física, acadêmica e administrativa, que deveria ser rebatido na construção de uma tipologia espacial com características de funcionalidade e beleza.

(Fonte: MEIRA, 1971, n.p.)

A proposta de Meira tomou como base as diretrizes da reforma explicitada pelo princípio da não duplicação de meios para fins idênticos ou equivalentes e pela integração das unidades de ensino e pesquisa básicas com as de ensino profissional e pesquisa aplicada, tendo o departamento como a célula mater. Do ponto de vista arquitetônico significava a racionalização dos espaços através do equilíbrio entre usos e tempo de ocupação, compatibilizados com uma organização que possibilitasse a integração entre eles. Com esse objetivo, a estrutura espacial destinada a abrigar programas diversos requeria atributos de flexibilidade, expansibilidade, integração, e dimensionamento, dentre outros (ver figuras 102 à 105). 


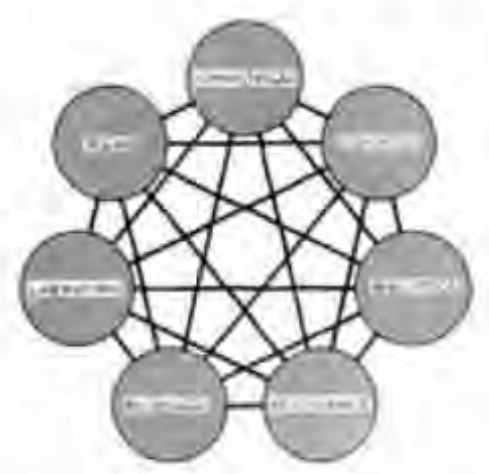

Figura 102: UFPB - Plano diretor de 1971 - Esquema de integração das funçốes universitárias.

As estruturas espaciais racionalizadas e integradas constituiriam um espaço universitário com eficiência funcional, máximo rendimento e eliminaçăo de duplicação de meios. (Fonte: MEIRA, 1971, n.p.)

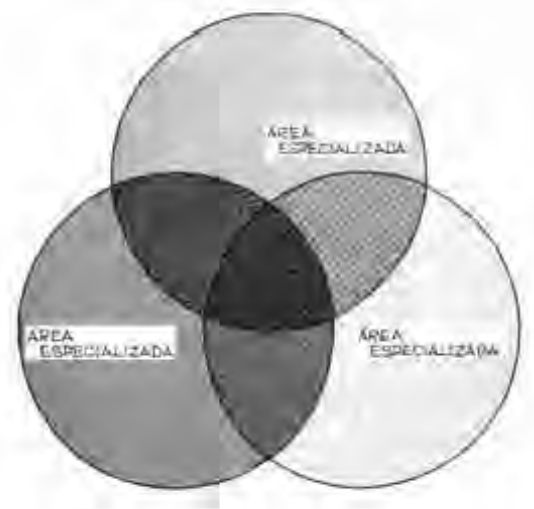

Figura 103: UFPB - Plano diretor de 1971 - Esquema de racionalização das funçōes universitárias. Atividades comuns estariam concentradas, eliminando áreas e equipamentos ociosos. A ocupaçăo integral com a utilizaçăo permanente de equipamentos traduzir-se-ia em um maior rendimento e eficiência das atividades universitánas.

(Fonte: MEIRA, 1971, n.p.)

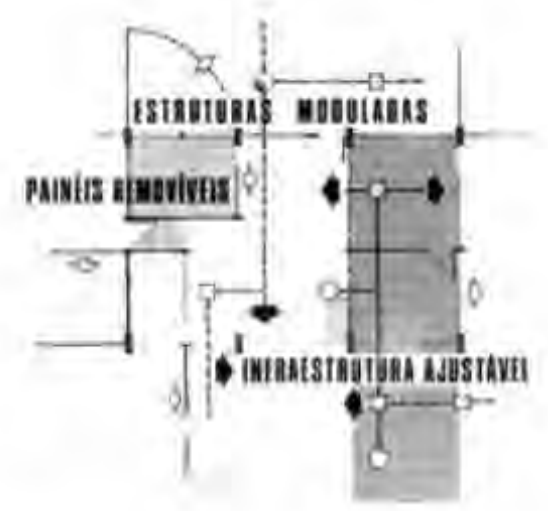

Figura 104 : UFPB - Plano diretor de 1971 - Esquema de flexibilidade do espaço universitário.

os espaços seriam criados, estruturados e desenvolvidos de modo a permitir a variaçăo das atividades e das interaçöes espaciais. Estruturas moduladas, painéis removíveis e infraestrutura ajustável eram características do espaço flexivel.

(Fonte: MEIRA, 1971, n.p.) 

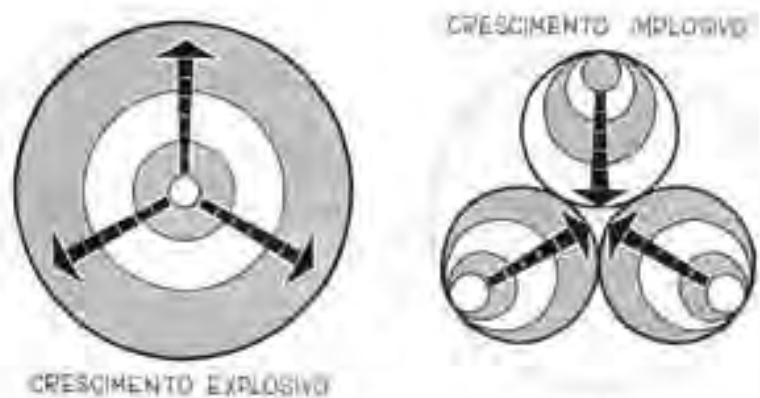

Figura 105: UFPB - Plano diretor de 1971 - Esquema de expansibilidade na estrutura espacial.

A definiçấo de uma lei de crescimento para garantir expansấo racional seria funçẫo da dispanibilidade espacial e da pressẫo de demanda estudantil. Isso significava um padrẫo orgânico de crescimento.

(F onte: MEIRA, 1971, n.p.)

Definidas as características do espaço universitário, sua organizaçấo física se daria por meio de quatro zonas funcionais independentes entre si que compunham o território da universidade: administrativa, de ensino, esportiva e de serviços gerais (ver figura 106). Assim como o plano anterior, a concepção urbanística considerava a existência das unidades acadêmicas já construídas, incorporando-as à sua re spectiva zona.

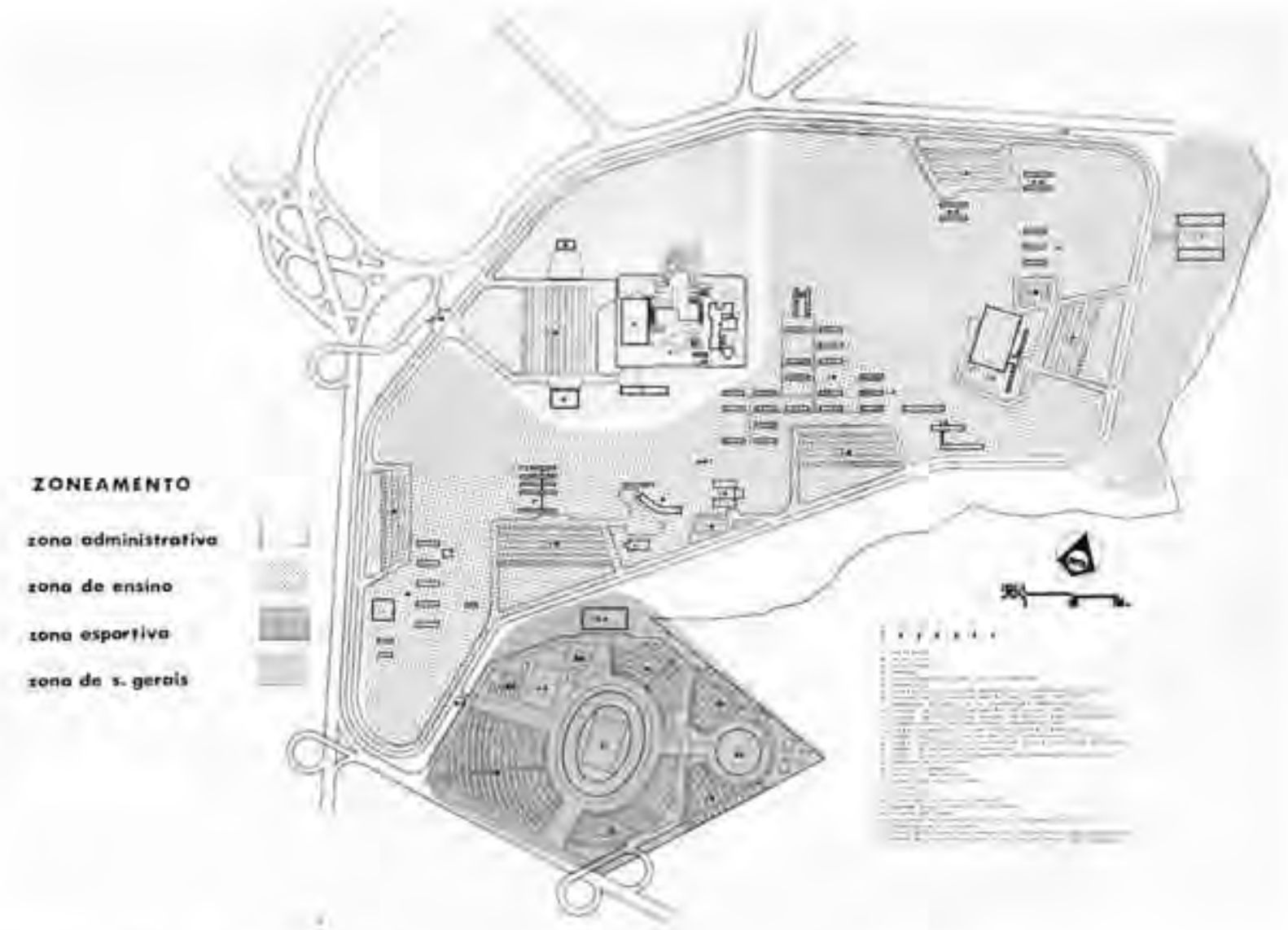

Figura 106: UFPB - Zoneamento funcional do Campus Universitário.

(Fonte: MEIRA, 1971, n.p.) 
A zona administrativa se distribuía em torno de uma praça, considerada como um espaço integrador dos seus respectivos setores: direção, recreaçầo e assistência e cultural. Esse último constituído pela biblioteca central e auditório. Sua loçalizaçẫo se dava no limite norte em função da proximidade com o acesso principal. A adoçẫo desse critério encontra correspondência nas diretrizes do Manual de Atcon (1970), pois evitaria a interferência de agentes externos nas atividades internas do camous.

A zona de ensino, que abrigava as atividades didáticas (ensino e pesquisa), seria composta pelos centros: tecnológico, biocientífico e humanístico. Cada centro, organizado em departamentos, teria os setores de aulas teóricas, de aulas práticas e de coordenação didática (ver figura 107). Sua ocupaçắn se estendia por toda a gleba, formando um conjunto de unidades dispersas.

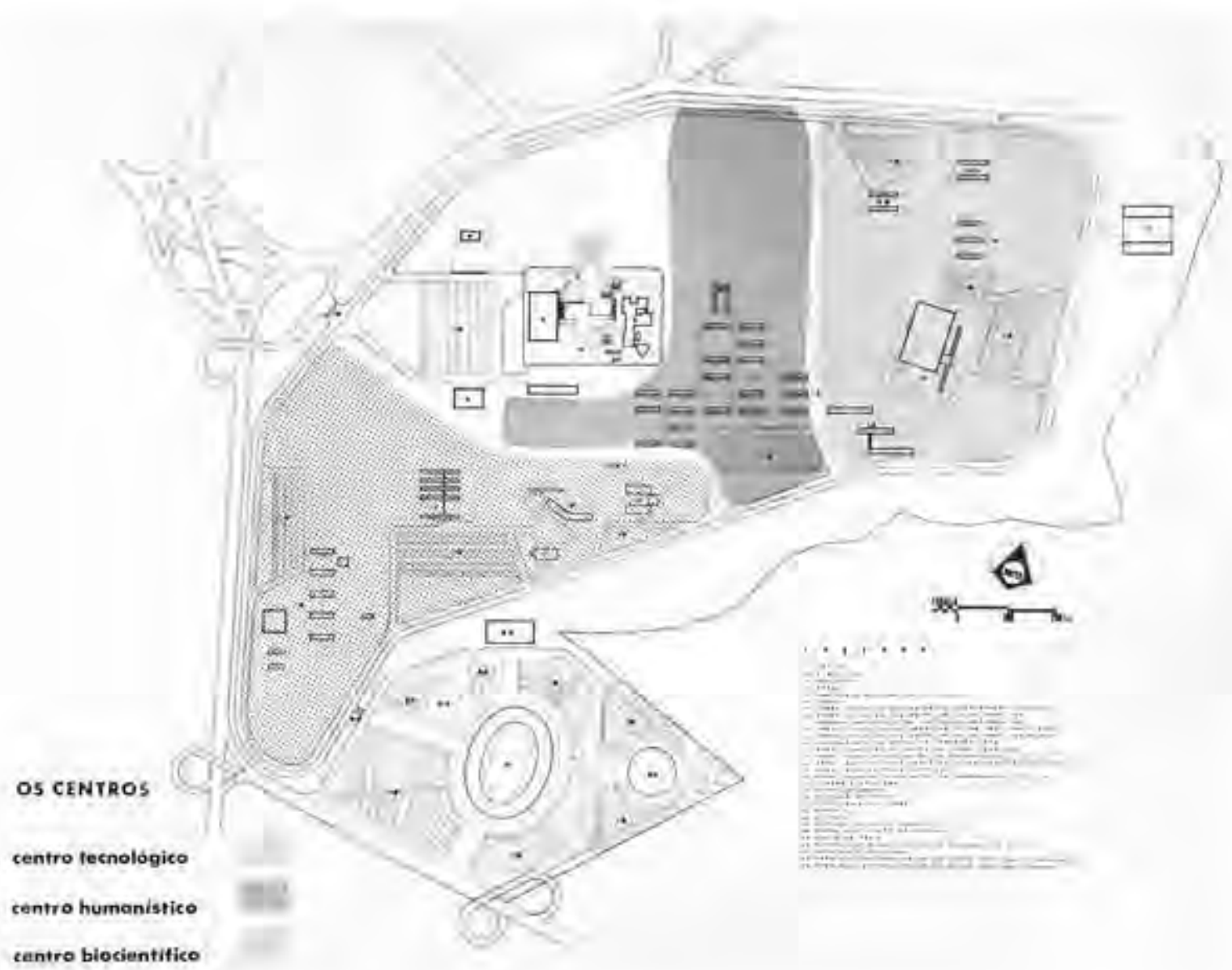

Figura 107: UFPB - Organizaçẫo espacial dos centros no Campus Universitário. (Fonte: MEIRA, 1971, n.p.)

A zona esportiva seria constituída por um conjunto de instalaçôes (ginásio, piscina, quadras etc.) que serviria tanto à populaçẫo universitária quanto à da capital que nẫo possuía essa 
infraestrutura (COUTINHO et al, 2010, n.p.). Sua localizaçầo seria externa às demais zonas, para garantir o acesso sem conflitar com as demais atividades do camous, conforme indicava o Manual de Atcon (1970). A soluçẫo acarretava a aquisiçẫo de uma área apensa à gleba existente.

A zona de serviços gerais, que agrupava as instalaçôes de garagem e oficinas, situava-se no limite leste, com total independência dos setores acadêmico-administrativo.

Q traçado urbanístico caracterizava-se pelo sistema viário, constituído por uma via principal de contorno que articulava o acesso aos setores por meio de bolsóes periféricos de estacionamento contornados por vias secundárias (ver figura 108). A soluçẫo garantia a independencia da circulaçẫo de pedestres, que se dava no interior do camous, desempenhando a funçẫo de ligaçã̃o das unidades. Ao final, a concepçẫo urbanística resultava num conjunto de unidades dispersas em meio à extensa cobertura vegetal existente, que poderiam se expandir sem restriçồes, conforme as novas demandas.

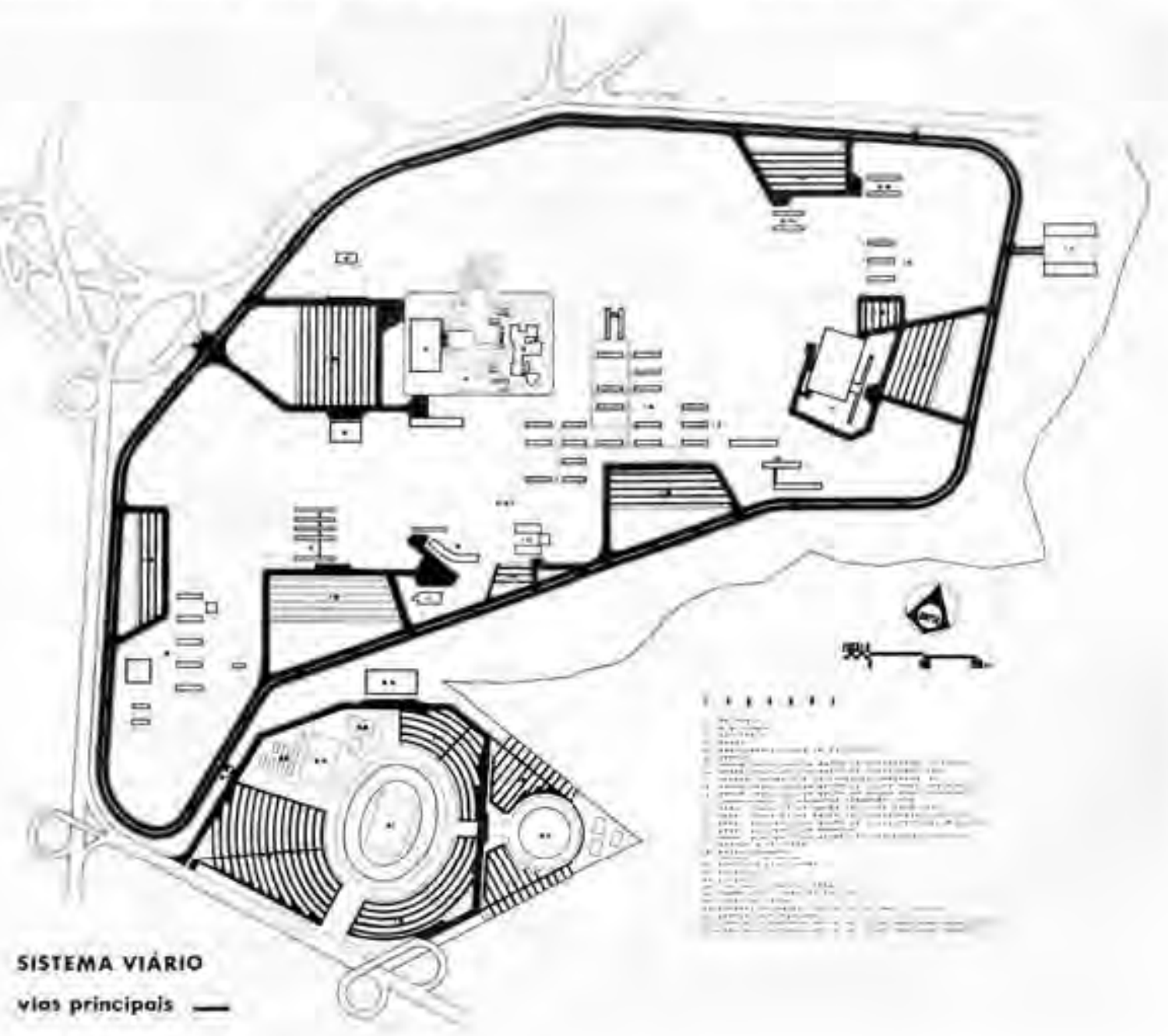

Figura 108: UFPB - Planta do sistema viário. (Fonte: Meira, 1971, n.p.) 
As novas edificações estavam indicadas como tipologias padronizadas, embora sua definição estivesse limitada a princípios construtivos: uso de materiais e técnicas locais, adequação climática por meio da ventilação cruzada, dos elementos de proteção solar, do uso de beirais, do emprego de elementos vazados e da redução de aberturas envidraçadas. A linguagem arquitetônica deveria manter uma unidade, dentro de um "padrão ecológico".

O plano, assim como os de outras universidades federais concebidos com a mesma finalidade (implantação da Reforma Universitária de 1968), caracterizava a infraestrutura do sistema de energia elétrica e iluminação, de abastecimento de água, de esgoto, de águas pluviais e de telefonia. Procedimento que não se verificou nos planos anteriores. É provável que fosse uma exigência do MEC para o financiamento de campi, haja vista que o governo federal captava recursos no BID, sendo necessário nesses convênios o orçamento detalhado de todos os itens de construção envolvidos.

O plano de Meira situava-se no nível de diretrizes, cujo desenvolvimento se daria por uma lei de crescimento orgânica, conforme as demandas acadêmicas, cuja densidade deveria ficar em torno de $95 \mathrm{~m}^{2}$ por aluno. A ocupação seria orientada exclusivamente pelo zoneamento funcional e pela hierarquia do sistema viário. Ao final, a base física do campus seria o resultado da junção das zonas funcionais, formando um tecido integrado sem marcos que diferenciassem onde um setor começava e onde terminava. Não havia um compromisso de parcelamento do solo e nem de eixos viários principais como acontecia no plano de Mário Rosa. Tal concepção estava claramente sintonizada com as diretrizes do Manual de Atcon (1970) e corroboram com tal evidência, as narrativas de Meira sobre a excelente convivência profissional que manteve com Rudolph Atcon, na década de 1960, durante sua permanência no $\mathrm{MEC}^{49}$.

\section{- O plano de $1972-2^{\mathrm{a}}$. proposta}

Em 1972, com a mudança na gestão da administração superior, um terceiro plano se sucedeu por solicitação do novo reitor ${ }^{50}$. Para elaborá-lo foi constituído um grupo de trabalho formado por profissionais da UFPB ${ }^{51}$, tendo sido concluído no prazo de quarenta e cinco dias. A proposta tomou como ponto de partida as unidades construídas e os planos e estudos anteriores (ver figura 109). Entretanto, predomina na concepção uma síntese das diretrizes formuladas no plano de Alcyr Meira, cuja tipologia espacial estava de acordo com

\footnotetext{
${ }^{49}$ Informação verbal fornecida na entrevista com o arquiteto Alcyr Meira em 10 de novembro de 2010 , na cidade de Belém (Pará). Segundo Meira, sua convivência com profissionais norte-americanos foi tão produtiva, que foi convidado pela Rice University, a proferir palestra sobre planejamento de campus universitário, tomando como referência o seu projeto para a Universidade Federal do Pará, no dia 3 de outubro de 1968, em Houston (Texas).

50 . Reitorado de Humberto Carneiro da Cunha Nóbrega (1971 a 1975).

51. Participaram da comissão os arquitetos Mario di Lascio, Antônio Amaral e Silva e Pedro Dieb, além de profissionais de engenharia civil, agronomia e direito (COUTINHO et al., 2010, n.p.).
} 
a modelo preconizado pela reforma (1968), condiçẫo imprescindivel para receber os aportes financeiros provenientes do Governo Federal.

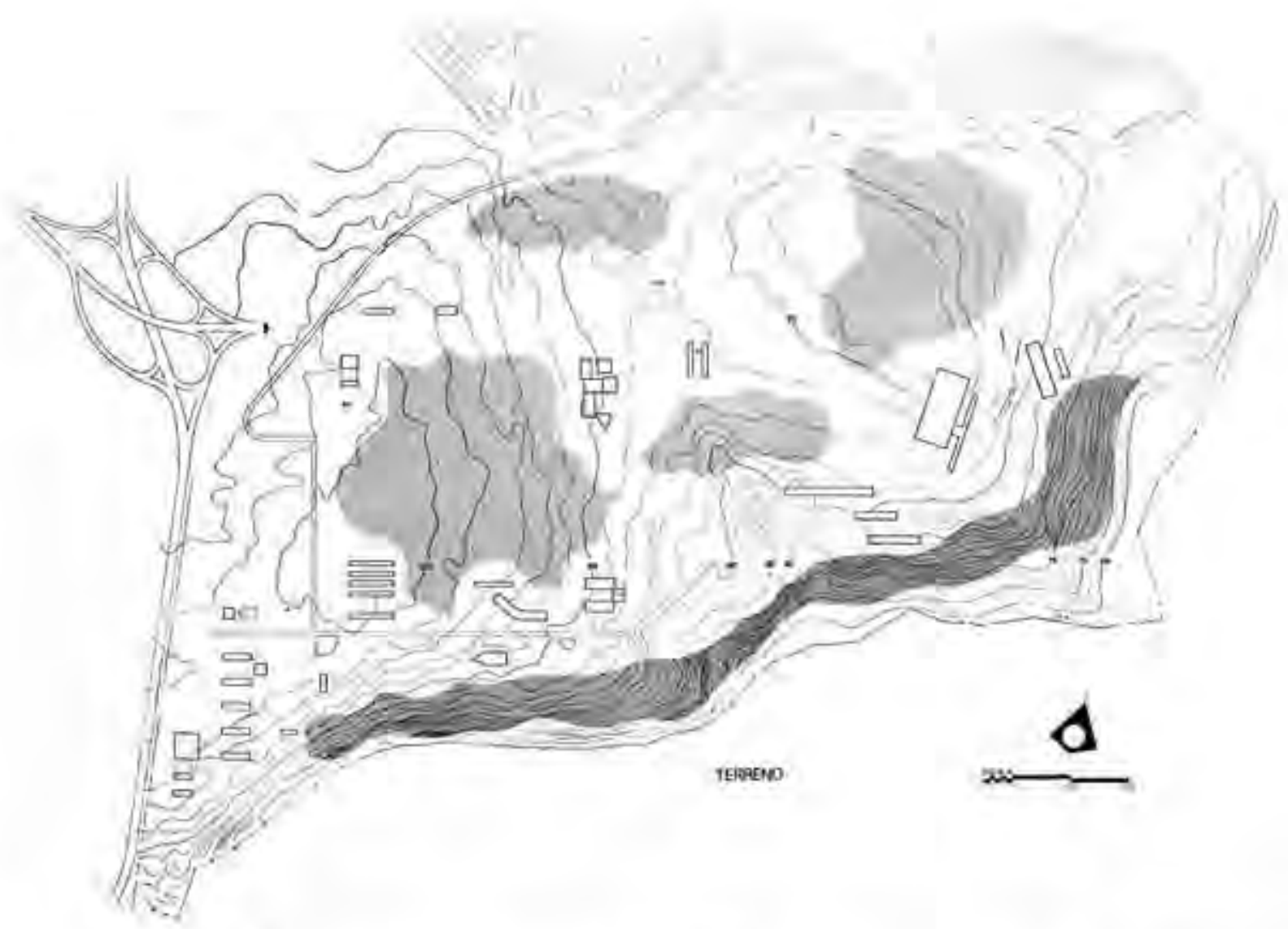

Figura 109: UFPB - Campus planta de constataçẫo (1972).

Pode-se verificar que a infraestrutura implantada no campus ainda nấo tinha uma definiçẫo precisa do traçado urbanístico. Estavam mantidas as primeiras construçổes e o sistema viário ainda incipiente năo articulav a a ligaçẫo entre todo o conjunto edificado. (F onte: UFPB, 1972, n.p.)

No bojo das diretrizes estavam conșolidados os princípios da racionalizaçấo, economia, flexibilidade e expansibilidade para um campus com populaçã̃o aproximada de 15.000 alunos. Nos parâmetros de implantaçẩo das edificaçổes mantiveram-se:

- o zoneamento funcional, com quatro áreas afins - administrativa, ensino, esportiva e integração. Esta última é sem dúvida um dos méritos da proposta, já que esclarecia como poderia fisicamente concretizar a uniẩo de tantos setores dispersos numa gleba de grande extensẫo. A integraçẫo deixa de ser um valor para ganhar corpo e espacializaçã̃o, através da passarela. Seu papel é orientar o fluxo de pedestres, articular o acesso às unidades edificadas e aos estacionamentos, e criar ambientes de lazer e de convivência, bem como constituir-se em elemento paisagístico. Isso significa que pode se expandir e se transformar 
em área de encontro, com pérgolas e alamedas, de maneira que o percurso no camous se tome um espaço de trocas e convívio, possibilitando que professores, alunos e funcionários constituam uma comunidade (ver figura 110).

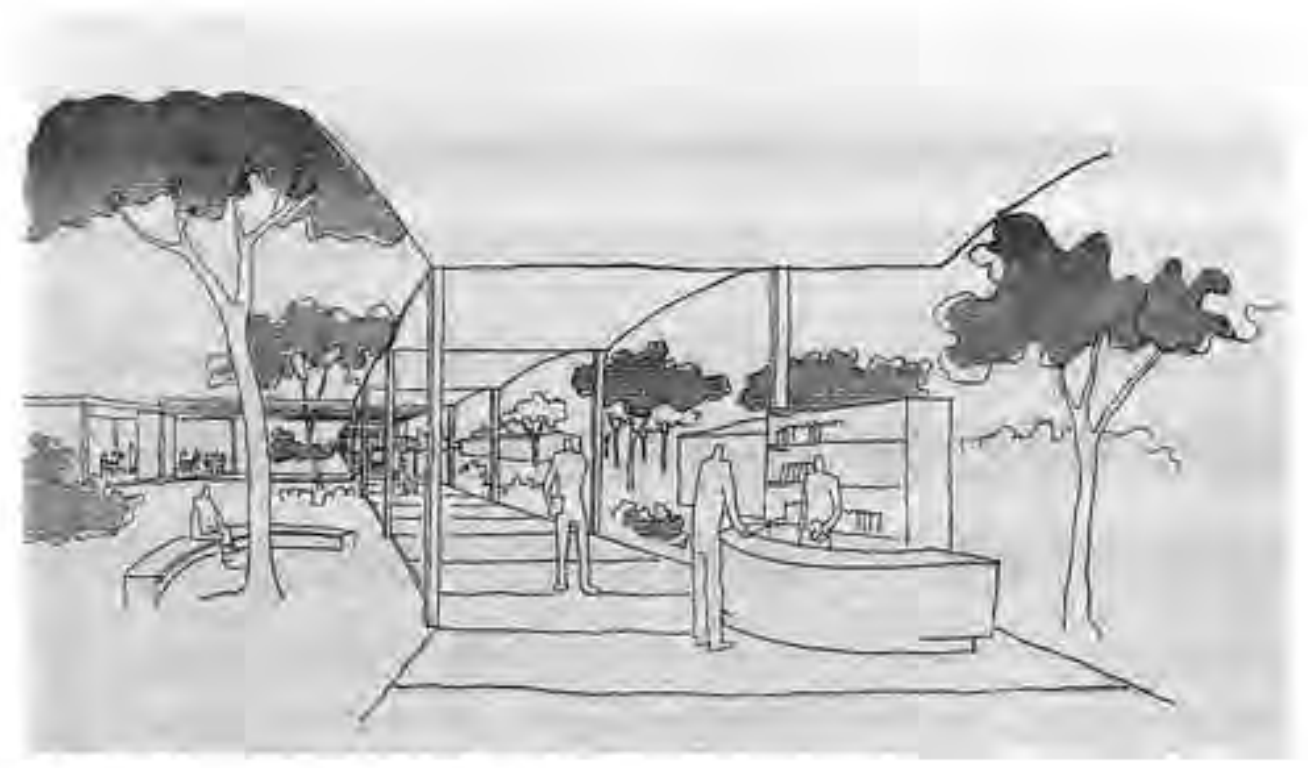

Figura 110: UFPB - Passarelas.

(F onte: UFPB, 1972, n.p.)

- a hierarquia do sistema viário, com o anel periférico provido de bolsốes de estacionamento. sem alternativas de possibilitar o cruzamento de veículos nas áreas funcionais e a clara definição da circulaçẫo de pedestres por meio da "grande passarela".

- e a adoção de extensas áreas verdes, com a preservaçăo da mata nativa e das características naturais do terreno.

O plano destaca estratégias adotadas no sentido de garantir "proteçẫo" à zona de ensinopesquisa tais como as reservas florestais a leste e a sul do terreno e a rodovia federal a oeste, que serviriam "de anteparo e proteçầo natural" nesses limites, assim como a implantaçẫo das zonas administrativa e esportiva como faixa protetora no limite norte. Nẫo fica claro que tipo de ameaça pairava no desenvolvimento da rotina acadêmica, merecedora de tais medidas protecionistas, é certo, porém que o Manual de Atcon preconizava a importância de impedir a penetração de elementos "indesejáveis".

O traçado urbanístico resultante caracteriza-se pela presença predominante do anel perifêrico que contorna o camous, onde as unidades edificadas estẫo imersas na vegetação nativa, e pela "grande passarela" que atravessa o camous no sentido leste-oeste, interligando as unidades da área de ensino-pesquisa (ver figura 111). 


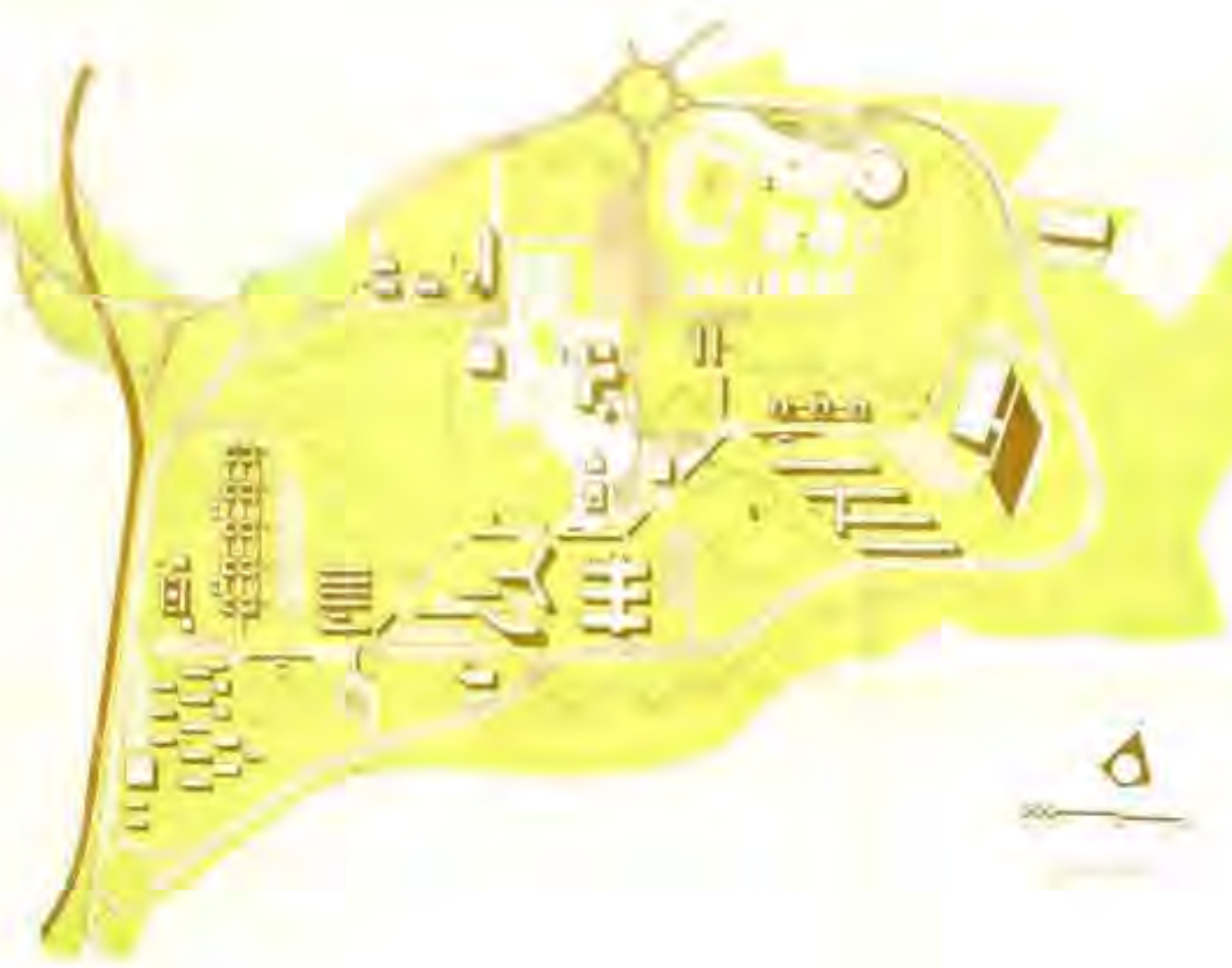

Figura 111: UFPB - Passarelas.

(Fonte: UFPB, 1972, n.p.)

A nova proposta tornou-se a versắo oficial e desse período (década de 1970) sắo o Centro de Ciências Exatas da Natureza e o Conjunto Humanístico composto pelo Centro de Ciências Humanas, Letras e Artes (CCHLA) e pelo Centro de Ciências Sociais Aplicados (CCSA) [que serẫo analisados na próxima seçẫo do capítulo]. Lembrando que em 1974 a reforma cêntrica foi aprovada pelo conselho universitário e a estrutura acadêmica da instituiçã̃o definiu-se por cinco centros sediados em Joẫo Pessoa. Seguindo o princípio da nẵo duplicaçẫo de meios para fins idênticos, merece mençã̃o a edificação destinada às aulas teóricas, que concentra em um só local esse tipo de atividade. Trata-se de um conjunto de blocos-padrões agrupados seguindo o sistema pavilhonar, que se articulam por uma passarela central de ligaçẫo.

No período de 1976 a 1980 , deu-se a transferência definitiva da reitoria para o camous, ocupando o edifício projetado para a biblioteca central, conforme já mencionado.

Em 1978, solicitou-se ao arquiteto José Galbinski, professor da UnB, um projeto para a nova Biblioteca, o qual foi implantado desconsiderando as determinaçỗes do Plano Diretor vigente. Essa decisẫo pôs fim à idéia original da Praça Cívica, gerando um novo 
núcleo no centro do campus, próximo ao Restaurante. Em 1979, ergueu-se à sua frente o centro de Vivência $[\ldots]$, instalando definitivamente uma tensẫo viária (COUTINHO et al, 2010, n.p.).

Também a diretriz de nấo atravessar as áreas de ensino-pesquisa com vas de veículos nầo foi mantida, falseando a proposta original. Ao final da década de 1970, a confomaçấo do territónio da UFPB implantado em área fora do perímetro urbano era um processo ireversivel, porém desvirtuado das concepçốes urbanisticas que the deram origem (ver figura 112).

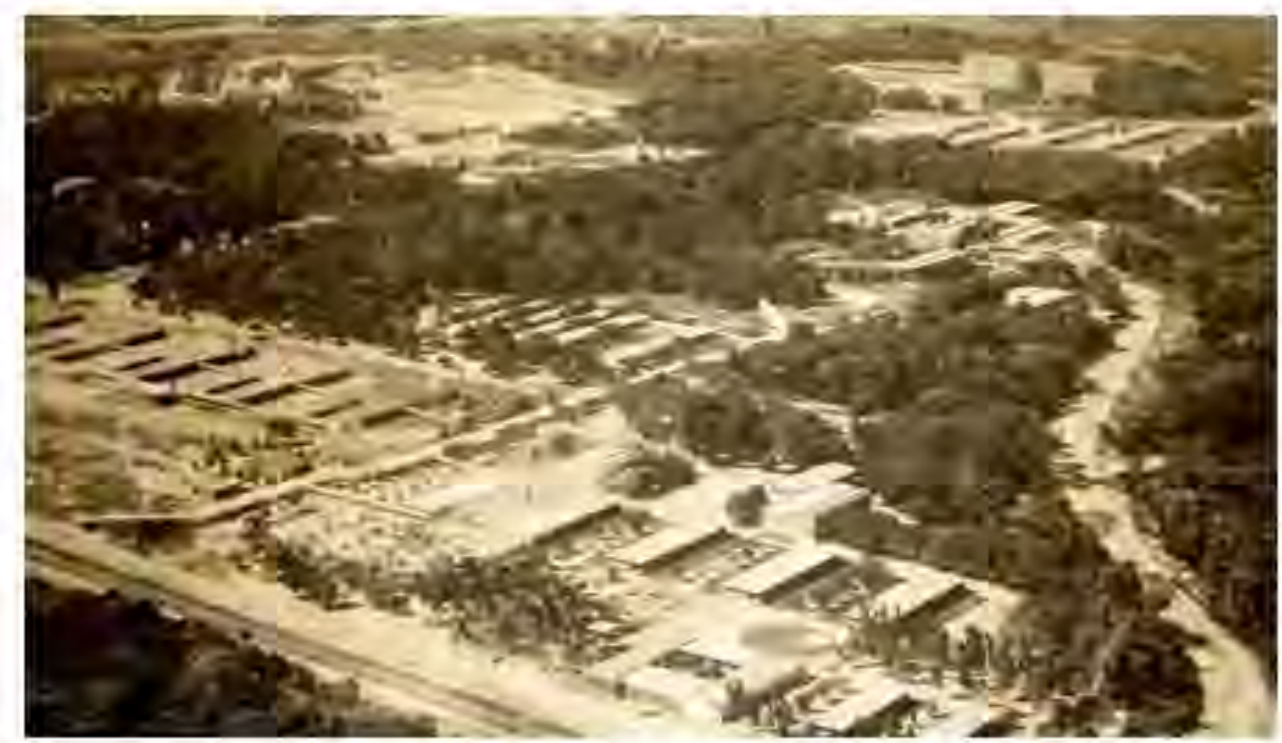

Figura 112: UFPB - Camous da UFPB - meados da década de 1970.

Estavam construídos os Centro de Tecnologia (primeiro plano), Conjunto Humanístico (à esquerda), Central de aulas (centro), Hospital Universitário (superior direito), Setor Esportwo (superior esquerdo).

(Fonte: Acervo Prefeitura do Campusuniversitánio)

A Refoma de 1968 deixou suas marcas pontuadas em um traçado urbanístico de rígido zoneamento das áreas afins e uma produçẫo de edifícios dispersos na gleba de grandes dimensỗes (ver figura 113). A forte presença do anel periférico evidencia a orientaçẫo do Manual de Atcon. Entretanto, a propalada integração limitou-se aos estudos formulados.

A presença de conjuntos habitacionais, já naqueles anos, implantando-se nos seus arredores delineava o panorama de cercamento dos seus limites pelo crescimento da cidade (ver figura 114). A via perimetral que circunda o campus integra-se as vias públicas, o que nẫo neutraliza o seu caráter de isolamento e autonomia, tornando-se um enclave do tecido urbano. 


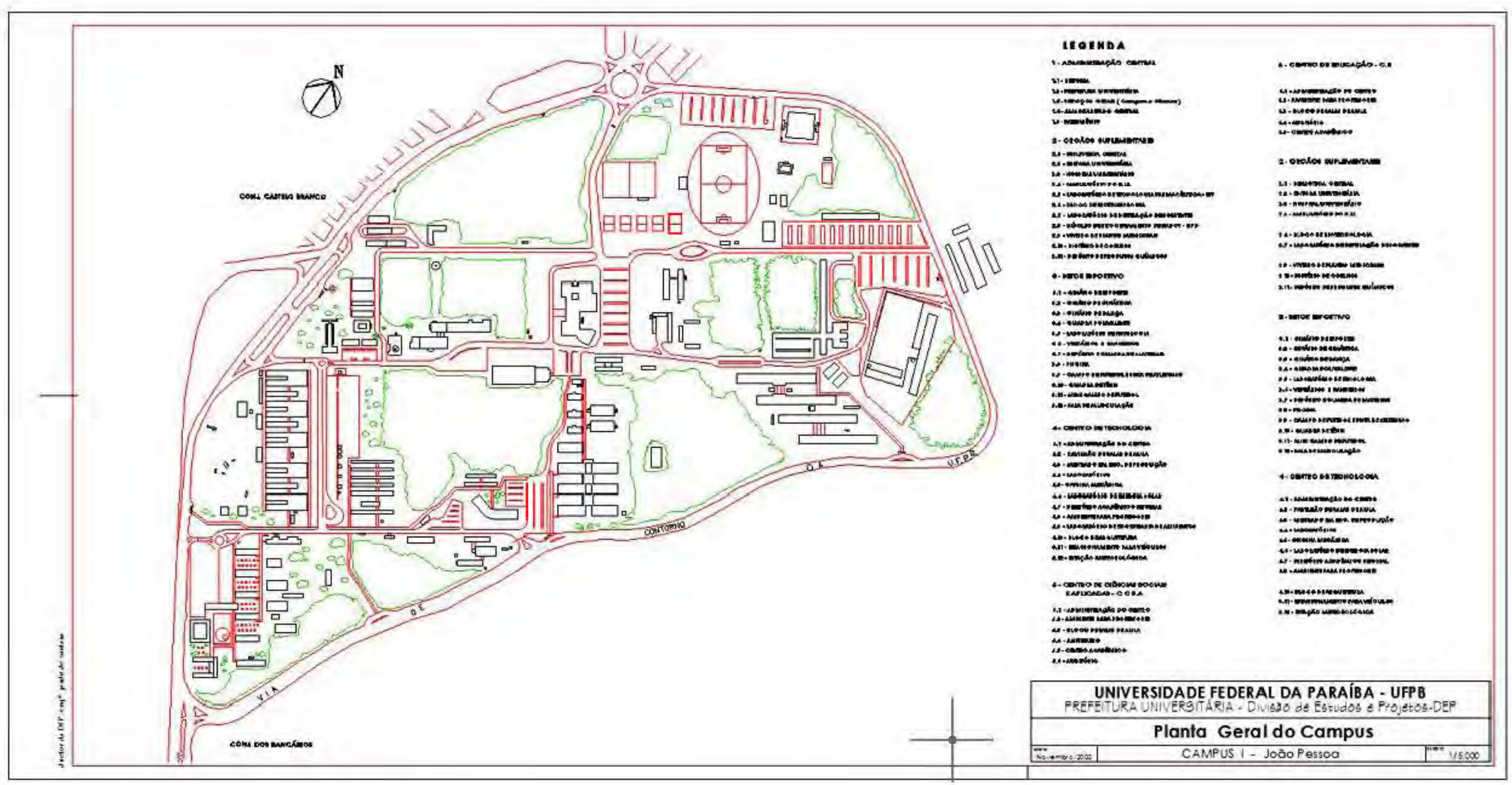

Figura 113: UFPE - Campus I - Planta Geral (ano 2002)
(Fonte: Acervo da Preteitura do Campus Universtataio) 


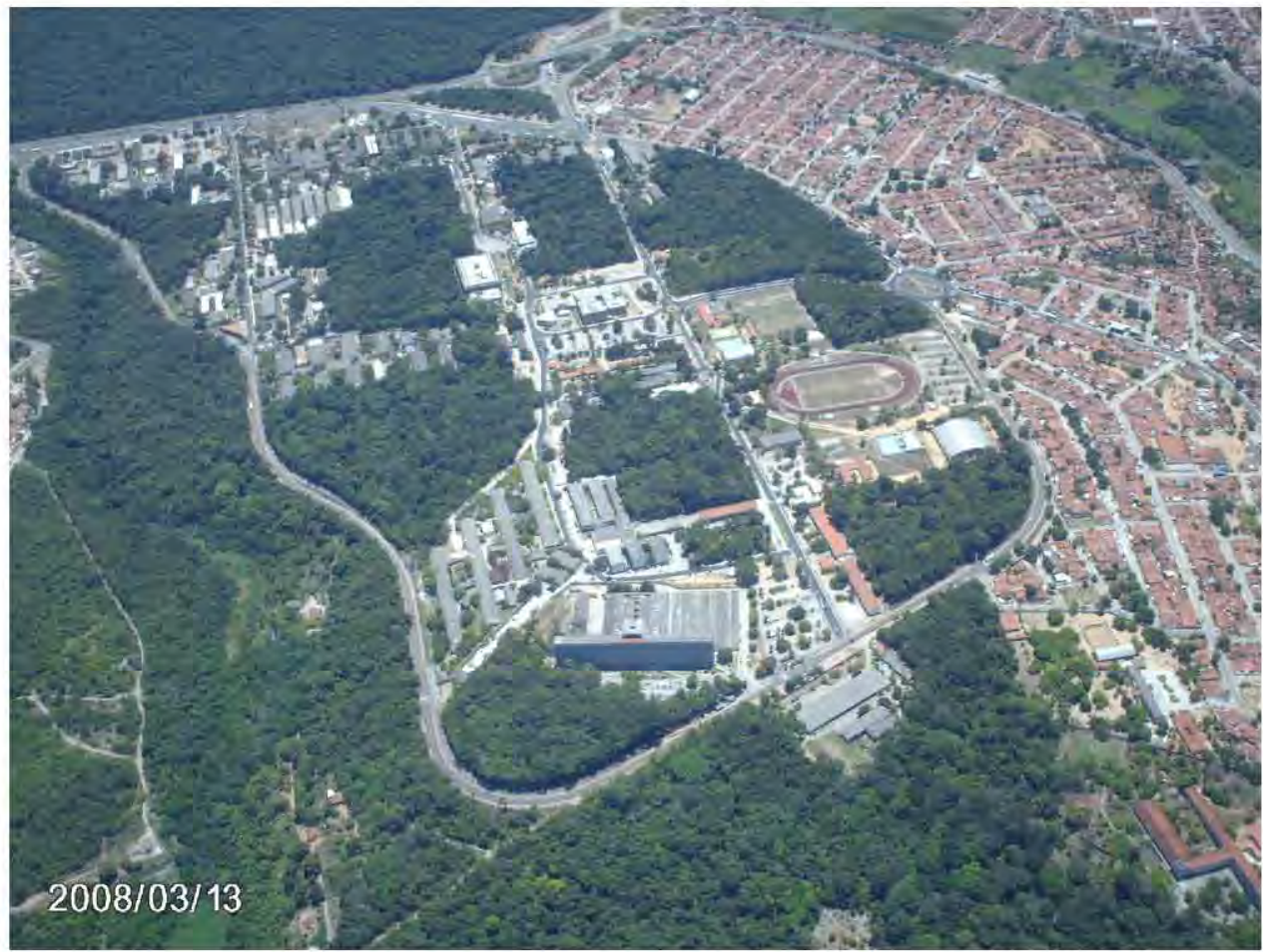

Figura 114: UFPB - Vista aérea do Campus Universitário - ano 2008

O campus encontra-se cercado por conjuntos habitacionais.

(Fonte: Acervo Prefeitura do Campus Universitário apud CAMPÊLO, 2010, n.p.)

\subsection{PRODUÇÃO ARQUITETÔNICA DA REFORMA}

As tipologias selecionadas para análise correspondem às mais significativas do ponto de vista da linguagem arquitetônica que fizeram parte da primeira etapa de construção (a Escola de Engenharia e o Hospital Universitário) e um exemplar de uma tipologia construtiva concebida pelo princípio da expansibilidade em atendimento ao modelo físico preconizado na reforma universitária de 1968 (exemplo do Conjunto Humanístico).

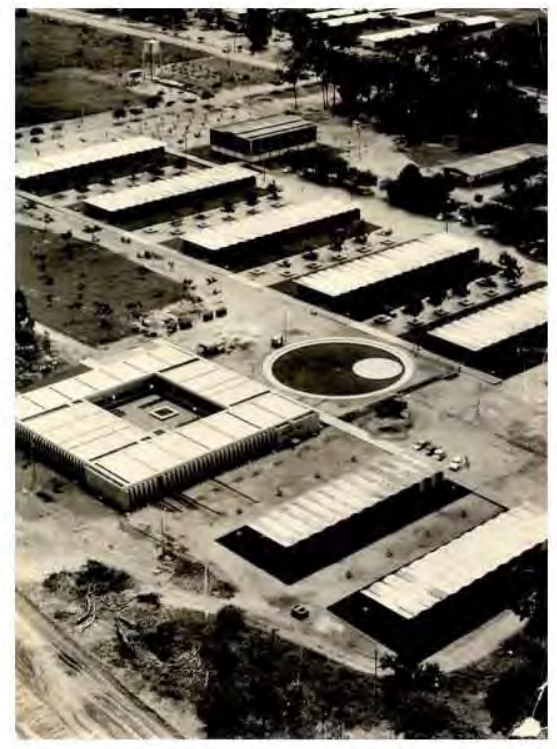

\section{- Conjunto da Escola de Engenharia}

A organização espacial do conjunto está marcada pela presença da praça com anfiteatro circular, que integra os setores administrativos e setor acadêmico (ver figura 115).

Figura 115: UFPB - Conjunto da Escola de Engenharia - 1974. A praça circular configura um elemento ordenador: blocos de geometria retangular para atividades acadêmicas e de configuração quadrada para o setor administrativo.

(Fonte: Acervo NDIHR/UFPB) 


\section{- Blocos Acadêmicos}

A concepção dos blocos acadêmicos apresenta uma orientação projetual que busca alcançar a racionalidade construtiva e a economia da obra sem prejuízo das soluções plásticas e funcionais adequadas. A distribuição espacial no terreno apoia-se no sistema de pavilhões paralelos entre si, que se interligam por uma circulação a céu aberto e perpendicular aos blocos. A proposta resulta em uma organização ordenada e sem hierarquia plástica.

O conjunto está composto de sete blocos de um pavimento, que abrigam programas específicos a cada um, distribuídos na planta de configuração retangular e dimensões de $14,00 \mathrm{~m} \times 51,15 \mathrm{~m}$ (ver projeto nas figuras $116 \mathrm{a}$ à $116 \mathrm{f}$ ). $O$ partido arquitetônico caracterizase pelo eixo da circulação lateral aberta ao exterior que articula a ala dos ambientes de trabalho (ver figura 117). Estes, por sua vez são abastecidos por sanitários concentrados na extremidade de cada planta.

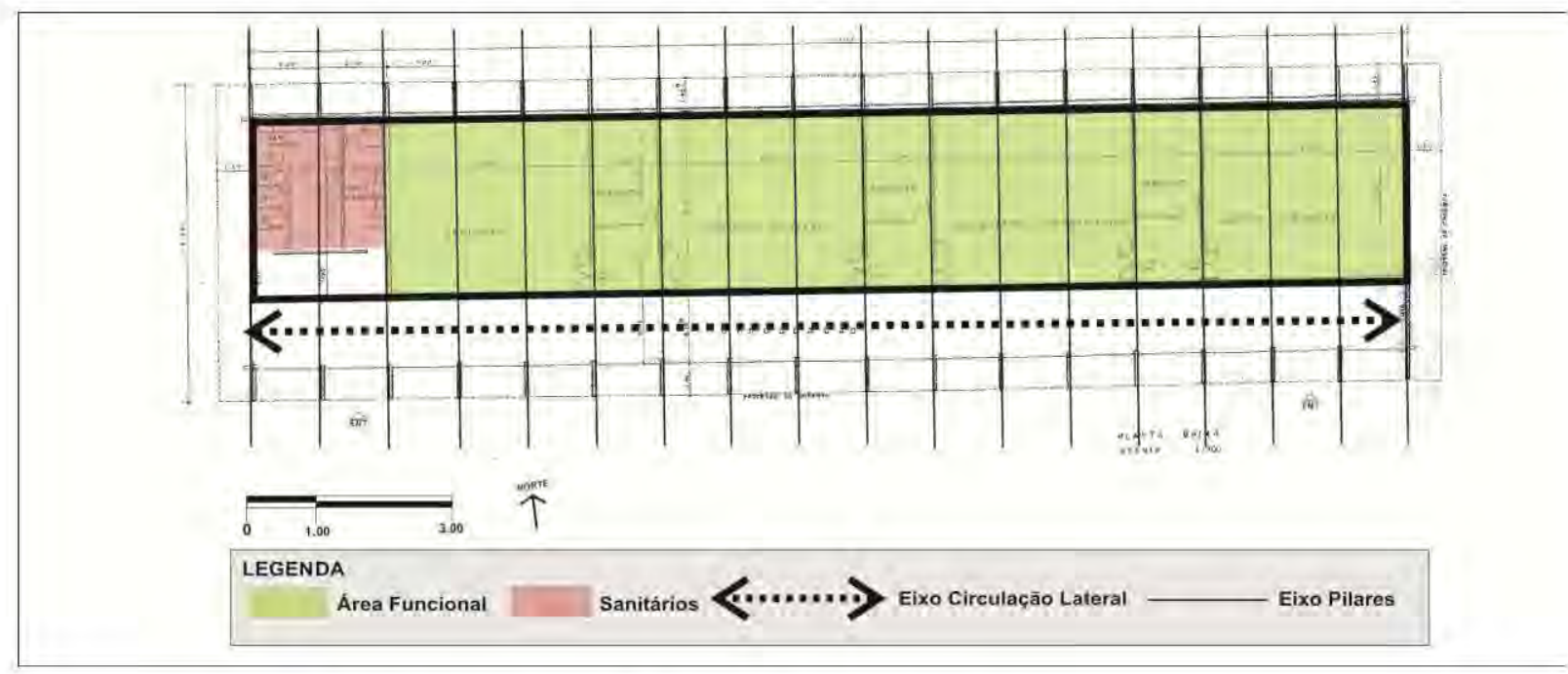

Figura 117: UFPB - Diagrama do partido arquitetônico.

A circulação lateral carrega a ala longitudinal que condensa os ambientes. (Fonte: Planta de arquitetura fornecida pela Prefeitura do Campus com edição nossa)

A planta livre desenvolve o programa associado à malha estrutural (pilares, vigas e laje em concreto aparente), com modulação de 3,00 m no sentido longitudinal e vãos de $11,20 \mathrm{~m}$ no sentido transversal, possibilitando a flexibilidade espacial requerida pela diversidade dos programas. As vedações em alvenaria ou divisórias de madeira podem ser remanejadas, conforme a necessidade de novos layouts. Entretanto, é importante destacar que a liberdade nos arranjos funcionais não está associada à flexibilidade das instalações prediais, uma vez que, embutidas nas vedações, tornam onerosas as alterações. 


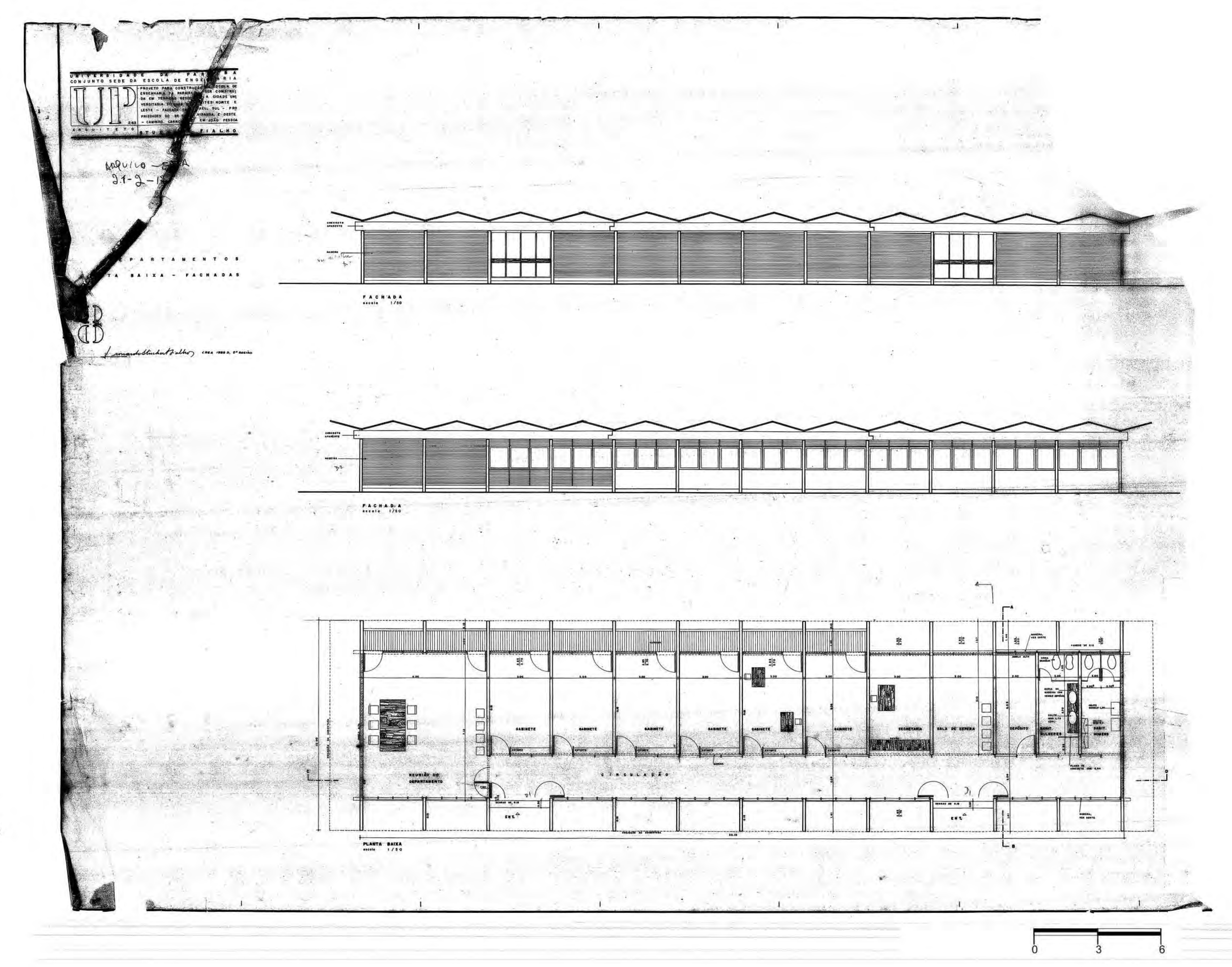




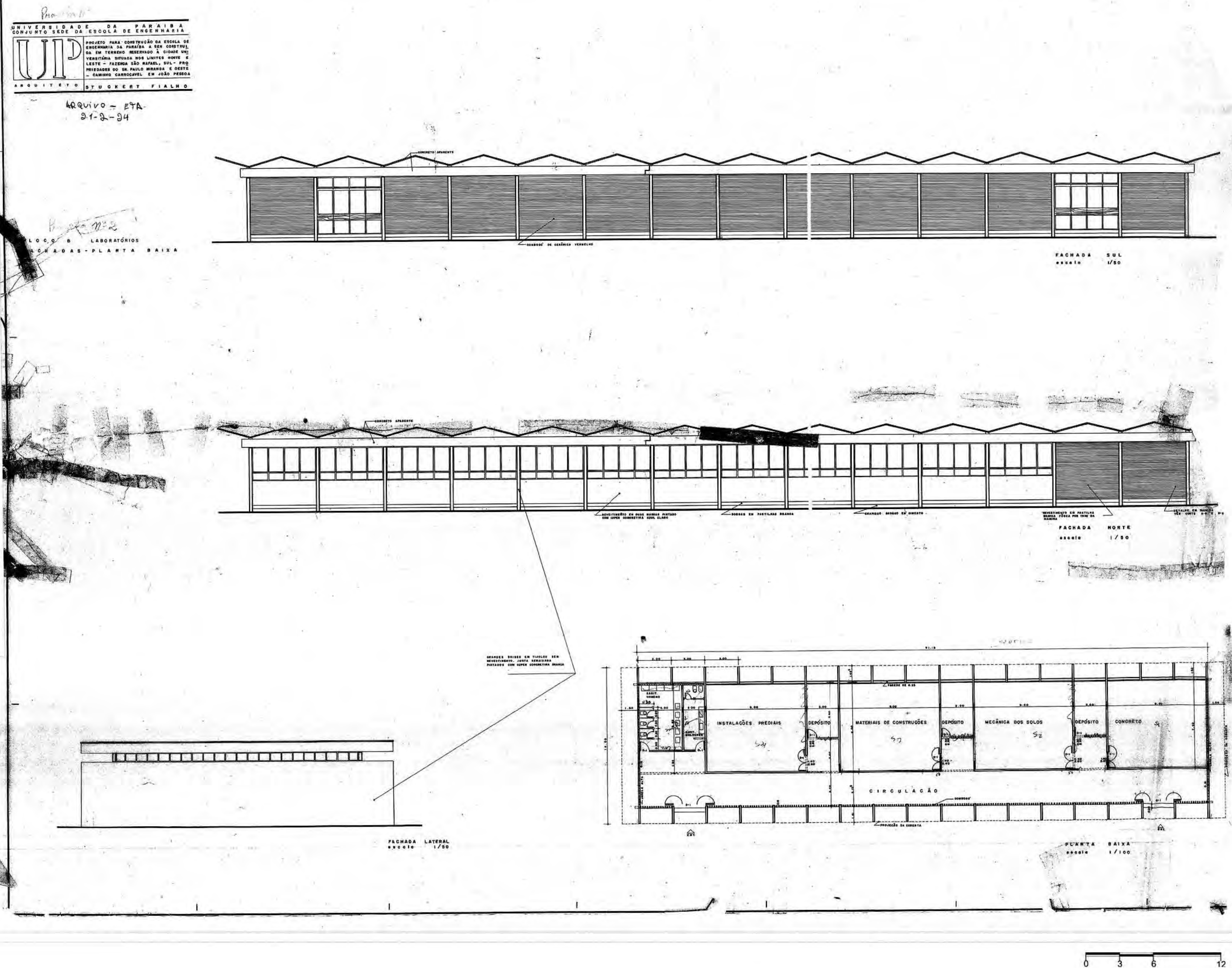




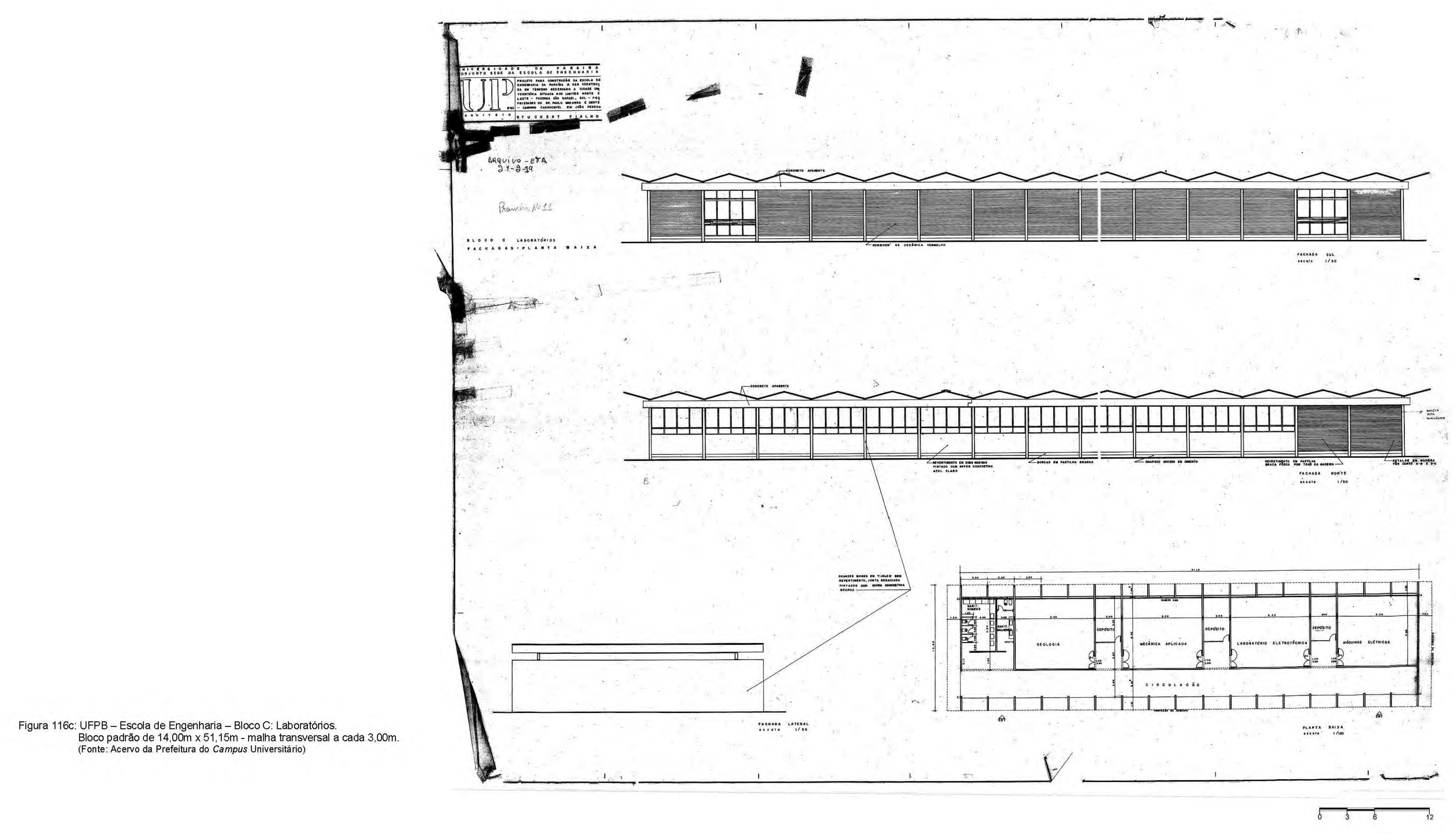




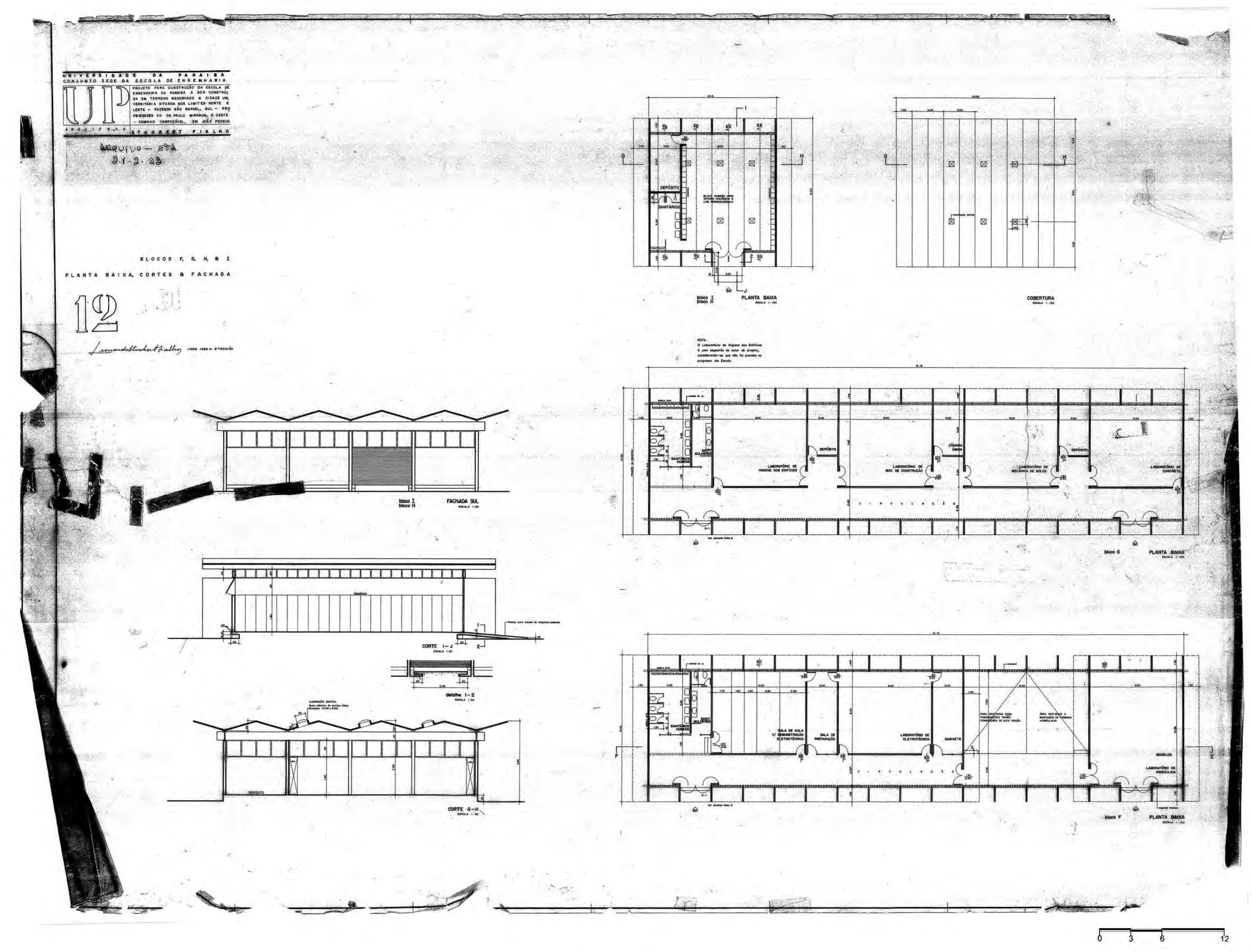




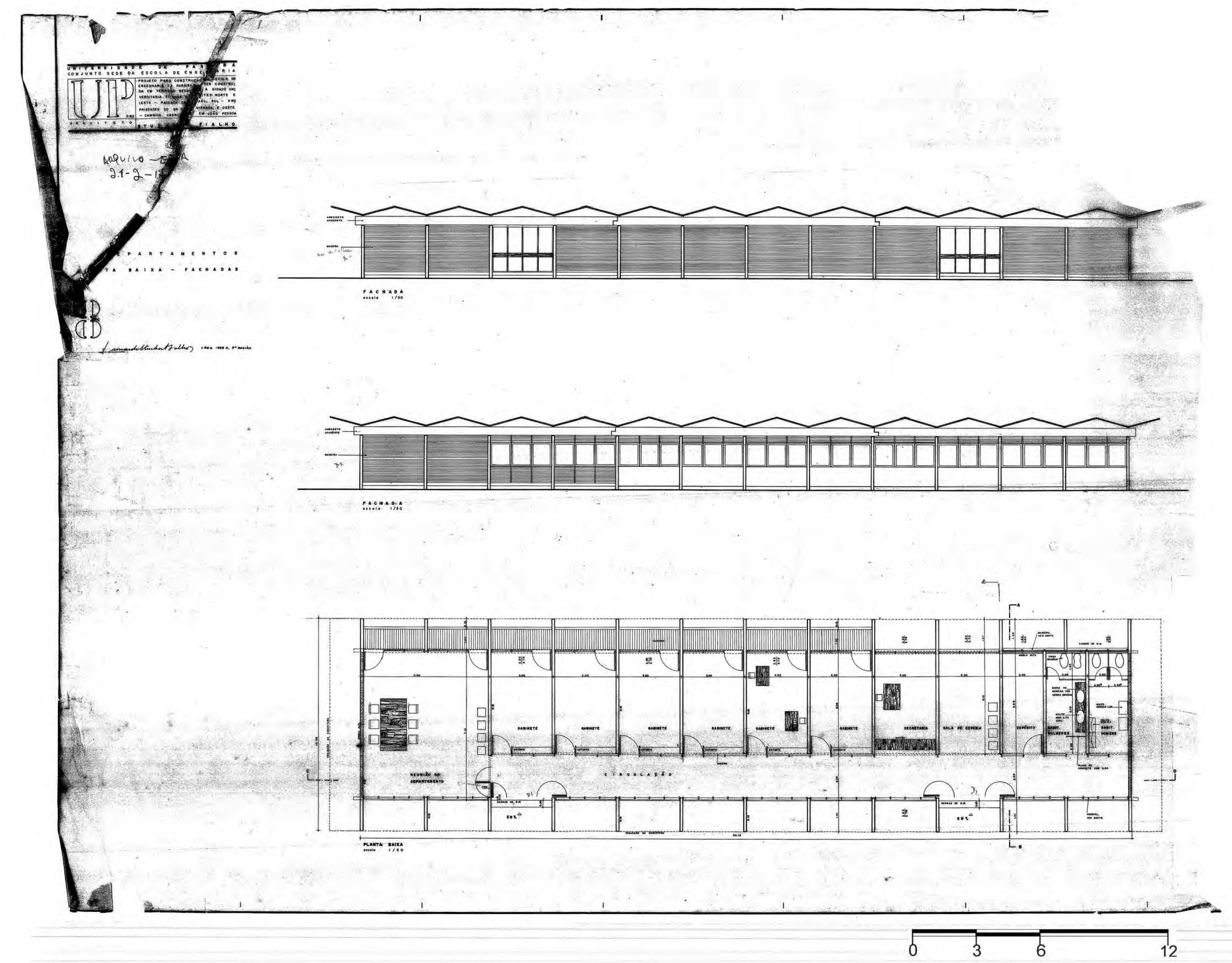




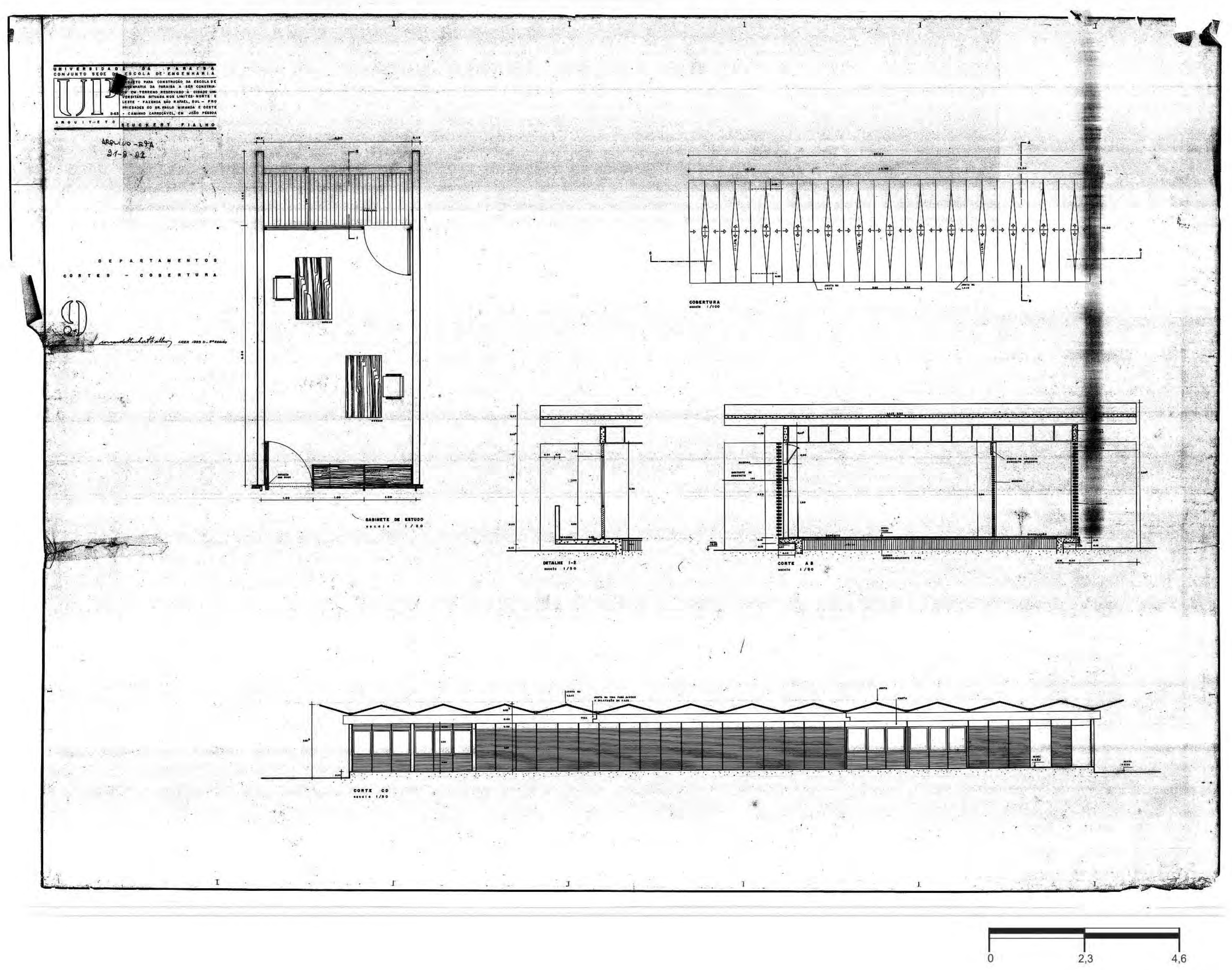


A solução construtiva adota o conceito da verdade estrutural, destacando os elementos construtivos (alvenaria, divisórias e esquadrias de alumínio e vidro) dos pilares e vigas em concreto aparente. Examinando-se as plantas de arquitetura, percebe-se o cuidado com o rigor construtivo, a partir dos elementos gráficos, importantes para a execução no canteiro de obras (ver figura 118).

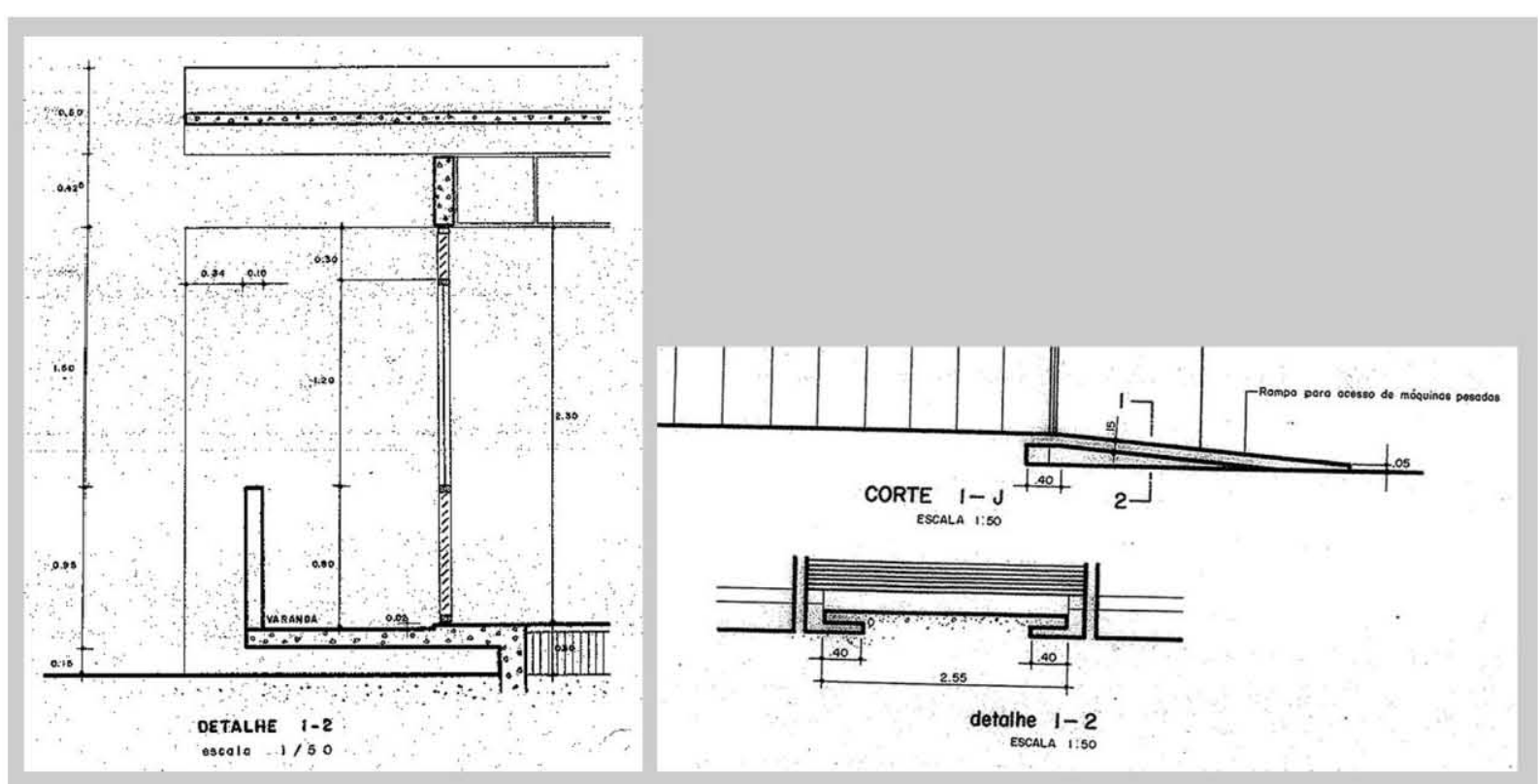

Figura 118: UFPB - Detalhes construtivos.

(Fonte: Prefeitura do Campus, edição nossa)

A forma arquitetônica, destacada pela coberta em laje de concreto aparente impermeabilizada, formando planos inclinados e arrematados por uma linha superior de cumeeira, associada à transparência das esquadrias em fita, apresenta uma escala dimensional que incorpora atributos de leveza e singeleza ao conjunto edificado.

O conforto ambiental é favorecido pela solução da coberta que possibilita a ventilação no nível do forro, removendo as massas de ar quente, e pela circulação lateral com dimensões de 3 metros, que protege a fachada sul da incidência solar direta (ver figura 119). Desprovida de elementos de proteção solar, a fachada norte permite a insolação direta, que tende a se transformar em ondas de calor, situação amenizada pelos ventos dominantes de sudeste que atravessam os ambientes. De todo modo, o excesso de luminosidade causa desconforto, fator suavizado por meio do uso de película tipo insufilme nos vidros das esquadrias, conforme pudemos constatar na pesquisa de campo. 


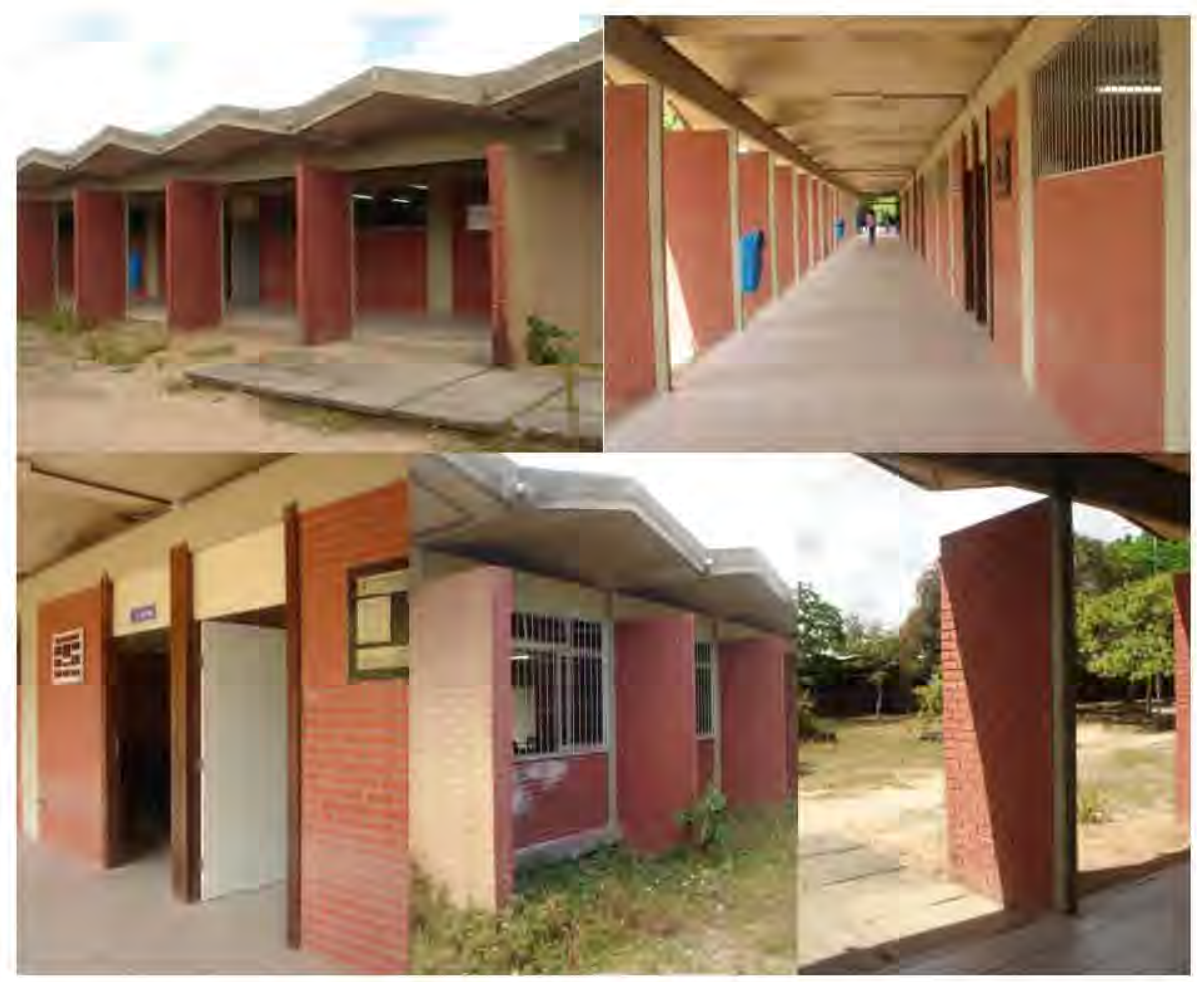

Figura 119: UFPB - Detalhes construtivos.

(Fonte: Acervo Magda Campêlo, 2009)

\section{- Bloco da Administração}

O edifício destinado às atividades administrativas destaca-se pela composição volumétrica que sugere a forma de caixa quadrada, vazada no centro por um pátio de mesma geometria, e superfícies das fachadas em concreto aparente, compostas predominantemente de elementos verticais que se contrapõem à linha longitudinal da platibanda conferindo horizontalidade ao edifício.

A volumetria externa, de aspecto contido, contrasta com a solução da planta que organiza o programa em torno do pátio central descoberto, o qual se integra aos ambientes por meio da circulação que o circunda, proporcionando um agradável espaço de transição e encontro que lembra as varandas próprias das construções do Nordeste.

O programa de necessidades inclui ambientes administrativos e de apoio, bem como um auditório, perfazendo uma área coberta de $2.079,11 \mathrm{~m}^{2}$. A planta livre expõe os pilares de concreto aparente em torno do pátio, arrematados pela platibanda de mesmo acabamento que esconde a telha da coberta. A estrutura em concreto aparente se destaca das vedações revestidas de cerâmica, das divisórias de madeira e das esquadrias de alumínio e vidro (ver projeto de arquitetura nas figuras $120 \mathrm{a}$ à $120 \mathrm{c}$ ).

Nas fachadas norte, sul e leste, o prédio exterioriza os elementos verticais que modulam os ambientes e as esquadrias a cada 1,0 metro, e amenizam o rigor da radiação solar direta, 


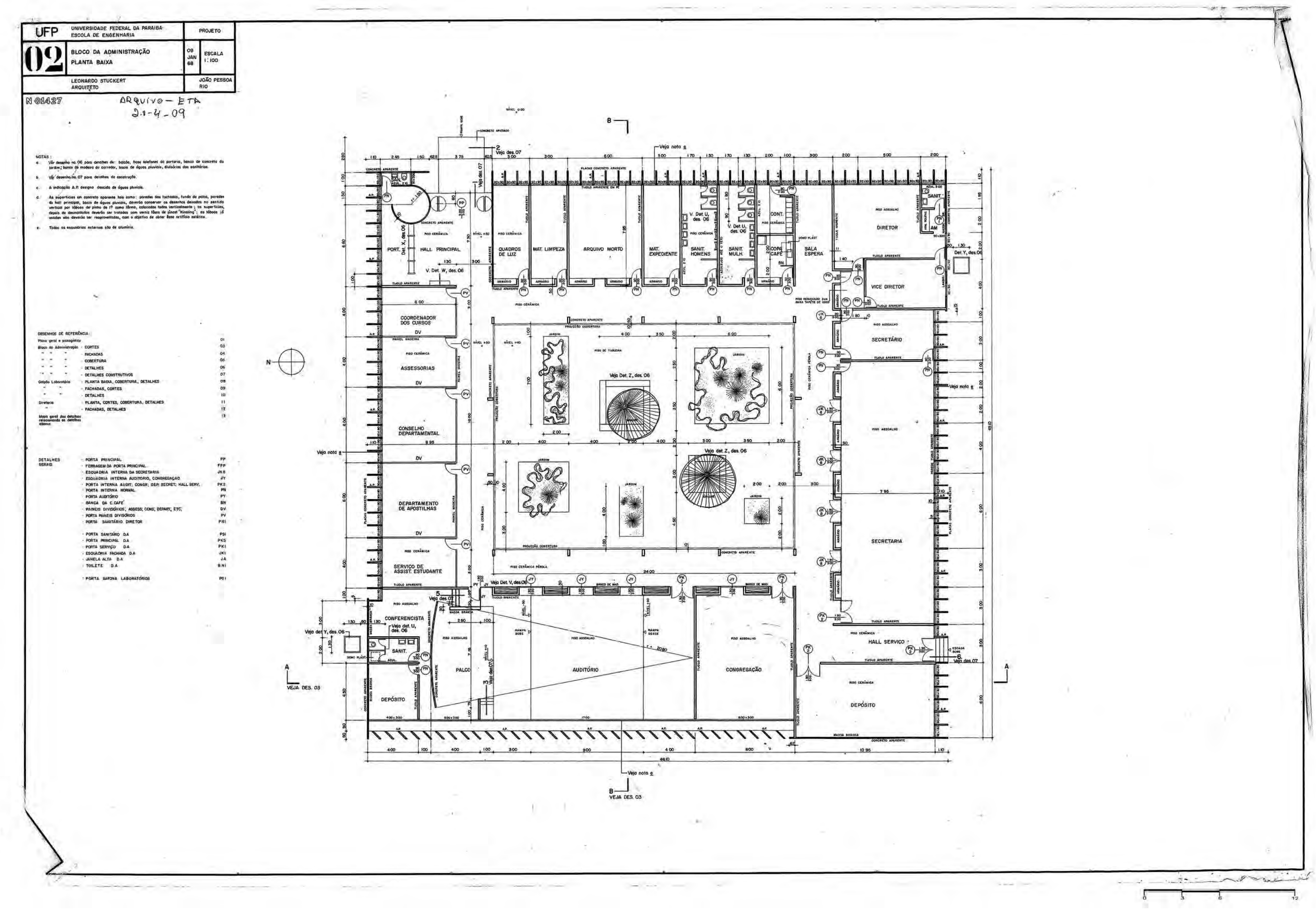




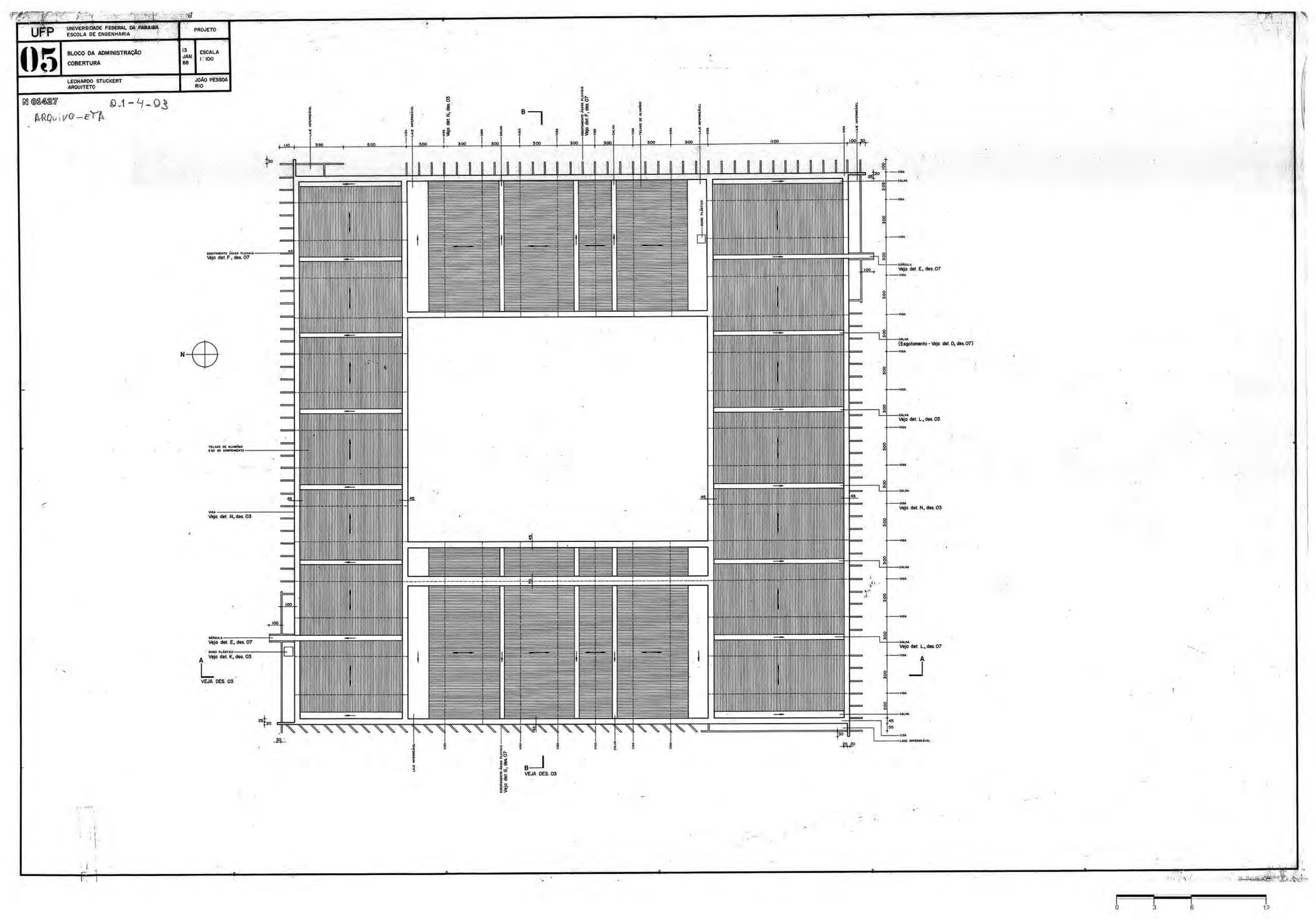



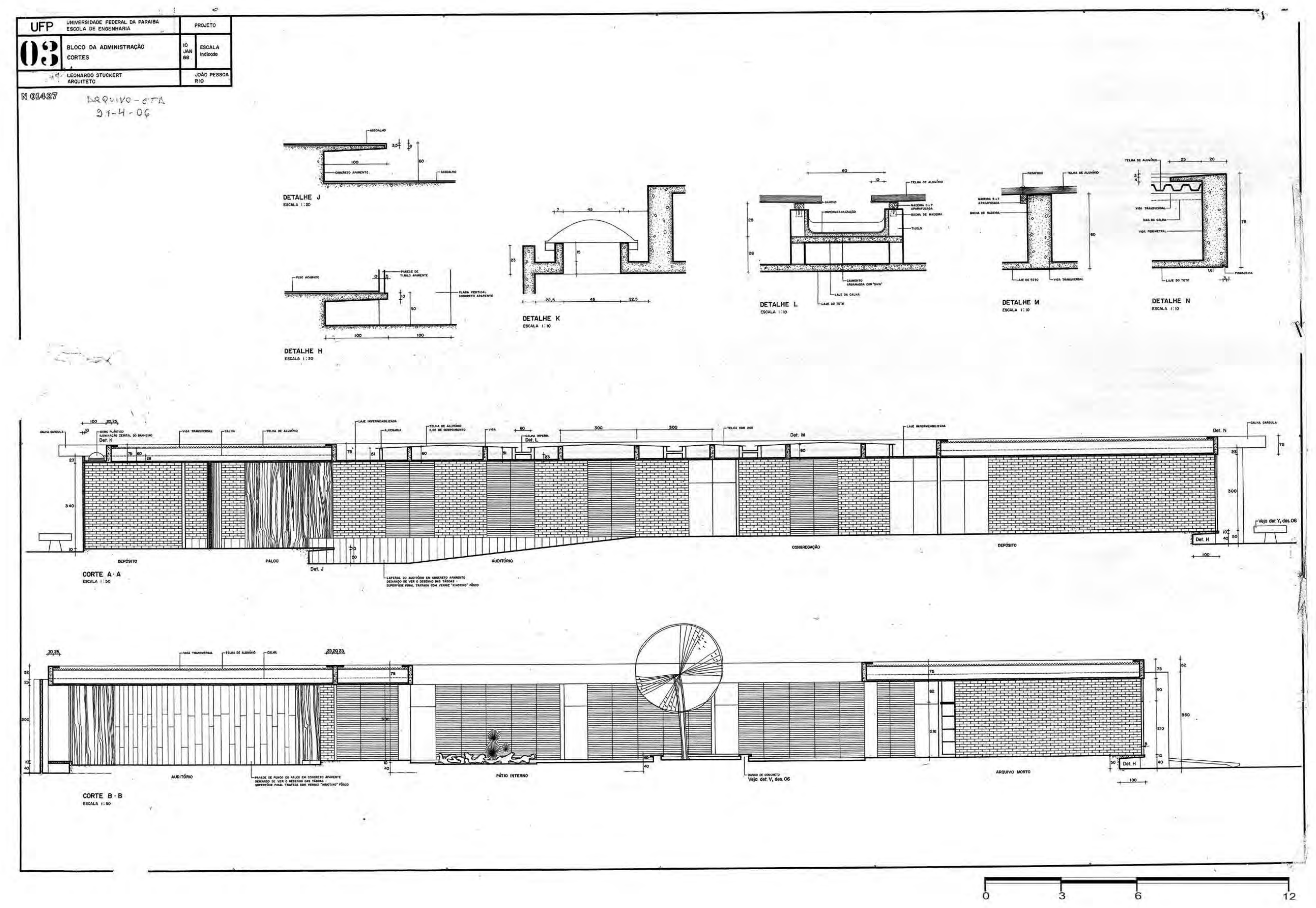
Parte 2 - Universidade Federal da Paraiba 
evidenciando a preocupação com o conforto térmico. Na fachada sul, o arquiteto tira partido dos elementos verticais para criar uma barreira de proteção contra a absorção do calor radiante na alvenaria externa que compõe o auditório. A platibanda de concreto aparente que esconde a coberta em telhas de fibrocimento criar uma expressividade plástica referenciada na arquitetura da laje plana (ver figuras 121 e 122).

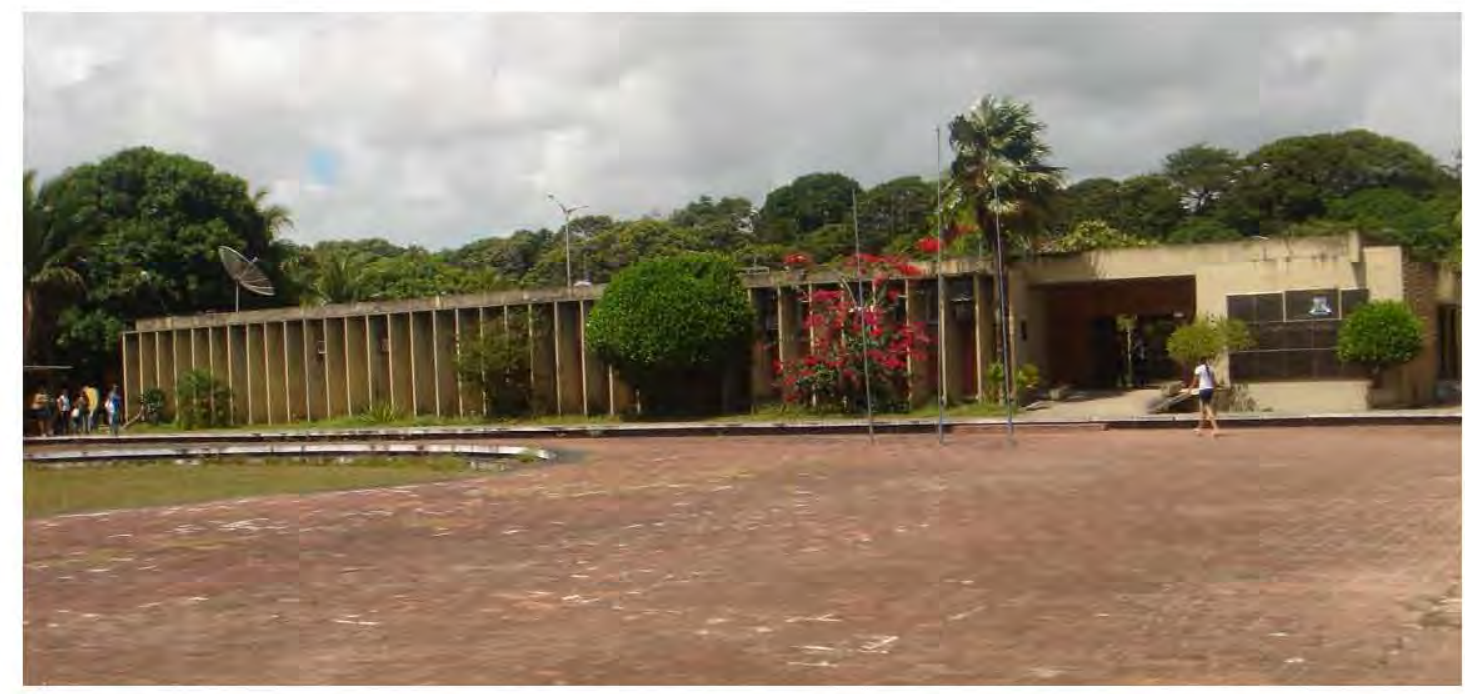

Figura 121: UFPB - Bloco Administrativo / Fachada principal.

A estrutura originalmente destacava-se das vedações em concreto aparente.

(Fonte: Acervo Magda Campêlo, 2009)

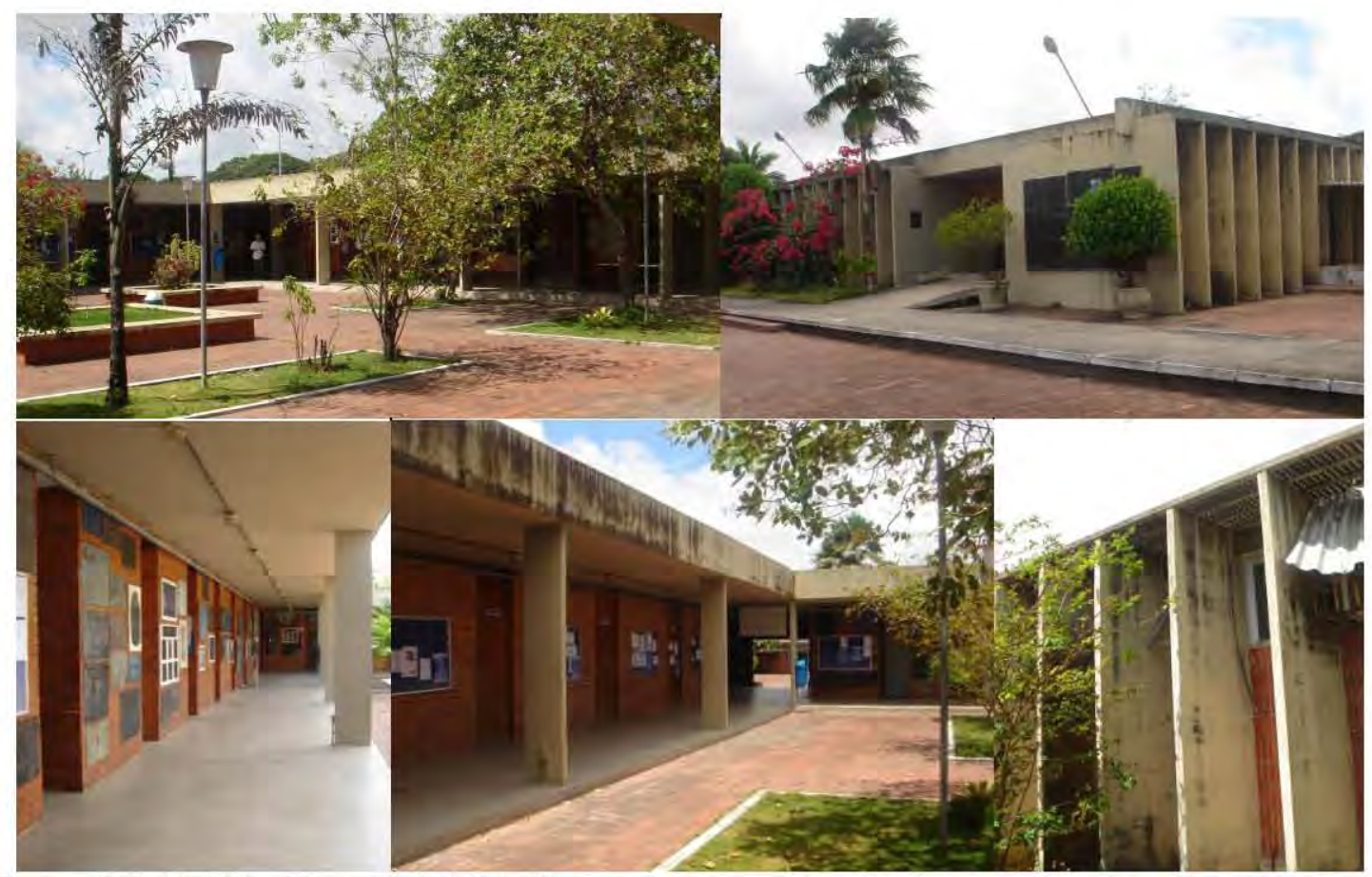

Figura 122: UFPB - Bloco Administrativo.

(Fonte: Acervo Magda Campêlo, 2009) 
- Galpão de Laboratórios de Hidráulica de Ensaios de Materiais e Pavilhão Mecânico

O projeto para o galpão de laboratórios de hidráulica de ensaios de materiais e pavilhão mecânico apresenta uma proposta direcionada para a solução funcional do programa que envolve questões eminentemente técnicas. As atividades a serem desenvolvidas requerem um layout específico das tubulações e equipamentos. A concepção sintética da planta aliada à modulação estrutural de $4 \mathrm{~m} \times 4 \mathrm{~m}$ evidencia o domínio do profissional sobre tais questões (ver projeto nas figuras $123,124 \mathrm{a}$ e $124 \mathrm{~b}$ ).

Os aspectos funcionais do programa não limitaram a criatividade do arquiteto que optou por um partido arquitetônico destacado pela solução formal e construtiva que utiliza a volumetria contida de "caixa" revestida por panos de tijolo cerâmico furado, paginados em função da modulação dos pilares de concreto aparente que marcam as fachadas. $O$ resultado confere a possibilidade de diferentes concepções da tipologia do galpão em estrutura metálica, comumente adotado nesse tipo de programa.

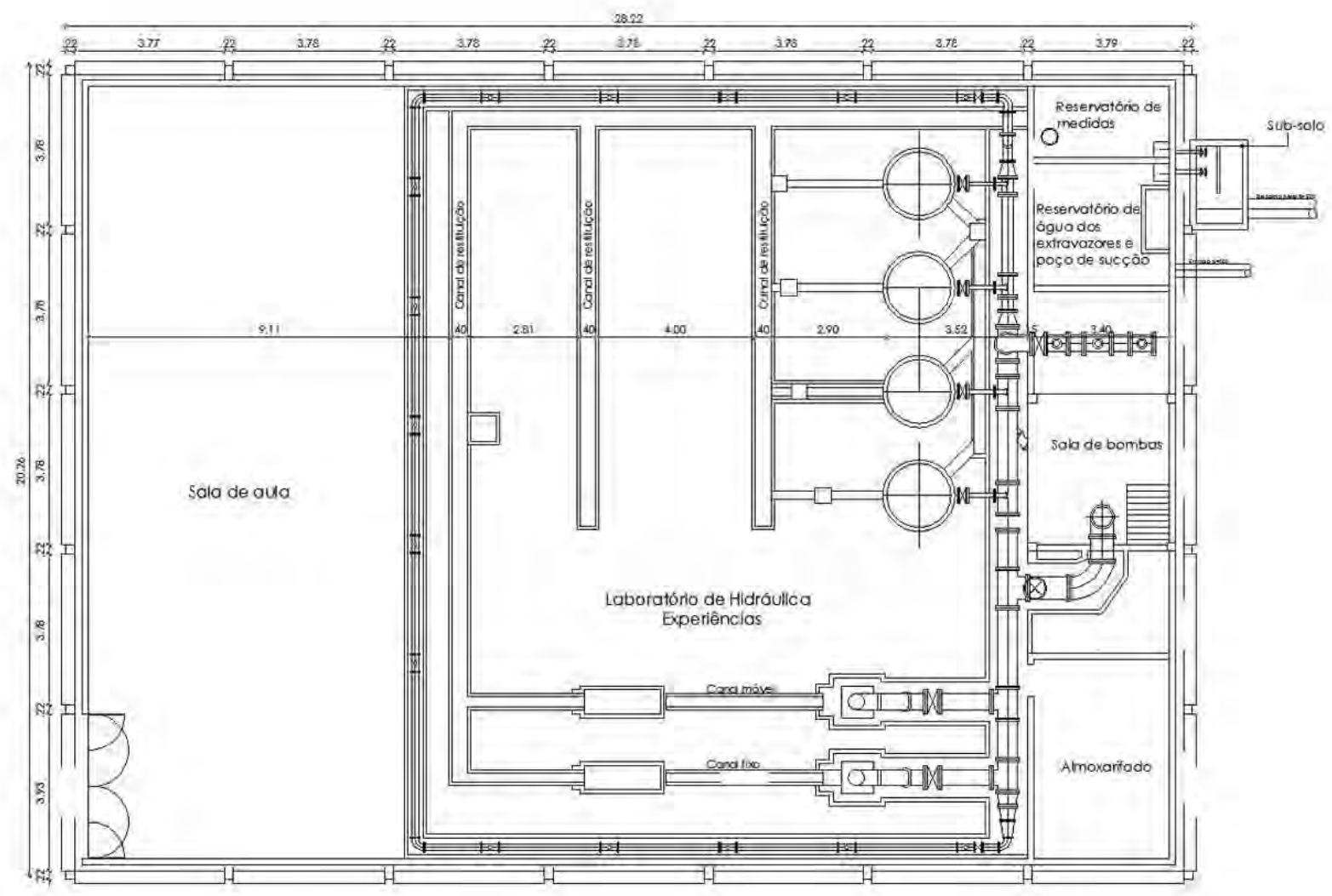

Planta baixa - lab. de hidráulica esc. $1 / 100$

Figura 123: UFPB - Laboratório de Hidráulica / Planta de Arquitetura. (Fonte: Acervo Prefeitura do Campus) 


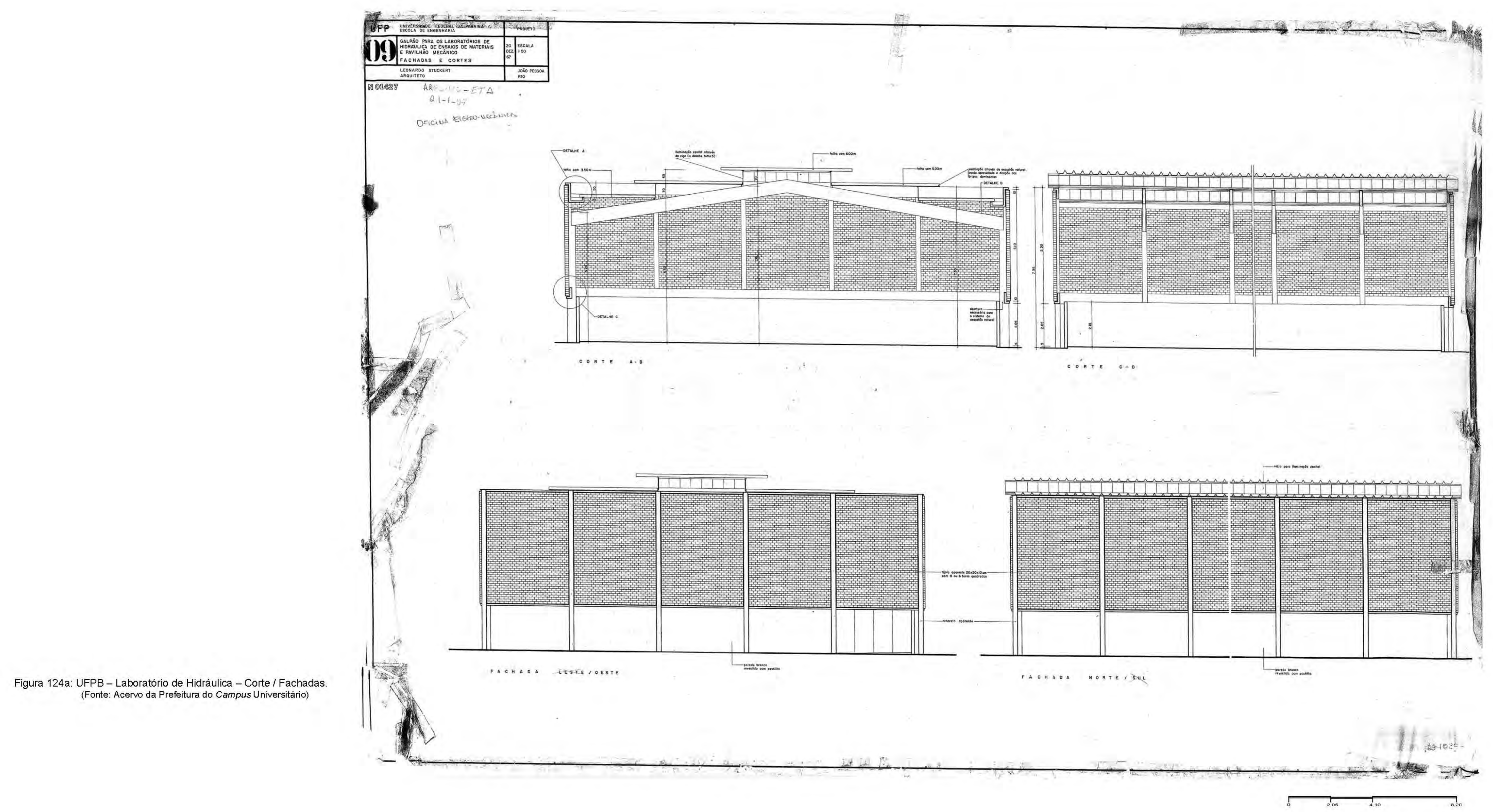




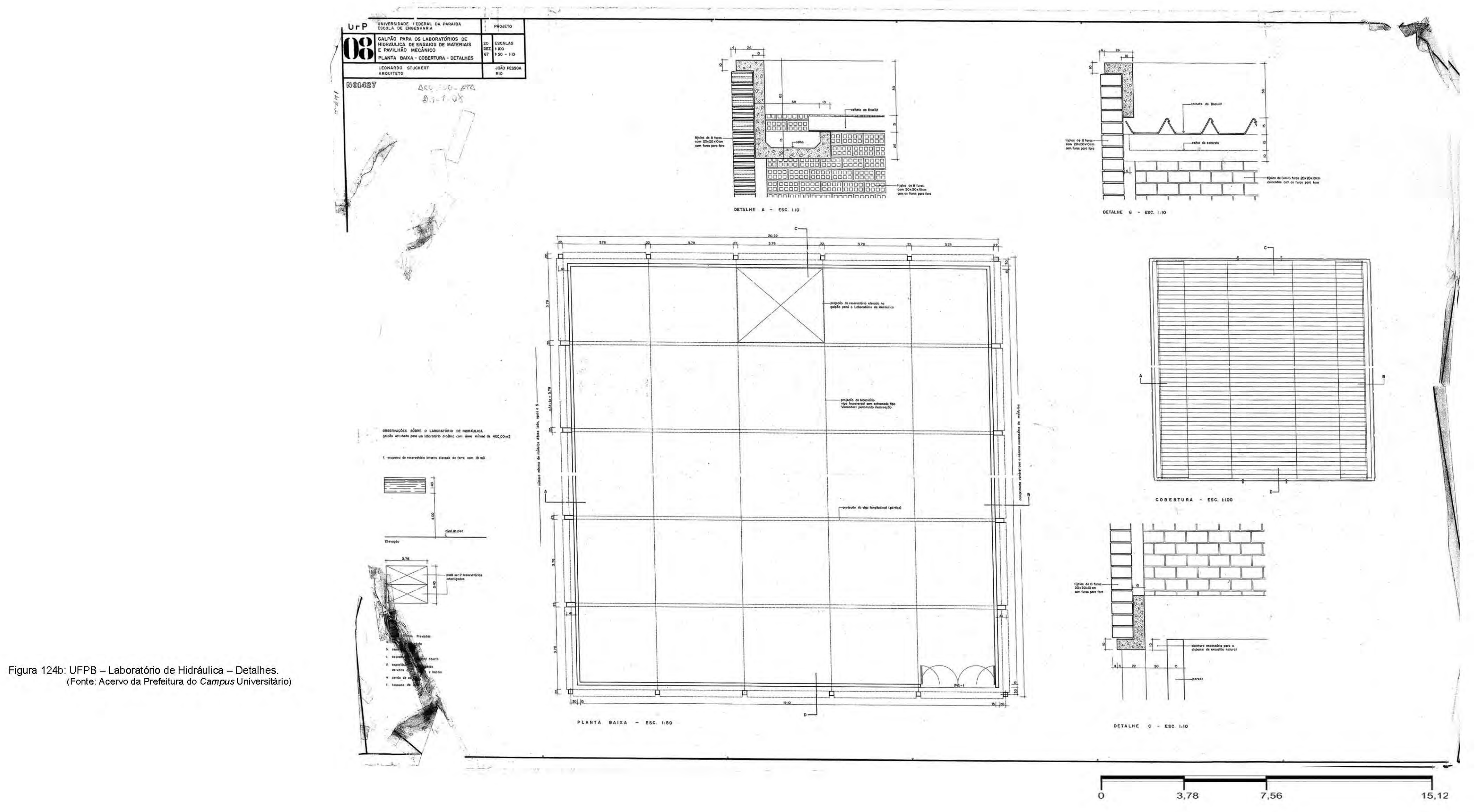


Ressalte-se ainda que a busca do conforto ambiental torna-se evidente pelo uso da cortina de tijolo cerâmico que desempenha a função de filtro solar e permite a ventilação cruzada no interior do edifício. Também é aplicado o conceito da exaustão por meio do efeito chaminé, por isso, a cobertura é dotada de abertura superior tipo lanternim, responsável ainda por proporcionar iluminação zenital. Corrobora a responsabilidade no detalhe construtivo parece ser uma constante na produção de Stuckert. É possível que as soluções não garantam temperaturas internas desejáveis ao longo de todo o dia, porém a preocupação em adequar as referências da arquitetura moderna às condições climáticas e tecnológicas da Paraíba, enseja uma produção de adaptação local (ver figura 125).

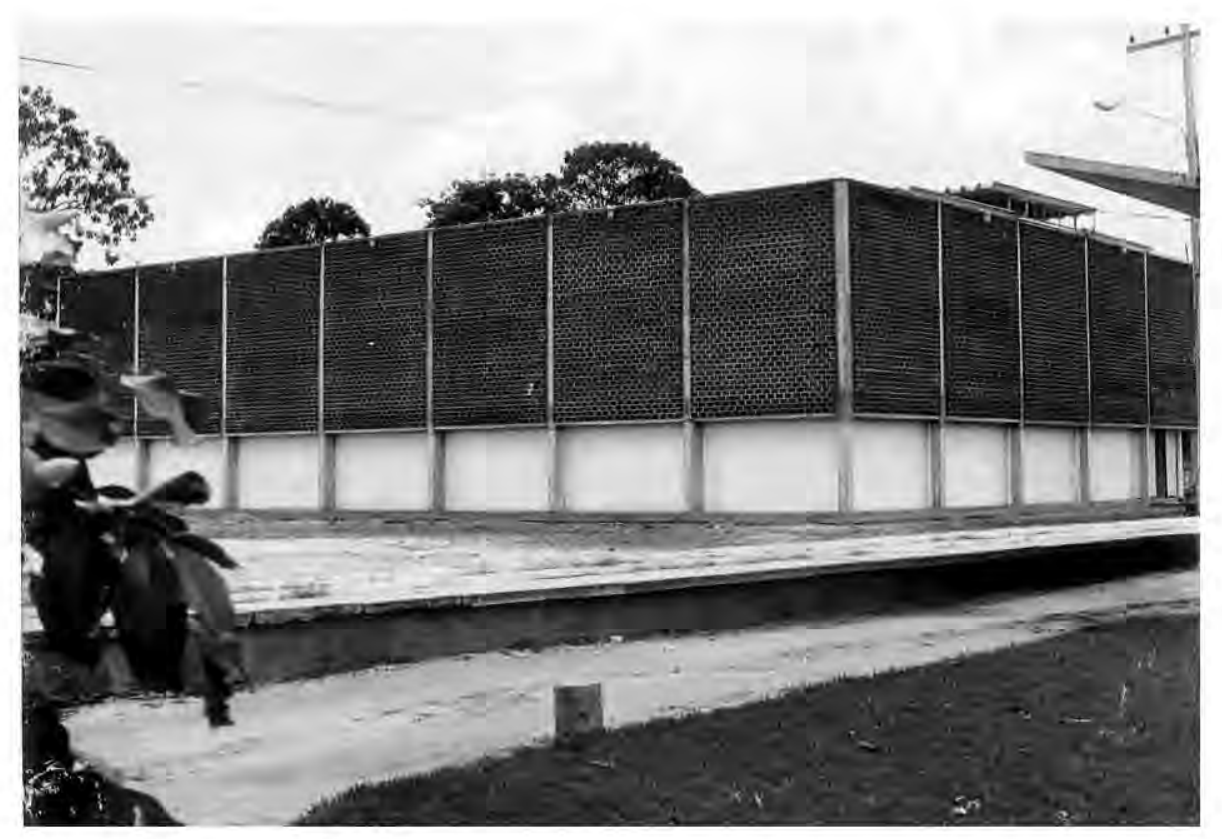

Figura 125: UFPB - Galpão para laboratórios de hidráulica de ensaios de materiais e pavilhão mecânico - década de 1960.

(Fonte: Acervo NDIHR/UFPB)

\section{- Hospital Universitário}

O hospital universitário está situado no limite oeste da gleba com acesso independente aos setores do campus. Qualificado como unidade de ensino e pesquisa, sua estrutura predial foi projetada para implantação dos serviços necessários tanto a um hospital-escola quanto a pacientes da rede pública.

Com uma área física de aproximadamente $44.000 \mathrm{~m}^{2}$, sua arquitetura se destaca pelo caráter funcionalista, cujo partido é o resultado da composição justaposta dos volumes funcionais: (1) a lâmina longitudinal de oito pavimentos superpostos, destinados às unidades de internação, que se unem por justaposição ao (2) prisma vertical da fachada oeste, 
responsável pelos fluxos de circulação vertical e que intercepta (3) o bloco horizontal tipo platô, destinado ao centro cirúrgico - em nível superior - e aos serviços de apoio e diagnóstico - nível térreo (ver figura 126).

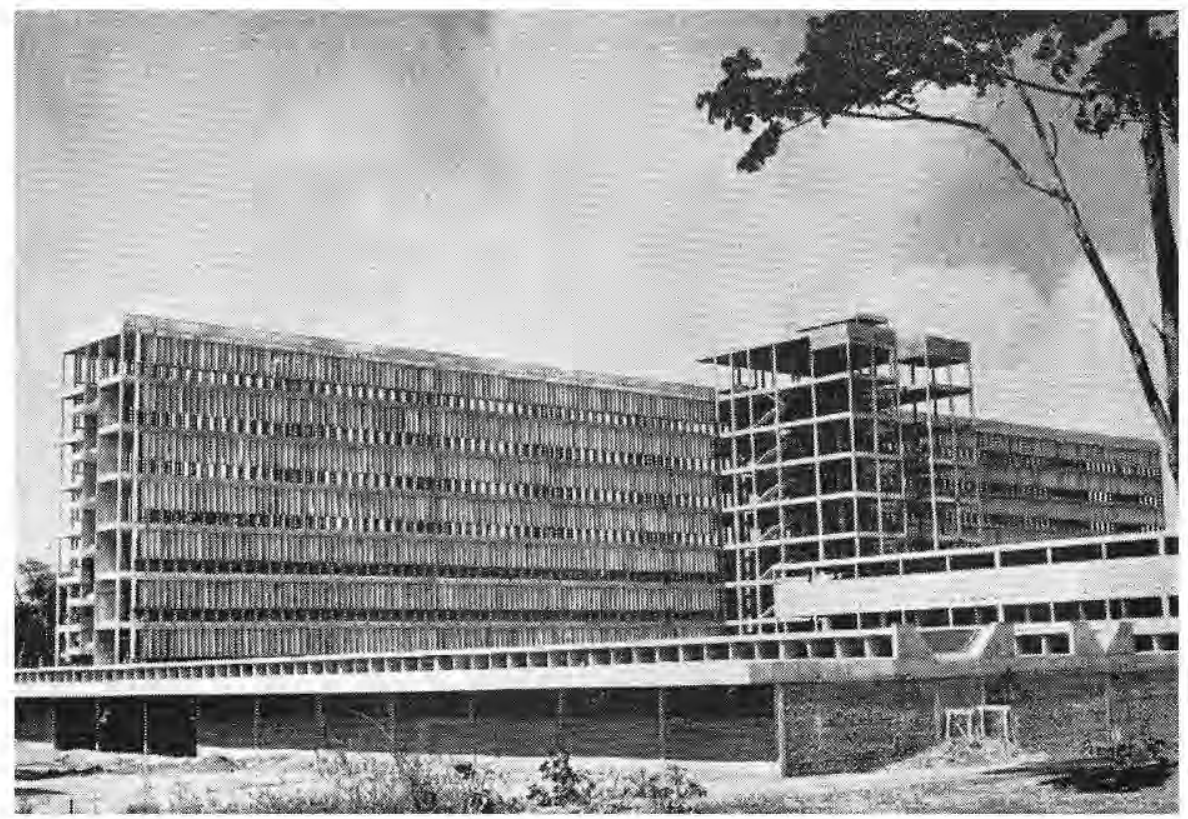

Figura 126: UFPB - Hospital Universitário Lauro Wanderley - início da década de 1970 O prédio, em construção, formava um conjunto com cerca de $44.000 \mathrm{~m}^{2}$, foi inaugurado oficialmente em 12 de fevereiro de 1980. (Fonte: MEIRA, 1971/1972, n.p.)

O bloco de internação, com dimensões de $10,75 \mathrm{~m} \times 151,20 \mathrm{~m}$, foi implantado com a fachada de acesso principal e maior dimensão voltada perpendicularmente à direção leste. A orientação adotada não é recomendada para o melhor aproveitamento dos ventos dominantes, que nesse caso favorece apenas os ambientes voltados para o leste e reduz as possibilidades do uso da ventilação cruzada. A configuração linear da planta livre organiza o programa com enfermarias de quatro leitos, ambientes de atendimento e ensino ao longo da circulação duplamente carregada (ver plantas de arquitetura nas figuras 127a e 127b) As extremidades do pavimento são providas com escadas de dois lances que se destacam do plano das fachadas norte e sul, dando volumetria à superfície plana de vedação. Os ambientes são divididos seguindo a modulação de $1,20 \mathrm{~m}$.

No centro do pavimento, a circulação é interceptada pela coluna de circulações verticais (escadas, elevadores de público e serviços) adequadamente diferenciadas das de público e serviço, que abastecem os pavimentos de internação. No $1^{\circ}$. Pavimento, o bloco das circulações faz a intermediação com o centro cirúrgico superposto sobre o platô técnico (provido de ambulatórios). A área de geometria retangular $(43,45 \mathrm{~m} \times 62,55 \mathrm{~m})$ apresenta 
Figura 127a: UFPB - Hospital Universitário - Planta Pavto. Tipo (Bloco AB). (Fonte: Acervo da Prefeitura do Campus Universitário)

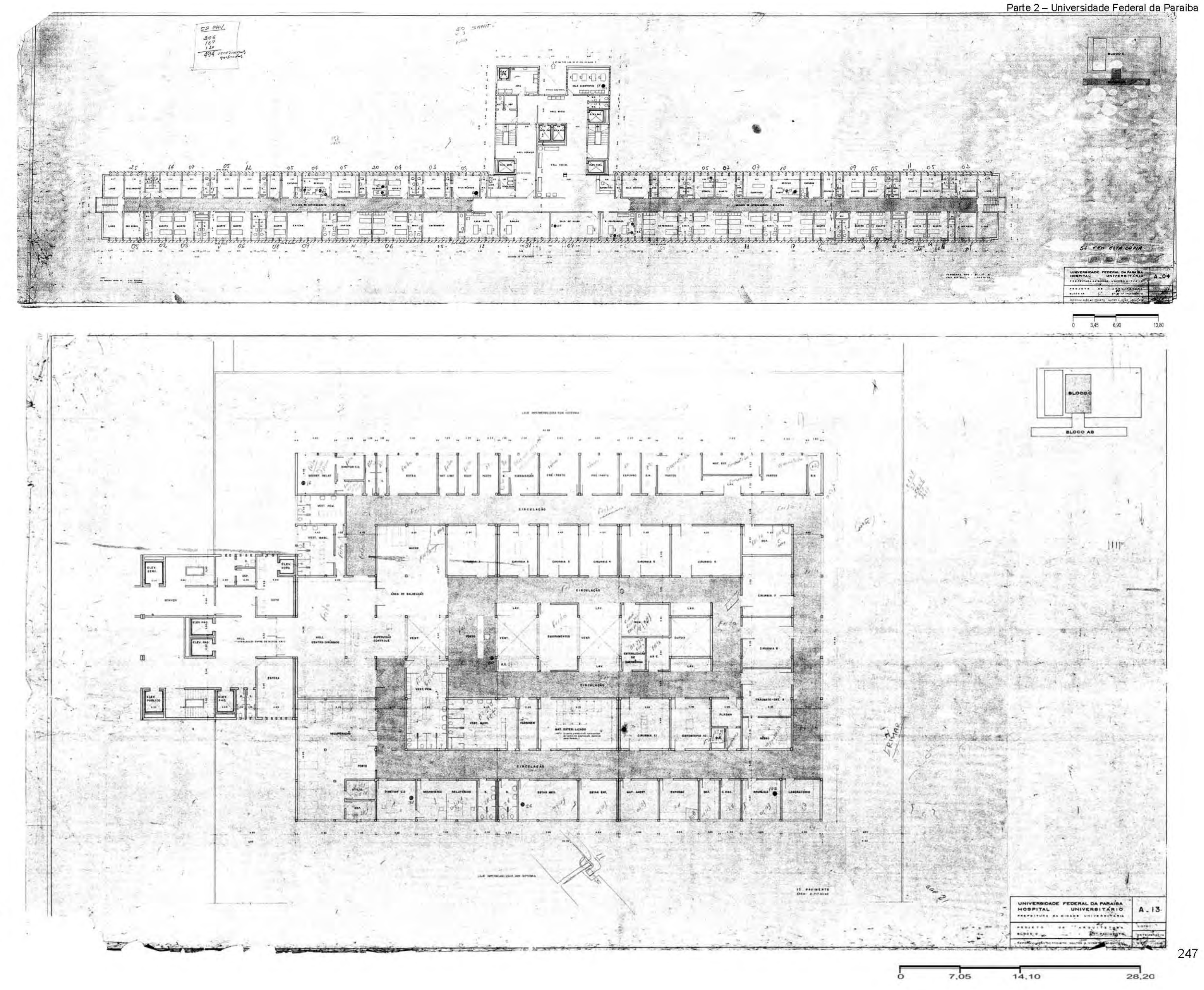


Parte 2 - Universidade Federal da Paraiba 
aberturas superiores na laje que desempenham a função de exaustão e iluminação naturais. A ausência das plantas do bloco técnico não nos permitiu uma análise da organização do programa ali instalado. A solução construtiva da planta livre e da iluminação indireta por meio da linha longitudinal de lanternim executado com laje inclinada e acabamento impermeabilizado. $O$ acesso aos ambulatórios é diferenciado e independente do bloco da internação, solução possibilitada pela extensão da gleba.

A preocupação com o conforto ambiental é manifestada pelo uso de brises verticais inclinados que eliminam parcialmente a radiação solar direta nos ambientes e direcionam a entrada dos ventos predominantes de sudeste, que associado ao emprego de esquadrias com venezianas horizontais articuláveis, incrementa o controle da radiação solar, embora tais soluções favoreçam somente a fachada leste.

O formalismo estético é uma consequência da razão funcional, ensejando uma linguagem referenciada na arquitetura moderna. A planta livre, a verdade estrutural, a adoção de brise soleil e a platibanda que enseja uma laje plana delineiam a tendência de uma arquitetura que assume como fato histórico passado a arquitetura moderna.

Trata-se de uma tipologia, que segundo Miquelin (1992, p. 59), pode ser chamada de mista. Essa abordagem do hospital como um edifício constituído por vários grupamentos de atividades e funções afins é um dos pilares básicos do arcabouço conceitual que dominou a arquitetura da saúde dos anos 1960 até a década de 1990 (MIQUELIN, 1992, p. 60)

\section{- Conjunto Humanístico}

O conjunto humanístico, de autoria do arquiteto Antônio José do Amaral e Silva, que fazia parte do escritório técnico da universidade, foi concebido para abrigar o CCHLA, CCSA e o Centro da Educação (CE). O projeto foi elaborado na primeira metade da década de 1970 e apresenta uma tipologia pavilhonar com blocos paralelos de um e dois pavimentos interligados por uma circulação central que atravessa o conjunto edificado, formando um percurso longitudinal de direção norte/sul (ver figuras 128 à 130).

Foram criados três tipos de blocos-padrões que se reproduzem ao longo da circulação. partido arquitetônico adotado procura concretizar a proposta do plano diretor (1972) que explicitava o princípio da expansibilidade. Com esse propósito a circulação foi concebida como elemento estruturante para o crescimento do conjunto, constituindo-se em vetor de expansão. O crescimento se daria por etapas, na medida em que cada bloco poderia ser construído em momentos distintos, conforme as demandas e/ou recursos financeiros, mantendo a unidade da composição. Da mesma forma, obedeceu à diretriz que preconizava uma composição de linhas predominantemente horizontais. 


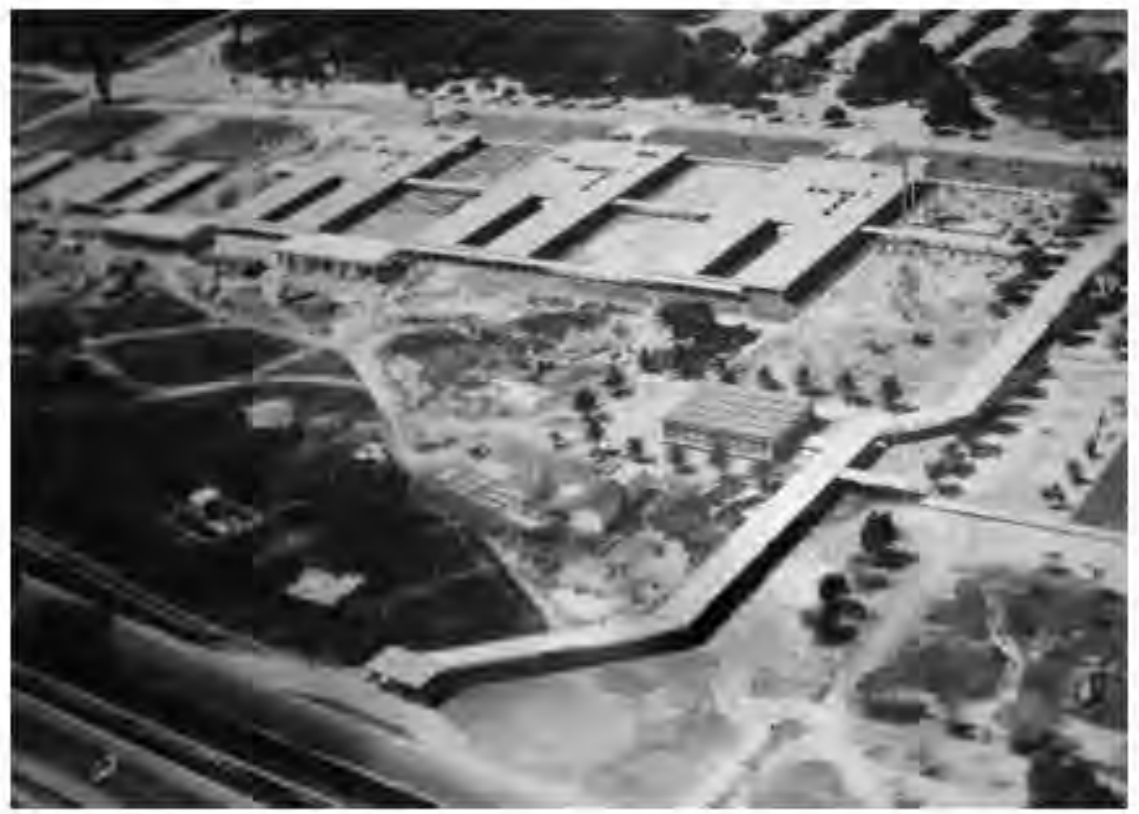

Figura 128: UFPB - Vista aérea do Conjunto Humanístico - Década de 1970. A passarela coberta margeia o setor, desempenhando o papel de via de pedestres.

(Fonte: Ac evo NDIHRJUFPB)

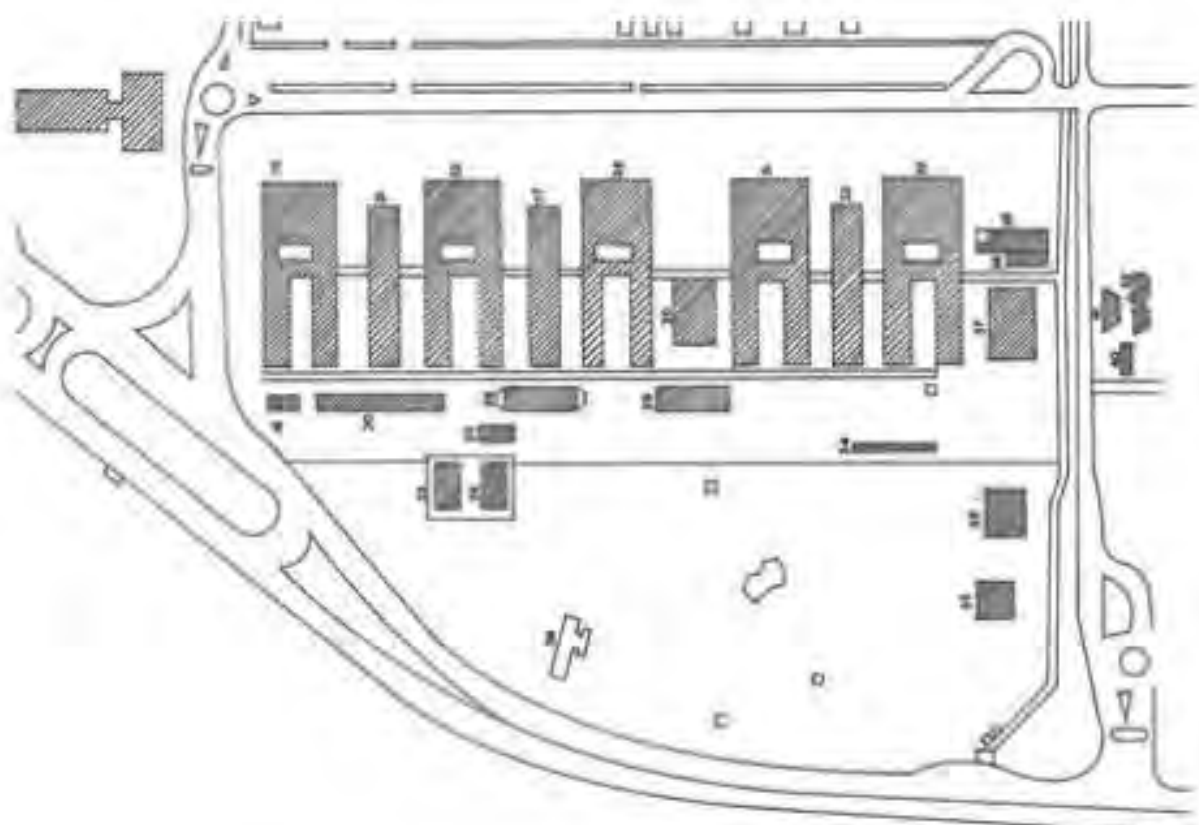

CA

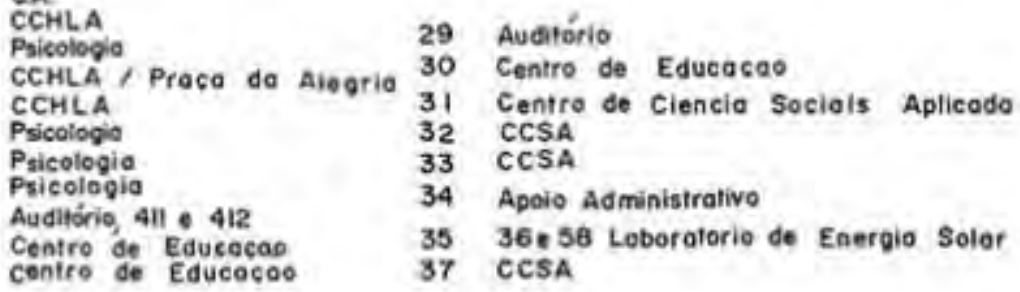

Figura 129: UFPB - Planta do Conjunto Humanístico.

(F onte: Acervo Prefeitura do Campus) 


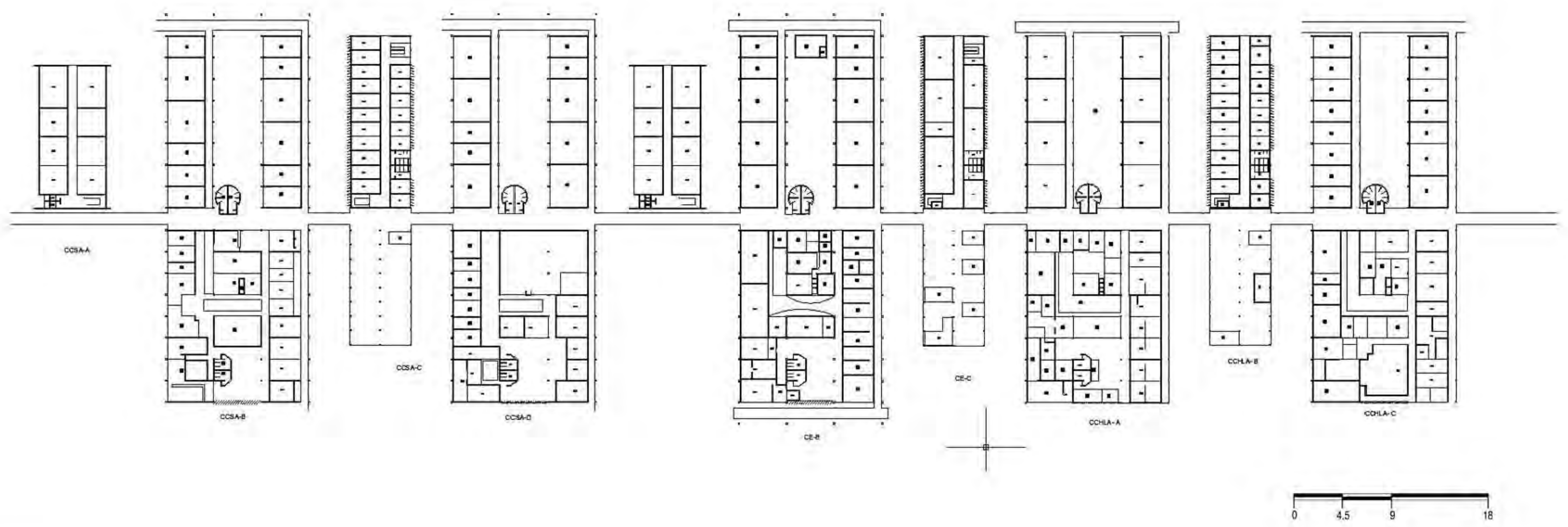


Parte 2 - Universidade Federal da Paraiba 
O programa arquitetônico foi distribuído segundo uma hierarquia de blocos didáticos, administrativos e de apoio ao corpo docente. Este último abriga no pavimento térreo uma área de convivência para todos os usuários que, incorporada à circulação central, se transforma em espaço integrador da comunidade daqueles centros.

A planta livre apresentou uma solução construtiva caracterizada pela estrutura de concreto aparente que se destaca das vedações - alvenarias revestidas por cerâmica com esquadrias de alumínio e vidro, e panos de combogós - e pela cobertura em telha de fibrocimento tipo Kalhetão, apoiadas em calhas impermeabilizadas e de concreto aparente, que seguem a modulação dos pilares de $4,50 \mathrm{~m}$, com descidas de águas pluviais aparentes, compondo as fachadas longitudinais. A percepção de uma laje plana é interrompida pela presença de um lanternim, no centro da cobertura como solução de exaustão do ar.

A busca pelo conforto ambiental fica evidente pelo uso de elementos verticais pré-fabricados de fibrocimento nas fachadas norte e sul, que, entretanto, pela configuração vertical não oferece proteção adequada à radiação solar direta, assim como o uso lanternim reforça as intenções de adequação as condições climáticas locais (ver figura 131). A composição homogênea, associada ao propósito funcional e de princípios econômicos, resulta, entretanto em um conjunto de sem referência para quem circula pela primeira vez e baixa expressividade arquitetônica (ver figura 132).

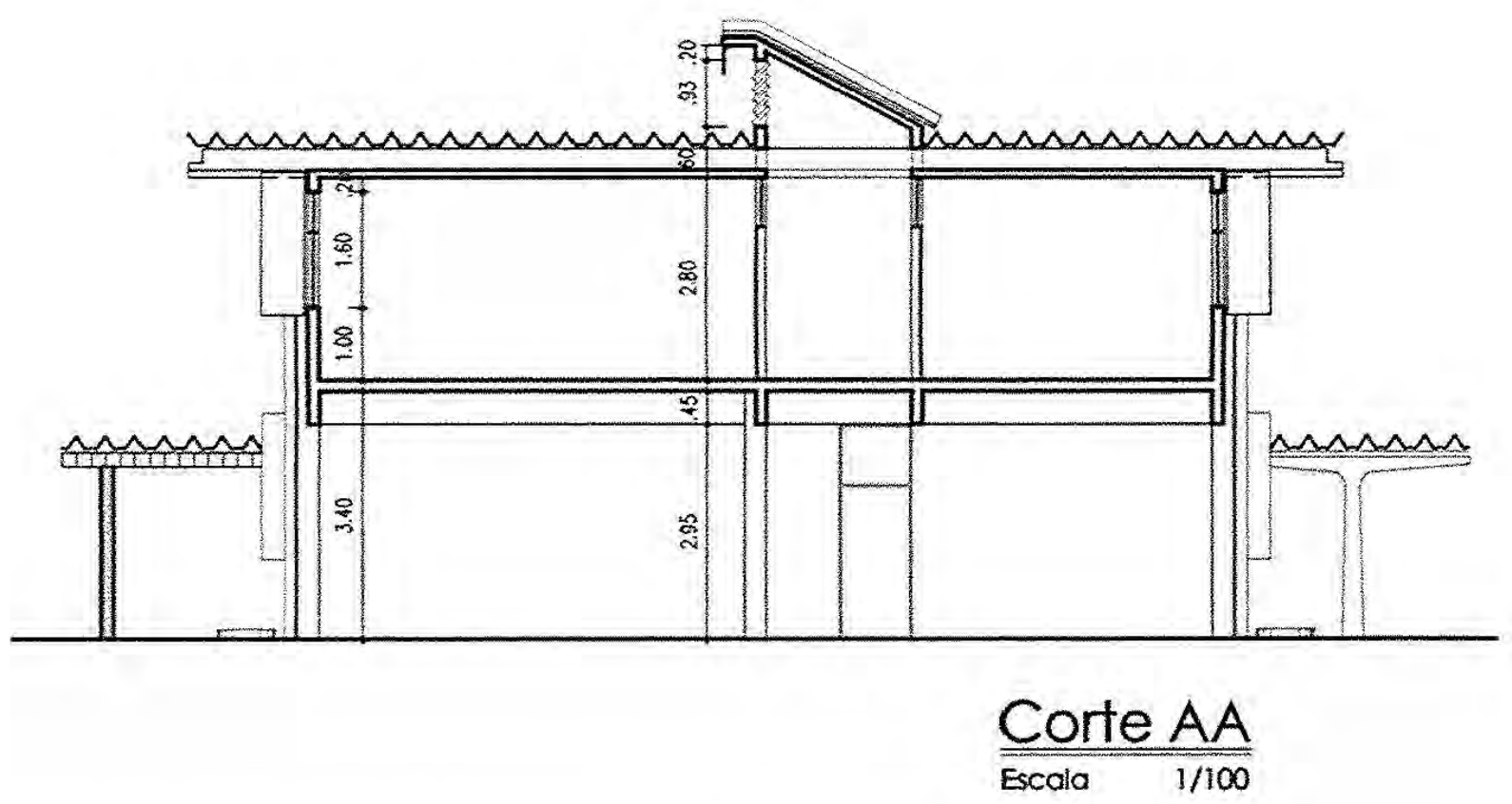

Figura 131: UFPB - Conjunto Humanístico / Corte Transversal.

A coberta de fibrocimento é apoiada no vigamento e o lanternim é adotado para exaustão do ar.

(Fonte: Acervo Prefeitura do Campus) 


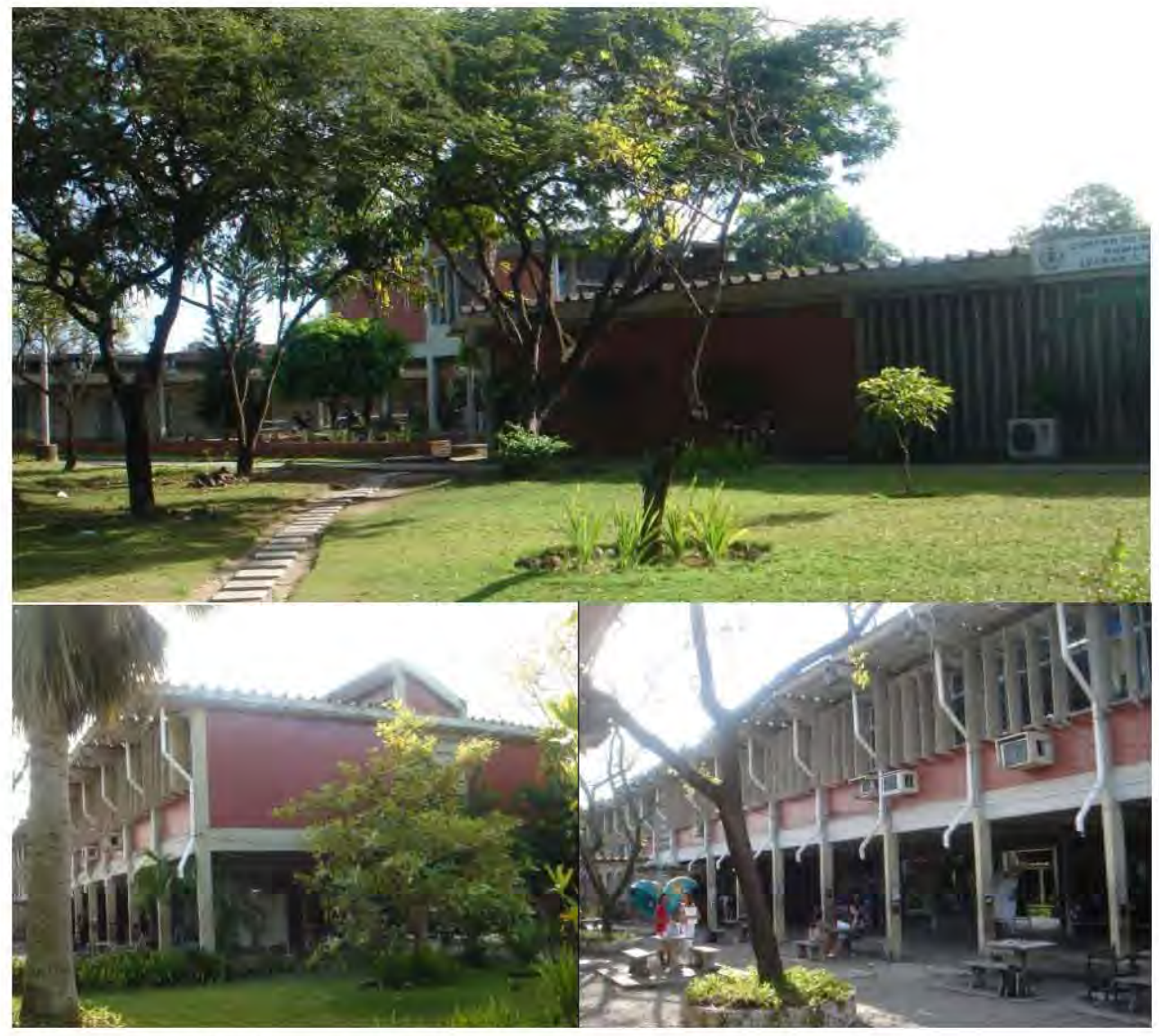

Figura 132: UFPB - Conjunto Humanístico - ano 2009.

(Fonte: Acervo Magda Campêlo, 2009)

\subsection{CONSIDERAÇÕES}

A formação do território da UFPB tem origem com sua fundação, em 1955, pela junção de escolas isoladas sob a égide de uma administração central. Começou a funcionar no ano seguinte como rede estadual de ensino, desenvolvendo as atividades em edifícios já existentes dispersos na malha urbana da cidade.

A proposta de um território autônomo e isolado do perímetro urbano, referenciado no modelo (ou estrutura espacial) de cidade universitária que vinha sendo adotado nas universidades brasileiras até a reforma 1968 foi uma idéia que se perseguiu. Mais do que uma organização acadêmico-administrativa, buscava-se, por meio do seu território, a identidade de uma instituição de feição moderna.

O governo estadual cedeu a Fazenda de São Rafael, uma gleba distante $4 \mathrm{~km}$ do centro urbano, na qual seria construída a infraestrutura física da universidade recém-criada. Sua 
localização compatibilizava-se com os planos de expansão do centro urbano, associando sua função de ensino à de vetor de crescimento da cidade.

As dificuldades financeiras para manutenção e operação dos cursos que a integravam eram obstáculos para a consolidação da Universidade da Paraíba. Diante de tais circunstâncias o intento de constituir seu território na Fazenda São Rafael foi substituído pelo de permanecer no centro da cidade, onde já havia uma infraestrutura urbana consolidada, que forneceria os serviços adequados a uma verdadeira cidade universitária. Tal concepção afastava-se do conceito que vinha sendo adotado pelas universidades brasileiras. $O$ episódio nos faz refletir que de fato a imagem da modernidade estava associada à conformação do seu território, que deveria transparecer o caráter moderno da instituição.

O agravamento da falta de recursos para operar a instituição encontrou no sistema de federalização a escapatória para superar uma situação que parecia ser irreversível. No bojo das universidades federalizadas no final do mandato presidencial de Juscelino Kubitschek, em 1960, a Universidade da Paraíba passou a ser vinculada ao MEC como Universidade Federal da Paraíba.

Em 1963, foi iniciada a construção da cidade universitária, tendo com base um plano piloto elaborado pelo arquiteto Leonardo Stuckert, o qual pelo repertório da sua produção referenciado na arquitetura moderna tornou-se representante do movimento moderno na Paraíba. As primeiras obras foram o conjunto da Escola de Engenharia, de autoria de Stuckert, que se destaca pela qualidade arquitetônica de inconteste linguagem moderna. $\mathrm{Na}$ direção contrária, a UFPB construía um edifício no centro da cidade destinado aos setores administrativos da universidade.

Mudanças no sistema acadêmico da UFPB, com a introdução de alguns institutos demandaram outras edificações, cujo processo construtivo apoiado nos princípios de economia resultou em exemplares de baixa expressividade plástica. São galpões com estrutura de concreto pré-moldado, vedações de alvenaria e divisórias de madeira e coberta com telha de fibrocimento.

O plano piloto não apresentava um traçado urbanístico a ser concretizado, mas tão somente a indicação de localização das primeiras unidades articuladas por uma via de circulação de veículos que se ligava à gleba. Em 1967, com a reestruturação da organização acadêmicoadministrativa baseada em institutos centrais e faculdades ou escolas, a UFPB demandou a consolidação de um plano diretor que orientasse o desenvolvimento físico do seu território. Foi então elaborado pelo arquiteto Mário Rosa Soares, do Escritório Técnico da USP, um plano diretor que definia a ocupação da gleba em todos os seus limites, organizando as 
unidades em setores funcionais que, articulados pelo sistema viário, resultavam no parcelamento da gleba em forma de superquadras. Entretanto, ele não foi implantado.

Em 1968, com a Reforma, a UFPB procedeu a uma nova reestruturação baseada em centros e departamentos. O território no modelo de campus universitário passou a ser a meta a ser concretizada. Com esse propósito, o MEC disponibilizou recursos financeiros para sua construção e a UFPB contratou o arquiteto paraense Alcyr Meira, que já prestava consultoria sobre planejamento de campus universitário, para elaborar o plano diretor para o território da reforma universitária. Meira projetou, em 1971, um plano baseado no conceito do zoneamento funcional e da rígida separação das vias de circulação de veículos e pedestres. Orientou a formulação de uma lei de crescimento de caráter orgânico que transformasse a base física do campus em um território integrador das atividades desenvolvidas. $O$ traçado urbanístico ganhou destaque pela presença do sistema viário em forma de anel circundante, sem possibilidades de outras vias atravessarem o campus. As características dos edifícios deveriam seguir uma tipologia regida pelos conceitos de flexibilidade, expansibilidade e economia.

A mudança de gestão na administração superior acarretou a formulação de outro plano, elaborado por uma equipe multidisciplinar de profissionais ligados à UFPB. O plano diretor que passou a ter vigência na universidade compilou conceitos e princípios do plano de Meira, acrescentando o elemento estruturador da integração, que seria a construção de uma grande passarela que atravessaria o campus articulando as unidades e, ao mesmo tempo, promoveria a convivência da comunidade universitária. Manteve a hierarquia das vias de circulação, que, porém não foi respeitada e já no final dos anos 1970, a universidade implantou vias de veículos que interceptam toda área do campus.

O campus, estratégico na implantação da nova organização acadêmico-administrativa, não se espacializou como território integrador, porém as marcas do traçado urbanístico são o testemunho de uma geração de tipologias espaciais que nasceram da Reforma Universitária de 1968.

Encontra-se atualmente cercado por bairros residenciais e a malha viária da cidade se integra com a via perimetral do campus. Funcionando como uma zona de função especializada, o cercamento dos seus limites configura um enclave na organização espacial da cidade. 


\section{UNIVERSIDADE FEDERAL DO RIO GRANDE DO NORTE (UFRN)}

A Universidade Federal do Rio Grande do Norte é uma instituiçầo de caráter público, arganizada sob a forma de autarquia de regime especial, vinculada ao Ministério da Educaçẳo e com sede na cidade de Natal, capital do Rio Grande do Norte. Atua em varias cidades do Estado com a seguinte estrutura: a Camous Universitário Lagoa Nova, onde fica a sua sede, e o Centro de ciências da Saúde, no bairro Petrópolis, ambos em Natal, o Centro Regional de Ensino Superior do Seridó (CERES), localizado nos municípios de Caicó e Currais Novos, o Centro Regional de Ensino Superior do Trairi, em Santa Criz, o Centro de Ensino Superior do Agreste, em Nova Cruz, o Núcleo de Ensino Superior de Macau, na cidade de mesmo nome, o Colégio Agrícola de Jundiaí (EJA), em Macaíba, e unidades dispersas tais como os museus, hospitais e clínicas (ver figura 133).

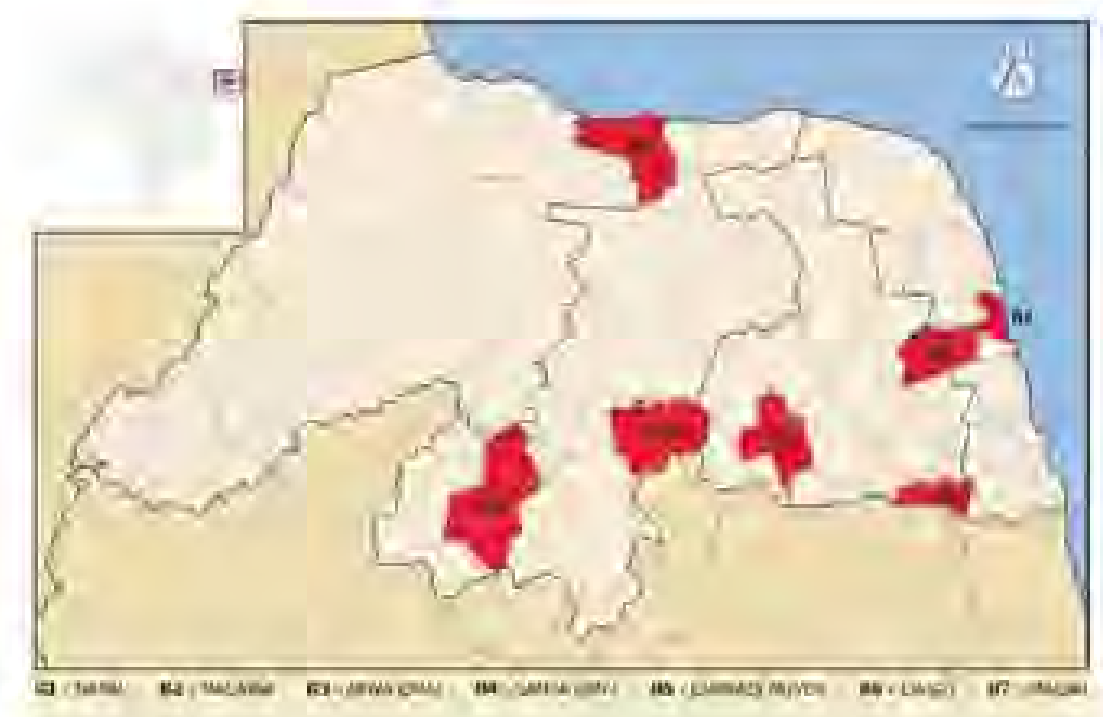

Figura 133:UFRN - Mapa do Rio Grande do Norte.

Localizaçẫo dos municipios que sediam a UIFRN.

(F onte: disponivel

em: Khtt \%/ptinkipedia.orgkiki/Anexo:Lista_de_munic\%C3\%ADpios_d

o_Rio_Grande_do_Norte $>$ Acesso em: 21 nov.2011).

\subsection{CRIAÇÃO DA UFRN}

Q nascimento da Universidade Federal do Rio Grande do Norte remonta ao surgimento das primeiras unidades de ensino superior, em meados do século $X X$. A historiografia da Instituiçẫo (GARCIA, 2008, p.26; NEWTON JúNIOR, 2008, p.17) destaca, entretanto, como 
experiência pioneira no Estado a criação, em 1923, da Escola de Pharmacia de Natal ${ }^{52}$, embora de curta duração, funcionando por um período de três anos. Garcia $(2008$, p.27) acrescenta que em $1^{\circ}$ de dezembro de 1923 o governo do Estado sancionou a Lei $n^{\circ} .570$, instituindo o Curso de Odontologia anexo àquela unidade, que passou a se chamar Escola de Pharmacia e Odontologia de Natal. O curso de Odontologia, no entanto, não chegou a funcionar e o de Farmácia logrou apenas a conclusão da primeira turma, em novembro de 1925 , com apenas dois formandos. Com esse resultado, a Escola foi desativada.

O Estado somente voltou a sediar outros cursos superiores na década de 1940 . historiador Itamar de Souza (1984apud NEWTON JÚNIOR, 2008) relaciona o contexto do pós-Segunda Guerra Mundial como fator determinante para a criação das escolas de nível superior. $O$ envolvimento das cidades de Natal e Parnamirim naquele conflito serviu para criar, na consciência das elites natalenses, de que somente as regiões com expansão no setor de ensino superior tinham registrado desenvolvimento na sua estrutura socioeconômica. Nas palavras do historiador,

A presença de oficiais brasileiros e norte-americanos, especializados em diversos ramos da ciência e da tecnologia, possibilitou que as elites de Natal percebessem o atraso intelectual em que viviam (SOUZA, 1984, p. 33-34 apud NEWTON JÚNIOR, 2008, p. 19).

Em 1941, foi instalado o Instituto Filosófico São João Bosco, voltado para a formação dos clérigos salesianos em Filosofia, Ciências e Letras, e pouco depois, a população de Natal vê surgir, a partir de 1945, uma série de cursos de nível superior em escolas e faculdades isoladas (NEWTON JÚNIOR, 2008, p.19).

Nesse ano, a Escola de Serviço Social foi instituída pela necessidade de se formar técnicos para atuarem na complexidade dos problemas sociais que assolavam o Estado, desencadeados pela aglomeração de pessoas trazidas pela Segunda Grande Guerra, e acrescidos dos originados pela seca que se alastrava pelo sertão (GARCIA, 2008, p.53).

Dois anos depois, foi fundada a Faculdade de Farmácia e Odontologia ${ }^{53}$, que passou a funcionar em 1948 por autorização do Governo Federal, Garcia (2008, p.53) ressalta que a nova Instituição foi o marco inicial do desenvolvimento do ensino superior do Estado, pois serviu de fonte motivadora para estimular a criação de outras unidades de ensino superior, que culminou como estabelecimento da Universidade do Rio Grande do Norte. Ressalvas a parte, é inconteste que a nova Faculdade recebeu forte apoio da comunidade natalense,

\footnotetext{
${ }^{52}$ Garcia (2008, p.26) esclarece que a Farmácia foi o primeiro curso superior do Estado, existente desde 02 de dezembro de 1920 , criado pela Lei Estadual $n^{\circ} .497$, e autorizado a funcionar pelo Decreto $n^{\circ} .192$, de 08 de janeiro de 1923.

${ }_{53}$ Criada pelo Decreto Estadual ${ }^{\circ} .682$, de 3 de fevereiro de 1947 , recebeu autorização para funcionar pelo Decreto Federal $n^{0}$. 25.973, em 6 de dezembro de 1948. Porém somente em março de 1949, foram iniciadas as aulas dos dois cursos (GARCIA, 2008, p.32-33).
} 
inclusive de outras instituições similares tais como a Faculdade de Odontologia do Ceará, que chegou a oferecer colaboração para sua organização e instalação ${ }^{54}$.

Sua relevância pode ser evidenciada pelos esforços empreendidos para adquirir suas instalações. A questão do espaço físico foi considerada prioritária. Num primeiro momento, os cursos funcionaram no prédio do antigo Colégio Atheneu (ver figura 134), após uma reforma de grandes proporções, mas logo se constatou sua inviabilidade para adaptação ao programa de necessidades dos cursos (ver figura 135). Houve muito empenho no sentido de se conseguir a construção de um novo prédio, chegando-se a elaborar o projeto de um edifício de dez pavimentos, que, no entanto, não chegou a ser concretizado por falta de recursos orçamentários (ver figura 136).Posteriormente, com o desdobramento da Faculdade de Farmácia e Odontologia, uma nova edificação foi erguida na década de 1960 para abrigar o curso de Odontologia, até hoje um importante exemplar da arquitetura moderna de Natal, conforme será referenciado na seção seguinte do presente capítulo.

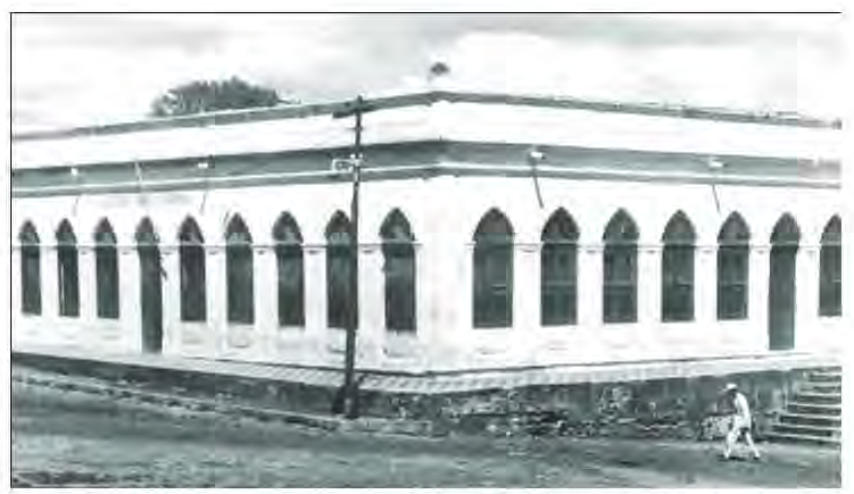

Figura 134:UFRN - Prédio do Colégio Atheneu.

Deu lugar às instalações da Faculdade de Farmácia e Odontologia.

(Fonte: Acervo UFRN apud TRIGUEIRO, 2008, p.54).

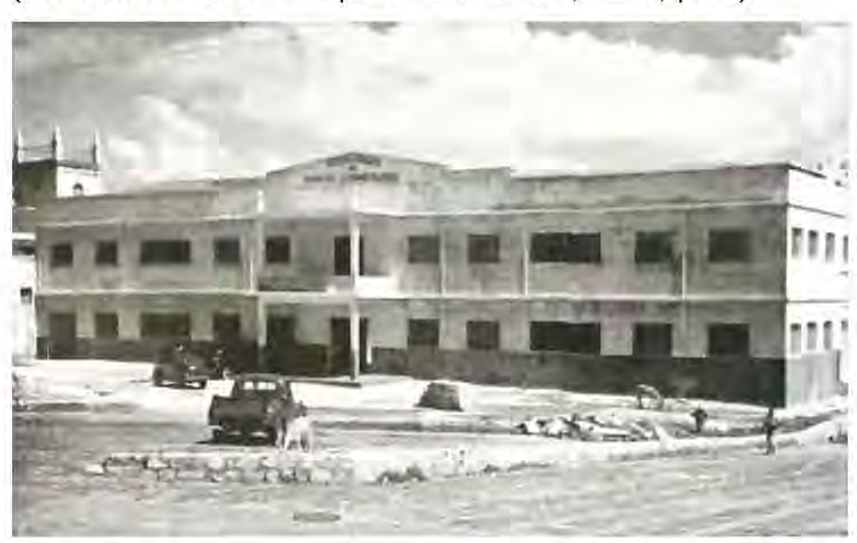

Figura 135:UFRN - Prédio reformado do antigo Atheneu.

A construção iniciada no primeiro semestre de 1954 incorporou um andar superior

(Fonte: GARCIA, 2008, p.51, edição nossa).

\footnotetext{
${ }^{54} \mathrm{~A}$ manifestação se deu por meio do então diretor da Faculdade de Odontologia do Ceará, Dr. Raimundo Gomes (GARCIA, 2008, p.32)
} 


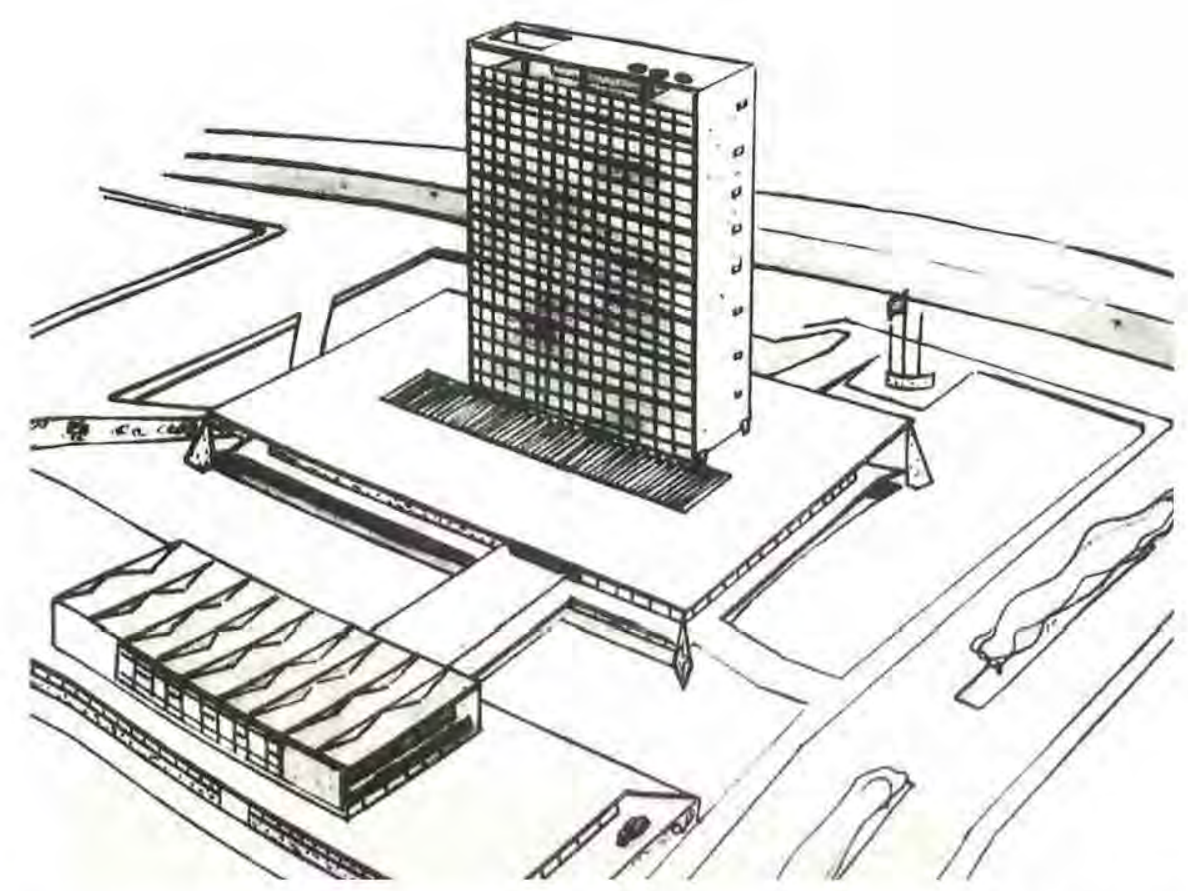

Figura 136:UFRN - Conjunto arquitetônico destinado à Faculdade de Farmácia e Odontologia.

Complexo projetado para ser construído na Praça Thomaz de Araújo, centro urbano de Natal (não foi identificada a autoria do projeto). $\bigcirc$ partido arquitetônico de volumes funcionais diferenciados e emoldurados pelas áreas livres da quadra revela as referências da arquitetura modernista brasileira.

(Fonte: GARCIA, 2008, p.1)

Os cursos vocacionais isolados que se seguiram sinalizam, em nível local, o que já vinha ocorrendo nacionalmente. Em 1949, foi fundada a Faculdade de Direito, mas efetivamente instalada e autorizada em 1954.

Em 1955, foi criada a Faculdade de Medicina pela Sociedade de Assistência Hospitalar, que incorporou o Hospital Miguel Couto, hoje Hospital Universitário Onofre Lopes, como sendo o campo das práticas. Posteriormente, com o estabelecimento da Universidade do Rio Grande do Norte (1958) foi por ela encampada, passando a denominar-se "Hospital das Clínicas" e assumiu a personalidade de hospital-escola, integrando-se à UFRN. Ao conjunto foi também incorporada a Maternidade-Escola Januário Cicco.

No mesmo ano (1955) foi também criada a Faculdade de Filosofia, fundada pela Associação de Professores do Rio Grande do Norte, que depois passou a ser denominada Faculdade de Filosofia, Ciências e Letras de Natal, quando em novembro de 1963 foi encampada pela Fundação José Augusto, órgão do governo estadual (GARCIA, 2008, p.54).

Em 1957, foi a vez da Escola de Engenharia, embora licenciada somente em 1959, quando a Universidade do Rio Grande do Norte já havia sido criada. Foi o governo estadual que, 
preocupado com o pequeno número de engenheiros no Estado, mobilizou-se para que fosse estabelecida uma escola de engenharia.

Também no ano de 1957, foi fundada a Faculdade de Ciências Econômicas, Contábeis e Atuárias uma instituição particular de ensino, que foi incorporada à UFRN em 1970.

Com a expansão do ensino superior, começou a surgir o ambiente favorável à abertura de uma universidade no Estado em função do número de instituições já existentes. As esperanças de concretização desse projeto, acalentado por membros da intelectualidade loca $\left.\right|^{55}$,tornou-se realidade com a sanção da Lei Estadual $n^{\circ} .2 .307$, de 25 de junho de 1958, criando a Universidade do Rio Grande do Norte. Foi constituída pela Faculdade de Farmácia e Odontologia, Faculdade de Direito, Faculdade de Medicina, Faculdade de Filosofia e a Escola de Serviço Social.

Dois anos depois, no mesmo passo das irmãs do Nordeste - Universidade de Alagoas e Universidade da Paraíba - foi federalizada no final do governo de Juscelino Kubitschek que sancionou a Lei $n^{\circ} .3 .849$ de 21 de dezembro de 1960, passando a se chamar Universidade Federal do Rio Grande do Norte. A Instituição era composta pela Faculdade de Medicina, Faculdade de Farmácia, Faculdade de Odontologia, Faculdade de Direito e Escola de Engenharia. Posteriormente, no período de 1966 a 1972, foram encampadas a Escola de Serviço Social, a Faculdade de Filosofia, Ciências e Letras, a Faculdade de Sociologia e Política e a Faculdade de Jornalismo Eloy de Souza.

Merece menção a instalação, em 1966, do Centro Rural Universitário de Treinamento e Ação Comunitária (CRUTAC), criado pela UFRN (ver figura 137). Tratava-se de um programa pioneiro no Brasil e que consistia no treinamento, nas áreas rurais, de estudantes concluintes dos mais diversos cursos da Universidade, com a consequente prestação de serviços às populações carentes do interior (NEWTON JÚNIOR, 2008, p27). O programa teve Figura 137: UFRN - Unidade do CRUTAC no Rio Grande do repercussão nacional, levando à criação de Norte - década de 1960. CRUTAC sem várias universidades brasileiras,

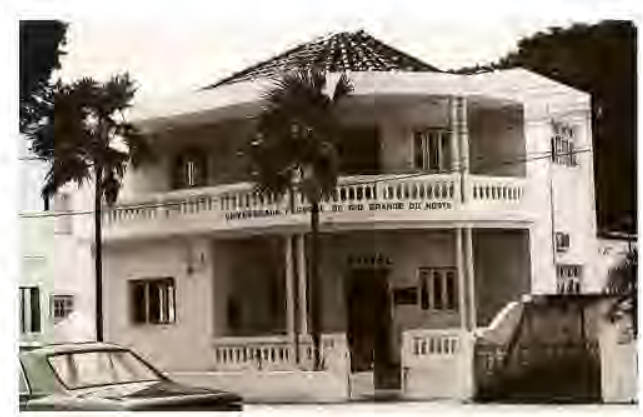
incluindo as instituições do Nordeste investigadas (Fonte: Acervo AGECOM/ UFRN) na presente pesquisa.

\footnotetext{
${ }^{55} \mathrm{~A}$ atuação do grande escritor natalense Luis da Câmara Cascudo, por sua notória atuação no desenvolvimento da cultura do Rio Grande do Norte, tendo inclusive liderado um movimento para criação de uma Universidade Popular em 1948, é exaltada por Newton Júnior $(2008$, p. 20).
} 
Em 1968, com a Reforma Universitária, um novo cenário tomou curso e a UFRN deu início ao processo de reorganização, marcando o fim das faculdades com o agrupamento de diversos departamentos que, conforme a natureza dos cursos e das disciplinas foi organizada em centros. A partir de então, a Universidade Federal do Rio Grande do Norte passou a se estruturar e se consolidar como instituição de ensino superior no novo modelo universitário implantado pelo governo militar.

\subsection{A CONSTRUÇÃO DO TERRITÓRIO: primeiras instalações - o modelo de edifícios isolados}

Suas atividades deram-se preliminarmente em prédios existentes, situados em área urbana, porém em diferentes pontos da cidade (SOUZA, 1999, p.197). Tratava-se de construções, que já sediavam as faculdades isoladas ou que foram doadas pelo governo do Estado, conforme se constata nessa passagem registrada por Garcia (2008) sobre a criação da Universidade do Rio Grande do Norte:

Coube ao Reitor a missão de instalar tanto a administração da Reitoria, em um prédio doado à Universidade pelo Governo do Estado, localizado na Avenida Hermes da Fonseca (hoje, sede do Comando Naval), como todos os seus anexos: a Secretaria, o Conselho Universitário, as Divisões de Pessoal, de Contabilidade e Finanças, Material e o Departamento de Obras Garcia (2008, p. 56, grifo nosso).

Na década de 1960, verificou-se uma expansão do patrimônio edificado da Universidade, que, embora inserido na malha urbana da cidade, não chegou a compor um espaço especializado voltado para o ensino superior. A ocupação em diferentes endereços e áreas revela uma estruturação espacial do ensino superior brasileiro, caracterizado por edificações urbanas dispersas, constituindo o modelo espacial de edifício isolado.

A arquiteta Edja Trigueiro, Professora do Departamento de Arquitetura da UFRN, registrou em publicações de sua autoria (TRIGUEIRO et al, 2010; TRIGUEIRO, 2008; TRIGUEIRO, 2005) a trajetória da arquitetura dos edifícios que abrigaram ou abrigam as atividades da UFRN. Tomando como referência as unidades universitárias, a professora desenvolve um panorama histórico da arquitetura do século XX no Rio Grande do Norte, revelando como as linguagens estilísticas nacionais e internacionais se manifestaram, em episódios de recriação e adaptação (TRIGUEIRO, 2008, p.47). Os trabalhos, que se constituem num rico acervo da produção arquitetônica da Instituição, serão por nós referenciados nesta seção, buscando introduzir nossas análises com foco na caracterização da formação do território universitário. 
O prédio da antiga Faculdade de Direito, inaugurado em 1908 para abrigar originalmente o Grupo Escolar Augusto Severo, sediou posteriormente outros estabelecimentos de ensino até ser adquirido para a implantação daquele curso. Constitui-se em importante exemplar da arquitetura eclética de Natal, tendo sido tombado em nível estadual no ano de 1991. Sua estrutura estilística é claramente identificável com o ecletismo da virada do século XIX para ○ XX, onde elementos de ascendências distintas são misturados.

\begin{abstract}
$\mathrm{Na}$ caixa mural, motivos ornamentais de inspiração romântica e vaga influência Artnouveau expressam-se através de materiais como o ferro forjado e fundido, o vidro e o estuque, e combinam-se a maneiras compositivas derivadas de um neoclassicismo residual, herdado de meados do século XIX (TRIGUEIRO, 2008, p.49).
\end{abstract}

Trigueiro (2008, p.49) destaca a relação do edifício com a rua, que evidencia a disseminação internacional do conceito de cidade-jardim, o qual assinalou uma fase ímpar nas relações entre espaço público e espaço privado no Brasil: quando a casa se abre para fora, por meio dos seus terraços e jardins, que embora protegidos por delicados gradis, permitiam sua exposição à rua, contribuindo para a qualidade urbana (ver figura 138).

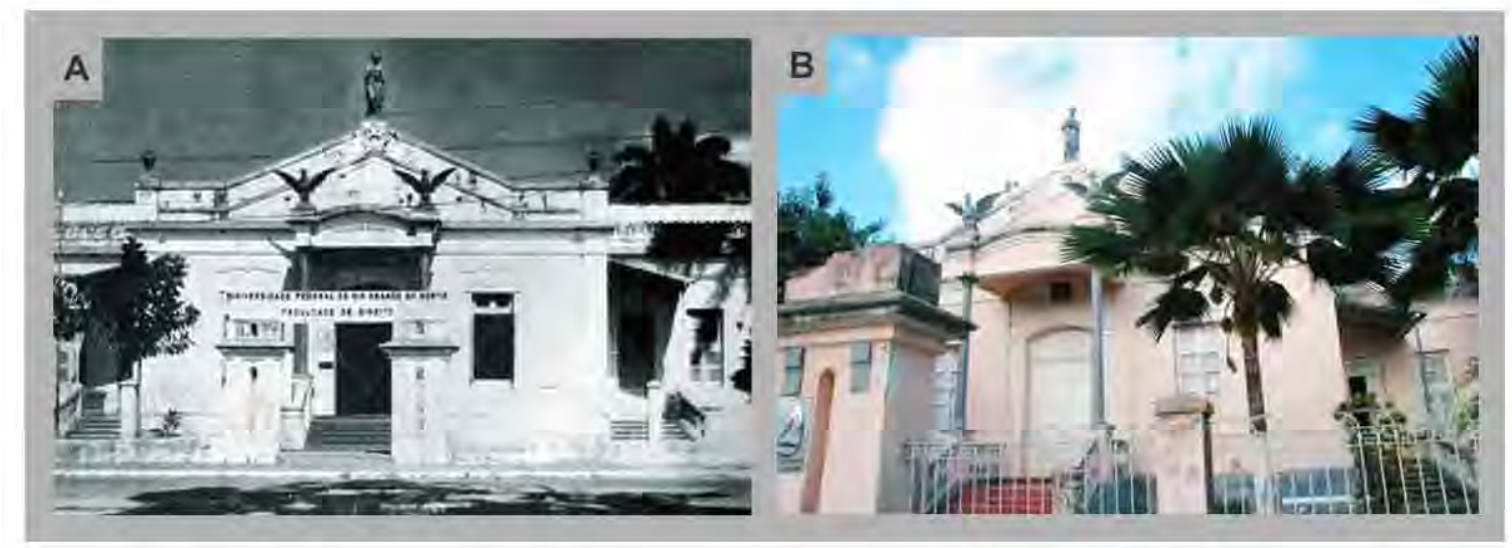

Figura 138:UFRN - Prédio da antiga Faculdade de Direito - (A) ano 1971 / (B) ano 2011.

Localizado na Praça Augusto Severo, foi concebido pelo arquiteto mineiro Herculano Ramos (também autor da praça).

(Fonte: (A) Acervo Lima e Melo apud TRIGUEIRO, 2008, p.47 e (B) Disponivel em:<http://diariodotempo.com.br/2011/04/o-predio-da-faculdade-de-direito-de-natal-podedesabar/>).

Outro importante exemplar do conjunto arquitetônico potiguar da primeira metade do século XX referenciado por Trigueiro (2008, p.49-51) é o prédio da Maternidade-Escola Januário Cicco, que faz parte do complexo de edifícios do Centro de Ciências da Saúde na UFRN (ver figura 139). Concebido em 1932 para abrigar a maternidade, foi ocupado, entretanto, 
com outras funções até 1950, quando então assumiu o papel para o qual foi projetado e depois encampado à Universidade do Rio Grande do Norte.

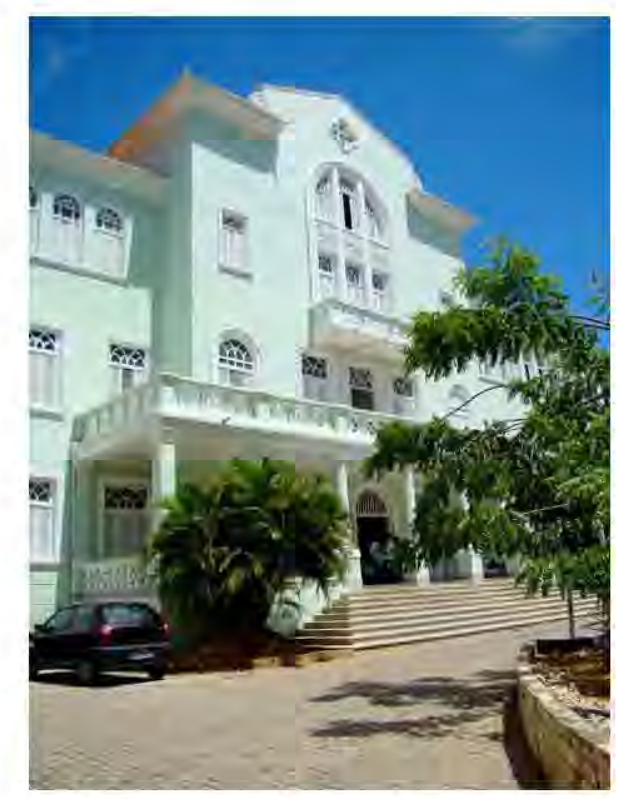

Figura 139: UFRN - Maternidade-Escola Januário Cicco ano [2008?].

Situada na Avenida Nilo Peçanha, Petrópolis, sua linguagem arquitetônica combina elementos de origem na arquitetura lusobrasileira.

(Fonte: Acervo UFRN / AGECOM)

As características formais de horizontalidade, os beirais com telhas de cerâmica tipo "capae-canal", as arcadas e janelas com vergas em arcos encontram referências no Movimento Neocolonial do Brasil, ainda que com menor expressividade estética. Trigueiro (2008, p. 49 -51), entretanto, categoriza o estilismo formal como ecletismo neocolonial, pois embora sob um desejo de independência cultural que inspirou o neocolonial luso-brasileiro, e que tinha seu maior contrário no ecletismo, defende que a linguagem neocolonial é, entretanto, parte desse mesmo ecletismo, por partilhar sua característica essencial - a de retomar e recriar elementos formais de estilos do passado (TRIGUEIRO, 2008). Na Maternidade, revela que se combinam

[...] a implantação recuada típica do perímetro eclético, repudiada a prática de se construir sobre o alinhamento da rua, como nas cidades coloniais; a distribuição do programa em volumes distintos, mas articulados, comuns nas igrejas e casas-grandes do Brasil colônia; a galeria de acesso, evocativa das galilés de antigas igrejas; os frontões ladeados por volutas e beirais cobertos por telhas de capa e canal; as superfícies lisas, livres dos 
estuques ornamentais que, neste, como em outros casos semelhantes, concentram-se nas cercaduras dos vãos (TRIGUEIRO, 2008, p. 50).

A Faculdade de Ciências Econômicas (figura 140) e a casa onde funcionou a primeira Reitoria (figura 141) também fazem parte do conjunto de exemplares que denotam sua filiação ao ecletismo neocolonial, embora escassos ou simplificados (TRIGUEIRO, 2008, p. $51-52)$.

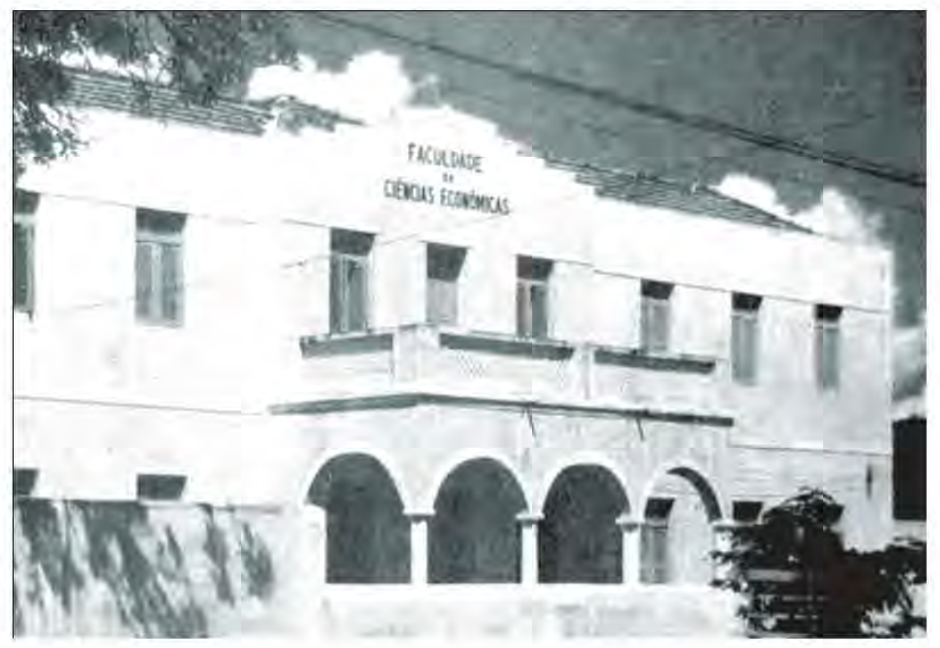

Figura 140: UFRN - Prédio da antiga Faculdade de Ciências Econômicas. Localizado à Rua Apodi, bairro do Tirol, apresenta uma redução ornamental, evidenciando sua filiação neocolonial apenas no frontão e no pórtico de entrada. (Fonte: LIMA e MELO, 1971 apud TRIGUEIRO, 2008, p. 51)

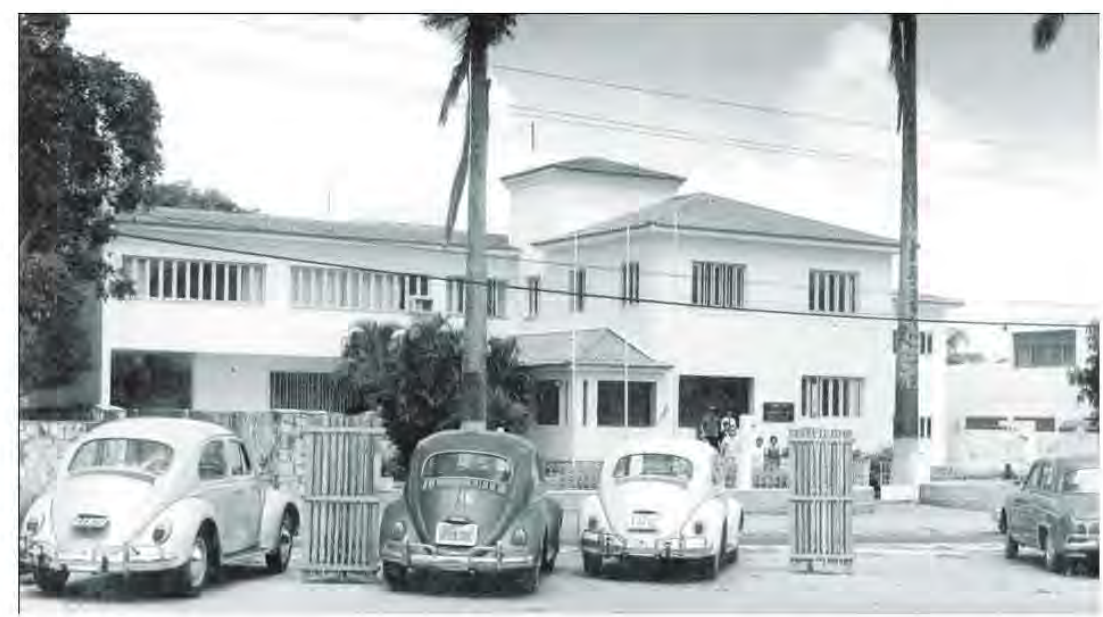

Figura 141: UFRN - Primeira sede da Reitoria da UFRN (foto do final da década de 1960). Situada na Avenida Hermes da Fonseca, $n^{\circ} .780$, no bairro Tirol, foi ocupada provisoriamente pela Universidade em 1959, quando da sua fundação e posteriormente adquirida e reformada para se adequar à Reitoria, que aí funcionou até sua transferência para o Campus Universitário, em 1975 (UFRN, 2008, p. 126).

(Fonte: Acervo particular de Selva Capistrano Lopes da Silva apud UFRN, 2008, p. 126) 
Pode-se verificar também, em edifícios que sediaram unidades da UFRN, no período correspondente às primeiras décadas do século $X X$, outra tendência que aponta para o protomodernismo, concordando com Trigueiro (2008, p. 53) que faz ressalvas aos traços ainda inseridos no contexto estilístico da arquitetura eclética. São eles: o prédio da antiga Escola de Serviço Social, o do Hospital Onofre Lopes (antigo Miguel Couto e depois Hospital das Clínicas) e a sede da outrora Faculdade de Farmácia e Odontologia.

O imóvel da antiga Escola de Serviço Social (ver figura 142) apresenta uma composição marcada pela simetria e pelos volumes coroados por platibandas que referenciam o cânon classicista, mas a rotação e o encaixe dos blocos, a predominância de cheios e vazios e as linhas retas nos balaústres, molduras e tratamento das superficies apontam tendências mais recentes, de influência Art Déco (TRIGUEIRO, 2008, p. 53).

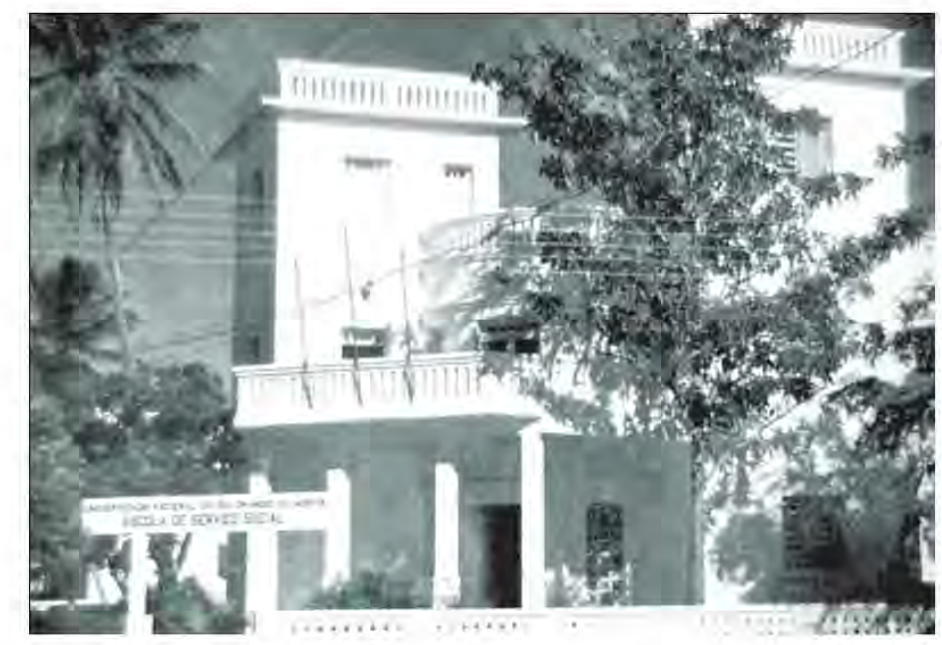

Figura 142: UFRN - Prédio da antiga Escola de Serviço Social - ano 1971.

(Fonte: LIMA e MELO, 1971 apud TRIGUEIRO, 2008, p. 53)

No Hospital Onofre Lopes (ver figura 143), há predominância das tendências protomodernas, destacada pela composição assimétrica, pelas marquises em balanço e no volume que anuncia as "caixas perfuradas" do modernismo internacional (TRIGUEIRO, 2008, p. 53).

O prédio da antiga Faculdade de Farmácia e Odontologia (ver figura 144) parece querer testemunhar a transição entre a fase eclética e a modernista no patrimônio edificado da UFRN. A eliminação do ornamento conjugado com a volumetria horizontal prenuncia a linguagem modernista que, combinada com a composição simétrica, cujo eixo se destaca 
pela presença do frontão e do pórtico de entrada, resulta numa composição que parece não querer se desligar do passado recente.

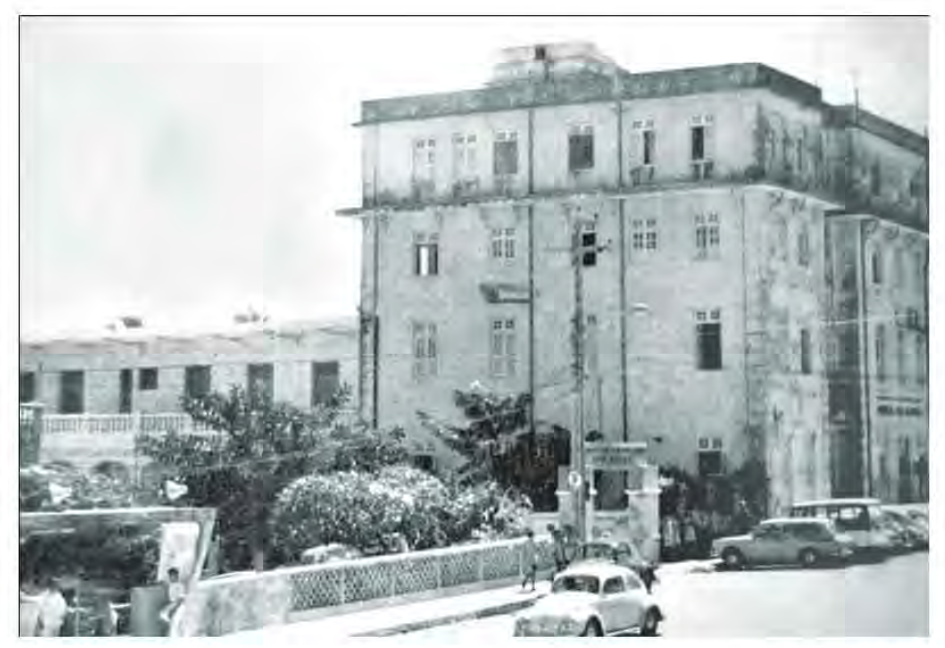

Figura 143: UFRN - Hospital Universitário Onofre Lopes, antigo Hospital Miguel Couto, depois Hospital das Clínicas ano 1971.

Localizado na Avenida Nilo Peçanha, sua arquitetura prenuncia as tendências protomodernas.

(Fonte: LIMA e MELO, 1971 apud TRIGUEIRO

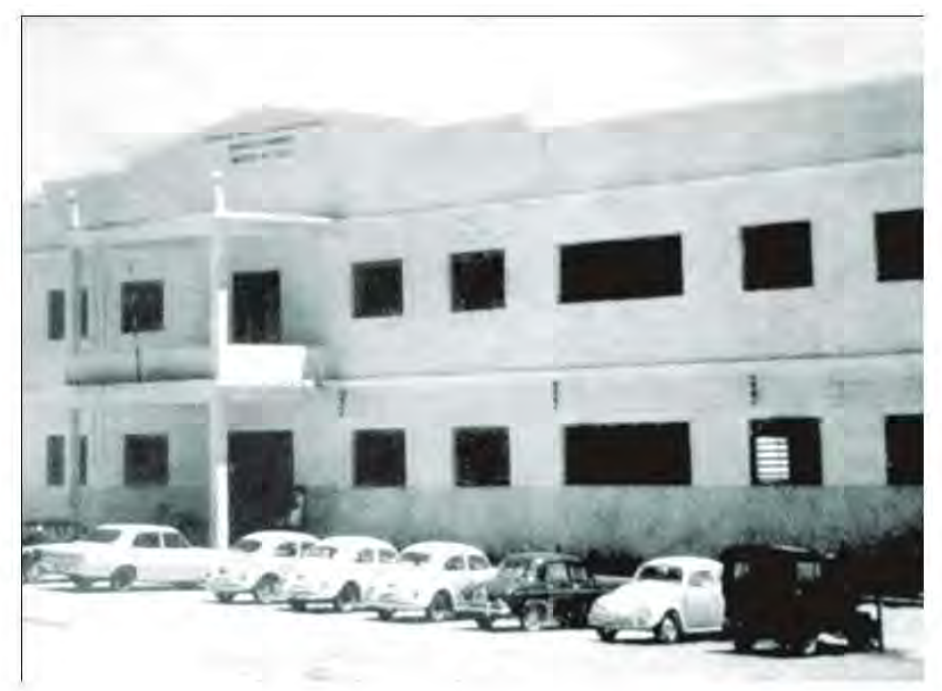

Figura 144:UFRN - Prédio da antiga Faculdade de Farmácia e Odontologia - Primeira metade da década de 1960. Localizado na Praça do Estudante, tem na sua forma arquitetônica a mescla de transição entre o ecletismo e - modernismo. O prédio abrigou posteriormente os Institutos de Física e Matemática (TRIGUEIRO, 2008, p. 54).

(Fonte: LIMA e MELO, 1971 apud TRIGUEIRO, 2008, p. 54) 
Na primeira metade de década de 1960, o panorama arquitetônico da UFRN apresenta os rumos da Arquitetura Moderna sob a atuação de arquitetos formados, em sua maioria, na Escola Nacional de Belas Artes do Rio de Janeiro que, influenciados pela obra e idéias do arquiteto franco-suiço Le Corbusier e reunidos em torno de jovens expoentes da arquitetura nacional, sobretudo Lucio Costa (TRIGUEIRO, 2008, p.57) introduziram a nova linguagem não apenas na Universidade, mas, sobretudo no cenário urbano da cidade de Natal.Edifícios implantados na malha viária evidenciam a ideia de uma Universidade inserida no contexto urbano da cidade.

O representante ilustre desse cenário na Universidade é o prédio da atual Faculdade de Odontologia, construído em decorrência do desmembramento da Faculdade de Farmácia e Odontologia. Inaugurado em 21 de abril de 1966, o projeto coube ao arquiteto potiguar Moacyr Gomes da Costa $^{56}$, graduado, em 1954, na Faculdade Nacional de Arquitetura da Universidade do Brasil, atual Universidade Federal do Rio de Janeiro (UFRJ).

A construção incorpora o repertório formal da Escola Carioca: a composição volumétrica funcional, de predominância horizontal, repousada diretamente no solo é dinamizada pela abertura e transparência das superfícies tratadas com painéis de combogó e esquadrias de vidro, criando uma porosidade que efetiva sua relação com o contexto circundante e com os condicionantes climáticos locais, que buscam maximizar a ventilação e minimizara insolação, aliando-se com a tradição da arquitetura moderna brasileira que trabalha os materiais para atingir níveis de conforto ambiental satisfatório (ver figuras 145 e146). Nas palavras de Trigueiro (2008).

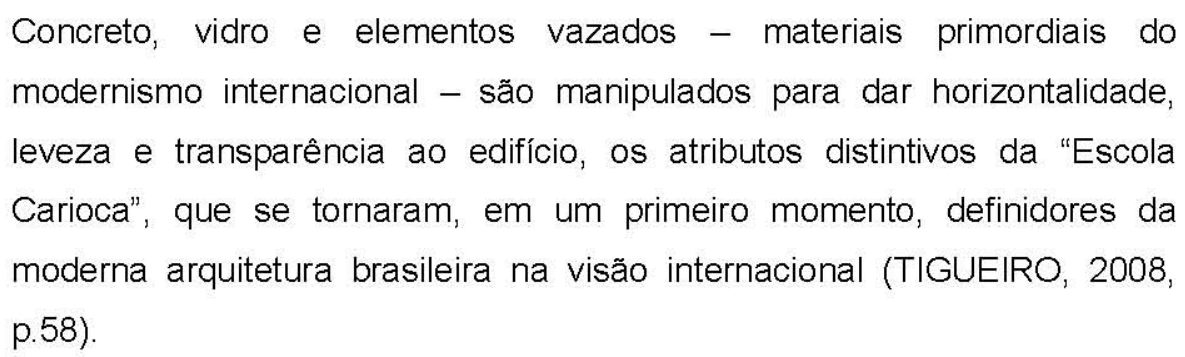

Construído em um terreno de esquina com a Avenida Salgado Filho e a Rua Antônio Basílio, sua implantação destaca o edifício solto no lote, a partir dos recuos adotados. A solução permite sua inserção na paisagem urbana, já que os limites entre lote e rua se dissipam e o edifício efetiva sua ligação a esta por meio de rampas (TRIGUEIRO, 2008, p.58).

\footnotetext{
${ }^{56}$ Moacyr Gomes da Costa nasceu em 1927, na cidade de Caicó. Especializou-se em Planejamento Urbano e Administração Municipal. Iniciou sua trajetória profissional no Rio de Janeiro, retornando posteriormente para Natal, onde seria o primeiro, e durante algum tempo, o único arquiteto. Trabalhando em equipe, integrou-se inicialmente ao grupo de engenheiros que já atuava na cidade e, posteriormente, a outros proeminentes nomes da arquitetura local como João Maurício e Ubirajara Galvão. Sua atuação abrange desde residências a edifícios públicos e privados de diversos usos e entre eles, o Estádio João Machado, - "Machadão", sua obra mais conhecida, que corre o rico de ser demolido para dar lugar a outro, com vistas aos jogos da copa de 2014 .
} 


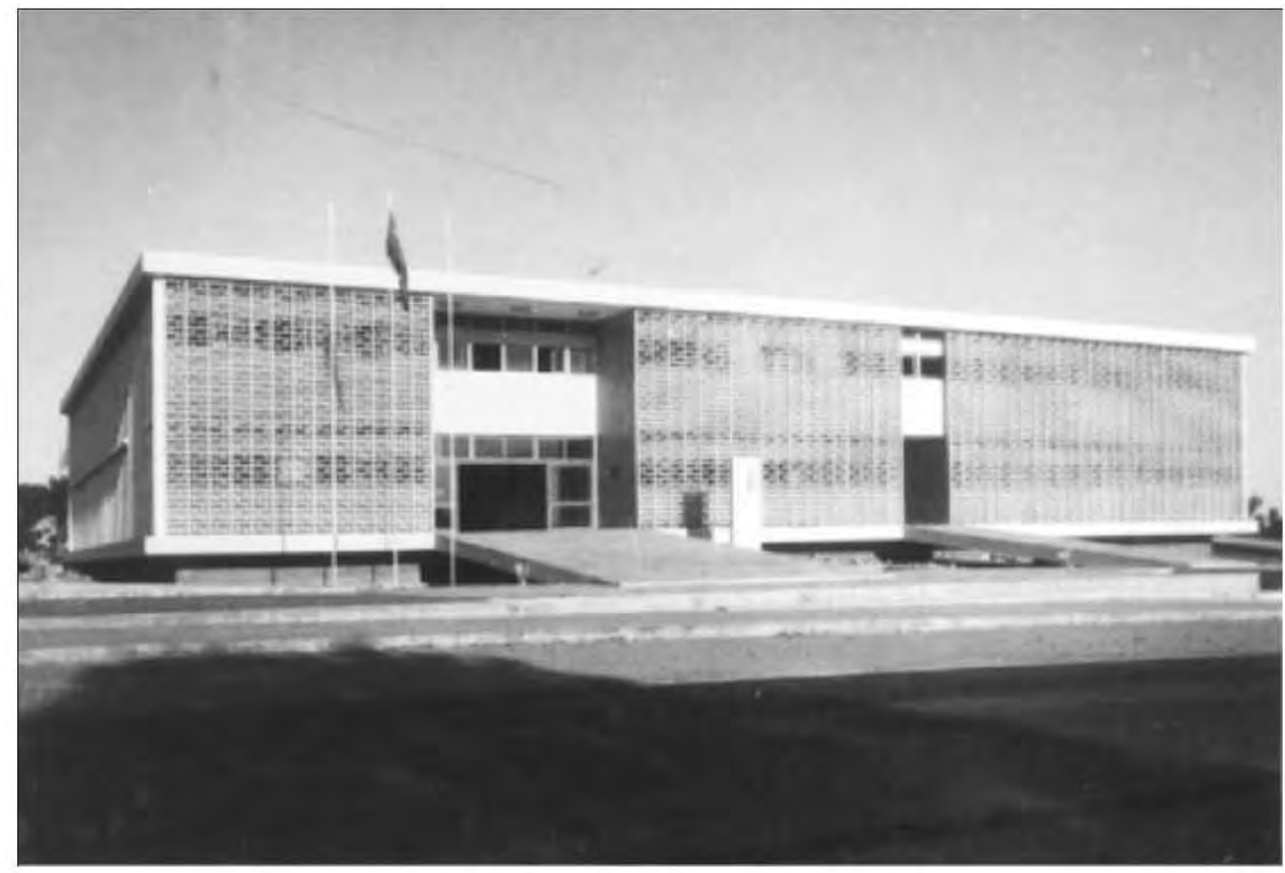

Figura 145:UFRN - Prédio da Faculdade de Odontologia - meados de 1960.

Vista da fachada pela Avenida Salgado Filho. O edifício se destaca na paisagem urbana e as rampasinterligam o espaço privado do lote e o espaço público da rua.

(Fonte: PEREIRA e NOBRE, 2008, não paginado)

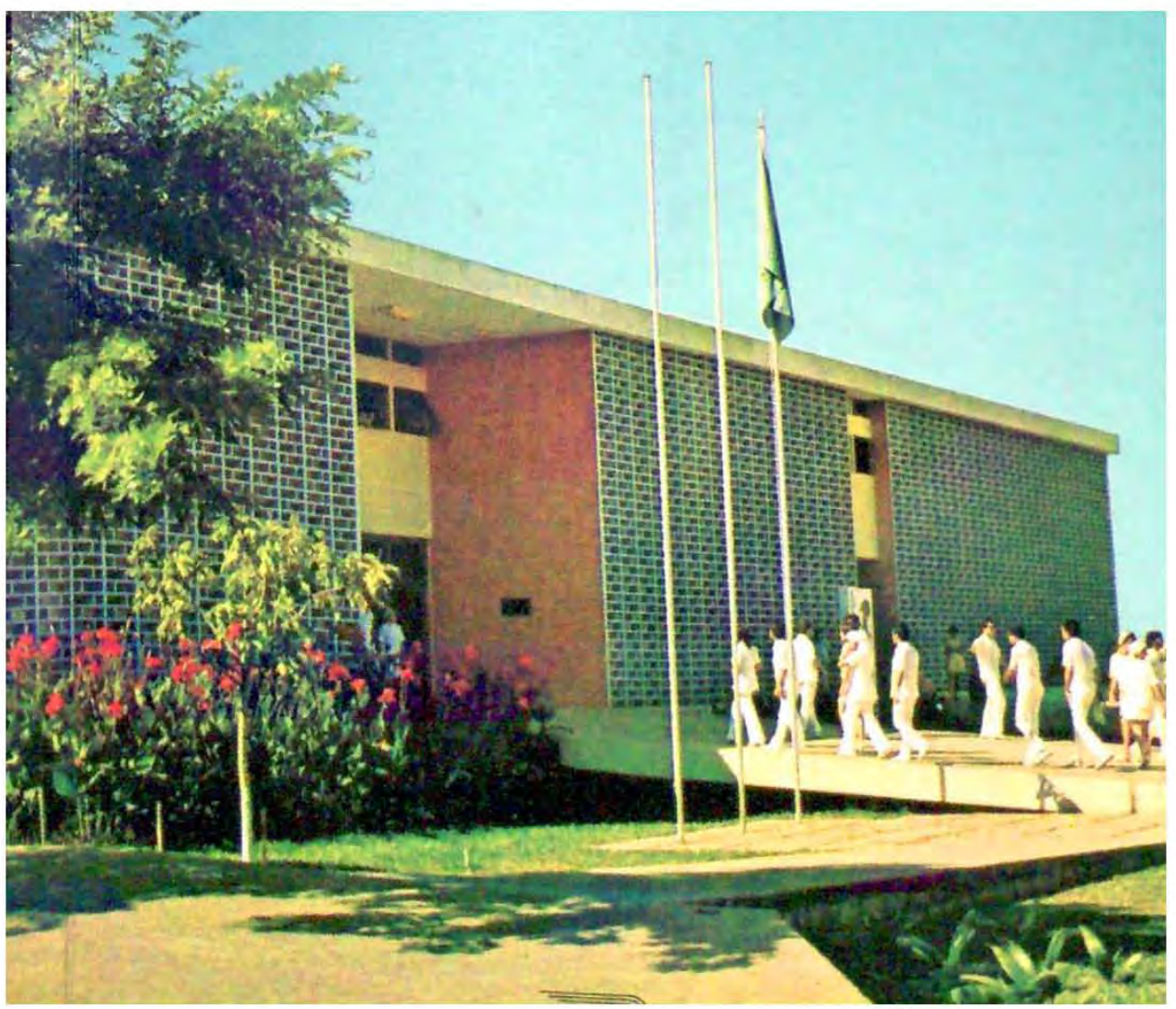

Figura 146:UFRN - Prédio da Faculdade de Odontologia -ano1966.

A linha horizontal da laje de cobertura e os painéis de combogó conferem leveza e transparência à forma arquitetônica.

(Fonte: GARCIA, 2008, capa, edição nossa). 
No mesmo ano (1966), a Faculdade de Farmácia tem suas novas instalações construídas com projeto de autoria de Manoel Coelho, também da primeira geração de arquitetos potiguares. Nesse exemplar, a arquiteta Edja Trigueiro referencia a tendência brutalista brasileira, que ganhou notoriedade nos anos 1960, quando passou a repercutir nacionalmente ${ }^{57}$, apontando que já pode ser observada sua influência no patrimônio da UFRN, que passa a conviver simultaneamente com a produção de edifícios baseada em outras orientações. O prédio da Farmácia adota um partido arquitetônico que se caracteriza pela geometria volumétrica fechada, fixada ao chão e sem qualquer intenção de compartilhamento com o entorno circundante. A superfície da forma arquitetônica demonstra sua adesão, ainda que amaneirada, às conotações formalistas daquela vertente (ver figura 147).

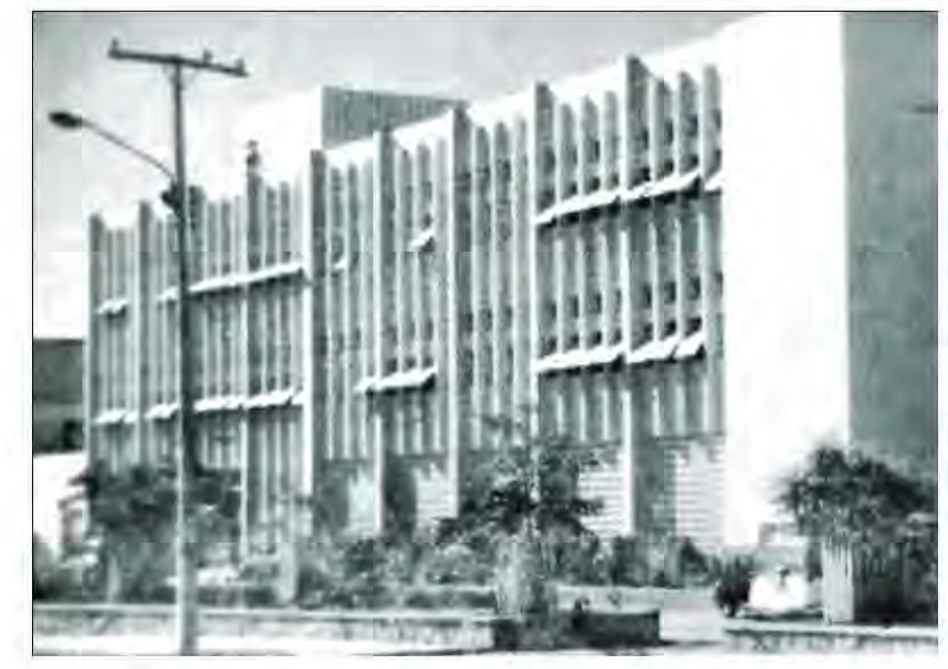

Figura 147:UFRN - Prédio da Faculdade de Farmácia - Segundametade da década de 1960.

Implantado na Rua Cordeiro de Farias, Petrópolis - área urbana da cidade de Natal.

(Fonte: LIMA e MELO, 1971 apud TRIGUEIRO, 2008, p.61)

Também de autoria do arquiteto Manoel Coelho, o imóvel, que abrigou inicialmente o Instituto de Antropologia e posteriormente o Museu Câmara Cascudo, foi mais uma unidade da Universidade implantada de modo disperso na cidade no ano de 1966. Seguindo a mesma linguagem formal da caixa sem transparência, o arquiteto mantém em curso sua filiação estilística experimentada no exemplar anterior (ver figura 148).

\footnotetext{
57 Sobre esse assunto, recomendamos a leitura da tese de autoria da arquiteta Ruth Verde Zein intitulada A Arquitetura da Escola Paulista Brutalista 1953 - 1973.
} 


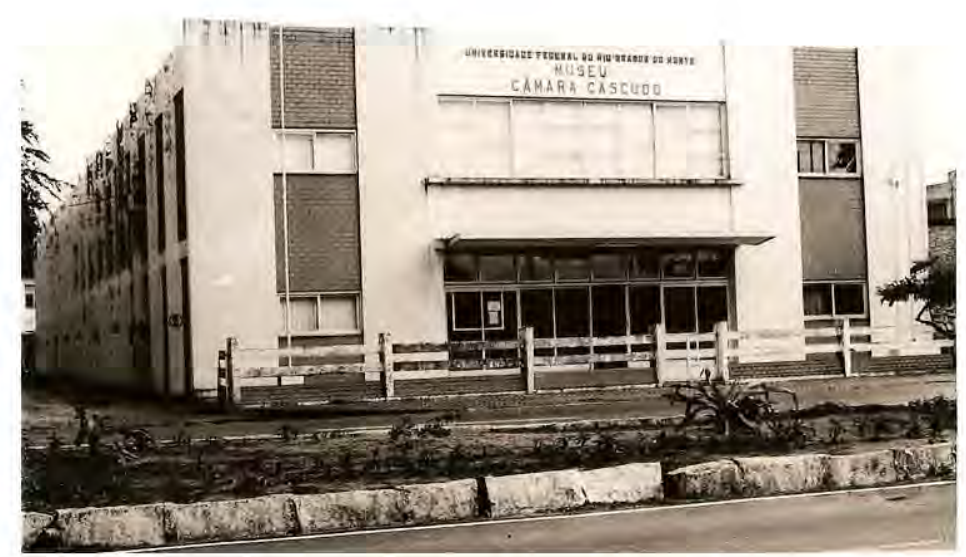

Figura 148:UFRN -Prédio do Antigo Instituto de Antropologia década de 1960.

O Antigo Instituto de Antropologia, atual Museu Câmara Cascudo, está localizado na Avenida Hermes da Fonseca, no bairro Tirol.

(Fonte: Acervo UFRN / AGECOM)

A expansão na primeira metade da década de 1960 incluiu a ampliação da infraestrutura da saúde com a construção do novo edifício destinado à Faculdade de Medicina, inaugurado em 1964 na área do complexo hospitalar. A arquitetura de volumetria horizontal e solução construtiva referenciada no conceito da verdade estrutural, vigas e pilares destacados das alvenarias de vedação, não chegam, entretanto, a compor uma referência moderna (ver figura 149). O caráter essencialmente utilitário da proposta se destaca em detrimento da linguagem moderna pioneira. Sua construção tendeu a consolidar a permanência do complexo da saúde no centro urbano, inviabilizando sua transferência para o futuro campus da Universidade.

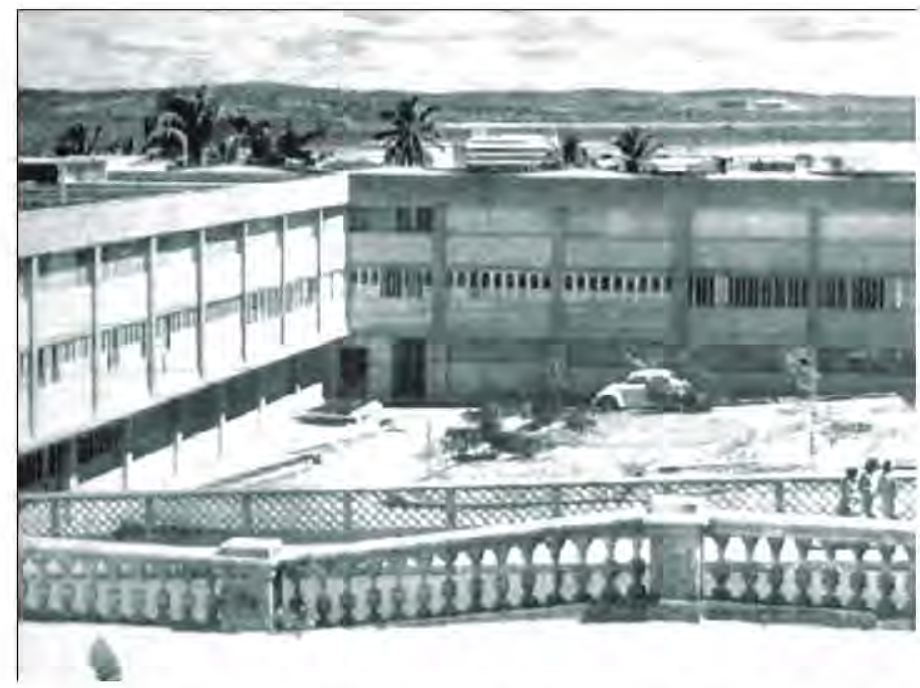

Figura 149:UFRN - Prédio da Faculdade de Medicina - década de 1960 (Fonte: LIMA e MELO, 1971 apud TRIGUEIRO, 2008, p.60) 
Trigueiro faz menção aos edifícios que abrigaram os antigos institutos tais como os de Ciências Biológicas, de Biologia Marinha, de Antropologia (acima mencionado), de Letras e Artes e de Matemática e Física (onde funcionou o antigo prédio da Farmácia e Odontologia), todos situados na malha urbana da cidade e cuja linguagem estilística afasta-se da leveza do modernismo, assumindo formas sisudas e repetitivas, de caráter essencialmente utilitário (TRIGUEIRO, 2008, p.61).

O registro dessas unidades evidencia a reestruturação acadêmico-administrativa que ocorreu na Universidade, na primeira metade da década de 1960, após a federalização e especificamente com os Decretos-Leis $n^{\circ}$ s. 53/18. nov.1966 e 252/28.fev.1967, que baixaram os princípios e normas de organização das universidades federais (abordado no capítulo 2), conformando a estrutura universitária com órgãos de ensino e pesquisa (institutos e faculdades).

A trajetória da consolidação física da URFN, implantada no primeiro momento em zona urbana, revela um importante aspecto a ser destacado. Parece-nos instigante observar que não há menções à concepção de um território unificado em área isolada como vinha ocorrendo na maior parte das demais instituições investigadas (exemplos: UFPB, UFAL, UFS, UFMA e UFPI), que desde a criação iniciaram procedimentos para a concretização da sua base física em glebas de extensas dimensões, segregadas da cidade e referenciada sou no modelo de cidade universitária - instituições fundadas na década de 1950 - ou no de campus universitário - com origem na década de 1960.

No caso da Universidade em questão, a construção das unidades dispersas em área urbana parecia estar caminhando para a consolidação da estruturação do espaço do ensino superior no modelo de edifício isolado ou conjuntos edificados (exemplo: o complexo da saúde com o Hospital, a Maternidade, a Faculdade de Medicina, o Centro de Radiologia, o Pavilhão de Pediatria, dentre outros), porém inseridos na cidade (ver figura 150). Há de se estranhar a ausência do propósito de um território periférico, que predominou na estruturação espacial do ensino superior brasileiro a partir da década de 1950 e instituído oficialmente pela Reforma Universitária de 1968, e que nessa Universidade só veio a ocorrer no início da década de 1970 com a construção do seu campus universitário. 


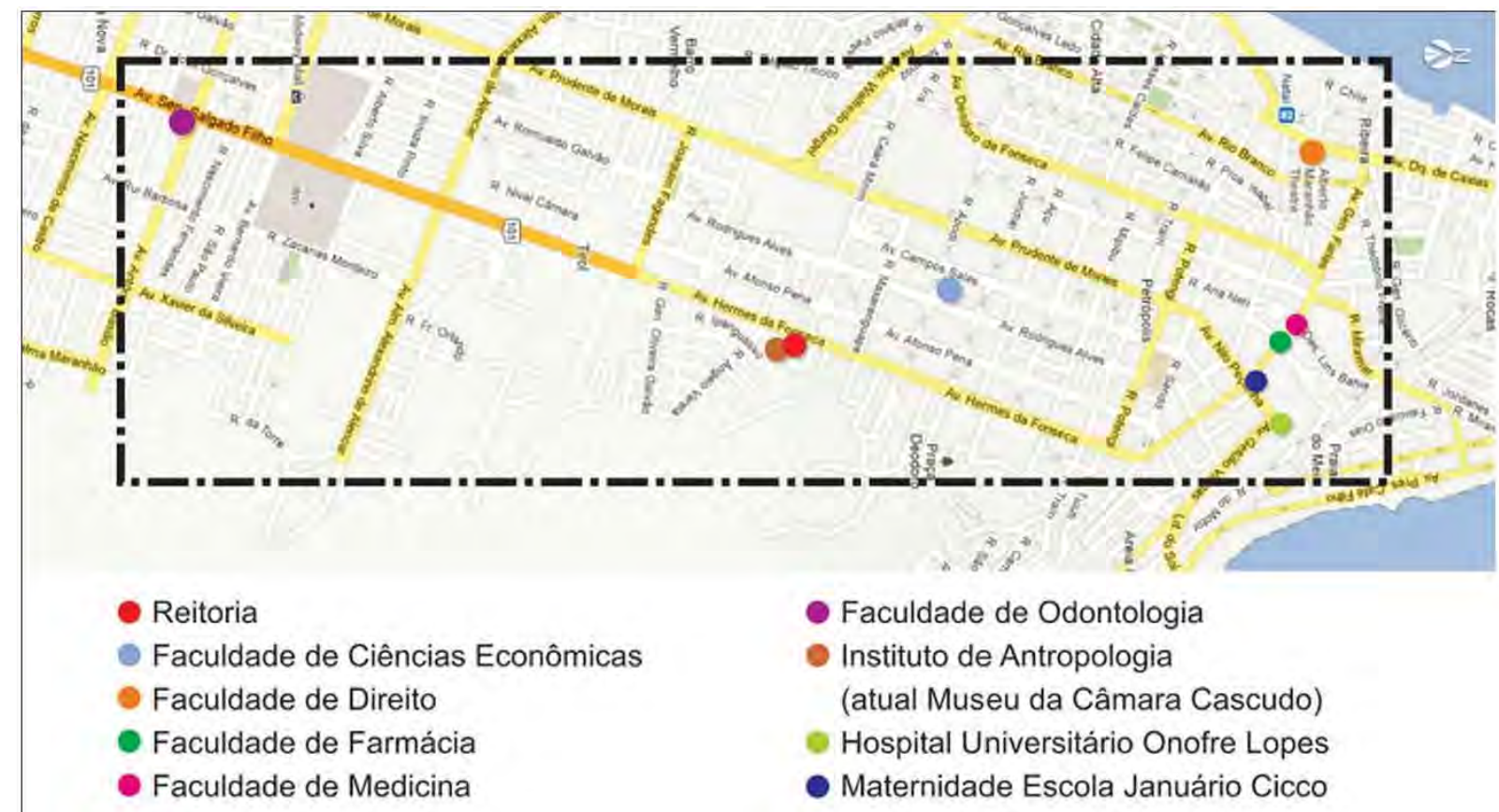

Figura 150: UFRN - Localização das unidades universitárias da UFRN no centro urbano de Natal. (Fonte: Adaptação da autora, Google Earth, 2012)

\subsection{CAMPUS CENTRAL: o território da Reforma}

Com anova estrutura acadêmica, alentada pelas diretrizes de integração e racionalização, a UFRN definiu sua organização em seis centros- Centro de Tecnologia (CT), Centro de Ciências Exatas e da Terra (CCET), Centro de Biociências, Centro de Ciências Humanas, Letras e Artes (CCHLA), Centro de Ciências Sociais Aplicadas (CCSA) e Centro de Ciências da Saúde (CCS)-os quais embasaram a organização do novo território cuja instalação se deu em terreno doado pelo governo do Estado.

Compreendia uma gleba de 123 hectares, com destaque para a presença das dunas, que circundavam o campus pela porção leste, atual Parque das Dunas, e uma topografia de trechos ondulados com declividades e solo predominantemente arenoso (ver figura 151), contribuindo para o clima de característica quente úmido. 


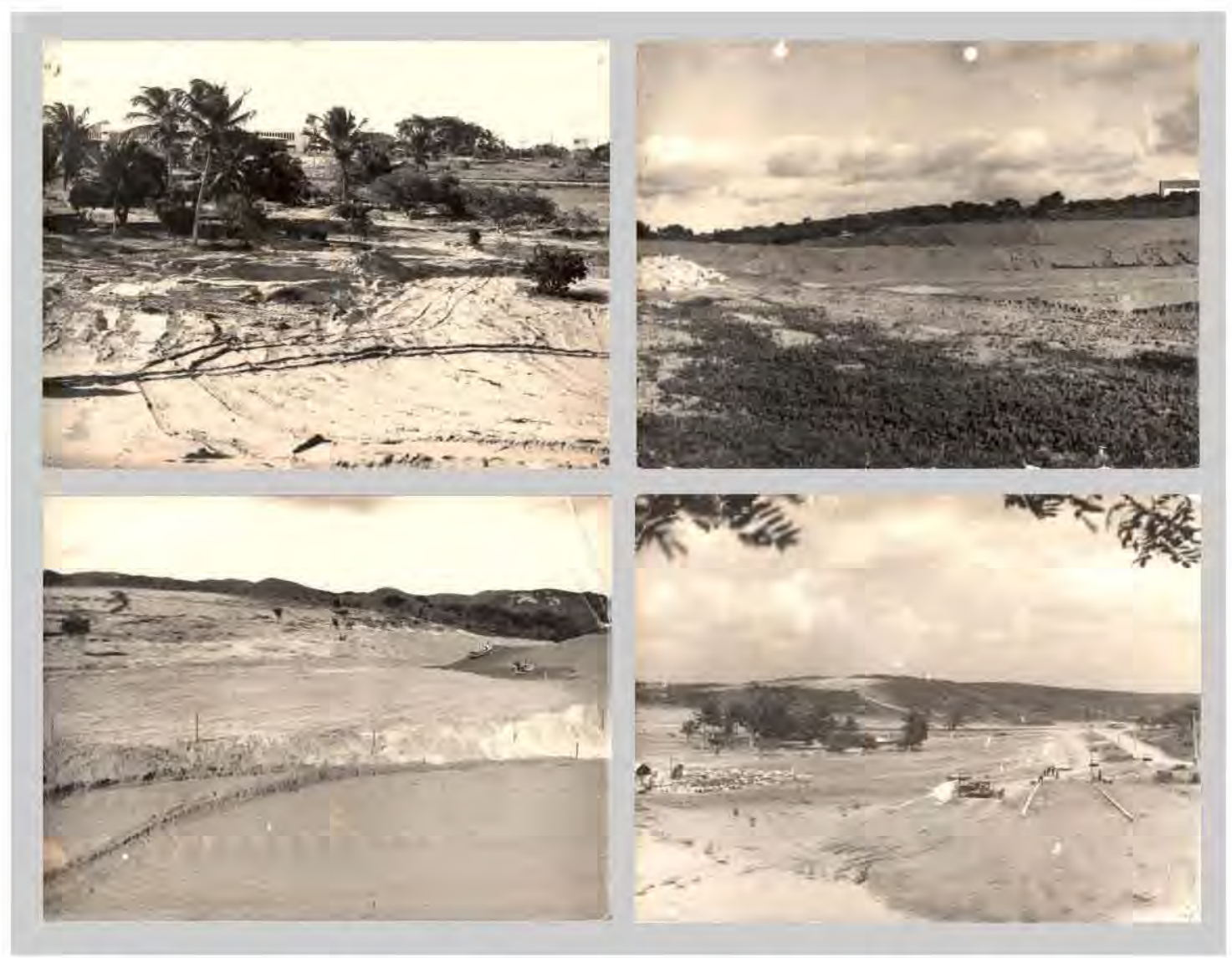

Figura 151: UFRN - Construção do Campus Universitário da UFRN - Primeira metade da década de 1970.

As fotos registram as obras de terraplenagem, revelando a topografia com trechos acidentados e de solo arenoso, tendo como pano de fundo a presença das dunas de praia.

(Fonte: Acervo AGECOM / UFRN)

Situava-se na BR 101, em uma área, naquele período, distanciada da zona urbana da capital. Em 1973, a revista O Cruzeiro fazia menção à sua construção:

"Durante a Segunda Guerra Mundial, um grande terreno vizinho à cidade do Natal servia como Campo de Tiro. Granadas e morteiros cruzavam o ar, interrompendo a circulação de veículos até que o treinamento terminasse. Passados 30 anos, neste mesmo terreno, desenvolve-se uma luta diferente. Máquinas pesadas e tratores realizam serviços de terraplenagem; jovens técnicos circulam com suas plantas acompanhando o ritmo incessante das obras; jipes atravessam o terreno ondulado, criando suas próprias estradas. São 130 hectares de terra para construir, urbanizar, integrar: é o campus da UFRN que está surgindo (apud MELO, 2008$, p. 27$)^{58}$.

\footnotetext{
${ }^{58}$ A notícia foi citada em discurso proferido a 15 de maio de 1975 , por ocasião da despedida do Reitor Genário Alves da Fonseca (1971 - 1975) - original datilografado. Nesse reitorado foi iniciada a construção do campus universitário e a implantação da TV universitária.
} 
Com a expansão da cidade, o campus integra hoje a área urbanizada de Natal (ver figura 152),

[...] limitando-se ao norte com o conjunto Habitacional de Potilândia e com o quartel do $7^{\circ}$. Batalhão Engenharia de Combate ( $7^{\circ}$. BEComb.), ao sul com o Conjunto Habitacional de Mirassol e a Cidade Jardim, a leste com o Parque das Dunas e a oeste com o bairro de Candelária (CARVALHO, 2005, p.63).

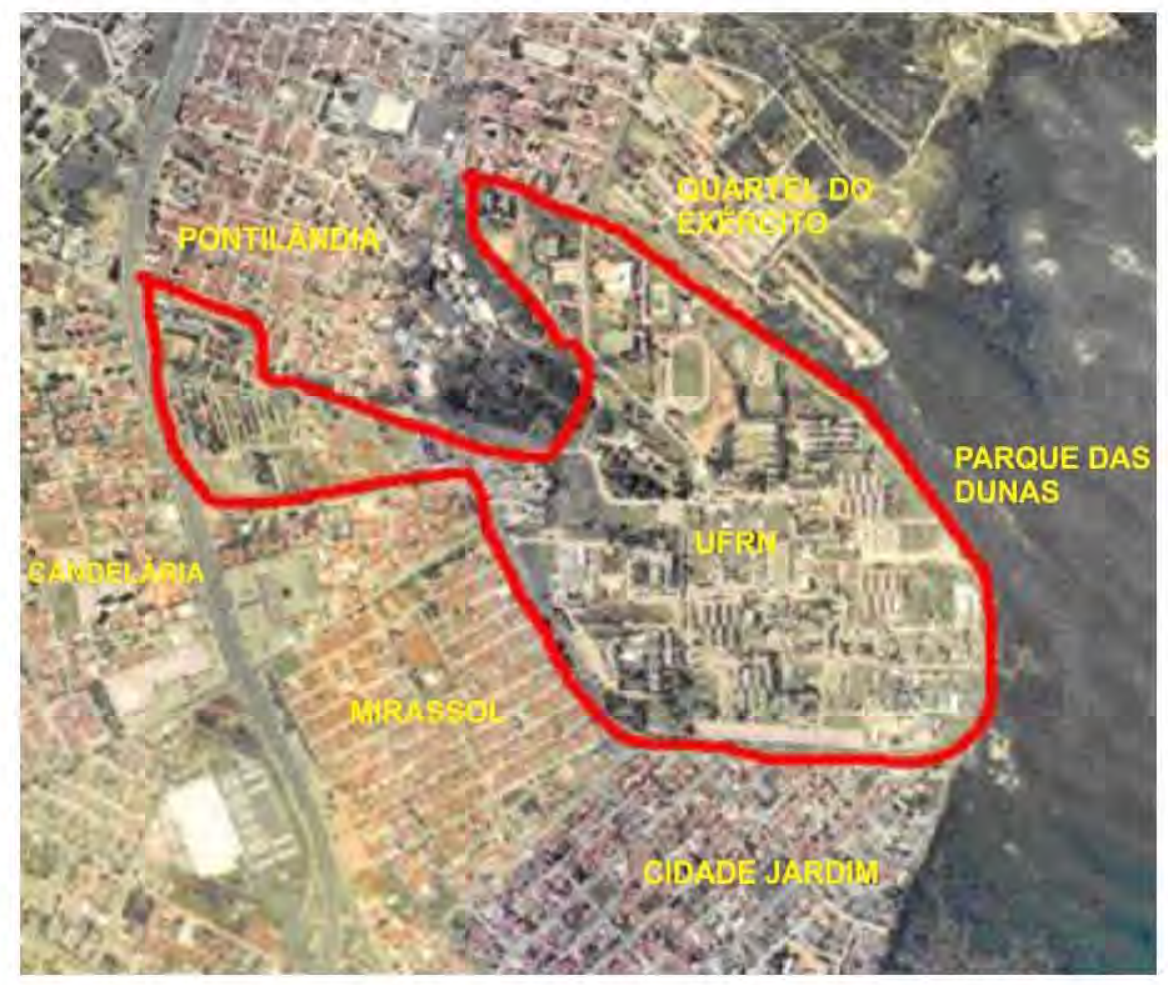

Figura 152:UFRN - Foto aérea do Campus Lagoa Nova.

Vários conjuntos habitacionais fazem limite com o Campus, configurando o bairro Lagoa Nova.

(Fonte: CARVALHO, 2005, p.57)

Carvalho (2005, p.60) afirma que a escolha do terreno isolado da cidade se deu por interesse do regime militar, que visava o controle e a observação da comunidade acadêmica. Em outra vertente, o ex-reitor Domingos Gomes de Lima (1975-1979), em entrevista conferida ao Diário de Natal (5.nov.2008), considerou que embora o terreno pertencesse ao Exército, que o utilizava para manobras e exercícios militares, a escolha se deu pelas suas características de grande extensão, propícia a esse tipo de território. Segundo ele, 
[... ] a área tornou-se inadequada para essa finalidade [manobras militares]. $O$ projeto do campus exigia uma área grande e bem localizada. O meu antecessor, com o apoio do Ministro da Educação e a colaboração do Governo do Estado, desenvolveu esforços e conseguiu a área para implantação do campus. O Governo do Estado desejava obter a mesma área para a implantação do centro administrativo, mas concordou em cedêla (LIMA, 2008).

Embora não sendo foco da presente pesquisa questionar as implicações da ditadura militar na configuração do território universitário, não nos parece convincente afirmar que o ideal de um zona unificada e segregada estivesse exclusivamente ligada aos interesses dos militares. Vários fatores podem ser apontados como condicionantes do isolamento físico da instituição universitária:

1. A trajetória das universidades brasileiras, criadas a partir dos anos 1930 , trazia no bojo de suas concepções o projeto de reunir suas unidades em um espaço de grandes proporções e configurações urbanas dissociadas da legislação municipal, onde se acreditava ser possível o desenvolvimento do verdadeiro espírito universitário ${ }^{59}$.

2. A ideia de uma área isolada e autônoma estava no imaginário da sociedade brasileira naqueles anos, onde Brasília, a nova capital do país, e sua Cidade Universitária, latejavam como símbolos de uma era que marcava também a modernidade do ensino superior no Brasil.

3. Outro aspecto a ser considerado diz respeito aos propósitos de expansão urbana, que poderia ser desencadeada com a implantação de um equipamento educacional em áreas específicas. Podemos citar o caso das Universidades Federais do Maranhão e Paraíba onde a escolha do território, em glebas apartadas da malha urbana, esteve ligada aos propósitos de expansão da região, articulados nos planos de governo do Estado ${ }^{60}$.

4. Outra linha de pesquisa foi defendida por Almeida (1983) que dissertou sobre a relação entre a autonomia universitária e a localização espacial do seu território. $O$ pesquisador infere que o isolamento físico encontra fundamentos no acirramento da defesa pela autonomia didática, administrativa e financeira da instituição

\footnotetext{
${ }^{59}$ Sobre esse assunto, recomendamos a leitura da tese de Cabral (2004) intitulada A Universidade de São Paulo - Modelos e Projetos.

${ }^{60}$ Sobre esse assunto, recomendamos a leitura da tese de Pereira (2008) intitulada Novo Edificios, Nova Versão Urbana Difusão da Arquitetura Moderna na Cidade de João Pessoa $(1956$ - 1974).
} 
universitária. Nas palavras de Almeida (1983, p.14), isto tem relação com o regime de propriedade dos prédios, equipamentos e terrenos.

5. Por último, a pesquisa de Oliveira (2005) sobre o processo de formação do território da Universidade Federal do Ceará, atesta que a Reforma Universitária de 1968, encontrou no modelo de território unificado e isolado daquela instituição, o ideal de funcionamento capaz de restabelecer o sentido de unidade comprometido pela fragmentação provocada com a dispersão das unidades acadêmicas na cidade.

As questões acima colocadas nos levam a considerar que não apenas um, mas uma conjunção de fatores levou à escolha do terreno para implantação do território universitário indicado pela Reforma (1968), no contexto da ditadura militar. Inferimos que a semente do isolamento, plantada em diversos níveis, floresceu por causa dos interesses dos militares, que já articulavam o controle do movimento estudantil.

\subsection{PLANO DIRETOR: as diretrizes de um território zoneado}

As obras do campus tiveram início em 1972, orientadas pelo plano diretor de autoria do arquiteto paraense Alcyr Meira e sua equipe ${ }^{61}$. A participação de Meira foi motivada por sua atuação em consultorias para o MEC no processo de construção dos campi universitários brasileiros com vistas à implantação da Reforma de 1968 (informação verbal ${ }^{62}$ ).

Em seu depoimento Meira revela que teve, em diversas oportunidades, encontros com o consultor Rudolph Atcon [referenciado no capítulo 2], ocasiões em que se discutia o planejamento do campus universitário brasileiro. O Manual de Atcon (1970, p.88) faz referência ao projeto do Campus da Universidade Federal do Pará, de autoria do arquiteto paraense ${ }^{63}$, destacando que as tipologias construtivas ali executadas eram uma referência a ser seguida, pois estavam em conformidade com suas recomendações. Embora Meira não tenha feito menção ao Manual (1970), as diretrizes desse documento foram incorporadas no Plano Diretor para o Campus da UFRN.

O plano foi concebido segundo princípios do zoneamento funcional e da hierarquia das vias de circulação - veículos e pedestres - com a presença marcante do anel viário periférico à gleba que, conforme orientação do Manual (1970) funcionaria como elemento protetor dos setores funcionais.

\footnotetext{
${ }^{61}$ A equipe era formada pelos profissionais Armando Couceiro, Alberto Rubim, Dirce Bibas e Jaime Bibas.

62. Entrevista concedida pelo arquiteto Alcyr Meira em 10 de novembro de 2009, na sede do escritório em Belém (PA).

${ }^{69}$ Informação fornecida em entrevista concedida pelo arquiteto Alcyr em 10 de novembro de 2009 , na sede do escritório em Belém (PA).
} 
Carvalho (2005, p.60) esclarece que o mesmo propunha a divisão em cinco zonas funcionais:

1. Zona Administrativa, constituída pela administração central - Reitoria, Secretaria, Finanças, Divulgação e Intercâmbio, Cultural, Registro e Controle Acadêmico; e Setor Cultural - Rádio, Televisão, Biblioteca, Auditório, Praça Cívica e Templo Ecumênico.

2. Zona de Ensino e Pesquisa, composta por quatro centros, conforme áreas de conhecimentos afins - Centro Tecnológico, Centro Biomédico, Centro Humanístico e Centro de Educação. Cada núcleo teria um setor didático-administrativo e uma biblioteca.

3. Zona de Recreação, que abrangia as instalações recreativas e assistenciais, assim como áreas comunitárias, restaurante, clube universitário e áreas de bosques.

4. Zona Esportiva, cujas instalações - piscinas, quadras, ginásio poliesportivo, pista de atletismo e campo de futebol - atenderiam variadas práticas de modalidades esportivas.

5. Zona de Serviços Gerais, que, correspondendo ao setor responsável pela infraestrutura do Campus, seria constituída pela Prefeitura do Campus, Setor de Manutenção, Setor de Transportes e Setor de Segurança.

O anel periférico foi proposto como via principal do sistema viário e constituído de duas mãos com canteiro central, que articulava a ligação aos setores funcionais, intermediado pelos bolsões de estacionamento de onde derivavam as vias de pedestres para então acessar os edifícios.

A planta da figura 153 assinada pelo arquiteto, porém não datada, corresponde a uma versão primeira do plano e a implantação do conjunto dos edifícios segue as orientações do Manual. Nele, o prédio da biblioteca desempenha o papel de elemento central da Zona de Ensino e Pesquisa, de onde irradiariam os centros, constituídos de tipologias construtivas que abrigavam o programa acadêmico e administrativo. Destacam-se nesse conjunto, a predominância da tipologia com a finalidade de aulas teóricas e outras, em menor proporção, com a função de abrigar o setor didático-administrativo e laboratórios. As unidades se apresentam independentes entre si, conformando edifícios autônomos, podendo ser construídos por etapas, e estão intercalados por áreas livres, que parecem funcionar como recuos padronizados.

A localização do setor esportivo foi concebida com acesso direto ao anel periférico, garantindo fácil escoamento, sem interferir nos demais. Em conjunto com esse setor, estava 

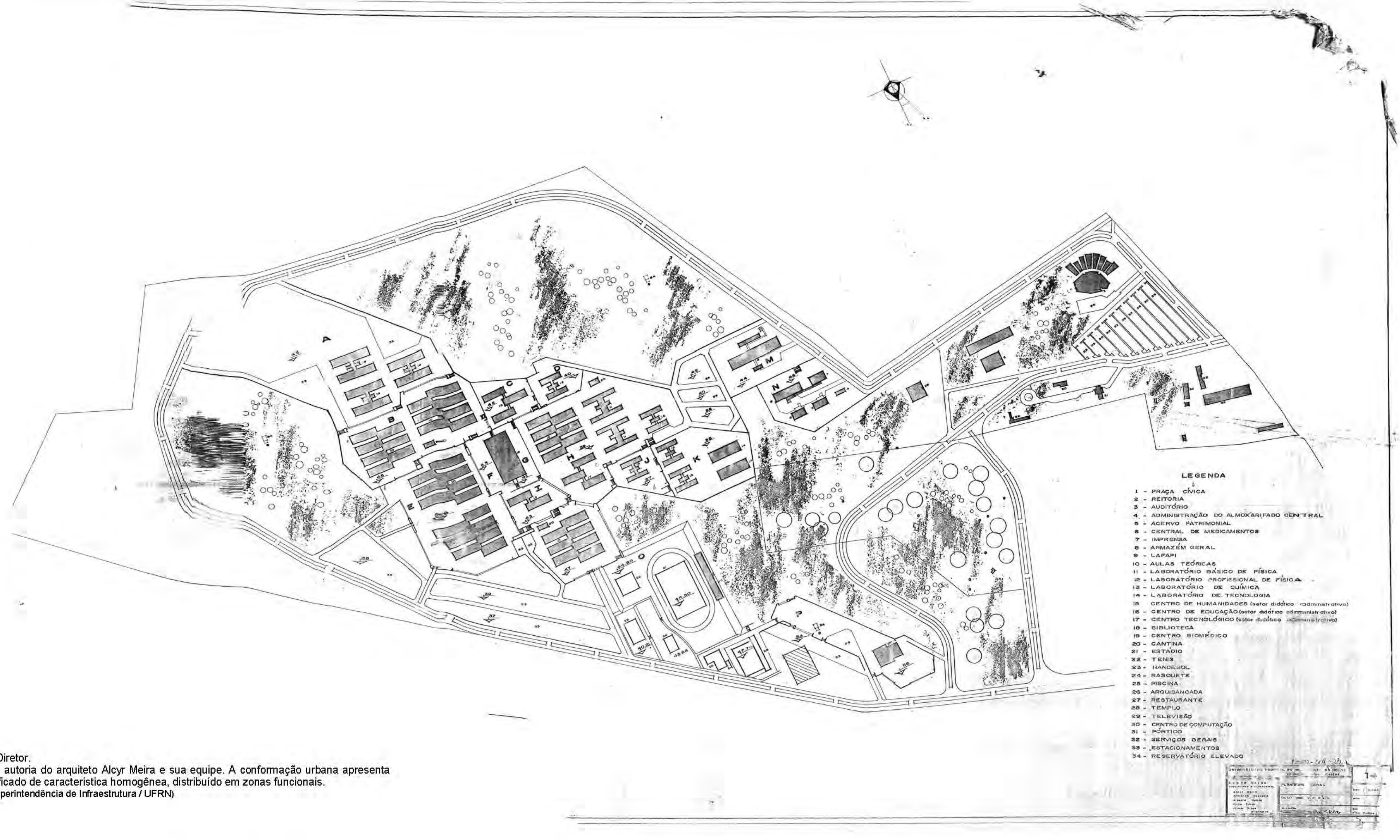
Parte 2 - Universidade Federal do Rio Grande do Norte 
articulado o restaurante, imerso em extensa área livre, indicando a possível presença de um bosque. Com a mesma orientação, a parte de serviços gerais, também estava implantada em área periférica e independente dos demais setores, funcionando como ponto de apoio às necessidades de infraestrutura do Campus.

O plano indicava o setor administrativo com acesso à BR-101 que se liga à malha viária da cidade. A implantação, em conformidade com o Manual, favorecia o acesso do público à Universidade sem a necessidade de cruzamento nas áreas internas do Campus. $O$ conjunto administrativo apresentava um programa composto pela reitoria, praça cívica e um auditório. O desenho urbanístico resultava num território com setores funcionais de contornos definidos fisicamente e ocupados por tipologias de características homogêneas. A uniformidade do conjunto edificado associada à escala do território de extensas dimensões configurava uma proposta sem clara referência de orientação para o futuro usuário, que teria que circular entre os edifícios.

A planta da figura 154, datada de outubro de 1972, referente ao levantamento planialtimétrico da gleba, registra as obras já construídas e as que estavam em execução, esclarecendo que o setor de aulas teóricas fez parte do primeiro conjunto edificado do Campus e que seguia a orientação do plano de Meira. Observa-se ainda a não inclusão nos limites da gleba da área em que foi edificado o prédio da então Escola de Engenharia, indicada no plano para a implantação do setor de serviços gerais. A menção a este registro é importante porque as publicações sobre a UFRN (TRIGUEIRO, 2008, p. 61; CARVALHO, 2005 , p. 58) relatam que o prédio daquela Escola foi a primeira construção do Campus, em 1966 [Ressalte-se que no referido ano a lei da Reforma ainda não havia sido promulgada]. É provável que a ausência do edifício na planta do levantamento se deva ao fato de que a área da Escola não fazia parte do sítio doado pelo Exército e somente depois foi incorporada, conformando um território único (ver planta da figura 155). O depoimento abaixo reforça as evidências mencionadas:

Segundo depoimento de Erivan Romão de Lima (14.07.2005), o primeiro terreno foi adquirido para a construção da Escola de Engenharia, que era uma faculdade isolada, depois foi que o Governo doou o terreno grande (CARVALHO, 2005, p.58). 


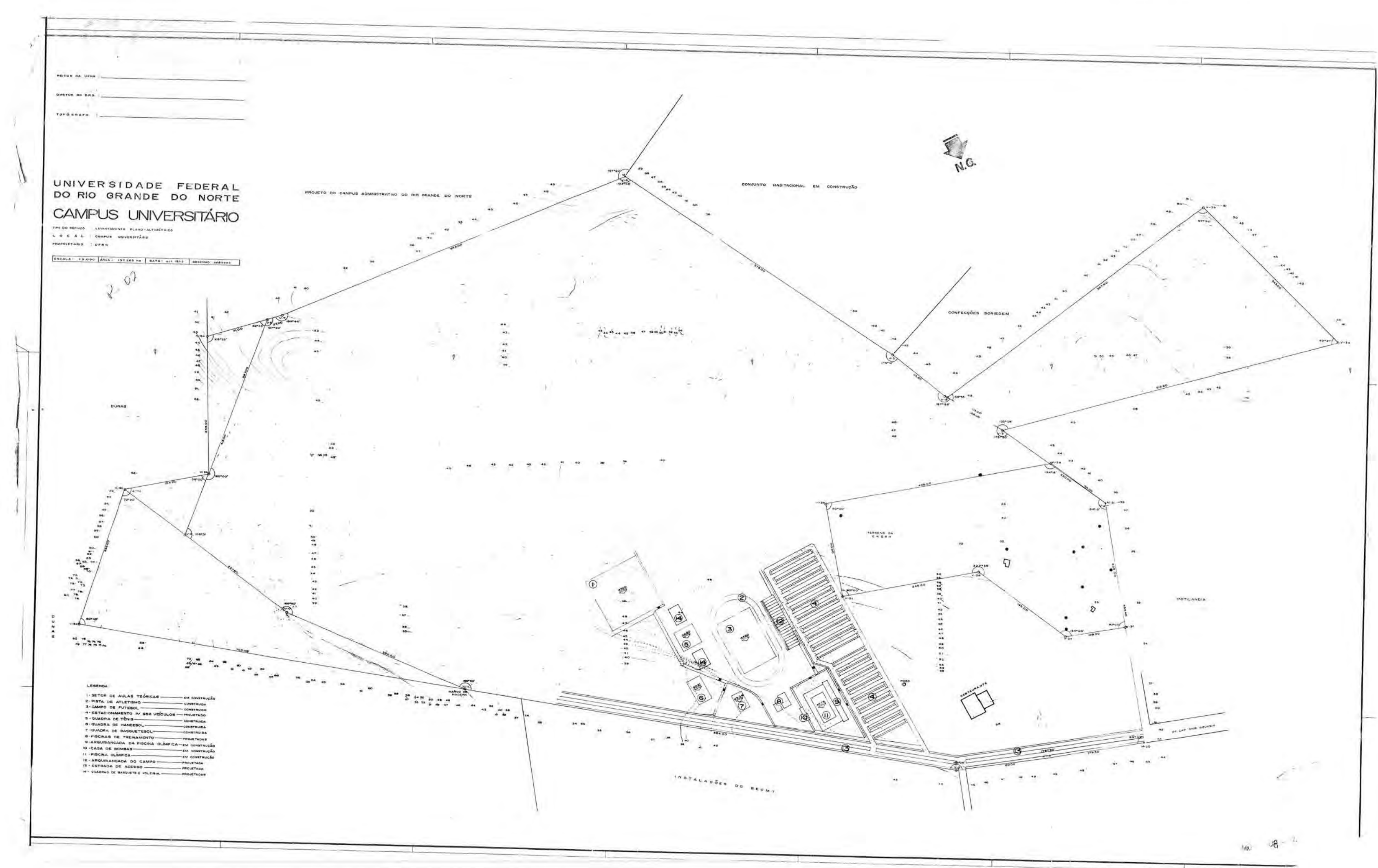

Figura 154: UFRN - Levantamento Planialtimétrico - 1972.
Os limites da gleba não inclúríam a área de impar

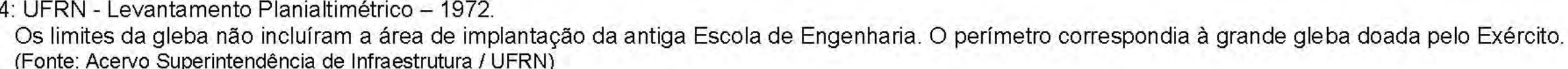




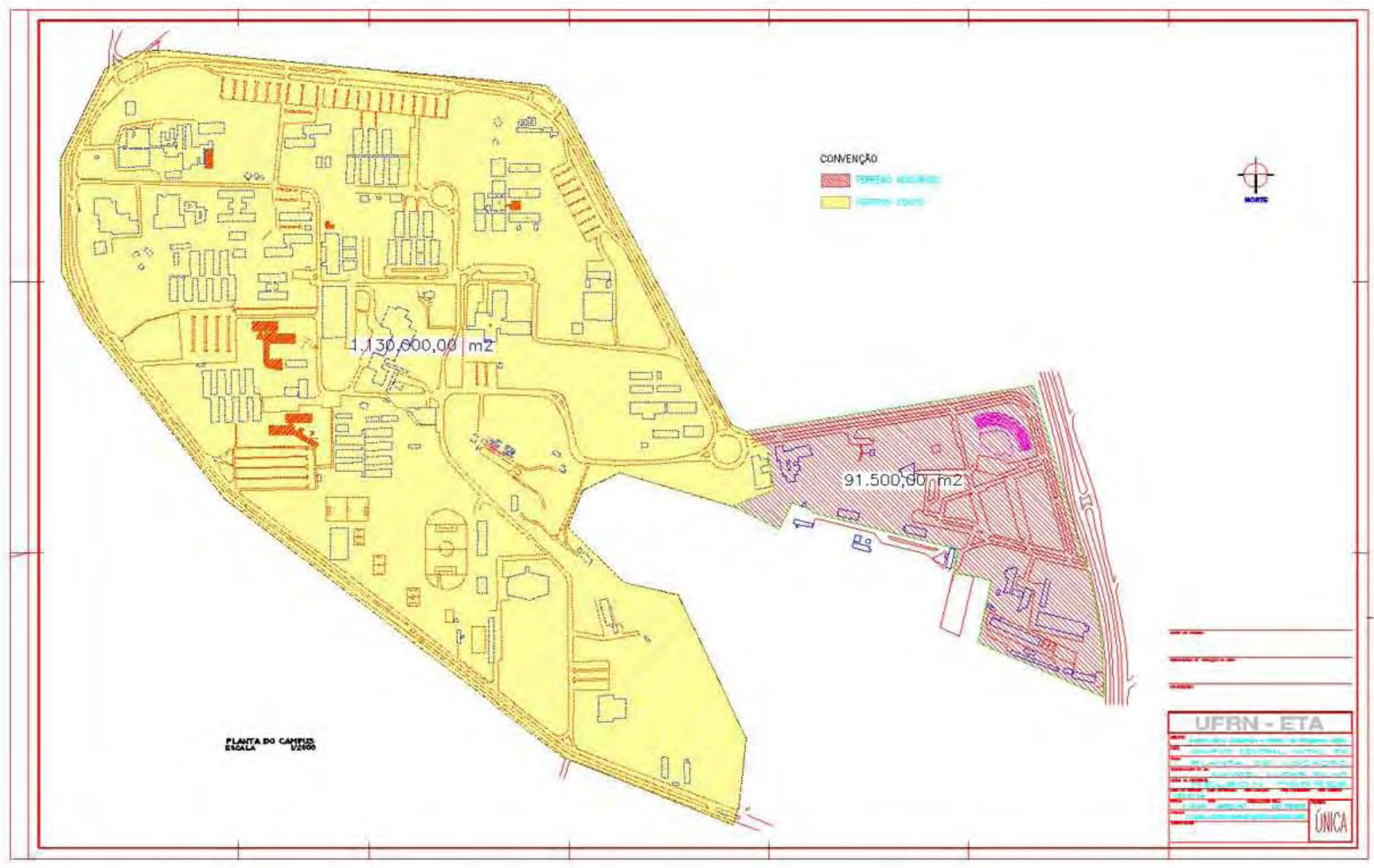

Figura 155: UFRN - Planta Geral do Campus - março de 1997.

A planta elaborada pelo escritório técnico da UFRN diferencia a área de terreno doada - cor amarela - da área de terreno adquirida - cor vermelha.
(F onte: Cadastro digtala da supenintendéncia de Infraestrutura / UFRN) 
Parte 2 - Universidade Federal do Rio Grande do Norte 
Um novo estudo foi realizado por Meira e sua equipe que, conforme a planta da figura 156, indicava adequações à proposta anterior. Nela, estão registradas as obras já executadas, que incluíam o setor esportivo, o restaurante, a praça cívica e algumas unidades de aulas teóricas - setor de aulas teóricas I - e didático-administrativa. Carvalho (2005, p. 61) esclarece que a prioridade à essas unidades foi definida no Plano Setorial de $1972 / 74$ e em 1974 já estavam concluídas. O estudo manteve o mesmo zoneamento, porém apresentava alterações no arranjo das tipologias construtivas no setor de ensino e pesquisa. A proposta confirma a concepção de um urbanismo rigidamente zoneado, formando setores de densa ocupação, conforme as funções acadêmico-administrativas planejadas.

Em julho de 1976, a Universidade definiu alterações significativas no plano de Meira, que foram aprovadas pelo Conselho Universitário através da resolução $n^{\circ}$. 23/1976 (ver figuras 157 e 158). Estas propostas não contavam mais com a participação do arquiteto Alcyr Meira e sua equipe, ficando sob a responsabilidade do escritório técnico da UFRN. As modificações estavam predominantemente focadas em um novo arranjo das tipologias destinadas a esse setor, com os laboratórios de ensino básico (química, física, ciências biológicas, etc.) situados em torno da Biblioteca, e com a definição das vias de pedestres, que desempenhavam a ligação entre o conjunto edificado e as ilhas de estacionamento, mantendo, porém, a concepção de bolsões periféricos ligados ao anel protetor. Também foi planejada uma nova localização para a Reitoria, ficando agora próxima ao setor de ensino e pesquisa. Os edifícios foram implantados com maior distanciamento entre si, tornando a ocupação de baixo adensamento e propiciando aumento nos deslocamentos realizados pela comunidade.

Carvalho (2005, p. 63) destaca que as unidades destinadas ao setor de aulas teóricas II, III, IV e $V$ tiveram suas locações deslocadas noventa graus em relação à implantação do setor I. Explica que a modificação visava melhorar o conforto térmico das salas de aula, já que o novo posicionamento direcionava as aberturas aos ventos predominantes de sudeste. A solução, entretanto, contraria estudos realizados com vista à adequação climática dos edifícios para a Região Nordeste (SILVEIRA et al, 2010; OLGYAY, 1998; BITTENCOURT e CÂNDIDO, 2008; dentre outros). É recomendável que a forma alongada do edifício esteja posicionada no eixo leste-oeste, de maneira que as maiores fachadas fiquem voltadas para a orientação norte e sul e dessa maneira os ventos dominantes de sudeste possam atravessar a edificação. A tipologia do setor de aulas teóricas constitui-se em um arranjo de blocos de mesma altura agrupados por uma circulação central, o que mereceria um estudo detalhado, pois as formas do fluxo de ar ao redor das construções são principalmente determinadas pela sua distribuição espacial (BITTENCOURT e CÂNDIDO, 2008, p. 53). 


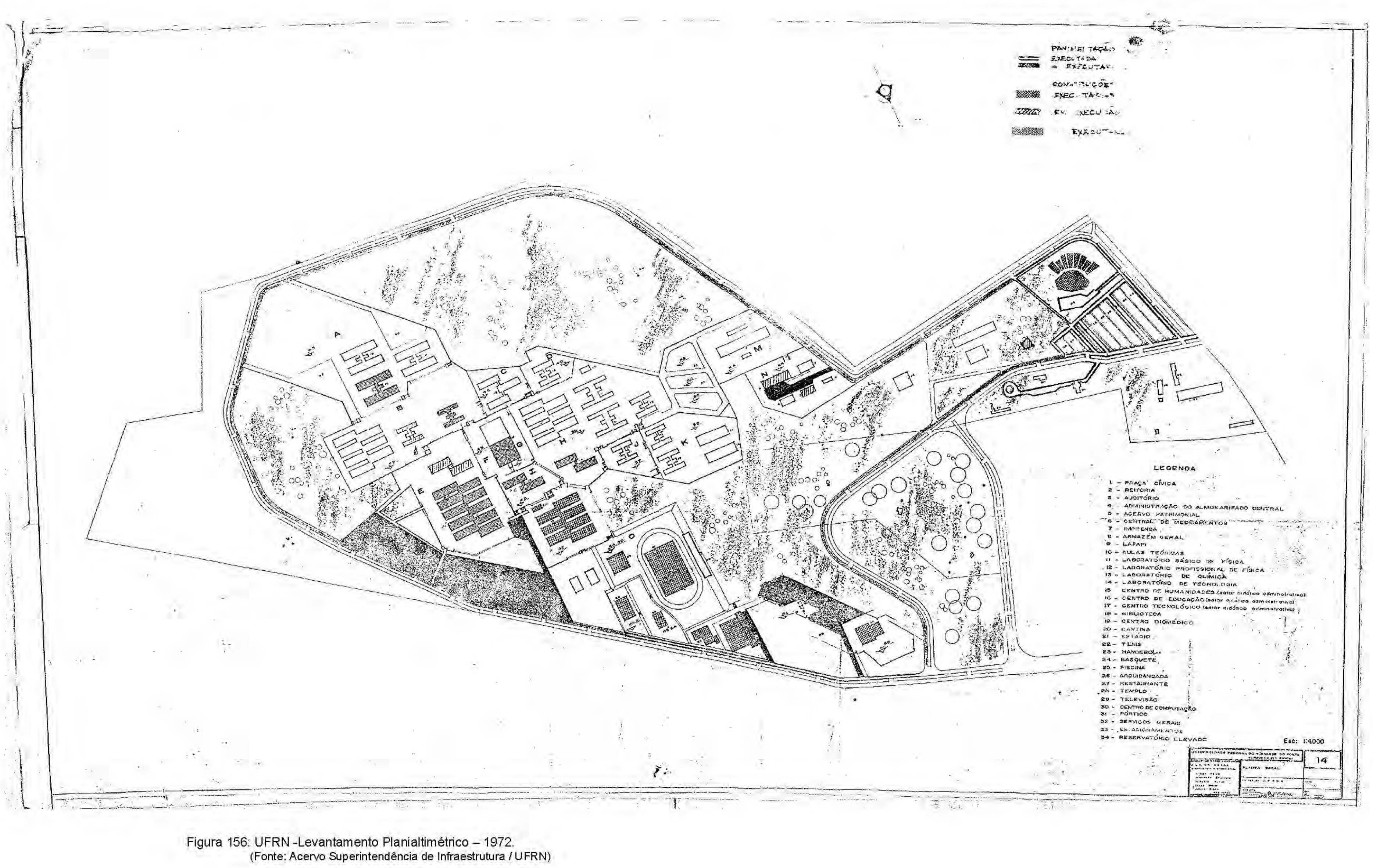




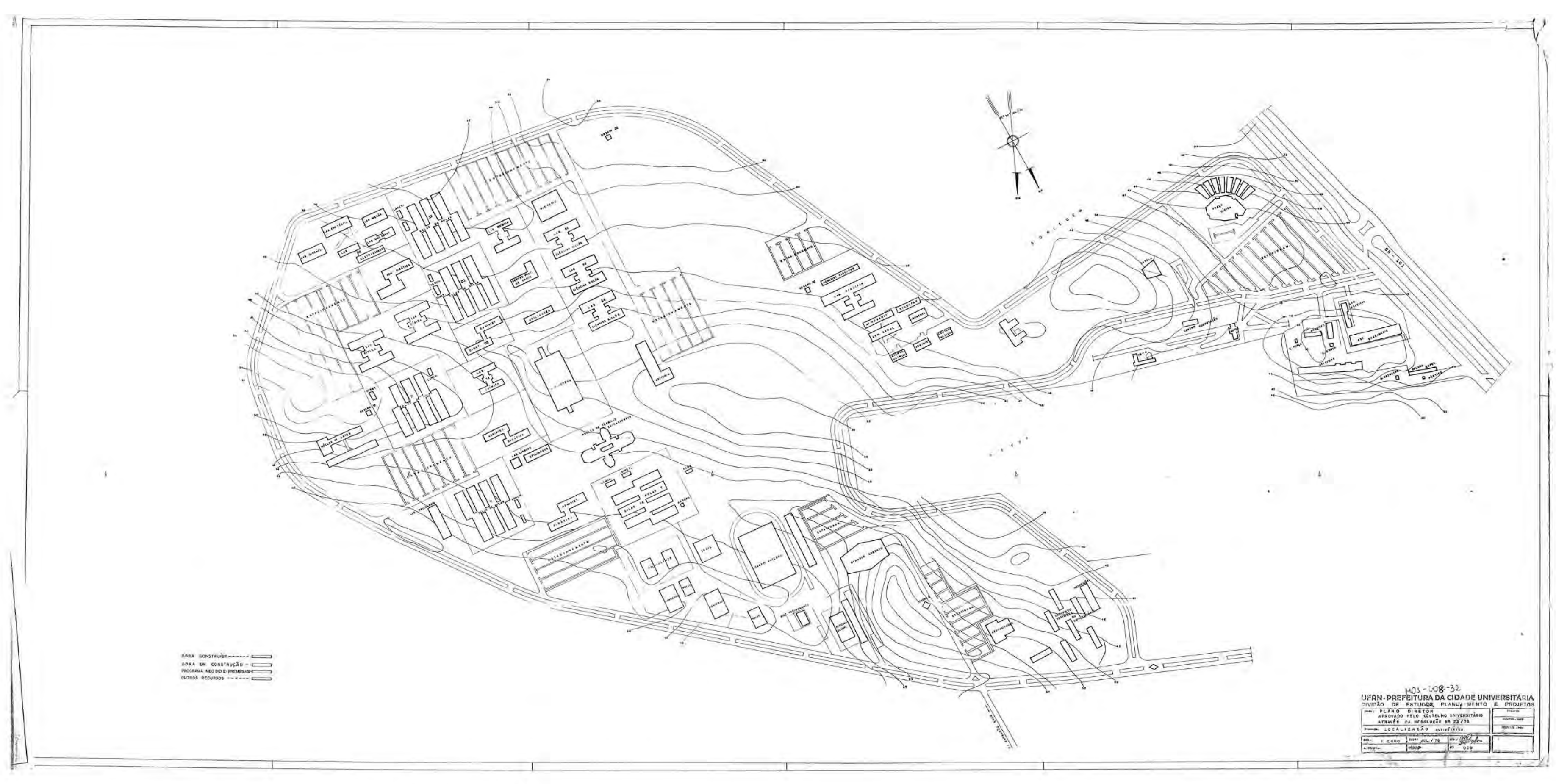

Figura 157: UFRN - Plano Diretor - julho de 1976

Aprovado pelo Conselho Universitário, a proposta mantém o zoneamento funcional inicial e incorpora um novo arranjo às tipologias do setor de ensino e pesquisa, (Fonte: Acervo Superintendencia de Infraestrutura / UFRN) 


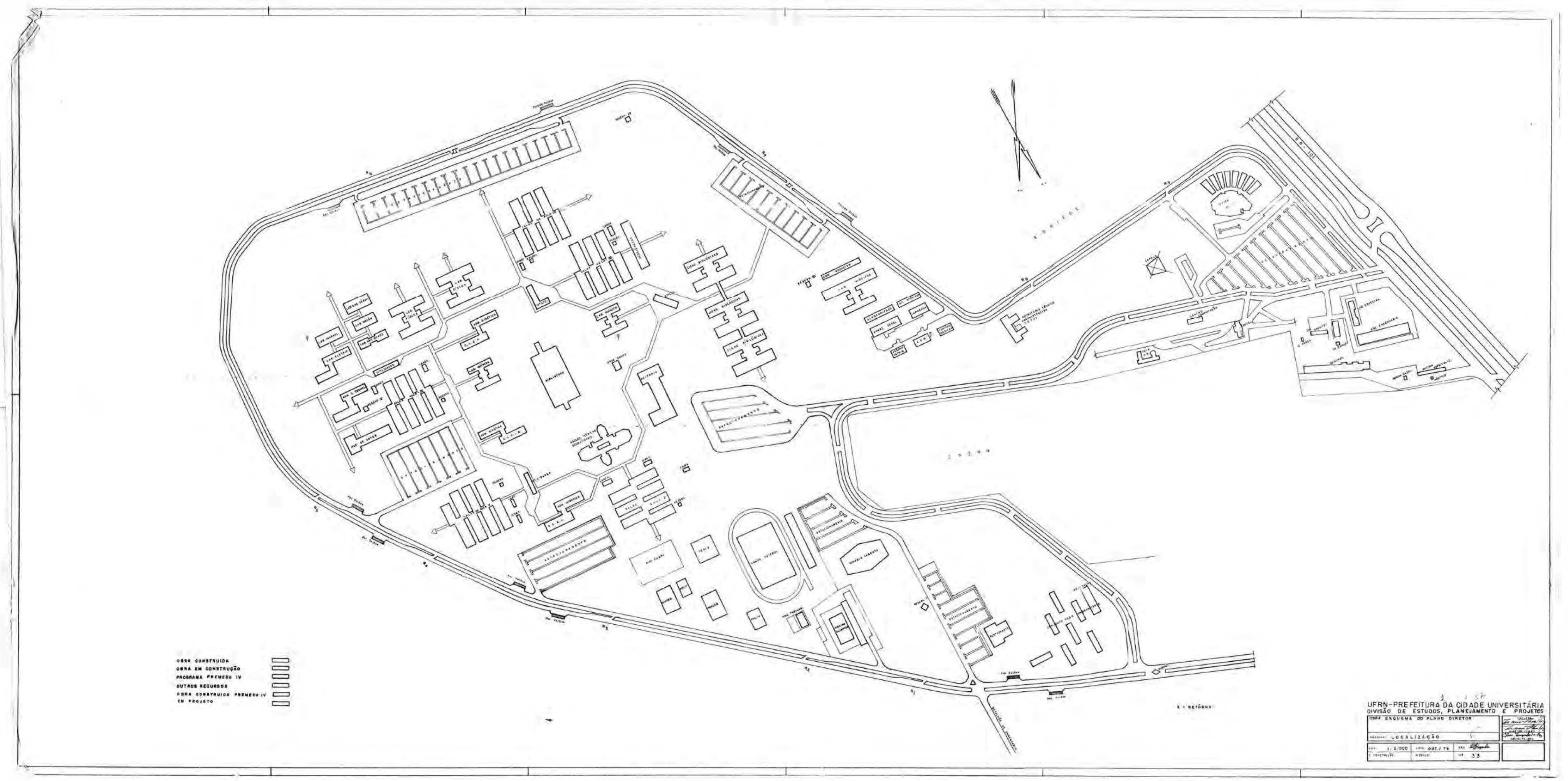

Figura 158: UFRN - Plano Diretor - outubro de 1976.

A proposta incorpora as vias de pedestres, criando um esquema de circulaçăa interna ao setor de ensino e pesquisa. 
A planta da figura 159 registra o Plano de 1976 que manteve a concepção das cinco zonas funcionais, nos permitindo afirmar que o campus universitário da UFRN seguia 0 curso indicado pelo modelo de território da Reforma Universitária de 1968. Entretanto, nenhuma das concepçōes referenciadas foi concluída na integra. Várias modificaçōes foram ocorrendo no decorrer dos anos seguintes, realizadas por arquitetos de outros Estados, como também por profissionais da Universidade, através do Escritório Técnico Administrativo (ETA) e da Prefeitura do Campus, setores que gerenciaram toda a construção do Campus, desde entâo (CARVALHO, 2005, p. 62).

A gradativa ocupação da gleba foi documentada por Carvalho $(2005$, p. 65$)$ nas plantas das figuras 160 e 161, que traçam a trajetória da construção do Campus e que conforme se pode constatar ao final de 1970, a configuração urbana, estruturada segundo o rígido zoneamento funcional, parecia indicar uma ocupação que se definia sem claras diretrizes de crescimento, conformando um território segmentado por vias de penetração que contornavam núcleos constituídos de edifícios isolados entre si (ver figura 162). A produção urbano-arquitetônica implantada contrariava assim a proposta de criar um complexo integrado propalado nos propósitos da Reform

\subsection{A PRODUÇÃO ARQUITETÔNICA DA REFORMA}

O conjunto edificado testemunha uma produção que procurava tornar perceptiveis os principios construtivos da obra arquitetônica e que, para Trigueiro (2008), encontra raizes no florescimento da proposta de viẻs Brutalista. Destaca que as ressonâncias dessa expressão arquitetônica no Campus evidenciam de modo exemplar as contradições embutidas na fase de disseminação internacional do Movimento, a começar pela implantação, estruturada segundo rígido zoneamento funcional. Adota-se, segundo Trigueiro (2008, p.64), o formato arquitetônico supostamente preconizado por um movimento de cunho renovador, em um contexto urbanistico contra o qual o mesmo movimento se contrapunha radicalmente.

Cabe esclarecer, ainda que sucintamente, que a atitude arquitetônica, cunhada com o termo brutalismo, pautava-se numa reação à ortodoxia do Movimento Moderno debilitada após a Segunda Guerra Mundial e que se concretizou na Europa nos anos de 1950.

Figura 160: UFRN - Mapa do Campus Central meados de 1970
(Fonte: SHELLA, 2005, p. 65)
Figura 161: UFRN - Mapa do Campus Central -

final de 1970.
(Fonte: SHELA, 2005, p. 65)
Figura 162: UFRN - Foto aérea do Campus Central - final de 1970 ,
(Fonte: Acervo Superintendência de
Infraestrutura / UFRN) 
Parte 2 - Universidade Federal do Rio Grande do Norte 
Resultou da postura crítica de jovens arquitetos europeus que denunciavam o afastamento dos arquitetos modernistas quanto aos princípios originais de honestidade construtiva e fidelidade aos requisitos programáticos, e contestavam a rigidez do paradigma modernista em relação às especificidades e identidades locais (TRIGUEIRO, 2008, p.63).

Contrariando o paradigma da máquina de morar, o Brutalismo teria se direcionado para uma manifestação em que buscava integrar o contexto local, o vernáculo, a expressividade de formas orgânicas e escultóricas, a estrutura do edifício aparente, a valorização dos materiais e o destaque dos componentes construtivos. No Brasil, segundo Bastos (2003, p. 6), esta arquitetura caracterizou-se pela ênfase na verdade construtiva - levando à exposição da estrutura, em geral em concreto, das alvenarias de vedação, feitas em tijolos ou blocos de concreto, das tubulações - e pela aspiração à industrialização da construção e ao desenvolvimento técnico. Complementa que na proposta urbanística, a rigidez do zoneamento modernista perdeu espaço para a noção de ambiente urbano, passando a considerar o edifício integrado ao contexto topográfico e urbano, e a ideia de lugar passou a ser corrente. Infere que é nesse período que ganha status a expressão formal arquitetônica desenvolvida pela chamada Escola Paulista, cuja linguagem reuniria características da vertente brutalista internacional e aceita como uma das manifestações mais relevantes e de alta qualidade da arquitetura moderna brasileira do século XX.

No Campus da UFRN, o repertório formal adotado na produção edilícia dos anos 1970 , encontra segundo Trigueiro um viés brutalista ainda que com características de acomodação local. Fazem parte desse conjunto os primeiros edifícios de autoria do arquiteto Alcyr Meira e sua equipe, com as obras iniciadas em 1972. O Restaurante Universitário, o Setor de Aulas Teóricas I, o Setor Didático-Administrativo e os Laboratórios são representativos desse período, constituindo-se de exemplares com mesmas características construtivas, em que se destacam a presença do concreto aparente em vigas, lajes e platibanda da coberta, o predomínio da pedra natural em pilares e planos verticais de vedação, os quais se conjugam ora com esquadrias de alumínio e vidro, aplicados de piso a laje, ora com panos de combogó. Predomina o forte contraste dos materiais, que permite tirar conclusões sobre a intenção de conceber uma arquitetura que mostrasse os princípios lógicos que serviam de fundamento à obra, muito embora o resultado demonstre um conceito mais estético do que ético.

No mesmo viés arquitetônico, a produção de profissionais e empresas de outros Estados tais como a do arquiteto paulista Antônio Carlos Bross, responsável pelo projeto do prédio da Reitoria e dos blocos para o Centro de Biociências, dentre outros, e a do arquiteto 
natalense João Maurício Fernandes de Miranda, com a planta da capela que compõe a Praça Cívica, são exemplares que marcam a produção do Campus da UFRN nos anos 1970. A investigação desse conjunto arquitetônico é foco de nossas análises e segue no texto de acordo com a cronologia de execução da obra. Apoiada em plantas gráficas, fotos e depoimentos inferimos uma investigação referente às ideias formais, espaciais e funcionais exploradas no projeto arquitetônico.

\section{- Restaurante Universitário}

O Restaurante Universitário apresenta uma forma arquitetônica dominada pela coberta com laje de concreto aparente em forma de calhas triangulares de vértices invertidos para baixo e que se pronuncia para fora do corpo do edifício. Como numa extrusão, o plano triangular se expande longitudinalmente e extravasa as superfícies de contorno externo do edifício, criando uma volumetria de forte efeito plástico e que, embora apoiada na viga superior da borda, transmite a sensação de carga excessiva sobre os apoios estruturais. A grande massa da coberta contrasta com as superfícies de vedações compostas por planos de esquadrias de alumínio e vidro na fachada de maior dimensão e por alvenarias de pedra adotadas em vários panos das demais, anulando qualquer intenção de leveza na composição formal. Observa-se ainda que o projeto procura tirar partido das descidas de águas pluviais, deixando a tubulação de escoamento aparente, por onde a água descendo em queda livre é recolhida em caixas de pedra, constituindo-se em mais um elemento compositivo da fachada (ver figura 163).

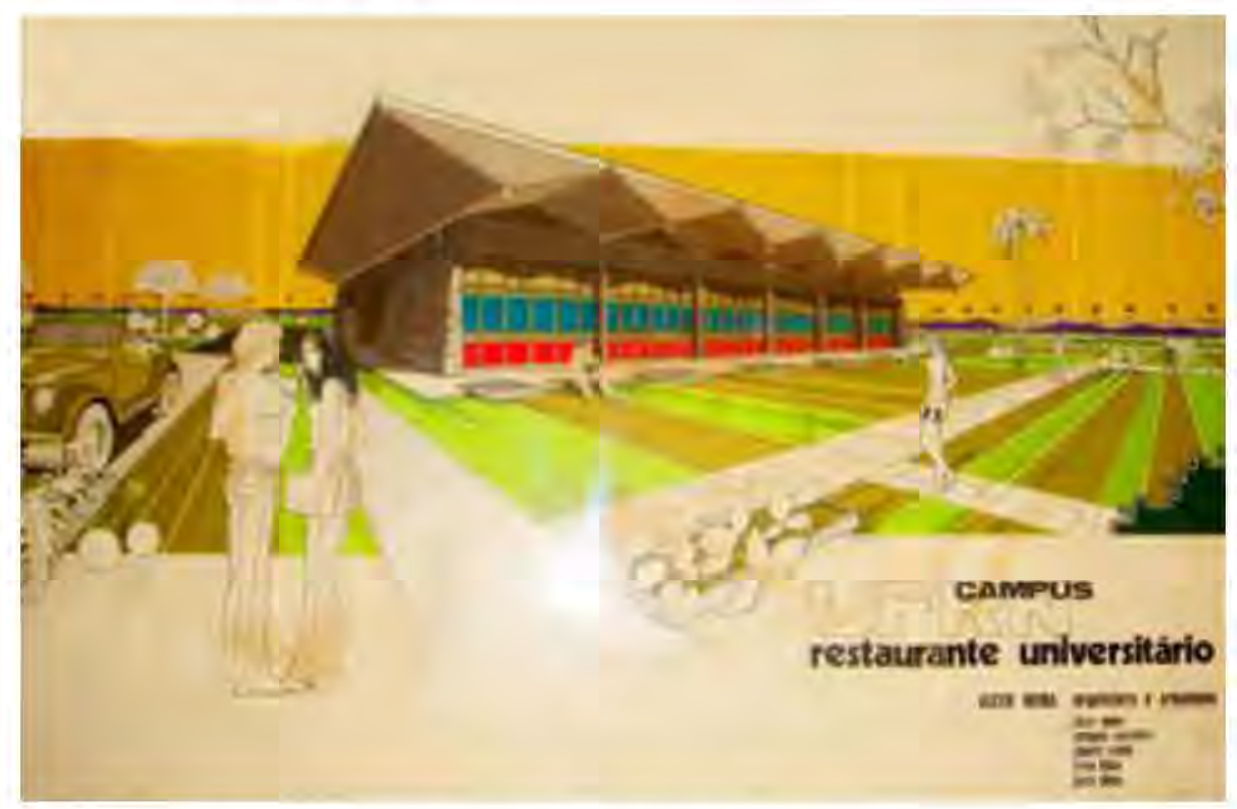

Figura 163: UFRN - Ilustração do Restaurante Universitário.

A proposta arquitetônica se destaca pela coberta de caráter monumental sobre o corpo do edifício projetado com vedações em alvenaria de pedra natural e painéis em estrutura de alumínio e vidro.

(Fonte: Acervo pessoal Alcyr Meira) 
O programa arquitetônico está organizado funcionalmente em duas áreas principais refeitório e serviços - que conformam um espaço voltado para o interior da edificação. $O$ refeitório é formado por um vão livre com dimensões de $13,20 \mathrm{~m} \times 38,00 \mathrm{~m}$, fachada principal - onde predomina o uso da pedra em piso e paredes, contrapondo-se aos rasgos padronizados das esquadrias de vidro e alumínio (ver planta do edifício na figura 164). Embora não tendo tido acesso ao interior do referido ambiente, o uso da esquadria maximar conjugada com a ausência de aberturas opostas, nos faz levantar a suspeita de que a ventilação não ocorra com intensidade suficiente para proporcionar boas condições de conforto térmico. O setor de serviços por sua vez possui um programa complexo que contempla as necessidades de uma cozinha com a produção de refeições em quantidade.

A arquitetura do Restaurante Universitário resultou numa proposta arquitetônica que tentava conciliar as ressonâncias da estética de viés brutalista com elementos de cunho construtivo local, embora adoções como a das esquadrias contrariem a intenção de uma arquitetura sintonizada com as condições climáticas da região. $O$ arquiteto Meira, convicto da importância de uma produção institucional embasada pelos propósitos de racionalização, ausente de monumentalidade e que viesse a refletir a verdade construtiva local projetou, entretanto, um edifício que mescla o monumental com revestimentos construtivos que tentam incorporar a imagem de uma produção de características regionais (ver figura 165).

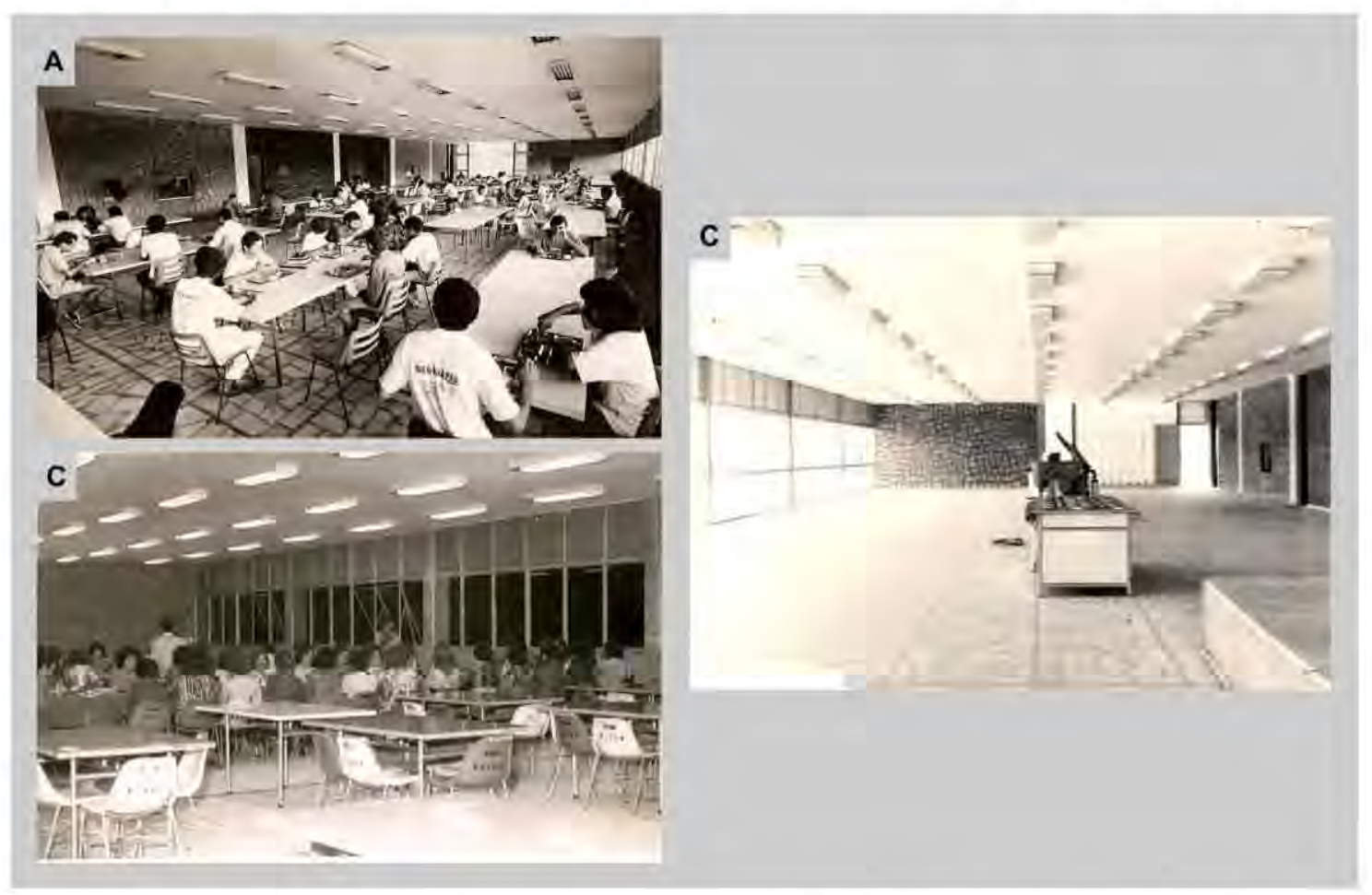

Figura 164: UFRN - Restaurante Universitário do Campus da UFRN - Primeira metade da década de 1970.

(A), (B) e (C) Fotos do refeitório. $O$ arquiteto aplica a pedra natural em piso e parede. A compacidade da pedra contrapõe-se à transparência dos painéis de alumínio e vidro.

(Fonte: Acervo AGECOM / UFRN) 


\section{- Setor de Aulas Teóricas I}

O Setor de Aulas Teóricas compõe-se de um conjunto de blocos térreos padronizados que se unem por uma circulação central em forma de passarela coberta. Trata-se de uma tipologia que foi adotada como edifício padrão para atender às aulas teóricas dos respectivos Centros. Ao todo foram edificados cinco setores no decorrer da década de 1970 . Embora sua concepção possa ser referenciada na ideia de um sistema pavilhonar, sua construção ocorreu a partir de um conjunto autônomo de unidades integradas por uma circulação coberta, onde cada conjunto formava um núcleo independente, implantado em diferentes áreas do Campus.

O primeiro exemplar, Setor de Aulas Teóricas I, foi construído no reitorado de Genário Alves Fonseca, ou seja, no período de 1971 a 1975 . O conjunto possui sete blocos de formato retangular organizados longitudinalmente em duas alas que se unem pela circulação central, ficando quatro unidades ao norte e três ao sul do eixo circulatório (ver figura 166).

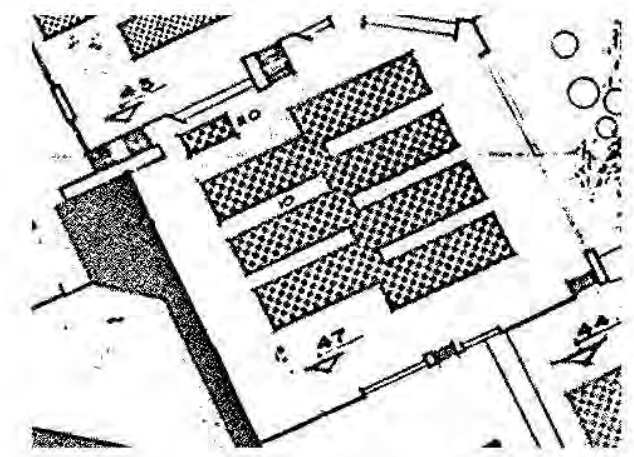

Figura 166: UFRN - Setor de Aulas Teóricas I

Blocos padronizados articulados pela circulação da passarela.

(Fonte: Acervo Superintendência de Infraestrutura / UFRN)

O programa de necessidades, que abrange seis salas de aulas e uma bateria de sanitários masculinos e femininos, distribui-se na planta livre obedecendo a uma sequência linear de divisórias removíveis que estão compatibilizadas com a malha estrutural concebida com dimensões de $6,20 \mathrm{~m}$ de eixo a eixo (ver projeto nas figuras 167 a 169). A proposta indica o intento de possibilitar alterações na organização espacial, criando novos arranjos funcionais. A solução estava embasada pelo conceito da flexibilidade defendido pelo arquiteto para os projetos universitários e que eram recomendados no Manual de Atcon (1970). Para Meira, a flexibilidade assim estabelecida estava coerente com a dinâmica da nova estrutura universitária. 
I1

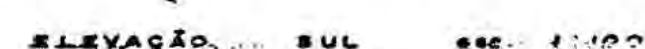
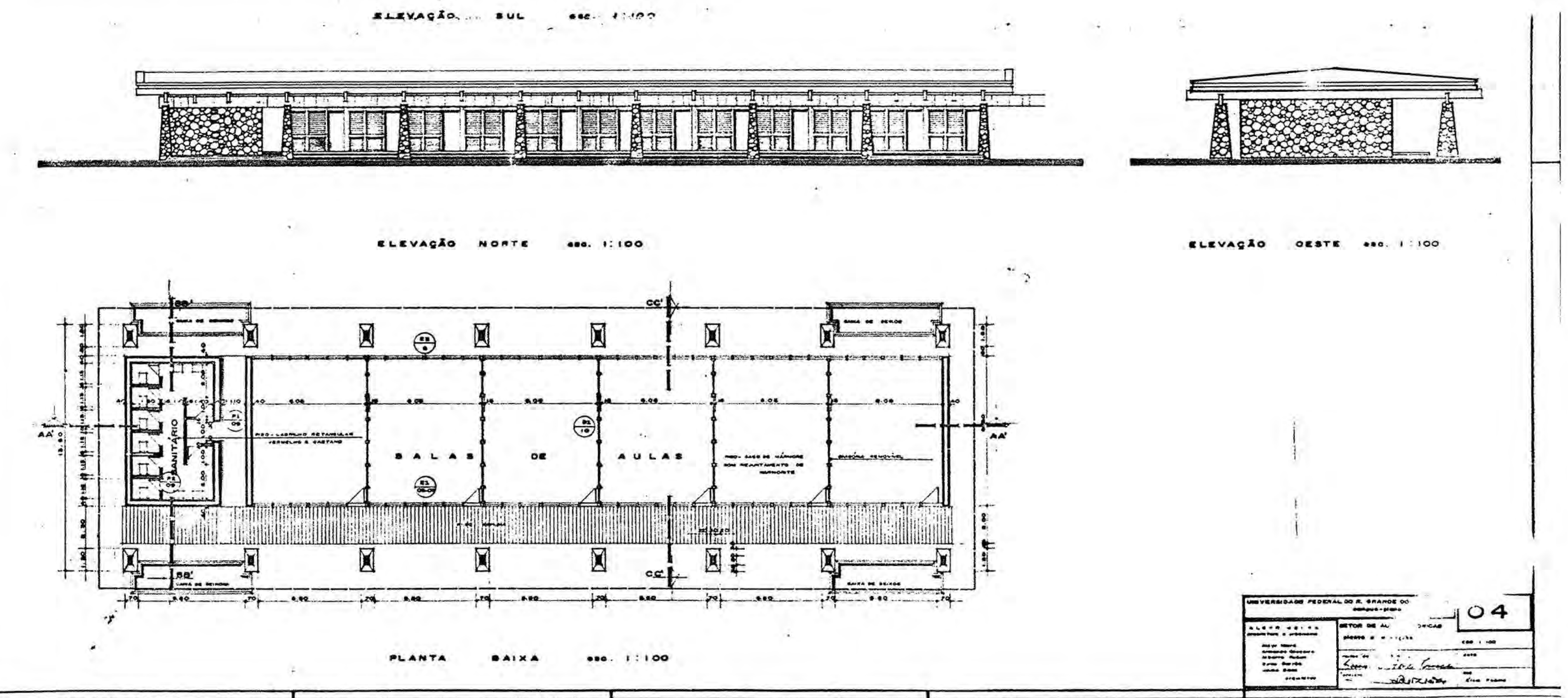

Figura 167: UFRN - Setor de Aulas Teóricas I - Projeto de Arquitetura / Planta 


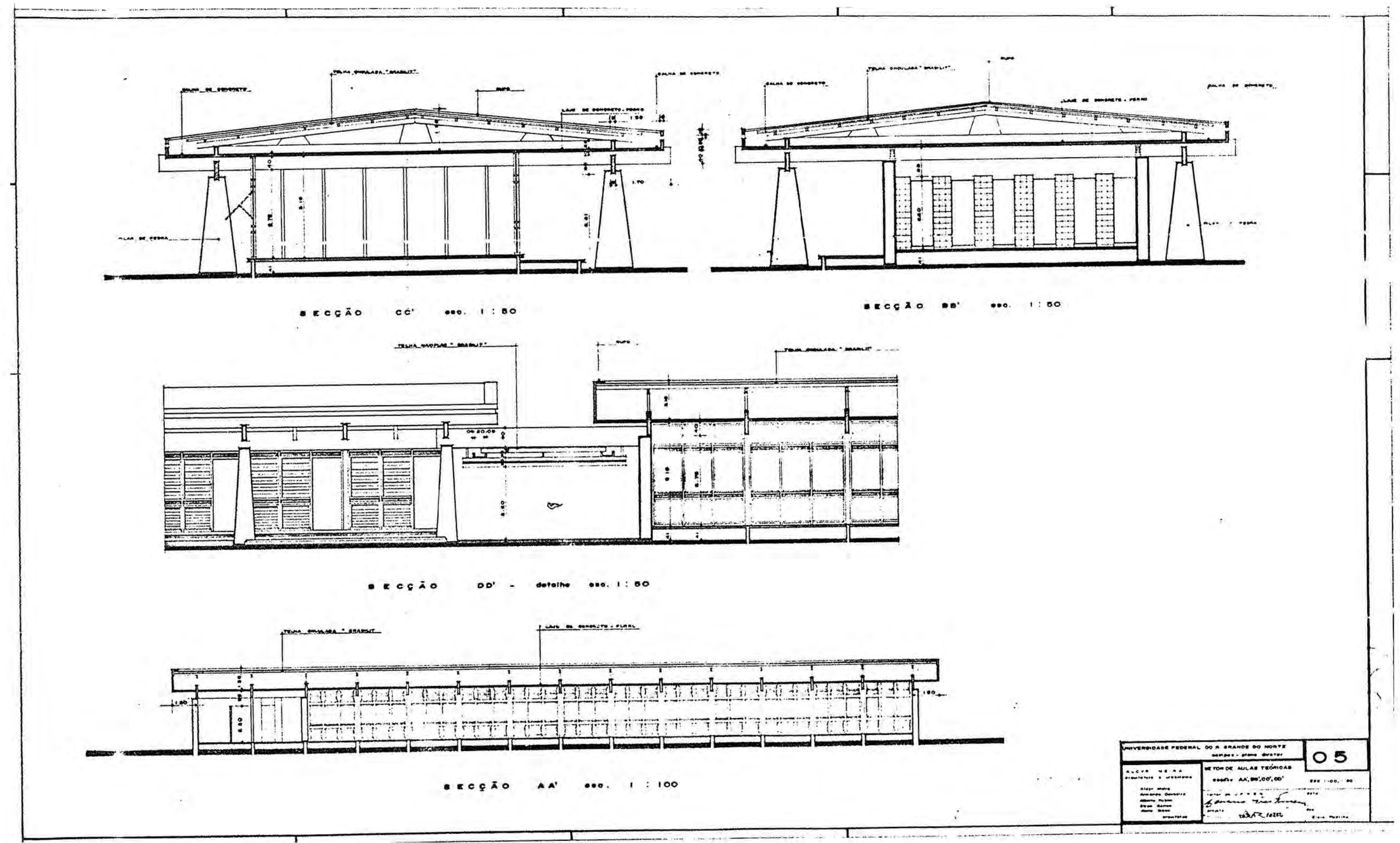

Figura 168:UFRN - Setor de Aulas Teóricas I - Projeto de Arquitetura / Cortes.
(Fonte: Acervo Superintendeñncia de Infraestrutura / UFRN) 


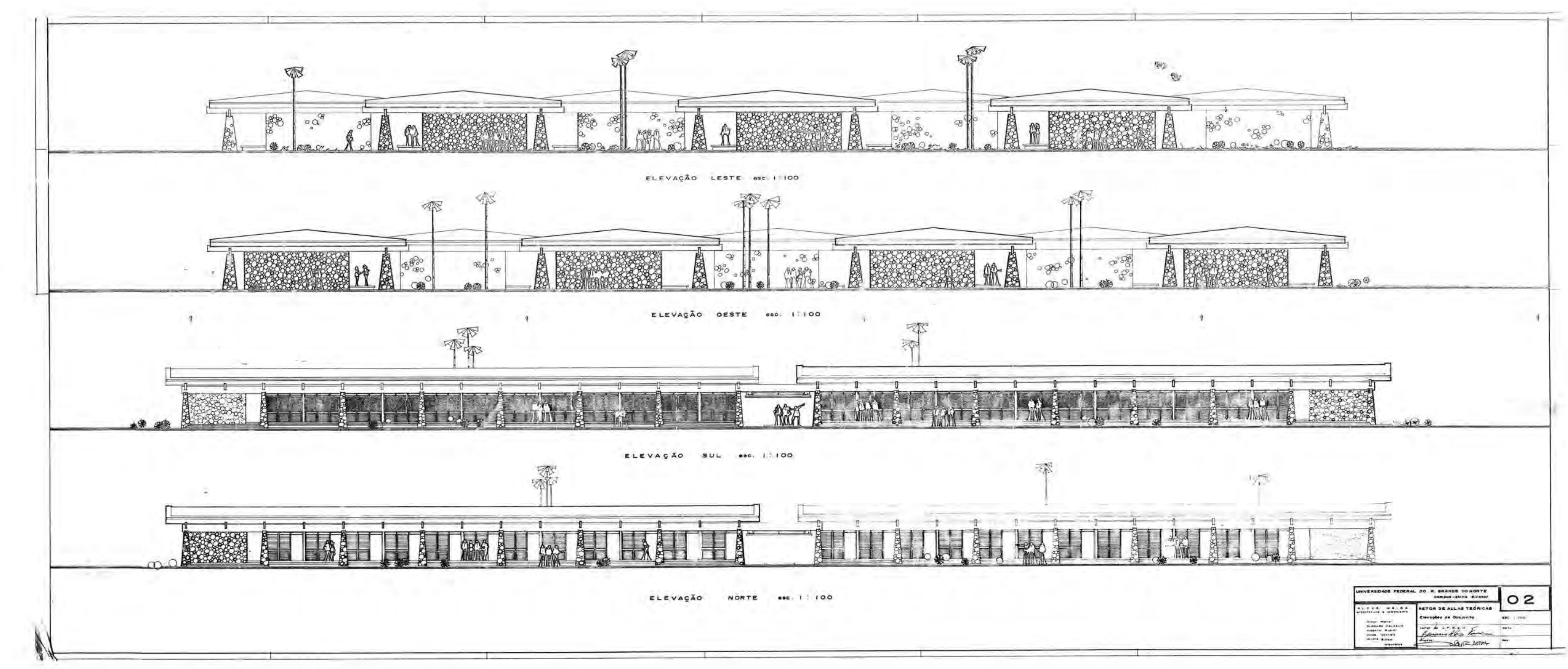

Figura 169:UFRN - Setor de Aulas Téricas I - Projeto de Arguitetura / Fachadas.
(Fonte: Acervo Superintendênncia de Infraestrutura / UFRN) 
O acesso às salas se dá por meio da circulação lateral aberta ao exterior que, assim como o uso da varanda nas residências do Nordeste, desempenha uma transição entre o rigor climático externo e a temperatura do ambiente. Os limites do edifício são definidos pela projeção da platibanda que se estende além da área construída. Uma laje plana coberta por duas águas de telhas de fibrocimento forma calhas impermeabilizadas nas extremidades que também desempenham o papel de beirais ao longo das fachadas norte e sul, associada à empena triangular das fachadas leste e oeste. A solução de sombreamento com vistas ao conforto térmico é, entretanto, neutralizada pelo modelo da esquadria adotada que não proporciona o uso da ventilação cruzada - mecanismo de conforto térmico recomendado para regiões de clima quente-úmido.

A forma arquitetônica é mesclada pela volumetria de escala horizontal - reforçada pela linha da platibanda em concreto aparente que percorre o edifício longitudinalmente - pelos planos revestidos de pedra e pelo ritmo regular dos pilares, também de pedra, que se sobrepõe ao plano das esquadrias. $O$ projeto de Meira mostra a tentativa de se criar uma arquitetura de aspecto regional envolvida com o conceito estético de expor os princípios construtivos da obra. O resultado é uma arquitetura de proporções robustas, sem visível identidade com a paisagem local (ver figura 170 e 171).

Somando-se ao conjunto dos blocos padronizados encontra-se a passarela central concebida como uma complexa estrutura de concreto aparente onde vigas em balanço se apoiam entre si para garantir um espaço sem obstáculos à circulação dos usuários (ver figura 172). A solução da coberta de aspecto engenhoso não destoa do partido geral adotado, ao contrário, transforma-se em espaço integrador e de convivência entre os que por ali circulam (figura 173).

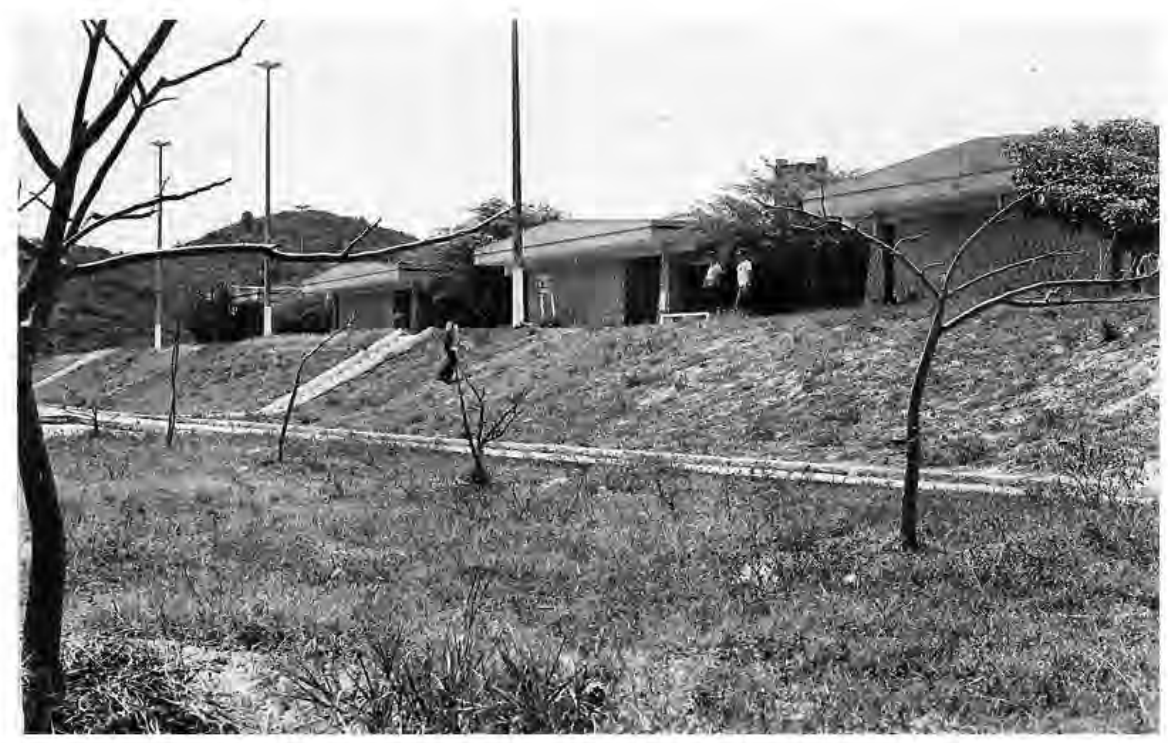

Figura 170: UFRN - Setor de Aulas Teóricas I - Primeira metade da década de 1970. (Fonte: Acervo AGECOM / UFRN) 


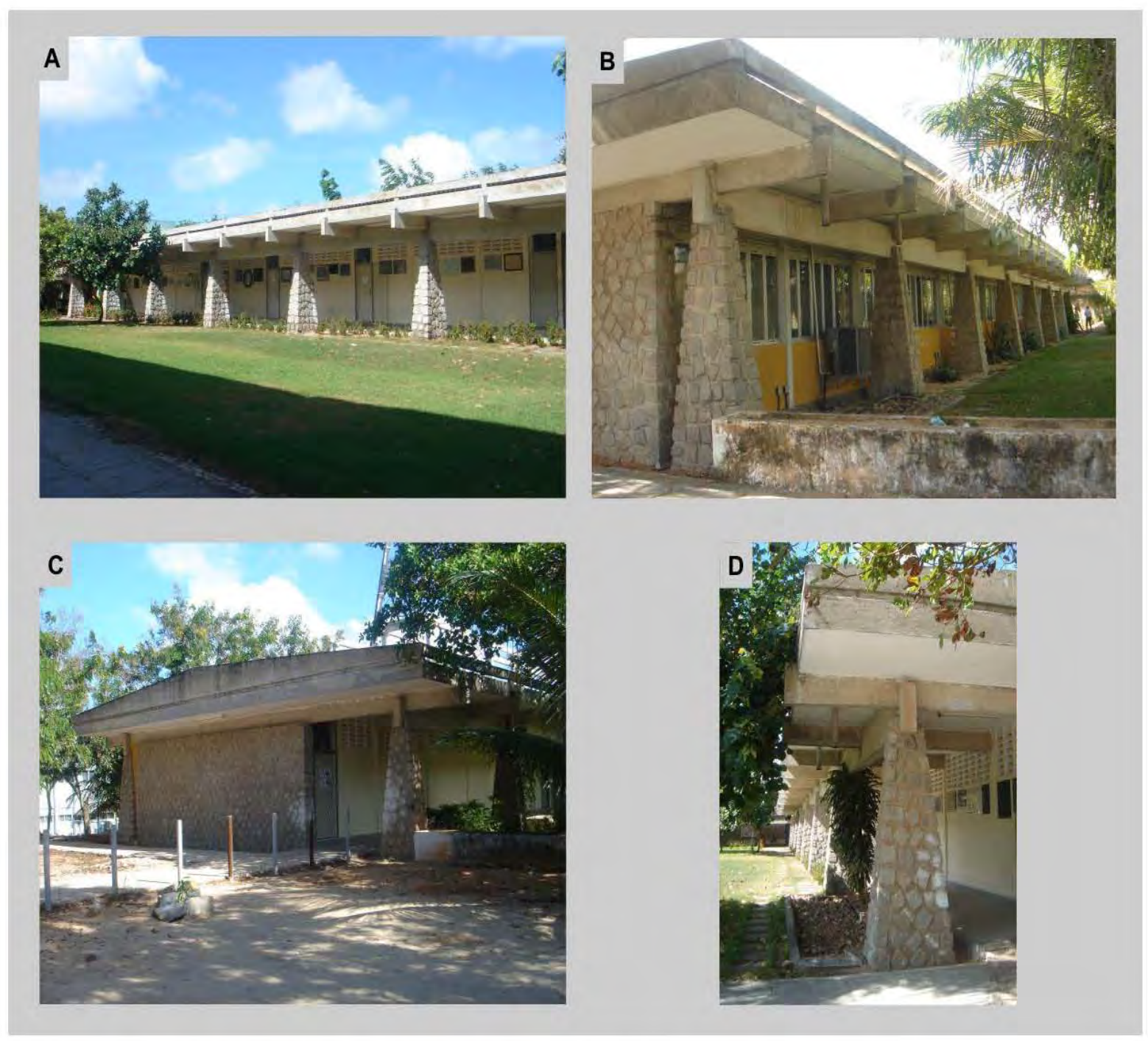

Figura 171: UFRN - Setor de Aulas Teóricas I - ano 2009.

(Fonte: Acervo Magda Campêlo, 2009)

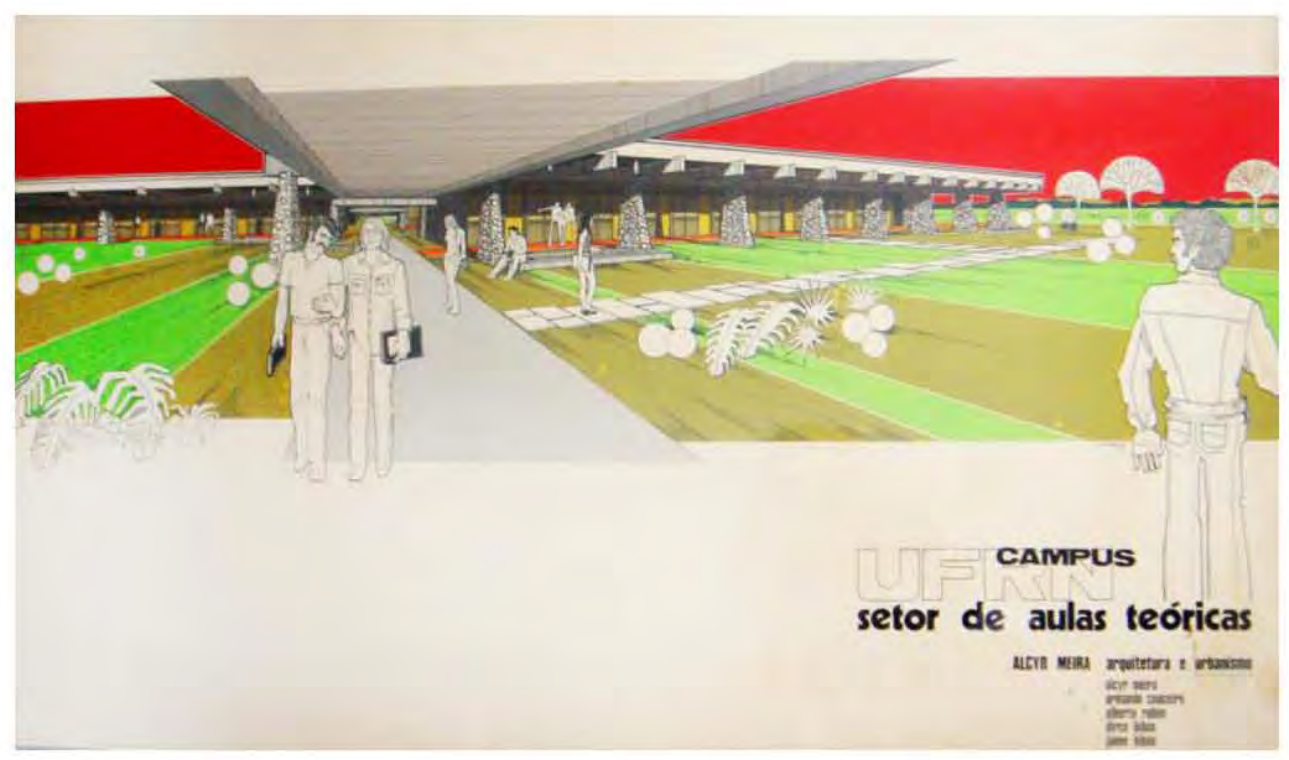

Figura 172: UFRN - Ilustração da Passarela do Setor de Aulas Teóricas. (Fonte: Acervo pessoal Alcyr Meira) 


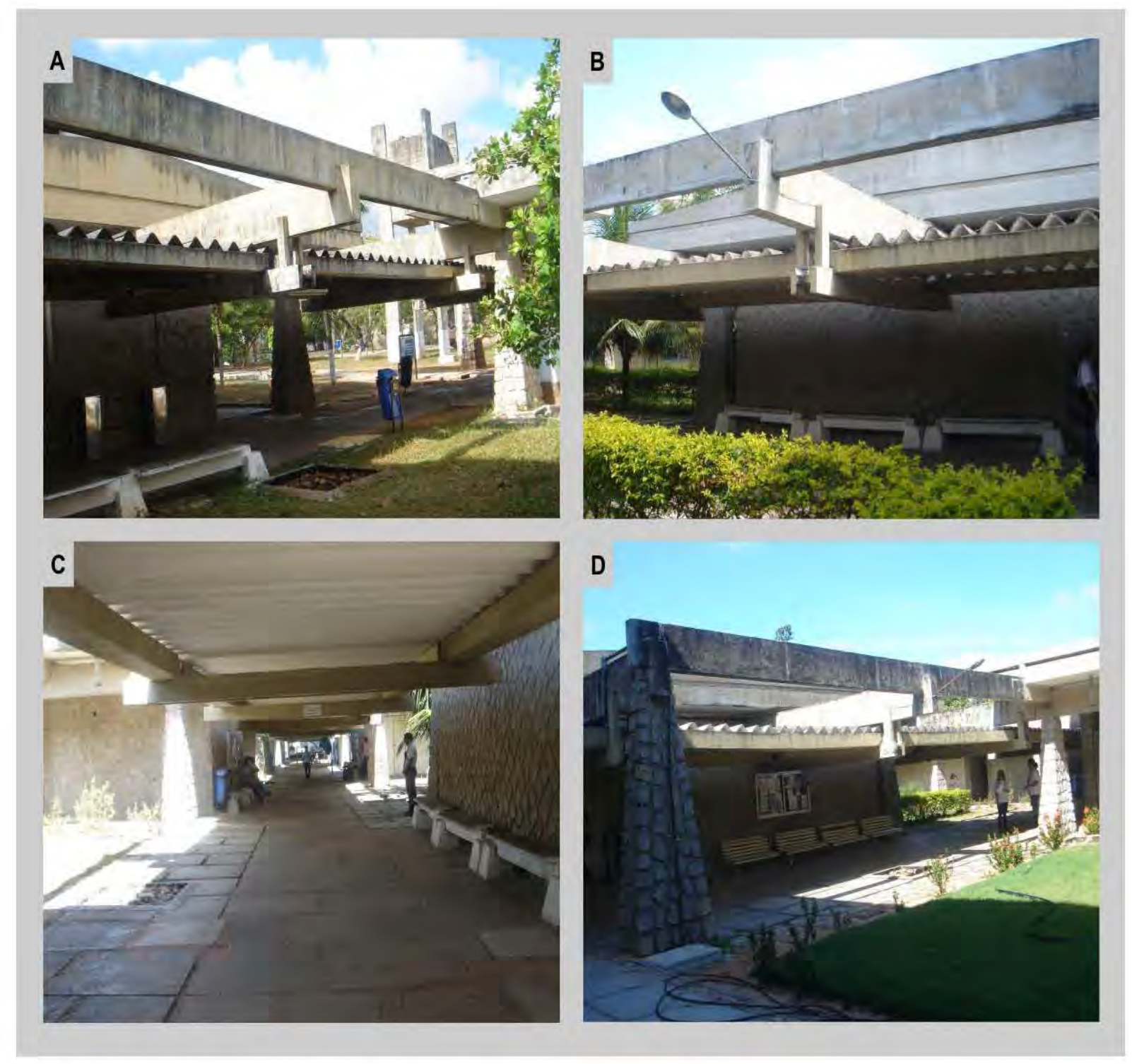

Figura 173: UFRN - Imagens da passarela do Setor de Aulas Teóricas.

(A) e (B) Detalhe da estrutura de concreto. (C) e (D) Detalhe da passarela com bancos para os usuários.

(Fonte: Acervo pessoal Alcyr Meira)

\section{- Setor Didático-Administrativo}

Atendendo ao modelo implantado pela Reforma (1968), baseado na estrutura departamental, os edifícios designados de Setor Didático-Administrativo foram projetados por Meira com a finalidade de abrigar as funções pertinentes aos departamentos criados pela nova estrutura. O programa incluía basicamente salas para professores organizadas na planta segundo um zoneamento funcional, de maneira que os ambientes concentravam-se por departamentos.

O setor didático-administrativo destinado aos departamentos de Química, Física e Matemática constituía-se de um bloco de dois pavimentos, dividido em duas plantas 
paralelas de configuração retangular, unidas na extremidade por corpo central composto de hall e escada de ligação ao pavimento superior, que desempenha a função de entrada e acesso aos departamentos, embora a identificação do acesso ao edifício não esteja claramente indicada.

Cada pavimento está abastecido por sanitários e serviços de copa e os ambientes se distribuem na planta formando duas alas longitudinais articuladas pela circulação central. Importante observar que as salas dos departamentos foram projetadas com áreas diferenciadas, cuja capacidade física estava relacionada ao potencial de horas contratadas para os professores, que poderiam ser de 12, 24 e/ou 40 horas. Quanto maior o número de horas contratadas, maior a área disponibilizada por professor, o que significava que 0 professor de 40 horas deveria ser contemplado com gabinetes individualizados, já que permanecendo maior tempo no campus sua carga de trabalho também era mais intensa, necessitando assim de maior espaço para conforto e concentração das suas atividades didáticas e de pesquisa. Observa-se ainda que não estavam previstos espaços de convivência e congregação, evidenciando, ao contrário, a concepção do isolamento e do privado.

A organização compartimentada da planta é regida pela modulação estrutural a qual submete as esquadrias e os elementos divisórios à padronização, revelando uma proposta construtiva embasada pelo princípio da racionalização ligada ao conceito da flexibilidade, onde alterações no programa de necessidades acarretariam menor custo financeiro e operativo das atividades (ver planta de arquitetura na figura 174).

A forma arquitetônica do edifício manteve a linguagem dos materiais - pedra, concreto aparente e elementos divisórios com estrutura de alumínio - adotados nos outros projetos. $O$ arquiteto, no entanto, não conservou o partido da coberta com platibanda. Ao contrário, expõe a telha de fibrocimento ondulada com beirais que, pelas dimensões, não parece trazer sombreamento às fachadas. Utiliza o recurso de elevar a telha da laje, para assim minimizar o acúmulo de ar quente decorrente, dentre outros, da baixa inclinação da telha, associada ao calor irradiado pelo fibrocimento (ver figura 175 a 177). A predominância prismática do edifício, reforçada pela modulação reguladora das vedações verticais, que fica exposta à radiação solar direta, levanta dúvidas quanto à adequação da proposta arquitetônica às condições climáticas do lugar. Meira parece mais convicto da relevância de apresentar uma feição que incorporasse modernidade ao edifício proposto pela Reforma (1968). 


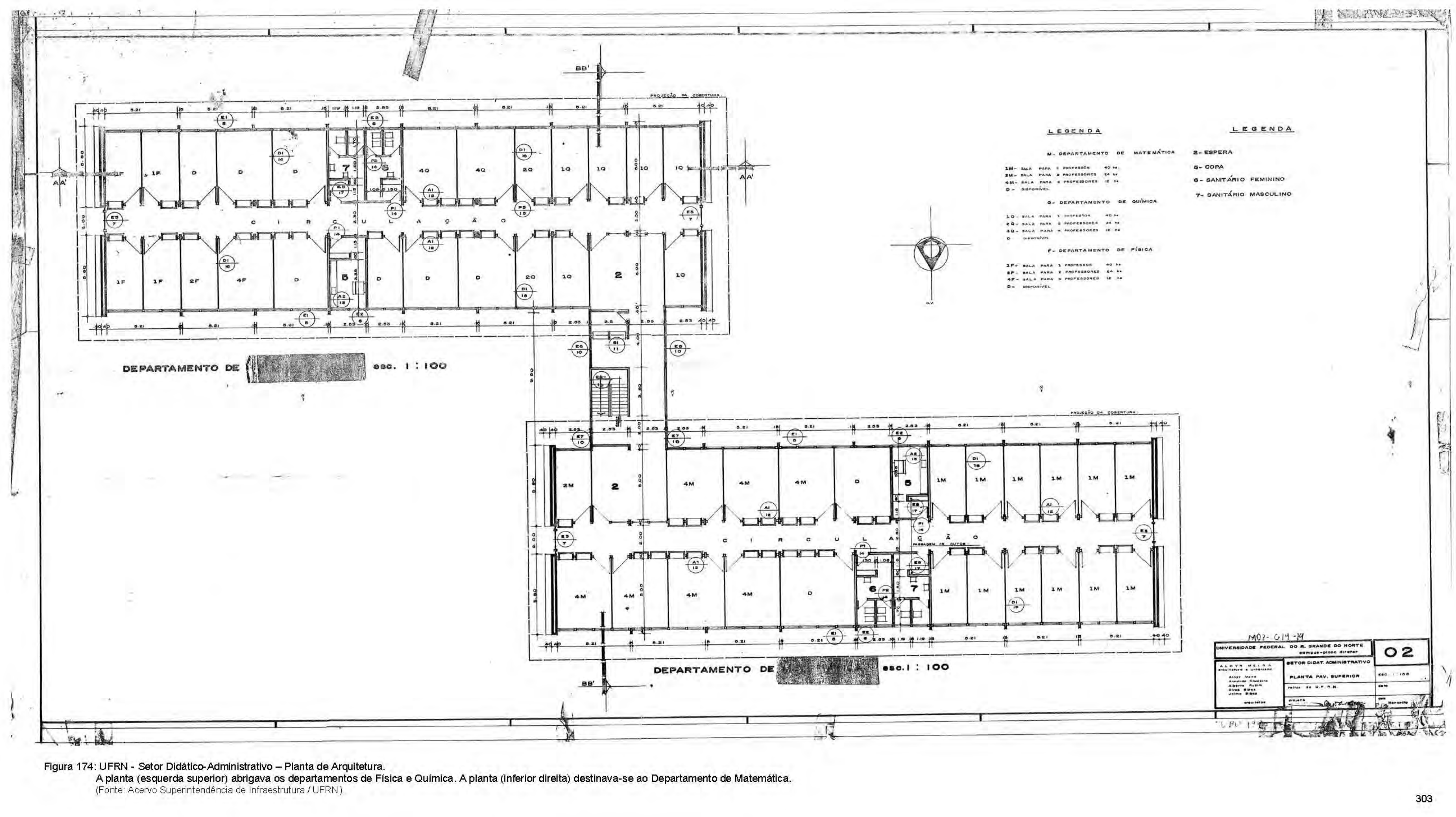


Parte 2 - Universidade Federal do Rio Grande do Norte 


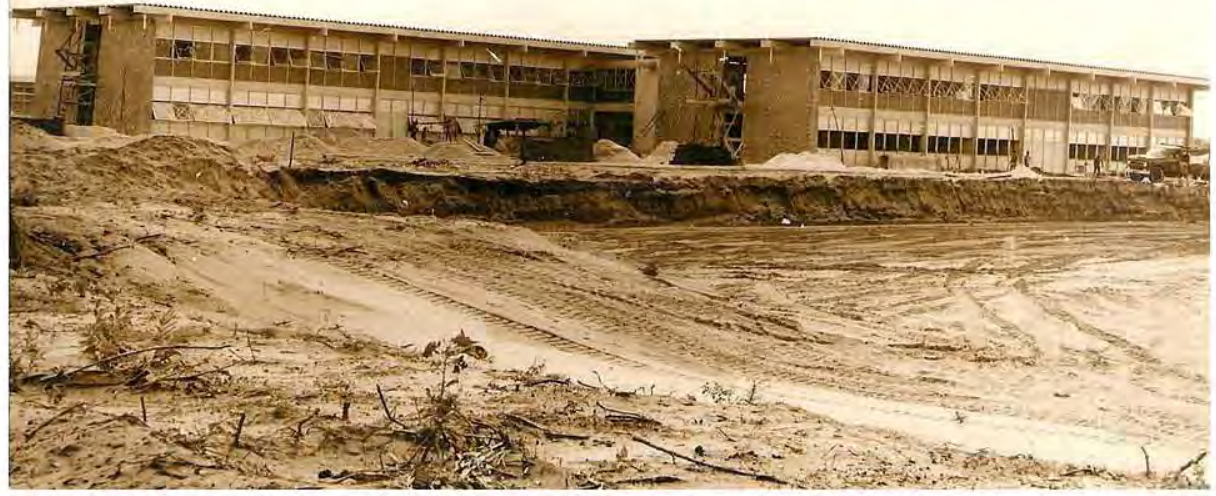

Figura 175: UFRN - Setor Didático-Administrativo - Primeira metade da década de 1970 .

(Fonte: Acervo AGECOM / UFRN)

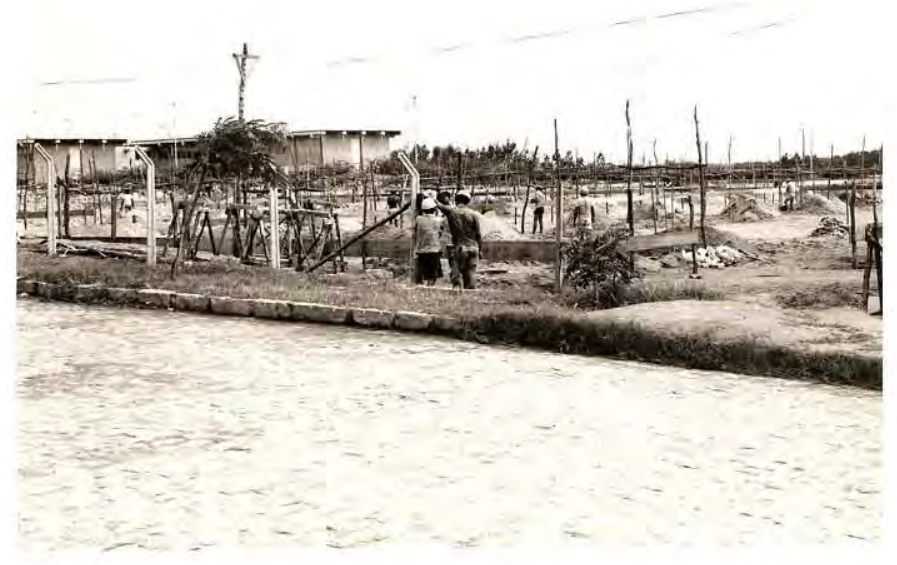

Figura 176: UFRN - Setor Didático-Administrativo Canteiro de obras.

(Fonte: Acervo AGECOM / UFRN)

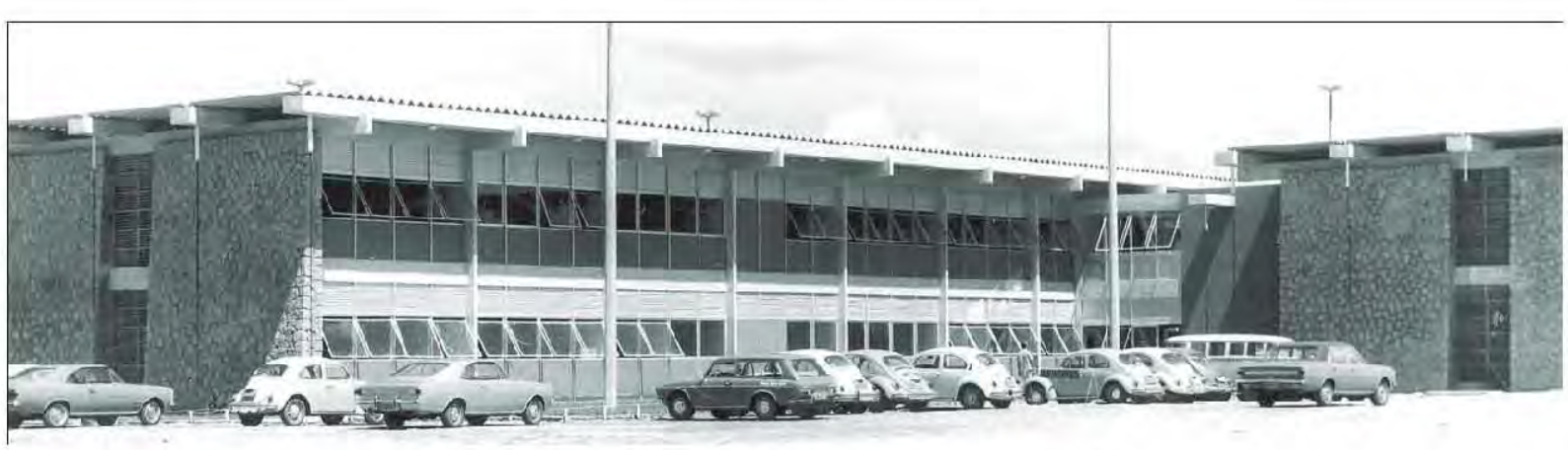

Figura 177: UFRN - Prédio da antiga Escola de Serviço Social - ano 1971.

(Fonte: LIMA e MELO, 1971 apud TRIGUEIRO, 2008, p. 53) 


\section{- Blocos de Laboratórios}

Os edifícios projetados por Meira para abrigar os laboratórios de Física e Química apresentam um partido funcional onde o programa de necessidades se distribui na planta constituída por duas alas laterais paralelas unidas por outra transversal centralizada, resultando numa organização em forma de "H" (ver projeto de arquitetura nas figuras 178 a 180). O arranjo funcional, rigorosamente simétrico, é mantido pela volumetria que embora com pé-direito diferenciado, onde a ala central se destaca com altura superior, criando uma hierarquia, que, entretanto, não altera o aspecto de equilíbrio do conjunto. Ao contrário, reforçado pela presença da marquise - elemento que marca a entrada do edifício - situada no centro do arranjo volumétrico e pelos planos da coberta definida pela platibanda de linhas horizontais, o partido arquitetônico é regido pelos princípios da horizontalidade e da simetria (ver figuras 181 e 182).

Meira repete a proposta da coberta que transborda os limites da planta criando assim beirais generosos que possibilitam o sombreamento nas fachadas. Também a circulação aberta ao exterior é mantida como solução de acesso aos ambientes, proporcionando, ao mesmo tempo, uma interface entre o espaço exterior e o espaço confinado. Outro aspecto a ser destacado refere-se à adoção da padronização sobre os elementos que compõem o corpo do edifício: alvenaria de pedra, painéis divisórios com estrutura de alumínio, coberta com telhas de fibrocimento sobre laje plana e vigas-calha em concreto aparente, caixas de seixos rolados para recolhimento de águas pluviais, dentre outros, são elementos que se repetem articulados pela malha modulada da estrutura de vigas e pilares, evidenciando uma proposta embasada pelos princípios da racionalidade construtiva. Da mesma forma que nos demais projetos, a arquitetura que resulta reflete a preocupação do arquiteto com as condições do lugar que, entretanto não chega a ser uma referência local.

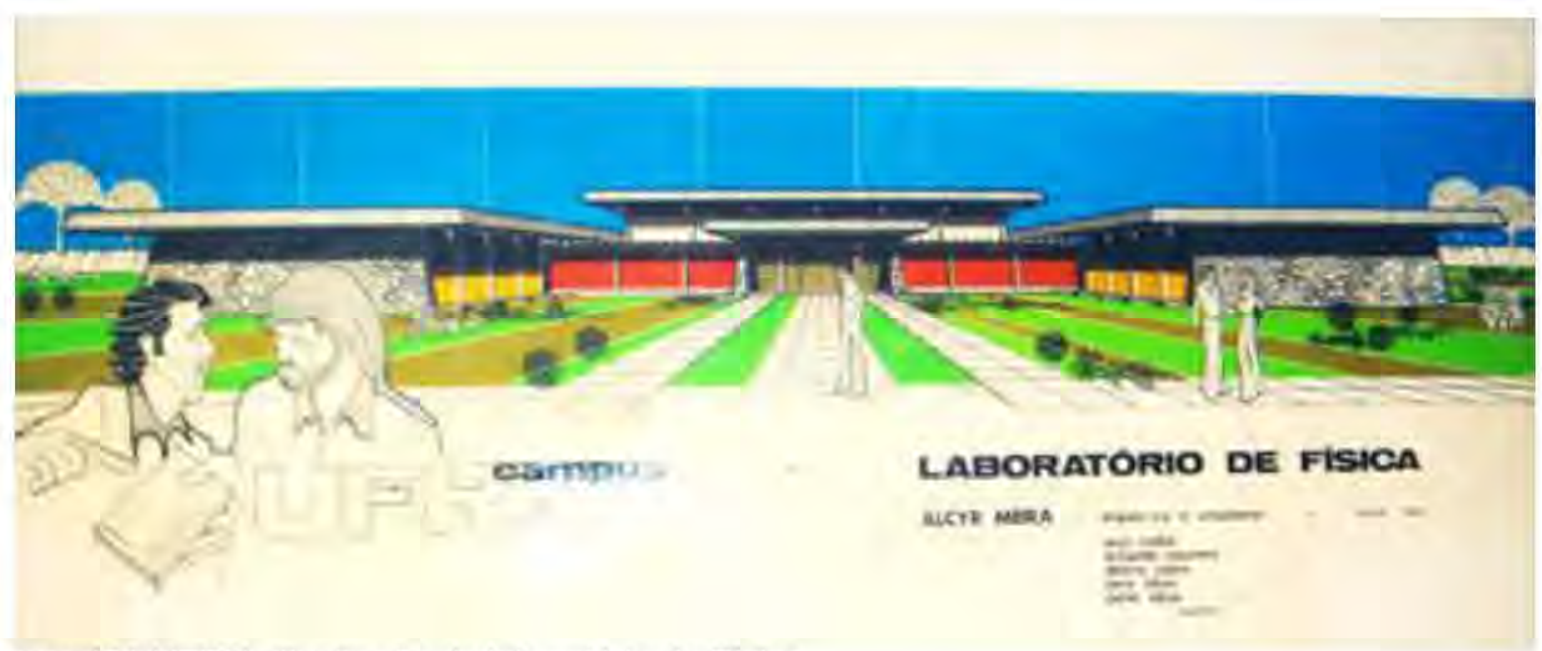

Figura 181:UFRN - Ilustração do laboratório de Física.

(Fonte: Acervo pessoal Alcyr Meira) 


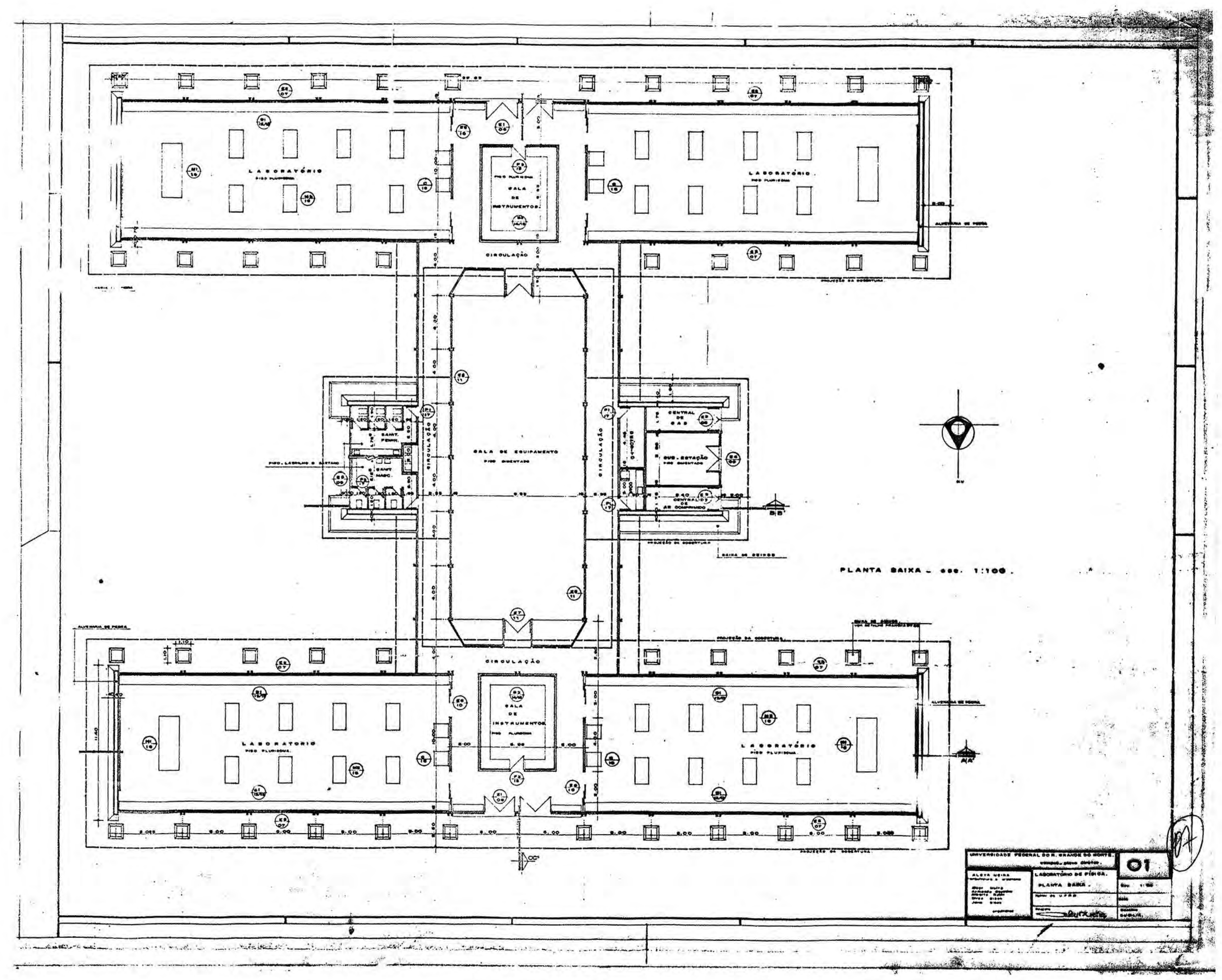


1.

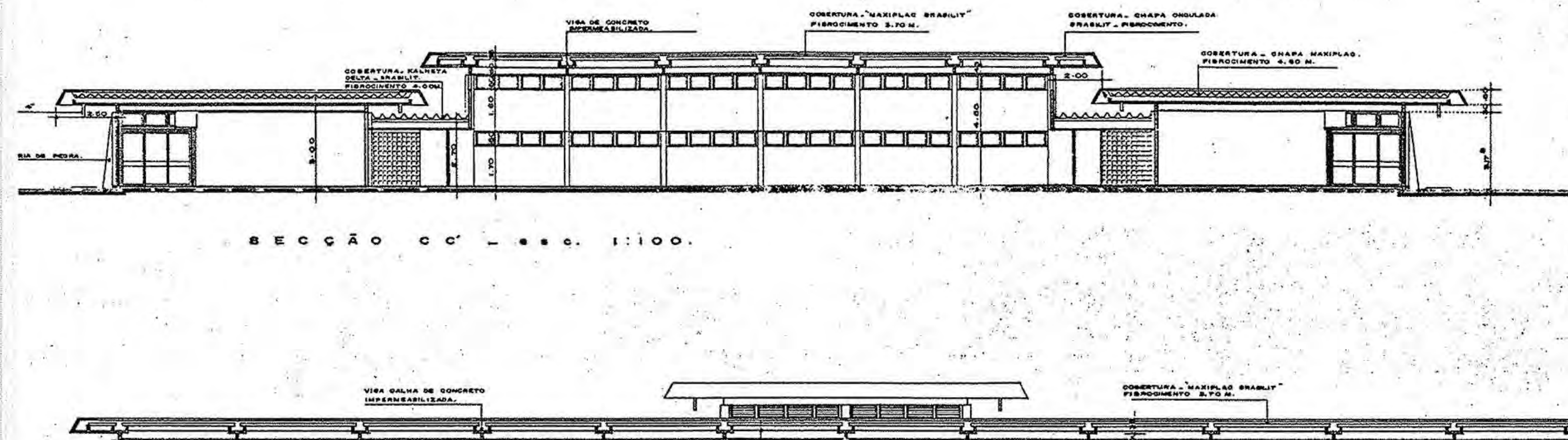

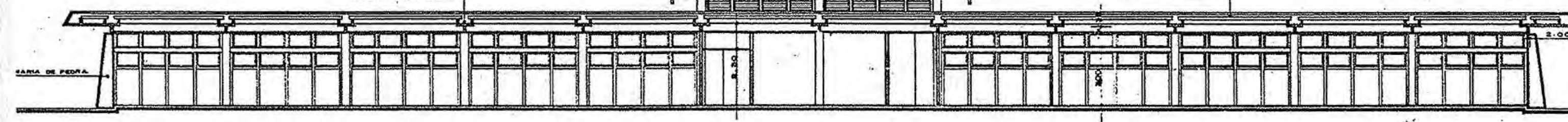

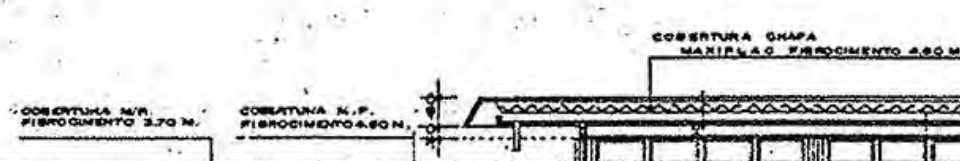

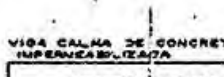

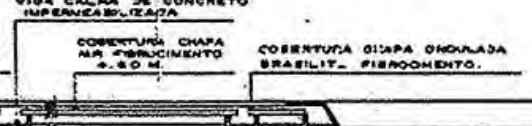

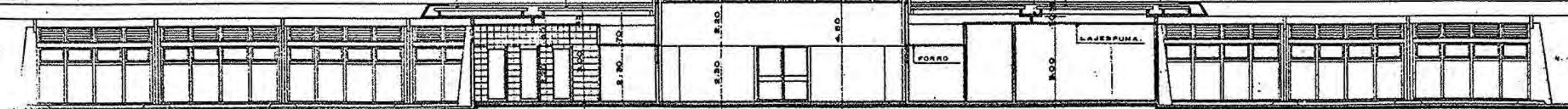


Parte 2 - Universidade Federal do Rio Grande do Norte 


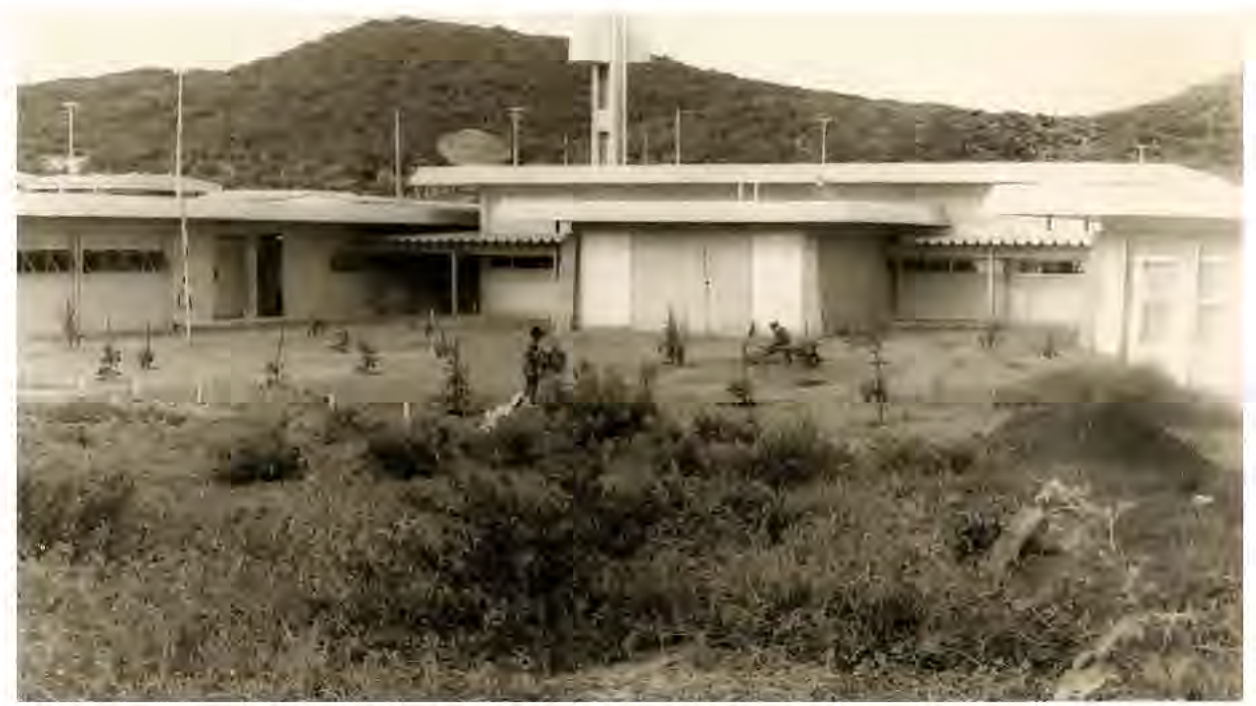

Figura 182: UFRN - Bloco de Laboratórios - Primeira metade da década de 1970. (Fonte: Acervo AGECOM / UFRN)

\section{- Biblioteca Central}

A Biblioteca Central, também parte do conjunto de obras de autoria do arquiteto Alcyr Meira executadas na primeira metade da década de 1970, apresenta uma proposta arquitetônica que mantém as mesmas características construtivas adotadas no restante da sua produção para o campus da UFRN: padronização dos elementos de vedação regulados pela malha modular da estrutura em concreto aparente, destacada pela presença dos pilares e vigas, panos de combogós e esquadrias de alumínio e vidro, que marcam as fachadas longitudinais oeste (com acesso principal) e leste (fachada de fundos), além das alvenarias de pedra que compõem a vedação das fachadas transversais norte e sul (ver projeto de arquitetura nas figuras 183 a 187). Esses elementos dão contorno a um edifício tipo "caixa" que, ocupando a projeção construída de $62,40 \mathrm{~m} \times 32,00 \mathrm{~m}$, define uma volumetria contida pelas vedações ausentes de transparência, exceto pelo vidro das esquadrias na fachada oeste, que, entretanto não chega a propor uma relação de troca visual entre o espaço interior do edifício e a paisagem externa do entorno (ver figura 188).

A forma arquitetônica é complementada pela coberta que predomina sobre a volumetria prismática, onde novamente Meira recorre ao uso da platibanda de extenso beiral que excede os limites de fechamento do edifício. A faixa de concreto aparente esconde a telha de fibrocimento e arremata calhas impermeabilizadas, padronizadas pela malha modulada da estrutura de vigas e pilares e alinhadas às fachadas de menor dimensão - norte e sul. 


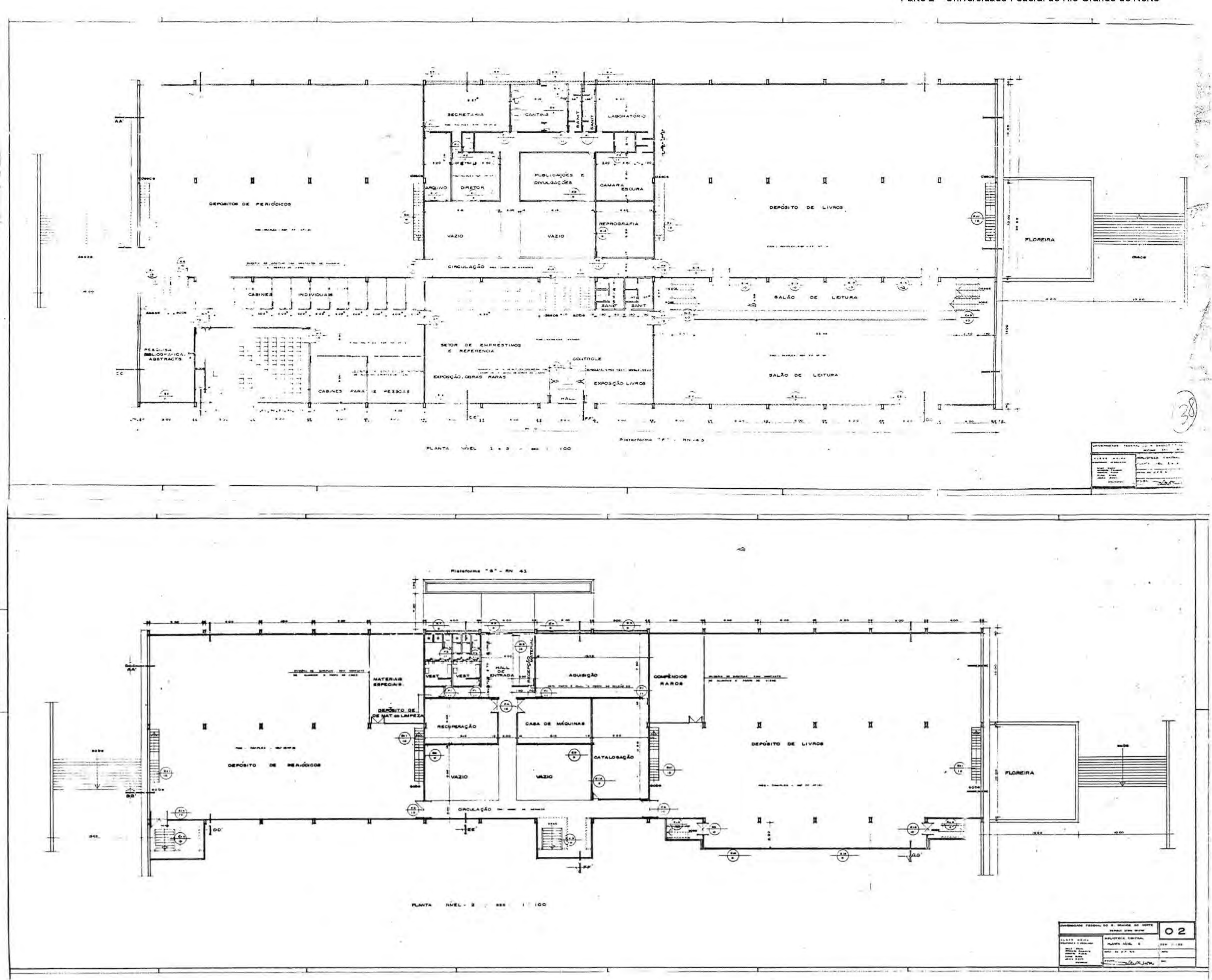



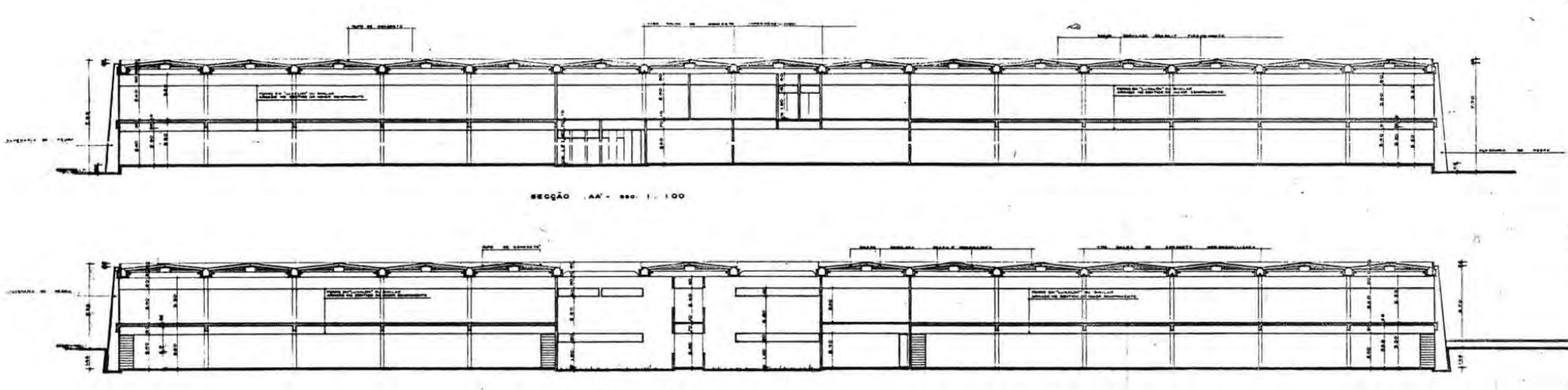

(I)

$$
\begin{aligned}
& 1
\end{aligned}
$$

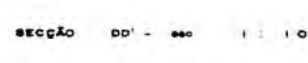

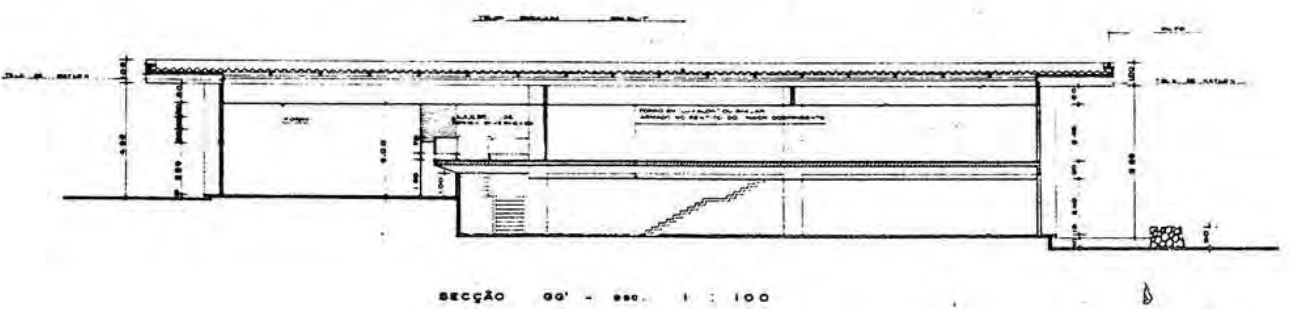

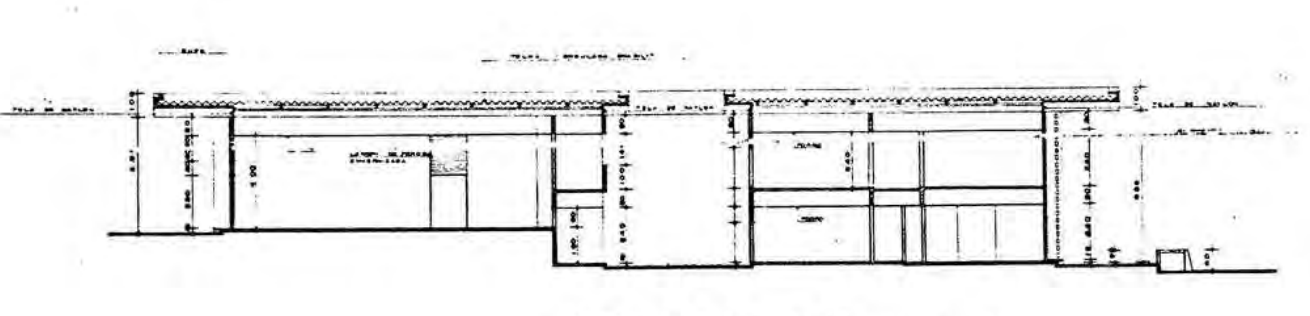

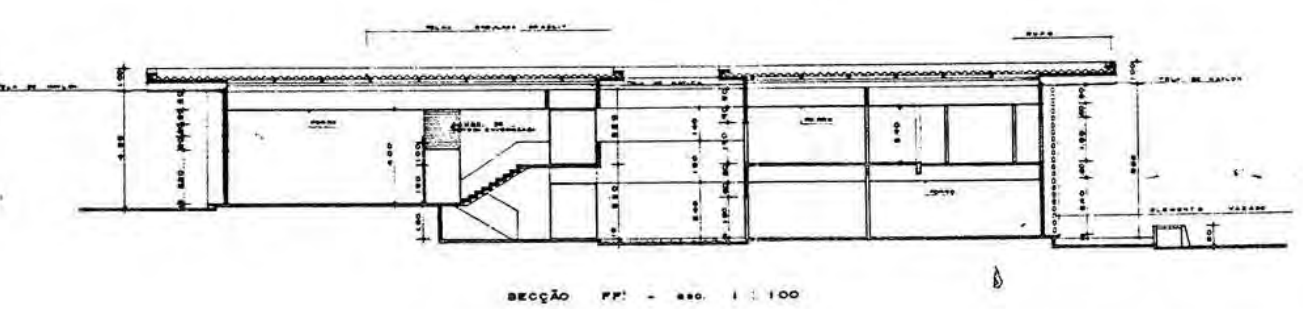




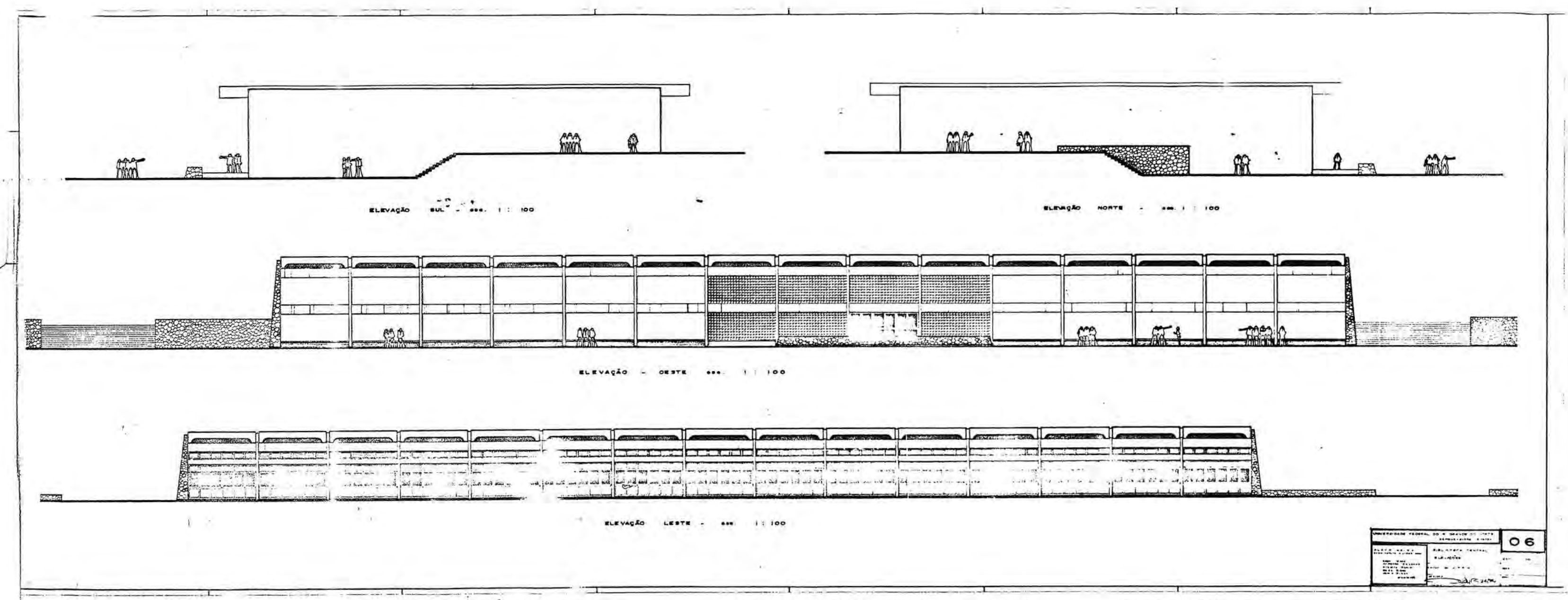

Figura 187: UFRN - Biblioteca Central - Projeto de Arquitetura/ Fachadas.
(Fonte: Acervo Superintendencia de Infraestrutura / UFRN) 


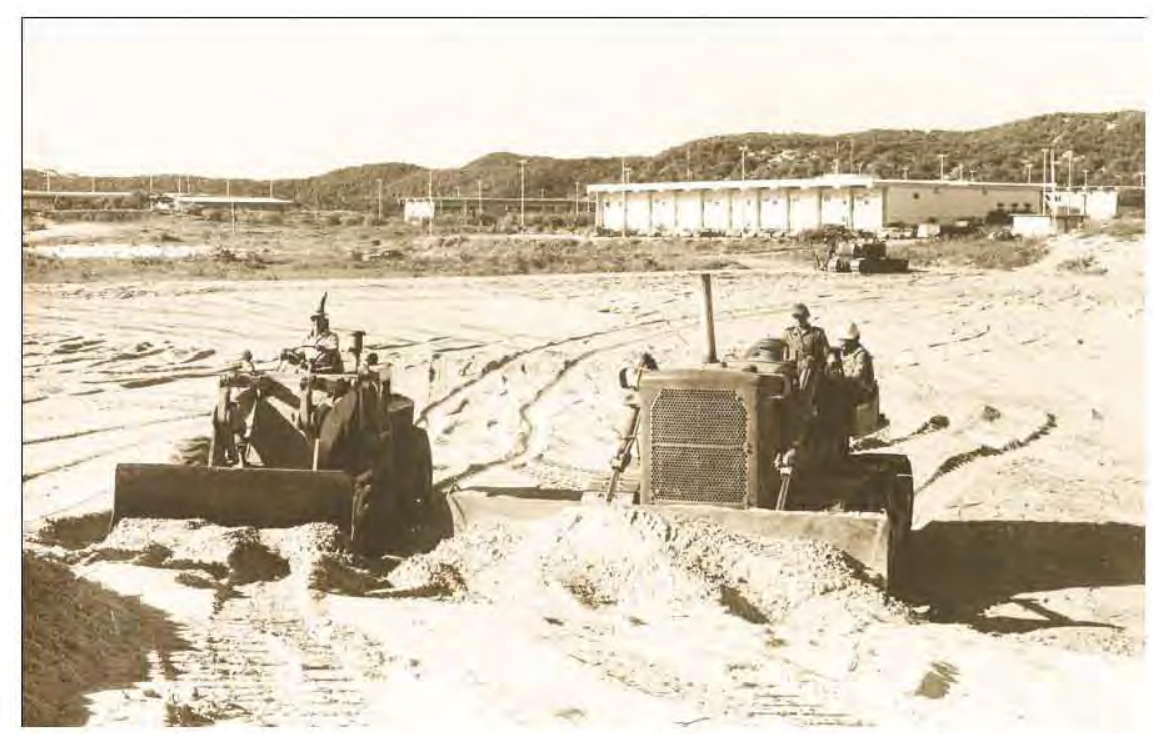

Figura 188: UFRN - Biblioteca Central - Primeira metade da década de 1970.

(Fonte: Acervo AGECOM / UFRN)

O caráter linear da platibanda confere aspectos de horizontalidade e estabilidade à composição do edifício, já introduzidos em decorrência da padronização construtiva. Importante destacar a frequência da solução adotada para escoamento das águas pluviais, resolvida por meio de canos de PVC aparente que direcionam o fluxo da água para caixas pré-moldadas distribuídas no jardim, em composição com a repetição dos elementos construtivos (ver figuras 189).

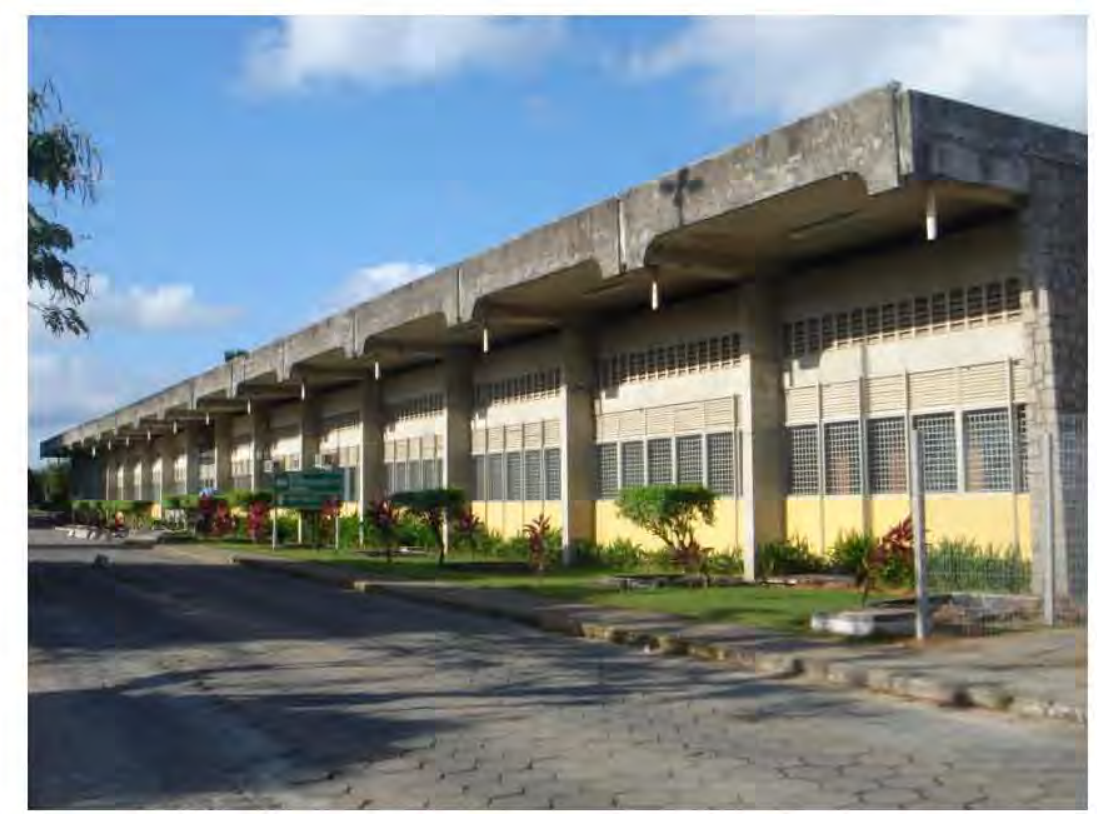

Figura 189: UFRN - Biblioteca Central - ano 2009.

(Fonte: Acervo Magda Campêlo, 2009) 
O extenso e complexo programa funcional da biblioteca, que envolve áreas de uso público (salas de leitura - individual e coletiva, acervo de livros e periódicos, setor de empréstimos e referências, exposições, anfiteatro, cantina, dentre outros) e espaços privativos (diretoria, secretaria, arquivos, restauração, catalogação, obras raras, etc.), além de uma criteriosa definição dos fluxos de serviços que dizem respeito à segurança do acervo contra roubos e vandalismo, bem como da garantia do silêncio requerido para o desenvolvimento do estudo e da pesquisa, foi organizado em três níveis de piso alternados, que tira partido do desnivel topográfico, e com pés-direitos diferenciados, onde vedações de piso a teto somente ocorrem nas áreas privativas.

A concepção proporcionou espaços visualmente integrados e de interação entre as atividades de uso coletivo. Nesse aspecto pode-se dizer que o projeto surpreende pelo espaço de caráter fluido, proporcionando uma dinâmica de uso e ocupação intensa, compartilhada pelos usuários, conforme se constata nos horários de funcionamento. Contrariando a forma contida e previsível, o espaço interno é dinâmico e imprevisível. 0 desenho reforça as considerações sobre a intenção de uma tipologia construtiva de caráter local, mas que não chega à síntese de uma arquitetura de síntese do lugar.

Em 1975, a Biblioteca foi ocupada temporariamente pela Reitoria, cuja transferência do centro urbano para o Campus havia se tornado irreversível. Quatro anos depois, com a inauguração do atual prédio da Reitoria, retomou sua função original de biblioteca central do Campus.

\section{- Praça Cívica}

No bojo das obras executadas na primeira metade da década de 1970, a Praça Cívica, composta pelo anfiteatro de autoria do arquiteto Alcyr Meira e sua equipe, e pela capela, projetada posteriormente pelo arquiteto natalense João Maurício Fernandes de Miranda ${ }^{64}$, destacam-se na paisagem constituindo um conjunto monumental, que marca a entrada do Campus (ver figura 190).

\footnotetext{
${ }^{64}$ João Mauricio Fernandes Miranda, formado pela Faculdade Nacional de Arquitetura, da então Universidade Brasil, no Rio de Janeiro, pertence à primeira geração de arquitetos potiguares, que disseminou a influência da Escola Carioca. A produção do arquiteto compõe o conjunto pioneiro da moderna arquitetura de Natal. São de sua autoria o Edifício Barão do Rio Branco, a Agência da Caixa Econômica Federal no bairro da Ribeira, e o Tribunal Regional Eleitoral, situado na Cidade Alta.
} 


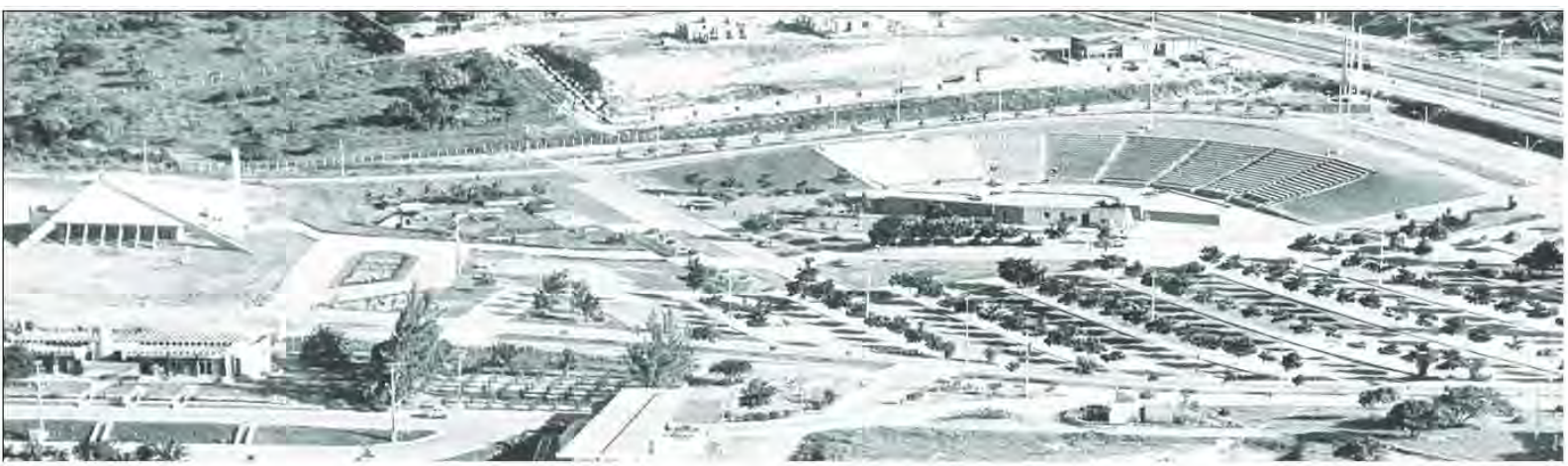

Figura 190:UFRN - Conjunto Monumental da Praça Cívica e Capela do Campus da UFRN.

(Fonte: Foto de Carlos Lyra apud TRIGUEIRO, 2008, p. 68)

\section{- Anfiteatro}

O anfiteatro, projetado em 1972, é um equipamento de grandes proporções destinado aos eventos universitários e apresenta uma solução arquitetônica que tira partido da topografia. As arquibancadas são divididas em módulos e intercaladas por circulações, que se desenvolvem ajustadas às curvas de nível, proporcionando adequação à declividade natural do terreno (ver planta de arquitetura da figura 191). O palco, também tirando partido da topografia, se divide em platôs com níveis diferenciados, permitindo uma distribuição hierárquica das atividades programadas (ver figura 192). Seguindo a mesma solução, o equipamento é abastecido pelo estacionamento que se distribui em níveis escalonados. $O$ projeto é rico na sua arquitetura e evidencia o domínio técnico dos profissionais autores do projeto sobre o programa. Trigueiro (2008) analisa que a localização desse equipamento, resultante do zoneamento rigoroso concebido pelo plano inicial, tem sido obstáculo para a sua integração com as atividades cotidianas da Universidade, fato que mantém a área desocupada na maior parte do tempo. Nas palavras da arquiteta o uso do equipamento sofre

[...] os efeitos do zoneamento excludente da urbanística modernista. Naquele vasto espaço não passa ninguém e, salvo em eventos ocasionais, quando se transforma em magnífico local de espetáculos, jaz em desuso, isolado por um complexo viário super-dimensionado e por um mar de vagas de estacionamento desertas. Não fosse a relação de segregação com os demais setores do Campus, imposta pelo modelo de implantação, esse espaço seria certamente mais usado (TRIGUEIRO, 2008, p. 68). 


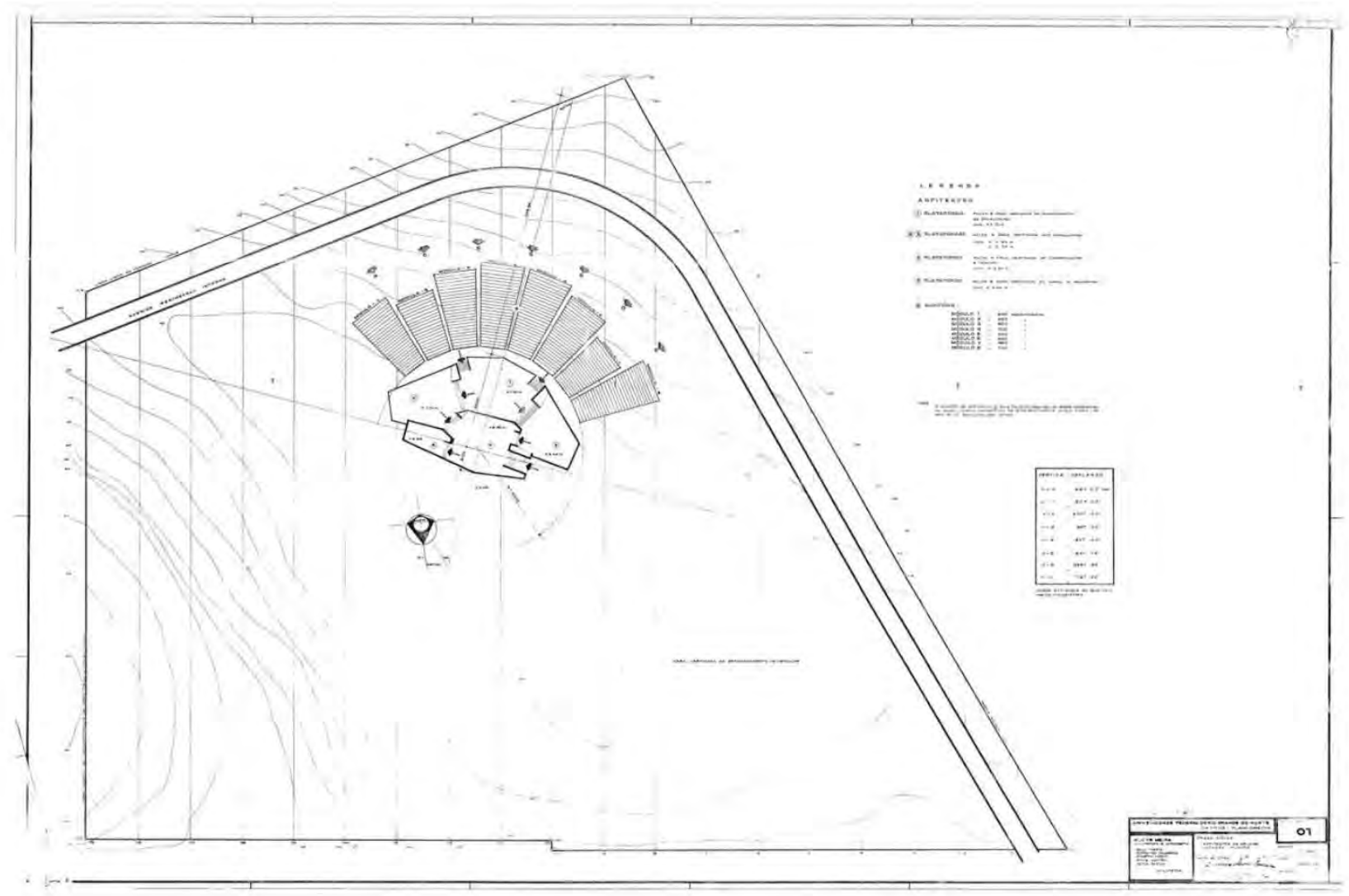

Figura 191: UFRN - Planta da Praça Cívica - junho de 1972.

De autoria de Alcyr Meira e sua equipe, o projeto constitui-se de um anfiteatro ao ar livre, tirando partido da topografia em declive.

(Fonte: Acervo Superintendência de Infraestrutura / UFRN)

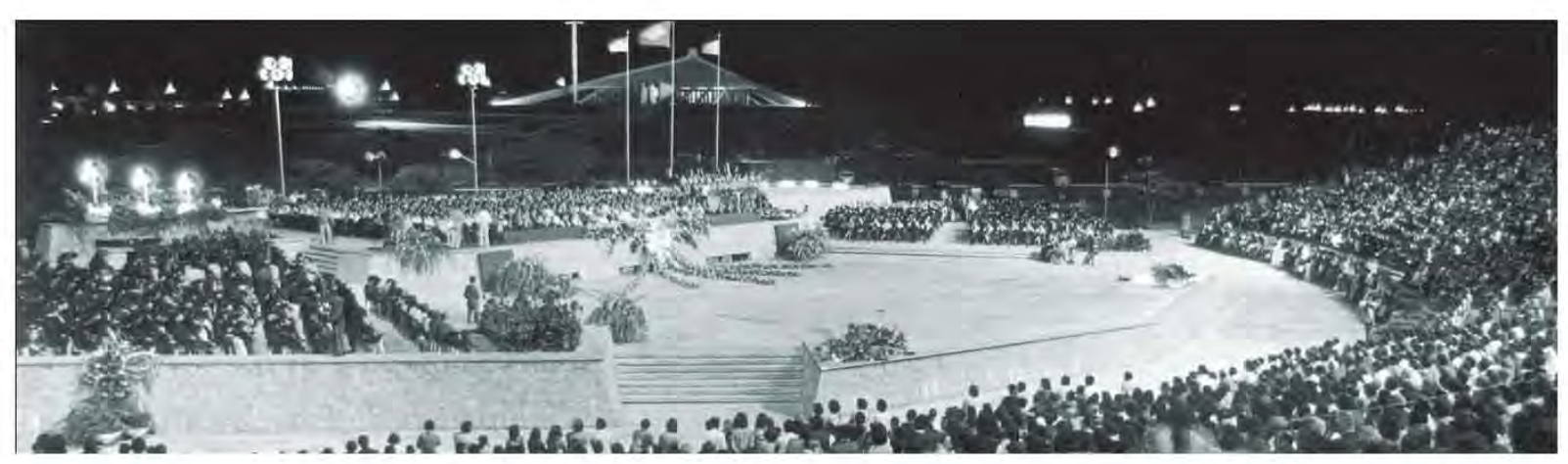

Figura 192: UFRN - Cerimônia de Colação de Grau na Praça Cívica do Campus da UFRN.

(Fonte: Foto de Carlos Lyra apud TRIGUEIRO, 2008, p. 69).

A avaliação de Trigueiro revela não apenas o equívoco urbanístico na localização do anfiteatro, mais do que isso, exalta a falácia do urbanismo moderno, que foi incorporado irrestritamente, sem uma reflexão sobre sua prática. 


\section{- Capela}

A capela, concluída em 1974, está implantada em um platô de cota elevada e se destaca por sua arquitetura de singelo efeito plástico, cuja forma arquitetônica revela a simbologia religiosa do seu programa. Com ênfase na verdade construtiva - levando à exposição da estrutura e dos materiais - o projeto resulta em um edifício com clara coerência entre forma e estrutura, ressaltada pela plasticidade do concreto aparente (ver figura 193).

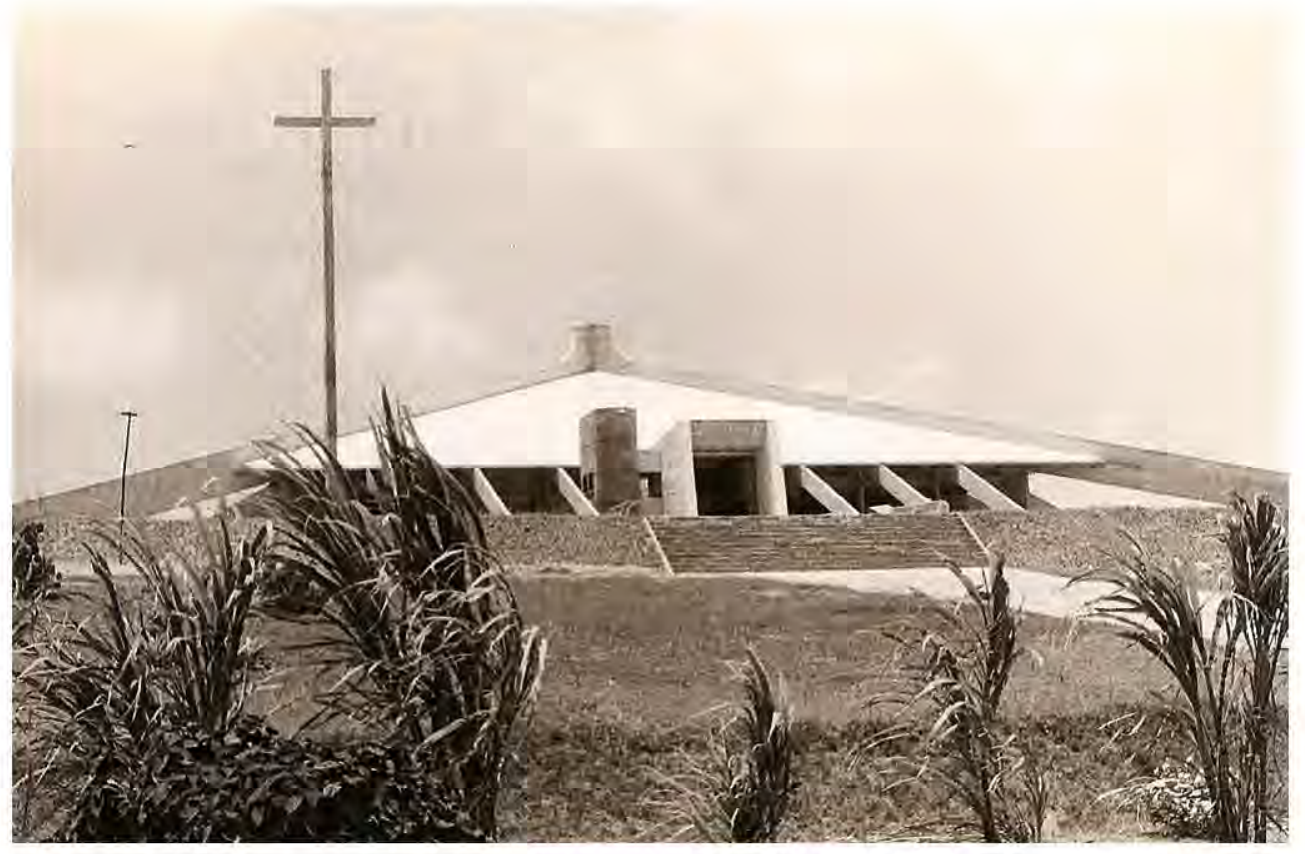

Figura 193: UFRN - Capela - concluída em 1974. (Fonte: Acervo AGECOM / UFRN)

Na sequência de execução das obras do Campus, em 1976 foi inaugurado o Ginásio Olímpico e em 1979, o atual edifício da Reitoria.

\section{- Reitoria}

Projetada pelo arquiteto carioca João Carlos Bross ${ }^{65}$, já mencionado, o edifício incorpora plasticamente a estética do concreto, embora a busca por uma maior expressividade e monumentalidade arquitetônica tenha dado lugar a um desenho de marcas rebuscadas.

O partido adotado no edifício da Reitoria (ver figura 194) caracteriza-se pela presença destacada da estrutura de concreto armado aparente - vigas, lajes e pilares - que define

\footnotetext{
${ }^{65}$. O arquiteto João Carlos Bross nasceu no Rio de Janeiro em 1934 e graduou-se pela Faculdade de Arquitetura da atual Universidade Presbiteriana Mackenzie, em São Paulo no ano de 1956. Fundador da Bross Consultoria (1991) é notadamente conhecido por sua atuação em projetos de arquitetura e engenharia de edifícios hospitalares, totalizando cerca de duzentos
} edifícios da saúde, cuja área soma mais de um milhão de metros quadrados. 
uma volumetria fragmentada constituída de fachadas diferenciadas, incorporando um ritmo plástico de cheios e vazios que suaviza a forma robusta do edifício (ver figura 195). Ao mesmo tempo desempenha a função de amenizador dos efeitos climáticos com a incorporação de jardineiras e placas verticais que tentam reduzir o efeito da radiação solar direta sobre as vedações de alumínio e vidro. A coerência do efeito plástico é rompida pela presença de alvenaria revestida por blocos de pedra com aplicação de esculturas, que funcionam como ornamentos. Talvez o arquiteto tenha buscado um contraponto de caráter vernacular ante a impessoalidade do concreto aparente. A solução, entretanto, causa estranheza ao edifício de forte caráter simbólico, que representa a administração central da Universidade.

Vale lembrar que a força simbólica do edifício da Reitoria contraria a recomendação do Manual de Atcon, o qual indicava a importância de eliminar as linhas de autoridade e de poder central, sob a argumentação de que na nova universidade a reitoria era um serviço e não um poder. Entretanto, a presença Reitoria se destaca na paisagem edificada com força de autoridade central.

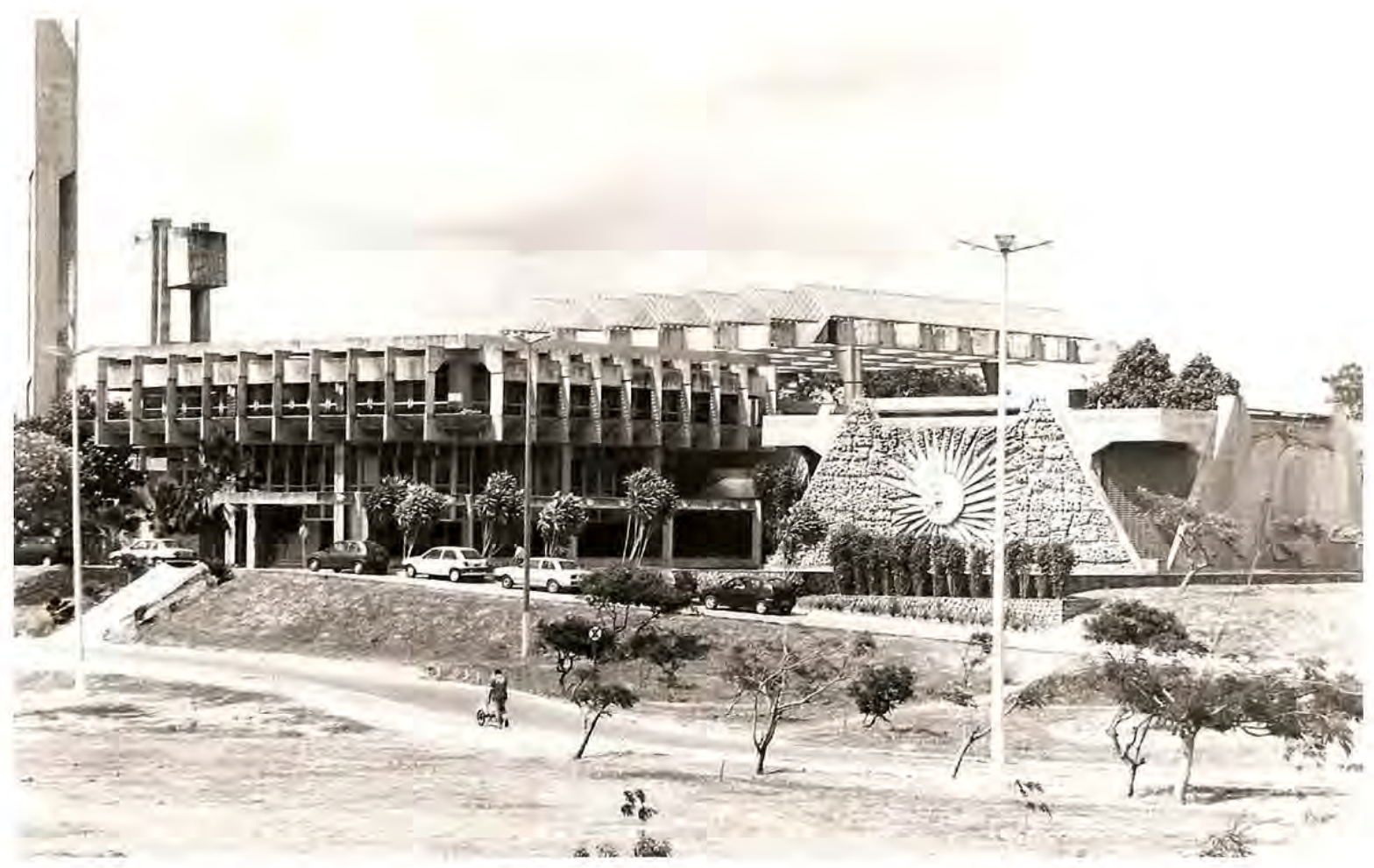

Figura 194: UFRN - Reitoria da UFRN - Final da década de 1970. (Fonte: Acervo AGECOM / UFRN) 


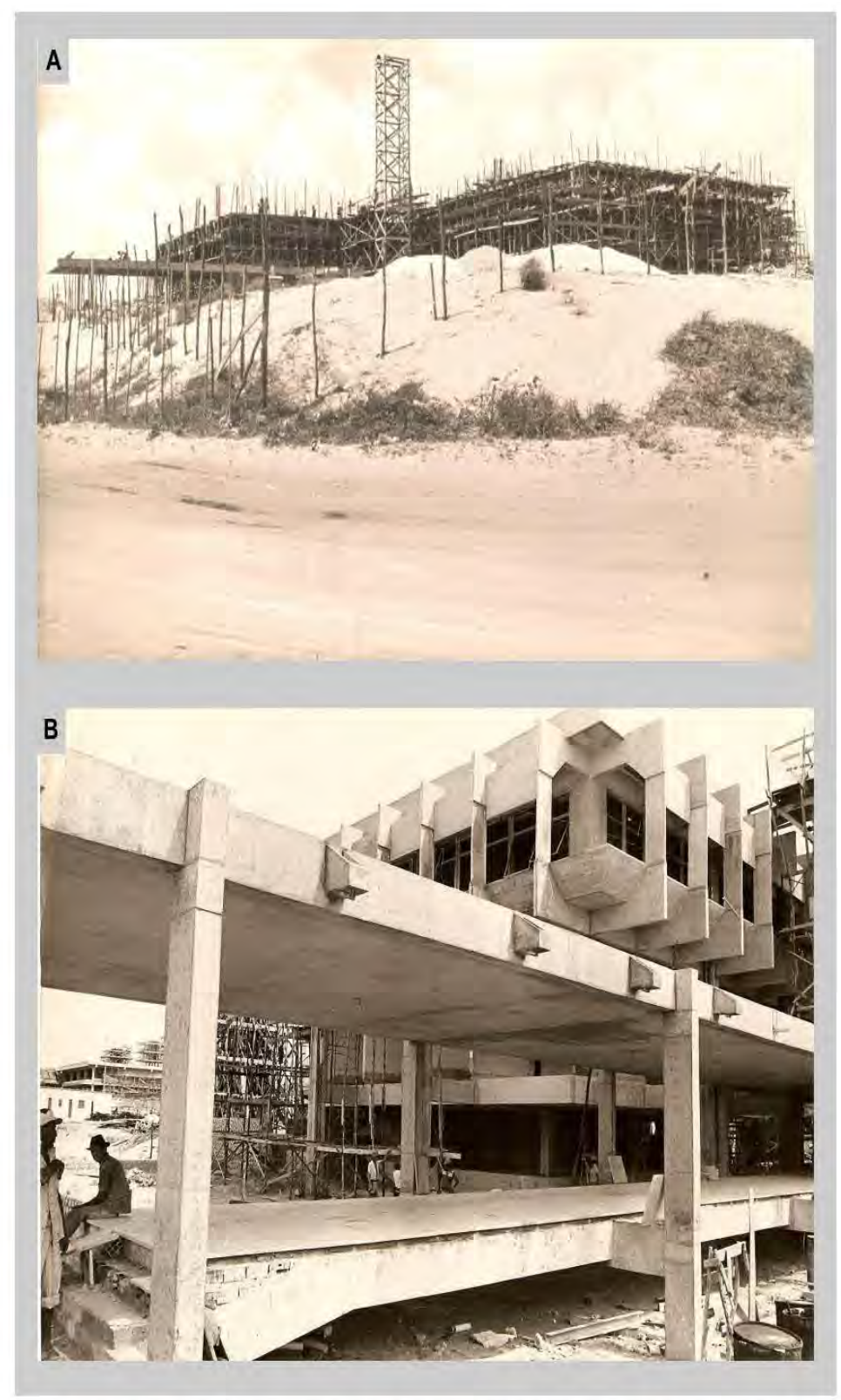

Figura 195: UFRN - Reitoria da UFRN - meados da década de 1970.

(A) Detalhe da construção. A estrutura de concreto armado se destaca como elemento de composição plástica, garantindo a expressividade escultórica do edifício.

(B) Execução da estrutura de concreto.

(Fonte: Acervo AGECOM / UFRN)

\section{- Centro de Biociências}

Ainda no ano de 1979, o arquiteto Bross projetou a construção do Centro de Biociências, decorrente do desdobramento do Centro de Ciências Exatas e Naturais (1974), em Centro de Ciências Exatas e Centro de Biociências. A obra recebeu financiamento do programa PREMESUIV, que na UFRN esteve em vigor no período de 1976 a 1980 . O conjunto, composto de blocos de um a dois pavimentos, adotou um sistema construtivo padronizado, com a estrutura de concreto aparente destacada das alvenarias de vedação em tijolos 
revestidos de cerâmica, e da tubulação de águas pluviais. A ênfase construtiva é adotada no partido construtivo, sem intenções de monumentalidade, constituindo um conjunto de arquitetura homogênea e singela com clara linguagem institucional (ver figura 196).

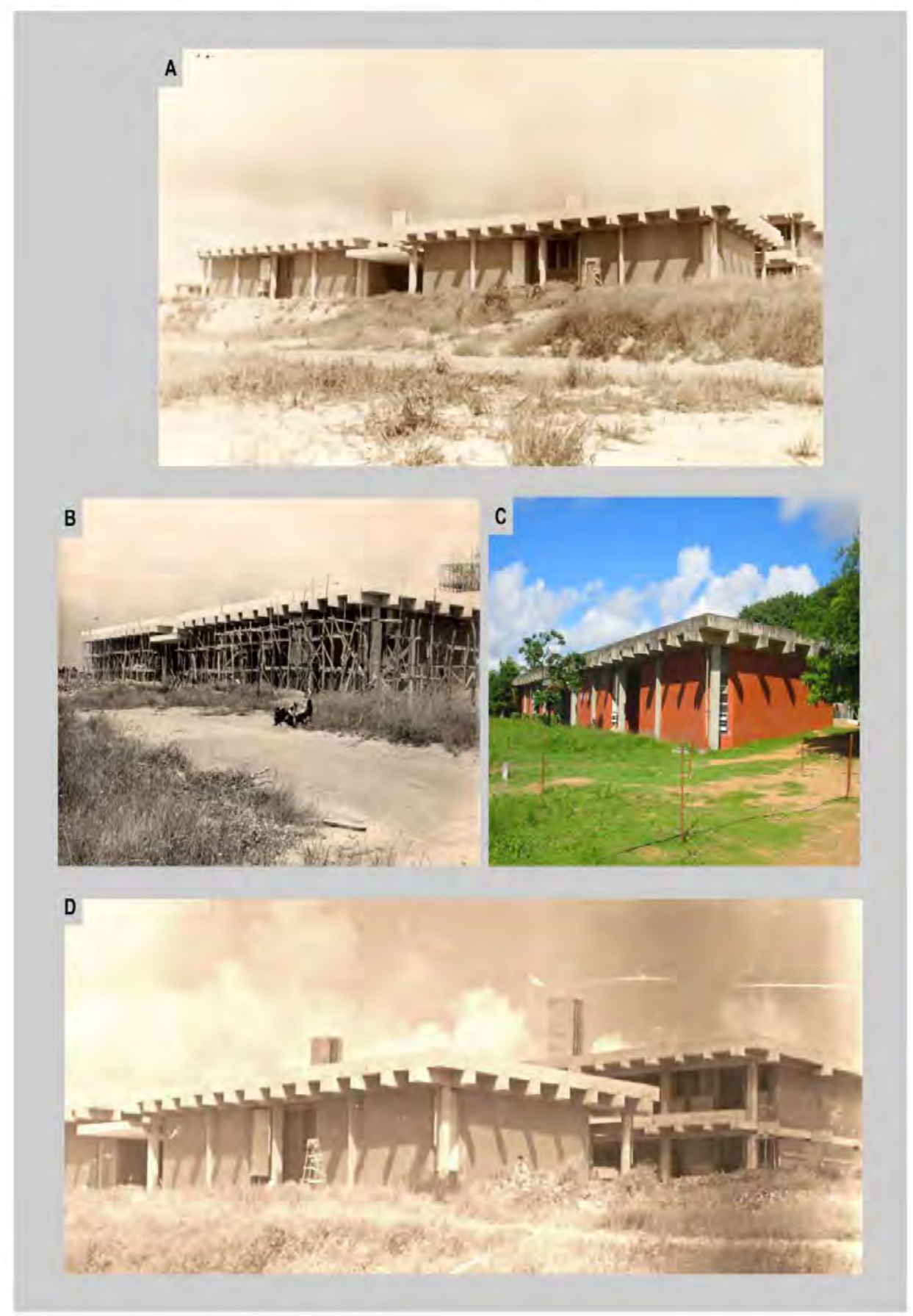

Figura 196: UFRN - Centro de Biociências.

(A) Vista do bloco de acesso em fase de acabamento -final de 1979.

(B) Vista da construção em fase de concretagem - agosto de 1979.

(C) Vista do bloco em junho de 2005. A estrutura de concreto aparente se destaca das alvenarias revestidas de tijolo cerâmico.

(D) Vista do conjunto, com o bloco de acesso e o de dois pavimentos - final de 1979.

(Fonte: A, B e D- Acervo AGECOM / UFRN;

C - Disponivel em <http://pt.wikipedia org/wiki/Ficheiro:Centro-de-Biociências-

UFRN>. Acesso em: 28 dez.2011) 


\section{- Laboratórios do Centro de Tecnologia}

O mesmo padrão de arquitetura foi seguido na construção do conjunto de laboratórios para - Centro de Tecnologia na segunda metade da década de 1970, projetados por uma empresa sediada em São Paulo ${ }^{66}$. Trata-se de um conjunto de blocos térreos padronizados cuja forma arquitetônica se destaca pela volumetria prismática e com clara separação entre a estrutura de concreto aparente e as alvenarias de vedação. Ao longo das fachadas longitudinais foi aplicada uma cortina de elementos pré-moldados, fixados na extremidade das vigas que se prolongam em balanço e perpendicularmente ao plano da fachada. $A$ solução proporcionou sombreamento aos vãos de aberturas resultando em um conjunto de características uniformes, que destaca visualmente o setor dos laboratórios na paisagem construída (ver figura 197).

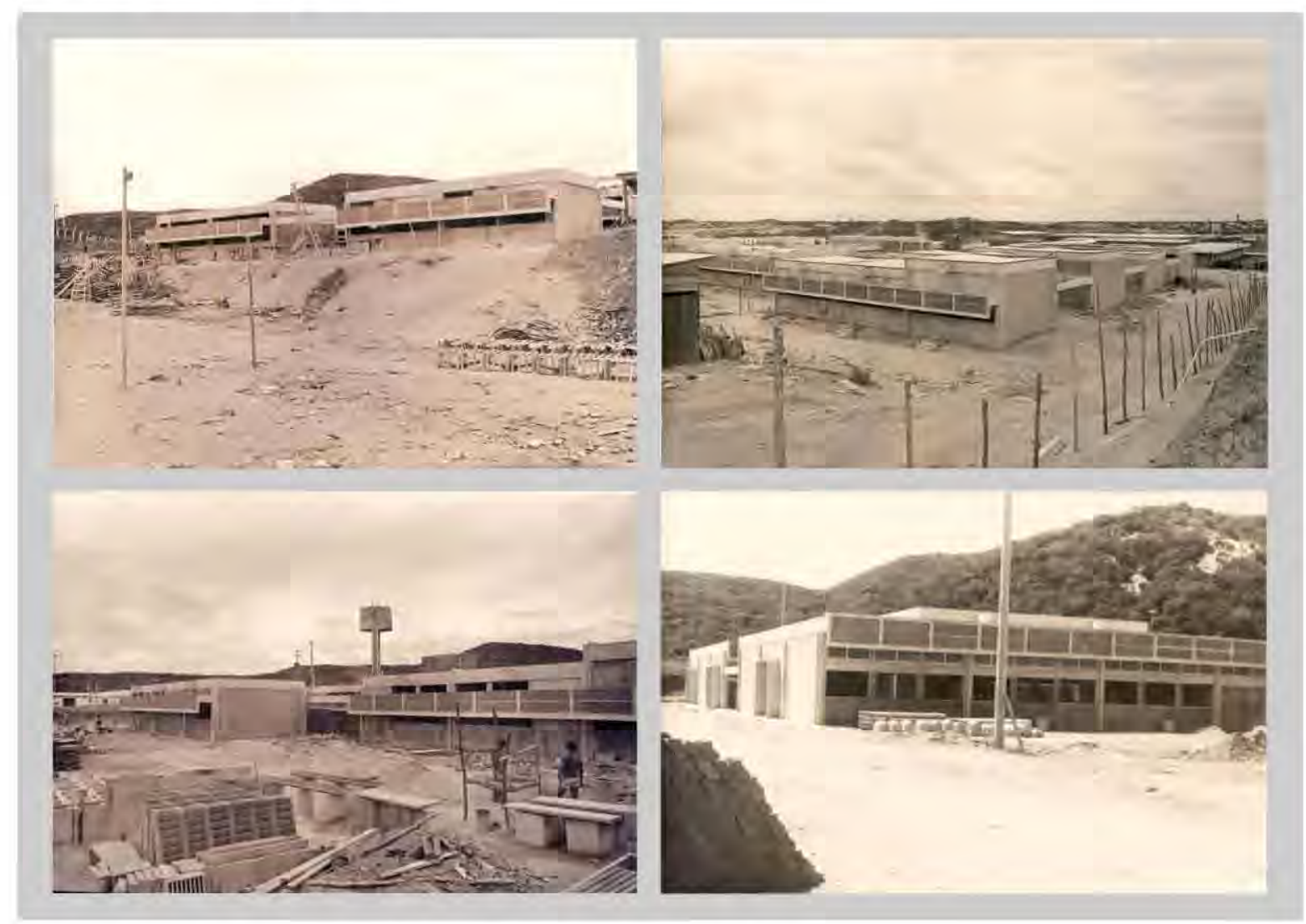

Figura 197:UFRN - Laboratório de Tecnologia - ano 1979.

(Fonte: Acervo AGECOM / UFRN)

No decorrer da década de 1970, o propósito de concretização do Campus mantinha os investimentos para obras de construção dos edifícios e da infraestrutura, transformando o território da Reforma (1968) em verdadeiro canteiro de obras, conforme se pode constatar na figura 198. Cabe mencionar que outras produções foram realizadas com a participação dos profissionais da própria UFRN, através de seus setores técnicos, que passaram a

\footnotetext{
${ }^{66}$ Não conseguimos identificar o registro do escritório paulista autor do projeto.
} 
gerenciar a construção do Campus. Dentre eles o projeto do Centro de Convivência, elaborado a partir da proposta de 1978, mas que foi construído somente na década seguinte, e onde foram instalados serviços de interesse geral como lanchonetes, agências bancárias, livrarias, galeria de arte e agência de correios, tendo a finalidade de integrar a comunidade universitária.

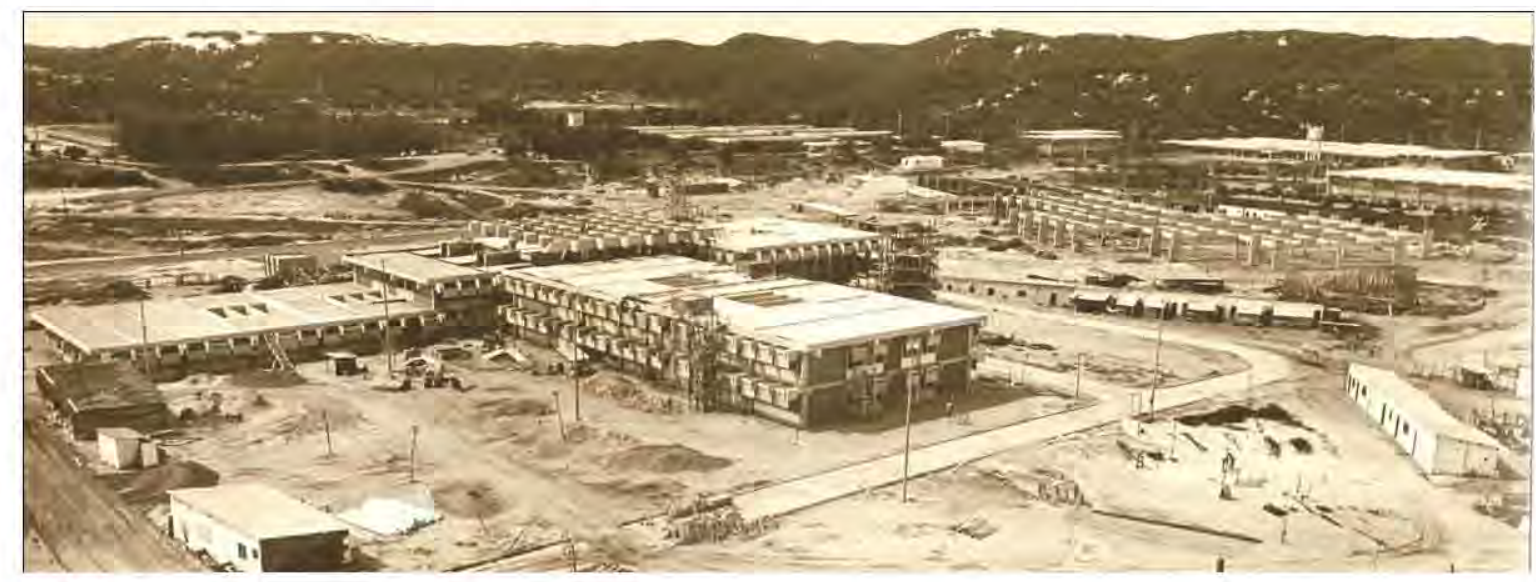

Figura 198: UFRN - Obras de construção do Campus Universitário. (Fonte: Acervo AGECOM / UFRN)

\subsection{Década de 1970: configuração de um território segregado}

Em cumprimento às determinações da Reforma Universitária, ao final dos anos 1970, a UFRN estava com parte das instalações implantadas no novo território, que se constituía no campus suburbano isolado da tecitura urbana, totalizando hoje uma área de $122.15 \mathrm{ha}$, circundada por um anel viário que o integra à malha urbana da cidade de Natal, conforme planta da figura 199. Atualmente, encontra-se cercado pelos bairros residenciais que foram surgindo com a expansão da cidade (ver figura 200).

O espaço produzido pela nova organização educacional resultava dos diferentes planos que atuaram na sua definição. A tipologia urbano-arquitetônica implantada com base no zoneamento funcional perpetuava a estrutura de unidades autônomas instaladas em edifícios distanciados entre si, propiciando

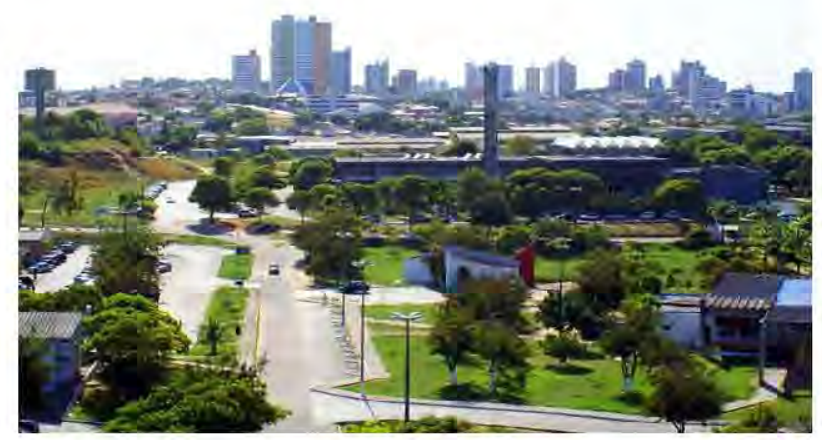
um ambiente disperso e fragmentado, que se afastava do ideal propalado pela Reforma.

Figura 200: UFRN - Vista aérea do Campus Central - [2008?].

Inicialmente isolado da zona urbana consolidada encontra-se atualmente cercado por bairros residenciais.

(Fonte: Acervo AGECOM / UFRN) 


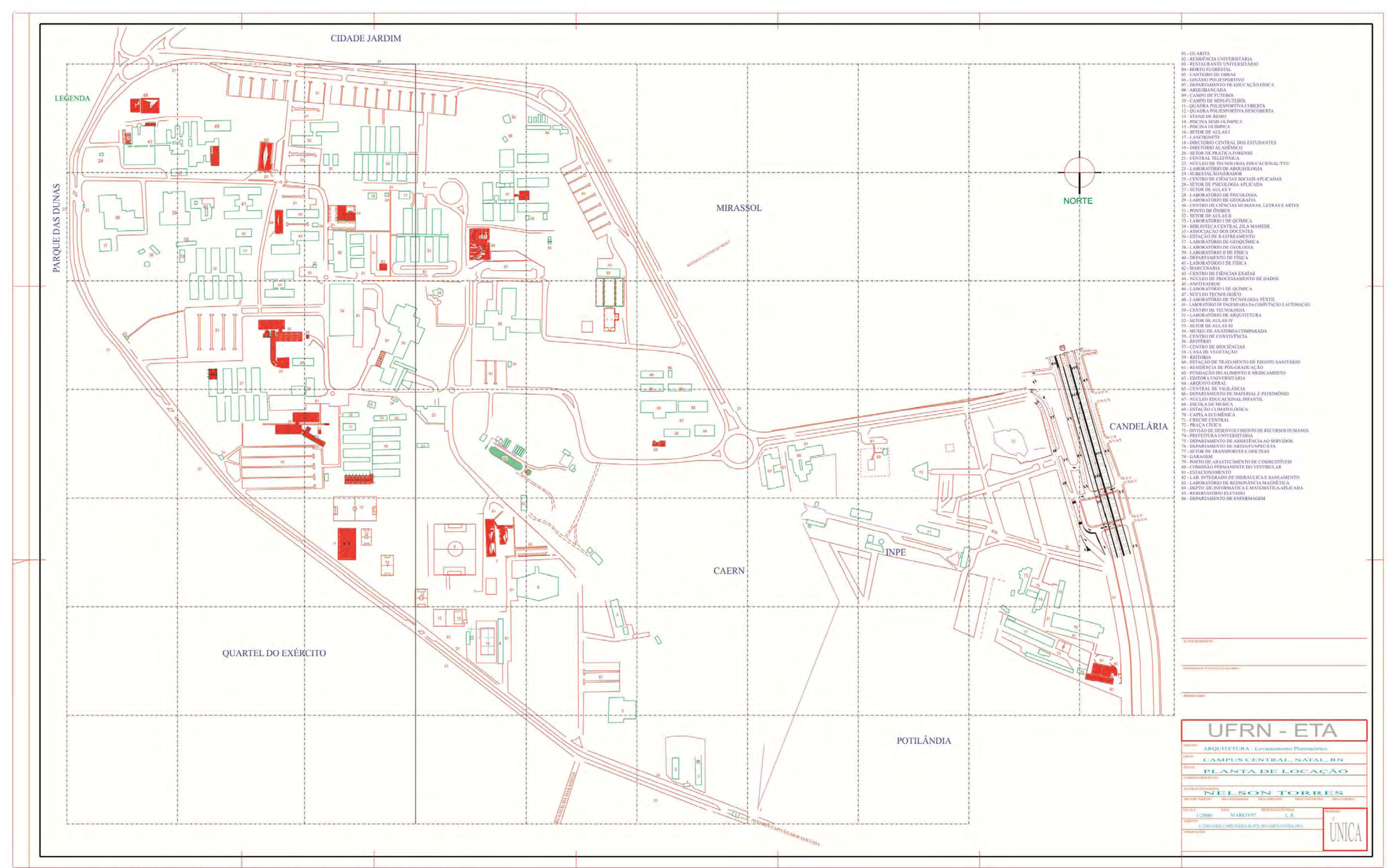


Parte 2 - Universidade Federal do Rio Grande do Norte 


\subsection{CONSIDERAÇÕES}

A UFRN tem origem na expansão do ensino superior que se deu no Rio Grande do Norte na década de 1940. O contexto histórico do pós-Segunda Guerra Mundial é apontado como fator decisivo para a conscientização das elites natalenses de que somente as regiōes com expansão no setor de ensino superior tinham registrado desenvolvimento na estrutura socioeconômica. A partir da instalação das Faculdades de Farmácia e Odontologia, de Direito, de Medicina, de Filosofia e da Escola de Serviço Social concretizou-se o número necessário de instituições de ensino superior para a criação da Universidade do Rio Grande do Norte, o que ocorreu em 1958, por iniciativa do governo estadual. Em 1960, foi federalizada durante a gestão de Juscelino Kubitschek, passando a se denominar Universidade Federal do Rio Grande do Norte, constituída pelas Faculdades de Medicina, de Farmácia, de Odontologia, de Direito e pela Escola de Engenharia. Posteriormente, no período de 1966 a 1972, foram encampadas a Escola de Serviço Social, a Faculdade de Filosofia, Ciências e Letras, a Faculdade de Sociologia e Política e a Faculdade de Jornalismo Eloy de Souza.

Sediada na capital, a nova instituição foi instalada em prédios onde já funcionavam os cursos que the deram origem ou que foram doados pelo governo do Estado, localizados em bairros diferenciados da malha urbana da cidade. A organização da nova Universidade seguiu a estruturação física que vinha sendo adotada pelo ensino superior brasileiro, caracterizada por um conjunto de edificações urbanas dispersas, constituindo o modelo de edifício isolado.

Tratava-se de prédios cujos elementos construtivos manifestavam adaptação às linguagens estilísticas nacionais e internacionais da arquitetura do século $X X$, revelando o percurso histórico da arquitetura do Rio Grande do Norte. Dentre essas, exemplificamos o ecletismo adotado no antigo imóvel que abrigou a Faculdade de Direito, o neocolonial brasileiro que referenciou as construções da Maternidade-Escola Januário Cicco e da Faculdade de Ciências Econômicas, e o protomodernismo da antiga Escola de Serviço Social, do Hospital Onofre Lopes (antigo Miguel Couto e depois Hospital das Clínicas) e da sede da antiga Faculdade de Farmácia e Odontologia, dentre outros. Exemplo de excepcional qualidade estético-construtiva é o edifício da Faculdade de Odontologia, inaugurado em 1966, que agrega o repertório formal da Escola Carioca. Do mesmo ano, a Faculdade de Farmácia com as novas instalações distancia-se das linhas modernas.

Instalada inicialmente em edifícios significativos, a UFRN confirma a trajetória de concretização do espaço universitário que vinha sendo adotado no modelo brasileiro. Fato 
relevante, entretanto, é a constatação de que, diferindo de outras congêneres instituídas na primeira metade do século $X X$, não há menção sobre iniciativas para aquisição de gleba destinada à construção de um território planejado e apartado do centro urbano, no propósito de criar uma cidade universitária. A compra e construção de novos edifícios na malha urbana, consolidando sua estrutura física, contrariava a regra de se transferir para uma área especializada e apartada da infraestrutura urbana. Foi somente a partir da Reforma Universitária de 1968 que a UFRN criou procedimentos para a organização do seu território no modelo de campus norte-americano.

Atendendo à organização acadêmica proposta pela Reforma (1968), a UFRN adotou a estrutura departamental, disposta em centros, os quais embasaram o planejamento do campus, cuja construção se deu em terreno doado pelo governo do Estado numa área de $123 \mathrm{ha}$, com aspecto físico destacado pela presença de dunas, solo predominantemente arenoso e clima quente úmido. Situado na BR 101, naquele período uma área distanciada da zona central da capital, o Campus integra hoje a parte urbanizada de Natal.

A construção teve início em 1972 e seu desenvolvimento obedeceu ao plano diretor de autoria do arquiteto paraense Alcyr Meira e sua equipe. O plano estabelecia cinco zonas funcionais (Administrativa, de Ensino e Pesquisa, de Recreação, Esportiva e de Serviços Gerais), circundadas por um anel viário no perímetro mais externo do Campus. O traçado urbanístico definia-se pela ocupação das tipologias acadêmicas (setor de aulas teóricas, setor didático-administrativo, laboratórios, Reitoria, Biblioteca, Restaurante, ginásio esportivo, dentre outros) de geometria predominantemente retangular, formando conjuntos funcionais de desenho homogêneo.

No decorrer da implantação, a proposta inicial foi passando por adequações que visavam ajustar o plano às necessidades da Universidade em expansão. Os primeiros ajustes, realizados ainda na primeira metade da década de 1970, tiveram a participação do arquiteto paraense, porém em 1976 um novo plano com base no de Meira foi aprovado pelo Conselho Universitário. A nova proposta manteve o caráter funcional da ocupação urbanística, aprofundando, porém a definição do traçado da circulação de pedestre, que na de Meira deixava indefinido o fluxo de ligação entre os edifícios. Introduziu, porém alterações significativas como a transferência da Reitoria para a zona de Ensino e Pesquisa, originalmente concebida na zona Administrativa, e estabeleceu uma baixa densidade de ocupação, ampliando as distâncias entre as edificações,

Nenhuma das concepções foi concluída integralmente e ao final da década, o Campus apresentava uma configuração funcional sem claras diretrizes de crescimento, conformando um território segmentado por vias que contornam setores de edifícios agrupados em função 
de suas especialidades, porém isolados entre si. A proposta urbano-arquitetônica implantada contrariava a concepção de um complexo integrado propalado nos propósitos da Reforma.

O conjunto arquitetônico edificado na década de 1970 é predominantemente embasado pelo princípio da racionalização construtiva que incorpora a coordenação modular dos componentes - adotando como medida de referência o módulo estrutural - a padronização dos materiais e dos elementos de vedação, assim como a geometria da forma e dos espaços. Da manipulação de tais conceitos emergiu uma produção que procurava tornar perceptiveis os elementos construtivos da obra arquitetônica, dando ênfase à verdade construtiva, com a exposição da estrutura em concreto aparente, destacada das vedações, executadas com soluções que variavam entre alvenarias de tijolos, alvenarias de pedra natural ou painéis em estrutura de alumínio e vidro, assim como das tubulações aparentes projetadas para o escoamento da água proveniente da coberta. $O$ resultado nos fornece evidencias de uma clara manifestação de aspiração à industrialização construtiva, ainda que predominasse o caráter artesanal no processo de execução.

A professora Edja Trigueiro, do Departamento de Arquitetura da UFRN, analisa que essa produção encontra referências na proposta arquitetônica de viés brutalista, que se disseminava no Brasil naqueles anos, embora com adaptações. Trigueiro infere que as ressonâncias dessa expressão arquitetônica no Campus são contraditórias, uma vez que se buscava um cunho renovador, para ser implantado em um contexto urbanístico concebido sob a rigidez do zoneamento modernista contra $\circ$ qual $\circ$ brutalismo se contrapunha radicalmente.

O conjunto arquitetônico projetado por Meira (setor de aulas teóricas I, setor didáticoadministrativo, laboratórios, Restaurante e Biblioteca Central) indicam o propósito de se reproduzir a estruturação acadêmica instituída pela Reforma. Salas de aula, laboratórios, ambientes administrativos e anfiteatros estão concentrados em tipologias que atendem às várias áreas de um mesmo centro, respeitando as diretrizes da racionalização e da não duplicação de meios idênticos, que, entretanto isolados entre si não chegam a propiciar a integração acadêmica propalada pela Reforma Universitária. A organização do programa na planta livre de vedação móvel buscava atender à diretriz da flexibilidade requerida pelo novo modelo acadêmico, onde novas necessidades deveriam ser incorporadas com rápidas alterações dos arranjos funcionais e, consequentemente, substancial economia de custos.

Neles estão os elementos formais articulados com modulação, padronização dos materiais e processos construtivos. Plantas funcionais de geometria retangular regulam o partido arquitetônico de formas prismáticas em edifícios de um pavimento. Sobressai o uso da 
pedra natural aplicada em vedações e pilares, que parece querer criar uma expressividade escultórica de caráter local. A composição, entretanto não resulta numa síntese da arquitetura do lugar, limitando-se a imprimir robustez à obra arquitetônica. Contrapondo-se à homogeneidade estilística do conjunto, soluções de volumetrias diferenciadas são adotadas na coberta, onde Meira lançando mão da plasticidade do concreto cria identidade funcional às tipologias projetadas. A planta livre de vedação móvel organiza o programa.

Outra produção, de autoria do arquiteto paulista João Carlos Bross, marca presença na paisagem construída do Campus. Trata-se do prédio da Reitoria que adota um partido de forte efeito plástico e que segundo Trigueiro incorpora muitas das características formais brutalistas, embora elementos ornamentais aplicados às fachadas denunciem uma vertente estilística de caráter adaptado. Do mesmo autor, os blocos destinados ao Centro de Biociências retoma o conceito da padronização e modulação, com base numa estrutura de concreto estandardizada e com vedação em tijolos aparentes (ênfase na verdade construtiva). $O$ resultado é um conjunto arquitetonicamente uniforme e de boa qualidade formal, Com a mesma proposta foram construídos os Laboratórios do Centro de Tecnologia, projetados por outra empresa sediada em São Paulo.

Ainda na construção edilícia do Campus, destaca-se a obra de profissionais potiguares, como a Capela da Praça Cívica de autoria do arquiteto João Maurício, que tirando partido do concreto aparente e da verdade estrutural, sintetiza uma proposta de efeito plástico, que chama a atenção pela qualidade arquitetural.

Ao final da década de 1970, o território da Reforma Universitária constituído no modelo de campus suburbano era, na UFRN, um projeto em desenvolvimento. Sua tipologia urbanoarquitetônica, concebida pela ação do planejamento, responsável pela definição de uma ordem urbanística pautada no rígido zoneamento funcional e na hierarquia das vias de circulação, e pela construção edilícia marcada pela racionalidade que embasava os princípios do projeto arquitetônico (padronização, modulação e técnicas) é o testemunho de uma geração criada para responder ao novo modelo de universidade instituído pelo governo militar. Construído como zona especial segregada na estrutura da cidade e como território unificado da Instituição, nenhuma das propostas elaboradas com vistas ao seu desenvolvimento físico materializou o ideal da integração, que acabou por consolidar um espaço cada vez mais fragmentado. 



\section{UNIVERSIDADE FEDERAL DE ALAGOAS (UFAL)}

A Universidade Federal de Alagoas é uma instituição de ensino superior, constituída como autarquia educacional de regime especial e vinculada ao Ministério da Educação com sede na cidade de Maceió, capital de Alagoas. Atua em várias localidades do Estado com a seguinte estrutura: Campus A. C. Simões (que sedia a Administração Superior) e Campus Delza Gitai, localizados em Maceió; Campus Arapiraca, situado no município do mesmo nome, com polos nas cidades de Palmeira dos Índios, Penedo e Viçosa e o Campus Sertão, implantado no município de Delmiro Gouveia com polo em Santana do Ipanema (ver figura 201). Conta ainda com unidades dispersas, dentre as quais se destaca o Espaço Cultural da UFAL, situado na Praça Visconde de Sinimbu, no centro de Maceió.

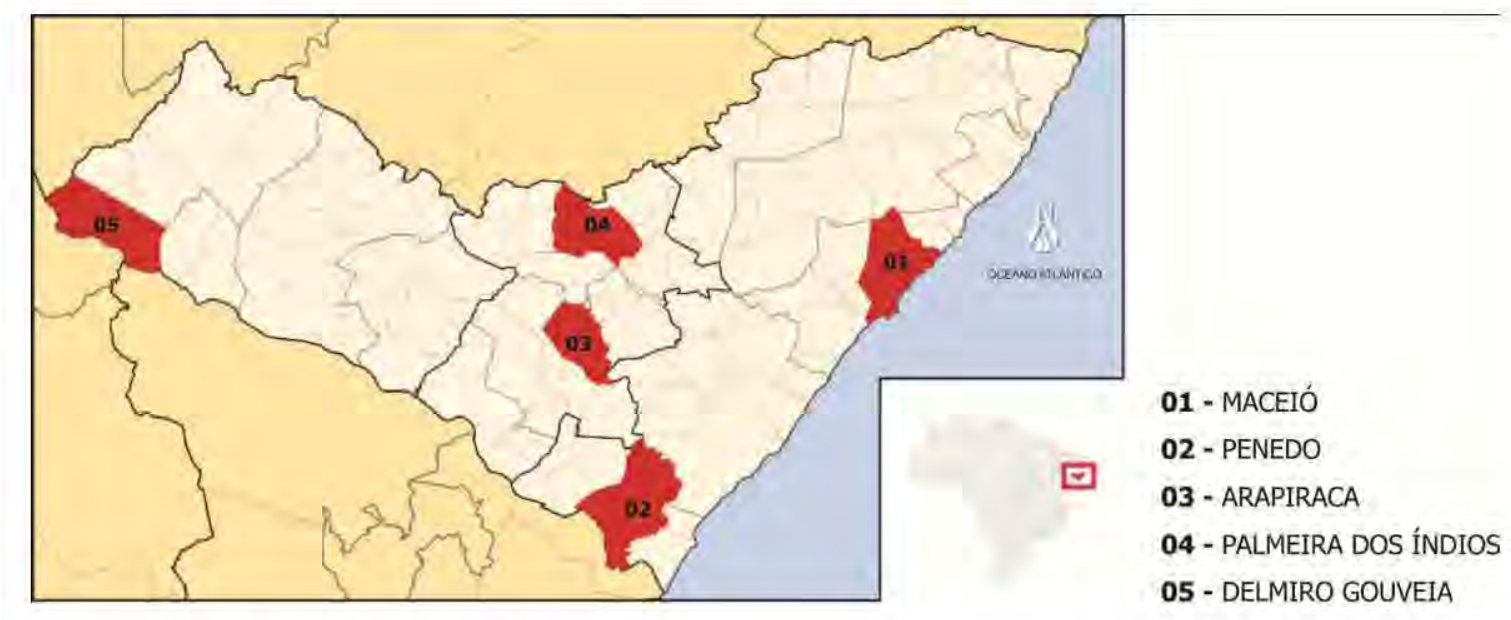

Figura 201: UFAL - Mapa de Alagoas.

Localização dos municípios que sediam a UFAL

(Fonte: disponivel em: <http://pt.wikipedia.org/Wiki/Ficheiro:Alagoas_MesoMicroMunicip.svg>. Acesso em: 1 mai. 2012).

\subsection{CRIAÇÃO DA UFAL}

Criada pela Lei $\mathrm{n}^{0} 3867$, em 25 de janeiro de 1961, a Instituição, apesar de federalizada, recebeu o nome de Universidade de Alagoas (UAL) e somente em 1965 teve o nome alterado para Universidade Federal de Alagoas (UFAL).

Sua criação se deve à existência de instituições isoladas de ensino superior no Estado, cujas dificuldades financeiras para manutenção e operação dos cursos culminaram no processo de federalização, integrando-as na forma de universidade. 
A primeira delas foi a Faculdade de Direito, criada em 1933 e que foi logo federalizada, garantindo os recursos financeiros necessários para operar suas funções. A Faculdade de Medicina, criada em 1951, tinha o curso mais dispendioso e para manter-se tentava, isoladamente, seu ingresso no sistema federal, porém sem êxito. Seguindo-se a esta, foram criadas as Faculdades particulares de Filosofia e de Economia, em 1952. Em 1955, foi a vez da Faculdade de Engenharia, seguida da Faculdade de Odontologia, em 1957. Havia ainda a Escola de Serviço Social que, no entanto, não demonstrou interesse em se integrar à Universidade.

Em 1960, a ideia de uma universidade federal começou a tomar corpo, ainda que de forma incipiente, tanto para alguns dirigentes dos estabelecimentos existentes quanto pela ação do movimento estudantil que decidiram intensificar uma campanha pela criação de uma universidade no Estado. Os estudantes justificavam que uma instituição de ensino superior federal representaria mais recursos para garantir a pesquisa, maior dedicação dos professores e, com isso, a formação de profissionais mais voltados para a realidade local (VERÇOSA, 1997, p. 124). Diziam que o verdadeiro espírito universitário seria formado pela atenção aos problemas do Estado, buscando soluções específicas (VERÇOSA, 1997, p.124; UFAL, Disponivel em: <http://hww.ufal.br/45anos/>), evidenciando a difusão dos debates nacionais que haviam se iniciado sobre a necessidade de uma reforma no ensino superior brasileiro.

A difusão da luta pela criação da Instituição ampliou-se e passou a ser reivindicado não apenas pela ação de estudantes e de professores, mas também de parlamentares e de toda comunidade alagoana, reunidos em torno da grande causa: a Universidade Federal de Alagoas $^{67}$. Nesta etapa, a historiografia da criação da Universidade registra a participação destacada do médico Aristóteles Calazans Simões, catedrático da então Faculdade de Medicina, que foi o principal articulador político, assumindo praticamente sozinho o desdobramento do processo de criação da Universidade (VERÇOSA, 1997, p. 126) e vindo a ser posteriormente o primeiro reitor ${ }^{68}$.

Com a possibilidade concreta surgida com o encaminhamento ao MEC dos pedidos para a criação das Universidades da Paraíba, do Rio Grande do Norte e de Santa Catarina, o catedrático, lançando mão do prestígio político e da habilidade de romper protocolos (VERÇOSA, 1997, p. 127) realizou a tramitação do processo de criação em tempo hábil de

\footnotetext{
${ }^{67}$ Sobre esse assunto recomendamos consultar a publicação UNIVERSIDADE FEDERAL DE ALAGOAS - 30 anos de vida 1961 a 1991 (1991).

${ }^{68}$ Verçosa $(1997$, p. 121-142) relata que o interesse imediato do doutor A.C. Simões era a federalização da Faculdade de Medicina, cujo processo, reapresentado pela direção da Instituição em junho de 1960 , "ele acompanhava pela segunda vez por delegação dos seus pares, graças à sua pertinência e aos contatos políticos e pessoais que mantinha na esfera federal". Os custos de manutenção e operação do curso da Faculdade de Medicina eram dispendiosos e difíceis de manter, fato que motivou o propósito da federalização.
} 
garantir a aprovação por ato do então presidente Juscelino Kubitschek, que já estava no final do mandato. Assim é que, como outras instituições nacionais similares, a UFAL foi instituída pela junção de seis estabelecimentos de ensino superior isolado (Faculdades de Direito, de Medicina, de Filosofia, de Economia, de Odontologia e da Escola de Engenharia), tendo como órgão executivo central uma Reitoria.

Passada a euforia inicial das comemorações e os sobressaltos logo advindos pelas notícias na imprensa local de que o recém-empossado presidente Jânio Quadros iria tornar inviável a existência da Universidade de Alagoas, o ano de 1961 seria todo ele dedicado à sua institucionalização, com a transferência de patrimônio, aprovação de estatuto, nomeação e posse de quase todos os professores vindos das escolas particulares, constituição do Conselho Universitário e finalmente organização da lista tríplice para a escolha do primeiro Reitor, que seria encabeçada [...] pelo $\mathrm{Dr}$. Aristóteles Calazans Simões (VERÇOSA, 1997, p. 133).

Assumindo a Reitoria em outubro de 1961, o doutor A. C. Simões conduziu os dez primeiros anos da recém-criada Universidade, que correspondem a três mandatos. Sua meta principal foi a construção das instalações físicas em território unificado, no modelo de organização espacial de cidade universitária. Uma verdadeira ideja fixa, conforme suas palavras registradas no histórico da UFAL (Disponivel em: <http://www.ufal.br/45anos/>). Oportuno mencionar que essa tipologia estava associada às ideias de integração universitária e convivência formadora do espírito universitário. A proximidade dos edifícios congregando as Unidades era entendida por muitos como fator essencial ao desenvolvimento de um espírito universitário, favorecido pelo convívio e pela integração da comunidade.

A meta instituída não encontrou resistências, já que a situação das seis Unidades que faziam parte da nova Instituição, apenas duas (a de Direito e a de Medicina) funcionavam em instalações condizentes. As demais estavam alocadas em espaços que não propiciavam o bom funcionamento das atividades, como a Escola de Engenharia que estava instalada no antigo prédio da Escola Técnica, a de Odontologia, mal acomodada num edifício que havia sido construído com propósitos residenciais, a de Filosofia utilizando as dependências do Colégio Guido de Fontgalland e a de Ciências Econômicas, em imóvel projetado para outros fins (Disponivel em: <http://uww.ufal.br/45anos/>). Faltavam ainda acomodações próprias para desenvolver as funções da Reitoria.

A ideia de cidade universitária não estava, porém, limitada à solução de espaços físicos funcionais. A crença no poder modernizador e reformador do território destacava-se nos discursos do reitor, que a ele se referia como um caminho a ser seguido por uma universidade nova, moderna, verdadeira e autêntica (VERÇOSA, 1997, p. 140). Estava 
assimilado que a renovação da Universidade seria consequência da criação e do desenvolvimento da Cidade Universitária, que marcaria definitivamente a superação do tradicionalismo e a entrada da instituição na modernidade (VERÇOSA, 1997, p. 137). O sonho ou a ideia fixa de um espaço exclusivo para a Universidade de identidade moderna foi exaltada em seu discurso de despedida, quando afirmou que Alagoas tinha então a sua pequena Brasilia Universitária, absolutamente irreversível (SIMÕES apud VERÇOSA, 1997, p. 141).

As palavras do reitor evidenciam a difusão da modernidade instalada com a inauguração de Brasília, a nova capital brasileira, em 1961. A Universidade de Brasília (UnB), prevista no Plano Piloto da cidade, repercutia nacionalmente com sua proposta educacional.

Concebida com a intenção de servir de elemento indutor da modernização da universidade no Brasil, a UnB propunha romper com o distanciamento da Universidade relativamente ao processo de desenvolvimento do país e constituir-se ainda em importante centro intelectual e científico ao nível latino-americano, além de formar quadros para docência e pesquisa (MARICATO; KOHL; PAMPLONA, 1974, p. 92).

Estruturada nos três componentes básicos - Institutos Centrais, Faculdades Profissionais e Órgãos Suplementares - a UnB foi situada no plano urbanístico de Brasília em área específica. Estava instalado um novo modelo de ensino superior associado a um território físico que incorporou a imagem da modernização universitária brasileira naquele início de década.

O projeto prioritário do doutor A. C. Simões logo encontrou correspondência nas reivindicações do movimento estudantil que em caráter nacional debatiam sobre a necessidade de uma reforma do ensino superior brasileiro e que repercutiu em Alagoas, pressionando por uma reestruturação na recém-criada Universidade. O paradigma da Faculdade de Filosofia, Ciências e Letras, com posição de escola central, estava associado ao modelo de universidade formada pela simples reunião de faculdades e escolas isoladas, tornando-se condição a ser superada. O reitor Simões assim expressava:

Em 1962 e 1963 iniciávamos, apenas, a nossa vida de universidade recém-criada e organizada à moda clássica brasileira. Éramos, como uma das mais novas universidades brasileiras, cópia fiel das mais antigas (SIMÕES apud AZEVEDO, 1982, p. 140).

Para dar cabo de tal intento, já em 1962, um grupo de trabalho foi instituído para pensar na reestruturação acadêmica, a ser moldada pelas unidades de Formação Básica e as de 
Formação Profissional, a partir da qual se daria encaminhamento ao plano de construção da Cidade Universitária - o corpo da nova estrutura universitária. Com esse propósito o processo de aquisição do terreno foi iniciado enquanto ainda ocorriam as discussões do referido grupo de trabalho ${ }^{69}$, tendo sido selecionada uma gleba localizada em subúrbio afastado (ver figura 202).

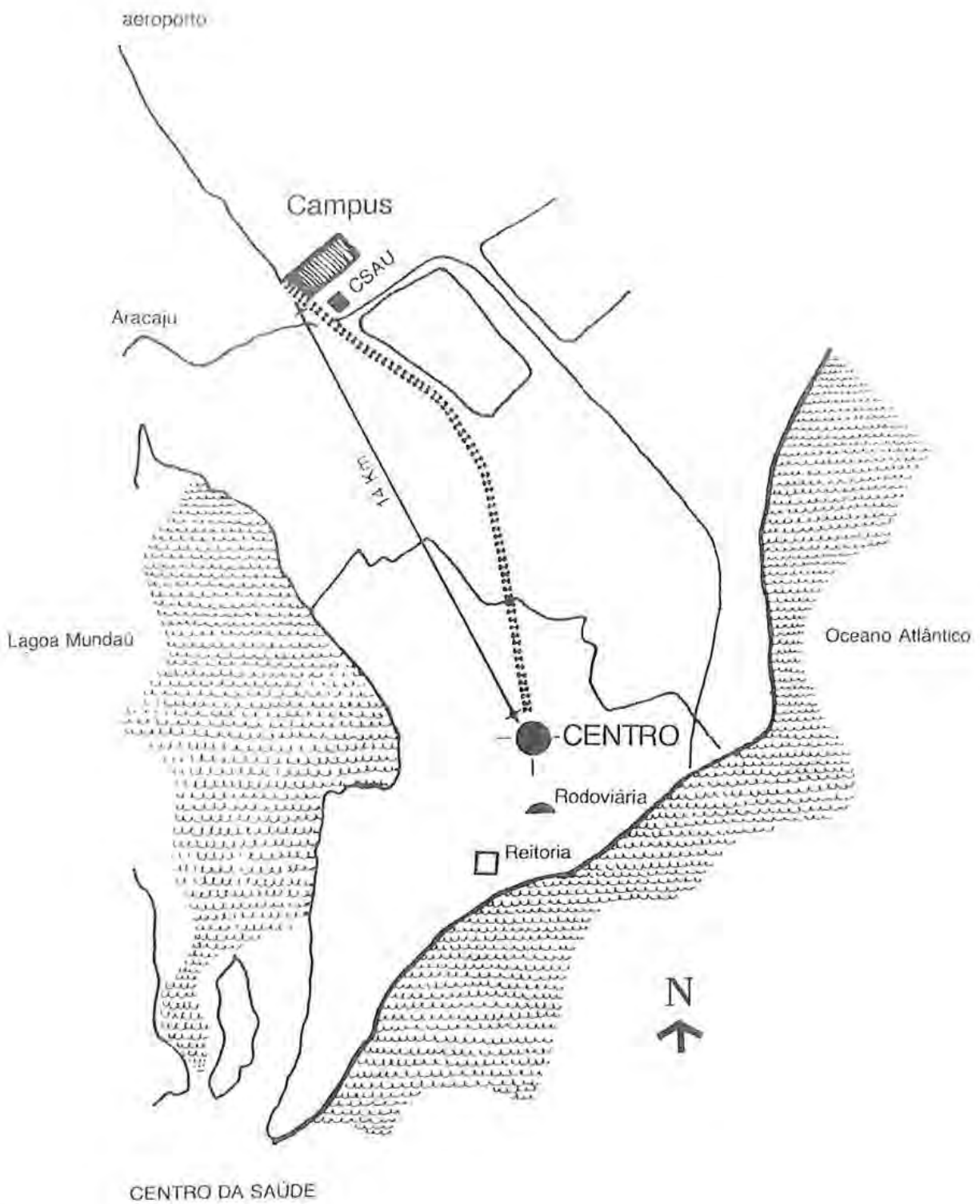

Figura 202: UFAL - Mapa de localização do Campus.p

O terrento adquirido na década de 1960 para a construção da Cidade Universitária e que na década seguinte passou a abrigar a estrutura acadêmica da Reforma, denominando-se Campus A.C. Simões, configurava uma gleba afastada do centro da cidade e desprovida dos serviços de infraestrutura urbana.

(Fonte: UFAL, [1982?], p. 22)

\footnotetext{
${ }^{69}$ Diferindo das Universidades do Piaui e do Maranhão, o terreno para a construção da UFAL não foi adquirido por doação e
} sim comprado com saldo de recursos orçamentários. Sobre esse assunto, consultar Verçosa (1997, p. 135-136). 
Em 1964, o Plano de Reestruturação delineou a organização da UFAL em Institutos de Formação Básica e em Faculdades encarregadas do ciclo de formação profissional.

\begin{abstract}
Esse desenho, qualificado pelo Reitor de 'plano didático que deveria presidir a construção da Cidade Universitária, terminou sendo aprovado em fins de 1967 [pelo Decreto $n^{0} 61.897$, de 13 de dezembro daquele ano], com algumas mudanças na proposta original de 1964 , sendo então criados os Institutos de Ciências Exatas, Letras e Artes, Filosofia e Ciências Humanas, Geociências e Ciências Biológicas, mantidas as Faculdades de Direito, Medicina e Odontologia tal qual vinham da fundação. Foram mudados os nomes da Escola de Engenharia, que passou a se chamar Faculdade de Engenharia, e da Faculdade de Ciências Econốmicas, que recebeu a denominação de Faculdade de Economia e Administração, sendo também extinta a Faculdade de Filosofia, Ciências e Letras e [...] criada a Faculdade de Educação (VERÇOSA, 1997, p.138-139).
\end{abstract}

A construção dos primeiros prédios foi iniciada, entretanto, em 1966, antes mesmo da aprovação final do Plano de Reestruturação, ação pela qual o reitor diria que a implantação da Cidade Universitária viria dar corpo e alma à tão decantada Reforma, crença que ele reafirmaria no ano seguinte ao declarar que somente o campus permitiria a existência do verdadeiro espírito de equipe para os que ensinam e o legítimo e salutar espirito universitário para os que aprendem (SIMÕES, apud AZEVEDO, 1982, p. 37, grifo nosso).

Oportunamente, destacamos que os dois termos, campus e cidade universitária, são empregados nessas passagens para referenciar o mesmo território, porém implicitamente com significados diferentes. Campus corresponderia ao espaço delimitado pelo conjunto de edifícios que, abrigando a organização administrativa e pedagógica, seria o lugar das interrelações universitárias. Cidade universitária seria a gleba do território isolada geograficamente do meio urbano e do entorno imediato. Nessa concepção o campus é contido, espacial e socialmente, pela cidade universitária. Em qualquer das alternativas podemos evidenciar a convicção de que o território especializado e isolado fisicamente era condição premente para inserir o ensino superior na modernidade.

O Plano acadêmico, aprovado em 1967, passou a ser revisto, ainda no mesmo ano, por outros estudos com base na publicação dos Decretos-leis n 53/1966 e 252/1967 e logo depois na Lei $\mathrm{n}^{\circ} 5.540 / 1968$, que instituíam a departamentalização do ensino. A reestruturação da Universidade com a criação dos Departamentos vinculados aos Centros em substituição aos Institutos e Faculdades, entretanto só veio de fato a ocorrer em 1973 , efetivada pelo Decreto $n^{\circ} 73.970$, de 22 de abril de 1974 . 
Em 1971, embalado pelo propósito de dotar a Universidade de feições modernas, com base no modelo espacial de cidade universitária, o reitor A. C. Simões finalizou sua gestão tendo conseguido transferir parte das Unidades para o novo território em formação. Em reconhecimento ao seu esforço construtivo, o conselho universitário the outorgou, no final daquele ano, a honra de denominar o território suburbano da UFAL de Campus A. C. Simões.

A partir daí, o desenvolvimento da Universidade caracterizou-se pelas transformações estruturais nos seus aspectos acadêmico e administrativo, ligadas estreitamente às linhas da Reforma de 1968, que acarretaram uma redefinição nas diretrizes da política de programação do setor físico (UFAL, 1975, n.p.). Questões como "planejamento racional", "execução racional dos programas", "reestruturação dos campos acadêmico e administrativo", "função do departamento", "institucionalização da carreira do magistério", "ensino, pesquisa e extensão", "taxa erosiva de ociosidade" e "desenvolvimento econômicosocial do Estado, em consonância com metas e bases do Governo Federal", dentre outros, passaram a fazer parte do projeto delineado pela nova administração, conforme será apresentado no decorrer do presente capítulo.

Para Verçosa (1997, p. 150-151) nada mais vinculado ao momento que se estava vivendo o regime militar pós-1964. Afinal, o reitor que tomava posse era general da reserva do Exército Nacional ${ }^{70}$ e o grupo que formava sua assessoria comungava com ele dos ideais da dita modernização de marco autoritário em curso no país. No bojo do projeto do Governo então no poder, outro Plano foi elaborado com a finalidade de implantar o campus universitário da Reforma de 1968. Cabia ao novo documento a dupla função de embasar a transferência das unidades que ainda estavam funcionando no centro urbano de Maceió para o território suburbano o qual paralelamente seria moldado para dar corpo à estrutura da Reforma em substituição à organização espacial conformada originalmente nos moldes de uma cidade universitária.

\subsection{O TERRITÓRIO DA UFAL: a transferência do centro urbano para o subúrbio}

As condições das instalações físicas das Unidades em funcionamento no centro da capital foram avaliadas como inadequadas para atender aos novos programas da Universidade recém-criada, conforme já mencionado, requerendo da Administração Superior constantes investimentos em construções e reformas. Paralelamente se iniciava a construção das

\footnotetext{
${ }^{70}$ Reitor Nabuco Lopes (gestão de 1971 a 1975).
} 
edificações e infraestrutura básica que conformariam a estrutura espacial da Cidade Universitária.

\section{- Faculdades de Medicina e de Odontologia: prenúncio do vocabulário modernista}

No conjunto dos edifícios, situados em área urbana consolidada, merecem menção os que abrigaram o Centro de Ciências Biológicas, onde originalmente funcionou a Faculdade de Medicina, e o da Faculdade de Odontologia, os quais estão referenciados na publicação Arquitetura Moderna: a atitude alagoana, de autoria da professora aposentada Maria Angélica da Silva, do Departamento de Arquitetura e Urbanismo da UFAL (SILVA, 1991).

A Faculdade de Medicina, autorizada a funcionar em 1951, recebeu por doação o antigo prédio do Quartel do $20^{\circ}$ Batalhão de Caçadores (BC) para a instalação da Escola. As obras de adaptação foram realizadas pelo arquiteto Joffre Saint'Yves Simon, nascido no Acre e formado em Recife no ano de $1944^{71}$. Seus primeiros trabalhos recebem a influência do estilo neocolonial, porém, conforme aferiu a arquiteta da UFAL, provavelmente diante da consolidação da linguagem moderna e movido pelo interesse de acompanhar sua evolução, Saint 'Yves Simon afasta-se do vocabulário passadista e opta por uma solução de padrão atualizado, com volumes de geometria bastante definida (SILVA, 1991, p. 65). No Quartel, o arquiteto mantém a linguagem arquitetônica do edifício de características neocoloniais e a volumetria retilínea e enfatiza a solução de verga em arco e a platibanda trabalhada. A entrada principal é demarcada pelo uso de arcos, colunas retorcidas e painel de azulejo (ver figura 203).

Em 1964, o arquiteto elaborou o projeto do novo bloco da Escola de Odontologia da UFAL. Tratava-se, segundo Silva (1991, p. 72), de um bloco retilíneo, com marcação de pilares da estrutura, que, no entanto passou por várias modificações.

Com as primeiras obras da Cidade Universitária, a infraestrutura acadêmica e administrativa da UFAL foi sendo transferida gradativamente, a partir de meados da década de 1960, para o território localizado no Tabuleiro dos Martins. ${ }^{71}$ Joffre Saint'Yves Simon, nascido no Acre, filho de franceses, desenvolveu nas décadas de 1950 e 1960 um número
expressivo de obras de caráter público na cidade de Maceió. Sobre esse assunto ver a publicação de Silva (1991, p. 65-82). 


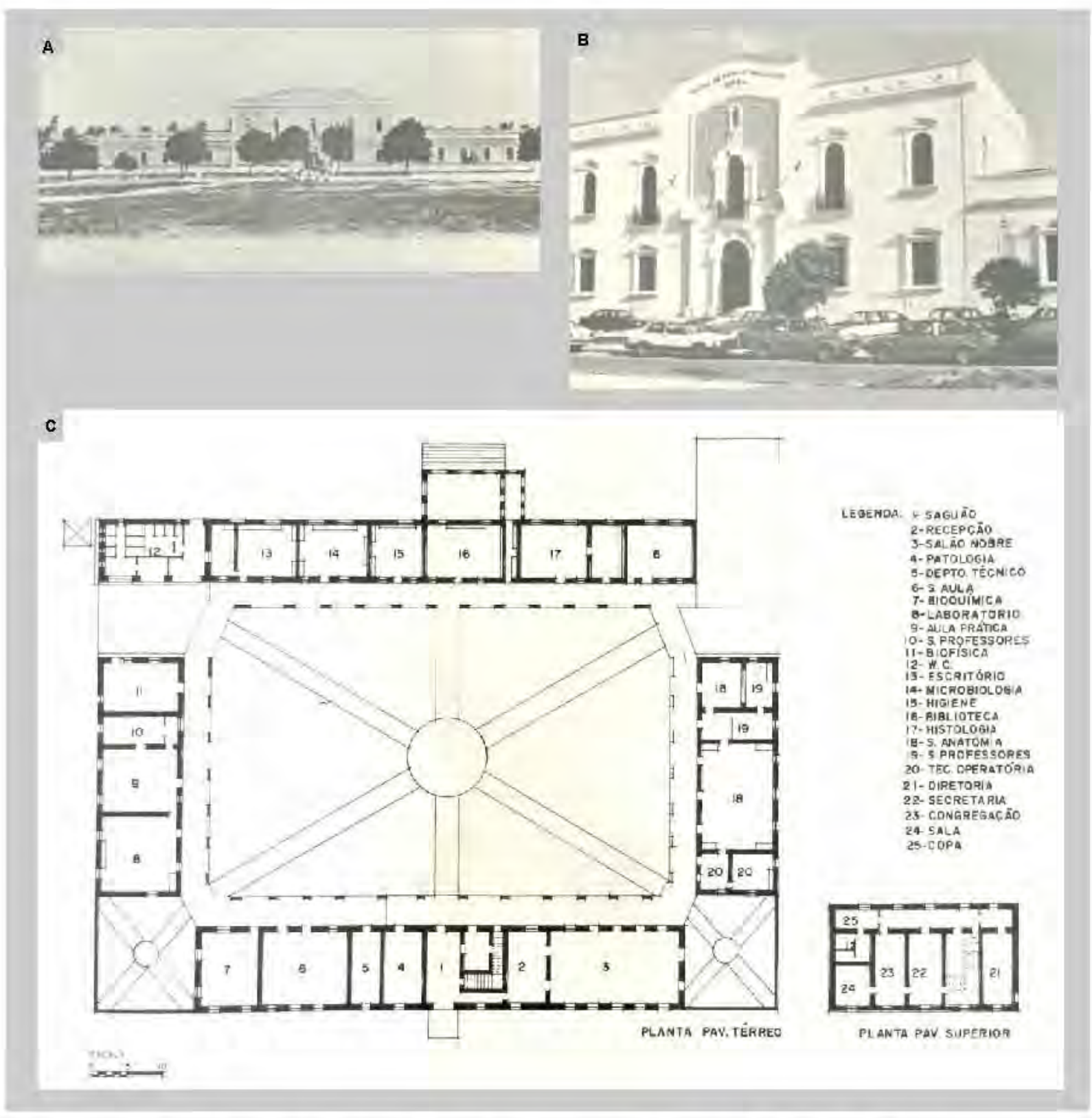

Figura 203: UFAL - Antiga Faculdade de Medicina - primeira metade da década de 1950.

(A) Prédio do Quartel do Exército.

(B) Prédio reformado para abrigar a Faculdade de Medicina e posteriormente o Centro de Ciências Biológicas da UFAL. Atualmente encontra-se em processo de tombamento.

(C) Planta de arquitetura.

(Fonte: SILVA, 1991, p. 66-67)

- Tabuleiro dos Martins: periferização da universidade

Diferindo de outras instituições similares, o terreno destinado à construção da Cidade Universitária, não foi uma doação de setores ou órgãos governamentais. Sua aquisição, em 1962, se deu por meio de saldos de recursos orçamentários da Universidade ${ }^{72}$. A gleba,

${ }^{72} \mathrm{O}$ entấo reitor A. C. Simőes lançou mão de um hábil recurso restringir o quanto the fosse possivel o preenchimento de vagas
para os cargos constantes do Quadro Oficial da Universidade que ainda năo estavam preenchidos e gratificar com um terço para os cargos constantes do Quadro Oficial da Universidade que ainda năo estavam preenchidos e gratificar com um terço 
distando em torno de $15 \mathrm{~km}$ do centro de Maceió, está situada à margem da BR-101 Norte, que liga Maceió a Recife com área de 210 ha (ver figura 204).

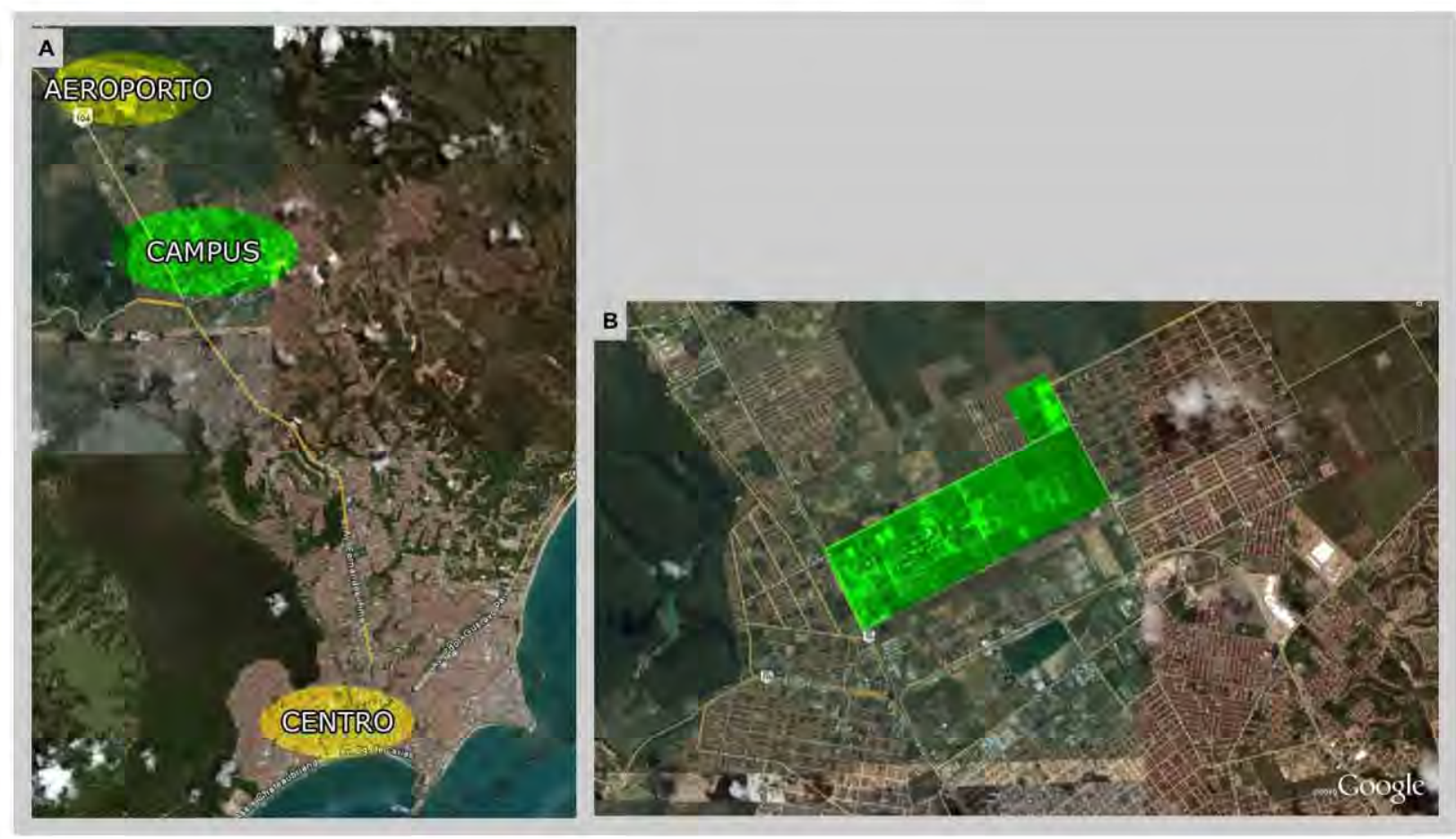

Figura 204: UFAL - Vista aérea do Campus A. C. Simões.

(A) Vista aérea de Maceió - Relação Campus/Cidade.

(B) A gleba encontra-se atualmente cercada por setores industriais, de serviços e conjuntos residenciais.

(Fonte: Google Earth. Acesso em 27 set. 2011)

A localização afastada do centro urbano conferia à área da Universidade características de isolamento e barreira quase intransponivel às funções da cidade, tanto em relação aos sistemas viários e de transportes, quanto à infraestrutura e serviços. Cercado de propriedades particulares extensas, seu entorno imediato não apresentava serviços comerciais significativos. Sua presença, à margem do eixo rodoviário, entretanto resultou em direcionador de crescimento urbano, gerando fluxos e demandas de serviços, resultando no $c$ adensamento desse eixo, pelos setores residenciais, industriais e de comércios.

Em termos físicos, caracteriza-se por estar situada num tabuleiro (Tabuleiro dos Martins), com relevo constante e uma altitude média de $100 \mathrm{~m}$, próxima ao mar. Predomina o clima quente e úmido da cidade de Maceió, que estando a uma latitude de $10^{\circ}$ apresenta intensa radiação solar, especialmente no período compreendido entre setembro a março, com umidades médias de $80 \%$ a $95 \%$ e temperaturas de $23^{\circ}$ a $25^{\circ}$ no inverno, e $28^{\circ} \mathrm{A} 35^{\circ}$ no verão. O solo é constituído exclusivamente de massapé, argiloso e impermeável até os $30 \mathrm{~m}$

deixassem o cargo vago, fazendo uma poupança à custa da limitação de pessoal (Verçosa, 1997, p. 135). A legislação da Universidade previa que os saldos de recursos orçamentários poderiam ser aplicados em bens patrimoniais. 
de profundidade, o qual, associado à pouca declividade, empoça as águas da chuva. Predominam os ventos de nordeste a sudeste.

Com sua aquisição o reitor Simões tratou de dar encaminhamento ao planejamento das obras de construção do território exclusivo da UFAL, referenciado no modelo de cidade universitária, que embasou as tipologias espaciais desenvolvidas nas universidades brasileiras até a primeira metade do século XX.

\section{- Cidade Universitária: o plano dos arquitetos Oscar Valdetaro e Roberto Nadalutti}

Com o plano didático de 1964, a Universidade contratou os arquitetos Oscar Valdetaro e Roberto Nadalutti para elaborarem o Plano Diretor da Cidade Universitária. Eles também projetaram os blocos dos Institutos, destinados a abrigar as atividades dos ciclos básicos e do Hospital Universitário ${ }^{73}$ que serão apresentados no decorrer do capítulo.

O Plano dos arquitetos, embora citado em documentos e publicações referentes à Universidade (SILVA, 1991, p.102; UFAL, 1982, p. 138 e [1982?], p.6), não foi localizado. Significativo é o documento da UFAL, do final da década de 1970 , elaborado com a finalidade de apresentar à comunidade universitária ações referentes aos eventos administrativos que lastrearam o dimensionamento de área física prevista para implantação total da Universidade (UFAL, [1982?], p. 6) e que faz referência ao Plano, que tinha características de uma cidade universitária. A menção deixa implícita a ideia de um modelo de organização espacial específica.

Com base em plantas com título de Plano Diretor, datadas dos anos 1970 e pertencentes ao acervo da atual Prefeitura do Campus, foi possível evidenciar e analisar a concepção predominante no plano urbanístico implantado na UFAL, que apresenta semelhanças com aquele desenvolvido por Valdetaro e Nadalutti para a cidade universitária da então recémcriada Universidade de Santa Maria, no Rio Grande Sul $\left(\right.$ UFSM) ${ }^{74}$, instituída em 1960 . O projeto da UFSM

[...] reproduzia os esquemas urbanos já consagrados e identificados com os princípios da cidade funcional: o zoneamento rígido, a hierarquização das vias, adoção do parque para as novas construções, a monumentalidade, a abolição do parcelamento do solo em quadras e lotes rigidamente definidos, e a criação de um tecido edificado marcado por barras e torres (SCHLEE, 2003, n.p.).

\footnotetext{
${ }^{76}$ Sobre outros projetos dos arquitetos na área da saúde consultar o artigo: Gênese e Sobrevida de um Edificio Moderno: 0 caso da Maternidade Popular Escola de Fortaleza (2010).

${ }_{74}$ A Universidade de Santa Maria foi criada em 14 de dezembro de 1960. Sobre o projeto consultar os trabalhos de Nadalutti e Valdetaro (1962) e Rocha (1962).
} 
A aplicação desses princípios resultou na solução caracterizada pela organização espacial em torno de um eixo central e ordenador (ver figura 205) que

[...] se desenvolve no sentido norte-sul, em linha reta, do pórtico de acesso principal até a grande praça cívica (delimitada por prédios isolados e funcionalmente expressivos, como o teatro, o museu e o planetário). Tal eixo tem seu ponto focal no prédio da Reitoria, único edifício em altura, cuja empena serve como 'fecho de composição'. As demais unidades distribuem-se paralelamente ao eixo principal e agrupam-se segundo as 'áreas de ocupação' ou setores acadêmicos (resolvidos em prédios, com dois ou três pavimentos sobre pilotis) (SCHLEE, 2003, n.p.).

O conjunto das obras de infraestrutura e das edificações construídas na UFAL, no decorrer da segunda metade da década de 1960, configura uma tipologia espacial cujas diretrizes urbanísticas seguem o mesmo conceito de implantação da instituição gaúcha. $O$ território universitário de Alagoas organiza o espaço por meio de um eixo estruturador central, que se desenvolve no sentido sudeste-nordeste, constituído por uma larga avenida de 20 metros de largura, em linha reta e que se mantém na atual estrutura viária do Campus. Nasce na BR 101, acesso principal da Universidade, e se prolonga até o bloco da imprensa.

Diferindo, entretanto, da proposta da UFSM as unidades se distribuem perpendicularmente ao longo da avenida central, que articula o acesso aos edifícios de geometria linear, agrupados segundo um zoneamento funcional. A partir da entrada principal, foi implantado à direita da via estruturante o Hospital Universitário - zona 1, à esquerda, o Núcleo Esportivo - zona 2, ao centro, os Institutos, a Biblioteca, a Faculdade Economia, que depois passou a abrigar o Centro de Ciências Tecnológicas e o Centro de Ciências Humanas - zona 3, e, finalizando a via, o bloco da Imprensa - zona 4 (ver figura 206). As obras concluídas eram provavelmente parte de uma primeira etapa do Plano, selecionadas conforme as demandas prioritárias da Universidade, que estavam limitadas aos recursos financeiros disponíveis ${ }^{75}$.

${ }^{75}$ As limitações financeiras na concretização da Cidade Universitária estão relatadas na publicação da UFAL, Documento Histórico, de 1982. 


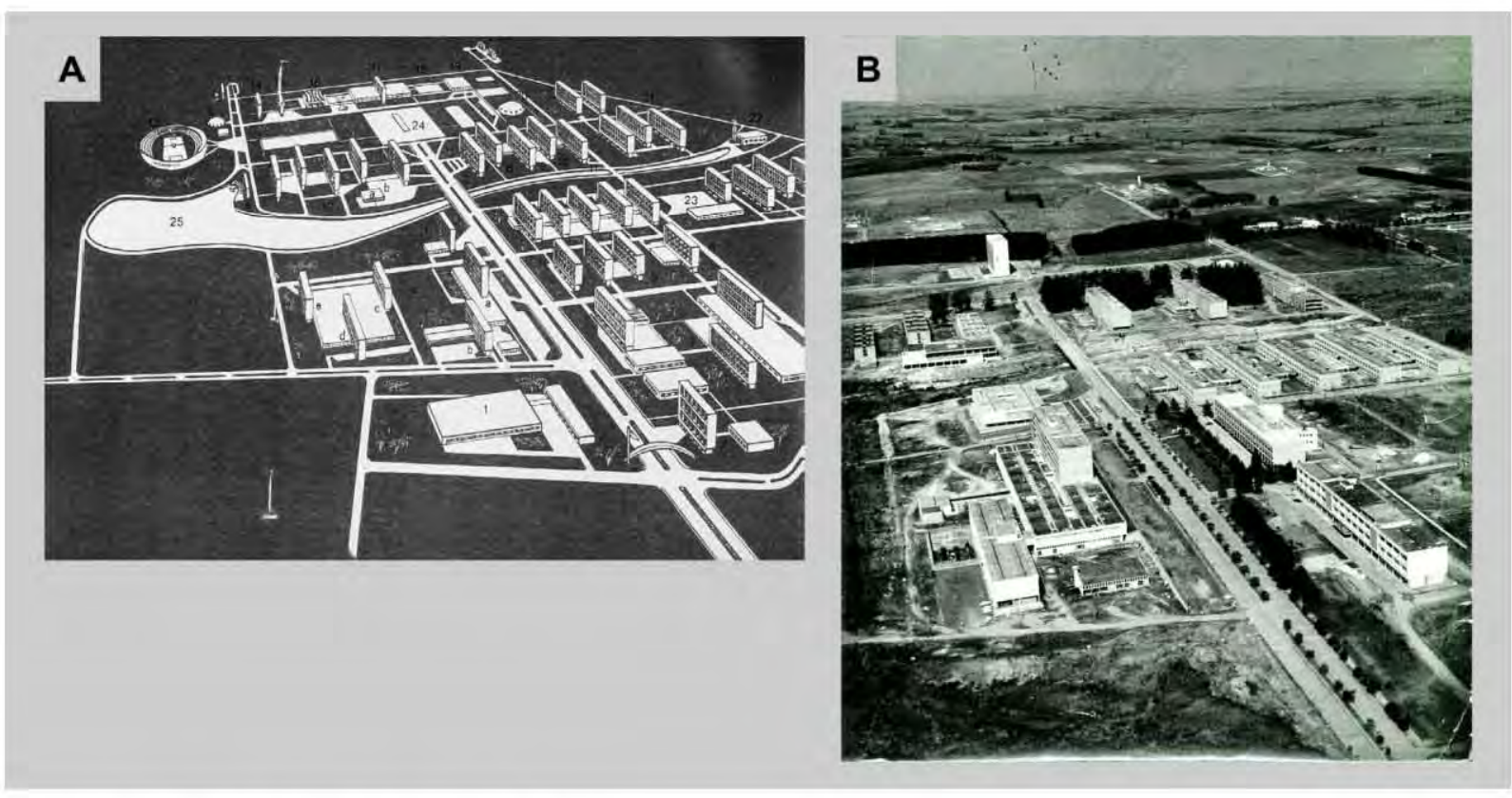

Figura 205: Cidade Universitária da UFSM

(A) Ilustração da Cidade Universitária com o eixo viário monumental de posição centralizada.

(B) Vista aérea da Cidade Universitária da UFSM - década de 1960

(Fonte: (A) CARDOSO, 1962, p. 2 apud SCHLEE, 2003, n.p.).

(Fonte: (B) Arquivo do autor apud SCHLEE, 2003, n.p.).

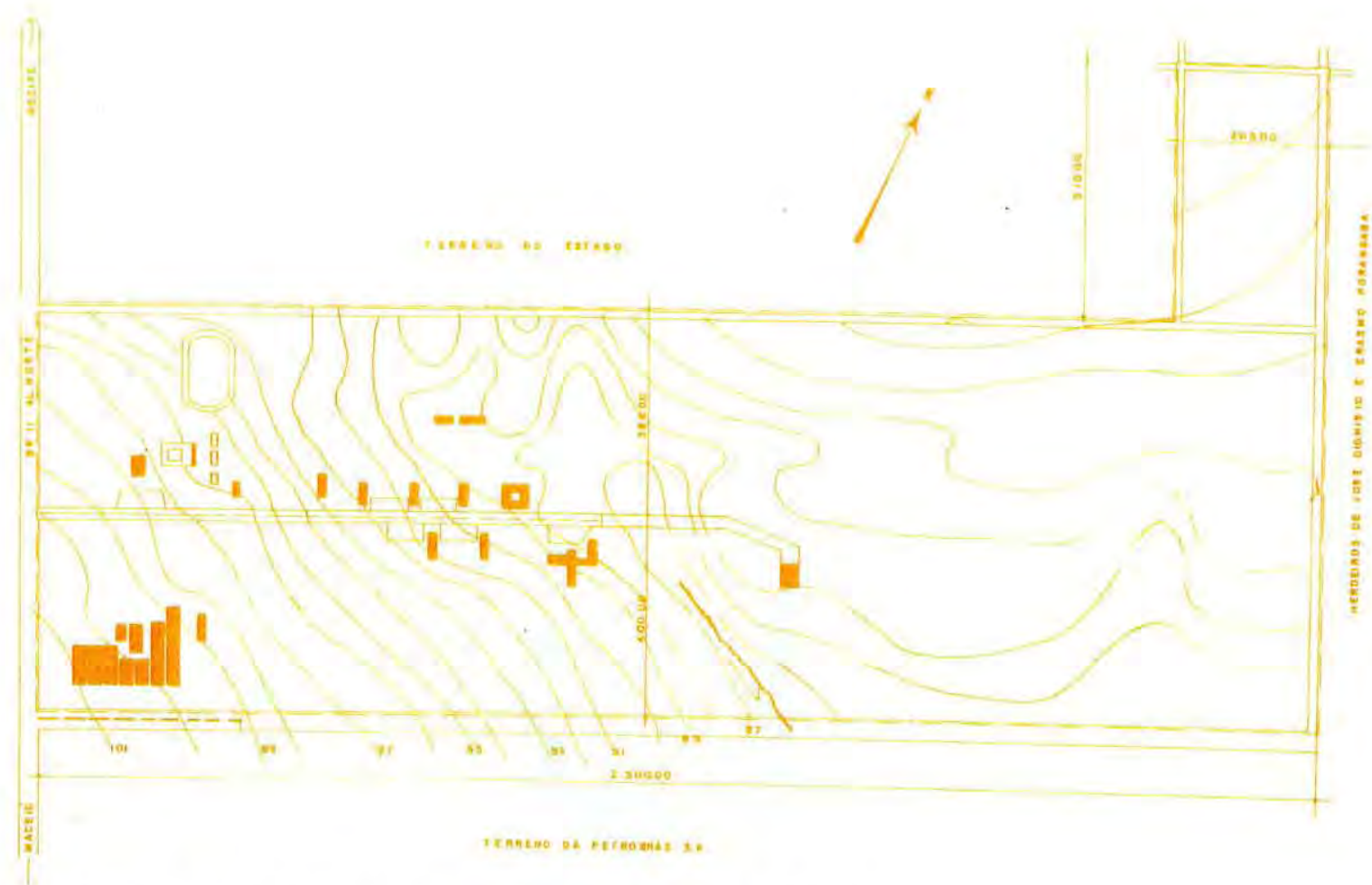

Figura 206: UFAL - Área urbanizada - Início da década de 1970.

A planta indica as edificações construídas, implantadas ao longo da via central e o hospital próximo à $B R$.

(Fonte: LUCINI, 1982, p. 35) 
Em 1973, a UFAL elaborou um Plano Diretor, segundo o qual, conforme planta da figura 207, o desenvolvimento físico da Universidade seria ajustado ao programa acadêmico estruturado na departamentalização e que foi aprovado pelo Decreto $n^{\circ} 73.970$, de 22 de abril de 1974. Nas palavras do reitor Simões:

Do plano didático então traçado [referência aos Institutos Centrais e Faculdades], partiu a execução do 'Plano Diretor' da Cidade Universitária. E quando vieram os Decretos-Leis $n^{\circ s} 53$ e 252 , impondo a reestruturação de todas as universidades brasileiras [referência à departamentalização do ensino], fácil foi ajustarmos o que havíamos feito e aprovado às nossas disposições legais (SIMÕES apud UFAL, 1982, p. 140).

É provável que a proposta tenha sido uma adequação do Plano de autoria dos arquitetos Valdetaro e Nadalutti, porém redimensionada por técnicos da Universidade.

A configuração urbanística do Plano de 1973 considera a existência das obras concluídas e mantém a via central como elemento estruturador da organização espacial. $O$ estudo contempla o centro cívico composto pela Reitoria, Concha Acústica, Biblioteca e o Centro de Interesse Comunitário. Juntamente com o Hospital e o Núcleo Esportivo conformavam uma faixa de ocupação fronteiriça situada às margens da BR-101. As unidades departamentais estavam implantadas nos antigos blocos dos Institutos que tinham previsão de ampliação e em áreas destinadas a futuras expansões. Conformava a zona central de ocupação com tipologias predominantemente de geometria retangular. Não estavam ainda agrupados em Centros.

O sistema viário está constituído por vias principais de caráter estruturante e vias secundárias que formam um tecido urbano reticulado com quadras de dimensões variadas a serem ocupadas pelos setores da Universidade. Fazem parte do sistema principal a via central estruturante existente e outra de caráter circundante, a ser implantada nos limites do terreno, abraçando a área de edificação. A validade da configuração urbanística do Plano de 1973 foi mantida até fins da década de 1970 , conforme podemos constatar pela planta da figura 208, elaborada em agosto de 1978.

As propostas desenvolvidas, embora não apresentem a qualidade do Plano da Cidade Universitária da UFSM, evidenciam as referências modernistas de cidade-parque, caracterizada pelo isolamento do centro urbano tradicional e a organização espacial baseada no zoneamento funcional, onde o preceito da monumentalidade foi adotado por meio do eixo estruturador. A organização perpendicular dos edifícios ao longo da via central parece buscar referências na Esplanada dos Ministérios da cidade de Brasília, resultado que talvez tivesse levado o reitor A. C. Simões a comparar o novo território da UFAL com a capital brasileira no seu discurso de despedida, já referenciado no presente capítulo. 


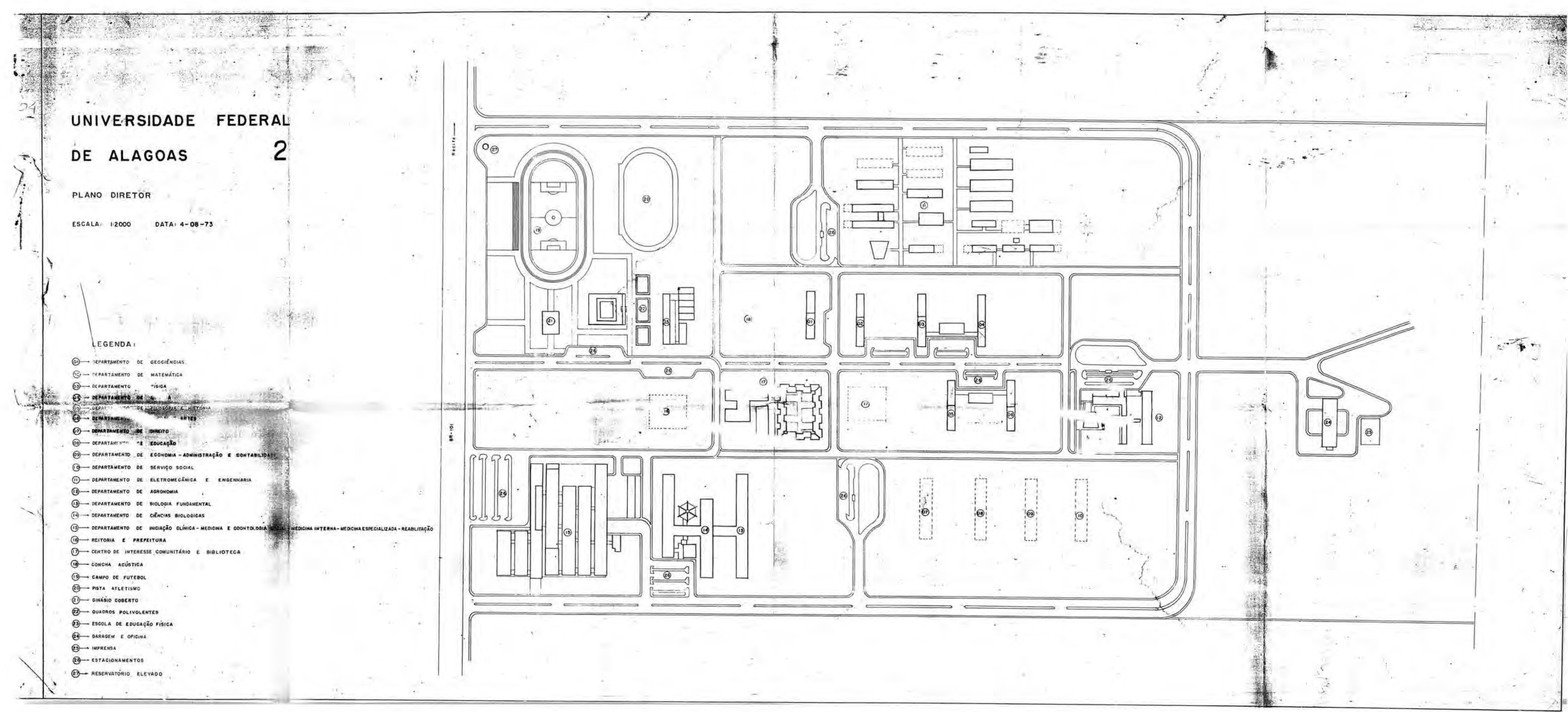

Figura 207: UFAL - Plano Diretor - 1973. 


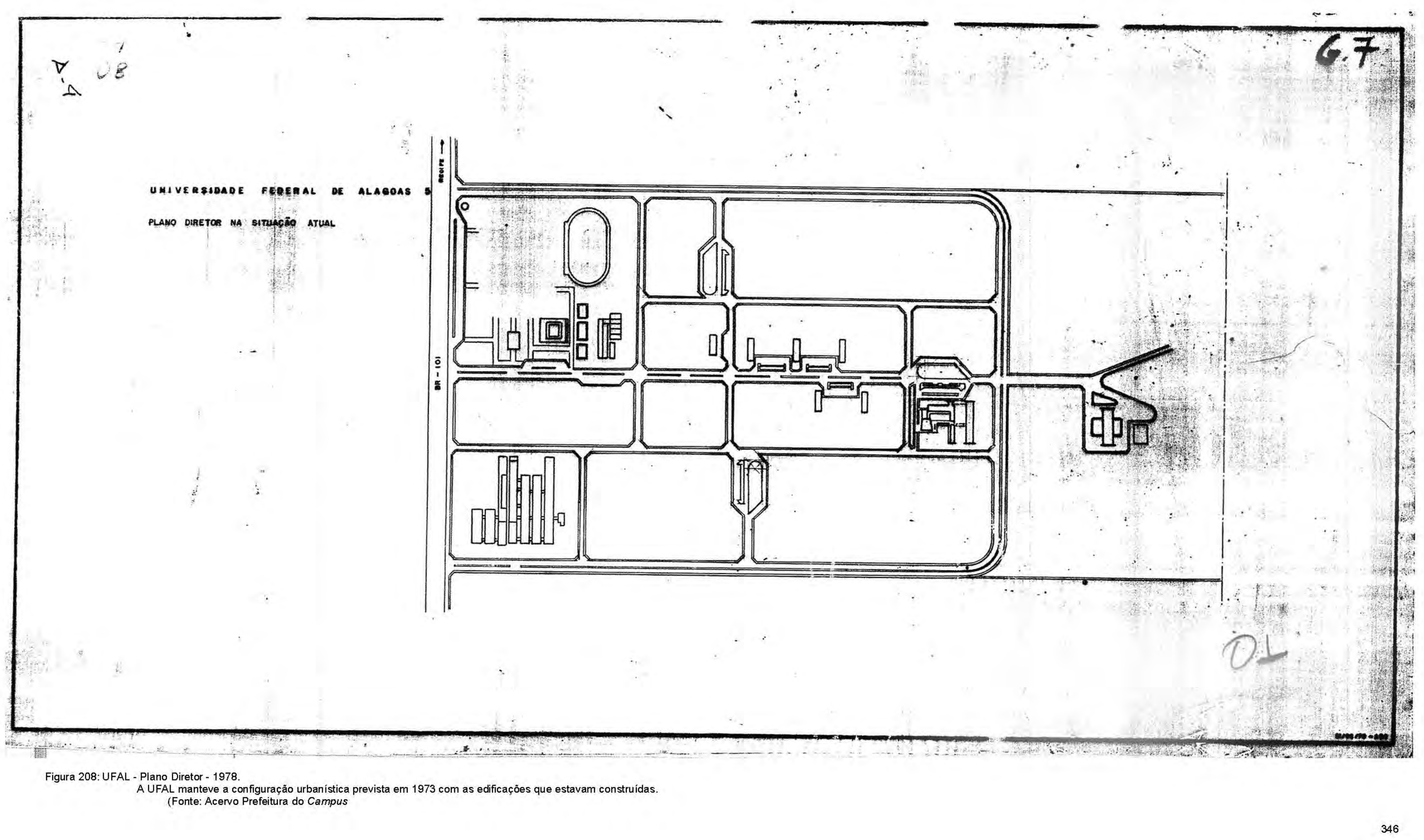


Importante observar que as plantas de 1973 e 1978, apresentadas na presente seção, não apresentam referências às tipologias espaciais de cidade universitária e/ou campus universitário. É somente a partir dos estudos realizados pela Universidade de São Carlos (UFSCar), visando elaborar o planejamento físico da UFAL compatível com a estrutura da Reforma, que a documentação gráfica referente ao território da Universidade passou a ser referenciada como Campus A. C. Simões, conforme se constata na planta esquemática da figura 209 elaborada pela instituição de São Paulo. A ilustração caracteriza a organização espacial existente, identificando a os setores já construídos (os edifícios originalmente destinados aos Institutos, o Hospital Universitário, a Faculdade de Ciências Econômicas, a Faculdade de Economia e o Setor Esportivo) que seriam reformados para adequação à estrutura acadêmica da Reforma. A via central não teve continuidade e uma via secundária de característica provisória faz ligação ao edifício da Imprensa.

C 4.2 TIPO DI ORGANIDACÃO ESPACIAL EXISTENTE

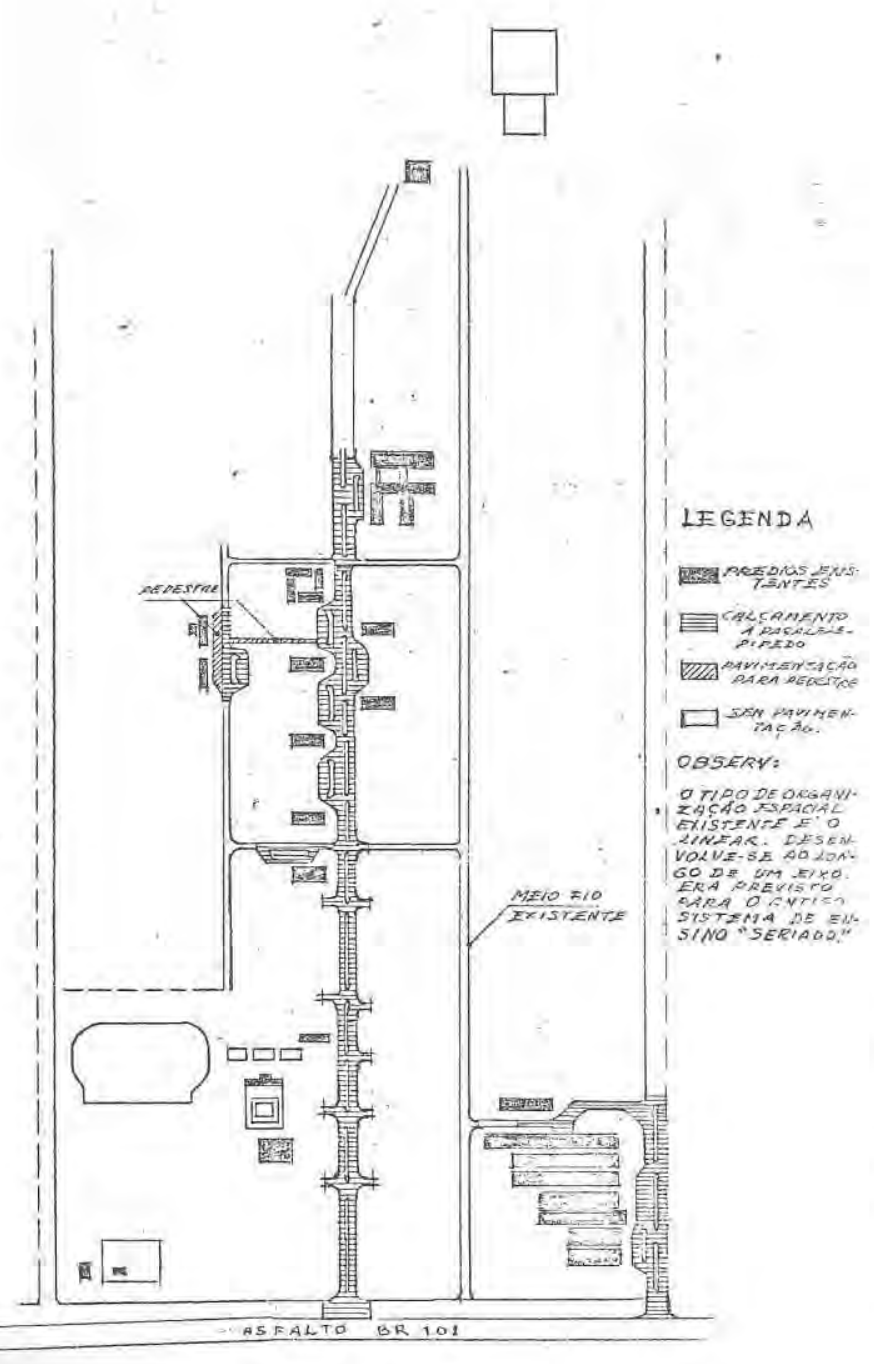

Figura 209: UFAL - Esquema de organização espacial do Campus A. C. Simões.

Constatação da estrutura física existente no final da década de 1970.

(Fonte: CONVENNIO UFSCar / UFAL, [1979?], n.p.). 


\section{- O Desenvolvimento Físico: décadas de 1960 e 1970}

Os investimentos empreendidos na concretização da estrutura física da UFAL durante as décadas de 1960 e 1970 refletiram, num primeiro momento, o desejo prioritário de construir a cidade universitária e posteriormente, com o projeto da Reforma, o cumprimento às orientações do projeto do governo militar que indicava o campus universitário como modelo de organização espacial. Embalada pela demanda de novos cursos, a Universidade ampliou as fronteiras da sua base física incorporando novos territórios situados em localidades distintas - o Campus Tamandaré e o Campus do Centro de Ciências Agrárias.

\section{- A Construção da Cidade Universitária - Década de 1960}

A construção do território exclusivo da UFAL foi iniciada em 1966, com as obras de infraestrutura e urbanização, como a execução de vias e do prédio da Faculdade de Economia e Administração, primeira unidade a entrar em funcionamento, já no ano seguinte, e do edifício da Imprensa Universitária (ver figuras 210 a 212). Ao mesmo tempo, porém, eram realizadas reformas nos prédios das unidades sediadas no centro de Maceió, tais como a Faculdade de Engenharia, a Faculdade de Filosofia, a Faculdade de Odontologia e - Lar da Universitária de Alagoas, cujos serviços foram concluídos em 1967. As obras de reforma das Faculdades de Direito e Medicina, que requeriam um cronograma mais extenso de execução mantinham-se em continuidade.

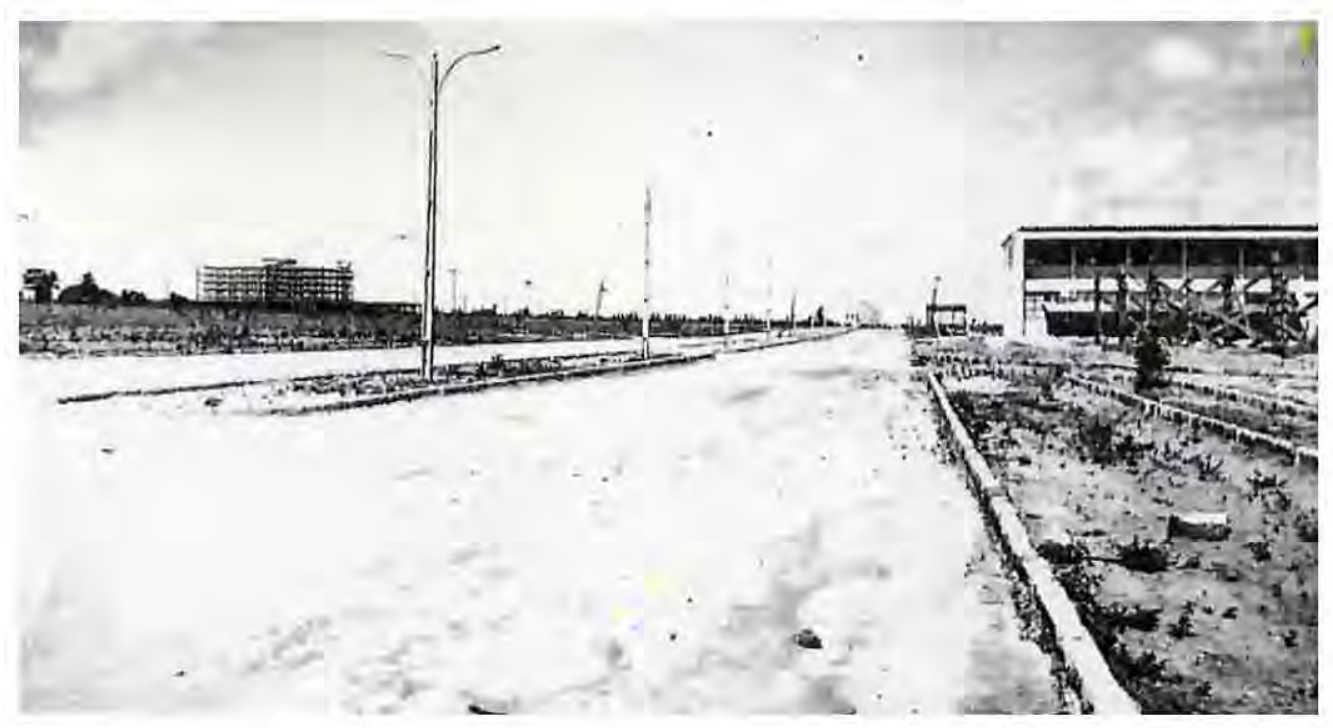

Figura 210: UFAL - Construção da Cidade Universitária - segunda metade da década de 1960. Início das obras de urbanização, vendo-se um dos institutos (à direita) e o Hospital Universitário (à esquerda) em fase de construção.

(Fonte: AZEVEDO, 1982, p. 137 - 143) 


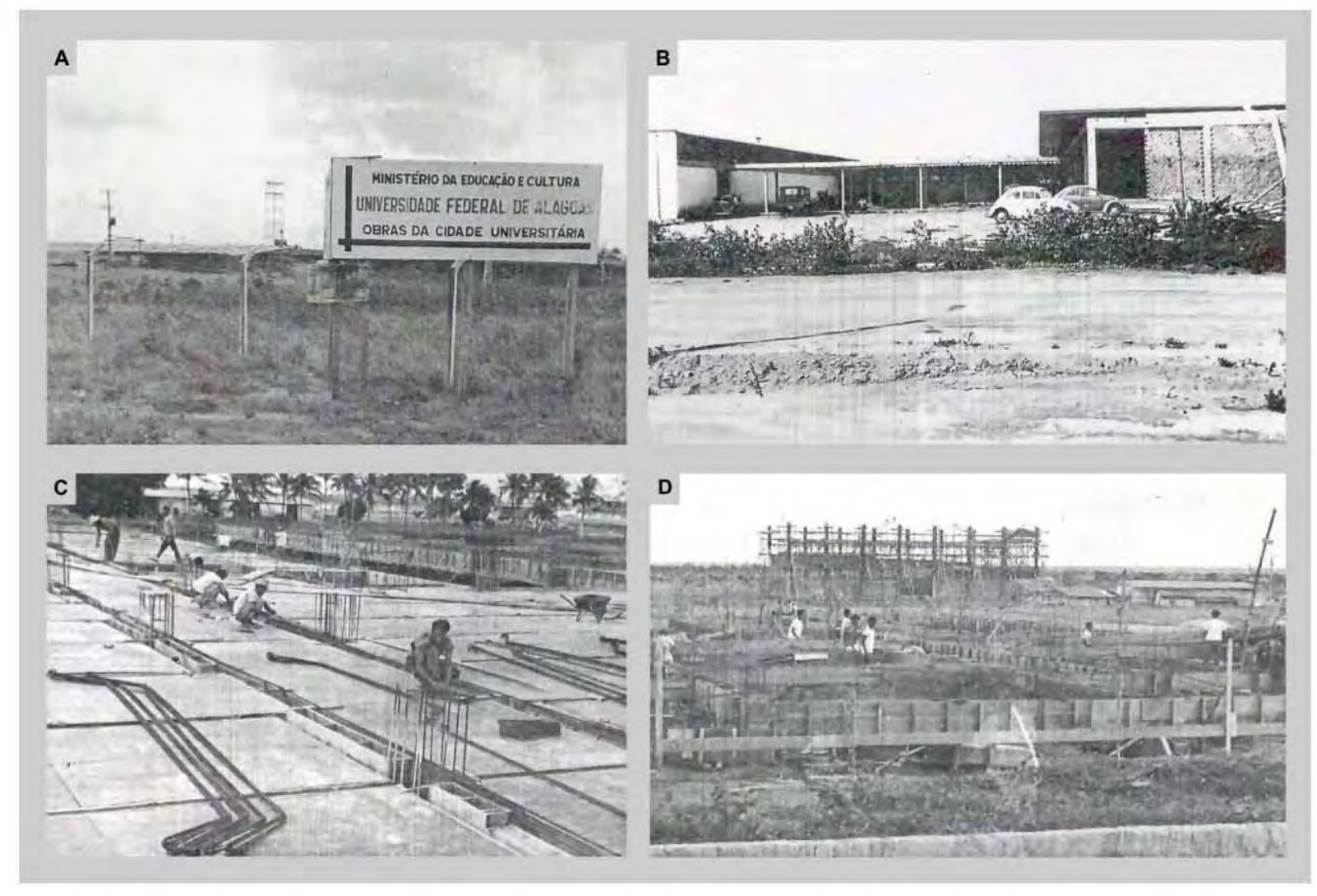

Figura 211: UFAL - Construção da Cidade Universitária - segunda metade da década de 1960.

(A) Placa de identificação das obras da Cidade Universitária

(B) Bloco da Faculdade de Economia e Administração.

(C) e (D) Aspecto das construções em 1968.

(Fonte: AZEVEDO, 1982, p. 137 - 141)

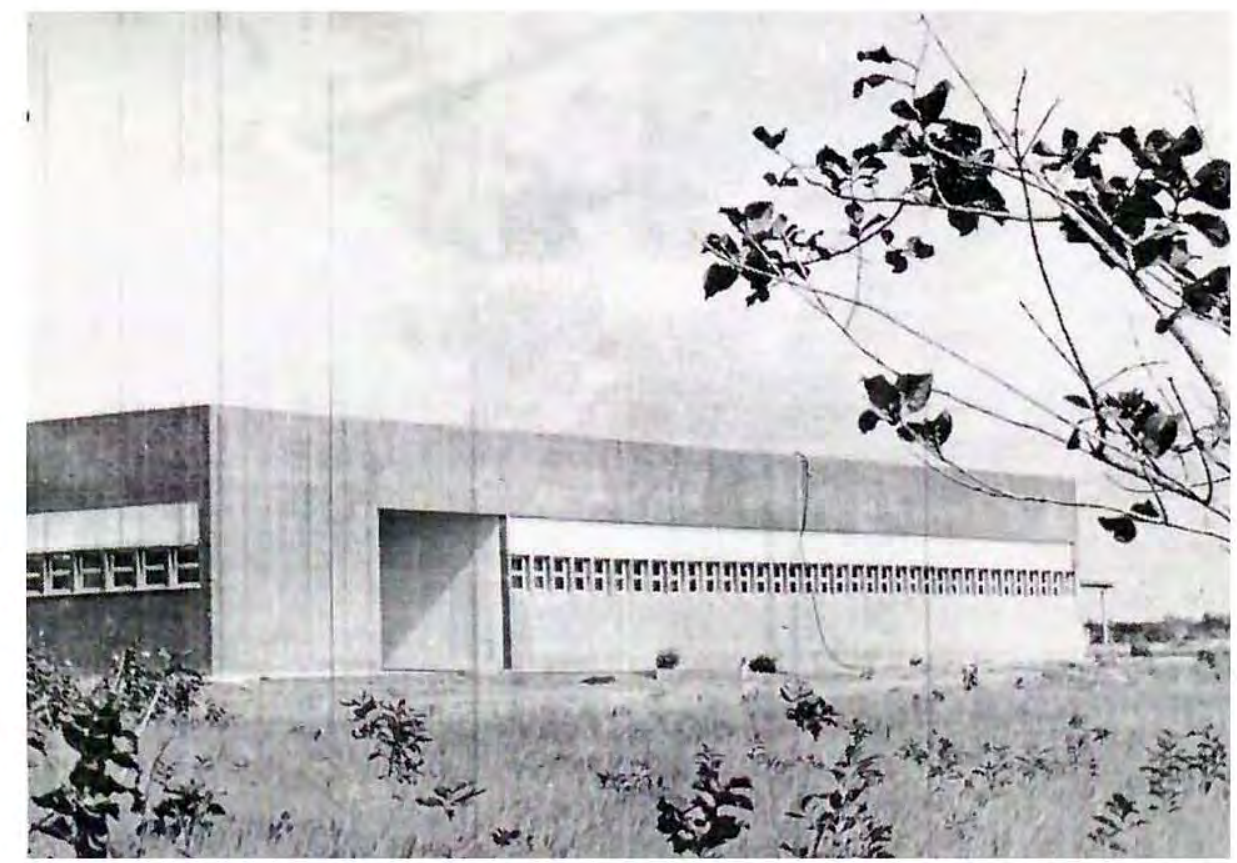

Figura 212: UFAL - Prédio da Imprensa Universitária - 1968.

(Fonte: AZEVEDO, 1982, p. 142) 
Em dezembro de 1967, foram iniciadas as obras do Hospital Universitário, que iria abrigar a sede da Faculdade de Medicina. A construção estava prevista para ser executada em duas etapas, tendo sido contratada a primeira, que correspondiam a uma parte da execução do concreto armado e área construída de $22.000 \mathrm{~m}^{2}$, com capacidade de duzentos e setenta e três leitos e todos os serviços gerais (ver figura 213).

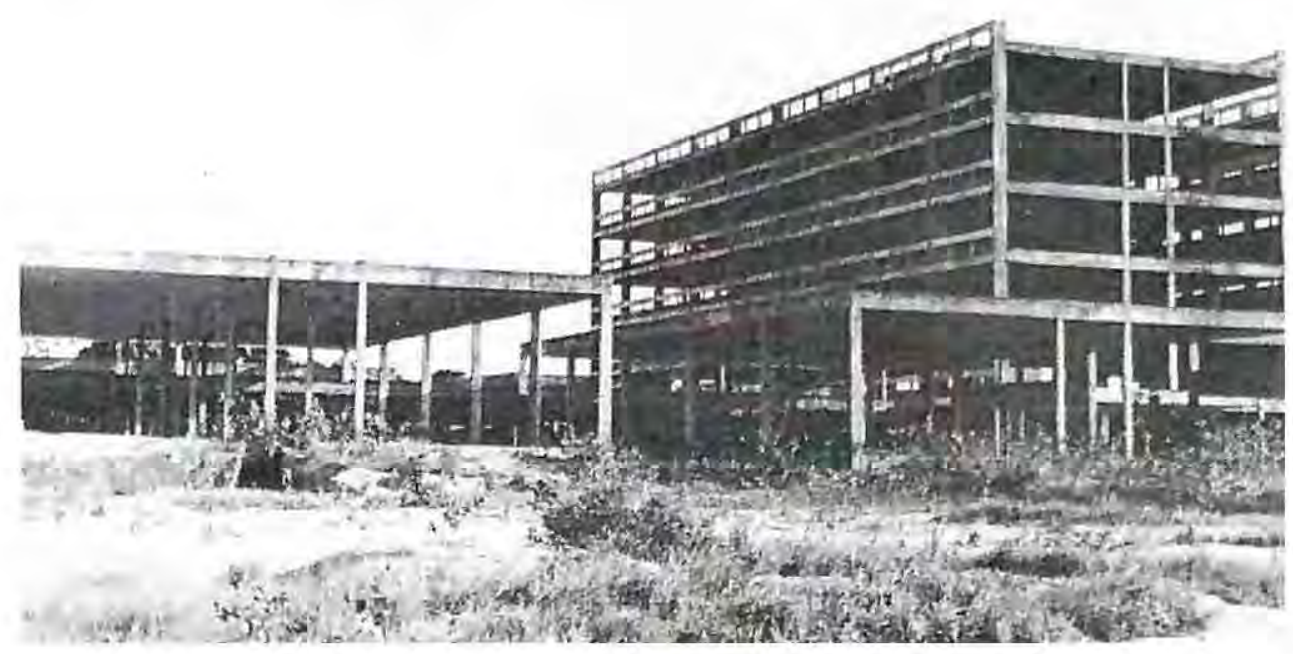

Figura 213: UFAL - Hospital Universitário - 1968.

Conclusão primeira etapa da estrutura de concreto armado.

(Fonte: AZEVEDO, 1982, p. 142)

No mesmo ano, com a aprovação do Plano de Reestruturação (por meio do Decreto $n^{\circ}$ 61.897, de 13 de dezembro de 1967), apreciado pelo Conselho Federal de Educação e aprovado pelo presidente da República, foi aberta concorrência para a construção de um Centro de Pesquisas Tecnológicas e dos Institutos de Física, de Química, de Geociências e de Filosofia e Ciências Humanas, com as obras iniciadas no ano seguinte.

Os edifícios dos referidos institutos compunham um conjunto de tipologias padronizadas, concebidas em blocos de dois pavimentos com a planta livre de geometria retangular, cortada longitudinalmente pela circulação central, formando duas alas paralelas de ambientes destinados às aulas, reuniões, gabinetes de professores, laboratórios, biblioteca, sanitários, dentre outros. Sua arquitetura manifestava referência aos princípios do modernismo internacional, com a organização de blocos isolados e indiferenciados, adotando a forma em "barra". Procurando moldar uma arquitetura de referências locais, adotou o combogó na fachada sudoeste como estratégia de amenização à incidência solar direta (ver figuras de 214 a 217 ). 
A
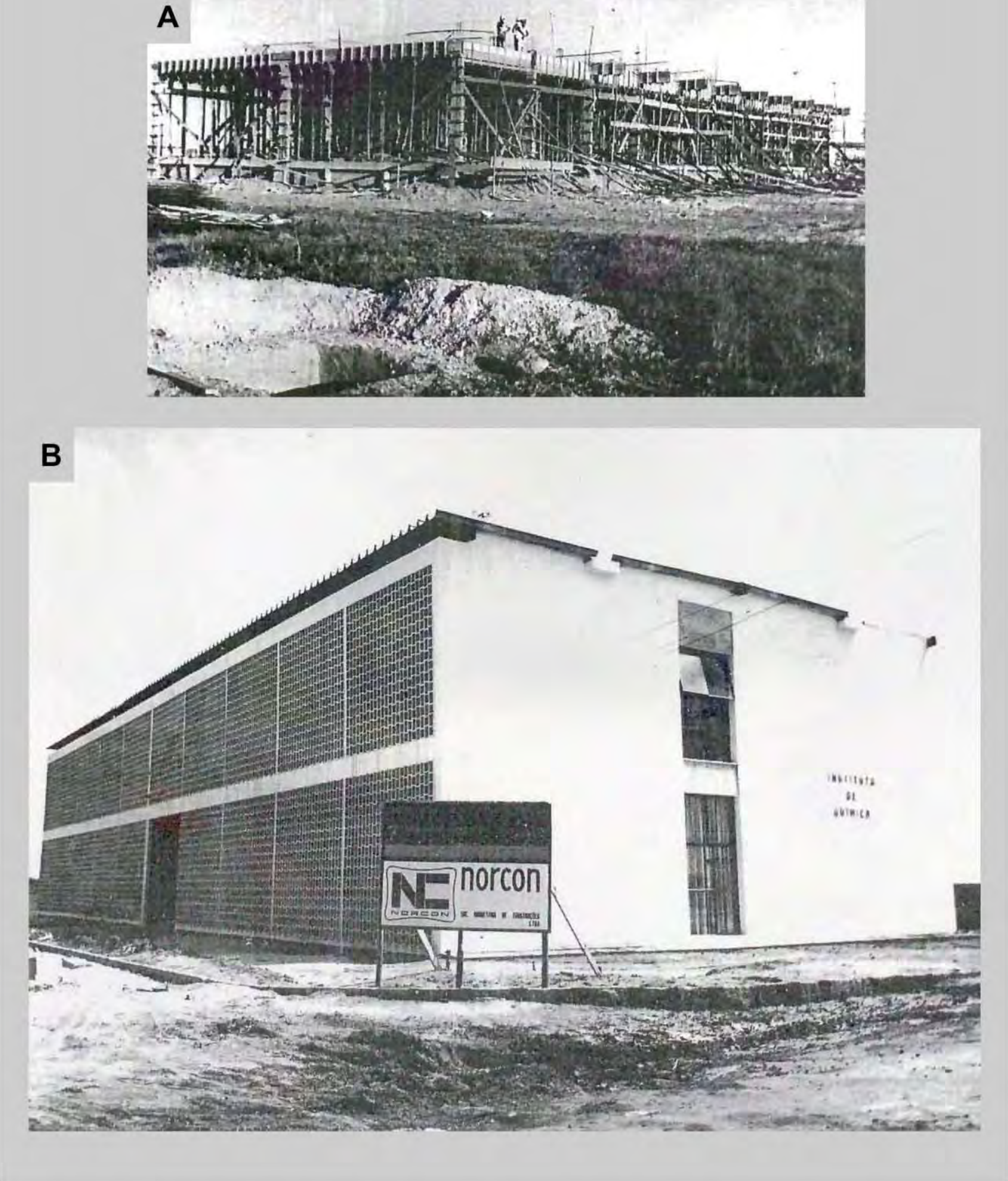

Figura 214: UFAL - Prédio do Instituto de Química - segunda metade da década de 1960 Ciencias Exatas e Naturais.
(A) Início das obras em 1968.

(B) Vista do prédio concluído em 1969.

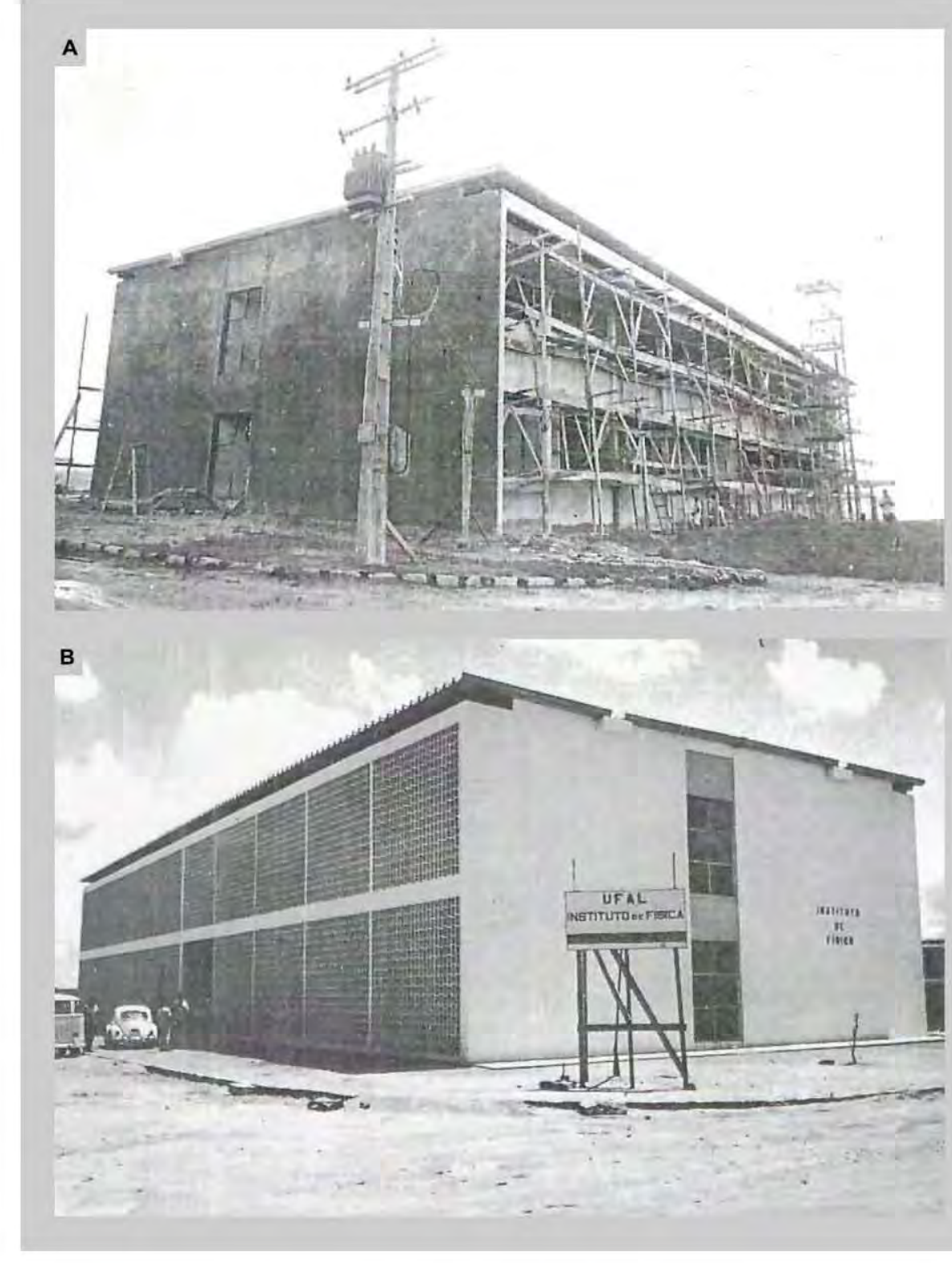

Figura 215: UFAL - Prédio do Instituto de Física - segunda metade da Com a reestruturaçáo académica passou a abrigar o
Departamento de Física do Centro de Ciênncias Exatas e Naturais.
(A) Ińcio e conclusăo em 1968.

(A) Ińicio e conclusăo em 1968.

(Fonte AZEVEDO, 1982, 130 e 146 , respectivamente)
Figura 216. UFAL_- Précio do Instituto de Geociências - segunda metade Com a reestruturaçăo académica passou a abrigar o Ciências Exatas e (A) Início e conclusăo em 1968.

(B) Vista do prédio condluído em 
Parte 2 - Universidade Federal de Alagoas 


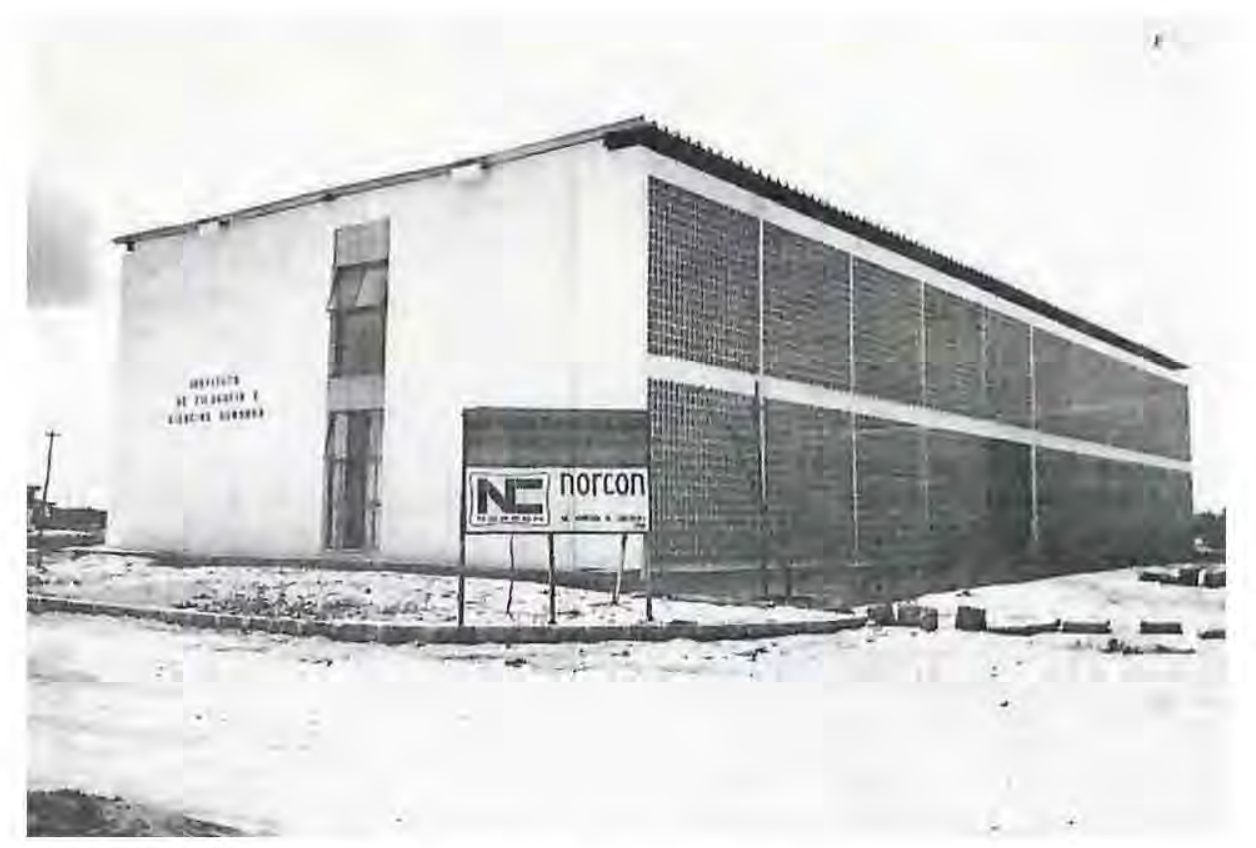

Figura 217: UFAL - Prédio do Instituto de Filosofia e Ciências Humanas - 1969.

Com a reestruturação acadêmica passou a abrigar o Departamento de Matemática do Centro de Ciências Exatas e Naturais e provisoriamente o gabinete do Reitor.

(Fonte: AZEVEDO, 1982, p. 147)

Questões financeiras, entretanto, levaram a Administração Superior a desenvolver a construção das obras em etapas, considerando um cronograma de médio e de longo prazo. O reitor assim se expressou:

Todas essas obras foram planejadas dentro de um sistema de flexibilidade tal, que as iremos executando parceladamente e também equipando por parcelas para que, gradativamente, sejam postas a funcionar, sem dificuldades futuras à sua complementação e ao seu definitivo acabamento. Não são 'elefantes brancos', mas planejados dentro de nossas possibilidades e para atender às nossas reais necessidades. [...] Estamos procurando fazer tudo sólido, sóbrio, flexível, confortável e executável, por etapas, a médio ou a longo prazo. Também não queremos adotar o sistema de construções provisórias, ligeiras que pouco duram e acabam saindo mais dispendiosas e muito menos confortáveis para os que dentro dela vão dedicar ao ensino e à pesquisa. A princípio parecem boas, mas dentro em pouco desaparecem, por faltar-lhes consistência ao desgaste natural do uso (SIMÕES apud AZEVEDO, 1982, p. 137).

Em 15 de dezembro de 1968, foi realizada a festa de formatura dos concludentes do curso de economia em plena Cidade Universitária, quando começaram a brihar as luzes de sua principal avenida (Simões apud AZEVEDO, 1982, p. 141). O evento marcou historicamente a implantação da Cidade Universitária. Naquele ano, foram efetuados dois outros contratos 
para execução de mais uma etapa do concreto armado do Hospital Universitário e concluídas as obras e reformas das unidades no centro de Maceió.

Em 1969, o Centro de Pesquisas Tecnológicas estava pronto, aguardando as máquinas para entrar em funcionamento (ver figura 218). Enquanto se desenvolviam as obras dos quatro Institutos Centrais mencionados, foram elaborados os projetos dos três restantes, 0 de Ciências Biológicas, o de Matemática e o de Letras e Artes, este último já com a concorrência aberta e os demais com previsão de construção para o ano seguinte. Com eles se daria a conclusão de todas as sedes das unidades do ciclo básico, que nas palavras do reitor A. C. Simões: alcançada que seja a construção de tudo que seja necessário ao ciclo básico poderemos afirmar que a Cidade Universitária, da Universidade Federal de Alagoas, se tornou como Brasília, absolutamente irreversível (Simões apud AZEVEDO, 1982, p. 143).

Foi contratada, ainda no mesmo ano, a segunda etapa do concreto armado do Hospital Universitário, apesar de a primeira encontrar-se atrasada pela falta de cimento no mercado. Havia ao todo sete obras em andamento, incluindo as de urbanização e do sistema de abastecimento de água, que se daria por meio de um poço artesiano com a capacidade de 15.000 litros horários.

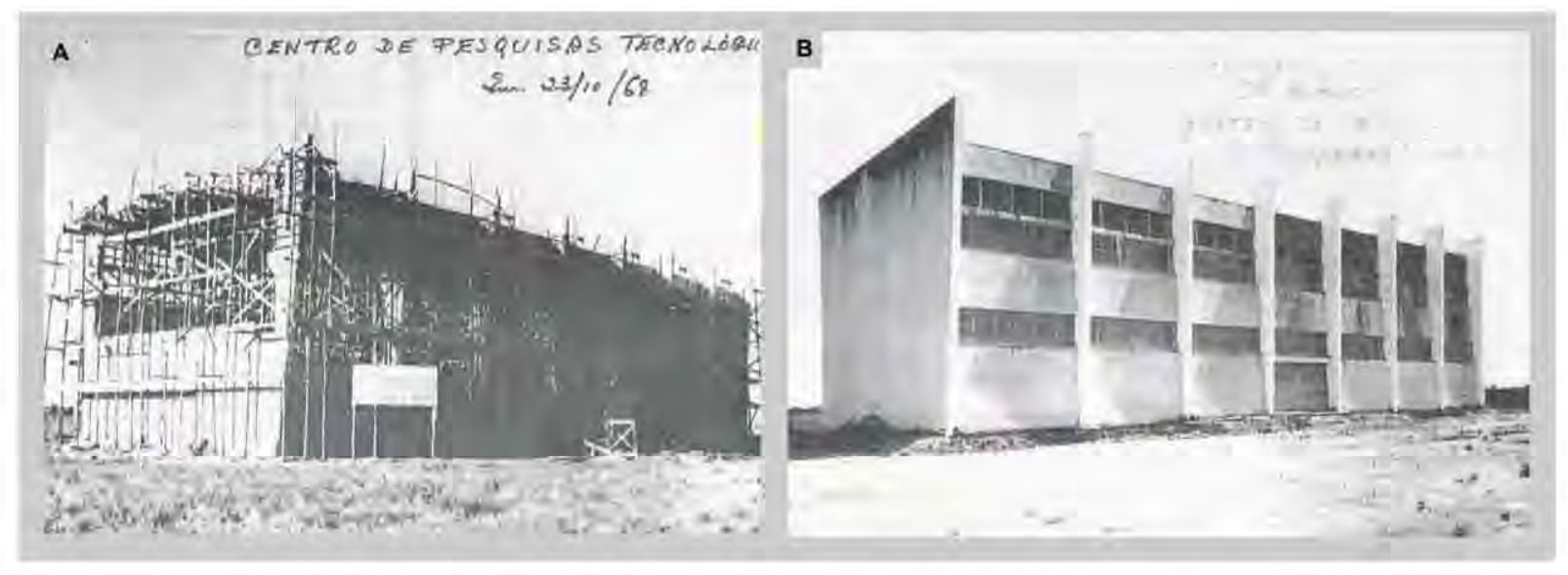

Figura 218: UFAL - Prédio do Centro de Pesquisas Tecnológicas.

(A) Início das obras em 1968.

(B) Vista do Prédio concluído em 1969.

(Fonte: AZEVEDO, 1982, p. 140 e 148 , respectivamente).

No final daquela década, as obras realizadas na Cidade Universitária correspondiam à reduzida parte da infraestrutura urbana (meio-fio, calçamento, esgotos, drenagem pluvial, dentre outros) e estavam concluídos os primeiros quatro prédios destinados aos então Institutos Básicos, o edifício da então Faculdade de Ciências Econômicas, o da Imprensa Universitária e estava iniciado o Hospital Universitário. O complexo universitário instalado no Tabuleiro do Martins naqueles anos passou a ser identificado a partir de 1971 como Campus A. C. Simões (ver figura 219 e 220). 


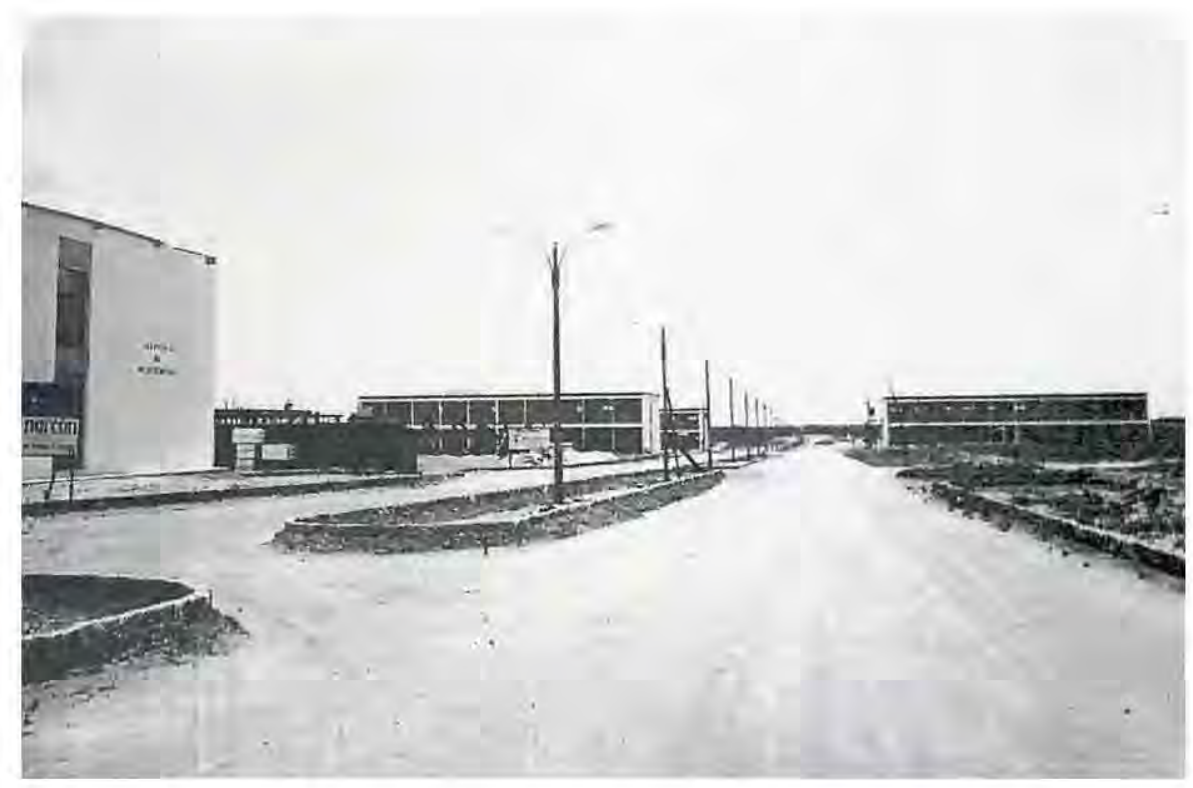

Figura 219: UFAL - Avenida Central - 1969.

Vista da avenida com os antigos Institutos. No plano urbanístico a via desempenhou o papel de eixo estruturador da organização espacial.

(Fonte: AZEVEDO, 1982, p. 144)

\section{- Campus da Reforma: um projeto apenas delineado - Década de 1970}

A década seguinte foi marcada pelas ações que visaram adequar a Universidade às diretrizes da Reforma Universitária de 1968. Inicialmente constatou-se que a Universidade, se por um lado havia dado início à base física com as novas instalações construídas na Cidade Universitária, pouco havia avançado na ampliação e qualificação dos quadros docente, técnico e administrativo, bem como nas atividades de pesquisa, que se resumiam a poucas tentativas isoladas de reconhecido valor científico, assim como nas ações voltadas para a melhoria do ensino e desenvolvimento de potencial socioeconômico e cultural do Estado.

Logo, por meio do Decreto-lei $n^{\circ} 70.516$, de 12 de maio de 1972 , tratou de dar início à reestruturação administrativa e no mesmo ano ampliou a oferta de vagas com a criação de catorze novos cursos (Serviço Social, Agronomia, Arquitetura, Enfermagem, Tecnólogo Mecânico, Tecnólogo Industrial de Açúcar de Cana, Licenciatura em Física, Matemática, Química, Biologia, Educação Física, Licenciatura curta em Pedagogia e, no ano seguinte, foram os de Tecnólogo em Bovinocultura e Tecnólogo em Saneamento Ambiental). No mesmo ano, voltado para a ampliação dos quadros de pessoal, o setor de planejamento da Universidade colocou em prática, o Plano de Expansão, com a realização de mais de 200 concursos e provas de seleção. O contexto de expansão acarretou maior capacidade 


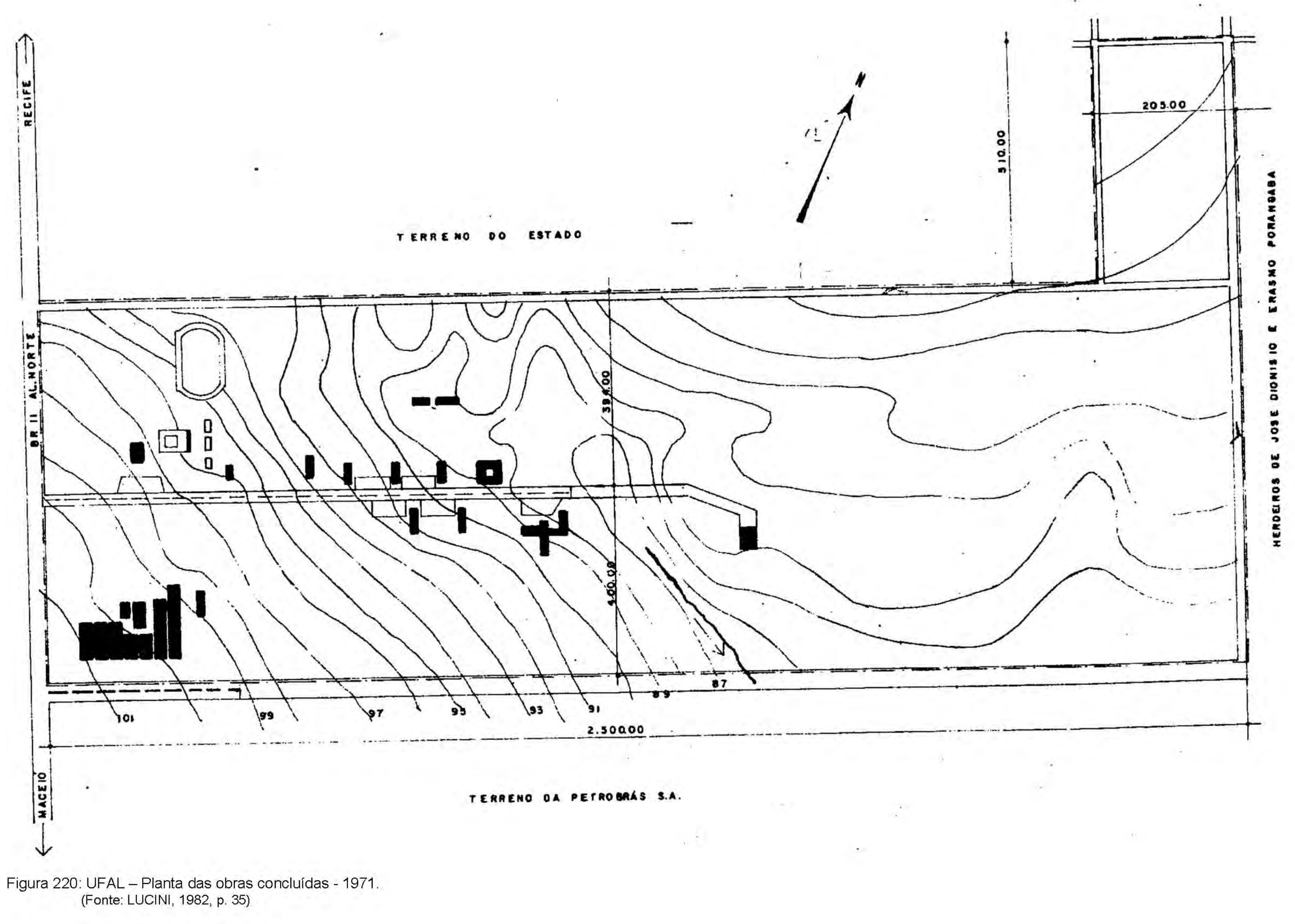


instalada. A Universidade, porém, não tendo como em curto prazo construir outras, procurou ajustar-se às edificações existentes.

\section{- Campus Tamandaré}

Para acomodar os cursos de Ciências Humanas e o Laboratório de Biologia Marinha, previsto para uma população estudantil em torno de 3.000 alunos ocupou, em regime de comodato, a Escola de Aprendizes de Marinheiro de Alagoas, no pontal da Barra. O novo complexo, inaugurado em 31 de março de 1973, foi denominado de Campus Tamandaré (ver figura 221). A localização, entretanto, logo demonstrou ser inviável em decorrência da implantação da Salgema Indústrias Químicas no Trapiche da Barra que, por apresentar riscos decorrentes de elevado índice de poluição do ar, motivou a desativação da Unidade em 1976 (Disponível em: <http://www.ufal.br/45anos/>). Foram então realizados, em 1977, estudos para aproveitamento de toda a capacidade ociosa do Campus A. C. Simões e sua adaptação para tornar possível a transferência do Campus Tamandaré.

Em 1973, o Decreto-lei $n^{\circ} 44.429$ deu prosseguimento à reestruturação administrativa e acadêmica com a criação de Centros e Departamentos e, no ano seguinte, com o Decreto $n^{\circ}$ 73.970, a Reforma Universitária foi oficialmente implantada. A nova estrutura era constituída pela Administração Superior, pelos Órgãos Suplementares ${ }^{76}$ e pela Unidade de Formação Acadêmica, estruturada pelos Centros agrupados por área do saber e classificados como Unidades de Formação Básica e Unidades de Formação Profissional, conforme tabela da figura 222.

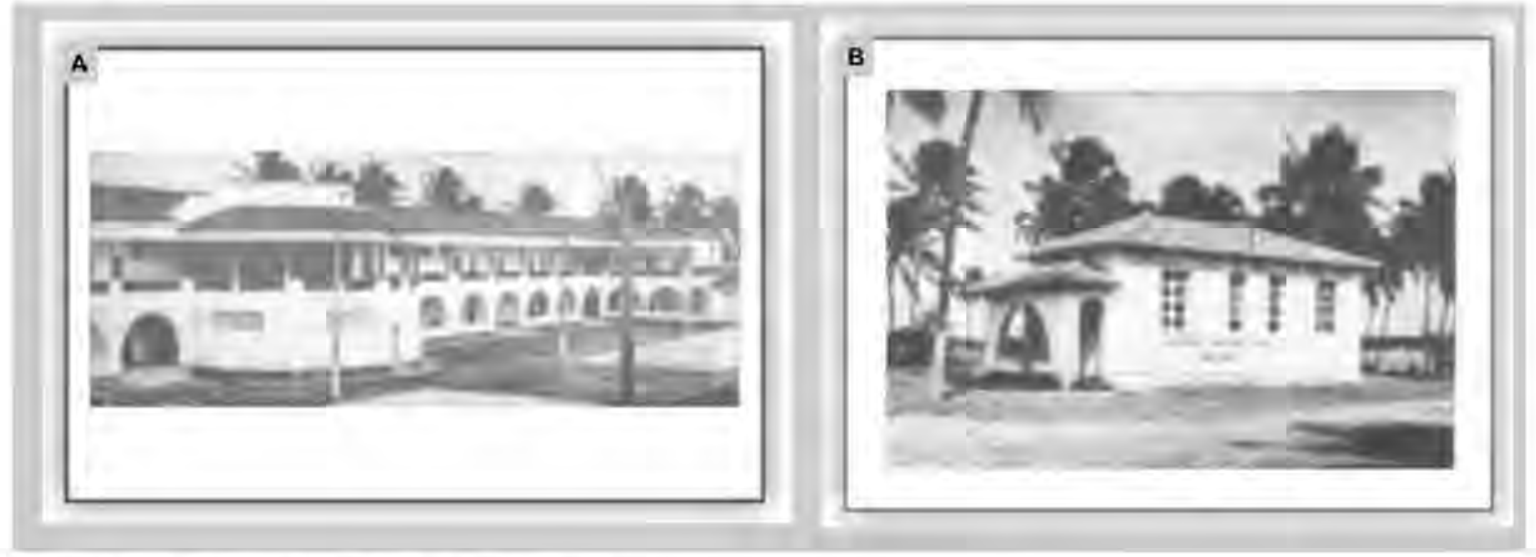

Figura 221: UFAL - Campus Tamandaré

(A) Vista das instalações físicas do Campus Tamandaré.

(B) Vista do Laboratório de Biologia.

(Fonte: Disponivel em

$<$ http://unww.ufal.br/45anos/index.php?pag=45anos/campus_tamandare\&s=Campus\%20Tamandar\% E9>. Acesso em: 20 nov. 2010)

\footnotetext{
${ }^{76}$ A Administração Superior estava composta pela Reitoria, Conselho Universitário, Conselho Coordenador de Ensino e Pesquisa e Conselho de Curadores. Os Órgãos Suplementares correspondiam à Biblioteca Central, Imprensa Universitária, Centro Universitário de Treinamento e Ação Comunitária, Núcleo de Pesquisas Tecnológicas, Núcleo de Processamento de Dados, Rádio e Televisão Educativos, Cine-Teatro Universitário, Núcleo de Educação Física e Desportos, Museu de Antropologia e Folclore Theó, Hospital Universitário e o Núcleo de Estudos e Ciências do Mar.
} 


\begin{tabular}{|c|c|c|}
\hline UNIDADE DE ENSINO & CENTROS & DEPARTAMENTOS \\
\hline \multirow{3}{*}{$\begin{array}{l}\text { 1. UNIDADE DE FORMAĊAO } \\
\text { BASICA }\end{array}$} & $\begin{array}{l}\text { Ciéncias Bialagl- } \\
\text { cas - CCBi }\end{array}$ & $\begin{array}{l}\text { Biologia - BIO } \\
\text { Fisiologia - FSO } \\
\text { Morlologia - MOR } \\
\text { Patologia - PAT }\end{array}$ \\
\hline & $\begin{array}{l}\text { Cièncias Exatas } e \\
\text { Naturan - CCEN }\end{array}$ & $\begin{array}{l}\text { Fisica - FIS } \\
\text { Geo-Ciéncias - GEO } \\
\text { Matemátıca Aplicada - MAP } \\
\text { Maternábuca Básica - MAB } \\
\text { Quimuca - QUI }\end{array}$ \\
\hline & $\begin{array}{c}\text { Cièncias Humanas, } \\
\text { Letras e Artes - } \\
\text { CHLn }\end{array}$ & $\begin{array}{l}\text { Esludos Sociais - ESO } \\
\text { Filosolia e Hislonia - FIH } \\
\text { Letras Clăssicas e Vernáculas - LCV } \\
\text { Letras Esirangeiras e Modernas - LEM }\end{array}$ \\
\hline \multirow{4}{*}{$\begin{array}{l}\text { 2. UNIDADE DE FORMACẢO } \\
\text { PROFISSIONAL }\end{array}$} & $\begin{array}{c}\text { Cièncias Agrátias } \\
\text { CECA }\end{array}$ & $\begin{array}{l}\text { Agronomia - AGR } \\
\text { Zootecnia - ZTE. }\end{array}$ \\
\hline & $\begin{array}{c}\text { Ciẻncias da Saóde } \\
\text { CSAU }\end{array}$ & $\begin{array}{l}\text { Clinica Cinurgica - CLC } \\
\text { Clinica Módica - CLM } \\
\text { Clinica Odonlológica - CLO } \\
\text { Educaçảo Fisica - EDF } \\
\text { Enlermagem - ENF } \\
\text { Medicina Social - MSO } \\
\text { Odontologia Reslauradora - ORE } \\
\text { Propedéutica Médica - PRM }\end{array}$ \\
\hline & $\begin{array}{l}\text { Ciẻncias Sociais } \\
\text { Aplicadas - CCSA }\end{array}$ & $\begin{array}{l}\text { Administraçáo e Contabilidade - ADC } \\
\text { Direito Privado - DPR - } \\
\text { Direito Público - DPU ' } \\
\text { Economia - ECO } \\
\text { Mélodos e Técnicas de Ensino - MTE - } \\
\text { Serviço Social - SSO } \\
\text { Teorias e Fundamenlos da Educaçáo - TFE - }\end{array}$ \\
\hline & $\begin{array}{l}\text { Tecnologia } \\
\text { CTEC }\end{array}$ & $\begin{array}{l}\text { Arquitetura - ARQ } \\
\text { Consiruçào Civil e Transportes - CCT } \\
\text { Engenharia Eletro-Mecánica - EEM } \\
\text { Engenharia Estrulural - EES - }\end{array}$ \\
\hline
\end{tabular}

Figura 222: UFAL - Composição dos Departamentos e Centros, por unidades de Ensino.

(Fonte: UFAL, [1982?], p. 9)

\section{- Centro de Ciências da Saúde}

Para implantar o Centro de Ciências da Saúde no Campus A. C. Simões, instalou-se, com aproveitamento parcial, no prédio do Hospital Universitário, que ainda não se encontrava totalmente concluído, e nas instalações provisórias de propriedade da Petrobrás (galpões de madeira e amianto), cedidas à Universidade por empréstimo e situadas em terreno vizinho ao Campus (ver figura 223).

Até 1973, a UFAL mantinha convênio com a Santa Casa de Misericórdia para o funcionamento da então Faculdade de Medicina, tendo em vista a inexistência de sede própria, gerando insatisfação na comunidade do setor de saúde, que via preterido o esforço de obter uma atuação integrada e globalizada para os seus diferentes cursos. 


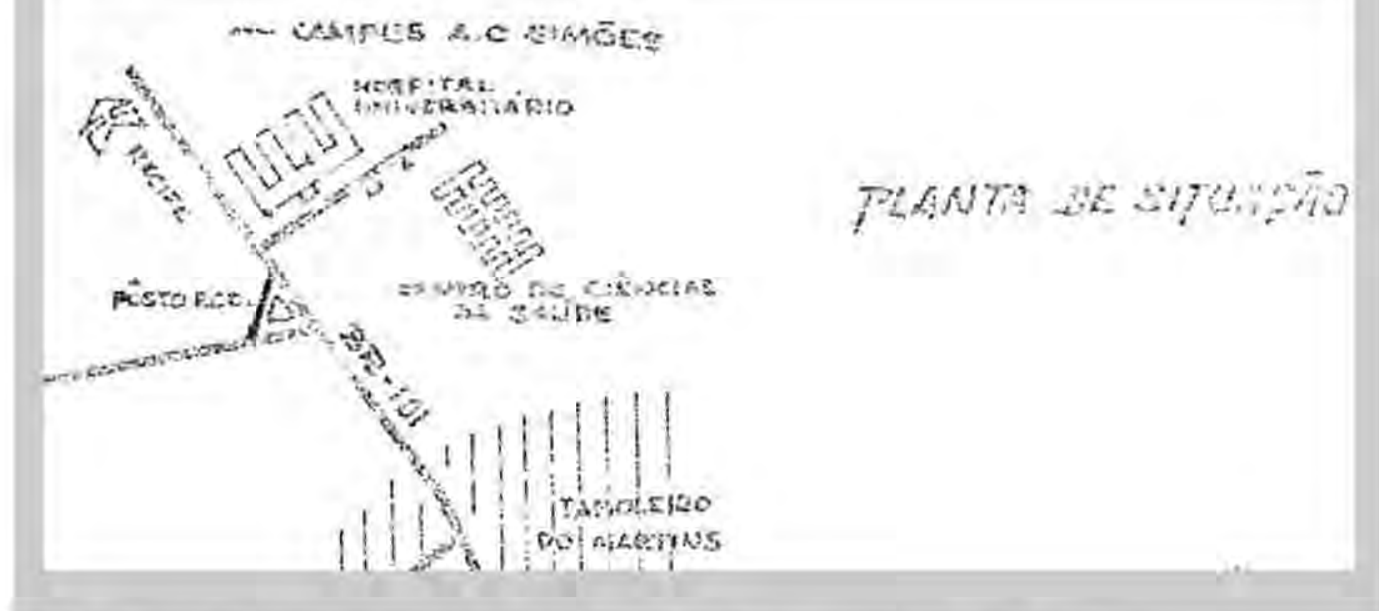

Figura 223: UFAL - Planta de situaçăo do Centro de Ciências da Saúde - 1974.

A unidade de formação profissional da saúde contava com o Hospital Universitário parcialmente concluído e com os galpões de propriedade da Petrobrás.

(Fonte: UFAL, 1974, p. 36 , edição nossa).

A utilização do referido prédio, com a conclusão parcial dos blocos destinados aos ambulatórios, veio solucionar alguns estrangulamentos existentes, principalmente, quanto ao Curso Médico, que se ressentia pela não conclusão dessa obra, acarretando indisponibilidade de instalações adequadas e suficientes, dificultava o aperfeiçoamento e expansão de tarefas específicas (ver figuras 224 à 226). Estas limitações determinaram a reprogramação do Hospital, objetivando a qualidade para o desenvolvimento das atividades de pesquisa, ensino e extensão de serviços e comunidade (UFAL, 1975, n.p.).

O projeto inicial, baseado no sistema de cátedras, teria capacidade para 612 leitos e área total de $33.597 \mathrm{~m}^{2}$, distribuída no complexo arquitetônico composto por sete blocos térreos articulados com o prédio de seis pavimentos (um térreo e cinco pavimentos-tipo). Com a nova filosofia acadêmica, definiu-se outra dimensão, a partir da conclusão da área correspondente a $23.475 \mathrm{~m}^{2}$, Os estudos identificavam que tal espaço comportava 280 leitos hospitalares, com disponibilidade para instalação dos cursos da área da saúde ${ }^{77}$. Foram realizados estudos para em curto prazo, instalar o Centro de Ciências da Saúde naquela área hospitalar, tendo em vista as dificuldades que vinham sendo enfrentadas no desenvolvimento das atividades e que se agravavam em virtude da expansão de novos cursos. O Hospital Universitário manteve-se, entretanto, até a década de 1980, inacabado. Em 1982, foi constatado que a lâmina vertical de concreto, cuja construção fora iniciada doze anos antes, já havia recebido investimentos para a recuperação do concreto e carecia de recursos para dar continuidade à obra (UFAL, [1982?], p. 12).

\footnotetext{
${ }_{77}$ Sobre esse assunto, recomendamos a leitura do documento formulado pela UFAL e apresentado na XIX Reunião Plenária do Conselho de Reitores das Universidades Brasileiras, realizada em Fortaleza, Ceará, de 29 a 31 de julho de 1974, tendo como tema: Operação e Funcionamento do Hospital Universitário.
} 


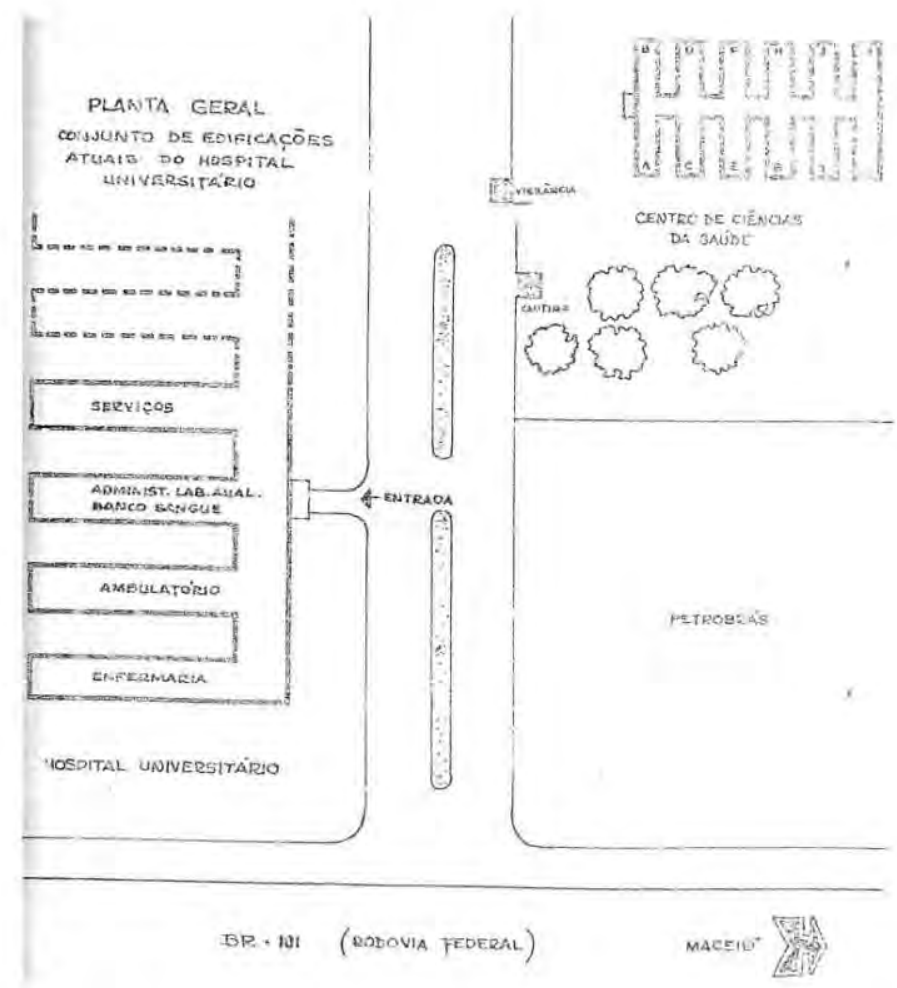

Figura 224: UFAL - Situação dos ambulatórios do Hospital Universitário - 1974.

Com a conclusão de parte dos blocos destinados aos ambulatórios o setor de saúde transferiu-se para o prédio do Hospital Universitário.

(Fonte: UFAL, 1974, p. 36, edição nossa).

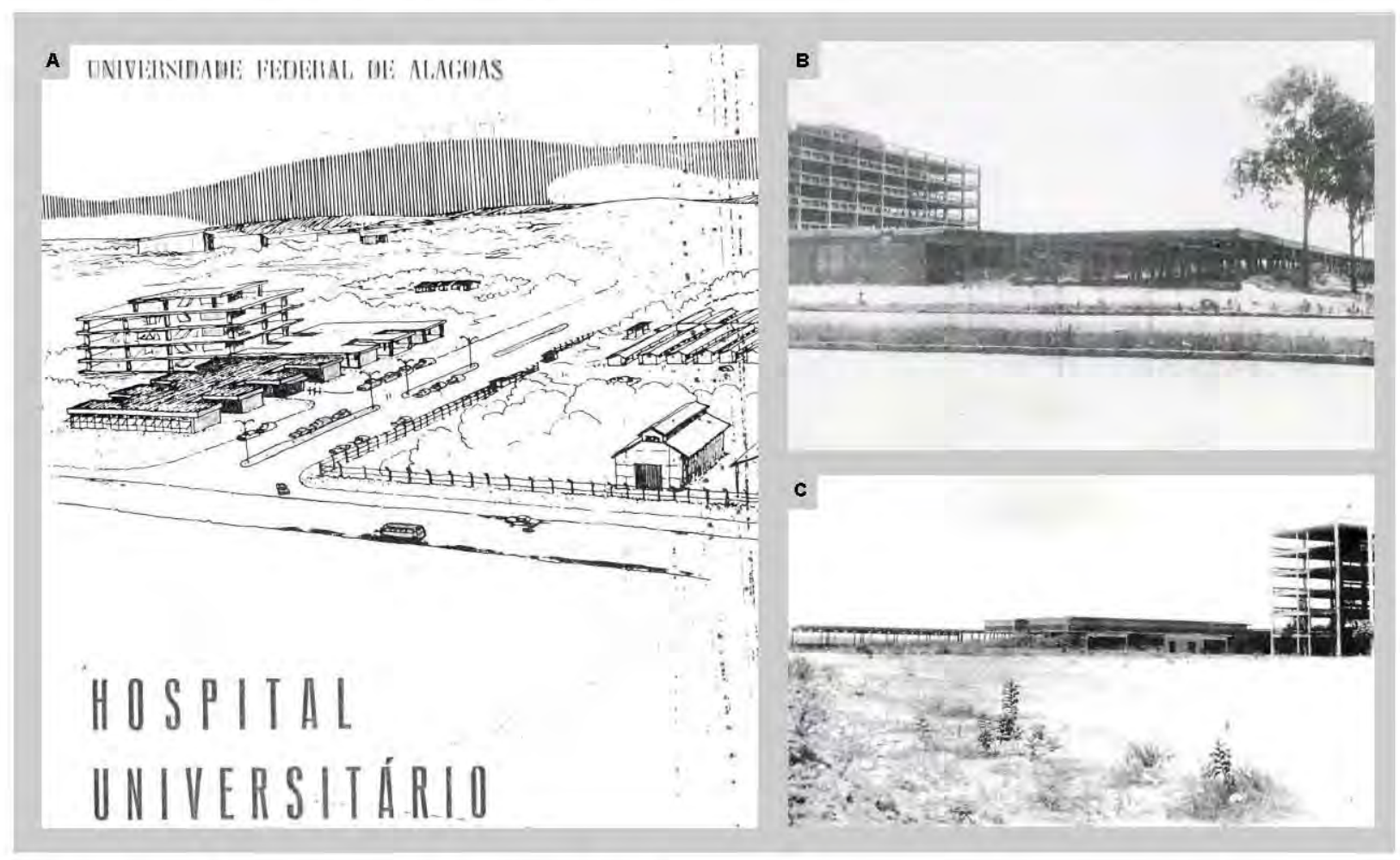

Figura 225: UFAL - Hospital Universitário - 1974.

(A) Ilustração das obras do Hospital Universitário e dos blocos destinados aos ambulatórios.

(B) e (C) Vista da estrutura de concreto concluída.

(Fonte: (A) UFAL, 1974, capa / (B) e (C) AZEVEDO, 1982, p. 145). 


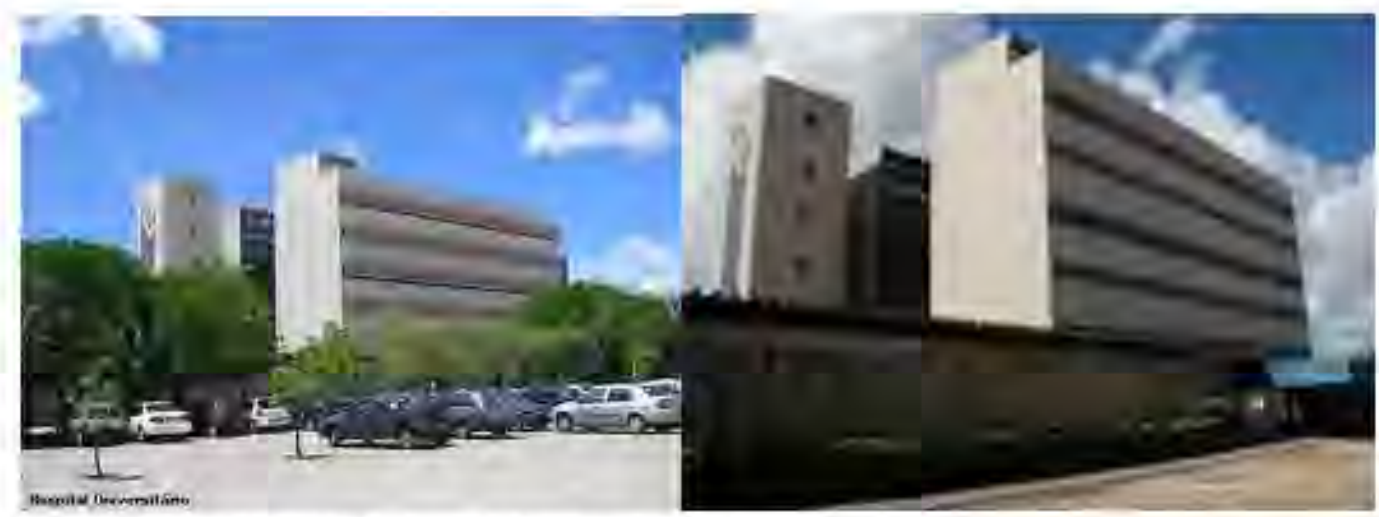

Figura 226: UFAL-Hospital Universitário - ano 2000.

(Fonte: UFAL, 2000).

\section{- Centro de Ciências Agrárias}

Ainda na primeira metade da década de 1970, foram dados os primeiros passos para a processo de interiorizaçã̃o, com a criaçä̃o do CRUTAC e do Centro de Ciências Agrárias, com o funcionamento do curso de agronomia, ambos localizados no município de Viçosa, no interior de Alagoas, a $100 \mathrm{~km}$, aproximadamente de Maceió, que, entretanto nẵo foram contemplados com investimentos em obras físicas (ver figura 227).

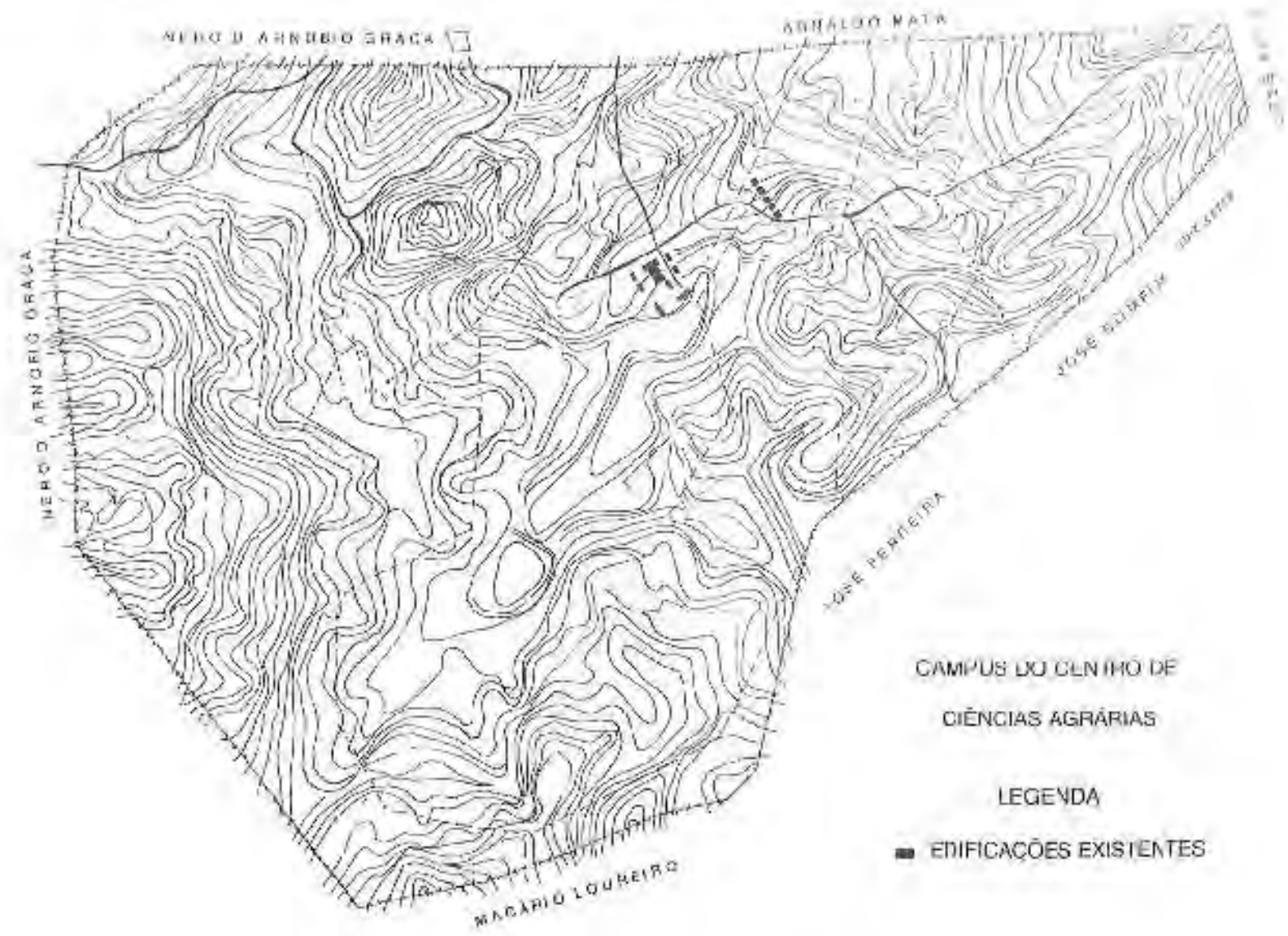

Figura 227: UFAL - Centro de Ciências Agrárias - 1982.

(F onte: UFAL, [1982?], p. 16) 


\section{- O esgotamento da estrutura física existente}

A partir de 1975 , a nova gestão administrativa ${ }^{78}$ deu ênfase à pesquisa, fundou a editora (EDUFAL) e institucionalizou a Biblioteca Central, que passaram a funcionar em instalações improvisadas. Em termos de obras físicas, no ano seguinte, foi dado prosseguimento aos serviços de infraestrutura do Campus, abrangendo os trabalhos de ampliação das redes elétrica, hidráulica, de esgotos e de drenagem de águas pluviais, bem como a continuidade das obras do Hospital Universitário, que se arrastava sem prazo de conclusão final.

Ainda no mesmo ano, com a crescente complexidade da infraestrutura física, foi criado o Escritório Técnico Administrativo, destinado a gerir as atividades de controle, fiscalização e execução dos programas de construção da UFAL. De 1978 a 1979, foram ampliadas as instalações do Centro de Tecnologia para funcionamento do Curso de Arquitetura e construídos o depósito de materiais para a pista de atletismo e a Estação de Meteorologia. Foi também instalada a Central Telefônica.

A contínua expansão, face ao crescente número de discentes e à oferta de novos cursos, levou a UFAL a chegar ao fim da década de $1970 \mathrm{com}$ sua capacidade instalada em situação insustentável, já que não conseguia oferecer espaço físico para o funcionamento adequado de suas funções de ensino, pesquisa e extensão. As edificações do Campus $A$. C. Simões apresentavam um grave quadro de deterioração construtiva, decorrendo daí a aplicação dos investimentos em serviços de recuperação, adaptação e reparos. As unidades que ainda funcionavam no centro de Maceió também apresentavam deficiência de instalações em boas condições de uso.

No Campus A. C. Simões, o Centro de Ciências Exatas e Naturais, funcionando nos prédios dos antigos institutos, apresentava insuficiência de áreas e condições físicas precárias, necessitando de reformas e adaptações para utilização satisfatória; a Biblioteca, classificada como mero depósito de livros, estava instalada em um galpão desconfortável que servia como salão de leitura; sem condições de ser realizada pesquisa bibliográfica (UFAL, [1982?], p.12); e o Hospital Universitário continuava inacabado e a estrutura de concreto apresentava sinais de deterioração.

Já o Centro de Tecnologia e o de Ciências Sociais Aplicadas, sem adequadas instalações, não possuíam laboratórios para o ensino prático e o desenvolvimento de pesquisas; 0 Núcleo de Educação Física não tinha condições de oferecer um curso de graduação, pois não havia salas de aula específicas para a prática, nem equipamento suficiente; as quadras de esportes necessitavam de reparos urgentes e a unidade de tratamento da única piscina não podia ser recuperada, necessitando ser substituída. Também as redes de infraestrutura 
(esgotos sanitários e pluviais, reservatório de água, sistemas de comunicação e elétrico) estavam incompletas e faltava um sistema viário compatível. O Centro de Ciências da Saúde continuava funcionando nos galpões cedidos pela Petrobrás.

Dentre as unidades situadas no bairro central (ver figuras 228 e 229), o Centro de Ciências Biológicas ficava no prédio do antigo quartel [já apresentado] com instalações inadequadas; - Departamento de Odontologia Restauradora e a Clínica Odontológica funcionavam em imóvel em estado de conservação ruim, necessitando de reparos; a Reitoria continuava em acomodações improvisadas do antigo prédio da Escola Industrial Federal, que serviu também à Escola de Engenharia de Alagoas; o Restaurante, por sua localização, não atendia à população do Campus $A$. C. Simões e a situação do imóvel era precária; e o Museu, que estava funcionando em um prédio antigo, mas em caráter definitivo, carecia de reparos.

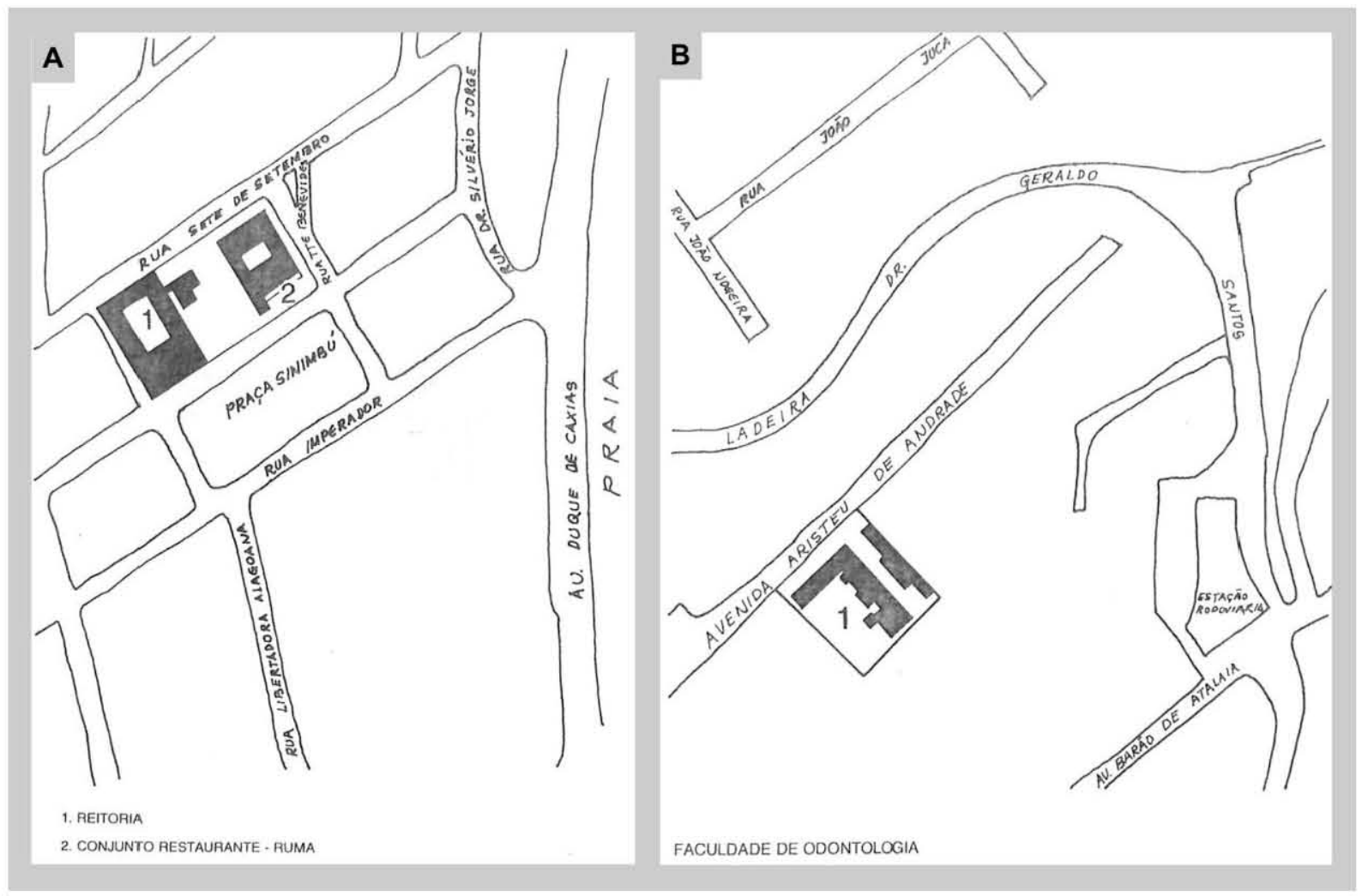

Figura 228: UFAL - Planta de situação das Unidades Dispersas - 1982.

(A) Reitoria e Restaurante.

(B) Faculdade de Odontologia

(Fonte: UFAL, [1982?], p. 20-21) 

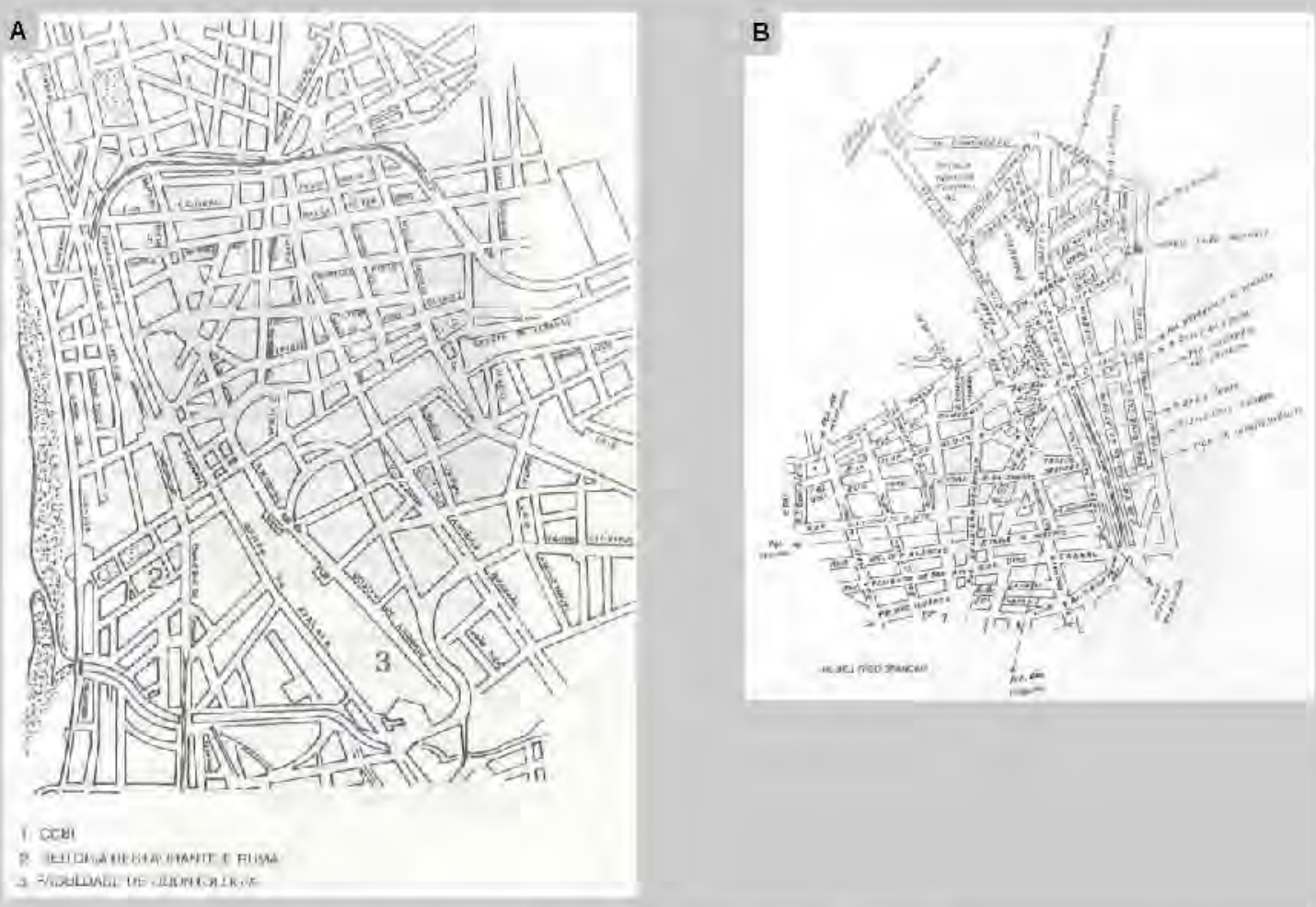

Figura 229: UFAL - Planta de situação das Unidades Dispersas - 1982.

(A) Centro de Ciências Biológicas, Reitoria, Restaurante e Faculdade de Odontologia.

(B) Museu Theó Brandão

(Fonte: UFAL, [1982?], p. 18-19)

A compatibilização da organização física-espacial com o plano acadêmico da Reforma era apenas um projeto de contornos ensejados. O pretenso Campus A. C. Simões, que mantinha a configuração física construída para atender ao antigo sistema de ensino seriado (ver figura 230), abrigava a nova unidade de formação acadêmica, distribuída nas instalações existentes segundo um zoneamento funcional formado pelos Centros criados na reestruturação de 1974 (ver figura 231). Diante das dificuldades que se avolumavam e inexistindo uma diretriz planejada e necessária à obtenção de recursos para superar o quadro acima esboçado, a Universidade partiu para elaborar um Plano Diretor Físico, contando com o apoio da Universidade Federal de São Carlos (UFSCar).

\subsection{CAMPUS A. C. SIMÕES: o território da Reforma}

A UFAL referendou a escolha do Tabuleiro dos Martins para materialização do seu campus universitário. A Instituição entendia que era o local adequado por apresentar maior área e uma infraestrutura física iniciada que daria melhores condições de implantação e funcionamento em futuro próximo. Com esse propósito, em 1977, a UFSCar deu início aos trabalhos para formulação de um Plano de Desenvolvimento Físico, alinhado com a nova estrutura acadêmica. Sua finalização permitiu a inclusão da Universidade no Acordo 
MEC/BID III, abrindo o financiamento para a concretização do Campus Universitário A. C. Simões. Porém, somente em 30 de dezembro de 1982 , por meio da portaria $n^{\circ} 920$, a UFAL, com os projetos executivos de cada obra dimensionados, assumiu a atribuição de implantar a nova estrutura constante no Plano Diretor Físico.

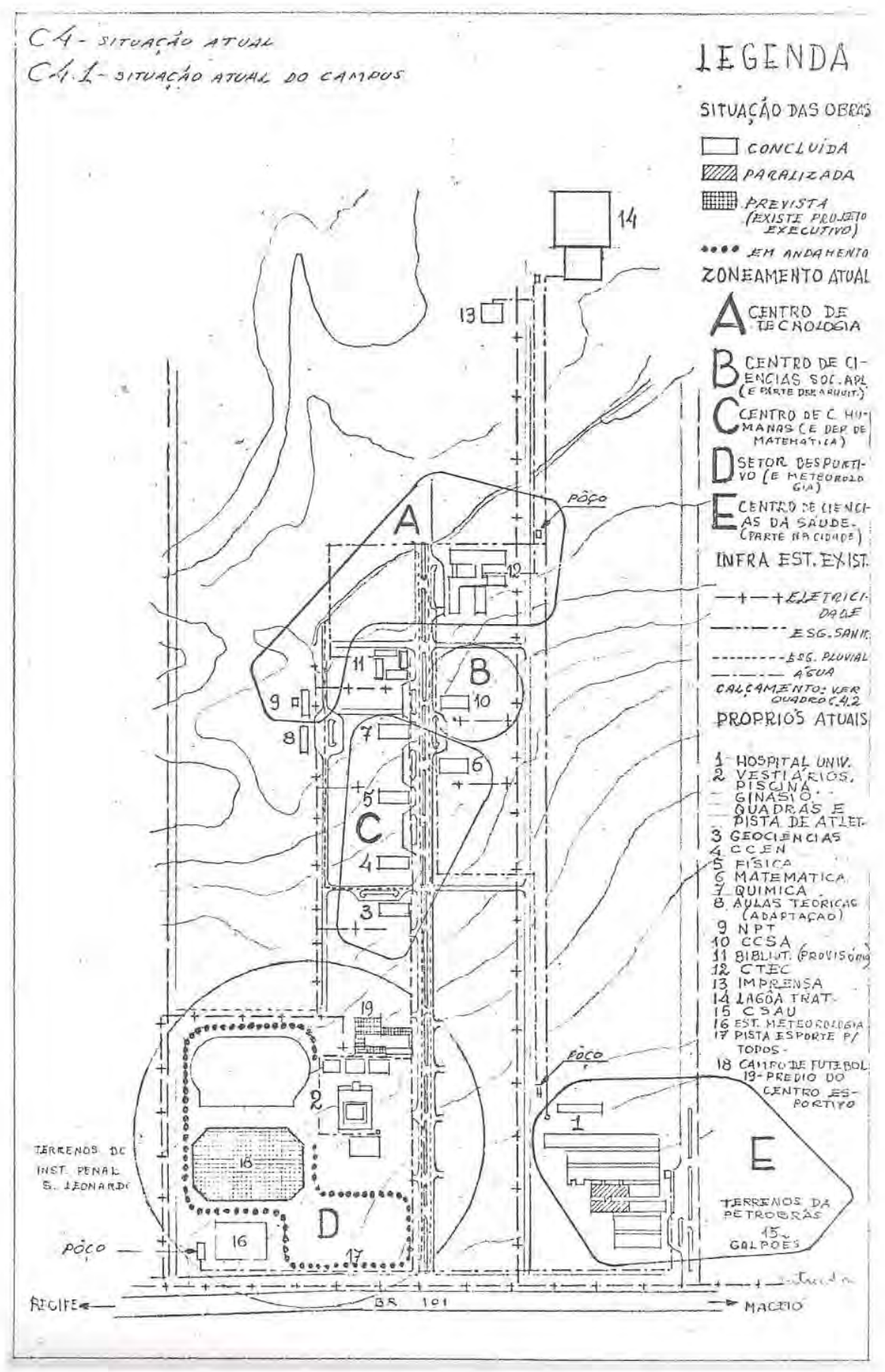

Figura 230: UFAL - Esquema de organização espacial do Campus A. C. Simões - Final da década de 1970

As unidades acadêmicas da Reforma estavam funcionando ajustadas à estrutura física existente e distribuídas segundo um zoneamento constituído pelos Centros (de Tecnologia, Ciências Sociais Aplicadas, parte do da Saúde e Setor Esportivo).

(Fonte: CONVÊNIO UFSCar / UFAL, [1979?], n.p.). 
Figura 231: UFAL-Área urbanizada do Campus A. C. Simőes - Final da década de 1970 As unidades académicas da Reforma estavam funcionando ajustadas à estrutura física existente 
- Plano Diretor: concepção do modelo de desenvolvimento físico

O Plano de Desenvolvimento Físico elaborado pela Assessoria de Planejamento da Universidade Federal de São Carlos (ASPLAN - UFSCar) por meio de convênio com a UFAL, no final da década de 1970 , foi coordenado pelo arquiteto Hugo Camilo Lucini, também responsável pelo plano da Universidade Federal do Maranhão, conforme apresentado na seção referente a essa Instituição. Os dois projetos seguiam a mesma concepção, ajustando-se, porém, às especificidades de cada Instituição.

As diretrizes do planejamento eram norteadas pelo imperativo de articular uma política de implantação e crescimento físico da Universidade com uma política de desenvolvimento global que incluísse o Plano Diretor Físico como um elemento regulador orgânico de crescimento do campus, em constante estudo e renovação de diretrizes (LUCINI, 1982, p. 19). Nesse tocante, o objetivo fundamental seria garantir o crescimento coerente, equilibrado e organizado das instalações em função dos múltiplos e complexos programas de ensino, pesquisa e extensão da Instituição, no decorrer do tempo (LUCINI, 1982, p. 19), que resultaria da correta relação entre necessidades e recursos disponíveis. A planta física seria a estrutura possibilitante dessas atividades programadas, onde a participação da comunidade universitária era fundamental para sua definição, pois somente ela poderia desempenhar o papel de avaliador e caracterizador dos processos de produção do espaço físico da Universidade.

Conceitualmente, o Plano procurou incorporar parâmetros de integração urbana à estrutura física da Reforma a partir (a) da caracterização de uma rede de relações entre os distintos sistemas da Universidade formados pelos setores acadêmico, administrativo e de serviços, suplementares e pelos fluxos viários, de pedestres e pelas redes de infraestrutura, conformando uma malha a ser lançada sobre o terreno, denominada Trama Funcional (ver figura 232) e (b) da caracterização de alternativas tipológicas construtivas, que respondessem aos sistemas acima e que fossem compativeis com as características fisiográficas e ambientais do meio. A localização da referida rede no terreno direcionaria a inserção das distintas tipologias, de maneira que a organização espacial e arquitetônica final dos conjuntos das edificações se desenvolvesse de acordo as disponibilidades de recursos no decorrer do tempo.

Em síntese, o objetivo perseguido seria formular um modelo flexível de desenvolvimento físico, que possibilitasse uma sistemática de ocupação na área urbanizável do Campus, por meio da construção de uma malha de serviços, que ele chamou de Trama Direcional, constituída pelas redes de infraestrutura e viária, que direcionariam a implantação das distintas unidades acadêmicas e administrativas sem, entretanto, pré-definir as soluções 
arquitetônicas e construtivas. O modelo permitia flexibilidade para acoplar atividades e espaços conforme o grau de inter-relação funcional e exigências de localização e instalações derivadas dos programas acadêmicos e administrativos, assim como 0 crescimento horizontal da área urbanizada, conformando a organização espacial do campus.

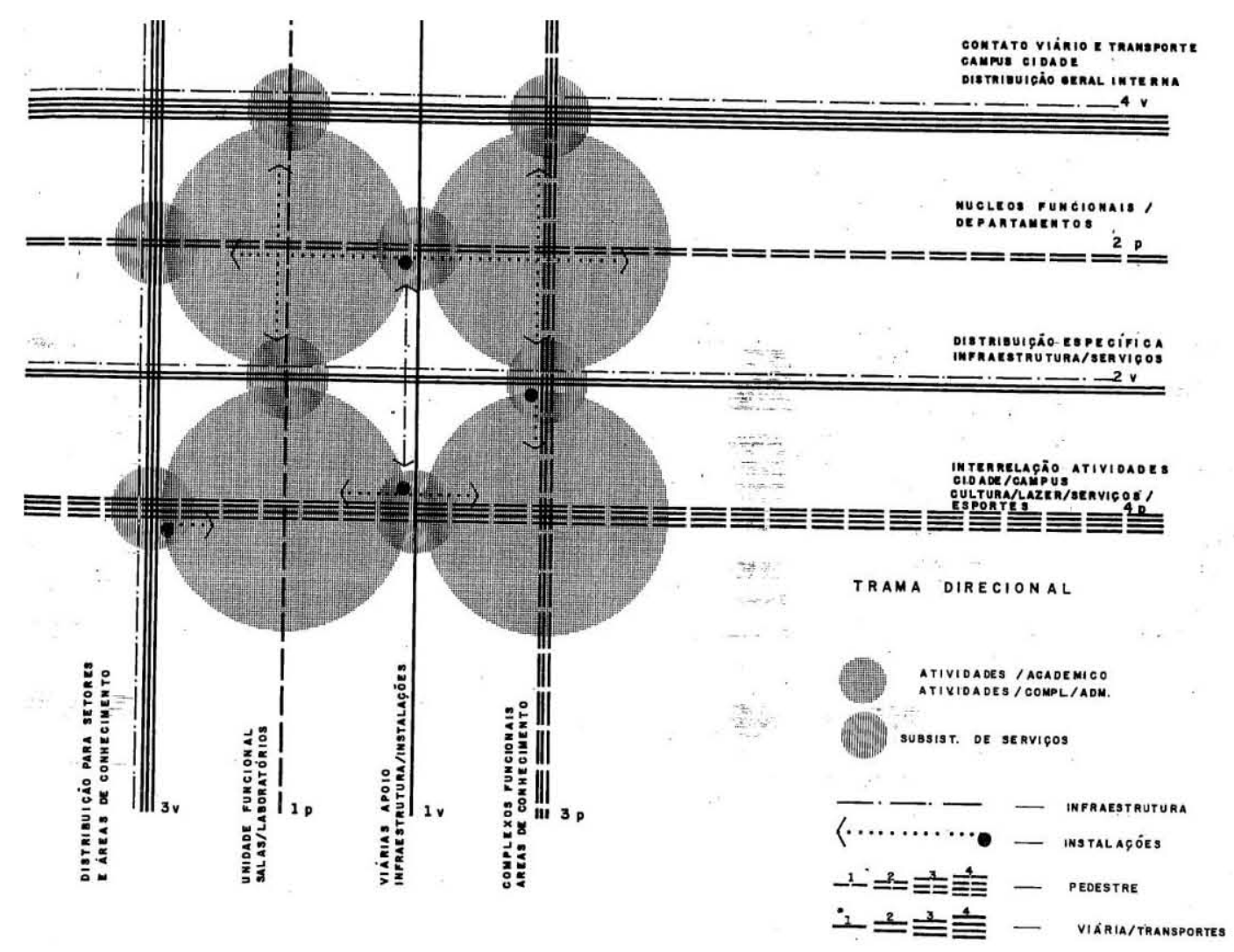

Figura 232: UFAL - Modelo da Trama Direcional.

A malha resultava da compatibilização entre os eixos de circulação (viário e de pedestres), as redes de infraestrutura e instalações, que abasteciam as zonas de atividades. Lançada sobre o terreno, a trama orientava a implantação dos setores macros (ex.: centros) conforme a inter-relações das atividades afins e exigências de localização e instalações derivadas dos programas acadêmicos e administrativos.

(Fonte: LUCINI, 1982, p. 79)

Nesse sistema de organização física, a circulação de pedestres tinha relevante importância no desenvolvimento do conjunto edificado. Além da função de conexão das estruturas espaciais, desempenhava o papel de aglutinador da comunidade acadêmica à medida que sua área construída se transformasse em ambientes de estar e convívio. Conformaria um edifício distribuidor com múltiplas possibilidades de ocupação e expansão, transformando a Universidade em um verdadeiro edifício aberto. O espaço produzido estaria vinculado aos programas universitários embasados pela departamentalização do ensino. As características das atividades e suas inter-relações norteariam a localização espacial das unidades acadêmicas e administrativas bem como das quantificações e dimensionamentos, onde o departamento era a unidade lógica considerada no estudo global (LUCINI, 1982, p.41). 
Outro condicionante era o fluxo dos recursos disponibilizados para as obras caracterizado pela concentração e descontinuidade, situação que comprometia uma dinâmica contínua de desenvolvimento e qualificação do espaço físico na Universidade. Para superar essa contingência, as tipologias, concebidas com capacidade de flexibilidade de uso e crescimento neutralizariam esses aspectos da produção do espaço na Instituição. Com esse propósito foram formuladas as seguintes alternativas:

- Tipologias de desenvolvimento linear com um ou dois pavimentos, destinadas às atividades de ensino e pesquisa, conforme caracterização dos espaços (sala de professores e administração departamental, salas de aulas teóricas, laboratório de ensino/pesquisa com equipamento sobre bancada, laboratório de ensino/pesquisa com requerimento especial de espaços e instalações - tipo pavilhão com pés-direitos maiores).

- Sistema modular de crescimento livre para atividades de circulação/ comunicação/ permanência/ serviços à comunidade (áreas de vivência e serviços menores, circulação de pedestres, lanchonetes/assistência à comunidade, postos de saúde, telefônicos, bancos, correios, etc.).

- Tipologias espaciais para atividades específicas complementares e administrativas centrais (Reitoria e Administração Central, Bibliotecas, Restaurante Universitário, Centro de Processamento de Dados, Centros Culturais - Museus/Cine/Teatro/Anfiteatro).

Essas estruturas seriam inseridas na trama funcional por etapas, conforme a expansão da Universidade e interconectadas através de espaços intermediários (eixos circulatórios), permitindo a sua construção gradativa sem incidir no funcionamento do conjunto (ver figura 233). Ao final, previa-se ter a nível urbanístico, um tecido integrado e harmônico.

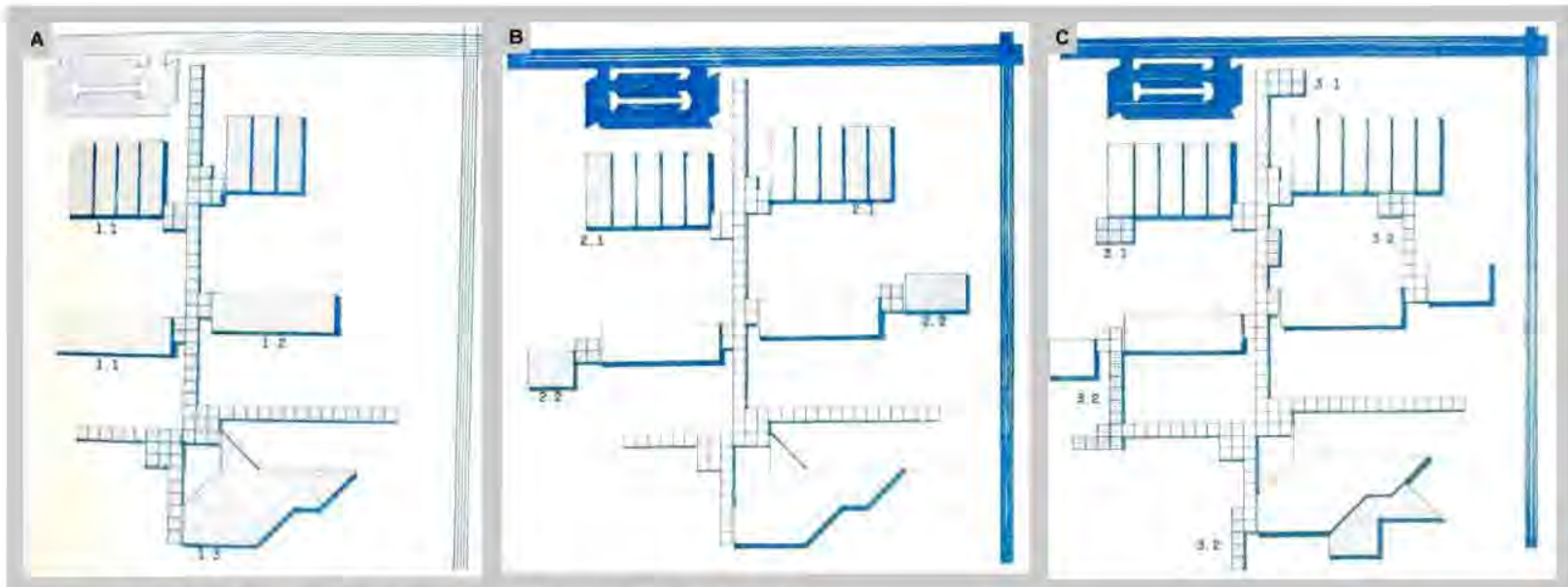

Figura 233: UFAL - Tipologias do Plano Diretor Físico.

O Plano indicava as possiblidades de crescimento e expansão da estrutura física por meio do acoplamento de tipologias construtivas ao sistema circulatório de pedestres, que funcionaria como edifício distribuidor da ocupação do campus.

(Fonte: LUCINI, 1982, p. 93) 


\section{- Conformação do urbanismo racional moderno}

O desenvolvimento físico para o Campus da UFAL teve como eixo norteador a compatibilização dos prédios e infraestruturas existentes com os conceitos de crescimento e organização definidos na concepção do modelo de desenvolvimento físico do Plano. diagnóstico elaborado pela UFSCar constatava que a configuração urbanística existente, caracterizada pela Avenida Central como eixo estruturador e com a implantação linear dos conjuntos de ensino, demonstrava ser contraditória com a filosofia de integração dos cursos. Aplicando o modelo de organização espacial baseado na estrutura de Trama Direcional, foi definida a malha funcional que, lançada sobre o terreno, redefiniu o zoneamento dos setores e estabeleceu os eixos circulatórios de conexão entre as estruturas espaciais. A solução rompia com a concepção do eixo estruturador formado pela Avenida Central e redefinia o eixo viário em vias primárias e secundárias que conformavam a estrutura física do campus em um tecido reticulado por quadras de geometria retangular com dimensões em torno de $400 \mathrm{~m} \times 800 \mathrm{~m}$ (ver figuras 234 a 237 ).

As unidades de formação básica ocupavam o centro da área urbanizada em conjunto com o Restaurante e a Biblioteca Central, ficando o setor de formação profissional distribuídos nas quadras vizinhas. O Plano manteve a localização do Setor Administrativo e de Esportes na faixa frontal do terreno, margeado pela BR -101, em conjunto com o Hospital Universitário.

A zona central era formada por uma praça de configuração longitudinal, via principal destinada à circulação de pedestres, onde seriam incorporadas as atividades de uso comum a toda a Universidade e de contato com a cidade (ver figura 238). Constituía o edifício distribuidor e definidor dos espaços para atividades de apoio, serviços e áreas de estar e convívio, local promotor do encontro informal de docentes e alunos. Possibilitaria o acoplamento das diversas unidades em momentos distintos conforme as condições financeiras da Instituição. Com esta solução esperava-se que as inter-relações funcionais nas áreas acadêmicas se materializariam fisicamente, para promover instâncias de encontro e convivio em diferentes escalas na totalidade do Campus $^{79}$ (LUCINI, 1982, p.99).

\footnotetext{
${ }^{79} \mathrm{~A}$ ocupação dos edificios existentes, onde funcionaram os antigos ibrutalismonstitutos, teriam uso restrito aos departamentos, ficando nos novos a circulação de maior fluxo, conforme estudos realizados pelo arquiteto da ASPLAN / UFSCar, Getúlio Alho (ALHO, 1980, p. 1).
} 


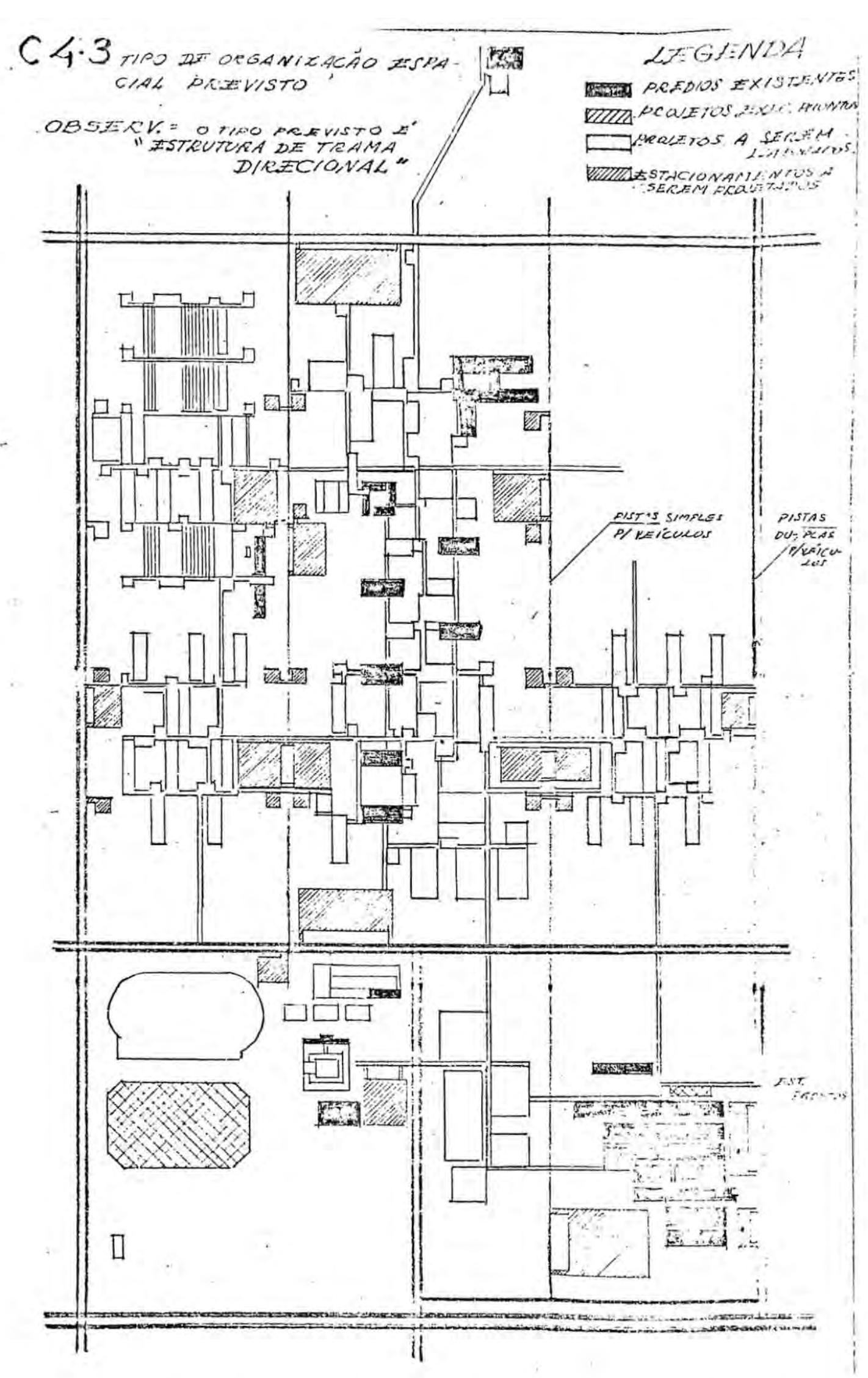

Figura 234: UFAL - Esquema da organizacẵo espacial em estrutura de Trama Direcional.

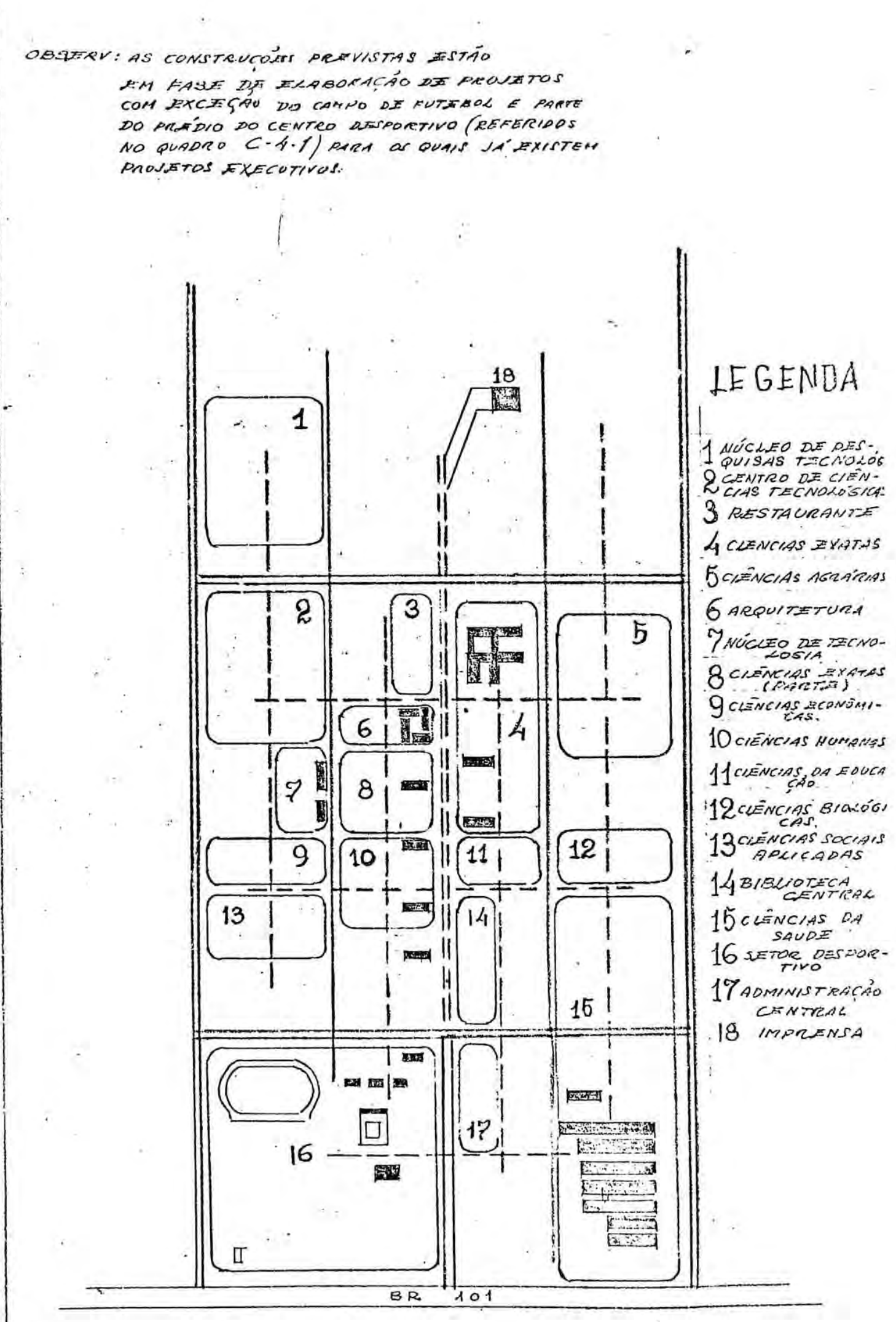

Figura 235: UFAL - Estudo do zoneamento funcional no Campus A. C. Simões O esquema identificava a organizacăa espacial dos setores embasado pelo
zoneamento funcional $A s$ instalaços zoneamento funcional. As instalaçōes existent
ao programa da Reforma.
(Fonte: CONVENNO UFSCar / UFAL, [1979?], n...).
Figura 237: UFAL - Zoneamento funcional proposto.

ncional, os setores foram organizados por atividades afins.
(Fonte: LUCIN), 1982, p. 105
Figura 236: UFAL - Trama Direcional lançada sobre o terreno da UFAL. A malha era composta pelos sistemas circulatórios (veículos e pedestres), redes de infraestrutura e instalaçōes
(Fonte: LUCINI, 1982, p. 103) 
Parte 2 - Universidade Federal de Alagoas 


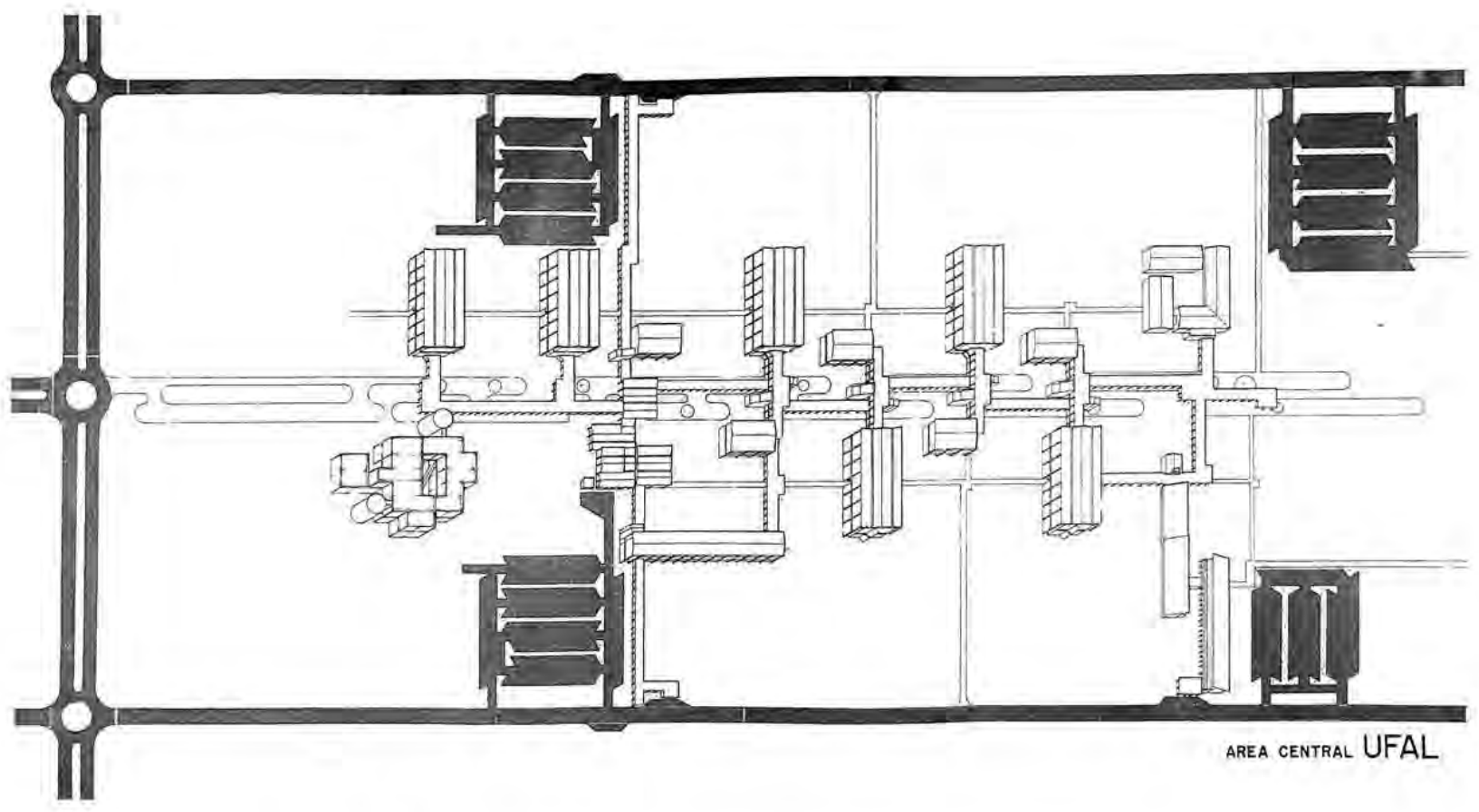

Figura 238: UFAL - Zona Central.

(Fonte: LUCINI, 1982, p. 123)

As áreas verdes se inserem na proposta, articuladas com as edificações, para criar espaços sombreados delimitados por passarelas e construções em escala compatível com o pedestre, além de caracterizar o distanciamento necessário entre prédios, para uma correta ventilação.

O sistema viário estava hierarquizado em duas categorias de fluxo veicular: um formado por um anel interno de uso restrito a baixa velocidade e outro que compunha um sistema perimetral e transversal de média velocidade, funcionando como principal distribuidor e conector das atividades com a cidade, desativando assim a barreira existente das relações entre a Instituição e os setores urbanos que a circundam. Os estacionamentos foram pensados também dentro das premissas do fluxo: específicos, para conjuntos acadêmicos, e gerais, para áreas de uso coletivo (Administração Central, a Biblioteca, o Restaurante, Centro Esportivo), localizados na periferia das vias de distintas hierarquias.

Construído, o Campus Universitário da UFAL conformaria um conjunto edificado de escala horizontal sobre extensas quadras de organização geométrica cartesiana, contornadas pelo sistema viário e ocupadas por setores de funções afins (zoneamento funcional), que consolidam núcleos densos no interior da quadra. A organização espacial baseada na Trama Direcional terminaria, entretanto, por configurar uma contradição entre as possibilidades de flexibilidade na inter-relação das distintas atividades e de fragmentação 
entre os setores especializados, que se tornam individualizados e autônomos na gleba de grandes extensões. Os longos percursos entre quadras recaem na forma de circulação eminentemente veicular, o que é contraditório com o espírito de integração da população universitária. Essa contradição espelha os conflitos do urbanismo racional moderno baseado na rígida separação das funções articuladas por um sistema de circulação em que predomina o uso do veículo. O edifício distribuidor, com sua finalidade de promover contatos interdepartamentais e espaços de integração e convivência, constitui, entretanto, uma concepção inovadora a ser perseguida. A estratégia de promover integração à zona urbana por meio do sistema viário perimetral e transversal interno rompe com o caráter de isolamento, permeando o campus pelas funções da cidade no nível do sistema viário, que se integra à malha viária urbana (ver figura 239).

Para implementar as diretrizes do planejamento físico, a UFAL recorreu ao então Ministério da Educação e Cultura pleiteando recursos para o seu financiamento, o que foi conseguido somente com o início do Programa MEC/BID III, com vigência de 1982 a 1985 . Os recursos, entretanto não abrangiam toda execução do Plano. Foram então selecionadas como prioritárias as áreas de tecnologia, saúde e educação, além dos prédios de salas de aulas teóricas, Biblioteca Central, Lanchonete/Restaurante e Prefeitura Universitária. Devido à limitação dos recursos na área de infraestrutura foi priorizado o sistema viário e urbanização, telefonia e rede elétrica de alta tensão com o objetivo de possibilitar condições básicas de instalações adequadas de funcionamento às edificações a serem implantadas.

A organização espacial proposta no Plano não foi concretizada na íntegra. Permanece até os dias de hoje a configuração urbanística do eixo monumental, marcado pela Avenida Central. O edifício distribuidor ficou na utopia de criador de espaços integradores e conectores das funções acadêmicas. Concebidos no princípio da especialização funcional, as distâncias e o sistema viário que separam os setores universitários os tornam isolados entre si. Sem pontos de convergência e assolados pelo clima de intensa radiação solar, os percursos desprotegidos não conseguem promover locais naturais de adensamento da presença de público ou da permanência de pessoas. Os setores autônomos entre si, perpetuam no espaço construído os vestígios de uma estrutura acadêmica que se pretendia superar (ver figuras de 240 a 242). 


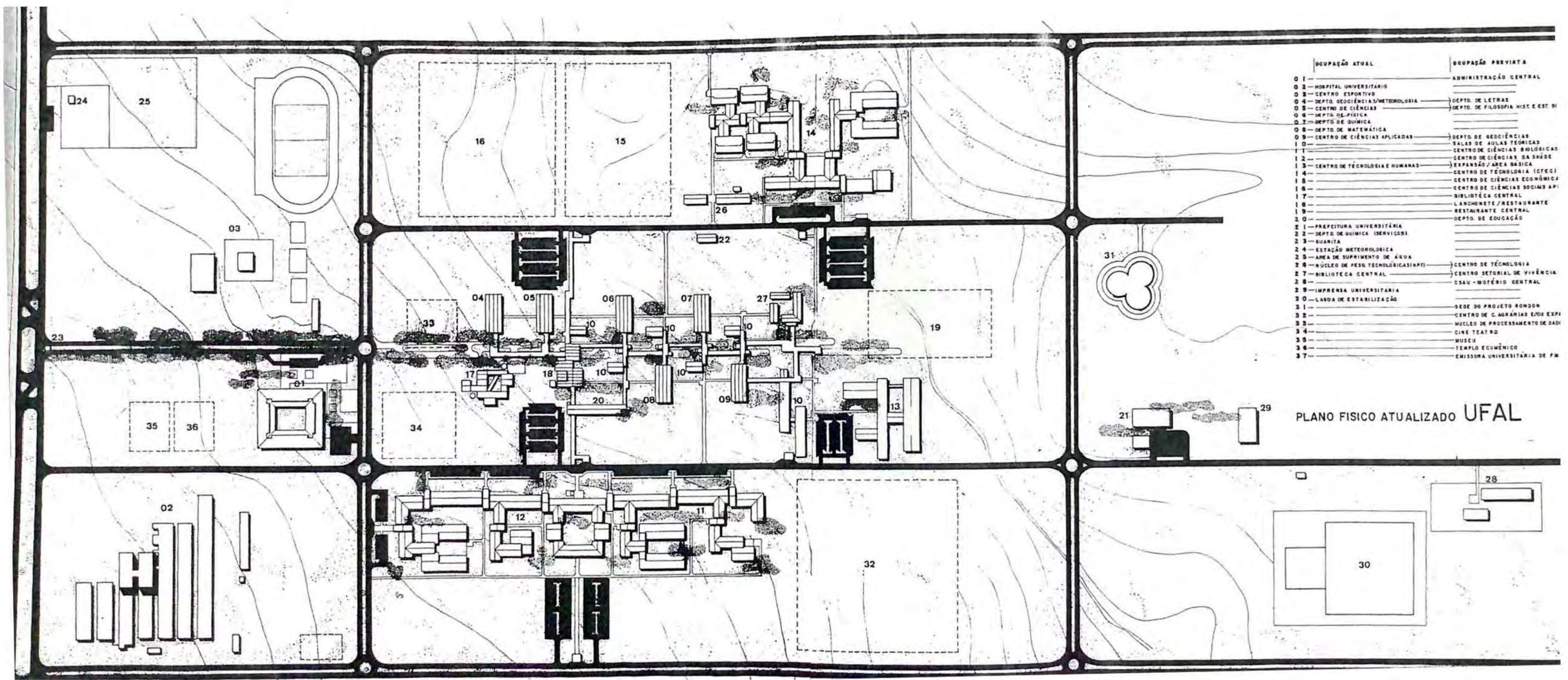

Figura 239: UFAL - Plano Fisico Final. 
Parte 2 - Universidade Federal de Alagoas 


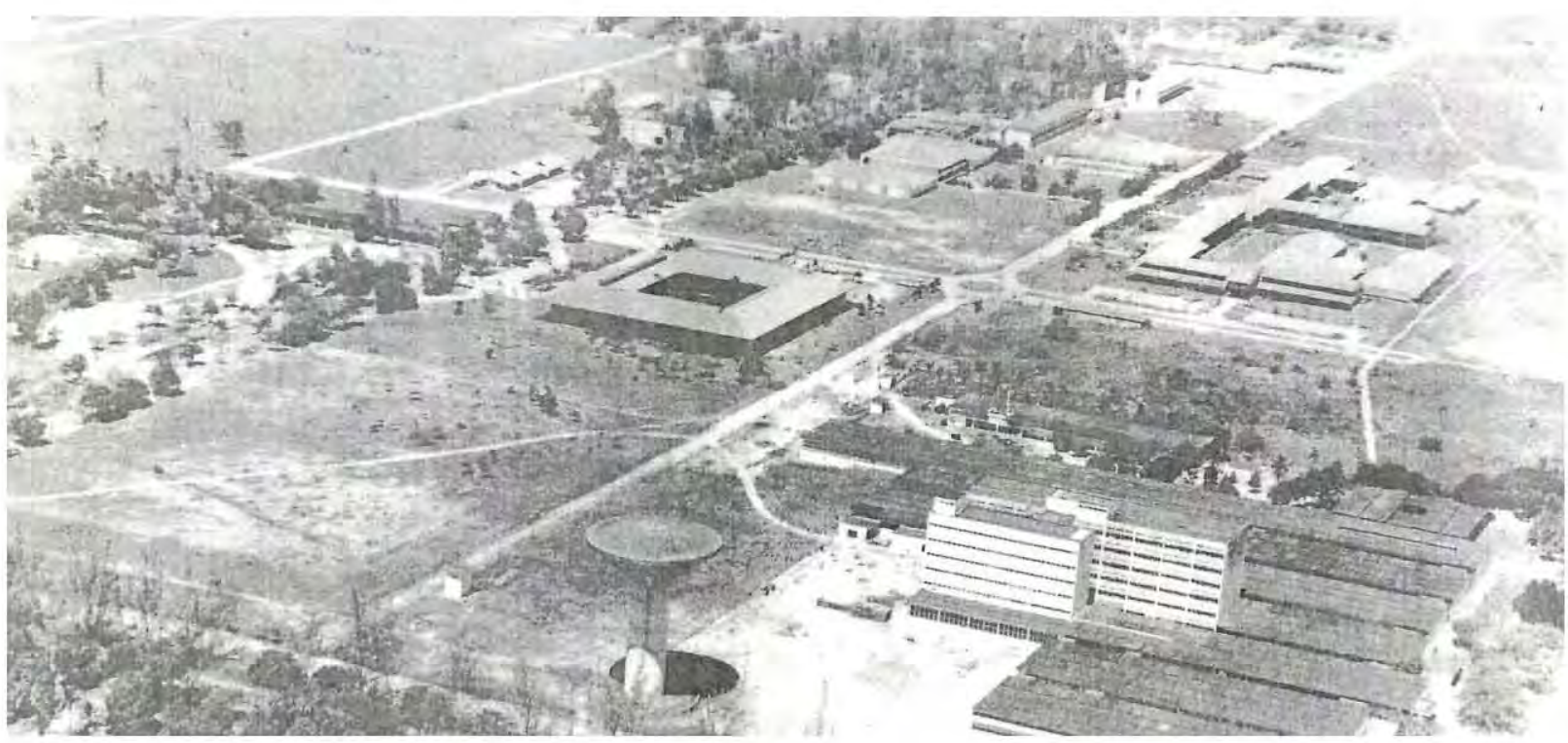

Figura 240: UFAL - Vista aérea do Campus A. C. Simões - Início da década de 1990.

No plano inferior à direita está o complexo hospitalar, atrás o Centro da Saúde. À esquerda no primeiro plano encontra-se a Reitoria, seguida do prédio da Biblioteca Central.

Foram executadas parte do sistema viário proposto e as unidades contempladas pelo Acordo MEC/BID III. A extensão das quadras e o sistema viário que as separam tornam os setores individualizados e autônomos.

(Fonte: GITAl, 1991, p. 72)

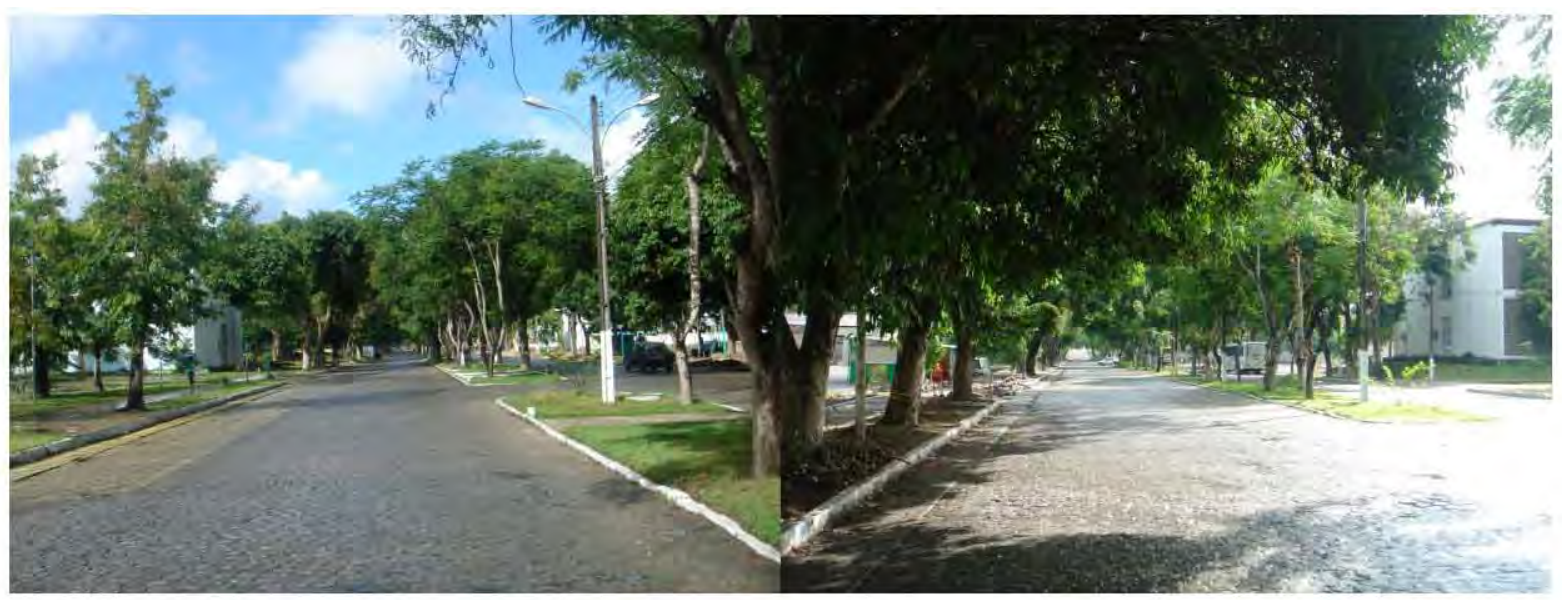

Figura 241: Vista da Avenida Central do Campus A. C. Simões - ano 2009.

A UFAL mantém a configuração urbana de um eixo central constituído por via dupla de veículos e canteiro central, cujas dimensões totais de $20 \mathrm{~m}$ conferem monumentalidade ao urbanismo proposto.

(Fonte: Acervo Magda Campêlo, 2009) 


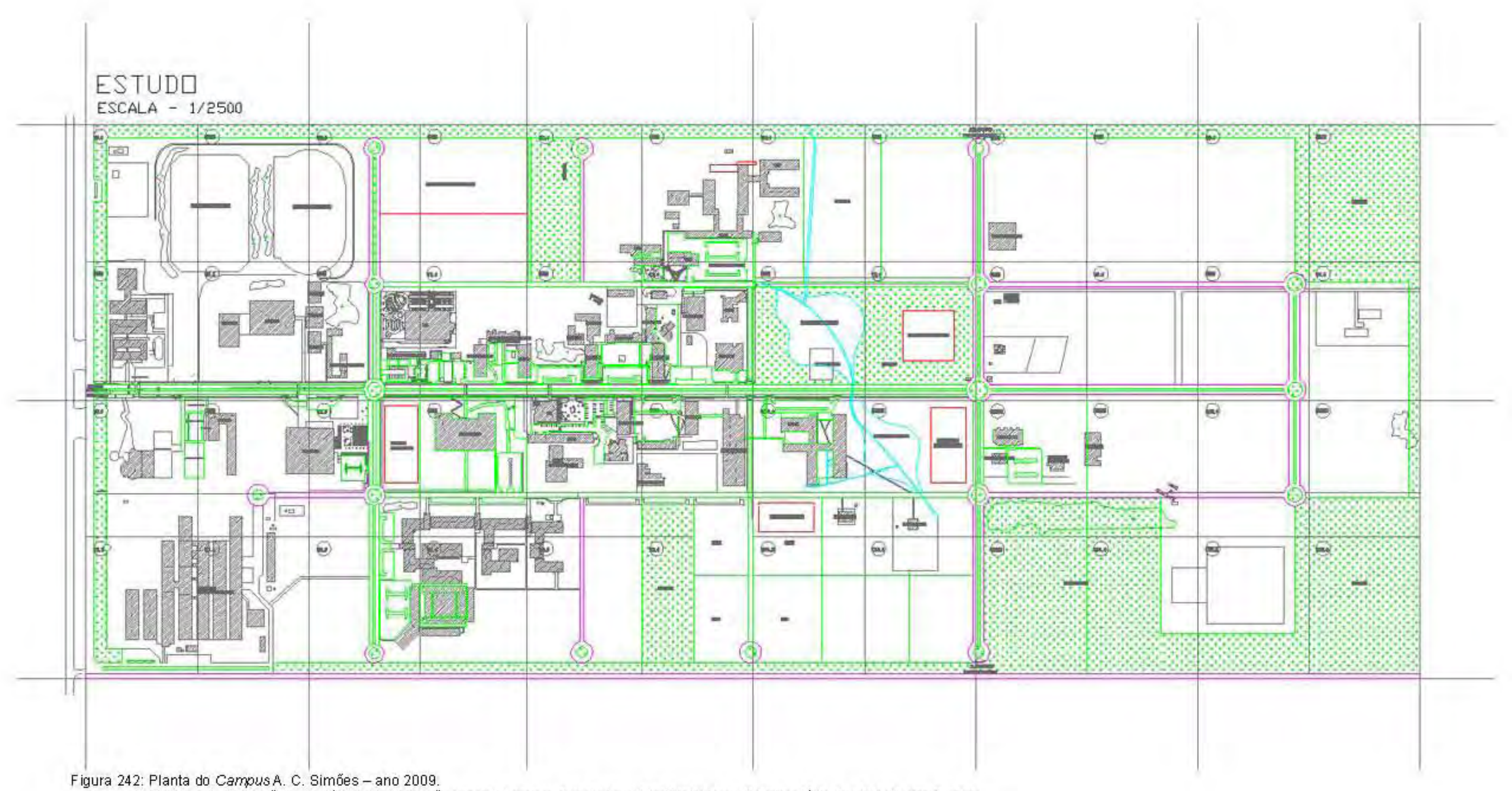

Figura 242: Planta do Camous A. C. Simóes - ano 2009.

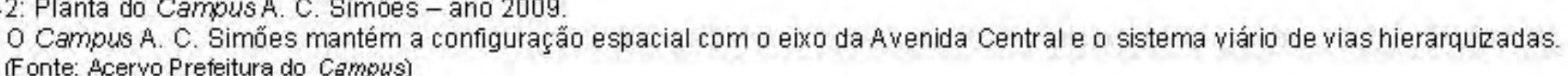

Patte 2 - Universidade Federal de Alagoos 


\subsection{CONSIDERAÇÕES}

A origem da Universidade Federal de Alagoas, como outras organizaçōes nacionais similares, resultou de uma federação de escolas particulares existentes às quais se juntou, como órgão executivo central, uma Reitoria. Criada pela Lei $n^{\circ} 3.867$, de 25 de janeiro de 1961, logo tomou providências para tornar sua estrutura compatível com o espírito da reforma que se discutia a nível nacional. Em 1962, instituiu uma comissão para estudar a reestruturação baseada em unidades de Formação Básica e de Formação Profissional.

$\mathrm{Na}$ visão do primeiro reitor, o professor catedrático da faculdade de Medicina, Aristóteles Calazans Simões, era preciso, antes de tudo, investir na infraestrutura física. Nos dez anos em que esteve à frente da administração central, priorizou os recursos para a reforma dos prédios das faculdades que deram origem à recém-criada universidade e para a construção da cidade universitária, situado no Tabuleiro dos Martins, a $15 \mathrm{~km}$ do centro urbano.

Embalado pela ideia fixa de tornar a UFAL uma instituição de identidade moderna, iniciou em 1966, antes mesmo da aprovação do plano de reestruturação, que só foi efetivado em 1967, as primeiras obras para a sua construção. Exaltava ela daria corpo e alma à tão decantada Reforma.

Foram contratados os arquitetos Oscar Valdetaro e Roberto Nadalutti para elaborar o projeto, concebido como uma cidade-parque, isolada do centro urbano tradicional e organizada seguindo rígido funcionalismo e hierarquização de vias.

O urbanismo adotado inha como característica marcante a implantação da Avenida Central, que corta a gleba de geometria retangular em duas faixas paralelas de $400 \mathrm{~m}$ de largura por quase $1.500 \mathrm{~m}$ de comprimento, conformando um eixo monumental e estruturador da organização espacial, que até hoje continua inalterado. Os arquitetos também projetaram os institutos e o Hospital Universitário, que logo tiveram suas construções iniciadas no novo território da UFAL.

Os Institutos foram concebidos com o mesmo partido arquitetônico, conformado por um bloco de dois pavimentos com a planta livre de geometria retangular, cortada longitudinalmente pela circulação central, formando duas alas paralelas de ambientes destinados às aulas, reuniões, gabinetes de professores, laboratórios, biblioteca, sanitários, dentre outros. O projeto foi adotado como tipologia padrão para todos os institutos, que depois foram ajustados para abrigar os departamentos.

O desenvolvimento físico da Universidade, na primeira década de sua criação, foi marcado pelo esforço construtivo de concretizar a estrutura física da cidade universitária. Já em 1967 , 
foi inaugurado o prédio da Faculdade de Economia. Questões financeiras, entretanto, levaram a Administração Superior a desenvolver a execução dos trabalhos em etapas, considerando um cronograma de médio e de longo prazo, o que acabou resultando em obras que se arrastavam sem prazo de finalização. Exemplo marcante foi o Hospital Universitário, que só veio a ser concluído na década de 1990.

A UFAL entrou nos anos setenta sem ter implantado a Reforma Universitária. O Plano acadêmico de 1967 - embora tenha começado a ser revisto ainda no mesmo ano de sua aprovação com base na publicação dos Decretos-leis $n^{\circ} 53 / 1966$ e 252/1967 e logo depois na Lei ${ }^{\circ} 5.540 / 1968$, que instituía a departamentalização do ensino -, só foi introduzido em 1974 com a criação dos Departamentos vinculados aos Centros.

A Universidade constatava que embora tivesse se empenhado no desenvolvimento físico com a construção da Cidade Universitária, pouco havia avançado na ampliação e qualificação dos quadros docente, técnico e administrativo, bem como no crescimento da pesquisa. Da mesma forma, as ações voltadas para a melhoria do ensino e o aumento do potencial socioeconômico e cultural do Estado eram um processo incipiente.

Para superar essas condições, ampliou a oferta de vagas com a criação de novos cursos, e aumentou os quadros de pessoal. Essa expansão acarretou a necessidade de maior capacidade instalada. A Universidade, não tendo como construir outras instalações em um prazo curto, procurou ajustar-se às edificações existentes.

Decorreu daí a acomodação dos cursos de Ciências Humanas e do Laboratório de Biologia Marinha na Escola de Aprendizes de Marinheiro de Alagoas, no pontal da Barra, mas que durou apenas três anos. O novo complexo ficou conhecido como Campus Tamandaré. $O$ Centro de Ciências da Saúde teve suas atividades acomodadas nos ambulatórios do complexo hospitalar que estavam parcialmente concluídos e em galpões cedidos pela Petrobrás, localizados no terreno defronte ao HU. O Centro de Ciências Agrárias foi implantado no município de Viçosa, no interior de Alagoas, que, entretanto não contou com investimentos em obras físicas.

A contínua expansão, face ao crescente número de discentes e também pelas ofertas de novos cursos, fez com que a UFAL chegasse à segunda metade da década de 1970 com a capacidade instalada em situação insustentável, já que não conseguia oferecer espaço físico ao funcionamento adequado de suas funções de ensino, pesquisa e extensão. A compatibilização da organização física-espacial com o plano acadêmico da Reforma era um projeto apenas delineado.

Para superar a condição de extrema deficiência de instalações em boas condições de uso e diante das dificuldades que se avolumavam e sem uma diretriz planejada e necessária à 
obtenção de recursos para superar o quadro acima esboçado, a Universidade contou com o apoio da Universidade Federal de São Carlos (UFSCar). Esta elaborou um Plano Diretor Físico, a partir do qual a instituição de Alagoas pleiteou recursos nas instâncias do Governo Federal para a concretização do seu campus universitário indicado pela Reforma.

O Plano elaborado pela universidade paulista configurou o Campus A. C. Simões em zonas funcionais reunidas pelo sistema viário hierarquizado em ruas de primeira e de segunda categoria. Tinha a concepção inovadora da organização espacial baseada na Trama Direcional, que se constituía de uma malha composta dos sistemas viários (veículos e pedestres) e das redes de infraestrutura e instalações. Lançada sobre o terreno direcionava a implantação dos setores funcionais conforme as demandas e disponibilidades financeiras da Instituição. Para promover as relações interdepartamentais e criar espaços de convívio e integração concebeu um sistema circulatório de pedestres transformado em praça, que se desenvolvia ao longo das unidades acadêmicas, conformando o edifício distribuidor responsável pela integridade no desenvolvimento das atividades universitárias. No sentido de romper com o isolamento do campus propunha a integração do sistema viário interno com a malha viária da cidade.

A aplicação do modelo, entretanto, esbarrou na rígida separação dos setores funcionais implantados em quadras de grandes extensões que obrigava a longos percursos transformando as vias de veículos no tipo de circulação predominante. Sem pontos de convergência e com percursos desprotegidos da intensa radiação solar o urbanismo adotado não conseguiu promover locais naturais de convívio. Prevaleceu a organização espacial de setores especializados isolados e autônomos, que manteve no espaço construído os vestígios de isolamento e fragmentação que se pretendia superar.

Apesar do esforço empreendido para moldar o espaço de acordo com a Reforma, o Campus A. C. Simões chegou ao final da década de 1970 sem solução para o problema de sua área física. O propósito de consolidar a tipologia espacial de território único e apartado das funções da cidade na gleba do Tabuleiro do Martins garantiu, entretanto, os benefícios da política de investimentos financeiros do governo militar na concretização do campus universitário da UFAL.

Para implantar a nova organização espacial, a Universidade foi contemplada com recursos provenientes do Programa MEC/BID III, que só foi criado em 1982. Os recursos tiveram uma abrangência menor do que os pleiteados, limitando a execução do Plano. Na década de 1980 foram construídos os prédios da Reitoria, Biblioteca Central, Centro de Ciências da Saúde, dentre outros. Essa é outra geração que ainda está para ser estudada. 



\section{UNIVERSIDADE FEDERAL DO MARANHÃO (UFMA)}

A Universidade Federal do Maranhão é uma instituição oficial de ensino superior, pesquisa e extensão, estruturada sob a forma de fundação de direito público, mantida pela União, vinculada ao Ministério da Educação, nos termos da Lei $n^{\circ} 5.152$, de 21 de outubro de 1966, com sede em São Luís, capital do Estado do Maranhão. Sua estrutura está distribuída em seis campi localizados nos principais polos geoeconômicos do Estado: em São Luís, com o Campus do Bacanga (que sedia a Administração Superior), em Imperatriz com o Campus II, em Bacabal, com o Campus III, em Chapadinha, com o Campus IV, em Pinheiro, com o Campus V e em Codó, com o Campus VI (ver figura 243). Atualmente está ampliando seu processo de interiorização com a implantação de mais três campi: Balsas, Grajaú e São Bernardo.

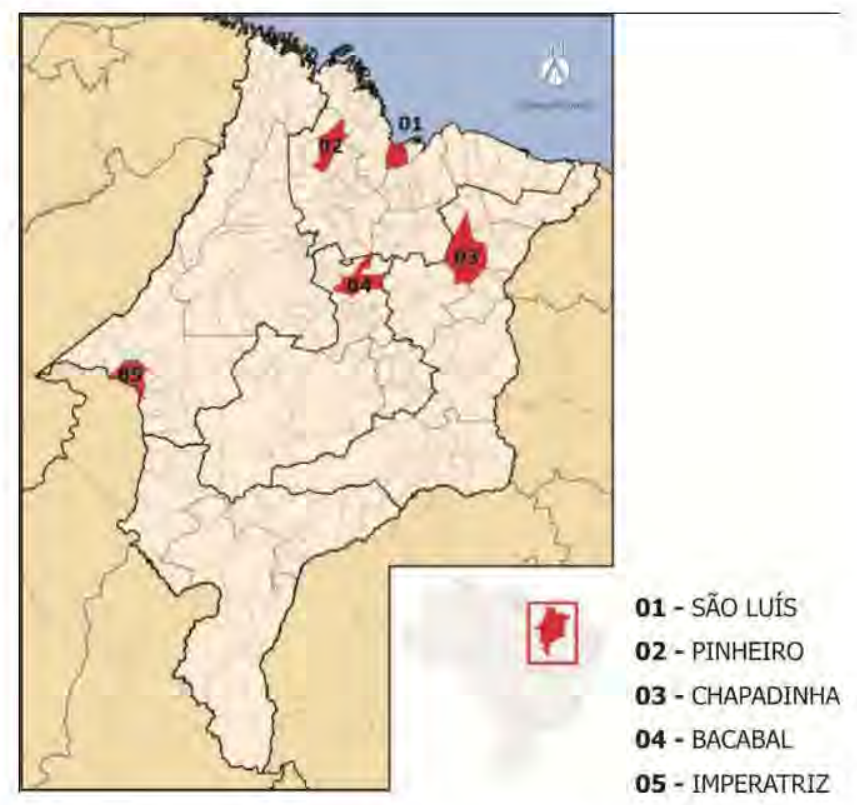

Figura 243: UFMA - Mapa do Maranhão com localização dos campi. (Fonte: Disponivel em: <http://asnovidades.com.br/mapa-domaranhao-para-colorir/>. Acesso em: 20. abr. 2012, edição nossa)

\subsection{A CRIAÇÃO DA UFMA}

A ideia de uma universidade no Maranhão remonta ao período de elaboração do anteprojeto da Constituição Maranhense após a proclamação da República, onde existe um artigo criando a Universidade Atlântida, a qual encamparia o Liceu Maranhense. Posteriormente, em 1926, chegaram a circular "bônus" para angariar fundos, visando criar uma Universidade (FUM, 1971a, p.13). 
A concretização desse projeto começou a tomar corpo com a fundação da antiga Faculdade de Filosofia de São Luís do Maranhão, embrião da futura Universidade do Maranhão, por iniciativa conjunta da Fundação Paulo $\operatorname{Ramos}^{80}$, da Arquidiocese de São Luís e da Academia Maranhense de Letras. Em 15 de agosto de 1952, em sessão solene, realizada na sede desta última, deu-se por criada a Faculdade de Filosofia de São Luís do Maranhão, tendo sido autorizada a funcionar pelo Decreto $n^{\circ} 32.606$, de 23 de abril de 1953.

Partiu dos professores dessa Faculdade a primeira tentativa para criar a Universidade do Maranhão. Em 1956, o grupo de docentes vislumbrou a oportunidade de levar o pleito por meio de memorial a ser entregue em mãos ao presidente Juscelino Kubitschek, que havia aceitado o convite para estar presente às solenidades comemorativas do Primeiro Centenário de fundação do município de Pinheiros. A visita prometida não se concretizou e frustrou o plano traçado (FUM, 1971b, p.16). Uma nova tentativa, ainda na segunda metade da década de 1950, também malograda, se deu por parte da bancada política maranhense $e^{81}$.

Foi com a chegada de dom José de Medeiros Delgado, em 1951, à Arquidiocese de São Luís, que rumos promissores foram se delineando para a efetivação do projeto da futura instituição universitária. Em 29 de janeiro de 1955, O arcebispo criou a Sociedade Maranhense de Cultura Superior, mais conhecida como SOMACS ${ }^{82}$, com o objetivo de promover a cultura no Estado e criar uma universidade católica.

Em 18 de janeiro de 1958, a SOMACS fundou a Universidade Católica do Maranhão, constituída pelas faculdades de Filosofia e de Ciências Médicas, pela Escola de Enfermagem de São Francisco de Assis e de Serviço Social, tendo sido reconhecida como Universidade Livre pelo Governo Federal, através do Decreto $n^{\circ} 50.832$, de 22 de junho de 1961. Havia a pretensão de que a Faculdade Católica de Direito fizesse parte do conjunto, com o propósito de "funcionar apenas no turno noturno, a fim de melhor atender aos que trabalhavam e queriam estudar" (TAJRA, 1985, p.26). Entretanto, não foi reconhecida oficialmente pelo então Ministério da Educação e Cultura que a considerou desnecessária, por já contar o Estado com uma Faculdade de Direito em São Luís, em pleno funcionamento

\footnotetext{
${ }^{80}$ A Fundação Paulo Ramos, instituição criada em 1944 no governo do interventor federal que the deu o nome, tinha por objetivo estatutário a manutenção das antigas Faculdades de Direito (1918) e de Farmácia e Odontologia, federalizadas pelo presidente Eurico Gaspar Dutra, em 1950 (FUM, 1971a, pag.15),

${ }^{81}$ Foi do deputado federal da bancada maranhense Antônio Jorge Dino, a tentativa frustrada de fundação de uma instituição superior no Estado, na segunda metade da década de 1950. Sobre esse assunto ver a publicação Catálogo Geral - 1971, de autoria da FUM.

${ }^{82} \mathrm{O}$ arcebispo dom José Delgado foi o protagonista na criação da Universidade Católica do Maranhão com a fundação da SOMACS. Nas palavras do ex-reitor José Maria Cabral Marques $(2005$, p.263) da UFMA - gestão de 1979 a 1988, a "ideia de D. Delgado, quando criou a SOMACS, a instituição mantenedora da Universidade, não era a de uma Universidade da Igreja e para a Igreja, até diferentemente de outras Universidades Católicas que surgiram no Brasil. Ele teve a preocupação de dotar o Maranhão de uma universidade forte, grande, capaz de ajudar decisivamente no desenvolvimento do Estado". A bibliografia pertinente à história do ensino superior naquele Estado destaca o relevante papel desempenhado por dom Delgado, quando assumindo o arcebispado da capital intensificou a atuação da igreja na difusão da cultura e em ações sociais voltadas para as camadas populares, principalmente para o meio rural (SILVA et al, [2008?], p.4-5).
} 
(TAJRA,1985, p.26). Além das quatro unidades de ensino superior congregadas na Universidade Católica, subsistiam, isoladas, as unidades federais de Direito e de Farmácia e Odontologia. Foram também integrados como órgão suplementares, a Rádio Educadora do Maranhão Rural Limitada, que com a Tipografia São José Limitada, constituiria um Departamento Universitário de Rádio, Imprensa e Livro (DURIL) e mais um Instituto de Líderes e Escola Normal de Morros.

O governo do Estado $^{83}$ doou então à Universidade a área do sitio 'Sá Viana', à margem esquerda da foz do Ibacanga [referência ao rio Bacanga], com 241 hectares [dados da Prefeitura do Campus da UFMA indicam, entretanto, que se tratava de 271 ha], para a construção do seu futuro campus (MEIRELES, 1981, p.30). A gleba, entretanto, só veio a ser ocupada no início da década de 1970 com a construção da primeira unidade acadêmica da então futura Universidade Federal do Maranhão, conforme será descrito no decorrer do presente capítulo.

A Reitoria foi instalada na antiga residência do Barão de Grajaú (ver figura 244), um sobrado de azulejos e sacadas de ferro, situado à Rua de São João, no centro da cidade, e que era então sede do Museu Pio XII, fundado anteriormente pela SOMACS (MEIRELES, 1981, p.29-30).

A Universidade Católica, entretanto, teve curta duração ${ }^{84}$, em virtude das dificuldades financeiras enfrentadas ao longo dos seis anos de existência, que se tornaram insuperáveis, já que a SOMACS, instituição mantenedora, não conseguiu dos poderes públicos subvenções suficientes para equilibrar as despesas com as receitas. Para garantir a sobrevivência da Instituição, a Secretaria do Ensino Superior do MEC sugeriu que a Igreja doasse a Universidade à União, propondo a criação de uma fundação que passasse a mantê-la, juntamente com as duas escolas federais existentes no Estado (Faculdade de Direito de São Luís e a Faculdade de Farmácia e Odontologia de São Luís, já referenciadas) que também seriam incorporadas ${ }^{85}$. E foi o que aconteceu.

A SOMACS, de acordo com esta sugestão, doaria seu acervo, avaliado em cerca de 2 milhões de cruzeiros e, em contrapartida, teria $1 / 3$ do Conselho Diretor e um Instituto de Teologia [que nunca foi criado]. A Fundação obrigar-se-ia a receber os Corpos Docente e Administrativo da Universidade Católica. (TAJRA, 1985, p.27)

\footnotetext{
${ }^{83}$ Naquele ano, o governador do Maranhão era José de Matos Carvalho (1957/1961).

${ }^{84}$ A Universidade Católica teve apenas dois reitores: dom Antônio Batista Fragoso, bispo auxiliar da Arquidiocese, e cônego José de Ribamar Carvalho, secretário do arcebispo. Como vice-reitor, o professor José Maria Cabral Marques. Meireles (1981, p.30) relata que as dificuldades foram intensas, chegando ao ponto de o arcebispo dom Delgado percorrer as capitais do Sul do País, dos Estados mais ricos, acompanhado da então Miss Maranhão, Ida Brasil, em 1958, na esperança de angariar precisos recursos.

${ }^{85} \mathrm{O}$ então diretor do Ensino Superior do Ministério da Educação e Cultura doutor Dumerval Figueiredo Mendes foi o autor da solução dada a dom Delgado como único meio de salvar a instituição que tanto lhe custara.
} 


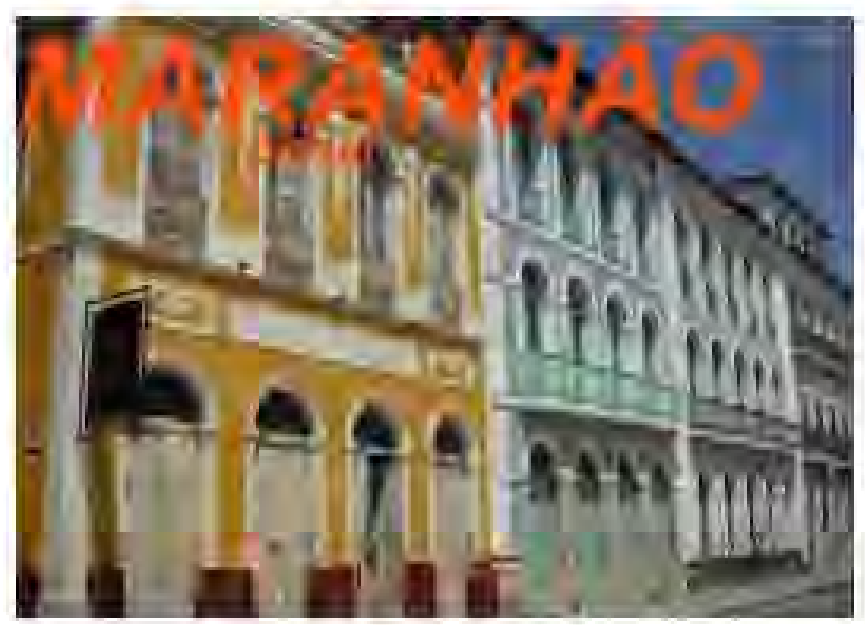

Figura 244: UF MA - Solar do Barão de Grajaú, construido na segunda metade do século XIX. - edificio de herança colonial tem a fachada revestida de azulejos portugueses. Pertenceu à Arquidiocese do Maranhấo e à Universidade Católica, que deram origem à UFMA. Nele foi instalado o Museu Pio XII, criado en 1956 e extinto en 1967. Atualmente funciona o Museu de Arte Sacra.

(Fonte:Disponivel emshttp Hhum portals aofrancisco.com.but alfabrasilsao-luis-17 php>.Acesso em: 17 ago, 2011)

A proposta, formalizada em memorial, foi apresentada ao $M E C$, resultando na Lei $n^{\circ} 5152$ de 21 de outubro de 1966, que autorizava o Governo Federal a instituir a Fundaçẫo Unversidade do Maranhẫo (FUM), entidade pública de direito privado, com a finalidade

$$
\begin{aligned}
& \text { de implantar progressivamente a Universidade do Maranhâo - instituiçấo } \\
& \text { de ensino superior, de pesquisa e de estudos em todos os ramos do } \\
& \text { saber, visando imediatamente contribuir para a soluçäo de problemas } \\
& \text { regionais de natureza econômica, social e cultural (BRASIL, 1966, } \\
& \text { p.1464). }
\end{aligned}
$$

Em seu art $4^{\circ}$ declara extinta a Universidade Católica do Maranhäo, mantida pela Sociedade.

Vale ressaltar que a criaçẫo da UF MA contou com o apoio do governo militar, o entấo presidente da República, marechal Humberto de Alencar Castelo Branco (1964/1967), que sancionou a lei de criaçấo da UFMA e que quando em visita a Sẫo Luís, para receber o título de doutor honoris causa, agraciado pela entẫo Universidade católica, destacou em suas palavras de agradec imento, que aguela era a primeira vez que o Governo Federai se unia a uma unicade confessional para fazer surgir uma universidade (apud MEIRELES, p.31) O fato evidencia a política de investimento do governo militar na expansão do ensino superior e que se conc retizava na construçấo do camous universitária. 
A nova instituição foi a princípio integrada por seis unidades de ensino superior: Faculdade de Direito de São Luís, Faculdade de Farmácia e Odontologia de São Luís, Escola de Enfermagem São Francisco de Assis, Faculdade de Filosofia, Ciências e Letras de São Luís, Faculdade de Serviço Social do Maranhão e Faculdade de Ciências Médicas do Maranhão. Posteriormente, em 27 de janeiro de 1967, no ato de instalação da UFMA, foi incorporada a Faculdade de Ciências Econômicas, perfazendo o total de sete unidades que conformaram sua estrutura inicial.

A administração da FUM coube a um conselho diretor, nomeado pelo presidente da República e que entre si elegeram seu presidente e vice-presidente. Aprovado o estatuto da Fundação por meio do Decreto $n^{\circ} 59.941$, de 06 de janeiro de 1967, tomou posse o primeiro Conselho Diretor, em 15 de abril de 1967 e no dia $1^{\circ}$ de maio foi a vez do reitor e dos vicereitore $^{86}$, nomeados por meio de lista tríplice votada pelo Conselho Universitário. O referido estatuto foi posteriormente modificado várias vezes, para atender às mudanças constantes nas leis do ensino que se sucederam na primeira metade da década de 1960 , culminando com a da Reforma Universitária de 1968, conforme se verá.

A Fundação Universidade do Maranhão nasceu e cresceu com a Reforma Universitária. Assumiu com prioridade a missão de adequar a Instituição de acordo com os princípios e as normas básicas da Reforma ${ }^{87}$. De imediato, recebeu o impacto dos Decretos-leis $\mathrm{n}^{\text {os }}$ $53 / 1966$ e 252/1967, a partir dos quais elaborou uma nova estrutura acadêmica baseada na departamentalização do ensino, organizada em ensino básico e profissionalizante.

Atendendo à legislação vigente, a FUM encaminhou ao Conselho Federal de Educação em agosto de 1967 o seu Plano de Reestruturação, que previa a criação de quatro Institutos Centrais, divididos em departamentos conforme os setores de conhecimento, onze Faculdades, incluindo as Escolas de Engenharia e Administração, embora ainda não pertencentes oficialmente à recém-criada Universidade, e sete Órgãos Suplementares (ver quadro 6).

O Plano não foi aprovado de imediato pelo referido órgão do $\mathrm{MEC}$ impossibilitando ser posto em execução, já em 1968. Acresceu-se a este fato a inexistência de recursos financeiros e de área física para pôr em prática o exigido pelos decretos-leis citados, conforme mencionado no estudo realizado pela FUM ([1968?], n.p.).

\footnotetext{
${ }^{86} \mathrm{~A}$ administração superior foi composta pelo reitor, professor Pedro Neiva de Santana, pelo vice-reitor administrativo, professor Mário Martins Meireles, e pelo vice-reitor pedagógico, cônego José de Ribamar Carvalho.

${ }^{87}$ Buzar (1985, p.29-39) elabora um minucioso relato sobre a implantação da Reforma Universitária na UFMA.
} 
Quadro 6: UFMA - Organização básica proposta pelo Estatuto de 1967. (Fonte: FUM, [1968?], n.p.,edição nossa)

Organização Universitária da UFMA - Estatuto de 1967

\begin{tabular}{l|l}
\hline \multirow{4}{*}{ Instituto de Ciências Físicas e Naturais } & $\begin{array}{l}\text { Departamento de Matemática e Estatística } \\
\text { Departamento de Física } \\
\text { Departamento de Química } \\
\\
\\
\text { Departamento de Biologia } \\
\text { Departamento de Geociências }\end{array}$ \\
\hline \multirow{3}{*}{ Instituto de Ciências Humanas } & Departamento de Antropologia \\
& Departamento de Sociologia \\
& Departamento de Psicologia \\
& Departamento de Economia \\
& Departamento de Política \\
& Departamento de Demografia \\
\hline \multirow{3}{*}{ Instituto de Letras e Artes } & Departamento de Linguística \\
& Departamento de Filosofia \\
& Departamento de Literatura \\
& Departamento de Desenho e Artes Aplicadas \\
\hline
\end{tabular}

Instituto de Teologia

Faculdade de Direito

Faculdade de Farmácia

Faculdade de Odontologia

Faculdade de Educação

Faculdade de Ciências Médicas

Faculdades

Faculdade de Serviço Social

Faculdade de Enfermagem

Faculdade de Ciências Econômicas

Faculdade de Filosofia e História

Faculdade de Engenharia

Faculdade de Administração

Biblioteca Central

Museu

Centro Desportivo

Órgãos Suplementares

Imprensa Universitária

Centro Audiovisual

Teatro

Casa do Estudante

A promulgação da Lei $n^{\circ} 5.540$, em 1968 , motivou a Administração Superior a contratar os serviços do escritório carioca Maximus de Estudos Econômicos e Contábeis Ltda., no mesmo ano, para montar a estrutura administrativa da Universidade voltada para a implantação dos princípios e normas emanados pela referida $l i^{88}$,

Em 1969, foi apresentado um anteprojeto do estatuto da Universidade do Maranhão referenciado na lei reformista. A proposta reiterava a estrutura universitária baseada em departamentos, porém com redução do número de unidades. A pesquisa e o ensino básico ficariam concentrados em três Institutos Centrais (ao invés de quatro), o ensino profissional e a pesquisa aplicada seriam realizados por oito Faculdades (não mais por onze), os

\footnotetext{
${ }^{88} \mathrm{Na}$ data de 14 de novembro de 1968 , catorze dias antes da promulgação da Lei $\mathrm{n}^{0} 5.540$, havia sido efetivado no cargo de reitor, o cônego José de Ribamar Carvalho, que logo tratou de implantar a Reforma na UFMA (BUZAR, 1985, p.26).
} 
programas de extensão caberiam aos Institutos e Faculdades e seriam mantidas as sete unidades de Órgãos Suplementares de natureza técnica, cultural, recreativa e assistência aos estudantes, conforme quadro 7 .

Quadro 7: UFMA - Organização básica proposta pelo Estatuto de 1969.

(Fonte: FUM, 1969a, edição nossa)

\begin{tabular}{l|l}
\hline \multicolumn{2}{c}{ Organização Universitária da UFMA - Estatuto de 1969} \\
\hline \multirow{4}{*}{ Instituto de Ciências Físicas e Naturais } & Departamento de Matemática \\
& Departamento de Física \\
& Departamento de Química \\
& Departamento de Morfologia \\
& Departamento de Ciências Fisiológicas \\
\hline \multirow{5}{*}{ Instituto de Filosofia e Ciências Humanas } & Departamento de Geografia \\
& Departamento de Sociologia \\
& Departamento de Psicologia \\
& Departamento de Filosofia \\
& Departamento de História e Ciências das Religiões \\
\hline \multirow{5}{*}{ Instituto de Letras e Artes } & Departamento de Letras \\
& Departamento de Estudos Lusos Brasileiros \\
& Departamento de Artes e Comunicação \\
\hline & Faculdade de Direito \\
& Faculdade de Farmácia \\
& Faculdade de Odontologia \\
& Faculdade de Educação \\
& Faculdade de Medicina \\
& Faculdade de Serviço Social \\
& Faculdade de Enfermagem \\
& Faculdade de Ciências Econômicas \\
\hline & Biblioteca Central \\
& Museu \\
& Estádio Universitário \\
& Editora \\
& Serviço de Rádio, Telecomunicação e Audiovisual \\
& Teatro Universitário \\
& Casa do Estudante \\
\hline \multirow{5}{*}{ Órgãos Suplementares } &
\end{tabular}

Adequando-se à Lei da Reforma, estabeleceu que a estrutura acadêmica fosse organizada em centros, mediante a futura eliminação dos níveis intermediários de institutos e faculdades, quando então os departamentos passariam a vincular-se diretamente aos respectivos centros (FUM, 1969a, p.9). Com esse propósito, previu em estágio provisório a formação de três centros de coordenação formados por unidades de áreas afins, responsáveis pelo planejamento, coordenação e controle dos cursos a eles vinculados. Estavam assim constituídos:

1. Centro de Estudos Gerais, constituído pelos Institutos de Ciências Físicas e Naturais; Filosofia e Ciências Humanas e Letras e Artes, com a função de planejar, coordenar e controlar o Ciclo Básico da Universidade. 
2. Centro de Coordenação da Área Médica, integrado pelas Faculdades de Farmácia, Odontologia, Enfermagem e Medicina, destinado a programar, coordenar e controlar o ciclo profissional desses cursos.

3. Centro de Coordenação de Estudos Sociais Aplicados, composto pelas Faculdades de Direito, Educação, Serviço Social e Ciências Econômicas, também com a função de programar, coordenar e controlar as atividades didáticopedagógicas e administrativas dos cursos a ele vinculados.

O agrupamento dos departamentos em unidades, institutos e faculdades, representava uma etapa de transição entre a velha estrutura universitária, baseada na cátedra, e a do sistema departamental, tendendo a desaparecer à medida que os centros de coordenação se tornassem atuantes e produtivos (FUM, 1971, p.24).

Em janeiro de 1970, com o Estatuto reformulado, a Reforma Universitária foi institucionalmente oficializada. Criou os institutos básicos comuns às áreas diferenciadas do ensino e departamentalizou o ensino em todos os setores de conhecimento. $O$ complexo acadêmico, a ser formado por centros e departamentos, era aceito como fator primordial para o desenvolvimento da Universidade.

Foi estruturado o Conselho Departamental dos Institutos e Faculdades, órgão consultivo e deliberativo, integrado pelos seus diretores e chefes de departamento e, na organização do ensino, implantou no mesmo ano o Ciclo Básico. Para a efetivação deste último, desmembrou a antiga Faculdade de Filosofia, Ciências e Letras, em duas unidades: 0 Instituto de Filosofia e Ciências Humanas e Letras e Artes e a Faculdade de Educação. Concomitante, foi implantado o Centro de Coordenação de Estudos Gerais, já referenciado, instalado no início do ano letivo de 1970 , responsável pela supervisão e coordenação dos estruturados Institutos a ele vinculado. Às sete Faculdades em funcionamento, foi acrescida, a Faculdade de Educação que passou a funcionar a partir de 31 de março daquele ano independente do Instituto de Filosofia e Ciências Humanas e Letras e Artes.

Ainda no mesmo ano (1970), em decorrência da Reforma, foi criado um órgão específico para o planejamento: a Superintendência de Planejamento e Desenvolvimento Educacional (SUPLAN), implantada em fevereiro de 1970. Ela realizou, dentre outras atividades, um levantamento referente à estrutura física existente, identificando as necessidades de reparos e adaptações e encaminhou os projetos das futuras instalações destinadas ao Instituto de Filosofia e Ciências Humanas, Restaurante Universitário, Superintendência de Ensino, Pesquisa e Extensão, Centro Rural Universitário de Treinamento e Ação Comunitária (CRUTAC) e Lar Universitário. 
Elaborou um levantamento funcional das salas de aula, visando melhor distribuição das turmas e aproveitamento de espaço. Este último estudo subsidiou os projetos das futuras instalações, conforme será abordado na seção referente às primeiras obras do campus.

Em 1971, adotou o regime de créditos e no ano seguinte implantou o CRUTAC, outro tento da UFMA no seu plano de Reforma (BUZAR, 1985, p.32). Configurando-se como uma tentativa de interiorização da universidade brasileira, através da sua maior integração com as realidades nacional, regional e local, constituiu-se na UFMA um programa que funcionava dentro da estrutura geral da Universidade. Esse programa, que funcionava dentro da estrutura geral da UFMA, consistia em uma tentativa integrar a universidade brasileira com as realidades nacional, regional e local.

Em 1973, entretanto, ao elaborar o Plano de Ação para 1974 a Instituição constatou que a Reforma Universitária iniciada em 1970 ainda não havia atingido seus verdadeiros objetivos em razão da inadaptabilidade da estrutura aos novos padrões sugeridos pela Reforma, tendo, por conseguinte, continuado sem alteração (FUM, 1973, p.10).

A modificação principal, que consistia na extinção dos institutos e faculdades para fazer surgir a estrutura formada pelos cursos e departamentos vinculados aos centros, ainda era um projeto a ser efetivado. Manifestava, porém, confiança na sobrevivência do novo modelo, acreditando ser um processo de ajustamento gradativo, até a sua total implantação. Ensejava que até 1975 estaria em funcionamento a estrutura assim constituída:

1. Sistema Básico, formado pelos:

- Centro de Ciências Biológicas

- Centro de Ciências Humanas e Letras

- Centro de Ciências Exatas

2. Sistema Profissional, constituído pelos:

- Centro de Educação

- Centro de Ciências de Saúde

- Centro de Ciências Sociais

- Centro Tecnológico

Dando prosseguimento às medidas cabíveis da Reforma, em 1975, adotou o concurso de vestibular unificado, idêntico para todos os cursos ou áreas de conhecimento afins. Em novembro de 1978 , estendeu seus serviços ao município de Imperatriz com a implantação 
dos Cursos de Pedagogia e Direito, por meio de convênio entre a Universidade do Maranhão e a Fundação do Ensino de Imperatriz.

Em 1979, elaborou o Plano de Restruturação da UFMA que deu ensejo à criação de um novo estatuto, o qual, segundo a Instituição, se adequava mais à estrutura organizacional da Reforma. Definiu a administração da Universidade em três níveis:

1. Superior - constituído pelos Órgãos Deliberativos (Conselho Diretor, Conselho Universitário, Conselho de Administração e Conselho de Ensino, Pesquisa e Extensão) e pelo Órgão Executivo (Reitoria).

2. Intermediário - formado pelos Centros de Estudos Básicos, de Ciências Sociais, de Ciências da Saúde e Tecnológico, com os respectivos Conselhos e Diretoria, com a função de realizar a integração da Administração Superior com as coordenadorias de Cursos e os Departamentos.

3. Departamental - constituído pela Assembleia Departamental e Chefia Departamental.

Em apoio ao Conselho de Ensino, Pesquisa e Extensão, foram concebidos os seguintes órgãos suplementares:

- Biblioteca Central

- Núcleo de Processamento de Dados

- Laboratórios de Tecnologia Farmacêutica

- Núcleo Superior dos Estudos Maranhenses

- Museu Universitário

- Laboratório de Hidrobiologia

- Núcleo de Esportes

- Imprensa Universitária

No final da década de 1970, a UFMA se consolidava como instituição de ensino superior, exaltando sua contribuição na melhoria da qualidade de vida do Maranhão, tendo a Reforma como condutora e estruturadora da sua atuação no campo do ensino, pesquisa e extensão. Nesse ínterim, a construção do seu território era também um processo de formação gradativo objetivando dar corpo à nova estrutura.

Para dar forma a uma Universidade integrada e funcional, dentro do espírito da Reforma, a UFMA elaborou projetos para materializar o seu campus universitário. 


\subsection{O TERRITÓRIO DA UFMA: a ascensão do campus universitário}

Dentre as primeiras providências, no propósito de constituir a base física, deu-se a transferência ao patrimônio da Fundação dos bens, móveis e imóveis, da Universidade Católica e das unidades federais. Incluso estava o Sítio Sá Viana, destinado ao futuro campus. $O$ antigo solar do Barão de Grajaú, onde até então funcionava a sede da Reitoria da Universidade Católica, foi cedido pelo Arcebispado para que continuasse a abrigá-la provisoriamente até a construção das instalações definitivas.

A FUM iniciou suas atividades enfrentando sérias dificuldades financeiras, tendo em vista que o orçamento da União para o exercício de 1967 não previra recursos para aquela entidade, criada no ano anterior. Deste modo, a Universidade, principalmente a Reitoria, começou a funcionar contando com recursos doados pelo Banco do Estado do Maranhão e pelo Banco do Maranhão.

Em 1968, todavia, com uma receita [...] em que $92,8 \%$ eram recursos orçamentários da União, já se encomendava ao escritório de arquitetura de Wit-Olaf Prochnik, do Rio de Janeiro, o planejamento da construção do Campus do Bacanga. (MEIRELES, 1981, p.32, grifo do autor).

A contratação do citado escritório se deu logo após a promulgação da Lei $n^{\circ} 5.540 / 1968$, fato que motivou a Reitoria ${ }^{89}$ a concretizar o território da nova Instituição dentro dos princípios e normas dela decorrentes. Chama atenção a postura decisiva da UFMA de construir o seu campus universitário. A Reitoria ${ }^{90}$ tinha a clara ideia de que $\circ$ mesmo era elemento integrador das funções universitárias. As palavras do reitor em exercício, o cônego José de Ribamar Carvalho, quando da inauguração do Campus, em 1972, evidenciam o convicto entendimento do papel a ser desempenhado pelo novo território. Assim se expressou:

[...] vencer uma barreira aparentemente insignificante, mas que na realidade apresenta o maior obstáculo ao processo de mudança: a descentralização das unidades de ensino [‥] a distância entre as unidades acentua a falta de entrosamento entre os estudantes dos diversos cursos ou áreas de conhecimento, não thes propiciando uma mentalidade interdisciplinar, uma melhor compreensão interprofissional e o espírito universitário. (CARVALHO, 1972 apud BUZAR, 1985, p.32-33, grifo nosso).

\footnotetext{
${ }^{89} \mathrm{Na}$ data de 14 de novembro de 1968 , catorze dias antes da promulgação da Lei $n^{\circ} 5.540$, havia sido efetivado no cargo de reitor, o cônego José de Ribamar Carvalho. O novo gestor logo tratou de implantar a Reforma na UFMA (BUZAR, 1985, p.26). ${ }^{90} \mathrm{O}$ reitor em exercício, o cônego José de Ribamar Carvalho (gestão de 1968 à 1972), direcionou esforços na construção do campus.
} 
Não havia dúvida da premente necessidade de moldar o espaço físico no modelo de campus universitário. Seria o território onde as unidades de ensino ficariam reunidas em um só local, com o propósito de racionalizar os fluxos de trabalho e comunicação necessários ao processo da Reforma que estava sendo implantada. Da mesma forma, as gestões que se seguiram mantiveram ações para que as obras do Campus mantivessem o cronograma de desenvolvimento.

Os fatos históricos referentes à criação da UFMA nos chamam a atenção tanto pela natureza da sua origem confessional, que difere das instituições congêneres do Nordeste, bem como pela convicção do seu papel como agente renovador, onde o campus era estratégico para a concretização dos ideais almejados. Estava assimilada uma nova percepção de universidade, comprometida com a filosofia da formação integral do homem e com as funções básicas de ensino, pesquisa e extensão e do seu papel no desenvolvimento do Maranhão. A Universidade assim se manifestava:

Estagnado, durante longo tempo, acorda o Estado para uma nova realidade econômica acelerada com o advento da energia de Boa Esperança, o petróleo de Barreirinhas e o Porto de Itaqui. Cabe por isso mesmo, à Universidade o preparo dos quadros humanos, que dinamizarão e disciplinarão o progresso vertiginoso imposto pela necessidade de recuperar o tempo perdido.

Criar esse profissional em número e qualidade exigidos pelo desenvolvimento maranhense tornar-se o catalisador do processo sócio cultural da nova civilização timbira, eis os objetivos a curto e longo prazo que a Universidade do Maranhão está visando.

Para tal urge preparar-se física, administrativa e didaticamente, para responder ao desafio posto pela civilização tecnológica do presente, que não pode, porém, prescindir dos elementos humanos de todos os tempos (FUM, [1968?], n.p., grifo nosso).

A citação acima também sugeria que a construção do seu território físico era uma das parcelas da equação a ser resolvida na reestruturação. 


\subsection{INSTALAÇÕES FÍSICAS: do Palácio Cristo Rei ao Campus do Bacanga}

Iniciando suas atividades em prédios locados e/ou de propriedade da Fundação, situados na área central da cidade, a Universidade transferiu gradativamente parte de suas unidades para o Campus, à medida que se construíam as novas edificações.

Dentre as primeiras instalações de origem, destaca-se por sua arquitetura o Palácio Cristo Rei, sede do Arcebispado de 1920 até 1953, quando foi cedido para a Fundação Paulo Ramos para abrigar as primeiras faculdades isoladas do Estado $^{91}$ e que com a criação da FUM, passou a ser propriedade da Universidade. O edifício foi reformado e em 1973 a Reitoria foi transferida de sua sede provisória no Solar do Barão de Grajaú para o Palácio Cristo Rei que passou a ser a sede oficial da Reitoria. Atualmente está implantado nesse prédio o Memorial Cristo Rei, inaugurado em 21 de outubro de 1993, cujo acervo, constituído pela documentação, fotos e peças variadas doadas pelos diversos setores da Universidade (UFMA, [2009?], n.p.), preserva a memória da UFMA.

Situado no Largo dos Amores, área do centro histórico da cidade, a edificação é um exemplar do estilo barroco ${ }^{92}$. Compõe o conjunto de prédios de São Luís, remanescente do século XIX (ver figura 245).

Composto de dois pavimentos, mirante de terminação em beiral. [...] na fachada principal térreo, uma sequência de óculos gradeados de ferro em vez de porta. No andar superior, portas, janelas com caixilhos fixos nas bandeiras e venezianas, apresentam balcão sacado, com piso em cantaria e gradil de ferro apoiado por um grupo de mísulas talhadas em lioz. (UFMA, [2009?], n.p.).

O funcionamento das unidades nas edificações de origem logo foi denunciado como inadequado às novas tarefas do ensino. O estudo realizado pela FUM ([1968?]) com a finalidade de estabelecer uma programação das obras de construção do futuro campus, identificava que a flexibilidade do ensino e da pesquisa ensejada pela Reforma, estava a exigir idêntica versatilidade da estrutura física, de modo a propiciar o maior rendimento das funções universitárias. A localização dos edifícios em vários setores da cidade e as características construtivas de origem colonial das edificações eram fatores entendidos como obstáculos à integração e à funcionalidade, dada a ineficiência dos transportes coletivos em São Luís e a inadaptabilidade da estrutura física dos prédios, antigos sobrados.

\footnotetext{
${ }^{91}$ Foram elas: Faculdade de Filosofia do Maranhão, que formava bacharéis e licenciados nas áreas de História, Geografia Letras Neolatinas e Filosofia.

${ }_{92}$ Construído pelo arquiteto Manoel José Pulgão.
} 


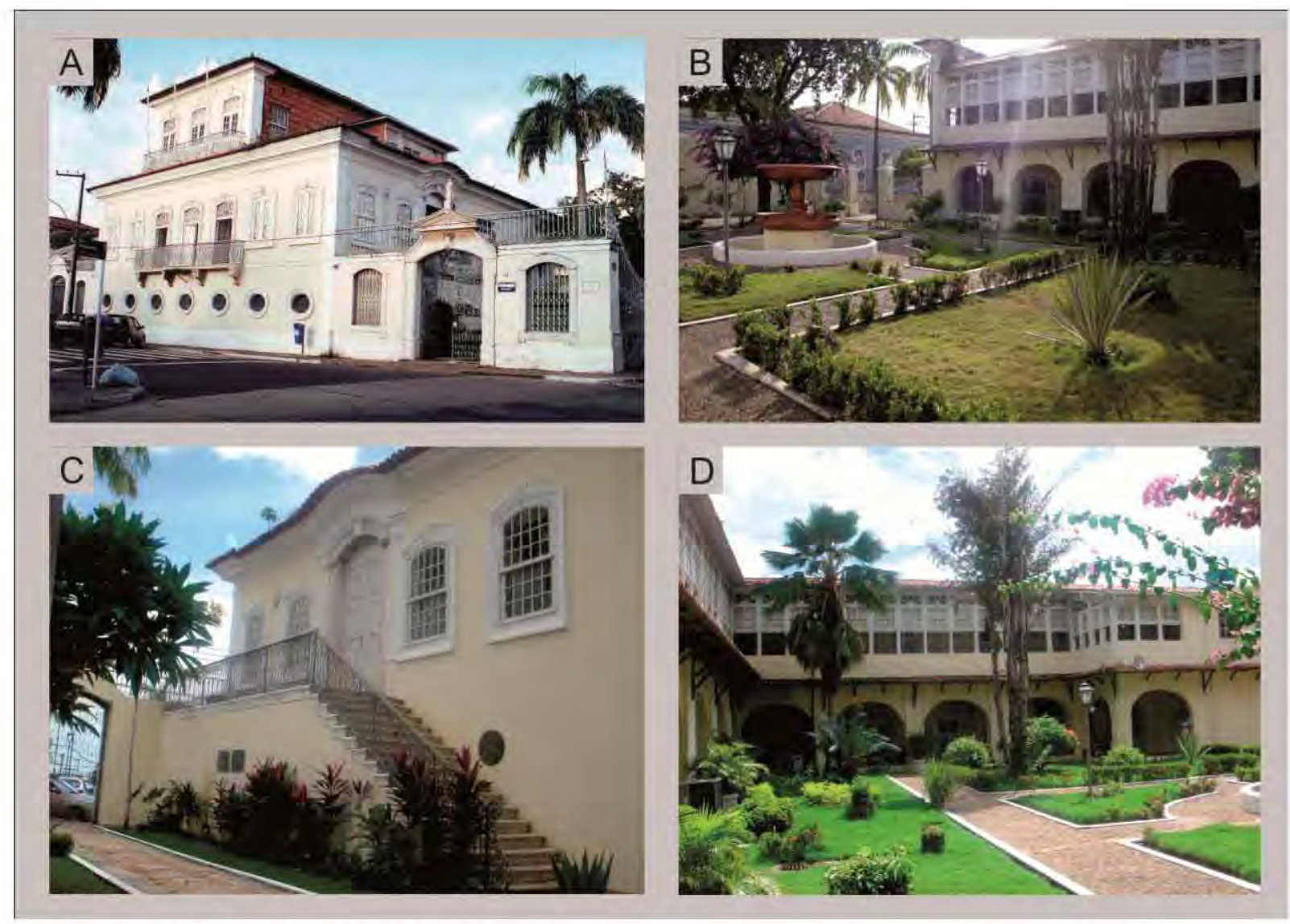

Figura 245: UFMA - Palácio do Cristo Rei.
(A) Vista da fachada principal. 24 ago. 2011).
(B) Vista do pátio interno com a fonte inglesa.
(Fonte: Jornal da Universidade - Edição Especial, 2009, p. 1)
(C) Vista da escadaria na fachada lateral.
(Fonte: Acervo pessoal da autora, 2009)
(D) Vista do pátio interno
(Fonte: Acervo pessoal da autora, 2009)

(Fonte: disponível em < http://static.panoramio.com/photos/original/11949331.jpg.>. Acesso em:

Exemplos mencionados foram os edifícios das Faculdades de Ciências Econômicas, de Ciências Médicas e de Filosofia, que embora tendo passado por reformas e adaptações mostravam-se ainda assim inadequados para atender ao novo programa universitário. De um modo geral não possuíam gabinetes de professores, salas para trabalhos extracurriculares, instalações sanitárias adequadas, condições acústicas condizentes, local de recreação e convivência, e apresentavam dificuldades para a manutenção devido aos aspectos construtivos característicos dos antigos sobrados (mármores, gradis de ferro trabalhados, tábuas de madeira de lei, azulejos seculares), que dificultavam a reposição dos materiais e oneravam os custos. Acrescia-se aos fatores mencionados, a impossibilidade de um plano de expansão devido à ausência de áreas para crescimento ou ao próprio caráter de monumento histórico dos edifícios, exigindo o atendimento a critérios preservacionistas. 
Por outro lado, as constatações mencionadas eram balizadas pelo potencial de revitalização das áreas históricas condenadas à obsolescência. Prevaleceu, entretanto, o projeto de um território em região periférica. Vale mencionar que a validade de conformar o campus da Universidade no centro histórico, valendo-se dos antigos sobrados, foi, na primeira metade da década de 1980, catalisador de um projeto de campus urbano para a UFMA articulado pelo CEDATE - MEC e com o aval do BID (RODRIGUES, 2001, p.180-182). O plano de ocupação do centro histórico foi apresentado em uma publicação de 1984 (BRASIL, 1984, p.33 apud RODRIGUES, 2001, p.182), em que detalha as quadras e imóveis a serem utilizados. A proposta, entretanto não teve a aceitação de ampla maioria da Administração Superior, que naqueles anos havia incorporado a ideia de um campus desvinculado da cidade, resultando no seu arquivamento ${ }^{93}$

A área escolhida para construção do campus universitário foi a do Sítio Sá Viana, às margens do Rio Bacanga, doado pelo governo do Estado em 1958 à extinta Universidade Católica do Maranhão, conforme já mencionado, e que havia sido incorporado ao patrimônio da FUM em 1966 (ver figura 246). Com esse propósito, foi contratado o escritório do arquiteto Wit-Olaf Prochinik, para elaborar o plano diretor, os projetos de infraestrutura básica e das unidades a serem instaladas no futuro Campus.

Situado a sudoeste da cidade de São Luís e tendo como divisor natural a presença do Rio Bacanga que o separava da zona urbana consolidada (ver figura 247), o Sítio Sá Viana, com área de 271 ha, caracterizava-se por ser uma região desprovida de infraestrutura. Apresentava o seguinte meio físico:

1. Topografia acidentada com níveis que variavam de $8 \mathrm{~m}$ a $34 \mathrm{~m}$ e existência de zonas alagáveis ocasionadas pela presença do Rio Jaburu, afluente do Rio Bacanga, cuja nascente se dava nos limites internos da gleba.

2. Solo com boas condições de trabalhabilidade, constituído nas camadas superiores de areia fina, pedregulho e areia muito compacta. Sondagens realizadas até a profundidade de $7 \mathrm{~m}$ indicaram a ausência de rochas e lençol freático.

3. Vegetação constituída pela presença de plantas nativas (umbamba, babaçu e pati) além de campos de pastagem.

4. Clima quente e úmido, com umidade relativa variável de $76 \%$ a $79 \%$ no período de menor incidência de chuvas (agosto a dezembro) e temperaturas médias máximas de $30^{\circ} \mathrm{C}$ a $31^{\circ} \mathrm{C}$ e médias mínimas de $22^{\circ} \mathrm{C}$ a $24^{\circ} \mathrm{C}$.

5. Ventos dominantes de nordeste.

\footnotetext{
93 Sobre esse assunto recomendamos a leitura da entrevista realizada por Luis Augusto Fernandes Rodrigues com o arquiteto Tancredo Maia Filho que participou da proposta (ver RODRIGUES, 2001, p.180-182).
} 
Figura 246: UFMA - Planta do Sitio Sá Viana.

Śá Viinnam posteriormente a gleba da UFMA. O terreno está situado à margem esquerda da estrada que liga 0 centro ao Ponto de llaqui - BR 755 e a margen esquerda do Rio Bacanga. A a rea total da UFMA alterados, em decorréncia de invasōes por comunidades carentes.
(Fonte: Acervo Prefietura do Campus)

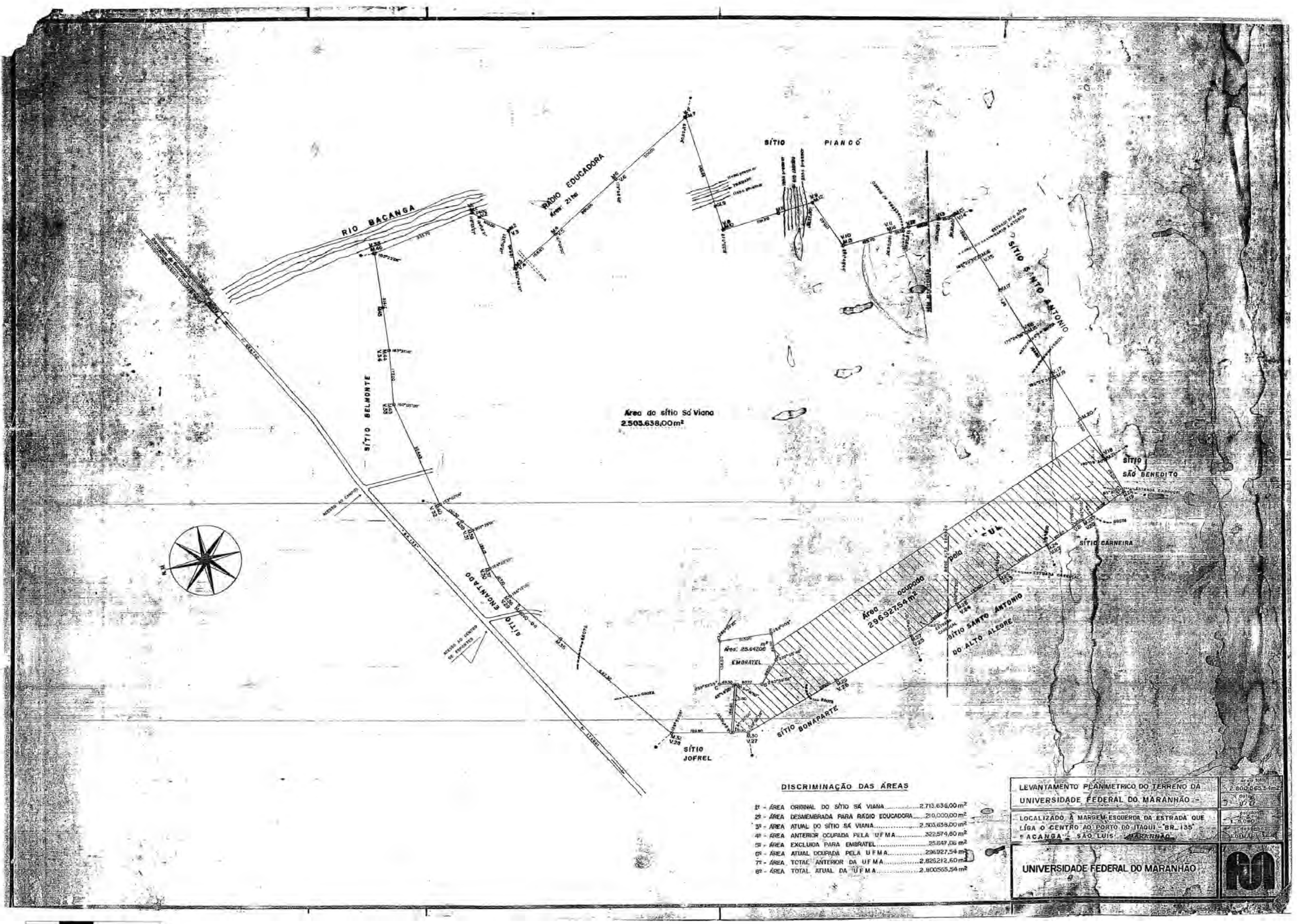




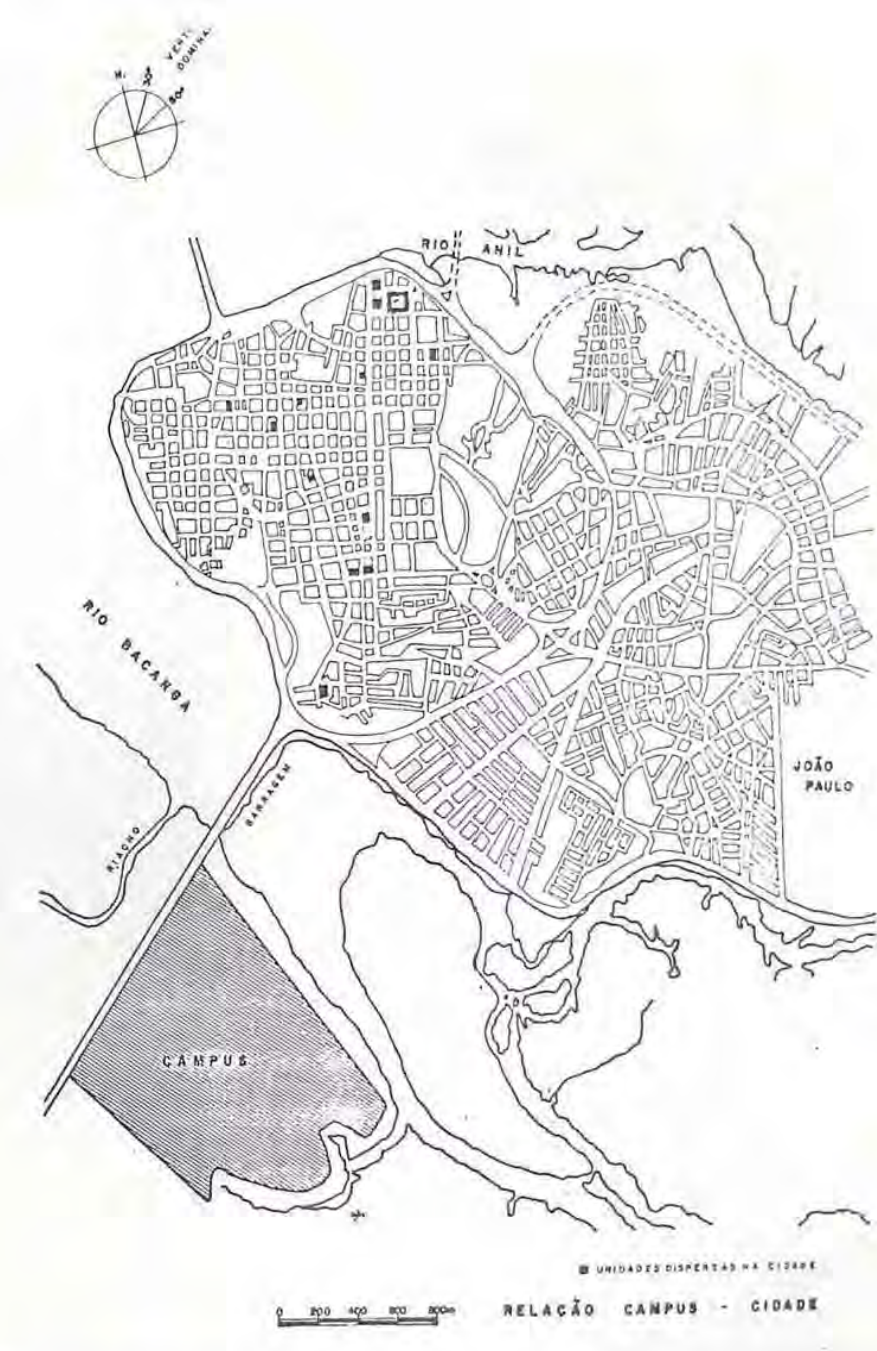

Figura 247: UFMA - Mapa da relação campus x cidade. (Fonte: LUCINI, [1980?], n.p.).

A efetivação da Universidade na gleba do Sítio Sá Viana foi favorecida pela implantação da barragem do Rio Bacanga no sistema viário urbano da cidade, na segunda metade da década de 1960, que efetivou o eixo viário São Francisco - Bacanga - Itaqui, possibilitando a ligação da Universidade com o centro urbano, uma distância de aproximadamente de $5 \mathrm{~km}$ (ver figuras 248 e 249). A localização às margens do lago artificial criado pela barragem deu origem ao nome de Campus do Bacanga.

O estudo realizado pela FUM (1968?) visando, dentre outras questões, subsidiar dados técnicos para a construção do campus justifica que a opção pelo Sítio Sá Viana se deu, dentre outros, pelo equacionamento do seu acesso com a construção da barragem, pela alternativa de uso imediato, já que pertencia ao patrimônio da Fundação, pela possiblidade de futuras expansões (indicava a área total da gleba com $1.411 .500 \mathrm{~m}^{2}$ ) e pela localização em sítio livre de perturbações estranhas como ferrovias, aeroporto, zonas industriais, favelas, etc. (FUM, 1968?). Nesse último fator há, entretanto, uma contradição com o 
processo de ocupação que vinha se dando pelo projeto de expansão urbana da cidade de São Luís promovido pelo governo do Estado, o qual incrementava a transformação daquela região em zona industrial. De toda forma, a ideia de um território periférico no modelo de campus estava assimilado na cultura universitária daquele período.

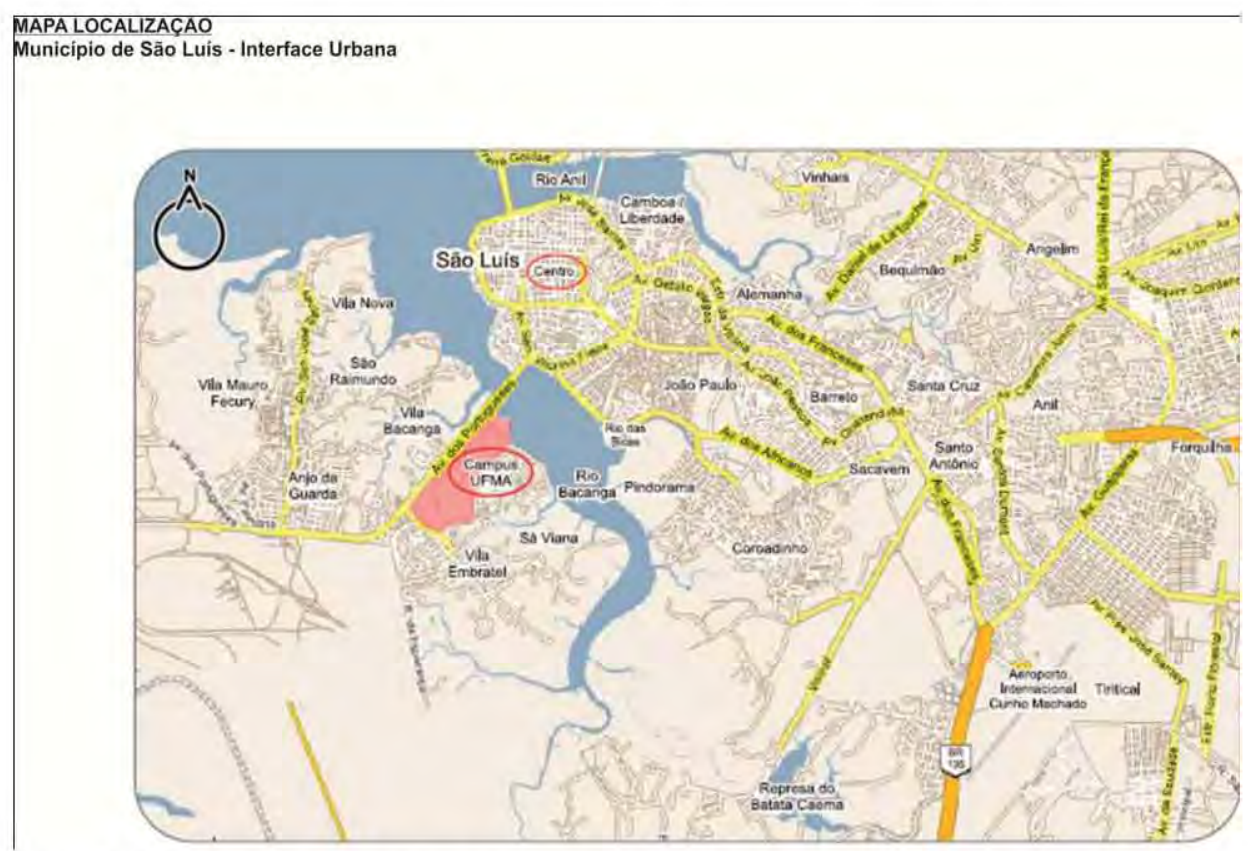

Figura 248: UFMA - Localização do Campus I - Bacanga.

A construção da Barragem do Bacanga possibilitou o acesso direto do Campus ao centro urbano. Sua localização às margens do lago artificial criado pela barragem deu origem ao nome de Campus do Bacanga.

(Fonte: Acervo da Prefeitura do Campus)

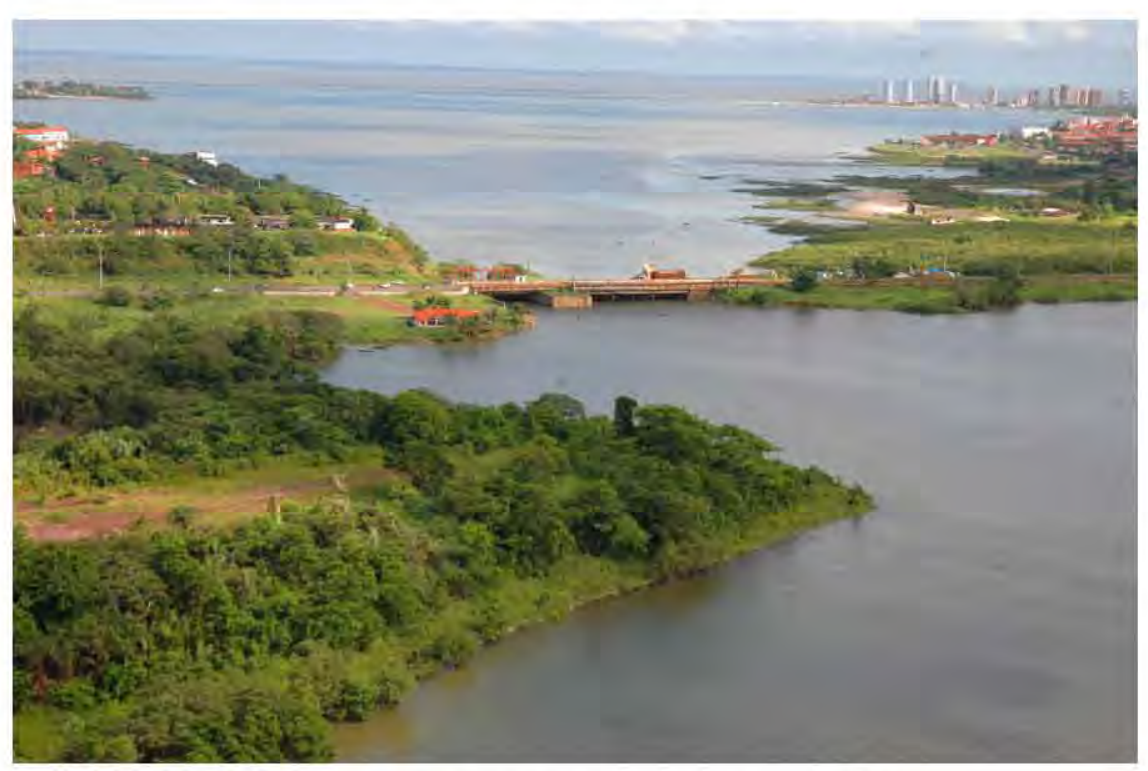

Figura 249: UFMA - Vista da Barragem do Bacanga (2008).

No sentido a direita faz ligação com a cidade e a esquerda faz ligação com o Campus da UFMA. As águas represadas do Rio Bacanga criaram o lago que margeia o Campus (à esquerda).

(Fonte: Acervo Prefeitura do Campus) 


\section{- Campus do Bacanga: a inserção no Plano Maranhão Novo}

Publicações de autores diversos (FONSECA NETO, 2002; LUZ, 2004; PEREIRA, 2005) criam evidências de que a execução do Campus naquela área foi impulsionada pelos grandes projetos empreendidos pelo governo José Sarney (1966/1970), com medidas políticas e econômicas de modernização ${ }^{94}$, que deram bases ao plano conhecido como "Maranhão Novo". Dentre eles, a área de expansão urbano-industrial hoje compreendida pelo eixo Itaqui/Bacanga foi eleita como um espaço estratégico para o processo de atualização. Estavam inclusos projetos industriais, a construção do Porto de Itaqui e de conjuntos habitacionais que contornariam aquela região, fornecendo a mão de obra requerida pelas indústrias que ali iriam se implantar. Sobre tal proposta, Luz (2004, p.27) destaca a Mensagem de Governo enviada à Assembleia Legislativa em 1968 na parte que trata de urbanismo:

Na Capital desenvolve-se um Plano Urbanístico que inclui o Distrito Industrial do Itaqui e área contígua destinada à habitação, estação rodoviária e ferroviária do Itaqui, e abertura de novas vias de circulação de tráfego e pavimentação de logradouros públicos. (Mensagem de Governo de 1968).

Para dar cabo de tal intento, o governo optou por fazer um acesso direto ao Porto de Itaqui, tendo sido prevista inicialmente a construção de uma ponte que ligaria a cidade ao porto, passando sobre o Rio Bacanga. Entretanto, por questões financeiras, o projeto da ponte foi substituído pela construção da barragem, já que possibilitava a sua execução com uma mão de obra menos qualificada e uma tecnologia mais simplificada ${ }^{95}$.

A construção do Campus do Bacanga no Sítio Sá Viana favorecia o projeto de expansão urbana tendo em vista sua localização ao longo da via de ligação da cidade com o Porto de Itaqui, a BR 135 (ver figuras 250 e 251). A Universidade entendia que a

[...] construção da ponte São Francisco sobre o rio Anil, a barragem do Bacanga e as obras de construção do Porto de Itaqui, situam o Campus da Universidade no centro de desenvolvimento urbano da própria cidade (FUM, 1971, 71).

\footnotetext{
${ }^{94}$ Josinaldo Santos da Luz em sua dissertação de mestrado "Lutas por Moradia e Expansão do Espaço Urbano" (2004) argumenta que, no início dos anos de 1960, as elites do Maranhão procuraram inserir o Estado nas mudanças que vinham ocorrendo no centro-sul do país e que diziam respeito à lógica do processo de modernização da economia, cujo traço principal estava baseado nos grandes projetos e no apoio irrestrito das elites locais e nacionais ao grande capital nacional e estrangeiro. No Maranhão, os programas governamentais dotaram a região de um parque exportador de produtos minero-siderúrgicos, com a finalidade de reverter a decadência econômica. Tais investimentos influenciaram de forma decisiva o processo de expansão urbana da capital e das cidades do interior do Estado. Em São Luis, foram executados projetos de renovação urbanística a exemplo do Aterro do Bacanga, a Ponte de São Francisco, a construção do Anel Viário e do Aeroporto Internacional do Tirirical. ${ }^{95}$ Sobre esse assunto ver a Dissertação de Mestrado de autoria de Hermes da Fonseca Neto (2002).
} 


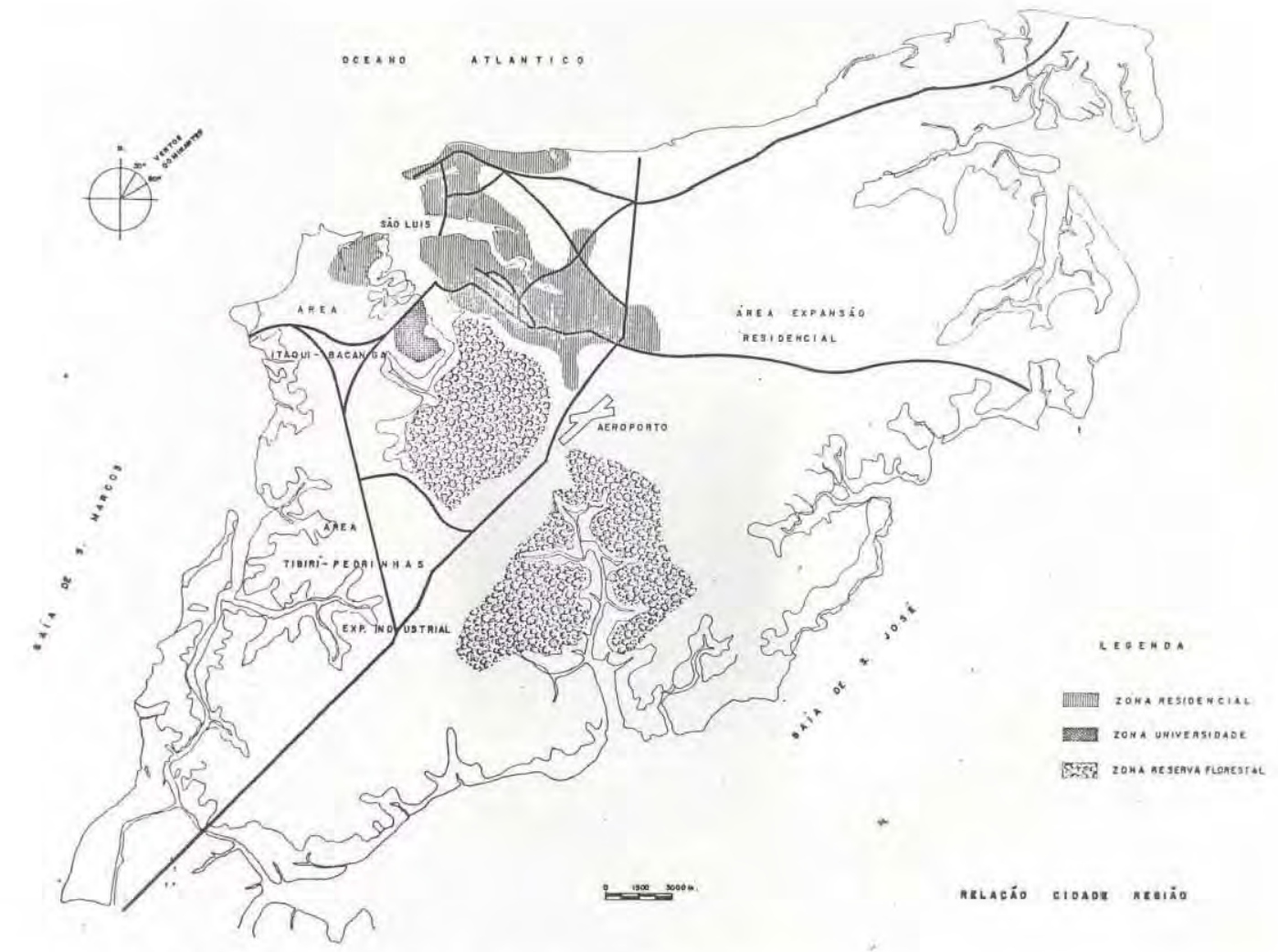

Figura 250 UFMA - Mapa da relação campus/região.

O Campus do Bacanga foi inserido no plano de expansão urbana do governo Sarney.

(Fonte: LUCINI, [1980?], n.p.)

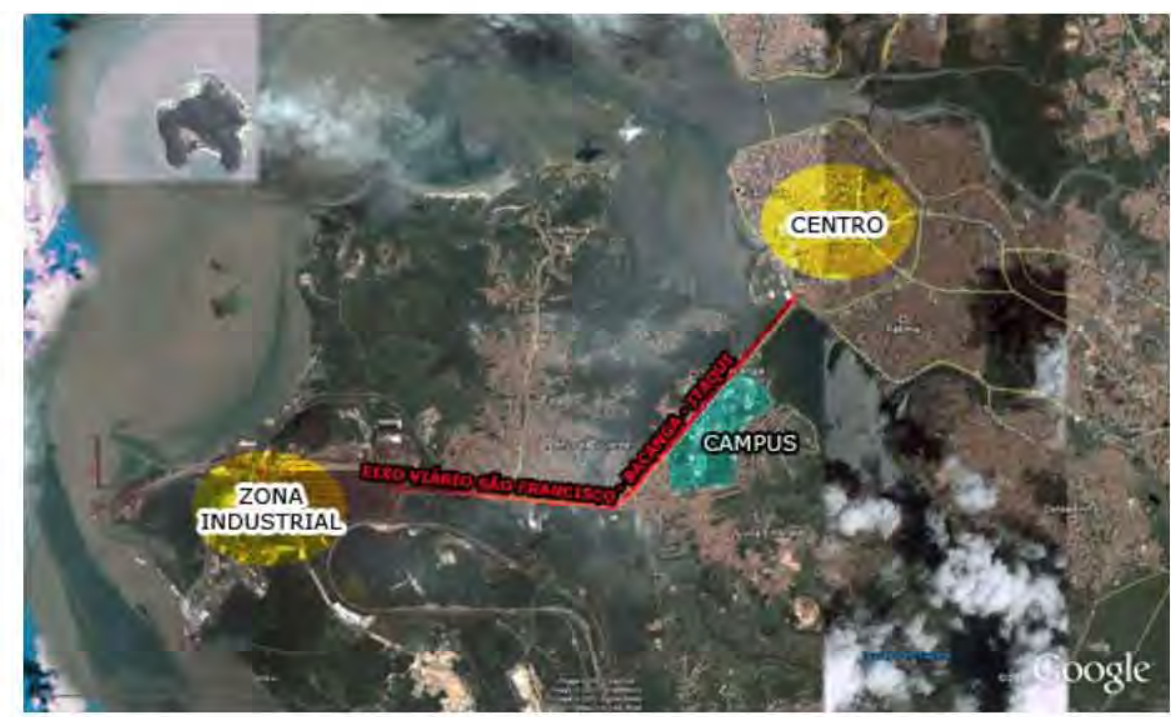

Figura 251: UFMA - Mapa do eixo viário São Francisco - Bacanga - Itaqui.

(Fonte: GOOGLE EARTH, grifo nosso. Acesso em 12 jan.2012)

Inserida nos planos do governo do Estado, a Universidade em parceria com a Secretaria de Viação e Obras Públicas do Município ${ }^{96}$ realizou os estudos de viabilidade, para implantação do Campus na área do Sítio Sá Viana, uma vez que ela se encontrava totalmente

${ }^{96}$ Os trabalhos contaram com a direção do prefeito Haroldo Lisboa Tavares. 
desurbanizada. Ressalte-se que a ausência de infraestrutura básica contrariava a orientação de Atcon (1970) na escolha do local para um futuro campus.

Nas palavras do reitor na época ${ }^{97}$, um grosso volume foi elaborado com os estudos de viabilidade, porque viviamos já, na era da racionalização e do planejamento (CARVALHO, 1972, grifo nosso apud TAJRA, 1985, p.33-34). Decerto as palavras racionalização e planejamento eram decorrência da difusão do conceito de "planejamento local integrado", que a nível urbano pretendia racionalizar os investimentos no desenvolvimento urbano e, a partir da identificação dos problemas intraurbanos, propor intervenções ditas modernizantes.

Não foi ao acaso que a FUM contratou os serviços do escritório de Prochnik. $O$ arquiteto, que já estava trabalhando, a convite do governo do Estado, na elaboração do Plano Diretor do Porto do Itaqui e no projeto do Aterro do Bacanga ${ }^{98}$, iniciou em julho de 1970 as primeiras obras do Campus no Sítio Sá Viana.

\section{- As primeiras obras do Campus: a produção do escritório Wit-Olaf ProchniK}

Prochnik $^{99}$ era profissional atuante na cidade de São Luís, tendo realizado projetos na área escolar - a Escola Normal (1967) e a Escola de Engenharia (1969) - e de planejamento urbano - Plano de Transportes e Desenvolvimento de São Luís (1975), Anel Rodoviário de Contorno de São Luís (1975), Terminal de Transporte Marítimo do Porto de Itaqui (1971) e o primeiro Plano Diretor da Cidade de São Luís em $1977^{100}$.

Era considerado um representante da arquitetura moderna brasileira. Trabalhou para o paisagista Burle Max e, segundo depoimento do arquiteto Frederico de Holanda, que fez parte da equipe no projeto para a Praça de Esporte (ver identificação na figura 272), desenhou

[...] do objeto à cidade. A modernidade dele [...] estava na mentalidade de que o arquiteto tinha de dar conta de tudo, de um simples objeto à

\footnotetext{
${ }^{97}$ Reitor cônego Ribamar Carvalho (1968/1972).

${ }^{98} \mathrm{O}$ arquiteto Wit-Olaf Prochnik elaborou para a cidade de São Luís projeto de um aterro ao lado do Centro Histórico, que saía do Jenipapeiro até encontrar o Terminal de Ônibus. Tratava-se de uma solução para problema semelhante ao do Aterro do Flamengo, projetado para resolver a passagem da praia do Flamengo, no Rio de Janeiro. Sobre o novo espaço, seriam desenhadas pistas de velocidade e jardins, completando o projeto de urbanização (PEREIRA, 2005, p.51).

${ }^{99}$ Wit-Olaf ProchniK Nasceu em Lvov (hoje Lviw), República da Ucrânia, em 5 de fevereiro de 1929, e veio para o Brasil ainda criança. Em 1951, formou-se em arquitetura na Faculdade Nacional de Arquitetura (FNA) - Universidade do Brasil, onde fez, também, o curso de urbanista no ano de 1955. Participou de associações técnicas, tais como o IAB/GB, IBAM e Urban Land Institute (Washington). Foi professor assistente da cadeira de arquitetura paisagistica do curso de urbanismo da FNA e assistente de urbanismo da Universidade da Califórnia - Berkeley. Prestou serviços ao escritório de Roberto Burle Marx (1940/1955), foi consultor de urbanismo do IBAM (1956/1974), chefe da seção de projetos do Departamento de Parques da Guanabara (1958), vice-presidente da Divisão de Planejamento do IAB (1964/1974). Faleceu em 1983. Teve projetos e obras publicados: Residência do Sr. Sebastião Diniz Freitas - Rio de Janeiro (05/1964), Parque e Pavilhão em Vila Nova Aldeota Fortaleza (07/1964), Residência em São Conrado - Rio de Janeiro (6/1965) e Lojas Rosemary - Rio de Janeiro (3/1966). Prochnik recebeu duas vezes o prêmio anual do IAB /GB: com o projeto da Galeria do Instituto Brasil-Estados Unidos, localizado no bairro de Copacabana - Rio de Janeiro (1963), e outro na categoria edifícios para fins diversos, com a obra do Monumento ao Operário do Paraná (1967).

${ }^{100}$ Sobre esse assunto recomendamos a leitura da Dissertação de Mestrado, 0 Estudo Preliminar de Wit-Olaf Prochnik:
} planejamento urbano e enunciados do Recife, de autoria de Pereira (2005). 
complexidade de uma nova cidade. Como se cada artefato fosse uma engrenagem, uma peça de maquinaria, na qual o arquiteto devesse transitar do todo para as partes, e das partes para o todo, com a mesma desenvoltura (HOLANDA apud PEREIRA, 2005, p.50).

Iniciou os trabalhos elaborando um levantamento preliminar do programa de necessidades destinado aos Institutos de Ciências Físicas e Naturais, de Ciências Humanas e da Casa do Estudante previstos na reestruturação delineada em 1969.

O estudo contou com um levantamento que identificava a distribuição físico-funcional das Unidades em operação (Reitoria, Biblioteca Central, Centro Acadêmico, Faculdades de Ciências Econômicas, de Ciências Médicas, de Direito, de Enfermagem, de Farmácia e Odontologia, de Filosofia e Instituto de Química) e que estavam distribuídas em imóveis situados no centro urbano. A publicação elaborada pela empresa Maximus Ltda. a partir dos trabalhos realizados pela SEPLAN (FUM, 1969b) indicava as áreas úteis disponiveis para o primeiro semestre de 1969 , com o intuito de servir de balizamento para o planejamento racional das futuras necessidades, evitando-se a duplicação de meios para fins idênticos, conforme objetivos da Reforma Universitária. Recomendava que antes de construir 0 Campus Universitário seria necessário elaborar um criterioso estudo de ocupação das salas de aula, em função dos turnos,

\section{- A tipologia flexível e integrada ao espaço rígido e disperso}

Em 1967, Prochnik elaborou projeto de acesso ao futuro Campus articulando a gleba ao eixo viário da BR-135 e situou os Institutos, Casa do Estudante e Hospital Universitário em área próxima ao citado eixo (ver figura 252).

Em vez da tradicional setorização rígida e dispersa, propõe para os Institutos uma tipologia que resulta do agrupamento das unidades articuladas entre si, conformando um corpo único de geometria irregular, que poderia expandir-se conforme as novas demandas, gerando um edifício com alto grau de flexibilidade e integrador das funções universitárias. O escritório chegou a desenvolver estudos em caráter preliminar para o conjunto dos Institutos conforme ilustrado nas figuras 253 e 254 e para a praça de esporte.

A concepção evidencia referências às ideias que vinham sendo debatidas internacionalmente nos anos 1960, quando as universidades, tornando-se instituições complexas precisavam encarar o desafio do crescimento e da mudança constantes. Exemplo emblemático foi o projeto do escritório Candilis, Josic \& Woods para a Universidade Livre de Berlim (1962). Nessa concepção, o projeto do campus deixa de ser visto como uma questão de planejamento e passa a ser um complexo problema de arquitetura (OLIVEIRA, 2005, p.126). 


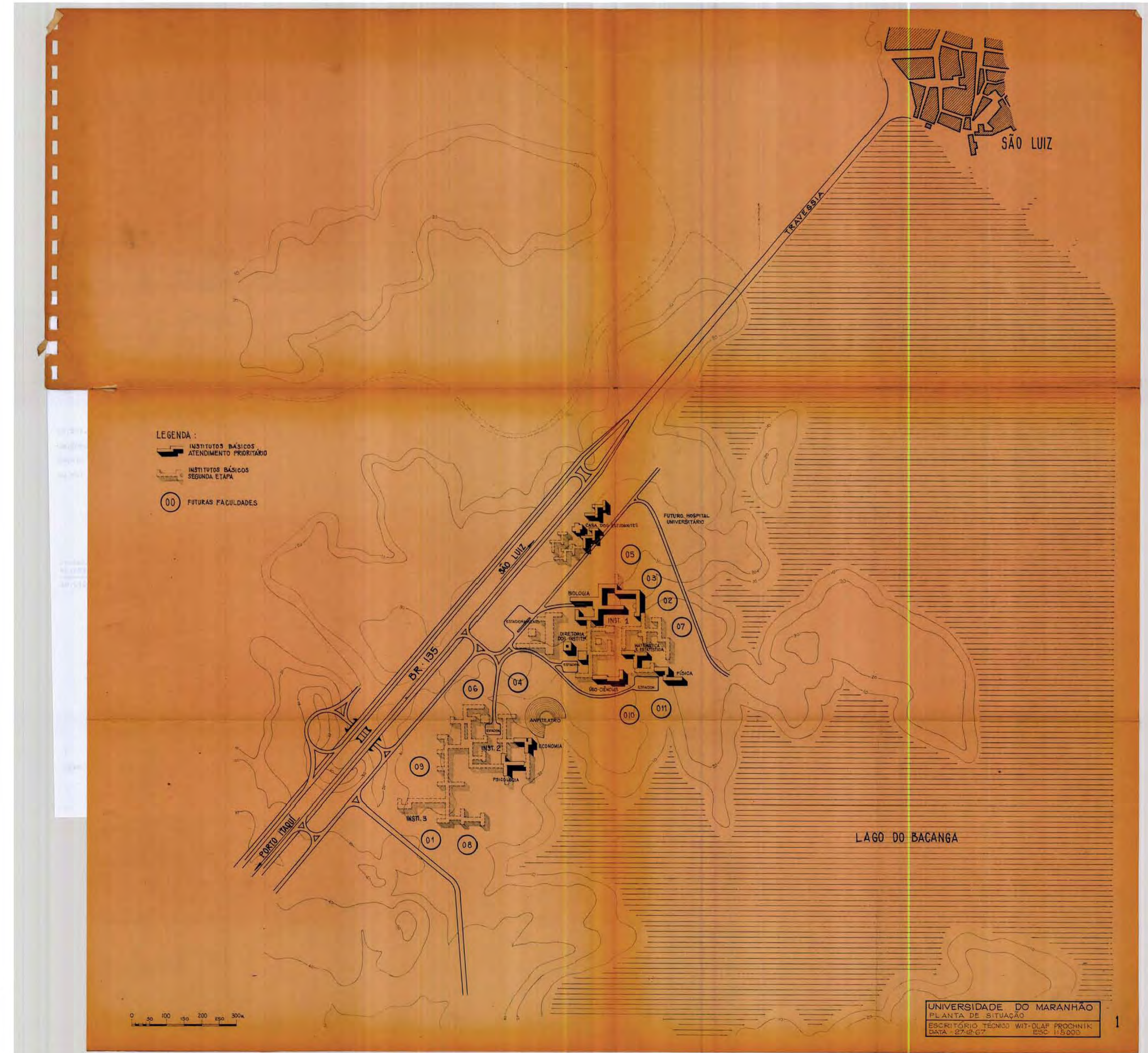


FOLHA VERSO DA FOLHA GRANDE - NÃO IMPRIMIR 


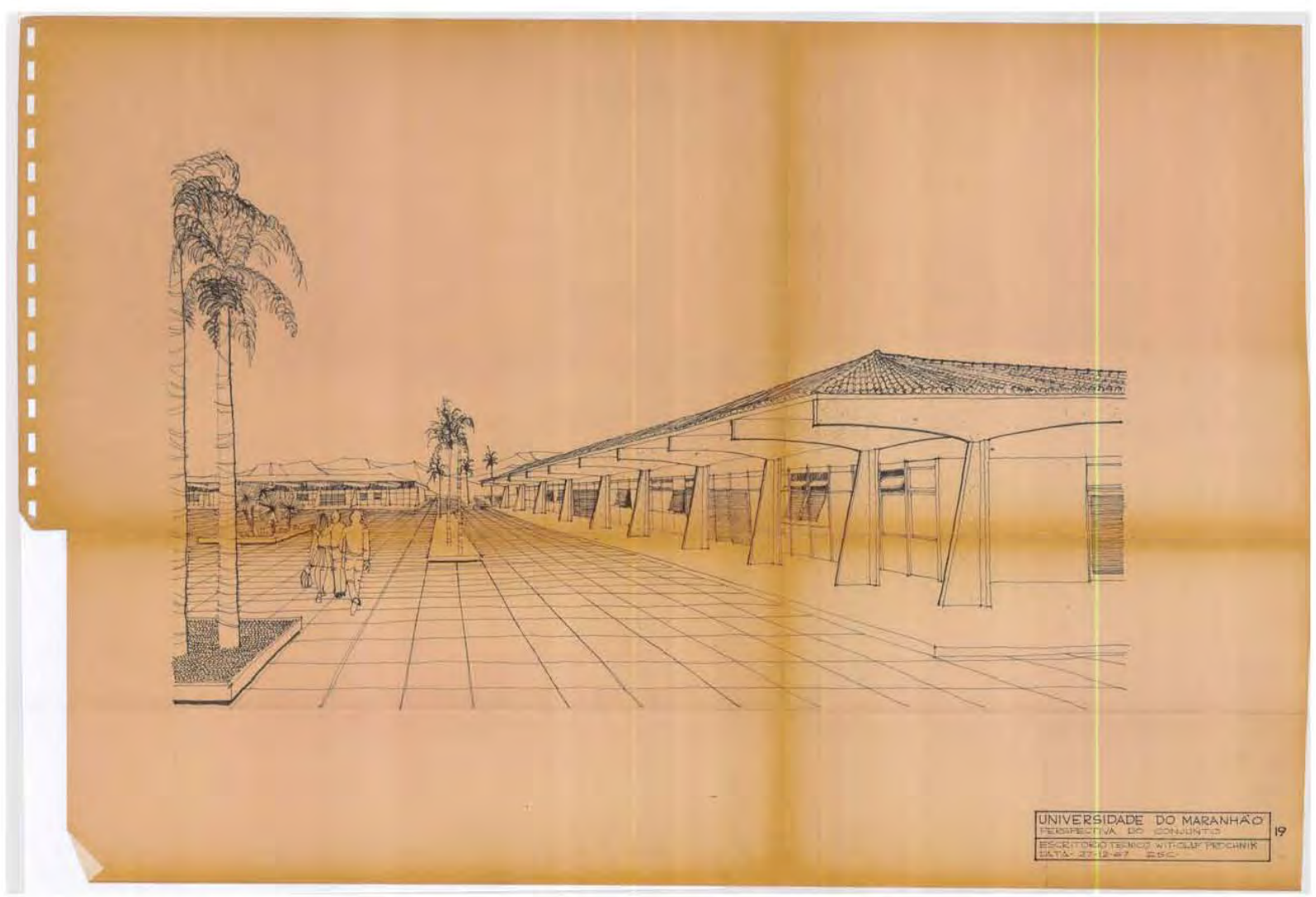

Figura 253: UFMA - Ilustração do conjunto arquitetônico para o Campus do Bacanga - 1967. (Fonte: Acervo pessoal da Família Prochnik)

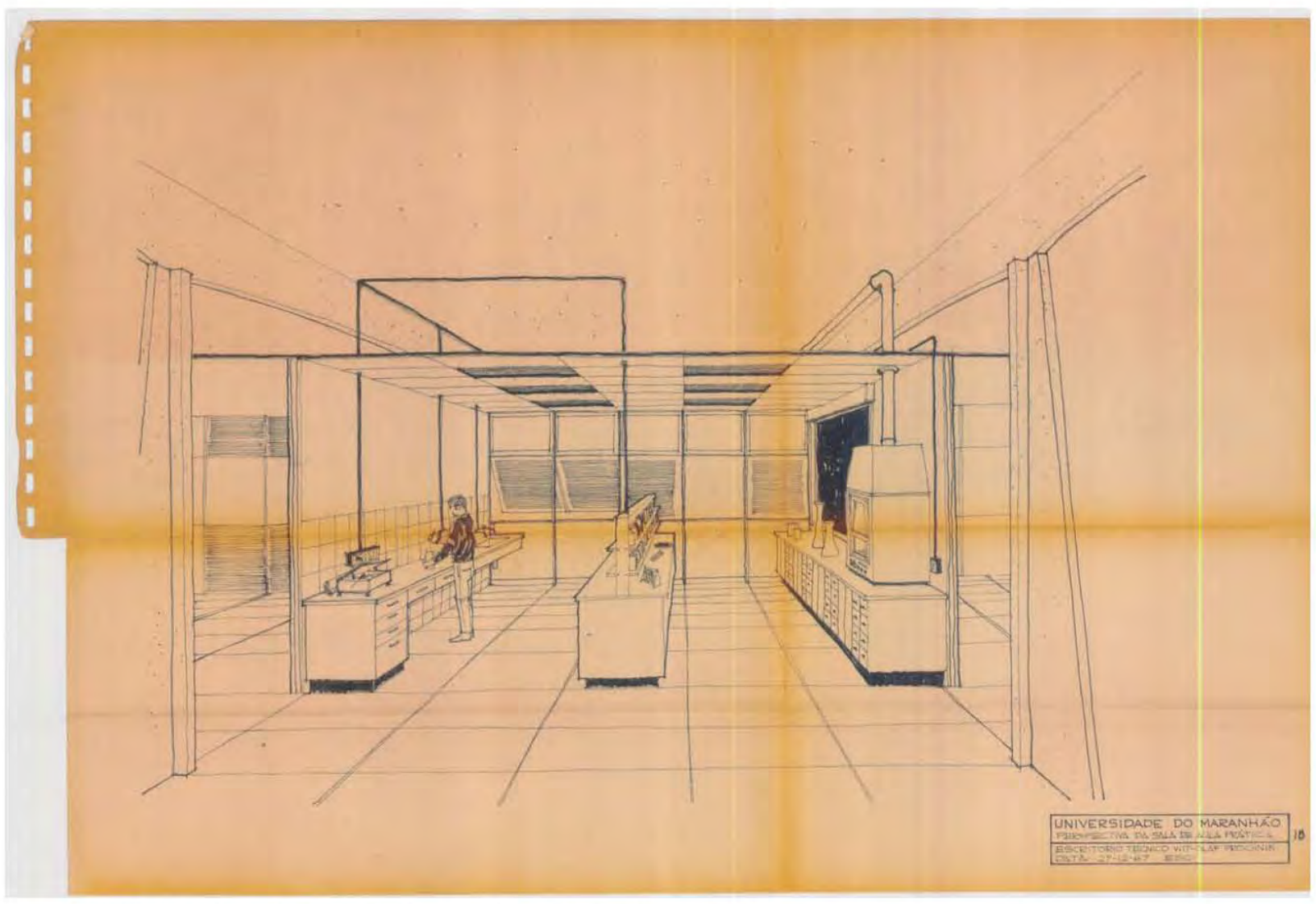

Figura 254: UFMA - llustração da sala de aula prática - 1967.

(Fonte: Acervo pessoal da Família Prochnik) 
Com a implantação da Reforma em 1970, Prochnik elaborou um novo plano de ocupação para o Campus. Distanciando-se da proposta anterior e aproximando-se da concepção que vinha sendo adotada para o campus na Reforma, o arquiteto propôs uma tipologia de organização espacial baseada no zoneamento de nove setores destinados às unidades previstas no planejamento da Universidade (ver quadro 8) esquematizado na figura 255.

Quadro8: UFMA - Zoneamento do Campus - Ano 1971.

(Fonte: UFMA, 1971, pag.72-76, edição nossa)

\begin{tabular}{c|l|c}
\hline \multicolumn{1}{|c}{ ZONEAMENTO DO CAMPUS UNIVERSITÁRIO } & Área \\
\hline Setor & \multicolumn{1}{c}{ Unidade Acadêmica } & \\
\hline I & $\begin{array}{l}\text { Instituto de Ciências Físicas e Naturais } \\
\text { Departamento de Física } \\
\text { Departamento de Matemática } \\
\text { Departamento de Química } \\
\text { - Laboratório Médico de Radioisótopos }\end{array}$ & $36.354 \mathrm{~m}^{2}$ \\
\hline II & Instituto Central de Filosofia & $22.032 \mathrm{~m}^{2}$ \\
\hline III & Instituto Central de Letras e Artes & $23.830 \mathrm{~m}^{2}$ \\
\hline IV & Instituto de Tecnologia & $43.034 \mathrm{~m}^{2}$ \\
\hline V & Área Biomédica & $53.502 \mathrm{~m}^{2}$ \\
\hline VI & Faculdade de Direito, Ciências Econômicas e Administração. & $27.054 \mathrm{~m}^{2}$ \\
\hline VII & Faculdades de Serviço Social e de Educação & $15.202 \mathrm{~m}^{2}$ \\
\hline VIII & Serviços Centrais & $34.700 \mathrm{~m}^{2}$ \\
\hline IX & Reserva & $14.100 \mathrm{~m}^{2}$ \\
\hline & \multicolumn{1}{c}{ Total: } & $265.406 \mathrm{~m}^{2}$ \\
\hline
\end{tabular}

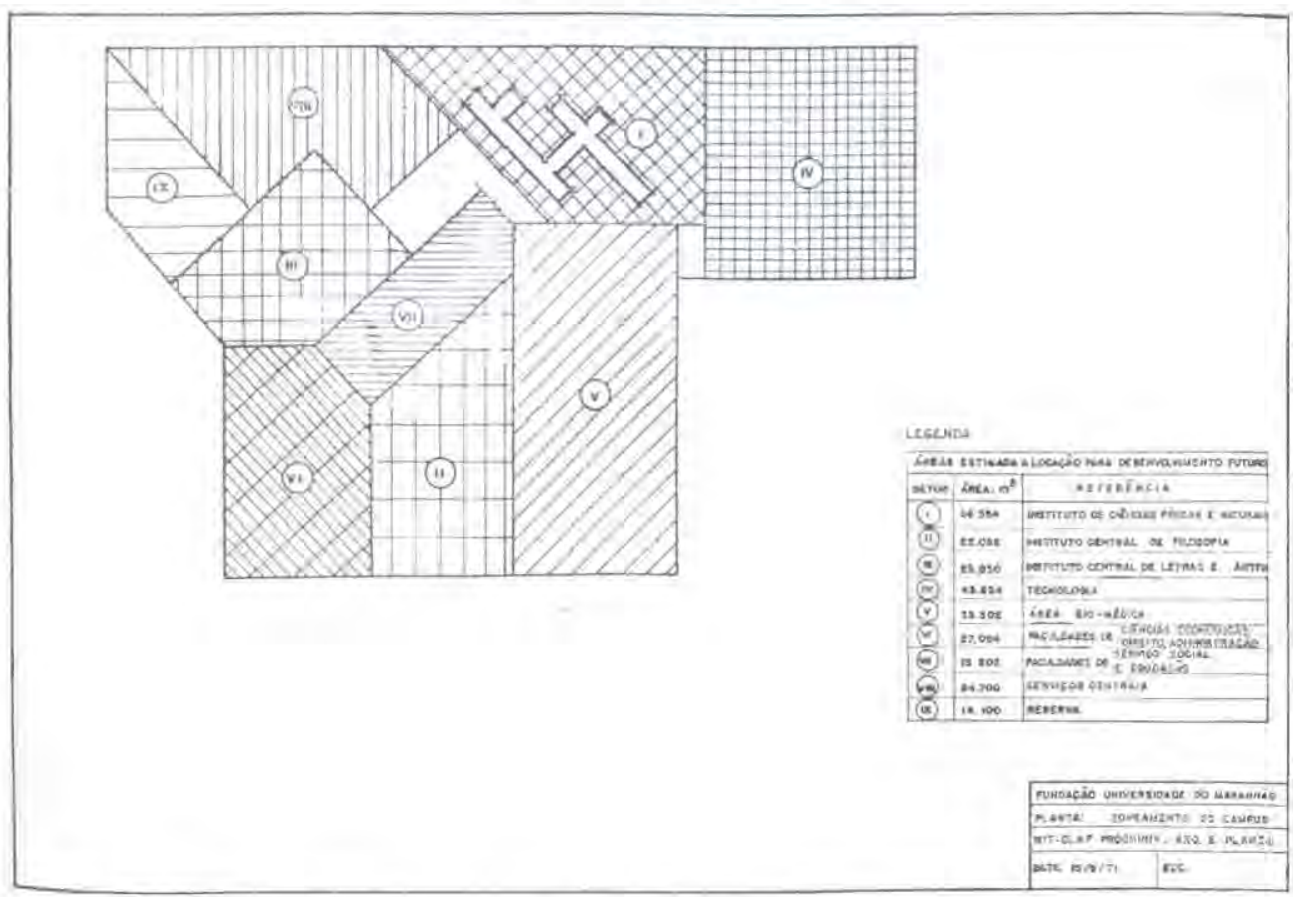

Figura 255: UFMA - Planta de zoneamento do Campus.

O estudo de ocupação se deu com base na gleba original do Sítio Sá Viana com área aproximada de 241 ha. O esquema ilustrativo com data de 1971 indicava a implantação do Instituto de Ciências Físicas e Naturais no Setor I, que já estava em construção.

(Fonte: FUM, [1971], p.73) 
A planta da figura 256 apresenta uma proposta mais precisa da ocupação, indicando a localização das unidades e o sistema viário básico. O urbanismo adotado seguia a fórmula do zoneamento funcional articulado pelo sistema viário hierarquizado.

O Campus estava envolvido por uma via de circulação periférica, assemelhando-se ao "anel protetor" recomendado por Atcon (1970), do qual derivavam as vias de caráter secundário que formam os bolsões de estacionamento, isolando o percurso dos pedestres. A morfologia de ocupação evidenciava a orientação de conformar uma área acadêmica única isolada pelas vias de circulação.

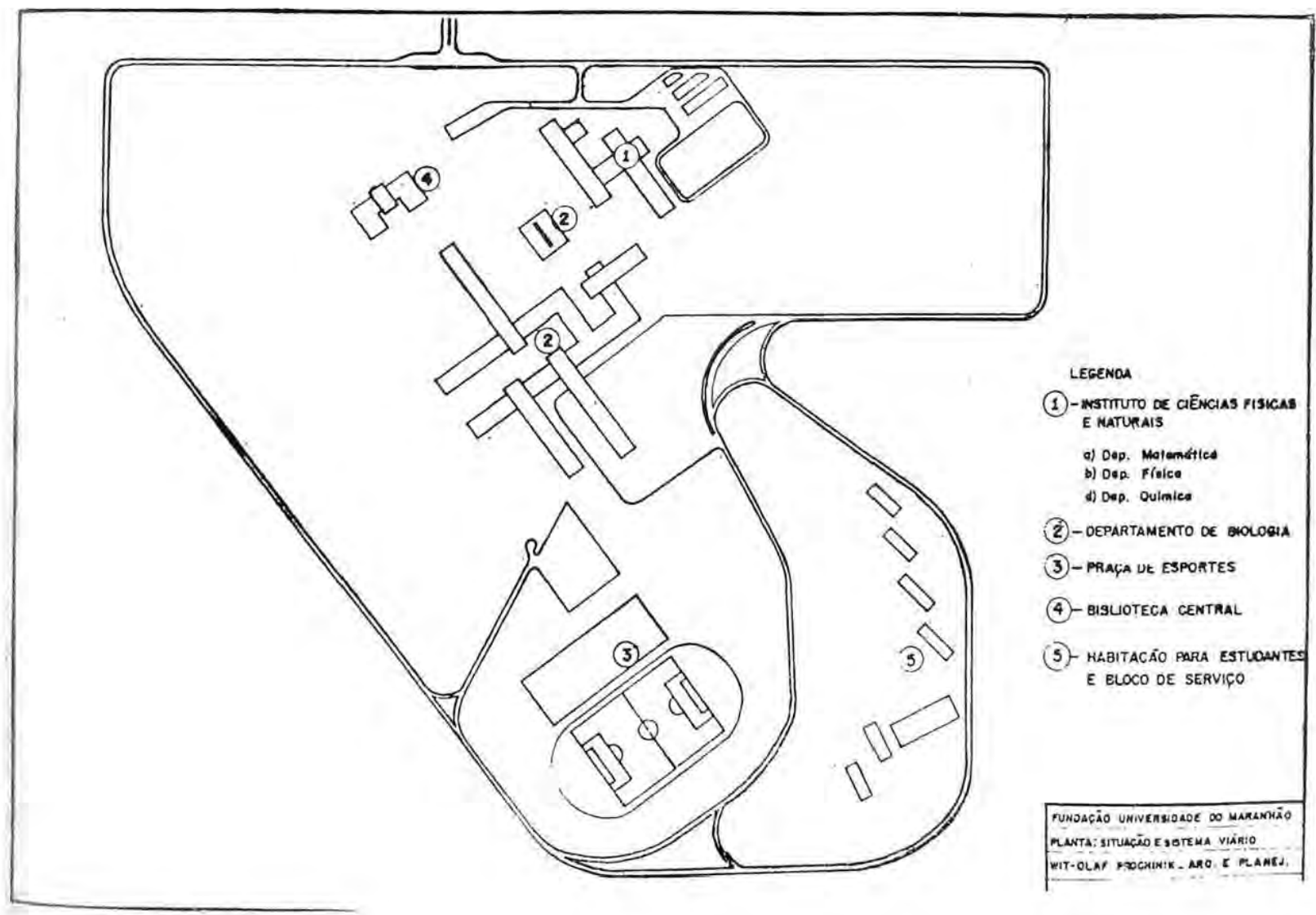

Figura 256: UFMA - Planta de situação das unidades e sistema viário do Campus. (Fonte: FUM, [1971], p.73)

A proposta mais detalhada nas plantas das figuras 257 e 258 indica uma zona de Serviços Centrais composto pela Reitoria, Biblioteca e Editora, em torno da qual irradiam os núcleos acadêmicos. Em área periférica ficavam os locais destinados ao alojamento de estudantes e centro de esportes, cuja proximidade propiciaria relações de convivência e de integração, além do que, conforme indicado no Manual de Atcon, não criariam perturbações aos outros setores. 


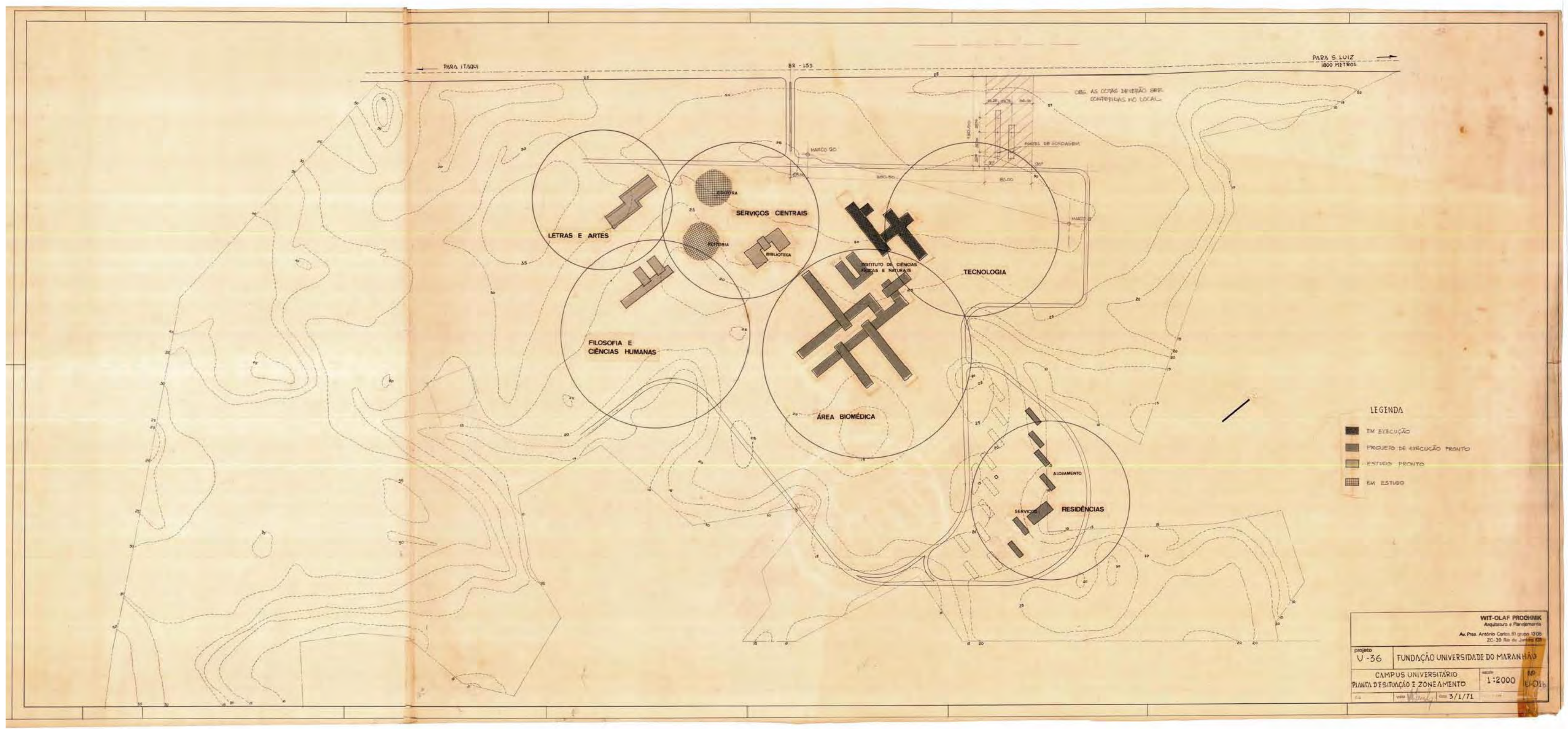

Figura 257: UFMA - Planta de situaçãa e zoneamento do Campus do Bacanga - 1971
Os setores acadêmicos locailizavam-se em torno da Reitoria e Biblioteca. 


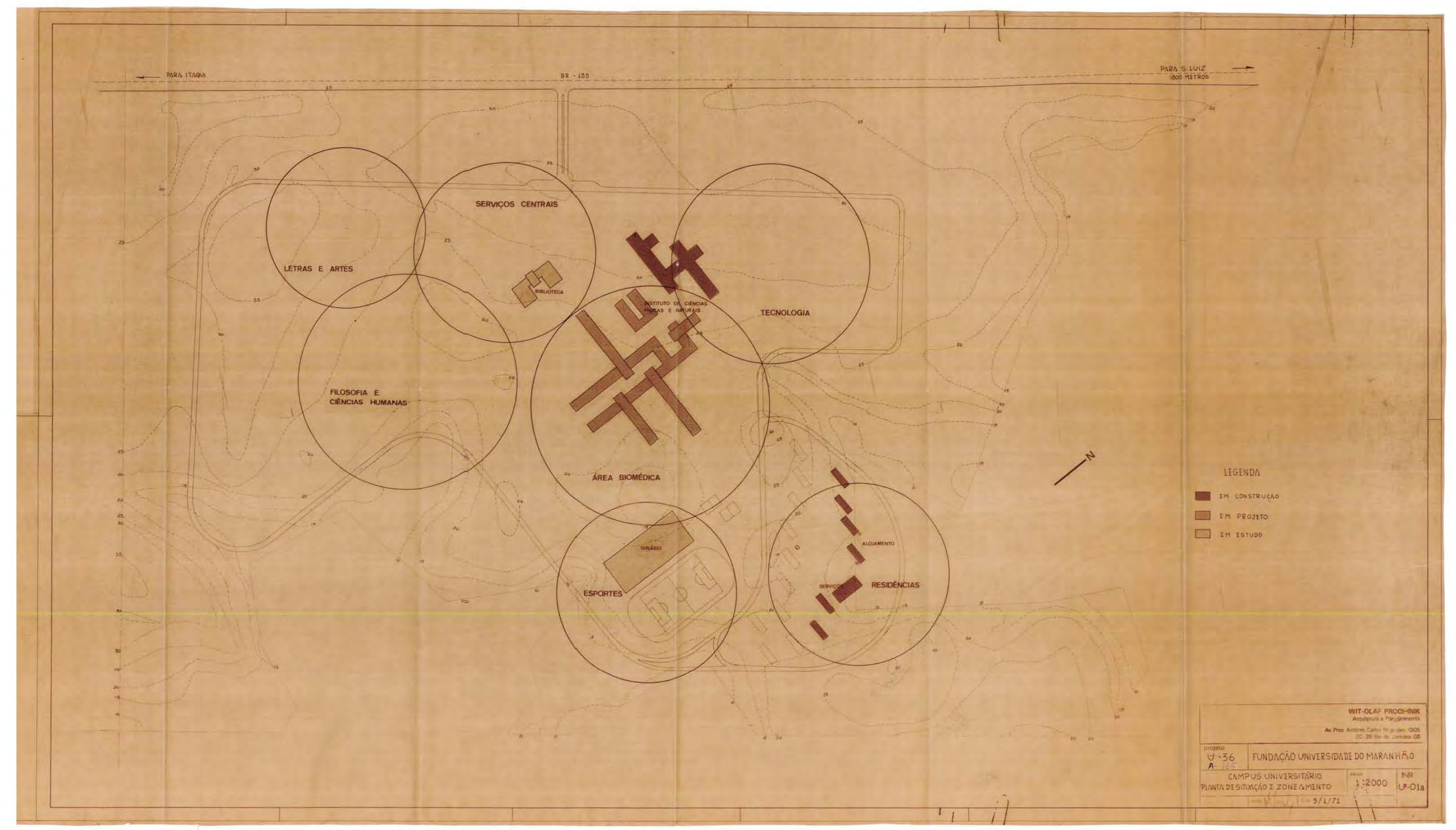

Figura 258: UFMA - Planta de situacãa e zoneamento do Campus do Bacanga - 1971. 
FOLHA VERSO DA FOLHA GRANDE - NÃO IMPRIMIR 
A locação das Unidades estava balizada pelas referências indicativas da trajetória solar naquela latitude próxima à linha do Equador $\left(2^{\circ} .33^{\prime} 00^{\prime \prime}\right.$ Sul) e do regime dos ventos dominantes de Nordeste. Com base nesses estudos o arquiteto estabeleceu que a orientação das edificações seria de 95 a 105 graus em relação ao Norte Verdadeiro (NM). A implantação resultou, entretanto, no distanciamento entre as unidades, evidenciando um possível isolamento entre elas.

A partir da definição das Unidades, foi estabelecido um programa de priorização das edificações. Foram adotados como critério os estudos que situavam a Universidade no desenvolvimento do Estado, a identificação dos pontos de estrangulamento nas áreas didáticas, a disponibilidade dos cursos em funcionamento no centro urbano da cidade e o estado de conservação dos sobrados coloniais que os abrigavam com ônus para reformas e adaptações.

O estudo resultou na seguinte ordem de prioridades: (1) Instituto de Ciências Físicas e Naturais (integrando os Departamentos de Física, Química, Matemática, Biologia e o Laboratório Médico de Radioisótopos), (2) Biblioteca Central, (3) Praça de Esportes, (4) Instituto de Tecnologia, (5) Faculdade de Educação, (6) Instituto de Letras e Artes, (7) Faculdade de Ciências Econômicas, (8) Faculdade de Serviço Social, (9) Faculdade de Administração e (10) Faculdade de Direito.

\section{- Instituto de Ciências Físicas e Naturais (ICFN)}

Com base no programa levantado nos primeiros estudos, Prochnik deu prosseguimento ao projeto do Instituto de Ciências Físicas e Naturais, que contemplava parte dos departamentos - Física, Matemática e Química - e com previsão de área total em torno de $4.000,00 \mathrm{~m}^{2}$.

Segundo Tajra (1985, p.34) pretendia-se atender a 540 alunos nos anfiteatros para as aulas teóricas, 144 alunos nos laboratórios para aulas práticas, perfazendo um total de 684 alunos por turno de aula, o que possibilitaria um aumento significativo de vagas no período de 1967 a 1971.

Implantado em cota de nível mais elevada, o arquiteto tira partido das condições topográficas, transformando sua presença em elemento de destaque na paisagem construída. Emoldurado por talude, o edifício é parte do conjunto urbanístico formado pela 
praça, que desempenha o papel orientador de acesso à entrada principal do Instituto (ver figura 259 ).

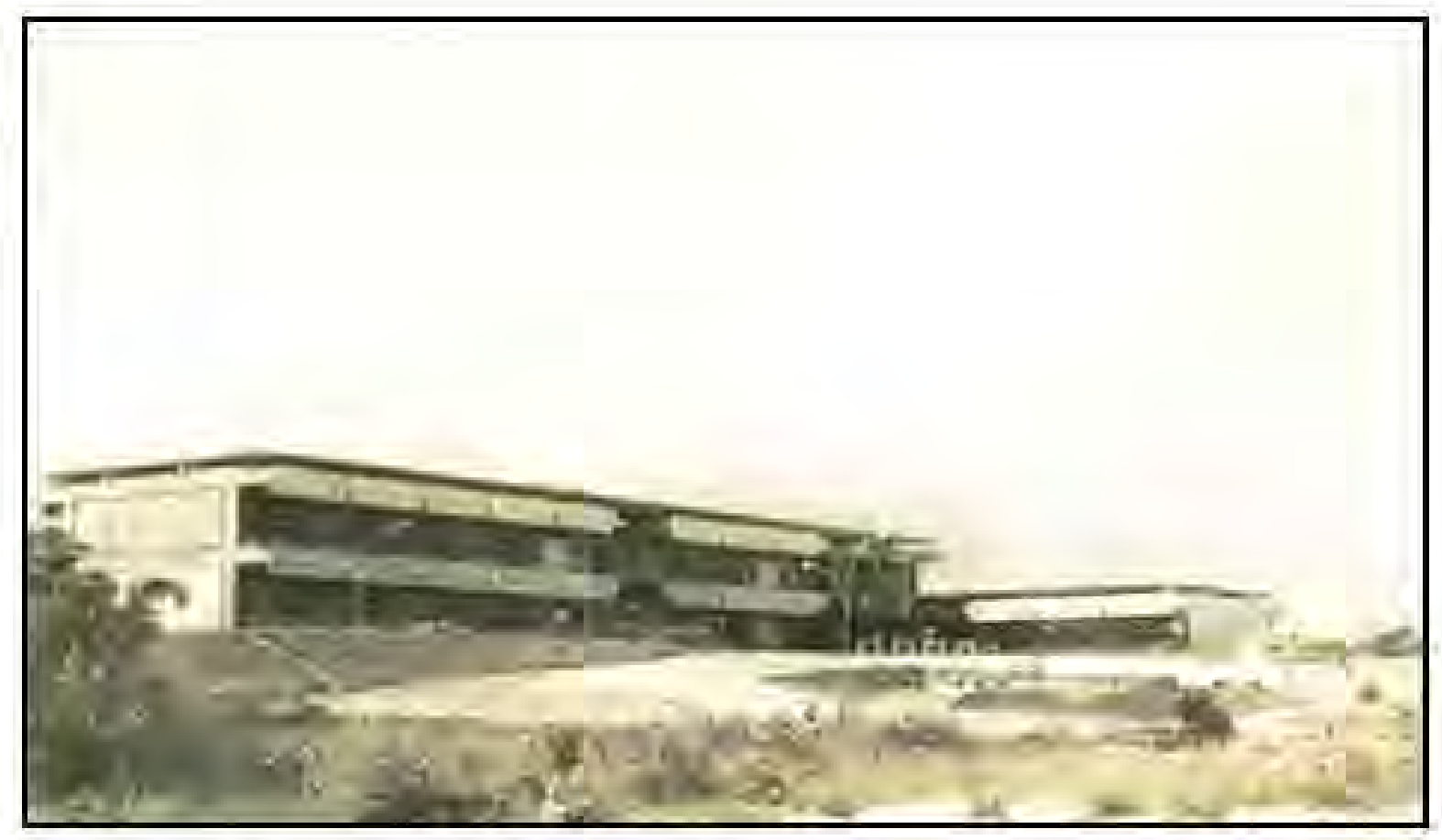

Figura 259: UFMA-Instituto de Ciências Fisicas e Naturais-1972.

A praça hierarquiza o espaço, destacando a fachada principal do conjunto. (Fonte: Aceno Preteitura do Campus)

A concepçẫo arquitetônica segue a filosofia de um organismo em constante crescimento, evidenciando a disposiçẫo de enfrentar o desafio da expansầo e das mudanças constantes. $\checkmark$ partido supổe modulaçẫo e padronizaçẫo.

Com essa diretric a planta liwre organiza o programa funcionalmente distribuido com base na malha madular de $1,25 \times 1,25 \mathrm{~m}$, configurando um desenho de geometria irregular que se expande emvárias direçốes (ver planta de arquitetura na figura 260 ).

A estrutura independente das vedaçỗes buscava um processo flexível de adaptaçẫo dos espaços e com esse propósito os ambientes passiveis de alteraçồes, como salas de aula, estavam divididos por divisórias móveis. A padronização dos elementos construtivos atendia aos imperativos de rapidez e bako custo da obra, atingindo o princípio da racionalização pretendida no projeto. 
Planta Pavimento Térreo

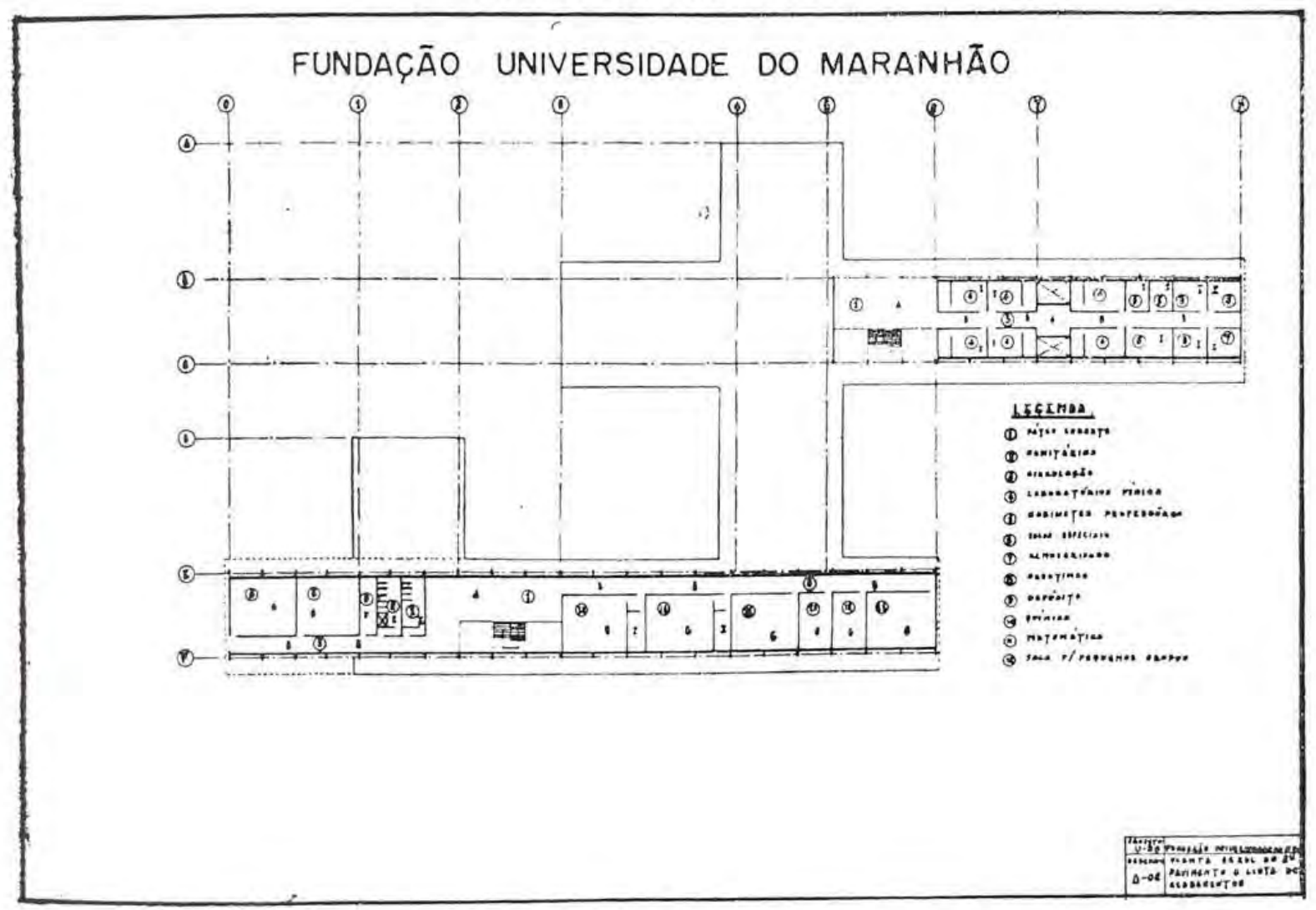

Planta Pavimento Superior

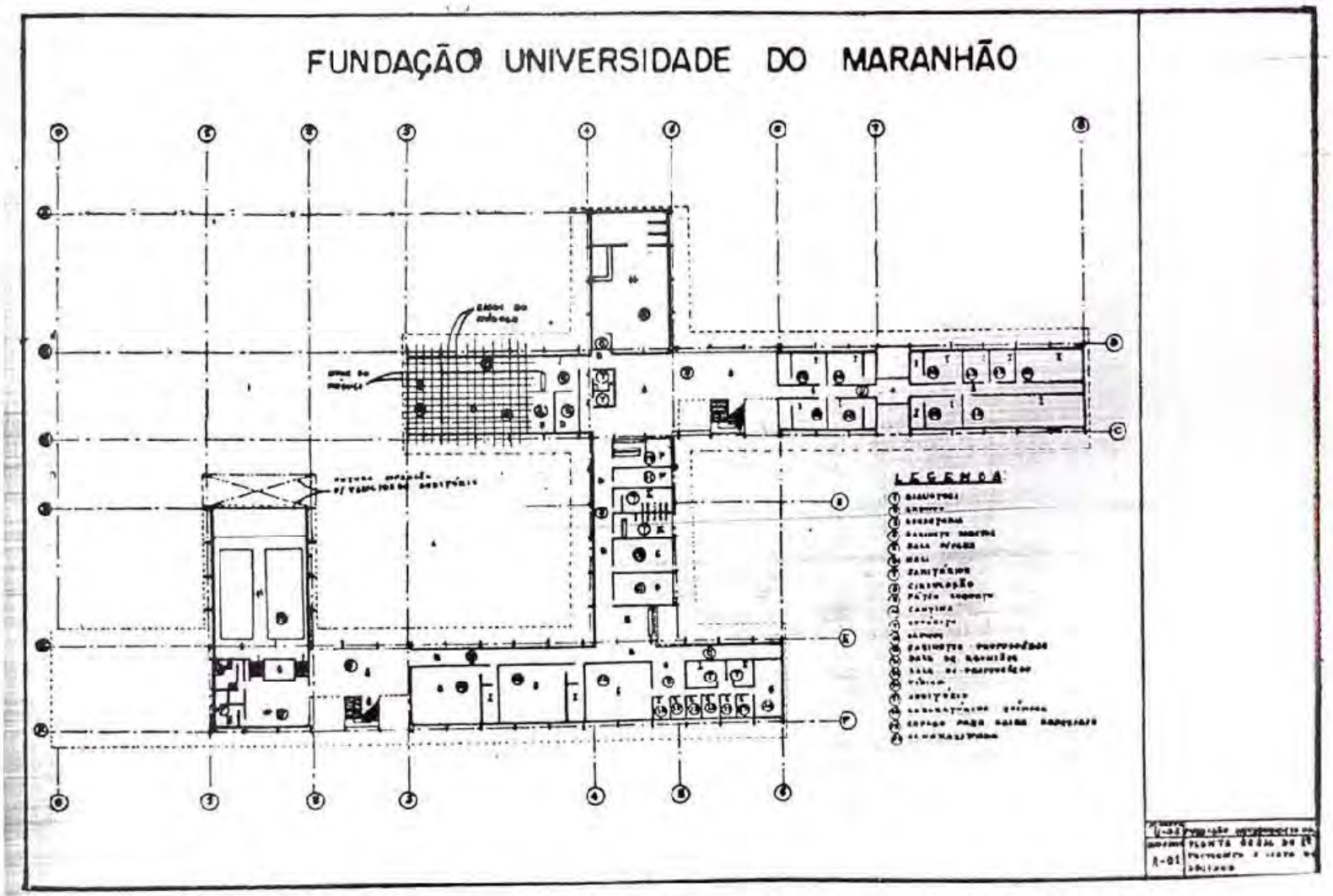

Figura 260: UFMA - Instituto de Ciências Físicas e Naturais - Projeto de Arquitetura. (Fonte: FUM, [1971], p.73) 
A forma arquitetônica resulta do conjunto volumétrico funcional conformado por blocos de um a dois pavimentos de geometria prismática e predominância horizontal, com ênfase na estrutura de concreto aparente. As fachadas norte e sul caracterizam-se pela composição do módulo-base estrutural a cada $5,00 \mathrm{~m}$, vencendo vãos transversais de $12,50 \mathrm{~m}$ que se projetam em balanço para fora do corpo do edifício, com extensão de $2,10 \mathrm{~m}$, tendo nas extremidades placas retangulares em concreto aparente que funcionam como elemento de proteção solar (ver figura 261).

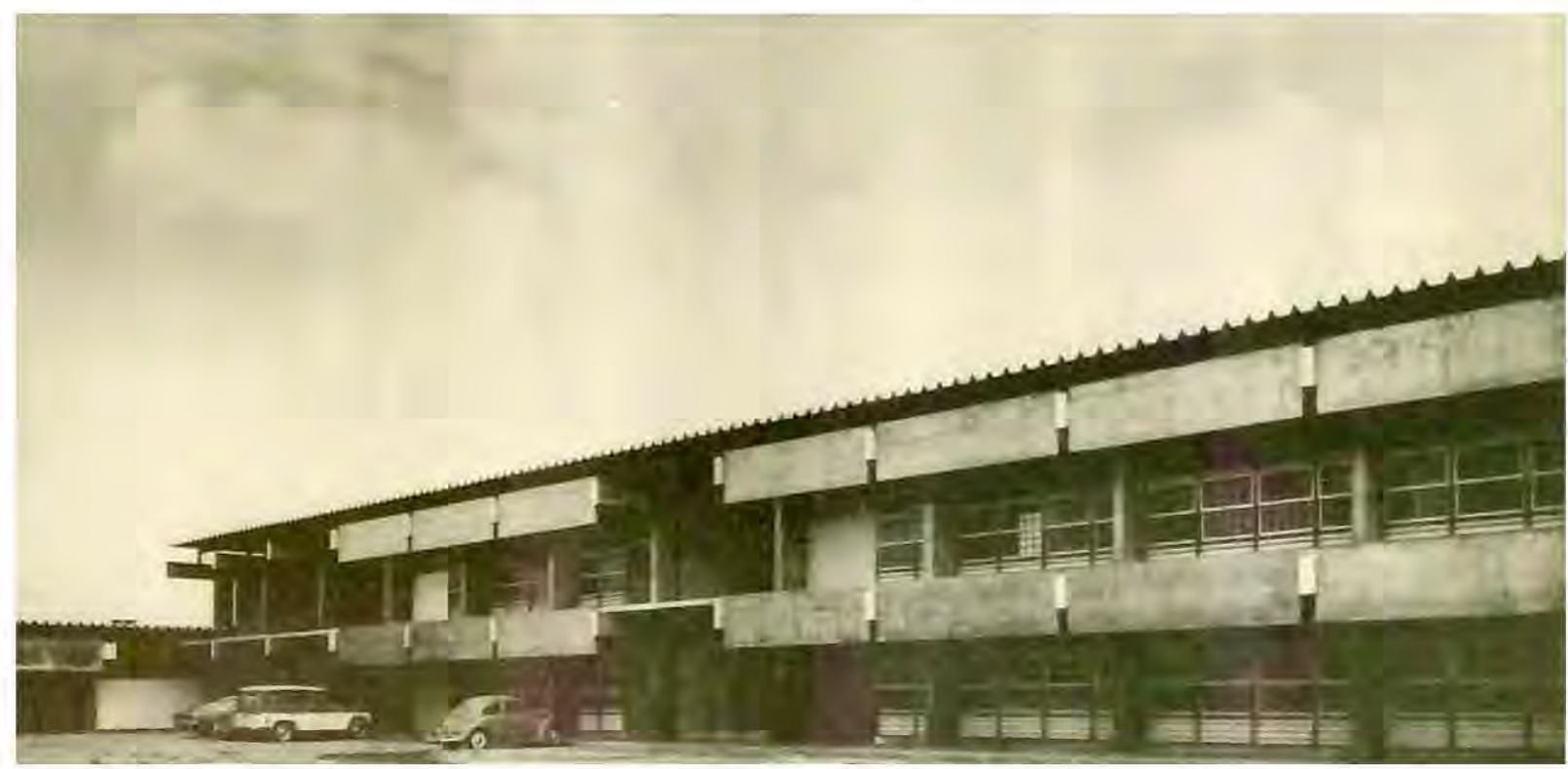

Figura 261: UFMA - Instituto de Ciências Físicas e Naturais - 1972.

Vista da fachada principal.

(Fonte: Acervo Pessoal da Família Prochnik)

Associadas à coberta em telha de amianto tipo Kalhetão 43 com beiral de $1,20 \mathrm{~m}$, conferem ao edifício uma arquitetura de característica despojada e de controle da escala humana sem, no entanto, eliminar o caráter de monumentalidade requerido pela representatividade da obra que desempenha a função de marco na inauguração do Campus.

Visando o conforto térmico no interior da edificação, são adotadas soluções de adequação aos condicionantes climáticos locais tais como: (1) implantação com o edifício alongado no eixo leste-oeste, de maneira que as maiores fachadas ficam orientadas para norte e sul, facilitando os ventos dominantes de nordeste atravessar a edificação, (2) uso de elementos vazados, tipo combogó, que possibilita a ventilação interna dos ambientes (3) coberta com a telha elevada da laje de forro, que permite a retirada de colchões de ar quente eliminando a transmissão do calor pela laje, (4) adoção do elemento de proteção solar que elimina a radiação solar direta nos ambientes (ver figuras 262 a 266). 


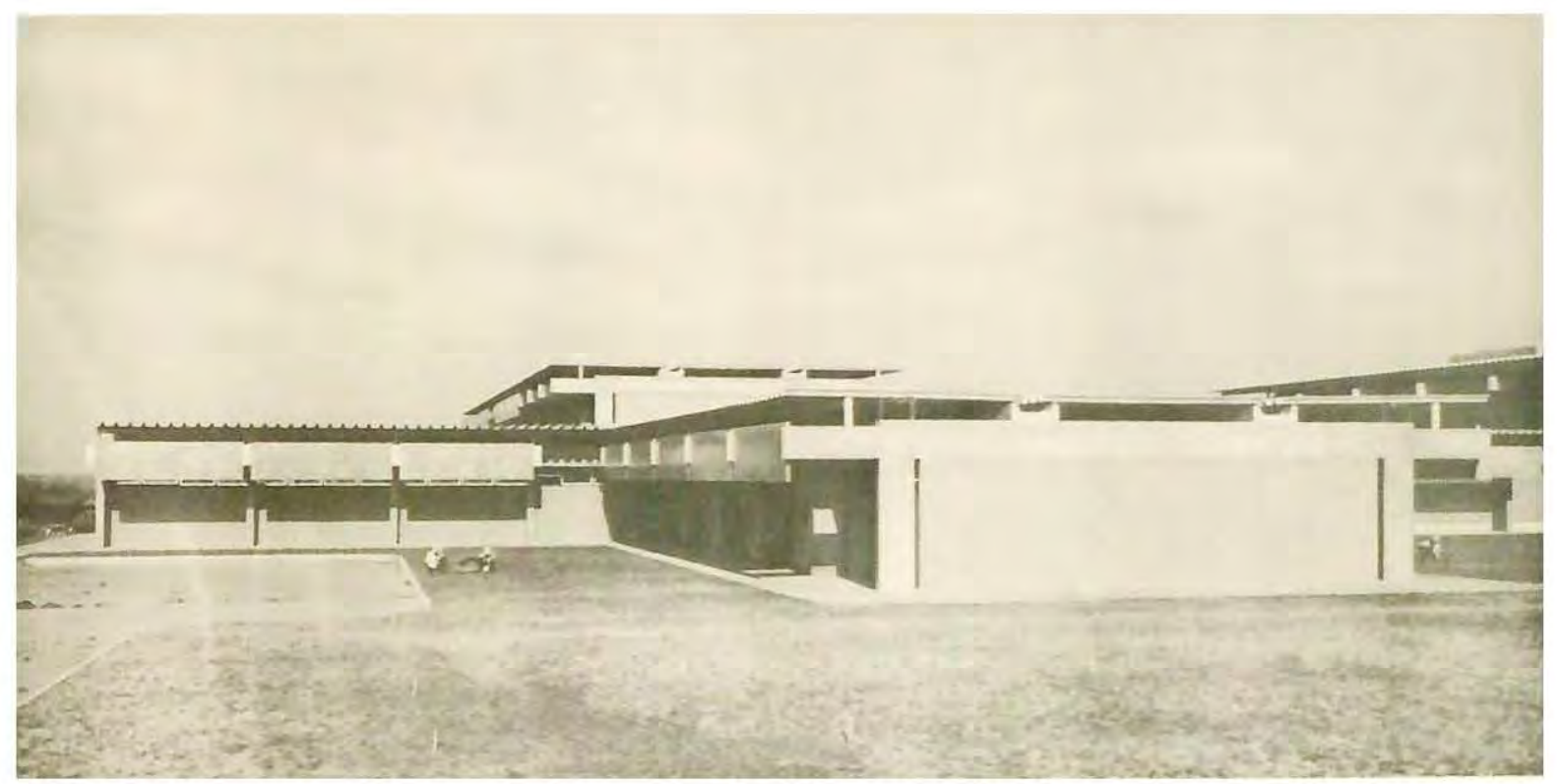

Figura 262: UFMA - Instituto de Ciências Físicas e Naturais - 1972.

Vista da Biblioteca e Secretaria.

A telha é elevada da laje para eliminar colchões de ar quente. As placas verticais em balanço proporcionam sombreamento às fachadas.

(Fonte: Acervo Pessoal da Família Prochnik)

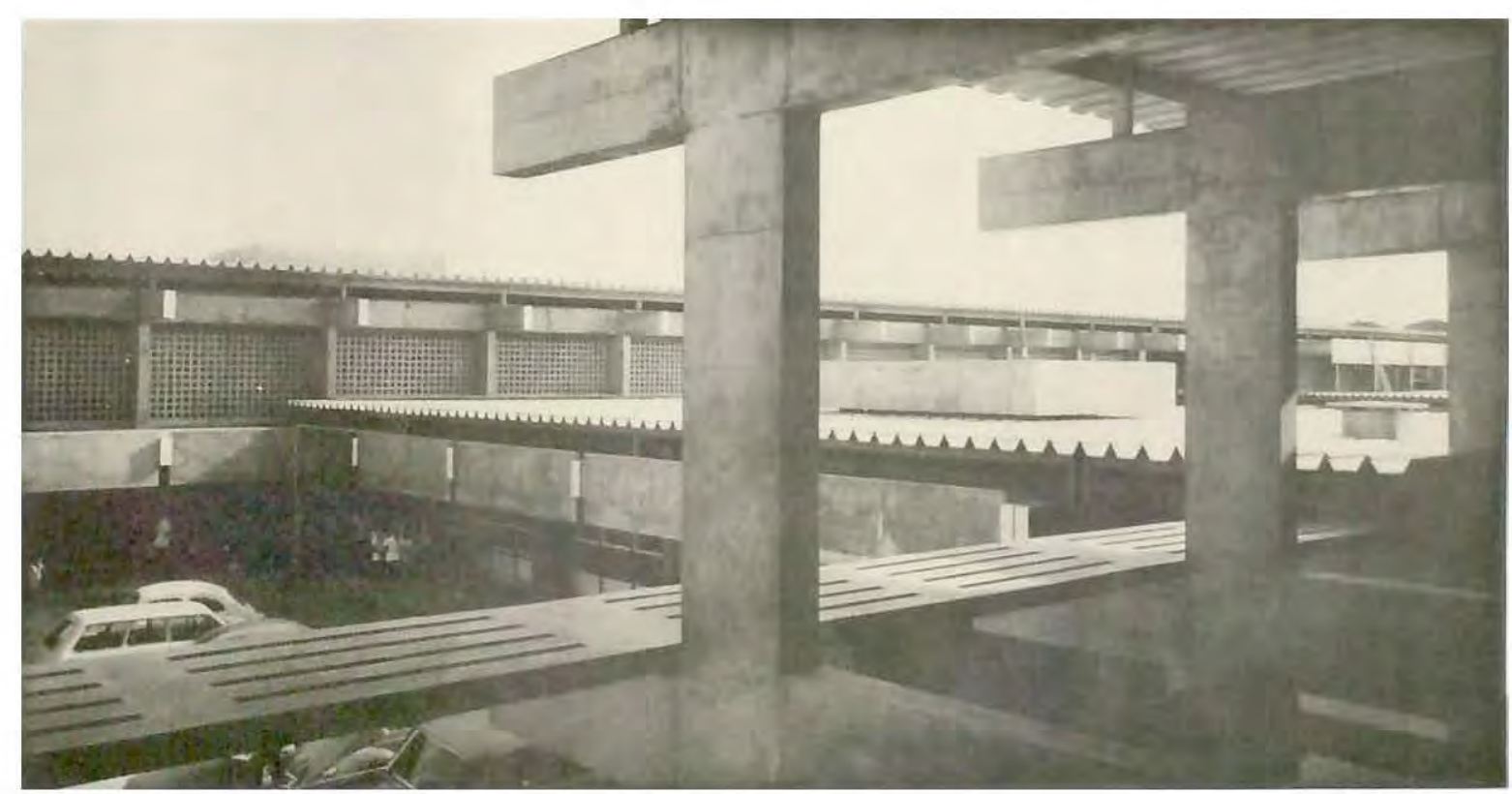

Figura 263: UFMA - Instituto de Ciências Físicas e Naturais - 1972.

Detalhe da estrutura de concreto aparente com vedação de combogó.

(Fonte: Acervo Pessoal da Família Prochnik) 


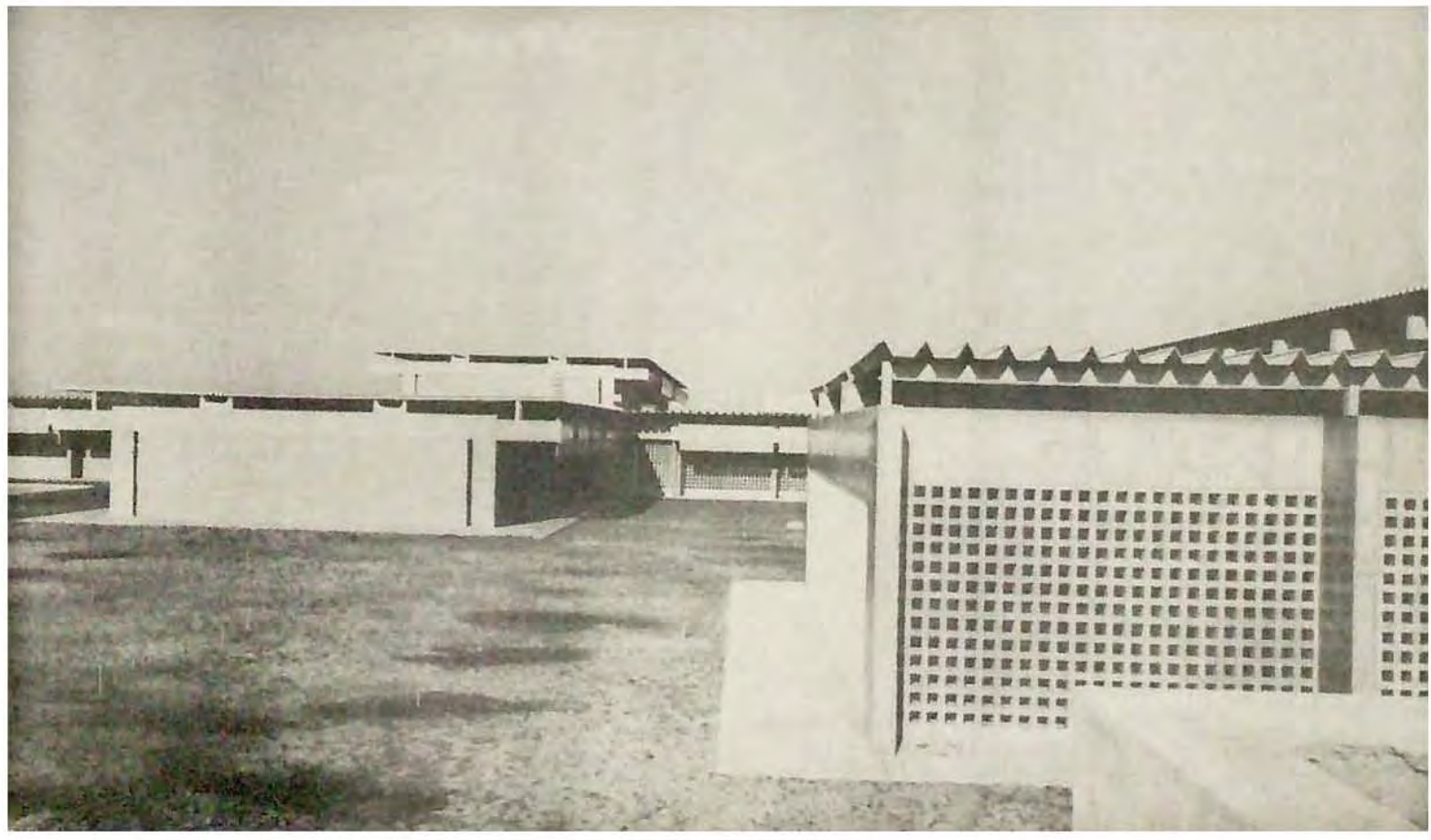

Figura 264: UFMA - Instituto de Ciências Físicas e Naturais - 1972.

Vista Externa - Detalhe do combogó.

(Fonte: Acervo Pessoal da Família Prochnik)

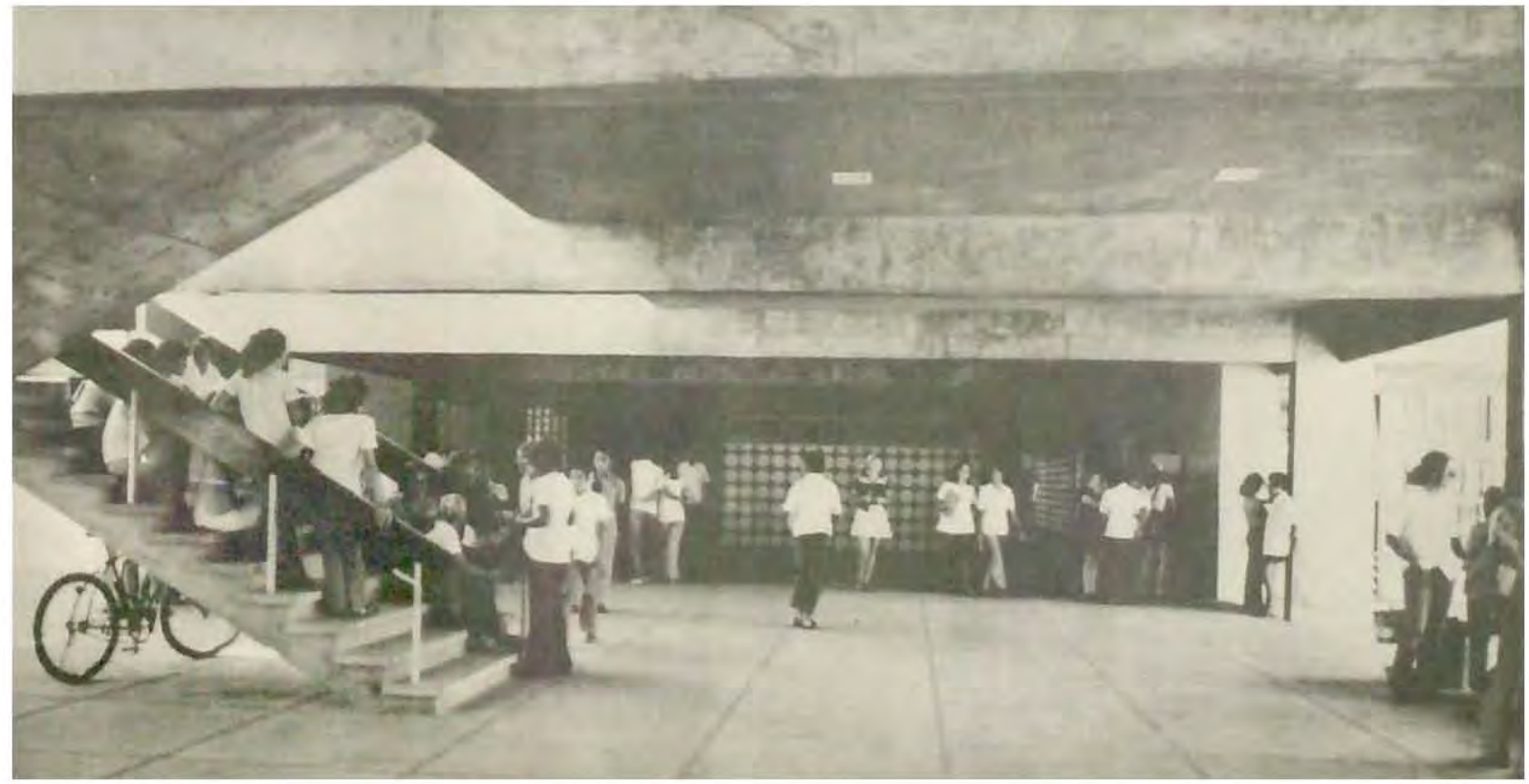

Figura 265: UFMA - Instituto de Ciências Físicas e Naturais - 1972.

Pátio coberto, aberto para áreas externas, cria espaço de convivência e integração. Predomina a estrutura de concreto aparente.

(Fonte: Acervo Pessoal da Família Prochnik) 


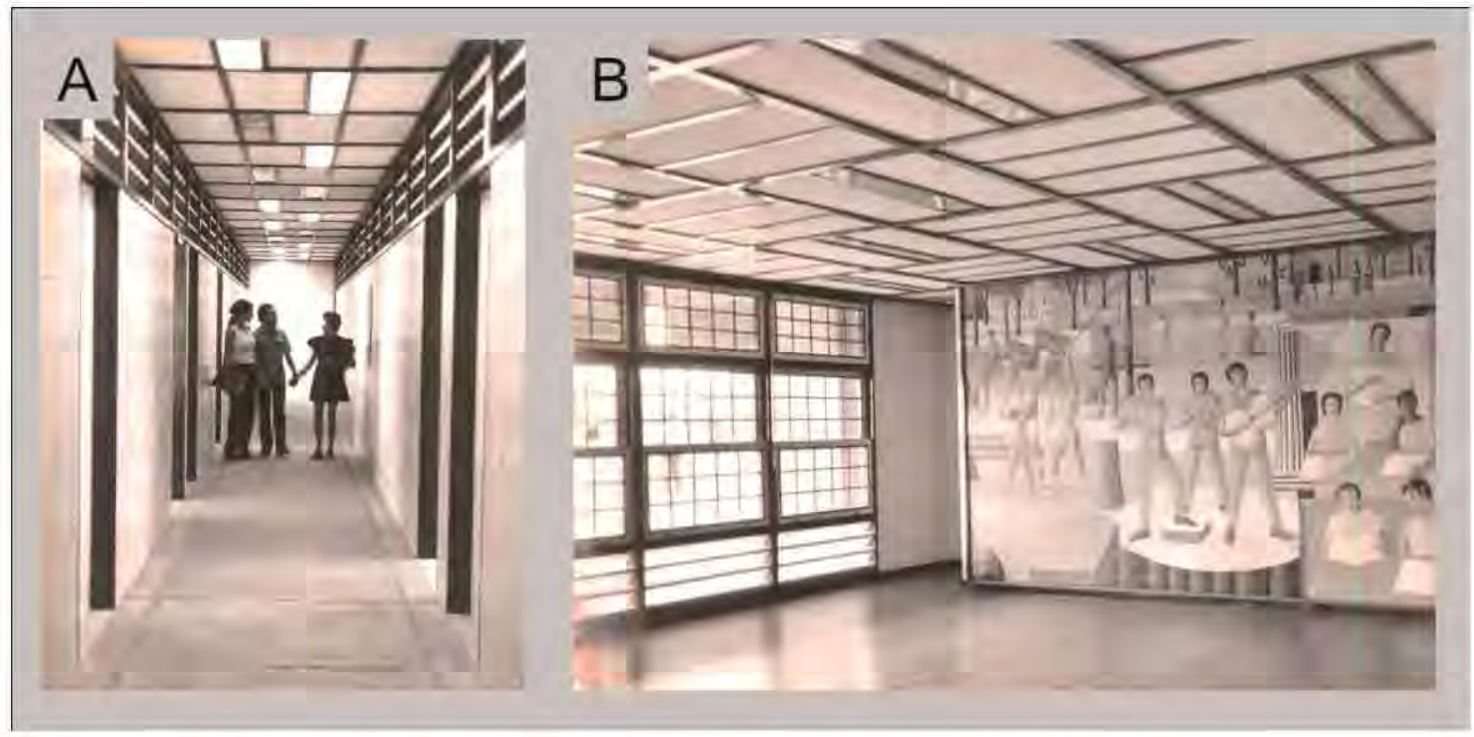

Figura 266: UFMA - Instituto de Ciências Físicas e Naturais - 1972.

(A) Detalhe do hall com painel cerâmico e esquadria pivotante horizontal.

(B) Detalhe da circulação interna de piso cimentado com juntas em seixo rolado, e esquadrias superiores para ventilação por efeito chaminé.

(Fonte: Acervo Pessoal da Família Prochnik)

A predominância do concreto aparente revela a adesão de Prochnik às experiências que estavam ocorrendo em outras regiões brasileiras. O resultado alcançado revela, entretanto, sua postura de respeito aos condicionantes regionais, produzindo uma arquitetura para o local, para o clima e para a Instituição, que se soma ao panorama da boa arquitetura.

O edifício foi inaugurado em 11 de novembro de $1972^{101}$ com o nome oficial de Marechal Castelo Branco em homenagem ao presidente da República que sancionou a lei de criação da Universidade, passando a ser identificado pela comunidade universitária com o apelido de Castelão. A partir daí a mudança da Universidade para o Campus se tornou irreversível com a gradativa construção de outras unidades.

Ofícios e contrato de autoria do arquiteto Prochnik ([1973a?],1973a, 1973b, 1973c, 1973d, 1973e, [1972?], 1972a, 1972b) revelam que o escritório foi incumbido de elaborar os projetos de infraestrutura do Campus (sistema viário, estação rebaixadora de alta tensão, e as redes de iluminação pública, de energia de alta tensão, de distribuição de água potável, captação, tratamento e armazenamento de água, de águas pluviais, de esgoto primário e de telefone) e os dos edifícios destinados à Biblioteca Central, Instituto de Filosofia e Ciências Humanas, Instituto de Letras e Artes, Departamento de Biologia, Habitação para Estudantes e o Bloco de Manutenção de Serviços. O projeto da Reitoria fez inicialmente parte desse conjunto, foi porém substituído pelo do Instituto de Filosofia e Ciências Humanas e o de Letras e Artes (PROCHNIK, 1973c).

\footnotetext{
${ }^{101}$ Periodo do segundo reitorado, tendo como reitor o cônego Ribamar Carvalho.
} 
Na pesquisa de campo realizada no acervo do escritório de Prochnik não foram localizados os projetos das unidades acima referenciadas, excetuando-se os estudos preliminares referentes ao Alojamento de Estudantes e Bloco de Serviços que, entretanto não tiveram continuidade (ver figura 267). Também não há registros no acervo da Prefeitura do Campus. As edificações construídas em meados da década de 1970 diferem da concepção arquitetônica desenvolvida pelo escritório de ProchniK e alguns exemplares têm autoria reconhecida de profissionais pertencentes ao quadro técnico da UFMA. A constatação nos levou a considerar que a atuação do arquiteto na Universidade não prosseguiu a partir de meados daquela década.

\section{- Núcleo de Processamento de Dados (NPD)}

A publicação da UFMA (UFMA, 1981) referente ao inventário físico dos setores da Instituição situados no Campus do Bacanga até 1981 nos dá conhecimento de que ainda em 1972 , foi concluído no mesmo período do ICFN e próximo a este, o prédio de um pavimento destinado ao Núcleo de Processamento de Dados (NPD). As características arquitetônicas deste edifício seguem a mesma linguagem e o mesmo processo construtivo do ICFN, o que nos permite considerar como de autoria do arquiteto ProchniK e sua última realização para a UFMA (ver figura 268). Corrobora com essa hipótese, a Planta de Situação da figura 269 referente ao Instituto (ICFN), com autoria de ProchniK, que indica também a situação do Laboratório de Aplicação Médica de Radioisotopos (LARIM). Possivelmente, o projeto inicial para o LARIM foi readequado para a instalação do NPD.

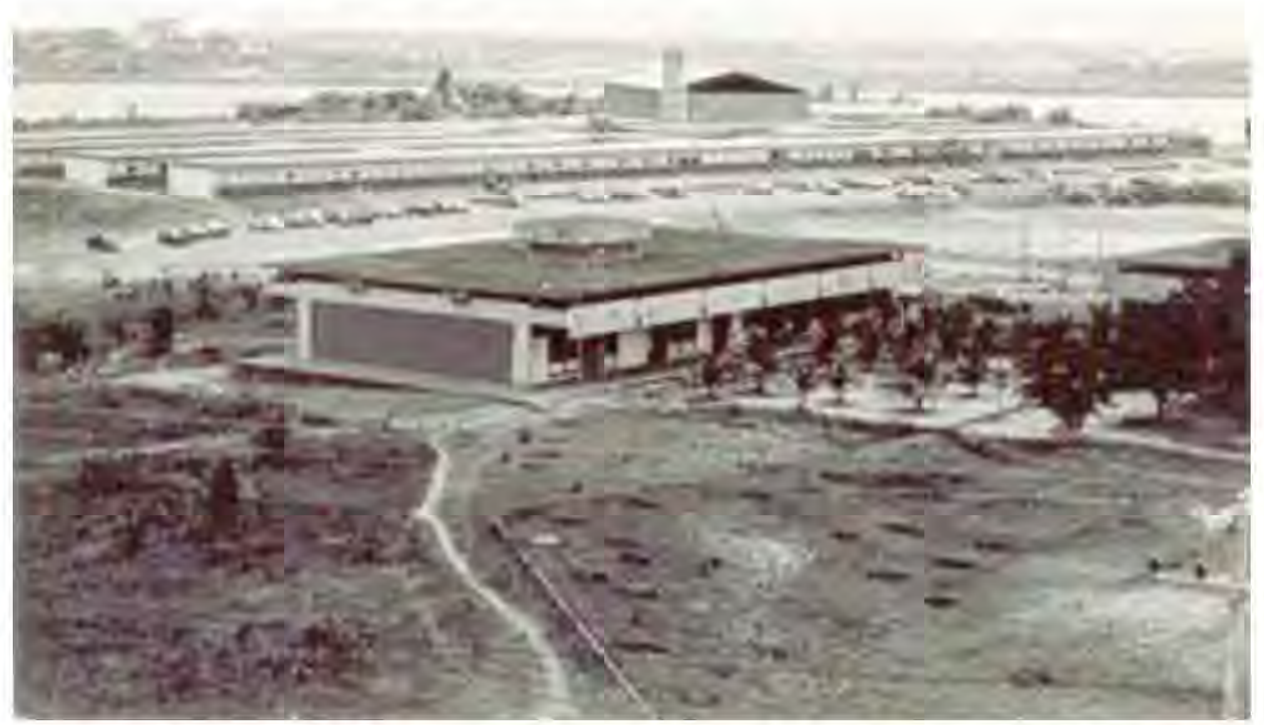

Figura 268: UFMA - Foto das primeiras edificações do Campus do Bacanga - Década de 1970.

Em primeiro plano, o prédio do antigo NPD; em segundo plano, o prédio que foi destinado ao Centro de Estudos Básicos, que atualmente é identificado pela comunidade acadêmica de CEB velho e abriga a Biblioteca. Ao fundo, vista do Rio Bacanga e do centro urbano de São Luís.

(Fonte: Acervo Prefeitura do Campus) 


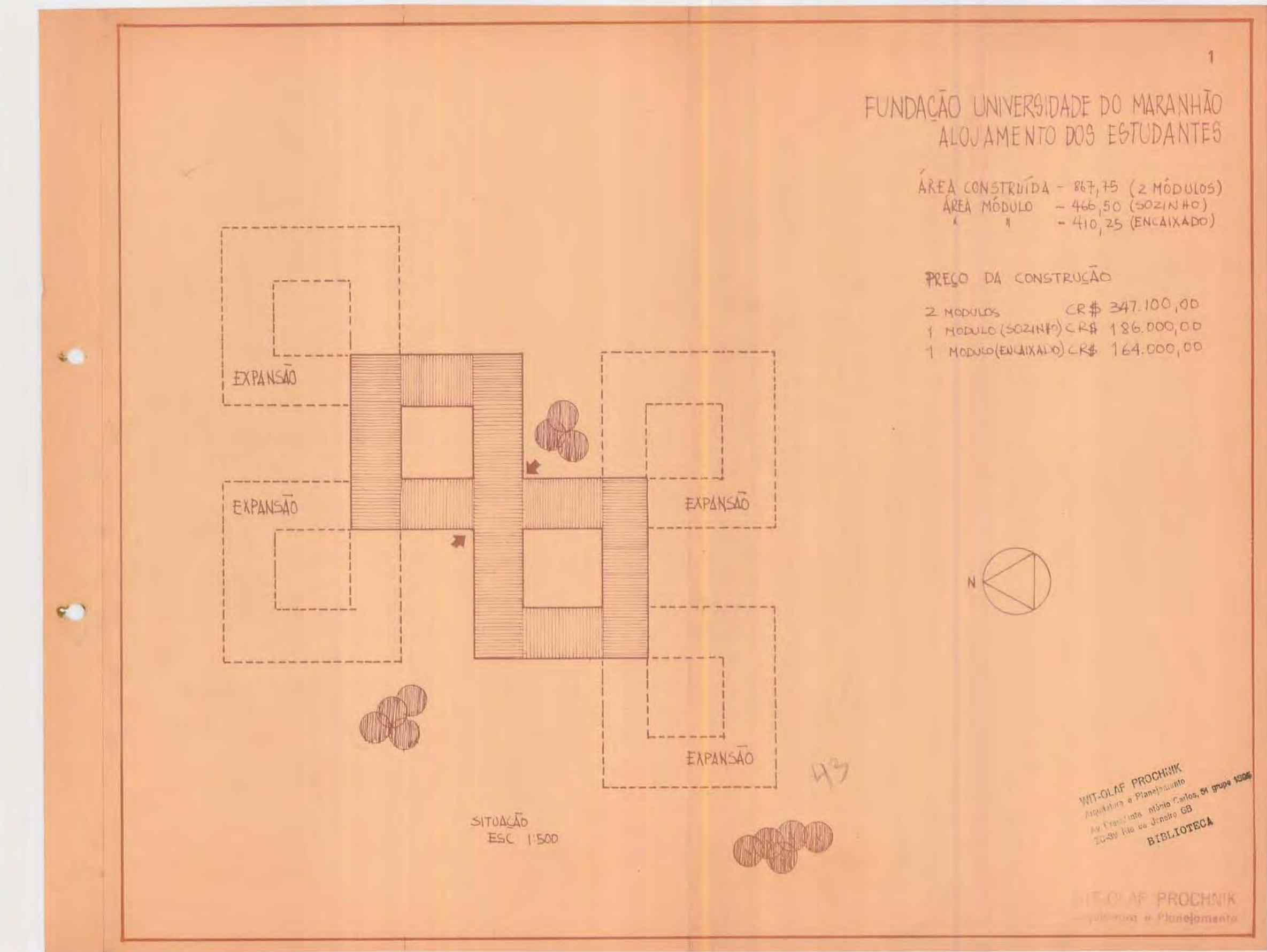

PLANTA SITUAÇÃO

Figura 267a: UFMA - Aljamento de Estudantes - [1971]. A proposta adota a concepçáo arqutitênicica do ICFN que possibilita a expansăo do edificio. O processo construtivo segue a proposta que destaca a estrutura de concreto e vedaçoes de combogó
(Fonte: Acervo Pessoal da Familia Prochnik) 


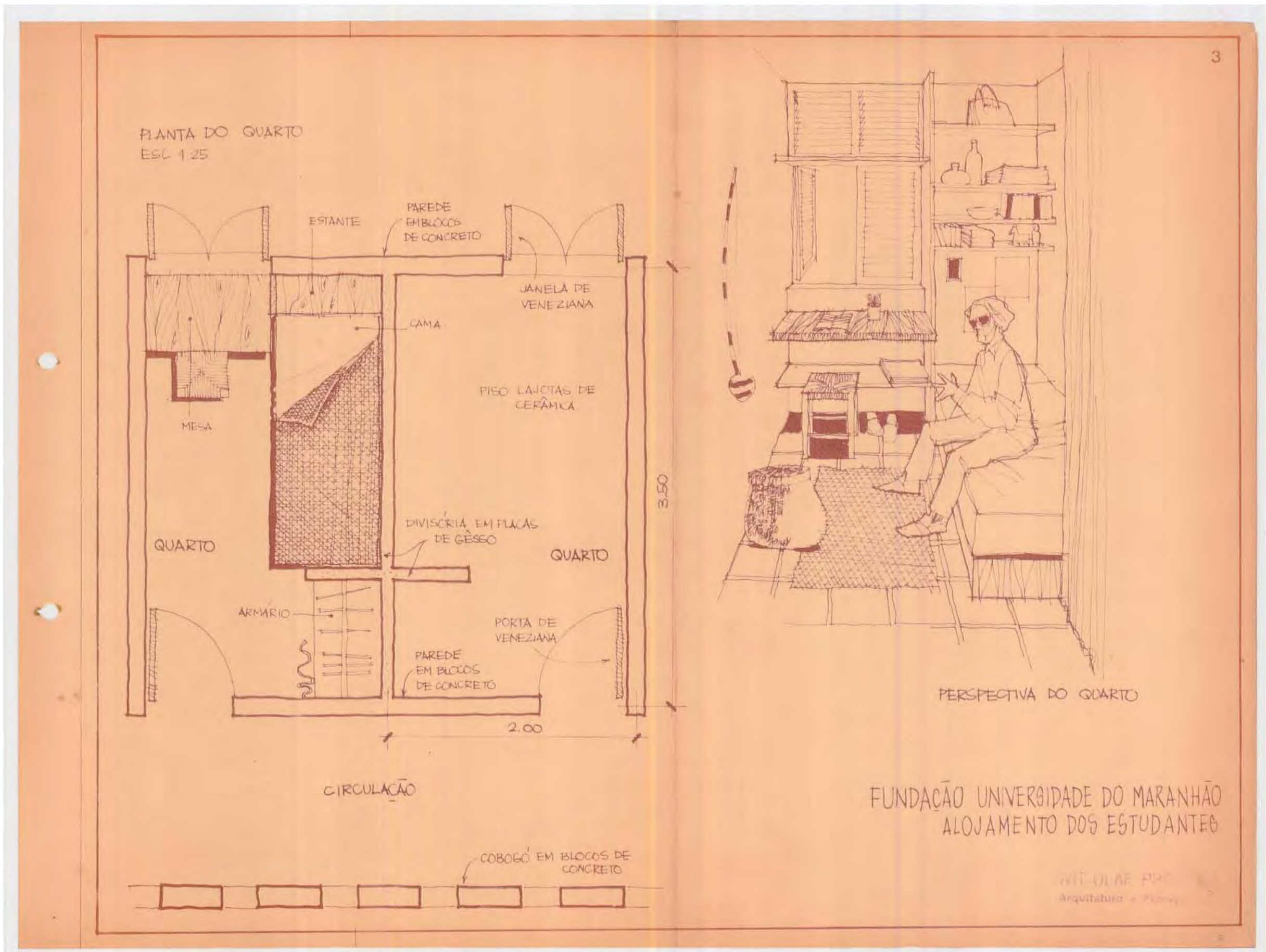

DETALHES

CORTES E FACHADAS

Figura 267b: UFMA - Alojamento de Estudantes - [1971]. A proposta adota a concepģao arquitetonica do ICFN que possibilita a expansăo do edifício. O processo construtivo segue a proposta que destaca a estrutura de concreto evedacōes de combogo
(Fonte: Acervo Pessoal da Familia Prochnik) 


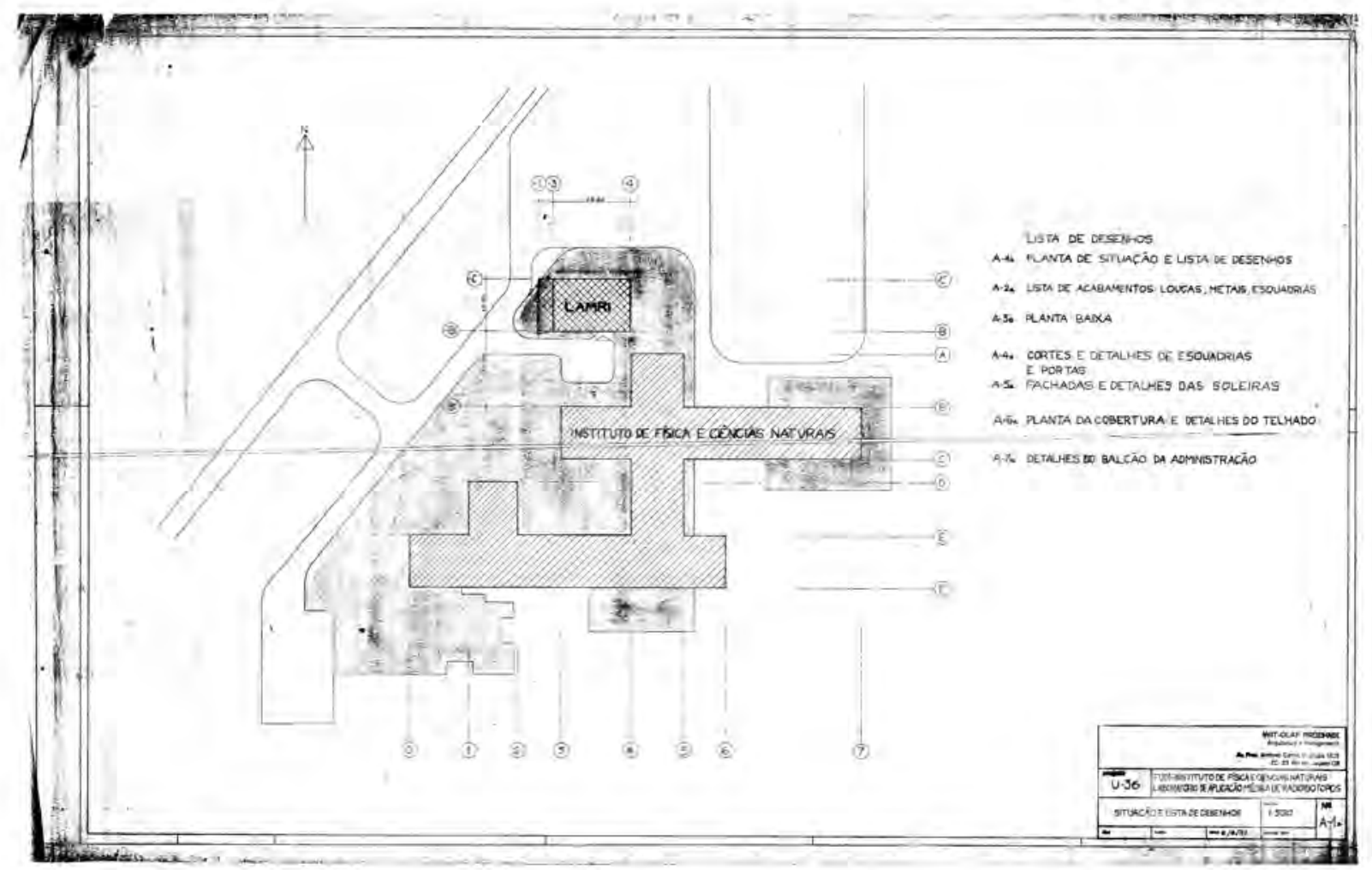

Figura 269: UFMA - Laboratório de Aplicação Médica e Radioisotopos - 1972.

Planta de Situação do ICFN e LARIM.

(Fonte: Acervo Pessoal da Familia Prochnik)

\section{- Desenvolvimento do Campus na segunda metade da década de 1970}

A ocupação do Campus a partir da segunda metade da década de 1970 afasta-se da proposta do plano de Prochnik e as edificações construídas embora adotando modulação, padronização e estratégias de adequação aos condicionantes climáticos locais evidenciam a ausência do arquiteto nessa produção. A informação verbal ${ }^{102}$ de técnicos da atual Prefeitura do Campus identifica que os projetos das unidades tiveram a participação do arquiteto maranhense aposentado da Coordenadoria de Obras da UFMA, Clayton Mendes da Rocha.

\section{- Centro de Estudos Básicos}

Em $1973^{103}$, segundo Meireles (1981, p.34) foi dado andamento à construção de um edifício de quatro alas paralelas, que duplicou, com vantagem, a capacidade de salas de aula. $O$ prédio de um pavimento foi destinado ao Primeiro Ciclo Básico das áreas de Ciências

\footnotetext{
${ }^{102}$ Durante a pesquisa de campo realizada em 2009 as entrevistas realizadas com os técnicos mais antigos daquele órgão referenciam a participação do arquiteto maranhense Clayton Mendes da Rocha nas edificaçöes que se seguiram após os prédios do Casteläo e NPD, atual NTI. Os dados de contato com o referido profissional não foram resgatados pela Universidade, o que nos impediu de realizar entrevista com o arquiteto.

${ }^{103}$ Periodo do terceiro reitor, professor Josué de Souza Montelo.
} 
Humanas e Sociais e nẫo há identificaçẫo da sua autoria. O Catálogo da UFMA (1981) indica, entretanto, que sua construçấo só foi iniciada em 1975 e em 1981 estava funcionando com o Centro de Estudos Básicos, o Centro Teconológico e a Biblioteca Central. Atualmente a edificação é reconhedida pela comunidade universitária com a nome de CEB Velho e abriga a Biblioteca Central, área de convivência e serviọs de lanchonete, correios e banco, dentre outros.

A edificaçấo constitui uma tipologia paviolhonar com blocos que se abrem para pátios internos. O partido adota o módulo base da estrutura de concreto e destaca as vedaçốes em alvenaria de tijolo e combogó. Na coberta é utilizada a telha de fibrocin ento Kalhetấo 43 , que se apoia diretamente na estrutura, propiciando o acúmulo de massas de ar aquecidas. O piso em cimento e seixo rolado segue a e specificaçấo do arquiteto Prochnik para o ICFN. A proposta construtiva embora referenciada na concepçấo do Instituto distancia-se da qualidade arquitetônica desenvolvida por Prochnik [o edificio foi referenciado na figura 267 e tern det alhe na figura 270 e 271].

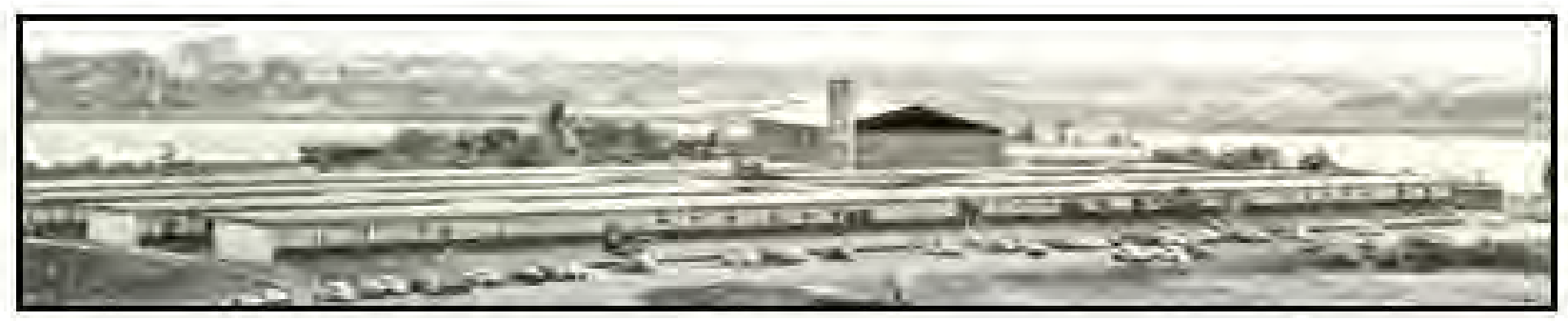

Figura 270: UFMA- C entro de Estudos Básicos - Década de 1970.

(Fonte: Aceno Prefeitura do Campus)

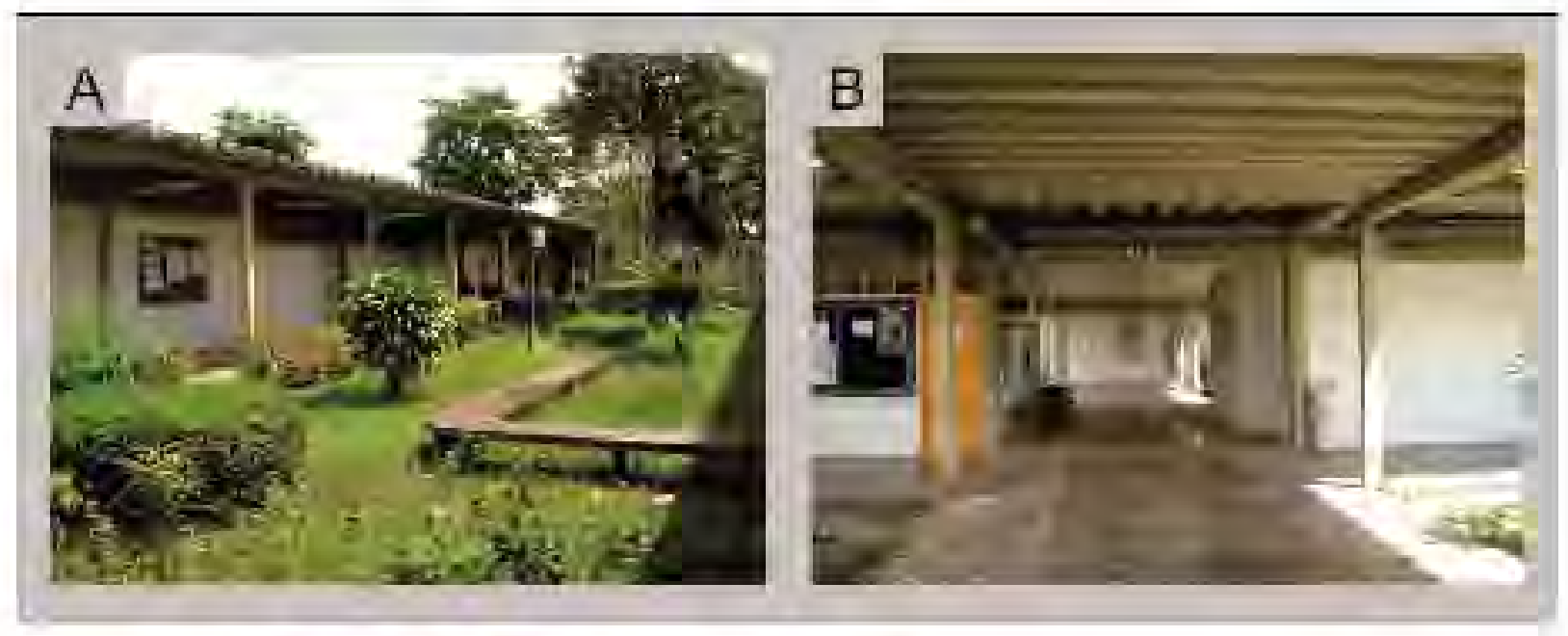

Figura 27 1: UFMA - C entro de Estud os Básicos - Ano 2009.

(A) Ds blocos se abrem apara pátios internos.

(B) A especificação constutiva está referenciada no ICFN, porém o resultado afasta-se da qualidade arquitetônica do Instituto.

(Fonte: Aceno Pessoal da autora) 


\section{- Centro de Esportes}

No período de 1973 a $1975^{104}$ a construção do Campus foi impulsionada com o projeto do Núcleo de Esportes (ver figuras 272 e 273), cuja obra teve início em 1974 (UFMA, 1981, p.35) e a construção de mais um prédio de quatro pavilhões, que segundo Buzar (1984, p.34) também duplicou a capacidade de salas de aula e, consequentemente, a matrícula da UFMA. O edifício referenciado constitui-se de um conjunto de blocos de três pavimentos interligados por uma circulação central, e foi concluído em 1978, quando passou a abrigar toda a estrutura do Centro de Ciências Sociais (UFMA, 1981) e que corresponde ao atual ccso.

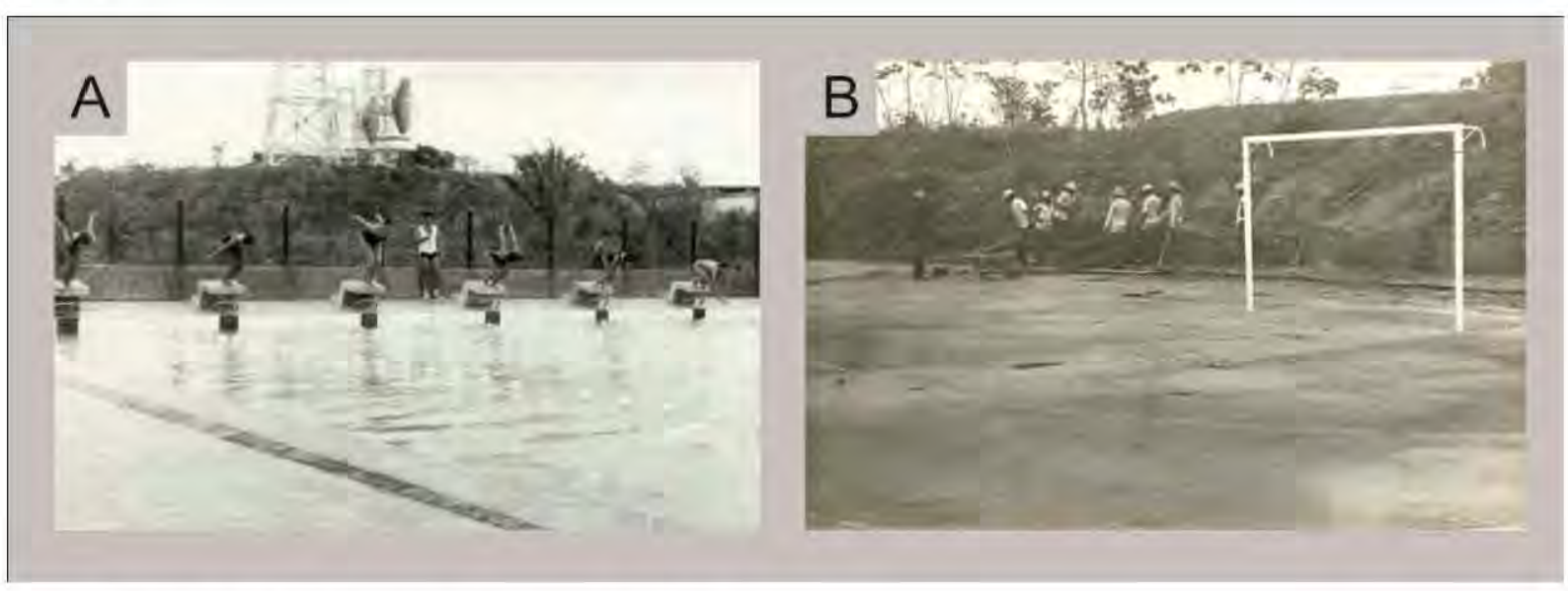

Figura 272: UFMA - Obras do Centro Esportivo.

(A) Construção das quadras em meados da década de 1970.

(B) A piscina olímpica foi concluída em 1980 e sua área é de $747,04 \mathrm{~m}^{2}$.

(Fonte: Acervo Prefeitura do Campus)

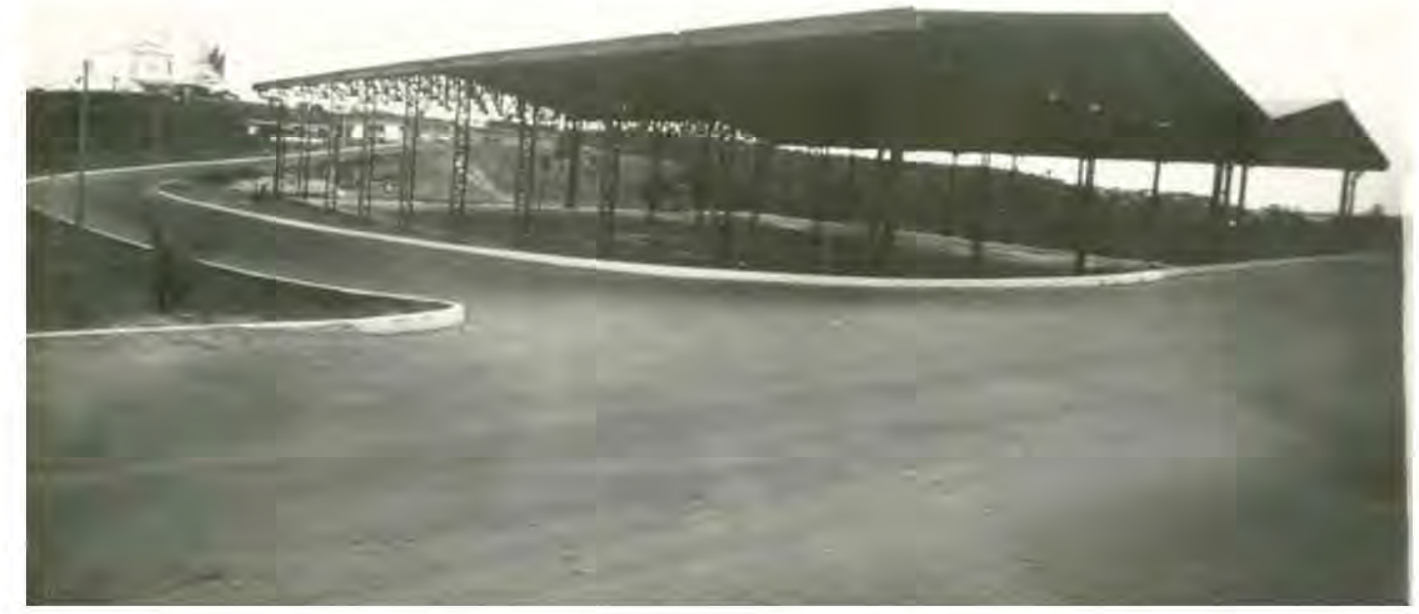

Figura 273: UFMA - Quadras cobertas do Setor Esportivo.

A coberta foi executada para proteção da insolação e das precipitações pluviométricas que ocorrem com frequência na região (UFMA, 1981, p.37)

(Fonte: Acervo Prefeitura do Campus)

\footnotetext{
${ }^{104}$ Período do quarto reitor, professor Manoel Soares Estrela.
} 
A localização do setor esportivo não seguiu a orientação do plano inicial do arquiteto Prochnik que, conforme já apresentado na planta da figura 258 do presente capítulo, seria construído na parte sudeste do Campus ao invés de sudoeste. $O$ arquiteto chegou a desenvolver um estudo para a praça de esportes referenciada na primeira implantação (ver figura 274).

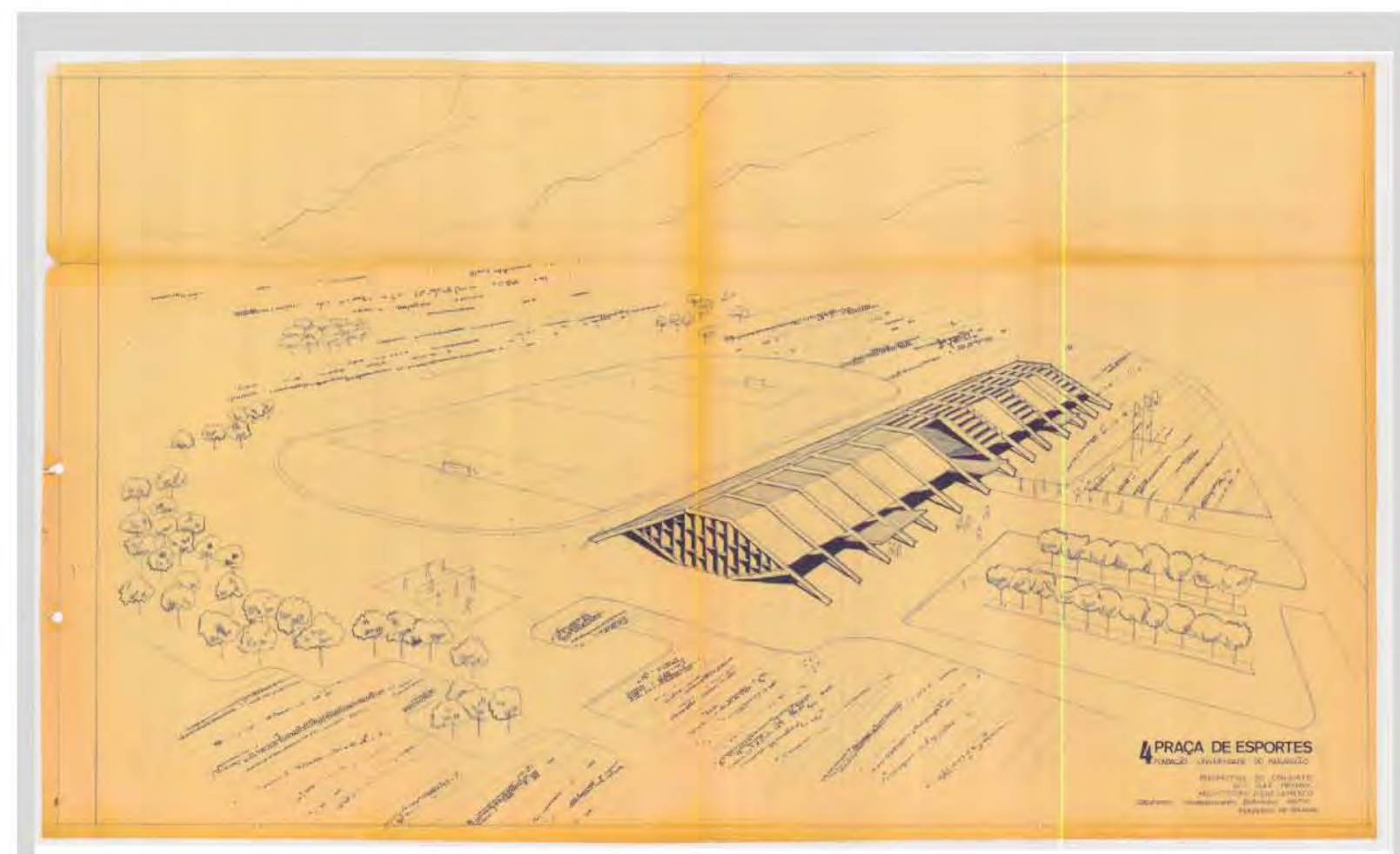

(A)

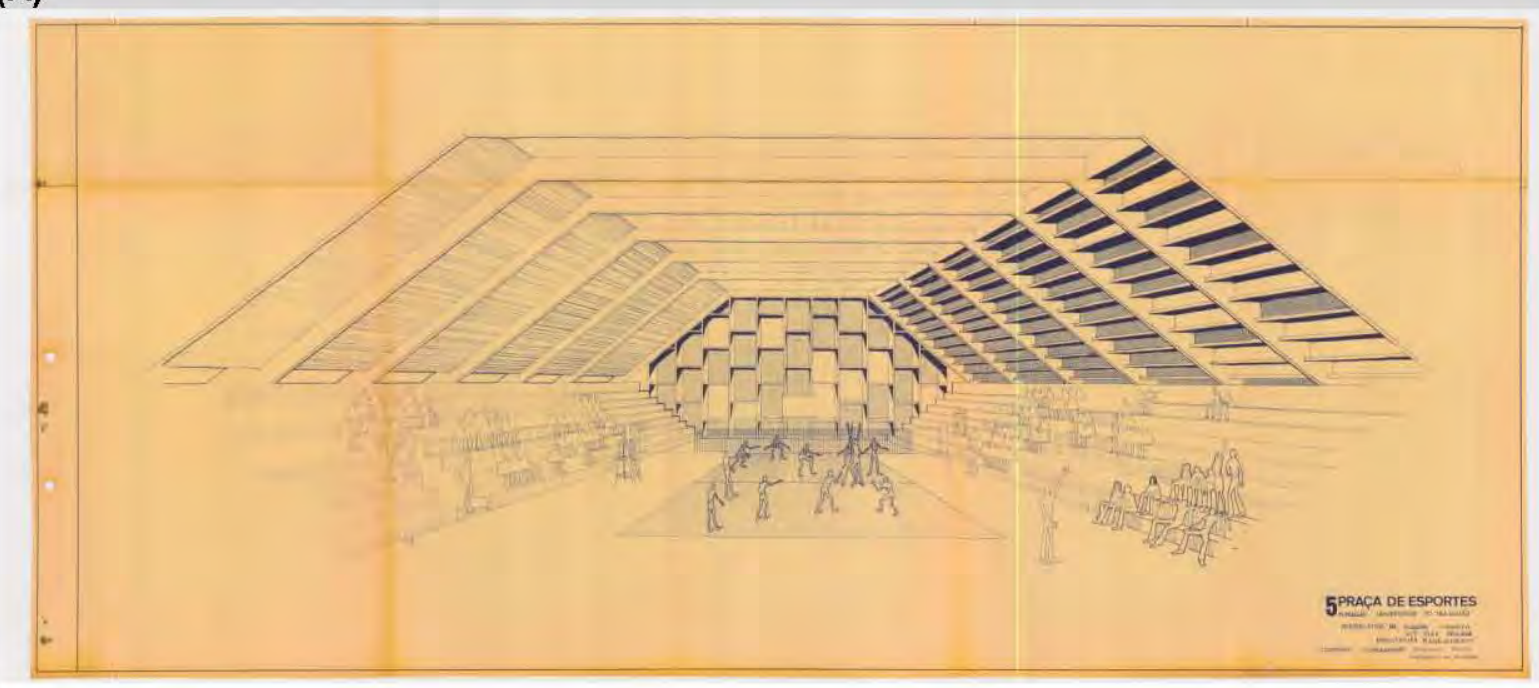

(B)

Figura 274: UFMA - Setor Esportivo - [1971]

(A) Ilustração do conjunto da Praça de Esportes.

(B) Detalhe ilustrativo da Quadra de Esportes Coberta

(Fonte: Acervo Pessoal da Família Prochnik) 
A alteração foi concebida pelo próprio escritório de Prochink conforme planta da figura 275 com data de 28 de dezembro de 1971. Um complexo de equipamentos esportivos estava indicado na nova configuração, que incluía campos de futebol e atletismo, parque aquático, ginásio coberto, escola de educação física, dentre outros. O projeto implantado, entretanto, não teve a participação daquele profissional. É provável que tenha sido desenvolvido pelo escritório técnico da UFMA.

\section{- Centro de Ciências Sociais}

O conjunto arquitetônico destinado ao Centro de Ciências Sociais está situado próximo ao eixo viário da BR-135 com a implantação obedecendo à orientação norte/sul para as fachadas longitudinais e cota de nível elevada, assim como o edifício "Castelão".

O projeto de autoria do arquiteto aposentado da Coordenadoria de Obras da UFMA, Clayton Mendes da Rocha, apresenta uma solução arquitetônica de característica pavilhonar constituída por um conjunto de sete blocos padronizados implantados a partir de uma circulação centralizada, ficando quatro blocos de um lado do eixo circulatório citado e três do outro. Predominantemente abertas ao exterior, o sistema circulatório é complementado pela circulação secundária que dá acesso aos ambientes.

O conjunto foi projetado para abrigar salas de aula no primeiro e segundo pavimentos, ficando o terceiro destinado ao setor administrativo do Centro. O programa previu ainda uma área destinada à cantina, que se agrega ao conjunto por meio da circulação central. Cada pavimento é abastecido por uma coluna de sanitários, que compõe um volume destacado e que se articula na planta por meio da circulação secundária. A composição organizativa na planta livre evidencia a intenção de racionalização das áreas, distribuídas segundo uma lógica funcionalista de quatro categorias: (1) ambientes de trabalho - didáticos e administrativos, (2) serviços - sanitários, (3) apoio - cantina e (4) circulações.

A solução estrutural, em pórticos modulados a cada $4,80 \mathrm{~m}$, que se destaca nas fachadas norte e sul, e com vãos transversais de $9,95 \mathrm{~m}$, visualizados nas fachadas leste e oeste, apropria-se da linguagem do concreto aparente. Compondo com a estrutura, foi adotado o uso de marquises de laje plana e concreto aparente a cada módulo do pórtico, que se projetam em balanço com vãos de $2,00 \mathrm{~m}$ pela fachada norte. Esses elementos desempenham a função de amenização da radiação solar direta que incide sobre as esquadrias em venezianas articuláveis de madeira. Ressalte-se que o modelo das esquadrias é amplamente utilizado na Região Nordeste, particularmente em áreas de clima quente e úmido e intensa radiação solar. A solução permite o controle da luz solar que penetra nos ambientes, ao mesmo tempo que possibilita a passagem do fluxo de ar. $\mathrm{Na}$ fachada sul, repete-se o uso de marquises, tendo agora uma solução que interage com 


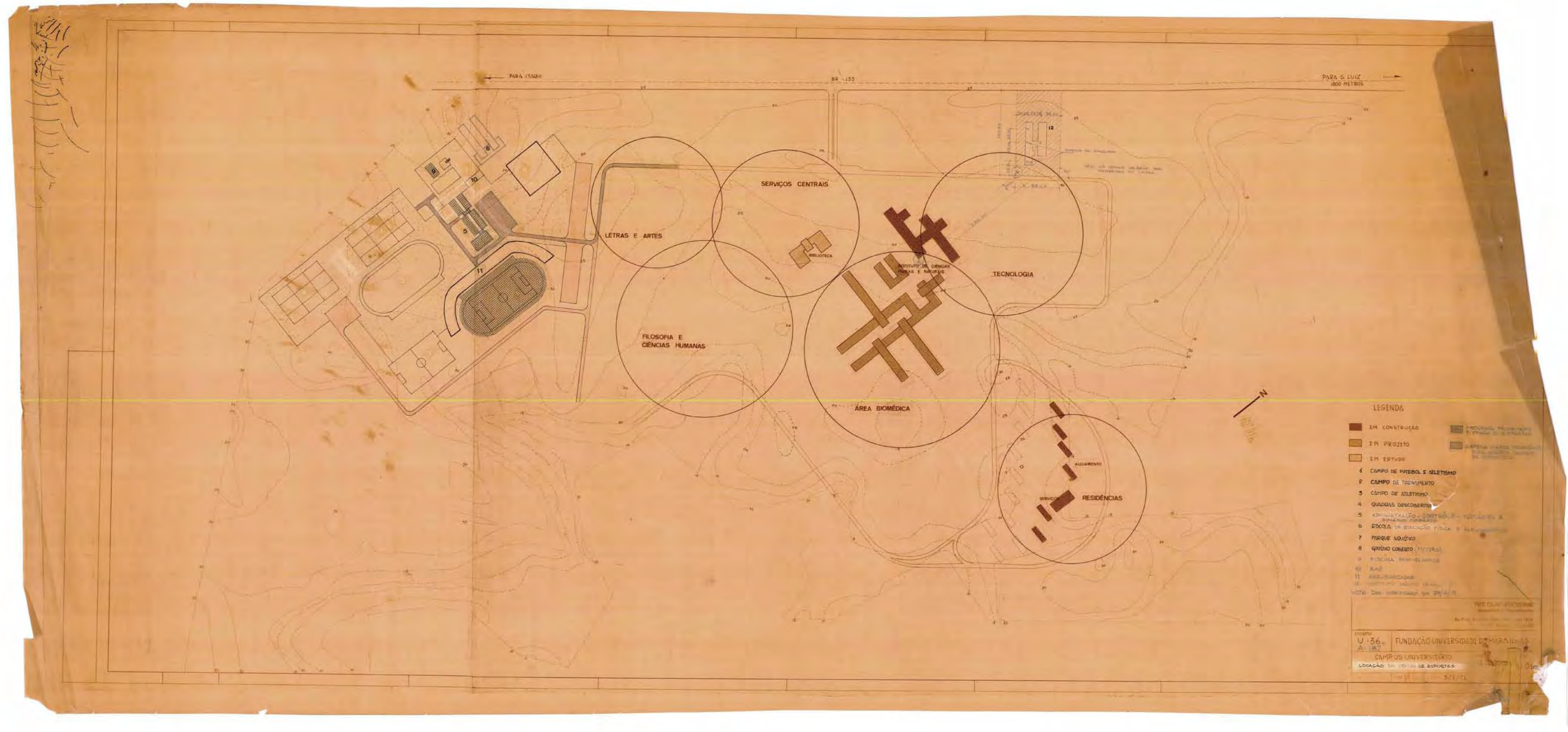

Figura 275: UFMA - Planta do Campus do Bacanga - 1971

A planta de autoria do eschitrio do arquiteto Prochnik foi alterada para indicar a nova situaçăo do Setor Esportivo 
esquadrias no vão superior das portas dos ambientes. Estes elementos também tentam contribuir para amenizar o rigor climático da região.

A coberta em telha de amianto compõe a forma arquitetônica com platibanda retangular nas fachadas norte e sul e empena triangular nas fachadas leste e oeste. A solução triangular não contribui para neutralizar a escala vertical e incorpora a ideia de um chapéu que pousa sobre o corpo do edifício. A concepção construtiva evidencia a orientação aos condicionantes climáticos do local e a proposta de racionalização construtiva com a padronização dos seus componentes. O resultado formal, entretanto, não atinge a síntese de uma arquitetura que reúne harmonia e equilíbrio ao corpo construtivo (ver figura 276).

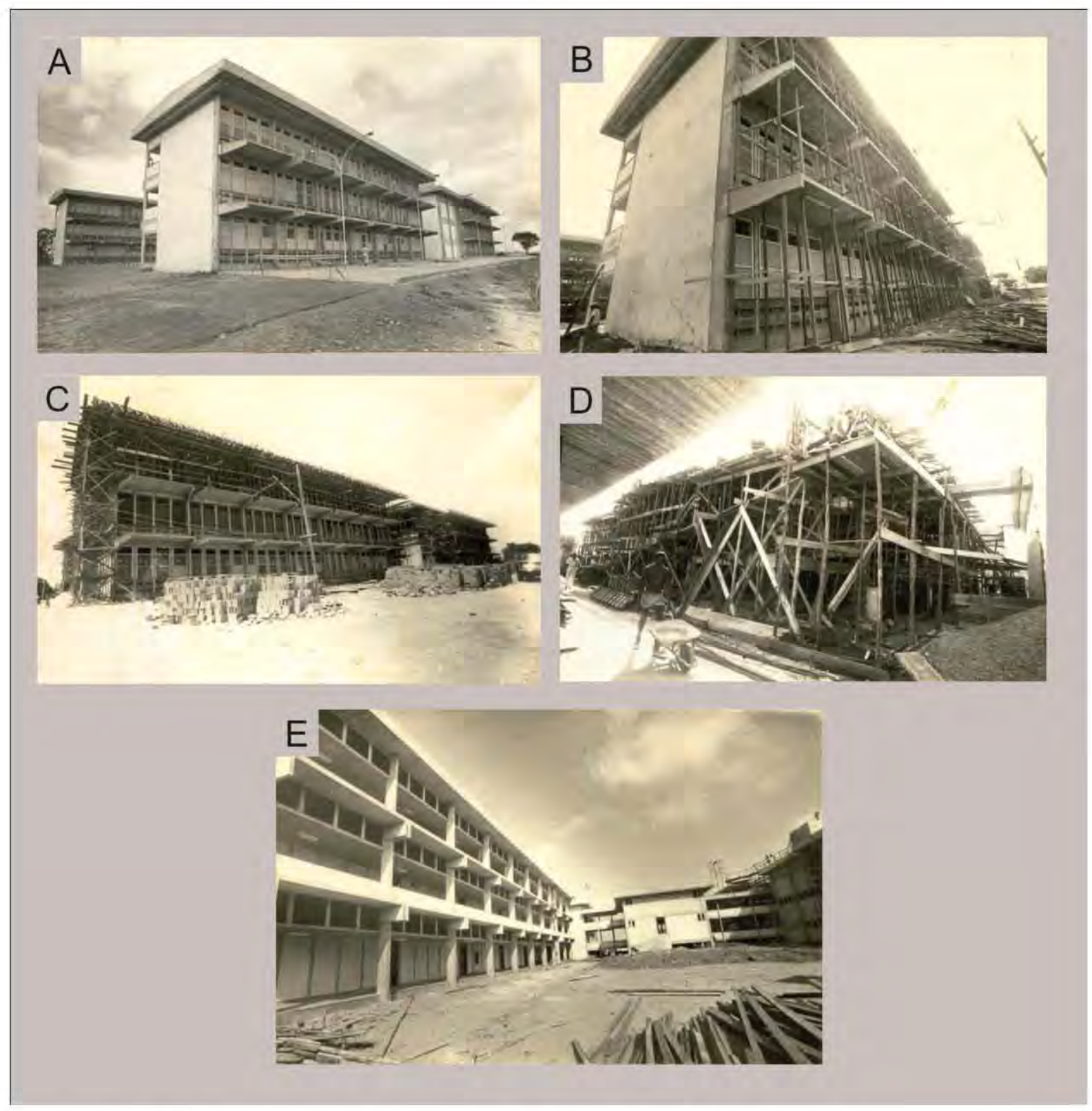

Figura 276: UFMA - Centro de Ciências Sociais - meados da década de 1970.

(Fonte: acervo Prefeitura do Campus) 


\section{- Unidades do final da década de 1970}

Por volta de 1977, foram iniciadas as obras do Restaurante Universitário, prédio de um pavimento e área construída de $2.305,78 \mathrm{~m} 2$ (ver figura 277); e da Área de Vivência, também de um pavimento com área construída de $1.043,83 \mathrm{~m} 2$. Ambos foram concluídos em 1981.

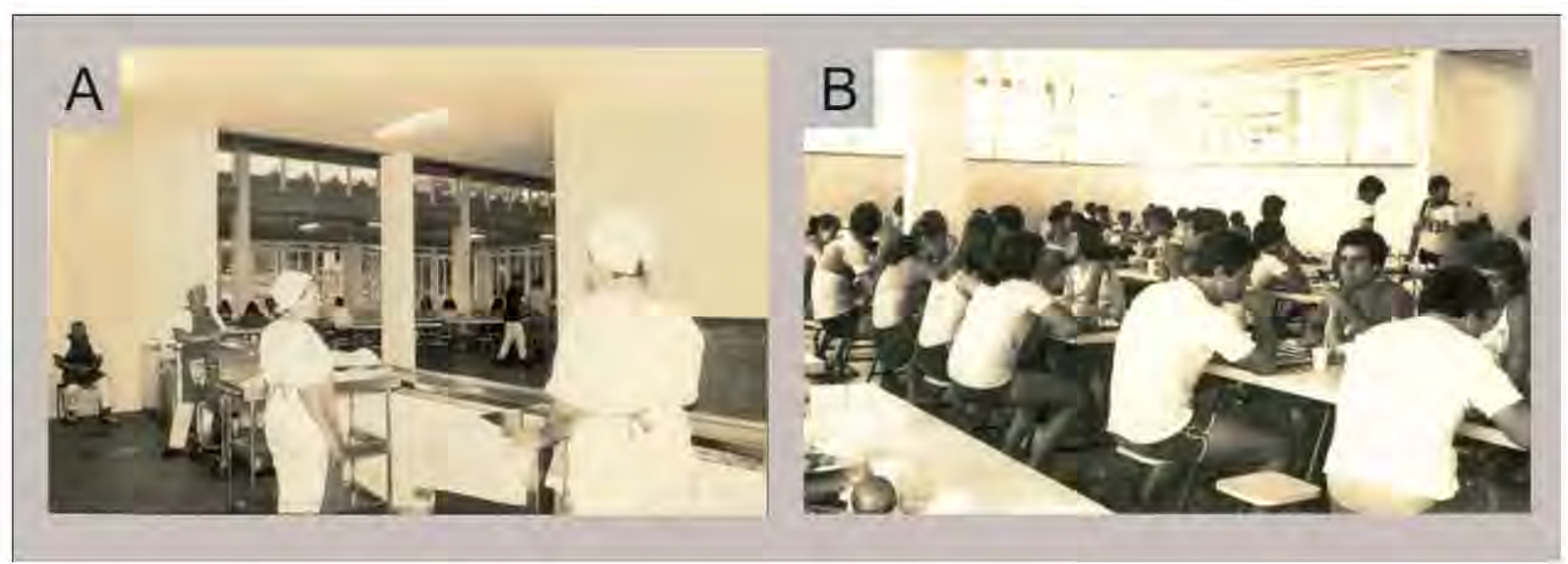

Figura 277: UFMA - Restaurante Universitário, concluído em 1981.

(Fonte: Acervo Prefeitura do Campus)

No ano de 1978 , foi construído o prédio destinado ao Biotério. Trata-se de uma edificação de um pavimento com área de $859,04 \mathrm{~m}^{2}$.

O último reitorado da década de 1970 (gestão de 1979 a $1988^{105}$ ), mantendo o imperativo de consolidar o Campus do Bacanga como nas gestões anteriores, deu prosseguimento às obras do Núcleo de Esporte, concluído em 1980; ampliou a Biblioteca Central, cujo acervo, segundo Buzar (1984, p.37) aumentou de 10.825 títulos com 31.932 volumes em 1979, para 17.013 títulos com 56.099 volumes em 1981 e finalizou também em 1980 as obras do Pavilhão Tecnológico, prédio de um pavimento com área de $308,40 \mathrm{~m}^{2}$, destinado à pesquisa do curso de engenharia elétrica do Centro Tecnológico. No final de 1979, a área do Campus foi ampliada com a aquisição de um imóvel situado na periferia do terreno onde até então funcionava a Escola de Engenharia da Faculdade de Ensino Superior do Maranhão (FESMA).

\section{- A conformação de um território invadido}

A determinação de consolidar o território unificado da UFMA era, entretanto, um processo incipiente, com várias unidades ainda funcionando no centro da cidade de São Luís (ver quadro 9) e padecia do conflito de ter sua área de ocupação reduzida em decorrência da gradativa invasão por comunidades carentes.

\footnotetext{
${ }^{105}$ Periodo do reitor, professor José Maria Cabral Marques, que teve dois mandatos consecutivos.
} 
As plantas das figuras 278 e 279 constatam a ocupação ainda rarefeita no Sítio Sá Viana com as unidades relacionadas no quadro 10 , com área total construída de $22.575 \mathrm{~m}^{2}$ no final da década de 1970 . Rodrigues (2001, p. 182) registra que no período do Programa MEC / BID III (1982 / 1983) a UFMA possuía $54 \%$ de suas edificações na cidade e $46 \%$ (27 mil metros quadrados) no campus do Bacanga, com área de 156 ha.

Quadro 9: Resumo das Edificações fora do Campus do Bacanga - final da década de 1970. (Fonte: LUCINI, [1980?], n.p.)

\section{Edificações fora do Campus do Campus do Bacanga (unidades na cidade)}

- Instituto de Artes e de Letras

- Centro de Ciências da Saúde

- Reitoria

- Hospital do INPS (Convênio)

- Pró-Reitoria de Estudos e Pesquisa

- Faculdade de Enfermagem

- Lar Universitário

- Faculdade de Farmácia e Odontologia

- Lar Universitário

- Centro de Saúde Paulo Ramos (Convênio)

- Hospital Santa Casa (Convênio)

- Hospital Socorrão (Convênio)

- Hospital Geral (Convênio)

Não foi apresentado o quantitativo de área construída.

Quadro 10: Resumo das edificações construídas no Campus do Bacanga - final da década de 1970. (Fonte: LUCINI, [1980?], n.p.)

\section{Edificações construídas no Campus do Bacanga}

- Edifício Castelo Branco

- Edifício de Salas de Aula - 1

- Edifício de Salas de Aula - 2

- Instituto de Tecnologia

- Biotério

- FESMA

- Instituto Médico Legal

- Departamento de Morfologia

- Coordenadoria de Obras (COB)

- Restaurante (em construção)

- Setor de Esportes 


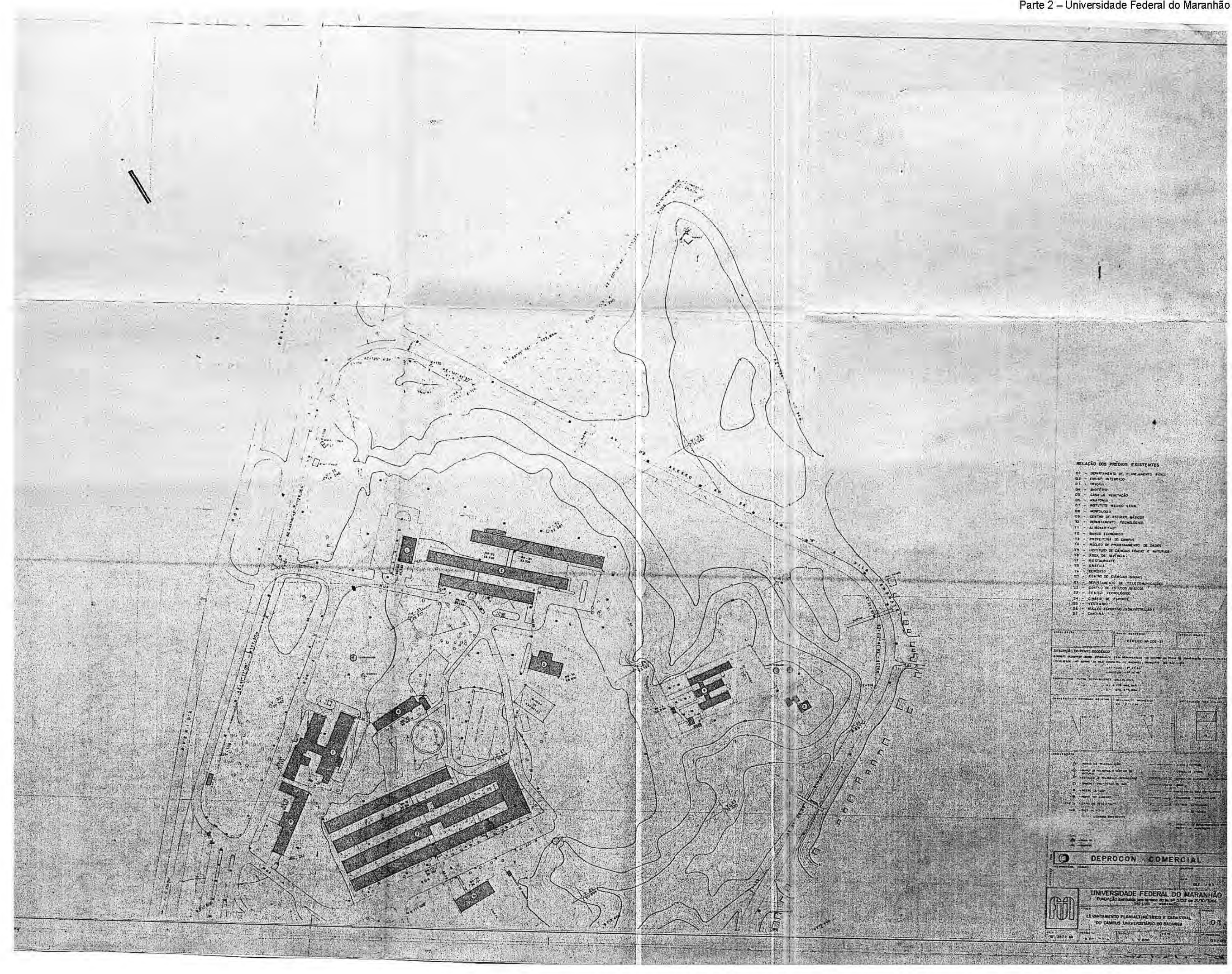


Figura 279: UFMA - Planta do Campus do Bacanga.
Parte do Setor de Esportes estava edificado Parte do Setor de Esportes estava edificado.
(Fonte: Acervo Prefeitura do Campus)

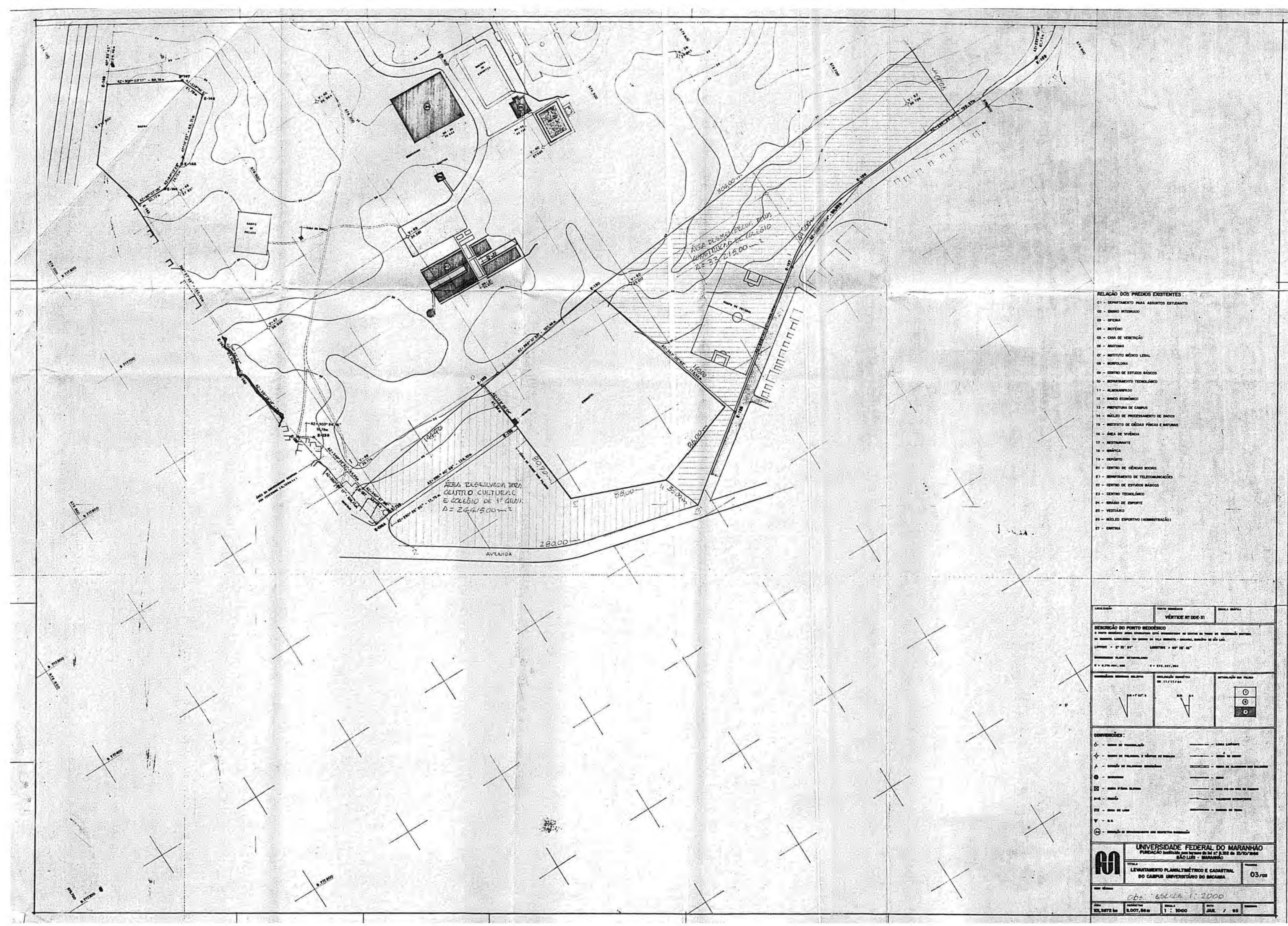


FOLHA VERSO DA FOLHA GRANDE - NÃO IMPRIMIR 
O processo de invasão que se deu na gleba do Sítio Sá Viana no decorrer da década de 1970 repercutiu nas suas dimensões culminando com a redução dos limites originais e que resultou na sua atual configuração física. A ocupação está relacionada à expansão da zona oeste da cidade, já referenciada, que transformou as áreas não edificadas do Campus em objeto de demandas sociais, em decorrência do déficit habitacional da cidade de São Luís e que acabaram sendo ocupadas por famílias de baixa renda - das comunidades Sá Viana e Vila Embratel - cuja mão de obra foi atraída pelos investimentos do setor industrial e/ou possibilidades de exploração de recursos dos mangues (ver figura 280).

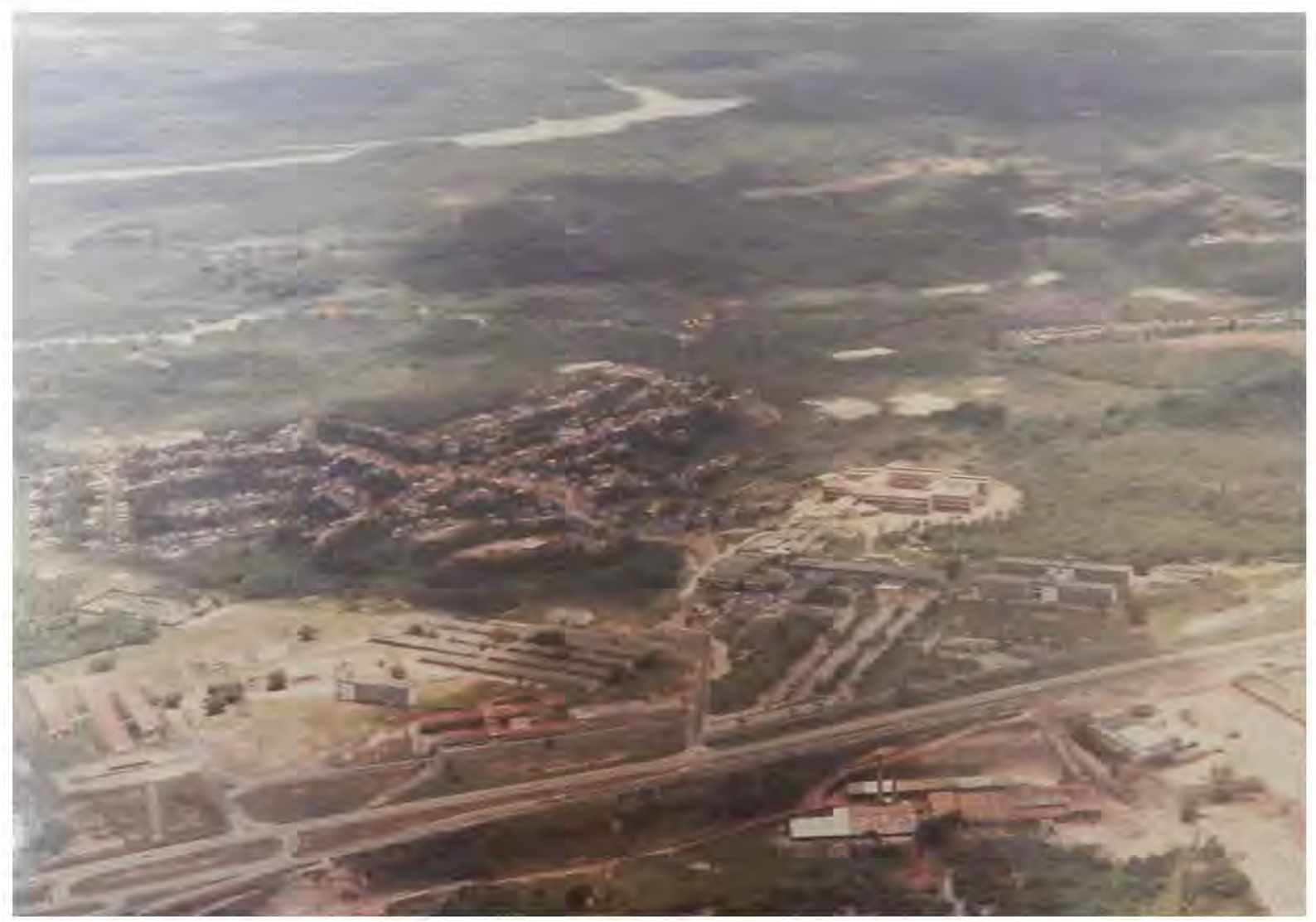

Figura 280: UFMA - Vista aérea do Campus do Bacanga.

A foto indica a ocupação do Campus na primeira metade da década de 1980 , ainda sem a redução dos seus limites originais. Em primeiro plano: ocupação das unidades universitárias, margeada pelo eixo viário (BR 135) que faz a ligação com o Porto Itaqui. Em segundo plano: área do Campus invadida pela Comunidade Sá Viana. Ao fundo: Rio Juburu, afluente do Rio Bacanga cortando a área original da gleba.

(Fonte: Acervo Prefeitura do Campus)

Em 1979, os trabalhos iniciados para elaboração de um plano de desenvolvimento físico para o Bacanga [será abordado na seção seguinte], visando superar a conformação dispersa da sua ocupação, constatou a degradação das áreas invadidas, que não tinham 
condições mínimas de higiene e habitações características de favelas, situação que conflitava com a proposta de expansão das futuras instalações na direção daquelas áreas.

Com esse diagnóstico, a Administração Superior tomou na década de 1980 medidas que resultaram em alterações significativas da área, que foi em parte cedida para a Comunidade Sá Viana, ocupada por invasão, e a da Vila Embratel, negociada pela Reitoria para a desocupação do Sá Viana, fato que resultou na perda das duas áreas (UFMA, 2007, p.6), restando os atuais 101 hectares. As plantas das figuras 281 e 282, referentes aos levantamentos planimétricos do terreno da Universidade Federal do Maranhão demonstram - processo de desmembramento do Campus do Bacanga no decorrer dos anos de 1970, resultando na atual configuração apresentada nas figuras 283 e 284 .

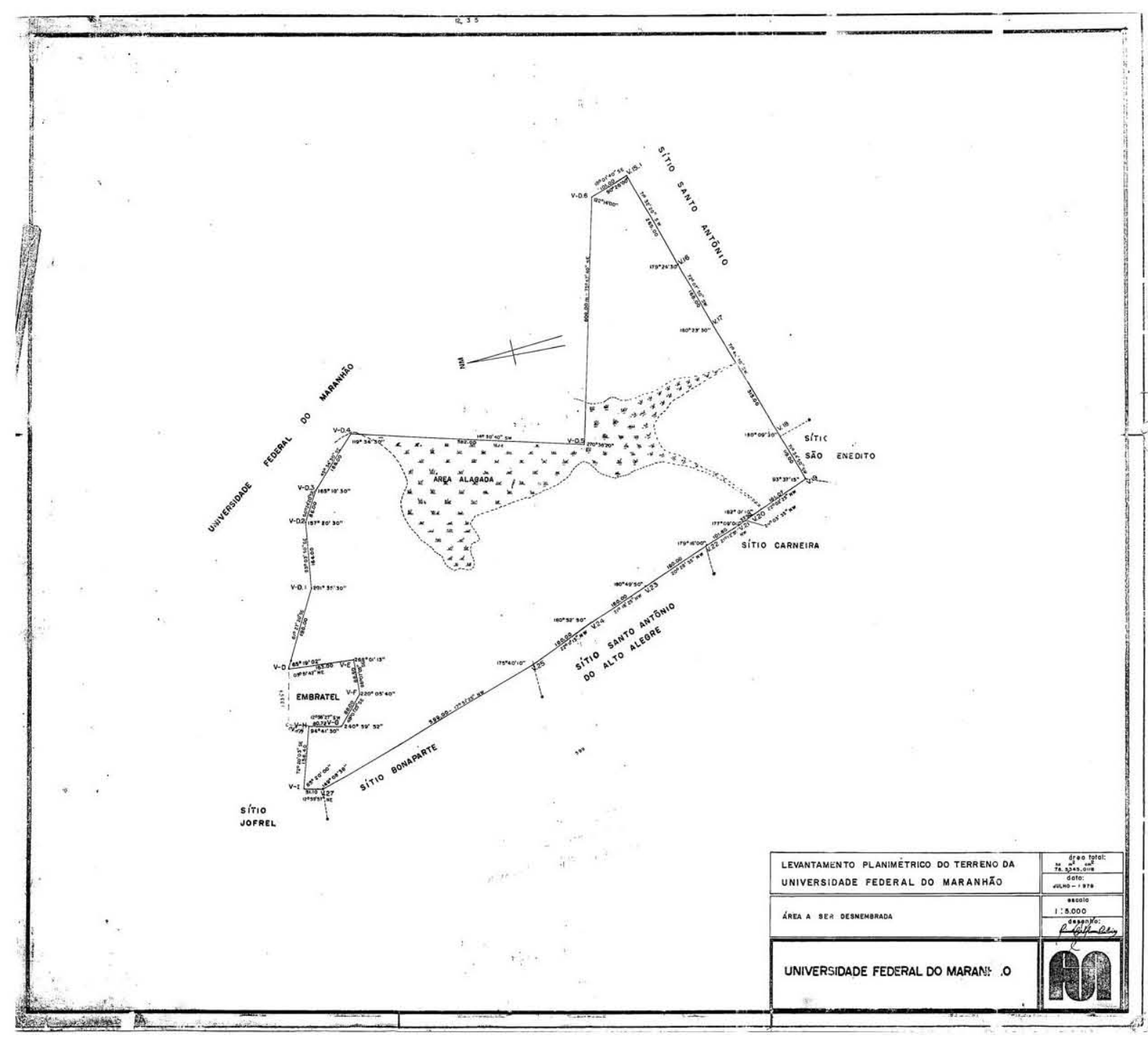

Figura 281: UFMA - Planta do desmembramento do Campus.

O levantamento realizado em 1979 indicava a redução de 78 ha.

(Fonte: Acervo Prefeitura do Campus) 


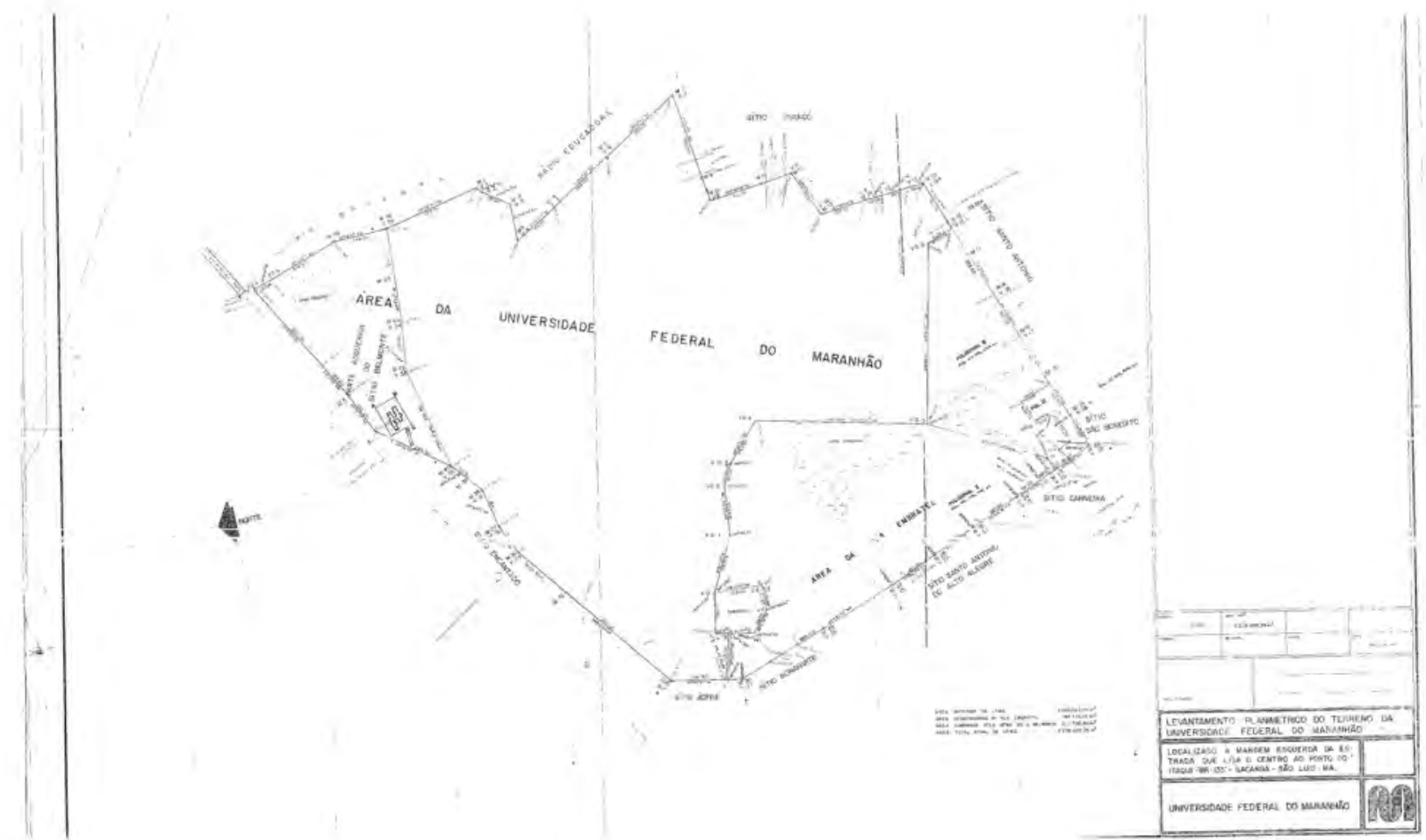

Figura 282: UFMA - Planta do Campus do Bacanga.

O levantamento realizado em 1980 indicava uma área aproximada de 220 ha.

(Fonte: Acervo Prefeitura do Campus)

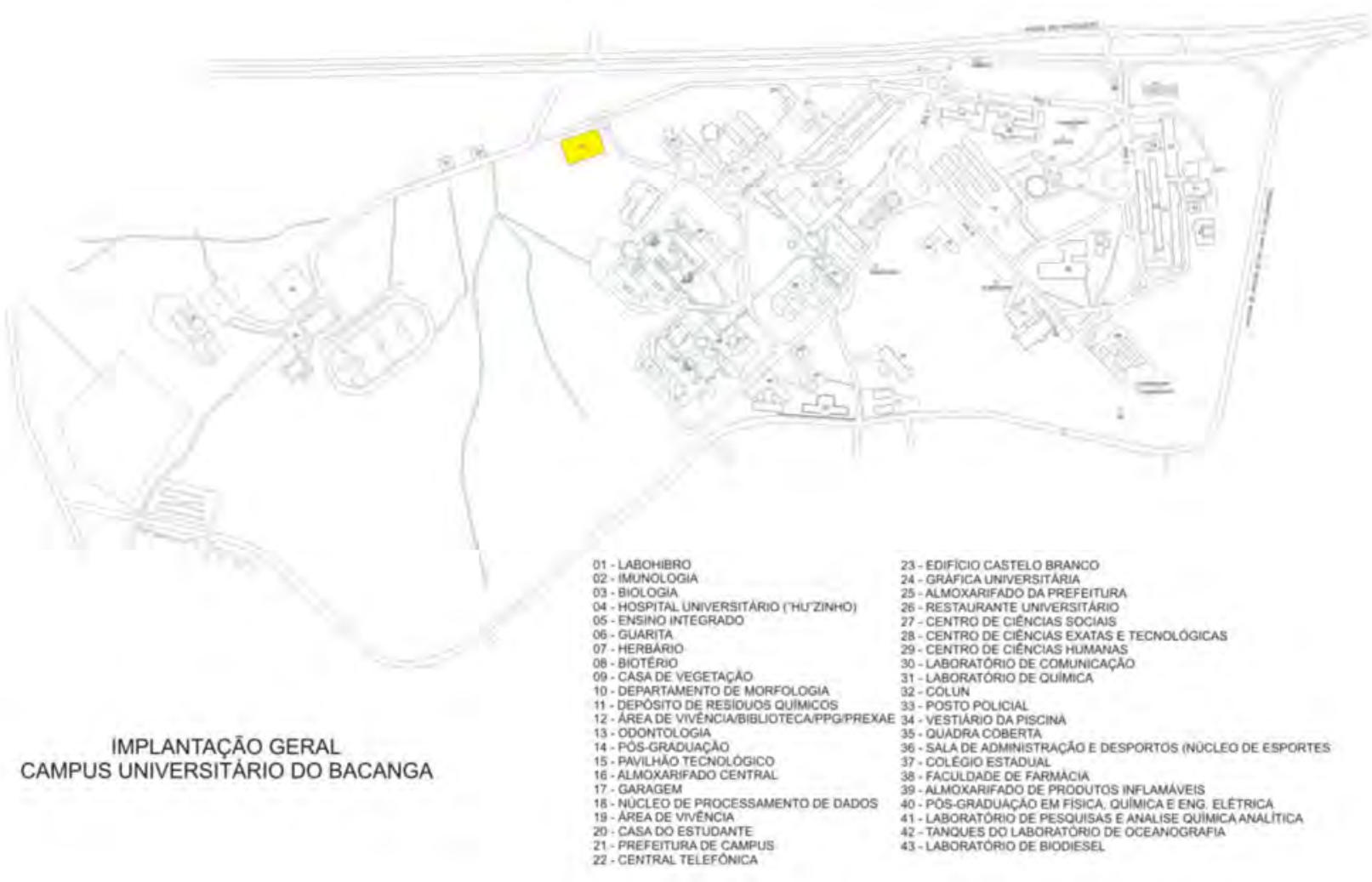

Figura 283: UFMA - Planta do Campus I - Bacanga - ano 2007.

Atualmente o Campus do Bacanga possui uma área aproximada de 110 ha.

(Fonte: UFMA, 2007) 


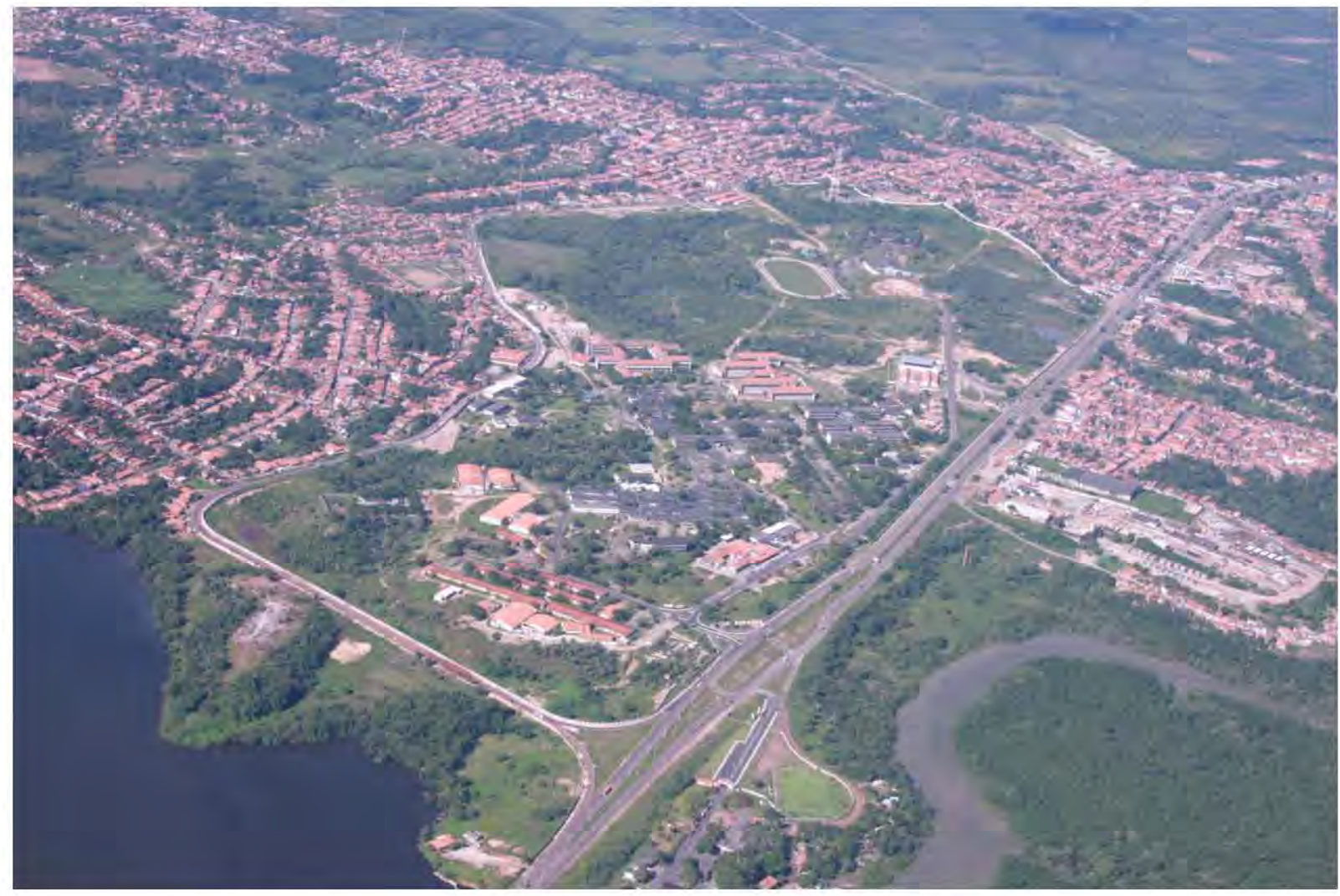

Figura 284: UFMA - Vista aérea do Campus I - Bacanga - ano 2009.

Ao centro encontra-se o Campus cercado pela construção do muro divisor, à direita margeado pelo eixo da BR-135, à esquerda a gleba encontra-se atualmente cercada por bairros residenciais de baixa renda.

(Fonte: Acervo Prefeitura do Campus)

\section{- Território da segregação}

A UFMA recebeu o apoio da Universidade de São Carlos (UFSCAR) que, por meio da sua Assessoria de Planejamento (ASPLAN) elaborou o plano de desenvolvimento físico para o Campus do Bacanga, dando origem ao documento intitulado Universidade Federal do Maranhão - Plano Físico (LUCUNI, [1980?]). Conforme se constata no seu detalhamento, as diretrizes formuladas indicavam a tentativa de superar o processo de loteamento do território que vinha se configurando com a fragmentação da departamentalização. O Plano Diretor Físico era parte da política do MEC adotada para liberação dos recursos financeiros com vistas ao desenvolvimento físico dos campi e a UFMA pleiteava a construção das instalações do Centro de Tecnologia, Centro de Ciências Humanas e Centro de Ciências da Saúde a serem instalados no Campus do Bacanga.

O estudo desenvolvido constatou inicialmente que a área urbanizada do Campus do Bacanga apresentava uma ocupação de configuração desordenada e o sistema viário evidenciava ser uma consequência da necessidade de articular os edifícios existentes, conforme se pode visualizar nas plantas das figuras 285 e 286 . A ocupação dispersa, na 
qual os prédios correspondiam rigidamente a departamentos isolados e separados por distâncias que reforçavam a segregação das atividades universitárias, era uma condição a ser superada. A concepção urbanística do Plano não foi implantada, porém as instalações para o Centro de Ciências Exatas e Tecnológicas e o Centro de Ciências Humanas foram construídas na década de $1980 \mathrm{com}$ base nos estudos tipológicos desenvolvidos pelo referido documento.

\section{- Plano Diretor Físico - final da década de 1970}

O Plano foi coordenado pelo arquiteto Hugo Camilo Lucini, que já vinha desenvolvendo estudos similares para outras universidades ${ }^{106}$, os quais apresentavam uma proposta que possibilitava a redução nos custos da construção por meio da administração direta do setor responsável pela infraestrutura física das instituições na execução das obras. Desse modo, era possivel montar o trinômio planejamento físico/ projeto/execução direta como alternativa para a produção do espaço físico.

O planejamento físico em estreito relacionamento com o planejamento acadêmico seria materializado por meio dos planos e projetos propostos e tinha a Reforma Universitária (1968) como balizadora das diretrizes adotadas. Nesse sentido, na estrutura do trabalho, expõe que a Reforma previa o desenvolvimento do campus universitário como o elemento integrador das atividades universitárias por meio da sua organização físico-espacial. Cabia ao projeto urbano-arquitetônico possibilitar e ampliar a trama das relações departamentais (LUCINI, [1980?], n.p.), garantindo o máximo possível de proximidade das áreas edificadas e a utilização efetiva dos seus equipamentos, criando perspectiva para eliminação da ociosidade e dirigida para a crescente elevação do rendimento dos recursos materiais disponíveis. Nesse sentido, o plano seria o elemento orientador e regulador do crescimento físico coerente da Universidade, o qual resultaria de uma correta relação entre necessidades e recursos disponíveis em função de uma política realista de implantação para o Campus.

O planejamento físico em estreito relacionamento com o planejamento acadêmico seria materializado por meio dos planos e projetos propostos e tinha a Reforma Universitária (1968) como balizadora das diretrizes adotadas. Nesse sentido, na estrutura do trabalho, expõe que a Reforma previa o desenvolvimento do campus universitário como o elemento integrador das atividades universitárias por meio da sua organização físico-espacial. Cabia

\footnotetext{
${ }^{106}$. O arquiteto Hugo Camilo Lucini já havia desenvolvido o projeto do Plano Diretor da Universidade Federal de São Carlos (SP), onde trabalhava como coordenador de desenvolvimento físico e estava finalizando o Plano Diretor da Universidade Federal do Acre. Lucini foi também solicitado a elaborar o plano da Universidade Federal de Alagoas, o que ocorreu quase que concomitantemente ao da UFMA. O arquiteto vinha desenvolvendo uma série de experiências e estudos sobre planejamento físico de campi, que se reverteram, através de convênios em propostas de Planos Diretores Físicos para várias Universidades
} (LUCINI, 1980, n.p.). 


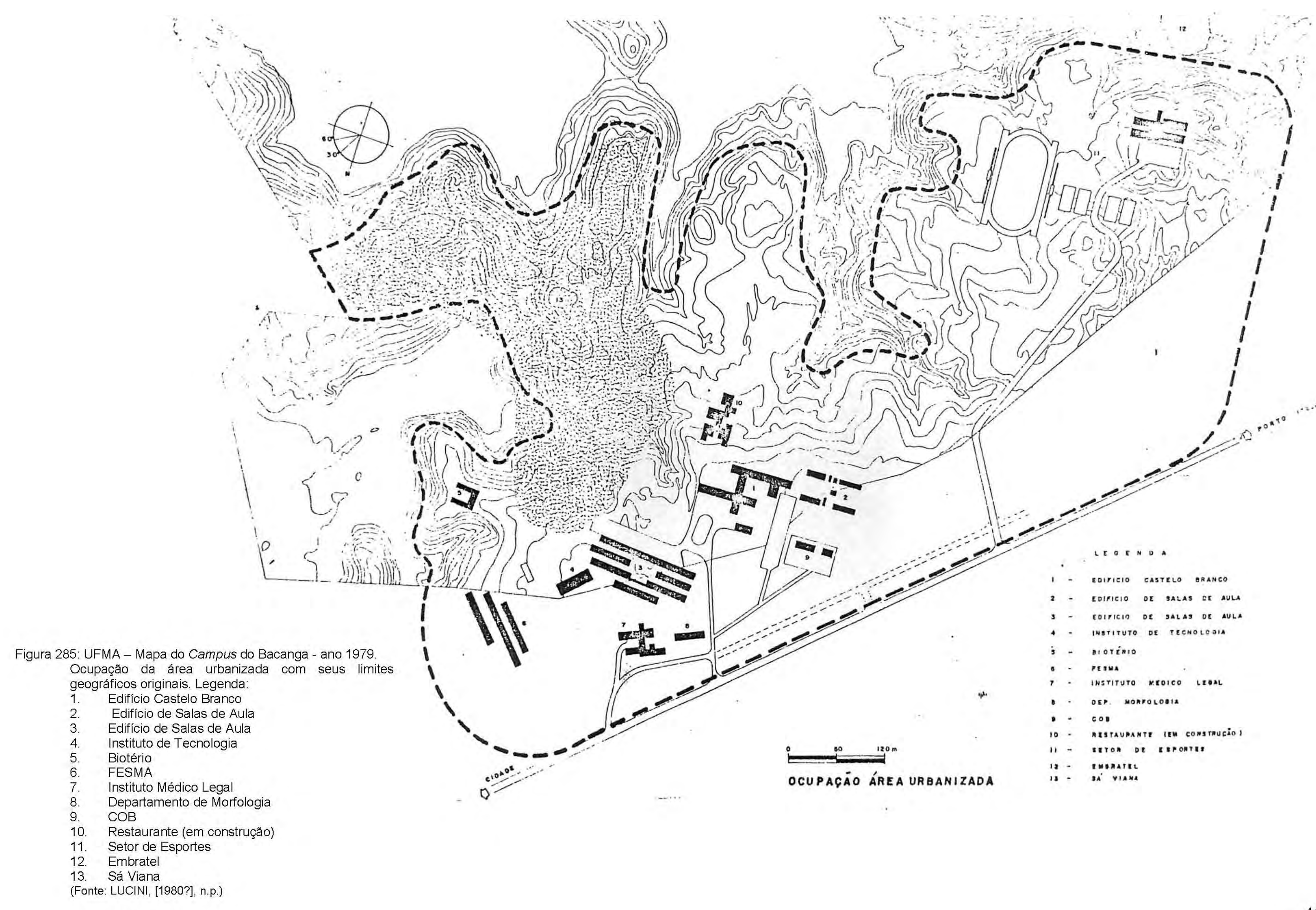




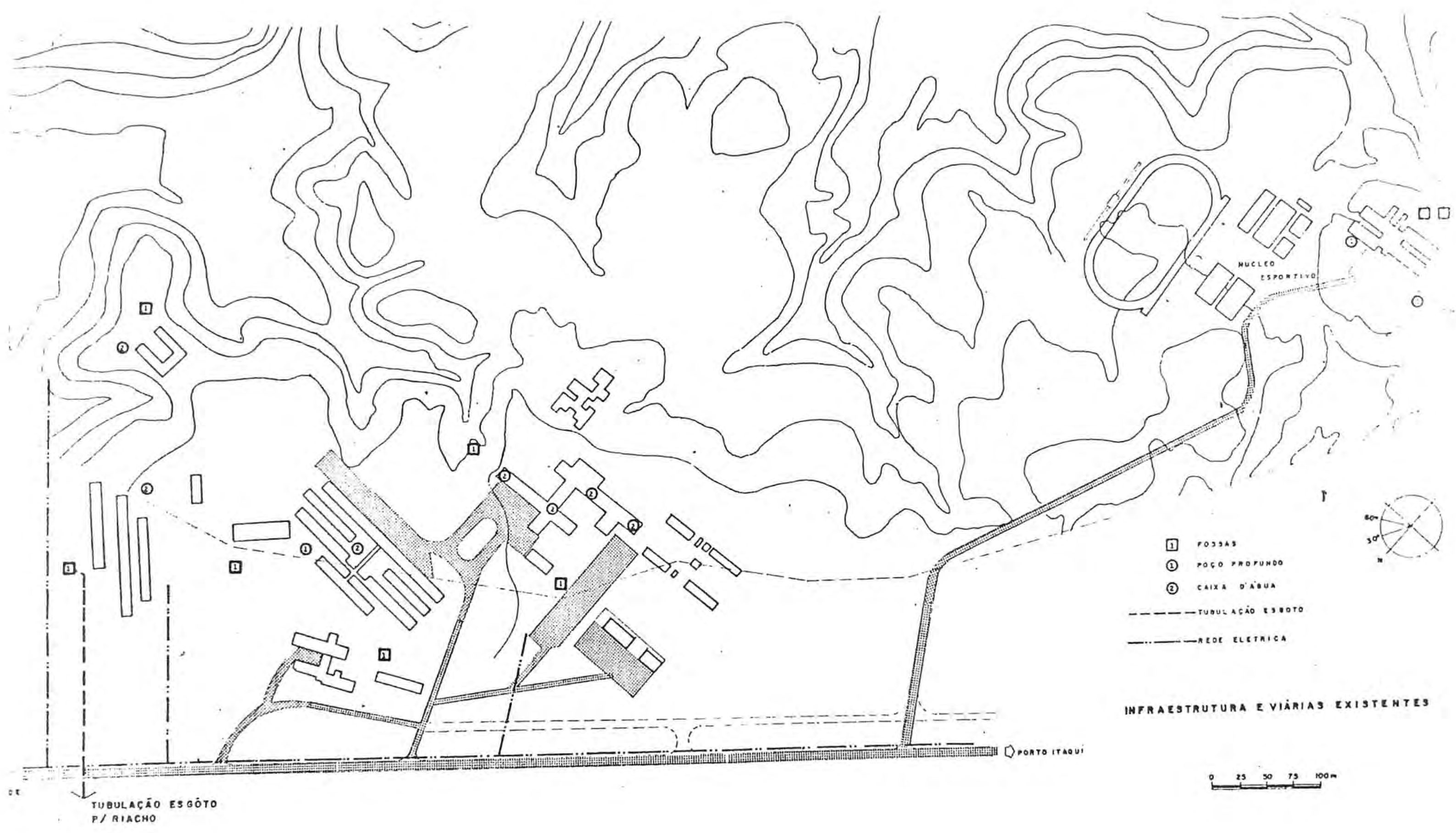

Figura 286: UFMA - Mapa do Campus do Bacanga - ano 1979. Sistema Viário Existente.
(Fonte: LUCINI, [1980?], n.p.) 
FOLHA VERSO DA FOLHA GRANDE - NÃO IMPRIMIR 
ao projeto urbano-arquitetônico possibilitar e ampliar a trama das relações departamentais (LUCINI, [1980?], n.p.), garantindo o máximo possível de proximidade das áreas edificadas e a utilização efetiva dos seus equipamentos, criando perspectiva para eliminação da ociosidade e dirigida para a crescente elevação do rendimento dos recursos materiais disponíveis.

Nesse sentido, o plano seria o elemento orientador e regulador do crescimento físico coerente da Universidade, o qual resultaria de uma correta relação entre necessidades e recursos disponíveis em função de uma política realista de implantação para o Campus.

O depoimento dado por Lucini revelou que o conceito de desenvolvimento físico formulado supunha estratégias que possibilitassem superar as contradições impostas pela Reforma, que propalava a integração como um objetivo a ser alcançado, mas que culminou com a segregação do território universitário. Nas suas palavras:

[...] levava implícita a tentativa de superar as diretrizes da Reforma de 68 [1968], no programa MEC-USAID. Mas na época era impossível deixar transparecer abertamente essas intenções. Então parti para metodologias complexas que permitissem garantir nos campi o que a Reforma não queria:

1. A inclusão urbana, através da própria estrutura urbanística do campus e seus vínculos com o entorno;

2. superar a fragmentação da departamentalização, através da inclusão de estudantes, professores, funcionários e comunidade, decorrente de um estudo bastante pormenorizado e atividades intra e extra curriculares, destino de áreas e algo pouco frequente que era a continuidade espaçoatividade-função no sistema de edifícios.

Daí que eliminei o conceito de campus como loteamento e posterior projeto individual de cada departamento, partindo para propor um sistema espacial / funcional contínuo que levava a transformar a universidade em um grande projeto por adição de partes dentro de um sistema estruturante integrador. O Plano Diretor final era realmente um projeto básico espacial e construtivo que transformávamos em maquete integral. Para a época, deixando de lado as ineficiências pessoais, ficava bastante interessante (informação verbal) ${ }^{107}$.

Com esse propósito, a estrutura do Plano se vale de um complexo processo de estudos e análises que envolvem questões sobre planejamento físico, produção do espaço físico

\footnotetext{
${ }^{107}$ Depoimento de Hugo Camilo Lucini. Mensagem recebida por hlucini@yahoo.com.br em 29 ago. 2011.
} 
universitário, estruturas funcionais, análise do sítio e situação, condições de produção e construção da região, quantificação e pré-dimensionamento do programa de necessidades, dentre outros, que se inter-relacionam, numa sistemática de retroalimentação, visando à espacialização do modelo urbanístico e das tipologias espacial-construtivas sintetizados no Plano Diretor (ver figura 287).

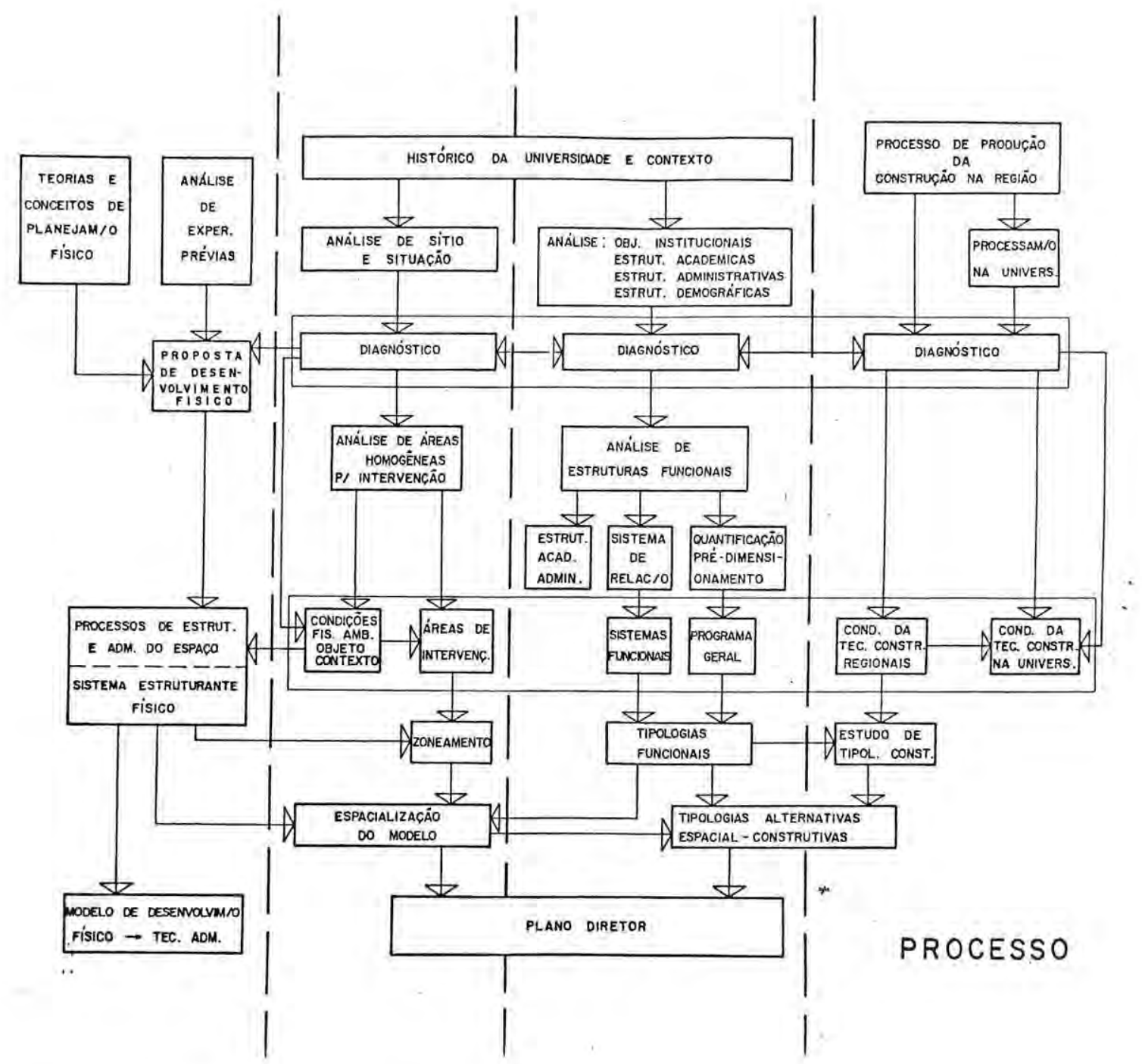

Figura 287: UFMA - Plano Diretor Físico.

Esquema do desenvolvimento físico do Plano

(Fonte: LUCINI, [1980?], n.p.)

\section{- Espacialização do modelo}

O Plano formula um modelo espacial baseado em uma trama constituída pelos eixos circulatórios de pedestres e de veículos e pela rede de infraestrutura física e instalações, identificada como sistema estruturante físico que, lançado sobre a área urbanizável do 
Campus, possibilitaria a integração das unidades (acadêmicas, administrativa e de serviços) organizadas segundo um zoneamento funcional. $O$ modelo permitia flexibilidade no desenvolvimento físico proporcionando o crescimento orgânico e ordenado do Campus em distintas direções, equilibrando as necessidades com os recursos disponíveis.

Dentro da trama de fluxos, o sistema circulatório de pedestres assume papel de relevância, identificado como o edificio distribuidor de pessoas e que sendo integrador e distribuidor, transformaria a Universidade num verdadeiro edificio aberto. Possibilitaria ao longo do seu desenvolvimento a implantação de distintas construções, permitindo o crescimento periférico da área urbanizada sem interferir nos núcleos já implantados.

O sistema viário, hierarquizado, seria o definidor das áreas destinadas aos estacionamentos e ao anel periférico, os quais seriam ajustados às características topográficas do terreno.

As áreas verdes, ao invés de espaços residuais externos à arquitetura, fariam parte da escala de valores do sistema organizativo, como elemento climatológico e vivencial.

As áreas de vivência integrariam o edifício distribuidor, promovendo espaços de intercâmbio sociocultural, que também poderiam se transformar em ambientes para diversas funções.

Ao final ter-se-ia uma rede flexível e integradora de relações entre os distintos setores da Universidade, tanto de atividades, como de suporte de atividades e programas, cujos subsistemas funcionais e de circulações, viários e de pedestres, conformariam o conjunto urbano-arquitetônico do Campus (ver figuras 288 e 289).

\section{- Tipologias Construtivas}

O Plano estabelece metodologia para definição de estruturas espaciais compostas de diferentes tipologias construtivas, que deveriam ter capacidade de acoplar-se corretamente ao sistema estruturante físico (trama urbana) com máxima flexibilidade e menor custo da obra.

A concepção tipológica é baseada numa malha modular de $1,20 \mathrm{~m} \times 1,20 \mathrm{~m}$ onde se desenvolvem as unidades funcionais definidas no programa de necessidades (salas de aula, laboratórios, auditório, gabinetes, salas administrativas, etc.) e que, conforme estudos de relações de interdependência são acopladas ao longo dos eixos de circulações abertas e/ou fechadas, conformando microestruturas funcionais (ex.: departamentos) que em conjunto compõem a macroestrutura arquitetônica (ex.; centros). 


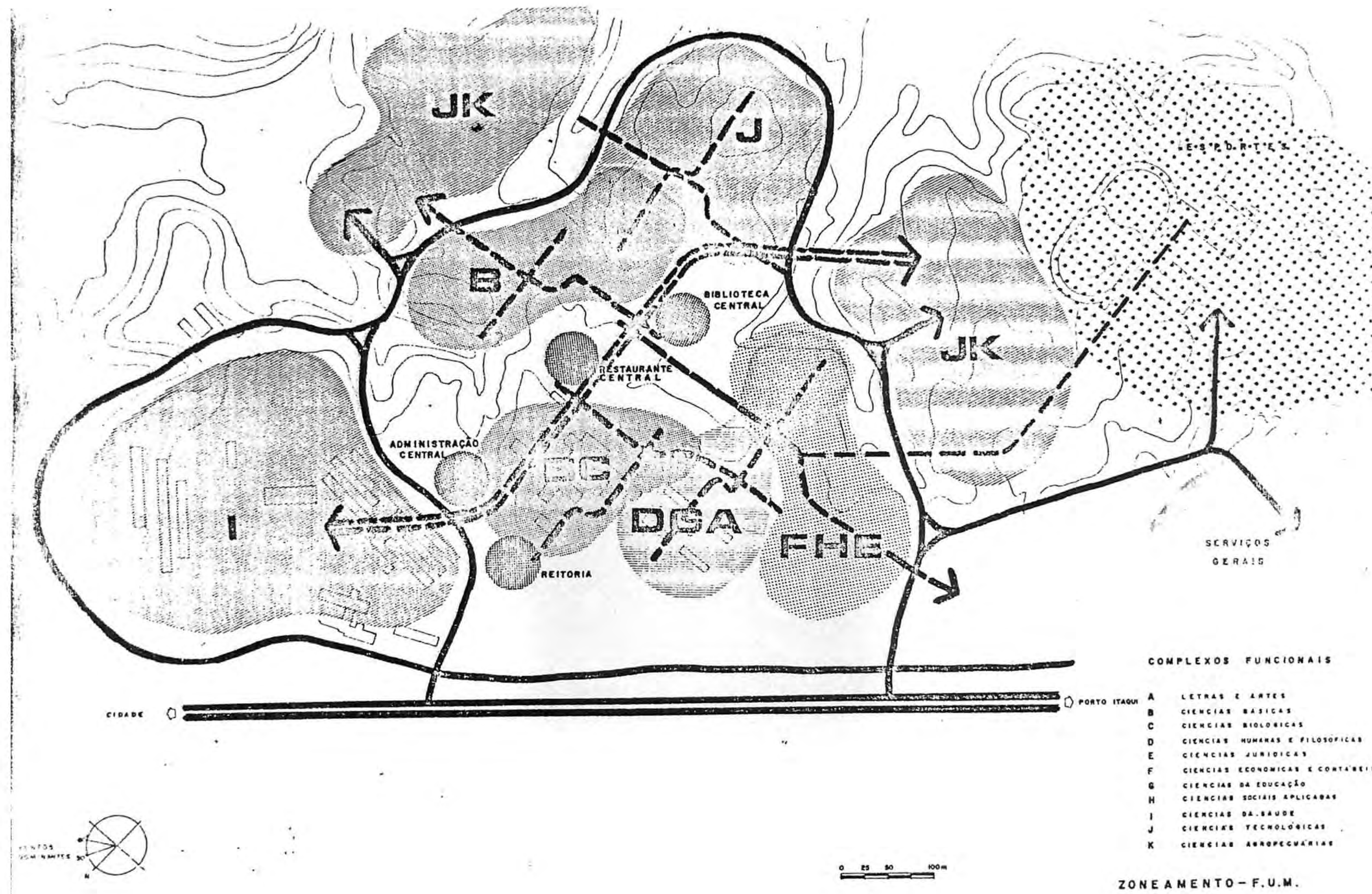




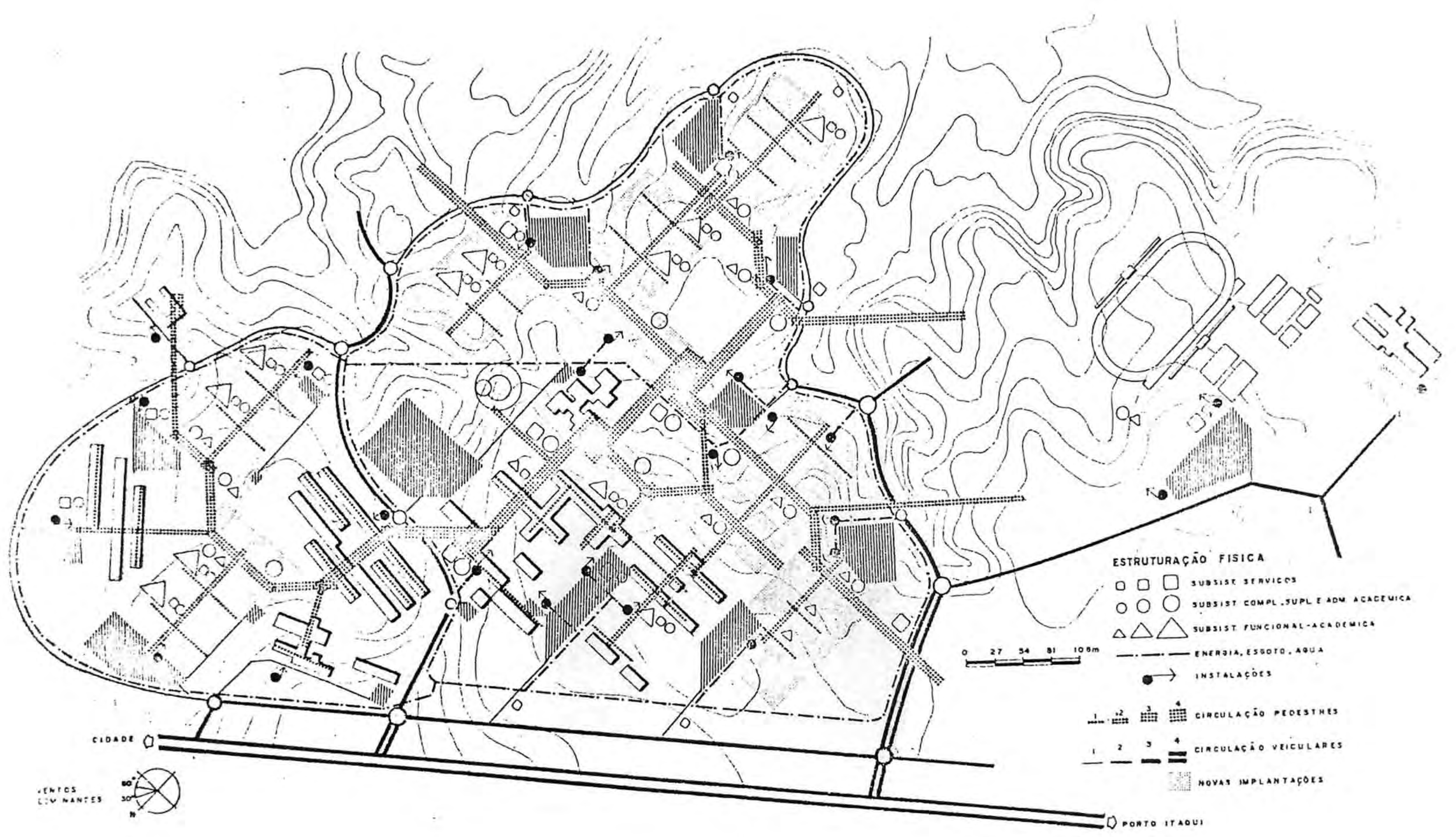

Figura 289: UFMA - Plano Diretor Físico - Modelo Espacial

Af un - Plano Diretor Físico - Modelo Espacial
(Fonte: LUCINII, [19800?], n.p.). 
FOLHA VERSO DA FOLHA GRANDE - NĀO IMPRIMIR 
A metodologia possibilitava o crescimento por etapas conforme as necessidades e disponibilidades dos recursos financeiros, resguardando os atributos arquitetônicos da tipologia construtiva proposta. Para isso, os sistemas construtivos contemplariam a capacidade de adaptação a diferentes condições de solos e terrenos e seriam produzidos ao nível de macromódulos interconectáveis através de espaços intermediários (eixos circulatórios), facilitando sua construção por etapas sem incidir no funcionamento total do conjunto (LUCINI, [1980?], n.p.).

Esses tipos poderiam ter distintas concepções arquitetônicas, segundo as diferentes condições e etapas de implantação da Universidade no tempo e no espaço. A proposta visava fundamentalmente produzir estruturas espaciais compostas de diferentes tipologias construtivas, mas corretamente inter-relacionadas com o desenvolvimento físico do sistema estruturante físico mencionado.

Com essa concepção, a UFMA construiu, na década de 1980, o Centro de Tecnologia e o Centro de Ciências Humanas ${ }^{108}$ (ver figuras 290 e 291). Entretanto, o modelo urbanístico, baseado no sistema estruturante físico não foi implantado. A ausência da malha constituída pelos fluxos de pedestres e sistema viário transformou as tipologias construtivas dos centros mencionados em estruturas espaciais dispersas, reforçando as evidências de Lucini (informação verbal) ${ }^{1}$. sobre o loteamento do Campus em função de um zoneamento preestabelecido, onde se destina cada lote a uma unidade acadêmica ou administrativa.

O conjunto arquitetônico concebido para os respectivos centros resultou em estruturas espaciais isoladas com as atividades enclausuradas por seus limites demarcados pela construção de muros de alvenaria (ver figuras 292 e 293). A proposta de construção por administração direta, também, não foi adotada como revela Lucini que

[... ] uma vez finalizado o Plano Diretor e começando a operar a estrutura de construção interna à Universidade, que era uma das nossas propostas para cortar drasticamente os custos de construção, a equipe [... foi desmontada e não se deu continuidade ao processo (informação verbal) ${ }^{109}$

\footnotetext{
${ }^{108}$ Os Centros foram construídos com recursos do Programa MEC BID III. Houve a proposição de construir também o Centro de Ciências da Saúde, porém, o MEC-PREMESU orientou para que as instalações daquele Centro fossem integradas ao projeto de recuperação da Praia Grande, bairro do Centro Histórico de São Luís. A ârea da saúde deveria ser implantada nos prédios onde anteriormente havia funcionado a Fábrica Cânhamo (MARQUES, In FARIA, 2005, p.281). Ao final, entretanto, os custos para reforma e adequação das instalações do Centro tornaram inviáveis a concretização desse projeto.

${ }^{109}$ Hugo Camilo Lucini. Mensagem recebida por hlucini@yahoo.com.brem 29 ago. 2011.
} 


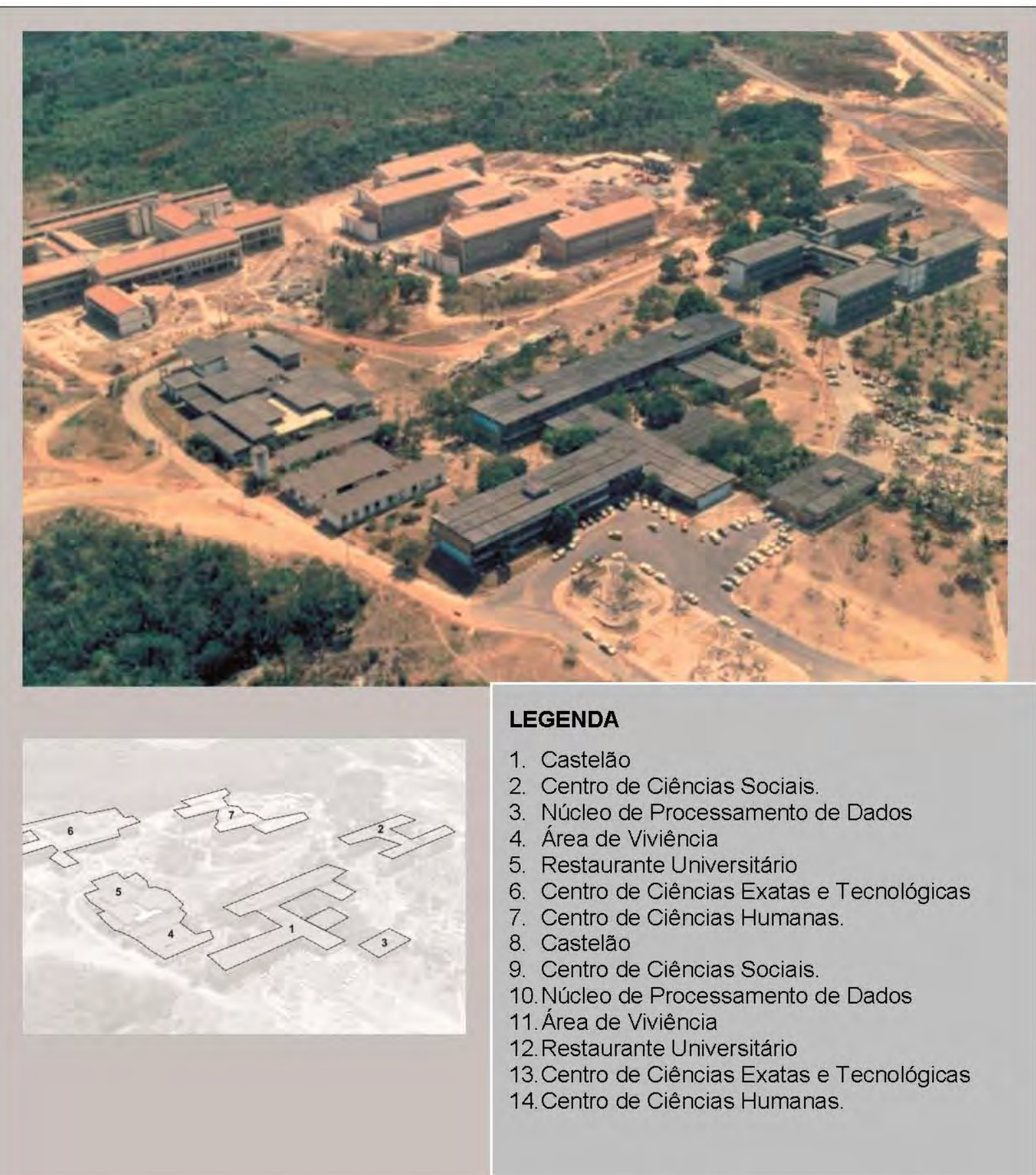

Figura 290: UFMA - Vista aérea do Campus do Bacanga. Estavam construídas as unidades, porém o sistema viário ainda permanecia indefinic
(Fonte: Acero Prefietura do Campus)

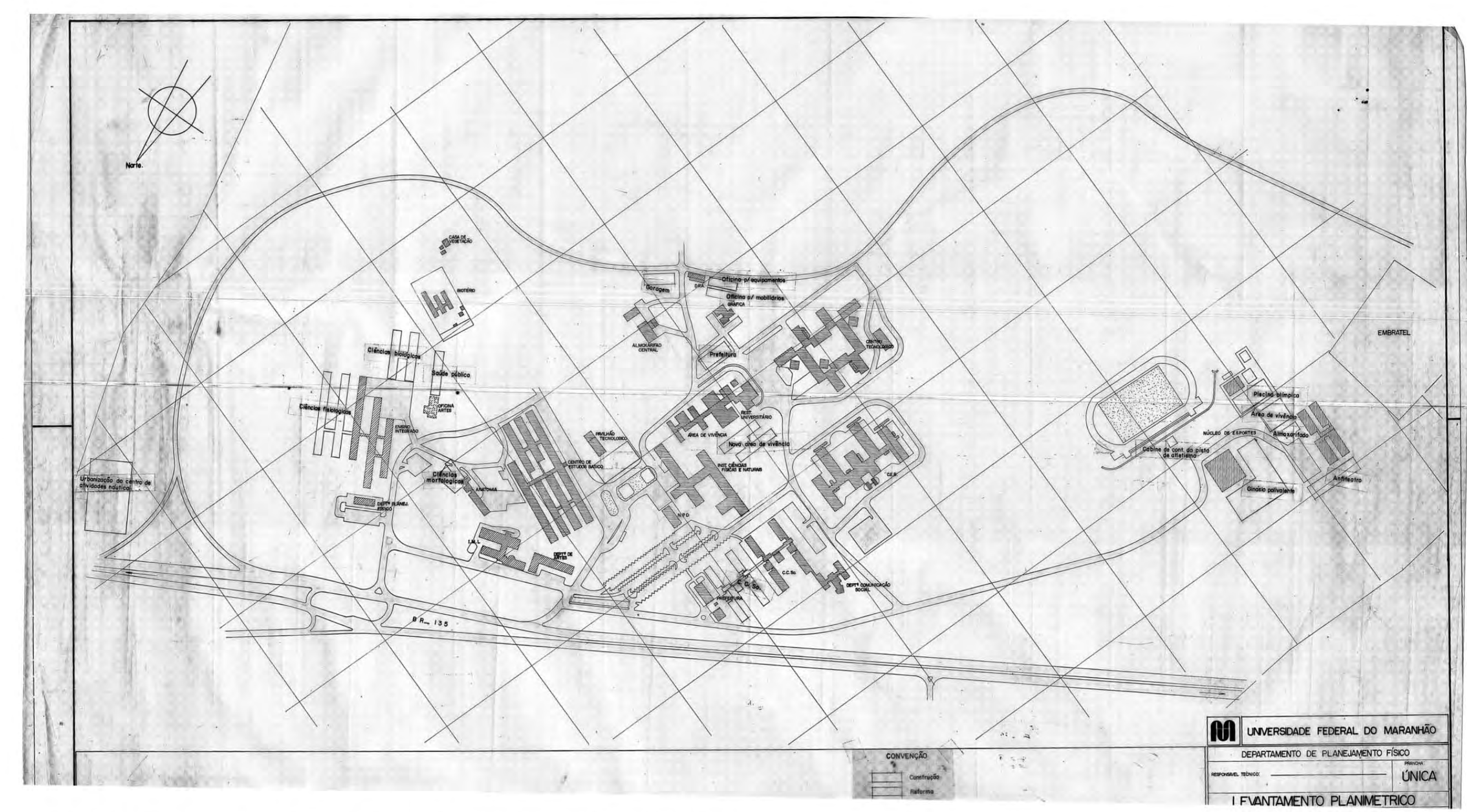

Figura 291: UFMA - Levantamento planialtimétrico do Campus do Bacanga - Década de 1980.
As unidades implantadas não estavam articuladas pelo sistema estruturador proposto pelo Plano. As unidades implantadas nao estavam
(Fonte: Acervo Prefeitura do Campus) 


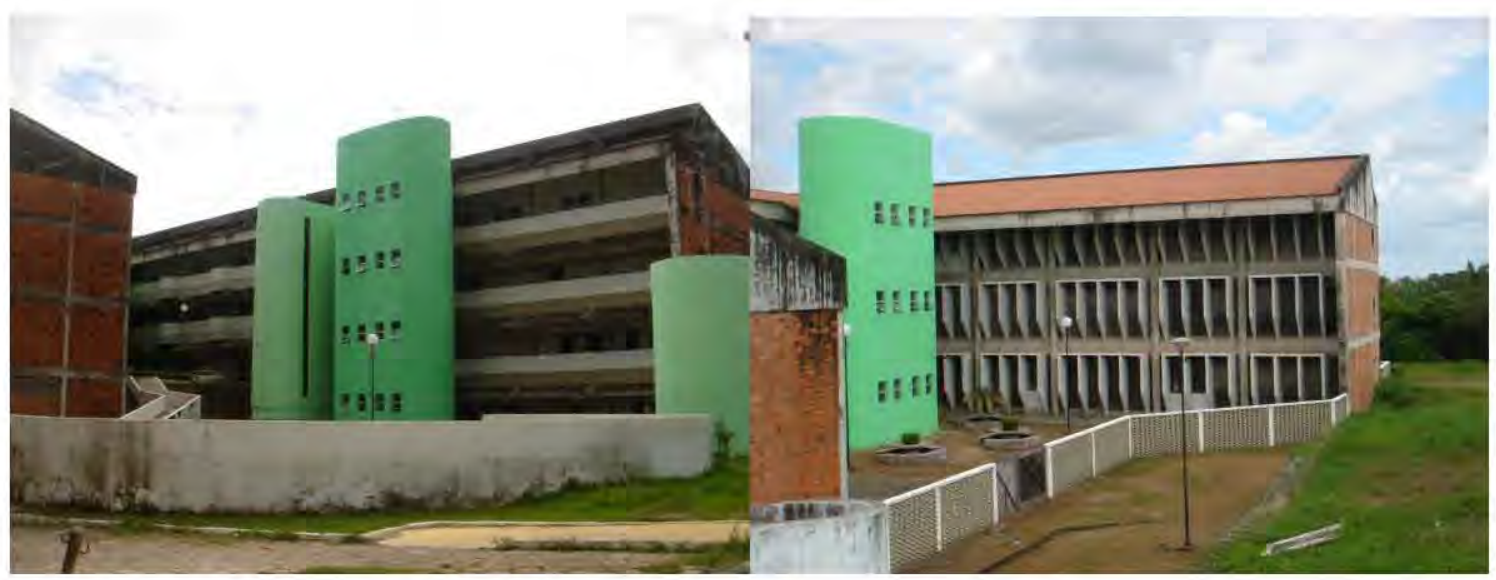

Figura 292: Centro de Ciências Humanas - 2009.

Tipologia construtiva para o $\mathrm{CCH}$ com base nos estudos tipológicos do Plano. Atualmente encontra-se isolada por muros divisores.

(Fonte: Acervo pessoal da autora)

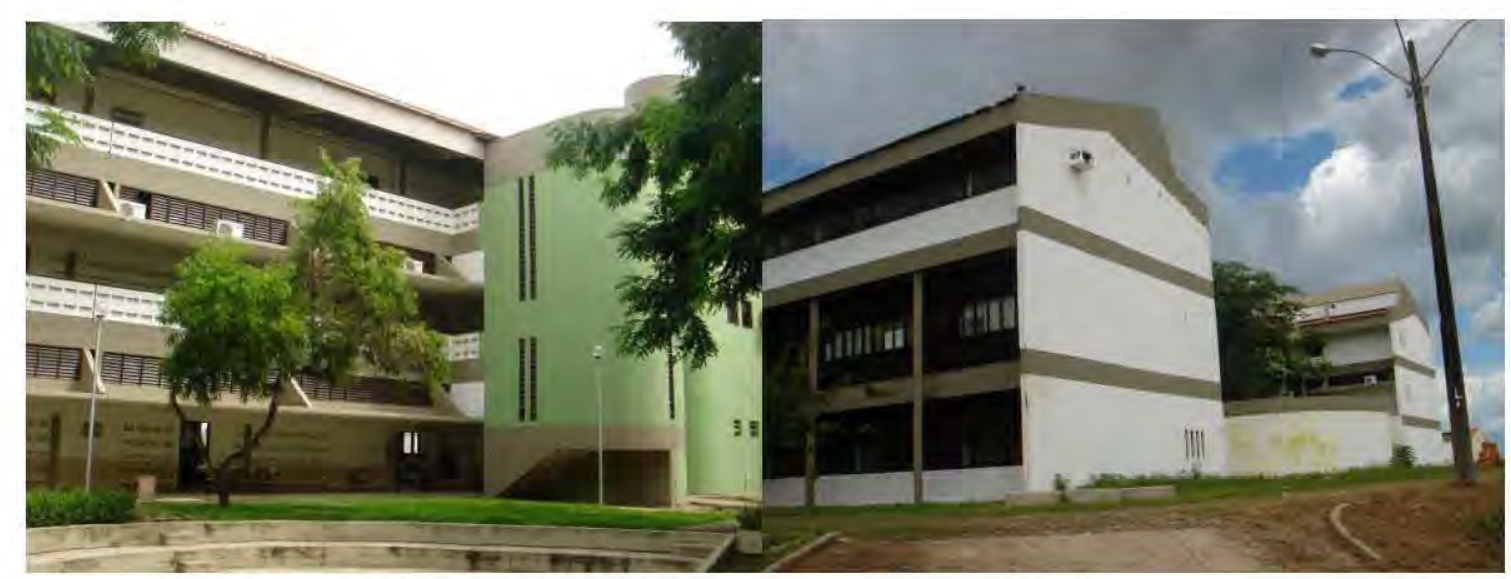

Figura 293: Centro de Ciências Exatas e Tecnológicas - 2009.

Tipologia construtiva para o CCET com base nos estudos tipológicos do Plano. Atualmente encontra-se isolada por muros divisores.

(Fonte: Acervo pessoal da autora)

A UFMA formulou em 2010 uma proposta preliminar de um novo plano diretor físico que se destina nortear a política de uso, ocupação, intervenção e conservação do espaço físico do Campus do Bacanga (UFMA, 2007, p.29-30). A organização espacial proposta é o resultado do redimensionamento da malha viária que articula um novo parcelamento da gleba do Campus, caracterizado pela ocupação dispersa (ver figura 294). A área física institucional do Bacanga se consolida como o território das atividades universitárias, porém sem ter atingido a integração dos espaços universitários propalados pela Reforma de1968, que pretendia no campus a materialização de complexos integrados. 


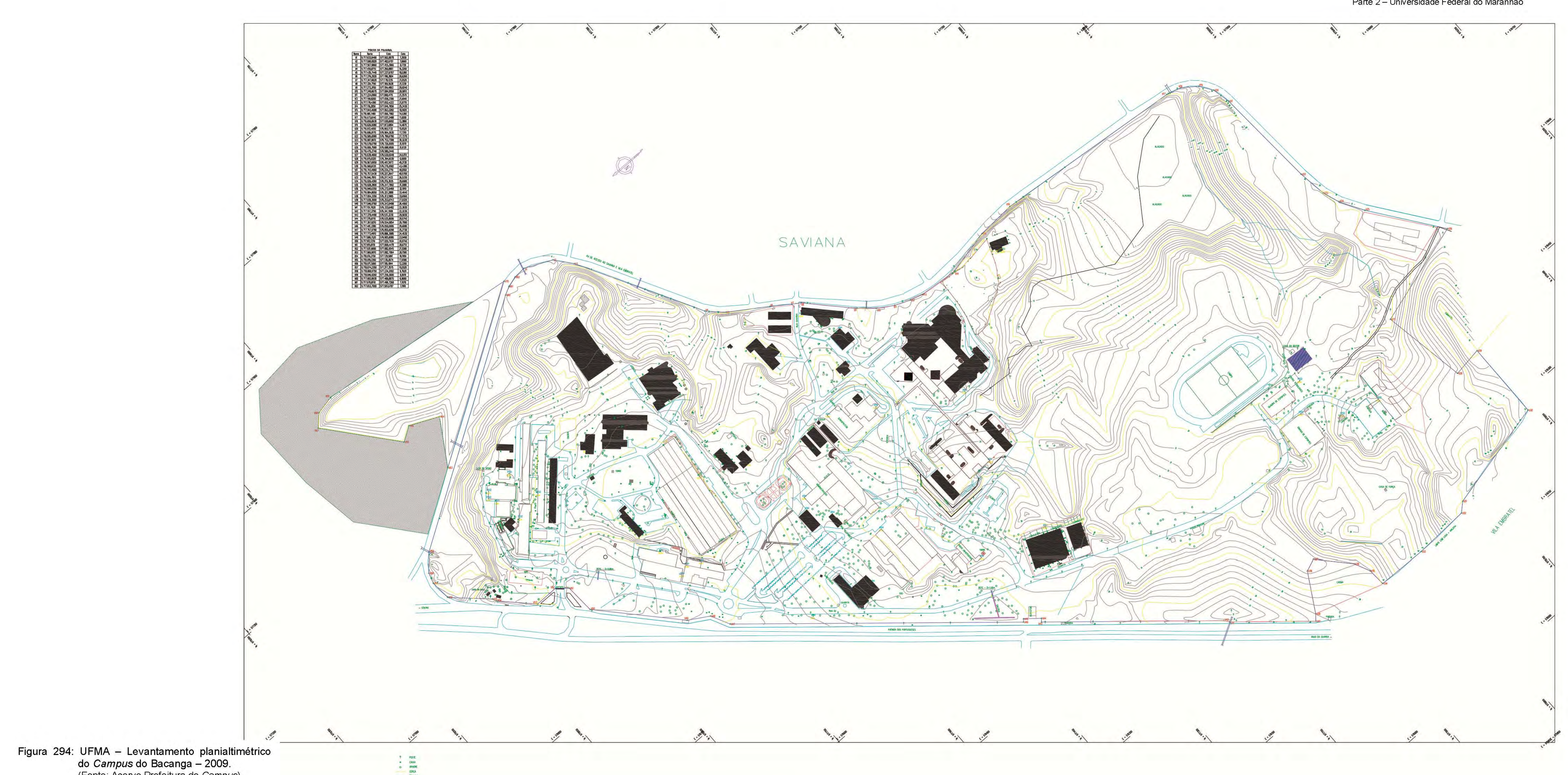




\subsection{CONSIDERAÇÕES}

Diferindo das demais universidades abordadas na presente pesquisa, a criação da Universidade Federal do Maranhão tem origem em uma instituição confessional, resultando da fusão da antiga Universidade Católica (1961) com as instituições isoladas federais Faculdade de Direito (1945) e a Escola de Farmácia e Odontologia (1945) - e uma particular, a Faculdade de Ciências Econômicas (1965). Instituída pelo Governo Federal em regime de Fundação foi criada pela Lei $n^{\circ} 5.152$, de 21 de outubro de 1966.

A Fundação Universidade do Maranhão nasceu e cresceu com a Reforma Universitária. De imediato recebeu o impacto dos Decretos-leis $n^{\text {os }} 53 / 1966$ e 252/1967 que reformularam a universidade brasileira em seus aspectos didáticos e administrativos. Logo em 1967, tratou de delinear sua estrutura organizacional atendendo à nova orientação acadêmica baseada na departamentalização do ensino, organizando-se em ensino básico - criou quatro Institutos Centrais comuns às áreas diferenciadas do conhecimento - e em ensino profissionalizante por meio de onze Faculdades, além de sete Órgãos Suplementares. 0 plano de reestruturação encaminhado ao Conselho Federal de Educação não recebeu, entretanto, aprovação imediata, o que impediu de colocá-lo em prática no ano seguinte.

A promulgação da Lei $n^{\circ} 5.540$, em 1968, motivou então a Administração Superior a contratar os serviços do escritório carioca Maximus de Estudos Econômicos e Contábeis Ltda., para montar a estrutura administrativa da Universidade voltada para a implantação dos princípios e normas emanados pela referida lei.

Em 1970, com seu estatuto a FUM implantou a Reforma Universitária com o agrupamento inicial dos Departamentos em Unidades de Institutos e Faculdades. Essa organização, entretanto, foi aceita como uma etapa de transição entre a velha estrutura universitária, baseada na cátedra, e a do Sistema Departamental, tendendo a desaparecer à medida que os Centros estivessem consolidados. Não havia dúvidas que o complexo acadêmico, a ser formado por Centros e Departamentos, era fator primordial para o desenvolvimento da Universidade.

Em 1973, entretanto, a Reforma Universitária iniciada em 1970 ainda não havia atingido seus objetivos. A modificação principal, que consistia na extinção dos Institutos e Faculdades, para fazer surgir a estrutura formada por Cursos e Departamentos, vinculados aos Centros, ainda era um projeto a ser efetivado. Esperava-se que até 1975 estaria em funcionamento o novo modelo acadêmico constituído pelo Sistema Básico - composto pelos Centros de Ciências Biológicas, de Ciências Humanas e Letras e de Ciências Exatas - e 
pelo Sistema Profissional - constituído pelos Centros de Educação, de Ciências de Saúde, de Ciências Sociais e Tecnológico.

Nesse ínterim a construção do território da Universidade era também um processo de formação gradativo objetivando dar corpo à nova estrutura. Foram tomadas providências para a construção do Campus Universitário no Sítio Sá Viana, uma gleba de 217 ha, às margens do Rio Bacanga, área afastada do centro urbano, doada à FUM para esse propósito. O campus era entendido como fator estratégico para concretização da Reforma. A origem confessional da UFMA refletia na convicção de uma nova Universidade, comprometida com a filosofia da formação integral do homem, com as funções básicas de ensino, pesquisa e extensão e com seu papel no desenvolvimento do Maranhão.

A concretização do território periférico da UFMA no modelo espacial da Reforma foi favorecida pelo plano de expansão do governo do Estado para a cidade de São Luís, que incluiu a construção da barragem do Bacanga, na segunda metade da década de 1960 , efetivando o eixo viário São Francisco-Bacanga-Itaqui e assim permitindo a travessia sobre o rio que separava o Sítio Sá Viana da zona urbana. A localização às margens do lago artificial criado pela barragem deu origem ao nome de Campus do Bacanga.

Foi então contratado o escritório do arquiteto Wit-Olaf Prochnik, com sede no Rio de Janeiro, para empreender os estudos e projetos com vistas à construção do futuro campus, visto que a empresa já se encontrava trabalhando no referido plano de expansão da cidade. A Wit-Olaf Prochnik - Arquitetura e Planejamento, com base no estatuto de 1970, elaborou um plano de desenvolvimento físico cuja organização espacial estabelecia um zoneamento funcional de nove setores destinados às futuras unidades acadêmicas.

A configuração urbanística proposta mantinha os princípios do planejamento racional moderno que vinha sendo implantado nas universidades brasileiras com as zonas funcionais articuladas por um sistema viário hierarquizado. O Campus estava envolvido por uma via de circulação periférica, assemelhando-se ao "anel protetor" recomendado por Atcon (1970), e com a formação de bolsões de estacionamento, isolando o percurso dos pedestres.

A Universidade, que até então mantinha o funcionamento das suas atividades exclusivamente em antigos sobrados de origem colonial situados no centro histórico de São Luís, inaugurou a primeira unidade do Campus em 1972 com a construção do Instituto de Ciências Físicas e Naturais, de autoria de Prochnik. O edifício adota o partido da modulação com a padronização construtiva. A planta livre organiza o programa na malha modular de $1,25 \times 1,25 \mathrm{~m}$, configurando um conjunto volumétrico que se expande em várias direções. $A$ proposta evidencia o propósito de permitir a expansão e as mudanças constantes sem mutilar os atributos arquitetônicos do edifício. $O$ partido construtivo enfatiza 0 concreto 
aparente. Mantendo a postura de respeito aos condicionantes climáticos e elementos construtivos locais, o arquiteto produz um edifício que se insere no panorama da boa arquitetura brasileira.

Prochnik elaborou outros estudos para o Campus, porém na segunda metade da década de 1970, uma produção de autoria dos profissionais pertencentes ao escritório técnico da Universidade passou a compor o patrimônio edificado da UFMA. O partido adotado nessas unidades incorpora os princípios da modulação, da padronização e da ênfase ao concreto aparente. $O$ resultado formal, entretanto, afasta-se da qualidade arquitetônica desenvolvida pelo escritório do Rio de Janeiro.

Em meados da década de 1970, a determinação de consolidar o território unificado da UFMA era um processo incipiente, com várias unidades ainda funcionando no centro da cidade de São Luís e o território periférico padecia do conflito de ter sua área de ocupação reduzida em decorrência da gradativa invasão por comunidades carentes. A paulatina ocupação do Sítio Sá Viana por populações de baixa renda nas circunvizinhanças do Campus culminou com a redução da sua área inicial, resultando na configuração física atual do Campus do Bacanga.

No final da década de 1970, o território da Reforma construído pela UFMA era uma tipologia espacial caracterizada pela segregação das atividades universitárias. A configuração urbanística implantada resultava da dispersão das Unidades construídas e ausente da conformação de um sistema viário estruturador. Com essa constatação a Universidade recebeu o apoio da UFSCAR para elaborar um plano de desenvolvimento físico que propiciasse 0 crescimento do Campus em sintonia com o planejamento acadêmico e superasse a condição desagregadora das suas unidades.

O Plano de autoria do arquiteto Hugo Camilo Lucini propunha um modelo espacial baseado em uma malha constituída por circulações (de veículos e pedestres) e redes de infraestrutura que se desenvolve gradativamente sobre o terreno, conforme a construção de novas unidades. Dentro da trama de fluxos, o sistema circulatório de pedestres age como elemento estruturador que articula a integração das unidades, transformando a Universidade num verdadeiro edifício aberto. Ao final, supunha-se que seria formada uma rede flexível e integradora de relações entre os distintos setores da Universidade, tanto de atividades, como de suporte de atividades e programas, cujas zonas funcionais e de circulações viárias e de pedestres - conformariam o conjunto urbano-arquitetônico do Campus.

São diretrizes para tipologias construtivas baseadas na malha modular de $1,20 \mathrm{~m} \times 1,20 \mathrm{~m}$ e com a orientação de sistemas construtivos que possibilitem o crescimento do conjunto, resguardando os atributos arquitetônicos da tipologia proposta. Esses tipos poderiam ter 
distintas concepções arquitetônicas, segundo as diferentes condições e etapas de implantação da Universidade no tempo e no espaço. Com essa orientação foram construídos os Centros de Ciências Exatas e Tecnológicas e o de Ciências Humanas, porém não foi concretizado o sistema circulatório de pedestres que funcionaria como elemento integrador, resultando em tipologias cercadas por muros divisórios, que reforçam a segregação da estrutura acadêmica da UFMA.

O Campus do Bacanga se consolidou como o território das atividades universitárias, porém sem ter atingido a integração almejada para os espaços universitários propalados pela Reforma de 1968, os quais conformariam o campus como complexos integrados.

O campus é hoje parte da estrutura urbana, em função da expansão de São Luís. A localização, entretanto, ainda se configura como afastado do centro da cidade. Mantem sua característica de território isolado voltado para dentro dos seus limites fronteiriços. 


\section{UNIVERSIDADE FEDERAL DE SERGIPE (UFS)}

A Universidade Federal de Sergipe é instituição oficial de ensino superior, estabelecida sob a forma de fundação de direito público, mantida pela União e vinculada ao Ministério da Educação. Atua em várias regiões do Estado com a seguinte estrutura: Campus da Cidade Universitária Prof. José Aloísio Campos (que sedia a Administração Superior) no município de São Cristóvão, Campus Rural, no Povoado Quissamã, também nessa cidade, com os setores de medicina veterinária e agronomia; Campus da Saúde, localizado no bairro Sanatório, na Grande Aracaju, denominado oficialmente por Campus Universitário da Saúde Dr. João Cardoso Nascimento Júnior, onde fica o Hospital Universitário; Campus de Laranjeiras, no município do mesmo nome, construído em área tombada pelo IPHAN, onde funciona o Curso de Arquitetura e o Campus de Lagarto, também no município do mesmo nome, voltado para o Centro de Ciências da Saúde. Possui também as seguintes unidades dispersas: em Aracaju, o Museu do Homem Sergipano, o Centro de Cultura e Arte (CULTART) e o Serviço de Psicologia Aplicada (SPA) da Estação UFS e em Canindé do São Francisco, o Museu de Xingó (ver figura 295).

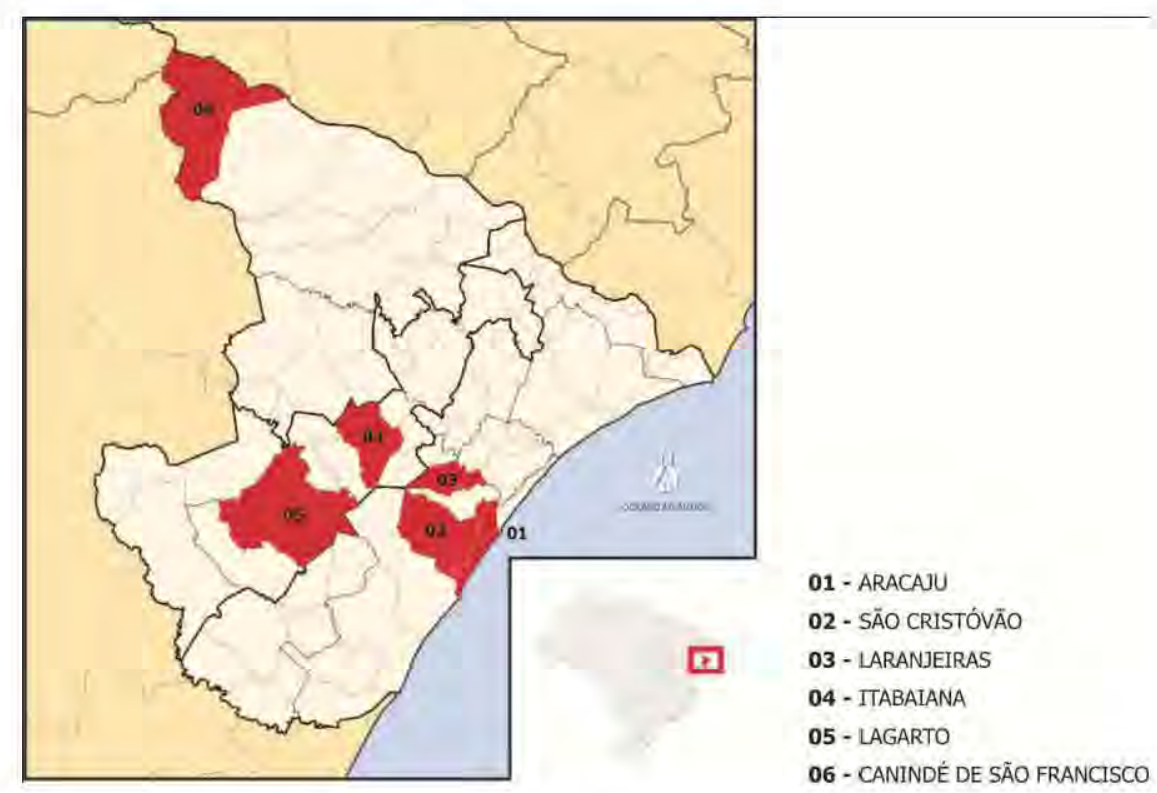

Figura 295: UFS - Mapa de Sergipe. Localização dos municípios que sediam a UFS, (Fonte: disponivel em: < http://pt.wikipedia.org/wiki/Anexo:Lista_de_ munic\%C3\%ADpios_de_Sergipe > Acesso em: 01 fev. 2012). 


\subsection{CRIAÇÃO DA UFS}

A história da Universidade Federal de Sergipe remonta ao processo de implantação do ensino superior iniciado na década de 1920 , quando, numa tentativa frustrada, o governo do Estado criou os cursos de Direito, Odontologia e Farmácia, mas que não chegaram a funcionar.

No final da década de 1940 , em uma nova iniciativa do governo estadual, foram instalados os primeiros cursos superiores com a criação das Escolas de Ciências Econômicas, em 1948, e de Química, em 1950. Em 1951, surgiram as Faculdades de Direito e a Católica de Filosofia, esta última por iniciativa da Arquidiocese de Aracaju (UFS, 1980, p. 3).

Em 1954, a Congregação das Irmãs de Jesus Crucificado, com o auxílio do governo do Estado, criou a Escola do Serviço Social e, em 1961, foi a vez da Faculdade de Ciências Médicas. Completava-se então o número de escolas superiores, necessário para se pleitear a criação de uma Universidade em Sergipe (UFS, 1980, p.3).

A partir daí, em 1963, a Secretaria de Educação do Estado desencadeou o processo, que culminou com a criação da Universidade sob a forma de fundação, nos termos do Decretolei $n^{\circ} 269$, de 28 de fevereiro de 1967, com sede e foro na cidade de Aracaju, capital do Estado, e hoje sediada no Campus do município de São Cristóvão. A instalação ocorreu em 15 de maio de 1968, com a incorporação das seis unidades de ensino superior. Os Anais Científicos da UFS (1972) destacam que nascida sob o signo da Reforma Universitária, a UFS

[...] tratou logo de organizar um sistema integrado de vida universitária, entrosando as Unidades de ensino então existentes e atomizadas, reestruturando-as, criando outras para melhor atender à diversificação dos cursos, instituindo outros órgãos na área acadêmica e administrativa, dinamizando as matrículas, iniciando enfim uma série de providências para se dar condições de crescimento nas linhas da reforma universitária, sob cuja égide ela nascera (UFS, 1972, p. 6, grifo nosso).

A Universidade conformou sua estrutura acadêmica, a partir do desdobramento das instituições de ensino que Ihe deram origem (Escolas Superiores e Faculdades), passando a ser constituída por cinco Faculdades e cinco Institutos. As unidades criadas atendiam a duas áreas de conhecimento afins: de Humanidades (ministrada nas Faculdades de Ciências Econômicas, de Direito, de Educação e de Serviço Social e nos Institutos de Filosofia e Ciências Humanas e no de Letras, Artes e Comunicação) e de Ciências Exatas e 
Naturais (ministrada na Faculdade de Ciências Médicas e os Institutos de Biologia, de Química e de Matemática e Física). Cada área tinha um Centro de Coordenação, dirigido por um coordenador. Às Faculdades caberia ministrar os cursos de graduação profissional e aos Institutos, o ensino e a pesquisa em determinada área fundamental.

Para atender à orientação preconizada pela Reforma, a Universidade procurou também, quando da sua instalação, contatos com firmas especializadas para a organização da estrutura administrativa, dentro dos padrões de ensino que se implantava naquele período (PINTO, 2004, p. 195). Tomou ainda providências para capacitar o corpo técnico administrativo, contando com o patrocínio do Conselho de Reitores das Universidades Brasileiras.

Sobre este aspecto Os Anais Científicos da UFS (1972) exaltam que:

[...] com os primeiros passos da reforma universitária, a Universidade Federal de Sergipe surgia trazendo o compromisso básico de aplicá-la o mais brevemente possível. Seus dirigentes compreenderam muito bem este compromisso e nas providências tomadas desde o início, foram armando paulatinamente um dispositivo capaz de executar de maneira adequada e sistemática os planos e programas reformistas que, no seu tempo, deveriam ir sendo introduzidos (UFS, 1972, p. 36, grifo nosso).

De fato a formulação dos seus Estatutos evidencia esse compromisso, incluindo pontos básicos sintonizados com as diretrizes da Reforma, que expressava a necessidade de adequar a Universidade com o desenvolvimento econômico, social e cultural do País e especialmente da Região e do Estado. Mais do que isso, os princípios específicos da Reforma, estavam consagrados em capítulos que especificavam:

a. Criação dos Institutos Básicos, distribuídos nas duas Áreas de Conhecimento;

b. Organização dos Departamentos e criação dos Conselhos Departamentais;

c. Instituição do Primeiro Ciclo de Ensino e Sistema de Créditos.

Com este arcabouço jurídico-acadêmico a Universidade oficializava o compromisso de caminhar para a Reforma. Os Institutos eram entendidos como um passo significativo, pois permitiriam dividir o ensino em duas etapas, sendo uma introdutória, destinada a fornecer ao alunato um preparo intelectual e científico básico, e outra que visava o campo profissional. Com a nova filosofia foram criados os cinco institutos, já citados, os quais foram passando por transformações que culminaram com a extinção, dando lugar aos Departamentos agregados aos Centros. 
A departamentalização das Unidades, embora aprovada em 1969, não aconteceu a um só tempo em todas as Unidades, mas gradativamente conforme a estruturação dos currículos dos diversos cursos, sendo efetivamente consolidada em 1979, quando a Estrutura Departamental foi instituída legalmente no Anexo I do Regimento Geral (RGU).

A Universidade recém-criada não perdia o foco de ajustar-se aos padrões ditados pela Reforma. A criação de novos cursos e a expansão da matrícula estavam associados à meta de minimização de custos e aumento da eficiência operacional, e eram discutidas ações para efetivar a integração entre o ensino, a pesquisa e a extensão ${ }^{110}$.

A compatibilização da estrutura reformista com a organização espacial de campus universitário embora tenha sido tentada nos primeiros anos da sua criação não foi premissa prioritária. Na contramão desse propósito empreendeu ações para ampliação da capacidade instalada implantada em zona urbana consolidada.

\subsection{TENTATIVA DE CONSTRUÇÃO DO TERRITÓRIO}

Seguindo o paradigma adotado na criação de outras universidades brasileiras congêneres, que se deu pela reunião de estabelecimentos profissionais existentes, a estruturação espacial da UFS caracterizou-se no primeiro momento pelo funcionamento das unidades isoladas, em edificações urbanas dispersas.

A partir da reestruturação acadêmica, com a criação dos Institutos e Faculdades, agrupados nas duas áreas de conhecimento afins, a UFS atuou na tentativa de materializar a sua base física em edificações situadas em quarteirões próximos, integrados à malha urbana da cidade, contrariando a orientação da Reforma de consolidar essa estrutura em base unificada e isolada das funções urbanas, constituindo o campus universitário, o que só veio a ocorrer na década seguinte da sua fundação (ver figura 296).

Com a organização espacial urbana, a Universidade abrangia, naquele período, uma área física total de $26.881,94 \mathrm{~m}^{2}$, sendo que $72 \%\left(19.285,40 \mathrm{~m}^{2}\right)$ correspondiam aos dois grandes núcleos acadêmicos (Área de Humanidades e Área de Ciências Exatas) que distavam entre si cerca de $400 \mathrm{~m}$. Fora daqueles dois grandes conjuntos ficavam a Reitoria e outras Unidades, dentre elas a Faculdade de Direito e a Faculdade de Ciências Médicas.

\footnotetext{
${ }^{110}$ Mais dados específicos sobre as ações empreendidas pela UFS, visando à integração universitária estão documentada na Tese de Doutoramento de Zenilde Soares Pinto (2004, p.198-200).
} 


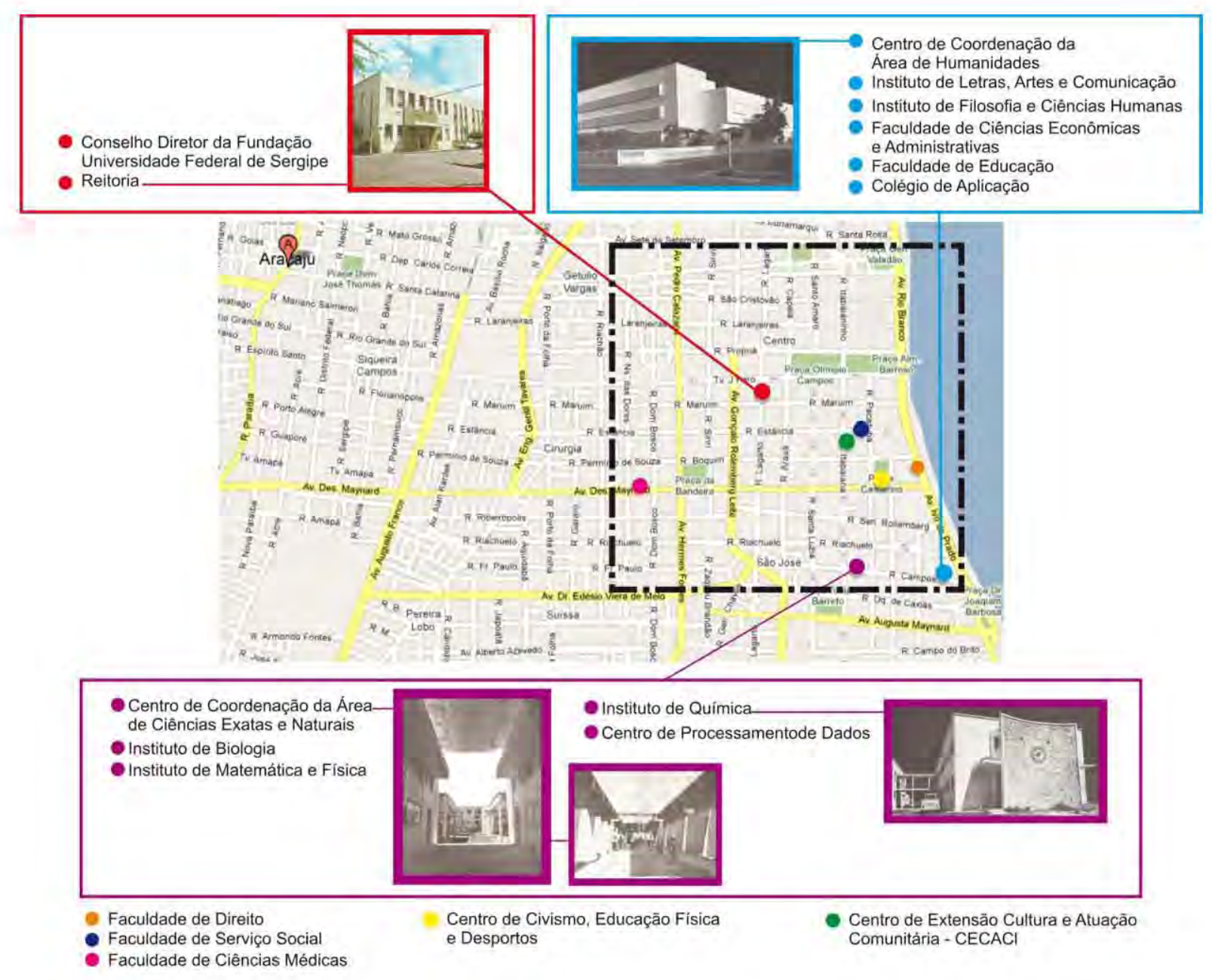

Figura 296: UFS - Mapa de localização das Unidades no centro urbano - década de 1960.

A UFS manteve base física em território urbano até a construção do seu campus, inaugurado em 1980.

(Fonte: Elaboração própria a partir do Google Earth. Acesso em: 10 jun. 2010)

Para encarregar-se do desenvolvimento de sua estrutura física, a Universidade dispunha de uma Diretoria de Obras responsável pela programação dos projetos e construção de novas edificações, ampliações e/ou adaptações das instalações existentes. O órgão operativo definiu que os novos prédios seriam concebidos em dois pavimentos - térreo e superior - e deveriam obedecer a uma filosofia consubstanciada nos seguintes princípios:

a) estrutura dinâmica das construções, possibilitando modificações futuras com um mínimo de gastos e sem prejudicar a harmonia arquitetônica dos edifícios;

b) utilização das áreas em construções que obedecem sempre o sentido de integração da vida universitária;

c) adaptação dos prédios antigos às condições impostas pela modernização do ensino (UFS, 1972, p. 31). 
A filosofia de construir minimizando custos e com possibilidade de adaptações remetem aos princípios recomendados pelo Manual de Atcon (1970) na concepção das tipologias construtivas que deveriam pautar-se pela transitoriedade (transformação contínua) e pela flexibilidade (capacidade de ajustar os espaços às mudanças programáticas).

A política de investimentos financeiros com vistas à progressiva melhoria das instalações realizou para o quadriênio 1967/1971 um plano de obras com intervenções construtivas de vulto. O objetivo era dotar a Reitoria e as diversas unidades de ensino em condições de funcionamento para atender às exigências do seu programa de expansão.

Foram construídos na Área de Humanidades, quatro blocos com dois pavimentos cada, destinados às instalações da biblioteca e aumento do número de salas de aula no seu núcleo central e executadas ampliações e reformas nas Faculdades de Direito e de Serviço Social. Para a Área de Ciências Exatas e Naturais foram edificados os pavilhões do Instituto de Biologia e do Centro de Processamento de Dados, e executadas reformas na Faculdade de Ciências Médicas, dentre outros. Houve também investimentos maciços na aquisição de equipamentos e máquinas para atender aos vários setores da UFS ${ }^{111}$ (UFS, 1972, p. 32-33).

O programa de investimentos acima exposto corrobora com os dados da pesquisa realizada pelo Convênio MEC/DAU - UFBAISP, em 1973, que teve a finalidade de elaborar uma avaliação da implantação da Reforma Universitária [já referenciada na introdução do presente capítulo], destacando que a UFS no tocante ao desenvolvimento físico implantou mais de $50 \%$ de sua área construída em zona urbana, mesmo depois da Reforma. Constatou também que a Universidade Federal de Alagoas ainda não possuía um campus universitário e nem um planejamento físico para efetivá-lo, mantendo seu funcionamento nas instalações do centro de Aracaju (CONVÊNIO MEC/DAU - UFBA/ISP, 1975, pp. 385398).

As pressões por parte do Governo Federal, para concretizar o campus da Reforma, culminaram com a aquisição do terreno destinado à sua construção, na primeira metade da década de 1970. Com essa medida, a Universidade sentiu a necessidade de realizar uma reformulação na sua estrutura e nos documentos legais que a respaldavam, com a finalidade principal de adaptar o seu funcionamento na organização física definida pelo Campus Universitário assim como a necessidade de envolvê-la com mais ênfase em programas de pesquisa pura e aplicada e em trabalhos de extensão que pudessem fazer com que a Comunidade sentisse mais de perto a sua presença efetiva (UFS, [1981?], p.4).

Esses objetivos foram formalizados nos documentos básicos da Universidade: Estatuto da Fundação Universidade Federal de Sergipe (1969); Estatuto da Universidade Federal de

\footnotetext{
${ }^{111}$ Esses dados estão detalhados nos Anais Científicos da UFS, no item Política de Investimentos (1972, p. 32-34).
} 
Sergipe (1978); Regimento Geral com oficialização da Estrutura Departamental e da Estrutura Curricular; Normas de Estruturação e Funcionamento dos Ciclos de Graduação e Sistema de Créditos (1979) ${ }^{112}$.

\subsection{CAMPUS DE SÃO CRISTOVÃO OU CIDADE UNIVERSITÁRIA PROF, JOSÉ ALOÍSIO DE CARVALHO}

A intenção de construir o campus esteve presente já na gestão do seu primeiro reitorado ${ }^{113}$, embalado pela filosofia da integração universitária, que associava a continuidade espacial e a proximidade física como condição imprescindível á criação de um ambiente propício às inter-relações funcionais e programáticas.

O primeiro passo ocorreu com a tentativa de comprar um terreno na orla marítima, situado na zona sul da capital, uma área de 375 ha, conhecida como Coroa do Meio. Os estudos de viabilidade técnica, entretanto constataram que a ação da corrosão provocada pelo ar marinho traria prejuízos à aparelhagem dos laboratórios e outras instalações, inviabilizando assim sua aquisição.

Em 1974, após novos estudos, foi adquirido um terreno do Bairro do Jardim Rosa Elze com área inicial de 117 ha, situado no município de São Cristóvão ${ }^{114}$, zona oeste de Aracaju. 0 terreno, margeado pelo Rio Poxim, apresentava uma topografia suave, clima ameno e vegetação típica da região (ver figuras 297 e 298).

O passo seguinte se deu com a colaboração do Fundo de Construção da USP (FUNDUSP) incumbido de elaborar o Plano Diretor Físico, que iria definir as diretrizes urbanísticas e arquitetônicas para o território periférico da UFAL [a proposta será discutida no decorrer do capítulo].

\footnotetext{
${ }^{112}$ Dados sobre os documentos básicos da UFS podem ser encontrados na publicação Relatório 1980 (UFS, [1981?], p. 4).

${ }^{113}$ Logo após a sua fundação a direção da UFS foi confiada a um Conselho Diretor composto por representantes da Petrobrás $e$ dos governos estadual e federal, sendo nomeados pelo então presidente da República marechal Costa e Silva (1967-1969) o reitor João Cardoso Nascimento Júnior e o vice, José Lopes Gama, para o quadriênio de 1968-1972. O Conselho Universitário (CONSU) responderia pela administração da UFS (PINTO, 2004, p. 194-195). O segundo reitorado ficou a cargo do doutor Luis Bispo (1972-1976), seguido pelo professor José Aloísio de Campos (1976-1980).

${ }^{114}$ São Cristóvão é a quarta cidade mais antiga do Brasil, tombada pelo Patrimônio Histórico Nacional. Faz parte de sua estrutura urbana um centro histórico composto de igrejas, monumentos, sobrados, conventos e museus (PINTO, 2004, p. 193).
} 


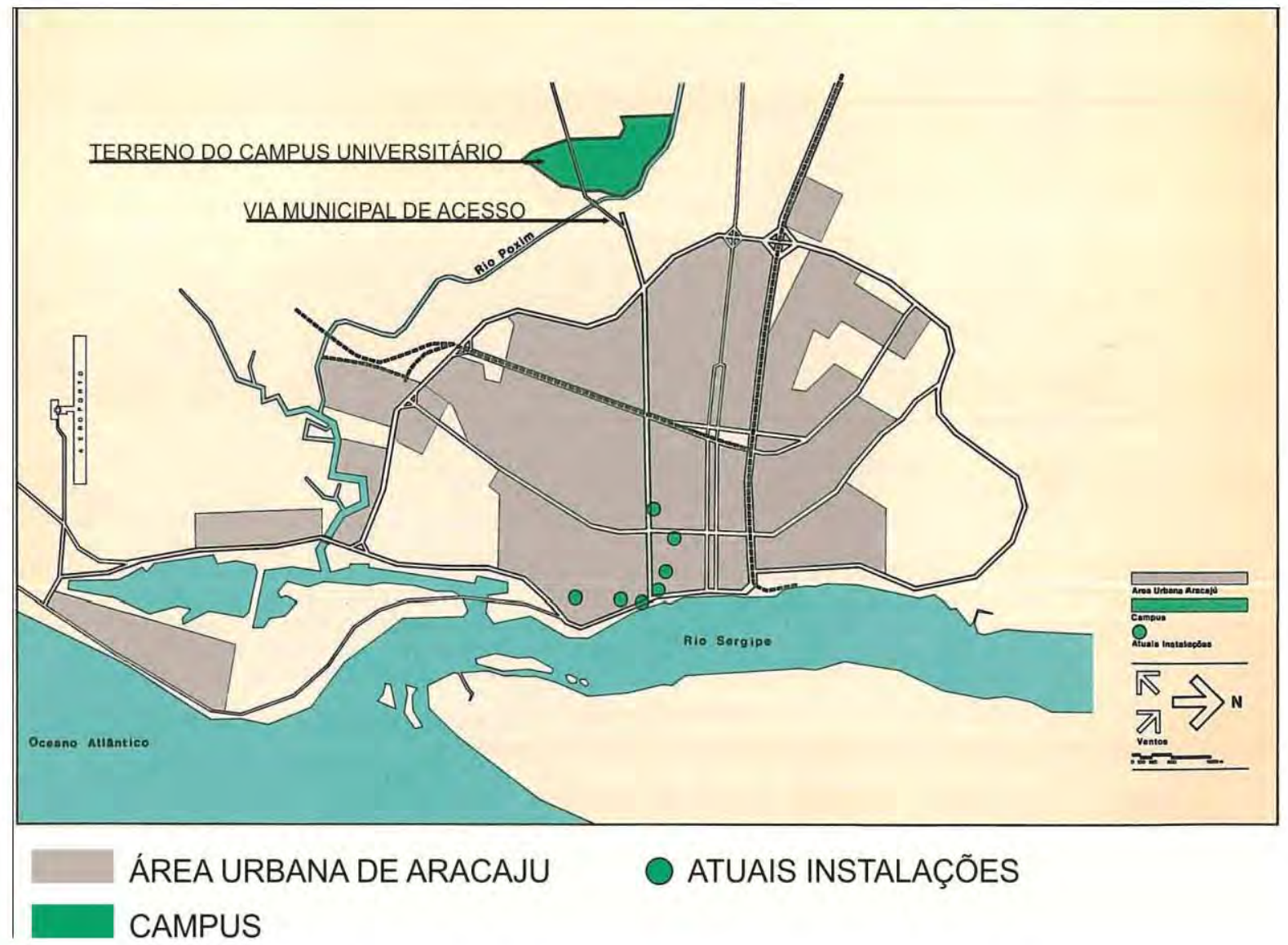

Figura 297: UFS - Planta de situação do Campus Universitário.

Distando $25 \mathrm{~km}$ do centro de Aracaju, o acesso era realizado por uma estrada municipal, que servia tanto ao Campus como aos loteamentos vizinhos. No decorrer do tempo a estrada foi substituída pelo prolongamento da Avenida Senador Maynard.

(Fonte: UFS, 1974, grifo nosso).

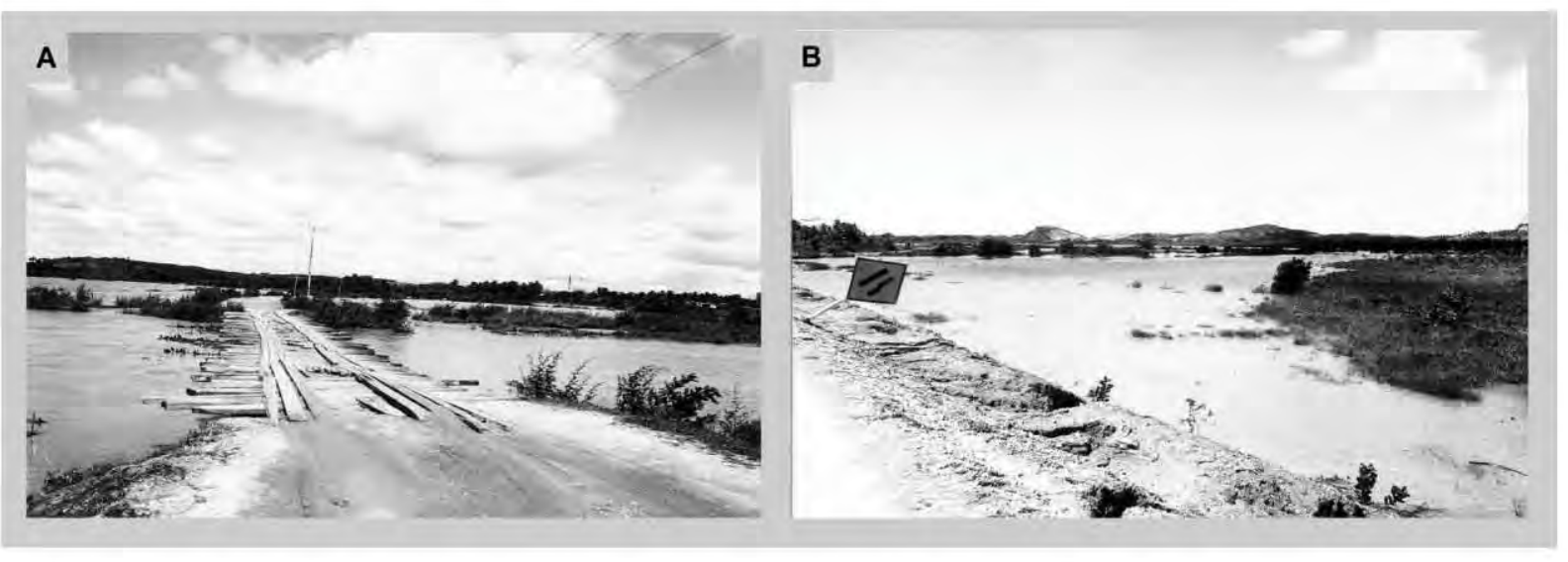

Figura 298: UFS - Vistas do terreno do Campus - início da década de 1970.

(A) Estrada municipal de acesso ao Campus, cortando o Rio Poxim.

(B) Terreno do Campus margeado pelo Rio Poxim.

(Fonte: Arquivo Geral - Prefeitura do Campus). 
A execução do campus foi programada em duas etapas, tendo sido a primeira concluída no final de 1980 , com previsão de atingir ao término, uma capacidade global de 10.000 alunos $^{115}$.

$\mathrm{Na}$ primeira etapa, foram construídos 3 prédios de didática, 3 de administração dos Centros de Ciências Sociais Aplicadas e de Educação e de Ciências Humanas, os prédios da Reitoria, Biblioteca Central e Restaurante, além do Setor Esportivo compreendendo quadras de esportes, campo de futebol com pista de atletismo, ginásio coberto polivalente, ginásio coberto de ginástica rítmica e edifícios de salas de aula de práticas esportivas (UFS, 1981? p. 42).

Também foram concluídas as obras de infraestrutura que abrangiam as redes de água, esgotos sanitários e drenagem, de luz e força, do sistema viário, passarelas cobertas, paisagismo e prédio da recepção; e os prédios de Serviços Gerais, o Conjunto Aquático, o prédio destinado aos Diretórios Acadêmicos, bem como os conjuntos do Centro de Ciências Exatas e Tecnologia e do Centro de Ciências Biológicas e da Saúde (UFS, 1981?, p. 42).

Dados do Relatório 1976-1980 (UFS, 1981?, p. 42-43) apontam que naquele período já estavam finalizados os projetos para a construção do Hospital Universitário e do Centro Comunitário, que compreendia 30 residências para estudantes, bloco de apartamentos para professores visitantes, capela ecumênica, creche para filhos de servidores e estudantes, e centro comercial (agências bancárias, correios e telégrafos, livraria, farmácia, lojas e salão de festas).

A execução dos mesmos estava, entretanto na dependência de financiamentos do PREMESU. Ficaram também pendentes de financiamento os projetos do Colégio de Aplicação e do Teatro Universitário. Entretanto, somente veio a ser construído o primeiro. $O$ Hospital Universitário foi implantado no município de Aracaju, constituindo atualmente o Campus da Saúde.

A implantação de uma zona residencial não estava indicada no Plano Diretor formulado, embora tenham sido elaborados projetos de unidades habitacionais, conforme relatado. A ausência desse setor alinhava-se com a orientação do Manual de Atcon (1970) que não incluía a implantação de área para vivência residencial no campus universitário brasileiro.

A implementação do plano de execução das obras do campus, se deu com investimentos do Programa MEC/BID II que visava atingir, em especial, as universidades do Nordeste, com período de vigência de 1976 a 1980 (RODRIGUES, 2001, p. 147 - 148).

\footnotetext{
${ }^{115}$ Dados encontrados em relatórios do arquivo da Prefeitura do Campus mencionam que a capacidade global projetada era de
} 13.200 usuários, sendo 10.000 alunos e 3.200 técnicos administrativos e docentes. 


\section{PLANO DIRETOR FÍSICO}

O Plano Diretor marcou o início do processo de planejamento da Instituição. Resultado do convênio firmado entre a UFS e a USP ${ }^{116}$ foi elaborado com base na área inicial de 117 ha. A porposta exaltava o pretenso atributo da flexibilidade em caso de reformulações no decorrer da sua implantação e tomou como ponto de partida:

1. A estrutura da Universidade (formada pelos Órgãos Superiores da Administração, Órgãos de Coordenação Interescolar, Órgãos de Assessoramento do Reitor, Órgãos Administrativos, Unidades de Ensino ${ }^{117}$ e Órgãos Suplementares ${ }^{118}$ ),

2. Os cursos de nível superior ministrados (ao todo $23^{119}$ ),

3. Os cursos de nível médio (ao todo dois ${ }^{120}$ ),

4. A população (composta pelo corpo discente, docente, pessoal técnico e administrativo ${ }^{121}$ ).

5. E a implantação definitiva da Reforma Universitária, que estava prevista para acontecer até 1983, reestruturando a Universidade com base no sistema departamental com 31 unidades, agrupadas em quatro centros: Centro de Tecnologia, Centro de Ciências da Saúde, Centro de Ciências Sociais Aplicadas e o Centro de Humanidades.

Somando-se aos dados acima, foi elaborado diagnóstico do terreno, o qual embora, conforme se constata na figura 299 , apresentasse uma extensa área sujeita a alagamento, restava outra não inundável que permitia a possibilidade de áreas edificáveis.

\footnotetext{
${ }^{116}$ A elaboração do Plano ficou a cargo do Fundo de Construção da Universidade de São Paulo (FUNDUSP), por meio do setor de planejamento, composto pelos arquitetos Sergio Luiz de Assumpção, Erika M. T. Giongo de Camargo, Marcos Aspahan e pelo engenheiro Carlos A. Ferreira Martins, sob a coordenação do arquiteto Luciano Bernini. A UFS participou por meio da Comissão do Plano formado pelo assessor de planejamento, economista Benjamim Machado Sobrinho, da Diretoria de Obras, composto pelo engenheiro José Álvaro de Lima, pelo arquiteto Wilson Brito Couto e pelo professor Antonino Campos de Lima. O trabalho foi desenvolvido durante a gestão do reitor Luis Bispo.

${ }^{117}$ As Unidades de Ensino estavam assim constituídas: Instituto de Biologia, Instituto de Filosofia e Ciências Humanas, Instituto de Letras, Artes e Comunicação, Instituto de Matemática e Física, Instituto de Química, Faculdade de Ciências Econômicas e Administrativas, Faculdade de Ciências Médicas, Faculdade de Direito, Faculdade de Educação e Faculdade de Serviço Social. ${ }^{18}$ Os órgãos suplementares correspondiam ao Centro de Processamento de Dados, Centro de Civismo, Educação Física e Desportos, Centro de Extensão Cultural e Atuação Comunitária.

${ }^{119}$ Os cursos de nivel superior eram: administração, ciências econômicas, ciências contábeis, direito, filosofia, geografia (licenciatura), história (licenciatura), letras modernas (licenciatura), letras estrangeiras (licenciatura), letras vernáculas (licenciatura), jornalismo (F), pedagogia (com especializações), serviço social, ciências biológicas, engenharia química, física (licenciatura), matemática (licenciatura), engenharia civil ( $F$ ), odontologia, medicina, química industrial (bacharelado), química, educação física (F). Os cursos assinalados com (F) estavam com a implantação prevista até 1983

${ }^{120}$ Os cursos de nivel médio correspondiam ao colégio de aplicação e aos cursos técnicos (sua implantação deveria acontecer até 1983).

${ }^{121}$ A população em 1973 correspondia a 3.005 pessoas e estimava-se seu crescimento, em 1983, para 14.911. O Plano Diretor estabeleceu a expansão baseado nesse aumento estimado.
} 

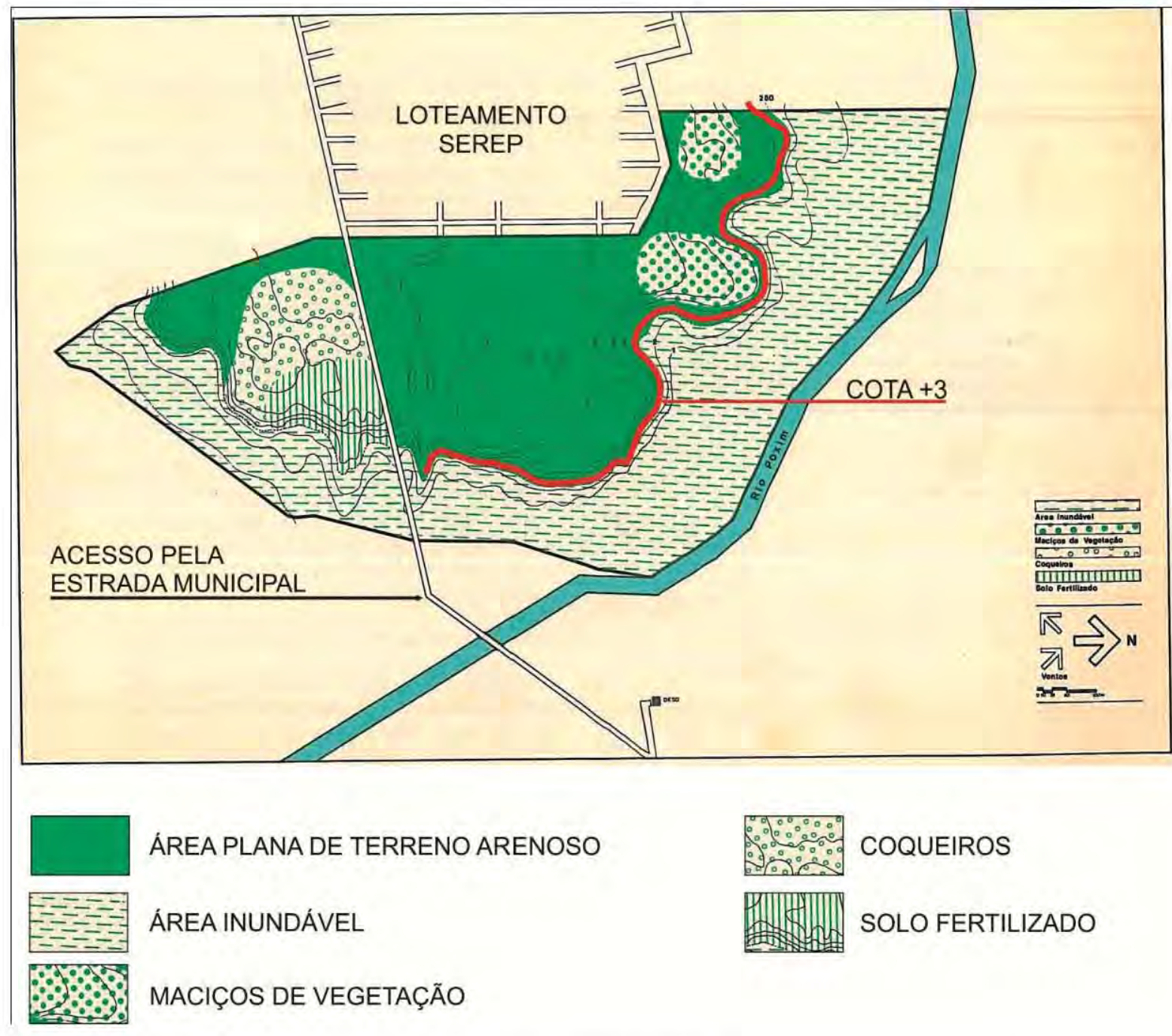

ÁREA PLANA DE TERRENO ARENOSO

ÁREA INUNDÁVEL

COQUEIROS

SOLO FERTILIZADO

\section{MACIÇOS DE VEGETAÇÃO}

Figura 299: UFS - Planta do terreno do Campus Universitário.

Limitado a nordeste e a leste pelo Rio Poxim, a oeste pelo loteamento SEREP, a sudeste e sul pelo leito morto do Rio Poxim, já retificado. Aspectos fisiográficos; área de alagamento no período de cheia do Rio Poxim, compreendendo 40 a $50 \%$ do total; outra, a partir da cota +3 , praticamente plana e não inundável, de terreno arenoso, prevista pelo Plano para utilização em curto prazo. O clima é tropical, úmido, caracterizando-se pela temperatura média anual de $25,5^{\circ} \mathrm{C}$, umidade relativa média do ar de $80 \%$ e predominância de ventos SE e NE (este em menor escala).

(Fonte: UFS, 1974, n.p., grifos nosso)

A organização espacial do Campus evidencia a observância aos princípios do urbanismo moderno, especialmente em relação ao zoneamento, com sua cuidadosa divisão de funções em áreas bem definidas, distribuindo as zonas acadêmico-científicas, administrativas e de serviços em setores distintos, e na hierarquia dos fluxos de circulação. O Plano foi elaborado com base nos seguintes parâmetros:

\section{Zoneamento Funcional, setorizado em:}

- Área Acadêmica, que compreendia as instalações dos quatros Centros (Tecnologia, Ciências da Saúde, Humanidades e Ciências Sociais Aplicadas); 
- Administração Central, compreendendo a Reitoria, Prefeitura Universitária, Centro de Processamento de Dados e demais órgãos suplementares, além da direção dos Centros;

- Área de Apoio, compreendendo oficinas, garagens, Almoxarifado Central, Imprensa Universitária, centrais de gás, água, eletricidade, etc., localizadas de maneira a facilitar o acesso às instalações acadêmicas, através de eixos de serviço;

- Hospital, conceituado como hospital de ensino para atender ao ensino e à pesquisa na Área de Ciências da Saúde. Sua inclusão estava justificada "não só pela sua finalidade didática, como também pelo aspecto da assistência médica à região, extremamente carente de unidades de atendimento geral" (UFS, 1974, não paginado).

- Área de Vivência, localizada em área circunvizinha à acadêmica, as quais se interligam por meio da via de pedestre.

- Setor Esportivo, composto pelo Conjunto Aquático (piscina olímpica, tanque de saltos e piscina de recreação, circuit-trainning, compreendendo circuito de obstáculos para treinamento com arquibancada), das Quadras (abertas polivalentes com arquibancadas, de tênis e paredão), Edificação Central (compreendendo um ginásio e dois miniginásios, salas de aula e salas de professores para o Curso de Educação Física, depósito de material esportivo e local de vivência, vestiários e depósito específico para cada esporte, junto às quadras), Conjunto para Atletismo e Campo de Futebol.

- Horto e Viveiro, localizados visando à utilização de solo já fertilizado e possibilitando a extensão da Área de Vivência e do Setor Esportivo.

- Estacionamento, concentrado em dois grandes bolsões periféricos, procurando atender toda a área e visando menor percurso pelo pedestre. A localização desses espaços levou também em consideração a importância de evitar o desconforto térmico provocado pelo ar aquecido por causa da grande superfície pavimentada em clima de intensa radiação solar, determinando uma orientação de modo que a massa de ar quente, deslocada pelo vento, não circulasse pela área ocupada do campus (UFS, 1974, não paginado).

As áreas funcionais acima discriminadas estavam distribuídas conforme apresentado na figura 300 . 


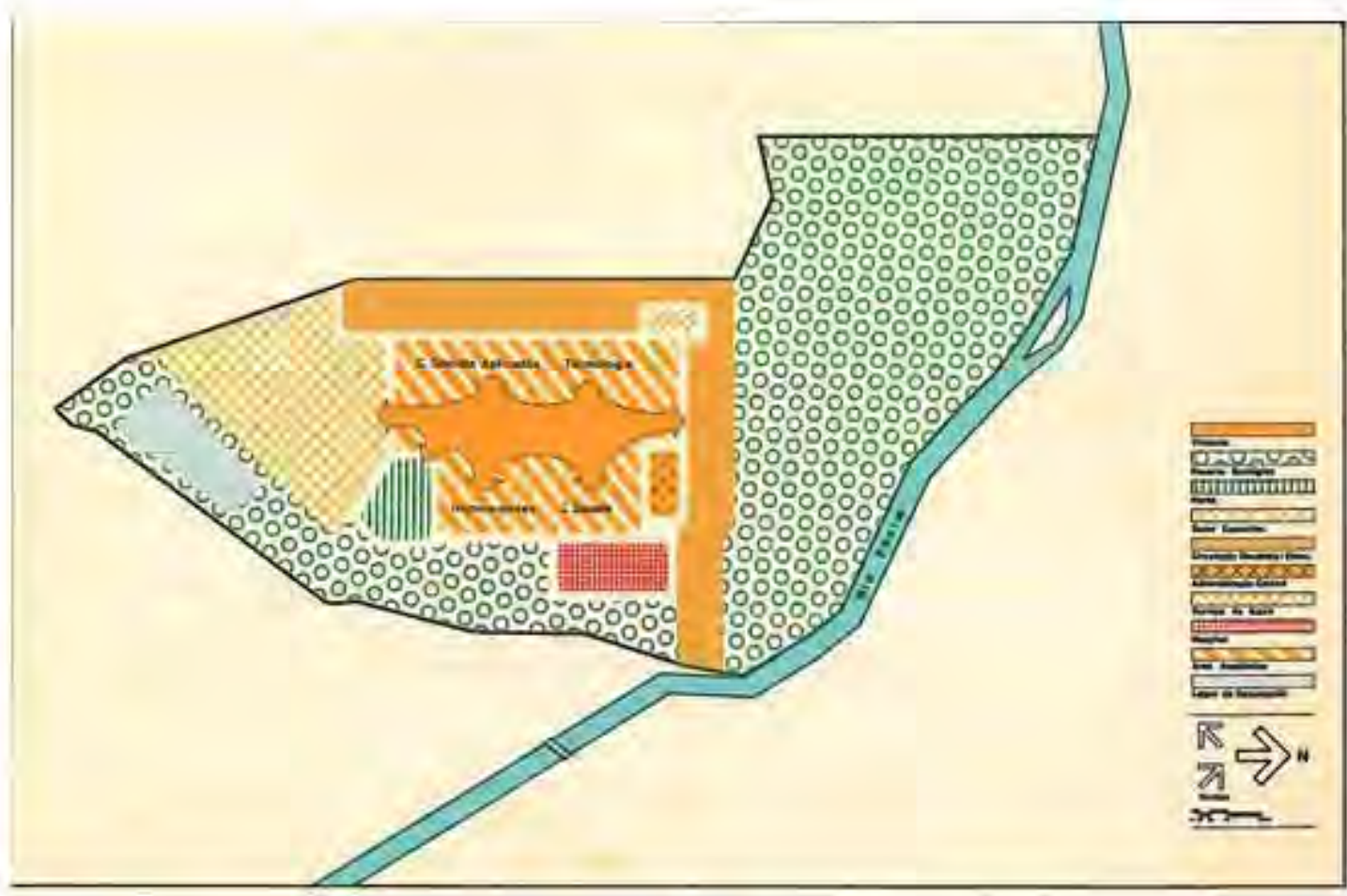

\section{VIVÊNCIA}

BÖ RESERVA ECOLOGICA

[IIIIIII HORTO

83 SETOR ESPORTIVO

Z3 ADMINISTRAÇAO GERAL

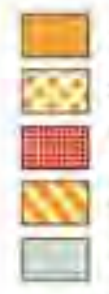

CIRCULAÇĀO MECANICA / ESTACIONAMENTO SERVICOO DE APOIO

HOSPITAL

AREAACADEMICA

LAGOA DE DECANTAÇĀO

(Estaçăo de Tratamento de Esgoto)

Figura 300: UFS - Zoneamento do Campus Universitário.

(Fonte: UFS, 1974, n.p.)

2. Circulação, caracterizada pela clara separaçẫo entre a "circulaçẫo mecânica" e a de pedestres, restringindo o tráfego mecânico à avenida de chegada e aos estacionamentos periféricos concentrados em bolsỗes. A circulaçầo de pedestres foi tratada com a intençẫo de proporcionar os contatos sociais e atividades de vivencia, compreendendo a circulação coberta, que articula as edificaçốes. Paralelamente a esta, foi prevista a circulaçã̃o de serviços e de emergência, de maneira a atender todas as edificaçỗes. Nesse eixo estavam reunidas as instalações de gás, água, eletricidade, telefone, ar comprimido, etc., de maneira a facilitar sua manutenção (ver figura 301).

3. Vivência, distribuida em eixos que articulam as áreas didáticas e onde estẫo os equipamentos de praça (bancos, bebedouros, pequenas lanchonetes, caixas para vegetaçẫo, porta-cartazes, etc.). 

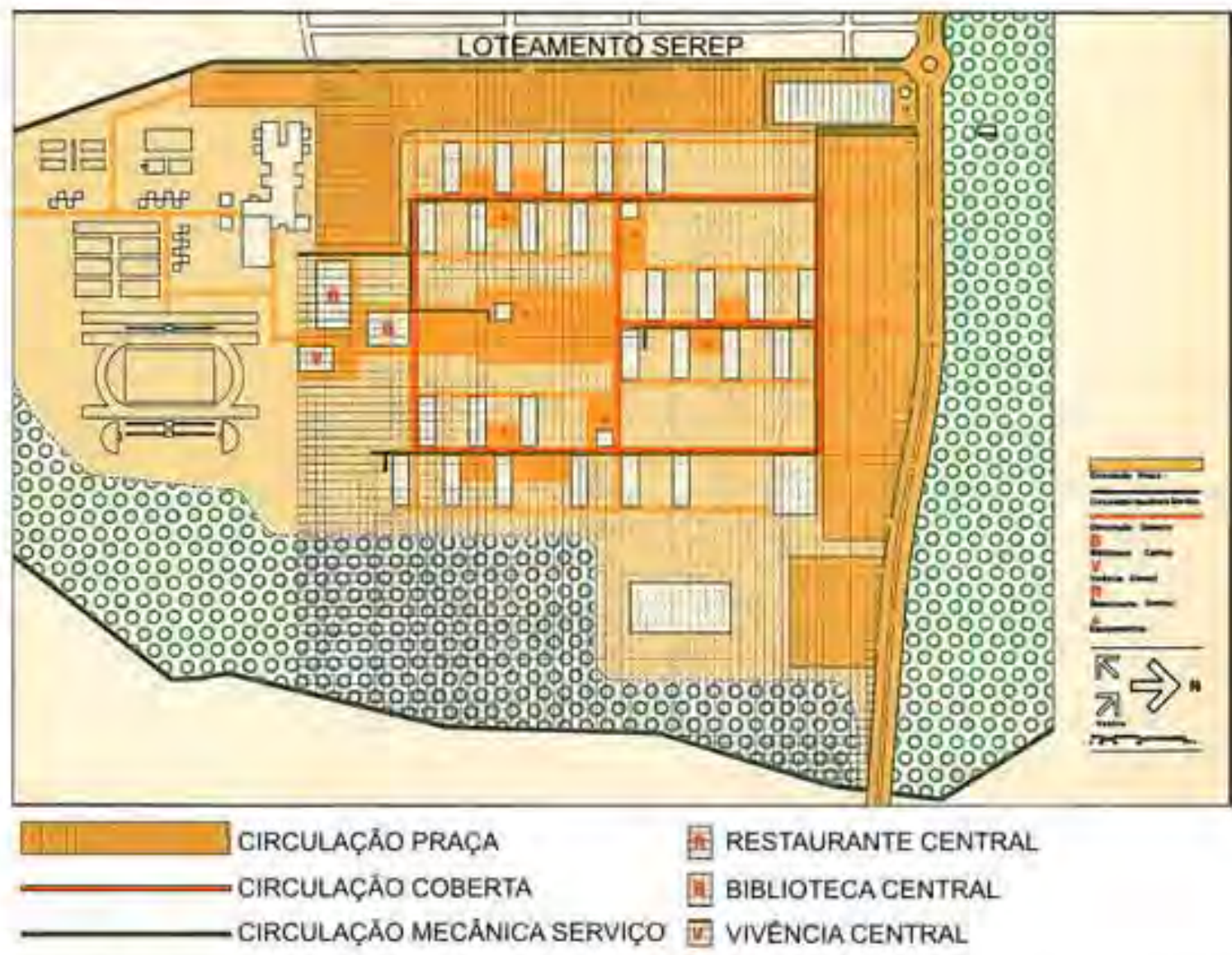

Figura 301: UFS - Sistema viário do Campus Universitário.

O eixo principal de vivência [ISTO ESTÁ CORRETO?] possui na extremidade os edifícios da Biblioteca Central, Restaurante Central e Centro de Vvência. Os laboratórios de ensino vêm em seguida e posteriormente, os de pesquisas, procurando uma diluição de fluxo de maneira a atender às áreas mais reservadas.

(Fonte: UFS, 1974, n.p., grifos nosso).

1. Definiçẫo de Tipologia/Atividades que configuram as edificações do campus a serem implantadas, tomando como base o partido pavilhonar, cujos blocos eram caracterizados por atividades afins e articulados pela circulaçã̃o de pedestres e permeados pelas áreas de vivência. Sua orientaçẫo visava à obtençẫo de boas

2. Condiçốes de conforto témico, em funçẫo da insolaçẫo e do regime de ventos. Ordenavam as áreas de predominância de uso:

- didática - preleção

- didática-laboratónios

- administraçẫo

- vivência

- setor esportivo 
- hospital

- serviços gerais de apoio

- estacionamento e sistema viário.

Esta proposta de concentraçẫo procurava atender aos critérios de melhor aproveitamento do terreno, economia, integração curricular, manutenção e facilidade de implantaçẫo gradativa (ver figura 302).

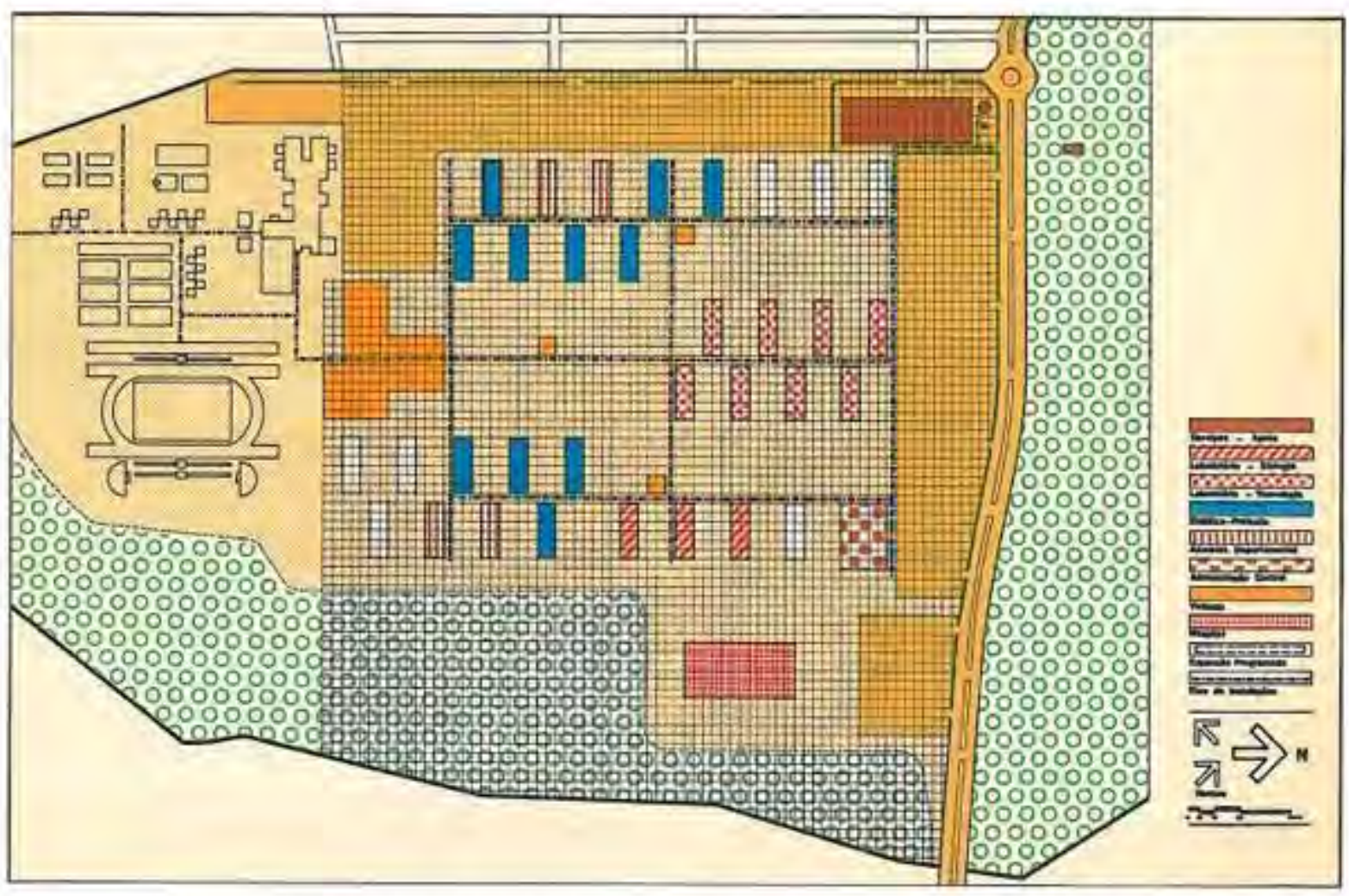

ADMINISTRAÇĀO DEPARTAMENTAL

UNIDADE DIDÁTICA

SERVIÇO DE APOIO

EIXO DE CIRCULAÇÃO
EE⿱T⿴囗十) ADMINISTRAÇÃO CENTRAL [DशPA LABORATÓRIO DE TECNOLOGIA HIIIIIIII HOSPITAL

NHES LABORATÓRIO DE BIOLOGIA

IIIII VIVÊNCIA

Figura 302: UFS - Tipologias construtivas do Campus Universitário.

Baseada no sistema pavilhonar, que permite a construçẫo por etapas, seguindo um padrão construtivo de linguagem homogênea. Seriam articuladas por circulação coberta e contornadas pela circulaçẫo mecânica.

(Fonte: UFS, 1974, n.p., grifos nosso) 
Os parâmetros de implantaçã̃o resultaram na configuraçẫo da planta geral apresentada na figura 303, caracterizada basicamente pela divisão da gleba em duas áreas separadas pela avenida de acesso ao Campus.

- a área norte, onde se encontram as manchas de vegetação natural, parcialmente inundável pelo Rio Poxim, destinada à reserva ecológica;

- a área sul, a ser ocupada pelas instalaçốes da Universidade, onde apenas uma pequena parte é sujeita a alagamento, reservada á implantaçẫo dos prédios em setores funcionais.

A elaboração do plano de desenvolvimento para a jovem Universidade se revestia de grande desafio, em razẫo do dinamismo que predominava nas instituiçỗes universitárias, caracterizado pelo contexto de mudanças constantes e crescimento acelerado. Em razẫo disso, a organização espacial pressupunha o ordenamento racional de suas áreas

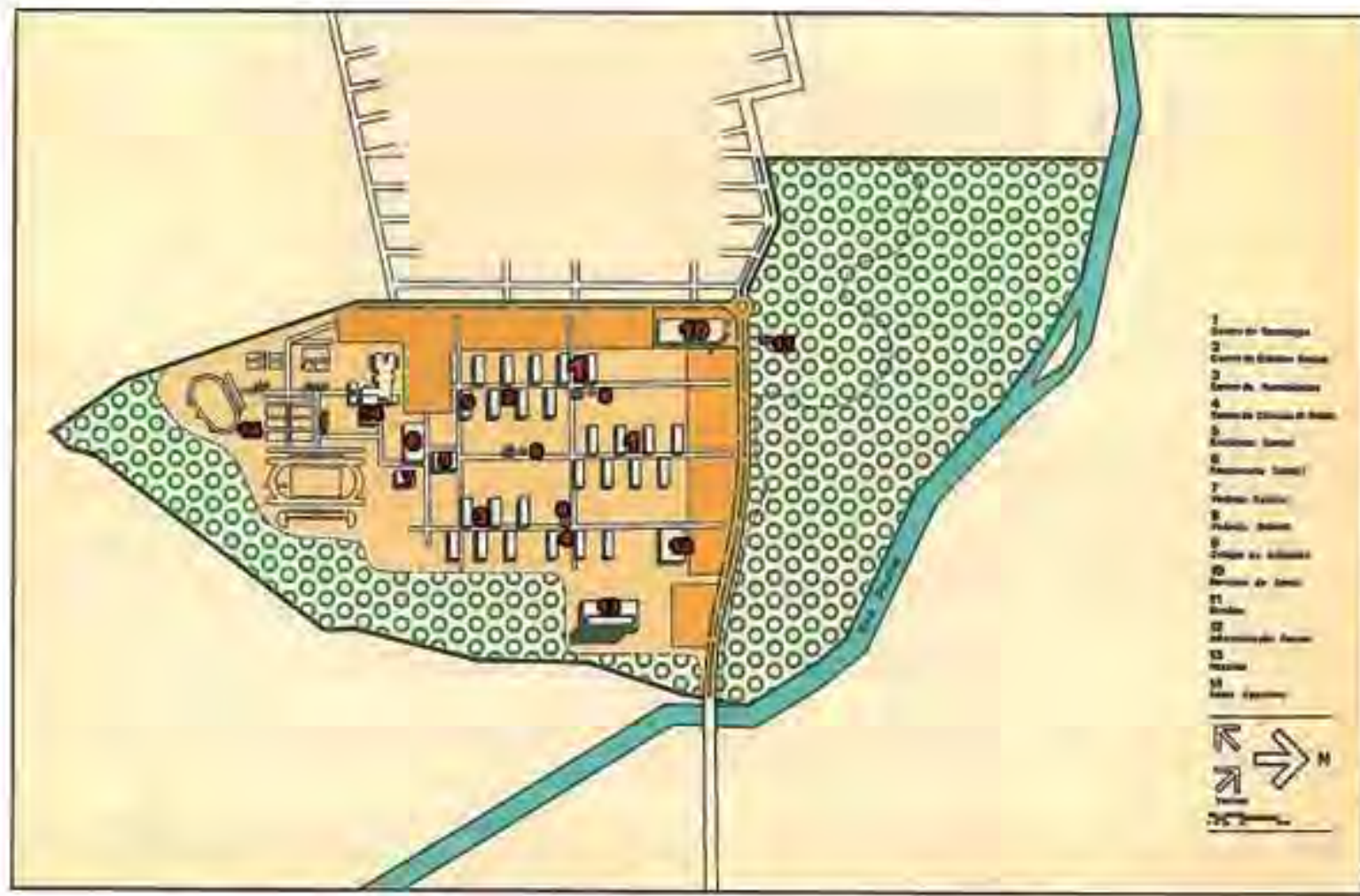

1 - CENTRO DE TECNOLOGIA

2. CENTRO DE CIEENCIAS SOCIAIS

3 - CENTRO DE HUMANIDADES

4. CENTRO DE CIÊNCIAS DA SAUUDE

5. BIBLIOTECA CENTRAL

6 - RESTAURANTE CENTRAL

7 - VIVÉNCIA CENTRAL

\section{8 - VIVÉNCIA SETORIAL \\ 9. COLÉGIO DE APLICAÇĀO \\ 10 - SERVICOS DE APOIO \\ 11 - BIOTÉRIO \\ 12 - ADMINISTRAÇÃO CENTRAL \\ 13 - HOSPITAL \\ 14 - SETOR ESPORTIVO}

Figura 303: UFS - Planta Geral do Campus Universitário. A ocupaçẫo da gleba era definida pela área norte, constituída de terreno inundável, e pela área sul, ocupada pelas edificaçốes distribuídas em setores funcionais.

(Fonte: UFS, 1974, n.p., grifos nosso) 
predominantemente acadêmicas, do fluxo de tráfego, da circulação de pedestres e das tipologias construtivas, alimentado pelo conceito de um zoneamento focado na funcionalidade e flexibilidade. Levado às últimas consequências, com sua criteriosa divisão de funçōes, o zoneamento chegou também aos edifícios que, moldados por suas finalidades, se transformaram nas unidades de planejamento do futuro campus.

A configuração urbanística resultou da composição dos eixos circulatórios de geometria rigidamente cartesiana, que desempenhavam duplamente a função de tráfego e de conector das tipologias funcionais. $O$ bloco isolado foi eleito como o que melhor se adaptava ao modelo, pois possibilitava sua implantação num processo de ocupação gradual, conforme as demandas e disponibilidades de recursos para sua construção. A proposta atendia, de forma eficiente, aos limites impostos pelo financiamento de que dispunha.

Apontando para a importância de criar um ambiente favorável à convivência universitária e ao inter-relacionamento acadêmico, a via central da retícula produz um ponto focal composto pelas unidades de uso comum - Biblioteca, Restaurante e Centro de Vivência provavelmente referenciado na ideia de um core. Nas vizinhanças desse conjunto se distribuem os demais setores que, de acordo com a necessidade de acesso por parte do público, se localizam em pontos periféricos, margeados pela via perimetral que abraça o conjunto edificado.

A soluc̣ão urbanistica traz, entretanto, na sua concepção de campus o contraponto do isolamento gerado pela organização espacial de caráter segregado que, agravado pelo isolamento da sua localização, não apresenta alternativas para torná-lo um território permeado pelas funções da cidade.

\section{- Produção arquitetônica da Reforma}

A construcão do Campus foi iniciada na segunda metade da década de 1970. Com o projeto executivo conclúido e elaborado em consonância com as diretrizes do Plano Diretor, conforme se constata na planta de concepção geral do Campus (ver figura 304), o Setor Esportivo foi o primeiro a ser edificado, a partir de 1976. A coordenação das obras ficou a cargo do Escritório Técnico Administrativo (ETA), que deu prosseguimento ao programa formulado pelo Plano (ver figura 305).

A primeira etapa da construção, conforme o planejamento institucional, foi conclúida em outubro de 1980, tendo sido erguidos os blocos didáticos, os de administração departamental, um conjunto de edifícios para o Centro de Ciências Exatas e Tecnológicas (CCET), outro para o Centro de Ciências Biológicas e da Saúde (CCBS), os prédios da

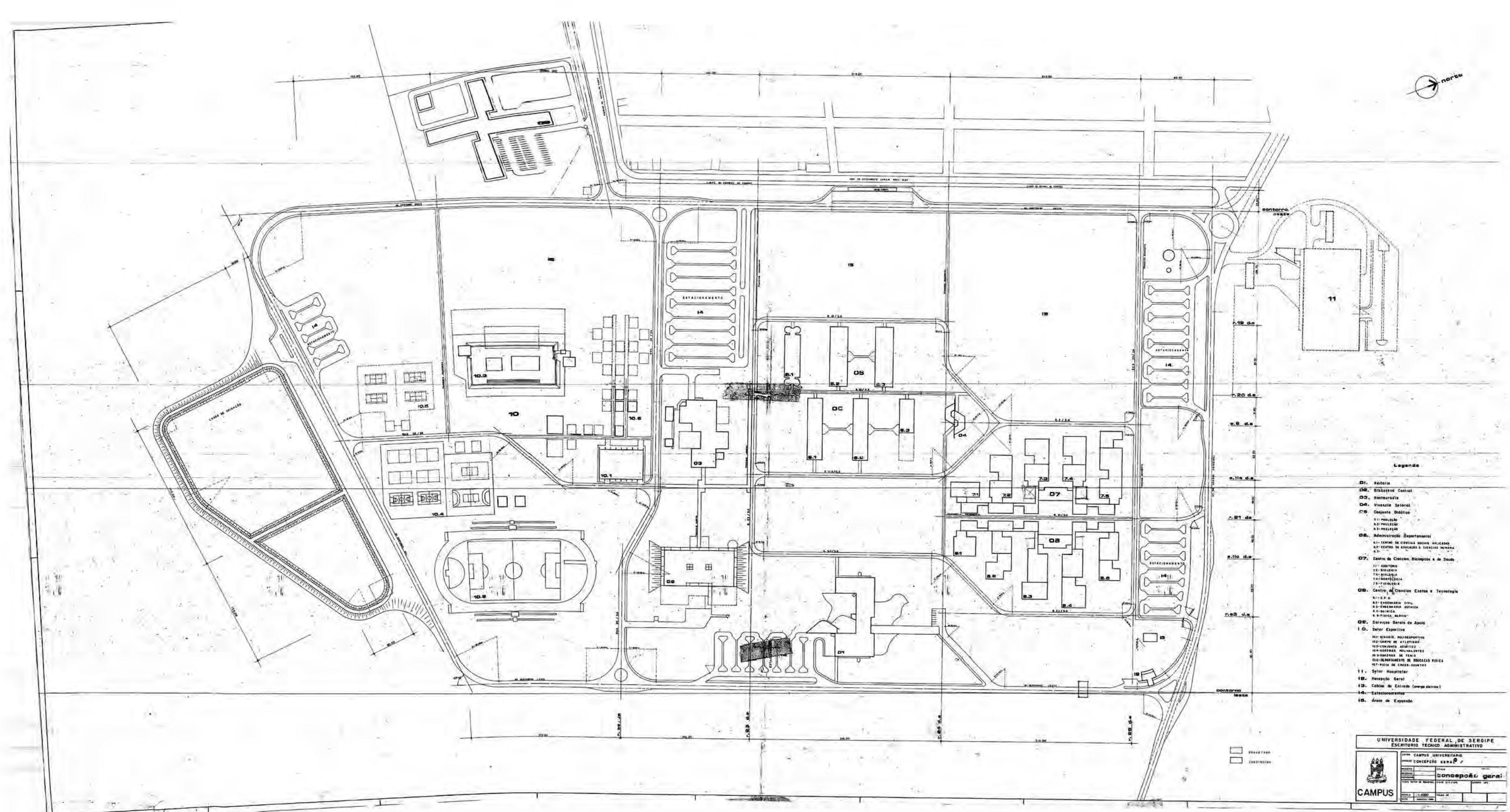

$\begin{array}{lll}50 \quad 100 \quad 200 & \text { LEGENDA } \\ 01 . \text { Reitoria }\end{array}$

01. Reitoria

02. Biblioteca Cen

04. Vivência Setorial

05. Conjunto Didático
s.1-PRELECKCOC

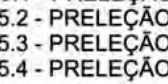

Figura 304: UFS - Planta do Campus - ano 1980.
(Fonte: Arquivo Geral - Prefeitura do Campus)

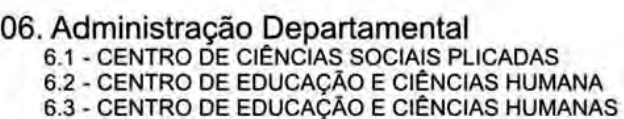
07. Centro de Ciências Biológicas e da Saúde

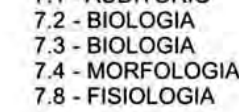

08. Centro de Ciências Exatas e Tecnologia

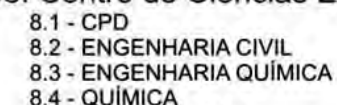

09. Servicos Gerais de Apoio
10. Setor 5 Esortivo

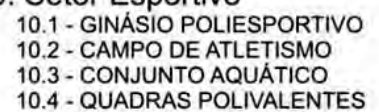

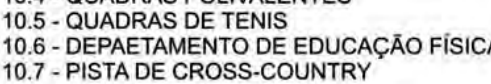

11. Setor Hospitalar

12. Recepçāo Gera

13. Cabine de Entrada (energia elétrica)

14. Estacionamentos

15. Áreas de Expansāo 
FOLHA VERSO DA FOLHA GRANDE - NÃO IMPRIMIR 
Reitoria, da Biblioteca Central, do Restaurante Universitário, da Prefeitura do Campus, da Vivência Setorial, além dos blocos para cabine de entrada e medição e para recepção, assim como a infraestrutura básica (ver figuras de 306 a 310).

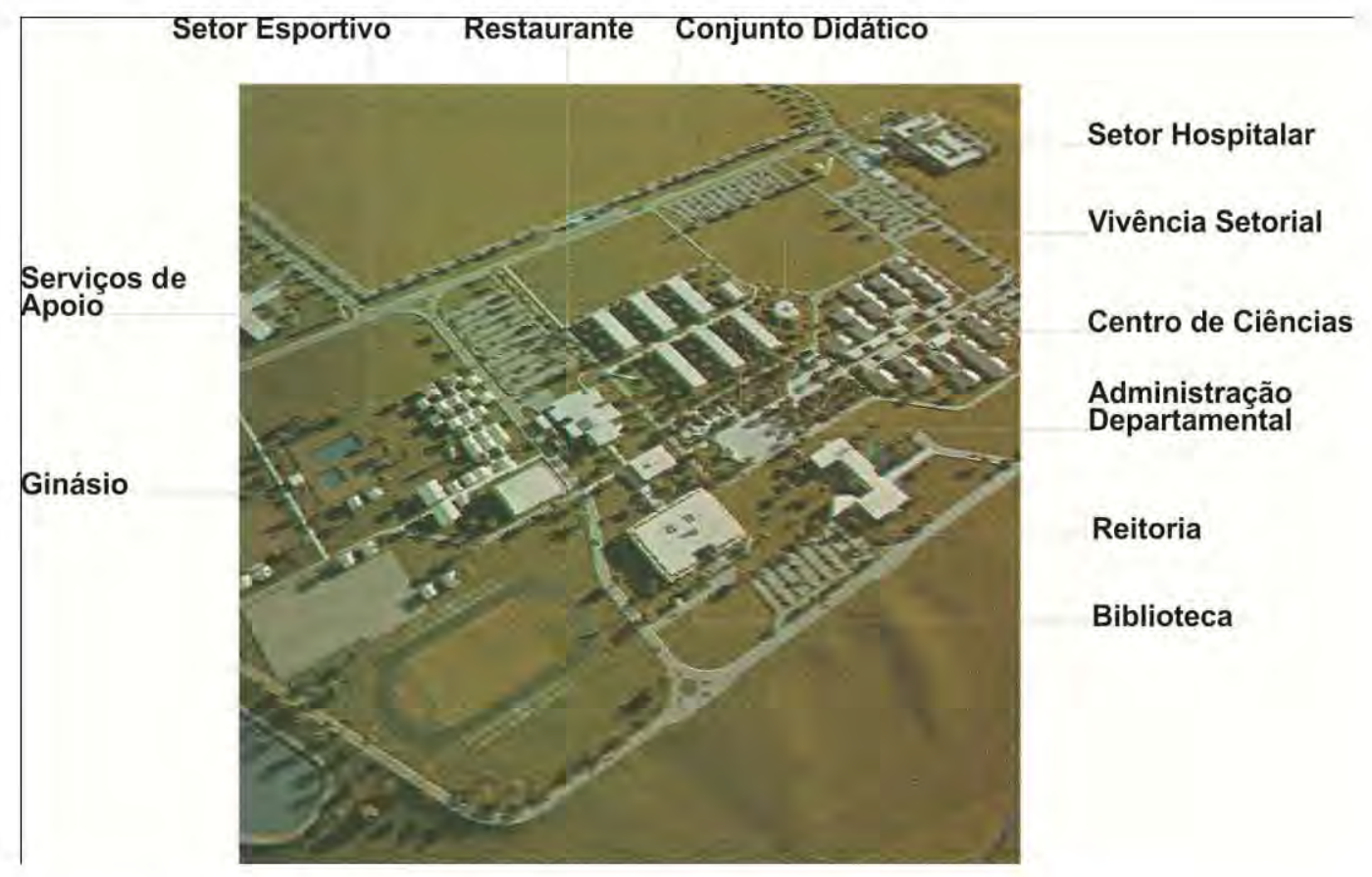

Figura 305: UFS - Vista da maquete do Campus - ano 1976.

A ilustração da proposta urbanística e arquitetônica concebida no Plano Diretor Físico. (Fonte: UFS, 1980, p. 41, grifos nosso)

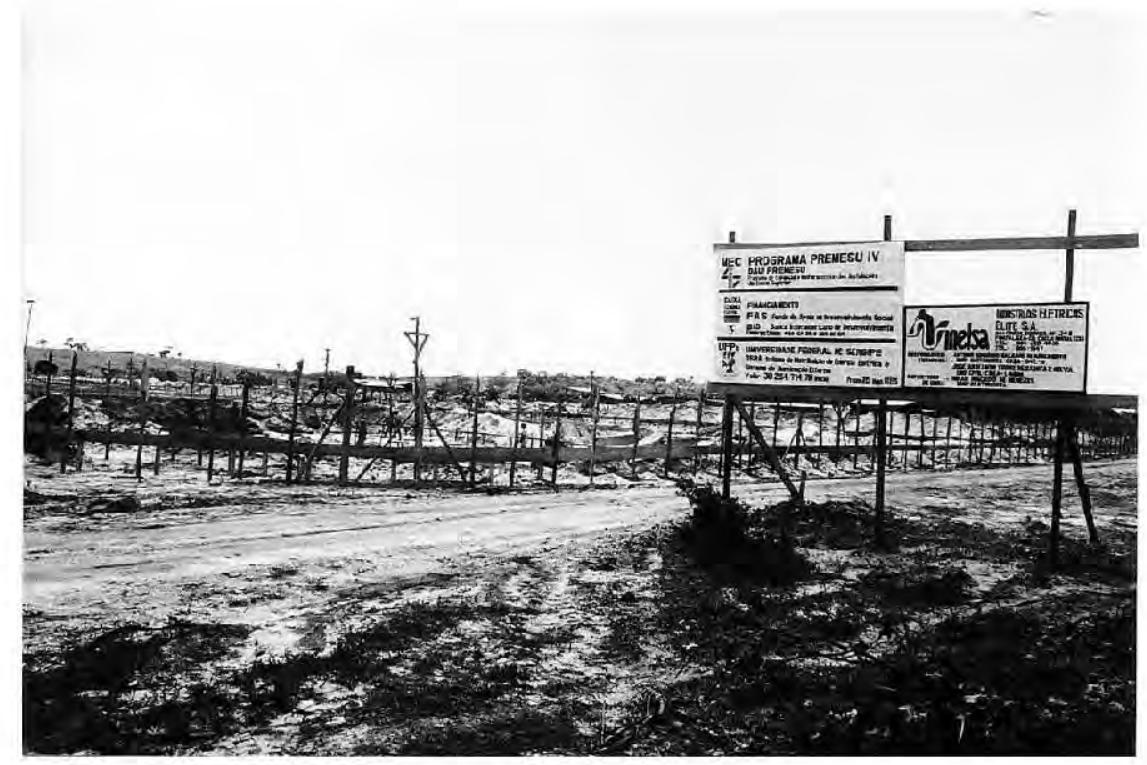

Figura 306: UFS - Vista das obras do Campus Universitário - meados da década de 1970.

Os investimentos financeiros estavam vinculados ao Programa PREMESU IV. A placa da obra indica a construção dos Sistemas de Energia Elétrica e de lluminação Externa a ser executada em 315 dias, com recursos financeiros do BID e do Fundo de Desenvolvimento Social (FAS). O terreno apresenta topografia plana, solo arenoso e vegetação rala.

(Fonte: Arquivo Geral - Prefeitura do Campus) 


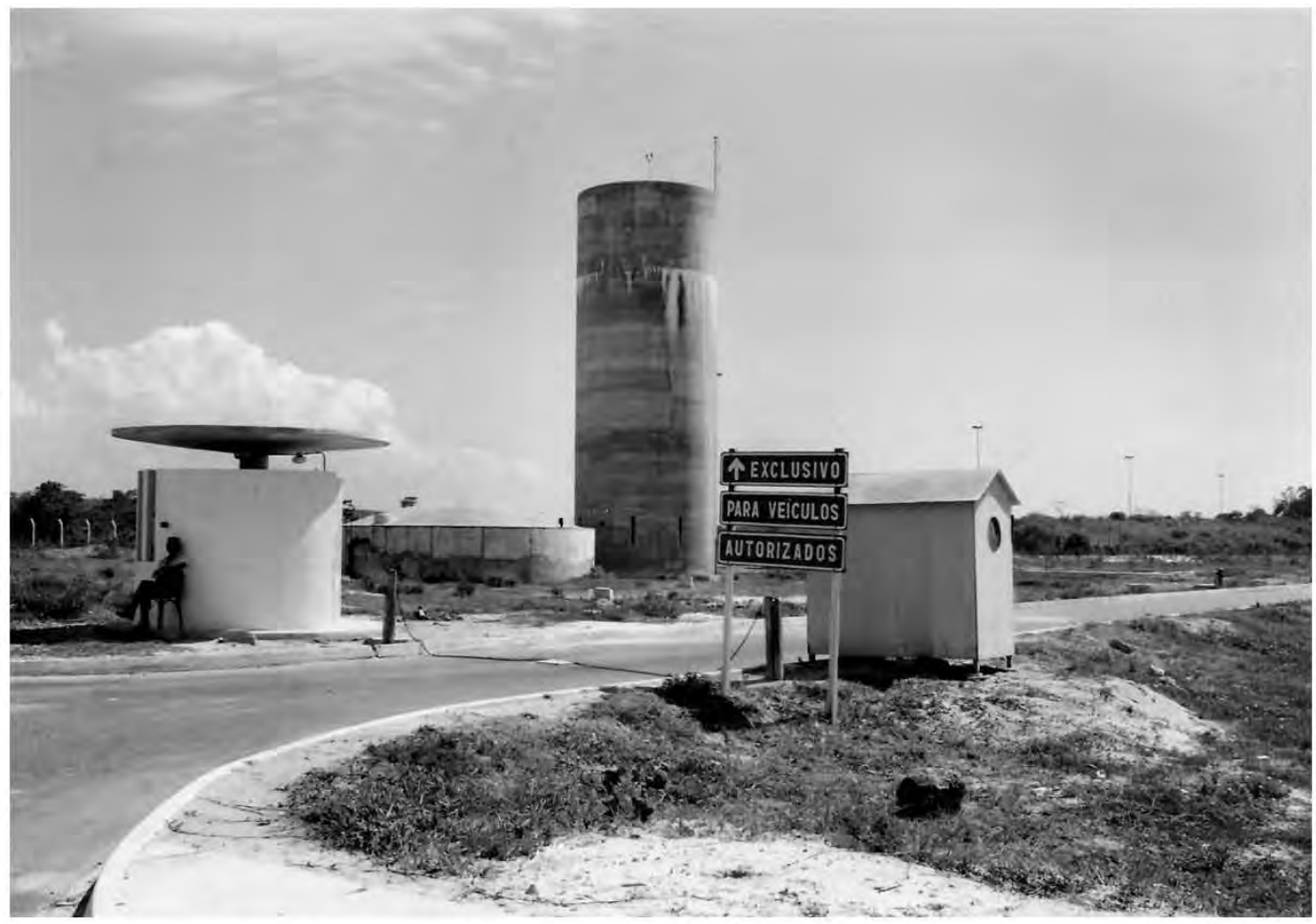

Figura 307: UFS - Vista da cabine de entrada e controle do Campus - segunda metade da década de 1970. A placa indicativa orienta o acesso de veículos autorizados. A foto permite visualizar a infraestrutura viária e a portaria com forma arquitetônica cilíndrica.

(Fonte: Arquivo Geral - Prefeitura do Campus)
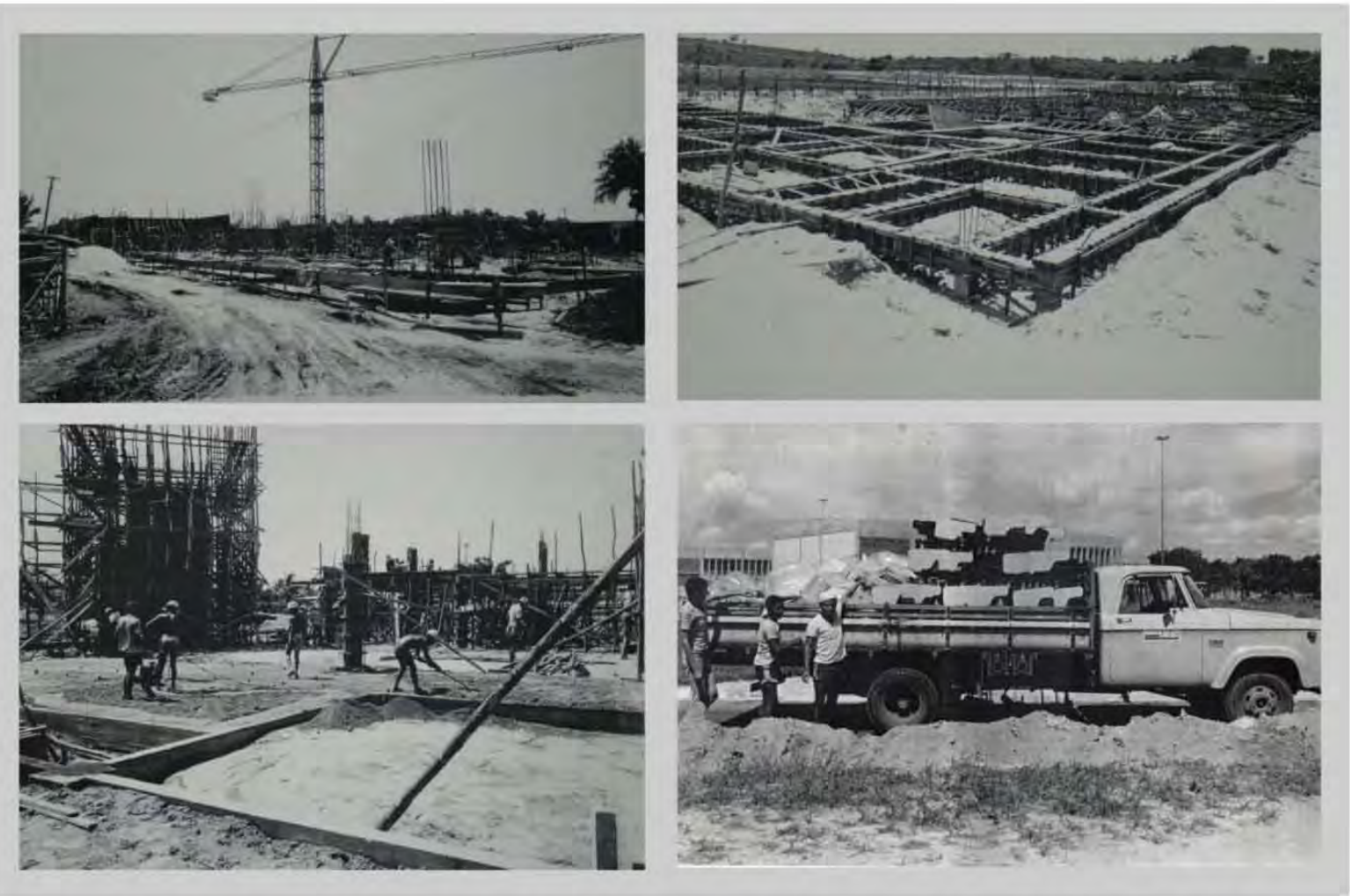

Figura 308: UFS - Obras de construção do Campus Universitário - meados da década de 1970. (Fonte: Acervo Assessoria de Comunicação e Arquivo Geral da Prefeitura do Campus) 


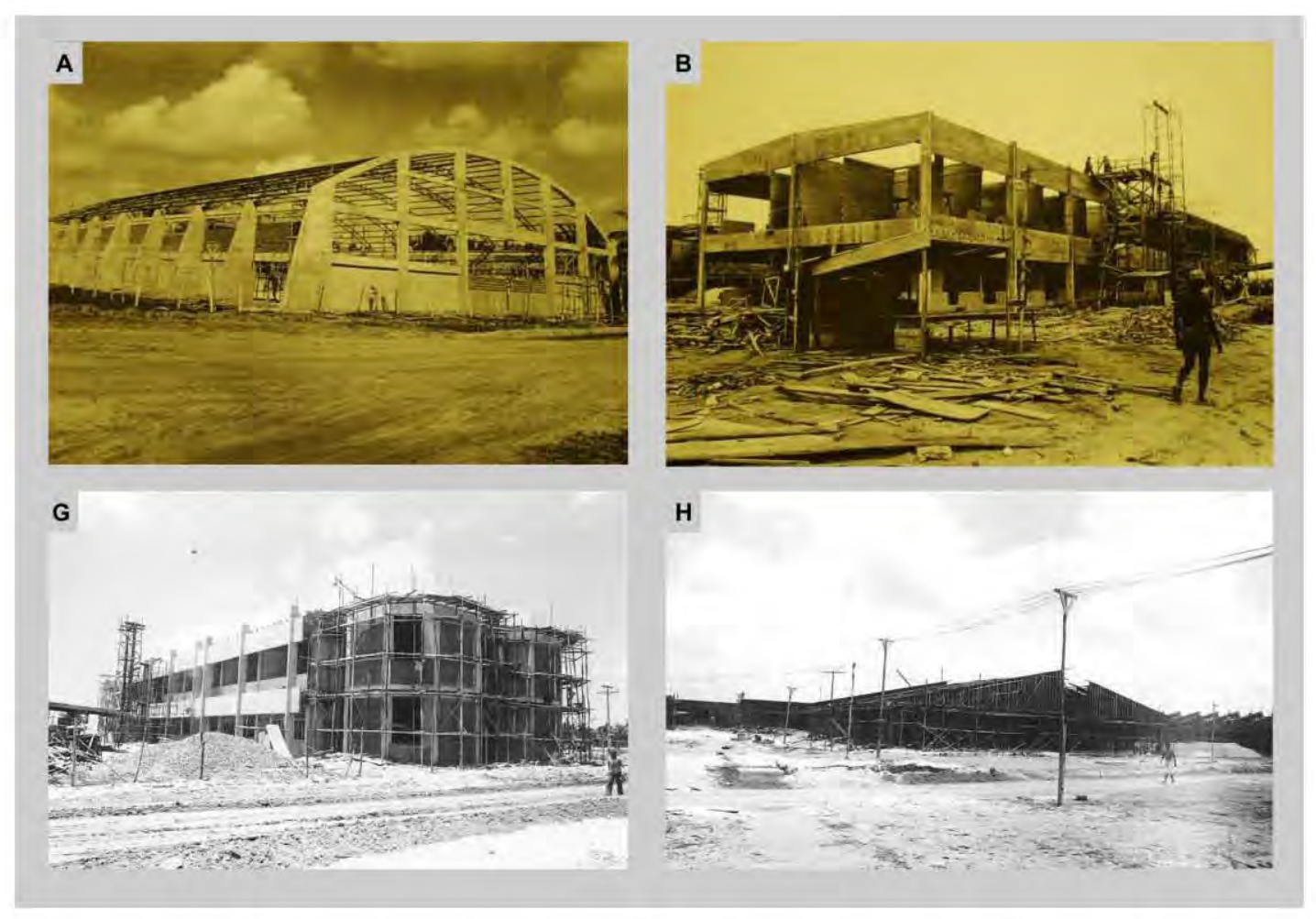

Figura 309: UFS - Obras de construção do Campus Universitário - meados da década de 1970.

Na figura A, o Setor Esportivo; na B e na $\mathbf{C}$ detalhes da construção do Setor Didático; e na $\mathrm{D}$, vista do Centro de Ciências Biológicas.

(Fonte: Acervo Assessoria de Comunicação e Arquivo Geral da Prefeitura do Campus)

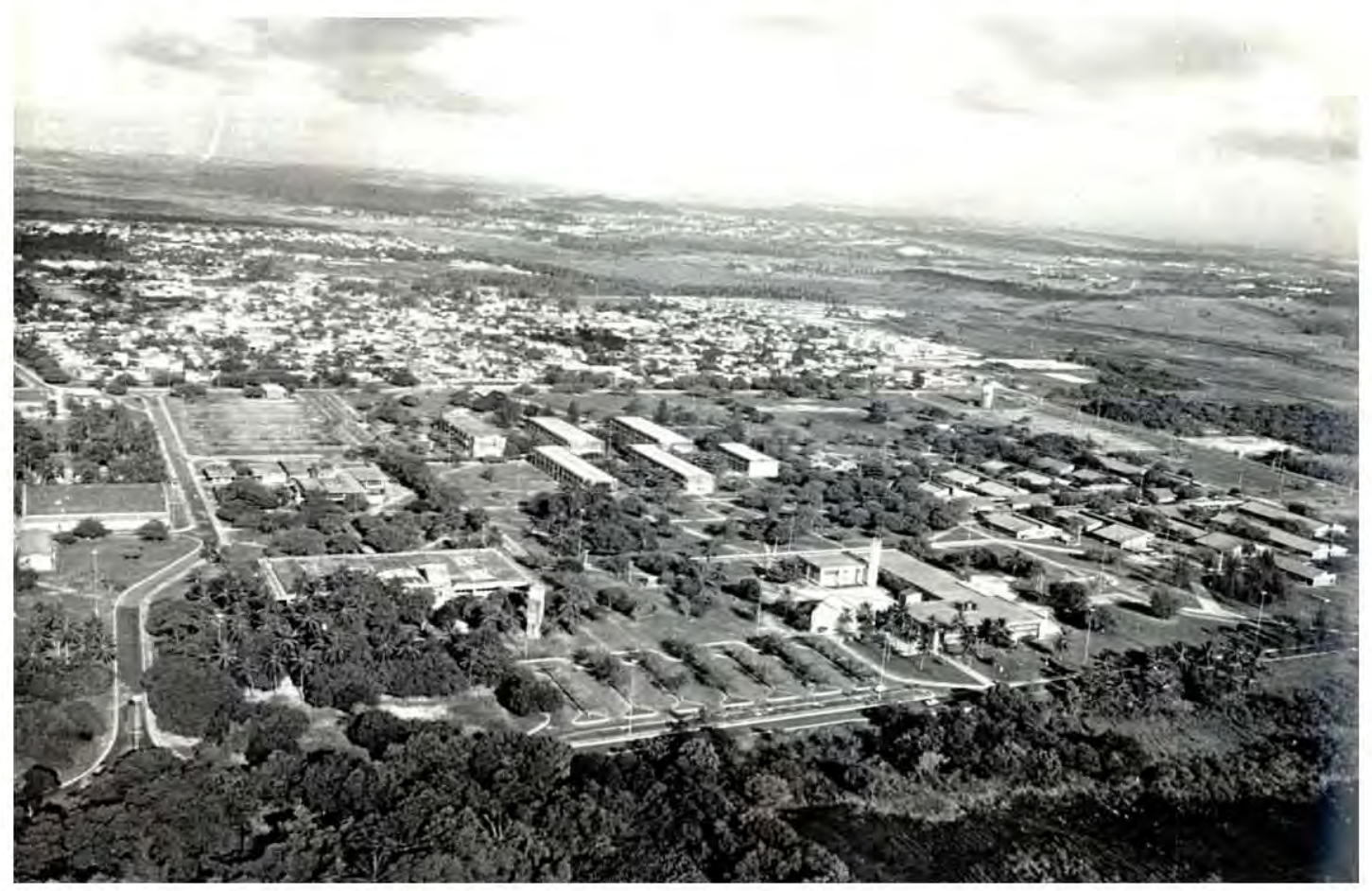

Figura 310: UFS - Vista Geral do Campus Universitário - década de 1980.

Já estavam construídos: a Reitoria, a Biblioteca, o Restaurante, os Laboratórios do Centro de Tecnologia, Unidades Didáticas e Departamentais, Setor Esportivo e as obras de infraestrutura. Pode-se visualizar o sistema viário com anel circular periférico e bolsões de estacionamento.

(Fonte: Acervo Assessoria de Comunicação - UFS) 


\section{- Setor Esportivo}

O Setor Esportivo (SE) teve inicialmente erguidos os equipamentos básicos para as aulas práticas de educação física, constando de: ginásio polivalente, campo de atletismo com pista olímpica de $400 \mathrm{~m}$, quadras polivalentes, conjunto aquático e o Departamento de Educação Física (ver figura 311).

A planta de concepção geral do Campus indica a projeção de futuras quadras de tênis, pista de cross-country, quadras polivalentes e ampliação do Departamento de Educação Física com a construção de outros blocos.

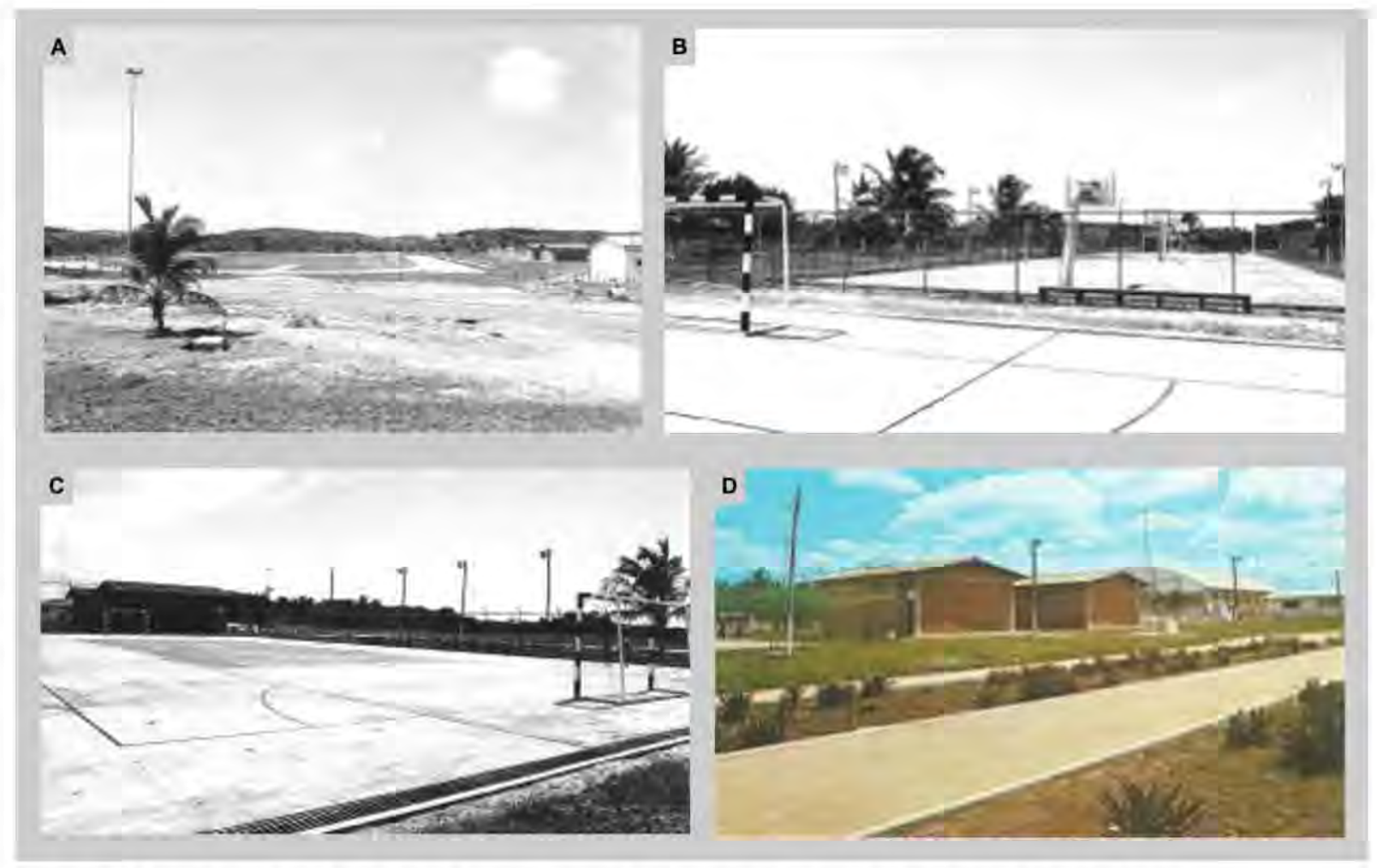

Figura 311: UFS - Vista do Setor Esportivo (SE) - segunda metade da década de 1970.

(A) Vista da pista de atletismo com campo de futebol, (B) Vista das quadras de basquete, (C) Quadra polivalente com detalhe da grelha de drenagem, (D) Vista dos blocos de apoio ao campo de atletismo e ao fundo o Ginásio Poliesportivo. A paisagem do SE é predominada pela vegetação nativa de característica rala e palmeiras tipo coqueiro. A arquitetura do SE adota blocos de linguagem homogênea, caracterizada por uma construção em tijolo aparente e coberta de telha canal. Os blocos se articulam por passarelas.

(Fonte: Arquivo Geral - Prefeitura do Campus)

A partir de setembro de 1976, foram iniciadas as obras do SE, cuja implantação seguiu as diretrizes do Plano Diretor, que indicava sua localização em área próxima à lagoa de estabilização e com previsão de extensa área. 
Podemos constatar que esta diretriz de implantação estava em acordo com o Manual de Atcon (1970), o qual indicava dentre as características do SE, sua localização em área "suficientemente grande" e o mais afastado possivel das demais atividades do campus, a fim de isolar os ruídos produzidos pelos esportes coletivos, bem como estar o mais longe possível do setor hospitalar, para evitar constrangimentos psicológicos aos enfermos (ATCON, 1970, p. 44).

\section{- Ginásio Poliesportivo (1976 - 1980)}

O projeto do ginásio polivalente foi elaborado pela equipe de técnicos da UFS. Sua implantação está em acordo com o Manual de Atcon (1970), próxima a uma via de circulação principal, sem interferência com as demais áreas do campus. A proposta arquitetônica buscou solucionar o programa (quadras polivalentes e áreas de vestiários e banheiros) em uma planta única coberta por arcos de estrutura metálica, apoiados nos pilares que marcam as fachadas longitudinais em conjunto com os combogós (ver projeto de arquitetura nas plantas das figuras $312 a, 312 b$ e $312 c$ ). A volumetria da edificação se destaca no conjunto esportivo indicando claramente sua função, sem evidência de intenção plástica formal, conforme se constata na figura 313 .

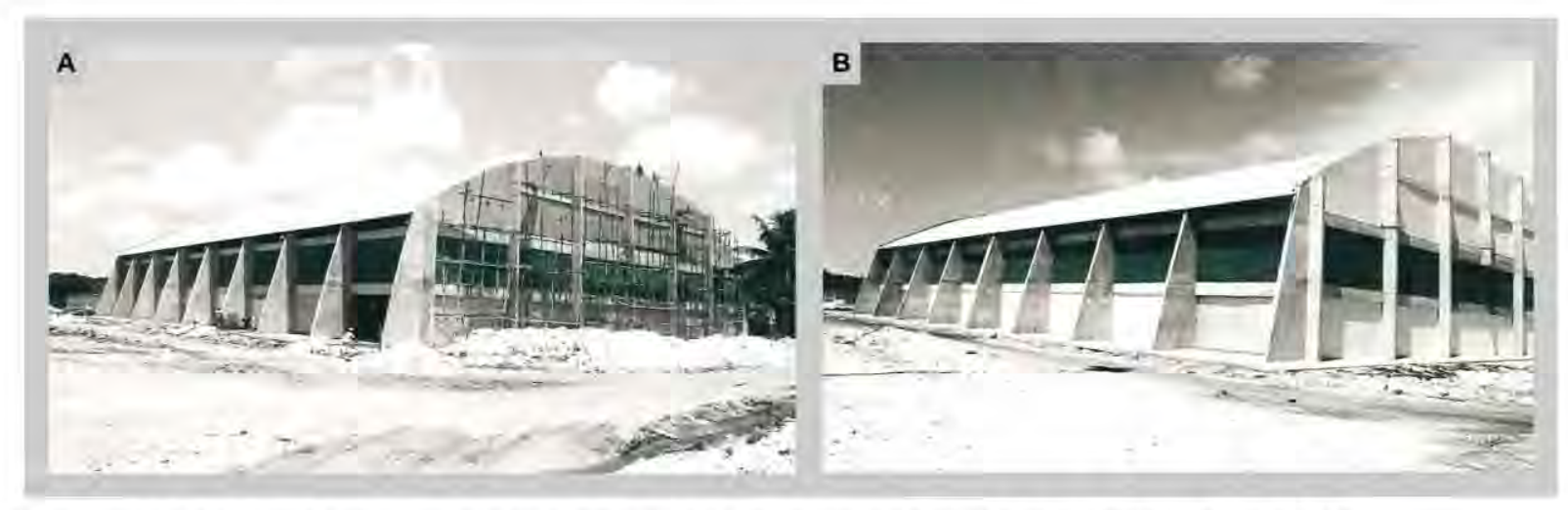

Figura 313: UFS - Vistas do ginásio poliesportivo - segunda metade da década de 1970.

(A) Vista do ginásio em construção.

(B) vista da fachada longitudinal, já concluída.

Destaca-se a estrutura de concreto aparente, diferenciando-se dos panos de vedação.

(Fonte: Arquivo Geral - Prefeitura do Campus)

\section{-Conjunto Didático e Administração Departamental}

O Conjunto Didático e a Administração Departamental formam o Setor Básico, constituído pelos blocos do Centro de Ciências Sociais Aplicadas e do Centro de Educação e Ciências Humanas. 
Parte 2 - Universidade Federal de Sergipe

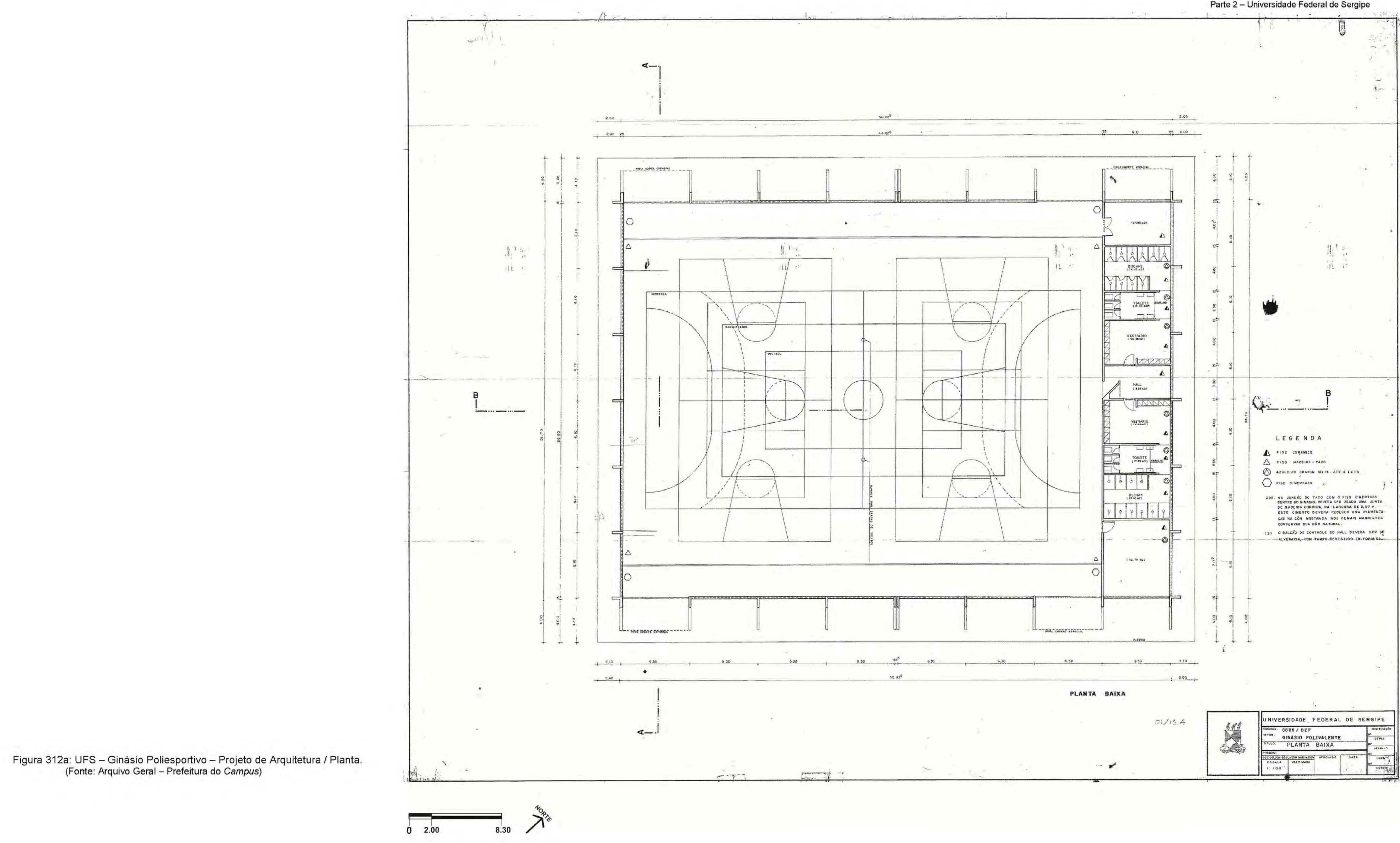




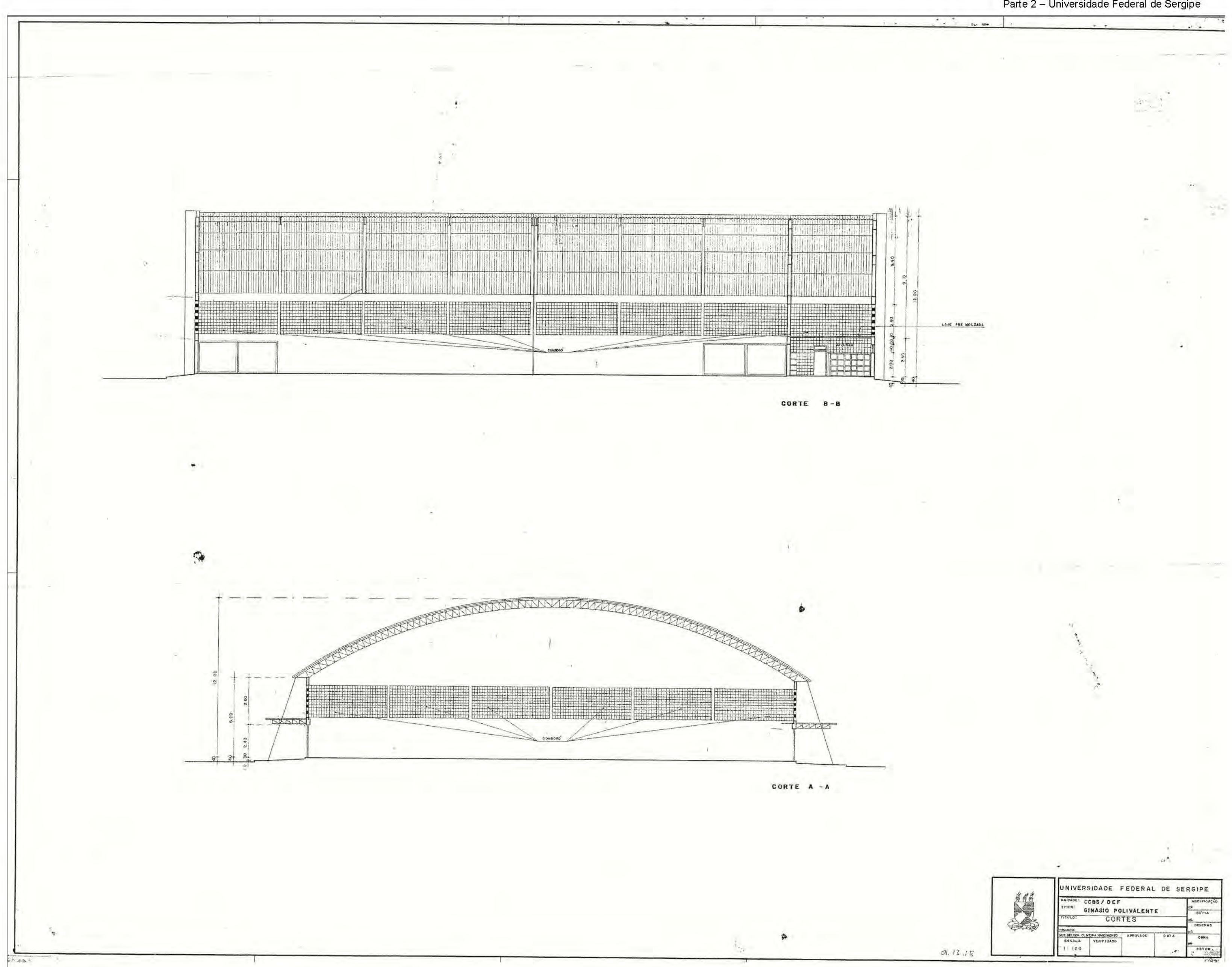




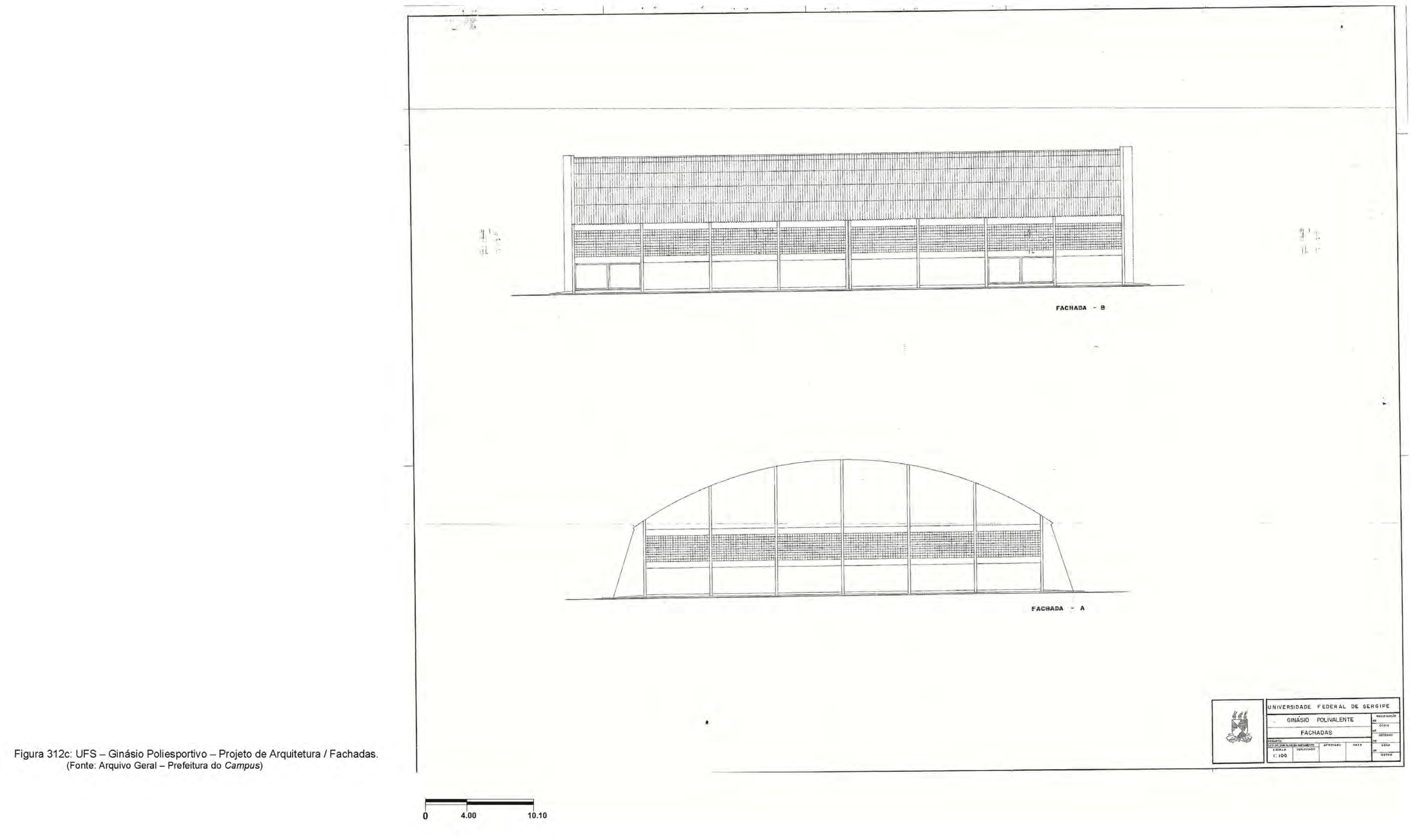




\section{- Implantação}

O conjunto, localizado em área central urbanizada, reflete a orientação do Manual de Atcon, que indicava o meio do Campus como local para a inserção do Setor Básico, entrelaçado com todos os demais, principalmente com aqueles que mais se abasteceriam dos serviços acadêmico-científicos (ver figuras 314 e 315 ).

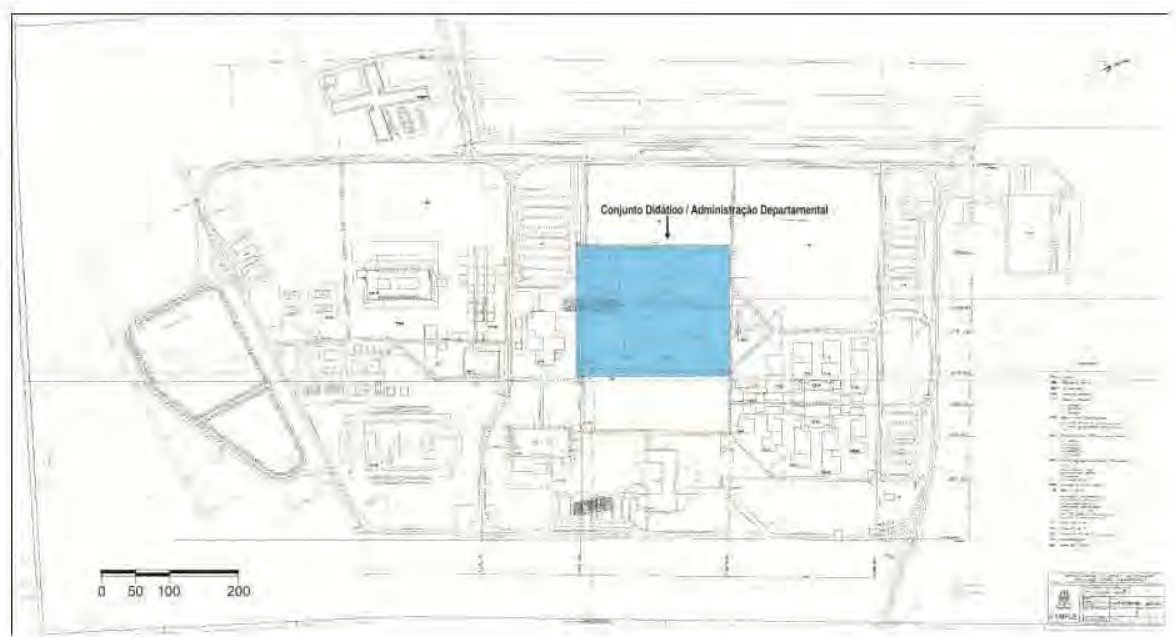

Figura 314: UFS - Localização do Conjunto Didático e Administração Departamental na planta do Campus Universitário.

A mancha azul indica a localização em área central. (Fonte: Acervo Prefeitura do Campus - UFS, grifo nosso)
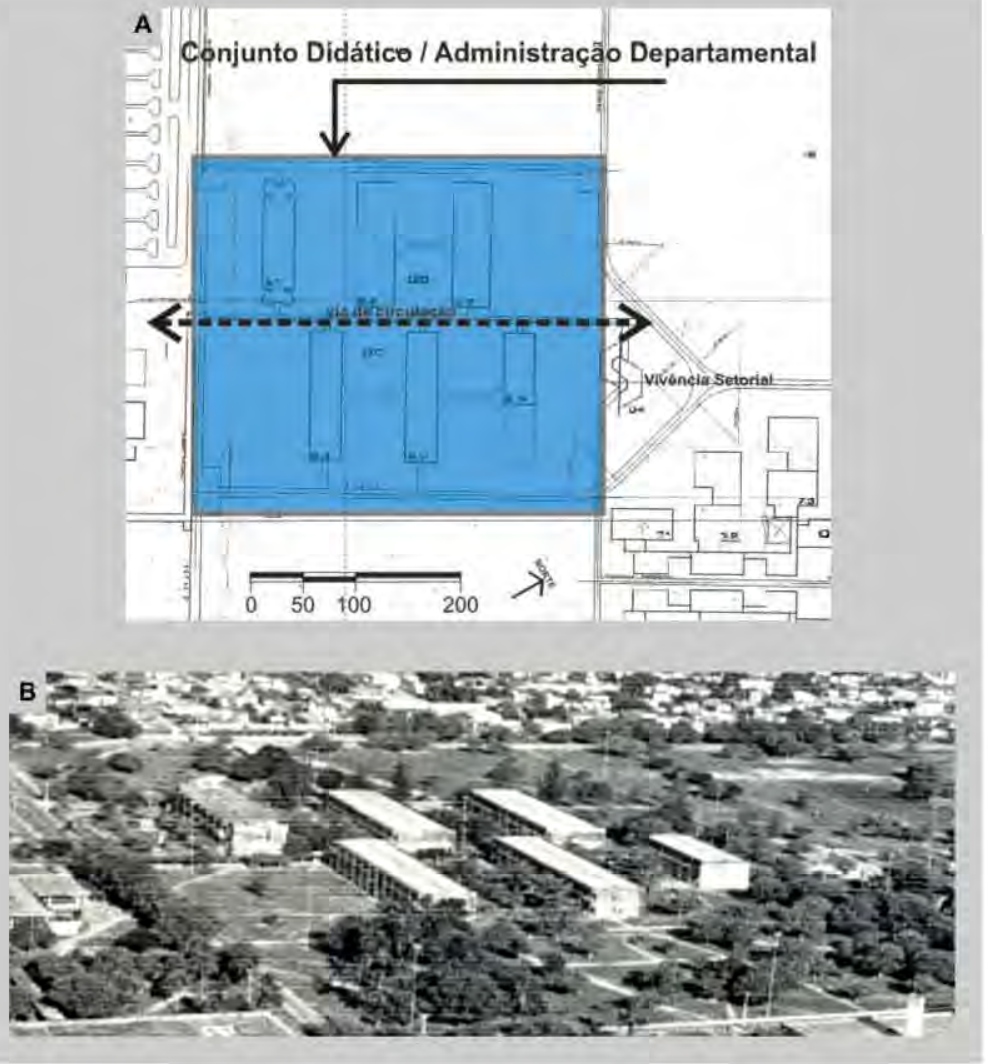

Figura 315: UFS - Detalhe do Conjunto Didático/Administração Departamental - década de 1980.

(A) O Conjunto adota o sistema pavilhonar e se articula através de uma via de veículos. No plano superior, as edificações $(5.1,5.2$ e 5.3) constituem as tipologias didáticas. Abaixo, os blocos (6.1, 6.2 e 6.3) constituem as tipologias departamentais. $O$ conjunto é abastecido pela unidade de Vivência Setorial, localizada na extremidade esquerda do eixo central.

(B) Detalhe do Conjunto Didático/ Administração Departamental.

(Fonte: Prefeitura do Campus e Arquivo Geral, grifos nosso) 
Adotando o sistema pavilhonar, forma um conjunto tipológico de linguagem homogênea, constituído por edificações de dois pavimentos que se articulam por uma via central de circulação motorizada e passarelas para pedestres entre os mesmos (ver figuras 316 e 317).

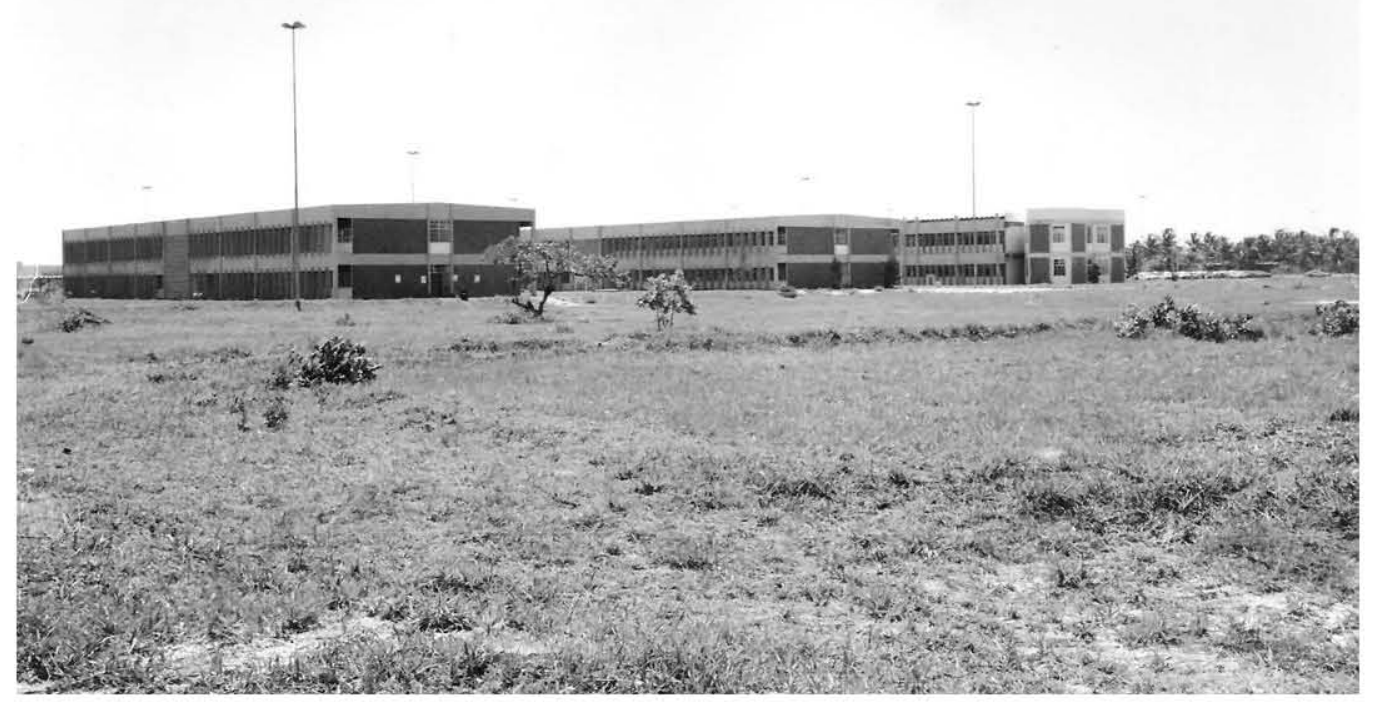

Figura 316: UFS - Vista do Conjunto Didático - segunda metade da década de 1970. No primeiro plano (à esquerda) dois blocos de didática Tipo 2 e (direita ao fundo) um bloco de didática Tipo 1. Estão implantados em extensas áreas de vegetação.

(Fonte: Arquivo Geral - Prefeitura do Campus)

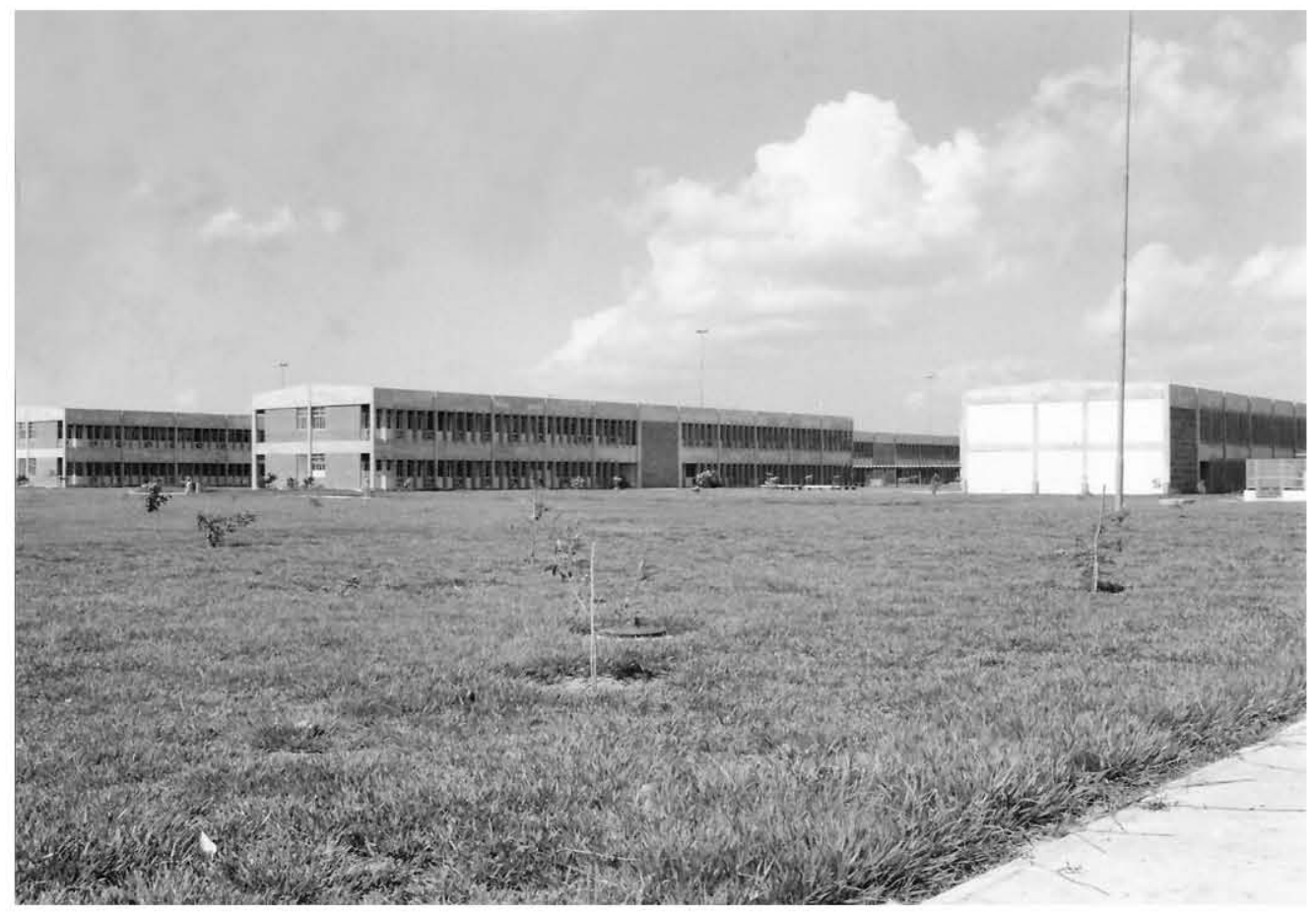

Figura 317: UFS - Vista do Conjunto da Administração Departamental - segunda metade da década de 1970.

(Fonte: Arquivo Geral - Prefeitura do Campus) 
A proposta pavilhonar estava associada à filosofia de construir por etapas, atendendo à disponibilidade dos recursos financeiros e às demandas do planejamento institucional. Implantados em extensas áreas de vegetação nativa, seguiam a recomendação do Manual (ATCON, 1970, p. 82) com vistas à expansão horizontal, a qual deveria ocorrer dentro da região reservada para o respectivo campo de conhecimento afim. Dessa forma, novas edificações poderiam ser gradativamente agregadas, sem transtornos para as atividades acadêmicas já em desenvolvimento e evitando custos onerosos com uma expansão vertical.

Atendendo aos princípios de racionalidade e flexibilidade que balizaram a forma de organização da Universidade, a arquitetura concebida fez da padronização o critério dominante dessas tipologias. O partido é definido pela modulação que padroniza o sistema estrutural e os componentes construtivos, resultando no desenho de cunho racionalista. Predomina o bloco de volumetria horizontal com ênfase na verdade estrutural. As unidades com programas semelhantes adotam os mesmos projetos.

\section{- Edifícios de Didática}

O conjunto é composto de três blocos que formam duas tipologias, sendo dois do Tipo 1 e o terceiro do Tipo 2 (ver figura 318).

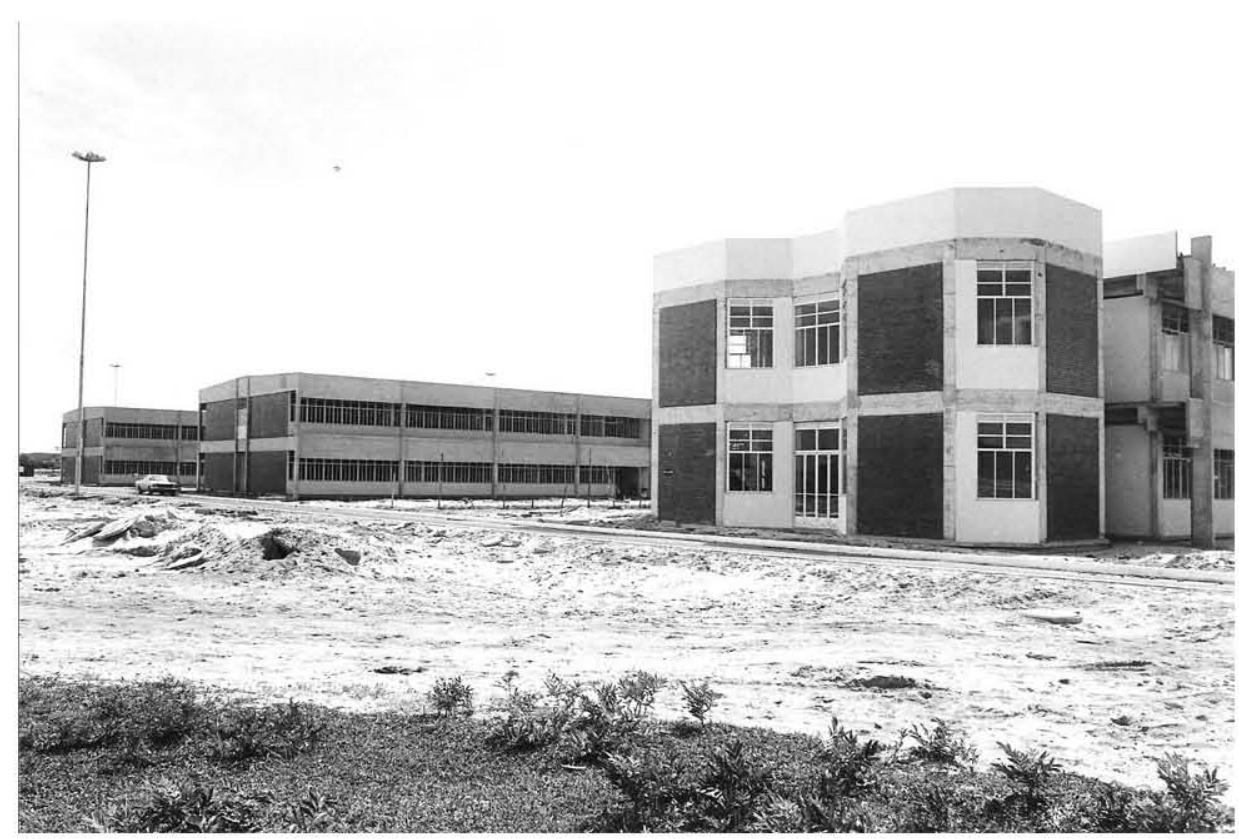

Figura 318: UFS - Detalhe do Conjunto Didático - segunda metade da década de 1970 .

No primeiro plano (direita) bloco de didática Tipo 1, no segundo plano (esquerda) dois blocos de didática Tipo 2.

(Fonte: Arquivo Geral - Prefeitura do Campus) 


\section{- Bloco Didático Tipo 1}

O projeto do Bloco Didático Tipo 1 foi elaborado pela empresa UNISPLAN - Consultoria, Planejamento e Arquitetura SiA Ltda., para atender ao programa de salas de aulas teóricas com capacidades diferenciadas, sendo 10, tipo 01 com capacidade de 36 a 42 alunos (equivalente a uma relaçẫo mínima de $1,35 \mathrm{~m}^{2}$ ialuno) e 4 , tipo 02 para atender de 24 a 30 alunos (equivalente a uma relaçẫo mínima de $1,16 \mathrm{~m}^{2} /$ aluno), distribuídas nos dois pavimentos. A área total da edific açẫo era de $985,92 \mathrm{~m}^{2}$ (ver projeto de arquitetura nas plantas das figuras $319 a$ e $319 \mathrm{~b})$.

O partido arquitetônic o adotou uma edificaçẫo de dois pavimentos (térreo e superior), definidos por um exo central de circulaçẫo longitudinal que articula as salas de aulas resultando em um volume prismático retangular e em cujas extremidades se agregam a volumetria correspondente ao setor de serviços e circulaçẫo vertical (sanitários e escada respectivamente), que se unem ao corpo principal formando uma composiçẫo volumétrica por uniẫo (figuras 320 e 321 ).

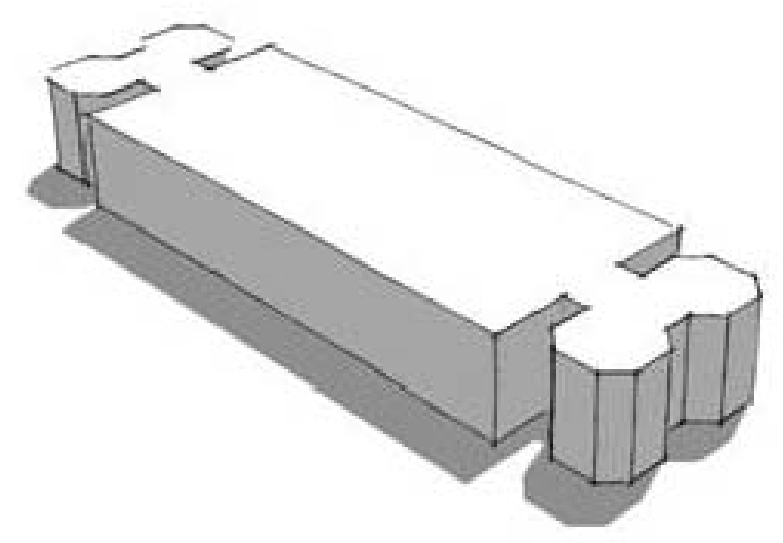

Figura 320: UFS - Bloco Didático Tipo 1 - Composiçẫo volum étrica.

$O$ edifício resulta da uniẫo dos volumes funcionais.

(Fonte: elabor ação da autora) 


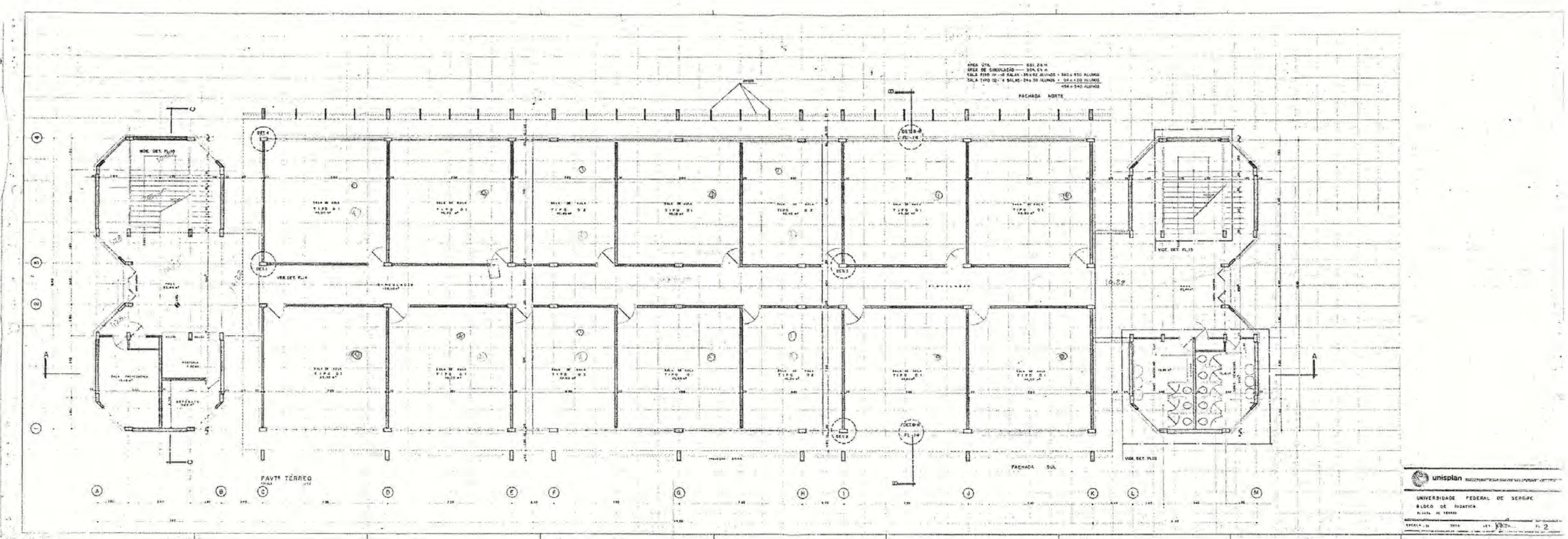


FOLHA VERSO DA FOLHA GRANDE - NÃO IMPRIMIR 


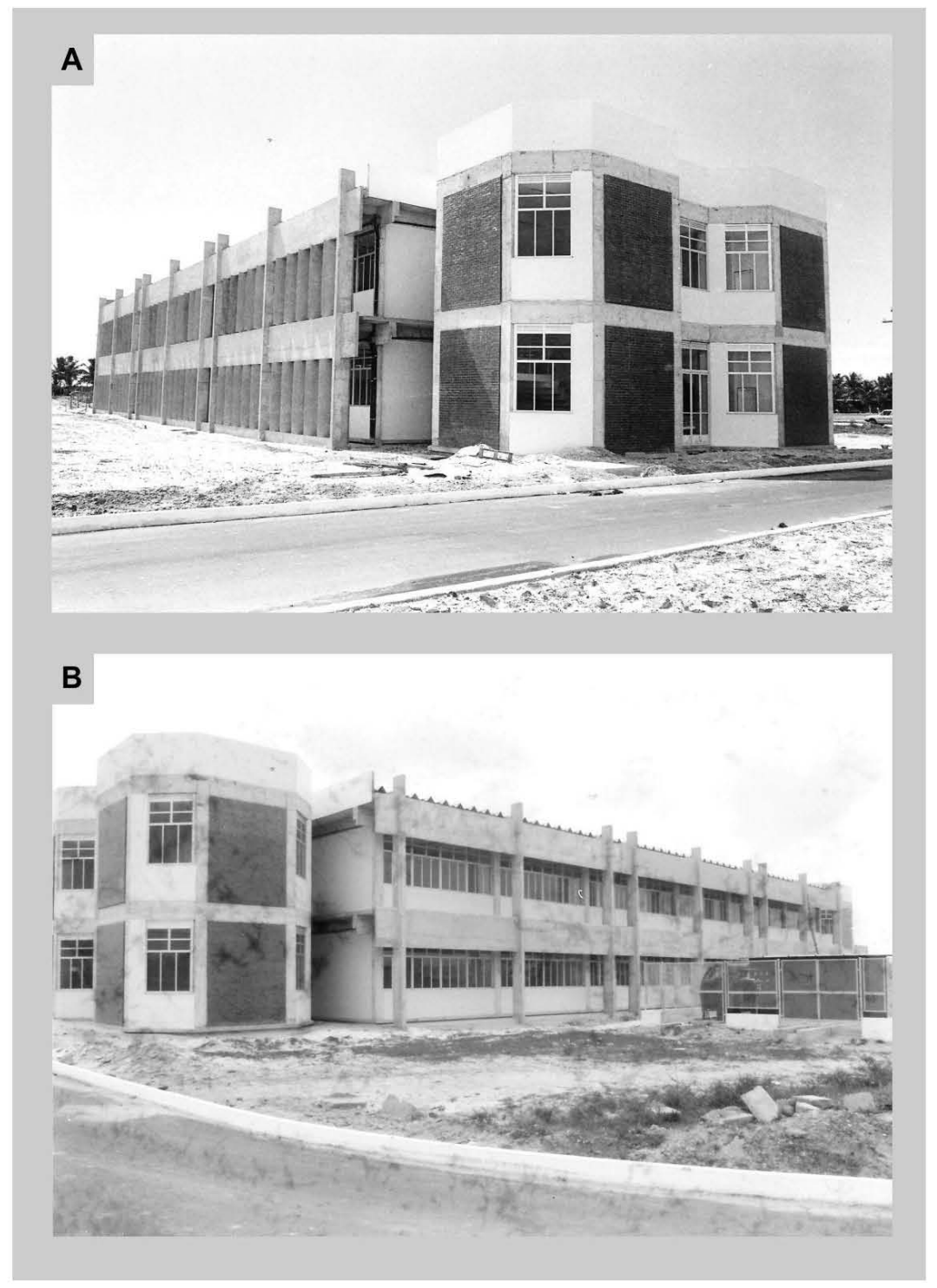

Figura 321: UFS - Tipologia didática Tipo 1 - segunda metade da década de 1970.

Os volumes funcionais se destacam numa composição por união (o volume prismático retangular das salas de aulas teóricas se une ao volume geométrico octogonal de serviços e circulação sanitários e escada).

A fachada sudoeste, mais ensolarada, utiliza elementos de proteção solar verticais e a fachada sudeste destaca as esquadrias de alumínio e vidro.

uso da platibanda reforça a composição volumétrica do prisma didático.

(Fonte: Arquivo Geral - Prefeitura do Campus)

O conceito construtivo caracteriza-se pela planta-livre, projetada sob uma malha modular quadrada de $1,20 \mathrm{~m} \times 1,20 \mathrm{~m}$, que associa o módulo estrutural $(7,20 \mathrm{~m} \times 7,20 \mathrm{~m}) \mathrm{em}$ concreto armado (pilares, vigas e laje), evidenciando a possibilidade de novos arranjos funcionais, dentro da ideia de flexibilidade (ver figura 322). O sistema estrutural em concreto 
aparente marca as fachadas com clara separação dos panos de vedação. Na fachada sudeste, o prolongamento da viga de contorno evidencia a função de elemento de proteção da radiação solar direta. A fachada norte, a mais ensolarada ao longo do ano, recebe elementos verticais em concreto aparente para proteção da radiação solar direta, embora naquela latitude $\left(11^{\circ} 04^{\prime} \mathrm{S}\right)$, para a eficiência da proteção, seria necessária a conjugação de elementos horizontais. As vedações são em alvenaria de tijolo revestidos por material cerâmico e com aberturas em esquadrias de alumínio e vidro. A coberta com platibanda também em concreto aparente reforça a geometria funcional da edificação.

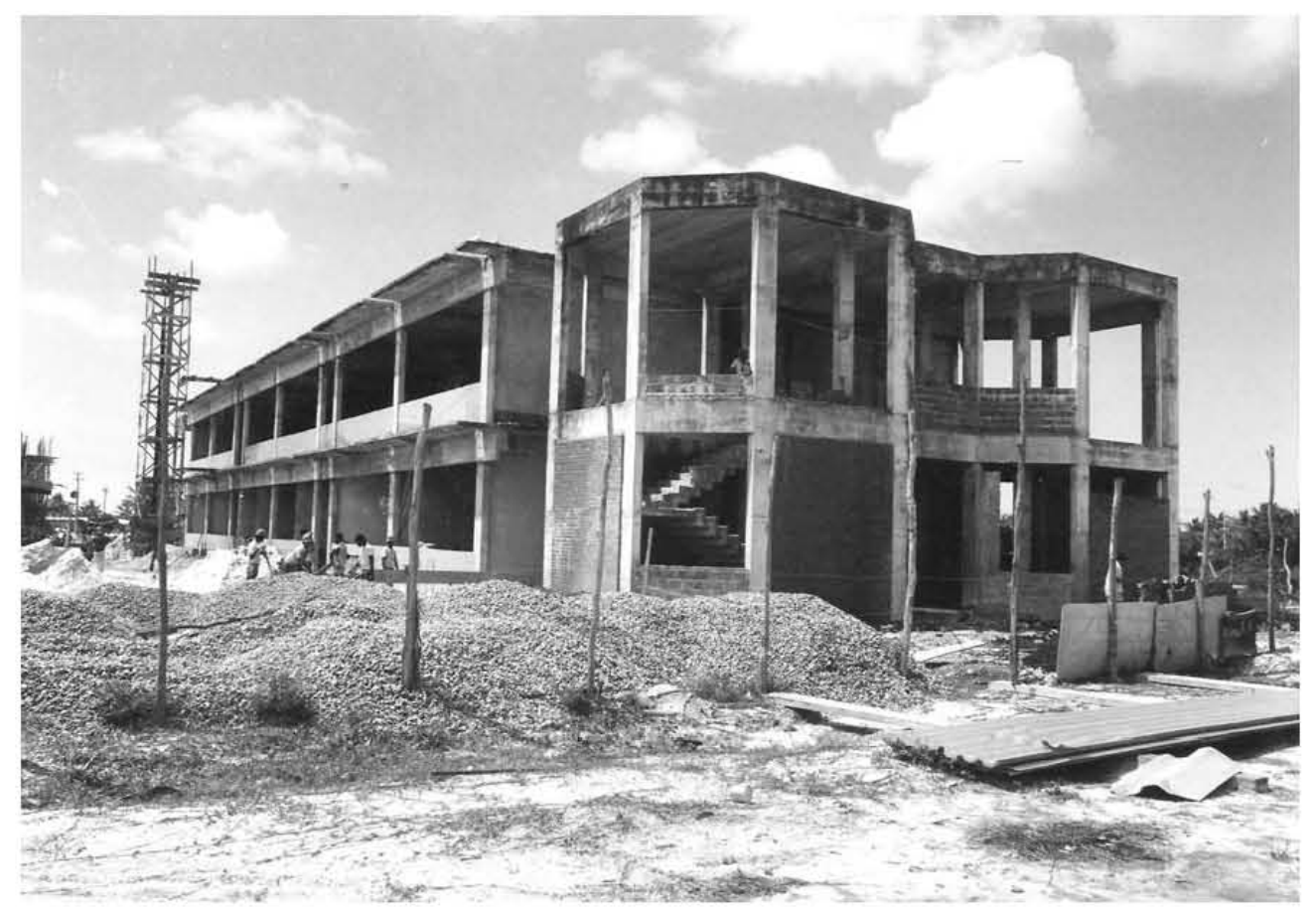

Figura 322: UFS - Execução do sistema estrutural da tipologia didática Tipo 1. A estrutura é independente com acabamento em concreto aparente (pilares, vigas e lajes).

(Fonte: Arquivo Geral - Prefeitura do Campus)

A organização funcional do corpo principal, caracterizada pelo arranjo linear das salas de aulas e dos setores de serviços, determina a forma arquitetônica que resulta da composição dos volumes geométricos funcionais com a superfície das fachadas, composta pela estrutura aparente que se conjuga com o revestimento de tijolo cerâmico, cujo acabamento natural em tom vermelho contrasta com a cor cinza natural da estrutura de concreto aparente (ver figuras 323 e 324). A análise dos projetos evidencia a organização da forma dentro dos princípios de simetria e hierarquização da volumetria, onde os volumes das extremidades fazem contraponto com o corpo prismático central. 


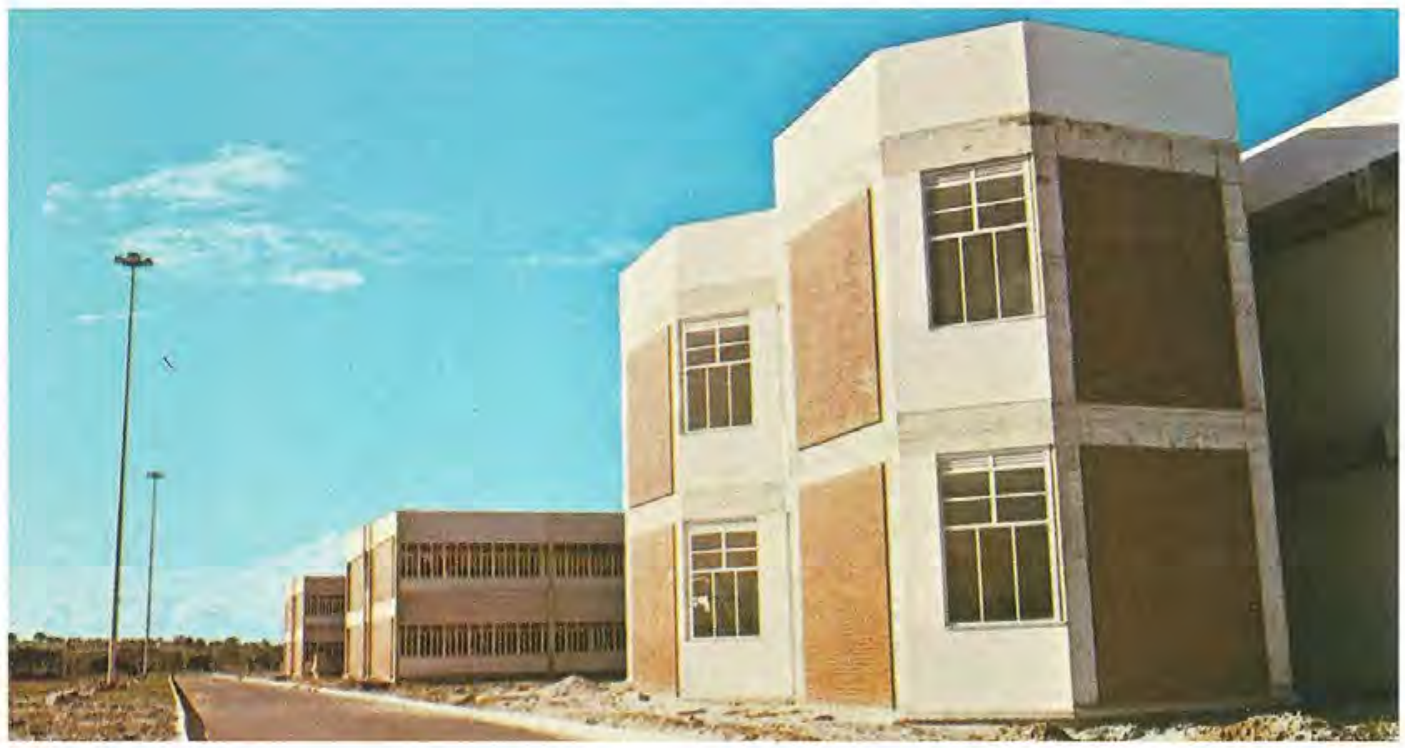

Figura 323: UFS - Bloco Didático Tipo 1 - segunda metade da década de 1970.

Adota o conceito da verdade construtiva com separação dos panos de vedação (alvenaria de tijolo cerâmico) e da estrutura de concreto (acabamento aparente). A platibanda reforça a volumetria de formas puras.

(Fonte: UFS, 1981?, p. 43)

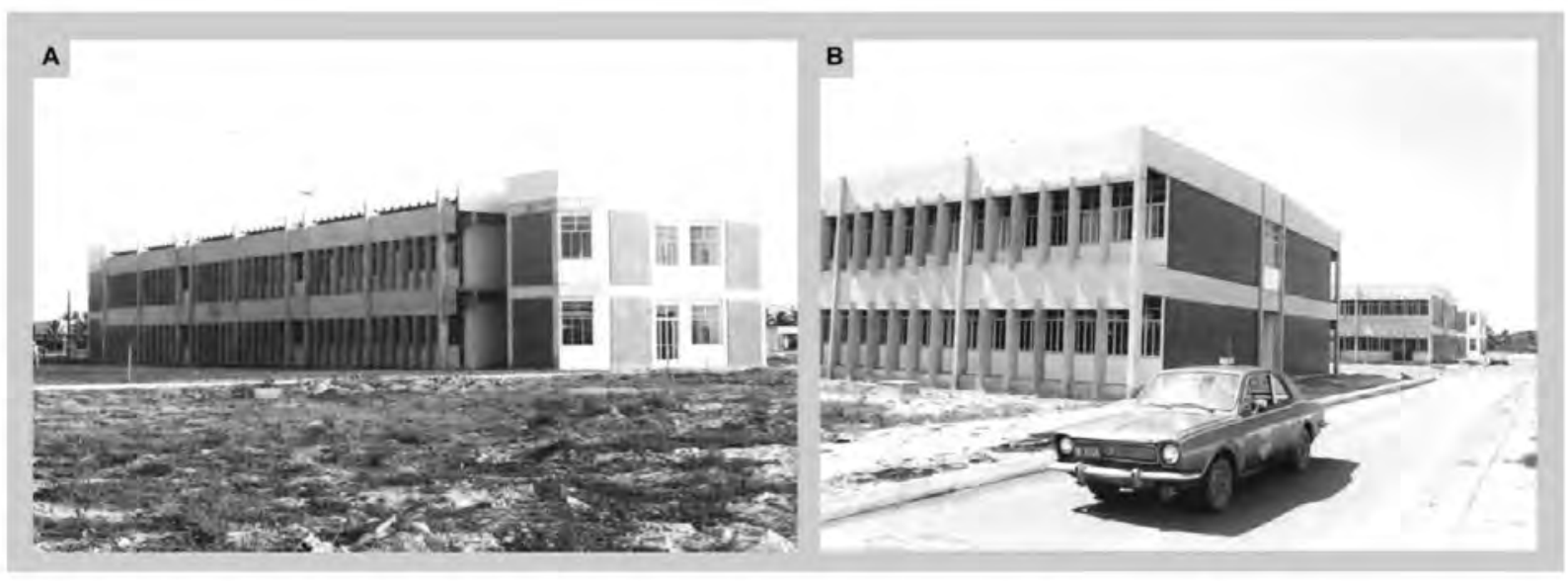

Figura 324: UFS - Vista do Bloco Didático Tipo 1 - segunda metade da década de 1970.

(A) Detalhe da fachada sudoeste com os brises verticais em concreto aparente.

(B) A via de veículos divide o conjunto didático da administração departamental e, ao mesmo tempo, articula o conjunto pavilhonar numa sequência de ordenação linear.

(Fonte: Arquivo Geral - Prefeitura do Campus)

\section{- Bloco Didático Tipo 2}

O projeto de arquitetura do Bloco Didático Tipo 2 foi elaborado pelo escritório técnico da Universidade Federal do Piauí, por meio do Convênio ETA UFSE/CEPRO FUPI ${ }^{122}$, em 1977. A planta de arquitetura do primeiro pavimento (não foi localizada a planta do térreo) atendeu ao programa de 12 salas de aula com área de $55,08 \mathrm{~m}^{2}$ (foi estimada a capacidade para 45

\footnotetext{
122 O projeto de arquitetura é de autoria dos arquitetos que estavam trabalhando na Prefeitura do Campus da UFPI: Ronaldo Marques, João Alberto Monteiro, Neusa Galvão e Francisco Washington Santos. Os dois primeiros foram entrevistados durante a nossa pesquisa de campo naquela Universidade.
} 
alunos, com a relação de $1,23 \mathrm{~m}^{2} /$ aluno), 4 salas para estudo de grupo e 2 salas de estar (ver projeto de arquitetura na planta da figura 31). A área total $\left(1.403,73 \mathrm{~m}^{2}\right)$ foi distribuída em dois pavimentos de mesmas dimensões que se sobrepõem (ver figuras 326 e 327).

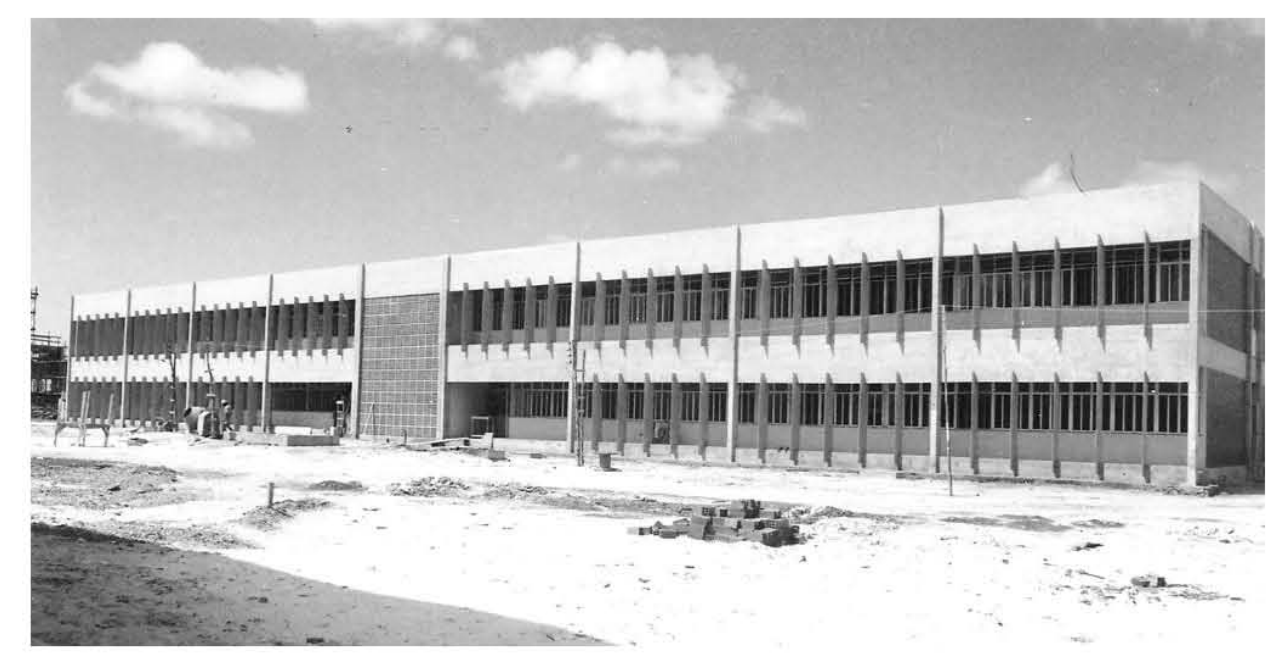

Figura 326: UFS - Bloco Didático Tipo 2/fachada norte - segunda metade da década de 1970.

Os brises verticais e a superfície de combogó buscam o controle da radiação solar e participam como elemento de composição da forma arquitetônica. A estrutura trazida aos limites da edificação evidência o princípio da "verdade estrutural".

(Fonte: Arquivo Geral - Prefeitura do Campus)

Figura 327: UFS - Vista do Bloco Didático Tipo 2 / fachada sul - segunda metade da década de 1970. Assim como na fachada norte, a superfície de combogó ameniza a linearidade da forma, e, ao mesmo tempo, atua como filtro solar.

(Fonte: Arquivo Geral - Prefeitura do Campus)

O partido arquitetônico adota as áreas dos sanitários e escadas (setor de serviços) como elemento central de ordenação da planta a partir do qual os demais ambientes se agregam por meio do eixo da circulação longitudinal que os articula dentro do princípio de organização linear. O setor de serviços se destaca no alinhamento externo da planta, cuja 
ELEVEAERO NORTE
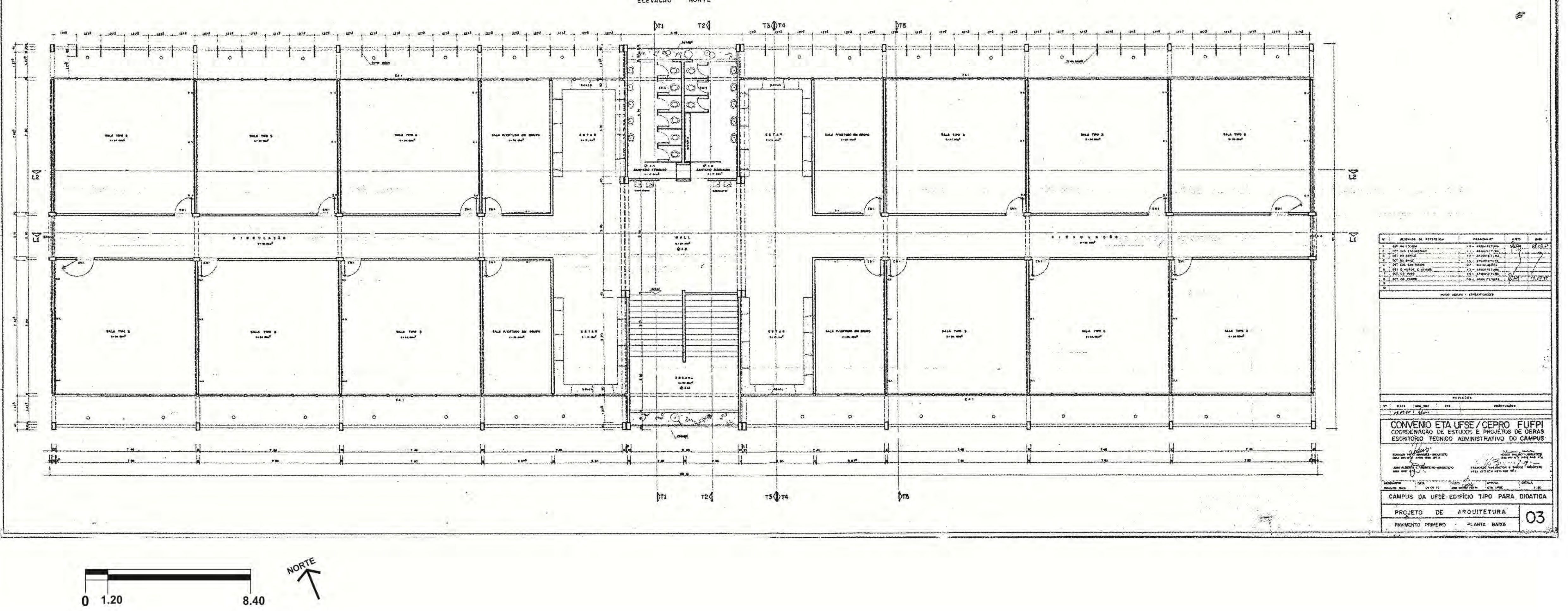

Figura 325: UFS - Bloco Didático Tipo 2-Projeto de Arquitetura / Planta Pavto. Térreo.
(Fonte: Arguivo Geral - Prefeitura do Campus) 
diferença é compensada na fachada norte pelo uso de brises verticais e na fachada sul pela estrutura de pilares e vigas. Com esta solução a composição volumétrica resulta em um volume prismático retangular, contido pelos elementos aparentes, constituindo o tipo "barra" (ver figura 328).

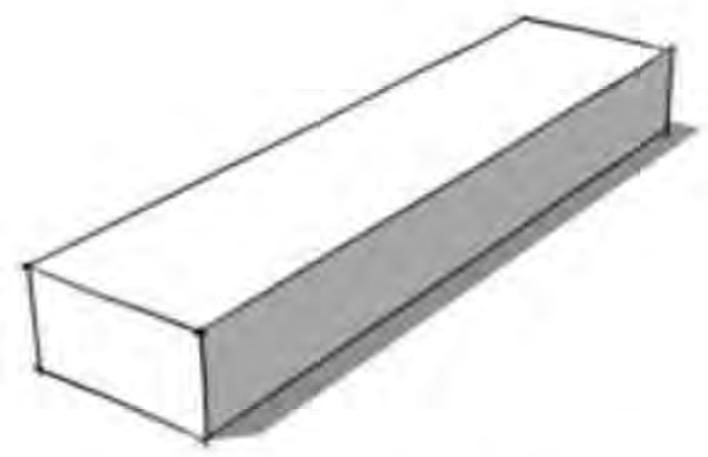

Figura 328: UFS - Bloco Didático Tipo 2/volumetria em bloco tipo barra. (Fonte: elaboração da autora)

O conceito construtivo da planta-livre adota o módulo estrutural $(7,20 \mathrm{~m} \times 7,20 \mathrm{~m}) \mathrm{em}$ concreto armado convencional (pilares, vigas e laje), que corresponde às salas de aula, sendo subdividido para criar os demais ambientes. A estrutura subordina o programa, evidenciando um rígido disciplinamento na organização da planta, que garante a volumetria geométrica prismática. A proposta utiliza os panos de combogó nas fachadas como elemento de simetria, resultando ao mesmo tempo em contraponto à linguagem homogênea da edificação, destacada pela modulação estrutural aparente, a qual é adotada como elemento explícito na definição plástica do edifício, evidenciando a busca do conceito da verdade estrutural. A organização da forma resulta da rígida composição funcional da planta (ver figura 329).

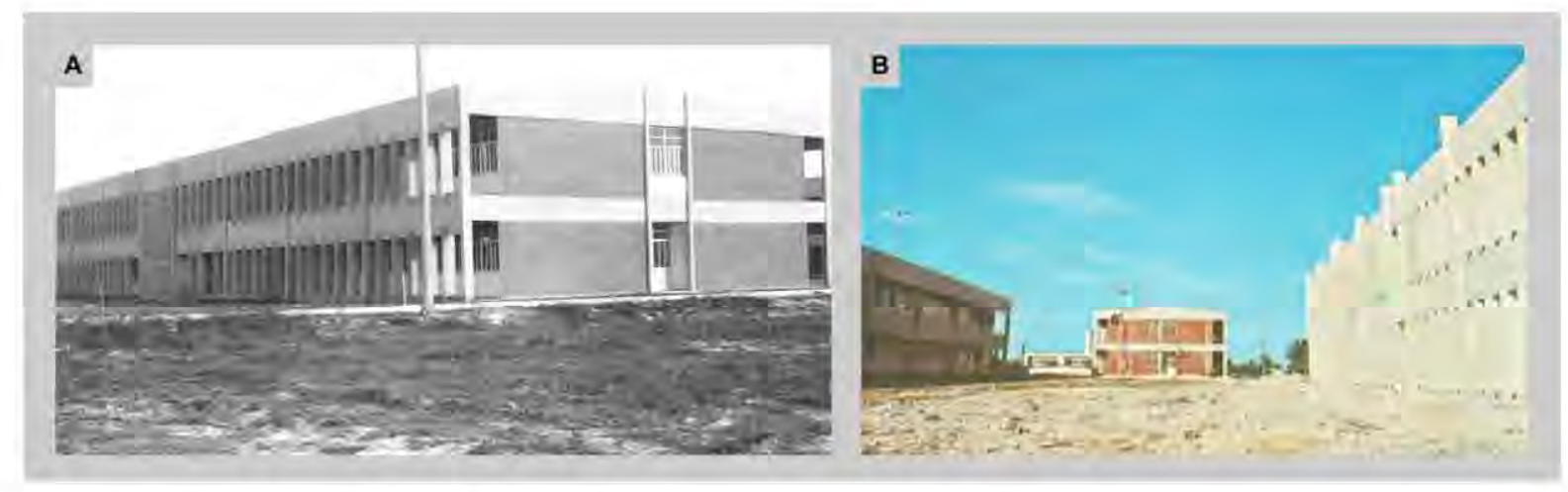

Figura 329: UFS - Bloco Didático Tipo 2 - segunda metade da década de 1970.

(A) Vista da fachada norte: os brises verticais de concreto aparente compõem a forma arquitetônica. (Fonte: Arquivo Geral - Prefeitura do Campus).

(B) Vista do conjunto das edificações: os panos de vedações em cerâmica vermelha enfatizam a estrutura independente.

(Fonte: UFS, 1981?, p. 43) 


\section{- Bloco Departamental Tipo 1 e Tipo 2}

O Bloco Departamental constitui uma tipologia de função administrativa que atende a dois diferentes programas, resultando na variação desta tipologia em Tipo 1 e Tipo 2, cujos atributos arquitetônicos mantêm a mesma matriz formal e construtiva. A elaboração do projeto de arquitetura coube também ao Escritório Técnico da Universidade Federal do Piauí, oriundo do mesmo convênio entre as duas instituições.

A demanda do programa envolveu áreas administrativas (diretorias, secretarias, assessorias, reuniões, salas de professores, salas dos departamentos, núcleos de pesquisa, dentre outros); de apoio (almoxarifados, arquivos, mecanografia, depósitos etc.); e de serviços (sanitários, portaria, depósitos) em todos os casos distribuídos em dois pavimentos.

O partido arquitetônico é o resultado da organização funcional na planta livre de geometria retangular, com dimensões de $17,05 \mathrm{~m} \times 70,70 \mathrm{~m}$, onde os ambientes se interligam pelo corredor longitudinal centralizado na maior dimensão, que cria duas alas paralelas de trabalho. As áreas dos sanitários e escadas compõem uma unidade de serviços concebida como núcleo central (ver projeto de arquitetura do Tipo 1 nas figuras 330 a a 330e e o projeto do Tipo 2 nas figuras $331 \mathrm{a}$ e $331 \mathrm{~b}$ ).

O sistema construtivo adota a estrutura em concreto armado convencional (pilares, vigas e laje), seguindo uma modulação de vãos a cada $6,45 \mathrm{~m}$ no eixo longitudinal. 0 módulo estrutural subordina a padronização das vedações em esquadrias de alumínio e vidro nas fachadas norte e sul, com a paginação da esquadria em seis módulos iguais. Da mesma forma, controla a compartimentação dos ambientes, cujas divisórias em alvenaria ocorrem em concordância com os montantes das esquadrias e das peças verticais de proteção solar, evidenciando a rigidez projetual subordinada ao conceito da modulação.

A forma arquitetônica resulta da planta funcional contida pela estrutura aparente (verdade estrutural), pelos panos de combogó (eixo de simetria da composição) e pelos elementos de proteção solar. Ressalte-se que em todas as tipologias do Conjunto Didático e da Administração Departamental, os brises verticais eliminam a radiação solar direta somente no início da manhã e final da tarde.

Evidenciam as referências ao vocabulário do movimento moderno, que adotava os dispositivos de proteção solar como elemento plástico formal. Comparece na composição da verdade construtiva o contraste de cor e textura dos materiais de revestimento de fabricação local com a estrutura aparente (ver figuras 332 à 34 ). 


$$
\overbrace{0.100^{5}}^{1.00^{5}}
$$

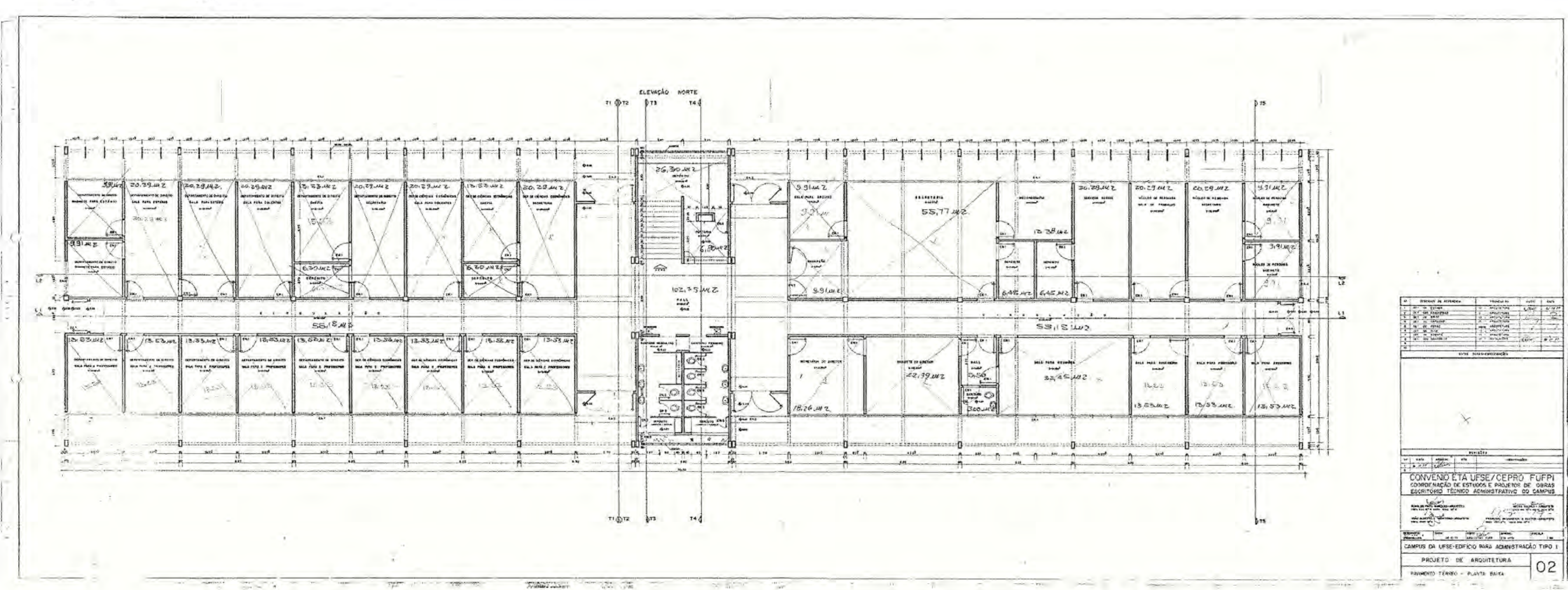




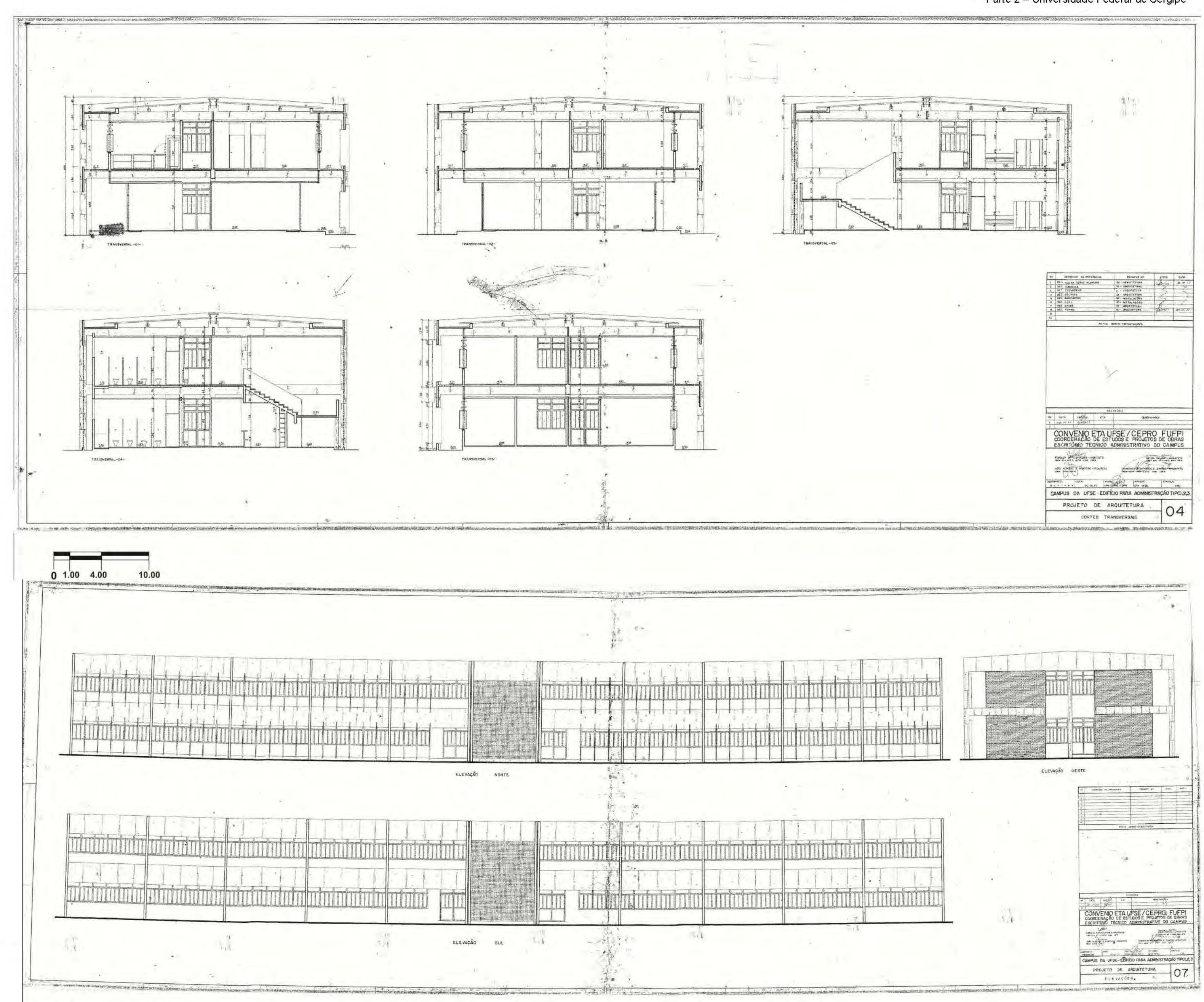



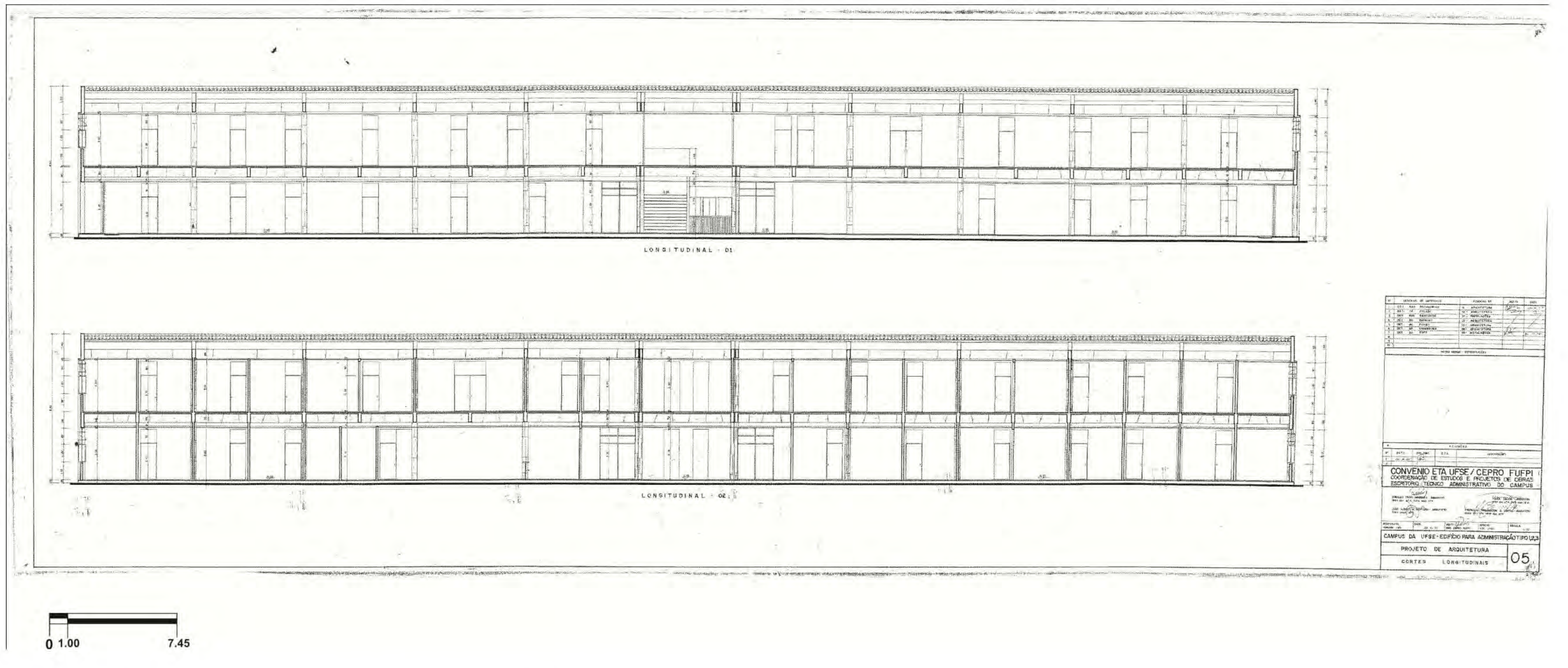

Figura 330e: UFS - Bloco Departamental Tipo 1 - Projeto de Arquitetura / Fachadas. 


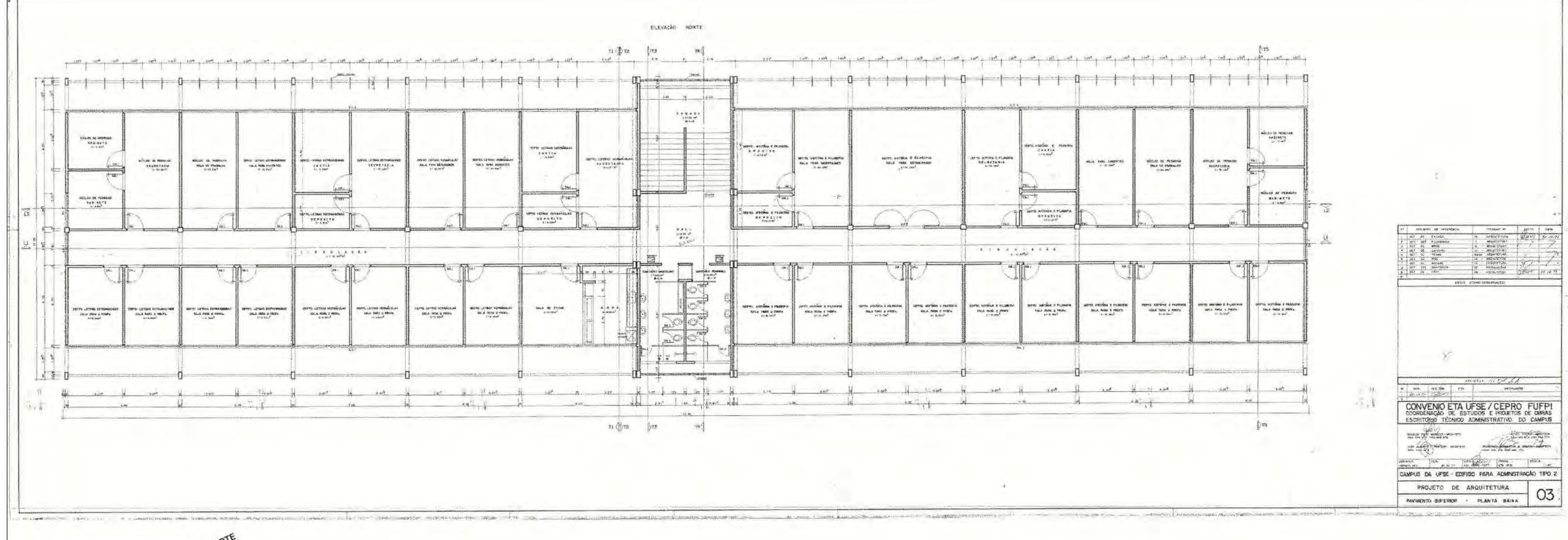

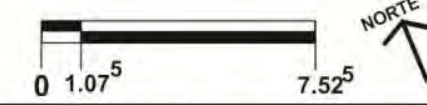

a.

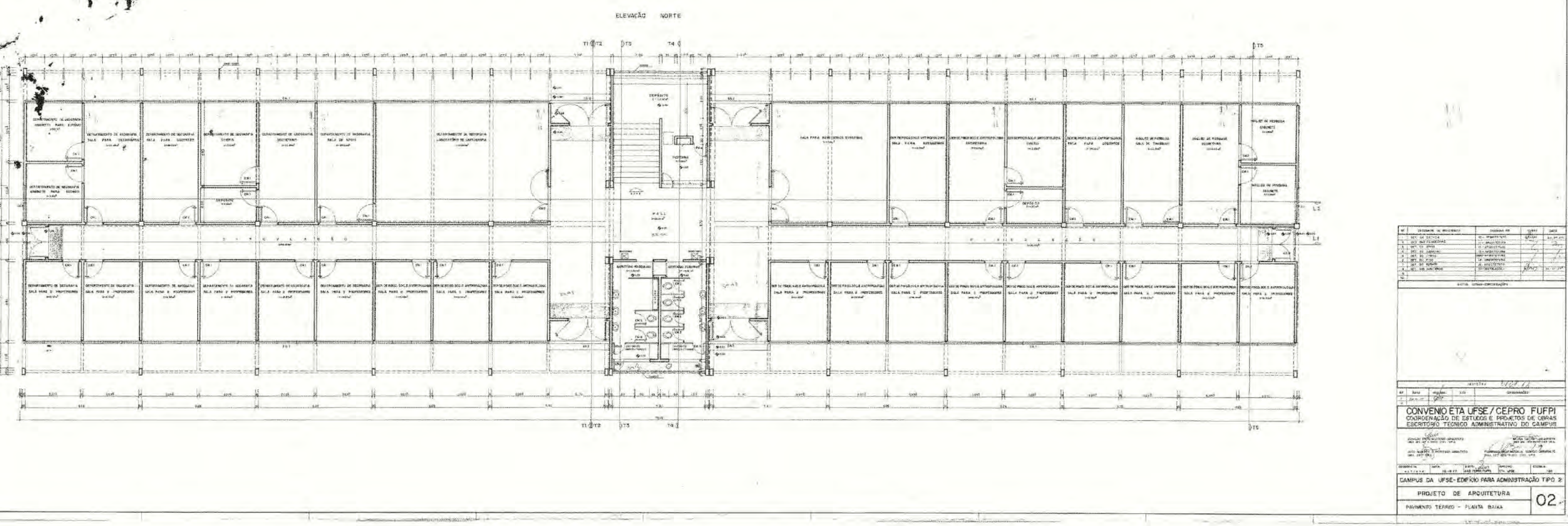


FOLHA VERSO DA FOLHA GRANDE - NÃO IMPRIMIR 


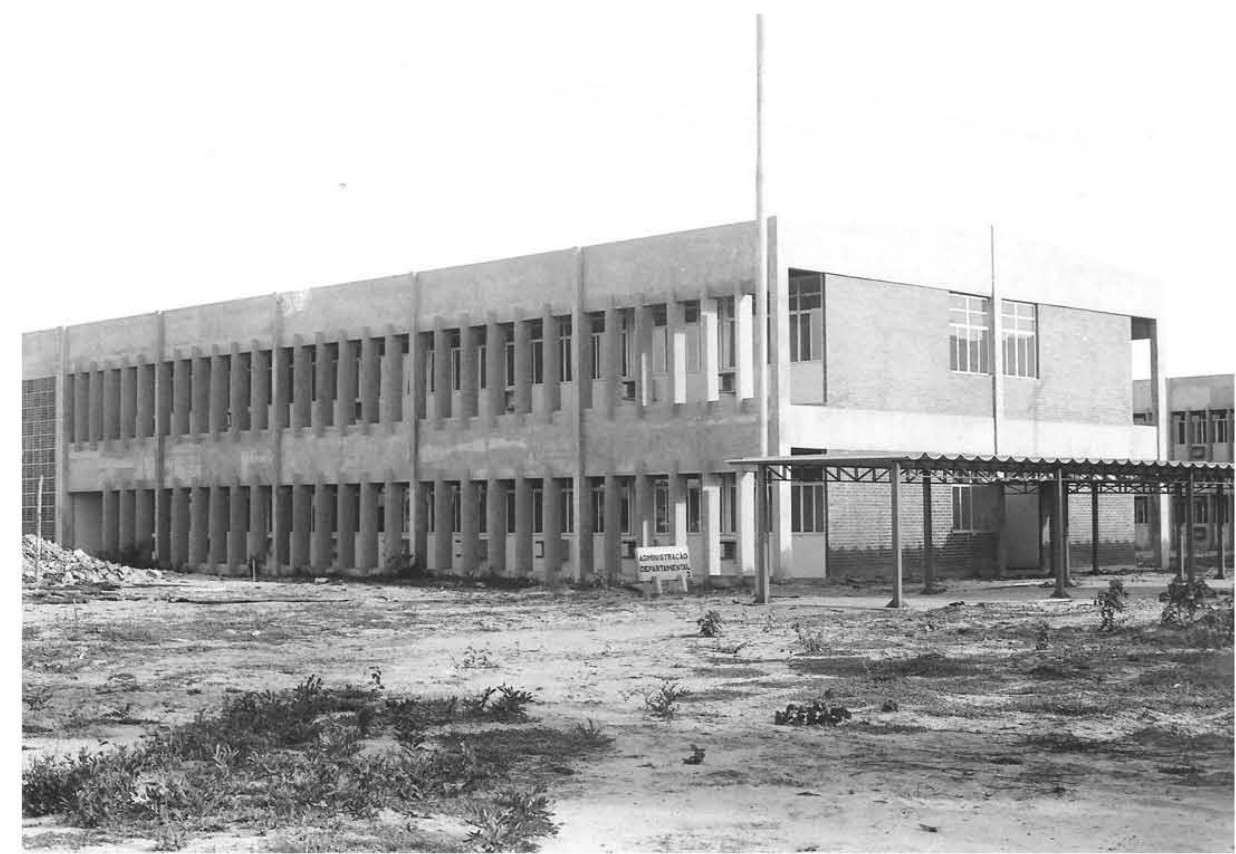

Figura 332: UFS - Bloco Departamental Tipo 1 - segunda metade da década de 1970. Vista da fachada norte que adota os brises verticais conjugados com a estrutura de concreto aparente, trazida para os limites da edificação. A composição atua como um filtro, criando uma película permeável que suaviza o impacto da forma prismática.

(Fonte: Arquivo Geral - Prefeitura do Campus).

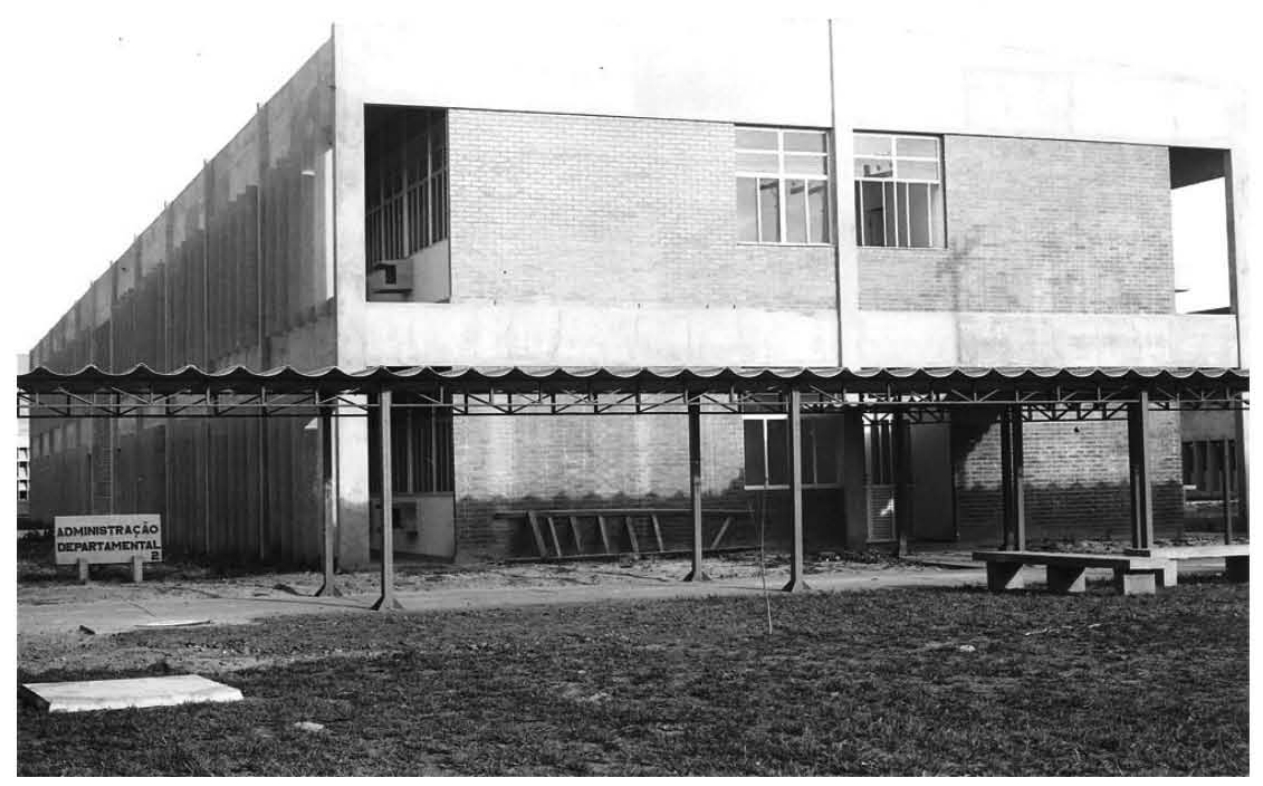

Figura 333: UFS - Bloco Departamental Tipo 1 - segunda metade da década de 1970.

Vista da fachada leste. Destacam-se os panos de vedação em revestimento cerâmico da estrutura de concreto. $O$ acesso ao edifício fica encoberto pela ausência de um elemento que marque sua presença.

(Fonte: Arquivo Geral - Prefeitura do Campus). 


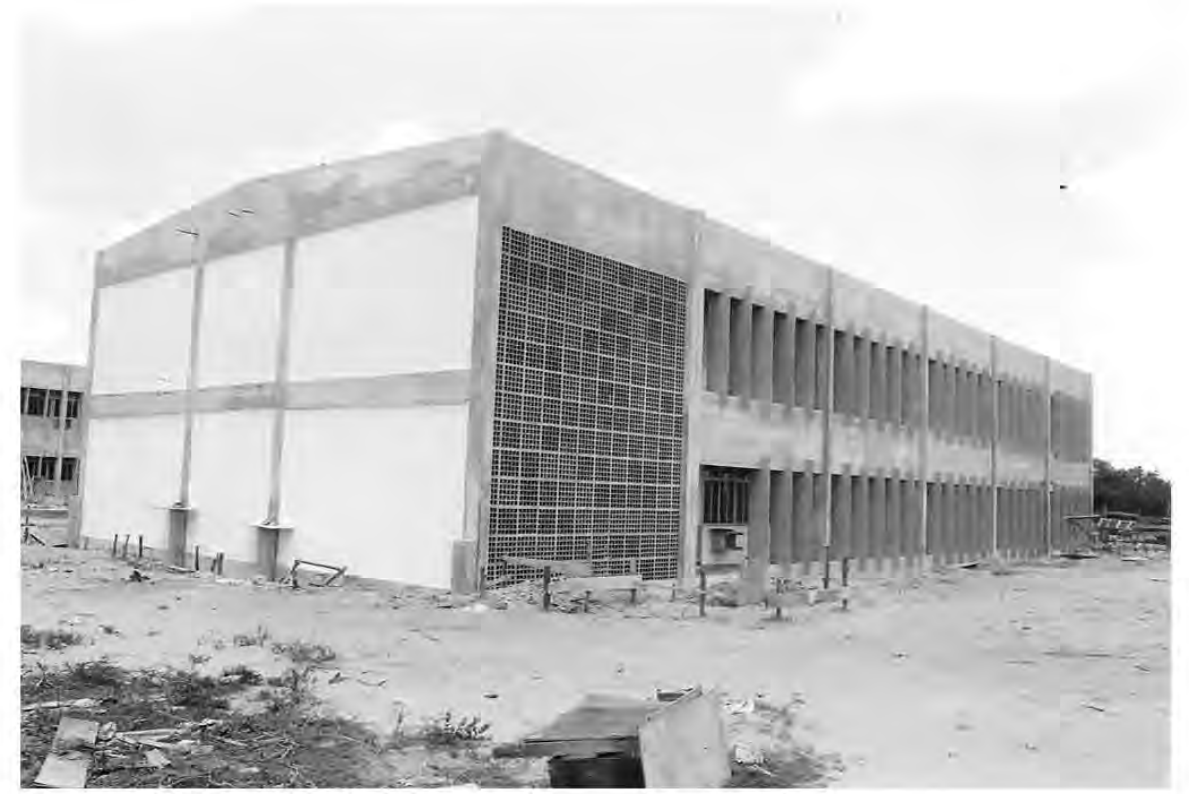

Figura 334: UFS - Bloco Departamental Tipo 1 - segunda metade da década de 1970.

Foi construída somente uma ala administrativa. O pano de combogó, que corresponde à área da escada e sanitários, permanece como elemento de articulação das demais áreas do programa.

(Fonte: Arquivo Geral - Prefeitura do Campus).

\section{- Biblioteca/Restaurante/Reitoria}

Os edifícios da Biblioteca, Restaurante e Reitoria formam um conjunto de equipamentos cuja localização evidencia uma proposta de ambiência urbana constituída por marcos arquitetônicos. Os atributos adotados revelam a intenção de destacá-los como referência na paisagem do Campus, desconsiderando a composição de identidade visual unificada adotada no Conjunto Didático/Administração Departamental (ver figuras 335 e 336).

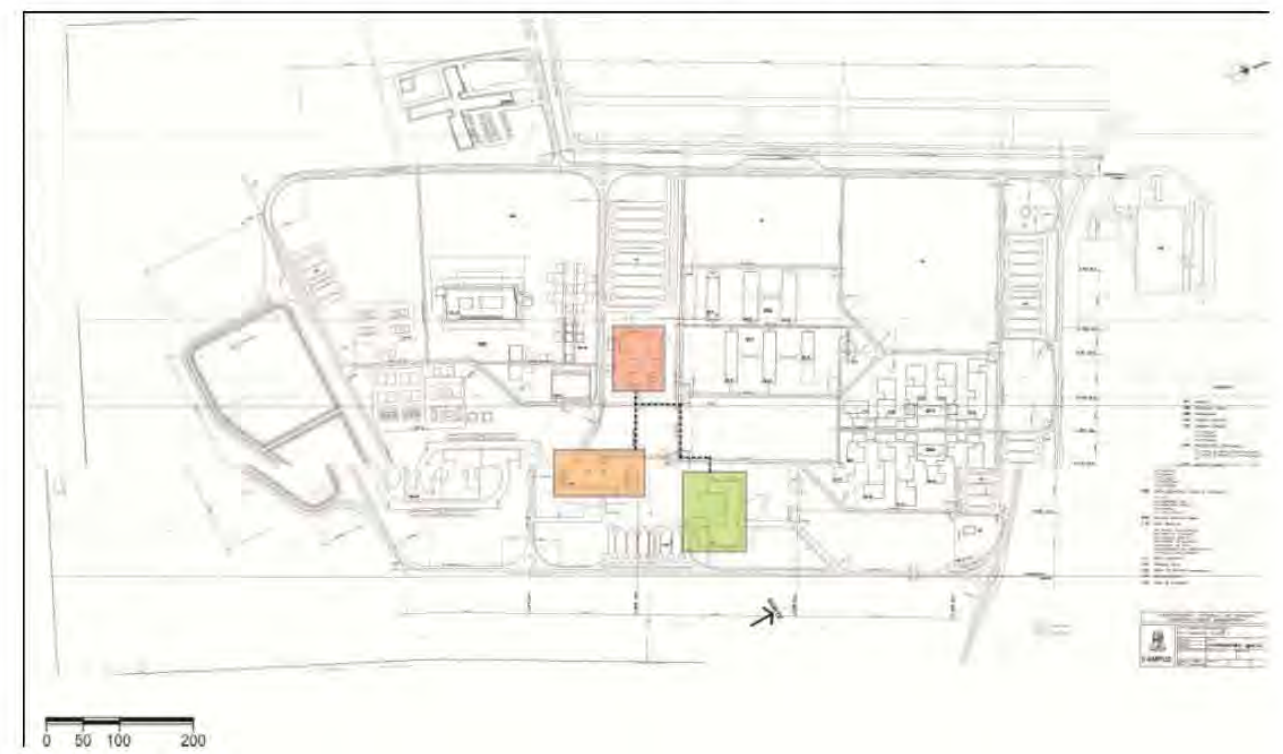

Figura 335: UFS - Implantação da Biblioteca, Restaurante e Reitoria. (Fonte: Prefeitura do Campus e Arquivo Geral). 


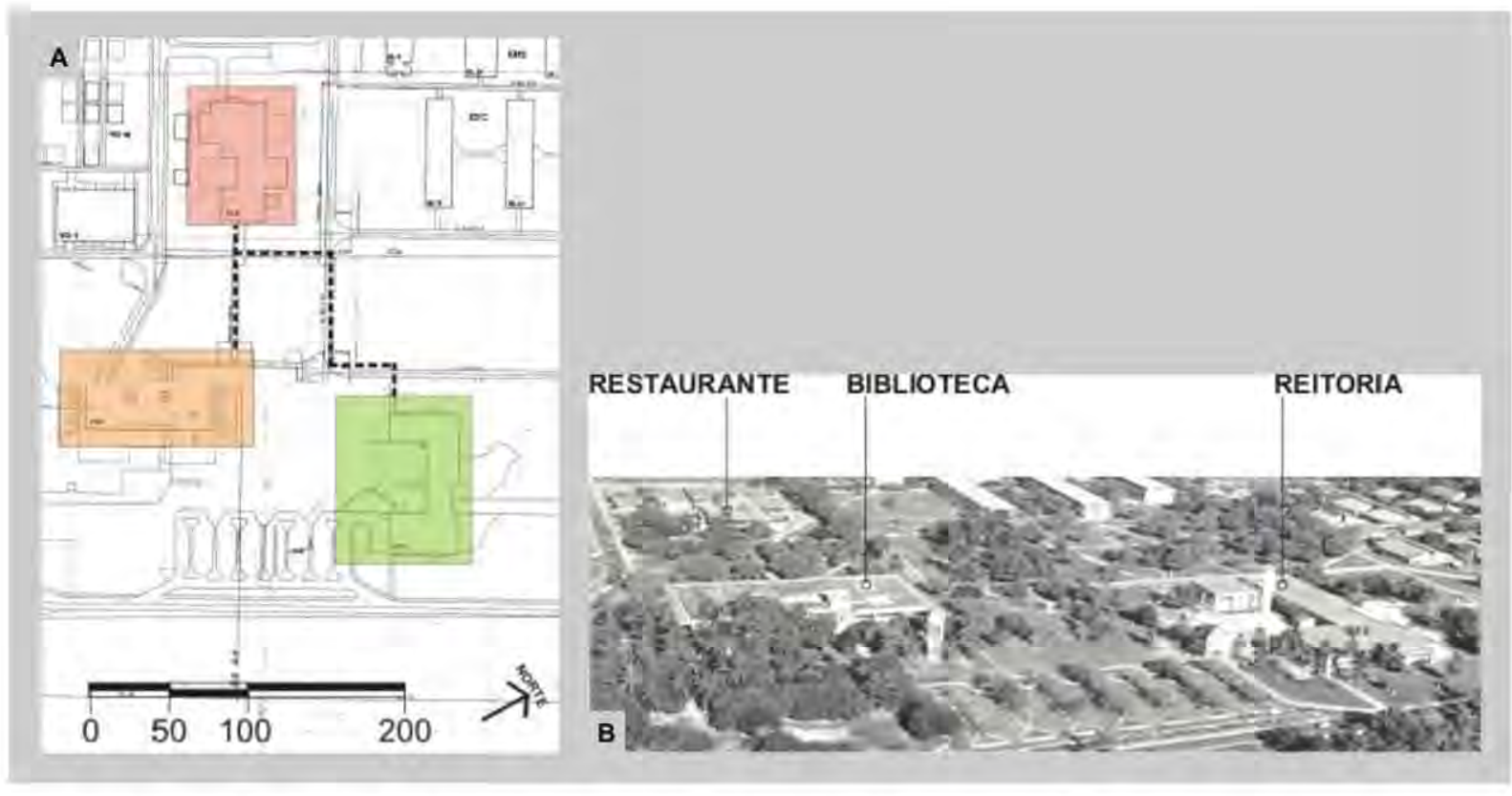

Figura 336: UFS - Detalhe da implantação da Biblioteca, Restaurante e Reitoria.

(A) Detalhe da implantação.

(B) Vista dos blocos da Reitoria, Biblioteca e Restaurante.

(Fonte: Prefeitura do Campus e Arquivo Geral).

\section{- Biblioteca}

A implantação da Biblioteca segue as recomendações do Plano Diretor, o qual indica sua localização articulada com o Restaurante. Embora o Manual de Atcon (1970, p.79 e 90) a aponte como local de congregação e de característica permanente, devendo estar localizada no centro do campus, com acesso para todos os setores, sua colocação não se configura como elemento central. Sugere, entretanto, 0 atendimento aos pressupostos modernos, onde o edifício se insere de maneira unitária, emoldurado pela vegetação do sítio, que configura o pano de fundo da obra.

Projetado em 1977, pela empresa Central de Projetos - Geotécnica S.A., com sede na cidade de São Paulo, o edifício tem uma área construída de $5.198,00 \mathrm{~m}^{2}$ e capacidade para movimentação de 200.000 volumes. O programa inclui as áreas de acervo (coleção geral, periódicos, coleção de referência), leitura, de apoio (microfilmagem, armazenagem, audição individual, escritório de referência, almoxarifado, dentre outros), administrativas (diretoria, reuniões), de acesso (saguão, exposições) e serviços (copa, sanitários, depósito etc.) com distribuição em dois níveis: térreo e superior (ver projeto de arquitetura nas figuras 337 a a $337 f)$. 


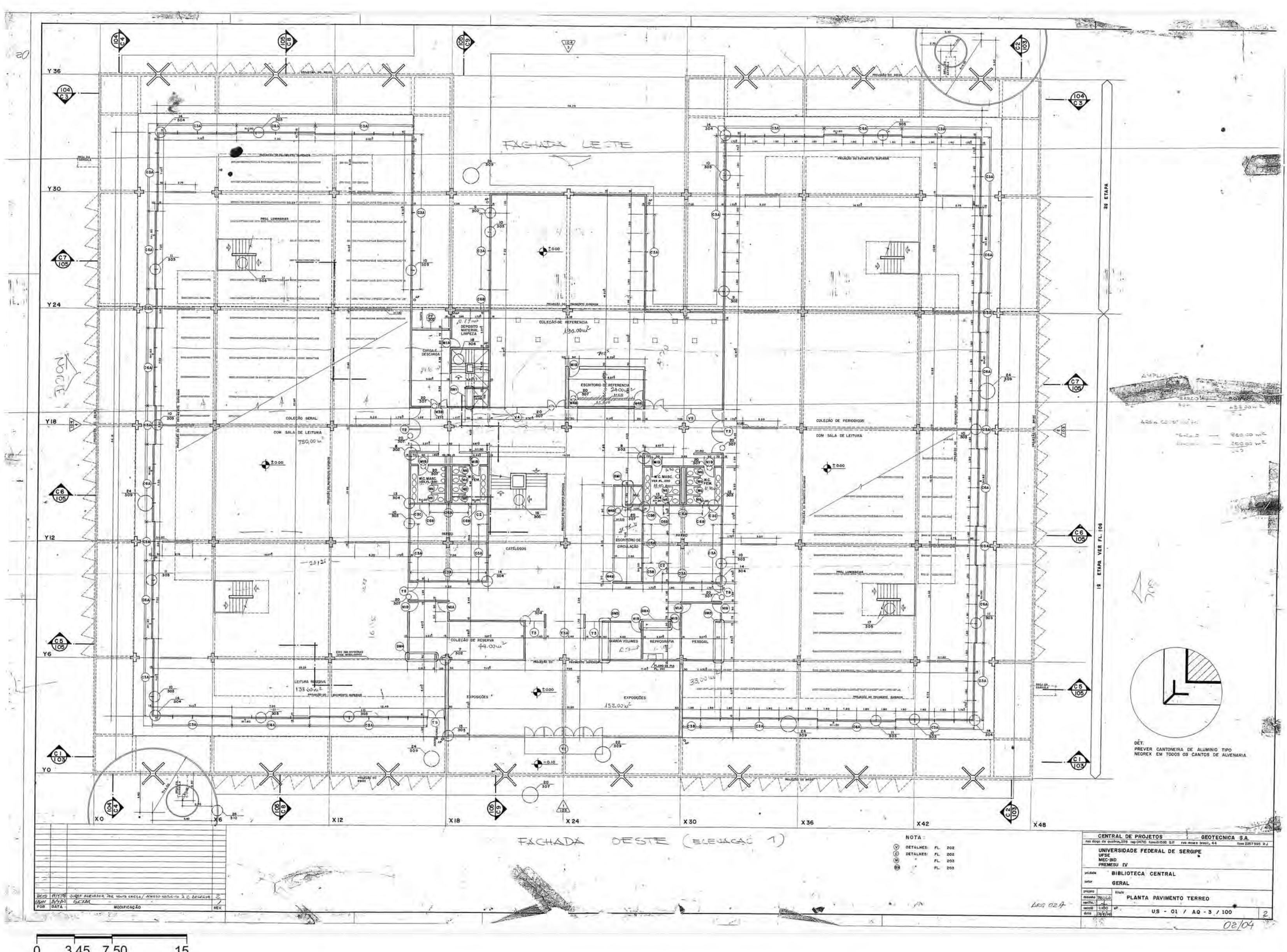




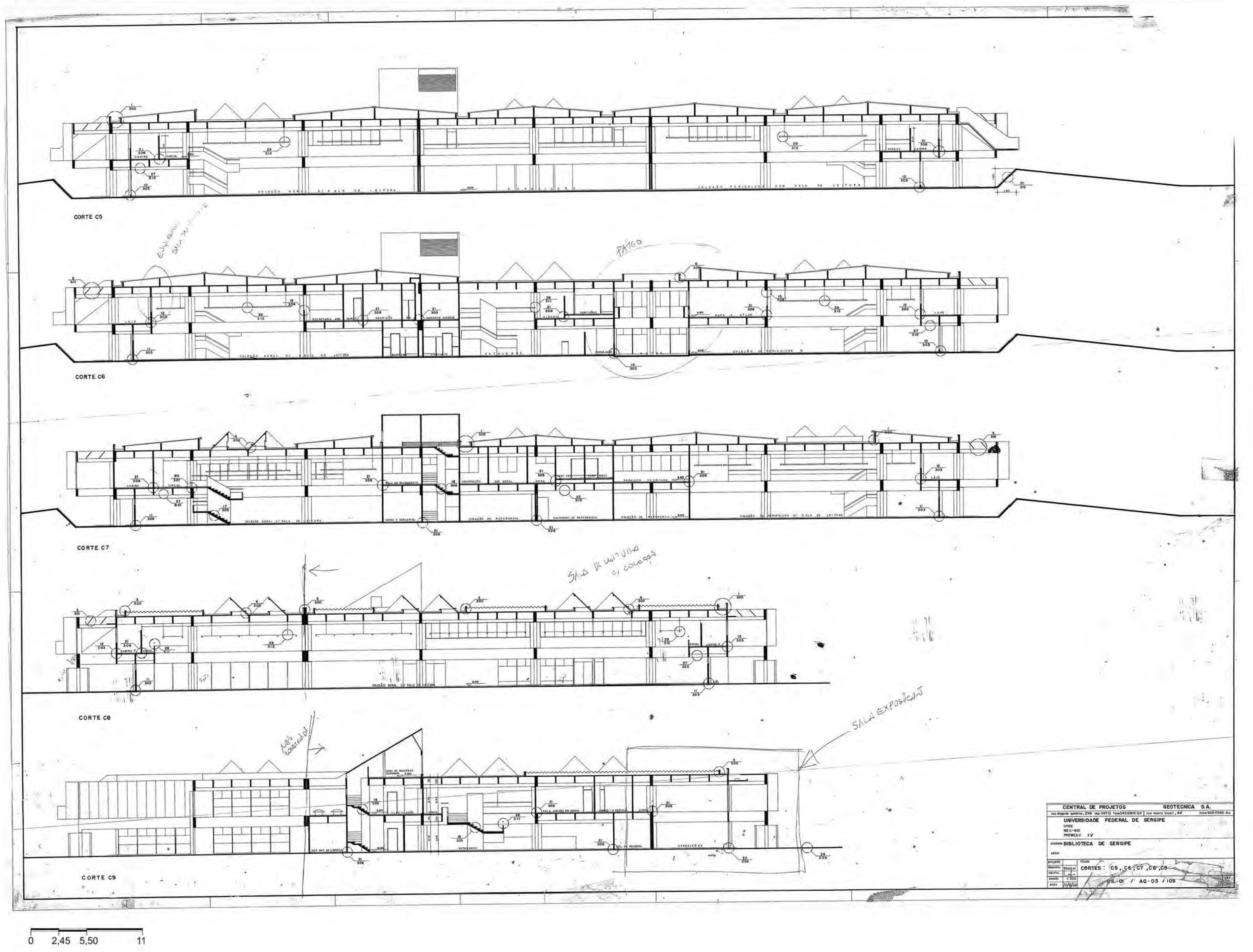




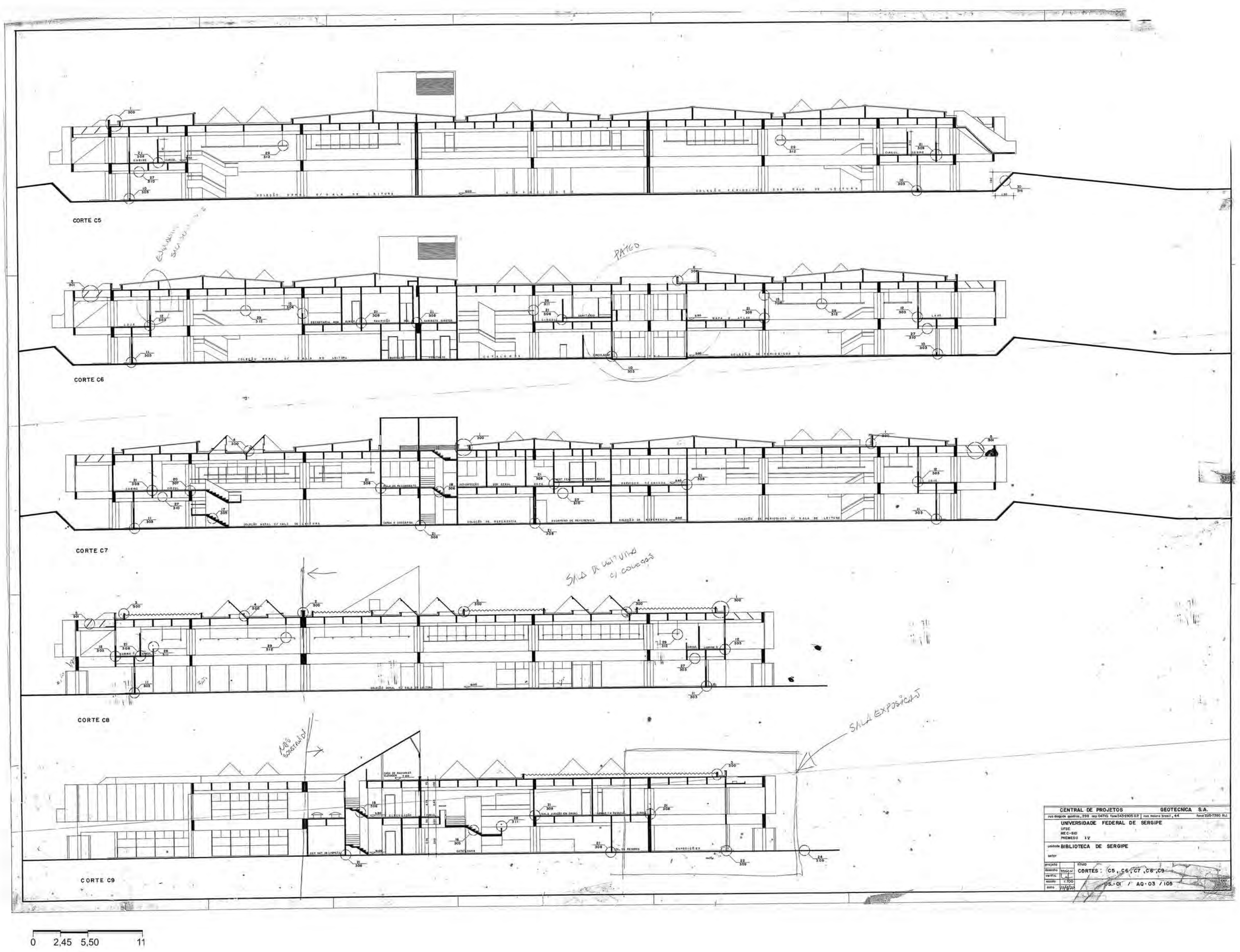




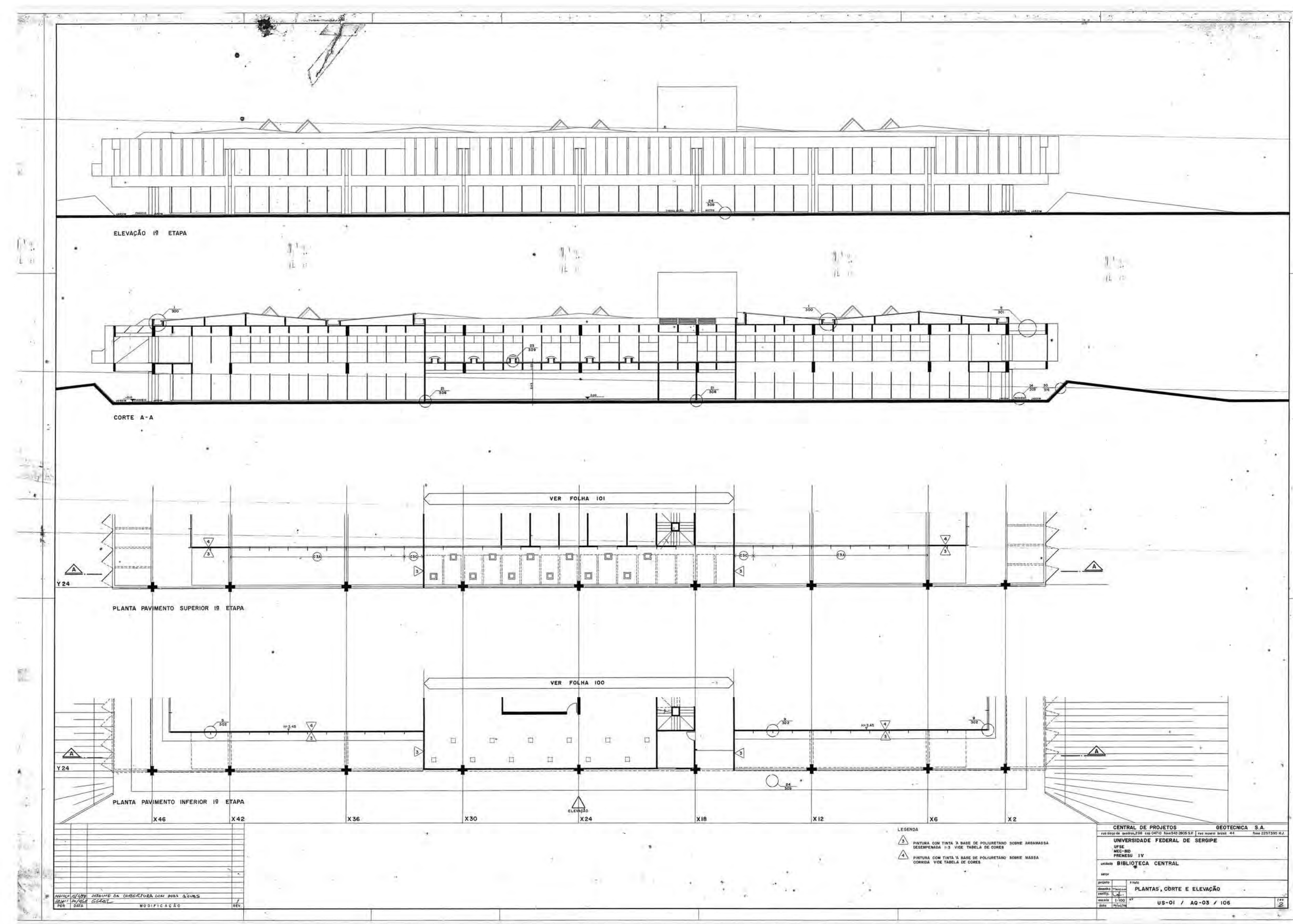


FOLHA VERSO DA FOLHA GRANDE - NÃO IMPRIMIR 
O partido arquitetônico destaca-se pelo conjunto do volume principal, que sugere a forma de caixa, com dimensões de $42,00 \mathrm{~m} \times 86,00 \mathrm{~m}$, e pela torre da caixa d'água, executados em concreto aparente, criando uma arquitetura de linguagem singular no Campus (ver figuras 338 e 339). A proposta evidencia as recomendações do Manual de Atcon que indicava que a arquitetura da biblioteca deveria destacá-la como o símbolo da universidade (ATCON, 1970, p. 90).

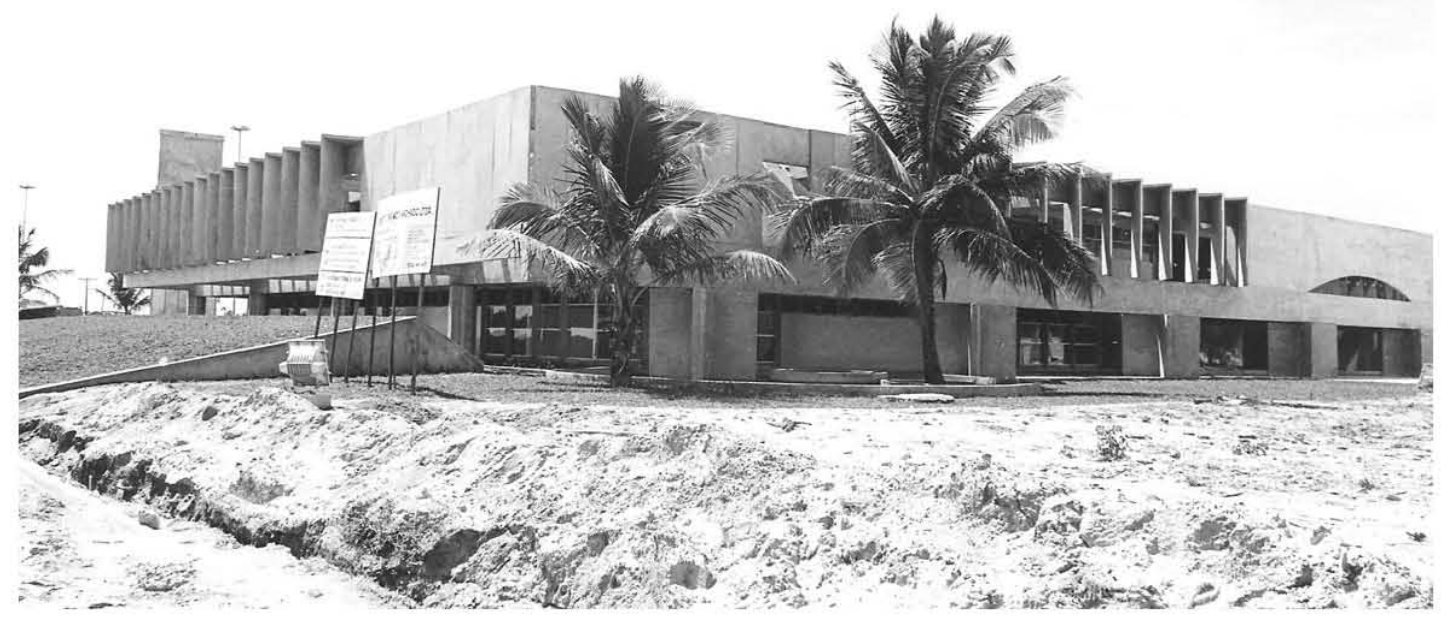

Figura 338: UFS - Vista do Bloco da Biblioteca em fase de finalização da obra - final década de 1970. No primeiro plano: a volumetria principal, que utiliza a linguagem do concreto aparente na forma de caixa fechada, sendo atenuada pelos elementos que funcionam como dispositivos de proteção solar.

À esquerda, segundo plano: o volume da caixa d'água que compõe o conjunto contrapõe a horizontalidade da volumetria principal.

(Fonte: Arquivo Geral - Prefeitura do Campus).

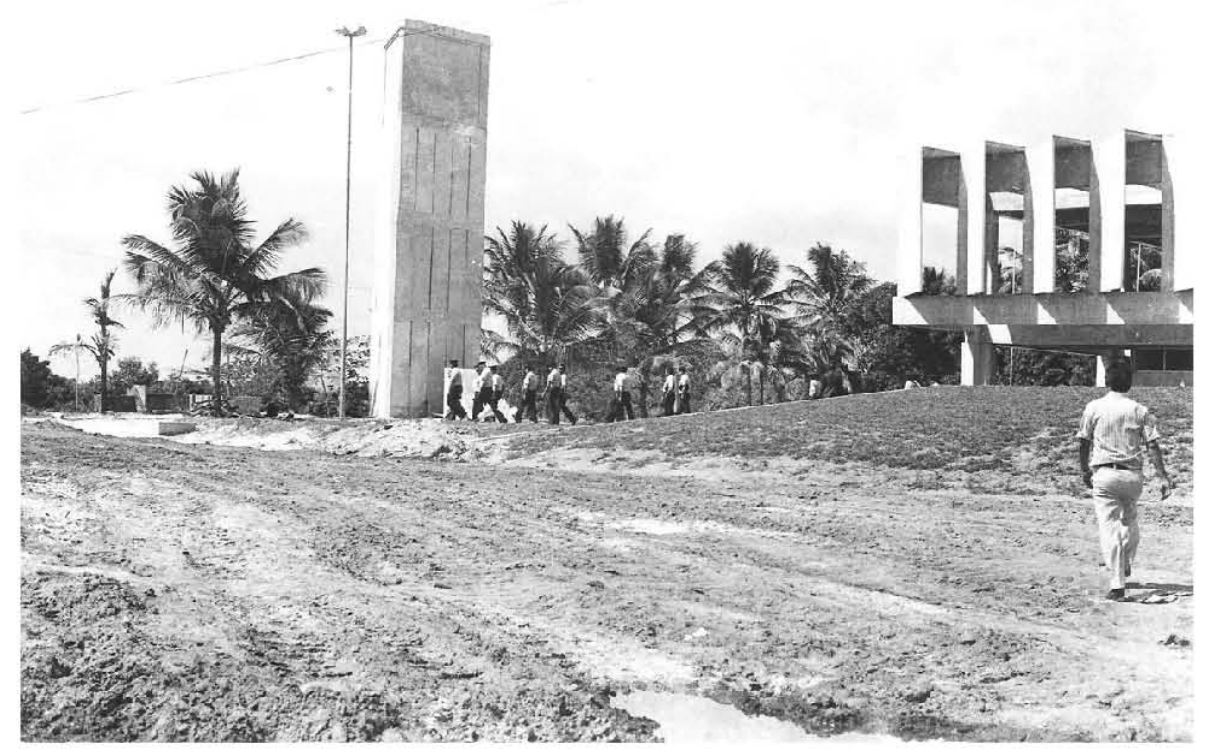

Figura 339: UFS - Vista da caixa d'água que faz parte do conjunto arquitetônico da Biblioteca. (Fonte: Arquivo Geral - Prefeitura do Campus) 
O conceito construtivo que explora o concreto aparente é o atributo predominante na arquitetura da edificação. A estrutura se destaca como elemento determinante na definição plástica do edifício, onde a forma esta associada à lógica estrutural que the dá suporte. Definida pela grelha de concreto armado, que por sua vez está subordinada à modulação ortogonal dos pilares de desenho em cruz em módulos de vãos livres de 10,80 m x 10,80 m (módulo principal), organiza a disposição interna do espaço (ver figuras 340 e 341). Com esta solução, a estrutura possibilita a total flexibilidade da planta, promovendo vãos generosos que se interligam pelos vazios do pé-direito duplo. O espaço é fluido, permitindo uma dinâmica visual das atividades ali desenvolvidas.

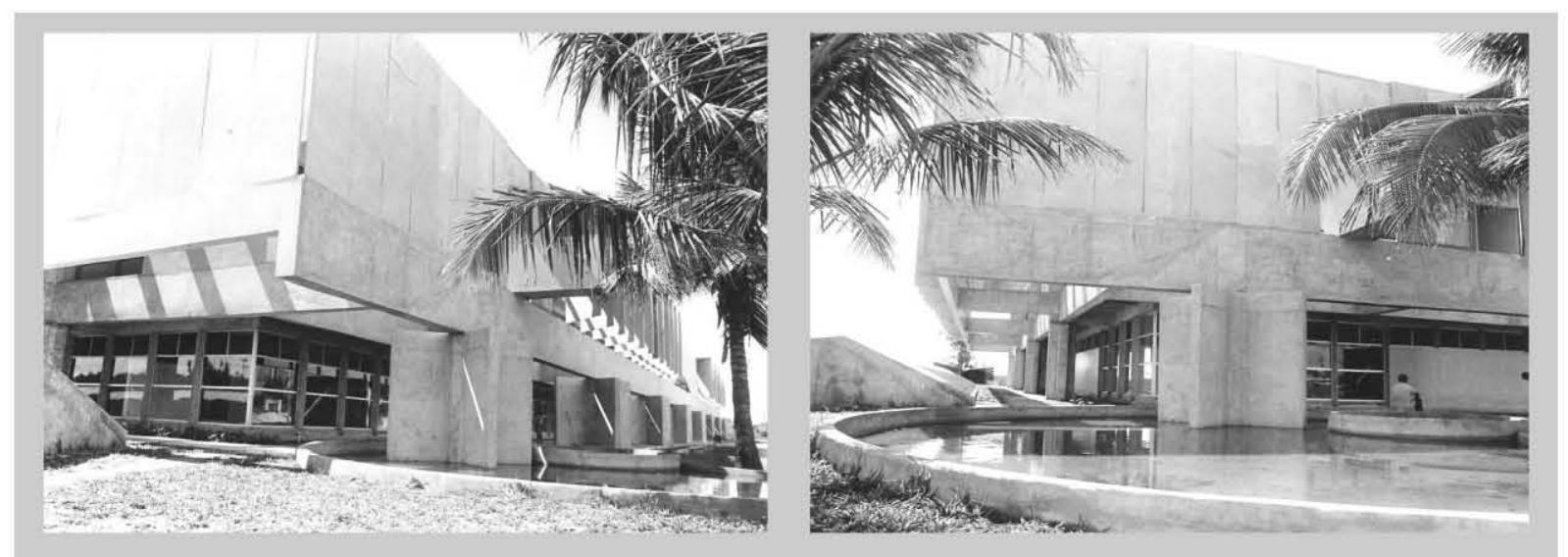

Figura 340: UFS - Detalhe da estrutura de concreto aparente - final década 1970. Os pilares externos em $\mathrm{X}$ e empenas com elementos de proteção solar. (Fonte: Arquivo Geral - Prefeitura do Campus).

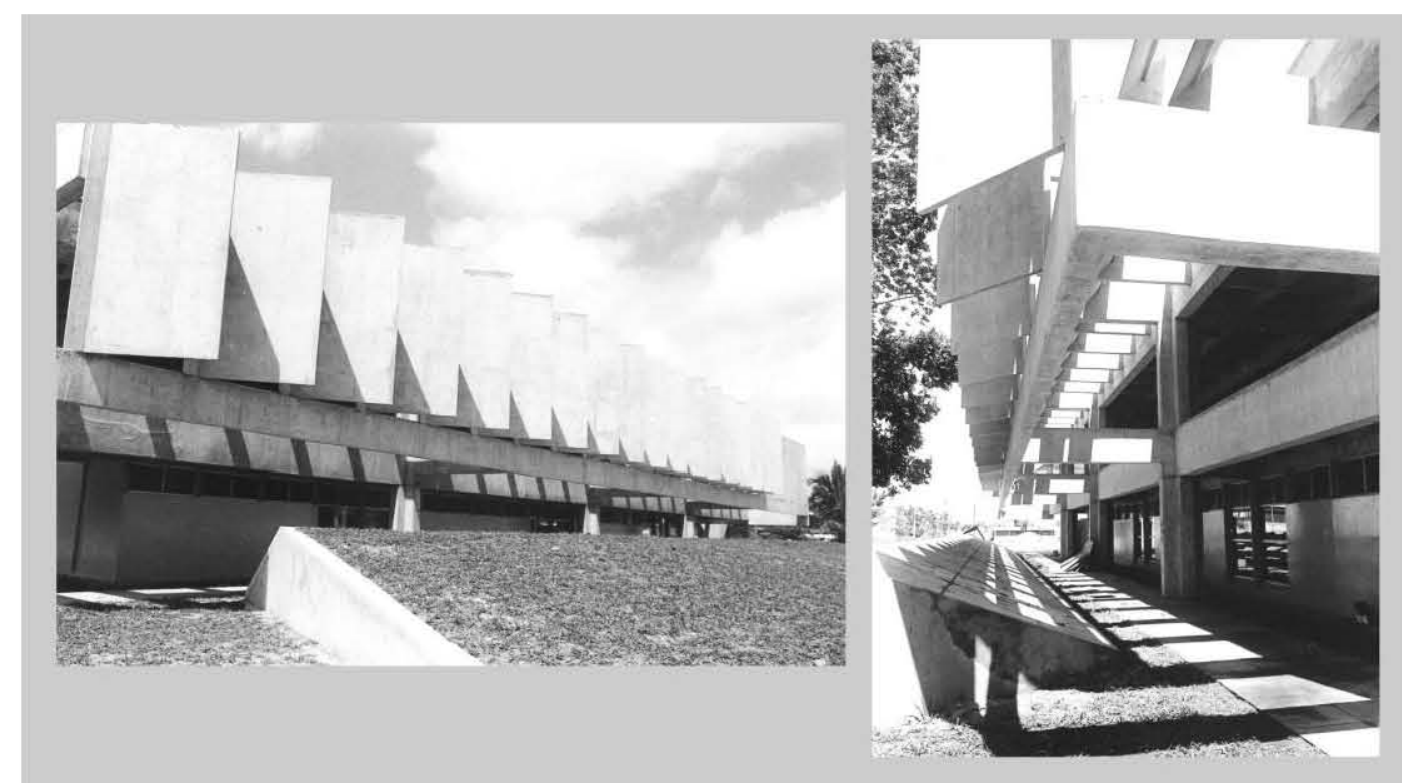

Figura 341: UFS - Detalhe dos elementos de proteção solar - final década de 1970.

Depoimentos de usuários identificam a intenção simbólica da forma plástica com a ideia das páginas de um livro. A radiação solar direta é desviada para outros ângulos de incidência, proporcionando sombreamento nas superfícies da edificação e ao mesmo tempo criando uma circulação externa protegida da insolação.

(Fonte: Arquivo Geral - Prefeitura do Campus). 
Participam da composição plástica as empenas de concreto aparente, conjugadas com elementos de proteção solar que se projetam além do corpo principal em torno de toda a edificação e tiram partido para solucionar os imperativos do clima local, em especial a radiação solar direta, proporcionando sombreamento aos ambientes internos, contidos por panos de vidro, os quais conferem transparência e prolongamento visual com o exterior circundante (ver figura 342).

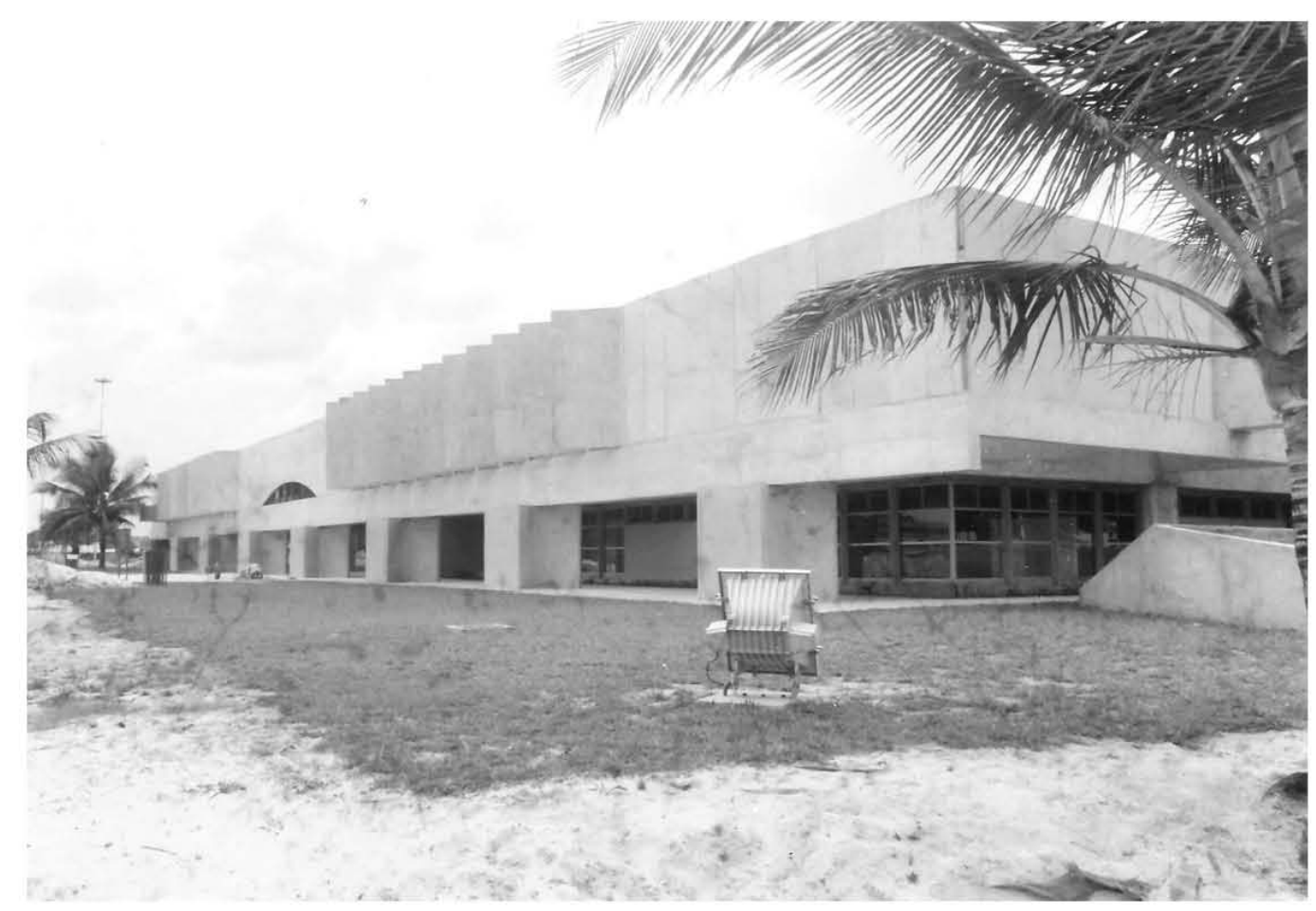

Figura 342: UFS - Vista da fachada de acesso principal - final década 1970.

O pavimento térreo é recuado da empena que circunda toda a edificação, conferindo leveza à composição plástica e sombreamento aos ambientes internos limitados pelos panos de vidro.

(Fonte: Arquivo Geral - Prefeitura do Campus).

A organização funcional se estabelece sem qualquer intenção de subordinação à estrutura de concreto, afastando-se da compartimentação dos ambientes, adotada no Conjunto Didático/Departamental. A área central, constituída pelos setores de serviços e apoio, estabelece um eixo de simetria a partir do qual se articulam as áreas de acervo, divididas em duas alas laterais de pé-direito duplo. Iluminadas pelo sistema zenital com sheds em concreto aparente, sua organização sugere a configuração de um pátio fechado. As circulações são incorporadas aos espaços de atividades, integrando-se sem contornos de início e fim.

No pavimento térreo, o programa se distribui criando uma zona central de apoio a partir da qual se estabelecem as áreas do acervo em duas alas simétricas. A entrada do edifício 
ocorre pelo hall com pé-direito duplo, que antecede a catraca de controle de acesso. $O$ espaço central orienta o fluxo da circulação para as áreas de acervo. Junto aos sanitários há um pátio que recebe iluminação zenital (ver figura 343).

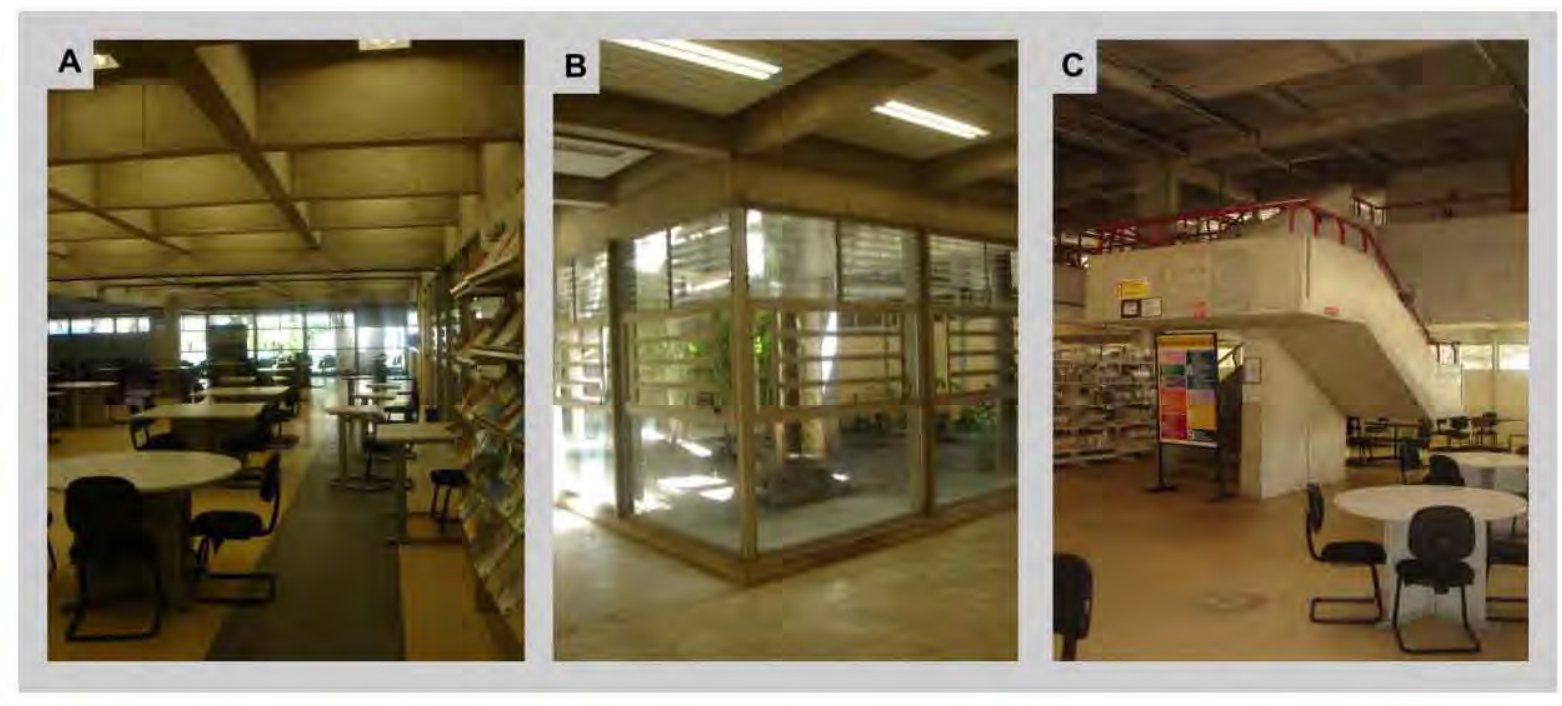

Figura 343: UFS - Biblioteca Central - ano 2009.

(A) Vista da área de leitura e acervo (térreo).

(B) Vista do pátio com iluminação zenital.

(C) Vista da área de leitura e acervo com uma das escadas que articula os pavimentos com pé-direito duplo. O concreto aparente participa como elemento construtivo do espaço. (Fonte: Acervo Magda Campêlo, 2009).

As características formais e construtivas do edifício evidenciam as ressonâncias das experiências com o concreto aparente praticada em outras regiões do país que explorava suas possibilidades plásticas (ver figura 344 ).

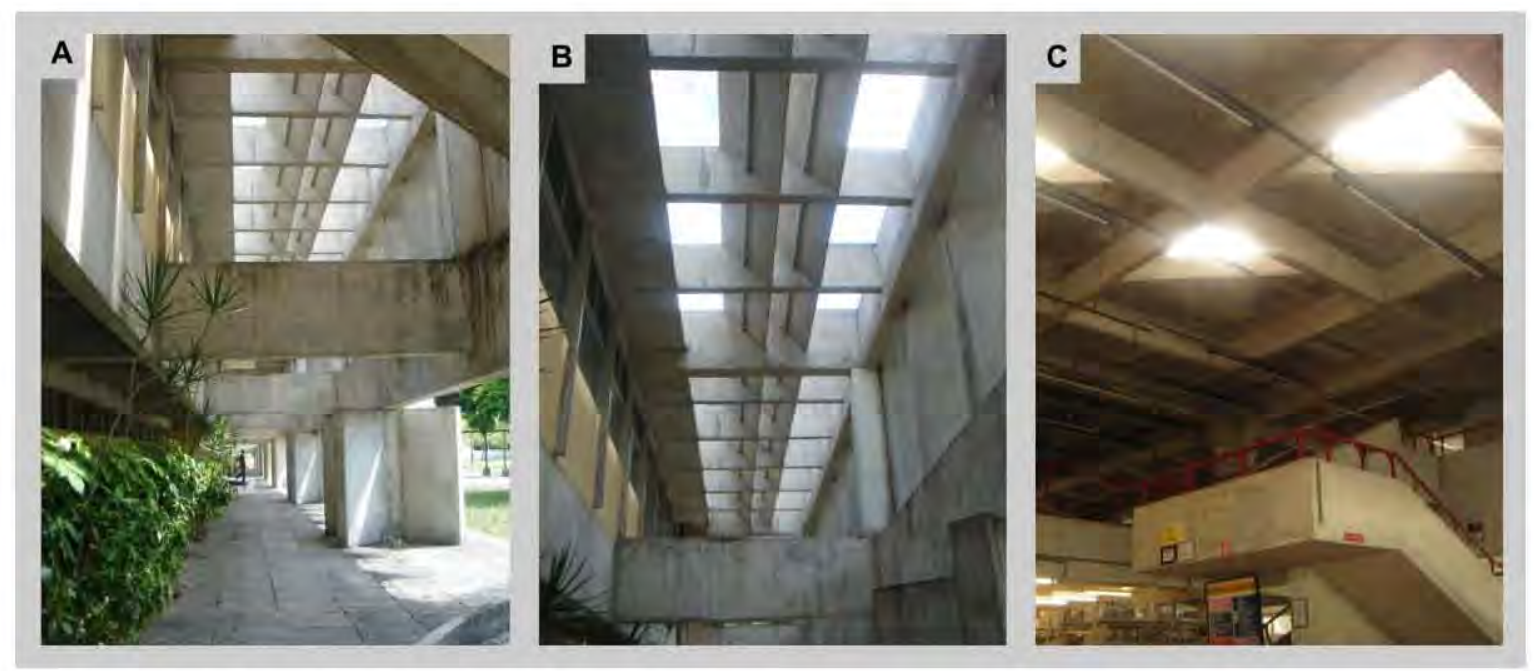

Figura 344: UFS - Biblioteca Central - ano 2009.

(A) Vista da circulação periférica.

(B) Detalhe da estrutura de concreto.

(C) Vista da iluminação zenital sobre a escada do acervo e área de leitura.

(Fotos: Acervo Magda Campêlo, 2009). 


\section{- Reitoria}

A implantação do bloco da Reitoria está situada próxima à via de acesso (via de contorno) e deslocada do centro do Campus, permitindo a entrada de público sem interferência nos demais setores e provavelmente com a intenção de eliminar a imagem do "poder", conforme orientação do Manual de Atcon (1970 p. 73-74). A colocação segue a tendência moderna, onde o edifício se insere de maneira unitária no terreno, emoldurado pelas áreas verdes circundantes, com sua visualização sem barreiras visuais e físicas.

O projeto foi elaborado, em 1978 , pelo arquiteto goiano Miguel Juliano ${ }^{123}$ e teve a obra concluída em 1979 (ver projeto de arquitetura nas figuras 345a a 345d). O partido adotado afasta-se da visão do edifício centrado nas formas puras, voltando-se para uma proposta em que a planta se desenvolve em direções distintas, conformando um desenho de composição mais orgânica, que resulta num conjunto funcional hierarquizado: bloco principal de funções administrativas, bloco do auditório e torre da caixa d'água (ver figura 346 ). O projeto original complementava o conjunto com espelhos d'água que emoldurariam a edificação principal, e uma rampa que daria acesso ao bloco principal conforme se constata na maquete da figura 347. Estes, porém, não foram executados, tendo sido substituídos por áreas ajardinadas e via pavimentada.

O programa de necessidades abrange os setores administrativos (da reitoria, das próreitorias e assessorias), de apoio (reuniões, arquivo, almoxarifado, dentre outros), serviços (sanitários, copa, depósito etc.) e o auditório com capacidade para 196 lugares distribuídos em dois pavimentos que se superpõem, ocupando uma área em torno de $5.100 \mathrm{~m}^{2}$.

O partido arquitetônico está definido pela junção da volumetria funcional (administrativa, auditório e caixa d'água) que se estabelece a partir da planta, a qual organiza a disposição interna dos setores e os articula por meio de circulações horizontais que ocupam a extensão longitudinal e transversal do bloco principal, funcionando como ruas de interligação dos ambientes. Este percurso é interceptado ora pelo saguão de entrada com pé-direito duplo, ora pelas escadas situadas nas extremidades da circulação longitudinal e outra no eixo próximo ao saguão. A planta é rodeada por uma circulação periférica protegida pela platibanda e pelos elementos verticais de pé-direito duplo (ver figura 348), formando uma cortina que ameniza a ação da radiação solar no interior da edificação. O saguão destinado às atividades culturais, como exposições, abre-se para o pátio exterior em que se encontra o espelho d'água, jardins e o volume do auditório (ver figura 349).

\footnotetext{
${ }^{123}$ O arquiteto Miguel Juliano nasceu em Rio Verde, Goiás, em 1928, formou-se na FAU / Brás Cubas, em Mogi das Cruzes, SP, em 1973. Lecionou na FAU / Mackenzie.
} 


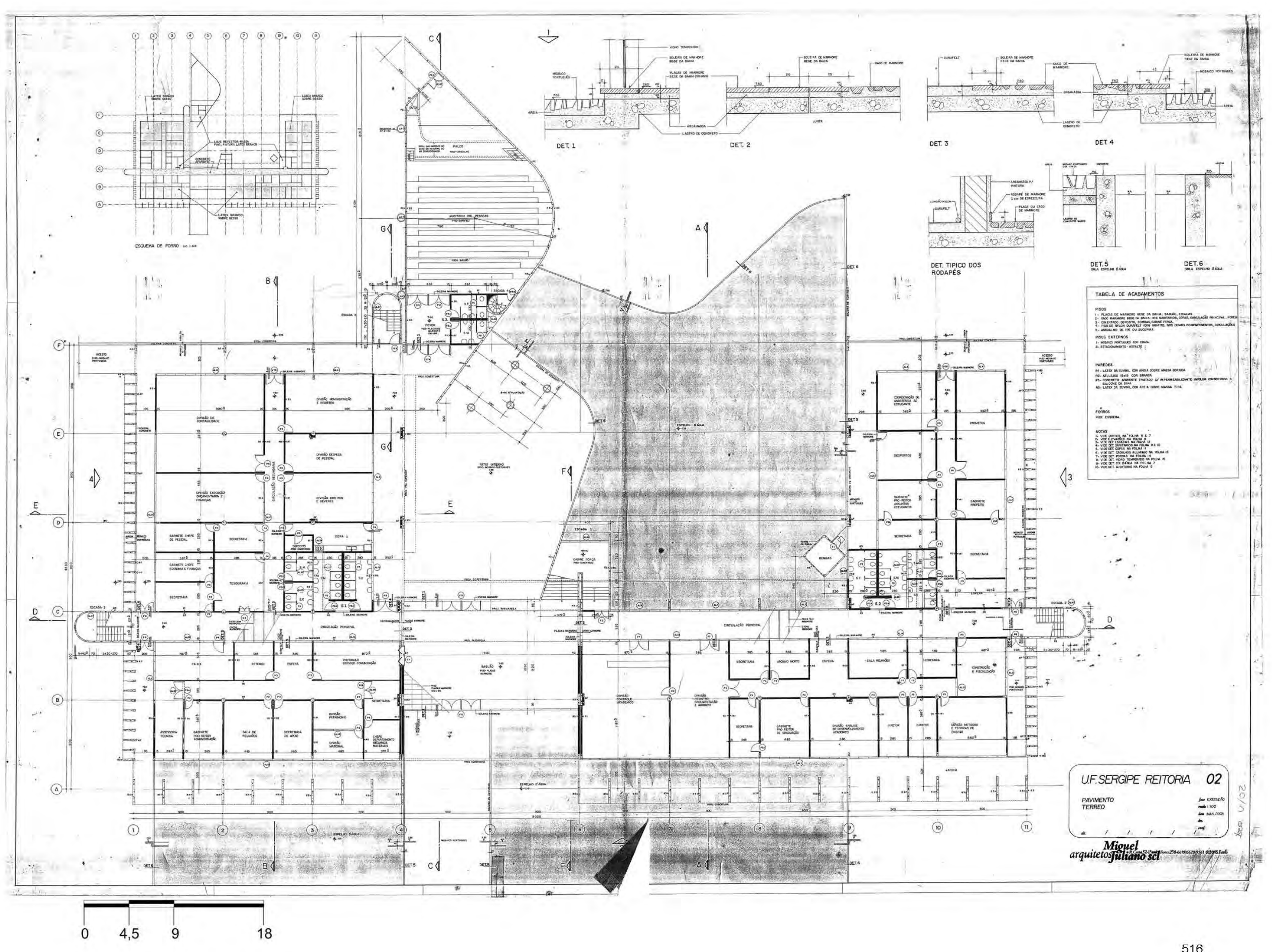




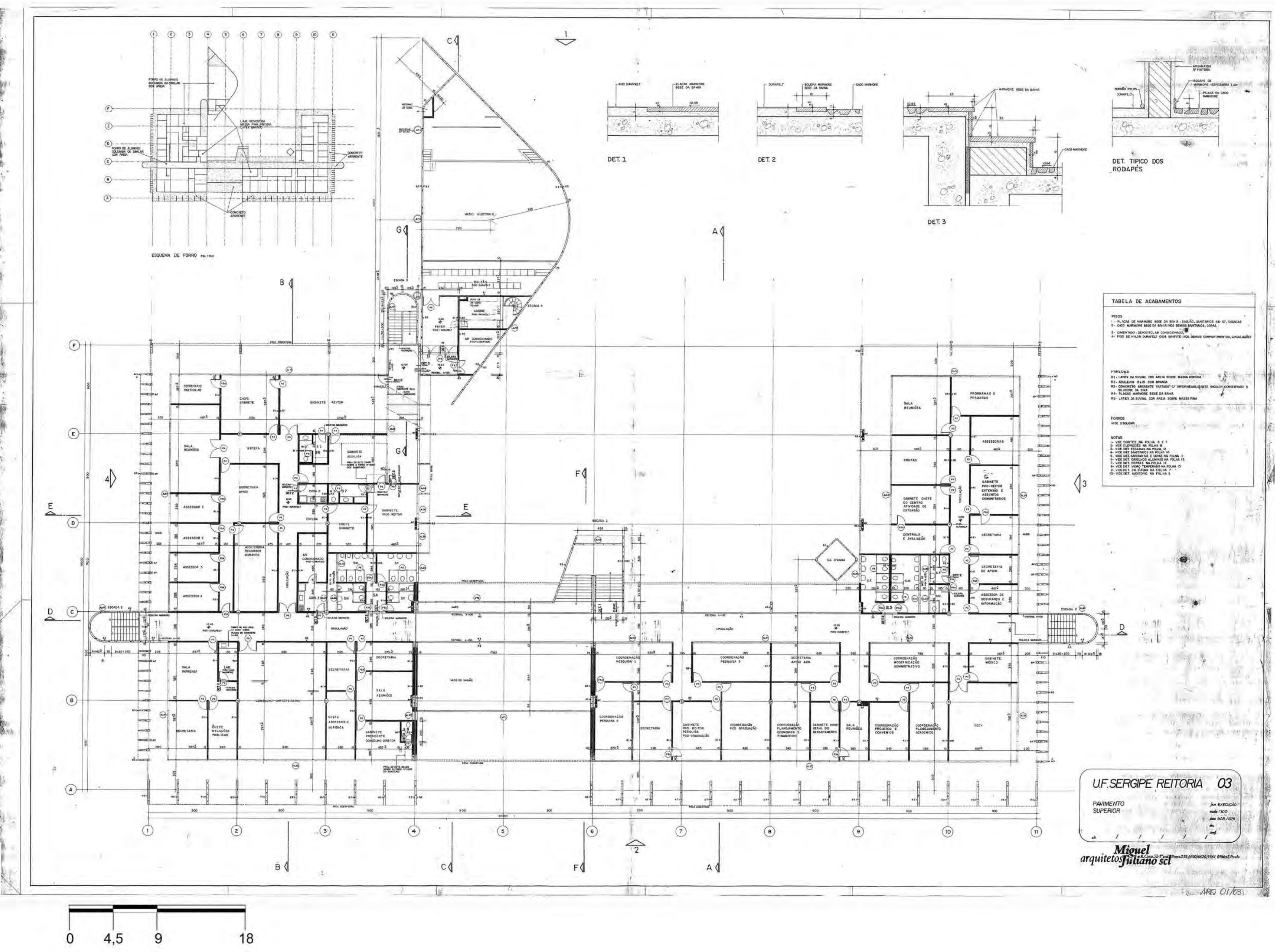


Parte 2 - Universidade Federal de Sergipe

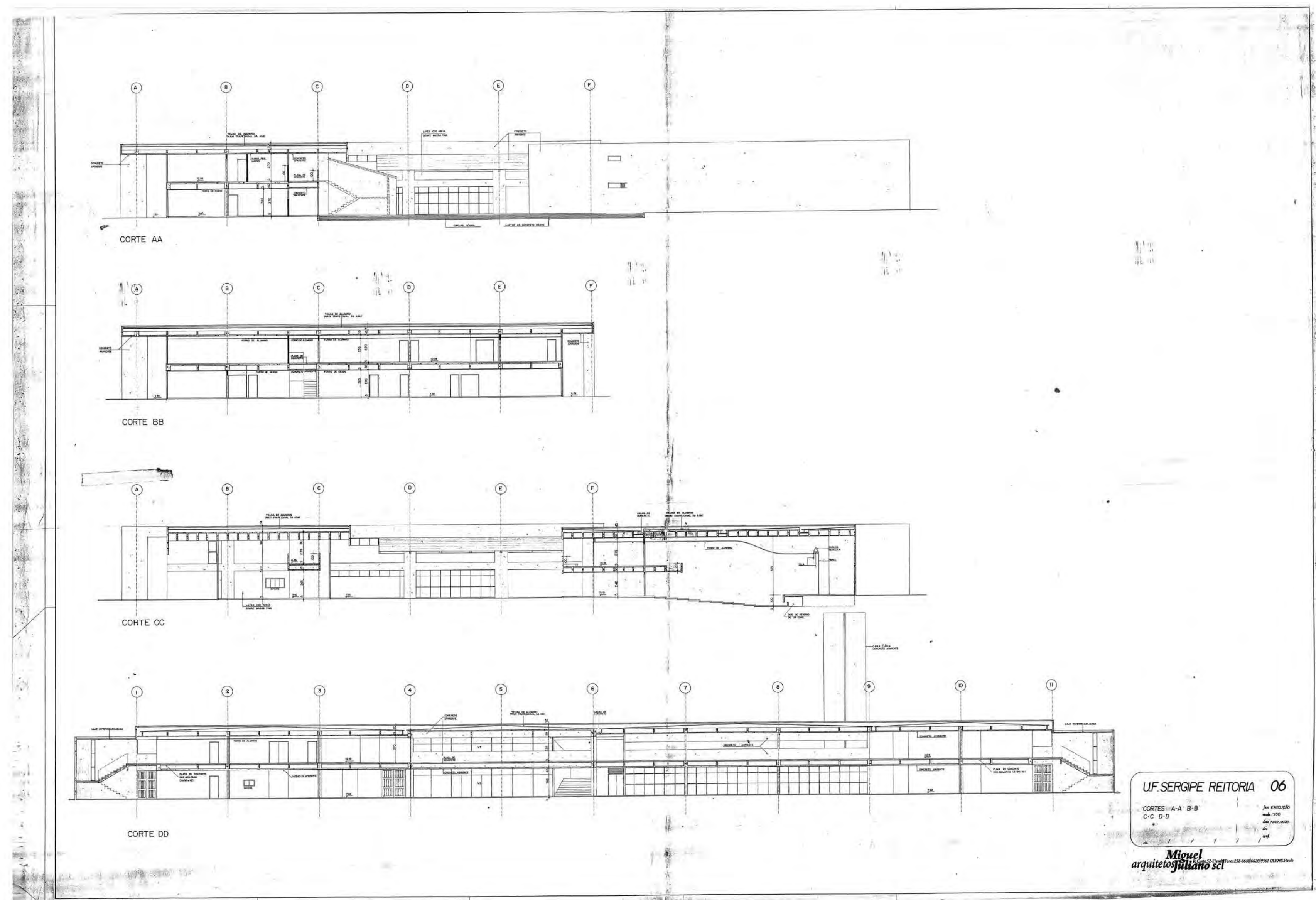

$\overbrace{2,7}^{5,4} \quad 10,8$ 
FOLHA VERSO DA FOLHA GRANDE - NÃO IMPRIMIR 


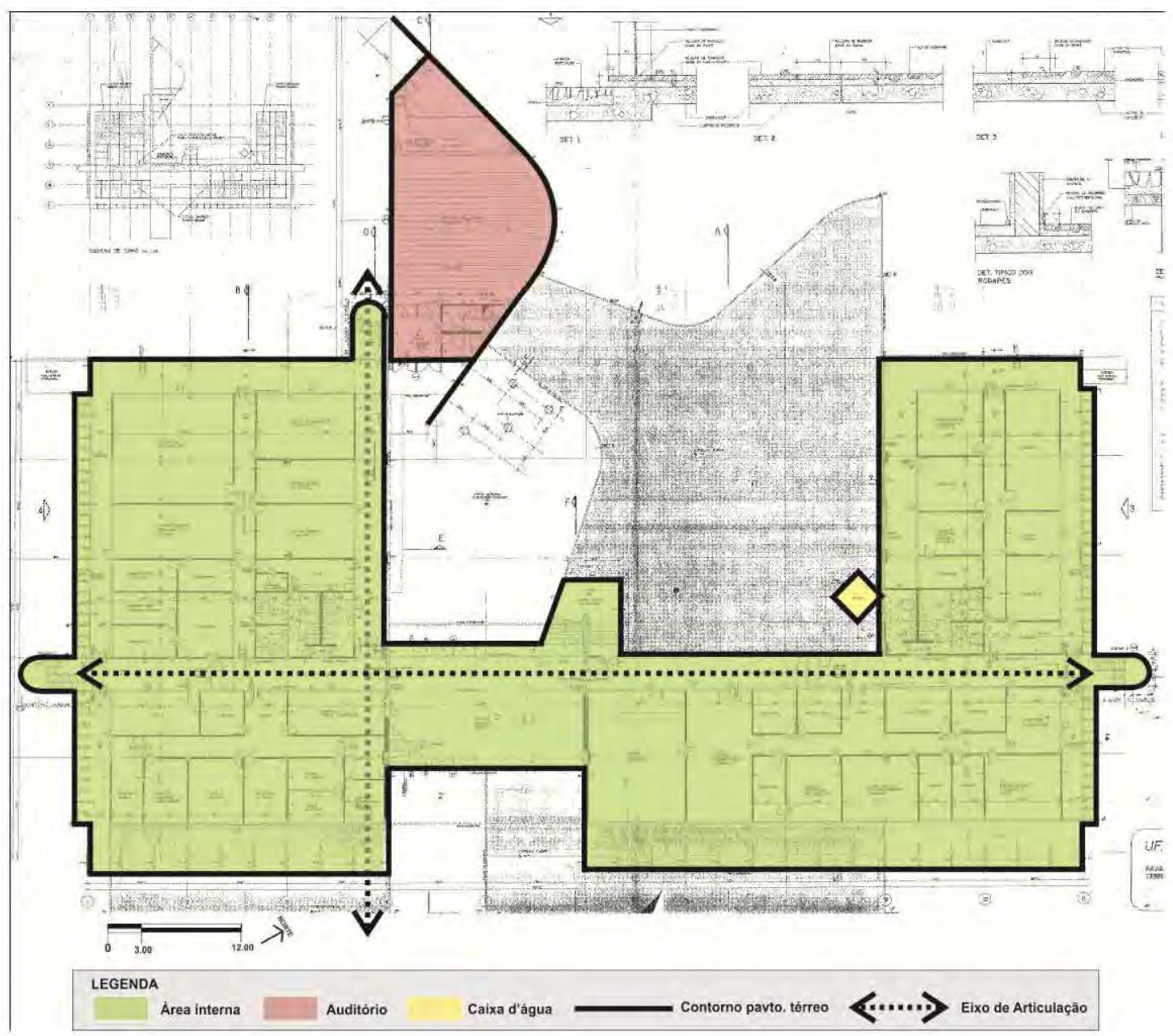

Figura 346: UFS - Esquema ilustrativo da planta da Reitoria. (Fonte: elaboração própria)

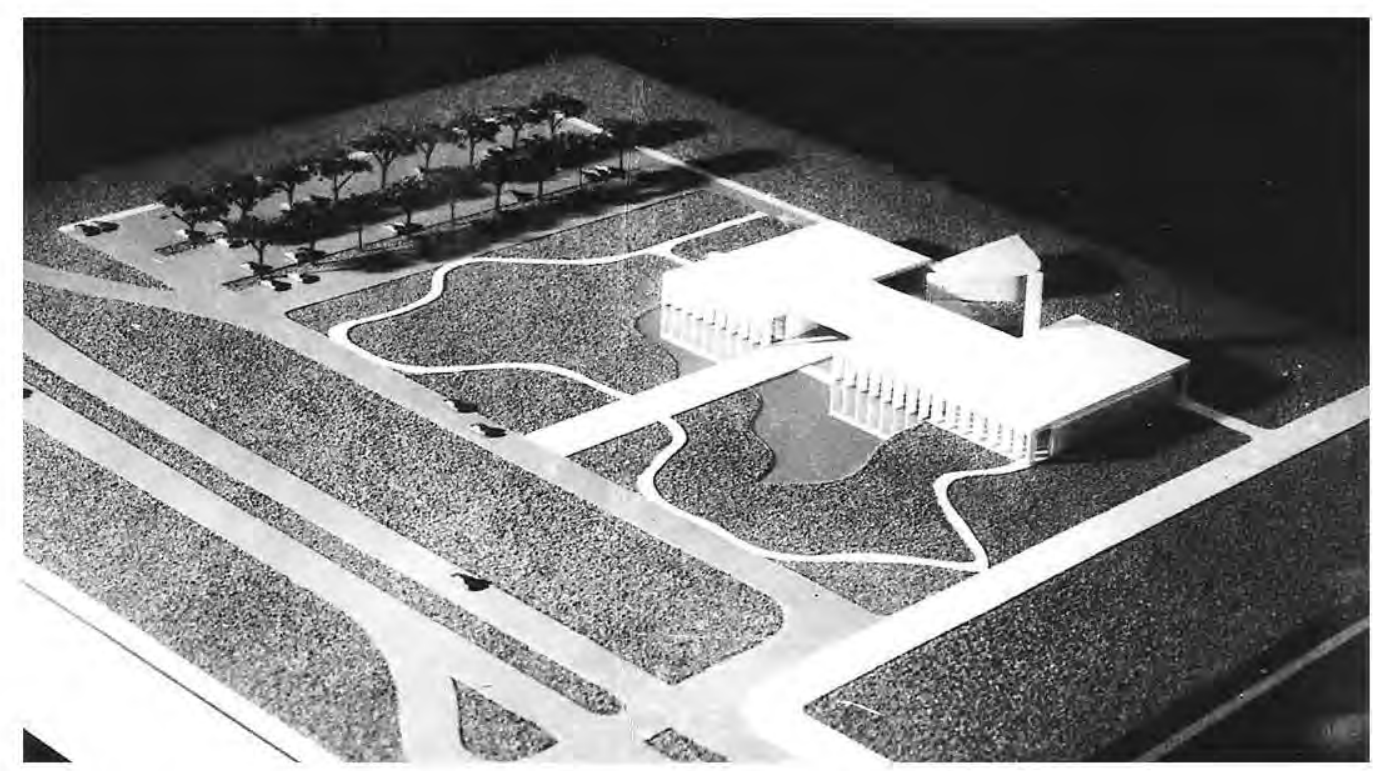

Figura 347: UFS - Maquete da Reitoria (1978).

Bloco principal (administrativo), auditório (ao fundo) e caixa d'água. (Fonte: Arquivo Geral - Prefeitura do Campus). 


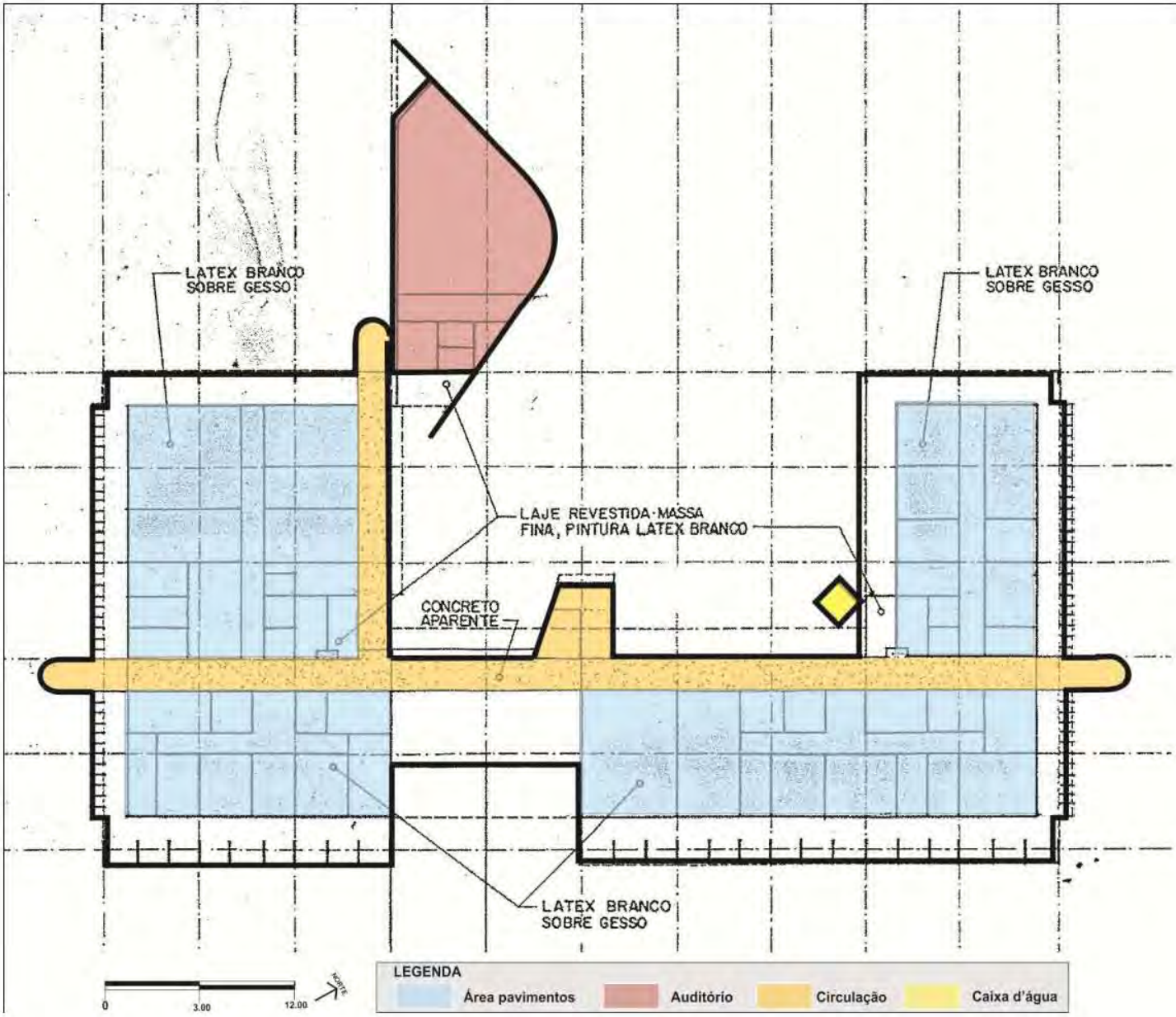

Figura 348: UFS - Esquema do partido arquitetônico.

Adota o conceito de ruas de circulação que organiza a planta e distribui os volumes funcionais, resultando no conjunto volumétrico do prédio administrativo, do auditório e caixa d'água.

(Fonte: elaboração própria)

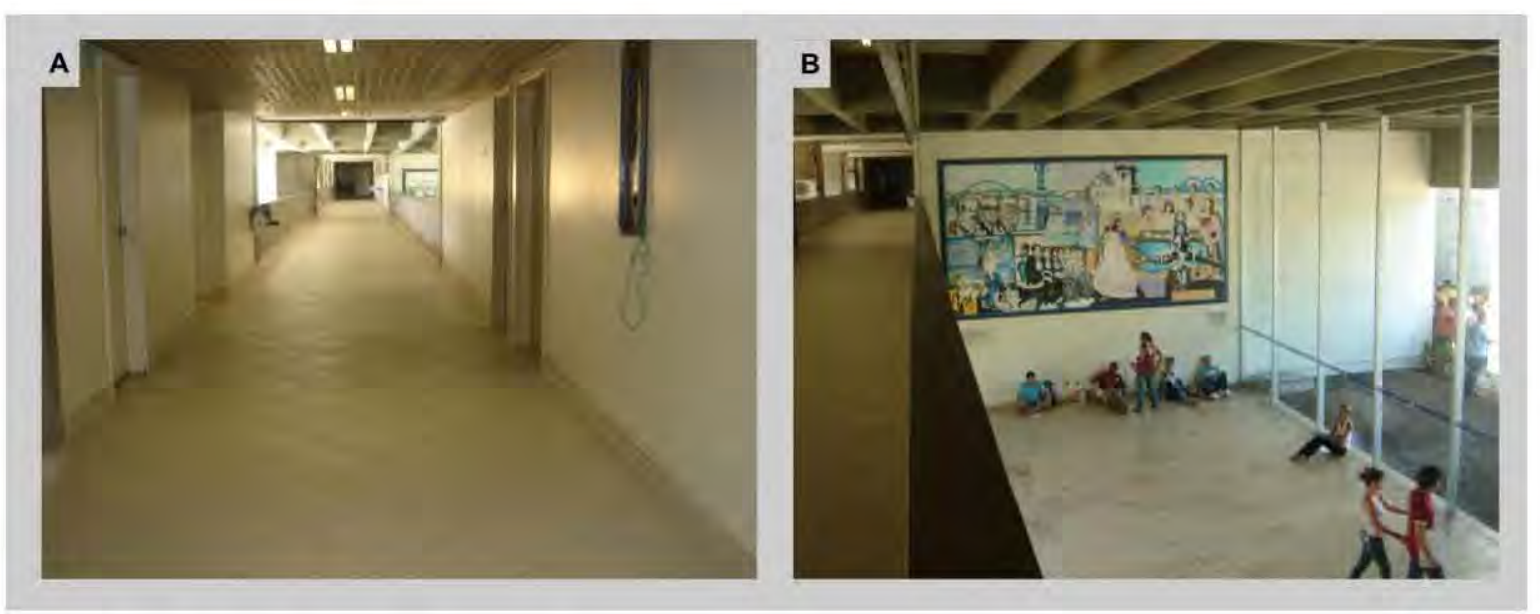

Figura 349: UFS - Reitoria - ano 2009.

(A) Vista da rua corredor.

(B) Vista do hall de acesso ao bloco administrativo: concepção em pé-direito duplo

(Fonte: Acervo Magda Campêlo, 2009) 
Prevalece o conceito da estrutura independente projetada com uma modulação de 9,00 m x $9,00 \mathrm{~m}$, com pilares que ora assumem a forma retangular nas fachadas compostas pelas cortinas dos brises, ora a forma octogonal contida na planta. A estrutura subordina a organização dos ambientes na planta, definidos pelas alvenarias divisórias. $O$ auditório implantado no prolongamento da circulação se une ao bloco principal por justaposição, conferindo com sua forma inusitada singularidade ao edifício. Predomina na forma arquitetônica a linguagem do concreto aparente, adotada em todas as fachadas (ver figuras 350 e 351).

A arquitetura proposta ratifica os princípios projetuais que vinham sendo adotados (modulação e padronização dos componentes construtivos), associados ao concreto aparente como linguagem plástica predominante. Assim como na Biblioteca, a arquitetura produzida na Reitoria reflete as ressonâncias da boa arquitetura praticada no Brasil.

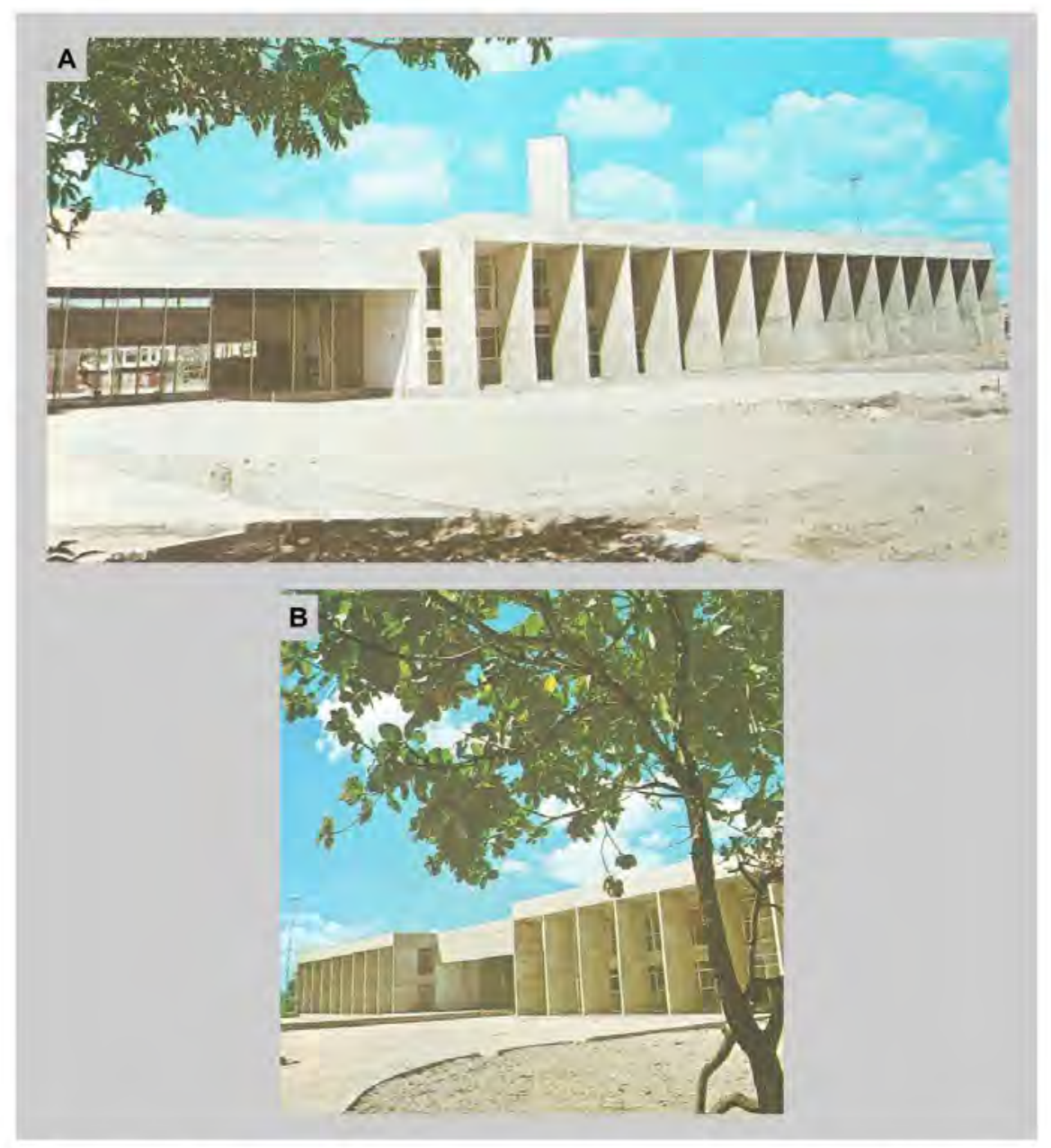

Figura 350: UFS - Edifício da Reitoria/fachada principal (final da década 1970).

(A) À esquerda, hall de acesso envidraçado que permite visualizar o saguão.

(B) A platibanda com os brises verticais de pé-direito duplo avança do corpo envidraçado e promove o sombreamento dos ambientes internos.

(Fonte: UFS, 1981?, p. 45) 


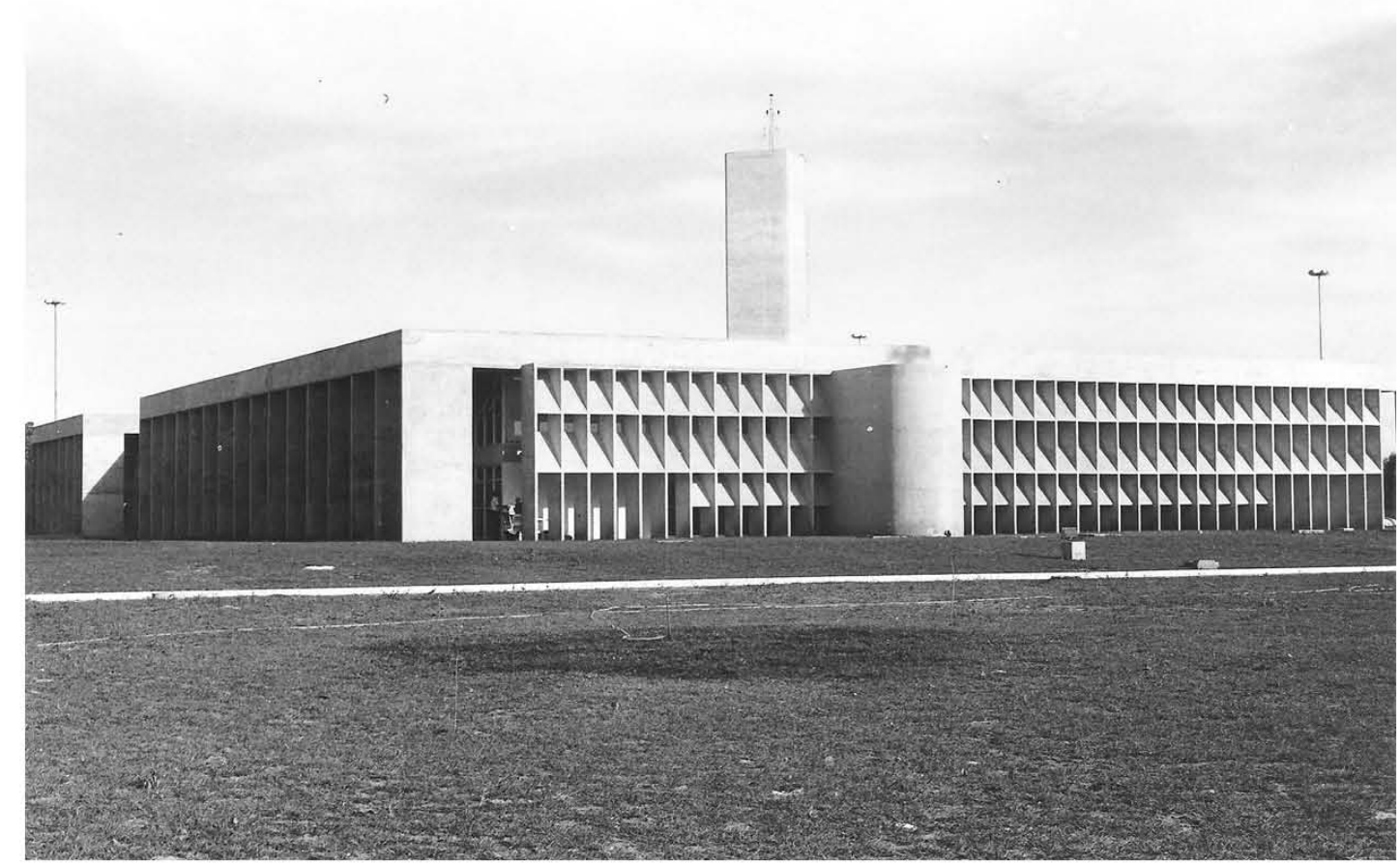

Figura 351: UFS - Edifício da Reitoria/fachada sul (final da década 1970).

Destaca-se a composição dos brises, interceptados pela volumetria da escada (Fonte: Arquivo Geral - Prefeitura do Campus).

\section{- Restaurante}

A implantação do edifício do Restaurante segue a diretriz do Plano Diretor (1974), que indica sua localização próxima à Biblioteca e à Vivência. $O$ projeto de arquitetura foi elaborado pelos profissionais do Escritório Técnico Administrativo (ETA) da Universidade Federal da Bahia por meio de convênio com a UFS, em 1978. Previsto para ser executado em duas etapas, a primeira das quais seria de $2.700,00 \mathrm{~m}^{2}$ e a segunda, de 650,00 $\mathrm{m}^{2}$ (UFS, 1980, p. 07). Foram construídos $2.943,00 \mathrm{~m}^{2}$ com previsão para um atendimento a 1.400 refeições por cada turno (UFS, 1980, p. 07). O programa abrangia áreas de vivência, refeitórios, cozinha industrial, administração, sanitários de público e de funcionários, estes com vestiários, e um restaurante à la carte, distribuídos em um edifício de dois pavimentos, e as áreas de apoio mecânico (subestação e casa de caldeiras) em duas edificações circunvizinhas de pavimento térreo (ver projeto nas figuras 352 a a 352 c).

O partido arquitetônico resulta do caráter orgânico da planta do edifício principal, que organiza os setores de maneira sequenciada, mas sem um eixo específico de ordenamento, onde os espaços se estabelecem a partir de hierarquias funcionais (1) acesso e vivência do público, 2) refeitórios, 3) cozinha, 4) serviços de apoio), que se espalham no terreno, ensejando uma planta com a composição geométrica ortogonal de feição irregular, que por sua vez resulta na composição destacada pelos volumes funcionais. 


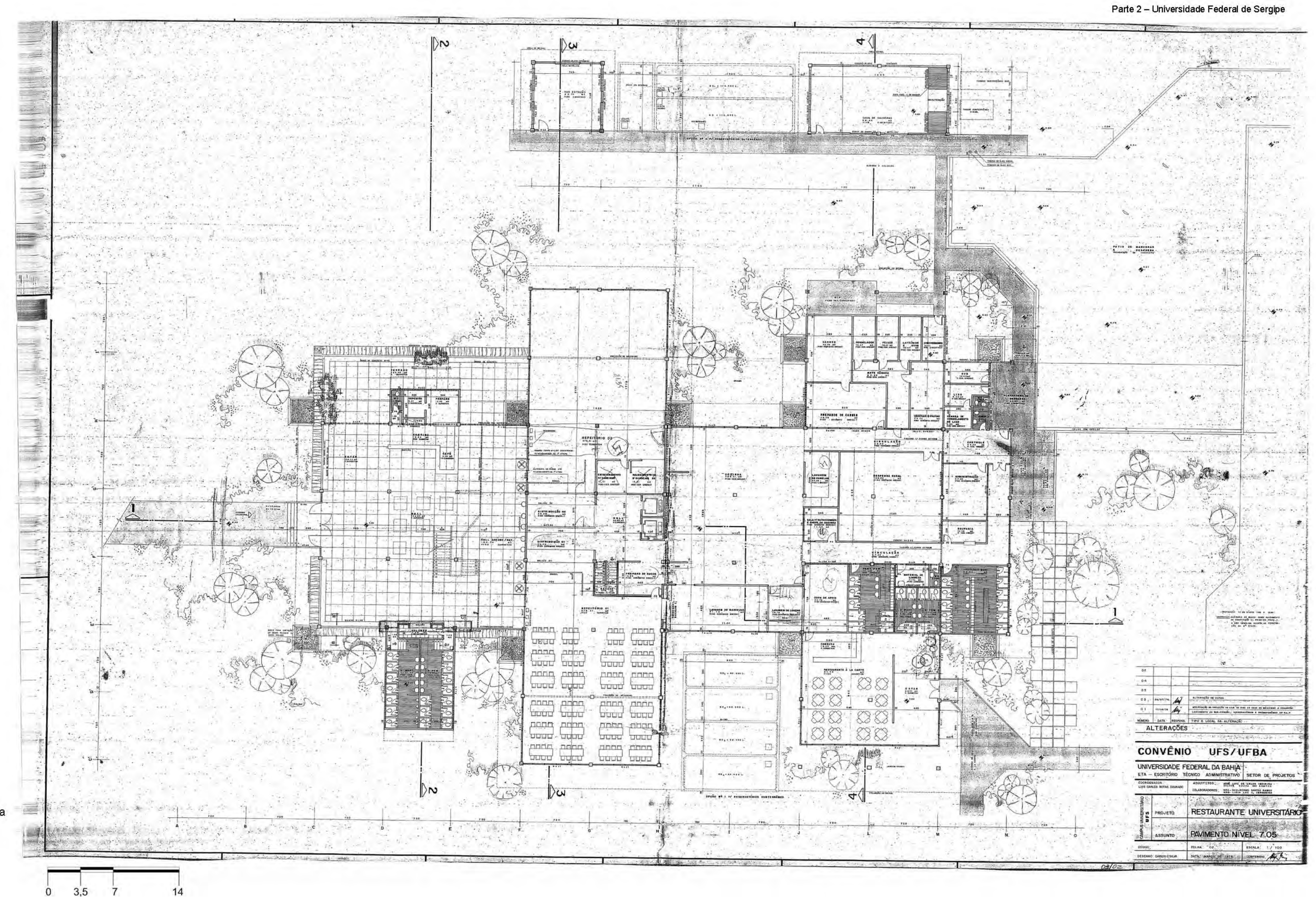




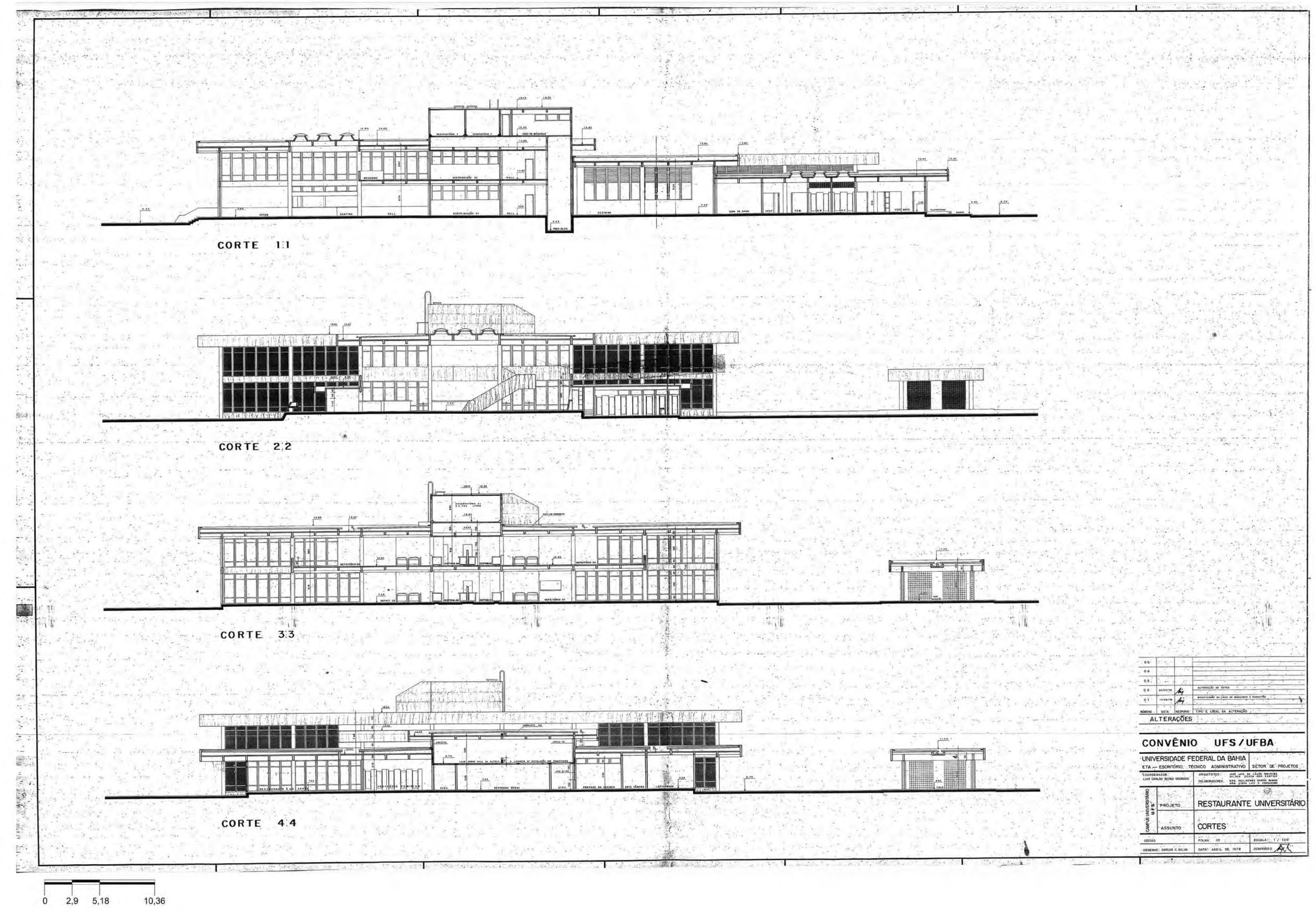




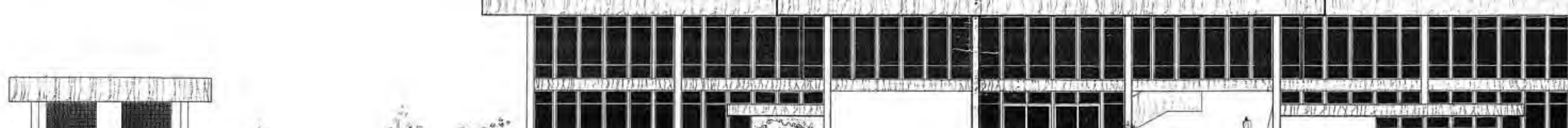

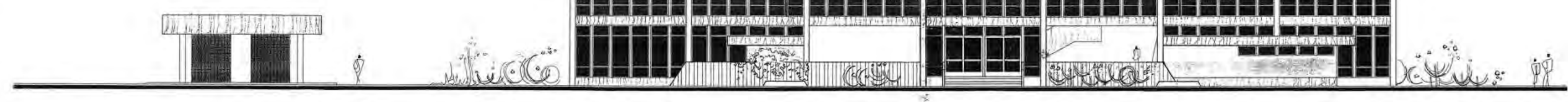

FAchadA LESTE

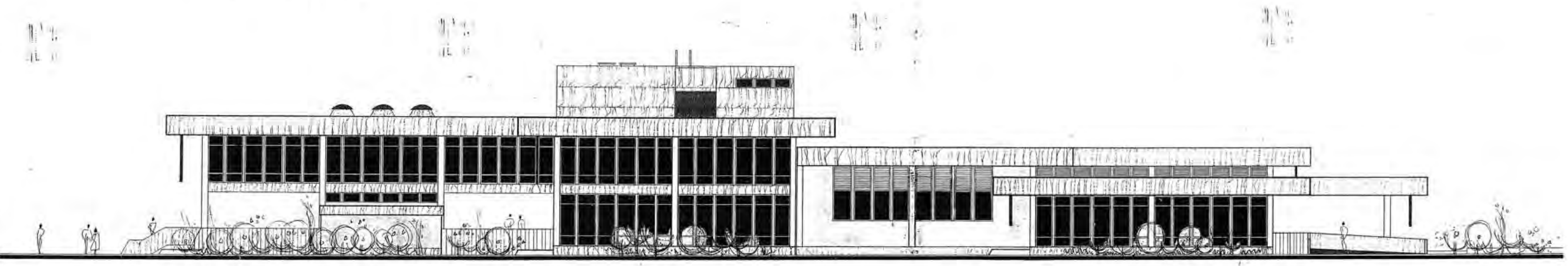

FACHADA NORTE

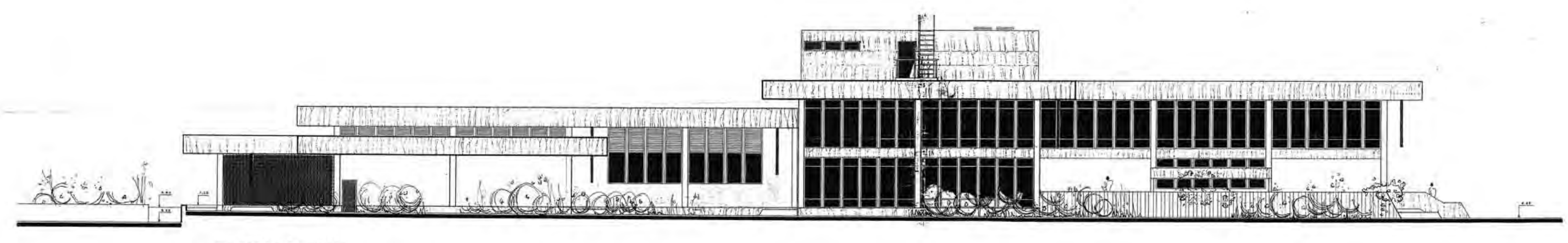
FACHADA SUL

IIIIIIII + III

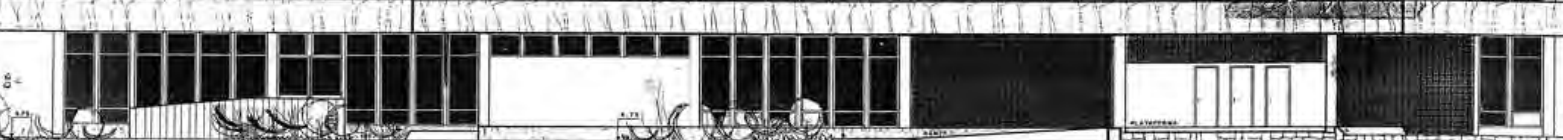


FOLHA VERSO DA FOLHA GRANDE - NÄO IMPRIMIR 
A proposta mantém a mudança do partido centrado na forma única. Há uma transformação da visão racionalista como objeto autônomo: uma intenção de fragmentação do edifício que inclui, além da organização funcional de caráter orgânico da planta, a diferenciação das fachadas pelo uso de pé-direito em diversas dimensões. O resultado é dinâmico e o todo é a junção de volumes que se articulam por justaposição, eliminando a homogeneidade da volumetria (ver figura 353 ).

Prevalece o conceito da estrutura independente, com laje nervurada projetada com uma modulação de $7,20 \mathrm{~m} \times 7,20 \mathrm{~m}$, indicando as possibilidades de flexibilidade no arranjo funcional do programa. Predomina a ênfase na verdade construtiva com a exposição dos elementos estruturais destacados das superfícies envidraçadas, que se por um lado conferem transparência e fluidez à edificação, por outro permitem a radiação solar direta, trazendo desconforto aos usuários (ver figuras 354 a 356).

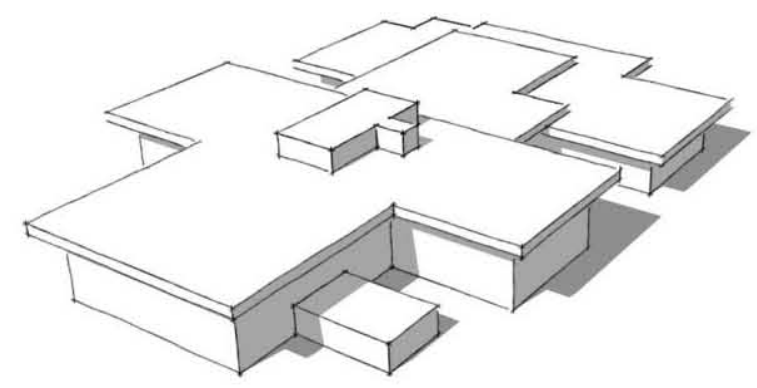

Figura 353: UFS - Restaurante - Composição volumétrica. (Fonte: elaboração própria)

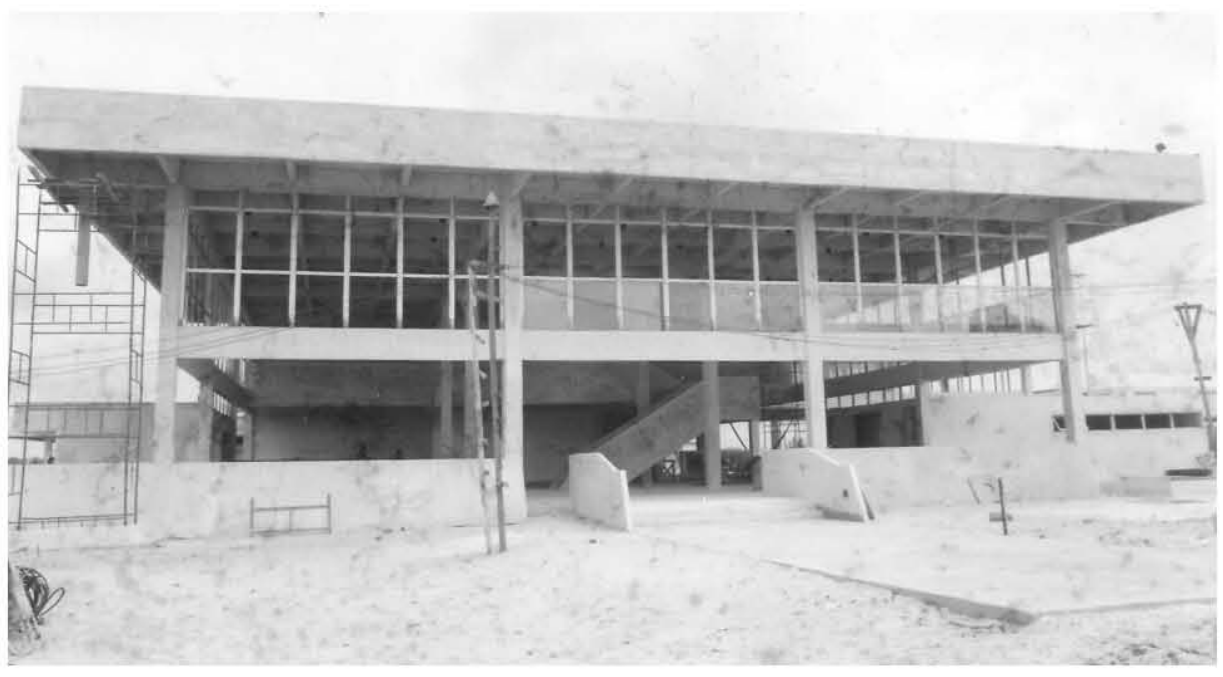

Figura 354: UFS - Restaurante (final década 1970, em fase execução).

Destacam-se os elementos estruturais do edifício em concreto aparente e as superfícies envidraçadas recuadas da platibanda.

(Fonte: Arquivo Geral - Prefeitura do Campus). 


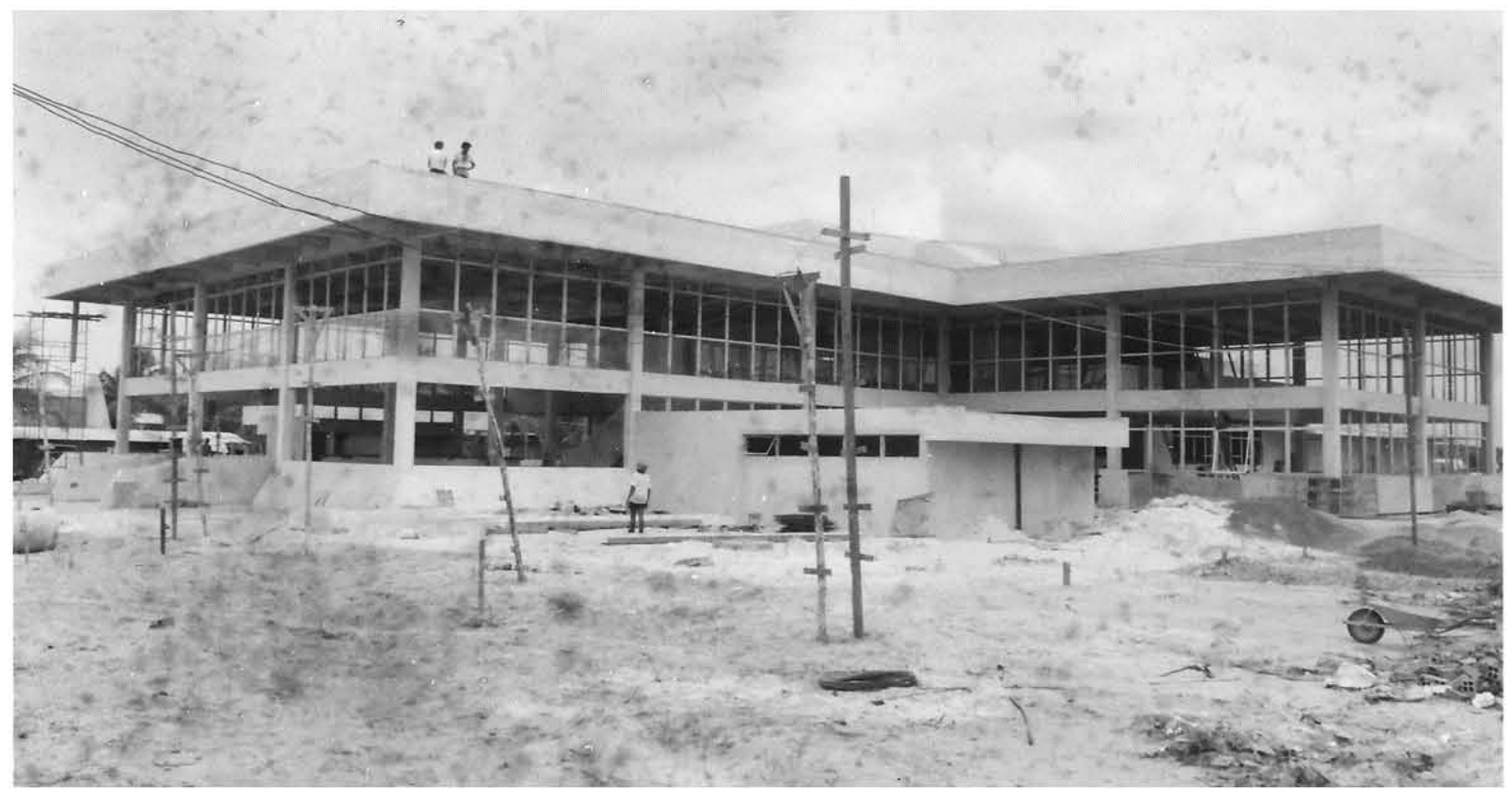

Figura 355: UFS - Restaurante (final década 1970 em fase execução).

Destaca-se a composição volumétrica funcional por justaposição, caracterizada pela estrutura do edifício aparente e as superfícies envidraçadas.

(Fonte: Arquivo Geral - Prefeitura do Campus).

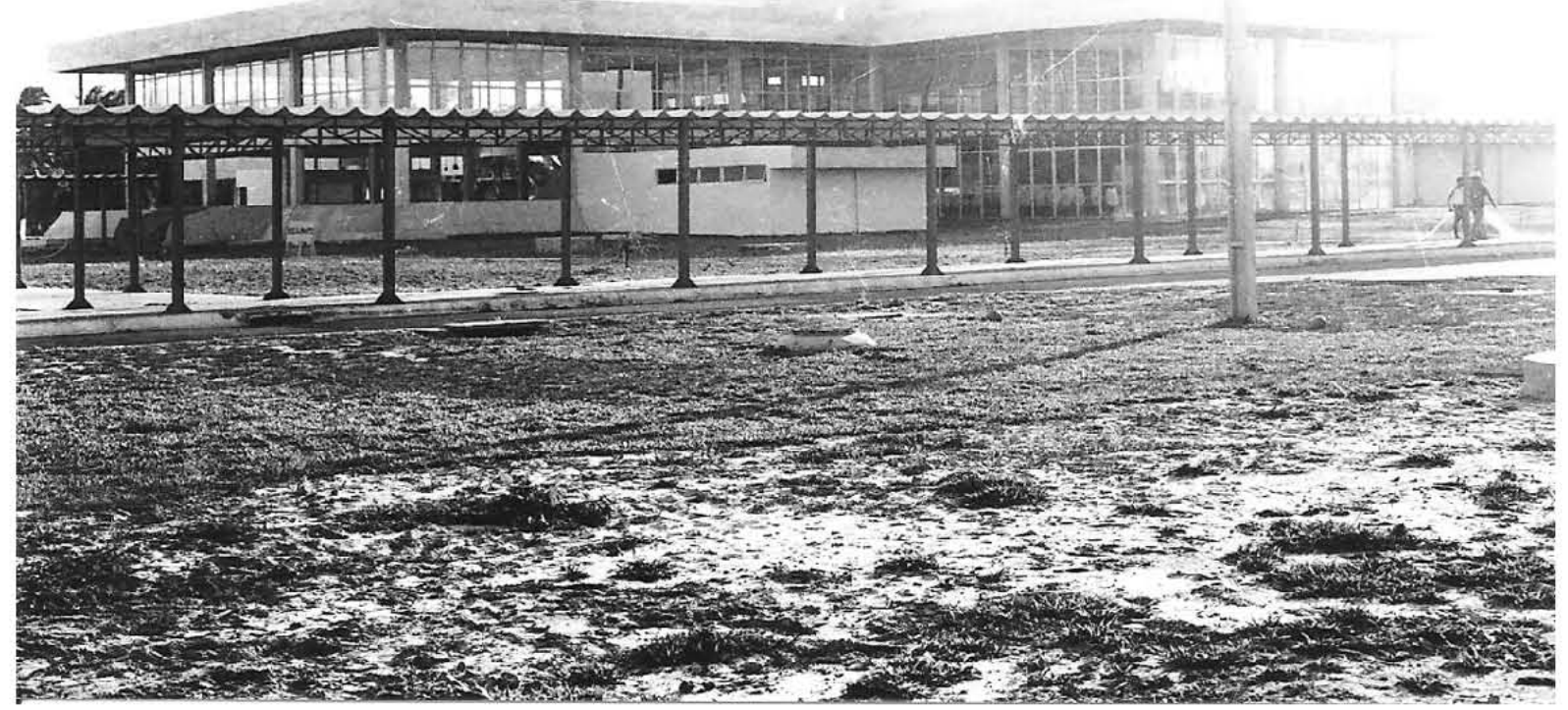

Figura 356: UFS - Restaurante (década de 1980)

A passarela coberta (primeiro plano) articula o Restaurante com as edificações do entorno. As áreas envidraçadas permitem a incidência solar direta no interior dos ambientes.

(Fonte: Arquivo Geral - Prefeitura do Campus).

O partido arquitetônico adotado para o Restaurante desvincula-se da intenção de se integrar aos condicionantes climáticos locais. $O$ uso dos extensos panos de vidro com esquadria de 
alumínio no fechamento das fachadas principais evidencia a pouca responsabilidade de produzir uma arquitetura para o lugar. A proposta afasta-se da qualidade arquitetônica desenvolvida nos edifícios da Biblioteca Central e da Reitoria.

\section{- Centro de Ciências Biológicas e da Saúde/Centro de Ciências Exatas e Tecnológicas}

O conjunto de edifícios que forma o Centro de Ciências Biológicas e da Saúde e o Centro de Ciências Exatas e Tecnológicas foi elaborado por meio de convênio com a Universidade de Brasília, já no final da década de 1970 , com construção iniciada nos primeiros anos da década de 1980. Uma equipe de arquitetos dessa universidade desenvolveu uma proposta cujos edifícios se organizam em um sistema "pavilhonar" modulado e integrado, formando um conjunto de características construtivas homogêneas, interligados por passarelas e pátios abertos, destinados às cantinas e pontos de encontro, evidenciando a diretriz de criar espaços que estimulem o encontro e a convivência (ver figura 357 ).

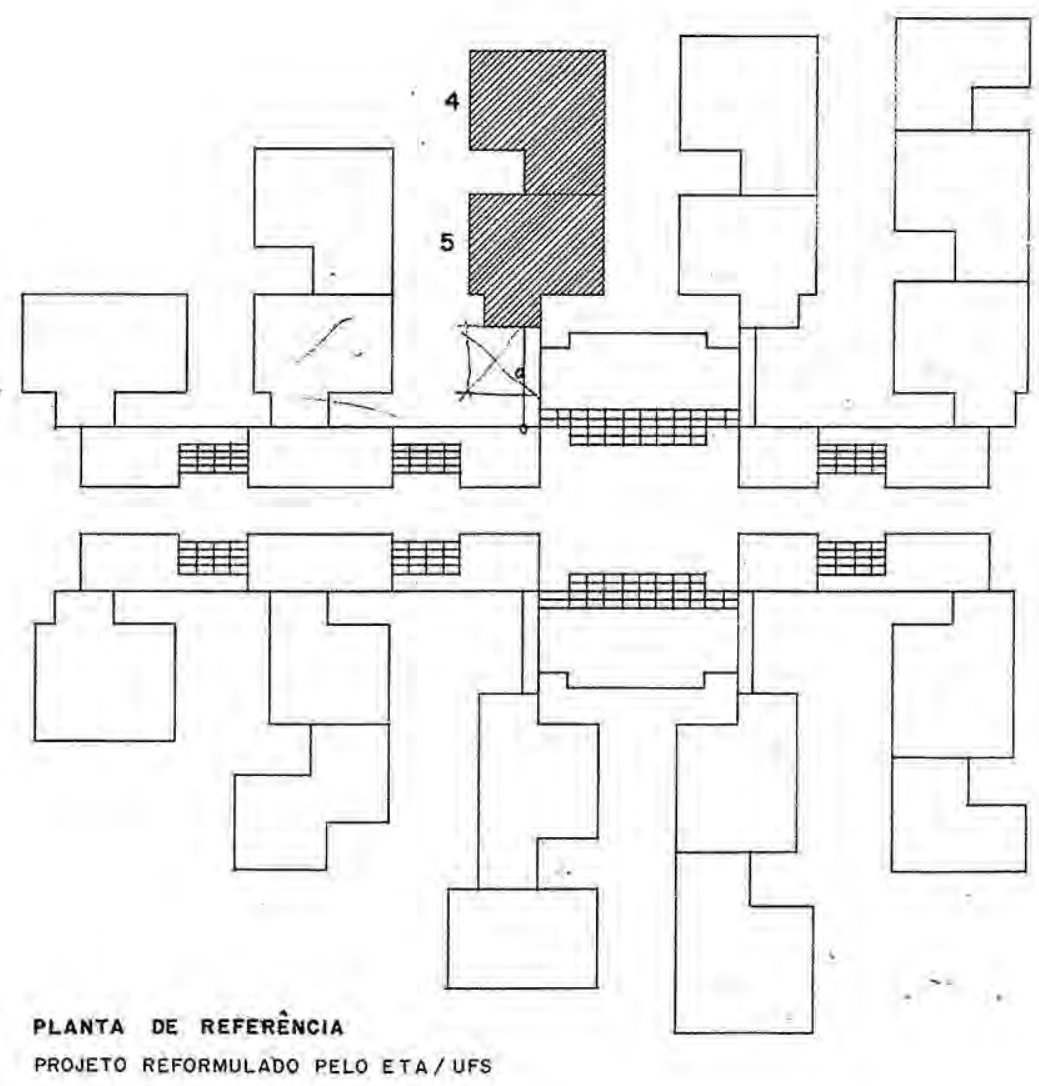

Figura 357: UFS - Centro de Ciências Biológicas e da Saúde e Centro de Ciências Exatas e Tecnológicas.

(Fonte: Arquivo Geral - Prefeitura do Campus) 
A proposta apresenta possibilidades de expansão e flexibilidade do sistema, conforme as novas demandas do programa, onde outras edificações podem ser acrescidas sem comprometer os atributos do conjunto arquitetônico. As partes formam o todo que não pode ser tomado como construção acabada, mas como suporte de um sistema em constante desenvolvimento. Pensada como uma construção de edifícios de baixa altura, somente pavimento térreo, o conjunto não apresenta entrada principal ou diferenciação entre qualquer das fachadas, bem como näo indica um foco central. O complexo é constituído por diferentes plantas, que correspondem a uma função específica.

A planta destinada aos laboratórios de Biologia II, Blocos 4 e 5, organiza o programa, formando setores funcionais compartimentados que se subordinam a um módulo transversal de $3,22^{5} \mathrm{~m}$ e se conectam pela circulação central que permite acessos laterais e nas extremidades. Cada bloco é abastecido por bateria de sanitário, que se interliga com as circulações abertas do conjunto. As esquadrias das fachadas obedecem ao mesmo módulo, garantindo sua padronização, e são protegidas por brises verticais pré-moldados (ver figura 358).

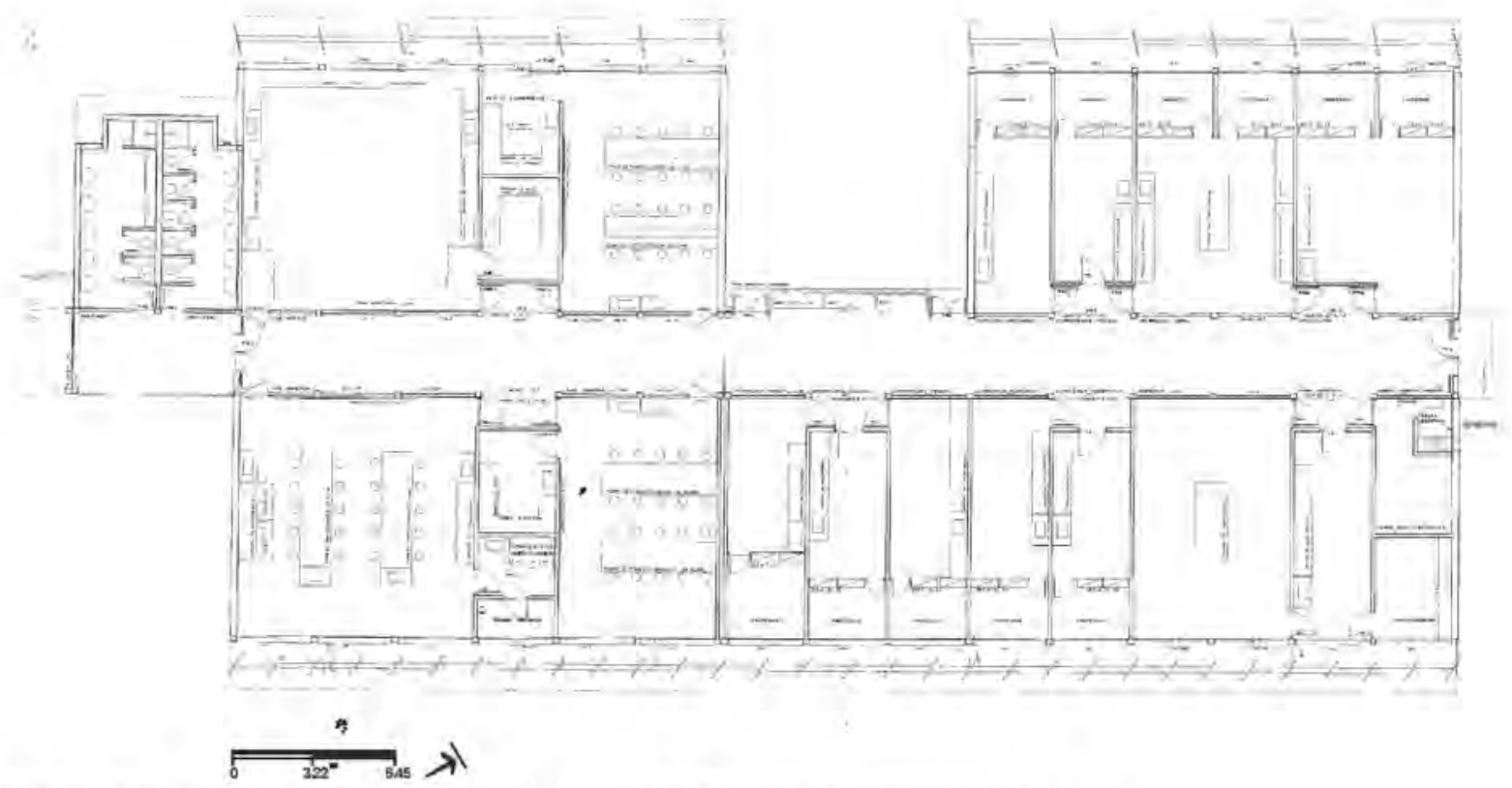

Figura 358: UFS - Planta dos Laboratórios de Biologia II - Blocos 4 e 5

(Fonte: Arquivo Geral - Prefeitura do Campus).

A tectônica dos edifícios é marcada pelo padrão da coberta em telha cerâmica do tipo colonial e empenas laterais que acompanham a inclinação da telha. A solução indica o atendimento aos requisitos de conforto térmico por meio da ventilação, utilizando a solução do tipo efeito chaminé. As esquadrias da fachada são padronizadas em madeira e vidro a partir do módulo construtivo que fixa suas dimensões (ver figuras 359 a 364). 


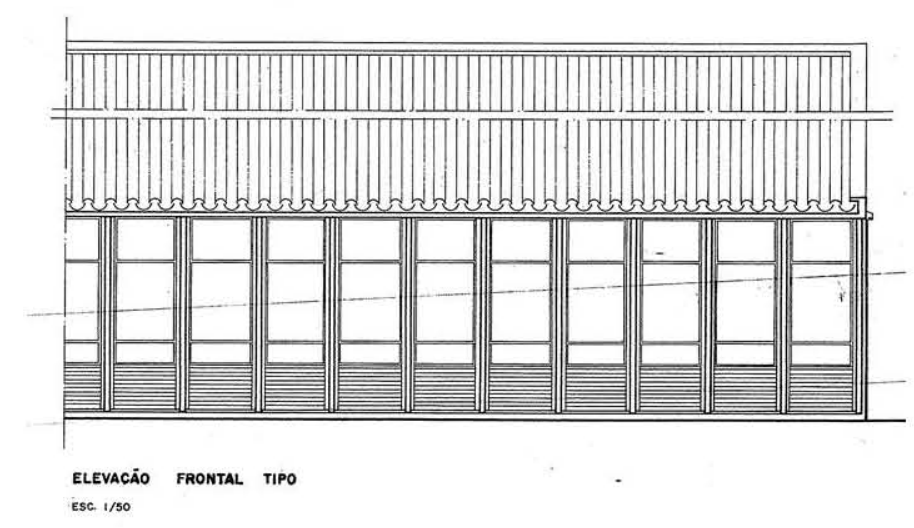

Figura 359: UFS - Laboratórios de Biologia.

Detalhe das esquadrias padronizadas em madeira e vidro

(Fonte: Arquivo Geral - Prefeitura do Campus).

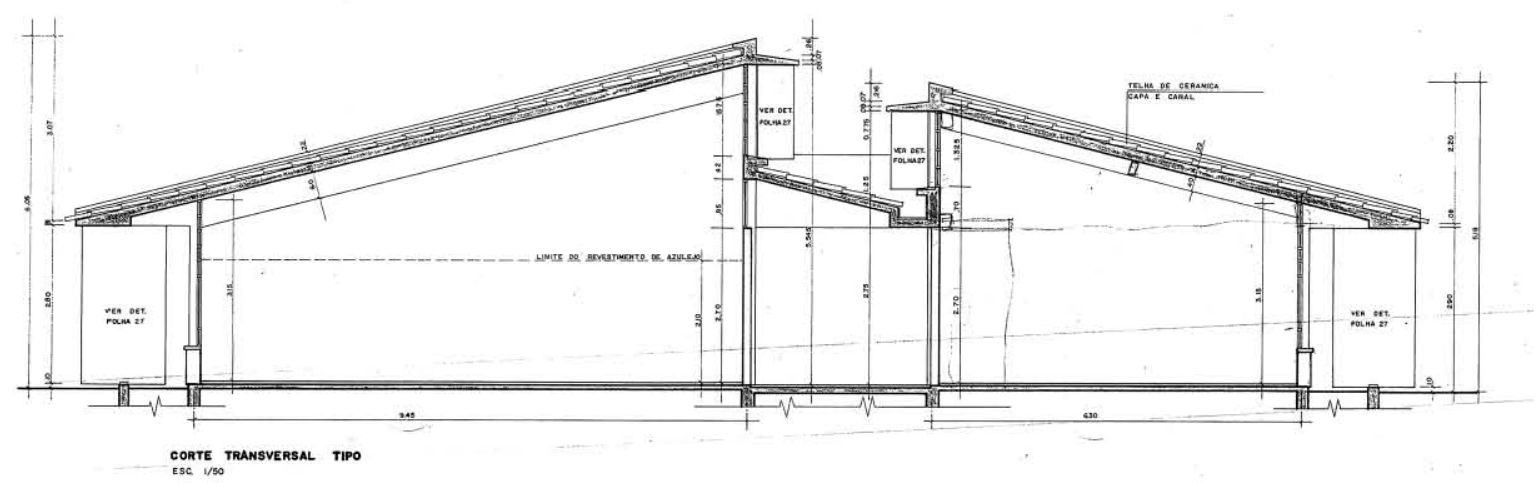

Figura 360: UFS - Laboratórios de Biologia - Corte transversal.

As esquadrias da fachada, em altura inferior às aberturas voltadas para a circulação, permitem a ventilação do tipo efeito chaminé. Brises verticais são empregados para eliminação da radiação solar direta.

(Fonte: Arquivo Geral - Prefeitura do Campus)

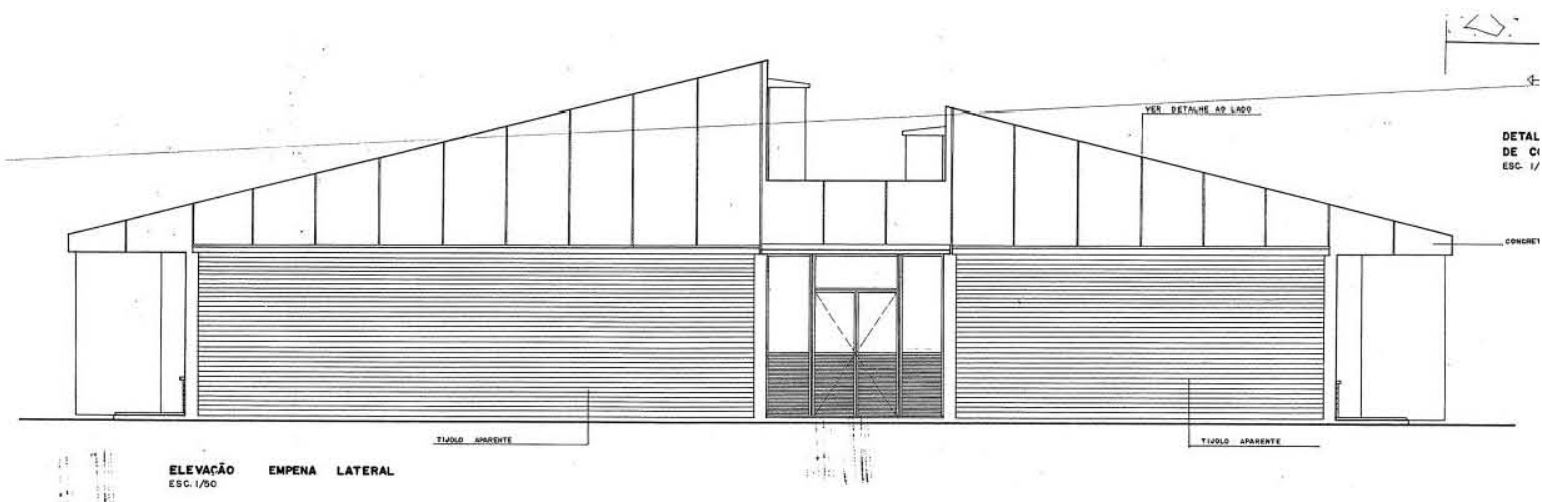

Figura 361: UFS - Laboratórios de Biologia - Fachada de um bloco-padrão.

A empena em placas pré-moldadas e o tijolo de revestimento cerâmico das vedações criam uma composição de contrastes

(Fonte: Arquivo Geral - Prefeitura do Campus). 


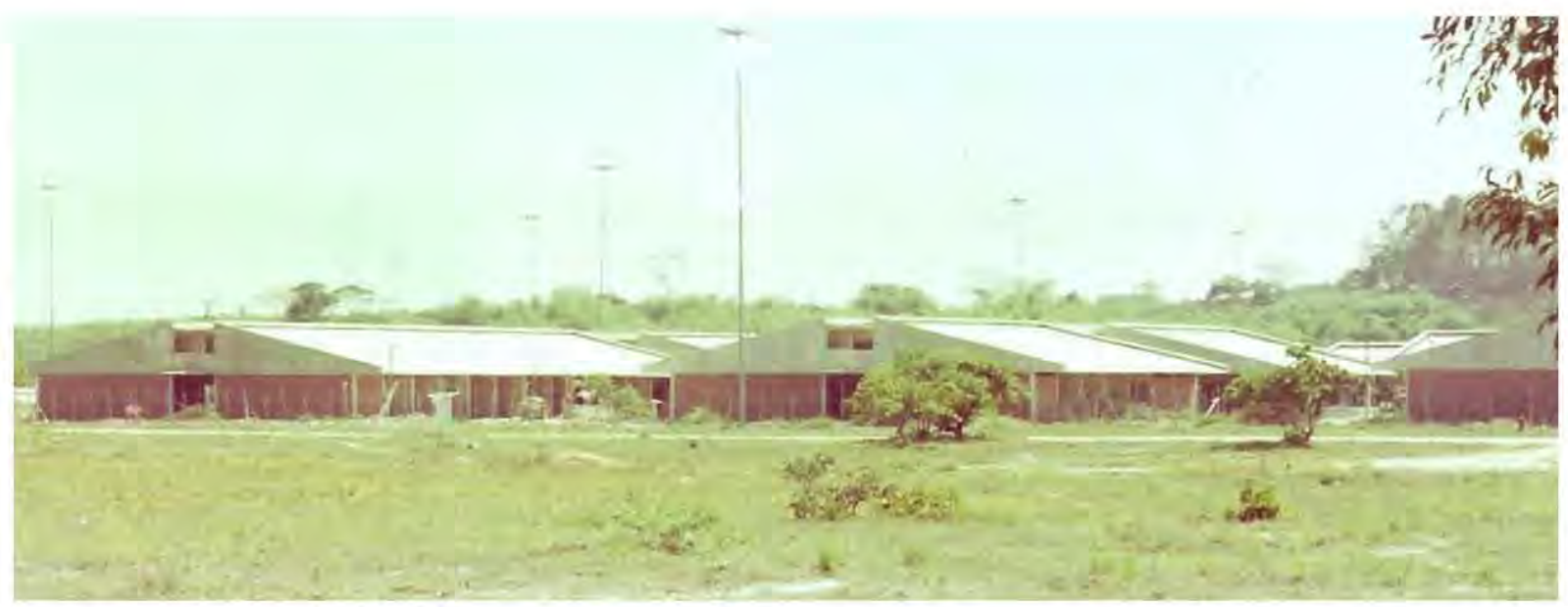

Figura 362: UFS - Conjunto do Centro de Ciências Biológicas e da Saúde e do Centro de Ciências Exatas e Tecnológicas em construção (meados da década de 1980).

A solução privilegia uma arquitetura de características homogêneas e proporciona uma percepção de totalidade do conjunto

(Fonte: Arquivo Geral - Prefeitura do Campus).

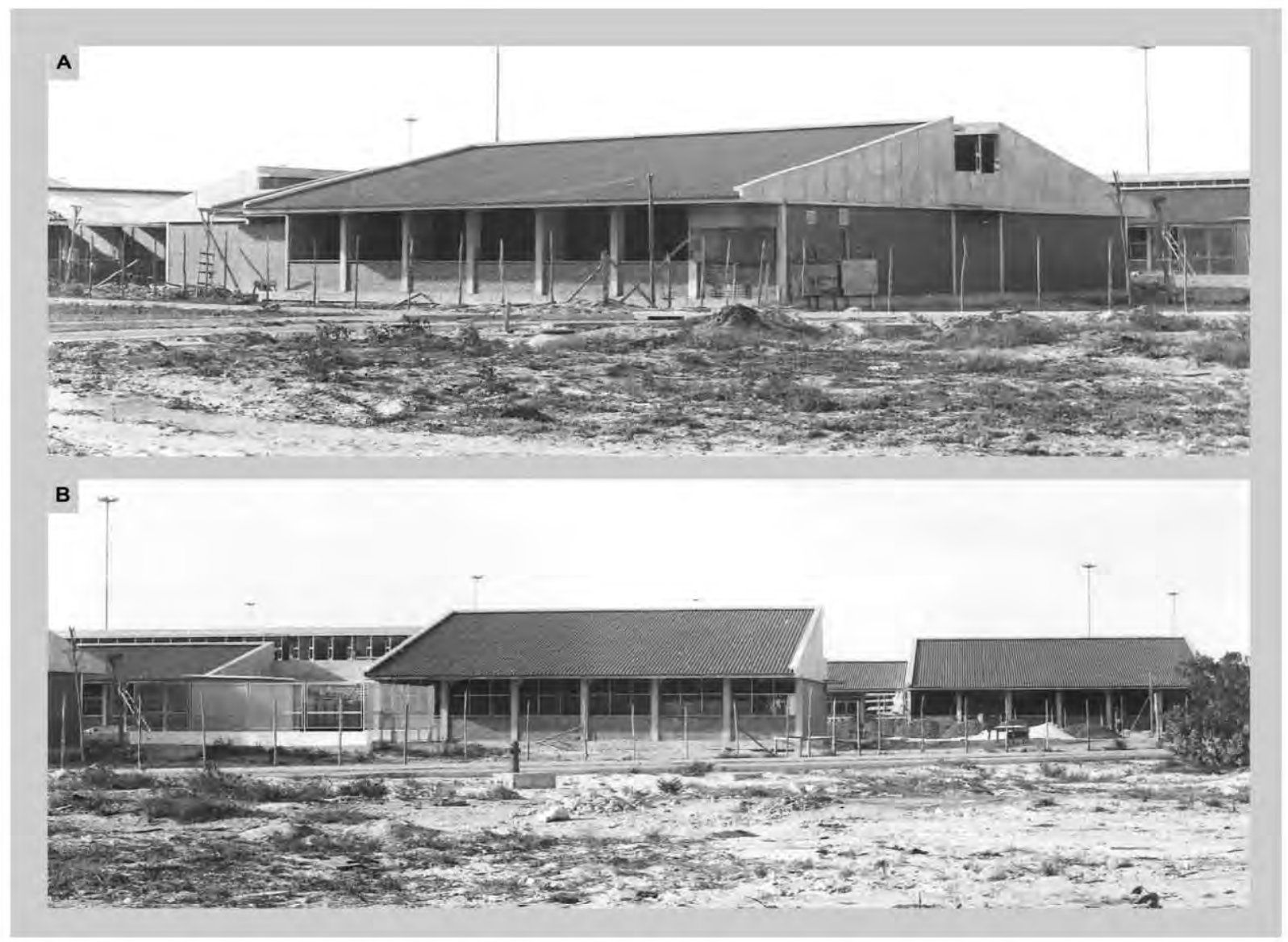

Figura 363: UFS - Centro de Ciências Biológicas e da Saúde e Centro de Ciências Exatas e Tecnológicas (meados da década de 1980).

(A) Bloco padrão em construção: coberta em telha cerâmica e empena em placas de cimento pré-moldadas.

(B) A modulação construtiva permite a padronização das esquadrias e destaca os pilares separados dos panos de vedação - alvenarias e esquadrias.

(Fonte: Arquivo Geral - Prefeitura do Campus). 


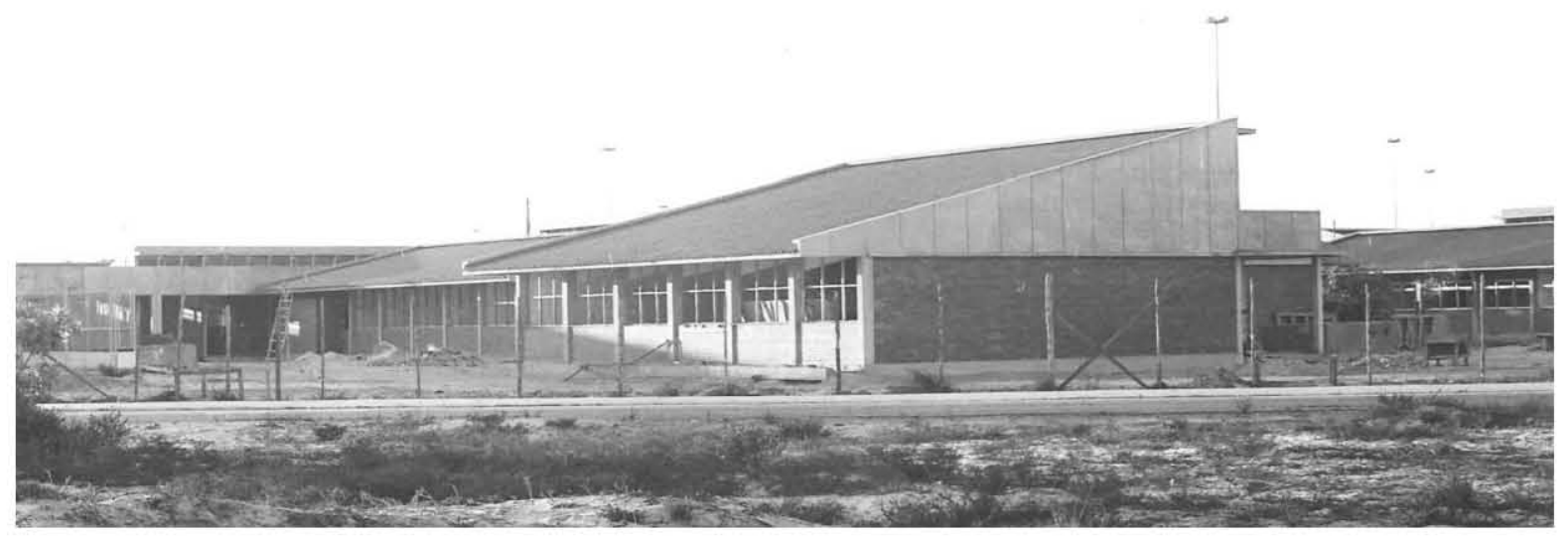

Figura 364: UFS - Centro de Ciências Biológicas e da Saúde e Centro de Ciências Exatas e Tecnológicas (meados da década de 1980).

Modulação construtiva permite a padronização das esquadrias e destaca os pilares separados dos panos de vedação - alvenarias e esquadrias.

(Fonte: Arquivo Geral - Prefeitura do Campus).

As características dessa arquitetura distanciam-se das propostas que vinham sendo executadas na UFS. Mesmo ○ Conjunto Didático, que adota o sistema pavilhonar, não concretiza um complexo integrado. A proposta implica novo conceito de planejamento, porém mantendo a diretriz projetual orientada pelo princípio da flexibilidade, da modularidade e da racionalização construtiva, onde os atributos arquitetônicos evidenciam a busca de uma arquitetura adaptada aos condicionantes locais.

A proposta para o Centro de Ciências Biológicas e da Saúde/Centro de Ciências Exatas e Tecnológicas evidencia os debates que começaram a surgir no final da década de 1970 e que passaram a colocar em cheque a forma de organização interna do Campus, que não promovia a integração das relações interdepartamentais. Sua construção foi iniciada na década seguinte.

As características dessa arquitetura distanciam-se das propostas que vinham sendo executadas na UFS. Mesmo ○ Conjunto Didático, que adota o sistema pavilhonar, não concretiza um complexo integrado. A proposta implica novo conceito de planejamento, porém mantendo a diretriz projetual orientada pelo princípio da flexibilidade, da modularidade e da racionalização construtiva, onde os atributos arquitetônicos evidenciam a busca de uma arquitetura adaptada aos condicionantes locais.

A proposta para o Centro de Ciências Biológicas e da Saúde/Centro de Ciências Exatas e Tecnológicas evidencia os debates que começaram a surgir no final da década de 1970 e que passaram a colocar em cheque a forma de organização interna do Campus, que não promovia a integração das relações interdepartamentais. Sua construção foi iniciada na década seguinte. 


\subsection{CAMPUS x CIDADE: configuração de território segregado}

A produção urbano-arquitetônica, que resultou do propósito de consolidar a base física da UFS, compatibilizada com a estrutura da Reforma, chegou ao fim da década de 1970 sem ter tido o projeto original concretizado na íntegra. Entretanto, as linhas gerais do urbanismo projetado mantêm a configuração inicial como testemunho do projeto do Governo Federal de construir o espaço da Reforma (ver figura 365).

A situação de isolamento inicial decorrente da concepção de um território autônomo e apartado da malha urbana da cidade apresenta nos dias atuais alterações que se configuram num processo gradativo de "conurbação". A ocupação das áreas circunvizinhas da gleba de extensa dimensão por conjuntos habitacionais que conformam o Bairro Rosa Elze, localizado nos limites oeste do terreno e a ampliação da malha viária com a Avenida Marechal Rondon que faz a ligação com o centro da capital envolvem o Campus transformando-o em barreira intransponível para a permeabilidade da infraestrutura e serviços urbanos (ver figura 366). No contexto urbano, o território de base unificada da UFS mantém até os dias de hoje seu caráter original de segregação.

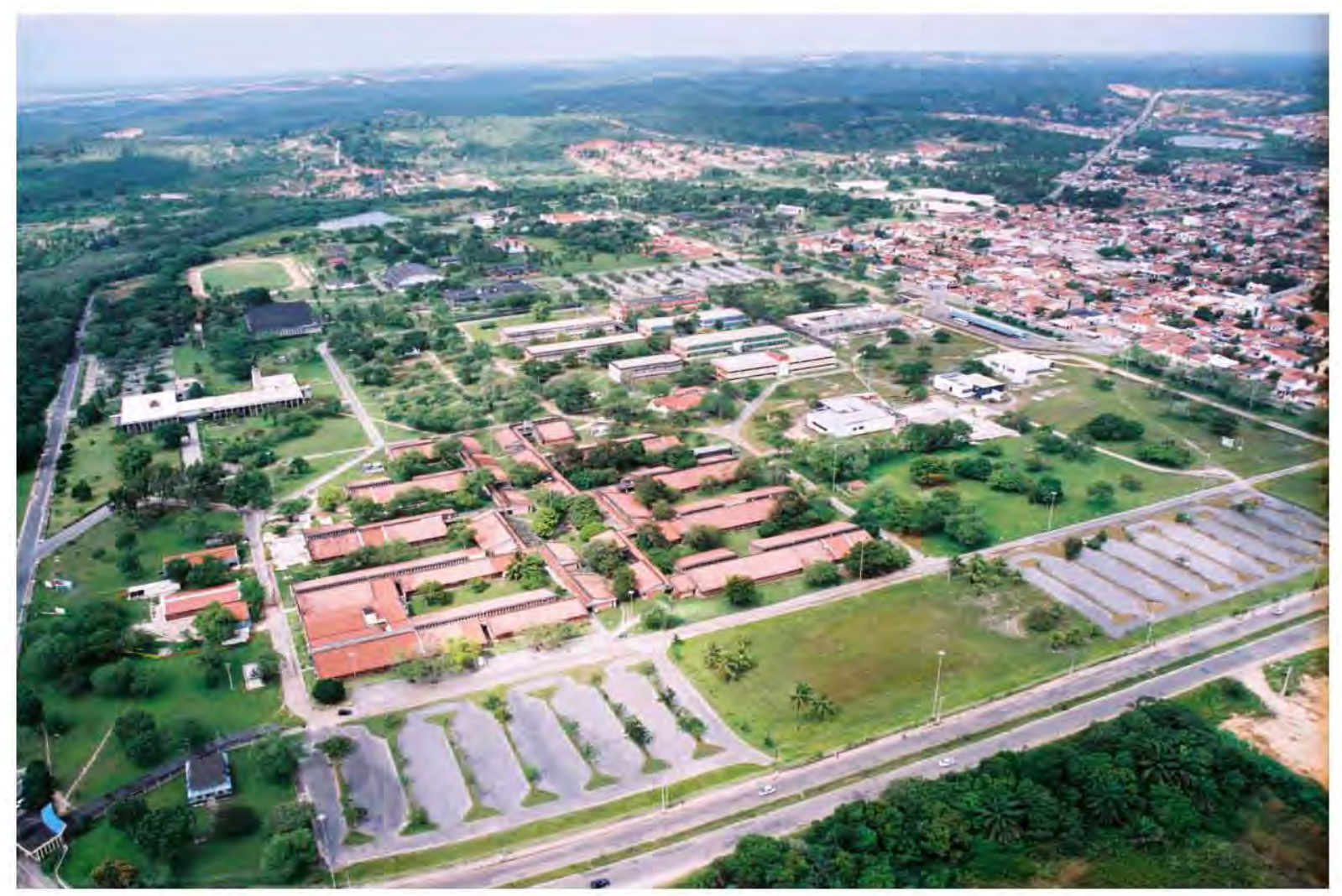

Figura 366: UFS - Vista Aérea do Campus Universitário de São Cristóvão (agosto de 2007). A organização espacial mantém a configuração urbanística de origem.

(Fonte: Acervo Prefeitura do Campus - UFS) 
Parte 2 - Universidade Federal de Sergipe

Figura 365: UFS - UFS - Planta geral do Campus (atualização em 2008). zoneamento funcional e sistema viário básico
(Fonte: Acervo Prefeitura do Campus - UFS).

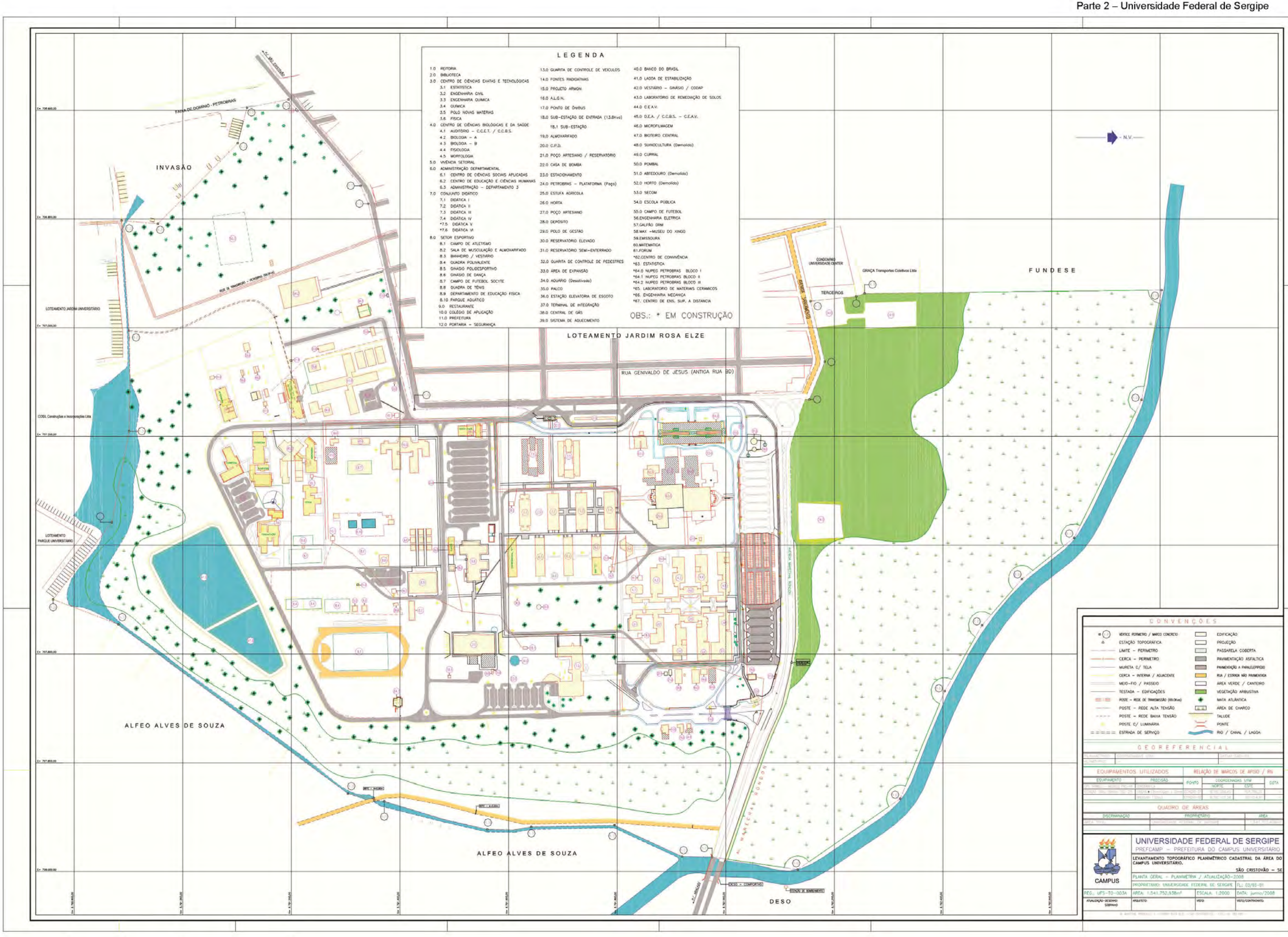

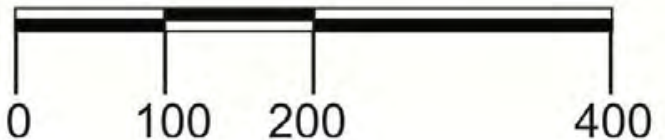


FOLHA VERSO DA FOLHA GRANDE - NÃO IMPRIMIR 


\subsection{CONSIDERAÇÕES}

A Universidade Federal de Alagoas, criada a partir da justaposição de estabelecimentos profissionais isolados, tendo como órgão executivo central, a Reitoria, foi instituída nos termos do Decreto-lei ${ }^{\circ} 269$, de 28 de fevereiro de 1967, sob a forma de fundação com sede em Aracaju. Nascida sob a égide da Reforma Universitária logo tomou providências para reestruturar sua organização baseada no sistema departamental, passando a ser constituída num primeiro momento por Faculdades e Institutos que compunham os ciclos de Formação Básica e de Formação Profissional. As novas unidades atendiam às duas áreas de conhecimento afins: Humanidades e Ciências Exatas e Naturais.

Instalada inicialmente nas instituições que the foram incorporadas e que se encontravam dispersas na capital, empreendeu esforços construtivos para conformar um território em área urbana consolidada, contrariando a orientação da Reforma que indicava a compatibilização da nova estrutura com a organização espacial em território unificado e isolado das funções urbanas. Implantou, mesmo depois da Reforma, mais de $50 \%$ de sua área construída em quadras próximas, integradas à malha urbana da cidade. Essa condição, entretanto, inicial foi decorrente da tentativa frustrada de adquirir um terreno para a construção do novo território.

Diferindo das edificações de origem, cuja arquitetura estava identificada com os ditames do ecletismo (exemplo: a Faculdade de Direito), as novas instalações evidenciam o abandono dos estilos históricos e a difusão dos elementos definidores do vocabulário modernista. A eliminação do ornamento, a volumetria de formas puras e as aberturas de linhas retas testemunham o prenúncio da difusão da arquitetura moderna em Aracaju (exemplos: o edifício central da área de Humanidades e o da Reitoria).

As obras e projetos eram coordenados por uma Diretoria de Obras, responsável pelo desenvolvimento físico da nova instituição, que propalava a filosofia de construir possibilitando modificações futuras com um mínimo de gastos e sem prejudicar os atributos arquitetônicos concebidos. Deveria ser almejada a utilização das áreas com vistas à integração universitária.

A intenção de construir o campus em território periférico estava presente já no primeiro reitorado com a tentativa de adquirir um terreno situado na orla marítima, mas que demonstrou ser tecnicamente inviável em função da ação da corrosão provocada pelo ar marinho, que traria prejuízos à aparelhagem dos laboratórios e outras instalações. Somente em 1974, foi comprada a área de 117 ha, situada no município de São Cristóvão, zona oeste 
de Aracaju, onde se instalou o espaço universitário moldado com base na estrutura da Reforma (1968).

A organização espacial foi orientada pelo Plano Diretor Físico, elaborado pelo Fundo de Construção da USP (FUNDUSP), que definiu as diretrizes urbanísticas e arquitetônicas para o futuro território unificado da UFAL. O planejamento do Campus evidencia a permanência aos princípios do urbanismo moderno, especialmente no zoneamento e na hierarquia dos fluxos de circulação. Seguiu a proposta do edifício isolado, que atendia aos condicionantes de crescimento e expansibilidade horizontal da estrutura universitária, ajustada às disponibilidades de recursos para sua construção. Atendia, de forma eficiente, aos valores delimitados pelo financiamento de que dispunha.

A solução espacial trazia, entretanto, na sua concepção, o conflito do urbanismo funcional que, com sua rígida separação em zonas especializadas, conformadas por extensas áreas com edifícios isolados e sem alternativas para permeá-las com as funções da cidade, transformou-se num local de caráter segregado.

A construção do Campus foi iniciada em 1976, financiada com recursos do Programa $\mathrm{MEC/BID} \mathrm{II,} \mathrm{com} \mathrm{previsão} \mathrm{de} \mathrm{conclusão} \mathrm{em} \mathrm{duas} \mathrm{etapas,} \mathrm{sendo} \mathrm{a} \mathrm{primeira} \mathrm{com} \mathrm{término}$ programado para 1980. O projeto executivo do Campus definiu as áreas acadêmicas funcionais constituídas pelos Centros de Ciências Exatas e Tecnológicas e Ciências Biológicas e da Saúde, pelo setor didático e departamental, que formavam um conjunto de blocos padronizados e pelos Setores Esportivo, de Serviços Gerais de Apoio e Hospitalar. Este não foi construído, consolidando seu funcionamento em Aracaju, atualmente o Campus da Saúde. Implantados em partes distintas, eram articulados por vias de circulação hierarquizadas, formando um conjunto circunscrito por um anel viário perimetral com bolsões de estacionamento periféricos. As linhas gerais da estrutura física projetada estavam alinhadas com as orientações do Manual de Atcon.

Foi contemplada na primeira etapa, a construção dos blocos didáticos e de administração departamental, um conjunto de edifícios para o Centro de Ciências Exatas e Tecnológicas (CCET), outro para o Centro de Ciências Biológicas e da Saúde (CCBS), os prédios da Reitoria, da Biblioteca Central, do Restaurante Universitário, da Prefeitura do Campus e da Vivência Setorial, além dos blocos para cabine de entrada e medição e outro para recepção, assim como a infraestrutura básica.

A produção arquitetônica do conjunto edificado até 1980 estava balizada pelos conceitos da modulação e padronização, atendendo aos requisitos de menor custo e rapidez de execução. Objetivava com as soluções da planta livre ordenada pelo módulo-base estrutural, a flexibilidade dos espaços sujeitos a modificações. As linhas da arquitetura 
produzida mesclavam o legado da arquitetura moderna com as ressonâncias das experiências que estavam ocorrendo com o concreto em várias regiões do país.

O Conjunto Didático/Administração Departamental reproduz tipologias de configuração tipo barra, ressaltando a verdade construtiva: estrutura e vedação estão nitidamente separadas. O concreto aparente é adotado no sistema estrutural e nos componentes de proteção solar, que com pouca eficiência para barrar a radiação direta, evidenciam a intenção de incorporar um vocabulário identificado com a modernidade da arquitetura que se desenvolvia nos grandes centros do país naquele período. Mais do que ser, era parecer moderno.

Os edifícios projetados para a Biblioteca Central e a Reitoria reproduzem as linhas da arquitetura que encontra no concreto aparente o elemento plástico predominante. No projeto da Reitoria, de autoria do arquiteto Miguel Juliano, o partido se desenvolve em torno de um pátio central aberto que concilia os diversos setores. A estrutura modular de concreto armado se destaca na fachada sul, enquanto que nas demais, os pilares se juntam aos brises verticais que formam cortinas de proteção solar, evidenciando a intenção de adequação aos condicionantes locais.

O edifício, de linhas retas e de configuração horizontal, se destaca na paisagem construída por sua qualidade arquitetônica. Especificamente na Biblioteca, o desenho primoroso da estrutura de concreto armado em linhas retas, com os pontos de apoio da grelha sobre os pilares, a exploração plástica de elementos funcionais, como as gárgulas para escoamento das águas da chuva inseridas na empena que conforma o edifício em caixa, são explorados com maestria.

No final da década de 1970, o projeto para as instalações do Centro de Ciências Biológicas e da Saúde e do Centro de Ciências Exatas e Tecnológicas evidenciam o propósito de superar 0 isolamento das unidades com maior concentração dos edifícios que, desenvolvidos sob a malha modular da estrutura de concreto armado, estão interligados internamente por uma série de espaços - cantinas, passarelas, pontos de encontro visando estimular a convivência. A forma arquitetônica explora o uso do tijolo cerâmico nos fechamentos, destacados da estrutura de concreto armado e associados à tradição construtiva da região com a coberta de telhas cerâmicas. Permanece o conceito da padronização construtiva assumida nas tipologias didática/departamental como princípio basilar da racionalidade pretendida. A proposta foi materializada com a construção dos citados Centros na década seguinte.

No mesmo percurso das universidades investigadas na presente pesquisa, a UFS não teve a organização espacial, proposta no Plano, concretizada na íntegra. As diretrizes do desenvolvimento físico, embasadas pelas linhas do urbanismo racional moderno, que 
caracterizaram a produção urbanística do seu território periférico moldado para a estrutura da Reforma Universitária, resultaram na localização dispersa dos conjuntos acadêmicos. A produção urbano-arquitetônica com implantação dos edifícios de forma isolada em meio a extensas áreas, obrigando a longos deslocamentos, sem proteção dos rigores climáticos, concorreu para desenvolver um ambiente segregado, contraditório com o espírito de integração universitária propalado nos objetivos da reestruturação do sistema de ensino implantada em 1968. Delimitado pelo anel viário periférico e isolado das funções urbanas, o Campus da UFS chega ao fim da década de 1970 como testemunho da fantasia de construir um espaço característico do ensino superior brasileiro que se pretendia moderno

Sua característica de isolamento inicial apresenta nos dias atuais transformações, caracterizadas pela ocupação em seus limites do Bairro Rosa Elze, e pela ampliação da malha viária com a Avenida Marechal Rondon que faz a ligação com o centro da capital. Esses elementos, estruturadores da área circunvizinha do Campus transforma-o em barreira intransponivel para a integração com as atividades da cidade. No contexto urbano, o território de base unificada da UFS mantém até os dias de hoje seu caráter original de segregação. 


\section{UNIVERSIDADE FEDERAL DO PIAUÍ (UFPI)}

A Universidade Federal do Piauí, criada sob a forma de fundação é uma universidade pública federal com sede localizada na cidade de Teresina, Piauí. Atua em várias regiões do Estado com a seguinte estrutura: Campus Ministro Petrônio Portella, que sedia a Instituição, em Teresina - funcionando juntamente com o Campus do Socopo, que abriga o Centro de Ciências Agrárias; Campus Ministro Reis Veloso, em Parnaíba; e, Campus Senador Helvídeo Nunes de Barros, em Picos, além de três Colégios Agrícolas nos municípios de Teresina, Floriano e Bom Jesus (ver figura 367).

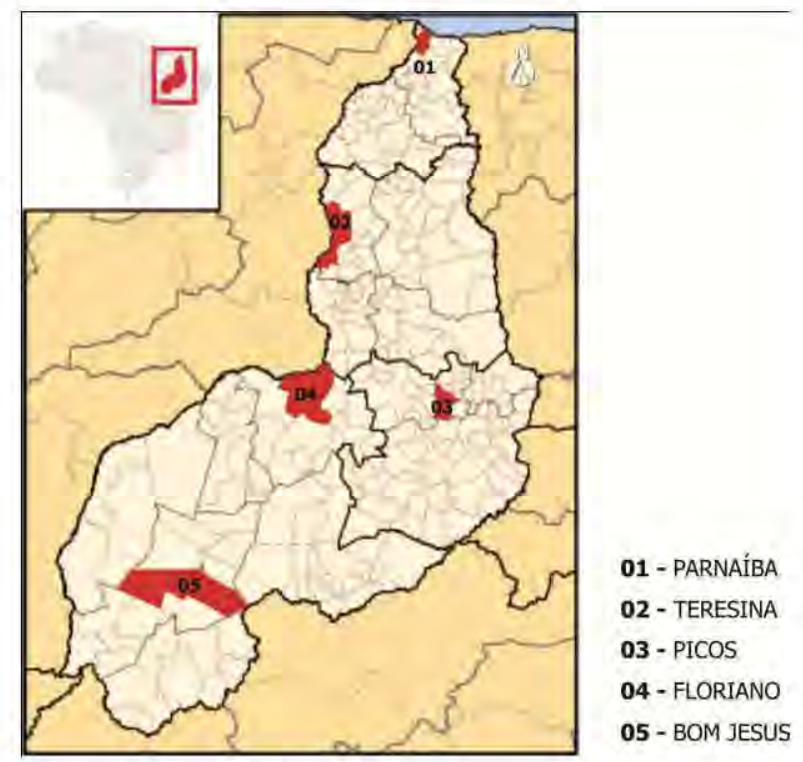

Figura 367: UFPI - Mapa do Piauí.

Localização dos municípios que sediam a UFPI.

(Fonte: disponivel em:

<http://pt.wikipedia.org/wiki/Anexo:Lista_de_munic\%C3\%ADp

ios_de_

Piauil . Acesso em: 01 fev. 2012).

\subsection{CRIAÇÃO DA UFPI}

A criação da Universidade Federal do Piauí (UFPI) tem uma trajetória marcada pelos esforços da sociedade piauiense que, por meio da classe política daquele Estado ${ }^{124}$, viabilizou a sua implantação, considerada um marco cultural na história do Piauí e que,

\footnotetext{
${ }^{124}$ Sobre a história da criação da UFPI, consultar a tese de Passos (1985) com o título Universidade Federal do Piaui e suas marcas de nascença: conformação da reforma unniversitária de 1968 à sociedade piauiense, descrita com riqueza de fatos e versões.
} 
segundo Kruel (2006, p.393) abriu as portas para a ascensão econômica e social de milhares de jovens.

A história da Instituição tem raízes entre os anos de 1910 e 1912, quando o governo do Estado tentou estabelecer uma escola de agrimensura, de nível superior, com o objetivo de solucionar os graves problemas fundiários existentes no Piauí. A ideia, porém, não vingou e a escola não foi instalada (FERREIRA FILHO, 1995, p.16).

Em meados de 1930, o governo estadual instituiu um curso para formação de professores na área de educação física, sob o patrocínio do MEC, o qual, apesar das positivas perspectivas de trabalho, lançando profissionais ao mercado, não se consolidou (FERREIRA FILHO, 1995, p.16).

O que chama a atenção naqueles anos são as ações empreendidas pela iniciativa privada que, antecipando-se à ação pública, criou cursos de nível superior, que não se firmaram. É o caso da Academia de Comércio que, mesmo depois de ter conferido diploma de nível superior a duas turmas, foi transformada em escola técnica de segundo grau. O mesmo aconteceu com a Faculdade de Filosofia, Ciências e Letras, em Teresina, que apesar de ter ministrado aulas para licenciatura em Geografia, História, Filosofia e Matemática, não conseguiu oficialização como faculdade livre, o que era proibido pela legislação em vigor (FERREIRA FILHO, 1995, p.16).

A iniciativa privada foi a responsável pela efetiva implantação do ensino superior no Piauí, com a criação da Faculdade de Direito em 14 de abril de 1931. Posteriormente foi estadualizada, voltou a ser privatizada, até que foi federalizada, em 1955.

Em 1957, mais um passo foi dado, desta vez por intermédio da Arquidiocese de Teresina, que criou a Faculdade de Filosofia com os cursos de Filosofia, Geografia, História e Letras e, posteriormente, de Matemática, e foi federalizada em 1964.

Em 1961, foi a vez da Faculdade de Odontologia, mais uma de caráter privado, posteriormente estadualizada e federalizada em 1966. A historiografia da criação dessa faculdade destaca a força de vontade e a decisão firme dos seus professores de se dedicarem a ela gratuitamente, declarando inclusive como pertencentes à instituição, os seus gabinetes dentários particulares, quando das fiscalizações do MEC (FUFPI, p.9, 1982).

Em 1963, os estudantes se mobilizam pela criação de uma universidade no Piauí por meio da União Estadual dos Estudantes. A implantação da Universidade de Brasília, em 1961, repercutia naquele Estado como resultado da luta de estudantes, professores e educadores intelectuais pela reestruturação do ensino superior brasileiro e pela ampliação do número de vagas. 
Passos (1985, p.41), entretanto, constata que embora os estudantes tenham se engajado plenamente no movimento de reivindicação da Universidade, suas ações estavam voltadas para as questões locais e, mais especificamente, para os eventos culturais, de lazer e acontecimentos sociais, o que não impediu que o movimento repercutisse entre as autoridades políticas, culturais e educacionais do Estado. Ao contrário, sendo o estudante do ensino superior membro das classes abastadas, suas atitudes encontraram fácil apoio da sociedade, que ratificava o entendimento sobre as condições existentes no Piauí para criar a Universidade.

Em 1964, o clima de instabilidade política gerado pelo golpe militar, moderou os movimentos, silenciando autoridades políticas e educacionais. No ano seguinte, as manifestações de interesse retornaram pelos mesmos grupos, mas os pleitos não foram considerados. Residiam dúvidas por parte da Presidência da República sobre o apoio da classe política piauiense ao golpe militar até que, nas eleições de $1966^{125}$, a vitória de políticos pertencentes ao partido que dava respaldo aos novos representantes da nação trouxe o retorno da reivindicação na administração pública federal.

Em 1968, faltavam ainda as duas faculdades que permitiriam a criação da UFPI, já que a lei vigente exigia a existência de, no mínimo, cinco escolas de ensino superior no Estado para a criação de uma universidade federal. Foi então instituída a Faculdade de Administração de Empresas, instalada no município de Parnaíba e paralelamente, nesse mesmo ano, com o mesmo intento ${ }^{126}$, passou a funcionar a Faculdade de Medicina em Teresina, que havia sido criada em 1966.

Apesar de já dispor do número necessário de cursos superiores, a criação da universidade ainda teve que esperar a neutralização dos fatores políticos ligados à ditadura militar que impediam sua concretização, até que a Lei $n^{\circ} .5 .528$, de 12 de novembro de 1968 , autorizou - poder executivo a instituir a Universidade Federal do Piauí sob a forma de fundação, com sede em Teresina.

O evento foi recebido com festividades pelo governo do Estado, contando com a presença de representantes do MEC, do Conselho Federal de Educação e das mais altas autoridades estaduais e municipais (KRUEL, 2006, p.381). A forma de fundação, entretanto, encontrou resistência na comunidade acadêmica e educacional local, ainda que esta modalidade de organização jurídica, que indicava a manutenção da instituição com recursos públicos e particulares, não fosse uma novidade, pois a Universidade de Brasília, em 1961, a

\footnotetext{
${ }^{125}$ Passos (1995) registra que a eleição de Petrônio Portella Nunes, de sete dos oito Deputados Federais e 28 dos 34 Deputados Estaduais, pertencentes ao partido que dava respaldo popular à Ditadura Militar, na eleição de 1966, era prova inconteste da fidelidade do esquema político dominante do Piaú aos novos mandatários da Naçäo (PASSOS, 1985, p.54).

${ }^{126}$ Ferreira Filho $(1995$, p.17) destaca o relato de professores sobre a luta intensa de vários profissionais da área, que contaram com a participação efetiva de dois piauienses ilustres, Petrônio Portela, então governador do Estado, e Deolindo Couto, presidente do Conselho Federal de Educação.
} 
Universidade Federal do Maranhão, em 1966, e a Universidade Federal de Sergipe, em 1967, já haviam adotado esse dispositivo jurídico. Além do que, a lei da reforma universitária também incluía a fundação dentre as formas jurídicas definidas para as instituições federais de ensino.

O temor dos estudantes, professores e intelectuais residia nas desconfianças de sua origem trazida dos Estados Unidos, que representava um modelo de privatização do ensino e a defesa pela escola pública era ponto inegociável. $O$ caráter polêmico da proposta não impediu, entretanto, sua aprovação.

Importante apontar que a lei da Reforma foi instituída 16 dias após a data de criação da FUFPI, fato que nos remete à efervescência que permeava o projeto do governo federal na preferência pelo modelo de universidade para a organização e funcionamento do ensino superior. Estruturada sob o signo do projeto reformista, a construção da UFPI é testemunho da concepção e do processo de implantação daquele novo modelo pedagógico.

Em 12 de março de 1971, três anos após a instituição da Fundação, a Universidade Federal do Piauí foi instalada com a junção das escolas isoladas de ensino superior existentes (Faculdade de Direito, Faculdade de Odontologia, Faculdade de Filosofia e Faculdade de Medicina em Teresina; e Faculdade de Administração de Empresas na Parnaíba). Seguindo a orientação da Reforma,

[...] estabeleceu, desde o primeiro Estatuto, organização baseada em departamentos; integração do ensino e da pesquisa, atividades de extensão; sistema de crédito; currículos estruturados em ciclo básico e ciclo profissional; instituição de órgãos colegiados centrais para a supervisão das atividades de ensino e da pesquisa e também para as administrações setoriais e superiores (PASSOS, 1985, p.12).

Obedecendo à Reforma Universitária nos seus aspectos estruturais, a UFPI baseou-se em centros ou unidades de ensino, os quais congregaram os cursos de áreas afins, que por sua vez, reuniram-se em departamentos. Silveira (1998), pesquisador em gestão universitária, tece em sua avaliação, que a Universidade foi inspirada no modelo da Universidade de Brasília (UnB), a qual encarnava no início dos anos 1960, o padrão norte-americano. Baseia-se o autor no modelo de administração adotado que se dava em dois planos:

[...] o executivo monocrático, exercido nos níveis de Reitoria, diretorias de Centros ou unidades e chefias de Departamentos; o deliberativo, desempenhado nos planos Superior (Conselho Universitário, de Administração e de Ensino, Pesquisa e Extensão) e setorial (Conselhos 
Departamentais $_{i}$ por Centro, e Assembléias Departamentais, por Departamento) (SILVEIRA, 1998, p.57).

A similaridade com a UnB, entretanto, é questionável à medida que a UFPI nasceu da junção de escolas isoladas diferentemente daquela que foi criada a partir do modelo estrutural de três componentes básicos: Institutos Centrais, Faculdades Profissionalizantes e Órgãos Suplementares. Sintonizados sim, com a Reforma, os dirigentes da UFPI a organizaram preocupados com os aspectos econômicos da educação tanto no que se refere à utilização dos recursos materiais quanto na contribuição ao desenvolvimento com a formação de profissionais, requeridos pelo mercado e pelo progresso tecnológico. Nesse sentido, Passos, ao avaliar as ações do primeiro reitorado, ${ }^{127}$ expressa que

a organização praticada buscava materializar as concepções do regime militar, definindo uma estrutura administrativa para a Universidade que propiciasse a maximização dos investimentos na educação $e$, consequentemente, a eficiência econômica que o regime desejava ostentar no período, em busca de legitimação (PASSOS, 1985, p.83).

De todo modo, deu-se início, por meio da recém-criada instituição universitária, ao sonho da superação do atraso e do subdesenvolvimento que marcava o Piauí. Sua fundação alinhava-se com a trajetória desse Estado, situado naquele momento às margens do desenvolvimento nacional. A ausência de uma economia forte o suficiente para garantir sua sobrevivência transformou a UFPI em mais do que uma instituição educacional, para representar as esperanças do piauiense de alavancar o Estado do isolamento não só geográfico, mas cultural e político. Reforçado pelo interesse da classe política hegemônica, o Piauí incorpora esse bem público orientado pelo projeto do governo militar.

\subsection{A CONSTRUÇÃO DO TERRITÓRIO: do centro urbano à zona periférica}

O propósito de constituir o campus universitário como o território que deveria reunir em um só lugar o complexo acadêmico constituído a partir das unidades de ensino superior que lhe deram origem, reestruturadas no sistema departamental de ensino era uma questão central da nova instituição. Nesse sentido, a localização do campus foi uma das preocupações do primeiro reitorado.

\footnotetext{
${ }^{127}$ Para implantar a UFPI, é designado para a Reitoria, o professor da Universidade de Brasília Hélcio Ulhôa Saraiva.
} 
Entretanto, a recém-criada universidade carecia de imediato, para fazer funcionar suas atividades, de instalações físicas, ainda que provisórias enquanto que a construção do campus demandava um cronograma de execução que não poderia ser resolvido em curto prazo. Para dar uma solução, foi reformado o edifício do antigo Seminário Arquidiocesano de Teresina ${ }^{128}$ (ver figura 368 ).

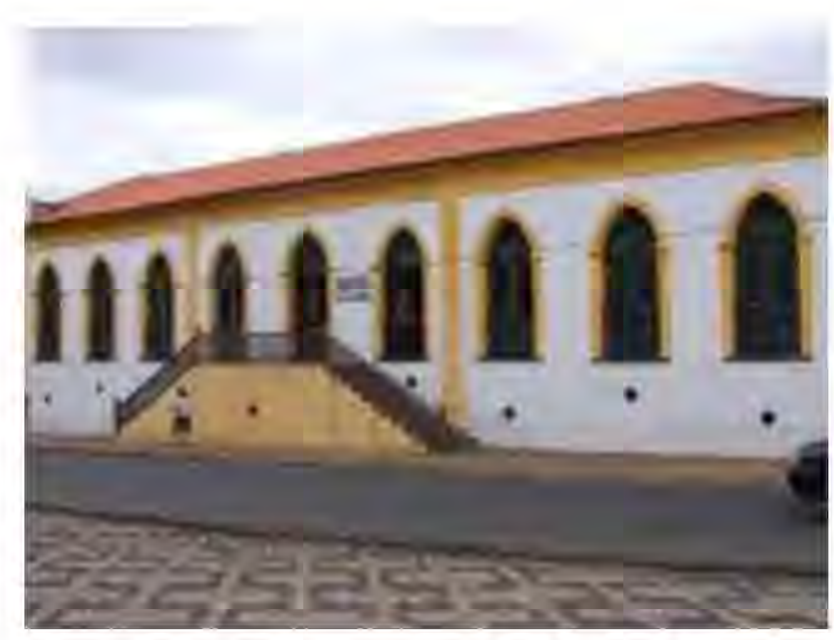

Figura 368: UFPI - Edifício do antigo Seminário Arquidiocesano de Teresina.

Atualmente funciona a Casa da Cultura da capital. 0 edifício abrigou as primeiras atividades didáticas e administrativas da UFPI, em 1971. É considerado um belo exemplar da arquitetura eclética piauiense da segunda metade do século XIX, com aplicação das tradicionais ogivas nas portas e janelas.

(Fonte: disponivel em: <http://culturapiauiense.webnode.com.br/news/casa-da-cultura-de teresina/s. Acesso em: 20 jul. 2011).

Posteriormente, constatando-se as condições de funcionalidade inadequadas daquele edifício, a Universidade foi transferida para uma casa alugada situada também na área urbana da cidade ${ }^{129}$ até a mudança para o campus, o que só veio a ocorrer em fevereiro de 1973 , com a inauguração das primeiras edificações.

Oportuno contextualizar que nos anos de 1970 a cidade de Teresina vivenciava um incremento na produção de edifícios de referências modernas ${ }^{130}$, contrastando com os de linguagem eclética que até então eram predominantes (ver figuras 369 e 370). Constituiu

\footnotetext{
${ }^{128}$. O edifício foi construído entre 1870 e 1880 para fins residenciais. Segundo historiadores, além de residência, a casa serviu a outros fins até que em 1913 foi vendido para a Diocese de Teresina. Depois do Seminário, funcionou a sede do Departamento Nacional de Obras Contra as Secas (DNOCS) e posteriormente o Colégio Pedro II. Em 1994, após restauração, passou a sediar a Casa da Cultura (<Fonte:<http://culturapiauiense.webnode.com.br/news/casa-da-cultura-de-teresinal $>$. Acesso em: 20 jul. 2011).

${ }_{129}$ Segundo o Jornal do Piauí (Passos, 1985, p. 218), a Reitoria saiu do antigo prédio do Seminário Arquidiocesano de Teresina, onde funcionou desde sua instalação e foi para uma casa alugada na Rua Monsenhor Lopes.

${ }^{130}$ Exemplos de edifícios institucionais modernos, dentre outros, da década de 1970: o Ministério da Fazenda (projeto de 1970), de autoria do arquiteto Antônio Luiz Dutra de Araújo; o Fórum Judiciário (projeto de 1972), de autoria do arquiteto Acácio Gil Borsoi; o Instituto de Educação Antonino Freire (projeto de 1973), elaborado pelo arquiteto Antônio Luiz Dutra e o Centro Administrativo do Governo do Estado do Piauí (projeto de 1979), de autoria dos arquitetos Marcus Vinícius Rios Meyer, Mário Pinto de Barros, Raul de Largos Cirne e Raimundo Dias, sendo esse último destacado na publicação de Afonso e Negreiros (2010, p. 277) como uma produção referenciada nas experiências brutalistas que vinham se desenvolvendo em várias regiões do País.
} 
uma nova produção que sinalizava para as transformações urbanas que estavam ocorrendo naquela capital, da qual fez parte a produção arquitetônica desenvolvida para a UFPI.

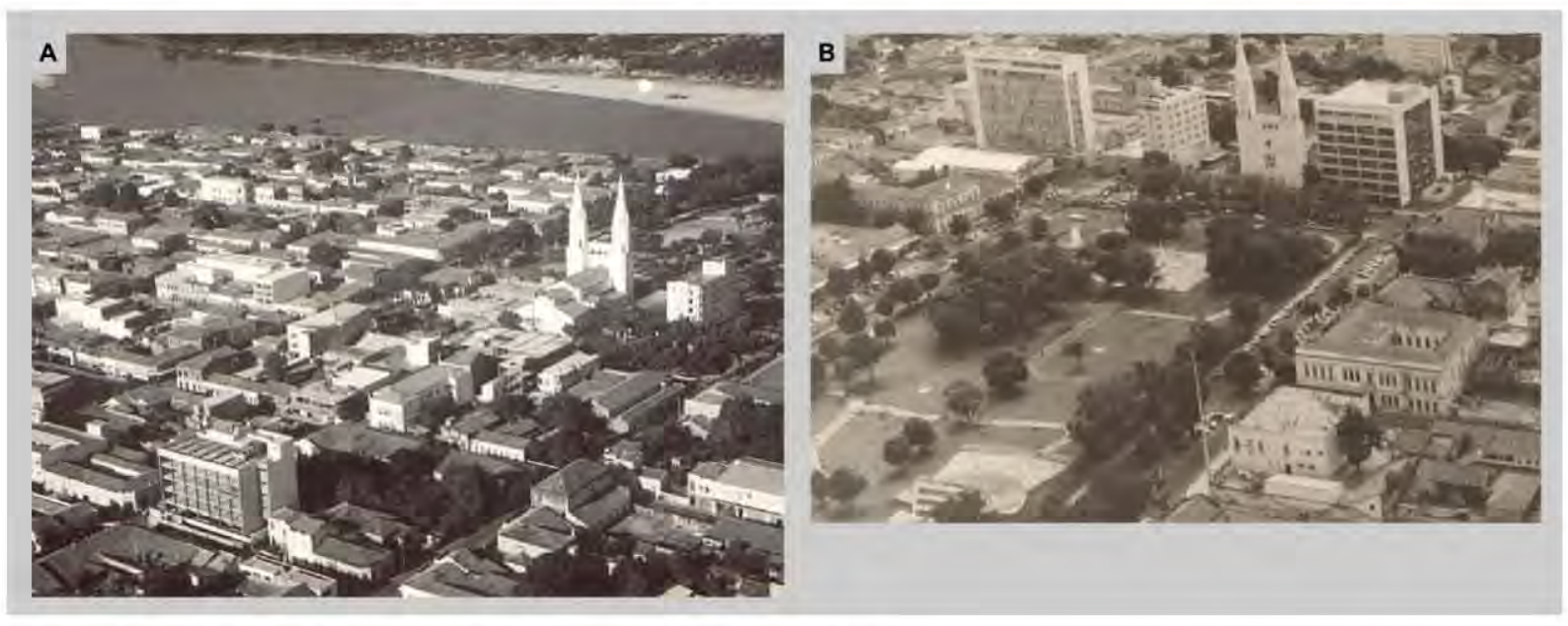

Figura 369: Vista da cidade de Teresina - década de 1960.

(A) Vista da cidade com a malha urbana de configuração reticulada e edifícios predominantemente horizontais.

(B) Vista da Praça Marechal Deodoro, no centro da cidade - década de 1970. Podemos visualizar edifícios de referências modernas em contraste com construções de linguagem eclética e neoclássica.

(Fonte: disponivel em <http://istoepiaui.blogspot.com/2011/02/fotos-antigas-do-piaui.htmll. Acesso em 19 jun. 2011)

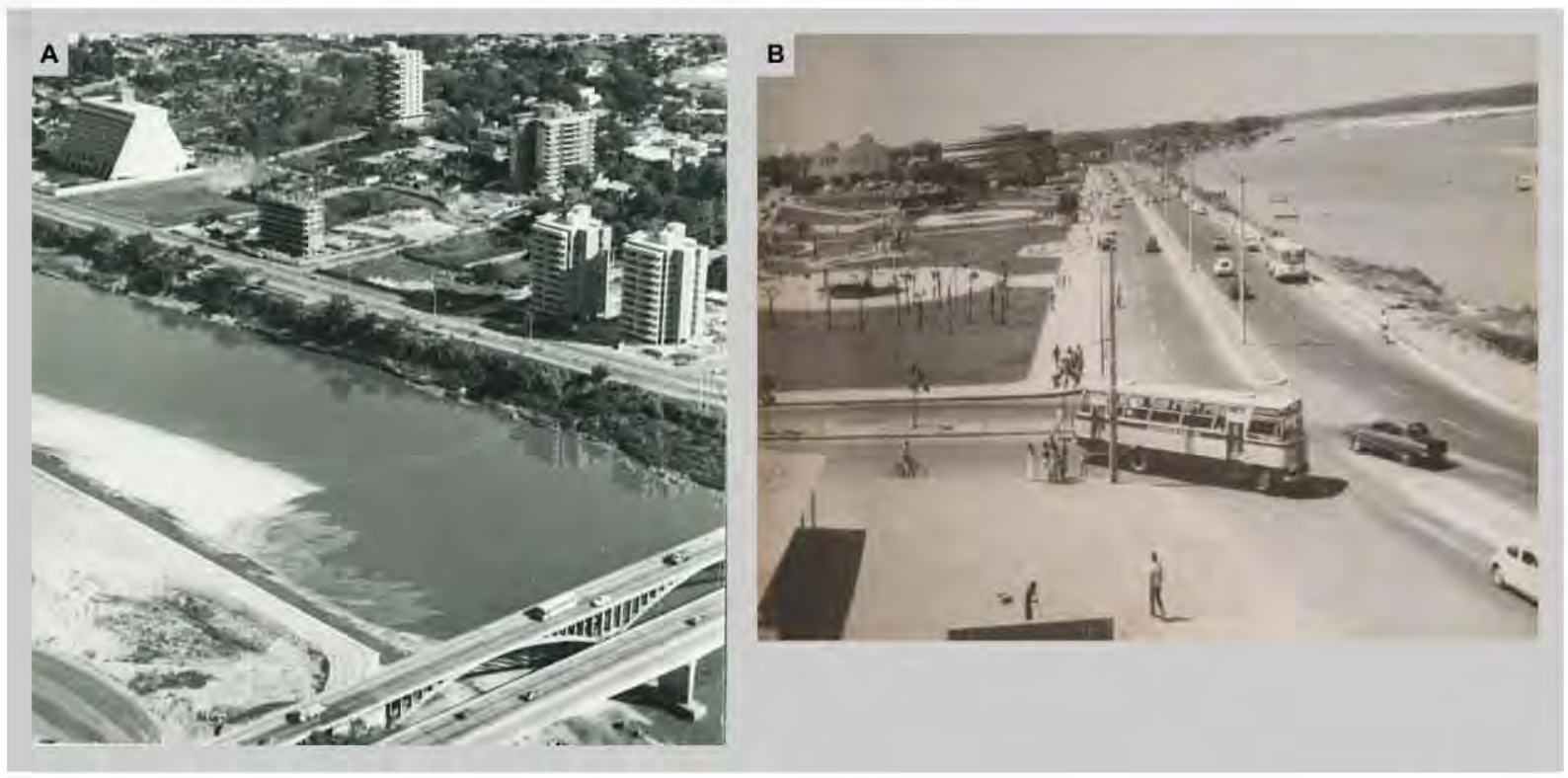

Figura 370: Vista da cidade de Teresina - década de 1970.

(A) Bairro llhotas, zona centro-leste da cidade - final da década de 1970.

Início da verticalização com edifícios para fins residenciais e hotelaria, situados à margem do rio Poti, na Avenida Marechal Castelo Branco. No canto superior esquerdo, o Rio Poty Hotel, o primeiro cinco estrelas da capital e exemplar da arquitetura de linguagem moderna do Piauí.

(B) Vista da Avenida Maranhão - década de 1970.

Ao fundo, à esquerda, vista do edifício CEPISA - Companhia Elétrica do Piauí S/A, de características modernistas, projeto de 1972, do arquiteto Antônio Luiz Dutra de Araújo. (Fonte: disponivel em <http://istoepiaui.blogspot.com/2011/02/fotos-antigas-do-piaui.html>. Acesso em: 19 jun. 2011). 
O início das obras do campus se deu efetivamente em 1971, com a nomeação do professor Hélcio Ulhôa Saraiva, reitor pro tempore, que veio da UnB para cuidar da instalação da Universidade, trabalhando ali durante três anos. Passos registra que o

[...] Reitor Hélcio Ulhôa Saraiva cuidou primeiro da instalação física da Universidade. Procurou, por um lado dar à Reitoria melhor infraestrutura, transferindo-a do prédio do antigo Seminário Arquidiocesano ${ }^{60}$ - de aluguel caro e péssimo estado de conservação e funcionalidade para as necessidades da nova instituição, onde tinha colocado o Reitor Robert Wall de Carvalho [primeiro reitor, que atuou nos primeiros três meses] -e, por outro, dar à Universidade instalação definitiva, definindo e adquirindo a área onde o Campus seria edificado (PASSOS, 1985, p. 218).

O gestor da Administração Superior constituiu a equipe de trabalho destinada à elaboração e coordenação dos projetos do campus com arquitetos convidados da Universidade de Brasília, já que não havia profissionais daquela área para atuar com tal finalidade. O grupo era ligado ao setor de planejamento físico da UnB - Centro de Planejamento Oscar Niemeyer (CEPLAN) $)^{131}$-, que deu suporte na elaboração dos primeiros trabalhos.

Oficialmente foi criada uma estrutura técnica e administrativa, que com o gradativo acréscimo de novas funções, abrangendo outras áreas de atuação, recebeu ao longo do seu funcionamento outros níveis no organograma, conforme a complexidade das funções desempenhadas. Essa nova estrutura operativa teve papel relevante na consolidação da estrutura física da UFPI.

De imediato, já em 1971, foi estruturada a Assessoria para Assuntos de Arquitetura e Urbanismo (AAUU). No ano seguinte, recebeu nova denominação, a de Assessoria Técnica de Engenharia, Arquitetura e Urbanismo (ATEAU) face às novas atividades que the foram conferidas. No final do mesmo ano, o conselho diretor da Fundação Universidade Federal do Piauí a transformou em Coordenação de Planejamento Físico (COPLAF) ${ }^{132}$, considerando a diversidade de atividades destinadas àquela assessoria. Posteriormente, em 1974, passou a ser Coordenação de Estudos e Projetos de Obras (CEPRO) ${ }^{133}$, constituída pelas Divisões de Projetos e de Obras. Em 1977, passou a atuar no nível de Diretoria de Projetos e Obras (DIPRO), com a estrutura formada pela Divisão de Projetos e Divisão de Obras $^{134}$ (FUPI/DIPRO, 1981, p. 1), que permanece na atual estrutura da UFPI.

\footnotetext{
${ }^{131}$ A Universidade de Brasília tem em sua estrutura administrativa o Centro de Planejamento Oscar Niemeyer (CEPLAN) que presta serviços de elaboração de planos, projetos e de consultoria técnica no âmbito de arquitetura e urbanismo e comunicação visual, tendo dentre seus objetivos o planejamento do campus.

${ }_{132}$ A Coordenação de Planejamento Físico (COPLAF) foi instituida através da resolução n ${ }^{\circ} 17 / 1972$, da FUPI, datada de 15 de novembro de 1972.

${ }^{133}$ A Coordenação de Estudos e Projetos de Obras foi instituida através da resolução ${ }^{0} 06 / 1974$, da Reitoria.

${ }^{134}$ A Diretoria de Projetos de Obras foi instituída através da resolução $n^{\circ} 065 / 1977$, da Reitoria.
} 
documento elaborado pela DIPRO para a comemoração dos dez anos de atividades daquele setor resumiu o início dos trabalhos no seguinte texto:

Com a criação da Fundação Universidade Federal do Piauí pela Lei $n^{0}$ 5.538 , de 12.11 .68 e a instalação da Universidade em 01.03.71, foi criada a Assessoria para Assuntos de Arquitetura e Urbanismo - AAUU, formada por técnicos da Universidade de Brasília, tendo como objetivo básico a execução do Plano Piloto da Universidade Federal do Piauí e adaptação de instalações provisórias, como as edificações das unidades isoladas de ensino superior existentes à época e o prédio recém-alugado do antigo Seminário de Teresina. Estes serviços foram iniciados no CEPLAN da Universidade de Brasília e concluídos em Teresina (FUPI/ DIPRO, 1981, p. 2).

A construção do território da UFPI não foi, entretanto, concentrada em um único lugar. Logo no início, em atendimento à política de interiorização adotada já nos primeiros dez anos de funcionamento, compôs sua base física em Teresina, com o Campus da Ininga e com a área do Socopo, situada na circunvizinhança, onde se instalou o Centro de Ciências Agrárias; com o Campus Ministro Reis Veloso, em Parnaíba, o de Irapuá, em Floriano, e o de Junco, em Picos.

O Campus da Ininga foi o primeiro a ser iniciado e sua organização espacial foi esboçada numa primeira proposta tão logo se definiu a área para sua implantação. Nós o selecionamos, dentre os demais, como objeto de investigação da pesquisa, pois foi o que recebeu os primeiros investimentos para a materialização do território da Reforma (1968).

Relevante assinalar que 0 desenvolvimento histórico que se seguirá sobre o desenvolvimento físico da UFPI tomou como principal referência o documento de autoria do setor técnico da DIPRO (FUFPI/DIPRO, 1981), já mencionado. Adotamos a configuração do seu texto que registra os projetos e obras desenvolvidos e executados respectivamente para a construção do campus da Ininga. Trata-se de um rico acervo sobre projetos, obras, licitações, planos e projetos econômicos realizados para a concretização da estrutura física da UFPI.

\subsection{CAMPUS DA ININGA: o território da Reforma}

Os primeiros trabalhos para escolha do local para sediar o campus tinham como intenção inicial situá-lo no bairro Socopo ${ }^{135}$, em uma faixa de terra doada pelo governo do Estado.

${ }_{135} \mathrm{O}$ primeiro reitor foi o professor Roberto Wall de Carvalho, da Faculdade de Direito do Piauí. Ele solicitou ao governador João Clímaco D'Almeida a doação de uma área no bairro Socopo que, por sua vez, enviou mensagem à Assembleia 
Entretanto, por questões que não foram esclarecidas o campus não foi ali instalado ${ }^{136}$. Coube então à Assessoria para Assuntos de Arquitetura e Urbanismo a escolha da área, tendo sido indicada a da Ininga, após estudos realizados pelos arquitetos da UnB.

Tratava-se de um terreno em subúrbio, na periferia de Teresina, localizado externamente ao rio Poti, inscrito numa grande curva definida pelo seu leito, contrapondo-se à zona mais antiga e densa da capital, que está circunscrita à bacia hidrográfica do rio Parnaíba (ver figura 371 ).

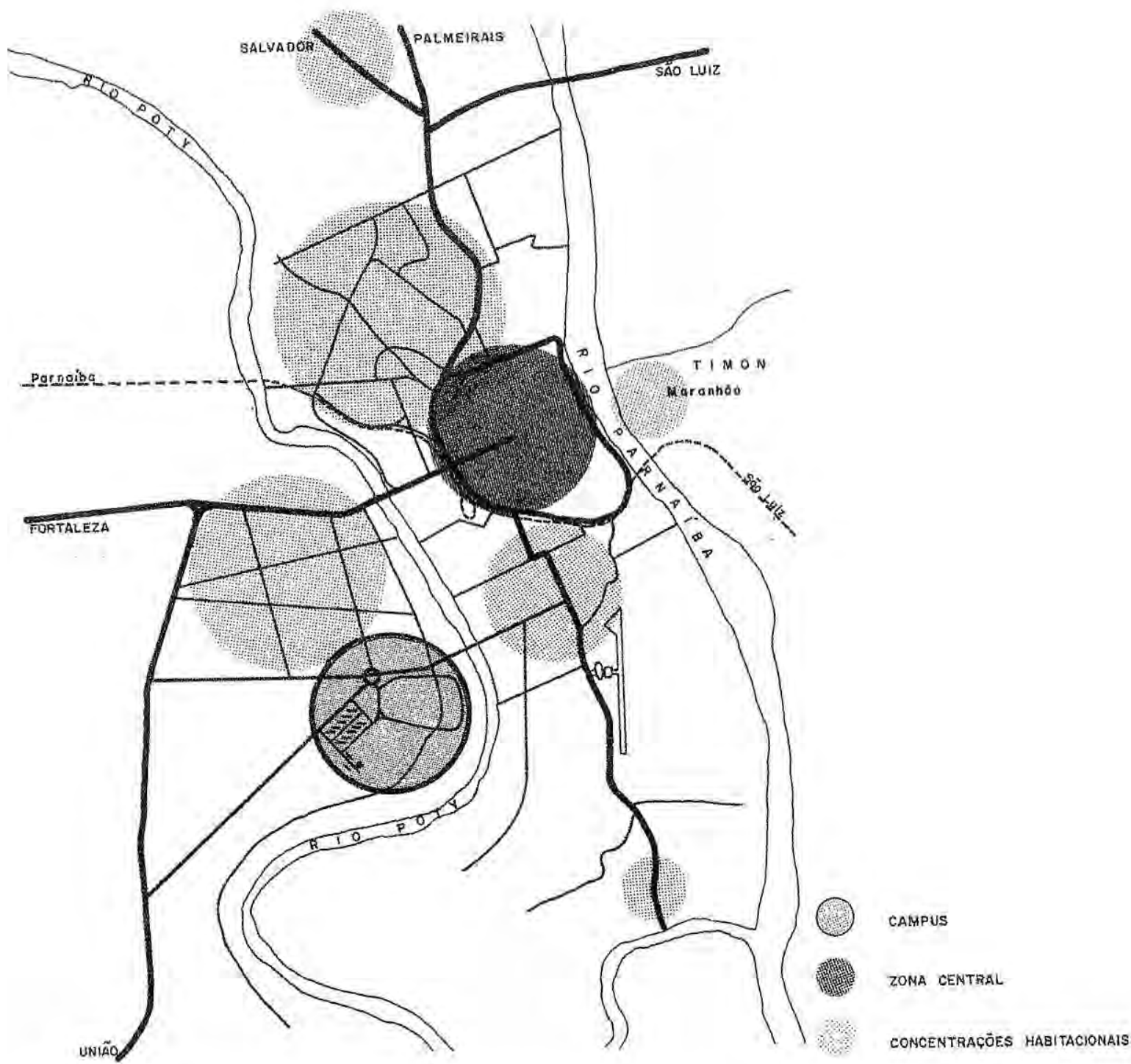

Figura 371: UFPI - Mapa esquemático da localização do Campus da Ininga, na cidade de Teresina. (Fonte: FUFPI/CEPRO, 1977, p. 6)

Legislativa, a ser tramitada em regime de urgência, solicitando aprovação para ceder, naquele bairro, um terreno na região do Gurupá.

${ }^{136}$ Sobre essa questão ver PASSOS (1985, p. 218). 
Sobre essa localização, a Coordenação de Estudos e Projetos de Obras (CEPRO) assim justificou:

[...] se a tendência natural da ocupação de Teresina era o crescimento para o sul; a eleição desta área como setor industrial fez com que a população de maior nível econômico transpusesse desordenada e intensamente o rio Poti, apressando a definição da zona habitacional que se processava vagarosamente.

Baseado certamente neste diagnóstico se decidiu pela implantação do Campus de forma a reforçar esta situação. Se a área em que está localizado não é equidistante às massas de população mais significativas da capital, a sua proximidade - cerca de $6 \mathrm{~km}$ - com o centro comercial e político de Teresina, de certa forma justifica e não o compromete (FUFPI/CEPRO, 1977, p. 6).

O terreno selecionado não possuía qualquer infraestrutura e era ocupado por áreas de cultivo rudimentar e vegetação abundante, cujo acesso se dava por meio de uma ponte de pequeno porte. Possivelmente o vetor de crescimento da cidade indicado para aquela direção, somado às condições da natureza local ainda intocada, tenham contribuído para aquela escolha, muito embora acreditemos que as questões econômicas tenham prevalecido já que se tratava, naquele momento, de uma área limítrofe de Teresina, tornando atraentes os custos de desapropriação.

O Estado comprou e doou o terreno, onde foi implantado o campus da Ininga, cujo nome referenciava a denominação secular do planalto da Ininga, onde o mesmo se localiza. A aquisição da gleba não foi, contudo, um processo tranquilo. As notícias sobre os procedimentos de avaliação para efeito de desapropriação acarretaram a especulação imobiliária por parte dos proprietários de terrenos na área escolhida (PASSOS, 1985, p. 219). Tal fato inviabilizou a desapropriação nas dimensões pretendidas pelo governo do Estado, que girava em torno de 266 ha, para a qual foi elaborado o primeiro plano físico. Não há registros acerca de estudos para a definição da área pretendida. $O$ arquiteto Ronaldo Pinto Marques, um dos autores do plano, levantou a hipótese de ter sido uma decisão aleatória do governo estadual ${ }^{137}$.

Em 1976, com a decisão do governo de não dar prosseguimento às desapropriações nos valores iniciais pretendidos, foi elaborado um segundo plano com base na área adquirida de 151 ha, conforme será detalhado no decorrer do capítulo.

\footnotetext{
${ }^{197}$ Entrevista concedida em outubro de 2009 pelo arquiteto Ronaldo Pinto Marques, professor aposentado da UFPI, formado na
} UnB, em 1967 


\section{- PLANEJAMENTO DO CAMPUS: Plano Piloto de 1971}

Considerando a perspectiva de aquisição da área inicial estimada (266 ha), foi apresentado em 29 de julho de 1971, um documento a ser encaminhado ao MEC, que se constituiu em um esboço para o Plano Piloto do Campus da Universidade Federal do Piaú, elaborado pelos arquitetos ${ }^{138}$ da AAUU que ainda estavam sob a coordenação do CEPLAN - UnB.

A proposta delineou os princípios norteadores da concepção urbanística e do desenho do campus, assim como as estratégias para sua inserção na trama urbana da cidade e o estudo do partido arquitetônico dos edifícios. A organização espacial era definida pelo zoneamento dos setores afins, cuja proposta urbanística resultou em um desenho que se destacava pela geometria circular do sistema viário que contorna a área central do futuro campus (ver figura 372).

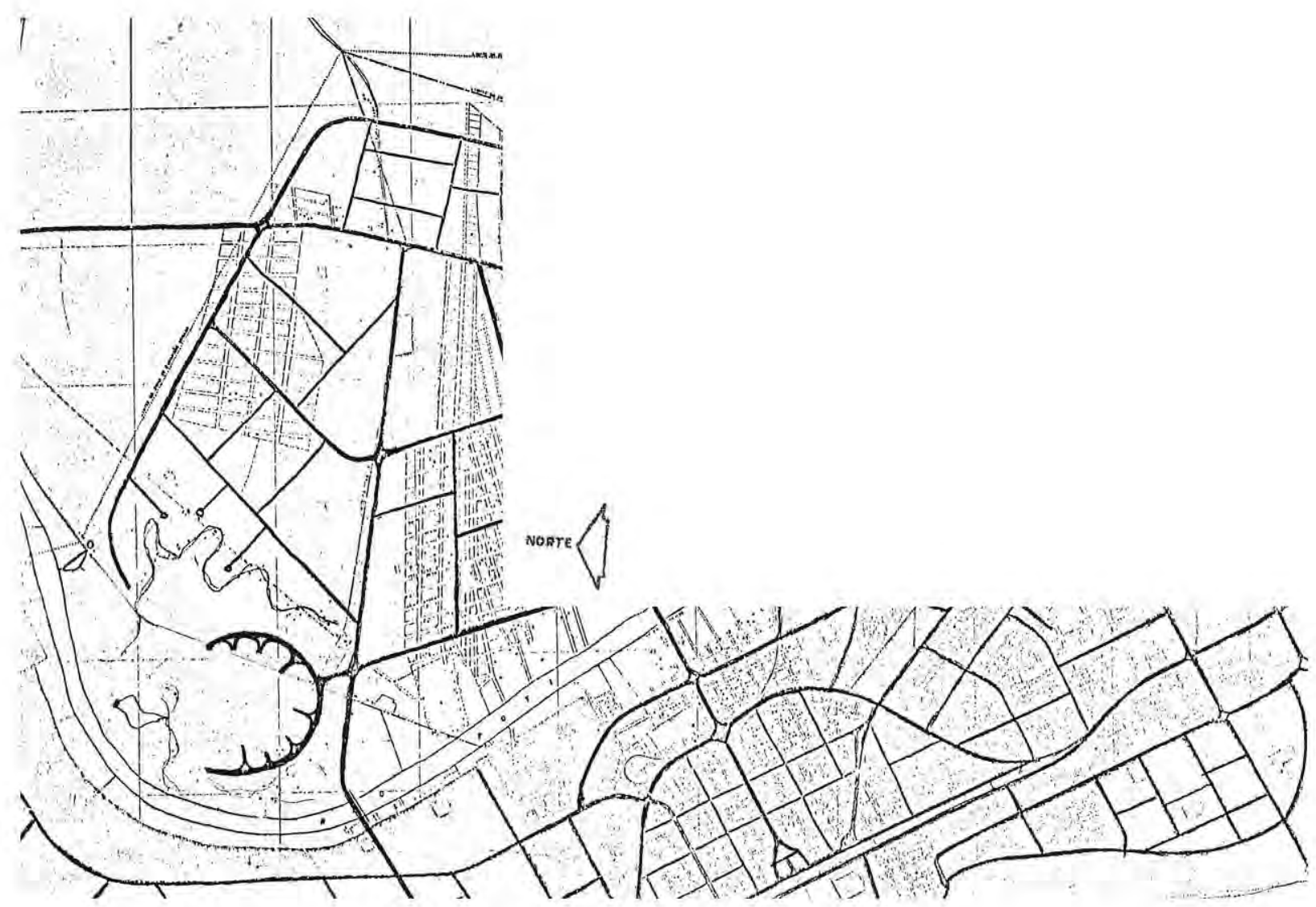

Figura 372: UFPI - Mapa esquemático da relação campus $x$ cidade.

O plano piloto propôs um desenho semicircular (canto inferior esquerdo) definido pelo sistema viário.

(Fonte: FUFPI, 1971, n.p.) ${ }^{138}$ Participaram da elaboração daquele documento os arquitetos da UnB, membros da então Assessoria para Assuntos de
Arquitetura e Urbanismo, Ronaldo Pinto Marques, Lourival Machado Rezende e Vasco de Melo. 
O programa de necessidades que deu sustentação ao plano era composto pelos seguintes setores: didático-científico - com áreas de Ciência e Tecnologia e de Artes e Humanidades; comunitário; administrativo - reitoria; esportivo; de serviços gerais; e habitacional (ver figura 373).

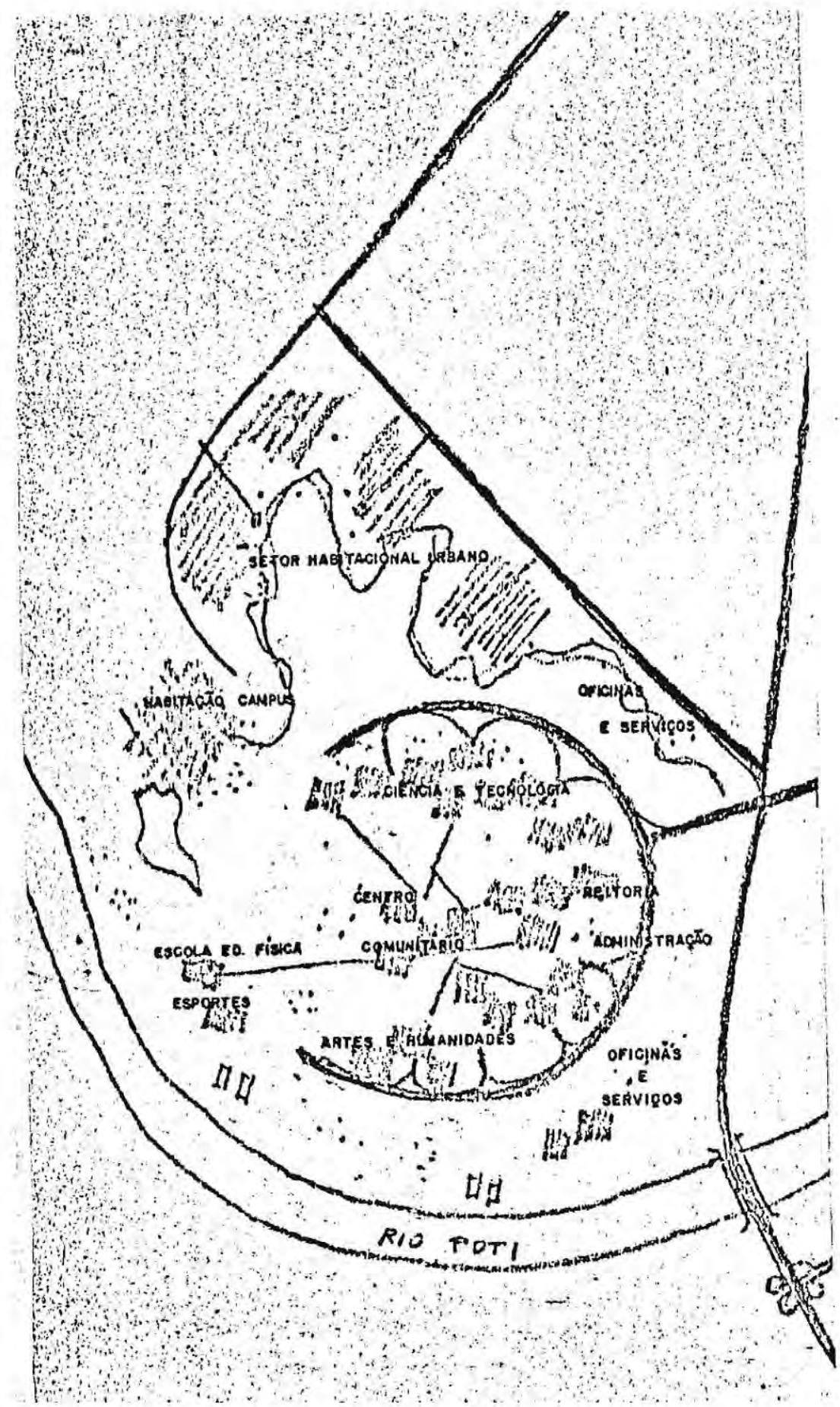

Figura 373: UFPI - Ilustração do campus com a distribuição dos setores funcionais. No centro do anel viário ficavam os setores didático-científico, comunitário e administrativo. Externamente ao anel viário, localizavamse o setor esportivo, o de serviços gerais e o habitacional. (Fonte: FUFPI, 1971, n.p.) 
Os recursos naturais também faziam parte do programa: zonas de vegetação, denominadas de "bosque", e os lagos. Os elementos do programa alinhavam-se com a orientação do Manual de Atcon (1970), que indicava a organização do campus pela distribuição das áreas acadêmico-científicas, administrativas e de serviços, organizadas pelo princípio do zoneamento funcional.

Do programa acadêmico, o primeiro Centro criado foi o de Ciências da Educação, considerado uma prioridade pela Universidade para a formação de professores do segundo grau e que absorveu vários professores da Faculdade de Filosofia ${ }^{139}$. O segundo foi o Centro de Ciências da Natureza para graduar professores nas áreas de física, química, matemática e biologia. Outra prioridade foi o setor esportivo, destinado à formação de professores de educação física.

\section{- Princípios norteadores}

A memória descritiva do Plano justificava que o princípio básico do estudo foi com a preocupação de criar um espaço organizado de modo harmônico, agradável e convidativo à especulação intelectual (FUFPI, 1971, não paginado). Com este objetivo, o Plano pontuou as diretrizes norteadoras da proposta:

1. Concentração, de modo a favorecer o convívio e o relacionamento das pessoas e a utilização racional e lógica do equipamento universitário.

A filosofia do convívio novamente é apontada como objetivo a ser alcançado, articulado agora com a idéia de racionalização no uso e ocupação dos espaços. A diretriz sugeria que fosse eliminado o desperdício de áreas, atendendo ao princípio da economicidade.

2. Relação veículo/pedestre: criar circulação independente para o uso de veículos e pedestres, de maneira natural e coerente, articulando e integrando os diversos setores, permitindo o uso integral do chão pelo pedestre.

A hierarquização das vias de circulação exaltava a presença do pedestre, sugerindo um desenho que garantisse 0 aproveitamento racional das vias de ligação entre os setores. Com esse propósito, propunha:

- Aos veículos: o anel periférico, que deveria ser ajustado à topografia local e que tivesse a função de tronco distribuidor de veículos, para permitir as ligações necessárias aos diversos setores da universidade (FUFPI, 1971, não paginado).

- Aos pedestres: propunha subanéis com diâmetro da ordem de $1 \mathrm{~km}$, envolvidos pelo anel periférico e cuja dimensão baseava-se na escala do homem a pé. Dentro desses anéis o plano sugeria que ali se daria a circulação, o convívio, o encontro natural e fecundo dos

${ }^{139}$ Informação fornecida pelo arquiteto Ronaldo Pinto Marques em entrevista concedida em outubro de 2009. 
habitantes do campus (ver figura 374). Para os autores, aí o homem da universidade realmente encontraria o seu ambiente.

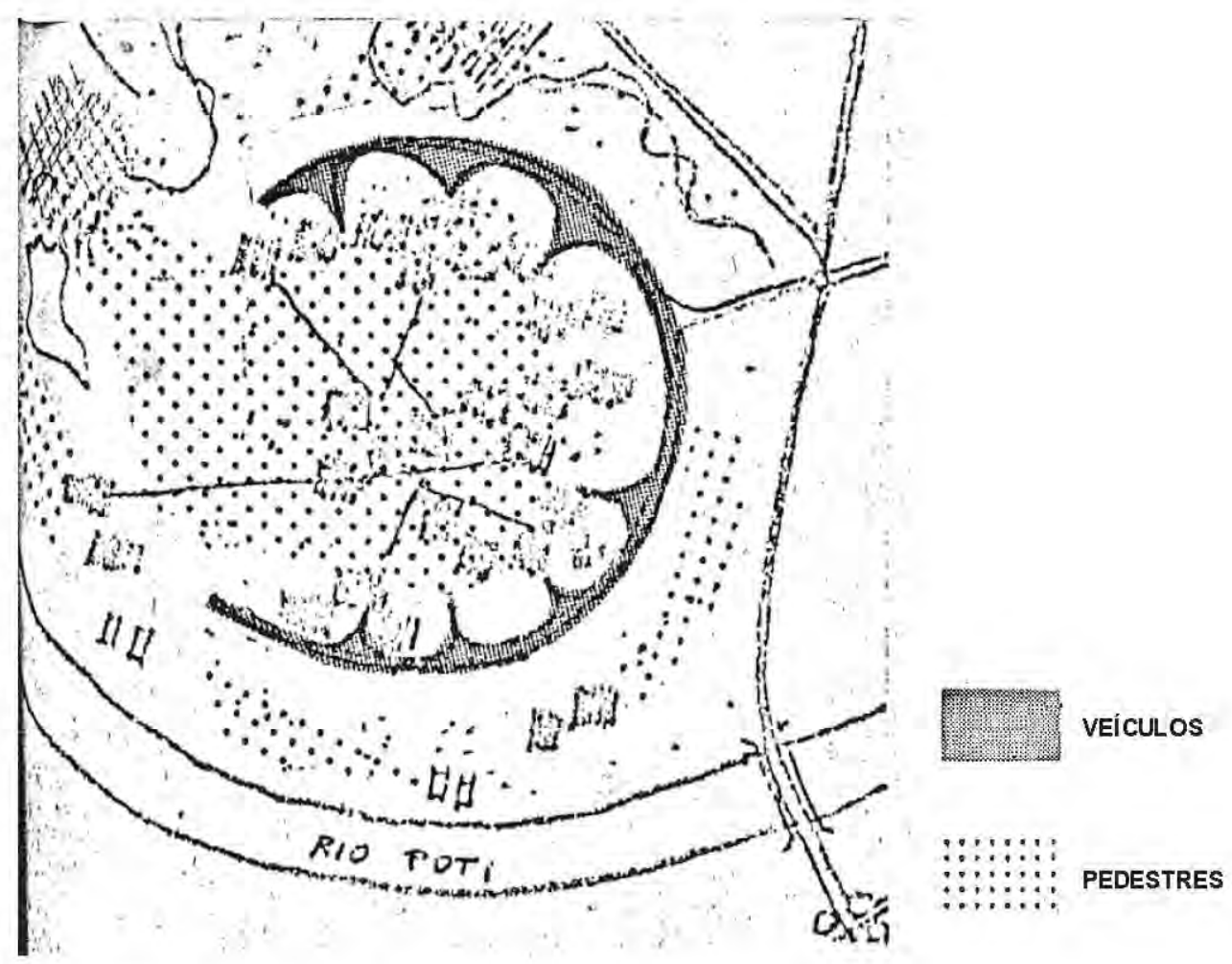

Figura 374: UFPI - Ilustração do sistema viário.

Era constituído pelo anel periférico semicircular, destinado aos veículos e acesso aos bolsões de estacionamento, separado das áreas de pedestres.

(Fonte: FUFPI, 1971, não paginado)

\section{Articulação e integração dos setores}

Novamente o plano incorpora os aspectos da integração. Acrescenta ainda que o campus deveria apresentar unidade, em qualquer etapa da construção. Com esses objetivos o desenho proposto organiza os setores por meio de um subzoneamento, que se articula criando o macrozoneamento do campus (ver figura 375):

- A reitoria, os órgãos colegiados e demais órgãos administrativos e deliberativos situavamse no primeiro semicírculo.

- A noroeste, estavam os setores de ensino e pesquisa ligados à área de artes e humanidades.

- A nordeste, os relativos à ciência e tecnologia.

- No seu interior, o centro comunitário, a biblioteca, o restaurante, os diretórios, as associações de professores e funcionários, o grande auditório da universidade. 
- Saindo do semianel, debruçados sobre o Rio Poti, mas integrados ao todo, o setor esportivo e a Escola de Educação Física entendidos como prática esportiva, recreação, competição e cultura.

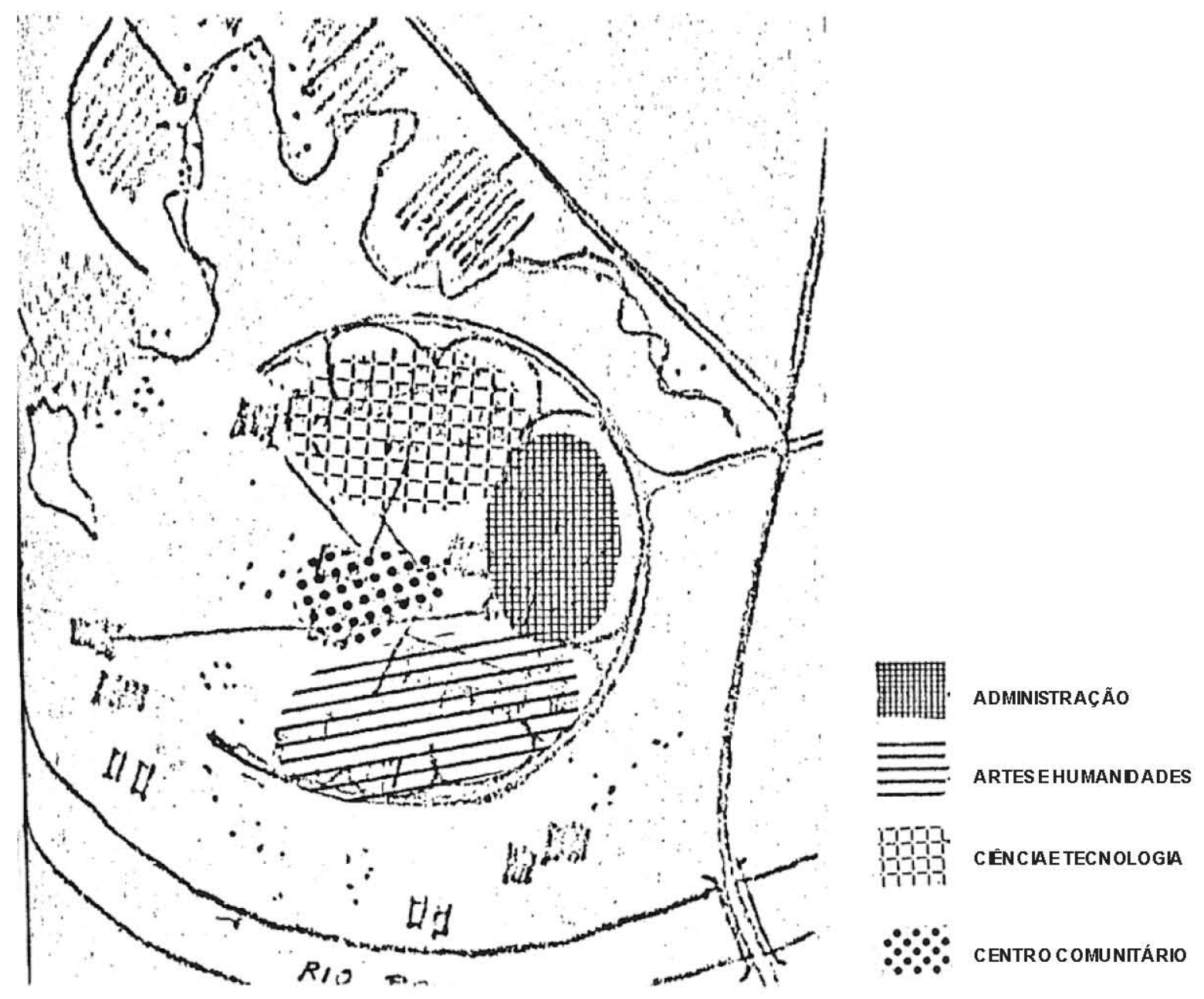

Figura 375: UFPI - Ilustração do zoneamento.

O anel semicircular articulava os setores criando unidade e integração.

(Fonte: FUFPI, 1971, não paginado)

4. Serviços gerais, as oficinas, os setores barulhentos da universidade, ficavam no lado externo do anel, mantendo as relações naturais e necessárias com o interior

5. Habitação no campus

O plano prevê um setor habitacional a ser implantado quando da expansão da universidade, destinado prioritariamente aos alunos, professores e funcionários vindos do interior do Estado. Depois de atendidos esses grupos, esse setor poderia receber moradores de outras cidades (ver figura 376). 
6. Implantação e expansão.

O campus se implantará por etapa de acordo com as necessidades e o crescimento da universidade, apresentando em qualquer etapa um todo harmônico e coerente.
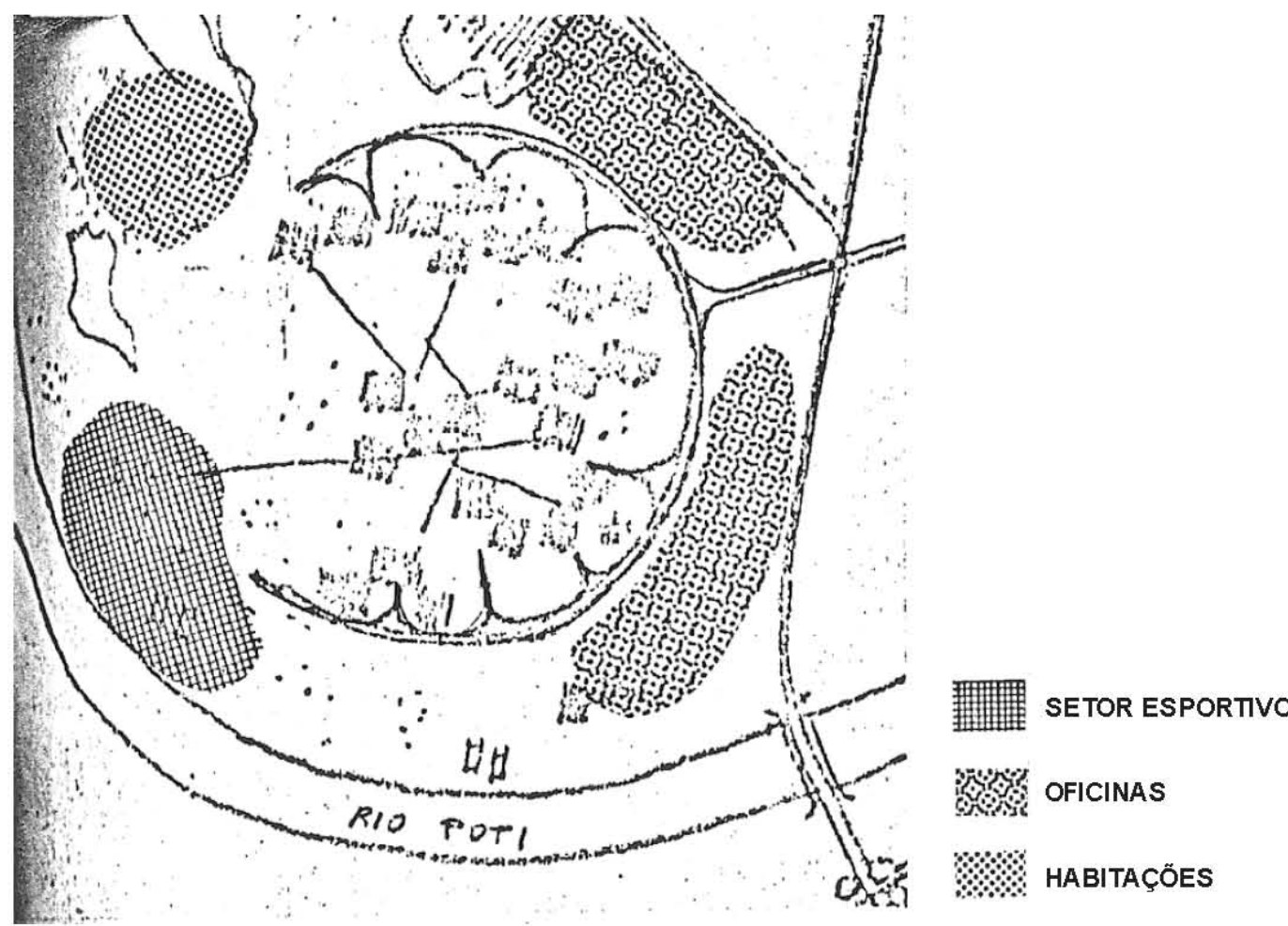

Figura 376: UFPI - Ilustração dos setores funcionais.

Externamente ao anel semicircular seriam implantados os setores esportivo, de serviços gerais e de habitação no campus.

(Fonte: FUFPI, 1971, n.p.)

A primeira etapa se destinaria às necessidades estabelecidas como imediatas e atenderia ao corpo discente, estimado em 2.000 alunos. Com base nessas definições, a implantação se iniciaria a partir do primeiro semicírculo, onde se localizariam a administração, reitoria, órgãos colegiados, biblioteca provisória, a noroeste ficariam os setores de artes e humanidades e a nordeste os de ciência e tecnologia (ver figura 377 ).

A expansão da área de artes e humanidades se daria no sentido nordeste e o setor administrativo e deliberativo se adensaria, pois entendiam os autores que seu crescimento físico era proporcionalmente menor do que os de ensino e pesquisa. 


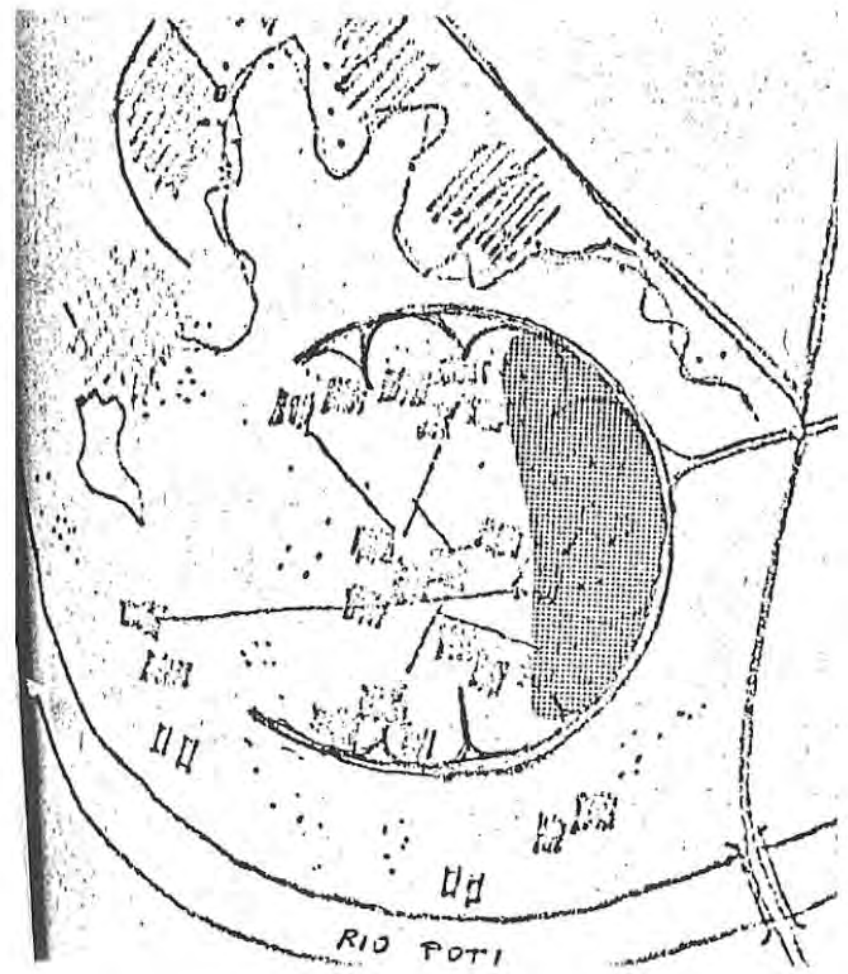

Figura 377: UFPI - A primeira etapa de implantação se daria no primeiro semicírculo. (Fonte: FUFPI, 1971, n.p.)

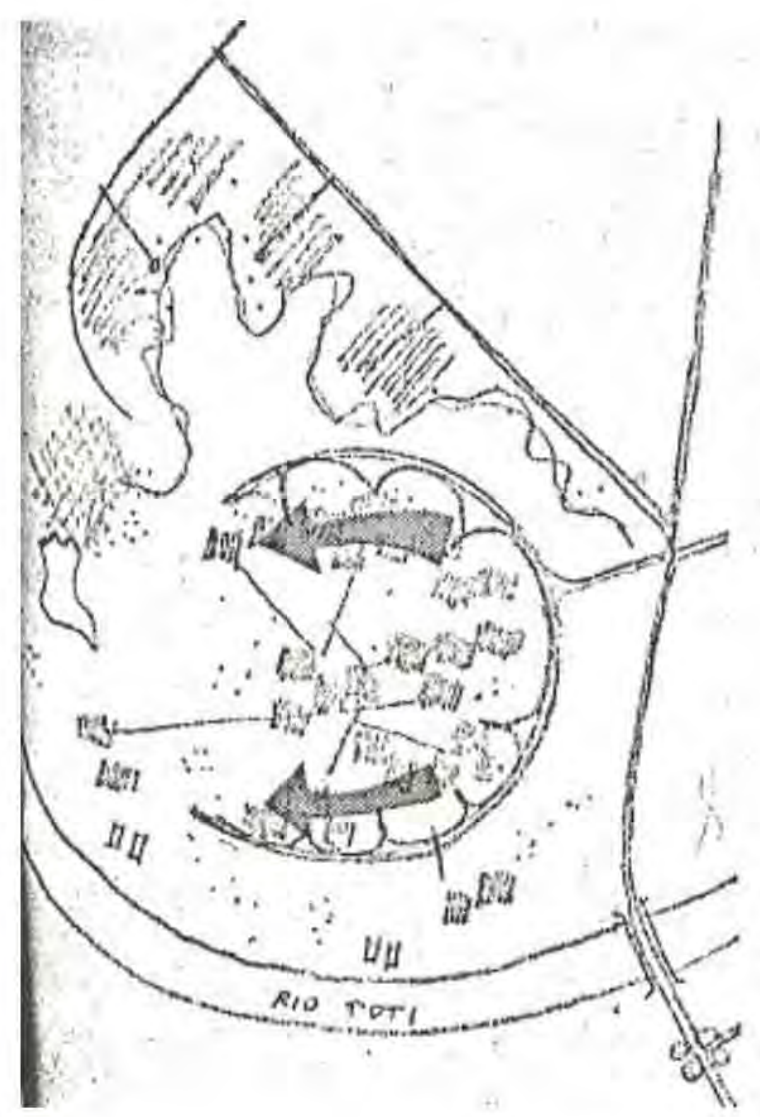

Figura 378: UFPI - Movimento de expansão das áreas internas ao anel semicircular. (Fonte: FUFPI, 1971, n.p.) 


\section{- A relação campus/cidade}

No estudo das relações do campus com a cidade, o plano evoca os benefícios a serem trazidos com o novo território. Nas palavras dos autores:

\section{Vemos no Campus um modo de vida urbano, favorecendo o encontro de indivíduos e grupos, as descobertas interpessoais, as trocas, a efervescência e burburinho criadores, a irradiação da cultura (FUFPI, 1971, não paginado).}

Destaca ainda que o campus da Universidade Federal do Piauí apresentava uma localização privilegiada e se constituiria num polo importante da cultura. Dois pontos nos chamam a atenção:

1. A convicção do poder de transformação na vida social da população, associada a uma nova crença na missão da instituição universitária. É perceptível que o plano ensejava o compromisso da universidade de não apenas formar profissionais para o mercado, mas também favorecer o desenvolvimento de um novo cidadão piauiense voltado ao interesse pela cultura.

2. A localização destacada como privilegiada toma, provavelmente, como referência a sua situação à margem direita do Rio Poti e os fatores climatológicos favoráveis, por se tratar de uma área livre de edificações que permitiria trabalhar a orientação dos edifícios para melhor aproveitamento da ventilação e controle da radiação solar. O terreno se apresentava, entretanto, bastante permeável, com faixas de potencial alagadiço, decorrente do transbordamento das águas do Rio Poti, no período chuvoso (FUFPI/CEPRO, 1977, p.11).

Outra ressalva importante é que a localização periférica tornava o campus dependente de intervenções no sistema de circulação da cidade para promover a sua inserção na trama urbana. Para tanto estimava uma ação articulada com a criação da Avenida Beira-Rio e do centro cívico. Propõe uma nova ponte sobre o Rio Poti, a ser implantada a médio prazo, que interligaria os dois setores da cidade: o campus criando uma avenida direta ao aeroporto, vinculada à Beira-Rio, ao centro cívico, e a áreas de interesse público (FUFPI, 1971, não paginado).

Propõe ainda a criação de um parque junto ao sanatório onde se pudesse encontrar paz e quietude, preservando o verde, os pulmões da cidade (FUFPI, 1971, não paginado); e de um setor habitacional da cidade, circundando o campus a leste e integrado à sua área verde. O conjunto edificado deveria adotar características próprias e influenciadas pelo campus (ver figura 379). 


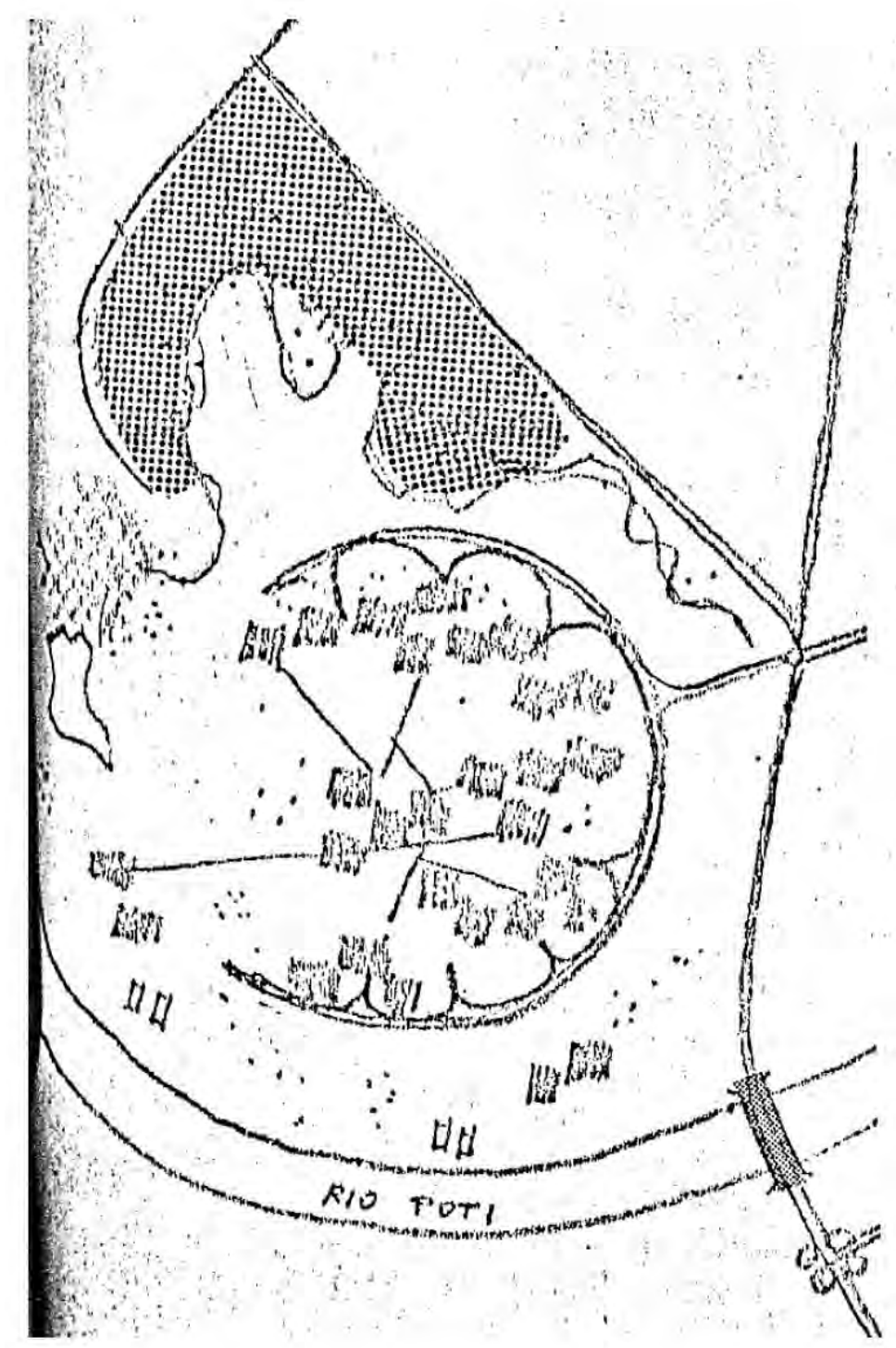

PONTE SOBRE O RIO POTY SETOR HABITACIONAL

Figura 379: UFPI - Proposta para a construção de uma nova ponte ligando o campus à cidade e a construção de um setor habitacional. O estudo previu uma nova ponte sobre o Rio Poti. (Fonte: FUFPI, 1971, n.p.)

Segundo depoimento do arquiteto Ronaldo Pinto Marques, as interligações propostas com a cidade encontravam obstáculos, pois o Estado e a prefeitura municipal não tinham em seus quadros técnicos profissionais de engenharia e arquitetura para elaborar os projetos pertinentes. Para resolver o impasse, a FUFPI, no decorrer de 1972, firmou convênio com ambos os setores, propondo-se a executar os projetos técnicos, por meio de sua assessoria técnica. Foram executados os seguintes projetos:

1. Com o governo estadual - levantamento de dados para a criação do centro administrativo e a execução do seu anteprojeto (no local onde hoje se encontra o Tribunal de Justiça e o Centro de Convenções). 
2. Com a prefeitura municipal - replanejamento do traçado urbano de Teresina; estudos viários para a Ponte do Ininga, Ponte do Contorno Rodoviário, Contorno Rodoviário, avenidas Petrônio Portela, Maranhão e Castelo Branco, bem como inúmeros logradouros públicos.

O arquiteto explicou que houve entendimento por parte das duas instituições de que o campus seria contemplado com um novo acesso, através da Avenida Nossa Senhora de Fátima, no traçado viário proposto.

\section{- Partido arquitetônico}

Para a arquitetura do campus, o plano destaca a importância de um projeto adequado às condições climáticas e aos recursos naturais e humanos da região (FUFPI, 1971, não paginado). Numa linguagem quase poética os autores expressam suas intenções:

Pensamos uma grande sombra, conseguida pela justaposição de abóbadas de tijolo, como cobertura, com estrutura independente. Essa sombra abrigará, em um ou dois pisos, as salas de aula, os laboratórios, os auditórios, a administração, etc.

O último piso se transformará, às vezes, em um terraço amplo e agradável, proporcionando o conforto ambiental desejado e conseguido pela sombra e orientação das abóbadas no sentido dos ventos dominantes.

Haverá sempre, nos edifícios do Campus, uma ventilação cruzada, proporcionando um microclima ameno, independente do uso de arcondicionado (croquis).

A paisagem local será preservada, num jogo interessante entre o babaçual e as abóbadas (croquis).

O partido arquitetônico será o mesmo em todo o Campus, com variadas e ricas possibilidades de organização do espaço (FUFPI, 1971, não paginado).

As estratégias de conforto ambiental são destacadas pelo uso da sombra, do terraço, da ventilação cruzada e da paisagem local, que estão em sintonia com um partido arquitetônico que busca amenizar os rigores climáticos daquela região, que se situa na área de transição entre a Amazônia úmida enflorestada e o sertão, de clima semiárido e de vegetação xerófila (FUPI-CEPRO, 1977, p.9). Localizado em plena faixa equatorial, inclui-se entre as áreas mais quentes do $\mathrm{Brasil}^{140}$.

\footnotetext{
${ }^{140} \mathrm{~A}$ cidade de Teresina apresenta uma temperatura que se caracteriza pelo nivel elevado em que se mantem o ano todo, estando suas médias mensais sempre acima de $25^{\circ}$. No decorrer de seu médio período seco, as máximas são habitualmente superiores a $35^{\circ}$, sendo que nos meses de setembro, outubro e novembro a própria média das máximas supera este índice, e
} 
Outro aspecto importante indicado é a intenção da padronização construtiva, que permitiria sua repetição em diferentes arranjos, apontando a racionalidade e economicidade.

O uso de abóbadas é indicado como solução construtiva e estrutural para a coberta que projeta o grande sombreado (FUFPI, 1971, não paginado). É adotada a abóbada de tijolo, segundo tecnologia desenvolvida pelos engenheiros Eládio Dieste e Enrique Montañez, oriundos da cidade de Montevidéu, no Uruguai. Complementando a solução construtiva, os pisos intermediários seriam em estrutura independente e as divisórias em alvenaria de tijolo (ver figura 380 ). Justifica o plano que

O tijolo abundante na região, a mão de obra fácil e disponível e a vantagem de introduzir uma tecnologia nova e coerente com o material existente, foram pontos importantes nessa adoção (FUFPI, 1971, não paginado).

Enfatiza ainda que o custo da construção proposta seria menor do que o obtido pela utilização do concreto ou do aço.

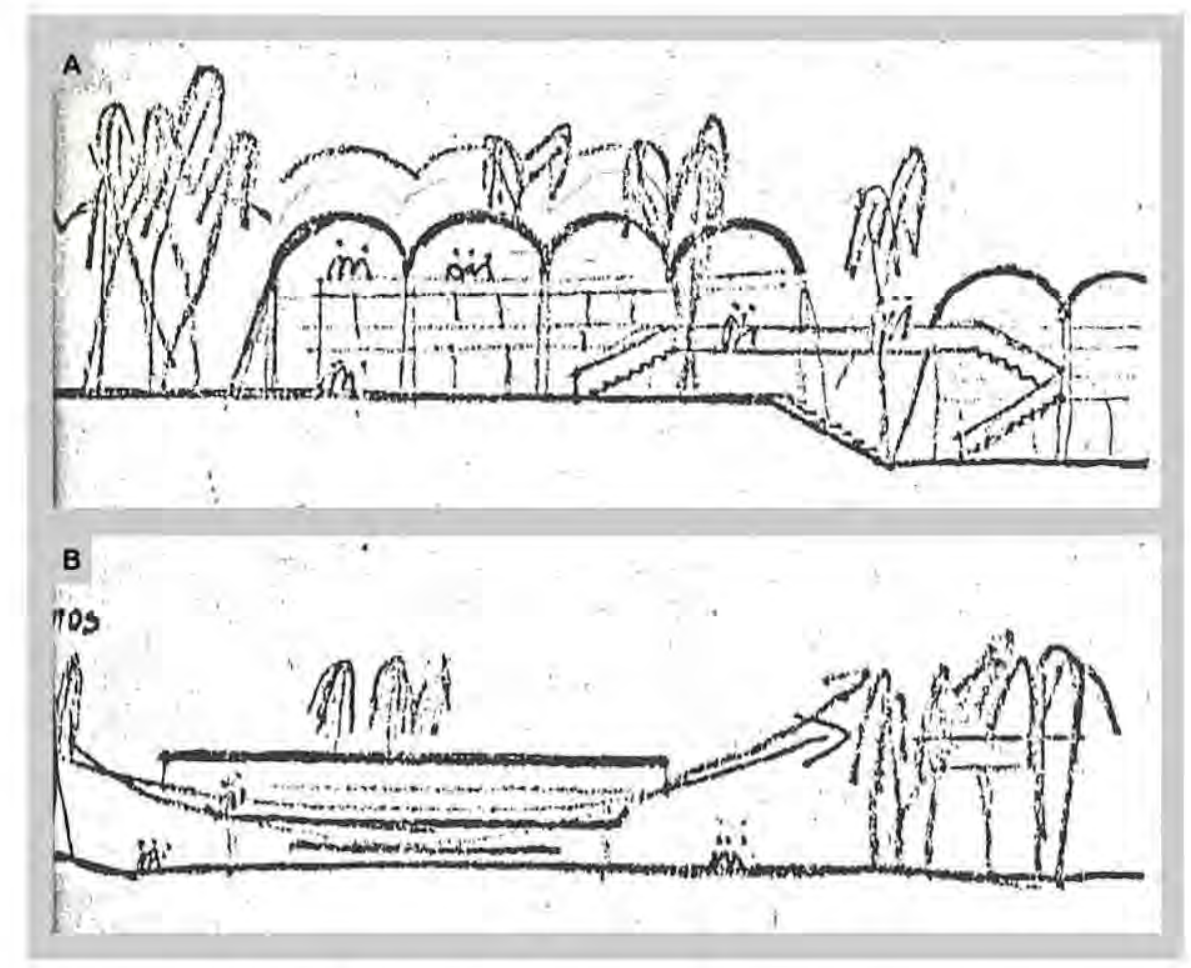

Figura 380: UFPI - Ilustração das estratégias de conforto térmico.

(A) O partido adotado previu estrutura independente, coberta de abóbadas de tijolo, pavimentos em níveis variados, articulados por escadas e circulações abertas.

(B) A ventilação cruzada era favorecida pela solução arquitetônica adotada.

(Fonte: FUFPI, 1971, n.p.)

os extremos se aproximam dos $40^{\circ}$. A quarenta e dois graus de longitude oeste, no Vale do Parnaíba, a capital piauiense situase na faixa limítrofe entre a umidade permanentemente elevada do Alto Amazonas e o sertão semiárido do Nordeste Oriental (FUFPI.CEPRO, 1977, p.12). 
Embora o plano não faça referência ao aspecto da flexibilidade, é oportuno avaliar que o uso de divisórias em alvenaria de tijolo determina limitações na possibilidade de novos arranjos espaciais, uma vez que o custo de demolição e remanejamento das instalações prediais torna o processo oneroso à adequação de novas necessidades.

O plano finaliza reafirmando a convicção na transformação social e cultural da cidade e da região pela universidade, destacando que também a arquitetura e o urbanismo tinham um papel a desempenhar naquela missão. Nas palavras dos autores:

A Universidade influenciará decisivamente o modo de vida urbano de Teresina, tendo ela própria, seu modo de vida urbano, interinfluindo e interagindo na região, absorvendo, criando e irradiando cultura, até mesmo pela sua arquitetura e urbanismo (FUFPI, 1971, não paginado).

Com o plano piloto aprovado, deu-se prosseguimento aos projetos executivos, que se iniciaram com a fixação da AAUU em Teresina, até então vinculada ao CEPLAN/UnB. Formou-se uma estrutura composta por arquitetos, engenheiros e desenhistas, ligada diretamente ao gabinete do reitor, com a denominação de Assessoria Técnica de Engenharia, Arquitetura e Urbanismo (ATEAU) ${ }^{141}$.

\section{- PLANO DIRETOR: primeira proposta de 1972}

A configuração urbanística adotada no Plano Diretor, concluído em meados de 1972 , manteve a organização das atividades baseadas no princípio do zoneamento funcional e na hierarquia do traçado viário como elemento estruturante do território e que dava forma ao campus. Conservou-se o desenho do anel viário circular, abraçando bolsões de estacionamento em forma semicircular, provido de dois acessos às vias municipais (ver figura 381).

A ideia, entretanto de instalar o curso da Medicina, não foi mantida, pois sua transferência para o campus revelou-se inviável, tendo em vista o alto custo dos seus laboratórios e equipamentos, que já se encontravam funcionando em hospitais da cidade ${ }^{142}$. Outra unidade que ficou fora do campus foi o Centro de Ciências Agrárias, implantado numa gleba vizinha à Ininga, atual bairro do Socopo.

O setor comunitário estava estrategicamente situado na área central do círculo, pois sendo o foco da vida social da universidade, desempenhava o papel de centro irradiador das relações acadêmicas e sociais para os demais setores.

\footnotetext{
${ }^{14}$ Foram requisitados os arquitetos Ronaldo Pinto Marques, Lourival Machado Rezende e Vasco de Melo, para prestarem serviços exclusivos à Universidade Federal do Piauí.

${ }^{142} \mathrm{Em}$ outubro de 2009 , constatamos que um hospital universitário encontrava-se em construção no campus da Ininga.
} 


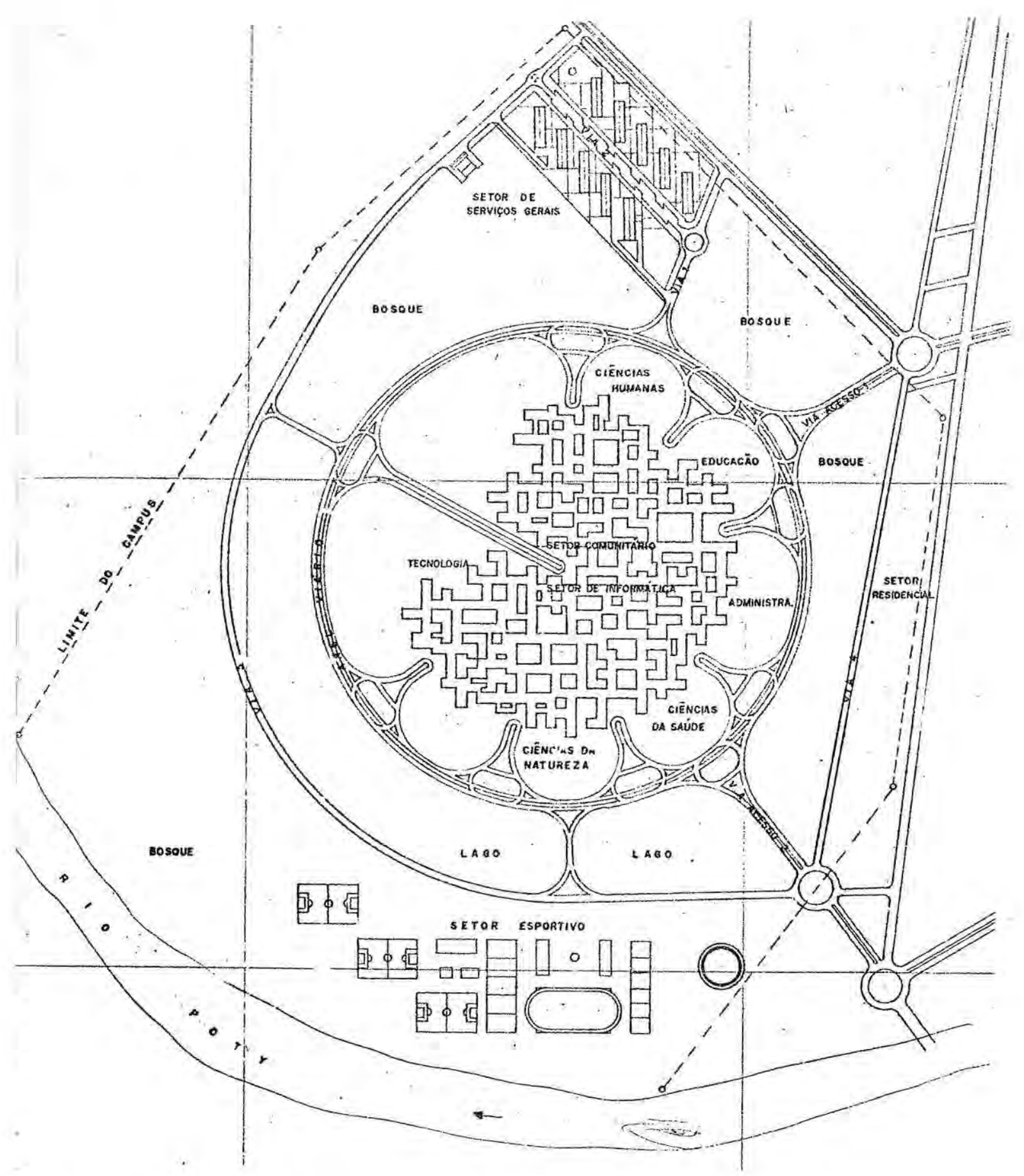

Figura 381: UFPI - Plano Diretor do Campus da Ininga (1972).

O plano urbanístico tem como diretriz central o sistema viário que ordena os setores funcionais.

(Fonte: UFPI, 1981, p.70)

Cada setor é abastecido por um bolsão de estacionamento específico, como forma de garantir a circulação dos veículos fora da área de atividades, resultando em sub-regiões funcionais. $O$ acesso aos setores é marcado por uma via principal de configuração linear que avança em direção ao centro do círculo, de maneira a atingir o setor comunitário, 
elemento irradiador das demais atividades, conforme mencionado. Essa diretriz contrapunha-se ao Manual de Atcon, que indicava a localização do setor básico como o centro irradiador, entrelaçado com os centros e respectivos departamentos, ao invés do setor comunitário.

Ao redor do anel circundante, pelo lado externo, o plano previa extensões de áreas de vegetação, "bosques", e lagos, criando uma faixa de proteção aos setores acadêmicos. Nas extremidades da poligonal do terreno, localizavam-se os setores esportivos, de serviços geral e residencial.

Para o arquiteto Marques, aquele desenho incorporava a concepção de um complexo integrado, que se almejava ser o campus universitário da Reforma. A integração era o princípio norteador daquele território e a forma circular, que abraça a comunidade, deveria expressar o estágio de uma educação superior que dava ênfase à interdependência das relações sociais. Enfatiza ainda que necessidade de conciliar a imprevisibilidade referente ao crescimento da universidade e a flexibilização dos espaços para adequação a novos usos, mantendo ao mesmo tempo a unidade do conjunto, foram diretrizes que permearam a proposta arquitetônica daquele plano.

O plano não deu prosseguimento ao edifício de partido construtivo com abóbadas de tijolo de autoria dos profissionais uruguaios. O pagamento de royalties para a transferência daquela tecnologia tornou-se inviável para a Universidade. A proposta inicial foi substituída pela ideia de um edifício constituído pelo conjunto de partes que vão sendo adicionadas gradativamente. Baseia-se na concepção construtiva padronizada que se desenvolve a partir de uma unidade modular de 1,0 $\mathrm{m} \times 1,0 \mathrm{~m}$, formando uma malha de eixos cartesianos que propicia o crescimento e expansão do edifício em direções distintas conforme o surgimento das demandas universitárias requeridas.

Trabalhando com a ideia de aglomeração, a proposta incorpora o princípio da formação de uma megaestrutura a partir de pequenos espaços de atividades, interligados pelas circulações internas de pedestres e pelos pátios abertos providos de vegetação. Propunha construções de baixa altura, basicamente o pavimento térreo.

Suas características de modularidade e extensibilidade traziam a garantia da adição de novas partes ao conjunto edificado, visando atender ao aos princípios da flexibilidade e a expansibilidade que configuravam a ideia de uma universidade de caráter dinâmico. $O$ partido arquitetônico adotado resultou, entretanto em um complexo labiríntico de infinitos elementos retangulares conforme podemos visualizar no detalhe da figura 382 . 


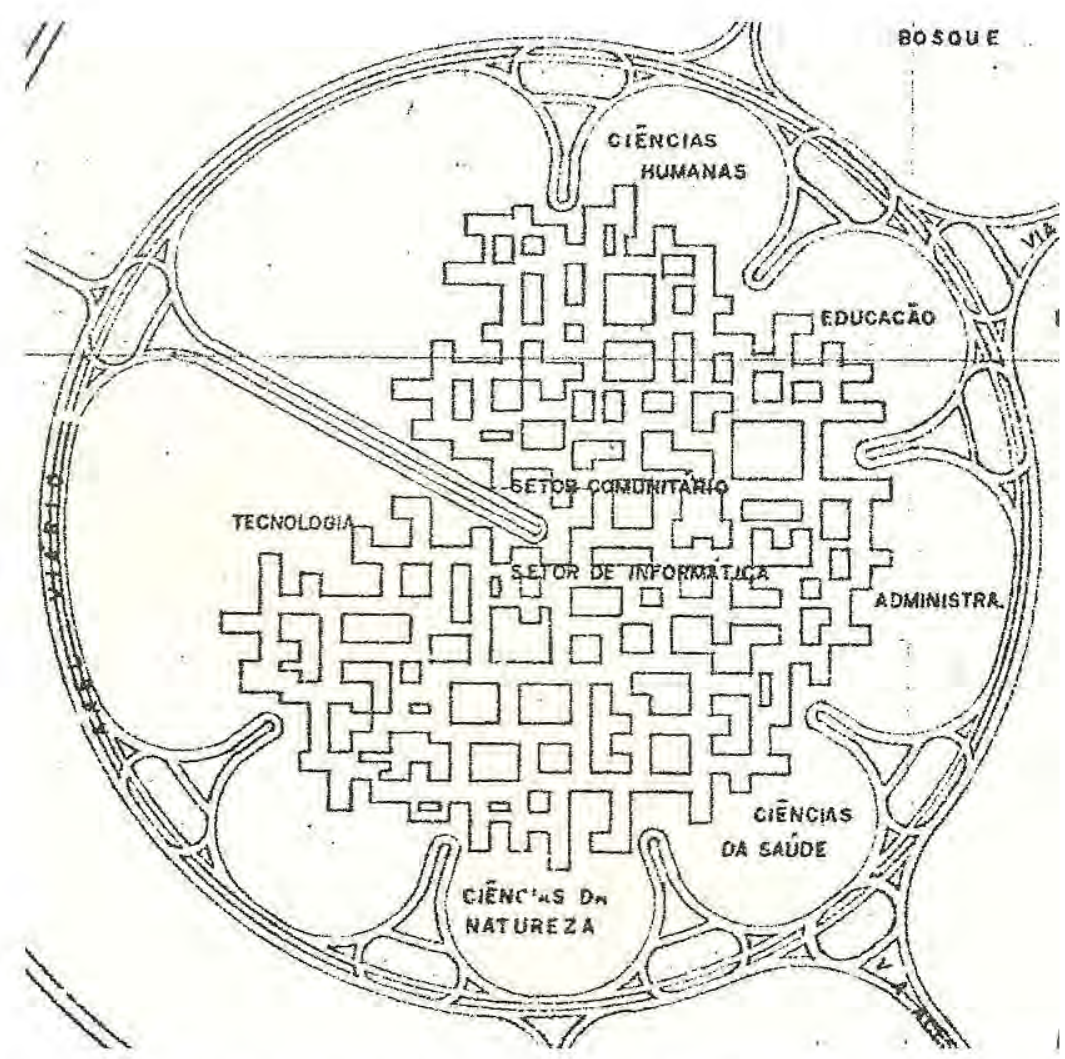

Figura 382: UFPI - Detalhe da proposta geral do Campus. (Fonte: UFPI, 1981, p.70)

A multiplicidade das funções acadêmicas, organizadas em departamentos e que deveria predominar suas inter-relações dava essência a essa tipologia construtiva que não tinha contornos definidos, mas que ao mesmo tempo apresentava um sentido de totalidade. Suas características de extensibilidade que permitiam acrescentar, de forma permanente ou não, partes novas ao conjunto, incorporavam o conceito de uma construção que não podia ser tomada como acabada, mas como uma estrutura em constante crescimento. Segundo depoimento do arquiteto Marques, autor do projeto, a proposta foi elogiada pelo MEC por seu caráter inovador.

Tais idéias parecem ter se apoiado nos debates e experiências internacionais ocorridas na década de 1960, quando os conceitos de indeterminismo, crescimento e flexibilidade davam suporte ao planejamento físico do campus universitário. Exemplo paradigmático foi o projeto para a Universidade Livre de Berlim na Alemanha, de autoria dos arquitetos Candilis, Josic, Woods e Schiedhelm. O projeto, de 1962, deu início a uma nova maneira de pensar, em que o compromisso com a mudança é que ocupa a atenção dos planejadores. Nesta proposta todas as formas de desenho desaparecem. Pensada como uma construção baixa, basicamente dois pavimentos e um subsolo, formava uma estrutura de blocos associados 
numa malha tridimensional que vai sendo ocupada conforme as solicitações do programa, sendo articulada por eixos de circulação e serviços.

Com esta concepção o edifício deixa de ter forma previamente definida, podendo se expandir no sentido horizontal e vertical, para acomodar diversas funções e atender as mudanças decorrentes dos seus usos. O resultado formal é uma composição espacial com volumes cheios e vazios que se unem formando o todo.

A concepção arquitetônica de um edifício aberto ao crescimento referenciado na Universidade de Berlim foi adotada na UFPI que deu início ao complexo dos Centros de Ciências da Educação e de Ciências Humanas. A proposta, entretanto, não teve prosseguimento para outros setores, tendo em vista a descontinuidade dos convênios financeiros destinados às obras de construção da Universidade. Em meados da década de 1980, o Centro de Tecnologia já adotava partido diferenciado com a concepção de edifícios dissociados e articulados por passarelas abertas.

\section{- IMPLANTAÇÃO DO CAMPUS DA ININGA: primeiras obras}

A construção do Campus foi definida a partir de um cronograma de execução das obras previsto inicialmente em três etapas e com início para o primeiro semestre de 1972 , programação que não foi cumprida em face da exiguidade dos recursos, que não foram disponibilizados conforme planejado.

O relatório da DIPRO (UFPI, 1981) relata que o projeto de financiamento para a construção do campus foi por diversas vezes reestruturado, devido à instabilidade financeira daquele período, que acarretava constantes aumentos nos preços dos materiais de construção.

Em virtude dos fatores econômicos e da urgência de implantação, as primeiras edificações construídas, iniciadas em abril de 1972, contrariaram a orientação do plano diretor, construindo galpões destinados ao Setor de Serviços Gerais (oficinas, gráfica, carpintaria, vigilância, dentre outros), para serem adaptados às atividades didáticas e administrativas, enquanto se aguardava o início da construção do complexo universitário proposto, o que só veio a ocorrer no final daquela década.

A intenção era de que uma vez construídos os edifícios, o Setor de Serviços Gerais passaria a abrigar as suas verdadeiras funções, atribuídas quando da concepção original do projeto do campus. Constata-se, entretanto, que até os dias de hoje (2011), aqueles galpões permanecem com funções didático-administrativas. Essa prática no uso e ocupação das instalações físicas universitárias, onde a exiguidade de recursos direciona a ocupação das atividades em espaços projetados para outros usos tem sido prática comum. Isso nos 
remete a uma reflexão sobre os atributos do espaço universitário: não teria o mesmo uma concepção arquitetônica de características próprias conforme as funções a que se destina, ou estaria tão somente restrito a uma adequação das instalações prediais?

Considerando que as edificações do setor de serviços retomariam suas verdadeiras funções, optou-se pela construção dos galpões, cujo partido construtivo era de fácil execução e baixo custo operacional e a estrutura, com cobertura independente e alvenarias de vedação, tinha a intenção de possibilitar flexibilidade para os mais diversos usos. Foram projetados com a capacidade de abrigar os cursos existentes e criados provisoriamente até a implantação dos prédios definitivos destinados às atividades didáticas, conforme já mencionado.

Dando prioridade às unidades consideradas com funcionamento espacial deficitário ou aquelas em fase de criação, foram projetados inicialmente três galpões que se destinavam a abrigar as ex-faculdades de Direito e Filosofia e os novos Departamentos de Ciências da Natureza e Educação. Posteriormente, foram projetados mais dois outros galpões, sendo um deles para abrigar o acervo das diferentes bibliotecas existentes e o segundo destinado às atividades administrativas que se encontravam em imóveis alugados, funcionando de maneira precária e deficiente.

A universidade iniciou suas atividades no campus da Ininga em fevereiro de 1973, instalada em cinco galpões padronizados que recebiam a denominação abreviada de Serviços Gerais - SG associada a uma numeração e às atividades à que se destinavam. Foram eles:

SG-2 - Ciências da Natureza

SG-3 - Ciências da Educação

SG-4 - Ciências Humanas e Letras

SG-5 - Biblioteca Central

SG-6 - Administração Superior (Reitoria)

Concentrado numa área periférica do campus, esse conjunto foi acrescido posteriormente de mais quatro unidades (ver figuras 383 e 384 ). 


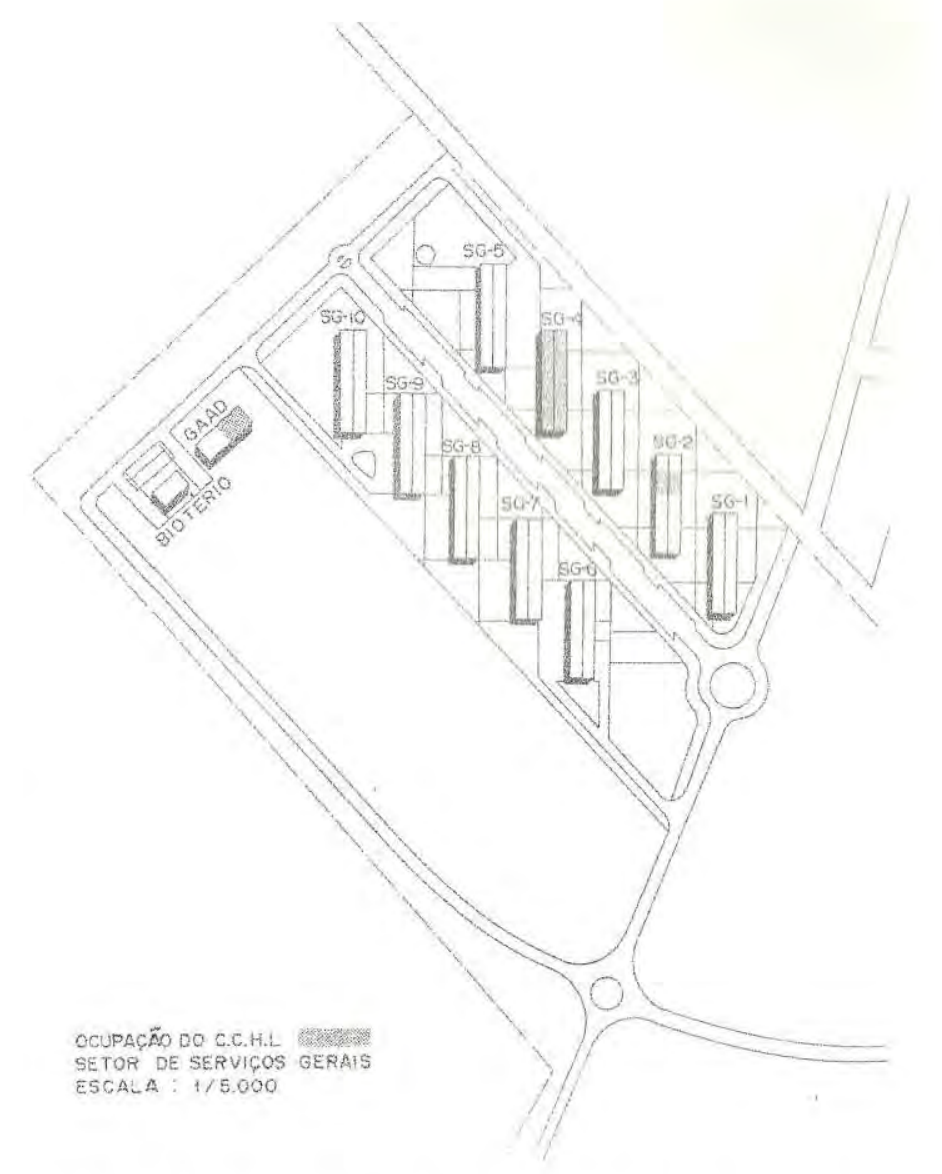

Figura 383: UFPI - Setor de Serviços Gerais (1977) (Fonte: FUFPI/CEPRO, 1977, p.26)

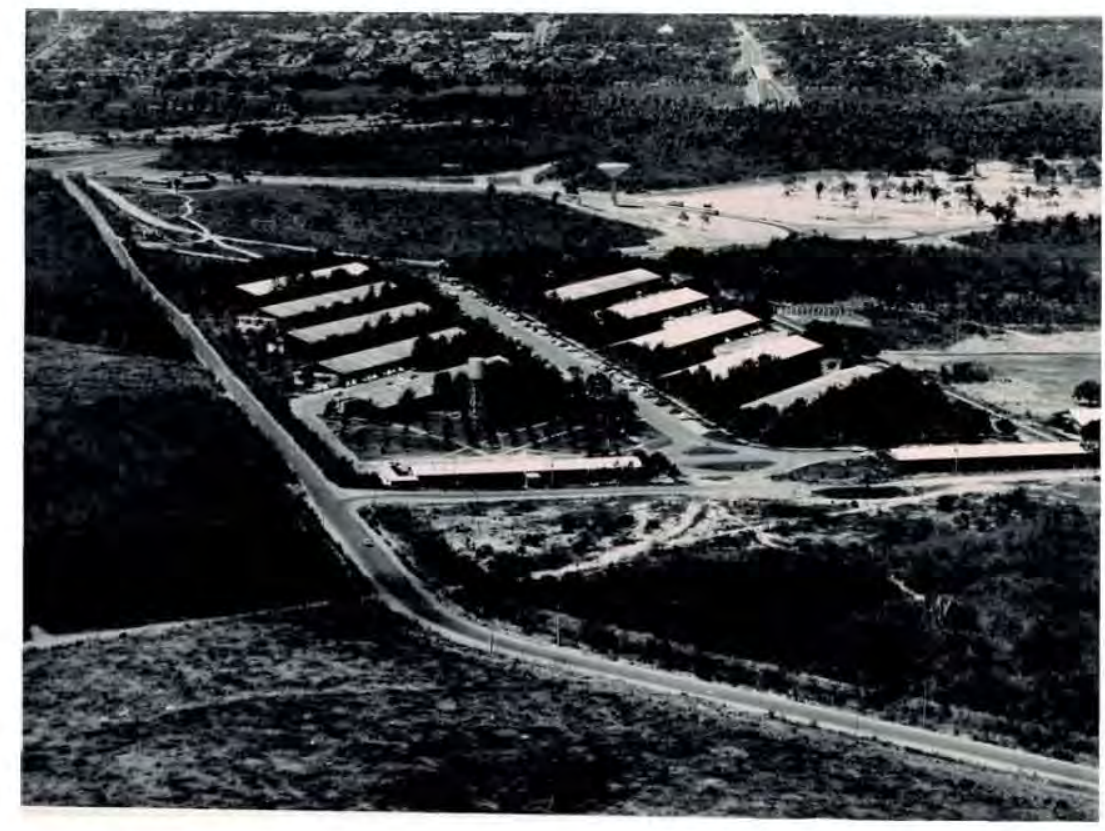

Figura 384: Vista aérea do Setor de Serviços Gerais - final da década de 1970. (Fonte: disponivel em

$<$ http://www.skyscrapercity.com/showthread.php?t=1188883>.

Acesso em: 19 jun. 2011) 
Em paralelo foram executadas as obras de infraestrutura que incluíram uma caixa d'água com capacidade para 100.000 litros, dois poços artesianos; rede geral de distribuição de água; rede geral de esgotos sanitários; rede de transmissão de força e luz em alta tensão, sistema telefônico e iniciado o sistema viário. No total, foram aplicados recursos em 9.756 $\mathrm{m}^{2}$ de edificações e mais de $5 \mathrm{~km}$ em redes (ver figuras 385 a 387 ).

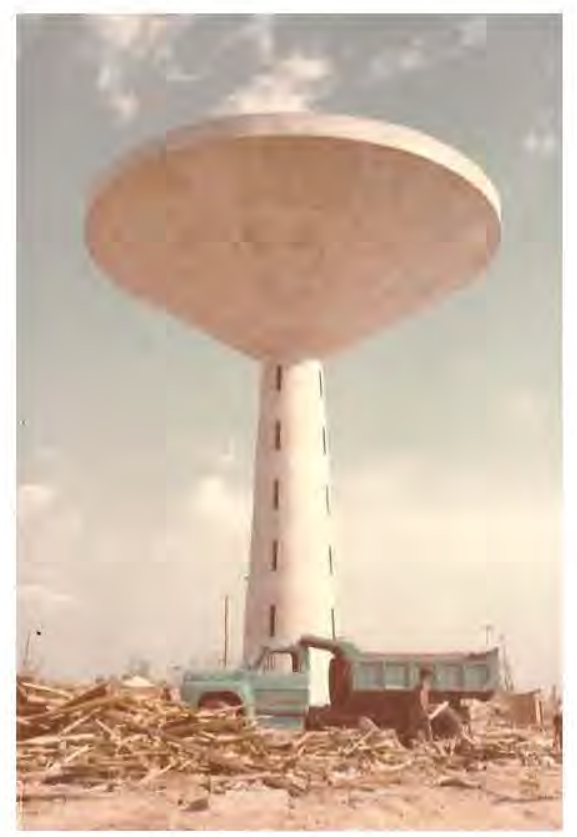

Figura 385: UFPI - Vista da caixa d'água, ano 1980.

A volumetria em forma de cogumelo executada em concreto aparente.

(Fonte: Acervo Pessoal Arquiteto Ronaldo Pinto Marques)

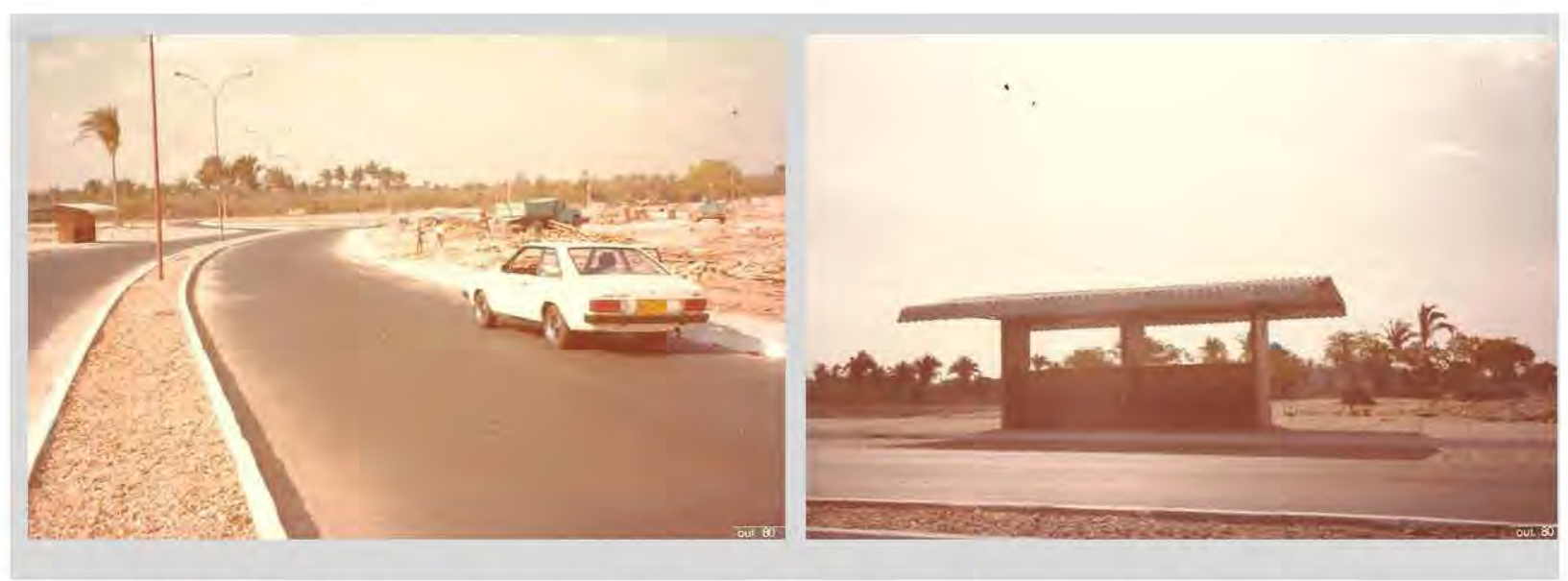

Figura 386: UFPI - Vista das obras de infraestrutura do Campus - final da década de 1970. (Fonte: Acervo Pessoal Arquiteto Ronaldo Pinto Marques) 


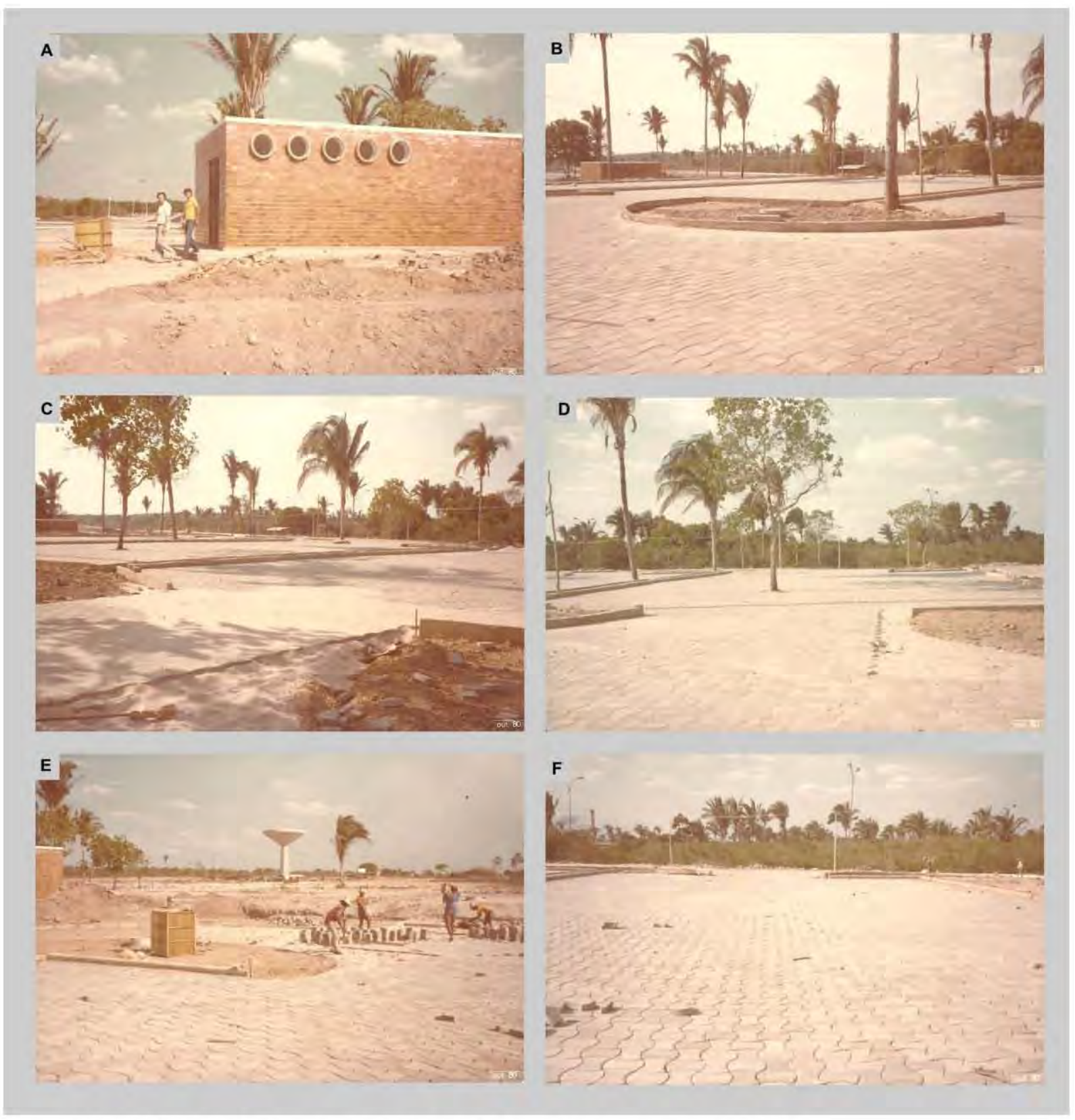

Figura 387: UFPI - Vista das obras de infraestrutura do campus - ano 1980.

(A) Vista da subestação abrigada.

(B), (C), (D), (E) e (F) Vista dos bolsões de estacionamento com a preservação da vegetação nativa de babaçu.

(Fonte: Acervo Pessoal Arquiteto Ronaldo Pinto Marques)

A expansão da universidade se dava em ritmo acelerado. As demandas para concretização do campus se tornavam assim cada vez mais complexas, exigindo uma ampliação do quadro técnico para atender às funções de planejar e executar o desenvolvimento físico, bem como controlar o andamento de obras a cargo de terceiros. Foi então criada a Coordenação de Planejamento Físico (COPLAF), em substituição à ATEAU. A COPLAF prosseguiu com os trabalhos de implantação do campus da Ininga, lançando também em 1973, as concorrências para as seguintes obras: 
- Construção do Galpão SG-10, destinado ao Centro de Ciências da Saúde - Odontologia, tendo sido entregue à comunidade universitária em 1974, quando se verificou a transferência desse curso para as dependências do campus.

- Construção do Galpão SG-1 destinado ao Centro de Ciências da Natureza Departamento de Biociências.

- Construção do Galpão SG-7, destinado à administração superior. Com tais obras, a área edificada totalizava $5.859 \mathrm{~m}^{2}$. Paralelamente, foram executadas as obras de infraestrutura complementares às primeiras.

Durante o mesmo período foi elaborado o projeto para o Setor Esportivo do Campus Universitário da Ininga, tendo sido a primeira etapa entregue no ano de 1974 , com os seguintes equipamentos: uma pista de atletismo, três quadras bivalentes para vôlei e basquetebol e três para handebol e futebol de salão.

Com a nova estrutura técnica, ainda em 1973, através de solicitação da Universidade delineou-se o projeto do Campus Ministro Reis Veloso na cidade de Parnaíba, cuja primeira etapa compreendeu as obras de infraestrutura (castelo d'água com capacidade para 100.000 I, $3 \mathrm{~km}$ da rede viária, estacionamentos, paisagismo) e de edificações (cinco módulos de edificações, com $2.004 \mathrm{~m}^{2}$ ). A política de interiorização da universidade se intensificava com a perspectiva de implantação de outros campi em diversos municípios do Estado.

Em janeiro de 1974, a FUPI assinou convênio com o PREMESU que garantiu o financiamento para conclusão do Setor de Serviços Gerais, que continuava funcionando como "campus provisório" das atividades didáticas e administrativas.

Durante a implantação desse projeto, a COPLAF ressentia-se de meios estruturais para acompanhar o crescimento da universidade. Foi então criada a Coordenação de Estudos e Projetos (CEPRO), com objetivos mais amplos e com um quadro funcional mais diversificado.

Cabia a ela, a elaboração de planos e projetos, a execução e fiscalização de obras relativas à construção e manutenção do campus. Sua estrutura era constituída pela Divisão de Estudos e Projetos e Divisão de Construção, Fiscalização e Manutenção.

Em 1975, deu-se continuidade na aplicação de recursos em infraestrutura, edificações e execução de projetos do anel viário do Campus da Ininga. Nesse ano, foram entregues para funcionamento $16.698 \mathrm{~m}^{2}$ de área construída, compreendendo: 
- Galpões SG - 1, 7, 8 e 9

- Biotério central

- Quadra polivalente coberta

- 2 quadras bivalentes p/handebol/futebol de salão

- Edificações no campus da Parnaíba
$7.812 \mathrm{~m}^{2}$

$404 \mathrm{~m}^{2}$

$5.590 \mathrm{~m}^{2}$

$3.888 \mathrm{~m}^{2}$

$2.004 \mathrm{~m}^{2}$

No final desse mesmo ano, foi encaminhada ao MEC uma proposta para o financiamento da conclusão das obras de infraestrutura que incluiam os sistemas viários, de galerias e águas pluviais; de abastecimento de água; de esgoto sanitário; telefônico; de força e luz; além do paisagismo do campus da Ininga. Nesse conjunto foi encaminhado orçamento para a construção do Centro de Ciências da Natureza; Centro de Ciências Humanas e Letras; Centro de Ciências da Educação e Setor Comunitário.

No ano de 1976, com a decisão do governo do Estado de não mais desapropriar o restante da área destinada ao Campus da Ininga, conforme já afirmado, foi realizada a readequação do Plano Diretor vigente.

\section{- PLANO DIRETOR: segunda proposta de 1977}

Com a redução da área, o Campus da Ininga teve sua configuração espacial reformulada com base no que já estava construído e com a projeção das futuras demandas. Na figura 388 , podemos visualizar a sua forma ajustada aos limites da gleba doada pelo Estado. Permaneceu a concepção do edifício expansivo com base na modular estrutural. Foram então elaborados estudos para o Centro de Ciências da Educação (CCE); o Centro de Ciências Humanas e Letras (CCHL) e o Setor Comunitário.

Com base no diagnóstico da base física existente, constatou-se que as edificações que compõem o Setor de Serviços Gerais e o Setor Esportivo já estavam com sua capacidade de atendimento esgotada assim como a respectiva infraestrutura de energia elétrica, água, esgoto e telefone. Após pesquisa, foram projetadas novas redes, independentes das existentes. O estudo definia o partido arquitetônico das edificações que viriam a servir a matriz acadêmica e realizou uma criteriosa análise referente aos condicionantes de conforto térmico com vistas ao controle da radiação solar e do uso da ventilação natural. Seu arcabouço foi sintetizado no documento que define o programa de necessidades para o CCHL (FUFPI / CEPRO, 1977). 


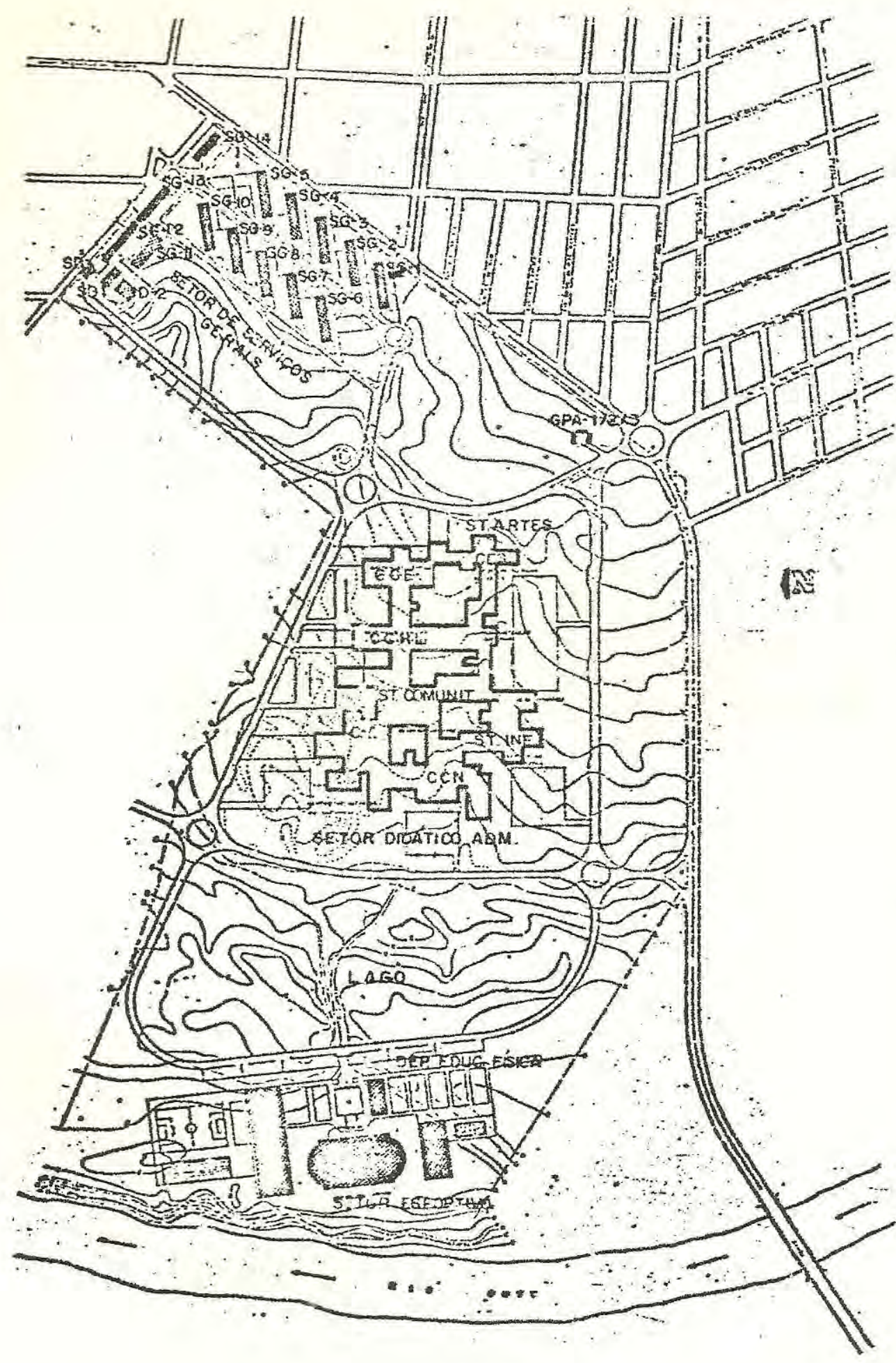

Figura 388: UFPI - Planta do campus da Ininga - 1976.

Com a redução da área de desapropriação o desenho teve sua planta readequada, substituindo o anel circular pela configuraçăo de uma superquadra de contorno irregular. (Fonte: UFPI, 1981, p.71) 
A reformulação da organização espacial manteve os elementos estruturadores das concepções anteriores que diziam respeito ao zoneamento, sistema viário, infraestrutura e partido arquitetônico.

\section{- Zoneamento}

O novo zoneamento estava estruturado em três áreas: o Setor de Serviços Gerais, que se encontrava em fase de conclusão, o Setor Esportivo com parte das construções concretizadas e o Setor Didático-administrativo, a ser iniciado. Na nova planta, este último situava-se na área central do campus, tendo a leste o Setor de Serviços Gerais, que continuava a acumular funções didáticas e administrativas e, a oeste, o Setor Esportivo, constituído por: Centro de Ciências da Educação, Centro de Artes, Centro de Ciências da Saúde, Administração Superior, Centro de Ciências e Letras, Setor Comunitário, Setor de Informática, Centro de Ciências da Natureza e Centro de Tecnologia. Previu-se entre os setores didático-administrativo e esportivo a implantação de um lago, como solução para o aproveitamento de uma área de depressão, sujeita a constantes alagamentos, com as cheias do Rio Poti (ver figuras 389 e 390 ).

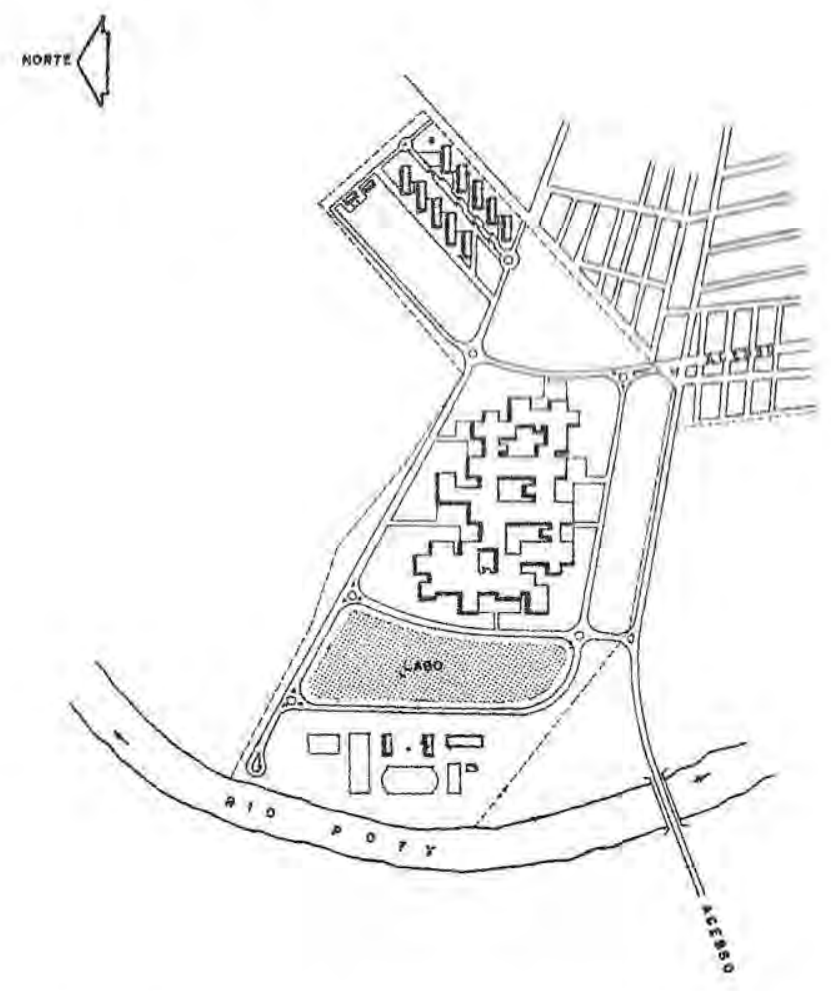

Figura 389: UFPI - Zoneamento do Campus da Ininga - 1977.

O Setor Didático-administrativo, situado no centro do terreno, está representado pela associação de retângulos volumétricos, indicando o partido adotado de edifício único sem forma definida. Ao norte, o Setor de Serviços Gerais está representado pela volumetria dos retângulos que indicam os galpões. Ao sul, o Setor Esportivo.

(Fonte: FUFPI. CEPRO, 1977, p.18) 

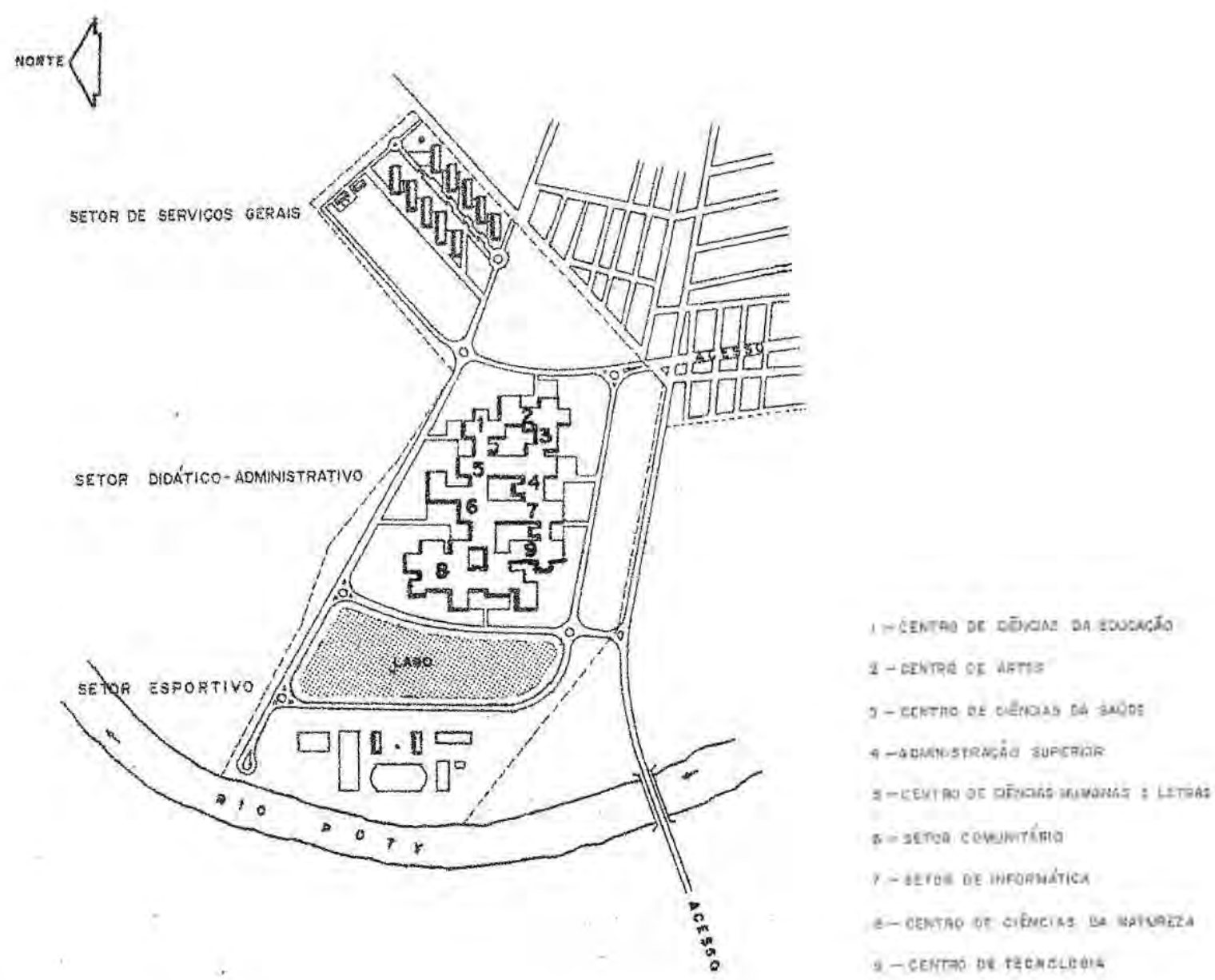

Figura 390: UFPI - Campus da Ininga - Setores funcionais.

(Fonte: FUFPI. CEPRO, 1977, p.25)

\section{- Sistema Viário}

O sistema viário foi reprogramado integrando-se às vias já existentes e eliminando a proposta do grande anel circular, passando a ser composto por ruas circundantes aos setores funcionais, articulados por rotatórias que desempenham a função de interligação entre os setores e os acessos ao campus. Aos anéis circundantes propunha-se acoplar, perifericamente, "bolsões" de estacionamento em conformidade com a disposição das novas edificações. Permitiu-se, dessa forma, que a área disponível para a implantação do Setor Didático-administrativo fosse cercada por vias que impediriam a circulação de veículos, que pudessem dificultar a locomoção de pedestres e sua integração aos centros. (ver figura 391). 


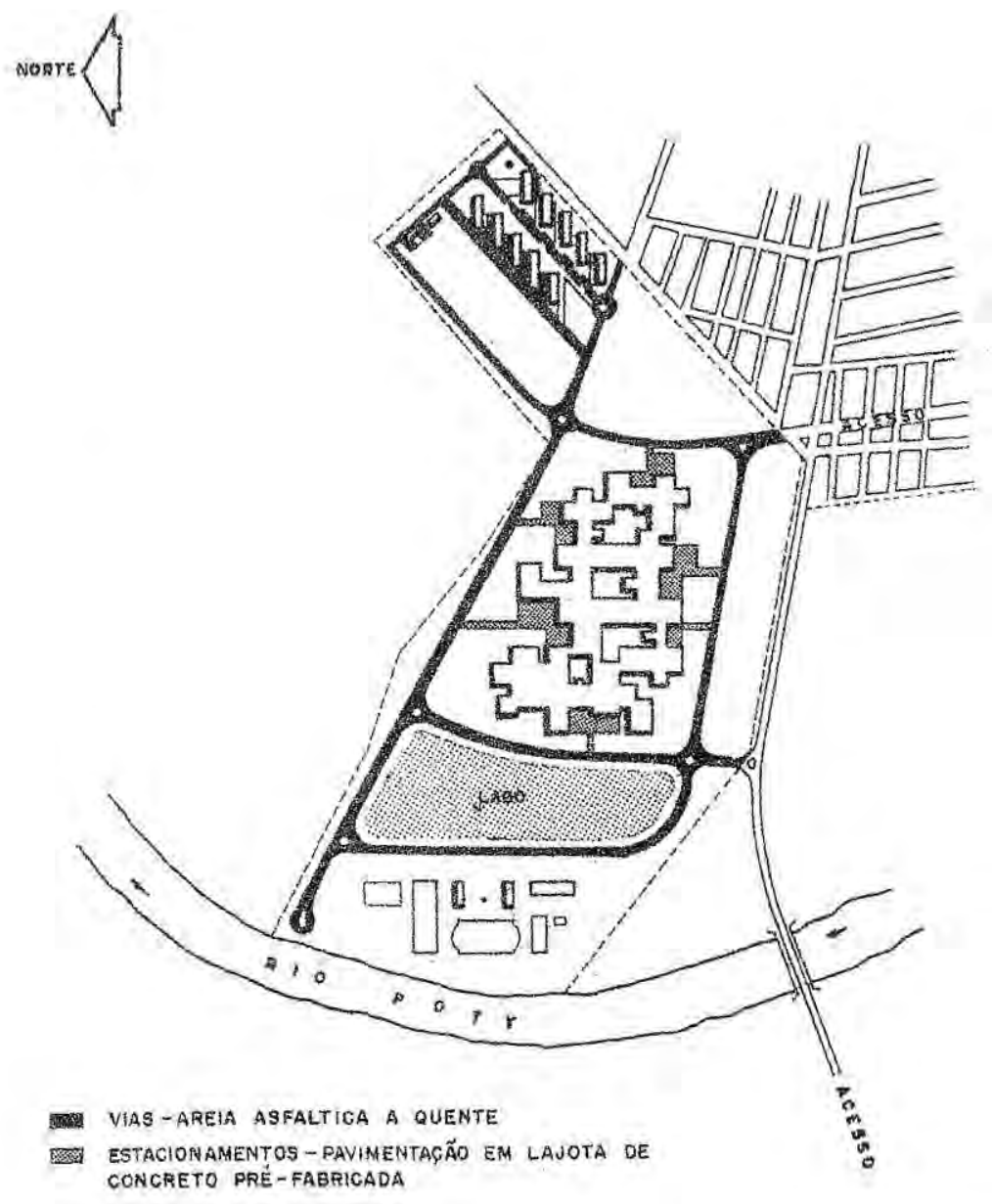

Figura 391: UFPI - Campus da Ininga - Sistema viário.

(Fonte: FUFPI/CEPRO, 1977, p.19)

\section{- Infraestrutura}

O plano incorporou um novo estudo da infraestrutura, reformulando a distribuição dos sistemas de energia elétrica, de captação e armazenamento de água, de esgoto sanitário, de coleta de águas pluviais e de telefonia. Observa-se que nessa etapa a concepção do "novo" foi substituída pela postura da "adequação", de maneira que as experiências acumuladas passaram a ser norteadoras do plano. Mudanças, indeterminismo e flexibilidade embasavam as soluções.

- lluminação

A distribuição de energia elétrica foi programada para ser feita através de redes de alta tensão, sendo que, diferentemente do que fora adotado para o Setor de Serviços Gerais, os transformadores em postes seriam substituídos por estações rebaixadoras, dimensionadas de acordo com a necessidade de cada centro. Esse sistema permitiria não só uma redução 
nos custos de distribuição, como também, garantiria maior flexibilidade para uma reprogramação das instalações. A iluminação do campus foi definida em dois tipos: postes altos com lâmpadas de vapor de sódio nas vias públicas e postes rebaixados com iluminação incandescente comum nas áreas ajardinadas (ver figura 392).

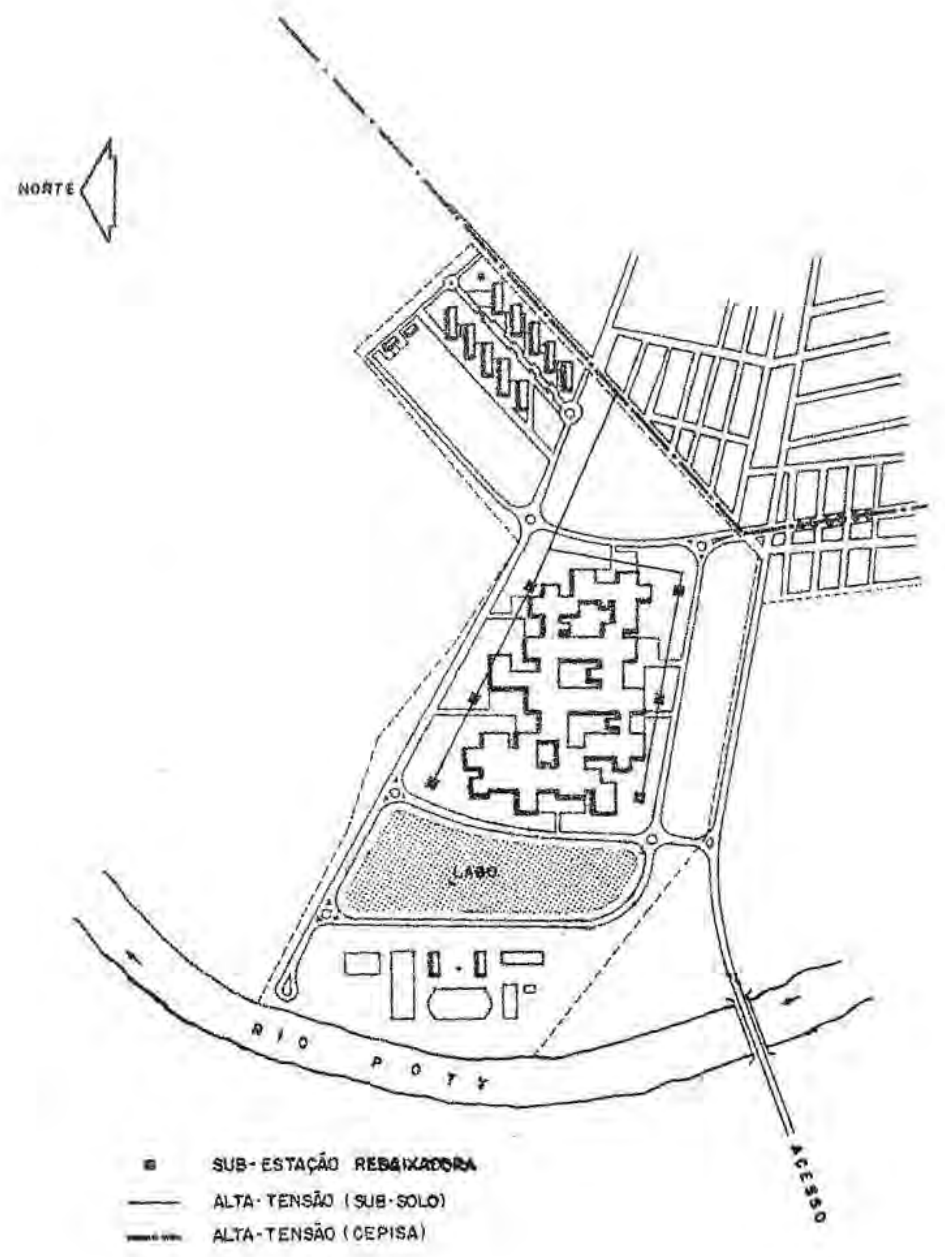

Figura 392: UFPI - Campus da Ininga - Redes de infraestrutura. (Fonte: FUFPI/CEPRO, 1977, p.20)

\section{- Água}

Para o sistema de captação e armazenamento de água, foi prevista a abertura de poços artesianos e a construção de quatro castelos d'água setoriais com as respectivas cisternas, a partir dos quais a distribuição seria feita por gravidade, para os diversos centros. Naquela etapa de implantação, um castelo d'água seria suficiente para abastecimento do campus (ver figura 393A). 


\section{- Esgoto}

Para o sistema de esgoto sanitário foram levantadas algumas soluções: fossa séptica com desaguamento simples no Rio Poti, galeria de esgoto conectada a uma estação de tratamento e sistema de fossa com vazão em lagoa de estabilização. Entretanto a definição final a respeito se daria posteriormente, após os estudos de viabilidade técnica e econômica, que estavam em fase de desenvolvimento (ver figura 393B).

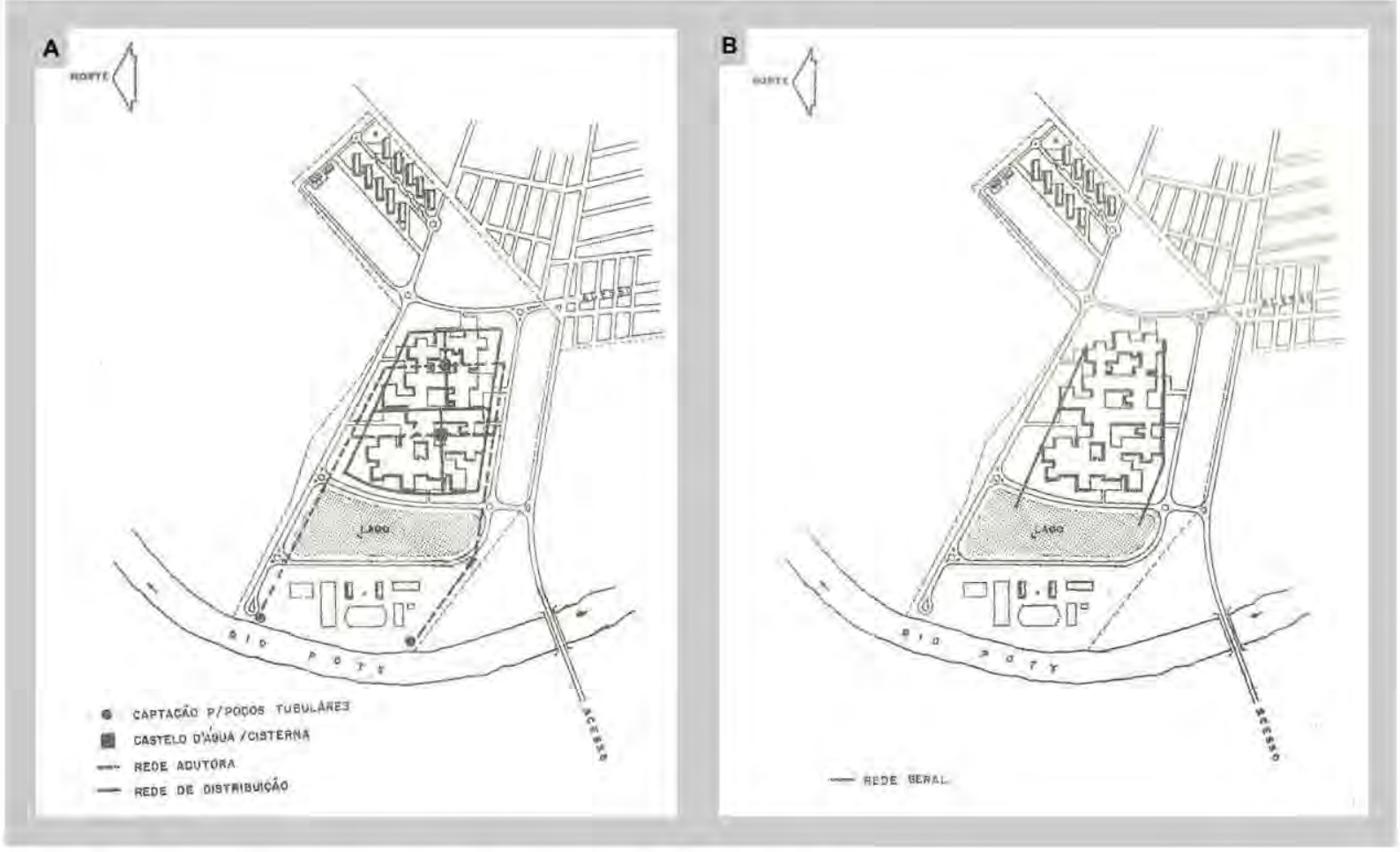

Figura 393: UFPI - Campus da Ininga - Redes de infraestrutura

(A) Planta do sistema de abastecimento de água.

(B) Planta do sistema de esgoto

(Fonte: FUFPI/CEPRO, 1977, p. 21-22)

- Águas pluviais

A coleta de águas pluviais foi planejada para ser feita através de um sistema de galerias locadas de acordo com a direção de caimento do terreno - leste/oeste - desaguando em última instância no lago artificial (ver figura 394A).

- Telefonia

O sistema de telefonia foi projetado para ser uma central telefônica com módulos PABX de 50 ramais, instalados no setor comunitário, expansíveis conforme as necessidades de implantação do campus (ver figura 394B). 

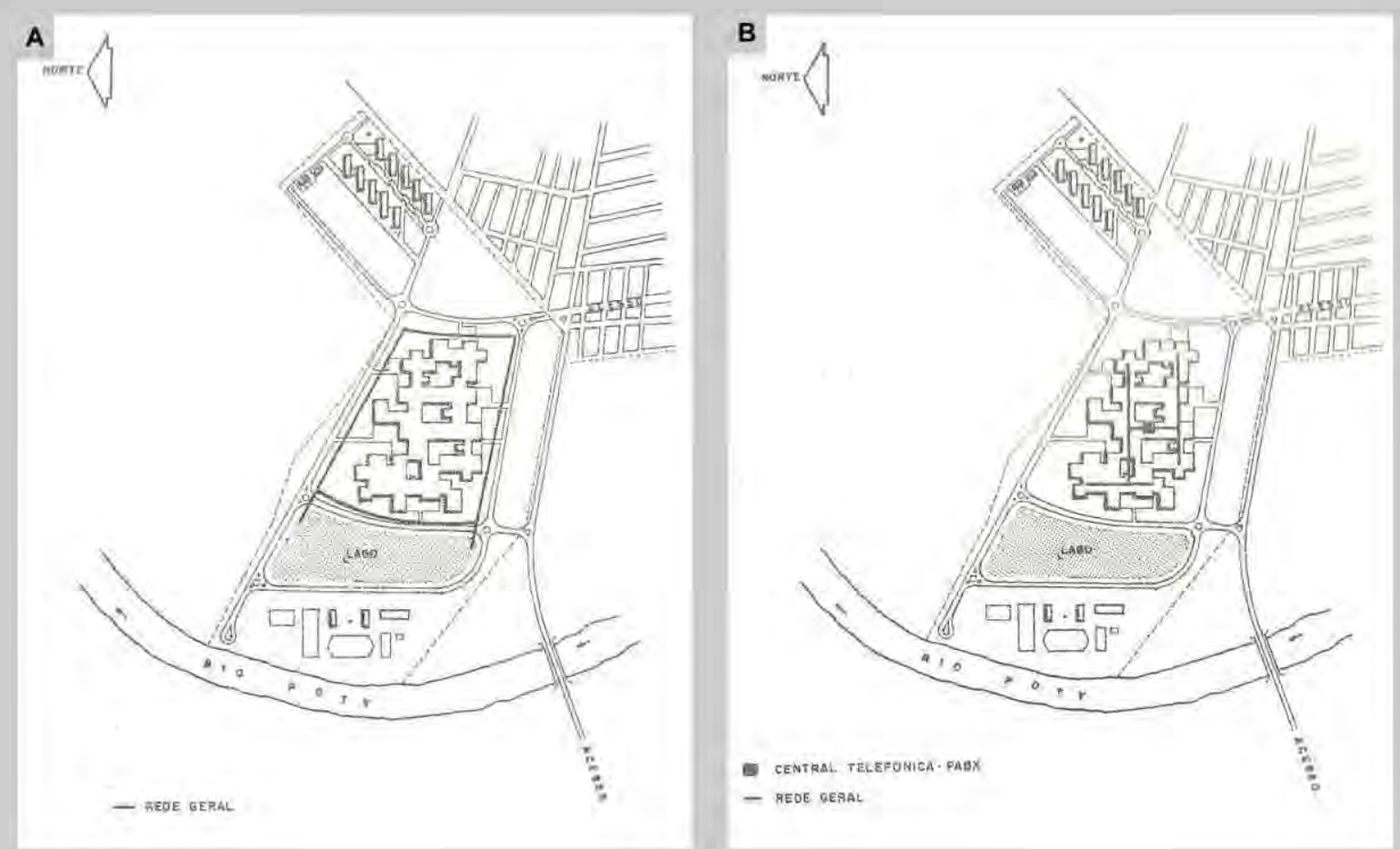

Figura 394: UFPI - Campus da Ininga - Redes de infraestrutura

(A) Planta do sistema de captação de águas pluviais.

(B) Planta do sistema telefônico.

(Fonte: FUFPI/CEPRO, 1977, p. 21-22)

\section{- Partido arquitetônico}

O partido arquitetônico manteve para as atividades didáticas e administrativas a proposta de um edifício único com a concepção de blocos associados que se desenvolvem sobre uma malha ortogonal, podendo crescer nas direções norte, leste e oeste do campus conforme as solicitações do programa. Ao final resultou de três grupos de condicionantes:

a. Do programa: condicionantes impostas pela estrutura universitária estabelecida pelas programações administrativas e departamentais e pela previsão de cursos, com as seguintes diretrizes:

1. Interdependência das atividades afins (departamentais, curriculares, administrativas), buscando sua proximidade e inter-relações (ver figura 395A).

2. Flexibilidade de uso dos espaços físicos.

3. Princípio de extensibilidade como forma de garantir as previsões de crescimento decorrentes da ampliação de cursos, e/ou departamentos ou justaposição de novas atividades universitárias (ver figura 395B).

4. Adoção de espaços livres e circulações contínuas (ver figura 395C). 
A

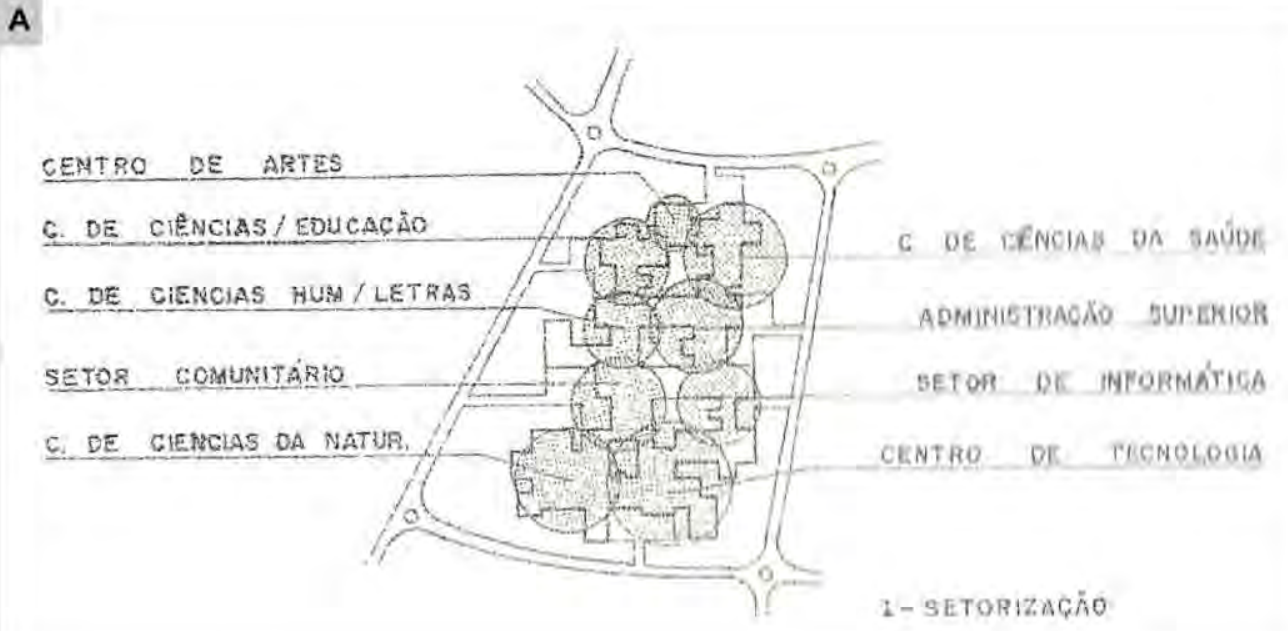

B

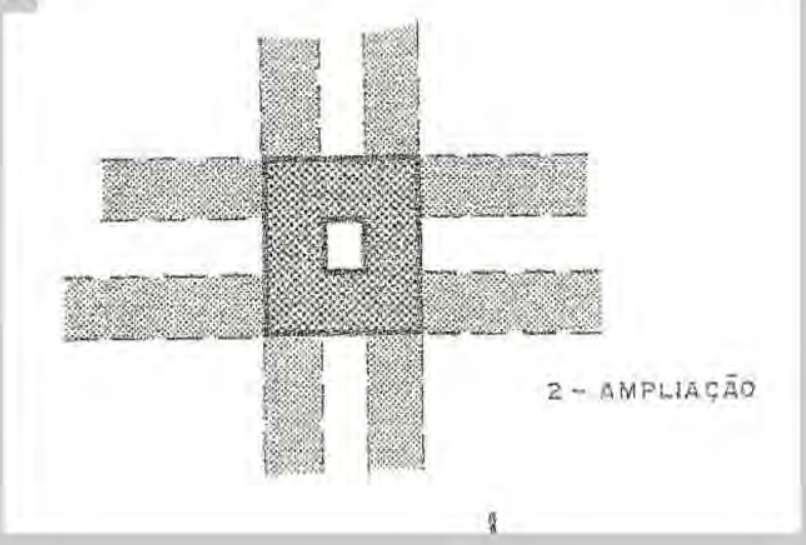

C

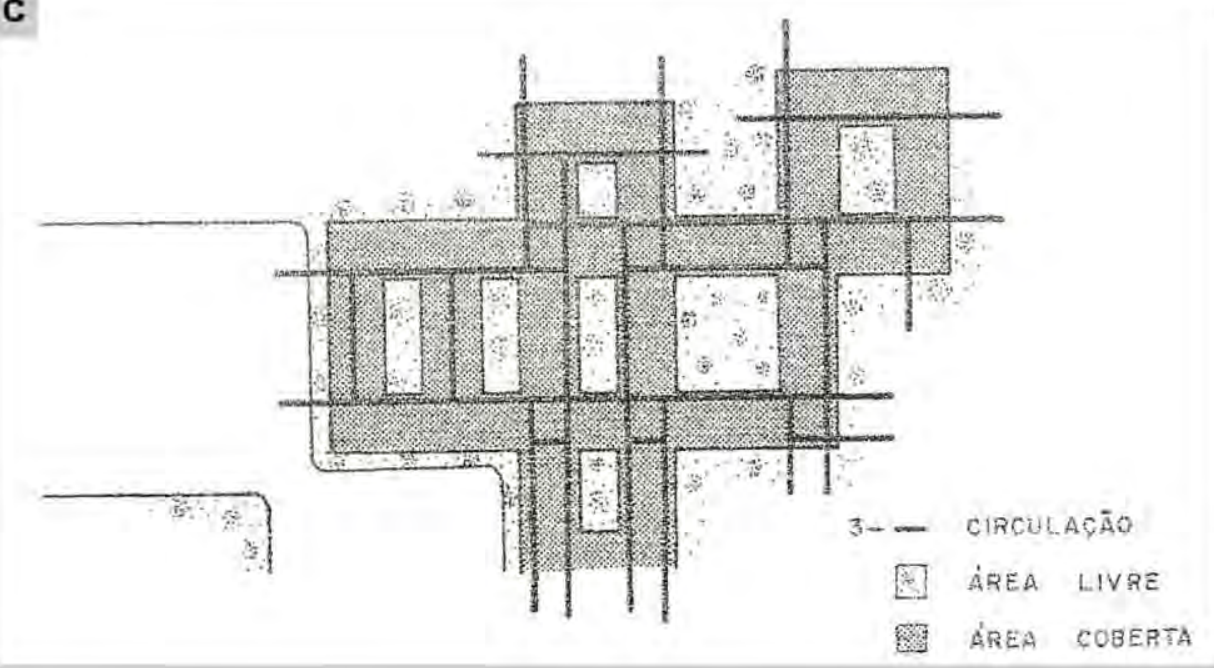

Figura 395: UFPI - Campus da Ininga - Partido arquitetônico

(A) Setorização: o programa se organiza por setores interligados.

(B) Ampliação: as unidades funcionais podem crescer em diferentes direções

(C) Circulação: as unidades funcionais se articulam pelas circulações e áreas livres. (Fonte: FUFPI/CEPRO, 1977, p.121) 
b. Naturais: envolvendo os aspectos climáticos e físicos do terreno:

1. Clima: ventilação, insolação, umidade, temperatura (ver figura 396A).

2. Topografia: possibilidade de a estrutura adaptar-se ao terreno (ver figura 396B).

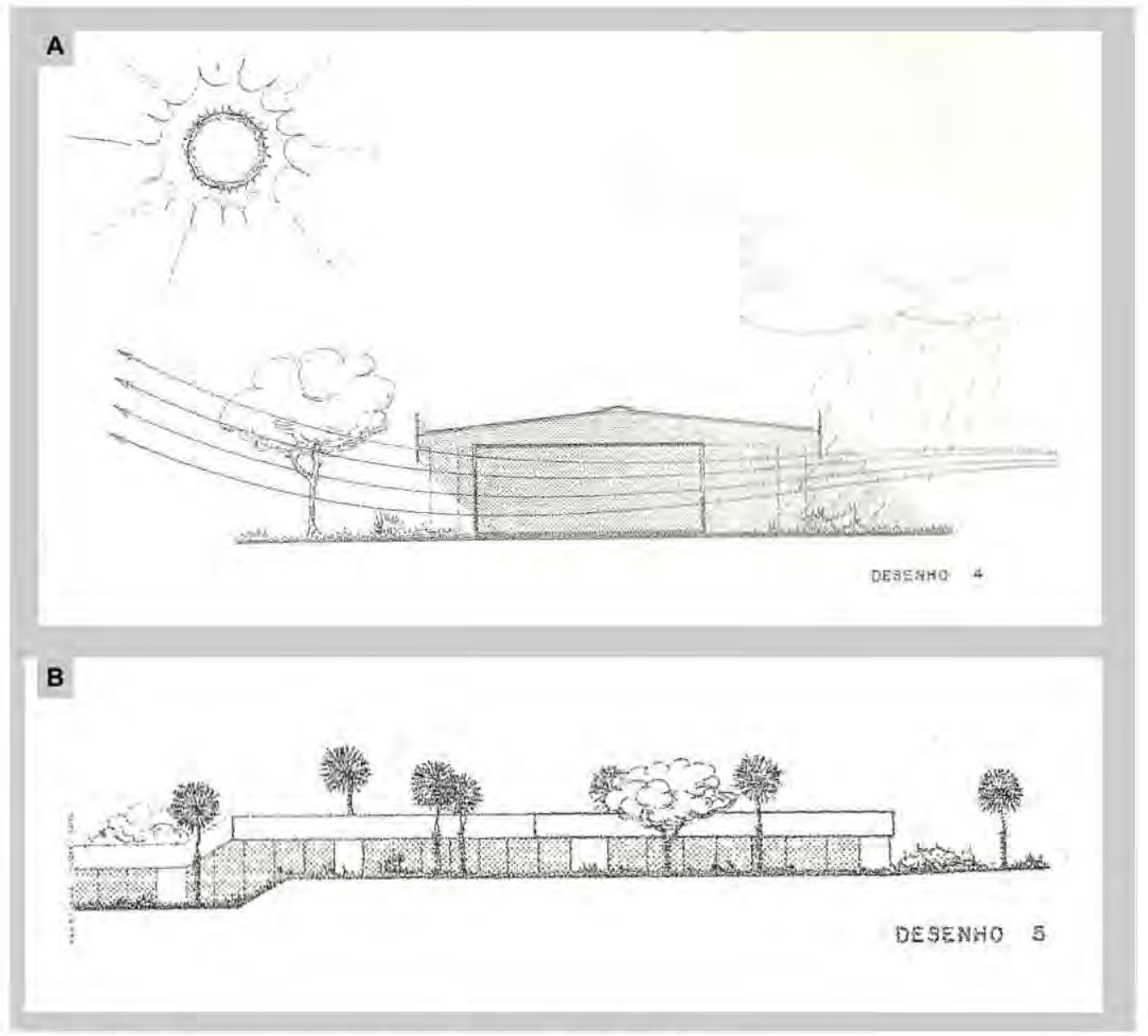

Figura 396: UFPI - Campus da Ininga - Fatores ambientais.

(A) Fluxo da ventilação - o partido adota a ventilação cruzada.

(B) O partido adequa-se aos desníveis do terreno.

(Fonte: FUFPI/CEPRO, 1977, p.122)

3. Dimensões do terreno: fator de limitação do espaço de solo a ser ocupado por edifícios.

4. Vegetação: aproveitamento das áreas ocupadas por concentrações vegetais de porte como zonas a serem preservadas, bem como tirar partido do babaçual nativo.

c. Econômicas: para obtenção do custo mínimo da construção sem perda do conforto ambiental necessário a cada atividade.

1. Materiais e técnicas construtivas (aproveitamento máximo da mão-de-obra e utilização de técnicas simples, mas que permitissem padronizações). 
O estudo dos condicionantes e das necessidades acadêmicas foi discutido exaustivamente em conjunto com o corpo docente, discente e administrativo da UFPI com o intuito de se estabelecerem as diretrizes gerais para a implantação definitiva do campus, bem como para definir as distâncias, orientação e localização dos edifícios, visando não só as condições de conforto ambiental e também soluções construtivas para atender ao binômio economia/funcionalidade (FUFPI. CEPRO, 1977, p.123). Note-se que o papel do arquiteto na concepção arquitetônica e urbanística deslocava-se do centro das decisões para assumir um papel de coordenador das demandas e anseios da comunidade acadêmica, elaborando um plano com características participativas.

Com essas diretrizes foi realizado o estudo preliminar para o Centro de Ciências Humanas e Letras, em 1977, que teve parte de sua construção concluída em 1980. Adotando o mesmo partido também foi erguido o Centro de Ciências da Educação. Os projetos desses edifícios serão discutidos no item das tipologias construtivas.

\section{- Continuidade na segunda metade da década de 1970}

As obras do Campus, embora com a dependência dos financiamentos, se mantinham em execução, motivo pela qual mais uma vez o órgão responsável pelo planejamento físico ressentiu-se da necessidade de ampliar seu quadro funcional para atender ao aumento da capacidade física da universidade, transformando o CEPRO em Diretoria de Projetos e Obras (DIPRO), estruturada em três partes: divisão de controle, divisão de projetos e divisão de manutenção.

Fato relevante nesse período foi a política adotada pelo PREMESU de integrar os escritórios técnicos administrativos dos campi das universidades brasileiras, no que diz respeito à execução de projetos e prestação de assistência técnica, fazendo com que as deficiências existentes em um deles fossem supridas, através de convênio, por outro, conseguindo com isto um compartilhamento do conhecimento adquirido sobre planejamento de campi. Com essa política, a DIPRO cumpriu o convênio celebrado entre a FUFPI e a Universidade Federal de Sergipe para a elaboração dos projetos de arquitetura e complementares de engenharia para os edifícios didáticos e departamentais desta universidade ${ }^{143}$ (UFPI, 1981 , p. 12).

Em 1977, foi realizada a contratação dos projetos para a conclusão definitiva da infraestrutura, pois a universidade constatara que havia chegado ao ápice do estrangulamento do seu espaço físico instalado no Setor de Serviços Gerais, campus

\footnotetext{
${ }^{143}$ Estes edificios estão apresentados na seção da Universidade Federal de Sergipe
} 
provisório, sem, contudo, ter conseguido a liberação dos recursos destinados ao campus definitivo.

Em 1978, a DIPRO, elaborou o plano de acesso ao Campus da Ininga e sua interligação ao Campus do Socopo, bem como os projetos de arquitetura, de infraestrutura e paisagismo e complementares de engenharia, do Campus do Irapuá, em Floriano, o Plano Diretor do Campus de Junco, em Picos, e os estudos preliminares da Escola de Educação Física e de urbanização do Setor Esportivo. No ano seguinte, manteve-se o ritmo de expansão com investimentos em todos os campi, cujas plantas mantinham diferentes propostas de ocupação (ver figuras de 397 a 400), conforme documento da DIPRO (UFPI, 1981, p.72-75)

No ano de 1979 , a complexidade das atividades demandou a cooperação técnica e de assessoria com o Centro de Tecnologia para a fiscalização das obras de infraestrutura do Campus da Ininga. No mesmo ano, foi elaborado novo plano de ocupação para o Setor Esportivo.

No final da década de 1970 , foram iniciadas as obras de construção do edifício destinado ao CCHL e CCE. Com o propósito de não ocorrer um processo de descontinuidade no desenvolvimento das obras do campus foi encaminhado ao MEC um novo projeto de financiamento para a conclusão do $\mathrm{CCHL}$ e a execução total do CCE. Entretanto, nos anos seguintes a redução dos investimentos em campi universitários por parte do governo federal atingiu a UFPI, que reduziu o ritmo das obras, limitando-se a construções de pequeno porte. A concepção do projeto para o setor didático-administrativo, iniciado com o CCHL e o CCE, não teve continuidade, e já na década de 1980 a construção do Centro de Tecnologia, sob a forma de blocos dissociados que se unem por passarelas cobertas, rompeu com a ideia de uma tipologia de malha expansiva.

Finalizamos o fluxo histórico descrito destacando que a DIPRO mantém até os dias de hoje as atividades de manutenção dos campi, serviços gerais, elaboração de projetos, construção e acompanhamento de obras, assumindo o papel de órgão de planejamento e gestão da infraestrutura física da UFPI.

Dando prosseguimento, apresentaremos os projetos dos edifícios que se constituíram nas primeiras edificações do Campus da Ininga: Galpões de Serviços Gerais (SGs), Centro de Ciências Humanas e Letras e Centro de Ciências da Educação. 


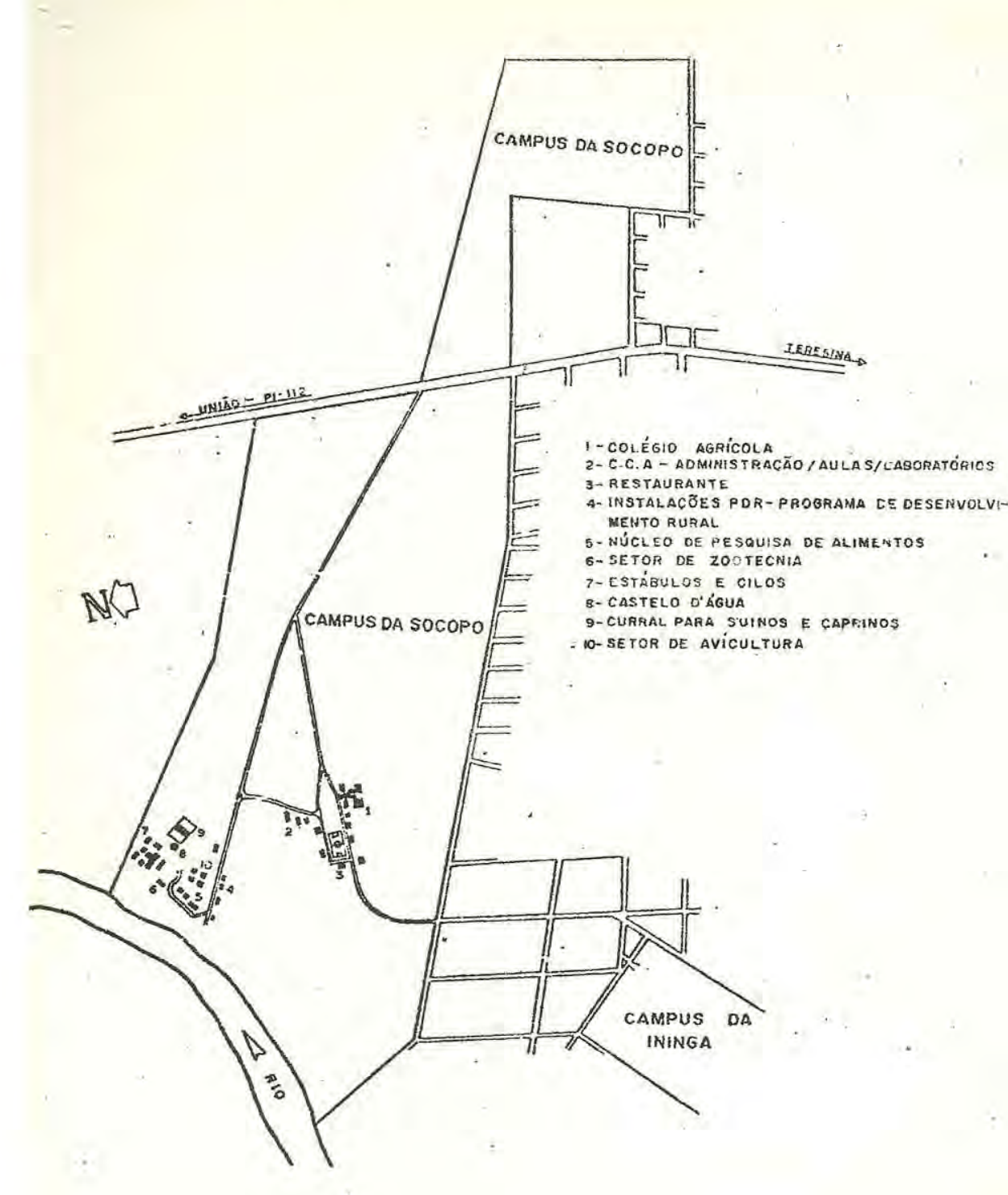

Figura 397: UFPI - Planta do Campus do Socopo Destinado ao Centro de Ciências Agrárias, situado próximo ao Campus da lninga.
(Fonte: UFPI, 1981, p.72)

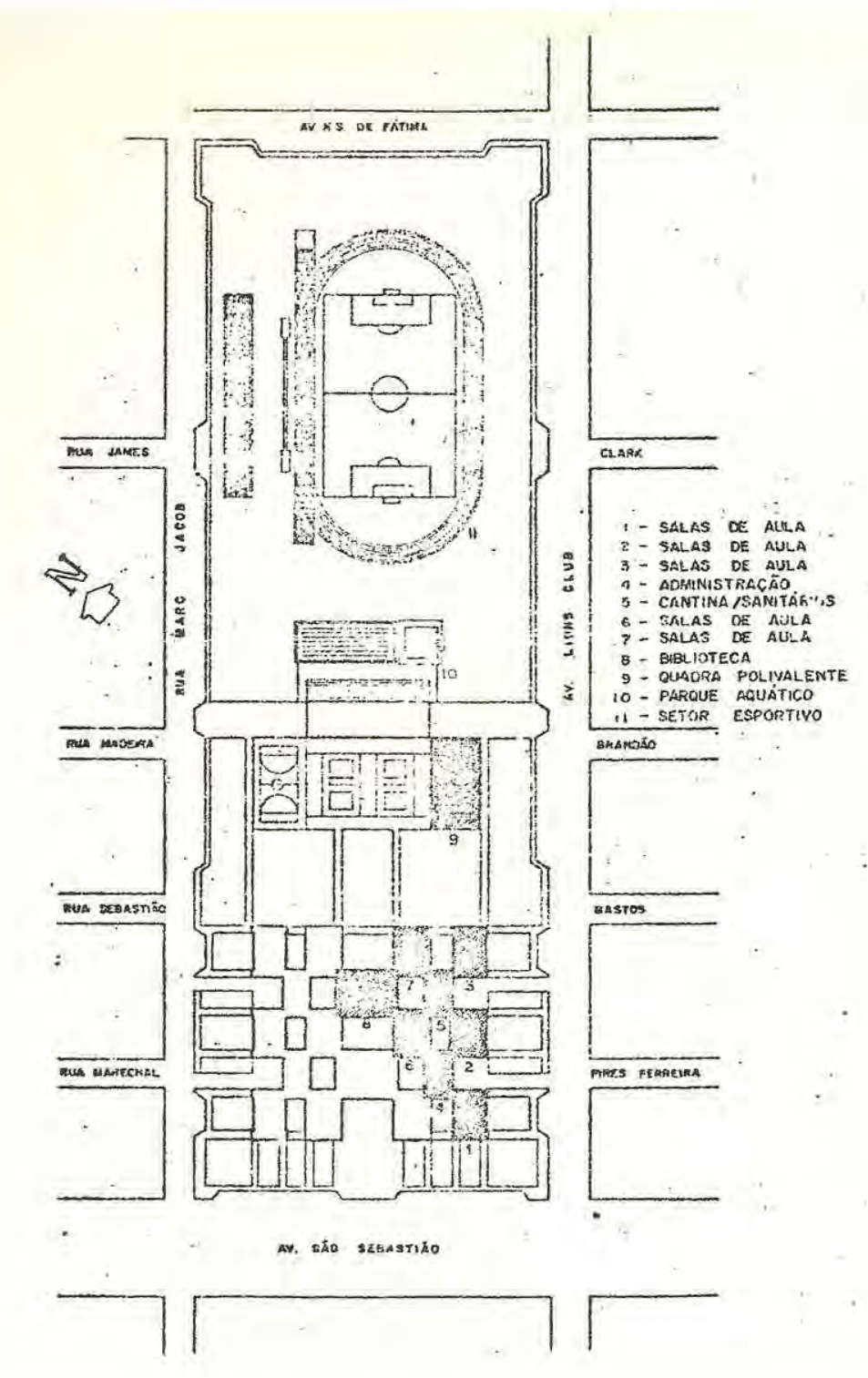

Figura 398: UFPI - Planta do Campus Ministro Reis Veloso, implantado na cidade de Parnaíba.
(Fonte: UFPI, 1981, p.73)
Figura 399: UFPI - Planta do Campus Arapuá, situado na cidade de Florian
(Fonte: UFPI, 1981, p.74)
Figura 400: UFPI - Planta do Campus do Junco, localizado na cidade de Picos.
(Fonte: UFPI, 1981, p.75) 
FOLHA VERSO DA FOLHA GRANDE, NÃO IMPRIMIR 


\subsection{TIPOLOGIAS CONSTRUTIVAS}

As análises que se seguem procuram assinalar os atributos predominantes que marcaram a concepção arquitetônica adotada. Questões como organização espacial, processo construtivo, estratégias de conforto térmico e o processo de projeto são aspectos dominantes dessa produção edilícia para responder à implantação da Reforma Universitária de 1968.

\section{- Galpão de Serviços Gerais}

O conjunto das dez unidades de galpões que compõem o Setor de Serviços Gerais foi implantado seguindo uma organização espacial do tipo pavilhonar, dividido em duas áreas de configuração longitudinal por uma via central de acesso para veículos, ficando com cinco unidades em cada lado. Atualmente o setor é composto por outras edificações e permanece abrigando funções didáticas e administrativas (ver figura 401).

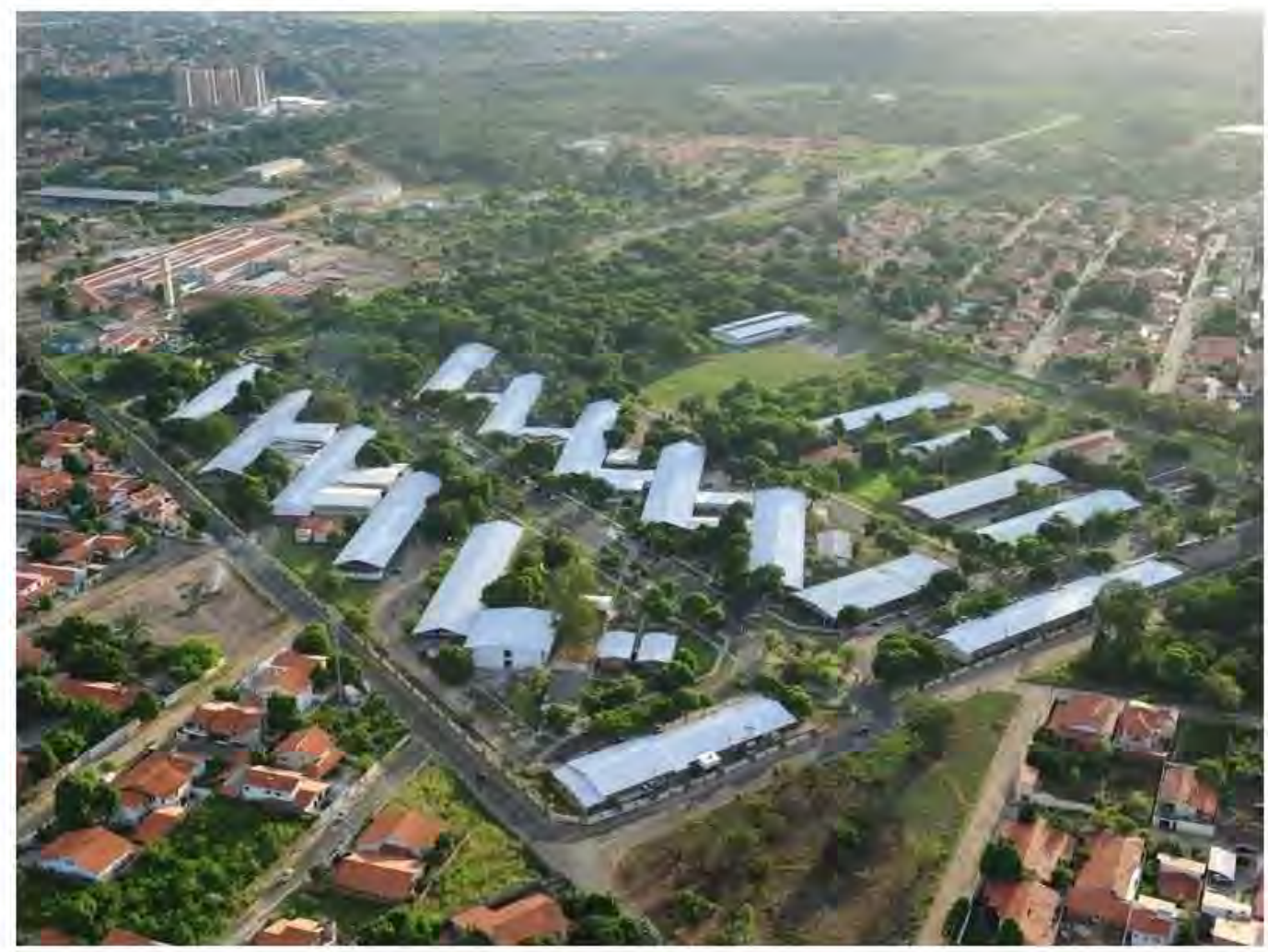

Figura 401: UFPI - Campus da Ininga, atual Campus Ministro Petrônio Portela - Século XXI. Vista do Setor de Serviços Gerais: a via central de veículos configura um arranjo urbanístico em forma de espinha de peixe. $O$ conjunto fica a nordeste do campus em faixa arborizada.

(Fonte: disponivel em <http://hww.skyscrapercity.com/showthread.php?t=1188883>. Acesso em: 19 jun. 2011). 
O partido arquitetônico caracteriza-se por uma tipologia de caixa prismática, que abriga as atividades funcionais, contornada por uma circulação periférica aberta e com sistema de cobertura em estrutura metálica treliçada de forma triangular e telha de fibrocimento (ver figura 402).

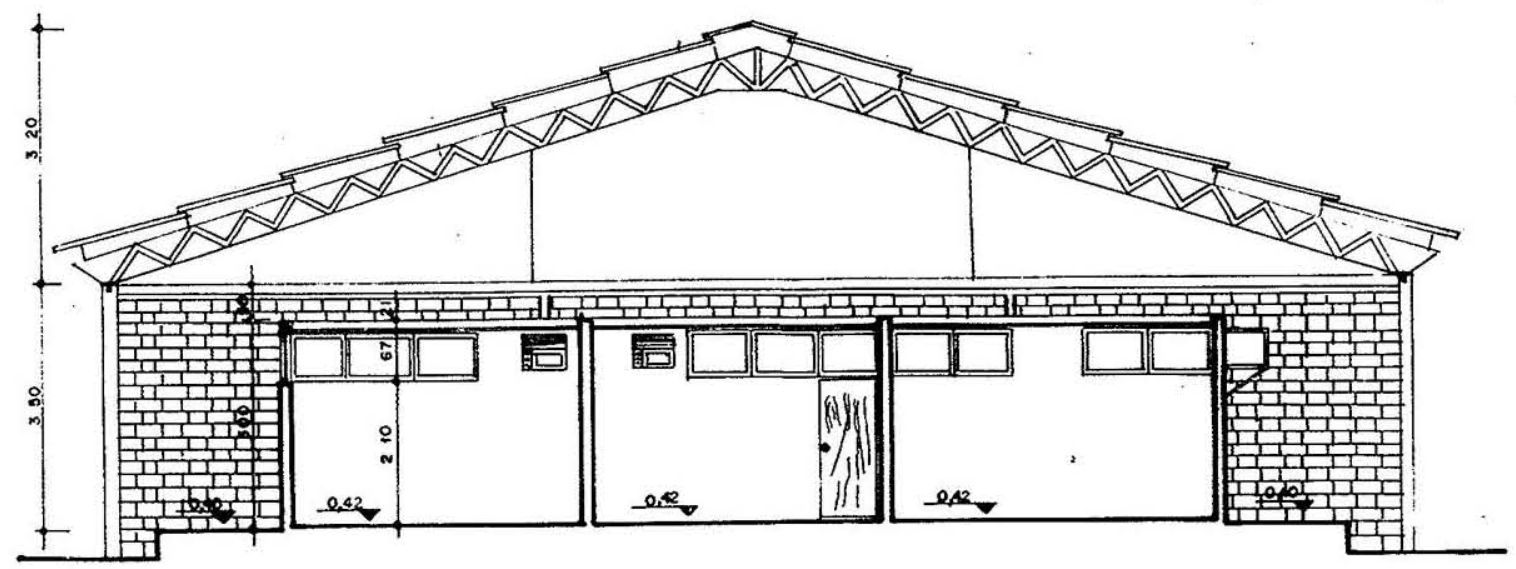

CORTE TRANSVERSAL-1

Figura 402: UFPI - Galpão metálico.

A coberta com estrutura metálica abriga no centro os ambientes divididos por alvenarias, bem como a circulação periférica que dá acesso aos mesmos.

(Fonte: Arquivo Geral - Prefeitura do Campus).

A concepção desta tipologia foi adotada à medida que demonstrou ser a solução mais rápida e de baixo custo para atender ao prazo limite de um ano de execução, quando então se daria a transferência das atividades da UFPI que ainda se encontravam funcionando em imóveis alugados no centro da cidade, para o Campus da Ininga.

A estrutura metálica foi executada por uma empresa cearense, a Hispano Estrutura Metálica Ltda., pois não havia naqueles anos indústria de metalurgia no Piauí. A trama vence um vão livre de $20 \mathrm{~m}$, com apoios em pilares de concreto aparente e espaçamento constante, formando uma malha estrutural que se desenvolve na direção longitudinal. A solução resulta na planta independente da cobertura. Pretendia-se com essa solução promover a ventilação cruzada para remoção do ar quente entre a telha e o forro, evitando-se assim o aumento da temperatura interna dos ambientes, ocasionado pela absorção da carga térmica através do forro.

O programa foi organizado de forma compartimentada na planta retangular, com divisões em alvenaria de tijolo e revestimento cerâmico, cercadas pela circulação periférica proporcionando uma faixa de sombreamento variável sobre as superfícies externas (alvenarias e esquadrias), conforme o movimento solar ao longo do dia (ver figura 403). 
Associou-se a esta solução o uso do forro em placas de gesso no interior dos ambientes e a distribuição de vãos de abertura com esquadrias de alumínio.

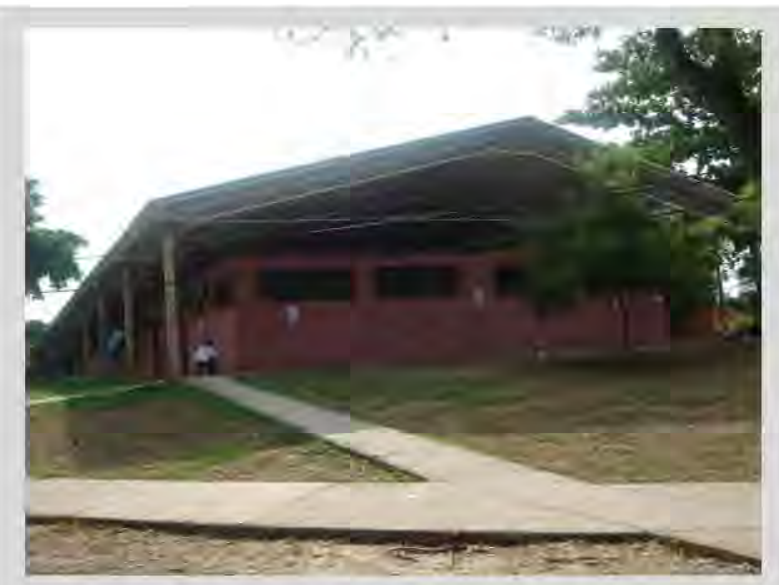

(A)

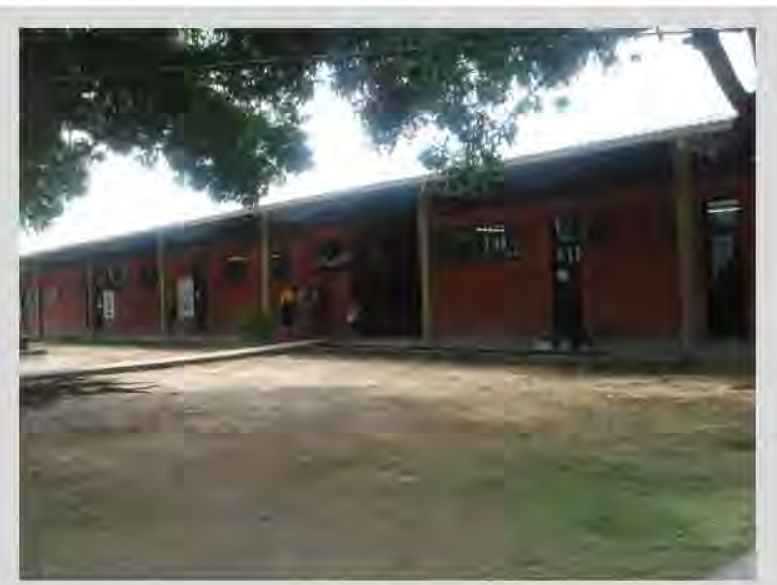

(B)

Figura 403: UFPI - Galpão do Setor de Serviços Gerais.

(A) Vista da fachada voltada para a via central de veículos.

(B) Vista da fachada lateral com acesso aos ambientes pela circulação periférica

(Fonte: Acervo Magda Campêlo, 2009).

A forma alongada da planta no eixo leste-oeste é recomendada para a Região Nordeste, a fim de que os ventos dominantes de sudeste atravessem a edificação, favorecendo o conforto ambiental (ABNT 2005; SILVEIRA, 2007, OLGYAY, 1998 apud AFONSO e NEGREIRO, 2010, p. 151). Com essa orientação, a implantação dos galpões com as maiores fachadas no eixo sudeste-noroeste assinala a provável intenção de adequação da proposta urbanística aos condicionantes climáticos.

De maneira geral, as soluções de projeto evidenciam o propósito de adotar estratégias para proporcionar o movimento do ar como meio de amenização do calor excessivo causado pelas altas temperaturas que caracterizam o clima da cidade de Teresina como um dos mais quentes do Brasil. Entretanto, os resultados não se revelaram suficientemente eficazes, uma vez que o movimento das massas de ar se dá somente no nível da coberta, não ocorrendo a ventilação no interior dos ambientes para retirada do calor, pois as esquadrias funcionam somente para entrada do ar, faltando no sentido oposto as aberturas de saída, solução que conduziria à retirada do ar quente no interior dos ambientes ou por meio da ventilação cruzada, ou pela convecção natural. Para amenizar o rigor das temperaturas, foi adotada a climatização artificial.

Analisando-se a planta de arquitetura do Galpão SG-04, destinado ao funcionamento temporário de atividades didáticas, as divisões ocorrem por meio de uma alvenaria de eixo 
central que cria duas alas com acessos por meio da circulação periférica que se prolonga de maneira a acessar o conjunto de salas situado em uma das extremidades do galpão (ver projeto da figura 404). A organização do programa de forma compartimentada na planta constitui uma concepção funcional referente ao Setor de Serviços Gerais. O padrão foi adotado em outros projetos similares, conforme se constata nos galpões SG-11, SG13 e SG16 (ver projetos nas figuras 405 a 407 ) construídos posteriormente.

Destaca-se o propósito de adotar um padrão construtivo que atendesse aos requisitos da adequação climática associados prioritariamente ao menor prazo e ao baixo custo de execução da obra. O resultado formal da tipologia não revela qualquer intenção plástica de caráter expressivo.

\section{- Centro de Ciências Humanas e Letras ( $\mathrm{CCHL})$}

O $\mathrm{CCHL}$ foi o primeiro a ter recursos disponibilizados para execução dos blocos definitivos que abrigariam suas atividades. Funcionava provisoriamente no Galpão SG4, situado no Setor de Serviços Gerais do campus, com área construída de $1.953 \mathrm{~m}^{2}$, além de ocupar $50 \%$ em uma edificação vizinha. Para atender o turno da noite, utilizava também parte do Galpão SG2. Entretanto, a necessidade de desmembramento da sua estrutura funcional, com a ampliação dos seus setores para atender à expansão de novos cursos, acarretou a carência de espaços físicos que já se encontravam limitados, uma vez que os edifícios nos quais estava instalado não tinham sido projetados para suas finalidades. As consequências dessa situação estão justificadas no seguinte texto:

Devido à carência de espaço, os professores do referido Centro estão privados de acomodações, o que além de impedir os trabalhos de preparação de aulas e a integração dos responsáveis pelas diversas disciplinas, representa ainda um desestímulo à permanência no Campus Universitário.

São consequências também da impossibilidade de expansão os sucessivos desmembramentos de seus setores, prejudiciais ao funcionamento global das atividades do Centro (FUFPI. CEPRO, 1977, p.26).

O documento explicita ainda que cabia ao $\mathrm{CCHL}$ a responsabilidade de coordenar o Ciclo Geral de Estudos (Básico Geral e Básico Específico de Humanidades), necessitando assim de instalações adequadas, até então inexistentes (FUFPI/CEPRO, 1977, p.27). Era premente a construção do novo edifício para o $\mathrm{CCHL}$. 


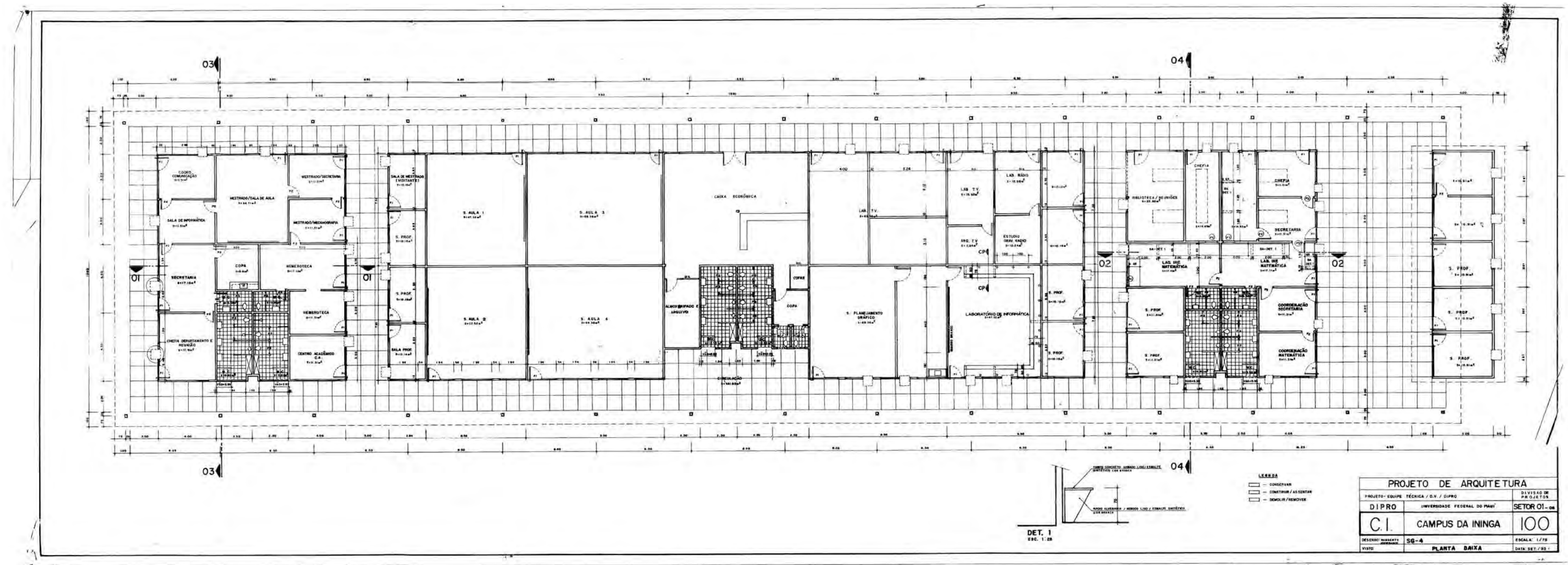

$\longdiv { 2 4 }$ 


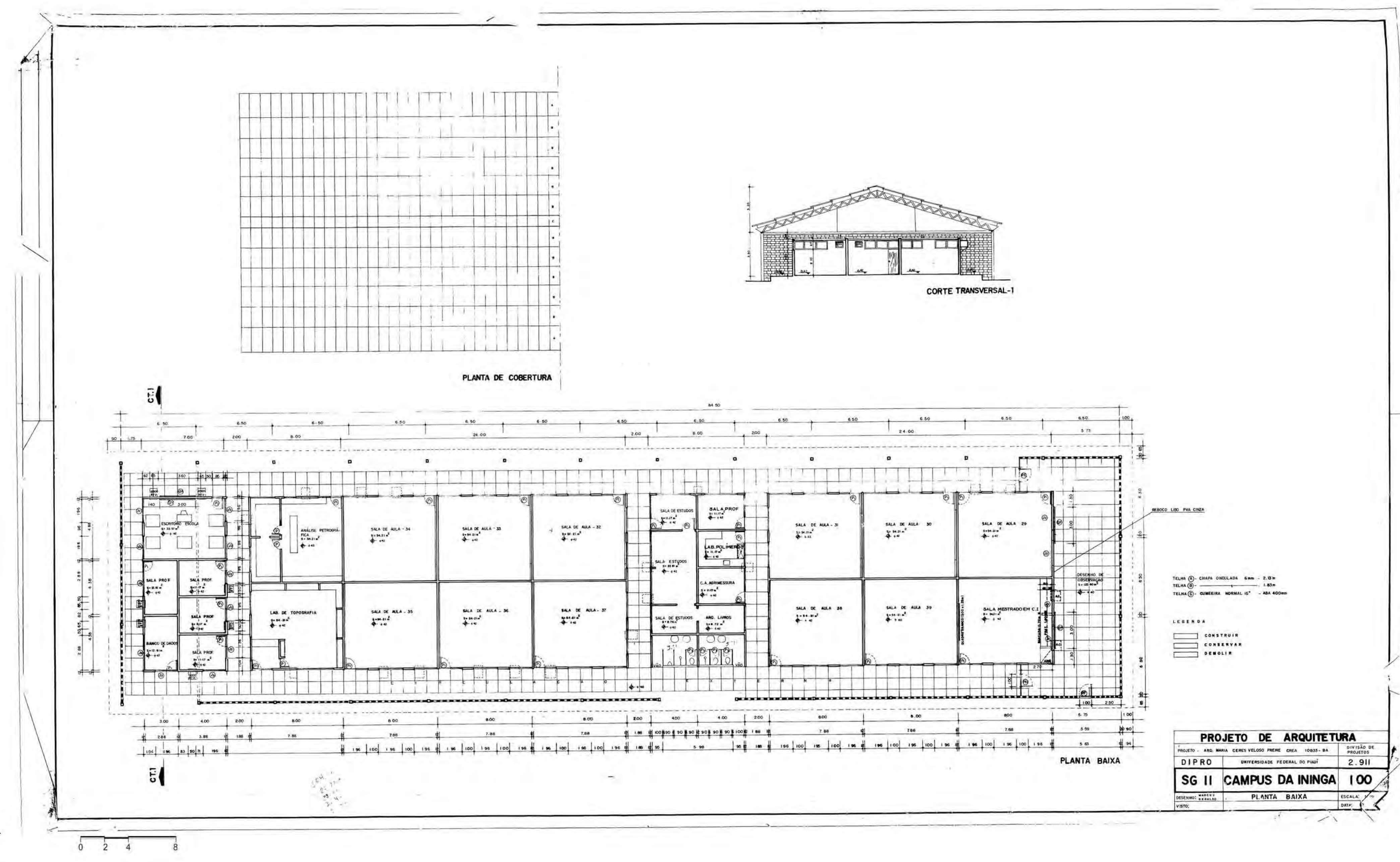



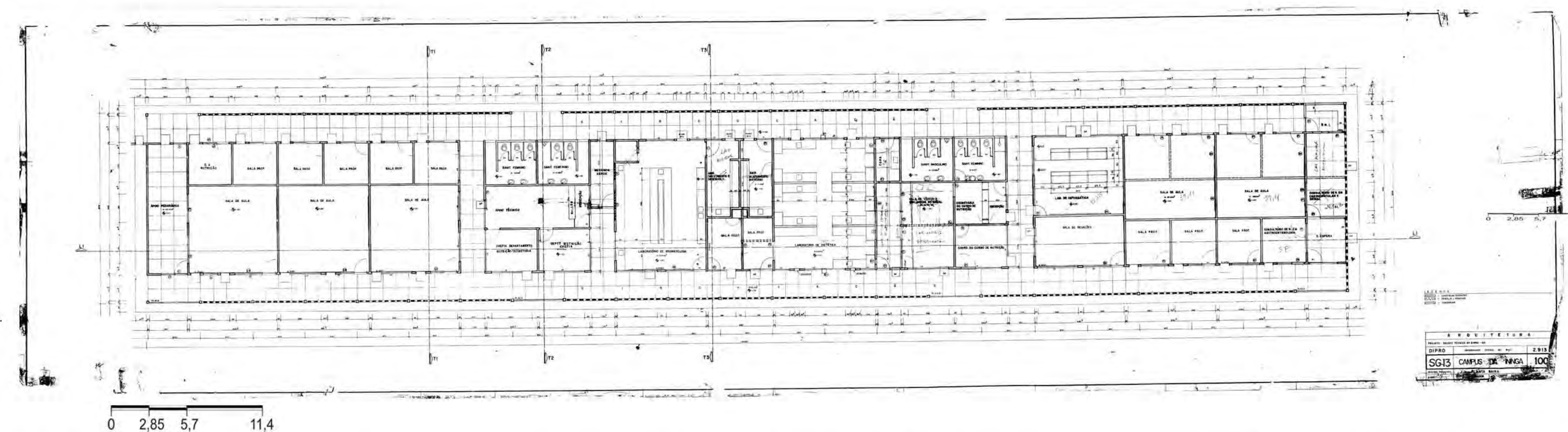

$\begin{array}{lll}0 & 2,85 & 5,7 \quad 11,4\end{array}$

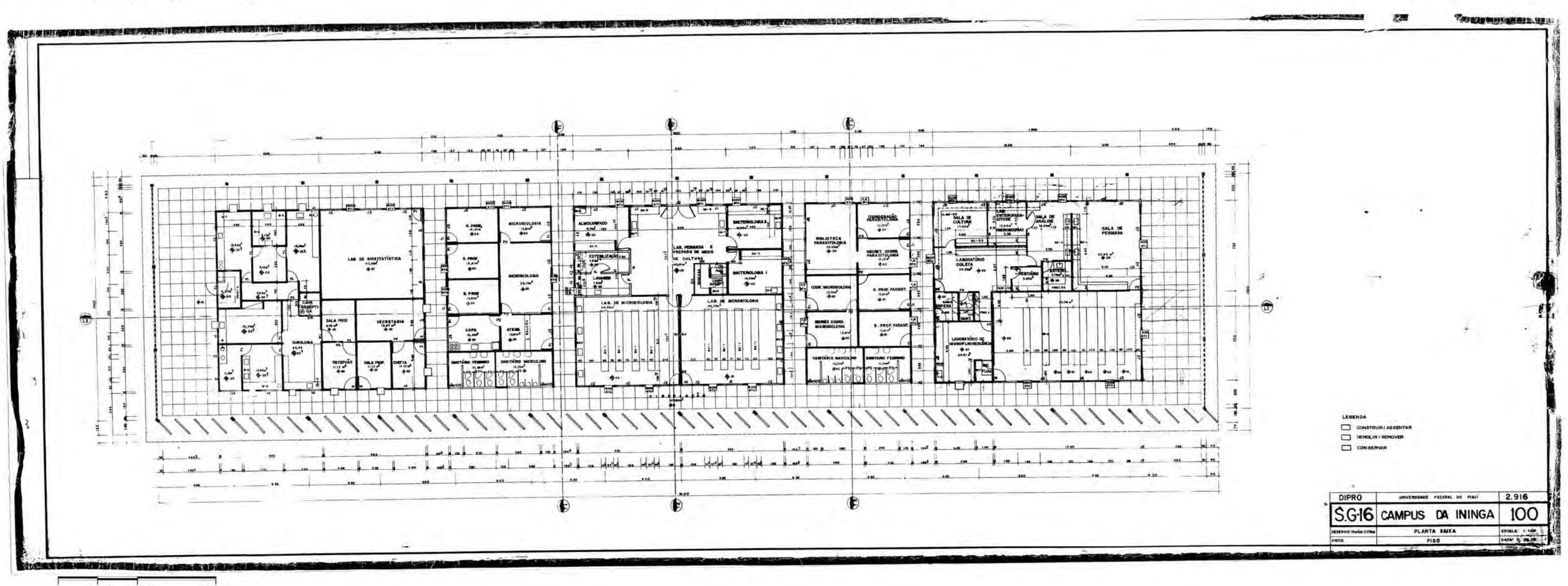


FOLHA VERSO DA FOLHA GRANDE, NÃO IMPRIMIR 
Com tais justificativas, foi iniciado o processo de projeto com a definição e dimensionamento do programa de necessidades. Esta etapa contou com a participação do corpo docente nas discussões sobre as carências específicas de cada departamento, da própria universidade e da região. Buscava-se uma abordagem que pudesse superar as dificuldades no levantamento dos dados, da falta de bibliografia especializada, e dos projetos econômicos, financeiros e de recursos humanos.

Estabeleceu-se como critério geral que o programa proposto deveria contribuir para o atendimento integrado de todas as necessidades levantadas, tanto curriculares como administrativas, emanadas do Regimento da UFPI e pelas diretrizes da Reforma Universitária (FUFPI. CEPRO, 1977, p.28, grifo nosso).

Considerou-se a projeção de expansão para 1980, tendo em vista que, de acordo com o projeto de implantação da universidade, naquela data, o crescimento estaria estabilizado. Foram contabilizados não só os alunos do $\mathrm{CCHL}$ como também aqueles das várias outras licenciaturas ministradas por outros centros, que tinham obrigação de cursar as disciplinas pedagógicas, conforme definição da política de ensino.

A demanda dos ambientes tomou por base o número de alunos, as cargas horárias curriculares e a distribuição do número de professores, segundo o regime de trabalho ( 40 ou 20 horas semanais). Os espaços para as atividades administrativas, de serviços de suporte e complementares foram quantificados através do próprio regime do $\mathrm{CCHL}$, enquanto aqueles destinados para as atividades programadas e de ensino foram calculados por departamento, com base nas atividades em desenvolvimento e na projeção calculada para 1980. Dado importante é que o número de alunos não estava relacionado ao aluno-cabeça e sim ao aluno/hora, por disciplina, isto é, ao produto do número de alunos de uma disciplina pela carga horária dessa disciplina. Esse é um dado que indica a orientação da Reforma Universitária no sentido de otimização dos meios para fins específicos.

Incorporando também as diretrizes do plano diretor que, conforme já exposto, havia se definido por uma tipologia que permitisse o acréscimo de áreas, de acordo com a necessidade de novas demandas, e com crescimento associado a uma malha modular ortogonal que ordenava a expansão em várias direções do campus foi dado início ao prédimensionamento dos ambientes.

Primeiramente foram realizados levantamentos in loco e análise de programas elaborados por outras universidades brasileiras para centros congêneres, como a Universidade Federal de Minas Gerais (UFMG) e a Universidade de São Paulo (USP), as experiências em trabalhos semelhantes da UFPI, dados fornecidos pelo Centro Brasileiro de Construções e Equipamentos Escolares (CEBRACE) e normas técnicas vigentes. 
Como método de projeto, foi elaborado um fichamento de todos os ambientes, contendo plantas de layout desenvolvidas sobre uma malha modular quadriculada com dimensões representativas de $1 \times 1 \mathrm{~m}$, características quantitativas referentes às dimensões e número de usuários por ambiente, as relações de interdependência entre os ambientes, as condições de conforto térmico e instalações prediais necessárias ao correto desenvolvimento das atividades. Um exaustivo estudo contendo índices, fórmulas, croquis e tabelas compuseram o documento que embasou o programa de necessidades. Estabeleceram-se índices de ocupação por ambiente, de utilização dos estacionamentos e de quantificação das instalações sanitárias (ver exemplos apresentados nas fig. 408 a 413).

A solução construtiva buscou responder aos aspectos funcionais e às condições de conforto térmico, embasada pela investigação detalhada da carga térmica solar absorvida nas fachadas e, consequentemente, soluções de proteção solar. A linguagem arquitetônica caracterizou-se pelos elementos de proteção solar tais como 0 uso de beirais para proporcionar sombreamento nas fachadas, placas horizontais e verticais para desviar a incidência solar indesejada nos ambientes e pelo sistema construtivo em concreto aparente.

O sistema construtivo empregado baseava-se na repetição de pórticos rígidos em concreto aparente, onde os pilares funcionavam como brises. O sistema de cobertura era composto por vigas metálicas, indicando a preferência pelo alumínio, para minimizar os problemas de oxidação. Para o forro foi indicada laje do tipo volterrana ou similar com luminárias embutidas e, para o piso, concreto polido. As paredes de vedação deveriam ser em alvenaria de tijolo à galga, rebocadas e revestidas com pintura à base de PVA com esquadrias de alumínio anodizado e abertura maximar (ver figura 414).

Organizado o programa de necessidades, passou-se à elaboração do partido arquitetônico orientado por parâmetros que intencionavam sintetizar uma proposta adequada aos condicionantes locais. Para os autores da proposta, tratava-se de um processo de fácil execução e adequado ao know-how da região. Esta é uma afirmação que parece basear-se na produção arquitetônica moderna que vinha se consolidando no local. De fato, a execução do concreto não apresentava complexidade, pois essa tecnologia vinha sendo empregada na cidade de Teresina, com mais intensidade, desde o final da década de 1960, quando começou a se desenvolver de forma mais contínua uma produção de linguagem moderna, que dava ênfase à estrutura do concreto aparente, grandes panos de esquadrias e arrojadas soluções arquitetônicas, tanto no partido adotado como no emprego de novos materiais ${ }^{144}$

\footnotetext{
${ }^{144} \mathrm{Com}$ a chegada de arquitetos como Antônio Luiz e Miguel Caddah,na cidade de Teresina, no final da década de 1960 , começaram a se desenvolver com continuidade intervençōes modernas na paisagem urbana (AFONSO; NEGREIROS; 2010 , p.24). Era uma produção que trazia, no seu bojo, a essência do movimento moderno, com a utilização de modulação, ênfase na estrutura e no uso de novos materiais como o concreto aparente.
} 


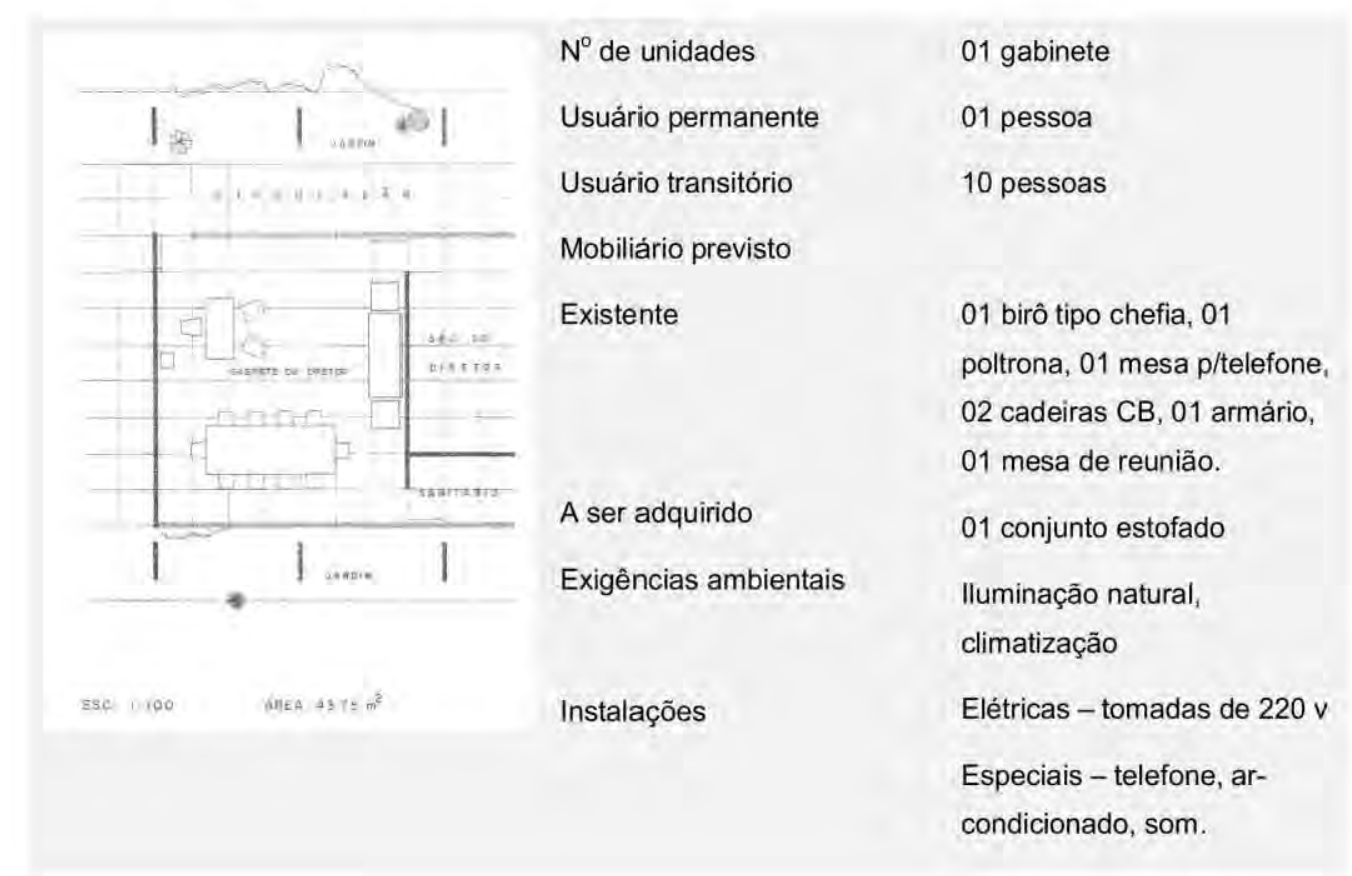

Figura 408: UFPI - Diretoria: gabinete do diretor
(Fonte: FUFPI. CEPRO, 1977, p.54)

- Coordenação de cursos/secretaria

Local destinado à recepção, espera e secretaria da coordenação.

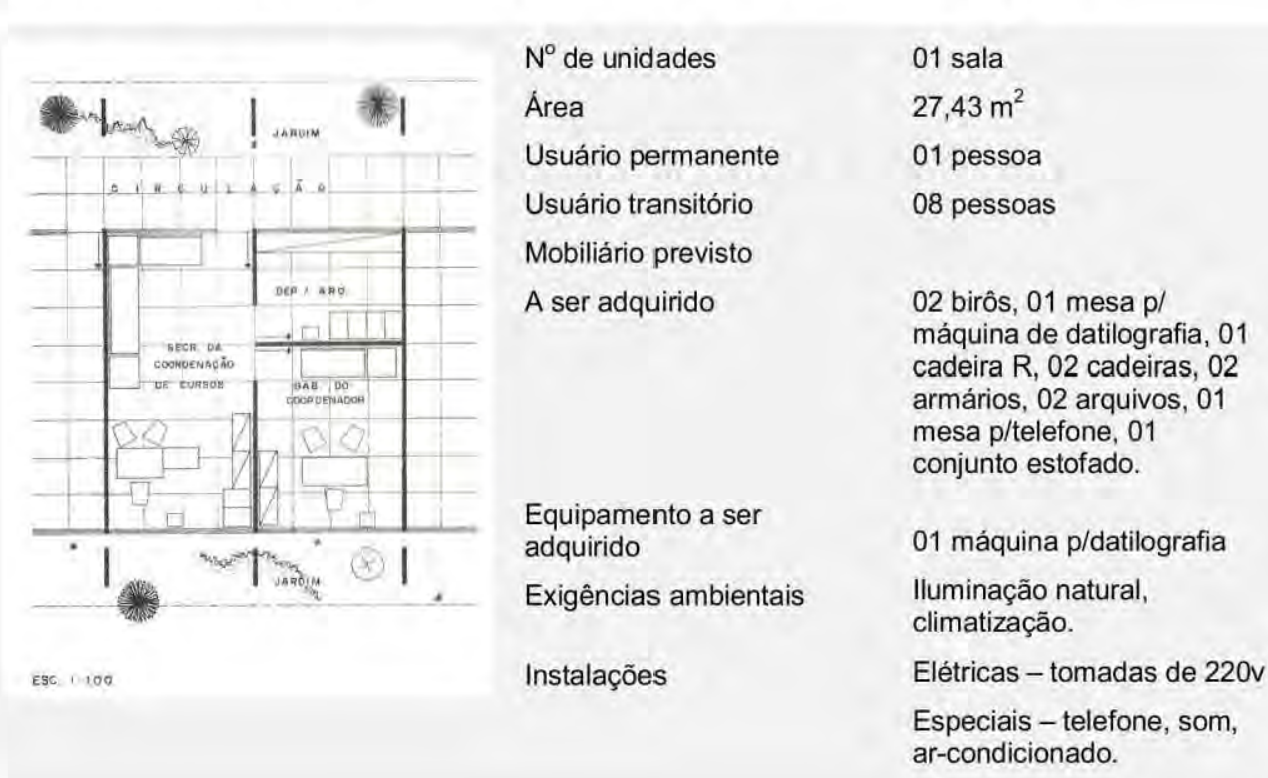

Figura 409: UFPI - Coordenaçăo de cursos: secretaria
(Fonte: FUFPI/CEPRO, 1977, p.71)
- Departamento/secretaria

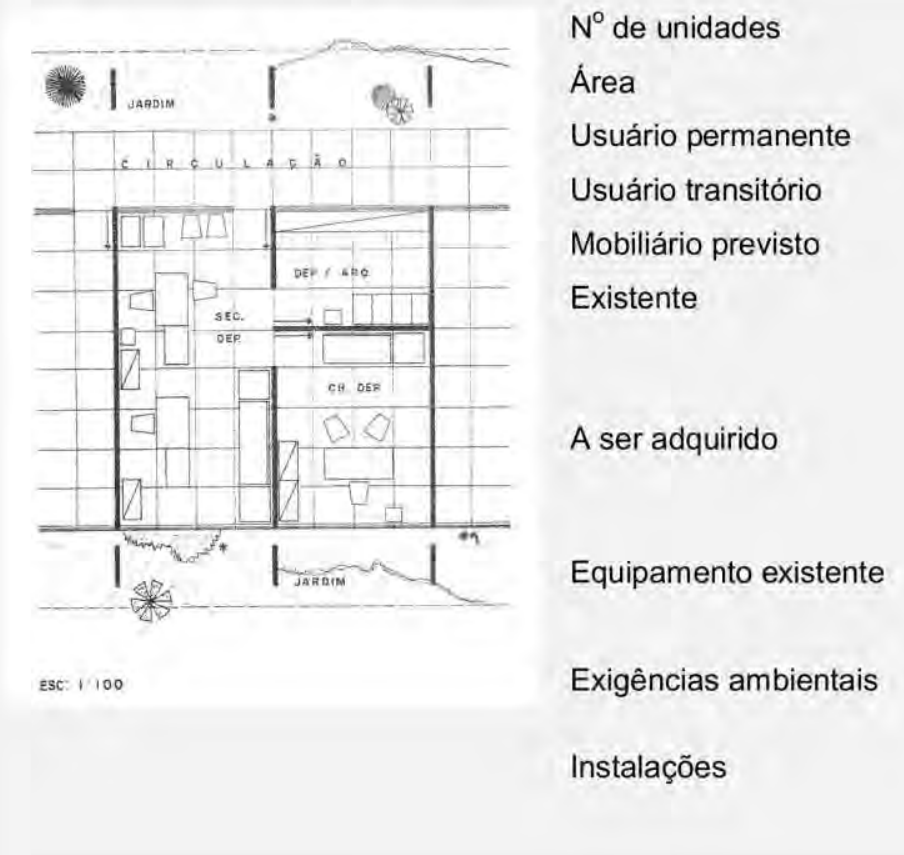

06 salas

02 pessoas

06 pessoas

02 birôs, 02 cadeiras $R, 01$

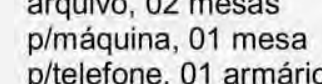

p/telefóne, 01 armário.

03 cadeiras B, 01 armáric
01 conjunto estofado.

02 máquinas p/datilografia lluminacăão ventilaçăo
naturais. naturais.
Elétricas - tomadas de $220 \mathrm{~V}$ Especiais - telefone, som quadros p/avisos.

Figura 410: UFPI - Departamento: secretaria.
(Fonte: FUFPI. CEPRO, 1977, p.74)

\section{- Departamento/sala para professores}

Local destinado a estudos, trabalhos, pesquisas, etc., de professores em regime de $40 \mathrm{~h}, 20 \mathrm{~h}$ e professores visitantes.

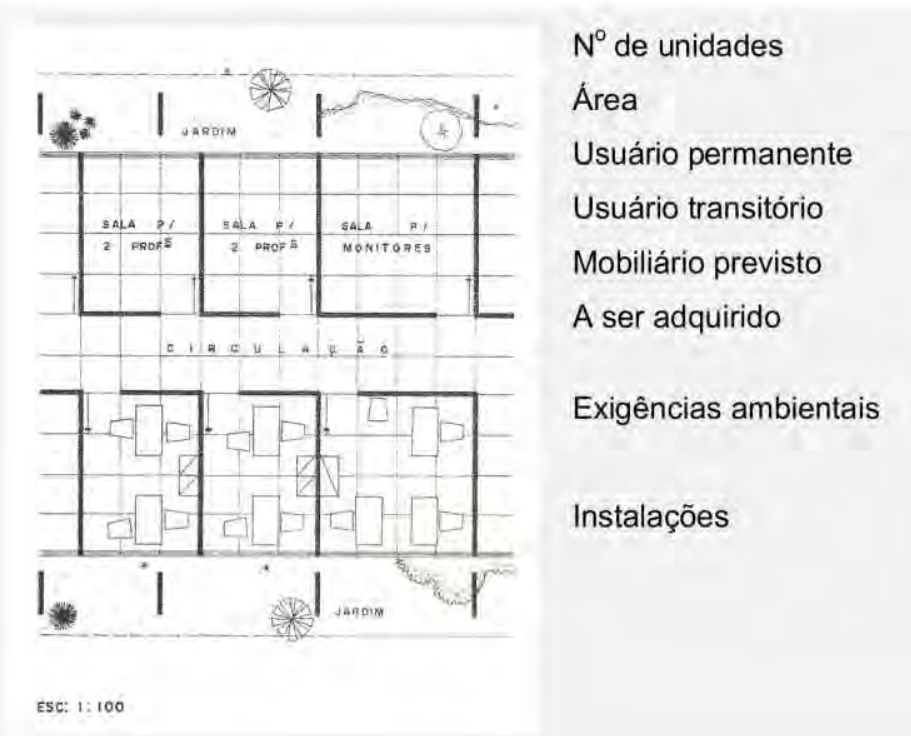

48 salas

(3)

04 pessoas

02 birôs, 04 cadeiras B, 02

Iluminaçăo e ventilaçăo

Elétricas - tomadas de $220 \mathrm{v}$

Especiais- som.

tse: : : : : 00

Figura 411: UFPI - Departamento: sala para professores / sala para monitores
- Sala para aulas expositivas/tipo 1- de 42 a 56 alunos

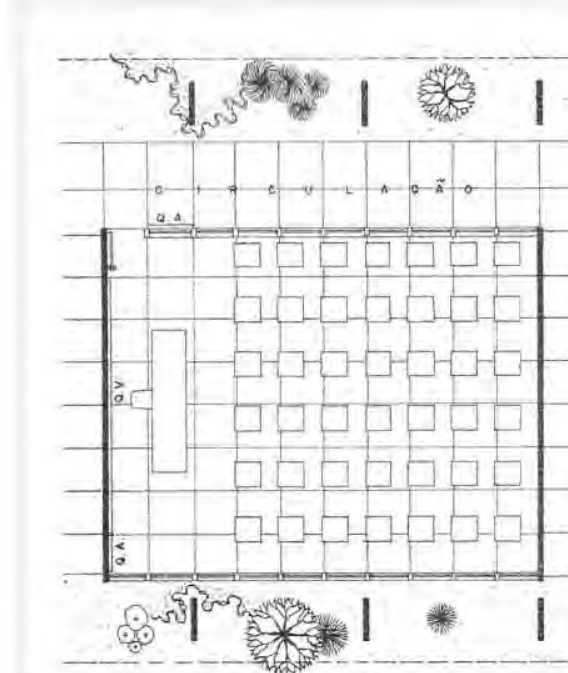

$N^{\circ}$ de unidades $\quad 12$ salas

Usuário transitório

Mobiliário previsto

Existente

1 pessoas

1 mesa tipo professor

1 cadeira, 42 carteiras

Equipamento previsto

A ser executado

Exigências ambientais

Quadro verde, quadros $\mathrm{de}$

Iluminação e ventilação

Instalaçōes

Elétricas - tomadas de
$220 \mathrm{v}$

Especiais - som
Figura 412: UFPI - Sala para aulas expositivas: tipo 1 - de 42 a 56 alunos.
(Fonte: FuFPl. CEPRO, 1977, p.91)

- Sala para aulas expositivas / tipo 2 - de 30 a 42 alunos

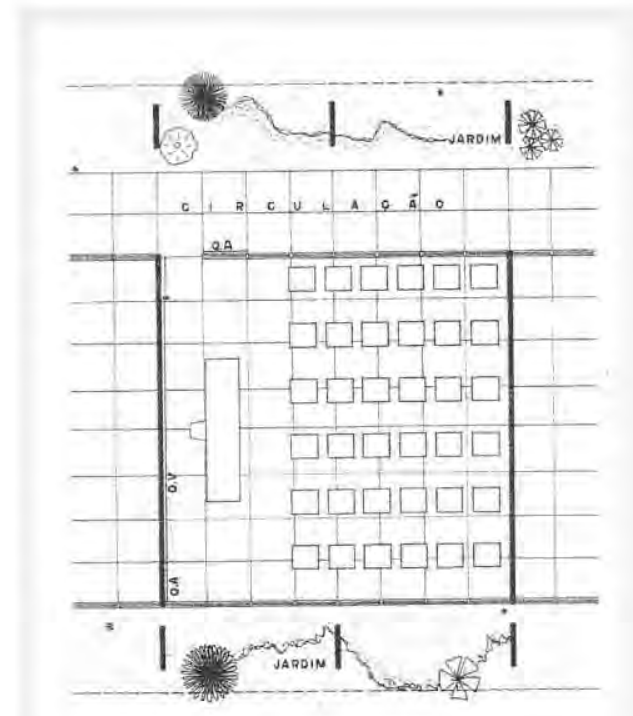

Usuário transitório

Mobiliário previsto

Existente

Equipamento previsto

A ser executado

Exigências ambientais

Instalaçōes

Elétricas - tomadas de
$220 \mathrm{v}$

Especiais - som
16 salas

01 mesa tipo professor, cadeira, 30 carteiras po escola lluminação e ventilação
naturąis 
FOLHA VERSO DA FOLHA GRANDE, NÃO IMPRIMIR 


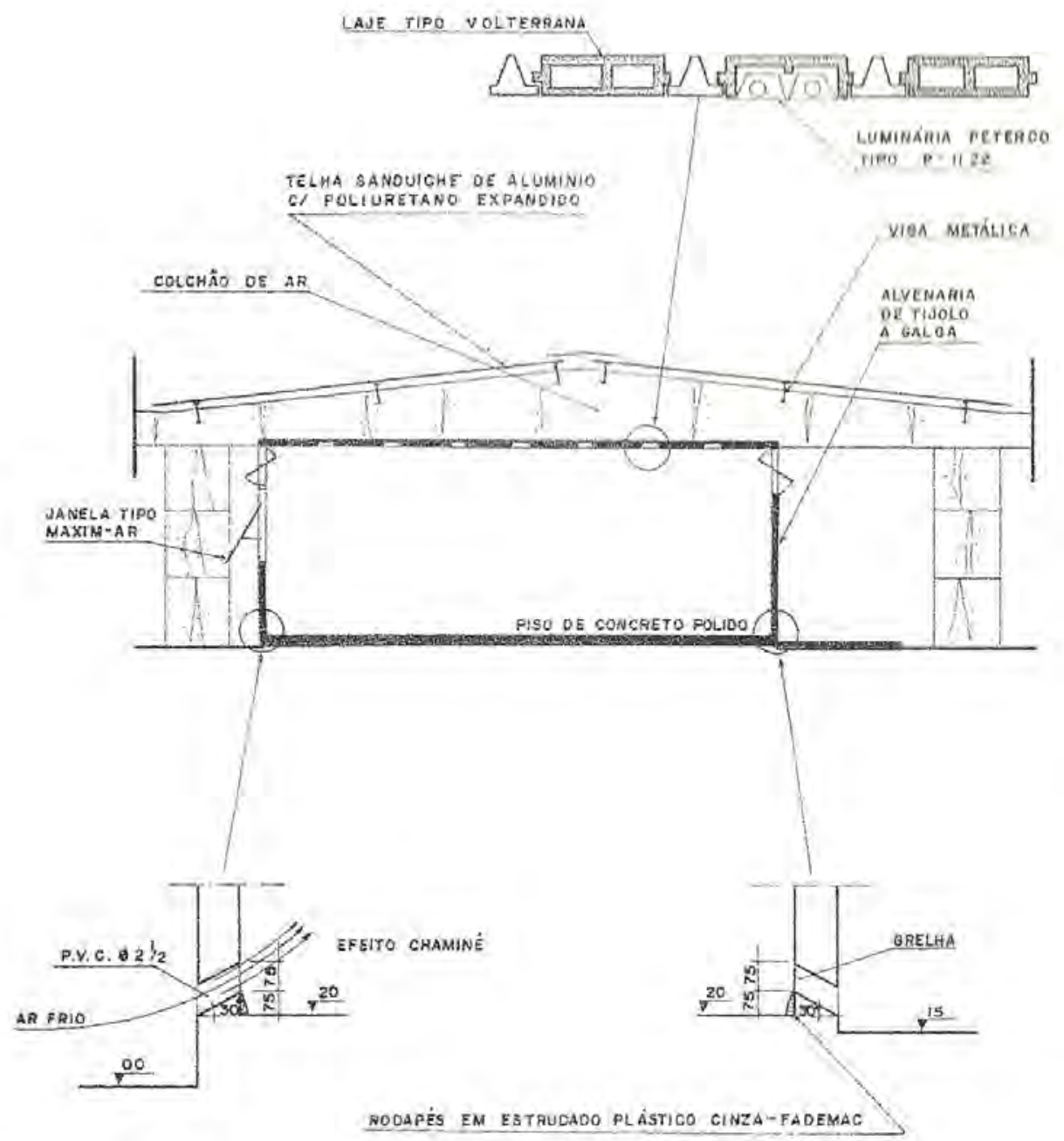

Figura 414: UFPI - Síntese do sistema construtivo proposto.

(Fonte: FUFPI. CEPRO, 1977, p.138)

Outro aspecto a se ressaltar é o amplo uso do tijolo na região, que tornava o processo construtivo de fácil domínio no canteiro de obras, além de baratear o valor da construção. Da mesma forma, o baixo custo dos revestimentos indicados e a facilidade de manutenção corroboravam a proposta que buscava responder aos aspectos de economia e funcionalidade.

No tocante aos condicionantes climáticos, eles foram determinantes na definição do partido arquitetônico. Os estudos relativos à trajetória solar e ao regime de ventos embasaram as definições referentes ao posicionamento dos blocos, o uso de dispositivos de proteção solar para as esquadrias e as soluçőes para aplicação da ventilação natural. As medidas adotadas eram orientadas pelo gráfico de insolação e referente à cidade de Teresina (ver figuras 415 e 416 ). 


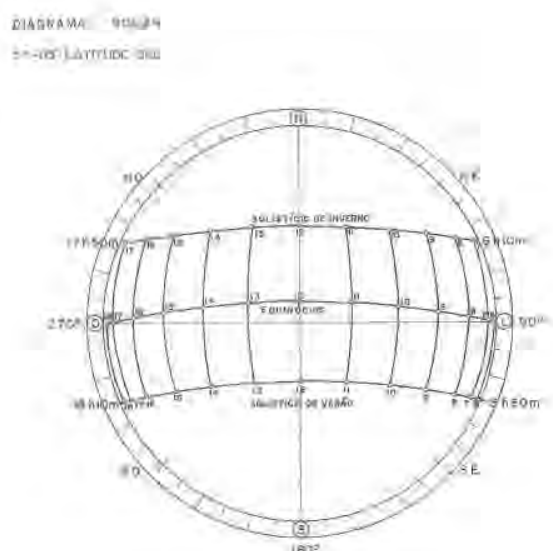

Figura 415: UFPI - Gráfico de insolação para o Campus da Ininga.

O movimento do sol na direção leste-oeste determinou o posicionamento das edificaçốes na direção norte-sul, que indicava ser a solução mais viável para obter proteção solar mais econômica e melhor aproveitamento dos ventos.

(Fonte: FUFPI. CEPRO, 1977, p.15)

O estudo da trajetória solar indicava que, para que a carga térmica de uma das edificações não se propagasse às unidades vizinhas, o distanciamento entre as mesmas deveria ser de três vezes a sua altura, o que possibilitaria a dissipação do calor acumulado pelas áreas livres circundantes. Nestas seria mantida a vegetação existente e plantadas árvores de copa larga e fuste alto. Para os bolsões de estacionamento deveria ser adotado o piso em lajotas de concreto pré-fabricadas, evitando-se a existência de superfícies escuras, tais como o asfalto (FUFPI. CEPRO, 1977, p.15).

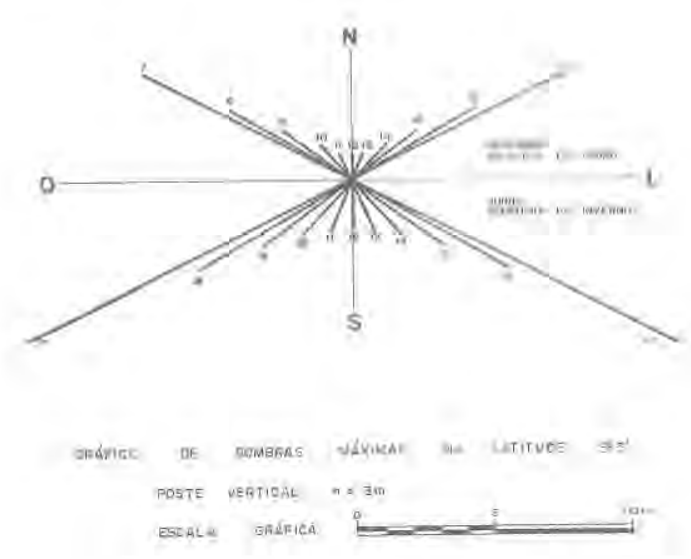

Figura 416: UFPI - Gráfico de sombras máximas na latitude $5^{\circ} 5^{\prime}$.

0 estudo revela que em consequência da posição equatorial da cidade de Teresina, a dimensão das sombras solares laterais, para norte ou para sul, dependendo dos solstícios (dezembro e junho), não diferem muito entre si. Ainda em consequência dessa posição geográfica e da altitude da cidade verifica-se que não há muita diferença entre as médias de temperatura durante o ano (cerca de $5^{\circ} \mathrm{C}$ ). Se em junho, no solstício de inverno, o sol se encontrando no hemisfério norte provoca uma queda de temperatura, em dezembro reduz a intensidade das radiações solares e aumenta a umidade do $\operatorname{ar}_{1}$ amenizando o rigor climático.

(Fonte: FUFPI. CEPRO, 1977, p.16) 
O estudo de sombras permitia afirmar que as fachadas orientadas na direção norte-sul, com variação de $5^{\circ} \mathrm{C}$, indicava ser suficiente beirais extensos. Já as fachadas com orientação leste-oeste, com variação de $5^{\circ} \mathrm{C}$, apontavam a necessidade de placas solares horizontais. Qualquer outro encaminhamento exigiria o uso de protetores verticais, sem dispensa dos beirais, o que encareceria a obra (FUFPI. CEPRO, 1977, p.16). A investigação resultou na adoção de lâminas pré-fabricadas de concreto sob a forma de beirais e brises, colocadas nas fachadas conforme análises apresentadas nas figuras de 417 a 421 .

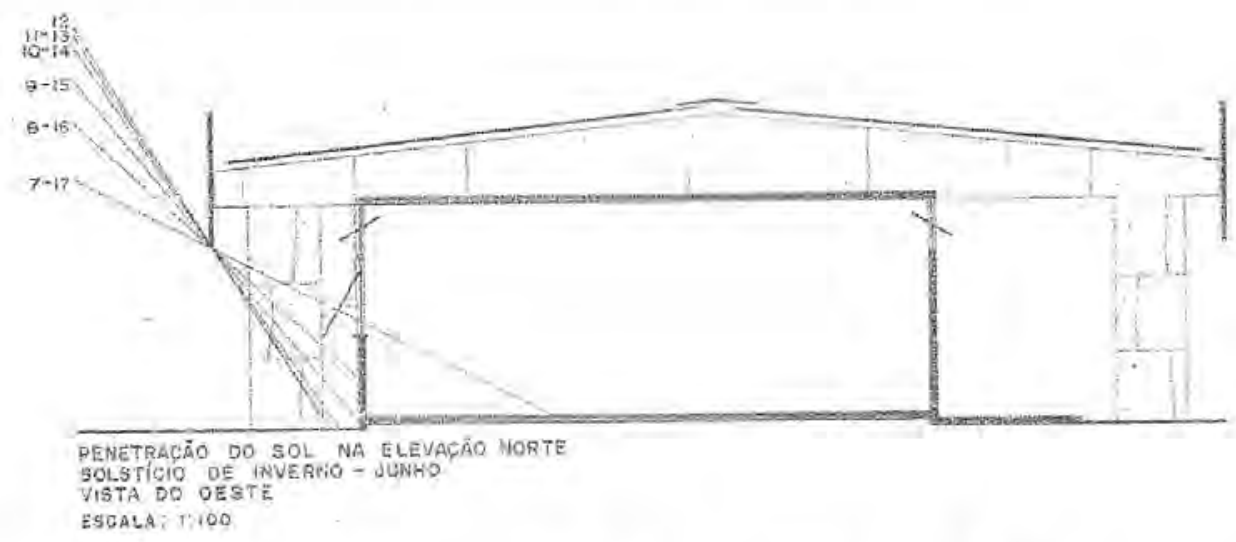

Figura 417: UFPI - Estudo do controle da insolação - Elevação norte.

Nesta fachada o solstício de inverno é crítico. O ângulo de penetraçăo do sol atinge o interior do ambiente a partir das $7 \mathrm{~h}$, quando ainda não há atividade no campus e das $17 \mathrm{~h}$ até $17 \mathrm{~h} 50 \mathrm{~min}$ (pôr do sol). Entretanto, a inclinação neste periodo se torna tăo horizontal e a luminosidade tão tênue que não haveria incômodos.

(Fonte: FUFPI. CEPRO, 1977, p.128)

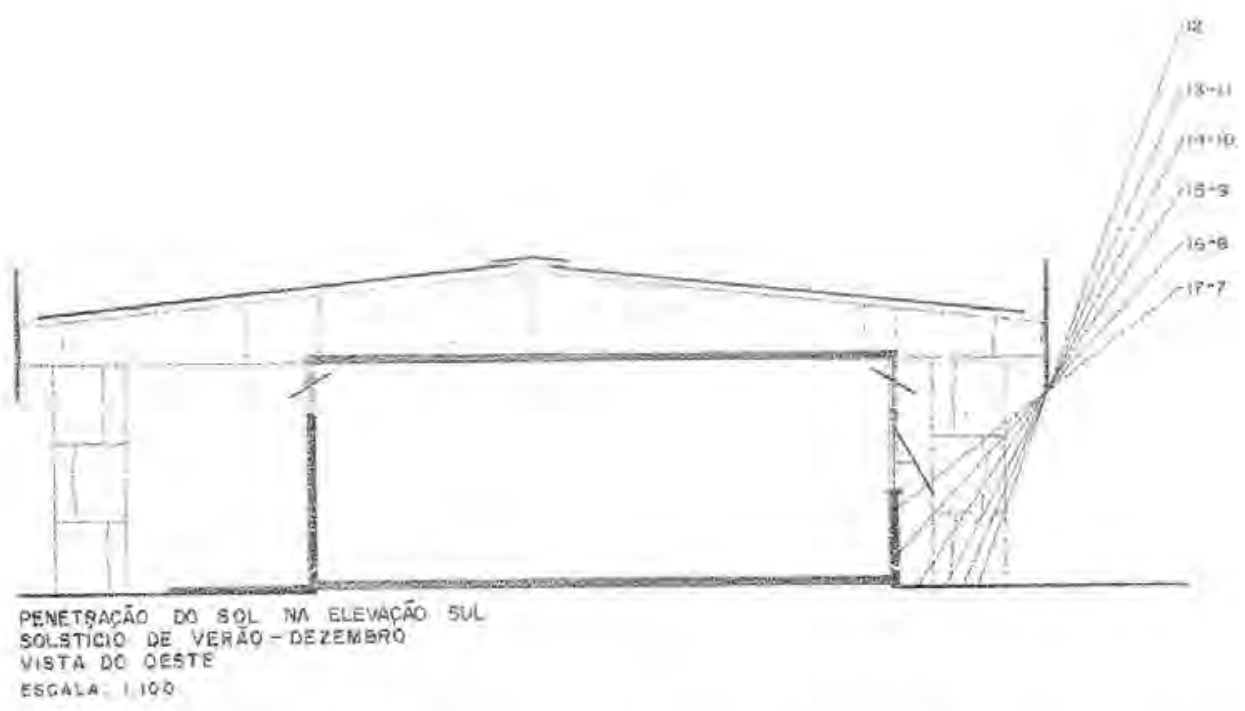

Figura 418: UFPI - Estudo do controle da insolação - Elevação sul.

Nesta fachada o solstício de verão é crítico, em dezembro. A inclinação do sol em relaçăo a um plano horizontal é menor do que na fachada norte, Portanto, poder-se-ia usar a mesma proteção em ambas as fachadas.

(Fonte: FUFPI. CEPRO, 1977, p.128) 


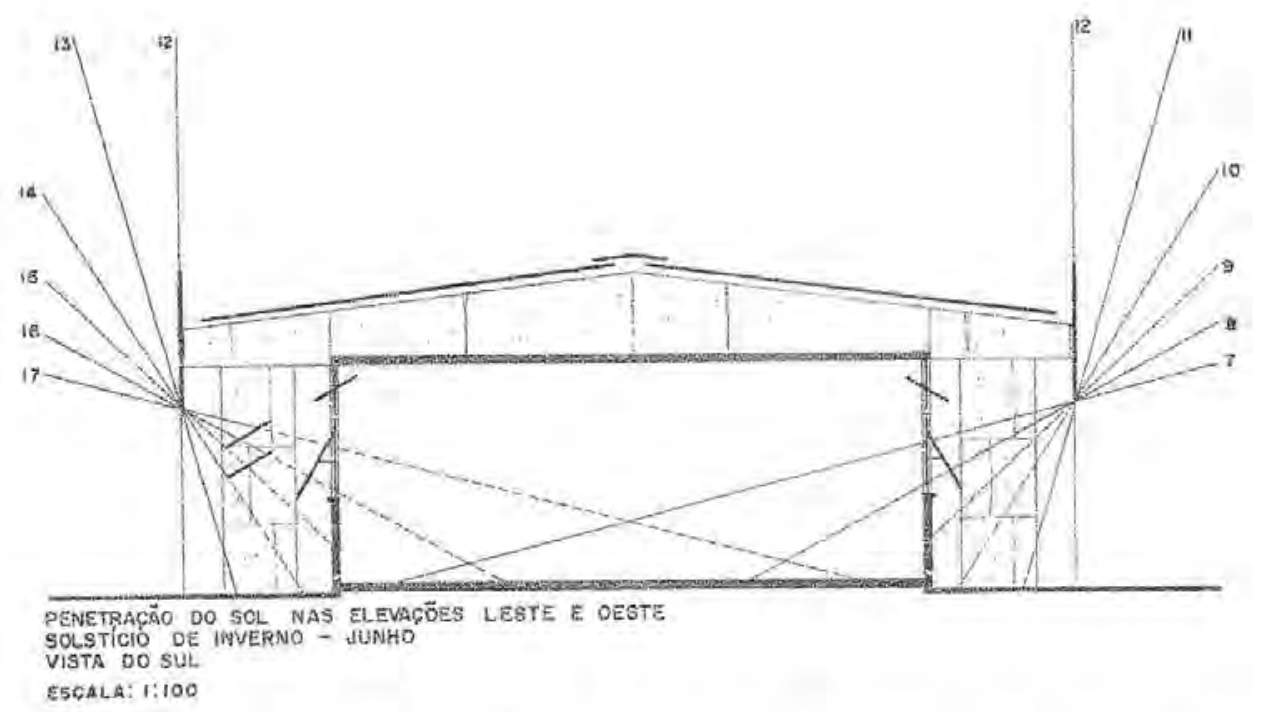

Figura 419: UFPI - Estudo do controle da insolação - Elevaçōes leste e oeste no solsticio de inverno.

Nelas, a intensidade de penetração dos raios solares depende mais da hora do dia do que da época do ano. Como se vê no desenho, a penetração do sol no interior do ambiente domina toda a extensão da sala até $7 \mathrm{~h}$ e depois a partir das $16 \mathrm{~h}$. Na primeira situação (insolação matinal) não há necessidade de proteção, já no horário da tarde, a insolação corresponde ao período do horário de trabalho, demandando o uso de duas lâminas horizontais na fachada oeste e apenas o beiral na fachada leste, conforme desenho.

(Fonte: FUFPI. CEPRO, 1977, p.129)

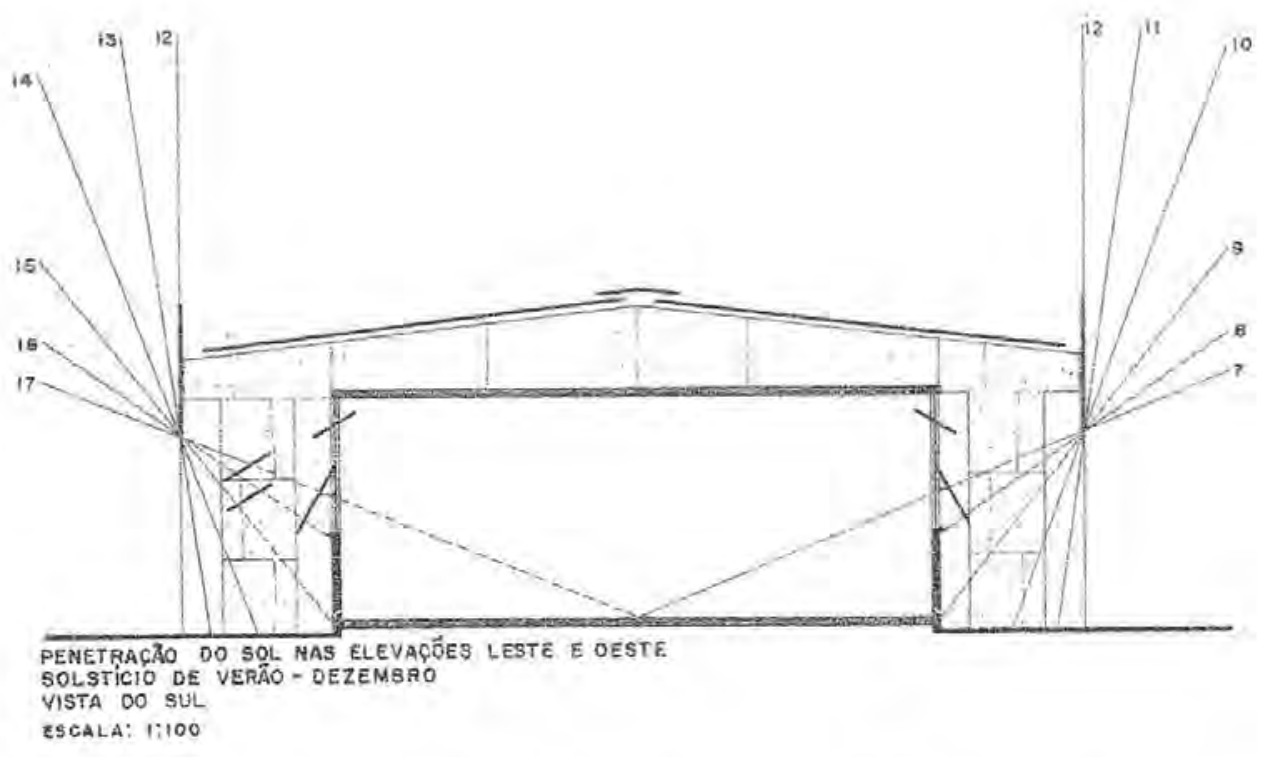

Figura 420: UFPI - Estudo do controle da insolação - Elevações leste e oeste no solstício de verão.

Neste período, embora haja uma diferença entre as projeções do sol com o solstício de inverno, o uso de protetores solares segue a mesma aplicação. (Fonte: FUFPI. CEPRO, 1977, p.129) 


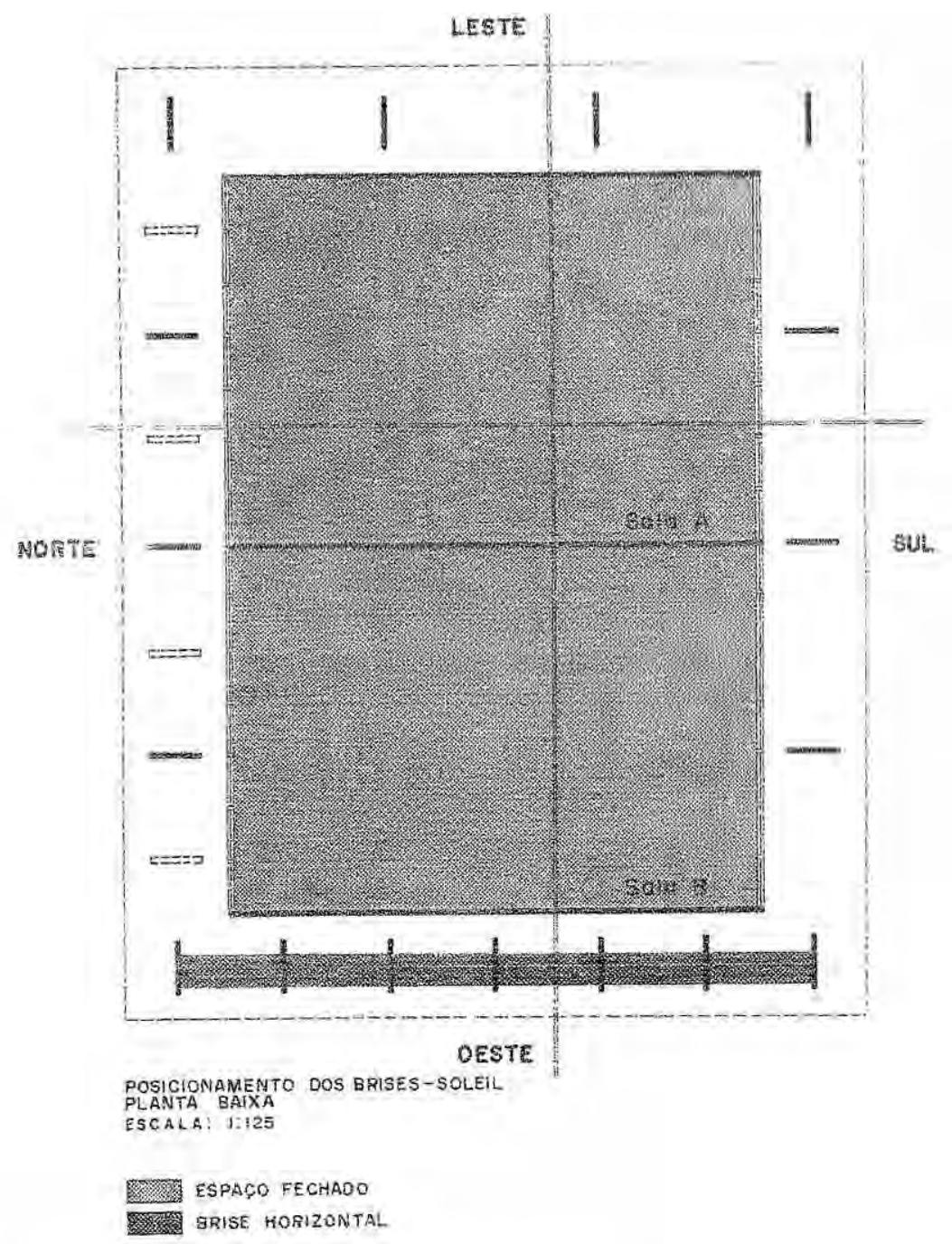

Figura 421: UFPI - Estudo de aplicação dos brises na planta.

O beiral garante o sombreamento do ambiente, exceto na fachada oeste. Neste caso, empregam-se duas lâminas horizontais apoiadas nos pórticos. Na fachada norte propõe-se o uso de brises verticais intercalados entre os pórticos ou de arborização próxima ao prédio. (Fonte: FUFPI/CEPRO, 1977, p.130)

Associados ao estudo da radiação solar foram realizados cálculos para renovação do ar nos ambientes e cobertura. $O$ primeiro tinha como finalidade dimensionar as aberturas das esquadrias para criar uma corrente de ar ascendente e cruzada (ver figura 422). O objetivo era forçar a circulação por meio do efeito chaminé e da ventilação cruzada. $O$ resultado revelou, entretanto, que considerando a velocidade média dos ventos dominantes da ordem de $0,5 \mathrm{~m} / \mathrm{s}$ na cidade de Teresina (índice de calmarias), a temperatura mínima interna ficaria em torno de $28^{\circ} \mathrm{C}$, quando o ideal seria $25^{\circ} \mathrm{C}$, situação que só se conseguiria com climatização artificial. No caso da cobertura, os cálculos de insolação da cobertura destinavam-se a obter uma solução construtiva que reduzisse os ganhos de calor nos ambientes, associada a menores custos, inicial e de manutenção. Optou-se, então, por uma 
cobertura em telha sanduíche de alumínio poliuretano expandido com grandes beirais aplicada a um mínimo de $50 \mathrm{~cm}$ de distância da laje de forro, o que evitaria ganho de calor proveniente da cobertura no ambiente.
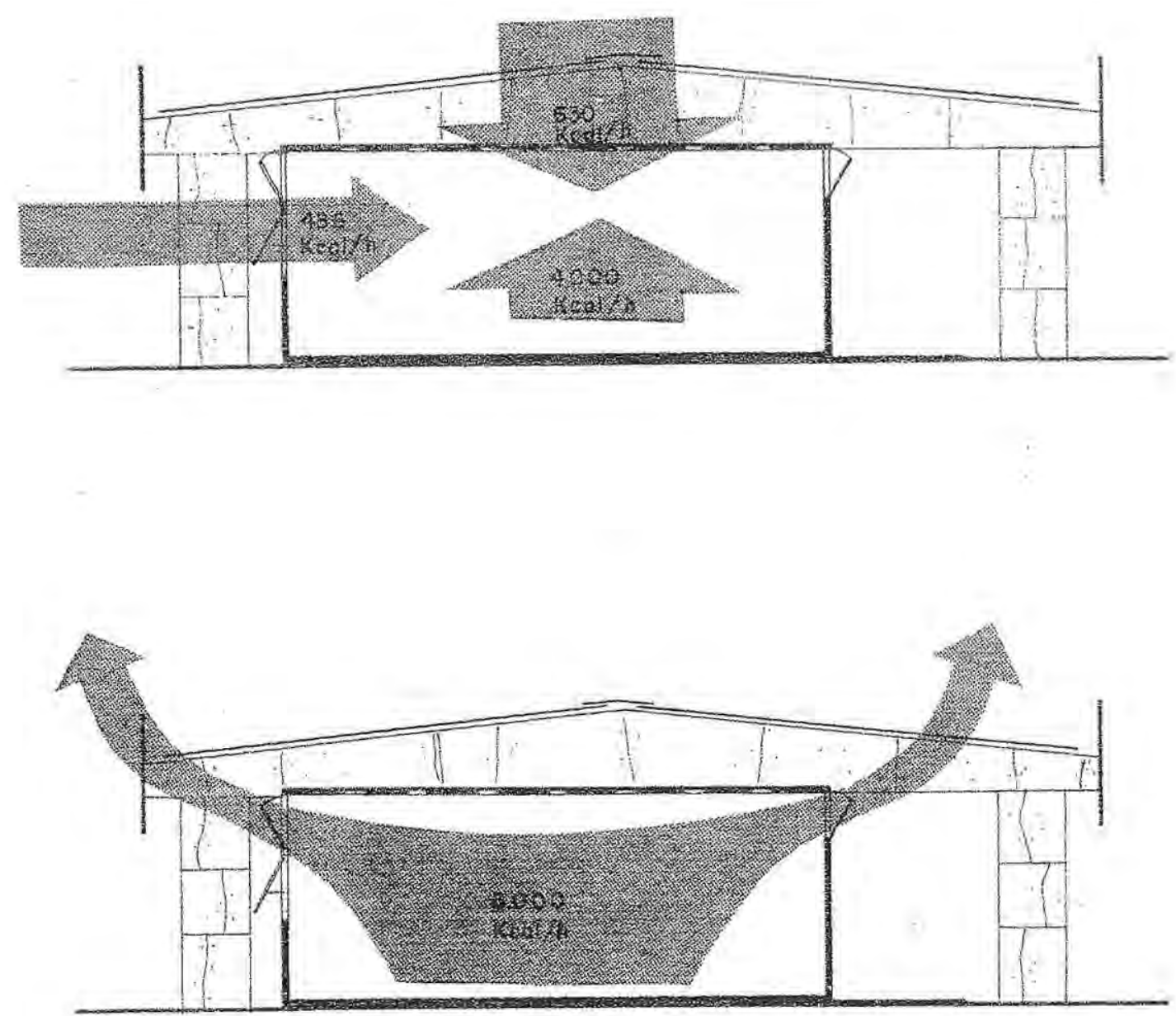

Figura 422: UFPI - Diagrama esquemático para cálculo de remoção do ar quente dos ambientes. (Fonte: FUFPI. CEPRO, 1977, p.134)

A planta do edifício resulta do conjunto de salas e pátios internos, formando setores funcionais que se desenvolvem sobre a malha modular de $1,0 \mathrm{~m} \times 1,0 \mathrm{~m}$, associada à modulação estrutural dos pórticos rígidos em concreto aparente, espaçados a cada $4 \mathrm{~m}$ (ver projeto na figura 423 ).

Os setores se articulam por meio das circulações horizontais, compondo uma planta de configuração irregular, que mais parece se espraiar no terreno sem limite de crescimento em quaisquer das direções. 


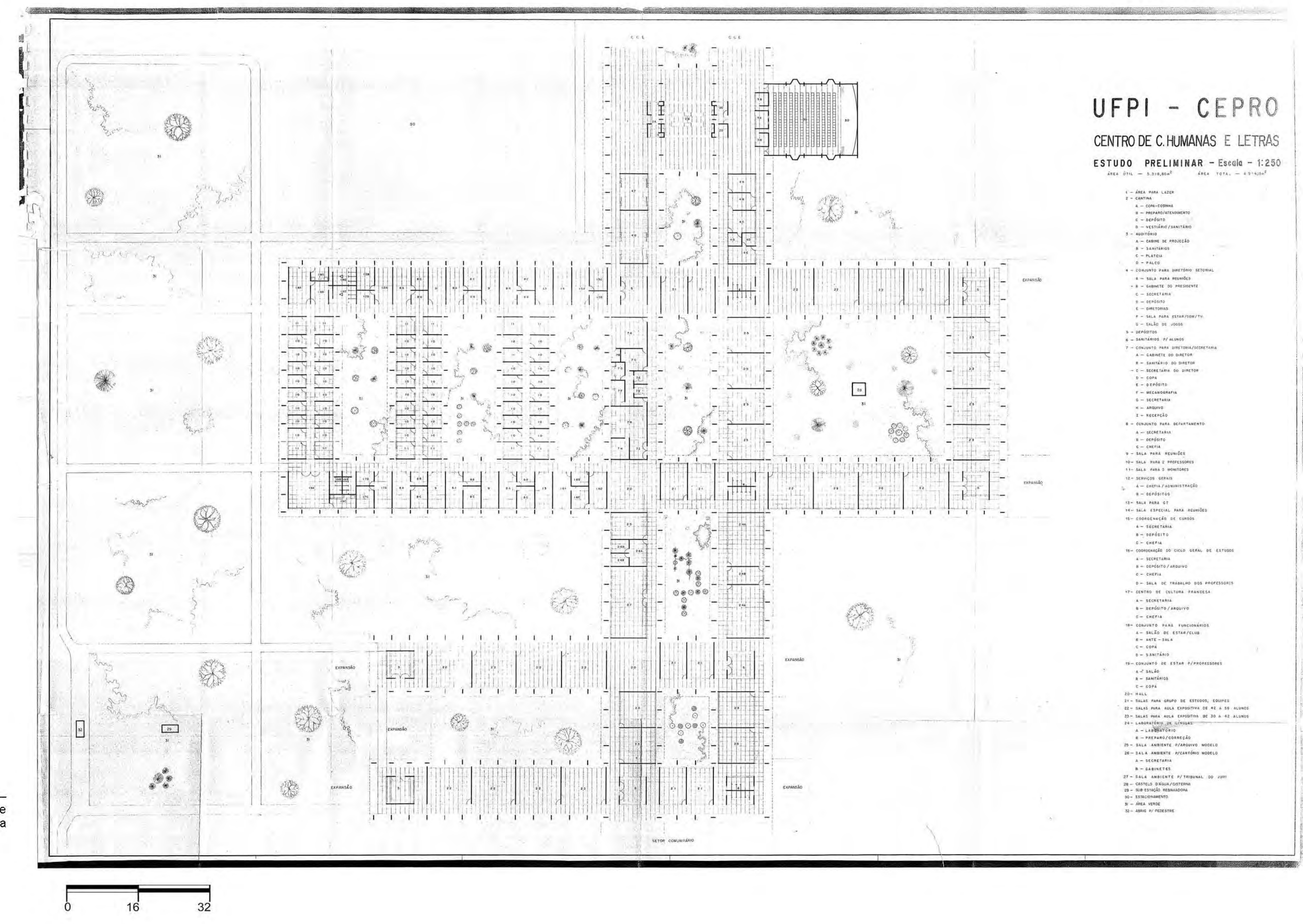


FOLHA VERSO DA FOLHA GRANDE, NÃO IMPRIMIR 
O estudo arquitetônico embora tenha sido elaborado pelo escritório técnico da UFPI, teve o projeto executivo desenvolvido pelo escritório técnico da Universidade Federal do Rio Grande do Sul. Segundo depoimento do arquiteto Marques, a transferência se deu pelo fato de que o prazo limite de aplicação dos recursos financeiros não seria cumprido pela equipe dos profissionais da UFPI, que estavam assoberbados com o ritmo acelerado das obras de construção do campus. Para superar o conflito, o estudo foi encaminhado ao escritório da universidade gaúcha.

O projeto executivo final não respeitou a proposta construtiva dos pórticos rígidos, tendo sido substituído pelo sistema de estrutura convencional em pilares, vigas e lajes. Também partes das soluções estudadas para promoção do conforto térmico foram alteradas, como no caso da telha térmica da coberta, que foi trocada pela de fibrocimento com emprego de lanternim de exaustão na cumeeira. Deste modo, os profissionais gaúchos esperavam promover o movimento do ar por convecção natural, mas eles não devem ter considerado o efeito de calmarias, ventos de velocidade menor do que $1 \mathrm{~m} / \mathrm{s}$, próprios do clima de Teresina (ver figura 424). O arquiteto Marques destaca também que a intenção de uma vegetação nos pátios internos foi substituída por pedras de seixo rolado. Executado, o edifício não conseguiu cumprir a promessa de uma arquitetura que amenizaria o rigor climático da cidade.
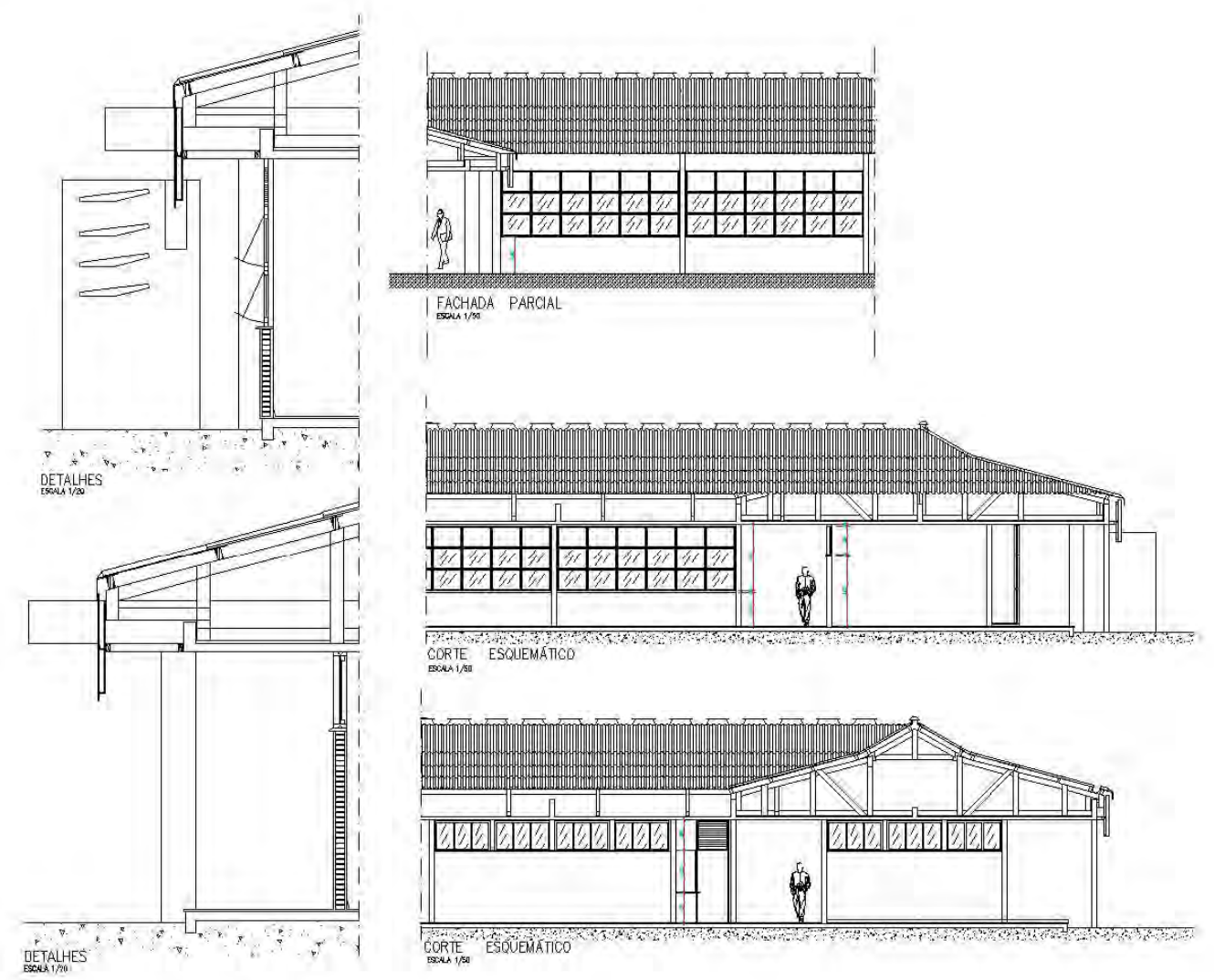

Figura 424: UFPI - Arquitetura CCHL - Detalhes.

(Fonte: Arquivo Geral - Prefeitura do Campus). 
A planta final assemelha-se à proposta original, embora tenha recebido acréscimos e alterações na organização funcional. A forma arquitetônica resulta numa composição volumétrica de predominância horizontal e a ênfase no uso do concreto aparente nos elementos da estrutura resistente. As fachadas são marcadas pela presença regular dos pilares de concreto aparente, intercalados por quatro placas horizontais, também de concreto aparente, e que têm a função de elementos de proteção solar. Esse conjunto é coroado por uma placa vertical de fibrocimento que arremata o beiral da coberta ao longo de todas as fachadas. Concluído parcialmente, o edifício causava admiração aos que ali passavam (ver figura 425).

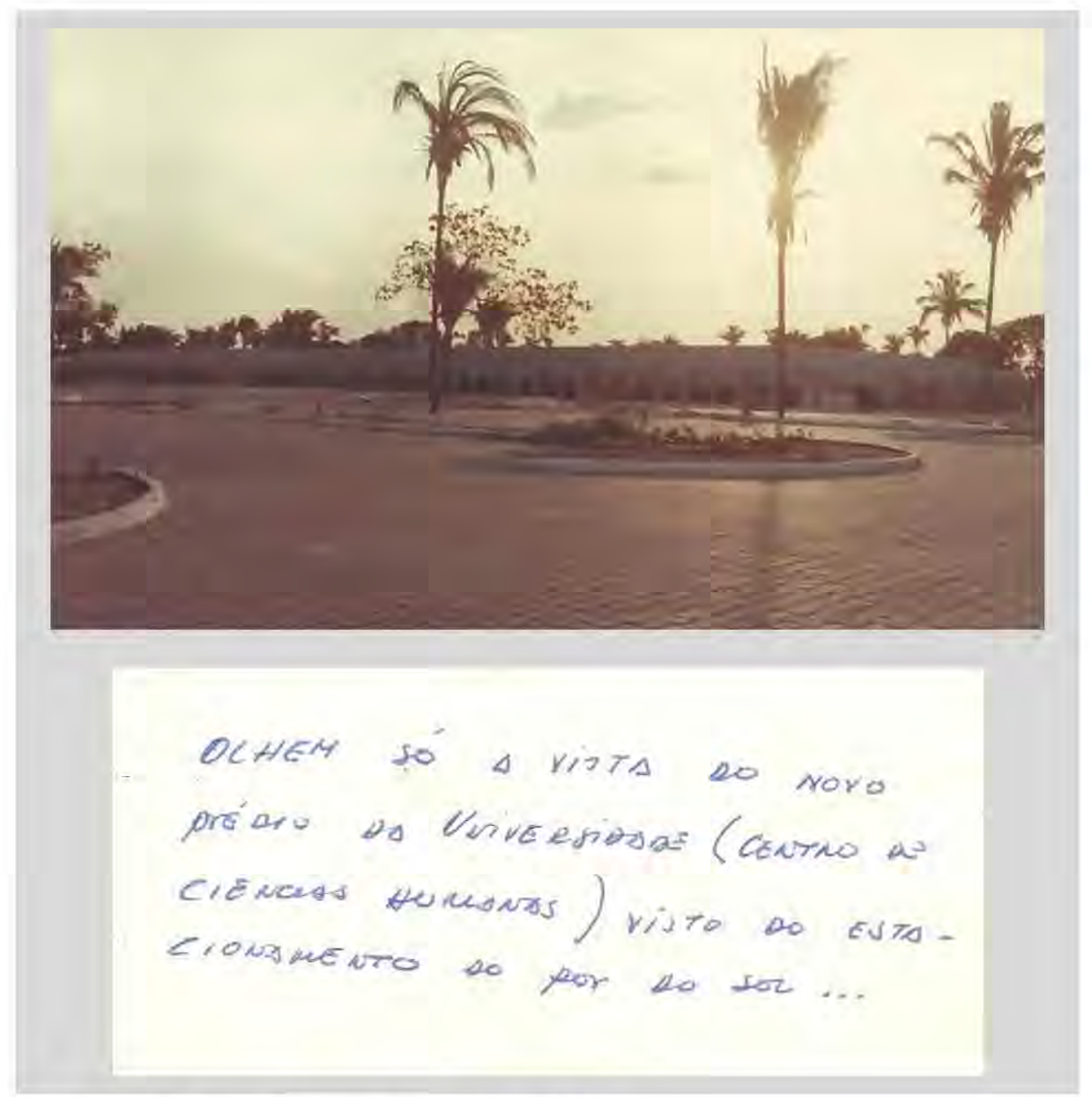

Figura 425: UFPI - Centro de Ciências Humanas (1980).

O edifício se estende no terreno cercado pelos bolsões de estacionamento.

A mensagem escrita no verso da foto exalta a arquitetura emoldurada pelo pôr do sol.

(Fonte: Acervo Pessoal arquiteto Ronaldo Pinto Marques)

\section{- Centro de Ciências da Educação (CCE)}

As instalações projetadas para o CCE eram parte do conjunto concebido para acrescer novas unidades de mesmo padrão construtivo conforme as demandas de crescimento da Universidade. Articulava-se com o $\mathrm{CCHL}$, compondo um conjunto edilício de identidade 
homogênea (ver figura 426). Iniciado na década de 1970, sua conclusão só se deu nos anos 1990.

Conforme planta de arquitetura da figura 427 (atualizada em 1996), o projeto seguiu o mesmo processo de desenvolvimento, orientado pelo módulo base da estrutura $(5,40 \mathrm{~m} \mathrm{x}$ $5,40 \mathrm{~m}$ ), embora com configuração diferenciada em função do programa de necessidades específico daquele Centro. Permaneceram os elementos arquitetônicos adotados para o controle da radiação e indução da ventilação cruzada (ver figura 428).

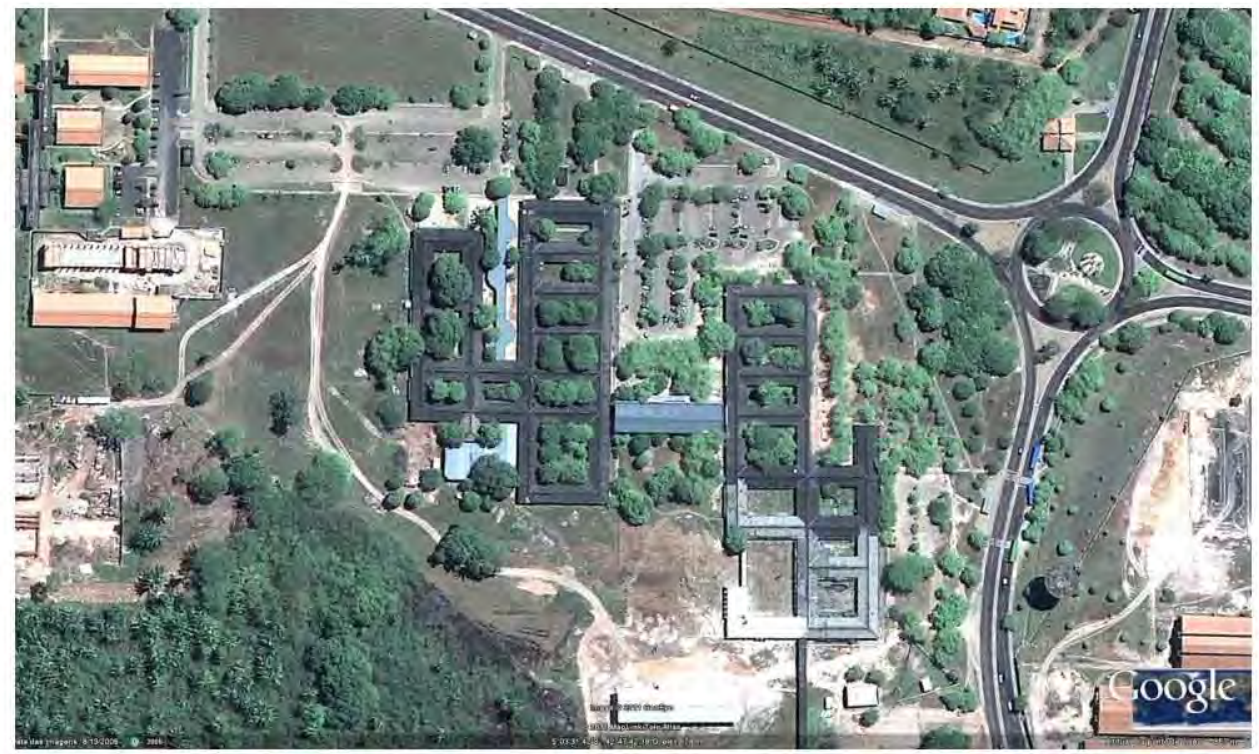

Figura 426: UFPI - Vista do conjunto do CCHL (esquerda) e do CCE (direita).

A proposta arquitetônica baseava-se na concepção de uma estrutura de blocos retangulares que poderiam crescer pela adição de novas partes.

(Fonte: Google Earth. Acesso em 13 ago. 2011).

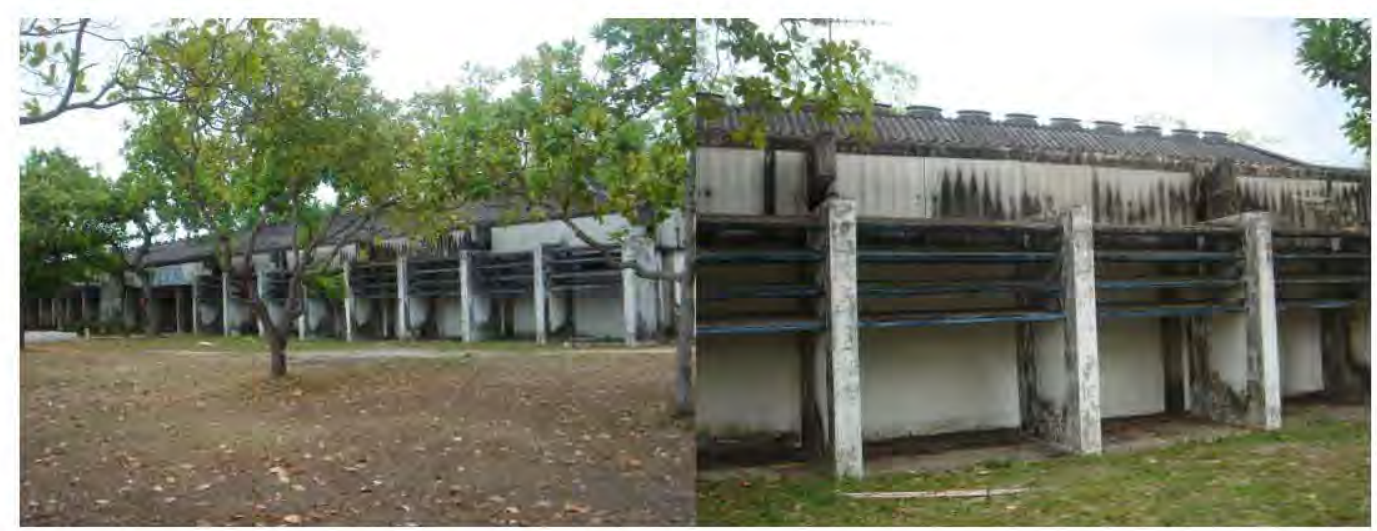

Figura 428: UFPI - Vista do edifício do CCE (2009).

Destaca-se na fachada a composição dos elementos de proteção solar constituídos pelas divisórias verticais, espaçados a cada $2,70 \mathrm{~m}$, que apoiam as placas horizontais.

(Fonte: Acervo Magda Campêlo, 2009) 


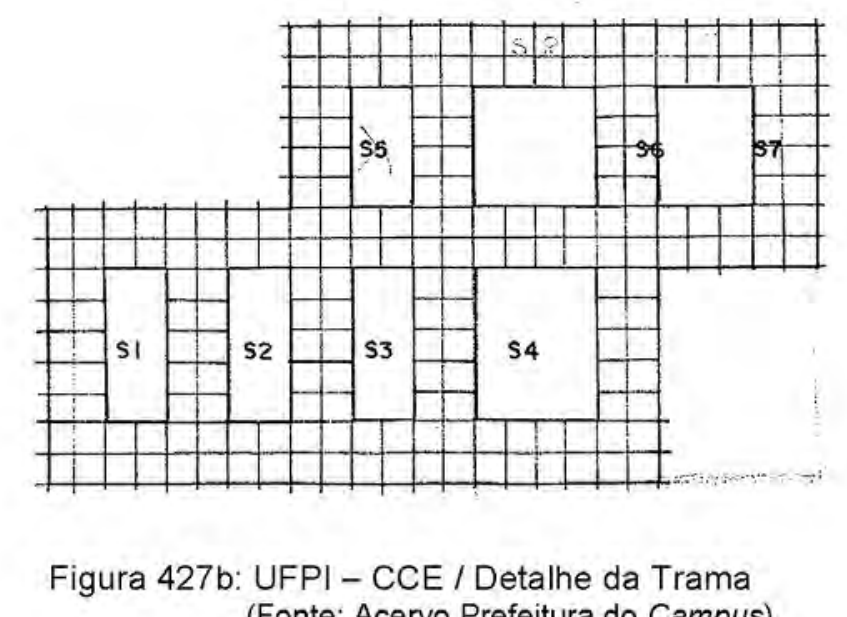

(Fonte: Acervo Preféturua do Campus)

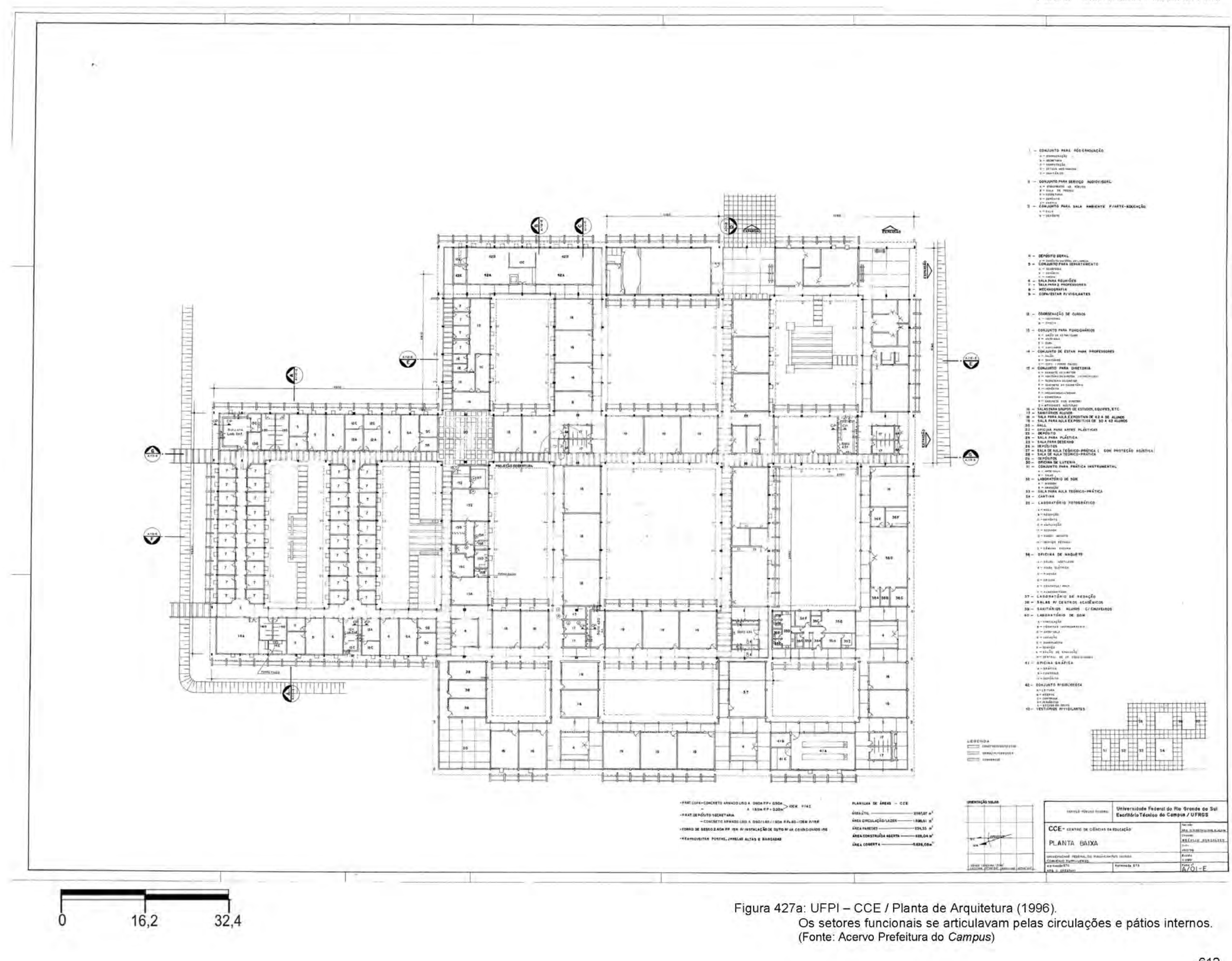




\subsection{ENCLAVE DA MALHA URBANA}

As diversas propostas elaboradas nos anos 1970 para compor o campus da UFPI não se concretizaram na íntegra. Prevaleceram, entretanto, as linhas gerais do Plano Diretor de 1976, com o zoneamento funcional dos setores e o sistema viário periférico. O setor central destinado ao campo acadêmico científico perdeu a garantia de uma estrutura construtiva unificada com a introdução de novas vias de veículos, que divide a área.

A solução contrariou a intenção original de garantir o fluxo de veículos independente do de pedestres, por meio de vias periféricas. Novas edificações foram implantadas em áreas dispersas, criando um padrão de ocupação que difere da proposta anterior. A planta do campus, atualizada em 2005, apresenta o estágio de ocupação física que vem sendo desenvolvido e que inclui o sistema viário, as edificações e áreas de recursos naturais (ver figura 429).

Campus da Ininga atual Campus Ministro Petrônio Portela possui sua área cercada por bairros residenciais e pela malha viária, confirmando os estudos da década de 1960, que indicavam o crescimento da cidade na direção da Ininga. Sua situação de isolamento inicial no contexto urbano, alterado pelo processo de "conurbação" que atinge também outros campi da Região Nordeste, não supera, entretanto, o conflito interno de isolamento que tem raízes no urbanismo baseado no zoneamento funcional. As características morfológicas da sua gleba de grande extensão, cercada pela via periférica configura um território especializado sem permeabilidade às atividades urbanas (ver figura 430 ).

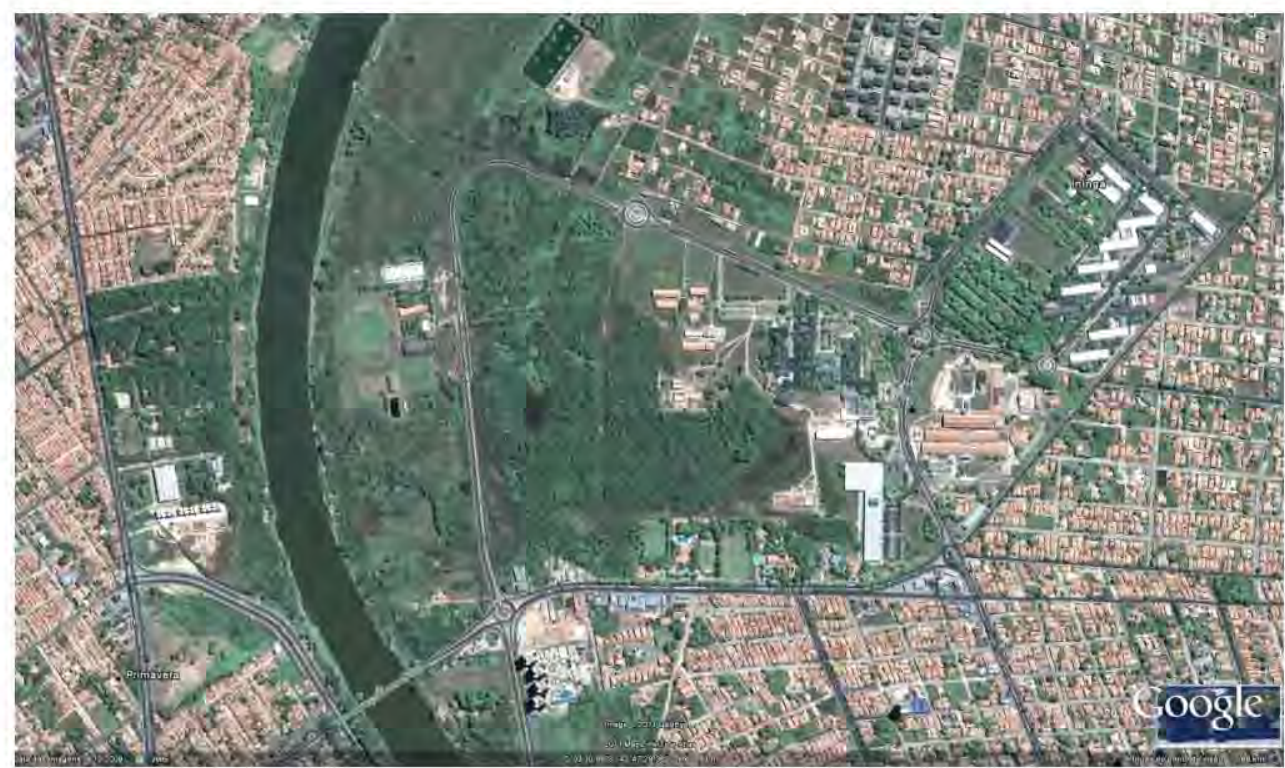

Figura 429: UFPI - Vista aérea do Campus Ministro Petrônio Portela. (Fonte: Google Earth, acesso em 01 jun. 2011) 


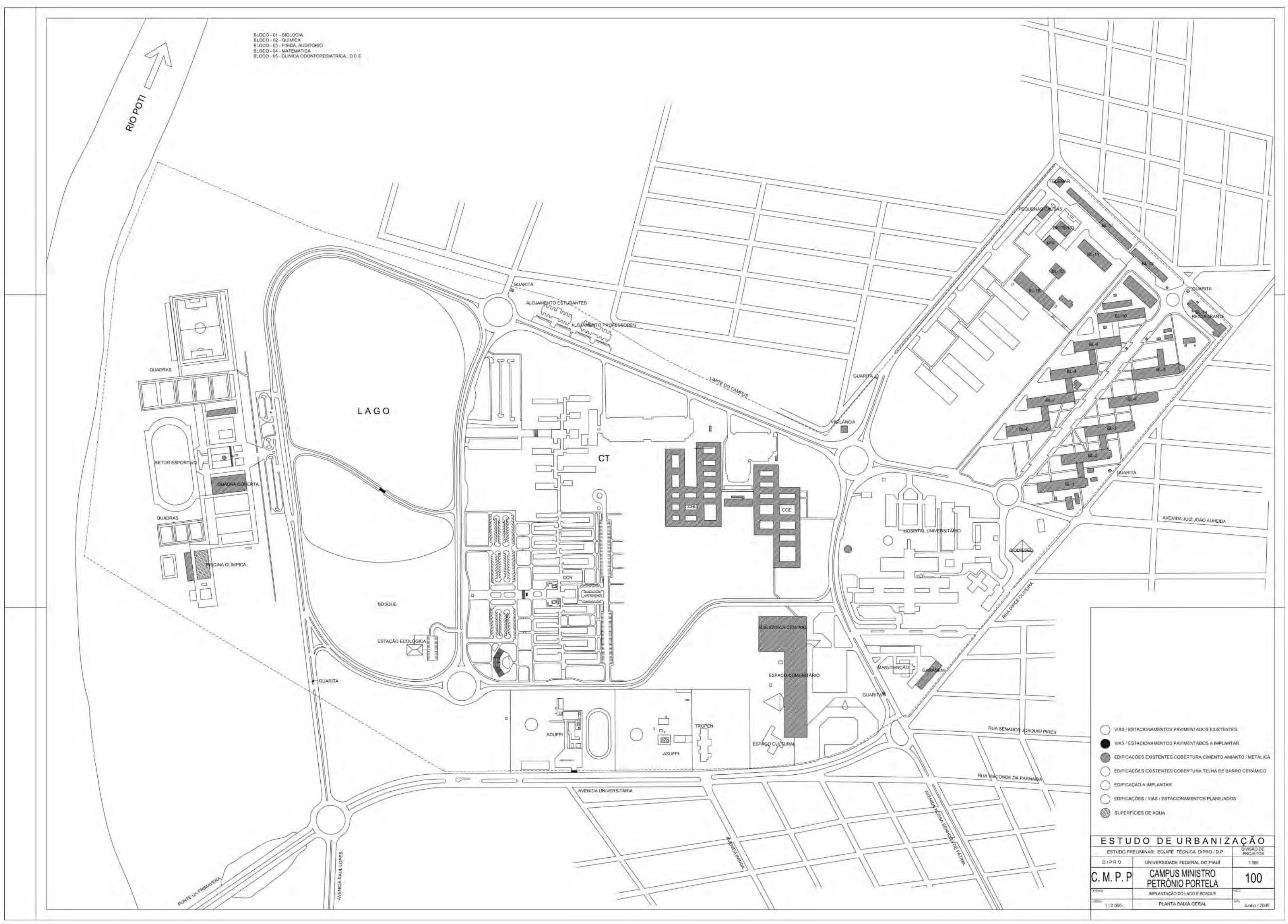




\subsection{CONSIDERAÇÕES}

Nascida da reunião de escolas isoladas, a Reforma Universitária foi determinante para a implantação da UFPI, originada pelo anseio de uma sociedade que vislumbrava vencer o isolamento econômico, político, cultural e geográfico que marcava o Estado do Piauí. A política adotada pelo governo militar de investir na construção de campi universitários favoreceu a concretização do seu território.

Para projetar e executar as obras do campus, a UFPI contou com profissionais do setor de planejamento da UnB, que se instalaram na cidade de Teresina em 1971. Participaram da escolha do terreno - a gleba da Ininga, afastada da zona urbanizada -, entre aqueles ofertados pelo governo estadual da época. Conceberam inicialmente um estudo com base na gleba de 266 ha, que tinha a integração como conceito primordial na sua proposta. A interpretação desse conceito foi levada ao extremo, resultando numa organização espacial de funções específicas, condicionada pelo formalismo do sistema viário de desenho predominantemente circular. A forma geométrica abraçando o setor acadêmico, administrativo e comunitário tinha a missão de contribuir para um espaço promotor da convivência e irradiador da produção do conhecimento.

A proposta incluía a concepção de uma estrutura edilícia com base numa malha modular de $1,0 \mathrm{~m} \times 1,0 \mathrm{~m}$, que subordinava a organização espacial dos compartimentos e permitiria o crescimento do edifício por etapas. A solução pressupunha um prédio de forma inacabada e a padronização dos elementos construtivos. O estudo encontra referências nas ideias desenvolvidas pelos arquitetos Candilis, Josic, Woods e Schiedhelm para a Universidade Livre de Berlim na Alemanha, em 1962. As soluções de projeto com o uso da modulação, da setorização das funções, da trama estrutural para racionalização da obra refletem o propósito da racionalização e da economia de meios.

A concepção não manteve continuidade e o Centro de Tecnologia foi construído com base num conjunto de edifícios ligados por passarelas cobertas.

A demora dos recursos para a concretização do plano elaborado pelos profissionais da UnB demandou a execução de instalações provisórias, prevendo-se que no futuro seriam ocupadas pelo Setor de Serviços Gerais do campus. Iniciadas em 1972, eram formadas por galpões com processo construtivo em estrutura metálica e alvenarias de tijolo. Essa tipologia permaneceu com a função de abrigar as atividades acadêmicas e administrativas até a segunda metade da década de 1970, quando então foi dado início aos edifícios definitivos. Com o término das obras dos citados galpões, em 1973, a UFPI transferiu suas atividades para o Campus da Ininga. 
Em 1976, o desenho da organização espacial inicial foi readequado em função da redução dos limites iniciais da gleba, que foi diminuída para 155 ha. As desapropriações planejadas não foram concretizadas na sua totalidade, decorrendo daí a necessidade de um novo projeto. Deu-se prosseguimento à implantação de uma nova proposta que manteve a setorização das funções, a hierarquia das circulações e a adequação aos condicionantes físicos do terreno alinhando-se com a concepção de um urbanismo acomodado às características locais. A ideia de um desenho com via principal circular foi substituída por um sistema de ruas, que se interconectam por rotatórias e se ligam a uma via perimetral, que percorre os limites da gleba.

Foi mantida a concepção do edifício que se conforma por etapas com crescimento ordenado pela malha modular $(1 \mathrm{~m} \times 1 \mathrm{~m})$ e com a padronização construtiva. Nessa orientação, foram construídos os Centros de Ciências da Educação e de Ciências Humanas, com obras iniciadas no final da década de 1970. Esses conjuntos configuram uma estrutura de construção térrea e identidade homogênea. Predomina a ênfase no concreto aparente e adoção de brises horizontais.

A configuração espacial executada não propiciou a integração almejada na medida em que - distanciamento físico entre os setores exige da comunidade acadêmica a travessia a céu aberto, que associada aos condicionantes climáticos com radiação solar intensa e luminosidade excessiva, desestimula os percursos conflitando com a tão propalada interação das unidades acadêmicas.

O campus da Reforma, atualmente denominado Campus Ministro Reis Veloso, possui seus limites físicos encurralados pelo crescimento da cidade com a ocupação de bairros residenciais. Se a condição suburbana inicial foi alterada, sua forma, de extensa gleba, com limites precisos definidos, o torna um enclave no tecido da cidade. 


\section{CONCLUSÕES}

A Reforma Universitária de 1968 alterou de forma significativa a estrutura das universidades, introduzindo uma nova matriz acadêmica baseada no departamento como unidade de ensino e a pesquisa em substituição à cátedra vitalícia.

A departamentalização, elemento fundamental desse projeto, foi criada com dois propósitos: um, de natureza operativa, procurando atender ao maior número de alunos com utilização plena da capacidade instalada e outra, de natureza pedagógica, visava o relacionamento das diversas áreas do conhecimento num único lugar. Seu funcionamento apontava para a concentração dos meios de modo a permitir uma administração otimizada do tempo e do espaço, supostamente conferindo maior racionalidade e produtividade à sua utilização.

\section{- Uma modernização falaciosa}

Ressalvados os aspectos discricionários pelo modo como foi introduzido, o modelo da Reforma trouxe avanços que, na nossa avaliação, estão centrados na indissociabilidade entre o ensino e a pesquisa, na oportunidade de qualificação profissional com o aumento do número de vagas e com a introdução de novos cursos compatibilizados com as necessidades do mercado de trabalho.

A Reforma tem sido destacada como um marco de modernização na universidade brasileira. A nosso ver, todavia, trata-se de uma afirmação falaciosa na medida em que, na prática, não acabou com o problema dos excedentes e a departamentalização tem demonstrado ser um espaço de alocação burocrático-administrativa de professores, tornando-se, em alguns casos, elemento limitador e até inibidor de um trabalho de produção de conhecimento coletivo (FÁVERO, 2006, p. 34).

\section{- Campus: um projeto apenas esboçado}

Os princípios econômicos do projeto reformista, implícitos nas ideias de eficiência e produtividade do ensino superior, transpareceram com a proposta de um território de base unificada referenciado no modelo de campus universitário norte-americano. Introduzido num contexto histórico peculiar, por força do estado de exceção, servindo a propósitos de desmobilização do movimento estudantil dos anos 1960, e movido pela fantasia de formar uma potência nacional, o projeto do campus brasileiro escorregou nas projeções irreais de crescimento econômico, culminando com a falta de recursos para sua consolidação integral. 
Nas universidades federais do Nordeste, o campus assumiu, na prática, a condição de unidade territorial de limites precisos, cercada de barreiras físicas. Sua conceituação partiu da organização espacial existente em cada instituição: unidades autônomas dispersas no centro urbano (UFRN, UFMA, UFS e UFPI), unidades dispersas em zonas distintas da cidade (a UFC dividia-se em zona urbana e suburbana) e cidade universitária em formação (UFPB e UFAL). As especificidades de cada instituição foram levadas em consideração na aplicação da Reforma Universitária, resultando, em grande parte dos casos, na definição de um campus principal que coexiste com um campus setorial, especialmente nas áreas da saúde e agrária. O campus único já nasceu adulterado da sua concepção de concentrar os edifícios universitários no mesmo lugar. Embora seja hoje uma realidade irreversível com predominância de unidades instaladas, o campus universitário como espaço próprio do ensino superior brasileiro é um projeto apenas esboçado e de construção ainda inacabada.

\section{- De campus suburbano ao campus conurbado}

A necessidade de um terreno de grande extensão para a implantação do campus, necessária principalmente para garantir a expansão futura, num contexto de crescimento acelerado e de mudanças constantes que se vislumbrava em plena fase do Milagre Brasileiro, só se tornaria viável com a aquisição de áreas de menor valor na periferia da cidade, em zonas de precária infraestrutura urbana. Essa condição foi enfrentada nos sete campi do Nordeste, resultando na configuração do campus suburbano.

As características das suas localidades de implantação contribuíram para o isolamento em relação ao centro urbano significativo, tornando-os um aglomerado à parte, voltado para dentro dos seus limites sem relações com seus entornos imediatos. A ideia de um campus único, capaz de concentrar e distribuir no espaço os meios que permitissem formar profissionais em grande número para atender à demanda do mercado, transformou-se numa zona especial segregada na estrutura da cidade.

Essa condição suburbana foi anulada a médio prazo pelo crescimento da cidade tradicional em volta dos campi, os quais, num processo de aparente conurbação, os tornaram parte da estrutura urbana mais densa. Essa nova realidade não eliminou, entretanto, as características de território exclusivo e isolado, transformando-os em verdadeiros enclaves no tecido das cidades. Nessa nova realidade, o campus da Reforma é a desvirtuação do seu sentido mais amplo, estrutural, já que não chega a desenvolver as relações com o meio urbano e com a população não-universitária dos entornos.

$\mathrm{Na}$ prática, nem as unidades permaneceram dispersas no espaço urbano, nem se transferiram totalmente para os campi suburbanos, potencializando as desvantagens de ambas as situações. 


\section{- Território segregado}

A espacialização, baseada na setorização rígida das áreas acadêmico-científica, administrativa, esportiva e de serviços, a partir do zoneamento funcional e com a hierarquização viária e separação pedestre-veículo, comparece de forma predominante nos sete campi do Nordeste.

A distribuição dos setores foi ajustada aos condicionantes físicos das respectivas glebas, resultando numa morfologia singular para cada campus, embora mantendo um padrão organizativo predominante de núcleos articulados pelo sistema viário. Excetua-se o Campus A. C. Simões da UFAL, que apresentou inicialmente uma organização linear, a partir de uma avenida centralizada na extensão longitudinal da gleba, padrão que vem sendo substituído gradativamente por uma ocupação de quadras retangulares. Na UFC a presença do Açude Santo Anastácio, que corta o Campus do Pici, condicionou a implantação nas suas margens os equipamentos comunitários: Biblioteca Central e Restaurante Universitário. Na UFPI, o Campus da Ininga apresenta uma área sujeita a inundação em função da presença do Rio Poty, que o margeia, condicionando o uso dessa faixa ao aproveitamento de uma lagoa de estabilização.

A localização dos setores funcionais espelha a orientação do Manual de Atcon: o setor básico encontra-se em área estratégica que favorece sua função de núcleo didático comum aos centros profissionalizantes. Os setores de serviços, esportivo e hospitalar (esse último só foi implantado nas universidades da Paraíba e Alagoas e a UFPI construiu seu hospital recentemente, nos anos 2000) estão localizados nas áreas periféricas da gleba, situação recomendada para permitir o acesso do público externo sem interferir nos demais setores universitários. O setor administrativo, também indicado no Manual em área extrema, só foi implantado nessa situação nas universidades de Sergipe e Alagoas. Nos demais campi, ele se encontra em áreas de convergência com os setores acadêmico-científicos. A UFC não transferiu a Reitoria para o Campus do Pici, apesar de sua previsão nas diversas propostas para a sua consolidação. A biblioteca, considerada por Atcon, como centro irradiador do conhecimento e que, deveria estar situada em local de boa visibilidade, contrapondo-se à concepção da cidade universitária que tinha na Reitoria seu ponto focal, teve sua implantação ajustada à morfologia de cada campus.

A hierarquização do sistema viário caracteriza-se nos sete campi pela presença de duas categorias de vias: (1) as que margeiam os setores funcionais articulando-os entre si e com acesso aos bolsões de estacionamento localizados nos seus limites periféricos e (2) o anel viário que contorna o conjunto acadêmico-científico e que, na maioria dos campi, segue os limites periféricos da gleba conformando um desenho preciso da poligonal do campus. A 
circulação de pedestres situada na área interna dos setores funcionais ocorre parcialmente por meio de passarelas cobertas (casos da UFC, UFPB, UFRN e UFS) ou por passeios a céu aberto.

A organização espacial que resultou dessa concepção funcionalista numa gleba de extensa área gerou problemas em diversos níveis. A separação dos setores, com distâncias dimensionadas para uma circulação interna eminentemente veicular, obriga os usuários a longos percursos desprotegidos, situação que, numa região com clima de altas temperaturas e intensa radiação solar, torna-se penoso e desestimulante. Os grandes deslocamentos passam a se constituir em obstáculos para as inter-relações funcionais das áreas de conhecimento, abortando as instâncias de encontros e convívio em diferentes escalas na totalidade do campus. Essa condição contradiz o campus integral de Atcon.

A implantação das unidades acadêmicas em setores rigidamente separados, subordinada à definição de prioridades pelos órgãos centrais e às condições de financiamento, comumente em etapas descontínuas, resultou numa ocupação rarefeita com edificações isoladas e distantes umas das outras, caracterizando a dispersão da organização espacial. Essa condição torna o campus uma aldeia de percepção confusa e de difícil orientação para quem nele circula, ficando dependente do uso de placas de sinalização.

O quadro exposto comprova a falácia da indispensabilidade do território de base unificada que, no Manual de Atcon, era condição fundamental para a integração e funcionalidade da estrutura acadêmica. Nesse sentido, podemos dizer que a justificativa de contrapor-se o campus concentrado ao padrão de unidades dispersas na cidade, cujas distâncias eram consideradas impedimentos para a integração e o convívio das relações universitárias, não demonstra pertinência. No campus, a dispersão foi reproduzida de outra forma, numa condição mais agravante já que a ausência da logística da cidade tradicional isola de forma intensa as relações interpessoais.

É conclusivo que a organização espacial dos campi, baseada nos princípios do urbanismo funcional racionalista, demonstra não apenas sua ineficiência, mas revela uma faceta perversa ao materializar um território segregado internamente, que não só dificulta a integração acadêmica, como transforma o campus, fora de determinados horários, num local sem vida e de segurança pessoal ameaçada.

\section{- Laboratório da arquitetura experimental}

A perseguição aos princípios econômicos da Reforma refletiu-se na concepção das tipologias que estavam impregnadas pelas ideias de racionalidade, flexibilidade e expansibilidade. Esses conceitos foram intermediados no edifício que se apoia na modulação estrutural e na padronização dos componentes construtivos. 
As experiências materializadas nos campi do Nordeste evidenciam uma produção de complexidade tecnológica, qualidade ambiental, crescimento e flexibilidade específicos de cada universidade, que delineiam um quadro experimental ante a problemática de construir espaços universitários para uma matriz acadêmica flexível e plena de indeterminismo.

Nos campi da UFC, UFPB, UFRN, UFAL e UFS, o edifício isolado com planta livre de geometria retangular, concebido pela modulação estrutural e com padronização dos componentes construtivos, foi adotado como o modelo capaz de se ajustar às necessidades de remanejamento contínuo da organização espacial e da capacidade de expansão, já que possibilitava sua implantação num processo de ocupação gradual conforme as demandas se apresentassem. $O$ espaço do campus se conformava a partir do arranjo dos blocos padrões surgidos por etapas.

Essa orientação promoveu uma arquitetura de linguagem homogênea e tipificada, embora com produção peculiar para cada instituição, que se caracteriza pela estrutura de concreto aparente destacada das vedações, cobertura plana com telhas de fibrocimento e adoção de elementos de proteção da radiação solar direta. O bloco prismático de um ou dois pavimentos com forma arquitetônica padronizada tornou-se emblemático para as unidades didáticas - blocos de salas de aula e laboratórios - e blocos departamentais - gabinetes de professores e salas administrativas.

A padronização adotada, ainda que de produção artesanal, demonstrou a potencialidade de rapidez na sua execução. Embora não se tenha dados para demonstrar a diminuição do custo médio da construção, não podemos deixar de considerar que a redução no tempo da obra em função menor número de componentes distintos, que por sua vez reduz a presença de profissionais na fiscalização da sua execução e o preço unitário do material, são fatores que trazem economia no custo final do edifício.

O conceito da flexibilidade para alteração dos arranjos funcionais estava limitado à mobilidade de painéis divisórios, não abrangendo uma solução correspondente de rápida execução e baixo custo para adequação das instalações prediais. Essa condição contradiz a racionalidade construtiva pretendida.

A expansibilidade foi intermediada pela reprodução do bloco padrão, articulado por circulações que poderiam ser em passarelas cobertas (casos da UFC, UFRN, UFPB) ou passeios abertos ao ar livre (casos da UFAL e UFS), conformando em ambas as situações conjuntos arquitetônicos homogêneos de predominância horizontal. Se a solução concilia os condicionantes financeiros com os recursos liberados em momentos distintos até o edifício finalizado, propicia por outro lado conflitos de ordem cognitiva para sua identificação por parte dos usuários que deles se utilizam, necessitando de placas indicativas. 
É predominante a preocupação com os aspectos climáticos da região. Em todos os casos podemos identificar soluções que têm na sua concepção a intenção de promover a ventilação natural e eliminar a radiação solar direta no interior dos ambientes. Soluções distintas foram adotadas. Alguns casos espelham adaptação aos condicionantes locais, como os blocos da UFC que utilizaram esquadrias de madeira com venezianas móveis e revestimento de pastilha cerâmica, ambos de fabricação local. Em outros campi foi usual a introdução de esquadrias de alumínio com vidro, que possivelmente devido à reprodução em escala, tornou-se menos onerosa do que o uso da madeira. A adoção de brises em concreto aparente foi aplicada nos campi da UFPB e UFS, embora suas dimensões e ângulos de inclinação não tenham eficiência contra o excesso de radiação solar.

A UFMA e a UFPI têm os prédios com partido arquitetônico embasado pela concepção da trama modular na qual o edifício único cresce por partes. Na universidade maranhense, $\circ$ bloco do Instituto de Ciências Físicas e Naturais, de autoria do arquiteto Prochnik pode ser considerado um projeto que respondeu às questões de flexibilidade e aspectos climáticos com qualidade arquitetônica. $O$ arquiteto criou nesse projeto espaços de convívio e circulações que promovem as inter-relações da comunidade universitária, o que não se visualiza no programa do bloco isolado restrito aos espaços de ensino. Nesse aspecto, 0 isolamento interno das unidades acadêmicas é na UFC e na UFS uma realidade que reforça a segregação da solução urbanística.

$\mathrm{Na}$ universidade piauiense, o partido do edifício de trama modular que conformaria uma grande estrutura revelou o conflito gerado por espaços de identidade única, criando uma ambiência de difícil identificação para os que neles circulam. Tanto na UFMA como na UFPI, os elementos de proteção solar dos prédios são desenhados de forma correta na sua aplicação.

A diversidade de soluções para responder aos aspectos funcionais da arquitetura demonstra que não se pode emitir uma avaliação genérica, que desconsidere as distintas realidades a que foram submetidas durante sua concepção. $O$ sucesso ou o insucesso dessa produção não se limita a uma aferição simplista dos conceitos funcionais, pois os resultados da sua aplicação estão intrinsecamente vinculados à criatividade do arquiteto quando os potencializa numa arquitetura de boa qualidade.

A produção arquitetônica representativa dos equipamentos comunitários (reitoria, biblioteca e restaurante universitário) realizada nos campi do Nordeste corrobora nosso posicionamento: o Manual de Atcon, com sua permissão de liberdade formal para a concepção dessas tipologias funcionais promoveu uma arquitetura que adotou a ênfase no concreto aparente, revelando diversidade de soluções e de qualidade em cada campus. 
Destacamos nesse conjunto os edifícios da Biblioteca e da Reitoria da UFS, cujos autores (esta última é do arquiteto Miguel Juliano), apropriando-se dos aspectos racionais da arquitetura e da tecnologia do concreto souberam explorá-los com maestria, resultando em obras que devem ser referenciadas no panorama da arquitetura brasileira.

O quadro exposto demonstra que, na mesma época e respondendo às mesmas premissas, realizou-se uma produção que evidencia respostas submetidas ao contexto local: edifícios isolados para as unidades acadêmicas departamentalizadas; prédios separados para atividades específicas - laboratórios, salas teóricas, gabinetes, etc. - caracterizados por conjuntos construtivos modulados e unidades complementares (bibliotecas, restaurantes, e prédios administrativos) que resgataram a concepção monumental que Atcon pretendeu eliminar.

As várias tipologias adotadas na organização dos campi no Nordeste não conseguiram superar a segregação da organização espacial materializada pela concepção urbanística racional moderna. O campus da Reforma, no Nordeste, reduzido a uma visão instrumental e utilitária promoveu o seu isolamento interno e com a cidade.

\section{- Viabilidade no contexto contemporâneo}

O legado arquitetônico e urbanístico deixado pela Reforma nos coloca, enquanto profissionais do espaço universitário, desafios que precisam ser enfrentados no sentido de não apenas de nele intervir, mas de compreender o campus como uma parte do território da universidade. $O$ campus das relações interacadêmicas tem que ser pensado como espaço da sociedade e não como local privatizado para poucos privilegiados.

Analisar o que já está feito, fazer consultas aos professores, estudantes e funcionários a fim de reunir elementos que possam concretizar uma proposta de campus universitário mais próximo aos anseios da comunidade acadêmica talvez seja o primeiro caminho efetivo a se tomar. O profissional do planejamento físico não pode mais se valer de salvo-condutos tecnicistas para propor intervenções pré-concebidas que não encontram vínculos com o espírito que se almeja para a universidade contemporânea.

A vocação dos territórios universitários deve ser respeitada, recuando-se da ideia de consolidar um território único como opção irreversível. Nas diversas modalidades, a integração deve ser um objetivo norteador para as respostas apresentadas. Nesse sentido, - campus como barreira quase intransponivel para as atividades urbanas deve ser estudado para transformá-lo em território permeado pelas funções da cidade, no nível de sistemas viários e serviços urbanos, ainda que tenhamos que enfrentar o componente da insegurança que ameaça nossa integridade física e recua as relações universitárias para o estágio do isolamento, criando enclaves no interior do campus. 
A busca pela urbanidade, abortada no seu modelo urbanístico, é possivelmente um princípio primordial na intervenção nesse território. As relações entre os espaços construídos e a condição oferecida pelo meio ambiente (clima, vegetação e geomorfologia), a eficácia econômica das infraestruturas que dão suporte, o tratamento das áreas livres - praças, circulações de pedestres - como espaços de convivência, a introdução de equipamentos e serviços capazes de promover a permanência dos usuários e estabelecer o contato entre pessoas de distintos interesses são algumas das realidades que foram banidas do campuse que devem ser revisadas como possíveis caminhos do planejamento físico para transformálo no espaço característico do ensino superior brasileiro.

Temos a convicção de que um campus não é passível de um projeto acabado. As previsões não ultrapassam um planejamento básico e flexível, se possível, obedecendo a critérios idênticos aos do espaço urbano de que é parte inseparável. 


\section{REFERÊNCIAS}

ALBERTO, Klaus Chaves. Formalizando o ensino superior na década de 1960: a cidade universitária da UnB e seu projeto urbanístico. Tese (Doutorado em Urbanismo), Programa de Pós-Graduação em Urbanismo, Universidade Federal do Rio de Janeiro, Rio de Janeiro, 2008.

Três projetos para uma cidade universitária do Brasil. Dissertação (Mestrado em Urbanismo), Programa de Pós-Graduação em Urbanismo, Universidade Federal do Rio de Janeiro, Rio de Janeiro, 2003.

AFONSO, Alcília; NEGREIRO, Ana Rosa. Documentos de arquitetura moderna no Piauí. Teresina: Gráfica Halley, 2010.

ALBUQUERQUE, José da Mota e. Discurso pronunciado por ocasião da solenidade de instalação da Fundação Universidade do Maranhão, a 27 de julho de 1967, no palácio do governo estadual, São Luís, 1967.

ALHO, Getúlio G. R. Anteprojeto da área central do campus da Universidade Federal de Alagoas: memorial físico. São Carlos: ASPLAN / ETC - UFSCar, 1980.

ALMEIDA, Cristóvão Domingos de, et al. Pesquisa documental: pistas teóricas e metodológicas. Revista Brasileira de História \& Ciências Sociais, ano I, $n^{\circ}, I, 2009$. Disponível em: <http://www.rbhcs.com/index_arquivos/Artigo.Pesquisa\%20documental.pdf>. Acesso em: 18 jan. 2010.

ALMEIDA, Jaime Gonçalves de. Campus do Milagre: contribuição à análise dos campus universitários brasileiros, implantados na década de 1970 , tendo em vista a relação entre autonomia da instituição e a organização espacial. Dissertação (Mestrado em Planejamento Urbano), Departamento de Urbanismo, Instituto de Arquitetura e Urbanismo da Universidade de Brasília, Brasília, 1983.

ARARIPE, J.C. Alencar. A Faculdade de Medicina e sua ação renovadora. Fortaleza: Imprensa Universitária, 1998.

ATCON, Rudolph P. Manual sobre o planejamento integral do campus universitário. [S.I.: s.n.], 1970. Conselho de Reitores das Universidades Brasileiras, Projeto CR-10-PE-5 / Código no III-4. MEC/DES, 1966.

Rumo à reformulação estrutural da universidade brasileira. Rio de Janeiro:

ASSOCIAÇÃO BRASILEIRA DE NORMAS TÉCNICAS. Norma $n^{\circ}$ 15220: desempenho térmico de edificações. Rio de Janeiro: ABNT, 2005.

AZEVEDO, J. F. (org.). Universidade Federal de Alagoas: documentário histórico. Maceió: UFAL, 1982.

BASTOS, Maria Alice Junqueira Bastos. Pós-Brasília: rumos da arquitetura brasileira. São Paulo: Perspectiva / FAPESP, 2003.

BERNINI, Luciano. Planejamento físico de campi universitários e sua aplicação prática. São Paulo: FUNDUSP, 1974.

BEZERRA, Francisco Chaves. História, cultura e ensino superior na Paraíba: implantação, estadualização e federalização. SAECULUM - Revista de História [15]; João Pessoa, jul./dez.2006. 
BITTENCOURT, Leonardo; CÂNDIDO, Christina. Introdução à ventilação natural. Maceió: EDUFAL, 2008.

Uso das cartas solares: diretrizes para arquitetos. Maceió: EDUFAL, 2004.

BOMENY, Helena. A Reforma Universitária de 196825 anos depois. Revista Brasileira de Ciências Sociais, ano $9, n^{\circ} .26,1994$, p. 51-65.

BOSCHETTI, Vania Regina. Plano Atcon e Comissão Meira Mattos: construção do ideário da universidade do pós-64. Revista HISTEDBR On-line. Disponível em:

<HTTP://www.histedbr.fae.unicamp.br/art18_27.pdf.>. Acesso em: 17 mar. 2009.

BRASIL. Universidade Federal do Maranhão no centro histórico de São Luís. Brasília, DF: Centro de Desenvolvimento e Apoio Técnico à Educação, 1984.

BRASIL. Leis, decretos, etc. Lei $n^{\circ} 5.152$, de 01 de outubro de 1966. Diário Oficial [da] República Federativa do Brasil, Brasília, 24 out. 1966. Art. $30^{\circ}$. p. 1464.

BRASIL, SECRETARIA DE ENSINO SUPERIOR. O Ensino Superior no Brasil: 1974/1978. Brasília: MEC/SESu/CODEAC, 1979.

BRASIL, MINISTÉRIO DA EDUCAÇÃO E CULTURA. Avaliação da implantação da Reforma Universitária: Universidades Federais. Salvador: ISP/UFBA, 1975.

Reforma Universitária 1968-1969: leis, decretos-leis, decretos, portarias, pareceres, resoluções. Brasília, DF: Ministério da Educação e Cultura, 1969.

Reforma Universitária - Relatório do grupo de trabalho criado pelo Decreto $\mathrm{n}^{\circ}$. 62.937/68. GB - Brasil: Fundação IBGE, 1968

Campus universitário: textos. Brasília, DF: CEDATE, 1984.

BRASIL, MINISTÉRIO DA EDUCAÇÃO E CULTURA - SG.CEDATE. Universidade Federal do Maranhão no centro histórico de São Luís. Brasília: CEDATE, 1984.

BRASIL, DECRETO N 62.937/68. Brasília: Ministério da Educação e Cultura, Ministério do Planejamento e Coordenação Geral, Ministério da Fazenda, agosto de 1968.

BUFFA, Ester; PINTO, Gelson de Almeida. Arquitetura e educação: câmpus universitários brasileiros. São Carlos: EduFSCar, 2009.

BUZAR, Solange Silva. O conteúdo da prática pedagógica. São Luís: UFMASSecretaria Educação, 1984.

CABRAL, Neyde Angela Joppert. A Universidade de São Paulo: modelos e projetos. Tese (Doutorado em Estruturas Ambientais Urbanas), Universidade de São Paulo, São Paulo, 2004.

Arquitetura moderna e o alojamento universitário: leitura de projetos. Dissertação (Mestrado em Arquitetura e Urbanismo), Universidade de São Paulo, 1997.

CABRAL, Renata Campello. Mario Russo, um arquiteto racionalista italiano em Recife. Dissertação (Mestrado em Arquitetura e Urbanismo - Tecnologia do Ambiente Construído), Escola de Engenharia de São Carlos da Universidade de São Paulo, São Carlos, 2003.

CAMPÊLO, Magda. Leitura e análise das interferências físicas na arquitetura dos edifícios para a educação superior: o caso da UFC. Dissertação (Mestrado em Arquitetura e Urbanismo), Faculdade de Arquitetura e Urbanismo da Universidade de São Paulo, São Paulo, 2005.

CAMPÊLO, Magda; FREITAS, Waldete; TARALLI, Cibele. Gênese e sobrevida de um edifício moderno: o caso da Maternidade Popular Escola de Fortaleza. In: $3^{0}$. DOCOMOMO NORTE - NORDESTE, João Pessoa, março, 2010. 
CARDOSO, Edmundo (coord.). USM: a nova universidade. Santa Maria: Associação Santamariense Pró Ensino Superior, 1962.

CARNEIRO, Maude; KOHLSDORF, Maria Elaine; ZIMBRES, Marcos Sant'Ana. O campus do pós-milagre: alternativa para o caso da UnB. In: SEMINÁRIO SOBRE DESENHO URBANO NO BRASIL, n. 2, 1986, Brasília, DF. São Paulo: Pini, 1986, p. 367-374.

CARVALHO, José de Ribamar. Discurso proferido a 11 de novembro de 1972, quando da inauguração da primeira unidade do Campus Universitário da Universidade Federal do Maranhão, São Luís, 1972.

CARVALHO, Sheila Oliveira de. Análise bioclimática como ferramenta para implementação do plano diretor do campus central da UFRN. Dissertação (Mestrado em Arquitetura e Urbanismo), Faculdade de Arquitetura e Urbanismo, Universidade Federal do Rio Grande do Norte, Natal, 2005.

CASTILHO, Fausto. O conceito de universidade no projeto da Unicamp. Alexandre Guimarães Tadeu de Soares (org.). Campinas: Editora da Unicamp, 2008.

CASTRO, Francisco Alves de Andrade e. Ensino e desenvolvimento das ciências agrárias no Nordeste (Ceará): 1918 - 1978. Fortaleza: BNB, 1979.

CASTRO, José Liberal de. Martins Filho, o edificador. In: MENEZES NETO, Paulo Elpídio (org.). Martins Filho de Corpo Inteiro. Fortaleza: Imprensa Universitária - UFC, 2004.

Fatores de localização e expansão da cidade de Fortaleza. Fortaleza: Imprensa Universitária - UFC, 1977.

CIÊNCIAS da Saúde no Ensino Superior do Estado do Piaú́. Revista Universidade Federal do Piauí - Edição Comemorativa do $10^{\circ}$. ANIVERSÁRIO da FUFPI, Teresina, v.1, n. 3, 1982. Número especial

CONSTRUÇÃO DA CIDADE UNIVERSITÁRIA. O Norte, João Pessoa, p.2, 27.nov.1956.

CONSULTEC. Universidade Federal da Paraíba: projeto da Cidade Universitária de João Pessoa. [S.I.:s.n.]: dez.1966, v.1 (Textos).

CONVÊNIO MINISTÉRIO DA EDUCAÇÃO E CULTURAVDEPARTAMENTO DE ASSUNTOS UNIVERSITÁRIOS - UNIVERSIDADE FEDERAL DA BAHIA/CENTRO DE ESTUDOS INTEDISCIPLINARES PARA O SETOR PÚBLICO (MEC/DAU - UFBAIISP). Avaliação da implantação da Reforma Universitária: universidades federais. Salvador: UFBA, 1975.

CONVÊNIO UFSCar/UFAL. Proposta de adaptação e ocupação dos edifícios existentes. [Maceió?], [1979?].

COUTINHO, Marco et al. Expansão no Campus de João Pessoa da Universidade Federal da Paraíba: entre o diálogo e a alienação. In: ANAIS DOCOMOMO 2010 - JOÃO PESSOA.

CUNHA, Luiz Antônio. Câmpus universitário: opção ou destino? In: Universidade em Questão. Brasília: NESUB - Núcleo de Estudos sobre o Ensino Superior da UnB/Editora Universidade de Brasília, 2003.

D'EÇA, Luiz Felipe da Gama Lobo. Administração de tempos e espaços. In: $2^{\circ}$. SEMINÁRIO DE ASSISTÊNCIA TÉCNICA DO CONVÊNIO MEC/BID - ADMINISTRAÇÃO E PLANEJAMENTO DE "CAMPUS" UNIVERSITÁRIO. Brasília: Universidade Federal de Santa Catarina, [1972?].

DUARTE, Hélio de Queiroz; MANGE, Ernesto R. C. Plano da cidade universitária de Santa Catarina. Florianópolis: Universidade de Santa Catarina, 1957.

DUARTE, Hélio de Queiroz. Espaços flexíveis: uma consequência em arquitetura. São Paulo: FAU/USP, [1957?]. 
DUARTE, Romeu, et al. Liberal de Castro: documento. Arquitetura \& Urbanismo, São Paulo, ano 11, n.65, p.74-82, PINI, 1996.

ESTADO DO MARANHÃO. Mensagens e planos de governo, 1968.

FARIA, Regina Helena Martins de. Memórias de professores: histórias da UFMA e outras histórias. Organizado por Regina Helena Martins de Faria, Antonio Torres Montenegro. Brasília: CNPq, 2005.

FÁVERO, Maria de Lourdes de Albuquerque. A universidade no Brasil: das origens à Reforma Universitária de 1968. Revista Educar, Curitiba, $n^{\circ} .28, p .17-36$. Editora UFPR, 2006. Disponível em: <http://www.scielo.br/pdf/er/n28/a03n28.pdf $>$. Acesso em: 21 jun. 2010.

Da universidade "modernizada" à universidade disciplinada: Atcon e Meira Mattos. São Paulo: Cortez; Autores Associados, 1991.

1977.

A universidade brasileira em busca de sua identidade. Petrópolis: Editora Vozes,

FERNANDES, Ari Vicente. Campus e meio urbano universitário. C.J. Arquitetura. Revista de arquitetura, planejamento e construção, São Paulo, n.4 (Educação), p. 72-91, 1974.

FERNANDES, Ari Vicente et al. 1960/1970: Dez anos para a universidade, a mais ou a menos? . C.J. Arquitetura. Revista de arquitetura, planejamento e construção, São Paulo, n.4 (Educação), p. 56-71, 1974.

FERNANDES, Florestan. Universidade brasileira: reforma ou revolução. São Paulo:

Editora Alfa-Ômega, 1975.

FERREIRA, Lúcia de Fátima Guerra; FERNANDES, David (org.). UFPB 50 Anos. João Pessoa: Editora Universitária / UFPB, 2006.

FERREIRA FILHO, Pedro Leopoldino. Avaliação institucional na universidade: fundamentos de uma ação. 1995. Dissertação (Mestrado em Gestão Universitária), Universidade Estácio de Sá, Rio de Janeiro, 1995.

FONSECA NETO, Hermes da. Potencial de integração de uma área periférica ao centro histórico: o caso do Aterro do Bacanga em São Luís - MA. Dissertação (Mestrado em Desenvolvimento Urbano), Universidade Federal de Pernambuco, Recife, 2002.

FRAUCHES, Celso da Costa. A livre iniciativa e reforma universitária brasileira. In: ANAIS DO IV COLÓQUIO INTERNACIONAL SOBRE GESTÃO UNIVERSITÁRIA NA AMÉRICA DO SUL. Florianópolis, 2004. Disponivel em: <http://www.inpeau.ufsc.br/coloquio04/a8.htm >. Acesso em 17 mar. 2009.

FREITAS, Waldete Cunha de. Espaço hospitalar: o caso do Hospital Universitário Walter Cantídio/UFC. Dissertação (Mestrado em Arquitetura e Urbanismo), Faculdade de Arquitetura e Urbanismo da Universidade de São Paulo. São Paulo, 2005.

FUNDAÇÃO UNIVERSIDADE DO MARANHÃO (FUM). Plano de ação para 1974. São Luís: SUPLAN, [1973].

Relatório de Atividades - Edição comemorativa do $5^{\circ}$ Aniversário da Lei 5.152 , de 21 de outubro de 1966, que autorizou a criação da Fundação Universidade do Maranhão. São Luís: FUM, [1971](a).

Catálogo Geral 1971. São Luís: UFMA, 1971(b).

$\frac{}{1969 a}$. Estatuto da Universidade do Maranhão (Anteprojeto) - 1969. São Luís: FUM,

Universidade do Maranhão - Distribuição Físico-Funcional (Projeto M-10-RA3/69). [São Luís]: MAXIMUS LTDA., 1969b. 
Estudo Preliminar para o Desenvolvimento da Universidade do Maranhão. São Luís: FUM, [1968?].

FUNDAÇÃO UNIVERSIDADE FEDERAL DO PIAUI, DIVISÃO DE PROJETOS (FUPI/DIPRO). Dez anos de atividades. Teresina: FUPI/DIPRO, 1981.

FUPI/CEPRO. Centro de Ciências e Letras: programa de necessidades/estudo preliminar/1977. Teresina: FUFPI, 1977.

FUPI. Projeto do campus: memória. Teresina: FUFPI, 1971.

GARCIA, Odilon de Amorim. A história da Faculdade de Odontologia da Universidade Federal do Rio Grande do Norte. Natal: EDUFRN, 2008.

GIRÃO, Célio Brasil. Memórias do Hospital das Clínicas. Fortaleza: Imprensa Universitária, 1994.

GITAI, Delza. Memória fotográfica. A Universidade sai do casulo. Maceió: UFAL, 1991.

GOROVITZ, Matheus. Os riscos do projeto: Universidade do Brasil, 1936. Dissertação (Mestrado), Faculdade de Arquitetura e Urbanismo, São Paulo, 1989, 2v.

GRACIANI, Maria Stela Santos. O ensino superior no Brasil: um estudo sobre a estrutura burocrática da universidade pós-reforma. Dissertação (Mestrado em Sociologia), Pontifícia Universidade Católica de São Paulo, São Paulo, 1980.

GUTEMBERG, Araújo. Discurso: 50 anos do Curso de Medicina. [São Luís]: [2008?].

Disponivel

em: $<$ http $: / /$ www.drgutembergaraujo.com.br/site/index.php?option=com_content\&view=article

$\& \mathrm{id}=81$ : discurso-50-anos-do-curso-de-medicina\&catid $=39$ : discursos\&ltemid $=95>$. Acesso em: 15 ago, 2011.

JOEDICKE, Jürgen. Candilis, Josic, Woods. Una década de arquitectura y urbanismo. Barcelona: Gustavo Gili, 1968.

KRUEL, Kenard. Djalma Veloso, o político e sua época. Teresina: Zodíaco, 2006.

LEAL, Vinicius Barros. História da Medicina no Ceará. Fortaleza: Secretaria da Cultura, Desporto e Promoção Social, 1979.

LIMA, Daladier Pessoa Cunha. Onofre Lopes. Disponível em

$<$ http://www.farn.br/novo/navegacao/noticias/artigos_reitor/artigo_reitor_62.php>. Acesso em: 21 nov. 2011.

LIMA, Domingos Gomes de; MELO, José Cláudio de Morais. 12 anos de universidade (1959-1971). Natal: Imprensa Universitária, 1971.

LIMA, Mayumi Watanabe de Souza; KOHL, Masako Matsumura. Introdução. C.J. Arquitetura. Revista de arquitetura, planejamento e construção, São Paulo, n.4 (Educação), p. 35-48, 1974.

LIMEIRA, Maria das Dores; FORMIGA, Zeluiza. Fundamentos históricos da UFPB: das origens à estadualização. In: FERREIRA, Lúcia de Fátima Guerra; FERNANDES, David (Org.). UFPB 50 Anos. João Pessoa: Editora Universitária/UFPB, 2006.

UFPB: implicações políticas e sociais da sua história. Textos UFPB-NDIHR, João Pessoa, 1986.

LOPES, L.J. Ciência e universidade no Terceiro Mundo: a experiência frustrada do Brasil. In: FURTADO, C. - Brasil: tempos modernos. Rio de Janeiro: Paz e Terra, 1977.

LUCINI, Hugo Camilo. Plano de desenvolvimento físico: Universidade Federal de Alagoas. [Maceió?]: Convênio UFAL/UFSCar, 1982. 

[1980?].

Plano físico: Universidade Federal do Maranhão. Campinas: ASPLAN/UFSCAR,

LUZ, Josinaldo Santos da. Lutas por moradia e expansão do espaço urbano na cidade de São Luís. Dissertação (Mestrado em Políticas Públicas), Universidade Federal do Maranhão, São Luís, 2004.

MACEDO, Adilson Costa. O desenho do campus universitário e seu projeto. São Paulo: Projeto, n`94, p. 104-106, dez. 1996b.

O desenho do campus universitário. São Paulo: Projeto, n93, p. 96-98, nov. 1996a.

Ideias preliminares para o projeto urbano da Cidade Universitária Armando de Salles Oliveira. Tese (Doutorado em Arquitetura e Urbanismo), Faculdade de Arquitetura e Urbanismo da Universidade de São Paulo, 1987.

MAHFUZ, Edson da Cunha. Teoria, história e crítica e seu papel no ensino de projeto arquitetônico. In: $V$ ENCONTRO DE TEORIA E HISTÓRIA DA ARQUITETURA NO RIO GRANDE DO SUL, Faculdade de Arquitetura e Urbanismo Ritter dos Reis, Porto Alegre, RS, out. 2000.

MALTA, Maurício. Campus universitário brasileiro: algumas sugestões. In: SEMINÁRIO SOBRE DESENHO URBANO NO BRASIL, $n^{\circ} .2$, 1986, Brasília, DF. São Paulo: Pini, p. 162$170,1986$.

MARQUES, José Maria Cabral. A criação da Universidade Federal. In: Memória de professores: histórias da UFMA e outras histórias. Organizado por Regina Helena Martins de Farias, Antônio Torres Montenegro. São Luís: Universidade Federal do Maranhão/Departamento de História; Brasília: CNPq, 2005.

MARTINS FILHO, Antônio. Criador e criatura. Universidade Pública, n²4, p.8-12, out/nov. 2004b.

Depoimentos para a história da UFC. Fortaleza: Imprensa Universitária - UFC,

Memórias - Maioridade, tomo II. Fortaleza: Imprensa Universitária - UFC, 1994.

Memórias - Maioridade, tomo I. Fortaleza: Imprensa Universitária - UFC, 1993.

O outro lado da história. Fortaleza: Edições UFC, 1983.

1996.

História abreviada da UFC. Fortaleza: Casa José de Alencar/Programa Editorial,

MARICATO, Ermínia; KOHL, Massako M., PAMPLONA, Telmo L. A ocupação do espaço: alguns casos. CJ. Arquitetura, São Paulo, ano 1, n. 4, p.95-98, fev./abr. 1974.

MATOS, Maria Madalena A. da C. As cidades e os campi: contributo para os estudos dos territórios universitários em Portugal. Tese (Doutorado), Universidade Técnica de Lisboa, Instituto Superior Técnico, Lisboa: [s.n.], 1999.

MEIRA, Alcyr et al, PB - a universidade: uma proposta espacial. Belém: Globo Editora, 1971.

MEIRELES, Mário Martins. $O$ ensino superior no Maranhão: esboço histórico. São Luís: Universidade Federal do Maranhão/Departamento de História e Geociência/Núcleo de Documentação e Pesquisa, 1981.

MELO, Paulo de Tarso Correia de. Os quatro precursores. In: NEWTON JÚNIOR, Carlos et al. Portal da memória: Universidade Federal do Rio Grande do Norte 50 Anos (1958-2008). Brasília: Senado Federal, 2008. Disponível em: <http://www.ufrn.br>. Acesso em: 16 nov. 2011. 
MELO, Zélia Cavalcante de. O processo de federalização da Universidade Federal da Paraíba. In: FERREIRA, Lúcia de Fátima Guerra; FERNANDES, David (org.). UFPB 50 anos. João Pessoa: Editora Universitária/UFPB, 2006.

MENEZES NETO, Paulo Elpídio (org.). Martins Filho de corpo inteiro. Fortaleza: Imprensa Universitária - UFC, 2004a.

Bárbara)b.

Martins Filho. Fortaleza: Edições Demócrito Rocha, 2004, (Coleção Terra

MINISTÉRIO DA EDUCAÇÃO E CULTURAICENTRO DE ESTUDOS INTERDISCIPLINARES PARA O SETOR PÚBLICO (MEC/ ISP). Avaliação da ímplantação da Reforma Universitária: universidades federais. Salvador: UFBA, 1975.

MINISTÉRIO DA EDUCAÇÃO E CULTURA. Secretaria Geral/CODEAP. Avaliação da Reforma Universitária no âmbito de uma universidade: a Universidade Federal do Ceará. In: II ENCONTRO DE REITORES DE UNIVERSIDADES PÚBLICAS E DIRETORES DOS ESTABELECIMENTOS PÚBLICOS ISOLADOS DE ENSINO SUPERIOR, Brasília, 1973.

MINISTÉRIO DA INTEGRAÇÃO NACIONAL/AGÊNCIA DE DESENVOLVIMENTO DO NORDESTE/INSTITUTO INTERAMERICANO DE COORPERAÇÃO PARA A AGRICULTURA. Plano estratégico de desenvolvimento sustentável no Nordeste: desafios e possibilidades para o Nordeste do século XXI: versão para discussão. Recife: Agência de Desenvolvimento do Nordeste (Adene), 2006.

Documento de base 4. Disponivel em

<http://www.integraregio.com.br/file.php/1/Biblioteca/Planejamento_Regional/PDNE.pdf>.

Acesso em: 3 set. 2010.

MIQUELIN, Lauro Carlos. Anatomia dos edifícios hospitalares. São Paulo: CEDAS, 1992.

MUTHESIUS, Stefan. The postwar university: utopianist campus and college. Londres: Yale University, 2000.

NADALUTTI, Roberto; VALDETARO, Oscar. Plano diretor e urbanização da Cidade Universitária. In: CARDOSO, Edmundo (coord.). USM: a nova universidade. Santa Maria: Associação Santa-mariense Pró Ensino Superior, 1962.

NEVES FILHO, Clóvis. A vitória dos vencidos. Dissertação (Mestrado em Educação), Pontifícia Universidade Católica do Rio de Janeiro, Rio de Janeiro, 1998.

NEWTON JÚNIOR, Carlos. Breve histórico da Universidade Federal do Rio Grande do Norte. In: NEWTON JÚNIOR, Carlos et al. Portal da memória: Universidade Federal do Rio Grande do Norte 50 Anos (1958-2008). Brasília: Senado Federal, 2008. Disponível em: <http://uww.ufrn.br>. Acesso em: 16 nov. 2011.

NEWTON JÚNIOR, Carlos et al. Portal da memória: Universidade Federal do Rio Grande do Norte 50 Anos (1958-2008). Brasília, DF: Senado Federal, 2008. Disponível em: <http://www.ufrn.br>. Acesso em: 15 nov. 2010.

NEWTON JÚNIOR, Carlos et al. Portal da memória: Universidade Federal do Rio Grande do Norte: 45 anos de federalização (1960/2005). Brasília, DF: Senado Federal, 2005.

NOBRE, Zélia de Melo Maia. Um sonho concretizado. DISCURSO de comemoração aos 20 anos de criação do Curso de Arquitetura e Urbanismo da Universidade Federal de Alagoas, Maceió, 2008.

NÓBREGA, Humberto Carneiro da Cunha. Depoimento do Humberto Carneiro da Cunha [25 set. 1979; 05 out.1979]. Entrevistadoras: Zélia Cavalcanti de Melo, Maria das Dores Limeira Ferreira dos Santos, Zeluiza da Silva Formiga Brandão. João Pessoa: NDIHR/UFPB, 1979. In: FERREIRA, Lúcia de Fátima Guerra, FERNANDES, Davis (org.). UFPB 50 Anos. João Pessoa: Editora Universitária/ UFPB, 2006. 
As raízes das ciências da saúde na Paraíba: Medicina, Farmácia, Odontologia e Enfermagem. João Pessoa: 1979.

OLIVEIRA, Antonio J. B. Das ilhas à cidade - a universidade visível. A construção da Cidade Universitária da Universidade do Brasil (1935-1950). Dissertação (Mestrado em História Comparada), Universidade Federal do Rio de Janeiro (UFRJ), Rio de Janeiro, 2003.

OLIVEIRA, Joaquim Aristides de. A universidade e seu território: um estudo sobre as concepções de campus e suas configurações no processo de formação do território da Universidade Federal do Ceará. Dissertação (Mestrado em Arquitetura e Urbanismo) Faculdade de Arquitetura e Urbanismo da Universidade de São Paulo, São Paulo, 2005.

OLGYAY, V. Arquitectura y clima: manual de diseño bioclimático para arquitectos y urbanistas. Barcelona: Gustavo Gilli, 1998.

ONOFRE, Carlos Eduardo Lins. Pé no campus: diretrizes de sinalização para os pedestres do Campus Central da UFRN. Trabalho final de graduação do Curso de Arquitetura e Urbanismo da Universidade Federal do Rio Grande do Norte, semestre 2008.2. Natal: UFRN, 2008.

PALHANO, Raimundo. A UFMA no contexto universitário brasileiro: a década dos anos 80. São Luís: CORSUP/EDUFMA, 1990.

PASSOS, Guiomar de Oliveira. A Universidade Federal do Piauí e suas marcas de nascença: conformação da Reforma Universitária de 1968 à sociedade piauiense. Tese (Doutorado em Sociologia), Universidade de Brasília, Brasília, 1985.

PAULA, Maria de Fátima de. A modernização da universidade e a transformação da intelligentzia universitária. Florianópolis: Insular, 2002.

PEREIRA, Cecília Ribeiro. O estudo preliminar de Wit-Olaf Prochnik: planejamento urbano e enunciados do Recife. Dissertação (Mestrado em Desenvolvimento Urbano), Universidade Federal de Pernambuco, Recife, 2005.

PEREIRA, Fúlvio Teixeira de Barros. Novos edifícios, nova versão urbana: difusão da arquitetura moderna na cidade de João Pessoa (1956 - 1974). Dissertação (Mestrado em Teoria e História da Arquitetura e Urbanismo), Escola de Engenharia de São Carlos da Universidade de São Paulo, São Carlos, 2008.

PEREIRA, Marizo Vitor, NOBRE, Paulo José Lisboa. Recife e Rio de Janeiro: influências na produção da arquitetura. In: $2^{\circ}$ DOCOMOMO NORTE-NORDESTE: Desafios da preservação: referências da arquitetura e do urbanismo modernos no Norte e no Nordeste, 2008, Salvador. Anais do $2^{\circ}$. DOCOMOMO NNE, 2008.

PINTO, Zenilde Soares. Concepção extensionista da Universidade Federal de Sergipe: processo histórico cultural da sociedade. 1928 - 2003. Tese (Doutorado em Ciências da Educação), Facultad de Ciencias de la Educación, Departamento de Teoria e História de la Educación, Universidad de Santiago de Compostela, Santiago de Compostela, 2004.

PLANEJAMENTO da Futura "Cidade Universitária" do Estado da Paraíba. A União, João Pessoa, p.3-4, 27 nov.1956.

PORTO, Severiano Mario. Planejamento do campus universitário: plano diretor. Manaus: Fundação Universidade do Amazonas, 1973.

PROCHNIK, Wit-Olaf. Arquitetura para fins educacionais: planejamento educacional e arquitetura escolar. Documento apresentado ao Banco Nacional da Habitação (BNH) para atuar nos Programas Habitacionais. Rio de Janeiro: Escritório Wit-Olaf Prochnik Arquitetura e Planejamento, 1981. 
Fundação Universidade do Maranhão: Centro de esportes - caderno de encargos. São Luís: Escritório Wit-Olaf Prochnik - Arquitetura e Planejamento, maio/ [1973b?]

CONTRATO. Contrato que entre si fazem a Fundação Universidade do Maranhão e a firma Wit-Olaf Prochnik - Arquitetura e Planejamento com vistas à elaboração dos projetos dos prédios do Instituto de Filosofia e Ciências Humanas, do Instituto de Letras e Artes, da Biblioteca Central; e da Infraestrutura do Campus da FUM, situado na região Itaqui-Bacanga (São Luís/MA). [S.I.]: Escritório Wit-Olaf Prochnik - Arquitetura e Planejamento, [1973a?].

Ofício $n^{\circ} 487 / 73$, de 22 de junho de 1973. Encaminha solicitação ao Magnífico Reitor da Fundação Universidade do Maranhão, Dr. Josué Montelo, para que sejam enviados o levantamento topográfico do Campus da FUM com vistas à elaboração do projeto de infraestrutura e os programas de necessidades referentes ao Instituto de Filosofia e Ciências Humanas e Instituto de Letras e Artes. Esclarece que o programa da Biblioteca Central está sendo tratado com a diretora do referido órgão. Rio de Janeiro: Escritório WitOlaf Prochnik - Arquitetura e Planejamento, 1973e.

Ofício $n^{\circ} 351 / 73$, de 24 de abril de 1973. Encaminha solicitação ao Magnífico Reitor da Fundação Universidade do Maranhão, Dr. Josué Montelo, para aditamento da minuta do contrato para os projetos do Instituto de Filosofia e Ciências Humanas e Instituto de Letras e Artes e Biblioteca Central a serem construídos no Campus da FUM (São Luís/MA), referente à clausula 3 - item 3. Rio de Janeiro: Escritório Wit-Olaf Prochnik Arquitetura e Planejamento, 1973d.

Ofício $n^{\circ} 325 / 73$, de 11 de abril de 1973. Encaminha proposta ao Magnífico Reitor da Fundação Universidade do Maranhão, Dr. Josué Montelo, para substituição do projeto da Reitoria pelos projetos do Instituto de Filosofia e Ciências Humanas e Instituto de Letras e Artes, constantes de proposta anteriormente enviada e aprovada pelos órgãos competentes da Fundação Universidade do Maranhão (São Luís / MA). Rio de Janeiro: Escritório Wit-Olaf Prochnik - Arquitetura e Planejamento, 1973c.

Ofício $n^{\circ} 172 / 73$, de 21 de fevereiro de 1973. Encaminha proposta ao Magnífico Reitor da Fundação Universidade do Maranhão, Dr. Josué Montelo, para elaboração dos projetos dos prédios da Reitoria e Biblioteca Central, a serem construídos no Campus da FUM (São Luís/MA). Rio de Janeiro: Escritório Wit-Olaf Prochnik - Arquitetura e Planejamento, 1973b.

Ofício $n^{\circ} 171 / 73$, de 21 de fevereiro de 1973. Encaminha proposta ao Magnífico Reitor da Fundação Universidade do Maranhão, Dr. Josué Montelo, para execução dos projetos de infraestrutura do Campus da FUM (São Luís / MA). Rio de Janeiro: Escritório Wit-Olaf Prochnik - Arquitetura e Planejamento, 1973a.

Departamento de Biologia - especificações técnicas: instruções para tomada de preços. São Luís: Escritório Wit-Olaf Prochnik - Arquitetura e Planejamento, maio / [1972?].

Ofício $n^{\circ} 166 / 72$, de 15 de março de 1972. Encaminha esclarecimentos à

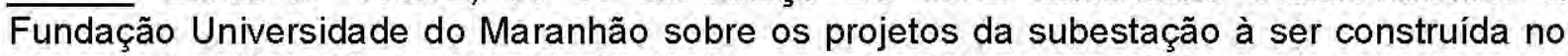
Campus da FUM (São Luís/MA). Rio de Janeiro: Escritório Wit-Olaf Prochnik - Arquitetura e Planejamento, 1972b.

Fundação Universidade do Maranhão: plano geral de desenvolvimento. São Luís: Escritório Wit-Olaf Prochnik - Arquitetura e Planejamento, maio/1972a.

Estudo Preliminar para o desenvolvimento da Universidade do Maranhão. São Luis: FUM, 1967.

RIBEIRO, Darcy. Universidade necessária. Rio de Janeiro: Paz e Terra, 1978b, $3^{a}$ ed.

ROCHA, José Mariano da. A nova universidade. In. CARDOSO, Edmundo (coord.). USM: a nova universidade. Santa Maria: Associação Santa-mariense Pró Ensino Superior, 1962. 
RODRIGUES, Luiz Augusto Fernandes. Universidade e a fantasia moderna: a falácia de um modelo espacial único. Niterói: EdUFF, 2001.

RODRIGUES, Claúdio José Lopes. Sociedade e universidade: um estudo de caso. João Pessoa: SEC-PB, 1986.

A universidade em positivo e negativo: a memória fotográfica da UFPB. João Pessoa: Editora Universitária/UFPB, 1997.

SAMPAIO, Leonardo. A História do Pici. Disponível em:

<leonardofsampaio. blogspot.com/2007/12/historia-do-pici.html>. Acesso em: 27 mar. 2012.

SANTOS, Carlos Nelson F. dos. O campus universitário no Brasil: Arquitetura - aspectos ideológicos. In: ENCONTROS COM A CIVILIZAÇÃO BRASILEIRA [S.I.], n. 16, p. 97 - 102, out. 1979.

SCHLEE, Andrey Rosenthal. Reproduzindo modelos - O plano piloto do campus da Universidade Federal de Santa Maria, RS. In: $5^{\circ}$. SEMINÁlO DOCOMOMO BRASIL, 27 a 30 de outubro de 2003, São Paulo. São Paulo: Universidade de São Paulo, 2003. Disponível em: <http://www.docomomo.org.br/seminario\%205\%20pdfs/020R.pdf>. Acesso em: 22 mai. 2010.

SEMINÁRIO SOBRE DESENHO URBANO NO BRASIL, 2, 1986, Brasília, DF. [Anais...] São Paulo: PINI; Brasília, DF: CNPq; Rio de Janeiro: FINEP, 1986.

SEMINÁRIO AVALIAÇÃO DA MORFOLOGIA URBANISTICA DO CAMPUS UNIVERSITÁRIO BRASILEIRO, 1985, Brasília, DF. [Papers...] Brasília, DF: MEC/CEDATE, 1985.

SEMINÁRIO DE CONCEITUAÇÃO DO CAMPUS UNIVERSITÁRIO BRASILEIRO, 1981, Brasília, DF. [Trabalhos...] Brasília, DF: MEC/CEDATE, 1984.

SEMINÁRIO NACIONAL SOBRE PLANEJAMENTO DE CAMPI UNIVERSITÁRIOS, 1985, Brasília, DF. [Anais...] Brasília, DF: MEC/PREMESU, 1978.

SILVA, Fábio Ronaldo da; MONTENEGRO, Rosilene Dias. A Escola Politécnica de Campina Grande pelo Diário da Borborema: uma análise de discurso. Disponível em < http://www.bocc.ubi.pt/pag/silva-fabio-escola-politecnica-campina-grande.pdf >. Acesso em 12.out.2011.

SILVA, Maria Ozanira da Silva e et al. O protagonismo do Maranhão no serviço social brasileiro. [São Luís]: [2008?]. Disponível em

< http://www.repositorio.ufma.br:8080/jspui/bitstream/1/156/1/protagonismo.pdf >. Acesso em: 15 ago. 2011.

SILVEIRA, Ana Lucia R. C. da; MELO, Jaísse Craveiro; CARVALHO, Thâmara Talita Costa de. Análise da adequação bioclimática de edifícios modernos em Teresina - PI. In: Documentos de Arquitetura Moderna no Piauí. Teresina: GRÁFICA HALLEY, 2010.

SILVEIRA, Charles Carvalho Camilo da. Processo decisório e racionalidade em organizações universitárias: o caso da UFPI. 1968. Dissertação (Mestrado em Gestão Universitária), Universidade Federal do Piauí, Teresina, 1998.

SOBRAL, Gustavo. Arquitetura Moderna Potiguar. Natal: EDUFRN, 2011.

SOUZA, Itamar de. Nova história de Natal: Lagoa Nova, um bairro nobre. Natal: Diário de Natal, 16p. Fascículo 19. Projeto Ler, 1999.

SOUZA, Itamar de. Universidade: Para quê? Para quem? Natal: Clima, 1984.

S. RAFAEL - local mais indicado para a cidade universitária. O Norte, João Pessoa, p. 4,8; 27.nov.1956. 
SUCUPIRA, Newton. A condição atual da universidade e a Reforma Universitária Brasileira. Brasília: Ministério da Educação, 1973.

SCHMERTZ, Mildred F. Campus planning and design. New York: McGraw-Hill, 1972.

SILVA, Maria Angélica da. Arquitetura Moderna: a atitude alagoana. Maceió: SERGASA, 1991.

SIMÕES, João Roberto Leme. Arquitetura na Cidade Universitária "Armando de Salles Oliveira" - o espaço construído. Dissertação (Mestrado em Arquitetura e Urbanismo), Faculdade de Arquitetura e Urbanismo da Universidade de São Paulo, São Paulo, 1984.

TAJRA, Leda Maria Chaves. Primeiro ciclo de estudos básicos da Universidade Federal do Maranhão: contribuições para reflexão. São Luís: EDFUMA/Secretaria da Educação, 1985.

TAMDJIAN, James Onnig; MENDES, Ivan Lazzari. Geografia geral e do Brasil: estudos para compreensão do espaço - ensino médio. São Paulo: FTD, 2004 (Coleção Delta).

TINEM, Nelci et al. Arquitetura moderna em João Pessoa: a memória moderna e local de um movimento internacional. Disponível em

$<$ http://www.docomomo.org.br/seminario\%206\%20pdfs/Nelci\%20Tinem.pdf > Acesso em: 20 out. 2011.

TRIGUEIRO, Edja et al. Modernismo potiguar: vida, reprodução e quase morte. In: $3^{\circ}$. DOCOMOMO NORTE-NORDESTE: Morte e vida severinas: das ressurreições e conservações (im)possíveis do patrimônio moderno no Norte e Nordeste do Brasil, 2010, João Pessoa. Anais do $3^{\circ}$. DOCOMOMO NNE, 2010. p. 1-26.

TRIGUEIRO, Edja. Arquitetura da Universidade Federal do Rio Grande do Norte. In: NEWTON JÚNIOR, Carlos et al. Portal da Memória: Universidade Federal do Rio Grande do Norte 50 Anos (1958-2008). Brasília: Senado Federal, 2008. Disponível em: <http://uww.ufrn.br>. Acesso em: 16 nov. 2009.

Arquitetura da UFRN. In: NEWTON JR, Carlos (org), TRIGUEIRO, Edja B.F. YAMAMOTO, Oswaldo $\mathrm{H}$. e MELO, Paulo de Tarso C. Portal da memória - Universidade Federal do Rio Grande do Norte: 45 anos de federalização (1960-2005). Brasília, DF: Senado Federal, 2005.

TURNER, Paul Vernable. Campus: an American planning tradition. New York: The Architecture History Foundation; MIT Press Series, 1987.

UNIVERSIDADE DE BRASÍLIA. Documentação: textos da Reforma Universitária. Brasília: UnB, 1969.

UNIVERSIDADE DO BRASIL. Cidade Universitária da Universidade do Brasil. Rio de Janeiro: ETUB, 1953.

UNIVERSIDADE FEDERAL DE MINAS GERAIS (UFMG). O território universitário: proposta de modelo para um sistema ambiental. Belo Horizonte: UFMG, 1970.

UNIVERSIDADE DE SÃO PAULO (USP), Centro de Preservação Cultural da. Cidades universitárias: patrimônio urbanístico e arquitetônico da USP. São Paulo: Editora da Universidade de São Paulo: Imprensa Oficial do Estado de São Paulo, 2005.

VICENTINI, Cláudio. Viver a história. São Paulo: Scipioni, 2002.

VIEIRA, Sofia Lerche. O (dis)curso da (re)forma universitária. Fortaleza: Ed. UFC/PROED, 1982.

O ensino superior: o discurso do projeto da reforma de 1968. Dissertação (Mestrado em Educação), Faculdade de Educação da Universidade Federal do Ceará, Fortaleza, 1980. 
UNIVERSIDADE FEDERAL DE ALAGOAS. Universidade Federal de Alagoas: 30 anos de vida - 1961 a 1991. Maceió: SERGASA, 1991.

A Universidade Federal de Alagoas. Maceió: Pró-Reitoria para Assuntos de Planejamento / UFAL, [1982?].

Universidade Federal de Alagoas. Maceió: Pró-Reitoria para Assuntos de Planejamento - UFAL, 1975.

Operação e funcionamento do hospital universitário: contribuição à XIX Reunião Plenária do Conselho de Reitores das Universidades Brasileiras em Fortaleza/Ceará. [Maceió?]: UFAL, 1974.

Breve histórico da Universidade Federal de Alagoas. Disponível em: < http://www.ufal.br/45anos/>. Acesso em: 19 set. 2011.

VERÇOSA, Elcio de Gusmão. O ensino superior em Alagoas: verso e reverso. Maceió: EDUFAL, 1997.

UNIVERSIDADE DO CEARÁ, A - Imprime novos rumos à Educação e Cultura - Separata dos Anais Científicos, $n^{\circ} 68$, São Paulo ,1960.

UNIVERSIDADE FEDERAL DO CEARÁ (UFC). Campus Avançado do Cariri: plano diretor físico. Fortaleza: COP / UFC, 2006.

Universidade Federal do Ceará - Campus Universitário: consolidação da área física. Fortaleza: PLANOP - UFC, 1996. UFC, 1980

Campus Universitário: plano diretor - 1980. Fortaleza: Imprensa Universitária -

Universidade Federal do Ceará: ano 20 - roteiro. Fortaleza: Imprensa Universitária - UFC, 1974.

Plano de Desenvolvimento - 1966. Fortaleza: Imprensa Universitária - UFC, 1966.

Boletim UFC, Fortaleza, $n^{\circ} 2, n^{\circ} 3, n^{\circ} 4, n^{\circ} 6, n^{\circ} 12, n^{\circ} 25, n^{\circ} 32, n^{\circ} 58$ e $n^{\circ} 59$

UNIVERSIDADE FEDERAL DO MARANHÃO (UFMA). Jornal da Universidade - 43 anos Edição Especial, Ano II, n5, São Luís, dez. 2009.

Diagnóstico da infraestrutura do Campus I - Bacanga. (org.) Grupo de Trabalho de Transição/Eixo Temático 6 - Infra - Estrutura. São Luís: Prefeitura do Campus I Bacanga, 2007.

Memorial Cristo Rei. Palácio Cristo Rei: abre as portas para você: catálogo. São Luís: UFMA, Memorial Cristo Rei, [2009?]. Catálogo de apresentação do acervo Memorial Cristo Rei. Obras, 1981.

Dados informativos para o Catálogo da UFMA. São Luís: Coordenadoria de UNIVERSIDADE FEDERAL DA PARAÍBA (UFPB). A UFPB: História. Disponível em: <http://www.ufpb.br/content/ufpb>. Acesso em: 11 out. 2010.

UFPB 50 Anos. Lúcia de Fátima Guerra Ferreira, Davis Fernandes (org.). João Pessoa: Editora Universitária/ UFPB, 2006.

Catálogo de graduação 77/78. João Pessoa: UFPB, [1980?].

UFPB CAMPUS: pLANO dIRETOR. João Pessoa: Imprensa Universitária da Paraíba, 1972.

UNIVERSIDADE FEDERAL DA PARAÍBA/PRÓ-REITORIA DE GRADUAÇÃO. Catálogo dos Cursos de Graduação: 1984/1985. João Pessoa: Pró-Reitoria de Graduação, [1983?]. 
UFRN / AGECON. UFRN aprova criação do Centro de Educação. Disponível em <http://www.agecom.ufrn.br/conteudo/jornal/noticia . php?id=237\&place=4>. Acesso em: 29 nov. 2011.

UFRN. Hospitais: Hospital Universitário Onofre Lopes. Disponível em <http://www.ufrn.br/ufrn/conteudo/servicos/hospitais/onofrelopes.php>. Acesso em: 21 nov. 2010

UFRN. Sítio eletrônico: <http://www.ufrn.br>. Acesso em: 7 nov. 2011.

Plano Diretor do Campus Universitário Central. Disponível em <www.ufrn.br/ufrn2/infra/conteudo/noticia.php?id=19>. Acesso em: 10 nov. 2011.

UNIVERSIDADE FEDERAL DE SERGIPE. Catálogo geral, 1980. Aracaju, 1980. [1981?].

Relatório da gestão do Reitor José Aloísio de Campos, 1976-1980. Aracaju,

Universidade Federal de Sergipe: planejamento do campus. Aracaju: UFS, 1974. Uma experiência em marcha de reforma e integração universitária. Aracaju, [ca.
1972]. Separata de: Brasil Universitário, n. 84 , ano 27 .

VILARINHOS, Maria Lúcia Ribeiro. O campus da UFRJ na llha do Fundão; análise de sua localização e organização espacial. Dissertação (PPGG), Universidade Federal do Rio de Janeiro, Rio de Janeiro, 2000.

ZEIN, Ruth Verde. Arquitetura da Escola Paulista Brutalista: 1953-1973. Tese (Doutorado em Teoria, Historia e Crítica de Arquitetura), Faculdade de Arquitetura, Universidade Federal do Rio Grande do Sul, Porto Alegre, 2005.

ZIMBRES, Paulo. Cidadelas do saber; novos edifícios nos campi universitários. Projeto, São Paulo, no. 167 , p.37-47, set. 1993.

A gestão democrática do espaço do campus. In: SEMINÁRIO NACIONAL SOBRE PLANEJAMENTO DE CAMPI UNIVERSITÁRIOS, 2, 1992. Goiânia: Universidade Federal de Goiás, 1992. 